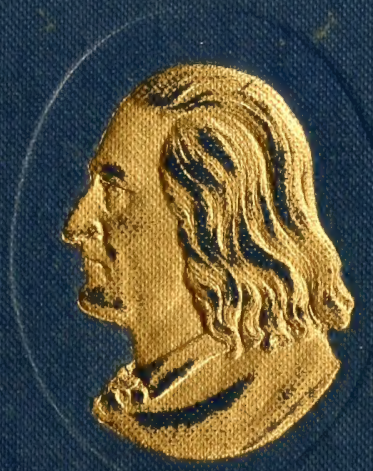





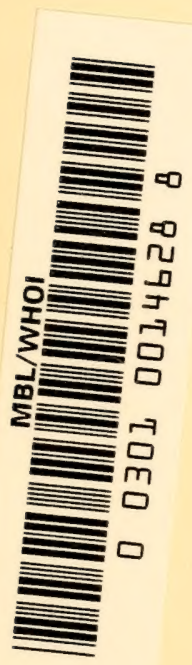




\section{AUDUBON THE}

NATURALIST 



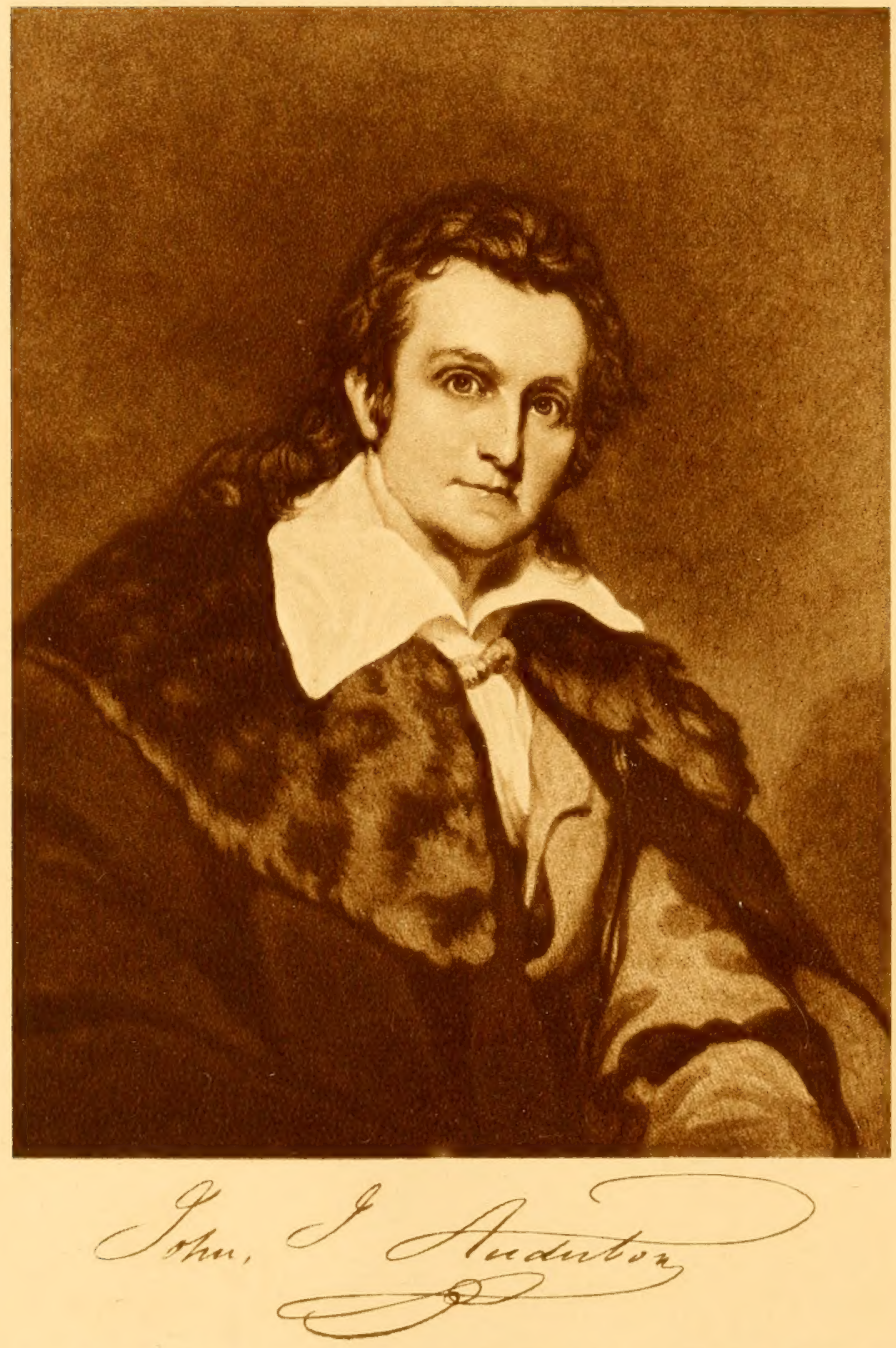

AFTER THE RARE ENGRAVING BY C. TURNER, A. R. A., OF THE MINIATURE PAINTED BY FREDERICK CRUICKSHANK. ABOUT 1831; PUBLISHED FOR THE ENGRAVER BY ROBERT HAVELL, LONDON, 1835. 

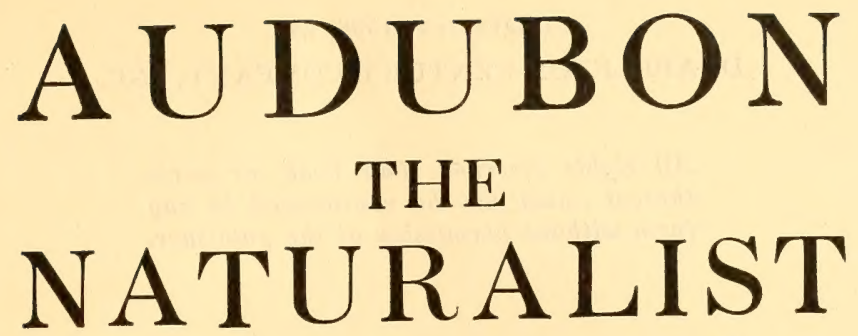

A History of his Life and Time

\section{By}

FRANCIS HOBAR'T HERRICK, Ph.D., Sc.D.

Professor Emeritus of Biology in Western Reserve University Author of "The American Eagle," "Wild Birds at Home," etc.

\section{ILLUSTRATED}

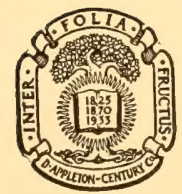

SECOND EDITION

TWO VOLUMES IN ONE

\section{APPLETON-CENTURY COMPANY} INCORPORATED

NEW YORK 
Copyright, 1938, вY

D. APPLETON-CENTURY COMPANY, INC.

All rights reserved. This book, or parts thereof, must not be reproduced in any form without permission of the publisher.

Copyright, 1917, by D. Appleton and Company PRINTED IN THE UNITED STATES OF AMERICA 
TO

ELIZABETH

M Y

SISTER 



\section{PREFACE TO THE FIRST EDITION}

The origin of the gifted ornithologist, animal painter, and writer, known to the world as John James Audubon, has remained a mystery up to the present time. In now lifting the veil which was cast over his early existence, I feel that I serve the cause of historical truth; at the same time it is possible to do fuller justice to all most intimately concerned with the story of his life and accomplishments.

The present work is in reality the outcome of what was first undertaken as a holiday recreation in the summer of 1903. While engaged upon a research of quite a different character, I reread, with greater care, Audubon's Ornithological Biography, and after turning the leaves of his extraordinary illustrations, it seemed to me most strange that but little should be known of the making of so original and masterful a character. As I was in England at the time some investigations were undertaken in London, but, as might have been expected, with rather barren results. After my return to America in the following year the search was continued, but as it proved equally fruitless here, the subject was set aside. Not until 1913, when this investigation was resumed in France, did I meet with success.

Every man, however poor or inconsequential he may appear or be, is supposed to possess an estate, and every man of affairs is almost certain to leave behind him domestic, professional, or commercial papers, which are, in some degree, a mark of his attainments and an indication of his character and tastes. In the summer of 1913 I went to France in search of the personal records of the naturalist's father, Lieutenant Jean Audubon, whose home had been at Nantes and in the little commune of Couëron, nine miles below that city, on 
the right bank of the Loire. The part which Lieutenant Audubon played in the French Revolution was fully revealed in his letters, his reports to the Central Committee, and numerous other documents which are preserved in the archives of the Préfecture at Nantes; while complete records of his naval career both in the merchant marine and governmental service (service pour l'Etat) were subsequently obtained at Paris ; but at Nantes his name had all but vanished, and little could be learned of his immediate family, which had been nearly extinct in France for over thirty years.

Again the quest seemed likely to prove futile until a letter, which I received through the kindness of Mr. Louis Goldschmidt, then American Consul at Nantes, to M. Giraud Gangie, conservateur of the public library in that city, brought a response, under date of December 29, 1913, informing me that two years before that time, he had met by chance in the streets of Couëron a retired notary who assured him that he held in possession numerous exact records of Jean Audubon and his family. The sage Henry Thoreau once remarked that you might search long and diligently for a rare bird, and then of a sudden surprise the whole family at dinner. So it happened in this case, and since these manuscript records, sought by many in vain on this side of the Atlantic, are so important for this history, the reader is entitled to an account of them.

Upon corresponding with the gentleman in question, M. L. Lavigne, I was informed that the documents in his possession were of the most varied description, comprising letters, wills, deeds, certificates of births, baptisms, adoptions, marriages and deaths, to the number, it is believed, of several hundred pieces. This unique and extraordinary collection of Audubonian records had been slumbering in a house in the commune of Couëron called "Les Tourterelles" ("The Turtle Doves") for nearly a hundred years, or since the death of the naturalist's stepmother in 1821.

Since I was unable to judge of the authenticity of the documents or to visit France at that time, my friend, Pro- 
fessor Gustav G. Laubscher, who happened to be in Paris, engaged in investigating Romance literary subjects, kindly consented to go to Couëron for the purpose of inspecting them. Monsieur Lavigne had already prepared for me, and still held, a number of photographs of the most important manuscripts, which are now for the first time reproduced, and, with the aid of a stenographer, in the course of two or three days they were able to transcribe the most essential and interesting parts of this voluminous material. But at that very moment sinister clouds were blackening the skies of Europe, and my friend was obliged to leave his task unfinished and hasten to Paris; when he arrived in that city, on the memorable Saturday of August 1, 1914, orders for the mobilization of troops had been posted; it was some time before copies of the manuscripts were received from Couëron, and he left the French capital to return to America.

These documents came into the hands of Monsieur Lavigne through his wife, who was a daughter and legatee of $\mathbf{G a -}$ briel Loyen du Puigaudeau, the second, son of Gabriel Loyen du Puigaudeau, the son-in-law of Lieutenant and Mme. Jean Audubon. Gabriel Loyen du Puigaudeau, the second, who died at Couëron in 1892, is thought to have destroyed all letters of the naturalist which had been in possession of the family and which were written previous to 1820 , when his relations with the elder Du Puigaudeau were broken off; not a line in the handwriting of John James Audubon has been preserved at Couëron.

In June and July, 1914, Dr. Laubscher had repeatedly applied to the French Foreign Office, through the American Embassy at Paris, for permission to examine the dossier of Jean Audubon in the archives of the Department of the Marine, in order to verify certain dates in his naval career and to obtain the personal reports which he submitted upon his numerous battles at sea, but at that period of strain it was impossible to gain further access to the papers sought.

Having told the story of the way in which these unique and important records came into my possession, I wish to ex- 
press my gratitude to Professor Laubscher for his able cooperation in securing transcriptions and photographs, and to Monsieur Lavigne for his kind permission to use them, as well as for his careful response to numerous questions which arose in the course of the investigation.

In dealing with letters and documents, of whatever kind, in manuscript, I have made it my invariable rule to reproduce the form and substance of the record as it exists as exactly as possible; in translations, however, no attempt has been made to preserve any minor idiosyncrasies of the writer. The source of all scientific, literary or historical material previously published is indicated in footnotes, and the reader will find copious references to hitherto unpublished documents, which in their complete and original form, with or without translations, together with an annotated Bibliography, have been gathered in Appendices at the end of Volume II. For convenience of reference each chapter has been treated as a unit so far as the footnotes are concerned, and the quoted author's name, with the title of his work in addition to the bibliographic number, has been given in nearly every instance.

Besides the many coadjutors whose friendly aid has been gladly a sknowledged in the body of this work, I now wish to offer my sincere thanks, in particular, to the Misses Maria R. and Florence Audubon, granddaughters of the naturalist, who have shown me many courtesies, and to the Hon. Myron T. Herrick, late American Ambassador to France, for his kindly assistance in obtaining documentary transcripts from the Department of the Marine at Paris. I am under special obligations also to the librarians of the British Museum and $\mathrm{Ox}$ ford University, the Linnæan and Zoölogical Societies of London, the Jardin des Plantes at Paris, the Public Libraries of Boston and New York, and the libraries of the Historical Societies of New York, Philadelphia, Boston and Louisiana, as well as to the Director of the Museum of Comparative Zoölogy of Harvard University, and to the American Museum of Natural History in New York City, for photographs of paintings and other objects, for permission to read or copy manu- 
scripts, and for favors of various sorts. Furthermore, I am indebted to the good offices of Mr. Ferdinand Lathrop Mayer, Secretary of Legation, Port-au-Prince, and of M. Fontaine, American Consular Agent at Les Cayes, Haiti, for a series of photographs made expressly to represent Les Cayes as it appears today. I would also acknowledge the courtesy of the Corporation of Trinity Parish, New York, through Mr. Pendleton Dudley, for an excellent photograph of the Audubon Monument.

I cannot express too fully my appreciation of the hearty response which the publishers of these volumes have given to every question concerned with their presentation in an adequate and attractive form, and particularly to Mr. Francis G. Wickware, of D. Appleton and Company, to whose knowledge, skill, and unabated interest the reader, like myself, is indebted in manifold ways.

My friend, Mr. Ruthven Deane, well known for his investigations in Auduboniana and American ornithological literature, has not only read the proofs of the text, but has generously placed at my disposal many valuable notes, references, pictures, letters and other documents, drawn from his own researches and valuable personal collections. I wish to express in the most particular manner also my appreciation of the generous spirit in which Mr. Joseph Y. Jeanes has opened the treasures in his possession, embracing not only large numbers of hitherto unpublished letters, but an unrivaled collection of early unpublished $\mathrm{Au}$ dubonian drawings, for the enrichment and embellishment of these pages. For the loan or transcription of other original manuscript material, or for supplying much needed data of every description, I am further most indebted to Mr. Welion H. Rozier, of St. Louis ; Mr. Tom J. Rozier, of Ste. Geneviève ; Mr. C. A. Rozier, of St. Louis; the Secretary of the Linnæan Society of London, through my friend, Mr. George E. Bullen, of St. Albans; Mr. Henry R. Howland of the Buffalo Society of Natural Sciences, of Buffalo; Mr. William Beer, of the Howard Memorial Library, of New Orleans; and Mr. W. 
H. Wetherill, of Philadelphia. For the use of new photographic and other illustrative material, I am further indebted to Mr. Stanley Clisby Arthur, of the Conservation Commission of Louisiana, and to Cassinia, the medium of publication of the Delaware Valley Ornithological Club.

Through the kindness of Messrs. Charles Scribner's Sons I have been permitted to draw rather freely from Audubon and His Journals, by Miss Maria R. Audubon and Elliott Coues, and to reproduce three portraits therefrom; original photographs of two of these have been kindly supplied by Dr. R. W. Shufeldt. I also owe to the courtesy of the Girard Trust Company, of Philadelphia, the privilege of quoting certain letters contained in William Healey Dall's Spencer Fullerton Baird.

To my esteemed colleague, Professor Benjamin P. Bourland, I am under particular obligations for his invahiable aid in revising translations from the French and in the transliteration of manuscripts, as well as for his kindly assistance in correspondence on related subjects. I have derived much benefit also from my sister, Miss Elizabeth A. Herrick, who has made many valuable suggestions. To all others who have aided me by will or deed in the course of this work I wish to express my cordial thanks.

Francis H. Herrick.

Western Reserve University, Cleveland.

July 2, $191 \%$. 


\section{PREFACE TO THE SECOND EDITION}

No less than ten volumes about, or by, Audubon have appeared during the past twenty years, or since the publication of Audubon the Naturalist in 1917, and three of these are more or less extended biographies. Certainly this is remarkable evidence of the curiosity that his adventurous and romantic life has aroused in the reading public, as well as of the engaging beauty of his delineations of animal and plant life.

Recent years (1929-1930) have seen the publication of the journal of Audubon's famous journey down the Ohio and Mississippi Rivers in 1820-1821, and also of his journal of 1840-1843, made while obtaining subscriptions to his Birds of America in America, as well as two volumes of letters, written in 1826-1840, the most fruitful period of his life's labors.

As a climax to this, all of Audubon's great and lesser bird plates, some five hundred in number, a century after their original publication in England and America, have now been reproduced in full color, though in reduced form, with a brief text, while the value of the original 435 hand-colored copperplate engravings of the double elephant folio edition of 18261838 has risen to fifteen times their original cost of one thousand dollars in America.

Audubon's "Book of Nature," as he often called his Birds of America, should be judged not alone by its fidelity or scientific accuracy, but also by the force of its example in sending direct to Nature, the fountainhead, all who would depict life and action. As an inspirer of youth, who can estimate the extent of its influence?

The late Louis Agassiz Fuertes, who was certainly one of the greatest delineators of bird life that has ever lived, wrote 
me in $\mathbf{1 9 1 7}$ that he owed his great desire to represent the beauty of birds to Audubon's Birds of America, a copy of which was given by Ezra Cornell to the institution that he founded and that bears his name. Those resplendent plates of birds and flowers enthralled the youthful Fuertes, who had free access to them in the library of Cornell University, and they determined the direction of his whole after life. Fuertes was no imitator, but it should be remembered that he had the advantage of following after a great pioneer.

The legitimate curiosity about the life and accomplishments of this singular genius has doubtless been whetted by the fantastic theory that Jean Jacques. Fougère Audubon was the real "lost Dauphin," son of Louis XVI and Marie Antoinette, in name the veritable King Louis XVII of France.

Although the authoritative historians of the world long ago may have rejected the idea that the Dauphin was "lost," except in the sense that he had died, and may consider the question of his survival after imprisonment in the Temple as too obsolete an issue to even merit refutation, the recent attempts to place John James Audubon at the end of a long line of false pretenders have made it necessary for me to deal with the question somewhat at length in the "Foreword and Postscript" to this edition.

In a case such as this, no honest writer can stoop to equivocation, or attempt to carry water on both shoulders, whether from a tender feeling for his subject, through domestic partiality, or by playing with enigma or mystery in order to heighten interest in his narrative.

The subject is of such historical importance that it must be treated with the strictest impartiality, by relying upon the preponderance of evidence, without personal animosity, and with the sole desire of uncovering the truth. The arguments that the proponents of the Dauphin-Audubon alliance have advanced were known to me twenty years ago, and were rejected then, as now, as wholly devoid of any proper and necessary documentary support. It should be remembered that Audubon 
made public no statement bearing upon his being the Dauphin of France.

Audubon was quite human, with plenty of faults, which may not always be excused, but with versatile talents which few could match. He showed that dogged perseverance in attaining his heart's desire which no poverty, no discords among family or friends, no lack of education, and no handicaps or misfortune could for more than a moment defeat or keep from eventual success. With all his lacks and all his faults Audubon was one of the most industrious and self-reliant among the successful men of his age. No longer can John James Audubon be called the "Melchizedek of Natural History," for to-day few men of his period are better known. Audubon was a man of great personal charm with a gift for friendship. A man who made and kept such friends as Edward Harris, William MacGillivray, the Reverend Dr. John Bachman, Dr. George Parkman, and Dr. George Cheyne Shattuck must have had a good heart.

Textual errors in the plates of the first edition have been corrected, and the bibliography has been extended to the present time. Those who are interested in the octavo editions of The Birds of America and of The Viviparous Quadrupeds of North America should consult an article in The Auk (see Bibliography, No. 245) for a more complete list of their perplexing issues. The "Foreword and Postscript" of the present edition is reproduced in substance from a paper in The Auk for October, 1937.

Francis H. Herrick.

Cleveland Heights, Ohio.

November 4, $193 \%$. 



\section{CONTENTS OF VOLUME I}

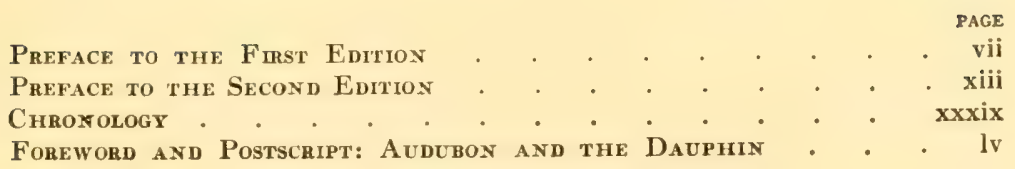

\section{CHAPTER I}

\section{INTRODUCTION}

Audubon's growing fame-Experience in Paris in 1828-Cuvier's patronage-Audubon's publications-His critics-His talents and accomplishments-His Americanism and honesty of purpose-His foibles and faults-Appreciations and monuments-The Audubon Societies - Biographies and autobiography-Robert Buchanan and the true history of his Life of Audubon . . . . . . . . .

\section{CHAPTER II}

\section{Jean Audubon and His Family}

Extraordinary career of the naturalist's father-Wounded at fourteen and prisoner of war for five years in England-Service in the French merchant marine and navy-Voyages to New foundland and Santo Domingo-His marriage in France-His sea fights, capture and imprisonment in New York-His command at the Battle of Yorktown-Service in America and encounters with British privateers

\section{CHAPTER III}

\section{Jean Audubon as Santo Domingo Planter and Merchant}

Captain Audubon at Les Cayes-As planter, sugar refiner, general merchant and slave dealer, amasses a fortune-His return to France with his children-History of the Santo Domingo revolt-Baron de Wimpffen's experience-Revolution of the whites-Opposition of the abolitionists-Effect of the Declaration of Rights on the mulattoes-The General Assembly drafts a new constitution -First blood drawn between revolutionists and loyalists at Port- 
au-Prince-Ogés futile attempt to liberate the mulattoes-Les Cayes first touched by revolution in 1790 , four years after the death of Audubon's mother-Emancipation of the mulattoes-Resistance of the whites-General revolt of blacks against whites and the ruin of the colony . . . . . . . . . . . .

\section{CHAPTER IV}

\section{Audubon's Birth, Nationality, and Parentage}

Les Cayes-Audubon's French creole mother-His early names-Discovery of the Sanson bill with the only record of his birth-Medical practice of an early day-Birth of Muguet, Audubon's sisterFougère and Muguet taken to France-Audubon's adoption and baptism-His assumed name-Dual personality in legal documents -Source of published errors-Autobiographic records-Rise of enigma and tradition-The Marigny myth . . . . . . 52

\section{CHAPTER V}

\section{Lieutenant Audubon as Revolutionist}

Background of Audubon's youth-Nantes in Revolution-Revolt in La Vendée-Siege of Nantes-Reign of terror under Carrier-Plague robbing the guillotine-Flight of the population-Execution of Charette-The Chouan raid-Citizen Audubon's service-He reenters the navy and takes a prize from the English-His subsequent naval career-His losses in Santo Domingo-His service and rank-Retires on a pension-His death-His character and appearance

\section{CHAPTER VI}

\section{School Days in France}

Molding of Audubon's character-Factor of environment-Turning failure into success-An indulgent step-mother-The truant-His love of nature-Early drawings and discipline-Experience at Rochefort-Baptized in the Roman Catholic Church . . . . . 9

\section{CHAPTER VII}

\section{First Visit to the United States, and Life at "Mill Grove"}

Audubon is sent to the United States to learn English and enter trade -Taken ill-Befriended by the Quakers-Settles at "Mill Grove" 
farm--Its history and attractions-Studies of American birds begun-Engagement to Lucy Bakewell-Sports and festivities . . 98

\section{CHAPTER VIII}

\section{Dacosta and the "Mill Grove" Mine}

Advent of a new agent at "Mill Grove"-Dacosta becomes guardian to young Audubon and exploits a neglected lead mine on the farm - Correspondence of Lieutenant Audubon and Dacosta-Quarrel with Dacosta-Audubon's return to France . . . . . . 1

\section{CHAPTER IX}

\section{Audubon's Last Visit to his Home in France}

Life at Couëron-Friendship of D'Orbigny-Drawings of French birds -D'Orbigny's troubles-Marriage of Rosa Audubon-The du Puigaudeaus-Partnership with Ferdinand Rozier-Their Articles of Association-They sail from Nantes, are overhauled by British privateers, but land safely at New York-Settle at "Mill Grove" . 127

\section{CHAPTER $\mathrm{X}$}

\section{"La Gerbetière" of Iesterday and Today}

Home of Audubon's youth at Couëron-Its situation on the LoireHistory of the villa and commune-Changes of a century

\section{CHAPTER XI}

First Ventures in Business at New York, and Sequel to THE "Mill Grove" MiNe

Audubon and Rozier at "Mill Grove"-Their partnership rules-Attempts to form a mining company lead to disappointment-Decision to sell their remaining interests in "Mill Grove" to DacostaDivision of the property and legal entanglements-Audubon as a clerk in New York-Business correspondence and letters to his father-Later history of the lead mine and Dacosta-Audubon continues his drawings in New York and works for Dr. Mitchell's Museum-Forsakes the counting-room for the fields-Personal sketch . 


\section{CHAPTER XII}

\section{Early Drawings in France and America}

Child and man-His ideals, perseverance and progress-Study under David at Paris-David's pupils and studios-David at Nantes arouses the enthusiasm of its citizens-His part in the Revolution - His art and influence over Audubon-Audubon's drawings of French birds-Story of the Edward Harris collection-The Birds of America in the bud-Audubon's originality, style, methods, and mastery of materials and technique-His problem and how he solved it-His artistic defects . . . . . . . . . 173

\section{CHAPTER XIII}

\section{Audubon's Marriage and Settlement in the West}

Audubon and Rozier decide to start a pioneer store at Louisville, Kentucky-Their purchase of goods in New York-"Westward Ho" with Rozier-Rozier's diary of the journey-An unfortunate investment in indigo-Effect of the Embargo Act-Marriage to Lucy Bakewell-Return to Louisville-Life on the Ohio-Depression of trade-William Bakewell's assistance-Audubon's eldest son born at the "Indian Queen"-The Bakewells-Life at Louisville . 186

\section{CHAPTER XIV}

\section{A Meeting of Rivals, and Sketch of Another Pioneer}

Alexander Wilson and his American Omithology-His canvassing tour of 1810 -His retort to a Solomon of the bench-Descriptions of Pittsburgh, Cincinnati and Louisville-Meeting with AudubonJourney to New Orleans-Youth in Scotland-Weaver, itinerant peddler, poet and socialist-Sent to jail for libel-Emigrates to the United States-Finally settles as a school teacher near Philadelphia-His friendships with Bartram and Lawson-Disappointments in love-Early studies of American birds-His drawings, thrift, talents and genius-Publication of his Ornithology-His travels, discouragements and success-His premature death-Conflicting accounts of the visit to Audubon given by the two naturalists-Rivalry between the friends of Wilson, dead, and those of Audubon, living-The controversy which followed-An evasive "Flycatcher"-Singular history of the Mississippi Kite plate . . 20 \& 


\section{CHAPTER XV}

\section{Experiments in Trade on the Frontier}

The Ohio a hundred years ago-Hardships of the pioneer traderAudubon's long journeys by overland trail or river to buy goodsThe "ark" and keelboat-Chief pleasures of the naturalist at Louisville-The partners move their goods by flatboat to Henderson, Kentucky, and then to Ste. Geneviève (Missouri)-Held up by the ice-Adventures with the Indians-Mississippi in flood-Camp at the Great Bend-Abundance of game-Breaking up of the iceSettle at Ste. Geneviève-The partnership dissolved-Audubon's return to Henderson-Rozier's successful career-His old store at Ste. Geneviève .

\section{CHAPTER XVI}

\section{Audubon's Mill and Final Reverses in Business}

Dr. Rankin's "Meadow Brook Farm"-Birth of John Woodhouse Audubon-The Audubon-Bakewell partnership-Meeting with NolteFailure of the commission business-Visit to Rozier-Storekeeping at Henderson-Purchases of land-Habits of frontier tradesmen -Steamboats on the Ohio-Popular pastimes-Audubon-BakewellPears partnership-Their famous steam mill-Mechanical and financial troubles-Business reorganization-Bankruptcy general-Failure of the mill-Personal encounter-Audubon goes to jail for debt

\section{CHAPTER XVII}

The Enigma of Audubon's Life and the History of His Family in France

Death of Lieutenant Audubon-Contest over his will-Disposition of his estate-The fictitious $\$ 17,000$ - Unsettled claims of Formon and Ross-Illusions of biographers-Gabriel Loyen du PuigaudeauAudubon's relations with the family in France broken-Death of the naturalist's stepmother-The du Puigaudeaus-Sources of "enigma."

\section{CHAPTER XVIII}

\section{Early Episodes of Western Life}

Methods of composition- "A Wild Horse"-Henderson to Philadelphia in 1811-Recorłs of Audubon and Nolte, fellow travelers, com- 
pared-The great earthquakes-The hurricane-The outlaw-Characterization of Daniel Boone-Desperate plight on the prairieRegulator law in action-Frontier necessities-The ax married to the grindstone

\section{CHAPTER XIX}

\section{Audubon and Rafinesque}

The "Eccentric Naturalist" at Henderson-Bats and new species-The demolished violin-“M. de T.": Constantine Samuel Rafinesque (Schmaltz) - His precocity, linguistic acquirements and peripatetic habits-First visit to America and botanical studies-Residence in Sicily, and fortune made in the drug trade-Association with Swainson-Marriage and embitterment-His second journey to America ends in shipwreck-Befriended-Descends Ohio in a flatboat-Visit with Audubon, who gives him many strange "new species"-Cost to zoölogy-His unique work on Ohio fishes-Professorship in Transylvania University-Quarrel with its president and trustees-Return to Philadelphia-His ardent love of nature; his writings, and fatal versatility-His singular will-His sad end and the ruthless disposition of his estate . . . . . . . .

\section{CHAP'TER XX}

\section{Audubon's Eneid, 1819-1824: Wanderings Through the West and South}

Pivotal period in Audubon's career-His spur and balance wheelResort to portraiture-Taxidermist in the Western Museum-Settles in Cincinnati-History of his relations with Dr. Drake-Decides to make his avocation his business-Journey down the Ohio and Mississippi with Mason and Cummings-Experiences of travel without a cent of capital-Life in New Orleans-Vanderlyn's recommendation-Original drawings-Chance meeting with Mrs. Pirrie and engagement as tutor at "Oakley"-Enchantments of West Feliciana-"My lovely Miss Pirrie"-The jealous doctor-Famous drawing of the rattlesnake-Leaves St. Francisville and is adrift again in New Orleans-Obtains pupils in drawing and is joined by his family-Impoverished, moves to Natchez, and Mrs. Audubon becomes a governess-Injuries to his drawings-The labors of years destroyed by rats-Teaching in Tennessee-Parting with Mason-First lessons in oils-Mrs. Audubon's school at "Beechwoods"-Painting tour fails-Stricken at Natchez-At the Percys' plantation-Walk to Louisville-Settles at Shippingport . • . 301 


\section{CHAPTER XXI}

\section{Début as a Naturalist}

Makes his bow at Philadelphia--Is greeted with plaudits and cold water -Friendship of Harlan, Sully, Bonaparte and Harris-Hostility of Ord, Lawson and other friends of Alexander Wilson-A meeting of academicians-Visit to "Mill Grove"-Exhibits drawings in New York and becomes a member of the Lyceum-At the Falls of Niagara-In a gale on Lake Erie-Episode at Meadville-Walk to Pittsburgh-Tour of Lakes Ontario and Champlain-Decides to take his drawings to Europe-Descends the Ohio in a skiffStranded at Cincinnati-Teaching at St. Francisville . . . . 327

\section{CHAPTER XXII}

\section{To Europe and Success}

Audubon sails from New Orleans-Life at sea-Liverpool-The Rathbones-Exhibition of drawings an immediate success-Personal appearance-Painting habits resumed-His pictures and methodsManchester visited-Plans for publication-The Birds of America -Welcome at Edinburgh-Lizars engraves the Turkey Cock-In the rôle of society's lion-His exhibition described by a French critic-Honors of science and the arts-Contributions to journals excite criticism-Aristocratic patrons-Visit to Scott-The Wild Pigeon and the rattlesnake-Letter to his wife-Prospectus-Journey to London.

\section{CHAPTER XXIII}

\section{Audubon in London}

Impressions of the metropolis-A trunk full of letters-Friendship of Children-Sir Thomas Lawrence-Lizars stops work-A family of artists-Robert Havell, Junior-The Birds of America fly to London-The Zoölogical Gallery-Crisis in the naturalist's affairsRoyal patronage-Interview with Gallatin-Interesting the QueenDesertion of patrons-Painting to independence-Personal habits and tastes-Enters the Linnæan Society-The white-headed Eagle -Visit to the great universities-Declines to write for magazines -Audubon-Swainson correspondence-"Highfield Hall" near Tyttenhanger-In Paris with Swainson-Glimpses of Cuvier-His report on The Birds of America-Patronage of the French Government and the Duke of Orleans-Bonayarte the naturalist . . . 377 


\section{CHAPTER XXIV}

\section{First Visit to America in Search of New Birds}

Settles for a time in Camden-Paints in a fisherman's cottage by the sea-With the lumbermen in the Great Pine Woods-Work doneVisits his sons-Joins his wife at St. Francisville-Record of journey south-Life at "Beechgrove"-Mrs. Audubon retires from teaching-Their plans to return to England-Meeting with President Jackson and Edward Everett . . . . . . . . 420

\section{CHAPTER XXV}

\section{Audubon's Letterpress and Its Rivals}

Settlement in London-Starts on canvassing tour with his wifeChange of plans-In Edinburgh-Discovery of MacGillivray-His hand in the Ornithological Biography-Rival editions of Wilson and Bonaparte-Brown's extraordinary Atlas-Reception of the Biography-Joseph Bartholomew Kidd and the Ornithological Gallery-In London again . . . . . . . . . . . 437 


\section{CONTENTS OF VOLUME II}

\section{CHAPTER XXVI}

Explorations in Florida and the South Atrantic

Obituary published in London on day of his arrival in New York-Assistance from the Government-John Bachman becomes his friend -Winter in Charleston-His folios as gifts-To Florida with two assistants-Letters to Featherstonhaugh-St. Augustine-Misadventures in the mud of East Florida-Audubon on Florida's future-At the sources of the St. John's-Aboard the MarionReturn from Key West-A merchant of Savannah-Disbanding of party at Charleston

\section{CHAPTER XXVII}

Eastern Visit and Explorations in the North Atlantic

Bachman's success as a canvasser-Boston visit-Journey to PortlandAscent of the St. John-Return overland-Victor Audubon becomes his father's agent-Winter in Boston-The Golden EagleStricken with illness-Expedition to Labrador planned-American support-Sails from Eastport with five assistants-Discoveries and adventures on the Labrador-Safe return-Another winter in Charleston-Sued for old debts-Experience with vultures-Advice and instruction to a son--Working habits-Return to England .

\section{CHAPTER XXVIII}

\section{Thorns on the Rose}

Contributions to magazines-Attacked in Philadelphia-Statement to Sully-The rattlesnake episode-Behavior of a Philadelphia editor -Mistaken identity in account of the reptile-Lesson of the serpent's tooth-Audubon's long lost lily rediscovered-"Nosarians and Anti-Nosarians"-Bachman and Audubon on vultures-Aim of the critics-Authorship in the Biography-His most persistent heckler-Pitfall of analogy . 


\section{xxvi AUDUBON THE NATURALIST}

\section{CHAPTER XXIX}

\section{Sidelights on Audubon and His Contemporaries}

What was a Quinarian?-Controversy over the authorship of the Ornithological Biography-Audubon's quaint proposal-Swainson's reply-Friendship suffers a check-Species-mongers-Hitting at one over the shoulders of another-Swainson as a biographer-His career-Bonaparte's grievance-A fortune in ornithology-Labors of John Gould and his relations with Audubon-The freemasonry of naturalists .

\section{CHAPTER XXX}

\section{Audubon and MacGillivray}

In London once more-MacGillivray's assistance continued-Return to Edinburgh-MacGillivray's character and accomplishments-Audubon's acknowledgments-Tributes of "Christopher North"-Results of overwork-Fusillades from "Walton Hall"--Progress of the large plates . . . . . . . . . . . . . 125

\section{CHAPTER XXXI}

\section{Third American Tour, 1836-1837}

In New York harbor-Collections from the Far West-Audubon's efforts to secure them-Return to Boston-Friendship of Daniel Webster-Renewed efforts to obtain the Nuttall-Townsend collections-Expedition to the west coast of Florida-Deferred governmental aid-Another winter with Bachman-Overland journey to New Orleans-On board the Crusader-Mistaken for pirates-With Harris and his son explores the Gulf coast--The Republic of Texas - Visit to its capital and president-Meeting in Charleston-Marriage of his son-Their return to England . . . . . . 146

\section{CHAPTER XXXII}

\section{Audubon's Greatest Triumph}

Extension of his work-Financial panic and revolt of patrons-New western collections-His "book of Nature" completed-Work on the letterpress in Edinburgh-Vacation in the Highlands-Commissions 
to Harris-Parting address to the reader-Dissolution of the Havell engraving establishment-The residuum of The Birds of America-Robert Havell, engraver, and his family-Lizars' first edition and the Havell reissues of plates-Brief manual for collectors-Appreciations-Total edition of The Birds of AmericaPast and oresent prices-The Rothschild incident .

\section{CHAPTER XXXIII}

\section{New Enter prises and Life at "Minnie's Land"}

Settlement in New York-The Birds in miniature, and work on the Quadrupeds-Marriage of Victor Audubon-Coöperation of Bachman in the Quadrupeds secured-Prospectuses-History of the octavo edition of the Birds-Baird's enthusiasm and efficient aidParkman's Wren-Baird's visit to Audubon in New York-"Look out for Martens," and wildcats-New home on the Hudson-Godwin's pilgrimage to "Minnie's Land" in 184

\section{CHAPTER XXXIV}

\section{Expedition to the Upper Missouri}

Ambitions at fifty-seven-Plans his last expedition in the rôle of naturalist-Credentials from public men-Canvassing tour in Canada described-Baird's plans to accompany Audubon west frustratedWestern expedition begun-Ascent of the Missouri and Yellowstone -Discoveries of new birds-A wilderness that howls - Buffalo hunting-Passing of the great herds-Return from Fort Union-Incident on the canal boat-Completion of the octavo edition of the Birds .

\section{CHAPTER XXXV}

\section{Final Work Days}

Painting the Quadrupeds-Assistance of Bachman and Audubon's sons - Copper plates of the Birds go through the fire in New YorkAudubon a spectator at the ruins-Bachman's ultimatum-Success of the illustrations of the Quadrupeds-Bachman's letterpressRecommendation of Baird-J. W. Audubon in London-Bachman's assistants-His life and labors-Decline of Audubon's powers-Dr. Brewer's visit-Audubon's last letters-His death at "Minnie's Land" . 


\section{CHAPTER XXXVI}

\section{Afterword: Audubon's Family in America}

Bachman completes his text on the Quadrupeds-Victor Audubon's success in canvassing-John Woodhouse Audubon's family-New houses at "Minnie's Land"-Second octavo edition of the BirdsVictor Audubon's illness and death-Attempt to reissue The Birds of America in America-The residual stock of this imperfect edition-Death of John Woodhouse Audubon-His career and work as an artist and field collector-Mrs. Audubon resumes her old vocation-Fate of "Minnie's Land"-Death of Mrs. Audubon-Her share in her husband's fame-Story written on Audubon's original drawings - Fate of the original copper plates of the Birds-A boy comes to the rescue-"Minnie's Land" today-The "Cave"-A real "Audubon Park"

\section{APPENDIX I}

\section{Original Documents}

1. Copy of the original bill rendered by Doctor Sanson, physician at Les Cayes, Santo Domingo, to Jean Audubon, containing the only existing record of the birth of his son, Jean Jacques Fougère Audubon, on April 26, 1785; Les Cayes, December 29, 1783October 19, 1785 .

1a. Translation of the Sanson Bill
2. Copy of the Act of Adoption of Fougère (John James Audubon) and Muguet (Rosa Audubon), Nantes, March 7, 1794 • 328

3. Copy of the Act of Baptism of Jean Jacques Fougère Audubon, Nantes, October 23,1800 .

4. Copy of a bill of sale of Negroes rendered by Monsieur Ollivier to Monsieur Audubon, Les Cayes, Santo Domingo, 1785 . . 329

. Statement of Accounts of Messrs. Audubon, Lacroix, Formon \& Jacques in the purchase of Negroes from M. Th. Johnston, Les Cayes, Santo Domingo, 1785 . • . • • . • • . 330

6. Copy of bill of sale of Negroes to Monsieur Audubon, and a statement of his account with Messrs. Lucas Brothers \& Constant, Les Cayes, Santo Domingo, August 7, 1785-June 9, 1788334

7. Accounts of William Bakewell of "Fatland Ford" as protégé of his future son-in-law, and as attorney or agent for Audubon \& Rozier, giving certain exact indications of the naturalist's early movements and personal relations, before and after finally leaving "Mill Grove," January 4, 1805-April 9, 1810 . .

8. Concerning a Power of Attorney issued by Lieutenant Audubon
and Anne Moynet Audubon to Ferdinand Rozier and John Au- 
dubon, the Younger, at Couëron, France, in 1805; parts in French translated by a Philadelphia notary; signatures of original document authenticated by the Mayor of Couëron, October 21, 1805; his attest of the legality of Anne Moynet Audubon's signature at Couëron, October 27, 1805; authentication of the signature of the Mayor of Couëron by the Subprefect of Savenay, November 27, 1805; attest of the Subprefect's signature by the Prefect .

9. Articles of Association of Jean Audubon and Ferdinand Rozier to govern their partnership in business; drawn up at Nantes, March 23, 1806 . . . . . . . . . . .

9a. Translation of the Articles of Association of Jean Audubon and Ferdinand Rozier

10. Power of Attorney issued by Lieutenant Jean Audubon, Anne Moynet Audubon and Claude François Rozier, to their respective sons, Jean Audubon and Ferdinand Rozier, at Nantes, France, April 4, 1806, eight days before the latter embarked to America to enter upon their partnership in business .

10a. Translation of the Power of Attorney issued by Jean Audubon, Anne Moynet Audubon, and Claude François Rozier to Jean Audubon and Ferdinand Rozier, April 4, 1806

11. Account current of John Audubon and Ferdinand Rozier with the estate of Benjamin Bakewell, late commission merchant in New York, showing their dealings and standing with this house during the first sixteen months of their business experience in the West. Covers the period August 1, 1807, to December 13, 1808 . 354

11a. Final Account of Francis Dacosta, rendered July 25, 1807, to Lieutenant Jean Audubon, his partner in the unfortunate mining enterprise at "Mill Grove"; later contested and settled by arbitration : • • • • • • •

12. Quit Claim or Release given by John James Audubon to Ferdinand Rozier on the Dissolution of their Partnership in Business, at Sainte Geneviève, Upper Louisiana (Missouri), April 6, 1811359

13. Copy of a portion of the first Will of Lieutenant Jean Audubon, Couëron, May 20, 1812 . . . . . . . . 360

14. Copy of the second and last Will of Lieutenant Jean Audubon,

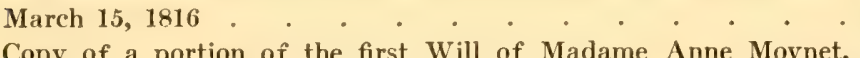

15. Copy of a portion of the first Will of Madame Anne Moynet, wife of Lieutenant Audubon, December 4, 1814 • • . . 363

16. Copy of a portion of the second Will of Madame Jean Audubon, May 10, 1816 . . . . . . . . . .

17. Copy of the third Will, "No. 169, of Madame Anne Moynet, widow of M. Jean Audubon, living at his house called "La Gerbetière," and situated near the village of Port-Launay, not far from Couëron," December 26, 1819 . . . • . . .

18. Copy of a portion of the fourth and last will of Madame Jean Audubon, living at the house of "The Turtle Doves" ("Les Tourterelles"), at Couëron, July 16, 1821 . . . . . . . 367 
19. Notice of the death of Lieutenant Jean Audubon, from the official registry of Nantes, Nantes, February 19, $1818 \quad$ • $\quad 369$

20. Letter of Lieutenant Jean Audubon to Francis Dacosta, his American agent and attorney, relating to the conduct of his son, and to the lead mine at "Mill Grove" farm, transliterated from photographic copy of duplicate (Letter No.4) in Jean Audubon's letter-book. Nantes, March 10, 1805 . . . . . 370

21. Letters of John James Audubon to Claude François Rozier, father, and to Ferdinand Rozier, son, immediately preceding and following his active partnership in business with the latter, 1807 and 1812

\section{APPENDIX II}

\section{Audubon's Early Dated Drawings Made in France and America}

Drawings now in the collections of Mr. Joseph Y. Jeanes of Philadelphia, and formerly belonging to Mr. Edward Harris, of Moorestown, New Jersey; of Mr. John E. Thayer, Lancaster, Massachusetts, and of Harvard University . . . . . . . . 375

\section{APPENDIX III}

\section{"The Birds of America"}

1. Final Lists of Subscribers to The Birds of America, folio edition, as published by Audubon in 1839 . . . . . 380

2. Prospectus of The Birds of America, as issued in 1828, when ten Numbers of the original folio were engraved . . . . 386

3. Prospectus of the Second (partial) Edition of The Birds of America, issued by John Woodhouse Audubon, through Messrs. Trubner \& Company, London, 1859 . . . . . . . 389

\section{APPENDIX IV}

Authentic Likenesses of Jean Jacques Fougère Audubon 392

\section{APPENDIX V \\ Bibliography}

Containing a fully annotated list of Audubon's writings, biographies, criticism, and Auduboniana . . . . . . . . 401 


\section{ILLUSTRATIONS IN VOLUME I}

Audubon. After a photograph of a cast of the intaglio cut by John C. King in 1844. Embossed medallion. . . . . . Cover

Audubon. After the engraving by C. Turner, A.R.A., of the miniature on ivory painted by Frederick Cruikshank about 1831; "Iondon. Published Jan. 12, 1835, for the Proprietor [supposed to have been the engraver, but may have been Audubon or Havell], by Robert Havell, Printseller, 77, Oxford Street." Photogravure . . . . . . . . . Frontispiece

Statue of Audubon by Edward Virginius Valentine in Audubon Park, New Orleans . . . . . . . . Facing

The Audubon Monument in Trinity Cemetery, New York, on Children's Day, June, 1915 . . . . . . . Facing

Les Cayes, Haiti: the wharf and postoffice . . . . Facing 40

Les Cayes, Haiti: the market and Church of Sacré Cour . Facing 40

First page of the bill rendered by Dr. Sanson, of Les Cayes, Santo Domingo, to Jean Audubon for medical services from December 29, 1783, to October 19, 1785 . . . . . . Facing

Second page of the Sanson bill, bearing, in the entry for April 26, 1785, the only record known to exist of the date of Audubon's birth . . . . . . . . . . Facing

Third page of the Sanson bill, signed as accepted by Jean Audubon, October 12, 1786, and receipted by the doctor, when paid, June 7, 1787 . . . . . . . . Facing

Audubon's signature at various periods. From early drawings, legal

Lieutenant Jean Audubon and Anne Moynet Audubon. After portraits painted between 1801 and 1806, now at Couëron . Facing

Jean Audubon. After a portrait painted by the American artist Polk, at Philadelphia, about 1789 . . . . . Facing

Jean Audubon's signature. From a report to the Directory of his Department, when acting as Civil Commissioner, January to September, 1793

Certificate of Service which Lieutenant Audubon received upon his discharge from the French Navy, February 26, 1801 


\section{xxxii AUDUBON THE NATURALIST}

"Mill Grove" in 1835 (about). After a water-color painting by Charles

Wetherill

"Mill Grove," Audubon, Pennsylvania, as it appears to-day . Facing 102

"Mill Grove" farmhouse, west front, as it appears to-day . Facing 110

"Fatland Ford," Audubon, Pennsylvania, the girlhood home of Lucy Bakewell Audubon . . . . . . . . Facing 110

Early drawings of French birds, 1805, hitherto unpublished: the male Reed Bunting ("Sedge Sparrow"), and the male Redstart Facing 128

Receipt given by Captain Sammis of the Polly to Audubon and Ferdi nand Rozier for their passage money from Nantes to New York, May 28, 1806

"La Gerbetière," Jean Audubon's country villa at Couëron, France, and the naturalist's boyhood home . . . . . . Facing 136

"La Gerbetière" and Couëron, as seen from the highest point in the commune, windmill towers on the ridge overlooking Port Launay, on the Loire . . . . . . . . . Facing 142

"La Gerbetière," as seen when approached from Couëron village by the road to Port Launay

Facing 142

Port Launay on the Loire . . . . . . . Facing 142

Beginning of the "Articles of Association" of John James Audubon and Ferdinand Rozier, signed at Nantes, March 23, $1806 \quad$ Facing 146

First page of a power of attorney granted by Jean Audubon, Anne Moynet Audubon and Claude François Rozier to John James Audubon and Ferdinand Rozier, Nantes, April 4, 1806 . Facing 152

Signatures of Jean Audubon, Anne Moynet Audubon, Dr. Chapelain and Dr. Charles d'Orbigny to a power of attorney granted to John James Audubon and Ferdinand Rozier, Couëron, November 20, 1806

Facing 153

Early drawings of French birds, 1805, hitherto unpublished: the Euro pean Crow, with detail of head of the Rook, and the White Wagtail

Facing 174

Early drawing in crayon point of the groundhog, 1805, hitherto unpublished . . . . . . . . • . Facing 182

Water-color drawing of a young raccoon, 1841 . . . Facing 182

Alexander Wilson . . . . . . . . . Facing 212

William Bartram . . . . . . . . . Facing 212

The "twin" Mississippi Kites of Wilson and Audubon, the similarity of which inspired charges of misappropriation against Audubon

Facing 228 
Audubon's signature to the release given to Ferdinand Rozier on the dissolution of their partnership in 1811 . . . . . 242

Ferdinand Rozier in his eighty-fifth year (186:) • • . Facing 246

Rozier's oid store at Ste. Geneviève, Kentucky • . Facing 246

Letter of Audubon to Ferdinand Rozier, signed "Audubon \& Bakewell," and dated October 19, 1813, during the first partnership under this style . . . . . . . . . . . 251

Audubon's Mill at Henderson, Kentucky, since destroyed, as seen from the bank of the Ohio River . . . . . Facing 254

An old street in the Couëron of today . . . . . Facing 264

"Les Tourterelles," Couëron, final home of Anne Moynet Audubon, and the resting-place of exact records of the naturalist's birth and early life . . . . . . . . Facing 264

Early drawings of American birds, 1808-9, hitherto unpublished: the Belted Kingfisher and the Wild Pigeon . . . . Facing 292

Bayou Sara Landing, West Feliciana Parish, Louisiana, at the junction of Bayou Sara and the Mississippi River . . Facing 314

Scene on Bayou Sara Creek, Audubon's hunting ground in 1821 . . . . . . . . . Facing 314

Road leading from Bayou Sara Landing to the village of St. Francisville, West Feliciana Parish . . . . . . Facing 318

"Oakley," the James Pirrie plantation house near St. Francisville, where Audubon made some of his famous drawings while acting as a tutor in 1821 . . . . . . . . Facing 318

An early letter of Audubon to Edward Harris, written at Philadelphia, July 14, 1824 . . . . . . . . . . 332

Note of Dr. Samuel Latham Mitchell, written hurriedly in pencil, recommending Audubon to his friend, Dr. Barnes, August 4, 1824

Crayon portrait of Miss Jennett Benedict, an example of Audubon's itinerant portraiture. After the original drawn by Audubon at Meadville, Pennsylvania, in 1824 . . . . . Facing 342

Miss Eliza Pirrie, Audubon's pupil at "Oakley" in 1821. After an oil portrait . . . . . . . . Facing 342

Early drawing of the "Frog-eater," Cooper's Hawk, 1810, hitherto unpublished . . . . . . . . Facing 348

Pencil sketch of a "Shark, 7 feet long, off Cuba," from Audubon's Journal of his voyage to England in 1826 . . . Facing 348

First page of Audubon's Journal of his voyage from New Orleans to Liverpool in 1826 
Cock Turkey, The Birds of America, Plate I. After the original engraving by $W$. H. Lizars, retouched by Robert Havell. Color . • . . • . . • • . • Facing 358

Title page of the original edition of The Birds of America, Volume II, $1831-183$

The Prothonotary Warbler plates, The Birds of America, Plate XI, bearing the legends of the engravers, W. H. Lizars and Robert Havell, Jr., but identical in every other detail of engraving

Facing 384

Reverse of panels of Robert Havell's advertising folder reproduced on facing insert . . . . . . . . . . . . . 386

Outside engraved panels of an advertising folder issued by Robert Havell about 1834. After the only original copy known to exist . . . . . . . . . Facing 386

Inside engraved panels of Robert Havell's advertising folder, showing the interior of the "Zoölogical Gallery," 77 Oxford Street Facing 387

Reverse of panels of Robert Havell's advertising folder, reproduced on facing insert.

Title page of Audubon's Prospectus of The Birds of America for 1831

English Pheasants surprised by a Spanish Dog. After a painting by Audubon in the American Museum of Natural History . Facing 394

Letter of William Swainson to Audubon, May, 1828 • • • . 402

Audubon. After an oil portrait, hitherto unpublished, painted in 1828 by C. W. Parker, an American artist . . . Facing 412

Part of letter of Charles Lucien Bonaparte to Audubon, January 10,1829

Mrs. Dickie's "Boarding Residence," 26 George Street, Edinburgh, where Audubon painted and wrote in 1826-27, and in 183031

The Academy of Natural Sciences, Philadelphia. After an old print . . . . . . • . . Facing 438

Title page of the Ornithological Biography, Volume I • • • . 441 


\section{ILLUSTRATIONS IN VOLUME II}

Audubon. After a portrait by George P. A. Healy, 1838. Photogravure

"Beechgrove," William Garrett Johnson's plantation house near St. Francisville, West Feliciana Parish, Louisiana, where Mrs. Audubon lived and taught from 1827 to 1829 . . . . Facing 6

John Bachman's house in Charleston, South Carolina . . Facing 6

Early drawing in water color of the Carolina Parrot on branch of the hickory, 1811, hitherto unpublished . . . . . Facing

John Bachman at thirty-two. After an engraving by Charles C. Wright of a portrait by A. Fisher . . . . . . . Facing

Robert Havell at eighty-five. After a photograph taken shortly before

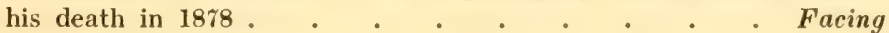

Letter of Dr. George Parkman to Audubon, May 25, $1833 \quad$ * . 43

Pileated Woodpeckers on the "Raccoon Grape," The Birds of America, Plate CXI. After the original engraving by Robert Havell, 1831. Color

Facing 46

Letter of Robert Havell to Audubon, June 15, 1833 . _ . . . . 51

John George Children . . . . . . . . . Facing 64

Edward Harris . . . . . . . . . . Facing 64

John Bachman

George Ord .

Samuel Latham Mitchell

Charles Waterton . . . . . . . . . . Facing 72

Dr. Thomas Cooper, President of South Carolina College. After a contemporary silhouette . . . . . . . . . .

Vindication of Audubon's representation of the fangs of the southern rattlesnake as recurved at their tips. Detail from The Birds of America, Plate XXI, and photograph of the skull of a recent Florida specimen . . . . . . . . . Facing

Bluebircis on a stalk of the "great Mullein," The Birds of America, Plate CXIII. After the original engraving by Robert Havell, 1831. Color 


\section{xxxvi AUDUBON THE NATURALIST}

William Swainson

Thomas Nuttall .

Charles Lucien Bonaparte.

Facing 118

Constantine Samuel Rafinesque

Facing 118

Facing 118

Audubon. After an engraving by H. B. Hall of a portrait painted by

Henry Inman in 1833 . • . . . . . . Facing 126

Letter of William MacGillivray to Audubon, October 22, 1834 • 131

Part of the original draft of Audubon's manuscript for the Introduc-

tion to Volume II of the Ornithological Biography, giving list of names of persons to whom Audubon carried credentials on his first visit to London in 1827 . . . . . . . Facing

Audubon's inscription in a copy of the Ornithological Biography, which

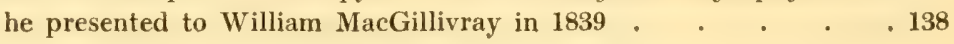

Early drawings of American birds, 1807-12, hitherto unpublished: the Whippoorwill and the American Robin, with details . . Facing 144

Bust of Audubon by William Couper, in front and profile views. After the original in the American Museum of Natural History, New York

Life mask of Audubon, hitherto unpublished, in front and profile views. After the original made by Robert Havell in London, now in possession of the Museum of Comparative Zoölogy of Harvard Universtty . . . . . . . . . . Facing

Canvas-backed Ducks, with distant view of the city of Baitimore, Maryland, The Birds of America, Plate CCCI. After the original engraving by Robert Havell, 1836. Color . • • . Facing 196

Victor Gifford Audubon . . . . . . . . Facing 210

John Woodhouse Audubon . . . . . . . . Facing 210

Title page of the paper covers in which parts of the first American (octavo) edition of The Birds of America were originally issued . 213

Audubon. After a portrait painted by John Woodhouse and Victor Gifford Audubon about 1841 . . . . . . Facing 226

"Minnie's Land," Audubon's home on the Hudson River, as it appeared in 1865. After a lithograph in Valentine's Manual . . Facing 236

"Minnie's Land," as it appeared in 1917 from the river front, pocketed by the retaining wall of Riverside Drive . . Facing 236

Audubon, with gun, horse, and dog. After a painting by John Woodhouse Audubon about 1841 . . . . . Facing 244

Letter of Edward Harris to Audubon, January 31, 1843 . . . 251 
Drawings for The Viviparous Quadrupeds cf North America: the American or Canada porcupine and rabbits. After the originals in water color in the American Museum of Natural History, New York .

Title page of Volume I of the English edition of the text of The Viviparous Quadrupeds of North America . . . . . . . . 275

John W. Audubon's inscription in a copy of Volume I of the text of the Quadrupeds (English edition), presented to John Edward Gray 280

Audubon. After an engraving by Nordheim of a daguerreotype possibly earlier than 1849 . . . . . . . . Facing 280

Audubon. After his last portrait, a daguerreotype made in New York about 1850 . . . . . . . . Facing 280

Letter of John Bachman to George Oates, November 7, 1846 282

Audubon's last (?) letter to Edward Harris, February 22, 1847 • . 287

House formerly belonging to Victor Gifford Audubon, east front, as it appears to-day . . . . . . . . Facing 294

House formerly belonging to John Woodhouse Audubon, south front, as it appears to-day . . . . . . . . Facing 294

Lucy Bakewell Audubon. After a miniature painted by Frederick Cruikshank in London, about 1831 . . . . . Facing 304

Lucy Bakewell Audubon. After an unpublished photograph of 1871 . 



\section{CHRONOLOGY}

\section{5}

A pril 26.-Fougère, Jean Rabin, or Jean Jacques Fougère Audubon, born at Les Cayes, Santo Domingo, now Haiti.

\section{9}

Fougère, at four years, and Muguet, his sister by adoption, at two, are taken by their father to the United States, and thence to France.

\section{4}

March 7 (17 ventose, an 2).-Fougère, when nine years old, and Muguet at six, are legally adopted as the children of Jean Audubon and Anne Moynet, his wife.

\section{0}

October 23 (1 brumaire, an 9).-Baptized, Jean Jacques Fougère, at Nantes, when in his sixteenth year.

$$
\text { 1802-1803 }
$$

Studies drawing for a brief period under Jacques Louis David, at Paris.

\section{3}

First return to America, at eighteen, to learn English and enter trade: settles at "Mill Grove" farm, near Philadelphia, where he spends a vear and begins his studies of American birds. 


\section{4}

December 15.-Half-interest in "Mill Grove" acquired by Francis Dacosta, who begins to exploit its lead mine; he also acts as guardian to young Audubon, who becomes engaged to Lucy Green Bakewell; quarrel with Dacosta follows.

\section{5}

January 12-15 (?).-Walks to New York, where Benjamin Bakewell supplies him with passage money to France. January 18 (about).-Sails on the Hope for Nantes, and arrives about March 18 .

A year spent at "La Gerbetière," in Couëron, where he hunts birds with D'Orbigny and makes many drawings, and at Nantes, where plans are made for his return, with Ferdinand Rozier, to America.

\section{6}

Enters the French navy at this time, or earlier, but soon withdraws.

March 23.-A business partnership is arranged with Ferdinand

Rozier, and Articles of Association are signed at Nantes. A pril 12.- Sails with Rozier on the Polly, Captain Sammis, and lands in New York on May 26.

They settle at "Mill Grove" farm, where they remain less than four months, meanwhile making unsuccessful attempts to operate the lead mine on the property.

September 15.-Remaining half interest in "Mill Grove" farm and mine acquired by Francis Dacosta \& Company, conditionally, the Audubons and Roziers holding a mortgage.

\section{6-1807}

Serves as clerk in Benjamin Bakewell's commission house in New York, but continues his studies and drawings of birds, and works for Dr. Mitchell's Museum. 


\section{7}

With Rozier decides to embark in trade in Kentucky.

August 1.--They purchase their first stock of goods in New York.

August 31.-Starts with Rozier for Louisville, where they open a pioneer store.

Their business suffers from the Embargo Act.

\section{8}

April 5.-Married to Lucy Bakewell at "Fatland Ford," her father's farm near Philadelphia, and returns with his bride to Louisville.

\section{9}

June 12.-Victor Gifford Audubon born at Gwathway's hotel, the "Indian Queen," in Louisville.

\section{0}

March--Alexander Wilson, pioneer ornithologist, visits Audubon at Louisville.

Moves down river with Rozier to Redbanks (Henderson), Kentucky.

December.-Moves with Rozier again, and is held up by ice at the mouth of the Ohio and at the Great Bend of the Mississippi, where they spend the winter.

\section{1}

Reaches Sainte Geneviève, Upper Louisiana (Missouri), in early spring.

A pril 6.-Dissolves partnership with Rozier, and returns to Henderson afoot.

Joins in a commission business with his brother-in-law, Thomas W. Bakewell.

December.-Meets Vincent Nolte when returning to Louisville from the East, and descends the Obio in his flatboat. 
The annus mirabilis in Kentucky, marked by a series of earthquakes, which begins December 16, 1811, and furnishes material for "Episodes."

Commission house of Audubon and Bakewell is opened by the latter in New Orleans, but is quickly suppressed by the war, which breaks out in June.

Spring.-Starts a retail store, on his own account, at Henderson.

November 30.- John Woodhouse Audubon, born at "Meadow Brook" farm, Dr. Adam Rankin's home near Henderson.

$$
\text { 1812-1813 }
$$

Storekeeping at Henderson, where he purchases four town lots and settles down.

\section{6}

March 16.-Enters into another partnership with Bakewell; planning to build a steam grist- and sawmill at Henderson, they lease land on the river front.

\section{7}

Thomas W. Pears joins the partnership, and the steam mill, which later became famous, is erected. (After long disuse or conversion to other purposes, "Audubon's Mill" was finally burned to the ground on March 18, 1913.)

Summer.-Receives a visit from Constantine Samuel Rafinesque, who becomes the subject of certain practical jokes, at zoölogy's future expense, and figures in a later "Episode." 
1819

After repeated change of partners, the mill enterprise fails, and Audubon goes to Louisville jail for debt; declares himself a bankrupt, and saves only his clothes, his drawings and gun. Resorts to doing crayon portraits at Shippingport and Louisville, where he is immediately successful.

\section{9-1820}

At Cincinnati, to fill an appointment as taxidermist in the Western Museum, just founded by Dr. Daniel Drake; settles with his family and works three or four months, at a salary of $\$ 125$ a month; then returns to portraits, and starts a drawing school.

\section{0}

Decides to publish his "Ornithology," and all his activities are now directed to this end.

October 12.-Leaves his family, and with Joseph R. Mason, as pupil-assistant, starts without funds on a long expedition down the Ohio and Mississippi Rivers, to New Orleans, hoping to visit Arkansas, and intending to explore the country for birds, while living by his talents: from this time keeps a regular journal and works systematically.

\section{1}

January 7.-Enters New Orleans with young Mason without enough money to pay for a night's lodging.

February 17.--Sends his wife 20 drawings, including the famous Turkey Hen, Great-footed Hawk, and White-headed Eagle.

Obtains a few drawing pupils; is recommended by John Vanderlyn and Governor Robertson, but lives from hand to mouth until June 16, when Audubon and Mason leave for Shippingport; a fellow passenger, Mrs. James Pirrie, of West Feliciana, offers Audubon a position as tutor to her daughter, and with Mason he settles on her plantation at St. Francisville, Bayou Sara, where he remains nearly five months; some of his finest drawings are made at this time. 
October 21.-Leaves abruptly and returns with Mason to New Orleans, where he again becomes a drawing teacher, and resumes his studies of birds with even greater avidity. December.-Is joined by his family, and winter finds them in dire straits.

\section{2}

March 16.-To Natchez with Mason, paying their passage by doing portraits of the captain and his wife; while on the way finds that many of his drawings have been seriously damaged by gunpowder; teaches French, drawing and dancing at Natchez, and Washington, Mississippi.

July 23.- Parts with Mason, after giving him his gun, paper and chalks, with which to work his way north.

September.-Mrs. Audubon, who was acting as governess in a family at New Orleans, joins him at Natchez, where she obtains a similar position.

Receives his first lessons in the use of oils from John Stein, itinerant portrait painter, in Natchez, at close of this year.

\section{3}

January.-Mrs. Audubon is engaged by the Percys, of West Feliciana parish, Louisiana, and starts a private school at "Beechwoods," belonging to their plantation, in St. Francisville, where she remains five years.

March.-Audubon leaves Natchez with John Stein and Victor on a painting tour of the South, but meeting with little success, they disband at New Orleans; visits his wife, and spends part of summer in teaching her pupils music and drawing.

Adrift again; both he and Victor are taken ill with fever at Natchez, but when nursed back to health by Mrs. Audubon, they return with her to "Beechwoods."

September 30.-Determined to visit Philadelphia in the interests of his "Ornithology," he sends on his drawings and goes to New Orleans for references.

October 3.- Starts with Victor for Louisville, walking part of the way. 


\section{3-1824}

Winter spent at Shippingport, where Victor becomes a clerk to his uncle, Nicholas A. Berthoud.

Paints portraits, panels on river boats, and even street signs, to earn a living.

\section{4}

To Philadelphia, to find patrons or a publisher; thwarted; is advised to take his drawings to Europe, where the engraving could be done in superior style; befriended by Charles L. Bonaparte, Edward Harris, Richard Harlan, Mr. Fairman, and Thomas Sully, who gives him free tuition in oils. August 1.-Starts for New York, with letters to Gilbert Stuart, Washington Allston, and Samuel L. Mitchell; is kindly received and made a member of the Lyceum of Natural History.

August 15.-To Albany, Rochester, Buffalo, Niagara Falls, Meadville, and Pittsburgh, taking deck passage on boats, tramping, and paying his way by crayon portraits.

September.-Leaves Pittsburgh on exploring tour of Lakes Ontario and Champlain for birds; decides on his future course.

October 24.-Returns to Pittsburgh, and descends the Ohio in a skiff ; is stranded without a cent at Cincinnati; visits Victor at Shippingport, and reaches his wife in St. Francisville, Bayou Sara, November 24.

\section{$1825-1826$}

Teaches at St. Francisville, and gives dancing lessons at Woodville, Mississippi, to raise funds to go to Europe.

\section{6}

May 17.-Sails with his drawings on the cotton schooner Delos, bound for Liverpool, where he lands, a total stranger, on July 21 . 


\section{xlvi AUDUBON THE NATURALIST}

In less than a week is invited to exhibit his drawings at the Royal Institution, and is at once proclaimed as a great American genius.

Exhibits at Manchester, but with less success.

Plans to publish his drawings, to be called The Birds of America, in parts of five plates each, at 2 guineas a part, all to be engraved on copper, to the size of life, and colored after his originals. The number of parts was at first fixed at 80 , and the period of publication at 14 years; eventually there were 87 parts, of 435 plates, representing over a thousand individual birds as well as thousands of American trees, shrubs, flowers, insects and other animals of the entire continent; the cost in England was $\mathfrak{1 1 7 4}$, which was raised by the duties to $\$ 1,000$ in America.

Paints animal pictures to pay his way, and opens a subscription book.

October 26.-Reaches Edinburgh, where his pictures attract the attention of the ablest scientific and literary characters of the day, and he is patronized by the aristocracy.

November, early.-William Home Lizars begins the engraving of his first plates at Edinburgh, and on the 28th, shows him the proof of the Turkey Cock.

Honors come to him rapidly, and he is soon elected to membership in the leading societies of science and the arts in Great Britain, France and the United States.

\section{7}

February 3.-Exhibits the first number of his engraved plates at the Royal Institution of Edinburgh.

March 17.-Issues his "Prospectus," when two numbers of his Birds are ready.

A pril 5.-Starts for London with numerous letters to distinguished characters and obtains subscriptions on the way. May 21.-Reaches London, and exhibits his plates before the Linnæan and Royal Societies, which later elect him to fellowship.

Lizars throws up the work after engraving ten plates, and it is transferred to London, where, in the hands of Robert 
Havell, Junior, it is new born and brought to successful completion eleven years later.

Summer.-Affairs at a crisis; resorts to painting and canvasses the larger cities.

December.-Five parts, or twenty-five plates, of The Birds of America completed.

\section{8}

March.-Visits Cambridge and Oxford Universities; though well received, is disappointed at the number of subscribers secured, especially at Oxford.

September 1.-To Paris with William Swainson; remains eight weeks, and obtains 13 subscribers; his work is eulogized by Cuvier before the Academy of Natural Sciences, and he receives the personal subscription, as well as private commissions, from the Duke of Orleans, afterwards known as Louis Philippe.

\section{9}

A pril 1.-Sails from Portsmouth on his first return to America

from England, for New York, where he lands on May 1.

Summer.-Drawing birds at Great Egg Harbor, New Jersey.

September.-To Mauch Chunk, and paints for six weeks at a lumberman's cottage in the Great Pine Woods.

October.-Down the Ohio to Louisville, where he meets his two sons, one of whom he had not seen for five years; thence to St. Francisville, Bayou Sara, where he joins his wife, from whom he had been absent nearly three years.

\section{0}

January 1.-Starts with his wife for Europe, first visiting New Orleans, Louisville, Cincinnati, Baltimore, and Washington, where he meets the President, Andrew Jackson, and is befriended by Edward Everett, who becomes one of his first American subscribers.

A pril 1.- Sails with Mrs. Audubon from New York for Liverpool. Settles in London; takes his seat in the Royal Soci- 
ety, to which he was elected on the 19th of March; resumes his painting, and in midsummer starts with his wife on a canvassing tour of the provincial towns; invites William Swainson to assist him in editing his letterpress, but a disagreement follows.

Changes his plans, and settles again in Edinburgh; meets William MacGillivray, who undertakes to assist him with his manuscript, and together they begin the first volume of the Ornithological Biography in October.

\section{1-1839}

The Ornithological Biography, in five volumes, published at Edinburgh, and partly reissued in Philadelphia and Boston.

$$
1831-1834
$$

In America, exploring the North and South Atlantic coasts for birds.

\section{1}

March.-First volume of the Ornithological Biography published, representing the text of the first 100 double-elephant folio plates.

April 15.-Returns with his wife to London.

May-July.-Visits Paris again in the interests of his publications.

August 2.-Starts with his wife on his second journey from England to America, and lands in New York on September 4 .

Plans to visit Florida with two assistants, and obtains promise of aid from the Government.

October-November.-At Charleston, South Carolina, where he meets John Bachman and is taken into his home.

November 15.-Sails with his assistants in the government schooner Agnes for St. Augustine. 
A pril 15.-In revenue cutter Marion begins exploration of the east coast of Florida; proceeds to Key West, and later returns to Savannah and Charleston.

Rejoins his family at Philadelphia, and goes to Boston; there meets Dr. George Parkman, and makes many friends. August.-Explores the coasts of Maine and New Brunswick, and ascends the St. John River for birds.

Returns to Boston, and sends his son Victor to England to take charge of his publications.

\section{2-183.3}

Winter.-In Boston, where he is attacked by a severe illness induced by overwork; quickly recovers and plans expedition to Labrador.

\section{3}

June 6.- Sails from Eastport for the Labrador with five assistants, including his son, John Woodhouse Audubon, in the schooner Ripley chartered at his own expense.

August 31.- Returns to Eastport laden with spoils, including few new birds but many drawings.

September \%.-Reaches New York and plans an expedition to Florida.

September 25.-Visits Philadelphia and is arrested for debt, an echo of his business ventures in Kentucky; obtains subscribers at Baltimore, and in Washington meets Washington Irving, who assists him in obtaining government aid; finds patrons at Richmond and at Columbia, South Carolina.

October 24.-Reaches Charleston and changes his plans; with his wife and son passes the winter at the Bachman home, engaged in hunting, drawing and writing.

$$
1834
$$

The number of his American subscribers reaches 62. A pril 16.-Sails with his wife and son on the packet North America from New York to England with large collections. Settles again in Edinburgh, and begins second volume of his Biography, which is published in December. 


\section{5}

Many drawings, papers and books lost by fire in New York. Part of summer, autumn and winter in Edinburgh, where the third volume of his Ornithological Biography is issued in December.

\section{6}

Audubon's two sons, who have become his assistants, tour the Continent for five months, traveling and painting. August 2.-Sails from Portsmouth on his third journey from England to the United States; lands in New York on Sept. 6 and canvasses the city.

September 13.--Hurries to Philadelphia to obtain access to the Nuttall-Townsend collection of birds, recently brought from the Rocky Mountains and Pacific Coast; is rebuffed, and bitter rivalries ensue; Edward Harris offers to buy the collection outright for his benefit.

September 20.- Starts on a canvassing tour to Boston, where he meets many prominent characters, and obtains a letter of commendation from Daniel Webster, who writes his name in his subscription book. Visits Salem, where subscribers are also obtained; meets Thomas M. Brewer, and Thomas Nuttall, who offers him his new birds brought from the West.

October 10.- Is visited by Washington Irving, who gives him letters to President Van Buren and recommends his work to national patronage.

October 15.-Returns to Philadelphia, where attempts to obtain permission to describe the new birds in the Nuttall-Townsend collection are renewed; he is finally permitted to purchase duplicates and describe the new forms under certain conditions.

November 10.- To Washington, to present his credentials, and is promised government aid for the projected journey to Florida and Texas.

\section{$1836-1837$}

Winter.-Spent with Bachman at Charleston, in waiting for his promised vessel; makes drawings of Nuttall's and Townsend's birds, and plans for a work on the Quadrupeds of North America. 


\section{7}

Spring.-Starts overland with Edward Harris and John W. Audubon for New Orleans; there meets the revenue cutter Campbell, and in her and her tender, the Crusader, the party proceeds as far as Galveston, Texas; visits President Sam Houston.

May 18.-Leaves for New Orleans, and on June 8 reaches Charleston. John Woodhouse Audubon is married to Bachman's eldest daughter, Maria Rebecca.

To Washington, and meets President Martin Van Buren.

July 16.- Sails with his son and daughter-in-law on the packet England from New York; reaches Liverpool on August 2d, and on the 7 th is in London.

The panic of this year causes loss of many subscribers, but Audubon decides to extend The Birds of America to 87 parts, in order to admit every new American bird discovered up to that time.

\section{8}

June 20.-Eighty-seventh part of The Birds of America published, thus completing the fourth volume and concluding the work, which was begun at Edinburgh in the autumn of 1826.

Summer.-By way of a holiday celebration tours the Highlands of Scotland with his family and William MacGillivray.

Autumn.-To Edinburgh, where, with the assistance of MacGillivray, the fourth volume of his Biography is issued in November.

\section{9}

May.-Fifth and concluding volume of the Ornithological Biography is published at Edinburgh. A Synopsis of the Birds of North America, which immediately follows, brings his European life and labors to a close. 
Late summer.-Returns with his family to New York, and settles at 86 White Street. Victor, who preceded his father to America, is married to Mary Eliza Bachman.

Projects at once a small or "miniature" edition of his Ornithology, and begins work on the Quadrupeds. Collaboration of Bachman in this project is later secured.

\section{$1840-1844$}

First octavo edition of The Birds of America is published at Philadelphia, in seven volumes, with lithographic, colored plates and meets with unprecedented success; issued to subscribers in 100 parts, of five plates each with text, at one dollar a part.

\section{0}

June.-Begins a correspondence with young Spencer F. Baird, which leads to an intimate friendship of great mutual benefit, Baird discovering new birds and sending him many specimens.

1841

Purchases land on the Hudson, in Carmansville, at the present 15\%th Street, and begins to build a house.

July 29.-Writes to Spencer F. Baird that he was then as anxious about the publication of the Quadrupeds as he ever was about procuring birds.

\section{2}

A pril.-Occupies his estate, now included in the realty section of upper New York City called Audubon Park, which he deeded to his wife and named for her "Minnie's Land." September 12.- Starts on a canvassing tour of Canada, going as far north as Quebec, and returns well pleased with his success, after spending a month and traveling 1,500 miles. Plans for his western journey nearly completed. 


\section{3}

March 11.-At fifty-eight, sets out with four companions for the region of the Upper Missouri and Yellowstone Rivers, but is unable to attain his long desired goal, the Rocky Mountains.

November.-Returns with many new birds and mammals.

\section{$1845-1846$}

The Viviparous Quadrupeds of North America, in collaboration with the Rev. John Bachman, issued to subscribers in 30 parts of five plates each, without letterpress, making two volumes, imperial folio, at $\$ 300.00$.

John W. Audubon, traveling in Texas, to collect materials for his father's work.

\section{5}

Engrossed with drawings of the Quadrupeds, in which he receives efficient aid from his sons.

July 19.-Copper plates of The Birds of America injured by fire in New York.

December 24.-Bachman, his collaborator, issues ultimatum through Harris, but work on the Quadrupeds, which had come to a stand, is resumed.

\section{$1846-1847$}

John W. Audubon in England, painting subjects for the illustration of the Quadrupeds of North America.

\section{6-1854}

The Viviparous Quadrupeds of North America, in collaboration with John Bachman, published in three volumes, octavo, text only, by J. J. and V. G. Audubon; volume i (1847) only appeared during the naturalist's lifetime. 


\section{7}

Audubon's powers begin to weaken and rapidly fail.

\section{8}

February 8.-John W. Audubon joins a California company organized by Colonel James Watson Webb, and starts for the gold fields, but his party meets disaster in the valley of the Rio Grande; he leads a remnant to their destination and returns in the following year.

\section{1}

January 2\%. - Jean Jacques Fougère Audubon dies at "Minnie's Land," before completing his sixty-sixth year. 


\title{
FOREWORD AND POSTSCRIP'T
}

\author{
AUDUBON AND THE DAUPHIN
}

I

Was John James Audubon Louis Charles, Dauphin and Duke of Normandy, who by hereditary right became titular King of France at the moment the head of his father, Louis XVI, fell under the guillotine in Paris, January 21, 1793? Was he the little boy prince who was "in the way" and "not wanted" by his uncles and many of his countrymen, his potential subjects? Was he that unfortunate child who, orphaned by regicides, was held a close prisoner for nearly three impressionable years of his young life? Was he the boy who, in consequence of such treatment, according to some reports, developed a tendency to scrofula which we should now call tuberculosis? Finally, was he the ten-year-old child who was officially declared to have died in the Temple prison, June 7, 1795, a conclusion which many historians accepted, although some have maintained that the true prince was spirited out of the Tower, but when or how, or where or how long he may have lived, are questions which have never been answered with complete certainty.

When we consider the fierce partisanship engendered during the Revolution, and the wide breach between what contemporaries spoke or wrote and what they really thought or believed, the testimony of eye-witnesses to events in or about the Temple must be considered very untrustworthy. Moreover, the failure of one hundred and forty years of hot debate to throw any clear light on the ultimate fate of the Dauphin tends more and more to convince us that he was "lost" only in the sense that he had died. If this be the hard truth, what more vain than refuting the claims of pretenders or their descendants? 
Whatever convictions historians may have reached upon this issue to-day, the questions respecting Audubon can receive but one answer-a decisive negative. I repeat them only because they have been seriously asked and, incredible as it may seem, have been given a warm welcome by two recent biographers. ${ }^{1}$

Miss Rourke mentions a number of reasons which have led her to favor the fantastic Dauphin idea. The fact that $\mathrm{Au}$ dubon was first called "Fougère," and later "Jean Rabin," while for a time he used the name "Laforest" is cited with suspicion. When Captain Jean Audubon finally returned from Santo Domingo to France, late in 1789, "how many children," she asks, "did he bring with him"; and, "if he was accompanied by a little boy, there is no certainty," she says, "that this was the same boy who was adopted as Fougère, three years later." If this were not the same boy, neither she nor Mrs. Tyler knows what became of the first or has any proof that Audubon was a substitute child. There was a long period, says Miss Rourke, between Audubon's birth (April 26, 1785) and his adoption (March 7, 1794) of nearly nine years, and "this gap has never been filled in. Where was this boy during this time? It is well within the range of possibility that after his return to France during the Revolution, a boy was entrusted to the care of Captain Audubon whose identity he was induced to hide. He may have used the approximate birthday and later the name of the little boy born in Santo Domingo to cover the history of another child. Some of those closest to Audubon during his lifetime believed implicitly that he was of noble birth."

Miss Maria R. Audubon, the naturalist's granddaughter, stated to me in 1914 that Jean Audubon and his wife settled some property upon "Jean Rabin, créole de Saint-Domingue," which he refused to accept under that name, saying, "My own name I have never been permitted even to speak; accord me

${ }^{1}$ See Audubon, by Constance Rourke (New York, 1936), and $I$ Who Should Command All, by Alice Jaynes Tyler (New Haven, 1937). 
that of Audubon, which I revere, as I have cause to do." This reference to property probably had to do with the wills of his father and stepmother, in which the objectionable name occurs many times. Audubon's dislike of the Rabin name does not seem to have persisted, for in view of the settlement of property under those wills, on July 25, 1817, a power of attorney was drawn in favor of his brother-in-law, Gabriel Loyen du Puigaudeau. In this curious document the naturalist refers to himself as "John Audubon" and as "Jean Rabin, husband of Lucy Bakewell." The Jean Rabin alias occurs four times in the text, over the signature of "John J. Audubon" at the end.

An English reviewer once expressed regret that I had probed the birth and parentage of Audubon, saying that he preferred to take this illustrious man at his word that he "belonged to every country." Such writers forget that a prime duty of every biographer is to make his subject known, and that this is impossible if he comes from nowhere, or, as John Neal facetiously remarked, if he is "one of those extraordinary men who are erected,--never born at all." Audubon's father "had other reasons," thinks Miss Rourke, "for sending Fougère to America which he did not disclose. . . . They could not have had to do with money.... Whatever his reasons were they persisted, and may have had to do with the boy's parentage."

Mirs. Tyler begins her book with a quotation, "History has the inalienable right to be written correctly," to which every honest person will subscribe, but which writers of biography are too apt to forget. Throughout her book she refers to me as "Robert," a prænomen I have never borne, but since names are easily confused, I forgive her. The naturalist's father, Jean Audubon, is called the "Admiral," a title he never bore, which gives a sense of unreality to her text. The highest rank that Jean attained in the French navy was lieutenant (lieutenant de vaisseaux), one grade below that of captain. In my Audubon the Naturalist I gave a summary of the naval career 
of his father in the merchant marine and navy of France, having obtained access in wartime to the official records of the navy department in Paris through the good offices of our ambassador, the late Hon. Myron T. Herrick. Jean Audubon held the rank of lieutenant from October 11, 1797, until his retirement for disability on January 1, 1801. Perhaps Mrs. Tyler followed the example of Miss Maria R. Audubon, who was accustomed to give this exalted rank to her grandfather; and perhaps Miss Audubon got it from a letter that Audubon carried with him when leaving Edinburgh for London, written by a Mr. Hay, and addressed March 15, 1827, to his brother, Robert William Hay, Downing Street, West, in which this statement occurs: "Mr. Audubon is a son of the late French Admiral Audubon, but has himself lived from the cradle in the United States, having been born in one of the French colonies." Audubon certainly should have known his father's naval rank, and also that he could not have lived from the cradle in the United States, but the last statement is now believed to have been true.

Strong presumptive evidence had led me to conclude that John James Audubon was the illegitimate son of Lieutenant Jean Audubon and Mademoiselle Rabin, a French creole of Santo Domingo. "Rather than tolerate the suggestion of illegitimacy in regard to their grandfather," says Mrs. Tyler, "the old ladies decided to bear the rigors of publicity if needs be, and to give to the world the information which would disprove this biography. To that end they released me from the promise to withhold publication of their 'secret,' and perhaps the world's secret also." This family secret of Audubon's noble birth, which is revealed in Mrs. Tyler's I Who Should Command All, was imparted by the naturalist in extracts from his private journals, sometimes sent in letters to his wife, and apparently written for her benefit alone, with no thought of their publication. The significant passages were copied by his granddaughter, Miss Maria R. Audubon, into a little black note-book, which I was permitted to see in 1914, but, out of respect to 
her wishes and those of her sister, Miss Florence Audubon, they were only briefly referred to in my biography of their grandfather in 1917. In the course of our conversation, Miss Maria confessed that she had really never known who her grandfather was, but that in the light of these journal entries she had come to think that he was-or, perhaps she said, might have beenthe lost Dauphin. In commenting on this question, Miss Audubon added that a gentleman to whom these extracts had been shown had said that possibly they had been written to obscure the unwelcome fact of illegitimacy, a wise remark, as the sequel has shown. I tried to dissuade Miss Audubon from her expressed intention of destroying the original manuscript, but to no avail.

The entries in this note-book, which form the basis of Mrs. Tyler's I Who Should Command All, have recently been published by Stanley Clisby Arthur in his careful biography. ${ }^{2}$ Mrs. Tyler says that I have "not recorded one biographical event between the year 1794, the date of Audubon's adoption, and 1800, the date of his baptism," and tries to put young Audubon in "Selkirk's Settlements," in Canada, at some time between these early years. All of these questions will be taken up later.

II

In 1914, at the very outbreak of the World War, a great flock of documents pertaining to Lieutenant Audubon and his family was discovered at Couëron, the seat of his country villa in France. Outstanding among them was the curious bill of Jean Audubon's family physician, Doctor Sanson, of Les Cayes, Santo Domingo, covering a period of nearly three years, 1783 to $1786 .^{3}$ This is particularly remarkable for recording the birth of a child to Mademoiselle Rabin on April 26, 1785. The

${ }^{2}$ See Audubon: An Intimate Life of the American Woodsman (Bibl. No. 264).

${ }^{3}$ See the reproduction of this bill in Chapter IV, and for translation, Appendix I. 
inference, supported by other documentary testimony, was that this referred to the identical child who later became John James Audubon and who was baptised in 1800 as Jean Jacques Fougère (Audubon).

Jean and Anne Moynet Audubon adopted this boy Fougère, then nine years old, and a seven-year-old girl, Muguet or Rosa, born also in Santo Domingo but to another woman, at Nantes on March 7, 1794.. ${ }^{4}$

The Jean Rabin alias was used in the six wills drawn by Lieutenant Audubon and his wife, and in the power of attorney of Audubon himself to which I have referred. ${ }^{5}$ It is these various legal documents, usually drawn under oath and attested by witnesses, that Miss Rourke and Mrs. Tyler set aside as "not proven"; yet they do not hesitate to place Audubon at the foot of a long list of spurious claimants to being the son of Louis XVI and Marie Antoinette, without a shred of documentary support to such a claim excepting the family tradition based upon extracts from Audubon's private journals which were intended for the perusal of his wife alone-and this in view of the further fact that it has never been definitely proven that the Dauphin did not die in the Temple or shortly after leaving it.

III

It is generally assumed that the person whose parents and near relatives are no longer living knows more about his early history than anybody else, and this is generally true, except in the case of a child's early adoption, substitution, or abandonment by its true parents.

What Audubon said publicly or privately about his birth, his age, and his parents forms a mystifying record. According to Vincent Nolte, Audubon, after parrying some prying ques-

- For translation of texts of the acts of adoption and baptisms, see Vol. I, pp. 59-61.

${ }^{5}$ For power of attorney, see Vol. I, p. 64, note, and for wills, Vol. I, p. 262, and Vol. II, pp. 360-368. 


\section{FOREWORD AND POSTSCRIPT}

tions about himself in 1811, admitted that he was a Frenchman by birth and a native of La Rochelle.

Joseph Robert Mason, youthful companion of Audubon on his famous journey down the Ohio and Mississippi Rivers in 1820-21, who was thus closely associated with him for twentyone months, told John Neal, fifteen years later, that Audubon had repeatedly represented to him that he was born in Santo Domingo. A statement to this effect was also made by James J. Walsh in 1904. ${ }^{6}$ Audubon's journal record of this river journey, which I was permitted to examine rather cursorily twenty years ago, was published in 1929 and is commented on by Mr. Arthur. ${ }^{7}$ While fortunate in escaping the fire and general mutilation by injudicious hands, this record has been tampered with at one critical point-in the entry for November 28, 1820, where Audubon spoke of his birth and parentage and related incidents which he thought that his family in the future might wish to know. The mutilator of his text, however, did not succeed in forever obscuring what the writer presumably intended to convey. In the two lines at this point that have been blotted out as effectively with a pen as could have been done with an ink-filled brush, we can reasonably infer that Audubon gave his own mother's name and either stated or implied that he was born out of wedlock and in Santo Domingo. This inference seems to be justified by the addition in what immediately follows, with the same kind of ink and probably by the same hand, of the prefix "re" to the word "married." As originally written by Audubon, the entry reads: "My Mother, who I have been told was an extraordinary beautiful Woman, died shortly after my Birth and my father having married in France I was removed thereto when only Two Years old and received by that Best of Women, raised and cherished by her to the utmost of her Means . .." It is evident that the person who

${ }^{6}$ See James J. Walsh, Bibl. No, 240.

'See Journal of John James Audubon, Bibl. No. 250, and for reproduction of the mutilated manuscript, Stanley Clisby Arthur, Bibl. No. 264, p. 118. 
obliterated those two lines and changed "married" to "remarried" was determined to make it appear that Captain Audubon had been first married to his boy's mother, and that after her death he took their child to France, where he was married again, this time to the woman who became the boy's stepmother, when the truth, as Audubon had stated it, was just the opposite.

A few years later, about 1824, when Audubon and his wife were living at "Beechwoods," a plantation near St. Francisville, Louisiana, the wife of his old friend and former clerk, Dr. Nathaniel Wells Pope, left a record of her reminiscences, quoted by Stanley Clisby Arthur, in which she said that Audubon had often described to her the cottage in which he was born that was situated on the banks of the Mississippi River, in Lower Louisiana, and surrounded by orange trees.

At Oxford in 1828 a lady who wanted his autograph asked Audubon to write his name and the date of his birth. The latter, he said, he could not do, "except approximately," and his hostess "was greatly amused that he should not know." As I have already noted, Audubon appears to have told Mr. Hay, a friend at Edinburgh, in March, 1827, that he was born in one of the French colonies.

In the Introduction to the first volume of his Ornithological Biography, Audubon, who was under no necessity of saying anything about his birth, made the vague affirmation, "I received life and light in the New World," and continued: "When I had hardly yet learned to walk, and to articulate those first words always so endearing to parents, the productions of nature that lay spread all around, were constantly pointed out to me"; and in the biographical sketch "Myself" he wrote that "the first of my recollective powers placed me in the central portion of the city of Nantes, on the Loire River, in France."

Again, in the Introduction to the second volume of the Ornithological Biography, Audubon spoke of America as "the land of my birth," and as the country in which "my eyes first opened to the light."

How do such statements support the theory that Audubon 
was the "lost" or mislaid Dauphin, or suggest the palace of Versailles, where Louis Charles was born, with forty or more servitors around him with assignments directed mainly to the care of the little prince, not to speak of his later governesses, tutors, or teachers? John James was not Louis Charles!

In the biographical sketch just referred to, supposed to have been written about 1835, which, though edited by his granddaughter, is replete with palpable errors, Audubon wrote that "the precise period of my birth is yet an enigma to me." He then spoke of his father going from Santo Domingo to Louisiana, and there marrying a Spanish lady of beauty and wealth, and of having three sons born to them, "I being the youngest of the sons, and the only one who survived extreme youth. My mother, soon after my birth [implying that he was born in Louisiana], accompanied my father to the estate (sic) of Aux Cayes, on the island of Santo Domingo, and she was one of the victims of the ever to be lamented period of the negro insurrection of that island."

The evidence now available from a variety of sources points more clearly than ever to the fact that the mother of Audubon was a French creole, Mademoiselle Rabin, of Santo Domingo, where her children were all born, and that she was not married to Audubon's father, who stated under oath in the act of adoption that the mother of his son had died "about eight years" prior to March 7, 1794, the date of the signing of the actthat is, in 1786, or one year after 1785, the year of the child born to Mademoiselle Rabin as recorded in the Sanson bill. Later items in the latter show that this child's mother was in declining health, and tend to confirm Audubon's statement, quoted above, that his mother had died shortly after his birth.

In various extracts from Audubon's European journal, written for the benefit of his wife, but not for the public, at various times from 1826 to 1828, chiefly at Edinburgh and Paris, he records a visit from the Countess of Selkirk, refers to his high birth, to walking the streets of Paris like a common man when he "should command all." He also refers to his 


\section{Ixiv}

hated uncle, "Audubon of La Rochelle," and speaks of the oath under which he was bound not to reveal his identity. The name of the Dauphin or Louis XVII does not appear in any of these excerpts, but the reference seems to be clear.

It should be remembered that when the Dauphin and his mother were separated in the Temple prison on July 3, 1793, the son was in his ninth year, and that the boy was nearly eight years old when his father was executed, so that the young prince had the memory of several years of both his parents, to whom, according to the testimony of all who had known them, he was devotedly attached.

Mr. Arthur speaks of Miss Harriet Bachman Audubon, daughter of John Woodhouse Audubon by his first wife, telling how she had read in one of her grandfather's journals this significant statement: he made reference to "my father, meaning Jean Audubon,- - and in the next sentence said 'my own father whom I saw shot.' He said 'shot,' because he was only eight years old and the word 'to guillotine' was not then invented." Miss Audubon was evidently promoting the idea that the naturalist's "own father" was Louis XVI and that her grandfather was the Dauphin; but if there is any truth in the quotation, it would definitely prove that young Audubon could not have been the Dauphin since the execution of Louis XVI was not witnessed by his own son or by any other member of the royal family.

In his Ohio and Mississippi journal, writing in 1820, Audubon spoke of himself as "a young man of seventeen sent to America to make money," in 1802, as he then thought. It is thus evident that at the age of thirty-five he looked upon $\mathbf{1 7 8 5}$ as his natal year, although he was a year short in his dating of that first American voyage, which actually occurred in 1803, when he was in his eighteenth year. When writing to Bachman in 1832, he gave his own age as forty-seven, which would imply that he was born in 1785, and this would again agree with the date of birth of a child born to Mademoiselle Rabin, as recorded in the Sanson bill. In writing to Bachman again six years later, on April 14, 1838, he speaks of his being 
then fifty-three years old, which would also point to the same birth date of 1785 .

On June 4, 1826, at sea, when on his way to England and to fame, Audubon wrote: "We are a few miles south of the Line for the second time in my life.-What ideas it conveys to me of my birth, and the expectations of my younger days." If this statement is true, it would explode the Audubon-Dauphin hypothesis, unless its proponents can explain how the boy prince could ever have been south of that Line before 1826 .

In a letter to his wife, written from New Orleans in 1837, as noted by Mr. Arthur, Audubon spoke of that town as "my natal city," and local newspapers of the time hailed him as a native of Louisiana. Moreover, Cuvier, in his report on The Birds of America to the Royal Academy of Sciences of Paris, September 22, 1828, made the same statement, which in this case could have come only from Audubon himself. When he sailed from Nantes for the United States with Rozier in 1806, his passport, which his father had procured for him, indicated that he was born in New Orleans.

To many it would seem strange that J. J. Audubon should have found so close a resemblance between himself and Jean Audubon unless his father by adoption were his "real father." Writing in 1820, Audubon said that "Major Croghan of Kentucky told me often that he [Jean Audubon] looked much like me and he was particularly well acquainted with him." In his "Myself" sketch he also said: "In personal appearance my father and I were of the same height and stature, being five feet, ten inches, erect and with muscles of steel. . . . In temper we much resembled each other also." One day in October, 1826, when Audubon returned to his rooms in Edinburgh and looked into a mirror, he saw, as he recorded in his journal, not only his own face, but "such a strong resemblance to that of my venerated father that I almost imagined that it was he that I saw; the thoughts of my mother came to me, my sister, and my young days, - all was at hand, yet so far away." It should be added that a year and half later, at Edinburgh also, 


\section{lxvi AUDUBON THE NATURALIST}

he wrote: "To-day, as I was shaving, I was struck by my resemblance to my father, not my adopted father, but my own father."

Those committed to the Dauphin theory see in Audubon's features a strong Bourbon likeness, but such fancied resemblances never carry much weight. Rev. John Halloway Hanson, ${ }^{8}$ biographer and protagonist of Eleazar Williams, was certain that this half-breed Indian was an aristocrat, and the Dauphin to boot, for he had the Bourbon features from top to toe.

In writing to young Spencer Fullerton Baird in 1842, Audubon expressed the curious, if purely fanciful, idea that his mother once lived on his father's "Mill Grove" farm, which was near Norristown in Pennsylvania.

The foregoing record probably does not exhaust all the possibilities, but it is amazing enough, and partly explains why John Neal was so often taunting Audubon for having as many birthplaces as the poet Homer. A remarkable fact about these statements is that nearly all of them come to us at second hand, that is, from private letters or edited journals, the quotations from the Ornithological Biography being the only ones that were published under Audubon's own signature.

From the account just given, it is obvious, I think, that Audubon was determined that the facts concerning his birth and parentage should not be made public, and that to achieve this end he resorted to enigma, as the best available smokescreen. If he thought that public knowledge of those facts would prove a stumbling-block in his own career, and in that of his two sons, whom he once said he hoped might rise to eminence, he was indubitably right; for strange as it may seem, and unjust as it assuredly is, the stigma of illegitimacy has long been a penalty which the public is ever ready to place on

${ }^{8}$ Author of The Lost Prince (New York, 1854). With this book, said William W. Wight, the habit began of referring to Louis XVII as "lost," as if he had been mislaid or hidden. "He was lost only in the sense that he had died." Hanson's mother was a daughter of a youngex brother of Oliver Goldsmith, the poet. 


\section{FOREWORD AND POSTSCRIPT Ixvii}

the head of the innocent. What strangers or what his intimates knew about those family matters was what Audubon was willing to tell them, and his own record shows plainly enough that he preferred to bear the taunts of the uncharitable rather than to face the reality; but so redoubtable a handicap should not be allowed to detract one iota from his just fame.

IV

"One of the great miracles of history would have occurred," writes Miss Rourke, "if Audubon were the lost Dauphin, but this is nothing against the idea." True enough, but the same could be said of Eleazar Williams or any other of the numerous pretenders impersonating that unfortunate prince. If there were solid, unmistakable evidence to support the conclusion that Audubon was the titular king of France, I should be only too glad to accept it, but the presumptive evidence is all the other way. The theory will not bear analysis; it is too weak to stand on its own feet.

"Some of those closest to Audubon during his lifetime," says Miss Rourke, "believed implicitly that he was of noble birth." Very true, but Audubon said many things, at different times and to different persons, which contradict point-blank what was said in letters or journals intended for his wife-as that he was born in the New World, or in one of the French colonies; that his mother died shortly after his birth; or that his first memories were of Nantes, and that the only mother he had ever known was his stepmother. In forming a judgment in the midst of so many contradictions, we are inevitably thrown back upon those family legal documents which have not been edited or in any way tampered with, and which were drawn up before the youth was grown to man's estate and obliged to fight his way in a hostile world. In striving to reach the truth in such a case, all domestic partiality must of necessity be laid aside.

"A long period exists," says Miss Rourke, "between the date given for Fougère's birth [April 26, 1785] and the date 


\section{Ixviii AUDUBON THE NATURALIST}

of his adoption [March 7, 1794] - nearly nine years-a gap which has not been filled in. Where was the boy during this time?" The evidence is fairly conclusive that Jean Audubon took his son to France late in 1789, so that this "gap" is reduced to about five years; and it seems to me that in his Ornithological Biography and the "Myself" sketch the subject has filled this interval quite well enough himself. In the latter he spoke of "being constantly attended by two black servants, who had followed my father from Santo Domingo to New Orleans and afterwards to Nantes." Mrs. Tyler thinks that "it can be only mental inertia which has allowed hundreds of intelligent people to read this sentence, and not press the inquiry why the illegitimate son of a common, seafaring captain of Nantes should have been constantly attended by one or two black servants." But what shall be said of the mental condition of the people who have first read the opening sentence of the very same paragraph about Audubon's first recollective powers placing him in the central part of the city of Nantes? If that statement were literally true, it would at once sterilize the idea of Audubon being the lost Dauphin. In any case, one would think that a household with an active boy rising five years (in 1790) and a girl rising three could keep any two black servants on their toes for a good long tiine. Audubon did not mention his little sister Rosa, but there is no reason to think that he monopolized all the attention of servants.

In 1789 Jean Audubon jumped from the frying-pan of Santo Domingo into the revolutionary fires which were then sweeping France. At Nantes he became an ardent revolutionist when his city was entering the most terrible years of its history. It withstood a determined siege by the loyalists of La Vendée under Charette, and a reign of terror under Jean Baptiste Carrier, whose recall on February 14, 1794, just twenty-one days before the act of adoption was signed, had given Jean Audubon and his fellow-citizens the first respite they had enjoyed in years.

At Nantes, Captain Audubon had occupied a number of 
different houses during a long intermittent residence; and he continued to live there with his family until his retirement from the navy for disability on January 1, 1801, when he settled in his country villa, "La Gerbetière," at Couëron, on the right bank of the Loire nine miles down the river.

During this earlier time, up to his sixteenth year, young Audubon had received little or no regular schooling, but he had enjoyed a good deal of desultory experience in natural history and drawing. Thereafter, from 1801 to 1803, when he first returned to America, and for a year or more in 1805 and 1806, when he was at Couëron, aside from slight digressions, he was roaming the countryside and making a collection of his own drawings of the native birds. According to his own account of these formative years, he received plenty of good advice, criticism, and admonition from his father, and it was at Couëron that Fougère first met Dr. Charles d'Orbigny, who might be called his father in natural history. For my part I do not see the need of doubting the identity of the youth whose life has been briefly sketched from 1789 to 1803 . If this was Audubon, who up to his eighteenth year had spent nearly five years in Santo Domingo, eleven years in Nantes, and parts of two years at Couëron, where does the Bourbon prince enter the picture?

Miss Rourke thinks that Lieutenant Audubon did' not tell all of his reasons for sending his son to the United States, and that "whatever his reasons were, they persisted, and may have had to do with the boy's parentage." This is unimportant, since what the father did not tell, the son apparently did. In writing to Miers Fisher in 1803 and to Francis Da Costa in the winter of 1804-05, Lieutenant Audubon expressly said that the compelling reasons for sending his son to America at that time were to enable him to learn English and to enter trade. "Remember, my dear Sir," the elder Audubon wrote, "I expect that if your plan [with the lead mine] succeeds, my son will find a place in the works, which will enable him to provide for himself, in order to spare me from expenses which I can with 
difficulty support." If young Audubon had been the hereditary king of France, Louis XVII, is it likely that Lieutenant Audubon, then retired, in poor health, impoverished, receiving a paltry annuity from the French Government of six hundred francs, would have been expected to meet all the expenses of sending a legal French king, though masquerading as his son, to America and of maintaining him there?

There was, to be sure, another reason why the retired sailor and soldier wanted to get his son Fougère out of France at that time, though he may not have wished to write it. The young man was eligible for conscription. The need for "cannon fodder" was soon to become acute all over France, for Napoleon became emperor in 1804. Audubon himself told the secret at a much later time, when going down the Ohio River in 1820. On November 26 of that year he wrote: "The conscription determined my father on sending me to America"; and he added: "A young man of seventeen [eighteen], sent to America to make money, for such was my father's wish."

\section{$\mathbf{v}$}

In his journal on March 15, 1827, at Edinburgh, Audubon recorded a visit from the Countess of Selkirk, and thought it strange that she should call upon him at his George Street lodgings. "Did she know, I wonder," he wrote, "who I am positively, or does she think that it is John J. Audubon, of Louisiana, to whom she spoke? Curious event, this life of mine!" It would be reasonable to suppose that the Countess called on Audubon out of curiosity, since he was becoming something of a social lion, and she had doubtless heard of this genius from the backwoods of America from her nephew, Captain Basil Hall, who was one of Audubon's confidential friends. Moreover, this friend was then planning to visit America and was getting much useful information from the naturalist.

On October 9, 1828, when in Paris, according to Mrs. Tyler, Audubon wrote in his journal (and afterwards copied the entry 
in a letter to his wife): "How often $\mathbf{I}$ thought that I might once more see Audubon of La Rochelle without being known by him, and try to discover if my father was still in his recollection, if he had entirely forgotten Selkirk's Settlements." In my version of this entry there is no $s$ at the end of the last word, but the vagueness which the plural number imparts really makes no difference in our interpretation of the Dauphin question. "And if," continued Audubon, ". . . if I say a few words more, I must put an end to my existence, having forfeited my word of honor and my oath."

This Lord Selkirk, whose interests in Canada were paramount but who never held any public office there higher than justice of the peace, had been much in the public eye in England in the early part of the nineteenth century. At the time of the Countess' call she had been a widow seven years, but it is possible that Audubon had heard all about the Earl's disastrous colonial expriments through her nephew. Whether this is true or not, this Selkirk reference is the slender thread on which Mrs. Tyler builds an amazing superstructure. "It would appear," she says, "that John James Audubon was, at some time, a member of Selkirk's Settlements in Canada." She writes: "The long suspense is over! At last we know the reason for Admiral Jean Audubon's abnormal solicitude, which took the form of the constant attendance of those black servants, who guarded John James Audubon, the supposedly illegitimate son of the rough sea captain of Nantes! That little nine-year-old boy, adopted by Jean Audubon on March 7, 1794, was a personage whose real identity might presumably be recognized by the wife of the Earl of Selkirk. The wife of the Earl of Selkirk had apparently known him personally when he was a settler in Selkirk's Settlements. It is not very likely that the Earl's wife habitually met the rough colonists sent out to the wilds of North America, unless by chance one of those colonists was not a real settler, but was a personage emigrating under this guise in order to hide his identity, and to seek the protection of the Earl's remote colony. If the Earl of Selkirk were hiding a 


\section{Ixxii AUDUBON THE NATURALIST}

person of importance in his Settlements in the Hudson Bay country, very probably the Earl's wife met that person before embarkation; or perhaps she gave him hospitality in her home, as was common in those days when England was the first destination of terror stricken French refugees."

"And that other Audubon of La Rochelle, who apparently had been with him in Selkirk's Settlements, was he the person entrusted to convey and guard that little boy of eleven years, on the long perilous journey to Hudson Bay?" Mrs. Tyler seems to have confused Hudson Bay with the Hudson's Bay Company, which drew its furs from a vast region, but none of Selkirk's Settlements was anywhere near Hudson Bay.

Audubon's claim that he was bound under a solemn oath to his father not to reveal his own identity Mrs. Tyler thinks explains many things about the early history of Audubon the naturalist. "Does it not explain why the wily old sea captain, Jean Audubon, adopted two children on the same day, to give a semblance of paternity to both acts? And does it not suggest why he registered the name of the mother of the girl, and omitted to register the name of the mother of the boy, whose recorded age almost paralleled that of Marie Antoinette's son, who had vanished from the Temple just forty-odd days before the date of this adoption?"

It is my opinion that Jean Audubon, who was only fortynine years old when this act of adoption was drawn, and who was but just then getting a breathing-spell after perilous times, knew what he was talking about, that he was no perjurer, but was perfectly honest in every statement sworn to and witnessed in this act. That he was a few days out in his memory of birth dates is not important. There is no evidence that he failed to mention the name of the mother of his son in order to conceal the woman's name. The surest way of doing this would have been to use a fictitious one. Judge Fougère, as quoted by Mr. Arthur, offers another explanation: since Mademoiselle Rabin was dead and could not enter a legal objection, it was not necessary to give her name; "but, on the contrary, Mlle. Cath- 
arine Bouffard, who had succeeded her in the Audubon home, was still alive, and when her daughter, Rosa, was adopted, Captain Audubon was forced to record her name because, as she was still in France, she could have entered a legal objection."

Mrs. Tyler reproduces the title of a book on the Red River Colony which she says "serves to prove that Selkirk's Settlements were preëminently suited for the purpose of hiding the little King of France far from a world on fire with his pursuit. . . And the by-products of this place of concealment were to exceed in importance to the world even his physical survival. The germinating genius of this growing boy which straight through life seemed to flower under adversity, was born of this forest life and intimacy with primeval nature.

"It would have been natural for Admiral Audubon to turn his eyes to those North American outbounds of civilization, which he had so extensively traversed, were he casting about to find asylum for his adopted son after Charette's death. . . . Something had to be done to get that little boy out of danger, and so completely beyond the reach of Carrier's followers that pursuit would be absolutely impossible. Nor would distance alone provide sufficient protection. Secrecy must again be invoked, and masquerading under some impenetrable guise, Selkirk's Settlements provided both requirements."

Mrs. Tyler even charts the course which she thinks Louis XVII, masquerading as John James Audubon, had taken in travelling from Nantes to the wilds of Canada; to England, "the first destination of so many French refugees, . . . SaintDomingue, Admiral Audubon's former home; and probably from there to New Orleans, and up the Mississippi to the Settlements. ...

"The name La Forêt, which Audubon assumed, and which has never had any explanation, probably dates from this period. It may be the name under which John James Audubon was known as a Selkirk ${ }^{\circ}$ Settlements colonist. . . . This name was probably dear to her [Mrs. Audubon], because she was the only 


\section{lxxiv AUDUBON THE NATURALIST}

person in Audubon's life, who knew about his Canadian sojourn.

"This thesis, if true, provides the explanation of so many inexplicable elements in the life of John James Audubon, that it is with a distinct sense of relief that $\mathbf{I}$ offer it as a working hypothesis, in the light of these letters. For, as I have said, no amount of wandering around the countryside of Couëron could have fitted this adolescent boy, John James Audubon, for his future life, and transformed him into one of the most powerful, resourceful woodsmen the new world possessed. . .

"And yet when John James Audubon came to the United States in 1803, when he was barely eighteen years of age, he could traverse the continent alone like an Indian, find his way through trackless forests, swim swollen rivers, shoot with the marksmanship of the wilderness, and he could survive with his naked fists in the primeval forest of North America. His contacts with the Indians had the sure touch of easy familiarity; his knowledge of wild life knew no bounds. . .

"Where had John James Audubon acquired this forest training? It is my belief that John James Audubon acquired all his forest training in the Selkirk's Settlements, somewhere between 1796 and 1800."

What an extraordinary picture we have here of the boy "king," whose sister once said that if he had actually escaped from the Temple prison, he could not have lived long on account of his weakened condition: hidden for a time in the heart of Nantes, under the roof of one who was, or who had recently been, an ardent revolutionist; adopted by this very man, Jean Audubon, in place of his own son-about whose fate neither of the writers quoted seems to have thought it necessary to inquire; taken secretly to England, where Mrs. Thomas Douglas, later to become the Countess of Selkirk, opens her heart and home to him. Then a mysterious uncle takes him to Santo Domingo, thence to New Orleans, and then up "Old Man River" to that vague destination called "Selkirk's Settlements," where the boy "king" first learned his Indian lore and woodcraft.

It is sad to relate that this ingenious picture bears no re- 
semblance whatsoever to reality. As a "working hypothesis" it fails to work. There is not an essential line or word of truth in it, not one! It cannot be true in any particular, since

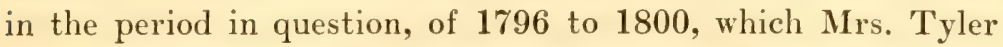
is endeavoring to fill, there were no Selkirk's Settlements anywhere in existence, and none indeed before 1803, when young Audubon, at eighteen, was leaving France and heading for his father's "Mill Grove" farm in Pennsylvania.

The Scottish nobleman Thomas Douglas (1771-1820), the fifth Earl of Selkirk and the seventh and youngest son of the fourth Earl, did not come into his title and fortune until the death of his father in 1799. He was a patriot who gave his fortune and himself for the development of the British Empire by laudable means, his great aim being to turn the flow of Scottish colonists from the Carolinas and New England to Canada. He sponsored three settlements in North America, the first in 1803 on Prince Edward Island, which was eventually fairly successful. The second, named "Baldoon" after a village on his ancestral acres, was situated in the western peninsula of upper Canada, between Lakes Huron and Erie, and never became more than a straggling pioneer village before it was finally plundered by Americans in the War of 1812.

The Selkirk Settlement of the Red River, in the Winnipeg region of what is now Manitoba, and over five hundred miles from Hudson Bay, was undoubtedly the one to which Audubon referred, and about it every reader of newspapers in England must have heard in the second decade of the last century. Its notoriety was due to its vast land area, the money at stake, and to the numbers of people involved. The legal battles fought over it in the courts, which lasted for upwards of ten years, with their strain and worry, caused, as many believed, the premature death of Lord Selkirk at forty-nine. The Earl died on April 8, 1820, at Pau, France, whither he had gone in the vain hope of recovering his health, and was buried in the Protestant cemetery there.

The directors of the Hudson's Bay Company had granted 
Selkirk an area of $\mathbf{1 1 6 , 0 0 0}$ square miles, comprising parts of what are now Manitoba, North Dakota, and Minnesota, and regarded as about the most fertile district on the whole North American continent. By the deed of January 12, 1811, Selkirk became the owner, in fee simple, of a tract five times the size of his native Scotland, stretching from Lake Winnipeg and the Winnipeg River on the east almost to the source of the Assiniboine on the west. This brought Selkirk and the Hudson's Bay Company in deadly conflict with the North-West Fur Company, whose directors were more interested in their fat dividends than in philanthropy. They gave Lord Selkirk no peace in the courts until, on the verge of financial ruin, his health broke. In 1821, the year after Lord Selkirk's death, the rival companies combined, and fifteen years later they made a financial settlement with the Selkirk heirs. The purchase of the territorial rights of this Company by the Dominion of Canada in 1869 led to Riel's rebellion, which was suppressed by British regulars under Colonel (later Lord) Wolseley. The Red River district entered the Canadian Confederation in $\mathbf{1 8 7 0}$ as the Province of Manitoba. Lord Selkirk seems to have lived fifty years ahead of his time. Sir Walter Scott is reported to have said of him: "I never knew in my life a man of more generous and disinterested disposition." A town and a county of Manitoba bear his name. ${ }^{9}$

Why did Audubon refer to Lord Selkirk in 1828, and why was he curious to know if "Audubon of La Rochelle" remembered Selkirk's Settlement? For no better reason, apparently, than why he should wish to know if this same Audubon of La Rochelle, whom we have supposed was the naturalist's uncle, remembered his own brother, Jean, with whom we are told that he had quarrelled.

A recent reviewer of Mrs. Tyler's book speaks of "Lady Selkirk, wife of Alexander Selkirk, who tried to establish a set-

${ }^{9}$ For facts concerning Lord Selkirk's life I am mainly indebted to Chester Martin, Lord Selkirk's Work in Canada, Oxford Historical and Literary Studies, Vol. VI (Oxford, 1916). 
tlement in the Hudson Bay country at the end of the eighteenth century." Verily, "man walketh in a vain shadow, and disquieteth himself in vain." The noble lord Thomas Douglas, who gave his all to his country, in after years is confounded with that notorious pirate Alexander Selkirk, who was buccaneering in the South Seas in the seventeenth century and, after having reformed, as we may hope, became the prototype of Robinson Crusoe!

Lord Selkirk's active' colonial work lasted seventeen years, 1803-1820, during which time Audubon, with the exception of parts of two years (1805-1806) at Couëron, was in the United States, engaged, when not hunting birds, in various business enterprises. On July 26, 1817, Audubon executed a power of attorney in favor of his brother-in-law, Gabriel Loyen du Puigaudeau, a little more than a year after his father had drawn up his last will, and but little over six months before his death. This will was at once contested by a number of nieces, in the courts of Nantes, on the ground that his illegitimate children, J. J. Audubon and Rosa du Puigaudeau, could not inherit Jean Audubon's property under existing French law. Nothing was said about the Dauphin or the personal identity of the son. When this litigation became known, Audubon seems to have broken off all relations with his father's family at Couëron, and in June, 1820, after the lawsuit had been settled by compromise, we find the brother-in-law writing him an appealing letter, saying that no word had come from him in two years and that Madame Audubon "does not cease to speak of you." Audubon did not ignore this appeal, but, as recorded in his journal on January 10, 1821, at New Orleans, he wrote letters to his brother-in-law and to his foster mother, at Couëron, a long neglected duty, as he acknowledged.

In his European journal Audubon spoke of "my mother, the only one I can truly remember; and no one ever had a better, nor a more loving one. Let no one speak of her as my stepmother. I was ever to her a son of her own flesh and blood, and she was to me a true mother." If such apparently spon- 
taneous statements are taken to mean what they say, they would be fatal to the theory that Audubon was a son of Marie Antoinette. In spite of such protestations, on the other hand, on August 6, 1826, Audubon writes in his journal of plans for going to "Nantes to see my venerable stepmother," who had died on October 18, 1821; and again in 1828 he spoke of this estimable woman as if she were then alive, although she had been dead seven years. This seems to show conclusively that Audubon had been out of touch with his father's family for a long time, although one must think that he had been notified of his stepmother's death since he was a beneficiary under her will.

VI

For some time I have been in correspondence with Stéphane Antoine Fougère, at one time mayor and now judge in the civil courts of Les Cayes, which has a present population of twenty thousand people and is one of the most important seaports of the Republic of Haiti. By perpetuation of a cartographical blunder this city is sometimes designated "Aux Cayes," which means "At the Keys" or "Cays," and is appropriately placed at the head of a letter or other document written at Les Cayes.

In a recent letter Dr. Donald F. Rafferty, now of Pass Christian, Mississippi, writes: "At the beginning of the World War I was ordered to Haiti, and stationed at Les Cayes, in charge of a French hospital. A friend sent me your book on Audubon ... and after reading it ... I loaned the book to Mr. Uriah Cardozo, who returned it to me with the comment that the author had not mentioned the fact that Audubon was actually born aboard a schooner in the roadstead of Les Cayes. Apparently the story had some foundation in fact as it was common knowledge among the intelligentsia of Les Cayes." If Audubon were actually born "on the sea," the fact might throw some light on his statement that he "belonged to every country."

The following information relating to Mademoiselle Rabin, 


\section{FOREWORD AND POSTSCRIPT Ixxix}

Audubon's mother; to her parents, in whom were united the Rabin and Fougère families; and to Belony Fougère, the reputed brother of Jean Jacques Fougère Audubon, I give on the authority of Judge Fougère, who considers himself a greatgrandnephew of Audubon in direct descent from Belony Fougère. His knowledge of his family history comes from his grandfather, Oxylus Fougère, who died at Les Cayes in 1908, at the age of eighty-five, and who had often spoken of his famous uncle who had lived in the United States, referring, of course, to J. J. F. Audubon. If the naturalist was correct in speaking of having had two (or three) older brothers, he was mistaken in thinking that all of them had been "killed in the wars," for Belony survived, and his descendants are living at Les Cayes to-day.

Audubon's mother, according to this account, came from two well-known land-owning families, the Rabins and the Fougères, who held estates respectively in the northern and southern parts of what is now the Haitian Republic. These tracts, according to Judge Fougère, still bear these family names, in accord with the French custom of naming sections of the public domain after the principal land-owners, and are so marked on the maps to-day. Judge Fougère, who has kindly investigated this matter for me, found that in S. Rouzier's Geographical and Administrative Guide Book of Haiti the Rabin division in the north is situated in the fourth rural section of the Commune of Port-de-Paix, and the Fougère division in the district of Miragoâne in the southern part of the country.

The father of Mademoiselle Rabin is said to have objected so strenuously to his daughter's consorting with Captain Jean Audubon, a married man, that she insisted on having her children by him bear the patronym, not of her irate father, but of her mother, who was presumably more complacent. Perhaps Audubon's early dislike of the Rabin name may be traced to this opposition expressed by his mother, but this is purely speculative. 
Mr. Arthur, in his detailed biography, has reversed the names of the parents of Audubon's mother, giving Fougère as the father's name. Since both of us have derived our information from the same source, I have recently appealed to Judge Fougère to settle this question if possible, and he has written me under date of May 22, 1937, as follows: "If I have written to Mr. Arthur that Mlle. Rabin was probably Rabin by her mother, and Fougère by her father, it may have been due to a lapsus calami,... nevertheless this false belief has been practised by the Fougère family for a good long time. I have been lately positively convinced of the fact that Mlle. Rabin was Fougère by her mother, through explanations received from a near relative. As to whether the Mademoiselle was Fougère by her mother or her father is, in my opinion, a matter of no real importance. What is of the utmost consequence to know is that the Fougère of Audubon's baptismal name came from one of the grandparents on his mother's side."

Belony Fougère, Audubon's older brother and Judge Fougère's great-grandfather, according to the family records that I am now following, married Francine d'Obcent (or d'Opsant)Dumont, who was owner of the large rural section of "Dumont" in the district of Les Cayes. He worked as a planter, at one time taught school, and also set up as a shoemaker. Belony had two sons, Oxylus and Tibère, and four daughters, Bèlomine, Telcila, Dulcinette, and Elmirène. Louis Joseph Simon, a son of Telcila now living at Les Cayes, was at one time Haitian Consul-General at New York. Belony spent his early life at Les Cayes, but later lived at Jérémie, where he died.

Oxylus Fougère, nephew of Audubon and grandfather of Judge Fougère, to continue this account, was a physician and also had a pharmacy at Les Cayes. He had three sons, Antoine, father of Judge Fougère, Fenimore and Marc, and a daughter, Marie. Antoine was a pharmacist of the first class at the University of Paris, and a former house surgeon in that city with the degree of licentiate in medicine. Fenimore was a physician and assistant surgeon in the French army in $\mathbf{1 8 7 0 .}$ 
Both Antoine and Fenimore were in Paris seventeen years. Some have thought that the name of La Forêt (La Forest or Laforest), which Audubon assumed for a time in his early life, was a fanciful one; but according to Judge Fougère, as noticed also by Mr. Arthur, Mademoiselle d'Obcent-Dumont, who became the wife of Belony Fougère, was descendant of a family bearing that name and having plantations at Jérémie. The La Forests living there to-day all have Negro blood.

VII

If Audubon had been the son of Louis XVI and Marie Antoinette, is it possible to believe that he would have been sent to Paris, probably in 1802, when the world had been "on fire with his pursuit," to study under Jacques Louis David, famous artist and Conventional regicide, who had voted to send his father to the guillotine, who had visited the son when a prisoner in the Temple, presumably with the intention of painting or drawing his portrait, and who had actually sketched the pathetic figure of his brave mother when on her way to the scaffold?

This reference to Marie Antoinette suggests another critical scene in the life of this young queen, who had grown old while still in her thirties. On that desolate winter morning of January 21, 1793, in Paris, in an upper room of the Templars' Tower, were gathered a stricken wife and mother, the Princess Elizabeth, familiarly known as "Aunt Babet," and the two royal children, Marie Thérèse Charlotte and Monsieur Charles, the Dauphin of France, in the presence only of their two watchdogs, the commissioners who were daily detailed from the Convention, and their faithful pantry boy, Turgy. In a set of significant questions that this last-named youth, when grown to manhood, sent to the spurious pretender "Charles de Navarre," in 1817, was this: "What took place on January 21, when the cannon were heard in that upper room? What did your aunt say at that instant, and what unusual thing was 


\section{lxxxii AUDUBON THE NATURALIST}

done for you?" No answer to these questions was ever received, and it is safe to say that not one of the numerous other claimants to having been that little boy-no more than John James Audubon, who at that very time, according to his own written statement, was under the roof of his father and devoted stepmother-could have met this test with any better success. Jean Jacques Fougère Audubon was not Louis Charles!

So far as anyone now knows, Turgy never answered his own query, but we may surmise that the mother and the aunt embraced the child, and said, perhaps, the traditional thing: "Louis Charles, the King, your father, is dead; long live the new King, his son!" Very likely they tried to explain to him the new position in which he and they were now placed. The Dauphin was then not quite eight years old, having been born on Easter Day, March 27, 1785. The boy Audubon was about a month younger.

I have stated a number of facts and circumstances which weigh strongly against the idea that Jean Jacques Fougère Audubon was Louis Charles, the Dauphin or Louis XVII, nominal King of France, but there is another consideration, that of physical marks upon the body, which, though seldom mentioned, is even more important and which ought definitely to settle the question. Those closest to the Dauphin knew of certain marks upon his body which, taken together, could identify him with absolute certainty. These were (1) vaccination marks on both arms; (2) a scar over the left eye, and another on the right side of the nose; and (3) a deformed right ear, which had its lower lobe excessively enlarged. The first two were unimportant, because they could be easily produced; Eleazar Williams or any other pretender might, and sometimes did, point to some such scars in the right places. But the deformed ear was another matter. That was a physical character which could not be imitated, and there was then no plastic surgery in France, or anywhere else, that could either produce or remove such a defect without trace. This deformity was not generally known, and it was probably actually known to 


\section{FOREWORD AND POSTSCRIP'T lxxxiii}

but very few, if any, outside the royal household, since the boy Dauphin, as seen in life and in his portraits, had always appeared with long locks, banged and hanging down over his ears, which they completely concealed. No doubt his fond parents were quite willing that his tresses should hide such a defect. It was a bodily mark which tripped many a brazen pretender in the eyes of the knowing.

Did anyone ever notice or know that John James Audubon's right ear was deformed? Not so far as is now known, and his numerous portraits give no suggestion of it. If Audubon's right ear was normal, as he and other artists represented it to be, he could not have been Louis Charles, the prince. Had he possessed such a deformity and been bound, under oath, as he said, not to reveal his identity, would he have consented to be shorn of his "ambrosial locks" in Edinburgh on March 19, 1827 ?

VIII

There is probably no parallel in history to the Dauphin racket, which began in France shortly after the reputed death of Louis Charles and lasted for the better part of a century, with reverberations still felt to this day. The causes that led to such an extraordinary succession of events do not seem to have been duplicated in either ancient or modern times.

Within five years after the death of the Dauphin, as recorded in the Temple's archives, seven boys all claiming to be Louis XVII had already come to the attention of the French police. Soon they kept bobbing up overnight, as Vogt says, like as many prairie dogs, here, there, and everywhere, and sometimes two were circulating in the country at the same time. Three who made such false claims lived at one time or another in the United States or Canada. Of one of these, Eleazar Williams, I shall speak later. The Dauphin's sister once remarked, when the impersonators of her lost brother had reached twenty-seven in number, that she believed every one of them to be spurious. Fifty years after the reputed death 


\section{Ixxxiv AUDUBON THE NATURALIST}

of Louis Charles, the number of those claiming to be, or who believed or imagined themselves to be, that prince had risen to forty, and some have estimated that the roll of false claimants by now has touched the seventy mark! They were an assorted collection of near-lunatics, unstable persons with delusions of grandeur or plain monomaniacs, mendacious liars, clever forgers, general swindlers or adventurers, and pious hypocrites. What did they expect to gain by such fraudulent claims? Probably not a diadem or kingly crown in most cases, but money and gifts of various sorts from the credulous, a share, perhaps, of the large private fortune of the sister of the Dauphin, and, above all, public acclaim and notoriety. The shrewdest forgers or the most consistent and accomplished liars often did obtain some of these things, such as jewels, coin of the realm, and a chance to live for a time at least in luxury. Several wrote fictitious memoirs, and many figured in the law courts, when they often drew fines and prison sentences. Their claims were usually thrown out of court, but if they were banished from France, they were almost certain to turn up again in the same rôle somewhere else.

Probably no boy in the world's history whose life, or that part of it about which anything is definitely known, extended to only ten years, two months, and two days, to follow the Temple record again, has had so many biographers, so many impersonators, or has been pronounced dead and buried so many times and in so many different places. Under such circumstances it is not surprising that the bibliography of this unfortunate prince has extended to extraordinary proportions. ${ }^{10}$ Over a hundred years after the reported death of the Dauphin, a monthly publication, Revue historique de la Question Louis XVII, was started in Paris in 1905, but seems to have run out of material in the course of five or six years. ${ }^{11}$

${ }^{10}$ See William W. Wight, who in his Louis XVII: A Bibliography (Boston, 1915) lists with annotations 478 titles, and these limited solely to material in his private library.

"According to Wight this began as a "monthly" in 1905, with but six issues, and these gradually diminished until there was but one issue in 1910 . 
Its editor began his address to prospective readers with a quotation from Renan. "I fear," said Renan, "that the work of the twentieth century will but consist of retrieving from the waste-basket a multitude of excellent ideas which the nineteenth century had heedlessly thrown away. The survival of Louis XVII, after leaving the prison of the Temple, is one of these ideas." This idea, which seemed so excellent to Renan, when put to the test, has proved to be sterile of practical results. This journal appears to have been intended to continue the work of an earlier publication, Bulletin de la Société d'Etudes sur la Question Louis XVII, which, according to Wight, was discontinued, after some change in name, in May, 1894.

There was a shrewd adventurer who suddenly appeared in France in 1830, coming apparently from nowhere and passing under the German name of Karl Wilhelm Naundorff, in recent times identified, though not with complete certainty, as Carl Benjamin Werg. After a long and checkered career he was thrown out of France and went to England, where he invented a bomb which was operated by clockwork. Failing to interest the English in his invention, he started for Holland in 1845 with a passport bearing the name of "Charles Louis de Bourbon." As he was detained at Rotterdam, the question of admitting him soon became one of international diplomacy between France and Holland. The Dutch appear to have wanted his bomb, but as they had little liking for Charles $\mathbf{X}$, the French King, the matter dragged over five months and ended in compromise. The French were willing to have the name "Charles Louis" appear in the document (the Dauphin's name having been Louis Charles), and for all they cared the bomb might be called the "Bourbon bomb," but they would not go a step farther. This was held, but on insufficient grounds, as a tacit admission that the Naundorff family was entitled to use the Bourbon name. The agreement was signed on June 20, 1845, and Naundorff, who had gone to Delft, was dead of typhoid fever less than two months later. 


\section{lxxxvi AUDUBON THE NATURALIST}

In 1851 the Naundorff family tried to get from the French Government an acknowledgment of their right to the use of the Bourbon name, but without success; they appealed against this verdict in 1874, but lost again. Finally, in 1911, the Naundorff descendants made a third attempt at having their claim of being scions and heirs of Louis XVI acknowledged in France, but were again denied, and there the matter now stands. Naundorff had neither the physiognomy nor the physical marks of the Dauphin, but many believed that he was rather better than the average run of pretenders. Minnegerode, whom I have followed in this statement of the Naundorff case, ${ }^{12}$ is undoubtedly right in saying that the admission wrung from France by the Dutch in $\mathbf{1 8 4 5}$ was one which no French court would for a moment have allowed. Nevertheless, Naundorff was buried with the honors of royalty at Delft, and his monument there bears this inscription: "Louis XVII, roi de France et de Navarre (Charles Louis duc de Normandie)." Only recently (July, 1937) the death was announced of one of Naundorff's descendants, most of whom had clung to the fiction of their Bourbon inheritance.

A much more difficult subject to understand than the Hervagaults, the Richemonts, or the Naundorffs is the psychology of an American pretender to royalty, Eleazar Williams, one-time missionary to the Indians. It is a pity that Gamaliel Bradford never psychographed him. He had no criminal record, but was a teacher among the Indians for many years, and Bishop Hobart, of New York, ordained him to the ministry of the Protestant Episcopal Church and baptised his Indian wife, giving her the name of Mary Hobart. Williams translated the Book of Common Prayer and numerous hymns into the Iroquois language, and at Green Bay, Wisconsin, started a school for half-breed Indian children. This was maintained until 1823, when he married one of his pupils. In 1839 Williams is said to have confided to a Buffalo editor that he was

${ }^{12}$ See Meade Minnigerode, The Son of Marie Antoinette: the Mystery of the Temple Tower (New York, 1934). 


\section{FOREWORD AND POS'TSCRIP'T Ixxxvii}

the real Dauphin of France, and ten years later an article, supposedly written or inspired by Williams himself, appeared in the United States Democratic Review, in which his definite claim to royalty was made public. Meanwhile Williams repeated his story to anyone who would listen, but the widespread notoriety after which he had evidently been striving came with the publication in Putnam's Monthly Magazine for February, 1853, of an article on "Have We a Bourbon among Us?" by the Rev. John Halloway Hanson. Hanson corresponded with Williams, visited him, and became such an enthusiastic supporter of his cause that he wrote his biography, in a volume of nearly five hundred pages which was published in 1855. Hanson was an idealist, without a particle of critical judgment, and, believing in the unimpeachable integrity of his hero, he accepted without question all of his yarns however amazing or impossible. I can relate but one of these stories, which came out in a conversation with Hanson, who said in effect: "Before you left the Temple, at the age of ten, you must have stored up in your mind many memory pictures of extraordinary events, some of which you will be able to recall. Now, I wish you would describe some of them." "A most remarkable fact," replied the self-styled Dauphin, "is that up to the age of thirteen or fourteen my mind was like a blank page: nothing was written on it. Consciousness seemed to be imperfect or entirely lacking, and at that early period I was practically an idiot. Then, this strange thing happened: one summer's day, when I was bathing with a number of Indian boys, my friends, in the waters of Lake George, in my foolish way I climbed a high rock over the water and dived. The shock rendered me unconscious, but my boy friends dragged me out, and when I was gradually restored to consciousness I was a changed person. My mind was restored to me, and the events, which had happened in my earlier years in Paris, came back. Pictures of soldiers and great personages were there, and there was a hard, cruel face, which I seemed to recognize with a start, when I suddenly came upon it in a steamboat or upon entering a 


\section{lxxxviii AUDUBON THE NATURALIST}

train. I think that what terrified me must have been a resemblance to my evil guardian of an early day, Simon the cobbler!" Intelligent people probably knew as well then as they do now that any sharp blow upon the head is not conducive to an improvement in mentality. The Reverend Mr. Hanson should have remembered the Old Testament proverb: "Though thou shouldest bray a fool in a mortar among wheat with a pestle, yet will not his foolishness depart from him."

Williams told Hanson that the Prince de Joinville, son of Louis Philippe, when in this country in 1841, came to Green Bay and tried to induce him to sign an abdication of his rights to the French throne. When this was denounced in France as a pure fabrication, Williams said to Hanson: "I do not trouble myself much about the matter. . . My story is on the wings of heaven, and will work its way without me. . . . God in His providence must have some mysterious ends to answer, or He would never have brought me so low from such a height. . . . I do not want a crown. I am convinced of my regal descent; so are my family. The idea of royalty is in our minds, and we will not relinquish it. You have been talking to a king tonight." They were then on a steamboat approaching Burlington, Vermont.

In concluding his article on "The Bourbon Question," the sequel to the one to which I have just referred, Hanson said: "To those who have charitably attributed to me the origination of a moon hoax ${ }^{13}$ to sell a magazine, or the credulity of adopting the baseless tale of a monomaniac, I reply . . . that I am content to leave the case to speak for itself, quite satisfied with the approbation of those, neither few, nor stupid, nor credulous, who entertain with me the strongest conviction of the high probability that beneath the romance of incidence there is here the rocky substratum of indestructible fact."

${ }^{13}$ Referring to the story in The Sun (New York) of August 25, 1835, sometimes called the greatest scientific fraud ever perpetrated, which purported to have been written by Sir John Herschel, but is now believed to have been the work of a clever reporter, Richard Adams Locke. 


\section{FOREWORD AND POSTSCRIPT lxxxix}

Eleazar Williams said that his story would work its way without him. It has, but it has taken a different course from that which he would have chosen, especially since the historians at the University of Wisconsin have made it their business to investigate his life history. It has been definitely established that Eleazar Williams was a half-breed Indian, son of Thomas Williams and Mary Ann Kenewatsenri. Thomas was a grandson of Eunice Williams, who was a daughter of John Williams, minister at Deerfield, Massachusetts. She was captured in 1784 in a French and Indian raid, was married to an Indian chief of Caughnawaga, and her descendants all took the Williams name. In 1824 Eleazar gave Sault S. Louis (Caughnawaga, Canada) as his birthplace, but he publicly maintained the fiction of being the French Dauphin up to his death in 1858.

Eleazar Williams stands in a class by himself among the better-known pretenders to royalty in relation to Louis Charles. Why did this minister and missionary worker choose to lead a life of duplicity? His dishonesty brought him no monetary rewards. His greatest weakness seems to have been an inordinate vanity. His bold claims and those of his credulous friends, who could not have known him any too well, made him a marked man, and wherever he went interest in him was aroused. If he preached in a country church, that was an event to be remembered. In a recently published work on old Historic Churches of America there is pictured a church at Longmeadow, Massachusetts, "with which," it was stated, "is associated the romantic story of Eleazar Williams, believed by many to have been Louis XVII of France."

What shall be said of the conjectures of Mrs. Tyler on this crude Williams hoax? "There is a persistent rumor in Canada," says Mrs. Tyler, "that the Dauphin lived there. When a legend of this kind lives through a century, it usually has some basis in fact, as is now seen [the basis being that Audubon was Louis XVII, and was secretly taken to Canada when eleven years old]. And this may even account for the story of the 'mythical Williams boy,' who was a missionary to 
the Indians, for Audubon's religious life was deeply spiritual, and he may have used his stay in Canada to this end; and the Williams boy's mother, Mrs. Williams, is reputed to be the indomitable and indefatigable Lady Atkyns, who gave Marie Antoinette her pledge that she would never stop till she had saved her son, Louis 17th. It may be that Lady Atkyn's pledge was thus fulfilled."

What a strange dénouement! Audubon, at the age of eleven, giving spiritual comfort to North American Indians, whom he had never seen, in "Selkirk's Settlements," which did not then exist, and in a country which he had never visited! What, I wonder, would Lady Atkyns-Walpole born, whose husband had been a Norfolk baronet-have thought, after all her money had been thrown to the winds in a vain, if worthy, cause, of being reputed the mother of a half-breed American Indian, and a pious impostor at that? Would not the ardent biographer of that "Williams boy," who protested that he was not starting a moon hoax, be equally surprised to know how much moonshine there was in his whole story?

Audubon's life was romantic enough. He does not need any false halo of royalty. He can stand on his own feet. 


\section{AUDUBON \\ T H E \\ NATURALIST}

VOLUME I 
Nothing extenuate,

Nor set down aught in malice. . . .

Shakespeare, Othello to his biographers.

Time, whose tooth gnaws away everything else, is powerless against truth.

\section{Huxley.}

What a curious, interesting book, a biographer, well acquainted with my life, could write; it is still more wonderful and extraordinary than that of my father.

Audubon, in letter to his wife, March 12, 1828. 


\section{AUDUBON \\ THE \\ NATURALIST}

\section{CHAP'TER I}

\section{INTRODUCTION}

Audubon's growing fame-Experience in Paris in 1828-Cuvier's patronage-Audubon's publications-His critics-His talents and accomplishments-His Americanism and honesty of purpose-His foibles and faults-Appreciations and monuments-The Audubon SocietiesBiographies and autobiography-Robert Buchanan and the true history of his Life of Audubon.

It is more than three-quarters of a century since Audubon's masterpiece, The Birds of America, was completed, and two generations have occupied the stage since the "American Woodsman" quietly passed away at his home on the Hudson River. These generations have seen greater changes in the development and application of natural science and in the spread of scientific knowledge among men than all those which preceded them. Theories of nature come and go but the truth abides, and Audubon's "book of Nature," represented by his four massive volumes of hand-engraved and hand-colored plates, still remains "the most magnificent monument which has yet been raised to ornithology," as Cuvier said of the parts which met his astonished gaze in 1828; while his graphic sketches of American life and scenery and his vivid portraits of birds, 
drawn with the pen, can be read with as much pleasure as when the last volume of his Ornithological Biography left the press in 1839. This appears the more remarkable when we reflect that Audubon's greatest working period, from 1820 to 1840 , belonged essentially to the eighteenth century, for the real transition to the nineteenth century did not begin in England before 1837; then came the dawn of the newer day that was to witness those momentous changes in communication and travel, in education, democracy and ideas, which characterize life in the modern world.

When Audubon left London for Paris on September 1, 1828, it took him four days by coach, boat and diligence to reach the French capital, a journey which in normal times is now made in less than eight hours. Mail then left the Continent for England on but four days in the week, and to post a single letter cost twentyfour sous. Writing at Edinburgh a little earlier (December 21, 1826), Audubon recorded that on that day he had received from De Witt Clinton and Thomas Sully, in America, letters in answer to his own, in fortytwo days, and added that it seemed absolutely impossible that the distance could be covered so rapidly. This was indeed remarkable, since the first vessel to cross the Atlantic wholly under its own steam, in 1838, required seventeen days to make the passage from New York to Queenstown.

"Walking in Paris," said Audubon in 1828, "is disagreeable in the extreme; the streets are paved, but with scarcely a sidewalk, and a large gutter filled with dirty black water runs through the middle of each, and people go about without any kind of order, in the center, or near the houses." The Paris of that day contained but one-fourth the number of its present population. 
Having reaped the fruits of the Revolution, it was enjoying peace under the Restoration; moreover, it was taking a leading part in the advancement of natural science, of which Cuvier was the acknowledged dean. It was but a year before the death of blind and aged Lamarck, neglected and forgotten then, but destined after the lapse of three-quarters of a century to have a monument raised to his memory by contributions from every part of Europe and America, and to be recognized as the first great evolutionist of the modern school.

Audubon had not seen his ancestral capital for upwards of thirty years, not since as a young man he was sent from his father's home near Nantes to study drawing in the studio of David, at the Louvre. Though in the land of his fathers and speaking his native tongue, his visit was tinged with disappointment. At the age of forty-three he was engaged in an enterprise which stands unique in the annals of science and literature. But fifty plates, or ten numbers, of his incomparable series had been engraved, and this work had then but thirty subscribers. That he was bound to sink or swim he knew full well. On August 30 he wrote: "My subscribers are yet far from enough to pay my expenses, and my purse suffers severely from want of greater patronage." This want he had hoped to satisfy in France, but after an experience of eight weeks, and an expenditure, as he records, of forty pounds, he was obliged to leave Paris with only thirteen additional names on his list. Yet among the latter, it should be noticed, were those of George Cuvier, the Duke of Orleans and King Charles $\mathbf{X}$, while six copies had been ordered by the Minister of the Interior for distribution among the more important libraries of Paris. Moreover, he had won the friendship and encomiums of 
Cuvier, which later proved of the greatest value. The savants who gathered about him at the meeting of the Royal Academy of Sciences, over which Cuvier presided, exclaimed, "Beautiful! Very beautiful! What a work!", but "What a price!", and acknowledged that only in England could he find the necessary support. Audubon concluded that he was fortunate in having taken his drawings to London to be engraved, for the smaller cost of copper on that side of the Channel was an item which could not be overlooked. Little did he dream that commercial greed for the baser metal would send most of his great plates to the melting pot half a century later. No doubt he was right also in concluding that had he followed certain advisers in first taking his publication to France, it would have perished "like a flower in October." It should be added that King Charles' subscription expired with his fall two years later, while that of Cuvier ended with his death in 1832.

Audubon was one of those rare spirits whose posthumous fame has grown with the years. He did one thing in particular, that of making known to the world the birds of his adopted land, and did it so well that his name will be held in everlasting remembrance. His great folios are now the property of the rich or of those fortunate institutions which have either received them by gift or were enrolled among his original subscribers, and wherever found they are treasured as the greatest of show books. The sale of a perfect copy of the Birds at the present day is something of an event, for it commands from $\$ 3,000$ to $\$ 5,000$, or from three to five times its original cost. All of Audubon's publications have not only become rare but have increased greatly in price; they are what dealers call a good investment, an experi- 
ence which probably no other large, illustrated, scientific or semi-scientific works have enjoyed to a like degree.

As has been said of Prince Henry the Navigator, though in different words, John James Audubon was one of those who by a simple-hearted life of talent, devotion and enthusiasm have freed themselves from the law of death. Audubon was a man of many sides, and his fame is due to a rare combination of those talents and powers which were needed to accomplish the work that he finally set out to do. His personality was most winning, his individuality strong, and his long life, bent for the most part to attain definite ends, was checkered, adventurous and romantic beyond the common lot of men.

Few men outside of public life have been praised more lavishly than Audubon during his active career. Though he had but few open enemies, those few, as if conscious of the fact, seemed to assail him the more harshly and persistently. In reading all that has been said about this strenuous worker both before and since his death, one is continually struck by the perverse or contrary opinions that are often expressed. He was not this and he was not that, but he was simply Audubon, and there has been no one else who has at all closely resembled him or with whom he can be profitably compared. One charges that he did not write the books which bear his name. Another complains that he was no philosopher, and was not a man of science at heart; that he was vain, elegant, inclined to be selfish, inconsequential, and that he reverenced the great; that he shot birds for sport; that he was a plagiarist; that he was the king of nature fakirs and a charlatan; that he never propnunded or answered a scientific question; and, 
finally, that though at times he wrote a graphic and charming style and showed occasional glimpses of prophetic insight, he cannot be trusted; besides, he might have been greatly indebted to unacknowledged aid received from others.

These or similar charges were brought against Audubon during his lifetime, as they have been made against many another who has emerged quickly from obscurity into world-wide renown. Many attacks upon his character were assiduously repelled by his friends, though seldom noticed publicly by himself; as if conscious of his own integrity, he was content to await the verdict of time, and time in America has not been recreant to his trust. Some of these charges it majy be necessary to examine at length, if found to be justified in any degree, while others may be brushed aside as unworthy of even passing consideration. Evidence of every sort is now ample, as it seems, to enable us to do justice to all concerned, to penetrate the veil that has hidden much of the real Audubon from the world, and to place the worker and the man in the fuller light of day.

The reader who follows this history may expect to find certain blemishes in Audubon's character, for the most admirable of men have possessed faults, whether conscious of them or not. The lights in any picture would lose all value were the shadows wholly withdrawn. If we blinded ourselves to every fault and foible of such a man, we might produce a sketch more pleasing to certain readers, but it would lack the vitality which truth alone can supply. The more carefully his character is studied, however, as Macaulay said of Addison, the more it will appear, in the language of the old anatomists, "sound in the noble parts, free from all 
taint of perfidy, of cowardice, of cruelty, of ingratitude, of envy."

In this attempt to present a true and unbiased estimate of Audubon in relation to his time, we have the advantage of dealing with a well rounded and completed life, not with a broken or truncated one. He impressed many of his contemporaries in both Europe and America with the force of his contagious enthusiasm and prolific genius, and their opinions have been recorded with remarkable generosity. On the other hand, "if a life be delayed till interest and envy are at an end," said an excellent authority, "we may hope for impartiality, but must expect little intelligence," because the minute details of daily life are commonly so volatile and evanescent as to "soon escape the memory, and are rarely transmitted by tradition." Such details, which often reveal character while they add color and life to the narrative, have been amply supplied, as the reader will find, by Audubon himself, not only in his journals and private letters already published but in the numerous documents of every sort that are now brought to light.

If "the true man is to be revealed, if we are to know him as he was, and especially if we are to know the influences that molded him and so profoundly affected him for good or evil, we must begin at the beginning and follow him through his struggles, his temptations, his triumphs." It might be better to start "in the cradle," or even forty years kefore he was born, for, as modern biology teaches us, nature is stronger than nurture and race counts for much. Certainly this man can never be understood if removed from the environment which time and circumstance gave him; he needs

\footnotetext{
${ }^{1}$ Samuel Johnson, The Rambler, No. 60.
} 
the historical background, furnished in part by his contemporaries, some of whom were rivals with whom he had often to struggle to make his way. In recounting this history, in many cases hitherto unwritten, we must recognize the proverbial difficulty of tracing human motives to their proper source, and endeavor to form no harsh judgments without ample basis in documentary or other evidence.

No more ardent and loyal American than John James Audubon ever lived. His adopted country, which he would fain have believed to have been that of his actual birth, was ever his chief passion and pride, and for him the only abode of sweet content. Few have seen more of it, of its diversified races, climates and coasts, its grand mountains, its noble lakes and rivers, its virgin forests and interminable prairies, with all the marvelous stores of animal and plant life which were first truly revealed to the pioneer woodsman, artist and naturalist. None has been more eager to hand down to posterity, ere it be too late, a true transcript of its wild and untameable nature while, as he would say, still fresh from the Creator's own hand. Audubon's beneficent influence during his long enforced residence abroad, as a representative of American energy and capacity, can hardly be measured, while in his own land few were more potent in bringing the nation to a consciousness of its unique individuality and power.

Audubon, as has been said, saw nature vividly colored by his own enthusiasm, and he never looked at her "through the spectacles of books." His writings, however unpolished or written with whatever degree of speed, have the peculiar quality of awakening enthusiasm in the reader, who, like the youth poring over 
Robinson Crusoe, feels within him a new ardor, in this instance, for hunting and studying birds and for leading a life of adventure in the wilderness. It would be as unjust to judge of Audubon's rare abilities as a descriptive writer from the letters, journal jottings and miscellaneous extracts given in this work, as to weigh his accomplishments as an artist from his itinerary portraits or his early sketches of animals in crayon point and pastel. Those cruder products of his pen and brush, however, as the reader will find, possess a high degree of interest from the light which they throw on the development of his character and art, as well as from their personal and historical associations. His best and only finished literary work, the Ornithological Biography, in five large volumes, with the revisions and additions which later appeared, abound in animated pictures of primitive nature and pioneer life in America as well as vivid portraits of the birds and other characteristic animals.

A good illustration of Audubon's habit of blending his own experiences with his biographies of birds is found in the introduction to his account of the Common Gannet:

On the morning of the 14th of June 1833, the white sails of the Ripley were spread before a propitious breeze, and onward she might be seen gaily wending her way towards the shores of Labrador. We had well explored the Magdalene Islands, and were anxious to visit the Great Gannet Rock, where, according to our pilot, the birds from which it derives its name bred. For several days I had observed numerous files proceeding northward, and marked their mode of flight while thus travelling. As our bark dashed through the heaving billows, my anxiety to reach the desired spot increased. At length, about ten o'clock, we discerned at a distance a white 
speck, which our pilot assured us was the celebrated rock of our wishes. After a while I could distinctly see its top from the deck, and thought that it was still covered with snow several feet deep. As we approached it, I imagined that the atmosphere around was filled with flakes, but on my turning to the pilot, who smiled at my simplicity, I was assured that nothing was in sight but the Gannets and their island home. I rubbed my eyes, took up my glass, and saw that the strange dimness of the air before us was caused by the innumerable birds, whose white bodies and black-tipped pinions produced a blended tint of light-grey. When we had advanced to within half a mile, this magnificent veil of floating Gannets was easily seen, now shooting upwards, as if intent on reaching the sky, then descending as if to join the feathered masses below, and again diverging toward either side and sweeping over the surface of the ocean. The Ripley now partially furled her sails, and lay to, when all on board were eager to scale the abrupt side of the mountain isle, and satisfy their curiosity. ${ }^{2}$

Audubon's accounts of the birds are copious, interesting and generally accurate, considering the time and circumstances in which they were produced. When at his best, his pictures were marvels of fidelity and close observation, and in some of his studies of mammals, like that of the raccoon (see p. 182), in which seemingly every hair is carefully rendered, we are reminded of the work of the old Dutch masters and of Albrecht Dürer; notwithstanding such attention to microscopic detail, there is no flatness, but the values of light and shade are perfectly rendered. In his historical survey of American ornithology, Elliott Coues was fully justified in designating the years 1824-1853 as representing the "Audubonian Epoch," and the time from 1834 to its close as the "Audubonian Period." "The splendid

${ }^{2}$ Oinithological Biography (Bibl. No. 2), vol. iv, p. 222. 
genius of the man, surmounting every difficulty and discouragement of the author, had found and claimed its own. ... Audubon and his work were one; he lived in his work, and in his work will live forever.'

There is no doubt that Audubon regarded an honest man as the quintessence of God's works, and though he sometimes set down statements which do not square with known facts, this was often the result of lax habits, or of saying what was uppermost in his mind without retrospection or analysis. When memory failed or when more piquancy and color were needed, he may have been too apt to resort to varnish, but for everything written on the spot his mind was as truth-telling as his pictures. In considering the good intent of the man, his extraordinary capacity for taking pains, and his vast accomplishments, criticism on this score seems rather captious. On the other hand, when it came to dealing with his own early life, that was a subject upon which he reserved the right to speak according to his judgment, and in a way which will be considered later.

Audubon left England to settle his family finally in America in the summer of 1839, when he was fiftyfour years old, and since he lived but twelve years longer, probably few are now living who retain more than a childish memory of his appearance in advanced age. Many Londoners will recall an odd character, an aged print dealer who used to sit alone, like a hoary spider in its web, in his little shop in Great Russel Street, close to the British Museum, and another of similar type, who may still haunt a better known landmark, the old "naturalist's shop" in Oxford Street, not far from Tottenham Court Road and but a min1890).

${ }^{3}$ Elliot+ Coues, Key to North American Birds, 4th ed., p. xxi (Boston, 
ute's walk from the spot where most of Audubon's Birds were engraved. Both had seen the naturalist walk the streets of London and had known him in business relations. He occasionally strolled into the old naturalist's shop, which has been occupied by father and son for nearly a century. The son, then a young clerk, is now (1913) the crabbed veteran who still waits on customers but never waits long; should you hazard a question before making a purchase, he will roar like the captain of a ship and leave you to your own devices; but show him money and the change in his demeanor is wonderful; his hearing improves, his tone softens, and he may recount for you what he remembers of times long past, which is not much. Audubon in the thirties seemed to him like an aged man, an impression quite natural to a youth. He also remembered seeing Charles Waterton, Audubon's declared enemy and supercilious critic, William Swainson, his one-time friend, and William MacGillivray, his eminent assistant; that they were great rivals expressed the sum of his reflections. He recalled the time when Oxford Street was filled, as he expressed it, with horses and donkeys, and of course knew well the old Zoölogical Gallery, No. 79 Newman Street, in which for a time Robert Havell \& Son conducted a shop in connection with their printing and engraving establishment. The latter, when moved by Robert Havell, Jr., to No. 77 Oxford Street, was nearly opposite the old Pantheon, which still lingers, and not far from the corner of Wrisley Street, the present site of Messrs. Waring \& Gillow's large store.

We already possess several biographies of Audubon, and many of his letters of a personal or scientific interest and most of his extant journals, though but a 
fraction of those which originally existed, have been published. "America, my Country," has not forgotten him. Mount Audubon rises on the northerly bound of Colorado as an everlasting reminder of the last and grandest of all his journeys, that to the Missouri River in 1843. American counties and towns, ${ }^{4}$ as well as parks and streets in American cities, bear his name. At least four of his beloved birds have been dedicated to him. In 1885, thirty-four years after his death, the New York Academy of Sciences began a popular movement through which a beautiful cross in marble was raised in 1893 above his grave in Trinity Cemetery. ${ }^{5}$ 'The "one hundred and twenty-fifth anniversary" " ${ }^{6}$ of the naturalist's birth was celebrated in New York in 1905, and at

${ }^{4}$ Audubon, in Audubon County, Iowa, in Beeker County, Minnesota, and in Wise County, Texas, as well as Audubon, Montgomery County, Pennsylvania, in which his old farm, "Mill Grove," is situated. Audubon Avenue is the first of the subterranean passages which lead from the entrance of Mammoth Cave, and is noted for its swarms of bats. Audubon Park, New York City, between the Hudson River and Broadway and extending from 156th, to 160 th Streets, embraces a part of "Minnie's Land," the naturalist's old Hudson River estate, but is a realty designation and is now almost entirely covered with buildings (see Chapter XXXVI).

${ }^{5}$ The Audubon Monument Committee of the New York Academy of Sciences was appointed October 3, 1887, and made its final report in 1893, when this beautiful memorial was formally dedicated. Subscriptions from all parts of the United States amounted to $\$ 10,525.21$. The monument is a Runic cross in white marble, ornamented with American birds and mammals which Audubon has depicted, and surmounts a die bearing a portrait of the naturalist, modeled from Cruikshank's miniature, with suitable inscriptions, the whole being supported on a base of granite; the total height is nearly 26 feet, and the weight 2 tons. It was presented to the Corporation of Trinity Parish by Professor Thomas Eggleston, and received by Rev. Dr. Morgan Dix. The cemetery has since been cut in two by the extension of Broadway; the monument is in the northerly section, close to the parish house of the Chapel of the Intercession.

The monument at New Orleans, mentioned below, was erected under the auspices of the Audubon Association, at a cost of $\$ 10,000$, most of which was secured through the efforts of Mrs. J. L. Bradford, $\$ 1,500$ having been contributed by residents of the Crescent City. The figure is in bronze, and stands on a high pedestal of Georgia granite.

The beautiful bust of Audubon at the American Museum of Natural History is by William Couper, of Newark, N. J.

${ }^{6}$ As will later appear, this was in reality the 120th anniversary. 
the American Museum of Natural History an admirable marble bust of Audubon was unveiled on a notable occasion, December 29, 1906, when similar honors were paid to Louis Agassiz, Spencer Fullerton Baird, Edward Drinker Cope, James Dwight Dana, Benjamin Franklin, Joseph Henry, Joseph Leidy, John Torrey, and Alexandcr von Humboldt. On November 26, 1910, a statue of Audubon, after an admirable design by the veteran sculptor, Edward Virginius Valentine, of Richmond, Virginia, was unveiled in Audubon Park, New Orleans, where the naturalist, with pencil in hand, is represented in the act of transferring to paper the likeness of a favorite subject. He also occupies a niche in the Hall of Fame at New York University.

In recent times Audubon's name has become a household word through the medium of the most effective instrument which has yet been devised for the conservation of animal life in this or any country, the National Association of Audubon Societies for the Protection of Wild Birds and Animals. This has become the coördinating center for the spread and control of a great national movement that received its first impulse in $1886 .^{7}$ Launched anew ten years later, it has advanced

${ }^{7}$ The first Audubon Society, devoted to the interests of bird protection, was organized by Dr. George Bird Grinnell, editor of Forest and Stream, in 1886, and 16,000 members were enrolled during the first year; Dr. Grinnell was also the father of the Audubonian Magazine (see Bibliography, No. 190), which made its first appearance in January, 1887; by the middle of that year the membership in the new society had increased to 38,000 , but with the disappearance of the Magazine in 1889 the movement languished and came to a speedy end. In 1896 a fresh start was taken by the inauguration of State societies in Massachusetts and Pennsylvania, and the movement gathered greater force through the inauguration in 1899 of the admirably conducted magazine, Bird-Lore, as its official organ. The State societies were federated in 1902, and the National Committee then created gave place in 1905 to the National Association. See Gilbert Trafton, Bird Friends, for an excellent summary of the work of the Audubon Societies, and the "Twelfth Annual Report of the National Association of Audubon Socirties," Bird-Lore, vol. xviii (1916). 


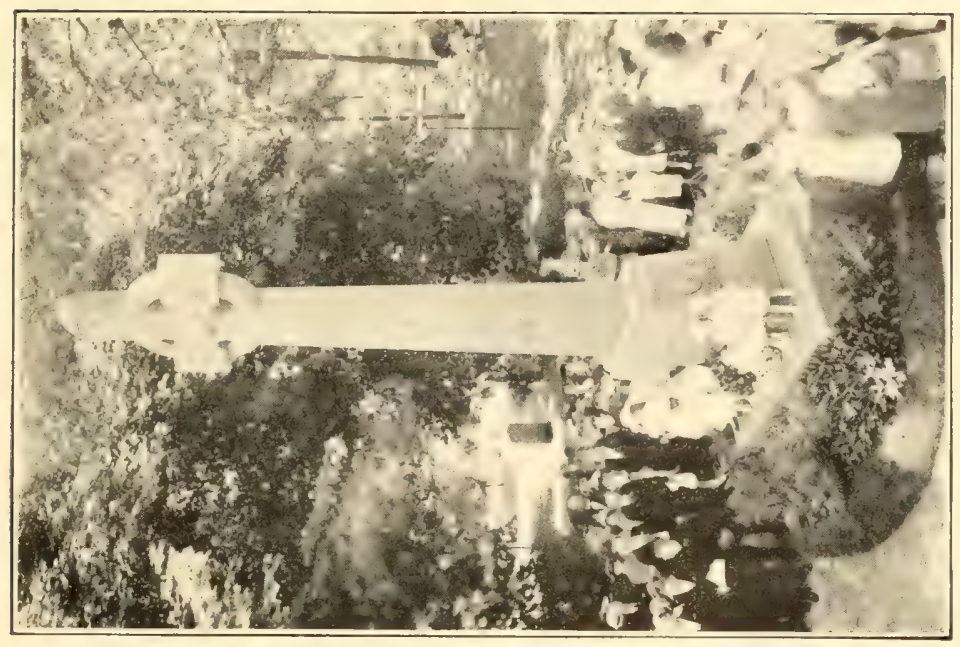

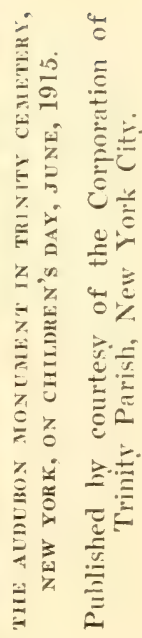
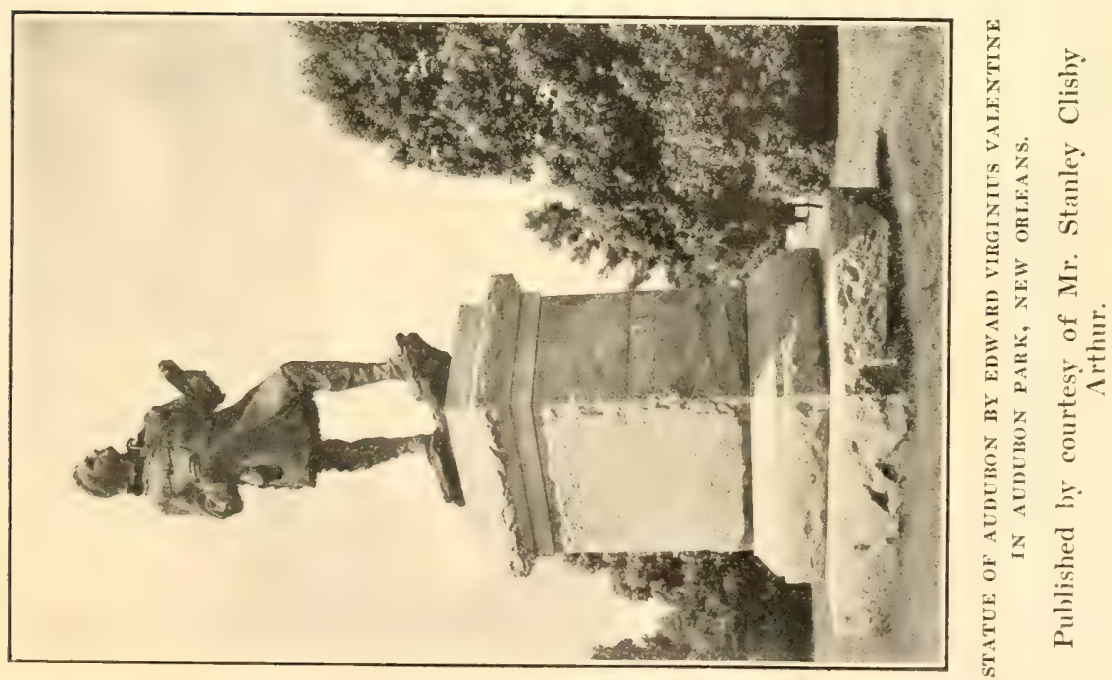

with ever increasing momentum, until now it is the governing head of twenty-nine distinct State societies, as well as eighty-five affiliated clubs and similar organizations. In 1916 it counted a life membership of 356, with 3,024 sustaining members, and realized a total income of over $\$ 100,000$. It should be added that during the past six years over 2,900 Junior Audubon Clubs have been formed in the schools, through which nearly 600,000 children have been instructed in the principles of the Audubon Society. Well may it be that this admirable organization, with its successful efforts for remedial legislation in state and nation; its initiative, with the aid of the National Government, in establishing Federal reservations or sanctuaries for the perpetuation of wild life; its educational activities through the extension of its influence to the pupils of the public schools; and its watch and ward over all the varied interests of its cause, will keep the name of Audubon greener to all future time than the most cherished of his works.

Of Audubon's works the public now sees but little and knows even less, all without exception having been long out of print. His admirable plates of birds and mammals have been widely copied and still serve for the illustration of popular books, but most of his publications were projected on too large and expensive a scale for general circulation, having been first sold to subscribers only and often at great cost. No complete reprint, revision or abridgment of his principal volumes has been made for half a century (see Bibliography, Appendix V). No complete bibliography of Audubon has ever been prepared, and none will remain completed long, for it is hard to imagine a time when comment on his life, his drawings, and his adventures will altogether cease. 
In May, 1834, William MacGillivray, who was assisting him in the technical parts of the Ornithological Biography, suggested that Audubon write a biography of himself, and predicted a wide popularity for such a work. Audubon entertained the idea but was then too deeply immersed in The Birds of America to give it much attention; yet in $\mathbf{1 8 3 5}$ he wrote out a short sketch, entitled Myself, addressing it in the fashion of that day to his two sons, and then laid it aside. Mrs. Audubon evidently had access to this manuscript when the life of her husband, to be referred to later, was in course of preparation, and thus it has furnished, directly or indirectly, nearly all that has been published concerning the naturalist's early life. This fragment, which extends to about thirty printed pages, was characterized by Audubon as a "very imperfect (but perfectly correct) account of my early life," and though written with an eye to its possible publication, which was clearly sanctioned, it was evidently never revised. The manuscript was long lost but eventually was "found in an old book which had been in a barn on Staten Island for years"; it was first published by the naturalist's granddaughter, Miss Maria R. Audubon, in 1893, and again in 1898. As will later appear, this account is inaccurate in many important particulars.

Audubon expressed the intention of extending his personal history, which he promised to delineate with a faithfulness equal to that bestowed on the birds, but the task was never resumed. Yet more than most writers have done, he wove the incidents of his own career into the pages of his principal works, and this strong personal flavor added much to their charm. Unfortunately, in giving such personal or historical details he is most vulnerable to a critic, who insists first upon 
accuracy, for errors of various sorts and confused and conflicting statements are far too common.

Of the more formal biographies of Audubon, the first to appear was a slender volume entitled $A$ udubon: the Naturalist of the New World, by Mrs. Horace Stebbing Roscoe St. John, published in England in 1856. In the same year this work was expanded and reissued by the publishers who at that time had charge of the sale of Audubon's works in America. ${ }^{9}$ The American publishers explained in their edition that inasmuch as "the fair authoress in preparing her interesting sketch of Audubon ... appears not to have been aware of the publication of his second great work, the Quadrupeds of North America (which had not been advertised, we believe, in Europe) they have taken the liberty of giving some account of it and making numerous extracts from its pages." 10 Perhaps the most interesting or valuable things in this little volume at the present day are the woodcut on the title page showing Audubon's house on the Hudson as it then appeared, surrounded by tall trees, and, inserted on a flyleaf, a list of all of Audubon's published works and the prices at which they could be procured in New York just prior to the Civil War (see Note, Vol. II, p. 204).

${ }^{8}$ In this year Charles Lanman, writer, and at a later time librarian of the Library of Congress, wrote to Victor Audubon as follows: "Are not you and your family willing now to let me write a book about your illustrious father? I feel confident that I could get up something very interesting and which would not only help the big work, but make money. I could have it brought out in handsome style, and should like to have well engraved a portrait and some half dozen views in Kentucky, Louisiana, and on the Hudson. Write me what you think about it." Lanman's letter is dated "Georgetown, D. C., Oct. 8, 1856"; on November 1 Victor Audubon replied, declining the proposal.

${ }^{9}$ Messrs. C. S. Francis \& Company, of 554 Broadway, New York.

${ }^{10}$ The publishers in this instance do not appear to have been better informed, for the text of the Quadrupeds, from which they quote, was written by John Bachman, and the first volume of it was issued in London in 1847; see Bibliography, No. 6. 
In 1868 there appeared in England a work of combined and confused authorship, commonly referred to as "Buchanan's Life of Audubon," the "sub-editor," as he called himself, having since become better known as an original, skilled and prolific writer of verse, drama, fiction and literary criticism. At that time Robert Buchanan was twenty-six years old, and had published five volumes of poems in rapid succession, some of which had been received with favor by the public. A second and third edition of this Life followed in 1869. Finally the work was resurrected and again sent to press, unrevised, in 1912, when it appeared in "Everyman's Library," at a shilling a copy, with an introduction which had served as a review of the work in 1869 .

A recent biographer of Alexander Wilson speaks of Buchanan as "commissioned by Mrs. Audubon to write her husband's life," but the lady herself, as well as Buchanan, has told a different story. It seems that in about the year 1866, Mrs. Audubon prepared, "with the aid of a friend," an extended memoir of her husband, which was offered to an American publisher but without success. The "friend," at whose home Mrs. Audubon was then living, was the Rev. Charles Coffin Adams, ${ }^{11}$ rector of St. Mary's Church, Manhattanville, now 135th, Street, New York. The Adams manuscript; which consisted chiefly of a transcript from the naturalist's journals, then in possession of his wife, was completed presumably in $\mathbf{1 8 6 7}$. In the summer of that year it was placed in the hands of the London publishers,

${ }^{11}$ Rev. Dr. Adams was rector of this parish for twenty-five years, from 1863 to his death in February, 1888; he was the author of three volumes on religious subjects and various smaller tracts; from 1855 to 1863 he had charge of a church in Baltimore, Maryland, and while there published an anonymous pamphlet entitled "Slavery by a Marylander; Its Institution and Origin; Its Status Under the Law and Under the Gospel" (8 pp. 8vo. Baltimore, 1860). 
Messrs. Sampson Low, Son, \& Marston, who without any authority turned it over to one of their hard-pressed, pot-boiling retainers, Robert Buchanan, poet and young man of genius. Buchanan boiled down the original manuscript, as he said, to one-fifth of its original compass, cutting out what he regarded as prolix or unnecessary and connecting "the whole with some sort of a running narrative." 12 Mrs. Audubon was unable to recover her property from either publishers or editor or to obtain any satisfaction for its unwarranted use. Whatever defects the Adams memoir may have possessed, this is much to be regretted, since, as her granddaughter has said, Mrs. Audubon had at her command many valuable documents, the originals of which have since been destroyed.

Buchanan, like Audubon, had been reared in comparative luxury, "the spoiled darling of a loving mother." After the failure of his father in various newspaper enterprises about four years before this time, he had gone up to London with but few shillings in his pocket and had begun life there literally in a garret. The reflection that Audubon had fought a similar but much harder battle in that same London thirty years before, and won, should possibly have awakened in him a somewhat friendlier spirit than was then displayed. It must be admitted, however, that Buchanan produced a very readable story, although there was not a word in his whole book which showed any real sympathy with

${ }^{12}$ Buchanan said that the manuscript submitted to him was inordinately long and needed careful revision; he added that "while he could not fail to express his admiration for the affectionate spirit and intelligent sympathy with which the friendly editor discharged his task, he was bound to say that his literary experience was limited." After copying a passage from one of Audubon's journals, this editor had the unfortunate habit of drawing his pen through the original; in this way hundreds of pages of Audubon's admirable "copper-plate" were irretrievably defaced. 
Audubon's lifelong pursuits, any knowledge of ornithology, or any interest in natural science. Though expressing unbounded admiration for the naturalist, his foibles and faults seem to have hidden from this biographer the true value of his distinguished services. In respect to a knowledge of natural history it should be added that Buchanan laid no claims, and of Audubon's accomplishments in this field comparatively little was said, the book, like the Adams' manuscript from which it was drawn, being mainly composed of extracts from the naturalist's private journals and "Episodes," as he called his descriptive papers. It was here that Audubon made the strongest appeal to this literary editor, who concluded his preface with the following words of praise: "Some of his reminiscences of adventure . . s seem to me to be quite as good, in vividness of presentment and careful colouring, as anything I have ever read."

Buchanan dilated on Audubon's pride, vanity and self-conceit, faults which may have belonged to his youth but which were never mentioned by his intimate friends and contemporaries except under conditions which reflected rather unfavorably upon themselves. Complaints on this score were spread broadcast by reviewers of this work, seventeen years after the naturalist's death and with the suddenness of a new discovery. They were undoubtedly based on the unconscious and allowable egotisms of such personal records as Audubon habitually made for the members of his family when time and distance kept them asunder. Vanity and selfishness could have formed no essential parts of a character that merited the eulogy which follows:

Audubon was a man of genius, with the courage of a lion and the simplicity of a child. One scarcely knows which to 
admire most-the mighty determination which enabled him to carry out his great work in the face of difficulties so huge, or the gentle and guileless sweetness with which he throughout shared his thoughts and aspirations with his wife and children. He was more like a child at the mother's knee, than a husband at the hearth-so free was the prattle, so thorough the confidence. Mrs. Audubon appears to have been a wife in every respect worthy of such a man; willing to sacrifice her personal comfort at any moment for the furtherance of his great schemes; ever ready to kiss and counsel when such were most needed; never failing for a moment in her faith that Audubon was destined to be one of the great workers of the earth. ${ }^{13}$

No one will deny, however, that Buchanan was right in saying that in order to get a man like Audubon understood, all domestic partiality, the bane of much biography, must be put aside; but it is equally important to make such allowances as the manifold circumstances of time and place demand, and to be a reasoner rather than a fancier. This work abounds in errors, but it is not clear to what extent they were due to carelessness on Buchanan's part.

It was certainly a mistake to attribute Buchanan's attitude to partiality for Alexander Wilson, who, like himself, was a Scotchman. It was a case of temperament only, for gloom and poverty had embittered his life. As his sister-in-law and biographer ${ }^{1+}$ said of him, "he was doomed to much ignoble pot-boiling. . . . He had few friends and many enemies," and "had received from the world many cruel blows," while "no man needed kindness so much and received so little." Per-

${ }^{13}$ Robert Buchanan, The Life of Audubon (Bibl. No. 72), p. vi.

${ }^{14}$ See Harriet Jay, Robert Buchanan: Some Account of His Life, His Life's Work, and His Literary Friendships (London, 1903). Robert Williams Buchanan was born at Caverswell, Lancashire, August 18, 1841, and died in London, June 10, 1901. 
haps the best key to the sad history of this able writer was given by himself when he said: "It is my vice that I must love a thing wholly, or dislike it wholly." His wife, we are told, was much like himself, and "like a couple of babies they muddled through life, tasting of some of its joys, but oftener of its sorrows." Undoubtedly Robert Buchanan was a genuine lover of truth and beauty; he has written numerous sketches of birds and outdoor scenes, but with no suggestion of nature as serving any other purpose than that of supplying a poet with bright and pleasing images.

It was with the purpose of correcting the false impressions created by animadversions in Buchanan's Life that Mrs. Audubon, with the aid of her friend, James Grant Wilson, revised this work and published it in America under her name as editor, in 1869. The changes then made in Buchanan's text, however, were of a minor character and most of its errors remained uncorrected. The naturalist's granddaughter, Miss Maria R. Audubon, was inspired in part by similar feelings in preparing, with the aid of Dr. Elliott Coues, her larger and excellent work in two volumes, entitled Audubon, and His Journals, which appeared in 1898. To her all admirers of Audubon owe a debt of gratitude for giving to the world for the first time a large part of his extant journals, as well as many new facts bearing upon his life and character. Other briefer biographies of Audubon which have appeared have been taken so completely from the preceding works, and have repeated and extended their errors to such an extent, as to call for little or no comment either here or in the pages which follow.

Through the discovery in France of new documentary evidence in surprising abundance we are obliged to 
draw conclusions contrary to those which have hitherto been accepted, and the new light thus obtained enables us to form a more accurate and just judgment of Audubon the man, and of his work. 


\section{CHAPTER II}

\section{JEAN AUDUBON AND HIS FAMILY}

Extraordinary career of the naturalist's father-Wounded at fourteen and prisoner of war for five years in England-Service in the French merchant marine and navy-Voyages to Newfoundland and Santo Domingo-His marriage in France-His sea fights, capture and imprisonment in New York-His command at the Battle of YorktownService in America and encounters with British privateers.

Few names of purely Gallic origin are today better known in America, or touch a more sympathetic chord of human interest, than that of Audubon, and few, we might also add, are so rare. John James Audubon first made his family name known to all the world, and though he left numerous descendants, it has become well nigh extinct in America, and is far from common in France. The great Paris directory frequently contains no entry under this head; Nantes knows his name no longer, and it is rare in the marshes of La Vendée, where at some remote period it may have originated.

The lists of the army of five thousand which Rochambeau's fleet brought to our aid in the American War of Independence show but a single variant of this euphonious patronym, in Pierre Audibon, ${ }^{1}$ a soldier in the regiment of Touraine, who was born at Montigny in 1756; but in the fleet of the Count de Grasse which coöperated with our land-forces at the Battle of Yorktown, on October 19, 1781, a ship was commanded by an officer with whom we are more intimately concerned. This

${ }^{1}$ For similar spelling of the name of John James Audubon, see Appendix I, Document No. 12. 
was Captain Jean Audubon, who was later to become the father of America's pioneer woodsman, ornithologist and animal painter.

By birth a Vendean, at the age of thirty-seven Jean Audubon had plowed the seas of half the world, and in the course of his checkered career, as sailor, soldier, West Indian planter and merchant, had met enough adventure to furnish the materials for a whole series of dime novels. Short of stature, with auburn hair and a fiery temper, he was then as stubborn and fearless an opponent as one could meet on the high seas, and one of the gamest fighting cocks of the French merchant marine. How much Jean Audubon's son owed to his French creole mother will never be known, but to this self-taught, thoroughly capable, and enterprising sailor we can surely trace his restless activity, his versatile mind and mercurial temper, as well as an inherent capacity for taking pains, which father and son possessed to a marked degree.

The true story of Jean Audubon's career has never been told, but even at this late day it will be found an interesting human document; and what is more to our purpose, it throws into sharp outline much that has hitherto remained obscure in the life of his remarkable son. The first Audubon to leave any imprint, however faint, upon the history of his time, this honest, matter-of-fact sailor, would have been the last to wish to appear in the garb of fiction, and we shall base our story solely upon the unimpeachable testimony of public and private records, which researches in France had happily brought to light before the beginning of the war in $1914 .^{2}$

${ }^{2}$ For notice of these records of Jean Audubon and his family, see the Preface, and for the most important dccuments, Appendix I. 
Jean Audubon came by his sailor's instincts and fighting prowess naturally, for his father, Pierre Audubon of Les Sables d'Olonne, was a seaman by trade. Like his son he captained his own vessel, and for years made long voyages between French ports in both the old and the new worlds. Pierre Audubon, the paternal grandfather of John James Audubon, and the first of that name of whom we have found any record, ${ }^{3}$ lived at Les Sables d'Olonne, where with Marie Anne Martin, his wife, he reared a considerable family in the first half of the eighteenth century.

Les Sables, at the time of which we speak, was a small fishing and trading port on the Bay of Biscay, fifty miles to the southwest of Nantes, but is now become a city of over twenty thousand people. Lying on the westerly verge of the Marais, or salt marshes and lakes of La Vendée, the inhabitants of the district, and more particularly of the Bocage, or plantations, to the north and northeast, were noted from an early day for their conservatism, as shown in a firm adherence to ancient law and custom, as well as for their unswerving loyalty to the old nobility and to the clergy. Like their Breton neighbors on the other side of the Loire, the Vendeans were honest, industrious, and faithful to their civic obligations; they were also independent, resourceful, and knew no fear. When the neighboring city of Nantes planted trees of liberty and displayed the National colors in 1789 , the Vendeans were stirred to indignation and later to arms, while the Chouans on the right bank of the river were quick to follow their example; in short, the rebels of La Vendée raised such a storm that

${ }^{3}$ Pierre Audubon's service in the merchant marine of France is undoubtedly recorded in the archives of the Department of Marine in Paris, but all researches in that direction were suddenly halted by the war. 
for months the very existence of the infant Republic was threatened. This spirit of revolt to the newer order, the Chouanerie, as it came to be called, was stamped out for the time, but a few smoldering embers always remained, ready to burst into flame at the slightest provocation; recrudescent symptoms of this tendency had to be suppressed even as late as 1830 , when Charles $\mathbf{X}$, the last Bourbon king, lost his crown. Pierre Audubon's family, no doubt, shared many characteristics of their Vendean and Breton neighbors, but as the sequel will show, one at least did not approve of their political course, for he took up arms against them, and presumably against many of his own kith and kin.

Jean Audubon was born at Les Sables on October 11, 1744, and was christened on the same day, his godfather being Claude Jean Audubon, in all probability an uncle after whom he was named, and his godmother, Catharine Martin, presumably an aunt. Twenty-one children, according to the naturalist, blessed the union of Pierre Audubon and his wife, and were reared to maturity. Whether this statement is strictly accurate, or what became of so large a family cannot now be ascertained. ${ }^{4}$

${ }^{4}$ Jean Audubon had a brother Claude, and on February 27, 1791, he wrote to him, asking for 4,000 francs, which he needed for the purchase of a boat. It was probably this brother who lived at Bayonne, and left three daughters, Anne, Dominica, and Catherine Françoise, who married Jean Louis Lissabé, a pilot (see Vol. I, p. 263). If this inference be correct, and the sum referred to was demanded in payment of a debt, it may explain a statement of the naturalist that his father and his uncle were not on speaking terms.

Another brother is said to have been an active politician at Nantes, La Rochelle and Paris from 1771 to 1796 , when he dropped out of sight for a number of years. When heard of again he was living at La Rochelle in affluence and piety. This was apparently the Audubon to whom the naturalist referred in certain of his journals and private letters as one who, possessing the secret of his birth and early life, had done both him and his father an irreparable injury (see Vol. I, p. 270).

A sister, Marie Rosa Audubon, was married in 1794 to Pierre de 
Pierre Audubon was engaged by the French Government to transport the necessities of war to Cape Breton Island in $\mathbf{1 7 5 7}$, when the world-wide struggle between France and Great Britain for supremacy in the New World was at hand. The French were determined at all hazards to hold their great fortress of Louisburg, which had been taken by the English but again restored to the French not many years before. This was the strongest and most costly fortress on the American continent, as well as a great center for the valuable trade in salted fish. By a coincidence, or possibly out of compliment to his wife, Pierre's ship bore the name of La Marianne, and when he sailed from his home port of Les Sables d'Olonne on April 15, 1757, he took with him his own son, Jean, as cabin-boy, when the lad was but thirteen years old. In the following May Great Britain threw down the gauntlet to France, and the terrific seven years' struggle began. The great fortress of Louisburg fell in the following year to the English fleet, and was left a heap of ruins. His father's ship, the Mary $\boldsymbol{A} n n$, was involved, and young Jean Audubon, who thus began his fighting career at fourteen, was wounded in the left leg and made a prisoner. With many of his compatriots he was taken to England, landing on November 14, 1758, where he remained in captivity for five years; he was released but a short time

Vaugeon, a lawyer at Nantes; their only son, Louis Lejeune de Vaugeon, was living at Nantes as late as 1822 , when he deeded his former home to Henri Boutard. ('The substance of this and the preceding paragraph is based partly upon data furnished by Miss Maria R. Audubon.)

Jean Audubon gave his daughter, Rosa, the name of her aunt, but in later life seems to have broken off all relations with his brothers. Upon his death his will was immediately attacked by Mme. Lejeune de Vaugeon, of Nantes, and by the three nieces from Bayonne (see Chapter XVII). The naturalist does not give the name of the aunt who, as he said, was killed during the Revolution at Nantes, but I have found no reference to any other. 
before the treaty of peace was signed at Paris, February 10, 1763. Apart from her interests in the West Indies, France was stripped at this time of all her vast possessions in America, save only the two little islands of Saint Pierre and Miquelon.

Whether Pierre Audubon shared the fate of his son we are unable to say, for at this point he drops out of our records and we do not hear of him again. It is certain that he never made another voyage with Jean, who returned to his native town with his passion for the sea unabated, and at nineteen reëntered the merchant marine as a novice. His next voyage, on the ship La Caille, Captain Pigeon, was to execute a governmental commission at the Island of Miquelon. Five golden years of his youth had been spent in captivity; if productive of nothing else they had given him a knowledge of the English tongue, but they had also engendered bitter hatred of the English race, a feeling which his son confessed to have shared in his youthful days. ${ }^{5}$

The period from $\mathbf{1 7 6 6}$ to $\mathbf{1 7 6 8}$ was occupied in four voyages to Newfoundland, probably in the interest of the codfish trade, first as sailor before the mast in $L e$ Printemps, and then as lieutenant in a ship called also La Marianne, with alternate sailings from, and to, La Rochelle and Les Sables d'Olonne. On his third voyage to Newfoundland, which was made in 1767 , when he was twenty-three years old, Jean Audubon ranked as

'This was recalled by the naturalist on March 5, 1827, when he wrote: "As a lad I had a great aversion to anything English or Scotch, and I remember when travelling with my father to Rochefort in January, 1800, I mentioned this to him.... How well I remember his reply.... 'Thy blood will cool in time, and thou wilt be surprised to see how gradually prejudices are obliterated, and friendships acquired, towards those that we at one time held in contempt. Thou hast not been in England; I have, and it is a fine country." (See Maria R. Audubon, Audubon and His Journals (Bibl. No. 86), vol. i, p. 216). 
lieutenant of his vessel, but in the summer of 1768 he shipped again from Les Sables as sailor before the mast for a short trading cruise on the coast of France; in this instance the vessel, called Le Propre, was captained by Pierre Martin, who was possibly an uncle. At this juncture Jean Audubon enlisted in the French navy (service for the State) as a common sailor, and made two voyages on governmental business from the port of Rochefort, serving altogether nearly nine months (1768-9). After the termination of this last engagement nothing is heard of Jean for over a year, when in $\mathbf{1 7 7 0}$ he makes his first appearance at Nantes, the city that was to know him in many capacities for nearly half a century. There he reëntered the merchant marine, and on November 1, 1770, began a series of eight voyages, lasting as many years, to the island of Santo Domingo, the western section of which was then in possession of France.

Since much of the mystery which hitherto has shrouded the early life of John James Audubon is involved in the West Indian period of his father's career, we shall now trace this history in considerable detail.

The great export trade of French Santo Domingo in those days was in brown and white sugar, then known as the "Muscovado" and "clayed" sorts, which for the year 1789 amounted to over $141,000,000$ pounds, valued at more than 122,000,000 francs; and in coffee, which in the same year totaled nearly $\mathbf{7 7 , 0 0 0 , 0 0 0 ~ p o u n d s , ~ e s t i - ~}$ mated to be worth nearly $52,000,000$ francs. ${ }^{6}$ While all

- In 1789 over $7,000,000$ pounds of cotton and 758,628 pounds of indigo were exported from the French side of the island, while further products of that year, including smaller amounts of cocoa, molasses, rum, hides, dye-woods, and tortoise shell, swelled the grand total of exports to 205,000,000 livres or francs. Bryan Edwards, however, whose deductions were based on official returns, placed the average value of all exports from French Santo Domingo for the years 1787, 1788, and 1789, at 
such estimates were no doubt very crude, they serve to illustrate the richness of the prize that attracted Frenchmen by hundreds to the colony, an island that to many seemed a paradise in prospect, but which proved to be a purgatory in disguise.

Jean Audubon's voyages were all made in the interest of this valuable trade. Since they commonly lasted from six months to nearly a year, they became doubly hazardous to a French sailor after the outbreak of the American Revolution, for if he escaped his Scylla, the inveterate pirate, he might expect to encounter an equally formidable Charybdis in an English privateer. Though the northwestern corner of Santo Domingo was the center of their forays, Jean never lost a ship to the buccaneers, and though sometimes caught by the English, he never surrendered. He made three successive voyages from 1770 to 1772 in La Dauphine, commanded by Jean Pallueau, first as lieutenant and later as captain of the second grade, but on his last five voyages to the West Indies he captained his own ships, known as Le Marquis de Léry (1774),

171,544,000 livres in Hispaniola currency, or $£ 4,765,129$ sterling; this would be equivalent to about $\$ 23,158,426$, and imply a purchase value of the French livre or franc of about $13 \frac{1}{2}$ cents in American money.

The number of plantations of every kind in the French colony was estimated by Edwards in 1790, at the outbreak of the Revolution, at 8,536 ; there were over 800 sugar plantations, over 3,000 coffee estates, to mention two such resources. If to these items we add nearly half a million slaves, the total valuation of the movable and fixed property of the French planters and merchants of this period would reach $1,557,870,000$ francs. In 1788, 98 slave ships entered the six principal ports on the French side, and landed 29,506 negroes; Les Cayes received 19 of these ships, which delivered at that port 4,590 blacks. These slaves were sold for $61,936,190$ livres, or at the rate of $2,008.37$ livres each; according to Edwards this was equivalent to $£ 60$ sterling, or to about $\$ 291.60$ in American money, at the rate of $14 \frac{1}{2}$ cents to the livre or franc. See particularly Francis Alexander Stanilaus, Baron de Wimpffen, A Voyage to Santo Domingo in the Years 1788, 1789, and 1790, translated by $\mathrm{J}$. Wright (London, 1817); and also Bryan Edwards, An Historical Survey of the French Colony in the Island of San Domingo (London, 1797). 


\section{Les Bons Amis (1775-6), and Le Comte d'Artois (1777-8).}

Captain Audubon was married on August 24, 1772, at Paimbœuf, to Anne Moynet, ${ }^{7}$ a widow of some property, who had been born at Nantes in $\mathbf{1 7 3 5}$ and was thus nine years his senior. Her married name was Ricordel. She possessed several houses at Paimbœuf, and acquired one in 1777, which was rented to the Administration at the time of the Revolution (see Vol. I, p. 80), as well as a dwelling at Nantes, where she lived while her roving sailor of a husband was in Santo Domingo or the United States. Madame Audubon was a woman of simple tastes, devoted to culture, and, as we shall see, possessed of a kind heart.

When Captain Audubon left Les Cayes, Santo Domingo, on his last trading voyage, in the spring of 1779, bound for Nantes with a valuable cargo, his ship, Le Comte d'Artois, was attacked by four British corsairs and two galleys. With the odds overwhelmingly against him, he fought until his crew were nearly all killed or disabled, and after an abortive attempt to blow up his vessel, tried to escape in his shallop. For the second time he was made a prisoner by the English, who in this instance took him to New York, then in the possession of British troops. He was landed in that city on May 12, 1779, and was held there as a prisoner of war for thirteen months. If our inference be correct, he finally owed his release to the efforts of the French Ambassador, Monsieur de la Luzerne, the same, we believe, who had been a Governor of Santo Domingo, and who in $\mathbf{1 7 9 0}$ became its Minister of Marine. As

"As signed by herself, but variously spelled "Moinet," or "Moynette" in family documents of the period. On August 28, four days after their marriage, they drew up and signed a mutual contract regarding the disposition of their property in case children should be born to them. 
will be seen presently, this diplomat again exerted himself in Captain Audubon's behalf.

It is interesting to find that on this occasion Jean Audubon was fighting not only for his life, but for his property. His vessel, Le Comte d'Artois, was very heavily armed. Though of only 250 tons, she carried no less than ten cannon, four of which were mounted on gun carriages, and ten bronze pivot guns, which might imply that she was originally designed as a privateer. The ship was not destroyed when her captain was made prisoner, but was taken by the English to Portsmouth, New Hampshire (?), and burned there before December 15 of the following year. ${ }^{8}$ Before starting on this disastrous voyage Captain Audubon had sold the vessel and his interest in her cargo to the Messrs. Lacroix, Formon de Boisclair and Jacques, with whom later he had extensive dealings in slaves; but he was not paid, and though an indemnity seems to have come from the British Government, he was never able to obtain a satisfactory settlement of the Formon claim. ${ }^{9}$

${ }^{8}$ The destruction of Le Comte d'Artois is noticed in a document bearing date of January 19, 1782; the name of the town only is given, but it is probable that it refers to the United States.

${ }^{9}$ For repeated reference to this unsettled claim, see his letter of 1805 to Francis Dacosta (Chapter VIII), where the name is written "Formont."

The bill of sale of Le Comte d'Artois was drawn on February 21, 1779, when Jean Audubon appeared "before the notaries of the king in the seneschal's court of Saint Louis," and was described as "resident at Les Cayes, opposite the Isle à Vaches." The document, which in my copy is incomplete, reads in part as follows:

"The present M. Jean Audubon, captain-commander of the ship $L e$ Comte d'Artois, of Nantes, armed for war and now laden with merchandise, anchored in this roadstead of Les Cayes, dispatched, and at the point of departure for France; armed by the Messrs. Coirond Brothers, merchants at the said city of Nantes, acting in his own name as one interested in the armament and cargo of the vessel, as well as in his capacity as captain; [he] acting as much also for the said furnishers of arms as for the others interested in the said armaments, and the merchandise, which will be hereafter mentioned, in consideration of the rights of each, promises to have these presents accepted and approved in due 
Jean Audubon's release from captivity in New York, in June, 1780, probably marks the period of his first intimate acquaintance with the United States. We know only that he did not return immediately to either Santo Domingo or France, but became an enthusiast for the American cause, and sought the earliest opportunity to avenge his wrongs at the hands of the British. He did not have long to wait, for through the exertions of the Ambassador de la Luzerne, he was placed in command of the corvette Queen Charlotte. With her, in October, 1781, he joined the fleet of the Count de Grasse before Yorktown, ${ }^{10}$ where he soon witnessed the surrender of Cornwallis and the humiliation of his enemies. After this turning point of the war Captain Audubon remained in the United States, and in April, 1782, commanded a merchantman called $L^{\prime}$ Annette, ${ }^{11}$ in which he was also personally interested, and delivered a cargo of Virginia tobacco at the port of Nantes. Shortly after his return to America in the

time; which said person, appearing in said names, in the quality aforesaid, by these presents has sold, ceded, given up, transferred, and relinquished all his legal rights in the aforesaid ship, to the business-associates Lacroix, Formon de Boisclair \& Jacques, three merchants in partnership, living in this town, purchasers conjointly and severally, for themselves and the assigns of each, to the extent of one third; To wit: the said ship Le Comte d'Artois, of the said port of Nantes, of about two hundred and fifty tons, at present anchored in this roadstead of Les Cayes, dispatched, and at the point of departure for France, with all its rigging, outfit, and dependences, which consist among other things of two sets of sail, complete, and newly fitted out, all the tools, and the reserve sets of these, with the munitions of war, consisting of ten cannon, four of them mounted on gun carriages, and all that goes with them...." (Translated from the French original in possession of Monsieur Lavigne.)

${ }^{10}$ The fact that Captain Audubon did not accompany Rochambeau's fleet which assembled at Brest in April, 1780, and reached Newport in midJuly, may account for the omission of his name from the lists that have been recently published. See Les Combattants François de la Guerre Américaine, 1778-1783 (Paris, 1903).

${ }^{11}$ Others interested in this vessel were Messrs. David Ross \& Company, with whom Captain Audubon later had financial difficulties (see Chapter VIII). 
same year he was placed in command of an American armed vessel The Queen and sent on another mission to France. Near the Chaussée des Saints he was attacked by a British privateer, but after a stubborn fight at close quarters he sank his enemy and entered the port of Brest. Nothing is said of the taking of prisoners on such occasions, and there were doubtless few survivors among the defeated crew. This command Jean Audubon held until peace was concluded between Great Britain and her former colonies in America, probably until the close of 1783 . The hostile army was disbanded in the spring of that year, the treaty of peace was made definitive in September, and on November 25,1783 , the last British troopers left the city of New York. 


\section{CHAPTER III}

\section{JEAN AUDUBON AS SANTO DOMINGO PLANTER AND MERCHANT}

Captain Audubon at Les Cayes-As planter, sugar refiner, general merchant and slave dealer, amasses a fortune-His return to France with his children-History of the Santo Domingo revolt-Baron de Wimpffen's experience-Revolution of the whites-Opposition of the abolitionists-Effect of the Declaration of Rights on the mulattoesThe General Assembly drafts a new constitution-First blood drawn between revolutionists and loyalists at Port-au-Prince-Ogé's futile attempt to liberate the mulattoes-Les Cayes first touched by revolution in 1790, four years after the death of Audubon's mother-Emancipation of the mulattoes-Resistance of the whites-General revolt of blacks against whites and the ruin of the colony.

After the American struggle for liberty had been finally won, Captain Audubon resigned his commission held in the United States and returned to his home at Nantes, but town or country could not hold him long. Lured by the prospects of great wealth which Santo Domingo offered to the merchant of those days, and having learned by long experience in her ports the devious methods by which fortunes were attained, he decided to give up the sea and embark in colonial trade. F or six years, from 1783 to $\mathbf{1 7 8 9}$, he lived almost continuously in the West Indies, and as merchant, planter, and dealer in slaves amassed a large fortune. Meanwhile his wife, who had seen little of him since their marriage in 1772 , remained at Nantes.

Captain Audubon traveled through the United States early in 1789, and again late in that year when on his way to France, probably in the first instance returning 
to Santo Domingo by way of the Ohio and the Mississippi. Symptoms of unrest were already prevalent in the northern provinces of the island but had caused no serious alarm in the south. Jean Audubon's aim seems to have been to collect debts due him in the United States and to leave the capital invested there. At all events it was on this occasion that he purchased the farm of "Mill Grove," near Philadelphia, the history of which will be given a little later (see Chapter VII). He had no intention, however, of living in Pennsylvania, for he immediately leased this estate to its former owner and hurried away.

July 14, 1789, found the elder Audubon enlisted as a soldier in the National Guards at Les Cayes. These colonial troops, which were originally militia organizations modeled after similar bodies in France, were reorganized at this time to meet any possible emergencies. Affairs in the southern provinces of Santo Domingo had followed, up to this moment, their normal course, and Jean Audubon, who could have learned nothing of what had transpired at home, decided to entrust his various interests to the hands of agents and return to France. This was probably in late August or early September, 1789, as we know that he first returned to the United States and visited Richmond, Virginia, at the close of that year. ${ }^{1}$ Strangely enough, on the twentieth day of the former month the National Assembly at Paris had voted the celebrated Declaration of Rights, which was destined to upturn the whole social system of Santo Domingo and to convert that island into a purgatory of the direst anarchy, strife, and bloodshed which the world had ever known, or at least remembered; but fully six weeks must have elapsed before news

\footnotetext{
${ }^{1}$ See letter to Dacosta, Vol. I, p. 121 .
} 
of this grave decision could have reached the colony. At this time Jean Audubon was no doubt regarded as a very rich man, and though he happened to leave Les Cayes at a critical moment, little could he have dreamed of the disaster that awaited him there as well as in his beloved France. His personal affairs during this eventful period, involving as they necessarily do the early life of his distinguished son, have hitherto been shrouded in the dark and sinister history of that ever smiling but ever turbulent island. Now, however, the veil of mist that has settled over the page can be penetrated at the most important points. In this and subsequent chapters we shall follow the life of father and son through the course of events which has been thus briefly summarized.

To return to the earlier threads of our narrative, at about the close of 1783 Captain Audubon was engaged by the Coirond brothers, colonial merchants at Nantes, to take charge of their foreign trade, which centered chiefly at Les Cayes, ${ }^{2}$ Santo Domingo, then a most thriving and populous town, as it is today the largest seaport on the southern coast of the Republic of Haiti. Their ships brought sugar, coffee, cotton and other West Indian products to France, and laden with

2 The proper name of this seaport town, as given by all French cartographers and writers, is Les Cayes, meaning "the cays" or "keys" (small islands, Spanish caỹos); omitting the article it is often simply written "Cayes." French residents on the island, however, when dating or addressing a letter or receipting a bill would naturally write "aux Cayes," meaning of course "at The Cays," where the document was signed or where the person by whom the letter was addressed resided (see the Sanson bill, and bills of sale of negroes, Appendix I, Documents Nos. 1, 4, 5, and 6). It was thus an easy step for Englishmen, in ignorance or disregard of the French usage, to call the town "Aux Cayes"; even as early as 1797 , Bryan Edwards, though giving the name correctly on his map, which doubtless had a French source, wrote "Aux Cayes" in his text; the corruption has survived, and is occasionally found in standard works, but is too egregious to be tolerated. 
fabrics, wines and every luxury known to the colonists of that day, returned to Les Cayes, as well as to Saint Louis, an important port a little farther to the east, where these merchants also possessed warehouses and stores.

In a short time Jean Audubon had acquired an independent business of his own, both as a planter and merchant. He made his home at Les Cayes, but extended his enterprises to Saint Louis and possibly to other points. From this time onward he commonly described himself as négociant, ${ }^{3}$ or merchant, and his son, when writing to his father from America, addressed him in this way. His business letters and other documents of the period refer to his house at Les Cayes, his plantations of cane and his sugar refinery, his exportation of colonial wares, his purchases of French goods, particularly at Nantes, and to his trade in black slaves which eventually assumed large proportions. How important his sugar plantations may have been is not known, but a tax-receipt shows that at one time he possessed forty-two slaves. ${ }^{4}$ The naturalist said that his father acquired a plantation on the Ile à Vaches, an island of considerable importance at the southern bound of the roadstead of Les Cayes and nine miles from the town, but we have found no other reference to it.

Great numbers of negroes must have passed through Jean Audubon's hands, as shown by his bills of sale, which strangely reflect the customs of a much later and sadder day on the North American continent (see Appendix I, Documents Nos. 4t-6). In one of these bills,

${ }^{3}$ And sometime as marchand, more strictly a retailer.

"Since a colonist's wealth was estimated upon the number of slaves he could afford, and since a slave was regarded as equivalent to a return of 1,500 francs a year, Jean Audubon's income on this basis would have been 63,000 francs. 
dated at Les Cayes, September 16, 1785, Jean is credited with one-half the net proceeds of the sale of forty negroes, bought originally of M. Th. Johnston for the sum of 60,000 franes, and sold by Jean Audubon and Messrs. La Croix, Formon \& Jacques for 71,552 franes; after deducting 183 francs for food and treatment, the net returns became 71,369 franes, and Jean's profits, on a half-interest basis, 5,684 francs, or about 142 francs per head. The prices of these slaves, which were sold to planters on the island when not retained for their own use, ranged from 1,500 to 2,100 francs, or from $\$ 300$ to $\$ 420$, at the present rate of exchange. It is interesting to notice that while these negroes were held for sale, the exact period of which is not stated, they received as food eighty bunches of bananas and three beef heads; though under the care of a physician, it is not surprising to find that one of them died. Another bill, bearing date of August 7, 1785, records the sale to Jean Audubon of ten negroes and three negresses for a total sum of 26,000 francs; 16,000 franes of this amount was paid in sugar, but what is particularly interesting now is the fact that a balance of 2,000 francs was finally cancelled on June 9, 1788, a year or more after Jean Audubon, according to the accepted accounts, is supposed to have lost his wife and his property and to have fled from the island. Mme. Anne Moynet Audubon never visited America, and her husband, as we have seen, left Santo Domingo in 1789, before the outbreak of the revolution. His property remained substantially intact until after 1792, and in some years, it is believed, yielded him in rents 90,000 francs, which at present rates in American money would be equivalent to $\$ 18,000$. In giving his certificate of residence at Nantes in that eventful year, Captain Audubon publicly declared that 


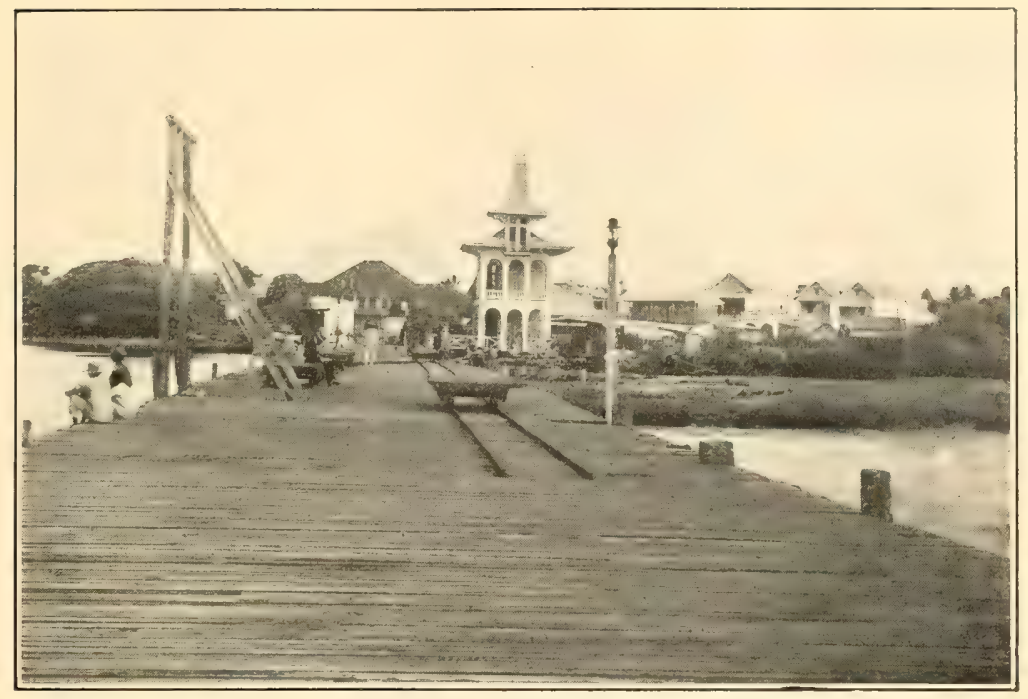

I,ES CAYES, HAITI: THE WIIAR AND POST OFFICE; AT TIL IEFT IS SEEN A PIL.? OF LOGWOOD AWATTING SIIIPMENT.

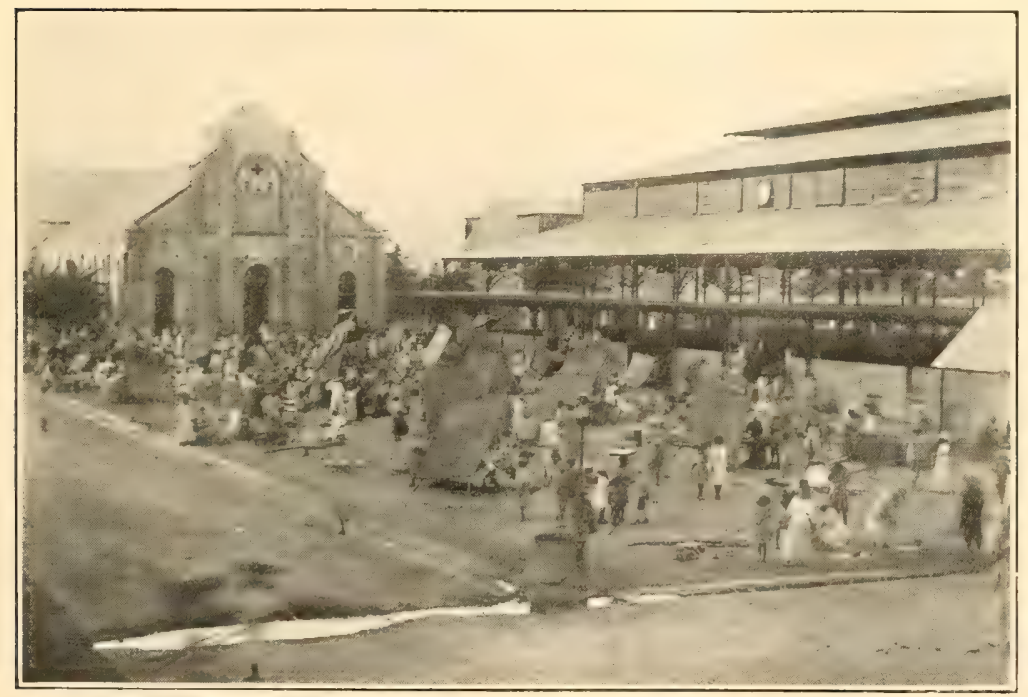

IES CAYES, HAITI: THE MARKET AND CHURCH OF SACRÉ COEUR.

After photographs made at I.es Cayes in June, 1917, and ohtained through the kinduess of Mr. Ferdinand I,athrop Mayer, Secretary of Legation, Port-au-Prince, Haiti. 

he possessed a dwelling, a sugar refinery, and warehouses or stores at both Les Cayes and Saint Louis. Moreover, his West Indian estate was not completely settled until 1820, two years after his death.

Slaves were regarded in Santo Domingo as an indispensable commodity, as they had been in Virginia and the Carolinas for a century past, and were still to be for three-quarters of a century to come; the "friends of the blacks" as the abolitionists were called, were considered by most planters as the enemies of the whites. Degradation and cruelty, ever attendant upon a system that drew its chief support from the self-interest of a class, were all too common in the island, yet there were many who earnestly strove to soften the lot of their slaves. Though a born fighter, Jean Audubon was humane, and the evidence, so far as it goes, shows that his own slaves were treated with kindness and consideration.

This period in Santo Domingo, particularly from the year $\mathbf{1 7 8 5}$ to $\mathbf{1 7 8 9}$, not only is important for our story, but happened to mark a crisis in French sovereignty in America. It will be necessary, therefore, to foilow certain events in a history which can serve only as a warning to mankind, for it contains little to satisfy the understanding and nothing to excite the fancy or gladden the heart. It is to be noticed first, however, that according to the accepted accounts, John James Audubon was born of a Spanish creole mother, in Louisiana, in 1780. Shortly after his birth, his mother is said to have gone to Santo Domingo, where she perished in a local uprising of the blacks, when Jean Audubon's plantations and property were totally destroyed; Jean managed to escape with only his two children, a few foithful slaves, and a part of his money and valuables, 
to New Orleans, whence he subsequently went to France. Investigation of existing records has proved that these statements are not in accord with the facts, but before entering into further personal details it will be well to examine those conditions on the island of Santo Domingo which led many into easy fortune only to involve them later in a ruin as complete and irretrievable as it was unforeseen and unnecessary.

For nearly a hundred years the western half of Santo Domingo had been held by France, and to every outward appearance it had enjoyed such unbounded and steadily increasing prosperity that it was regarded with envy on every side; in fine, it seemed to be one of the richest and most desirable colonies in the whole world. Historians, said an observer of a later day, ${ }^{5}$ were "never weary of enumerating the amount of its products, the great trade, the warehouses full of sugar, cotton, coffee, indigo and cocoa; its plains covered with splendid estates, its hillsides dotted with noble houses; a white population, rich, refined, enjoying life as only a luxurious colonial society can enjoy it." Few could then see the foul blot beneath so fair a surface, or realize that what had been bought by the misery and blood of a prostrate race would demand an equivalent, and that a settlement might be forced.

Negroes had been imported into Santo Domingo from the African coasts in incredible numbers, first by Spain after she had succeeded in exterminating the inoffensive native Caribs, and later by France. One hundred thousand blacks of all ages were entering the colonies each year, and to secure this number of bossals, as the native Africans were called, involved the death

${ }^{5}$ See Sir Spencer St. John, Hayti, or the Black Republic, ad ed. (New York, 1889). 
of nearly as many more, either through the fighting that preceded their capture on land, or from the terrors of pestilence or shipwreck that awaited chem at sea. By 1790 the blacks of Santo Domingo outnumbered the whites sixteen to one, and the number of blacks then in the island was estimated at 480,000 , in contrast to 30,800 whites, and about 24,000 free mulattoes or "people of color."

Under French rule the blacks had been subjected, as many believed, to a system of slavery unsurpassed for cruelty and barbarity. No doubt there were Frenchmen who, in their fierce struggle to become rich, worked their slaves beyond human endurance and did not hesitate to terrorize them with the severest punishment upon the first symptoms of revolt; but, on the whole, such sweeping denunciations were probably unjust. An impartial observer and historian of that day, himself an Englishman, ${ }^{6}$ declared that the French treated their slaves quite as well as the English did theirs, and clothed them better. He believed that the lot of the Santo Domingo blacks at the period of which we speak would compare favorably with that of the peasantry of Europe, a comment made familiar to American ears when applied to the slave population of the South. The real trouble came from the more enlightened disaffection of the mulattoes and free negroes, fanned by the fanatic zeal of abolitionists abroad, particularly of those who formed the society of Les Amis des Noirs in France, who were determined to carry out their policies by any means and at whatever cost.

The mulattoes were really in worse plight than the actual slaves, for they were virtually slaves of the State

\footnotetext{
${ }^{6}$ Bryan Edwards, Esq., M.P., F.R.S., \&c., An Historical Survey of the French Colony in the Island of San Domingo (London, 1797).
} 
and had no master to whom they could appeal, being subject to military service without pay, to the corvée or labor upon the highways, the hardships of which were insupportable, as well as to a constant and galling tyranny. The law was invariably framed in favor of the white man, who, if he struck a mulatto, was subject to a trivial fine, while retaliation by the man of color might cost him his right hand. It should be added, however, that custom was usually more lenient than the law, and that such atrocious enactments were generally a dead letter.

As might have been expected in the circumstances, the mulattoes took their revenge on the despised blacks, whom they were permitted to hold as slaves. They were notoriously the hardest taskmasters in the island, and in return they were naturally envied and hated by the ignorant mass of black humanity. The whites, to complete the discord, were divided among themselves, the Frenchmen from Europe affecting a superiority over the white creoles, the seasoned natives of the island, a condition that never made for good feeling. Moreover, the white planter, who endeavored to gain a foothold by producing sugar, cotton or coffee, seems to have had a just grievance against the merchants whom the law favored and who set the price for negroes and all other commodities that had to be bought in exchange for produce. Such at least was the conviction and experience of a keen observer, Francis Alexander Stanislaus, Baron de Wimpffen, ${ }^{7}$ who went to Santo Domingo in 1788, tried to establish himself as a coffee planter at Jaquemel, on the southern coast not far from Les Cayes, and after three years of fruitless effort, gave up the attempt in disgust, glad to escape, as from the flames 
of purgatory, to the United States, where he settled in Pennsylvania. Baron de Wimpffen's lack of success no doubt colored his impressions of the country to some extent, but after making due allowance on this score, we find in his letters, beyond a doubt, an essentially true picture of Santo Domingan society and plantation life at the very time and place with which our story is most intimately concerned. A sketch of the picture which the Baron has drawn, though in brief outline, will enable us better to understand the real condition of affairs.

The prevailing taste in Santo Domingo, according to this observer, was creolian tinctured with boucan, or with the characteristics of the buccaneers. White society on the island was divided into governmental or town officials, merchants, and planters, the several classes having their own interests, which were often conflicting. The planters were concerned only with negroes, their sugar, their cotton or their coffee, and could talk of nothing else; values were reckoned in negroes, or in sugar, for which slaves were commonly exchanged. The laxity of morals, the absence of schools, and the total lack of books were patent on every hand. After sunset dancing was the chief form of amusement in the towns, and handsome mulattoes were the acknowledged Bacchantes of the island. It was from this class that housekeepers were usually chosen by the greater part of the unmarried whites. They had "some skill," said Baron de Wimpffen, "in the management of a family, sufficient honesty to attach themselves invariably to one man, and great goodness of heart. More than one European, abandoned by his selfish brethren, has found in them all the solicitude of the most tender, the most constant, the most generous humanity, without being in- 
debted for it to any other sentiment than benevolence."

Expense of cultivation at this time is said to have risen out of all proportion to the value of the product. While negro service was a prime necessity to the planter, the African mine was becoming exhausted; even then slave dealers were penetrating a thousand leagues or more from the Guinea coast. Added to the cost of slaves, which was yearly increasing and had already reached to 2,000 or even 3,000 francs per head, the Government exacted a ruinous capitation tax, which bore with special weight on the planter. ${ }^{8}$ Physicians and lawyers, however ignorant, exacted exorbitant fees; masons and carpenters, however inefficient, demanded an unreasonable wage; they, we are told, with the merchant and official governmental class, were the only money makers on the island. The merchant whom we have seen taking the planter's produce at his own price, in exchange for slaves again at his own price, had the advantage in every business transaction; the planter, as a result, was his chronic debtor, and at usurious rates.

Subject to an enervating climate, which Europeans with their intemperate habits could seldom endure for long, the planter, though weak and sick himself, was often obliged to be overseer, driver, apothecary, and nurse to his negroes, the slave of his slaves. In spite of every care, out of one hundred imported negroes the mortality was nearly twenty per cent in the first year. Where less oversight was given to their food, the slightest scratch was likely to degenerate into a dangerous wound, while the most dreaded disease, then known in English as the "yaws" and in French as la grosse vérole

${ }^{8}$ The Superior Council, sitting at Port-au-Prince, in 1780 fixed the tax for the parish of Les Cayes at the rate of 2 francs, 10 centimes per head, which in this instance was certainly trifling. (Note furnished by M. L. Lavigne.) 
(to distinguish it from the smallpox, la petite vérole), was a scourge for which no remedy had then been found. Every slave was branded with a hot iron on the breast, with both the name of his master and that of the parish to which he belonged, but notwithstanding such precautions desertions were far from uncommon.

The Santo Domingan blacks were put to work in the morning with a crack of the arceau, a short-handled whip, delivered on their backs or shoulders, and so accustomed had they become to the regularity of this stimulus that they could hardly be set in motion without it. How to manage the true bossal, as distinguished from the African creole, with humanity and success was a problem to which many considerate planters must have addressed themselves in vain, if, as this one declared, the black's ruling passion was to do nothing, and he was by nature a thief, to whom indulgence was weakness and injustice a defect of judgment that excited both his hatred and his contempt.

Stanilaus further observed that the soil of Santo Domingo was then already becoming exhausted, and he believed that the day of rapid fortunes for the planter had passed. "Calculate now," said he, "the privations of every kind, the commercial vicissitudes, the perpetual apprehensions, the disgusting details, inseparable from the nature of slavery; the state of languor or anxiety in which he vegetates between a burning sky, and a soil always ready to swallow him up, and you will allow with me that there is no peasant, no day-labourer in Europe, whose condition is not preferable to that of a planter of San Domingo." "I never met," he adds, "a West Indian in France who did not enumerate to me with more emphasis than accuracy, the charms of a residence at Saint Domingo; since I have been here, I 
have not found a single one who has not cursed both Saint Domingo, and the obstacles, eternally reviving, which, from one year to another, prolong his stay in this abode of the damned."

Having followed De Wimpffen to this point, the reader is entitled to hear his parting epigrams. "The more I know," he said, of the inhabitants of Saint Domingo, "the more I felicitate myself on quitting it. I came hither with the noble ambition of occupying myself solely in acquiring a fortune; but destined to become a master, and consequently to possess slaves, I saw, in the necessity of living with them, that of studying them with attention to know them, and I depart with much less esteem for the one, and pity for the other. When a person is what the greater part of the planters are, he is made to have slaves; when he is what the greater part of the slaves are, he is made to have a master."

Whether Jean Audubon's long experience would have confirmed all that has just been said is doubtful, for he was primarily a merchant or dealer and thus belonged to the favored class. But what especially interests us now is that both he and De Wimpffen were owners of plantations in the southern province of Santo Domingo at the same time. The one who wished to retain a valuable property followed the custom of the time by confiding the management of his affairs to an agent, either at a fixed salary or on a profit-sharing basis; while the other, who stayed long enough to discern the trend of events, was glad to sell his land anc. his slaves and shake the dust of the island from his feet forever. ${ }^{9}$

Before resuming the intimate details of our narra-

${ }^{9}$ Baron de Wimpffen sailed from Port-au-Prince for Norfolk, Virginia, in July, 1790, about a year after Jean Audubon had left the island. 
tive, we must follow the whirlwind of political events already set in motion in the island colony. In the spring of $\mathbf{1 7 8 9}$ the white colonists of Santo Domingo took administrative matters into their own hands, and without vestige of legal authority, elected and dispatched eighteen deputies to the States-General, then sitting in France. These men reached Versailles in June, a month after that body had declared itself the National Assembly, but only six were ever admitted to its counsels. For a long time opposition to the planters had been fomented in Paris by the "Friends of the Blacks," the abolition society to which we have referred; stories of cruelty to the slaves, colored and intensified in passing from mouth to mouth, as invariably happens when atrocity tales are used as partisan weapons, added to the arrogance and extravagant habits of many planters when resident in the mother country, did not tend to soften the prejudice of the public towards their class. The planters could get no consideration at home, and, as we have seen, the Declaration of Rights followed promptly in August, while a legislative Assembly was ordered in September. Meantime the mulattoes on the island were clamoring for the political rights which the decree had promised them, and, to make matters worse, some of the influential whites espoused their cause, even preaching the enfranchisement of the blacks, from whom up to this time little had been heard. In short, the whites were divided as effectually as were blacks and mulattoes.

The dominant party in Santo Domingo, led by the Governor-General, were determined to uphold the old despotic régime, while the General Assembly, which met at Saint Marc in obedience to orders from the mother country, on April 16, 1790, drafted a new constitution. 
The clash came in July of this year, and in the northern province, where the first blood of the revolution was drawn at Port-au-Prince. On October 12, 1790, James Ogé, a mulatto, inspired, financed and equipped by the "Friends of the Blacks" in Paris, landed secretly in Santo Domingo, established a military camp at Cap François and called all mulattoes to arms. His plan was to wage war on the whites as well as upon all mulattoes who refused to join his standard of revolt; but Ogé and his company were quickly suppressed, and this incompetent leader, who fled to Spanish territory, was later extradited and broken on the wheel. This episode naturally infuriated the whites against all mulattoes, who took up arms at Les Cayes and at other points. The whites also armed, and a skirmish occurred at Les Cayes, Jean Audubon's old home, where fifty persons on both sides lost their lives, but a temporary truce was immediately effected. This was the first serious incident in which the town of Les Cayes figured in the bloody revolution of Santo Domingo; it occurred, we believe, in the late autumn of 1790. Audubon's mother had then been dead four years, and her son, the future naturalist, had left the country in the fall of 1789 ; in order to bring out these facts clearly it has seemed necessary to enter into this detail.

Later events in Santo Domingo now moved in a direction and with a velocity which few then were able to comprehend. The danger and the potency of the volcano that had long been muttering beneath their feet needed but a few touches from without to reveal its full explosive power. These were furnished not only by the mulattoes, many of whom, after having fought under French officers in the American Revolution, had returned to the island and there spread wide the spirit 
of disaffection and revolt; but also by the National Assembly in France, which by its vacillating policies destroyed every hope of reconciliation. In March, 1790, this Assembly granted to the citizens of Santo Domingo the right of local self-government, but only a year later, on May 15, 1791, tore up this decree and emancipated the mulattoes. When the news reached the island six weeks later, the colony was thrown into the utmost consternation; the whites as a class refused point-blank to accept the decision and summoned an Assembly of their own, which met in August. The mulattoes again took up arms, and the blacks, who by this time had been won to their side, started a general revolt which had its origin on a plantation called "Noé," in the parish of Acul, nine miles from Cap François. They began by burning the cane fields and the sugar houses and murdering their white owners. Thenceforth Santo Domingan history becomes an intricate and disgusting detail of conspiracies, treacheries, murders, conflagrations, and atrocities of every description. The only ray of light comes from the first genuine leader of the blacks, the gallant but unfortunate Toussaint, in 1793.

As has already been intimated, Jean Audubon's Santo Domingo property suffered long after he left the island, and certainly after 1792 when, as we shall soon see, revolutions were demanding his attention and all his energies at home. 


\section{CHAPTER IV}

AUDUBON'S BIRTH, NATIONALITY, AND PARENTAGE

Les Cayes-Audubon's French creole mother-His early names-Discovery of the Sanson bill with the only record of his birth-Medical practice of an early day-Birth of Muguet, Audubon's sister-Fougère and Muguet taken to France-Audubon's adoption and baptism-His assumed name-Dual personality in legal documents-Source of published errors - Autobiographic records-Rise of enigma and traditionThe Marigny myth.

Santo Domingo, though repeatedly ravaged by the indiscriminate hand of man, is a noble and productive land, which, for the diversity and grandeur of its scenery and the rare beauty of its tropical vegetation, was justly regarded as one of the garden spots of the West Indies and worthy to be in truth a "Paradise of the New World." For every lover of birds and nature this semitropical island, and especially Les Cayes, upon its southwesterly verge in what is now Haiti, will have a peculiar interest when it is known that there, amid the splendor of sea and sun and the ever-glorious flowers and birds, the eyes of America's great woodsman and pioneer ornithologist first saw the light of day.

Jean Audubon met somewhere in America, and probably at Les Cayes, a woman whom he has described unly as a "creole of Santo Domingo," that is, one born on the island and of French parentage, and who is now known only by the name of Mlle. Rabin. ${ }^{1}$ To them was

1 From a land-owning family in the northern part of what is now the Republic of Haiti. 
born, at Les Cayes, a son, on the twenty-sixth of April, 1785. This boy, who was sometimes referred to in early documents as "Jean Rabin, créole de Saint-Domingue," and who again was called "Fougère" (in English, "Fern"), received the baptismal name of Jean Jacques Fougère six months before his sixteenth birthday.

The bill of the physician, Doctor Sanson of Les Cayes, who assisted at young Audubon's birth still exists, and as the reader will perceive, it is a highly unique and interesting historical document. ${ }^{2}$ Written in the doctor's own hand, it is receipted by him, as well as approved and signed by Jean Audubon himself. This tardy discovery, along with other pertinent records in the commune of Couëron, in France, finally resolves the mystery which has ever hedged the Melchizedek of American natural history. The child's name, of course, is not given in the bill, but authentic records of Audubon's subsequent adoption and baptism agree so completely in names and dates as to establish his identity beyond a shadow of doubt. Much other documentary evidence which also has recently come to light is all in harmony with these facts, and further shows that the natal spot and time as given in the Sanson bill can refer only to this talented boy. But before turning to these legal documents we must examine the personal record of Jean Audubon's physician.

Dr. Sanson's carefully itemized account, to the amount of 1,339 franes, extends over a period of nearly two years, from December 29, 1783, to October 19, 1785; it was accepted and signed by Captain Audubon on October 12, 1786, and receipted by the doctor when

${ }^{2}$ For photographic reproduction see p. 54; and for transliteration and translation, Appendix I, Documents Nos. 1 and 1a; for "Fougère" see Appendix I, Documents Nos. 2 and 3; and for "Jean Rabin," Documents Nos. 14, 16, 17 and 18. 
paid on June 7, 1787. The bill is interesting as a commentary on the medical practice of an early day, as well as for the light which it throws on Jean Audubon's Santo Domingan career, his establishment at Les Cayes, and his treatment of black slaves and dependents. This quaint document, moreover, tends to confirm a remark of Baron de Wimpffen to the effect that every doctor in Santo Domingo grew rich at his profession, and also recalls what he said in regard to the household remedies of the period. "Every colonist," to quote this observer again, "is commonly provided with a small chest of medicines, of which the principal are manna, salts, and rhubarb; the country itself produces tamarinds, and the leaves of the cassia tree, a slight infusion of which, with a little orange juice, makes as good a purge as a mixture more scientifically composed."

This physician's chief resources are seen to have been ipecacuanha, purgative decoctions, including such as the tamarind tree provided, manna, mineral waters, lotions, plasters, and kino, an astringent juice derived from different legumincus plants, which gave a red color to the saliva, not to speak of "other medicines," the nature of which is not revealed, which were liberally supplied to whites and blacks, both old and young, alike. It will be noticed further that the slaves of African birth when not named are referred to as "bossals," though many young blacks and mulattoes are called "Joue"; ${ }^{3}$ that a cooper, attached presumably to the

"The word "Joue," which occurs eleven times in this document-as "mulatto Joue," "Joue mulatto," "negro bossal named Joue," and "little negro Joue"-suggests the English equivalent "Cheek," but no such usage appears to be authorized. It is evidently a proper name, and is more likely to prove the French rendering of a word common to one of the negro dialects of the island. On the other hand it might represent a corrupted pet name, like "joujou" or "bijou," bestowed by the French creoles of Santo Domingo upon their favorite négrillons or petits nègres, 


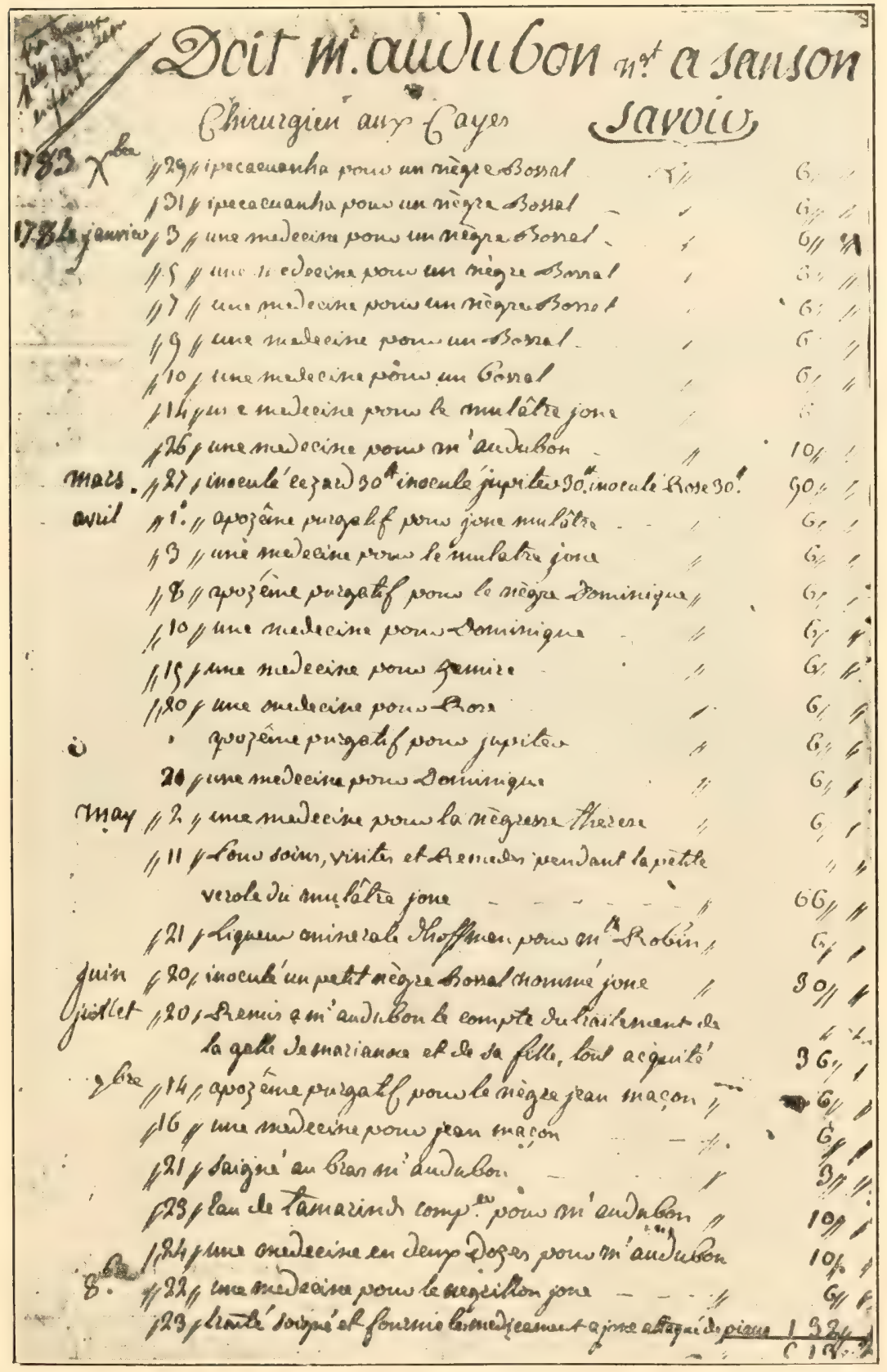

FIRST PAGE OF THE BIIL RENDERED BY DR. SANSON, OF LES CAYES, SANTO DOMINGO, TO JEAN AUDUBON FOR MEDICAI, SERVICES FROM DECEMBER 29,1783 , TO OCTOTER 19, 1785.

After the original document in possession of M. I. Lavigne, at Couëron. The note in upper left-hand corner, "très curieux Mlle. Rahin \& son enfant," has been added by a later hand. 


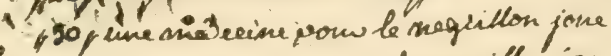

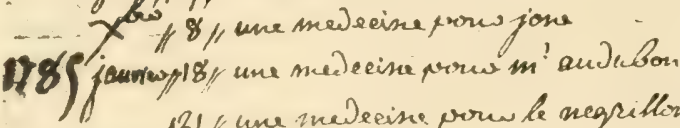

121 une ine Decise prow le negritlon jons

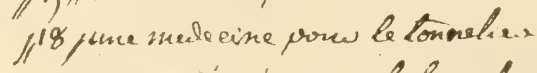

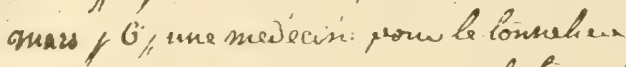

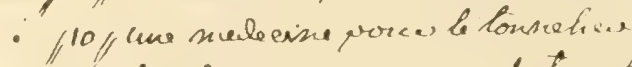

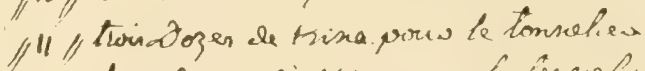

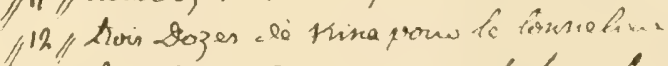

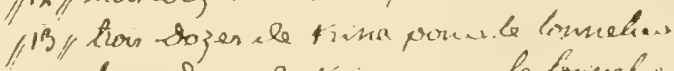

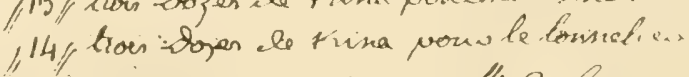

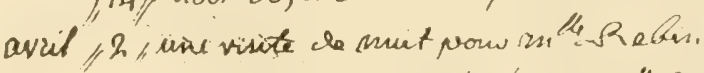

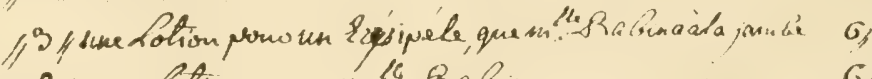

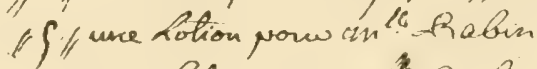

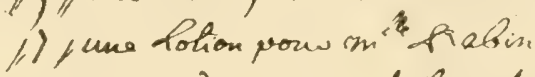

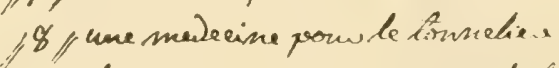

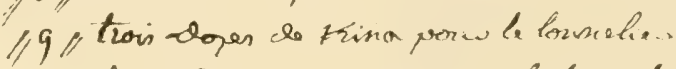

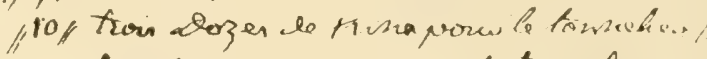

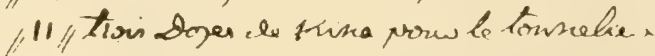

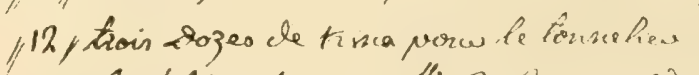

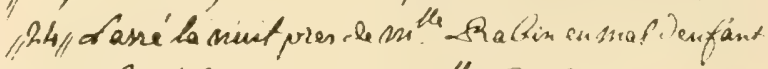

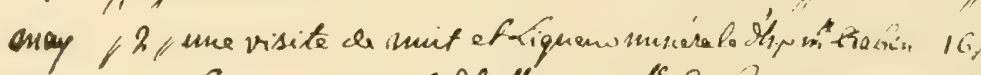

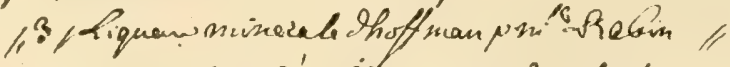

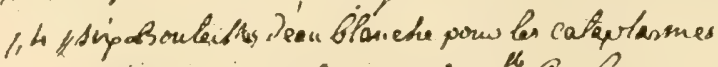

i. e

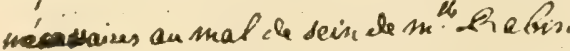

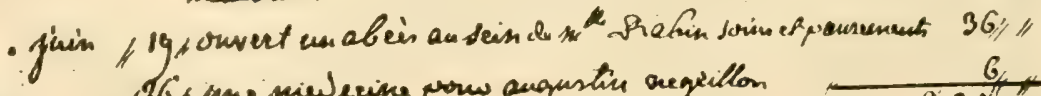

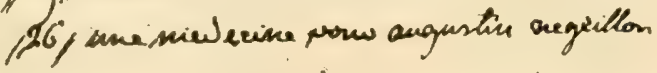

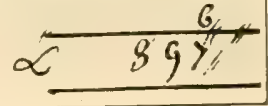




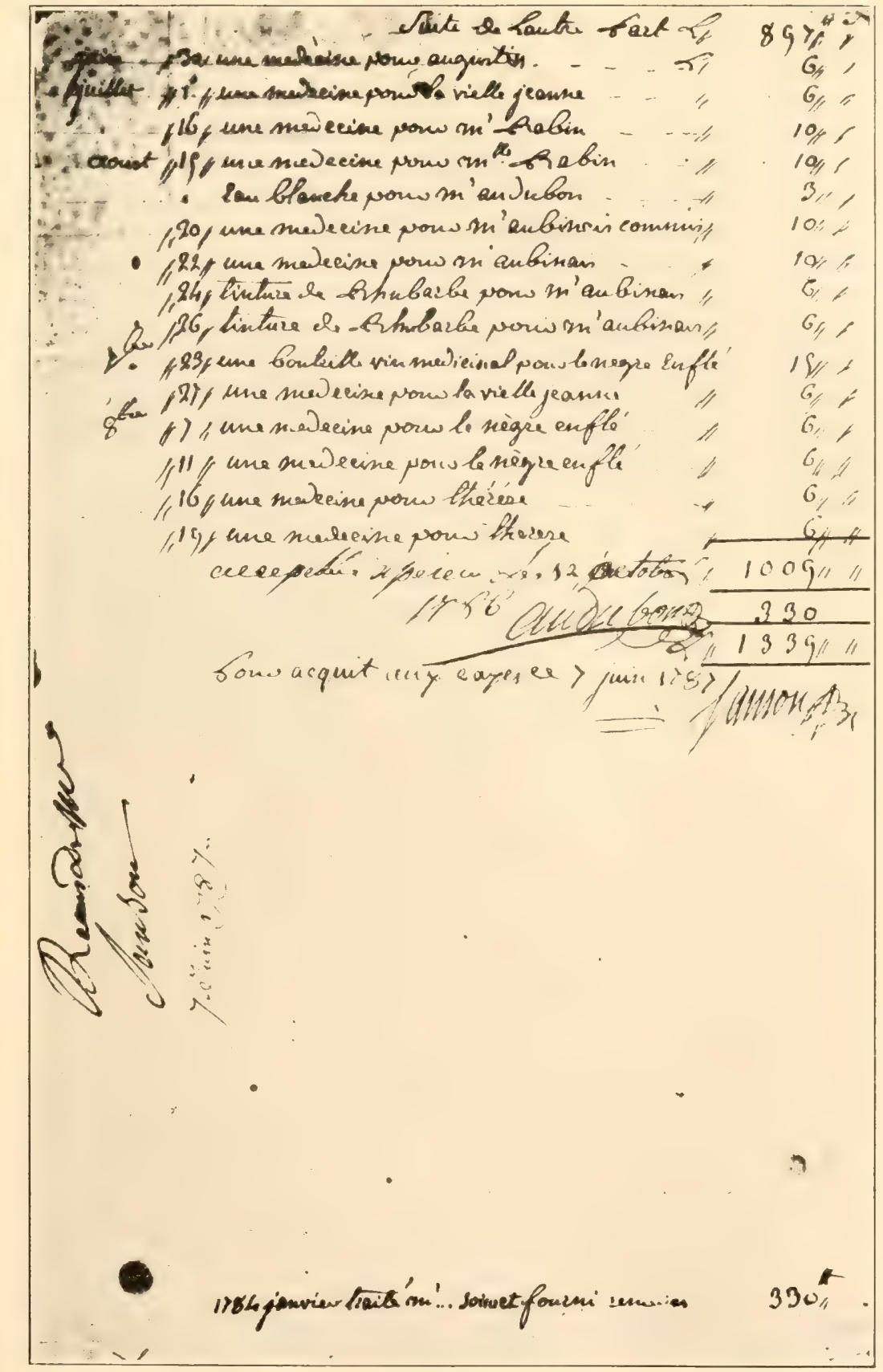

TIIIRD PAgE OF THE SAYSON BLLL, SIGNED AS ACCEPTED BY JEAN AUDUBON, OCTUBER IQ,

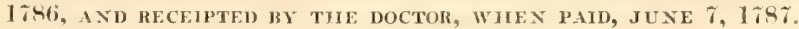



Audubon sugar refinery, was dosed thrice daily with kino on four days in succession; and that this favorite treatment was repeated a month later. A clerk in the establishment, Monsieur Aubinais, is mentioned as requiring frequent attention, as well as Jean Audubon himself, who was once bled at the arm.

In the entry for March 27, 1784, there is this interesting reference: "Inoculated Cæsar, Jupiter, and Rose, at thirty francs each, ninety francs"; and if there were any doubt why Cæsar had been inoculated, a hint is immediately given under May 11: "For attention, visits, and remedies, during the smallpox (la petite vérole) of the mulatto Joue, sixty francs"; again we read: "June 30, inoculated a little negro bossal, named Joue, thirty francs." Every fresh batch of negroes landed in the colonies led to a new outbreak of this terrible scourge, and but one other disease, la grosse vérole, ${ }^{4}$ was more common or more fatal among the blacks. For a long period it had been a common practice to inoculate both whites and blacks directly with the smallpox in order to secure some degree of protection against its most virulent form, but this method of fighting the devil with fire had its disadvantages. By the end of the eighteenth century opinion was about equally divided upon the advisability of continuing the measure, since induced variola or smallpox was apt to be virulent, and was often quite as infectious as when manifested in the usual and natural way. Then came Edward Jenner's grand discovery, made twelve years before this date but not announced until 1798, that vaccinia would prevent variola. Almost immediately vac-

which played a more or less ornamental rôle in many households, whether as footmen or servants. In any case the use of this word is doubtless purely local.

${ }^{4}$ See Vol. I, p. 46. 
cination spread like wild fire over Europe, and it has never been appreciated more fully or more highly lauded by the best representatives of the medical profession everywhere than at the present day.

The most interesting references in this historic document are to "Mlle. Rabin," whose name occurs no less than seventeen times, beginning May 21, 1784, and closing with the entry for the seventeenth of August, 1785. We learn that the physician spent the nights of April 24 and 25, 1785, at the woman's bedside, and that her child was born on the twenty-sixth day of that month, probably in the morning. It will be noticed further that she had been bled previously at the arm, that she had suffered also from the erysipelas, and that later she was treated for abscesses. These frequent attentions of the physician, extending over several months, the last record being for August 17, show only too clearly that at this time Audubon's mother was in feeble health. All that is further known about her is that she died either at the close of 1785 or in 1786 , when her infant son was probably less than a year old. ${ }^{5}$

A daughter of Jean Audubon, Rosa, who was first called Muguet (in English, "Lily of the Valley"), was also born in Santo Domingo, and probably at Les Cayes, on April 29, 1787. Her mother, Catharine Bouffard, "créole de Saint-Domingue," who subsequently went to France, had another daughter, born also at Les Cayes, named Louise, who was living at La Rochelle in $1819 .{ }^{6}$

${ }^{5}$ It was stated in the act of adoption, which was drawn up in March, 1794, that Audubon's mother had then been dead "about eight years," and the testimony of the Sanson bill shows that she was alive as late as October, 1785.

'The following letter of inquiry concerning Louise was written by Rosa's husband when Jean Audubon's will was being attacked in the courts at Nantes. It is dated at Couëron, June 26, 1819, and is addressed to "Monsieur Carpentier Chessé, engraver, place Royale, Nantes:"

"Following the friendly offer that you made me, I have the honor of 
When Captain Audubon finally left the West Indies in the autumn of $\mathbf{1 7 8 9}$, he took with him, in the care of trustworthy slaves, these two children, Fougère or Jean Rabin, aged four and a half years, and Muguet or Rosa, an infant of less than two. We know that he visited Richmond, Virginia, to collect a long outstanding claim against David Ross, then engaged in an iron industry near that city (see Chapter VIII, p. 121), and it is possible that he traveled by way of New Orleans and the Mississippi and Ohio rivers. After spending some time at the close of this year in the United States, he went to France and made a home for his children at Nantes. This city became essentially their permanent abode until their father's retirement from the navy on January 1, 1801, when he finally settled in the little commune of Couëron, on the north bank of the Loire. The storm that burst over Nantes soon after their arrival revealed the true colors of Jean Audubon's patriotism, and the man was seen at his best, as will be related in the following chapter.

Madame Audubon, who had no children of her own, tenderly received the little ones, thus wafted from over the sea to her door in the Rue de Crébillon. ${ }^{7}$ As the

asking you to undertake, at your next visit to La Rochelle, the following inquiries:

"1. There should be at La Rochelle (it is thought at the home of the widow Scipiot) a Miss Louise Bouffard, born at Les Cayes, Santo Domingo, in America.

"What is her position? What is she doing? What is her conduct? In short I should like to know absolutely all about her, being charged by the Madame, her mother, to make all inquiries."

(Translated from original in French, Lavigne MSS.)

${ }^{7}$ A principal street in the old quarters of Nantes, leading from the Place Royale to Place Graslin. Jean Audubon named this street as his place of residence in 1792 , when he was living in a house belonging to Citizen Carricoule. He made his home also at No. 39, rue Rubens, a short street, with many of its houses still intact, in the same quarter; this was rented of Françoise Mocquard for five years, beginning June 24, 1799 (le 6 Messidor, an 7 ), at four hundred franes per annum. He also dwelt 
story proceeds we shall see that she was a most kind, if over-indulgent, foster mother, and became excessively proud of her handsome boy. "The first of my recollective powers," said the naturalist when writing of himself in $1835,{ }^{8}$ "placed me in the central portion of the city of Nantes . . . where I still recollect particularly that I was much cherished by my dear stepmother . . . and that I was constantly attended by one or two black servants, who had followed my father to New Orleans and afterwards to Nantes."

Jean Audubon, who spent a good part of his life at sea and in a country almost totally devoid of morals, must be considered as the product of his time. He was better, no doubt, than many who made greater professions, better certainly than a Rousseau, who gave excellent advice to parents upon the proper methods of rearing their children but sent his own offspring to orphan asylums. As most men have their faults, said the son, the father "had one that was common to many individuals, and that never left him until sobered by a long life"; but, he added, "as a father, I never complained of him; his generosity was often too great, and his good qualities won him many desirable friends." Whatever his faults, Jean Audubon was just, generous and possessed of a kind heart. He was in reality a truer father than many who give their children their name but deny them sympathy and a wise oversight. Jean

at various times at No. 5, rue de Gigant, and in the rue des Carmes, where his wife possessed a house, as well as in the rue des Fontenelles and the rue Saint-Leonard. Very likely "La Gerbetière" at Couëron was occupied intermittently, especially in summer, after the outbreak of the Revolution and his reverses in fortune; even after his retirement there in 1801, he still kept a lodging (pied-d̀-terre) at Nantes, where, as it chanced, he died, though it was not his usual stopping-place. See Note, Vol. I, p. 86.

${ }^{8}$ See Maria R. Audubon, Audubon and His Journals (Bibl. No. 86), vol. i, p. S. 
Audubon not only cherished the two children but made them his heirs. On March 7, 1793, Fougère at the age of eight and Muguet at six were legalized by a regular act of adoption in the presence of witnesses at Nantes as the children of Jean and Anne Moynet Audubon.

This step was taken at the very moment when the storm had burst over La Vendée, when the fate of Nantes was trembling in the balance and the life of her citizens was most insecure. The act of adoption reads: ${ }^{9}$

Extract from the registers of births of the sections of La Halle and Jean Jacques of the commune of Nantes, department of the Loire inferrieure, on the seventh of March, 1794, the second year of the Republic, one and indivisible, at ten o'clock in the morning.

Before us, Joseph Theulier, public officer, elected to determine the public status of citizens, have appeared in the town hall, Jean Audubon, commanding the war sloop Cerberus, vessel of the Republic, aged forty-nine years, native of Les Sables d'Olonne, department of La Vendée, and Anne Moinet his wife, aged fifty-eight years, native of the former parish of SaintLeonard, of this commune, who, assisted by René Toussaint Julien Beuscher, manufacturer, aged twenty-five years, living in the section of La Halle, Rubens Street, and by Julien Pierre Beuscher, marine surgeon, aged twenty-four years, living in the section of La Fraternité, Marchix Street, and employed steadily in the said war sloop Cerberus, have declared before me that they do adopt and recognize from this moment as their lawful children, to wit:

A male child named Fougère, born since their marriage, which took place on the twenty-fourth of August, 1772, in the commune of Paimbœuf, in this department, to him, Jean Audubon, and a woman living in America, who has been dead about eight years, and a female child, named Muguet, born also since the

${ }^{8}$ For the original text of this act, here given in translation, see Appendix I, Document No. 2 . 
marriage aforesaid, to him and another woman living in America, named Catharine Bouffard, of whose fate he is ignorant.

The two children being present, the first aged nine years, that will expire on the 22d of next April, the second aged seven years, that will also expire on the 26th of April next, and both having been born in America, according to this declaration that the witnesses above mentioned have signified as true, I have drawn up the present act, which the natural father and the mother by adoption, as well as their witnesses have signed, together with myself in this said day and year.

It will be noticed that in this legally attested document, Bouffard, the true name of Muguet's mother, is given, while the name of the mother of Audubon is suppressed. It might therefore be inferred that the name Rabin, which appears later, was assumed, but as already remarked, such evidence is not conclusive.

Fougère, who was also called Jean Rabin, was baptized on October 23, 1800, by a priest of the church of Saint-Similien at Nantes. The archives of this church for the period in question have disappeared, but Jean Audubon's copy of the record has survived, and reads as follows: $:^{10}$

\section{The Act of Baptism of Jean Audubon-Rabin \\ October 23, 1800}

We, the undersigned, certify to have baptized on this day Jean Jacques Fougère Audubon, adoptive son of Jean Audu-

${ }^{10}$ Research at Nantes in 1915 revealed that the baptismal records of the parish of Saint-Similien were wanting for the period from 1792 to 1803, so it is probable that they were destroyed in the Revolution. The municipal archives of Nantes possess a book of baptismal records of the city without distinction of parishes, but this shows the names of neither "Fougère," "Rabin," nor "Audubon," for the year in question.

The Abbé Tardiveau was un prêtre assermenté, or one of those priests who had sworn in 1790 to recognize the civil constitution of the clergy.

For copy of the act of baptism in the French original, see Appendix I, Document No. 3. It is impossible to say whether the heading as given in my copy of this act was in the original or not. 
bon, lieutenant of a frigate of the Republic, and of Anne Moinet, his legitimate wife, who being present bear witness that the adoption of the said Fougère, made by them, is in accordance with the present act.

[Signed] Tardiveat, priest of SaintSimilien, of the town of Nantes.

The act of adoption was drawn at a time when Captain Audubon could have had little leisure to consult records had he been disposed to do so, but the dates of birth which he then gave for these two children were correct both as to the year and month. Fougère, however, was born on the twenty-sixth, instead of the twenty-second of April, and Muguet, on the twenty-ninth, instead of the twenty-sixth, of that month. Audubon's mother's name is indicated in numerous legal documents of later date, and, as will appear, in every instance her son's identity is clearly established.

Young Audubon, who disliked the names of Fougère and Rabin, and naturally wished to be rid of their early associations, adopted the fanciful name of "La Forest," 11 but used it only sporadically and for a short time. Some of his drawings of birds made at Nantes or Couëron as early as 1805, and in New York in 1806 and 1807, and possibly others of slightly later date, are signed "J. L. F. A.," or "J. J. L. Audubon." 12

Jean Audubon and his wife are said to have settled

${ }^{11}$ An English writer once gave the name of Audubon's mother as Mlle. La Forêt.

${ }^{12}$ Audubon's signature underwent frequent variations during the first twenty-five years of his life, but after $18: 0$ he almost invariably signed himself "John J.", or "J. J. Audubon." In the record of the civil marriage of his sister, at Couëron in 1805, his name appears as "J. J. L. Audubon;" in the "Articles of Association" with Ferdinand Rozier, signed at Nantes in 1806, it is "Jean Audubon," and in the release given on the dissolution of this partnership, at Ste. Geneviève, in 1811, the English form, "John Audubon," appears. 
some property upon "Jean Rabin, créole de Saint Domingue," which he refused to accept, saying, "my own name I have never been permitted even to speak; accord me that of Audubon, which I revere, as I have cause to do." 13 The reference in this instance was, I believe, to the final will of Lieutenant Audubon, ${ }^{14}$ according to which his property, after being held in usufruct by his wife during her lifetime, was to be equally divided between their two adopted children. In his first will the son was referred to as "Jean Audubon," but in the second and last document, executed in 1816, two years before the testator's death, he appears as "Jean Rabin." Madame Audubon drew four wills; in the first, dated December 4, 1814, her adopted son is called "Jean Audubon"; in the next, of 1816 , he is "Jean Rabin, créole de Saint-Domingue," while in a draft written December 26,1819 , he is styled simply "Jean Rabin"; finally, in her fourth and last testament of July 16, 1821, the wording is "Jean Audubon, called 'Jean Rabin." It is thus very plain that Audubon's foster parents considered it advisable to have his identity clearly set forth in legal documents. In one of his autobiographical sketches Audubon remarked that his own mother was said to have been as wealthy as she was beautiful, and if this were true, such caution might be explained and a key found to certain other enigmatical conditions which seemed to hedge his early life. But to such possibilities it will be necessary to revert at a later point of our story. ${ }^{15}$

This dual personality was set forth by the naturalist himself, but in a more curious form, in a power of attor-

\footnotetext{
${ }^{13}$ This statement was made to me by Miss Maria R. Audubon in 1914.

${ }^{14}$ For full text of the six wills drawn at different times by Jean Audubon and his wife see Appendix I, Documents Nos. 13-18.

${ }^{15}$ See Chapter XVII.
} 
Nearchanty. angus 1805

1805 IS F

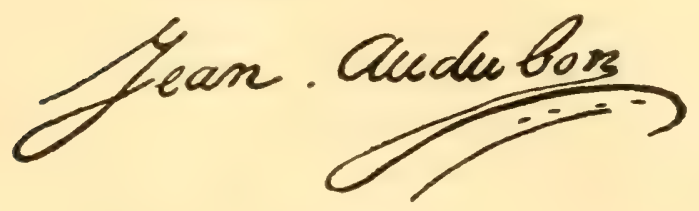

1806

C.." Stucubon

1807

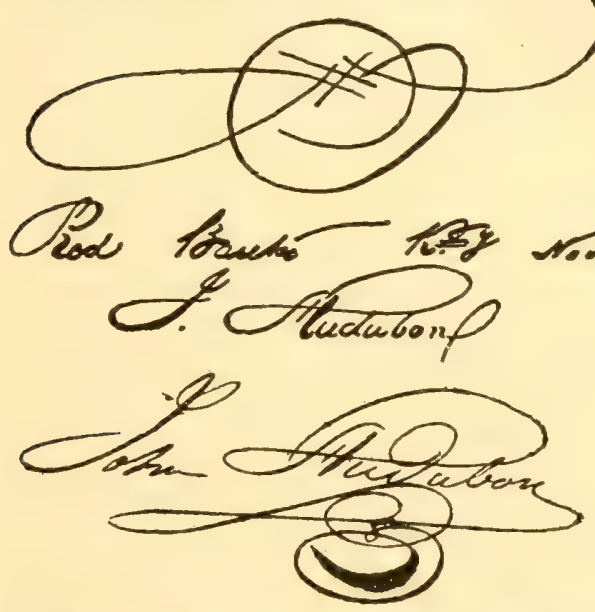

Afrit aye= 1872. Pera.

1811

drawer by \&.I Tabular

1812

ohm of

1836
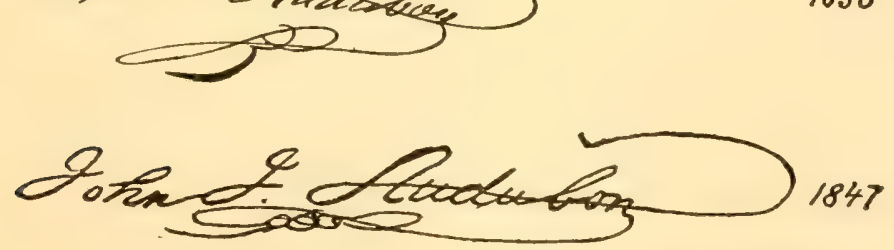

AUDCBON'S SIgNATURE A'T VARIOUS PERIODS FroM 1805 To 1847.

The first, fourth and sixth are from early drawings; the second from Audibon and Rozier's "Articles of Association"; the fifth from a release given to Rozier; and the remainder from letters.

63 
ney $^{16}$ executed at Henderson, Kentucky, on July 26, 1817, in favor of his brother-in-law, Gabriel Loyen du Puigaudeau. This measure was taken more than a year after Audubon's father had drawn up his last will, in which the son was referred to as "Jean Rabin," and was evidently designed to facilitate any settlement of this will which events in France might render necessary. The naturalist was then engaged in his famous but disastrous financial enterprises on the Ohio River, ${ }^{17}$ but whether any intimation had come to him of possible legal troubles, which later actually ensued in France, cannot be stated.

10 This unique document reads as follows:

"To all to whom these presents may come: know ye that I, John Audubon, having special trust and confidence in my friend, G. Loyen Du Puigaudeau, of the Department of Loire and [sic] Inférieure, and Parish of Couëron, near Nantes, in the kingdom of France, [do constitute him] my true and lawful attorney, and the true and lawful attorney in fact of Jean Rabin, husband of Lucy Bakewell, of the County of Henderson and State of Kentucky, in the United States of America, for us [?], the said Jean Rabin, and in our name to our use and benefit, to ask, demand, sue for, recover, and receive all and every part of the Real and Personal Estate, that is to say Lands, Tenements, Grounds, Chattels, and credits, which I have, or either of us, in the Department of Loire and [sic] Inferieure in the kingdom of France, aforesaid, and to maie sale of the same, either at auction, or by contract of the said Lands and Tenements, Goods, Chattells, and Credits, to receive the money arising from said sale, to give any Receipt, acquittance, or other discharge for the said money or any part thereof, if money or specie shall be received, or for any property he may receive in exchange or barter for said Real and personal Estate, and our said attorney, or the attorney of Jean Rabin aforesaid, is hereby authorized and empowered to make, give, execute, and deliver any Deed, Covenant, or transfer of said Real and Personal Estate to the purchaser of all or any part thereof for us, or for the said Jean Rabin, in as full and ample a manner as he, the said Jean, could do, was he personally present in said Department, in the Kingdom. In testimony whereof the said John Audubon has hereunto set his hand and affixed his seal the Twenty Sixth day of July, Anno Domini One thousand $\&$ Eight hundred and Seventeen.

Join J. Audubon [Seal within]

On the back of the preceding is the notary's certificate that Jean Audubon appeared before him; seal affixed, and dated July $26,1817$.

Signed, "A [urbroze] Barband,

${ }^{17}$ See Chapter XVI. Notary of Henderson County, Kentucky." 
In reading the published accounts of Audubon's early life many have been puzzled by the absence of definite dates, as well as by the numerous contradictions in which they abound. It is needless to burden this narrative with a tedious reference to all these errors or to attempt to trace their origin, which no doubt had many sources, but since we have given the first true account of the naturalist's birth, we cannot pass these matters without a word of comment. The situation is somewhat involved, since we should possibly differentiate between what Audubon at different times believed to be true, and what he wished to make known to his family or to the public; possibly also we should discriminate between what he actually published over his own signature during his lifetime and the material which has appeared since his death, even though originally written by his own hand.

The first definite date which Audubon ever gave concerning his own life was that of his marriage in 1808, when he was twenty-three years of age, and all that he ever published of a biographical nature is to be found in his Ornithological Biography. ${ }^{18}$ In the introduction to this work he simply said that he had "received light and life in the New World," and further that he returned to America from France, whither he had gone to receive the rudiments of his education, at the age of seventeen. Since Audubon's first return to America was in the autumn of 1803 , when he was actually about eighteen and one-half years old, this statement is not so wide of the mark as to imply that the date of his birth was not then well understood. Moreover, the record of his adoption, which was certified to at the time of his baptism in 1800 , was carefully preserved among the family docu-

$=8$ Vol. i, p. v; see Bibliography, No. 2. 
ments, and there is no reason to suppose that knowledge of his age was ever withheld from him. Nevertheless, Audubon was inclined to overestimate his years, a characteristic rare in these days; when at Oxford in 1828 he was asked for his autograph, and was begged to inscribe also the date of his birth; "that," he said in recording the incident, "I could not do, except approximately," and his hostess was greatly amused that he should not know.

While going down the Ohio River in 1820, bound for New Orleans, Audubon took advantage of a rainy day to write in his journal something about himself that he thought his children at some future time might desire to know. This brief record may or may not have been at hand when in $\mathbf{1 8 3 5}$ he wrote the more extended version that finally saw the light in $1893 .^{19}$ Since the manuscript of the later sketch was presumably in possession of Mrs. Audubon when the biography of her husband was prepared in New York about the year 1866, that account in its various versions has furnished biographers with practically all of the available material, not purely conjectural, concerning the naturalist's early life. Such additions as were made subsequently have proved to be very inaccurate.

In the first of these sketches, which, so far as it goes, is more in strict accord with facts, Audubon said nothing of his birth, and of his mother remarked only that he had been told that she was "an extraordinary beautiful woman," who died shortly after he was born. His father, he added, saw his wealth torn from him, until there was left barely enough to educate his two children, all that remained of the five, his three elder broth-

${ }^{10}$ Published by Maria R. Audubon (Bibl. No. 78) in Scribner's Magazine, vol. xiii (1893). 
$\mathrm{ers}^{20}$ having been "killed in the wars." He then believed, as he said, that his first journey to France was made when he was two years old.

The later and fuller biography, referred to above as written in 1835 and published in 1893, begins with these words : ${ }^{21}$

The precise period of my birth is yet an enigma to me, and I can only say what I have often heard my father repeat to me on this subject, which is as follows: It seems that my father had large properties in Santo Domingo, and was in the habit of visiting frequently that portion of our Southern States called, and known by the name of, Louisiana, then owned by the French Government.

During one of these excursions he married a lady of Spanish extraction, whom I have been led to understand was as beautiful as she was wealthy, and otherwise attractive, and who bore my father three sons and a daughter,-I being the youngest of the sons and the only one who survived extreme youth. My mother, soon after my birth, accompanied my father to the estate [sic] of Aux Cayes, ${ }^{22}$ on the island of Santo Domingo, and she was one of the victims during the ever-to-be-lamented period of the negro insurrection of that island.

My father, through the intervention of some faithful servants, escaped from Aux Cayes with a good portion of his plate and money, and with me and these humble friends reached New Orleans in safety. From this place he took me to France, where having married the only mother I have ever known, he left me under her charge and returned to the United States in the employ of the French Government, acting as an officer under Admiral Rochambeau. Shortly afterward, however, he

${ }^{20}$ Whether Jean Audubon had other sons born in Santo Domingo is not recorded, and this reference of the naturalist, which was repeated in his later sketch, cannot be verified.

${ }^{21}$ See Maria R. Audubon, Audubon and His Journals (Bibl. No. 86), vol. i, p. 7 .

${ }^{22}$ See Note 2, Vol. I, p. 38. 
landed in the United States and became attached to the army under La Fayette.

The true history of Jean Audubon's commercial, naval, and civic career is given in the preceding and following chapters.

The naturalist, in his letters and journals, made frequent allusions to his age, but, as his granddaughter remarked, with one exception, no two agree; hence, his granddaughter concluded that he might "have been born anywhere from 1772 to 1783 ." In the face of such uncertainty she adopted the traditional date of May 5, 1780 , adding that the true one was no doubt earlier. Audubon was thus five years younger than his biographers supposed, and twenty-one years were added to the age of his father, who actually lived to be only seventyfour years old, while his son died in his sixty-sixth year.

Wherever there is mystery there tradition is certain to raise its head, and though the naturalist carried his "enigma" to the grave, others, building upon his story, have fixed upon the very house in Louisiana in which he is said to have been born. Indeed, advocates of more than one house in that state as the probable scene of Audubon's nativity have arisen in recent times. We are obliged, therefore, to examine somewhat farther the now universally received but thoroughly erroneous idea that John James Audubon was a native of Louisiana at a time when that Commonwealth was part of a province of France.

Upholding a tradition of rather recent growth, Audubon's granddaughter has expressed the belief that the naturalist was born in a house belonging to the famous Philippe de Marigny and known as "Fontainebleau." 


\section{BIRTH AND PAREN'TAGE}

This was a sugar plantation on the north side of Lake Pontchartrain, three miles east of what is now the village of Mandeville and twenty-five miles due north of New Orleans.

Pierre Enguerrand Philippe de Mandeville, Ecuyer Sieur de Marigny, ${ }^{23}$ at one time owner of vast estates in and about New Orleans, was born in that city in $\mathbf{1 7 5 0 ,}$ and served as its alcade or mayor for two years. A lavish dispenser of hospitality, in $\mathbf{1 7 9 8}$ he entertained in great state the Duke of Orleans, later known as Louis Philippe of France, together with his two brothers who accompanied him. He died at New Orleans, leaving five sons, of whom the third, Bernard Marigny, later became the owner of "Fontainebleau," which it has been mistakenly assumed was inherited from his father. At the time of the Duke of Orleans' visit just mentioned Jean Audubon had been out of the country nine years; there is no evidence of his ever having owned property at New Orleans, or ever having sustained any relations with the Marigny family.

Before following the Marigny myth further, it will be interesting to notice a late echo of the "Fontainebleau" story. In 1910 the Reverend Gordon Bakewell, then in his eighty-ninth year, gave some interesting reminiscences of Audubon, and spoke very deñnitely concerning both the time and place of his birth. Dr. Bakewell was a nephew of Mrs. Audubon, and as a youth, in 1834, had passed some time at her home in London. John W. Audubon, with his father's assistance, painted at that time a portrait of young Bakewell, who at a

${ }^{23}$ See J. W. Crozart, "Bibliographical and Genealogical Notes Concerning the Family of Philippe de Mandeville, Ecuyer Sieur de Marigny, 1709-1800," Louisiana Historical Society Publications, vol. v (New Orleans, 1911). The portrait referred to below now hangs in the H. Sophie Newcomb Memorial College, New Orleans. 
later day was welcomed in their home on the Hudson. Dr. Bakewell's contribution was as follows: ${ }^{24}$

The uncertainty as to the place of Audubon's birth has been put to rest by the testimony of an eye witness in the person of old Mandeville Marigny now dead some years. His repeated statement to me was, that on his plantation at Mandeville, Louisiana, on Lake Ponchartrain, Audubon's mother was his guest; and while there gave birth to John James Audubon. Marigny was present at the time, and from his own lips, I have, as already said, repeatedly heard him assert the above fact. He was ever proud to bear this testimony of his protection given to Audubon's mother, and his ability to bear witness as to the place of Audubon's birth, thus establishing the fact that he was a Louisianian by birth.

We do not doubt the candor and sincerity of the excellent Dr. Bakewell, but are bound to say that the incidents as related above betray a striking lapse of memory and an even greater misunderstanding of recorded facts. Singularly a footnote to the paragraph quoted shows that the Marigny to whom he refers was, as must have been the case, Bernard Mandeville de Marigny, who was born in $\mathbf{1 7 8 5}$, the same year as the naturalist. Since both were in the cradle at the same time, he is hardly available as a witness. Moreover, the official records of the United States Government prove that the estate called "Fontainebleau" was not in possession of the Marigny family at the time of Audubon's birth. The land in question was granted to a creole named Antonio Bonnabel, on January 25, 1799, by Manuel Gayoso de Lemos, Governor-General of the Province of Louisiana and West Florida. Bonnabel sold his tract 
to Bernard Marigny in 1800, and Congress confirmed his title to it by a special act in $1836 .^{25}$

Bernard Marigny served in the French army towards the close of the Napoleonic period, and his return to the United States from France, about 1818, is said to have been hastened by a duel which he fought with one of his superior officers. On his return he named Bonnabel's old tract on Lake Ponchartrain "Fontainebleau," in remembrance of the place where his regiment had been assigned for duty in France, and eventually built upon the estate a sawmill and a sugar-house, and planted sugar cane, living meanwhile on another plantation two and one-half miles away. The latter estate was allotted by him in 1832, when he gave it the name of Mandeville; the settlement thus started has since grown to a village of some 1,500 people. Here a summer house which belonged to Bernard's father still exists, although in altered form; it has been raised to accommodate a lower story, and is now known as the "Casino." According to those who have most carefully investigated existing records, this is the only house in Mandeville which belonged to the elder Marigny at the time of which we speak.

${ }^{25}$ See Laws of the United States, Treaties, Regulations, and Other Documents Respecting the Public Lands, vol. i, p. 301 (Washington, 1836). In Number 756 , entitled " $\Lambda$ n Act for the Relief of Bernard Marigny, of the State of Louisiana," Marigny is mentioned as assignee of Antonio Bonnabel, and his claim, which was confirmed, is described as follows: a tract of land of $4,0 \% 0$ superficial arpents, in the State of Louisiana, parish of St. Tammany, "bounded on the southwest by Iake Ponchartrain, and on the northwest by lands formerly owned by the heirs of Lewis Davis."

I am informed by Mr. Gaspar Cusachs, president of the Historical Society of Louisiana, who has carefully investigated the titles of this property and to whom I am indebted for much information concerning it and its owners, that the tract described above included the estate of "Fontainebleau." Marigny's claim included also a smaller tract of 774 arpents in the same parish. This land was bounded on the southwest by Lake Ponchartrain, on the north by Castin Bayou, and on the south by the tract acquired from Bonnabel; it was granted to the heirs of Lewis Davis in 177\%, and certain of them filed a claim for it in 1812. 


\section{AUDUBON, THE NATURALIST}

Bernard Marigny was one of those who befriended Audubon when he was in desperate straits at New Orleans in 1821, by advancing him money in return for portraits or drawings of birds. He died in that city in 1868, when in his eighty-third year, a poor and honest man. 


\section{CHAPTER V}

\section{LIEUTENANT AUDUBON AS REVOLUTIONIST}

Background of Audubon's youth-Nantes in Revolution-Revolt in La Vendée-Siege of Nantes--Reign of terror under Carrier-Plague robbing the guillotine-Flight of the population-Execution of CharetteThe Chouan raid-Citizen Audubon's service-He reënters the navy and takes a prize from the English-His subsequent naval career-His losses in Santo Domingo-His service and rank-Retires on a pension-His death-His character and appearance.

The ancient city of Nantes, long famed for the beauty of its situation on the banks of a noble river, within easy reach of the sea, as well as for its importance in the arts of war and peace, numbered at the time of the Revolution 70,000 souls. The modern visitor to this favored spot will find quiet and orderly streets adorned with monumental statues (one of these representing Guépin, the revered historian of the city), the old buildings nearly all replaced by better, the Loire spanned by handsome bridges, and the ancient bounds of the town extended until it has become the sixth city of the Republic. Since Nantes formed a somber background to Audubon's youth, we shall follow in brief some of the ordeals through which his family, in common with thousands of other Nantais, were destined to pass during those eventful years which witnessed the close of the eighteenth century in France.

When Captain Audubon reached Nantes presumably not far from the beginning of 1790 , he found the city in a state of the greatest turmoil and agitation. The 
commons, or third estate, included hundreds of its rich and influential citizens, and their demands for a fair hearing and a representation equal to that of the other orders had then passed the stage of open revolt, for they had planted their "liberty tree" and were sworn to defend it. In August of 1789 a permanent Committee of Public Safety had been constituted at Nantes, and by the end of that month 1,200 had volunteered for service in the National Guard. There were many loyalists in the city but they could not crush the ardent spirit of this revolt, and when in September money was needed to equip the revolutionary soldiery, young school children raised large sums for the popular cause. Jean Audubon immediately cast his lot with the revolutionists and joined the National Guard, but how much service he saw in the field cannot now be determined; it is known, however, that he was with these troops in the spring of $1792 .^{1}$

In March, 1793, the loyalists of La Vendée rose to arms, and marching on Nantes under the able leadership of Charette, threatened to put its garrison to the sword if it were not surrendered within six hours. The National Guard met these invaders outside the walls and left the citizens to shift for themselves. Thus thrown upon their own resources, the Nantais showed that they could help themselves. They requisitioned and used for defense everything at hand; they exhumed the leaden coffins in their grand cathedral and appropriated waterspouts for ammunition, while their church bells were molded into cannon. Though held in check, the Vendeans laid siege to the city, and but for the resolution of its mayor, Baco, Nantes would probably have fallen - in which event Audubon would have had a different

${ }^{1}$ One period of this service bears date of May 31. 
history and would probably never have become a pioneer naturalist in America. Baco, disregarding the advice of his military chiefs, immediately placarded the walls of Nantes decreeing death to any who should suggest capitulation, and called all the inhabitants to arms, sparing neither woman nor child. The Vendeans had met their match, for they were dealing with many of their own blood, but though the siege began in early March, they were not effectually dispersed until the end of June, and then only after much bloodshed without the walls. When the immediate crisis had passed, the Constitution of the Republic was unanimously accepted by the eighteen sections of Nantes, on the twenty-first day of July, 1793.

A few months later in that fateful year a more terrible calamity befell the city, when the reign of terror under the notorious ultra-revolutionist, Jean B. Carrier, began. Carrier reached Nantes on October 8 and at once proposed to exterminate both the Vendean royalists and their Nantais sympathizers. He reorganized the entire administration to suit his purposes, and to carry out his plans recruited from the lowest classes a revolutionary army to spy upon, denounce and arrest private citizens, many of whom were sent to Paris for trial when not secretly dispatched. The whole district was soon paralyzed by the barbarity of the crimes then committed, and the unhappy Vendeans were dragged to Nantes, to be shot, guillotined or drowned, in such numbers that the city was unable to bury its dead or the river to discharge them to the sea. Thus perished thousands, uncounted if not unknown, and the pestilence of typhoid fever that immediately followed claimed another heavy toll regardless of political sympathies. While these dire scenes were being enacted, Jean Jacques 
Fougère Audubon, then a lad of eight years, was living in the heart of Nantes, and his father was one of its leading revolutionists. An aunt of the future ornithologist, according to his account, who was one of these wretched victims of revolutionary fury, was dragged through the streets of Nantes before his eyes, but apparently she did not actually meet her death at that time. ${ }^{2}$

That Jean Audubon moved his family out of Nantes during the revolutionary crisis is possible, and Couëron would have been available as a place of refuge. Many Nantais are known to have fled to Lorient on the coast of Brittany, where they found in the heroic youth Julien the ardent and fearless patriot who was destined to become the real savior of their stricken city. Young Julien denounced Carrier in his letters to Robespierre, and when one of these was intercepted, defied him in person. When his stirring appeals finally reached the Tribunal at Paris, its misnamed representative was recalled, and left Nantes under cover of night on February 14, 1794. During his mad reign of four months, Carrier had gone far towards carrying out his theory of republican government, that should begin, as he openly avowed, by "suppressing" half of the population of France. The records show that nearly nine thousand bodies were buried in Nantes in a little over three months, from January 15 to April 24, 1794. 'The plague of fever no doubt accounted for many of these, but the wide reaches of the Loire never told their full story.

Though the most grievous affliction of Nantes passed with the recall of Carrier, the city had no lasting peace until the execution of the Vendean leader, Charette, in March, 1796; "Poor Charette," said Audubon, writing in his journal at Liverpool, December 24, 1827, "whom

${ }^{2}$ See Note 4, Vol. I, p. 27. 
I saw shot on the place de Viarme at Nantes." This virtually ended the war in the Vendée, but the Chouans, under their intrepid chief, Dupré, the miller, called "Tête-Carrée," managed to furnish considerable excitement, and raided Nantes in 1799. Dupré's followers stole in secretly at three o'clock on the morning of October 19 and left before daylight, after liberating fifteen royalists from the prison, which seems to have been their chief purpose. The cannon of alarm was fired from the Chateau; the tocsin sounded, calling the city to arms; there was much street fighting, but it was too foggy and dark.to distinguish friend from foe, and when the $\mathrm{Na}$ tional Guard was finally assembled, the enemy had vanished. This brief attack cost the city twenty-one deaths and wounds for twice the number, ${ }^{3}$ but it was only a passing incident in comparison with events that had gone before. Thenceforth the history of the town is blended with that of the nation. ${ }^{4}$

We have only slight indications of Jean Audubon's activities from the close of 1789 , when, according to his own statement, he was in the United States, to the period of his service in the National Guard at Nantes in the spring of 1792 ; he was then living in the house of Citizen Carricoule, rue de Crébillon, and the lease of his "Mill Grove" farm, which was renewed in October, 1790, was dated at Nantes. We may safely assume that he was

${ }^{3}$ The mayor, Saget, at the moment he was crossing the Place Egalité (the Place Royale of today) received point-hlank a ball in his right thigh and another in his left leg, and lost both limbs.

${ }^{4}$ For the revolutionary history of Nantes I am chiefly indebted to M. A. Guépin's excellent Histoive de Nantes, ad ed. (Nantes, 1839); Hipp. Etiennez, Guide du Troyageur à Nantes, et aux Environs (Nantes, 1861); A. Lescadien et Aug. Laurent, Histoire de la Ville de Nantes, t. 2 (Nantes, 1836); F. J. Verger, Archives curieuses de la Ville de Nanies et des Départments de l'Ouest, t. 5 (Nantes, 1837-41); and to a scholarly monograph by Dugast-Matifeux, entitled Carrier à Nantes: Précis de la Conduite patriotique et révolutionnaire des citoyens de Nantes (Nantes, 1885). 
engaged in revolutionary business during most of this interval: his name begins to appear in the written records of Nantes and of the department of the Lower Loire in January, 1793, and existing documents ${ }^{5}$ show that he was engaged as a commissioner and member of the Department and as a member of the Council of the Navy until the twenty-fifth of June, when he enlisted for active service in the navy of the Republic. Jean Audubon served also on various republican committees, his duties comprising the enlistment of recruits, organizing the National Guard, soliciting funds and food supplies for Nantes, finding cannon and other military or naval materials, posting proclamations, administering the oath of allegiance, and watching the movements of loyalist troops in the district. We have seen that the father of the naturalist was a game and determined fighter, and there is ample written testimony to prove that in the commune of Nantes he was regarded as an ardent patriot, who could be relied upon to act with tact, and if necessary with force.

Having been appointed a Civil Commissioner by the Directory of the Department on January 17, 1793, Citizen Audubon was sent to Savenay, a town of some importance twenty-five miles to the northwest of Nantes. His instructions on this mission were to gather useful

${ }^{5}$ The unpublished documents of this Department are preserved in the archives of the Préfecture at Nantes, and through the courtesy of their custodians I was enabled to examine them freely. These documents deal with all the revolutionary changes in church and state consequent upon the breaking down of the old régime, and with the enrollment of volunteers and the dispatch of armed forces to centers of disturbance throughout that district. The present manuscripts are said to represent but a fraction of those which originally existed, the archives having been subjected to repeated raids, thefts, and wanton destruction by fire and other means. The most important have been listed and published by the Government in summary form under the title, Les Archives du Département de la Loire Inférieure, 1790-1\%99, Série L. (Nantes, 1909). 


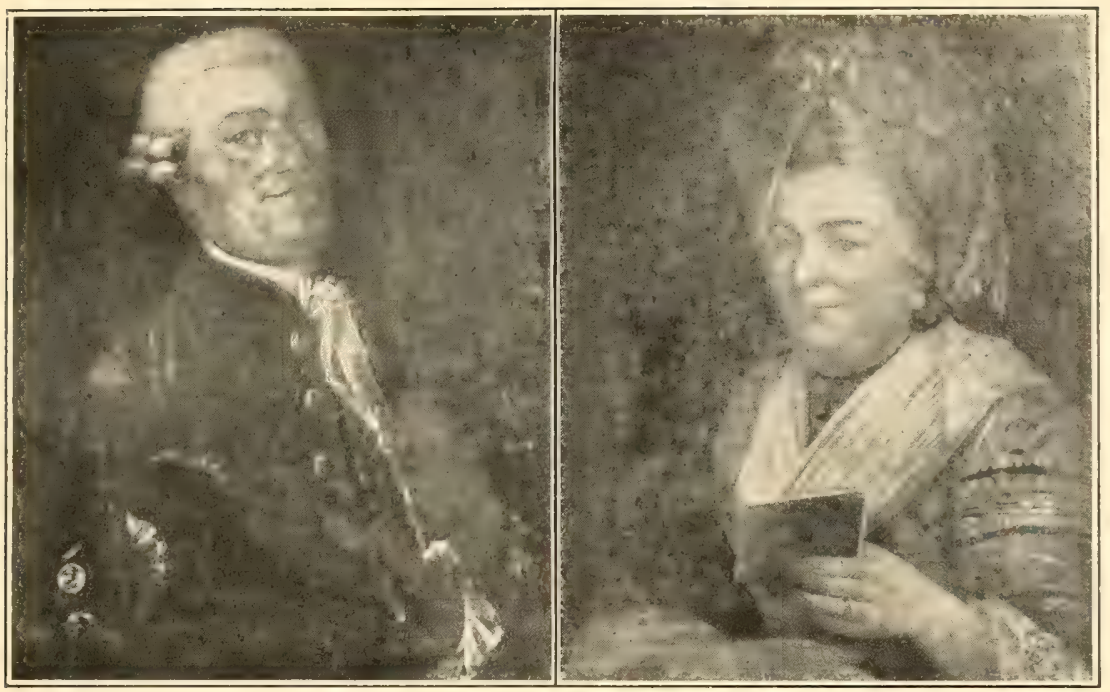

\section{IIEUTENAN'T JEAN AUDUBON ANTE MOYNET AUDUBON}

AFTER OIL PORTRAITS PAINTED BETWEEx 1801 AND 1806, NOW IN POSSESSION OF M. L. IAVIGNE, AT COUIRT)

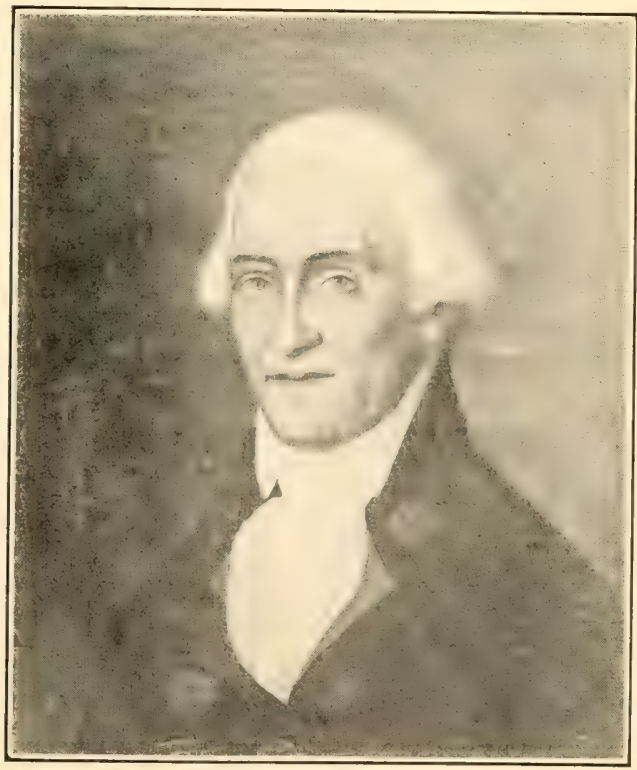

JEAN ALDUBON

AFTER AN OIL PORTRATT PAINTED BY THE AMERICAN ARTIST POLK, AT PIHLADELPHIA, ABOUT 1789, NOW IN POSSESSION OF MRS. MORRIS FRA TK TYLER. PUIBLISHED BY COURTFEY OF MISS MARIA R. ATDEBON. 

information on the civil, moral and political state of the district, "in order to bring a remedy," and to administer the oath of allegiance to all administrative and judicial bodies. Jean began operations without delay, and his report, which was kept in journal form and embraces the period from January 19 to September 10, 1793, is in interesting document; it covers fifty-one large foolscap pages, written now in a fine and again in a bold, regular hand, in the course of which his characteristic signature $^{6}$ occurs no less than twenty-two times, each

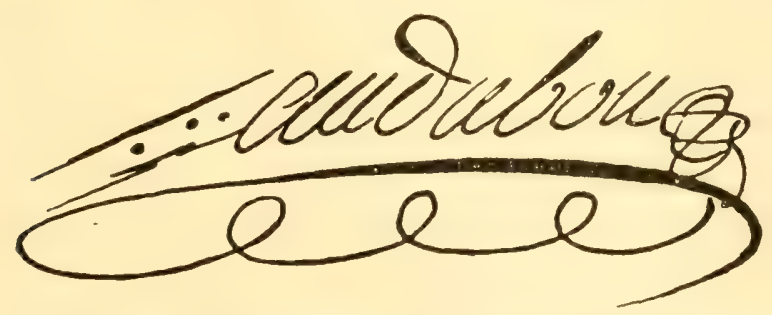

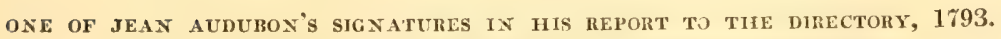
From the original in the archives of the préfecture at Nantes.

section of the report having been signed as completed. In one section of this journal he wrote: "Our operations having been finished, we assembled around the tree of liberty, and there sang the hymn of the Marseillaise, which was interrupted with frequent shouts of 'Vive la république!,' 'Vive la nation!,' and more than one charge of musketry."

Jean Audubon with eight others was charged with organizing the National Guard in the canton of Pellerin, and ordered to accompany the detachment that marched to the relief of Pornic, March 27, 1793. The Citizen was busy also in other directions. He said in his report:

${ }^{8}$ During the Revolution Jean $\Lambda$ udubon always added to his signature the cabalistic sign of three dots between parallel lines, which possibly stood for the three watchwords of the Republic-"Liberte, Egalité, Fraternité." 
In virtue of the power conferred upon us by the Central Committee, on the ninth of April we were transported to the parish of Couëron, where we arrived at seven o'clock in the morning. Proclamations were posted both at Couëron and at Port Launay close by, while some were sent across the river to Pellerin. We availed ourselves on this occasion of the services of two officers of a corsair, who demanded that we aid in removing from Pellerin four cannon with four-pound balls, and we succeeded in putting to flight a small barque and four men, who an hour later returned with cannon. . . The parish of Couëron appears very tranquil, and is in a better mood than [at first] seemed to us.

A little later Jean proceeded to Paimbœuf on a similar errand. His letters to the citizen-administrators of that commune are dated at Nantes on the seventeenth of April and the fourteenth of May; in one of these he refers to "the sum of four hundred franes" due from the Administration "for one year's rent of my house in calle Rondineau (à la calle rondino), which you have taken for a corps de garde" (see Vol. I, p. 32).

In July and August of this second year of the Republic, Citizen Audubon was sent to his native town of Les Sables d'Olonne to follow the movements of the loyalist generals Westermann and Boulart, ${ }^{7}$ a mission which

${ }^{7}$ In the published orders and correspondence of the royalist General Boulart the following letter, given here in translation, is addressed to Citizen Audubon: "I give you notice, Citizen, that my aide-de-camp will arrive immediately from Niort. I beg you to do all in your power to come this evening to confer with me, since I have something to ask you of the utmost importance. I also inform you that there has arrived at Les Sables Citizen Anguis, the people's representative. Perhaps it would be more advantageous that you should see him this evening, and that tomorrow early we attempt to bring all three together. You could depart in the morning for Nantes." [Signed] "The Geveral Boulart." Jean Audubon filed this letter from the enemy with his Department, but his answer is not given. See Ch. L. Chassin, Etudes Documentaires sur La Révolution Française: La Vendée Patriote, 1793-1800, vol. ii, p. 306, t. 1-4 (Paris, 1894-1895). 


\section{LIEUT. AUDUBON, REVOLUTIONIST 81}

could hardly have been agreeable if, as seems to have been the case, some of his own people were loyal to the old régime. Correspondence by sea between Les Sables and Nantes, which was open before the siege, was not broken at this time, for the royalists had named one of their representatives, Benoit, as a delegate "to fraternize with the citizens of Nantes, to invite the authorities to correspond, and beg them to send food if they had more than they required." Four of Jean's letters, dated at Les Sables on the fifth and eighth of July and the sixth of August, besides one from La Rochelle on the fourteenth of July, all addressed to the Administration of the Loire Inférieure, have been preserved.

In the manuscript records of the Department for 1793 is found also a notice of Jean's appointment as Special Commissioner, with a memorandum of all the money paid to reimburse him for the expenses of his numerous journeys. Thus, it is noted that he had been paid $\mathbf{1 4 5}$ franes for a service of twenty-nine days, which would represent the modest allowance of a dollar a day. Another item shows that he had received 100 francs for a tour of ten days; a note which was added to this item to explain the Directory's sanction for the payment of another forty-five franes and ten sous reads as follows: "by its order of the sixth of March last, the Council had, in effect, named Citizen Audubon as its Commissioner, to visit the coasts and to secure signatures, with full power to treat with all people, to acquire materials for the navy and other objects of his mission; if this mission did not prove successful, it was solely through force of circumstances, and not from any lack of zeal on his part." 8

${ }^{8}$ Délibérations-Arrêtés de Directoire du Département. In MSS. pp. 107-108. 
On the twenty-fifth of June, 1793, while engaged in duties to which we have just referred, Jean Audubon was appointed, with rank of ensign, to command the Republican lugger named the Cerberus. ${ }^{9}$ During this charge, which lasted until the twenty-second of November of the following year, he fought one of the stiffest engagements of his career. On the twelfth of July he encountered the Brilliant, an English privateer of fourteen cannon which had captured an American ship laden with flour; and after a desperate battle which lasted three hours, in the course of which Jean was wounded in the left thigh, the Englishman, beaten and obliged to surrender his prize, was glad to escape under cover of night. Jean towed the American into the port of La Rochelle, and afterwards sent to the Administration a full account of the engagement. ${ }^{10}$ Ensign Audubon's next command was a dispatch boat called L'Eveillé ("The Awakened"), on which he served for nearly nine months, from November 23, 1794, to August 14, 1795. He was then detailed for port duty at La Rochelle from August 15, 1795, to January 24, 1797. His last ship was L'Instituteur ("The Institutor"), which he commanded with the rank of ensign-commander from January 25 to October 3, 1797, while he was engaged in governmental business between the ports of La Rochelle and Brest.

The financial losses which Lieutenant Audubon sustained at Les Cayes in consequence of the revolution in Santo Domingo were a crushing blow to him ; he never recovered his fortune, later estimated by his son-in-law

Jean was actually in command of this war vessel in March of that year, as shown by a document given in full in Chapter IV (p. 59).

${ }^{10}$ These records are on file in the archives of the Department of Marine at Paris, but access to them will doubtless be denied until peace is restored in Europe. 
at a sum which at that day would have been fabulous. ${ }^{11}$ The business house in which he was interested failed; his plantations, refinery, houses and stores, the rents from which, as we have seen, in certain years after 1789, had yielded 90,000 francs, were presumably ravaged and partially destroyed. When the news of this misfortune reached him after $\mathbf{1 7 9 2}$, his hands were tied by revolutions at home. Though he applied to his Government for relief, as undoubtedly did a host of other losers, he was eventually granted only a small indemnity, not exceeding 30,000 francs.

Friends of Jean Audubon at Nantes had made repeated demands of the Ministry of Marine that he be given a rank more in accord with his patriotism and efficient service to the State, and on October 11, 1797, he was commissioned lieutenant-commander (lieutenant de vaisseau), ${ }^{12}$ one grade below that of captain. He held this rank for three years, during which he was engaged in vigilance service at Les Sables d'Olonne and in military duty at Rochefort, or until he was retired from the navy for disability, January 1, 1801 (le 11 nivose, an 9 ), at the age of fifty-seven. ${ }^{13}$ He had served the

${ }^{11}$ M. L. Lavigne writes that he possesses a copy of a letter addressed by M. G. L. du Puigaudeau to a lawyer in Paris, in which it is stated that Lieutenant Audubon's losses amounted to 1,500,000 francs. After making due allowance for the psychological tendency to overestimate losses, especially when sustained in remote and romantic lands, the true amount was no doubt large.

${ }^{12}$ Or "lieutenant of a frigate," and corresponding to "mate" in the merchant marine.

${ }^{13}$ The certificate which Lieutenant Audubon received at the time of his discharge is preserved among the Lavigne manuscripts and documents at Couëron, and is headed:

Port ETAT des Services du Citoyen Jean Audubon natif des

DE Sables d'Ollonne Département de La Vendée âgé de ROCHEFORT. 58 ans.

It is signed by the Chief of Administration, Daniel, the Naval Commander-in-Chief of the District, Martin, and by the naval commissioner and clerk, February 26, 1801 (le sept T'entose. an 9 de la République). 
B O $\mathrm{T}$
No.

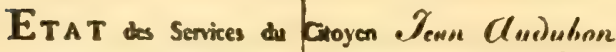

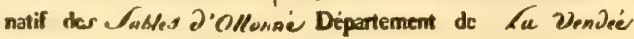
âgé the 58 and

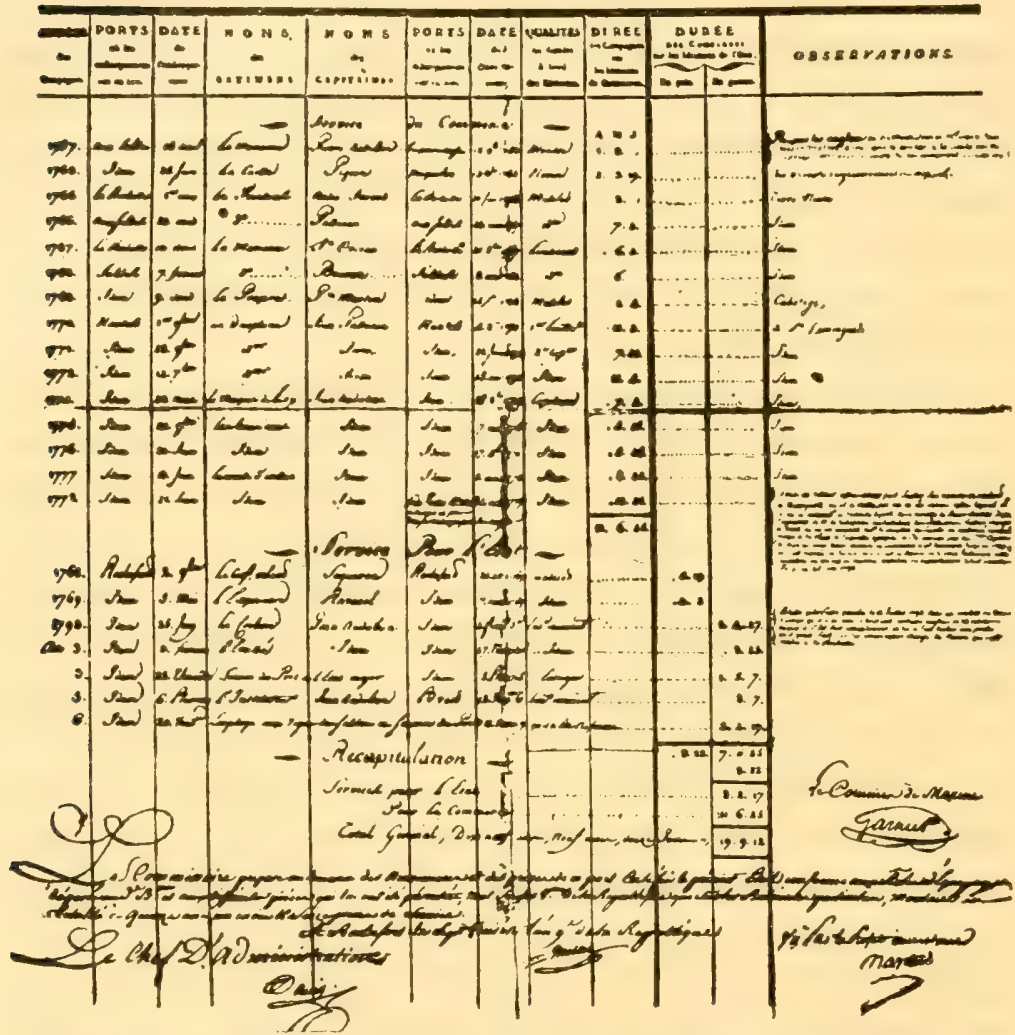

CERTIFICATE OF SERVICE OF LIEUTENANT JEAN AUdUboN, FEBRUARY 26, 1801. From a photograph of the original in the Lavigne MSS.

State for over eight years, and his total period of active duty on sea and land when employed in the merchant marine and navy of France, as estimated from port to port, amounted to nineteen years, nine months and twelve days, while it had extended with interruptions over more than forty years. ${ }^{14}$ After this long period

14 Jean Audubon was 11 years, 6 months and 25 days in the service of the merchant marine of France (service au commerce), in the course of 
of service, when, suffering from a pulmonary affection, he applied to his Government for a pension, he received the paltry annuity of 600 francs or $\$ 120$.

With this modest pension and a property yielding an income not above $\$ 2,000$ a year, ${ }^{15}$ Lieutenant Audubon retired to his quiet villa of "La Gerbetière," at Couëron, where he could indulge his taste for country life and for raising his favorite fruits and flowers; he is said to have kept some live stock, but could have been a farmer only on a modest scale. Meanwhile he continued to maintain a house, or at least rooms, at Nantes, whither he went periodically to conduct his correspondence and business affairs. The following letter of attorney, issued by Lieutenant Audubon a year after he had retired from the navy, shows that he still had interests in Santo Domingo, and was endeavoring to collect rents, long overdue, from houses and stores that belonged either to himself or to his clients. Whether through the dishonesty of agents or from what other cause, this property which the elder Audubon held in his own right seems gradually to have melted away:

The 19th pluviose, in the eleventh year of the Republic, one and indivisible [January 7,1802$]$, before the public notaries of the department of Loire inférieure, who reside in Nantes and Doulon, the undersigned have seen present the

which he rose to the rank of captain of the first grade in 1\%\%4. He served in the French navy (service à l'état) 8 years, $\mathcal{2}$ months and 17 days, ranking successively as sailor, ensign-commander, and lieutenantcommander (lieutenant de vaisseau); 8 months and 22 days of this period (1768-1;69) were in intervals of peace, and 7 years, 5 months and 25 days (1793-1801), in times of war. Any conflict which may seem to occur in titles must be attributed to this double service.

${ }^{15}$ This property was evidently encumbered to a considerable extent, for he repeatedly filed with the Department letters for the removal of restrictions placed upon it (lettres pour obtenir la main levée). I cannot give the dates of these letters, but believe that they were drawn in 1801 or shortly after. 
citizen Jean Audubon, lieutenant of frigate, retired, and proprietor at Santo Domingo, aged 59 years, infirm and unable in consequence of his infirmities to go himself to attend to his business affairs in Santo Domingo, living in Rubens Street, in the Mocquard house, ${ }^{16}$ No. 39, in the city and commune of Nantes, department of Loire inférieure:

Who has made and constituted for his general and special attorney Jean François Blanchard, merchant, and originally from the commune of Chataubriand, department of Loire inférieure, living at the town of Les Cayes, in the southern section of the island of Santo Domingo, opposite Ile à Vaches, to whom he gives full and complete powers to revoke for him, and in his name, every preceding bill of attorney, for the purpose of managing the stores [magazins] at Les Cayes, in the southern part of Santo Domingo, opposite Ile à Vaches: To demand and obtain all accounts from the holders of said properties, who have had or still have charge of them there; to examine the said accounts, to debate, close up and stop them . . . to lease the said properties, without the power of making any extensive repairs to them whatsoever, about which he had not informed the constituent in France, and that he has not authorized him there to do, at least by a special letter, it being understood that the actual tenant is obliged to make all the necessary repairs to the said houses and stores to the extent of 15,000 francs, and he should not use more than 4,000 francs yearly for the space of five years, counting from the month of thermidor, year 8 [July 19-August 17, 1800].

It is demanded of citizeness Fauveau, or of her assigns, to know the reason why she has failed, to the present moment, to pay to the constituent in France for the domicile of the citizeness Coyron, ${ }^{17}$ the twelve thousand six hundred francs that

${ }^{10}$ This house was rented at the time to Françoise Mocquard (see Note \%, Vol. I, p. 5\%), but it is probable that Lieutenant Audubon had reserved rooms which were occupied during his visits to the city while his permanent home was at Couëron. In the power of attorney issued by Jean Audubon, his wife, and Claude François Rozier, at Nantes, April 4, 1806, the senior Audubon gave his residence as "rue Rubens, No. 39." ${ }_{17}$ Presumably a widow of one of the Coyrons (or Coironds), mer- 


\section{LIEUT. AUDUBON, REVOLUTIONIST}

she should annually pay to him, according to the act of July 15, 1788, as given by Domergue, notary at Les Cayes. You will satisfy them with the state of the dwelling house in the plain of Jacob, opposite Ile à Vaches.

This was sold by the said act to the said citizeness Fauveau and to her late husband by the said constituents, to whom he will report regularly on the state of affairs, at least twice in the year....

[Signed at Nantes] J. Royer [one of the undersigned notaries]

Lieutenant Jean Audubon died at Nantes, ${ }^{18}$ when on a visit to that city, on February 19, 1818, at the age of seventy-four, "regretted most deservedly," said his son, "on account of his simplicity, truth, and perfect sense of honesty"; "his manners," he continues, "were those of a most polished gentleman . . . and his natural under-

chants at Nantes, whose business interests in Santo Domingo were entrusted to Jean Audubon's hands in 1783 ( see Chapter III, p. 38).

${ }^{18}$ The following extract from the registry of deaths at Nantes, which is here given in translation, indicates that Lieutenant Audubon passed away suddenly, since his death did not occur in his own apartments (for original see Appendix I, Document No. 19):

"In the year 1818, on the 19th day of February, at eleven o'clock in the morning, in the presence of the undersigned, deputies and officers of the civil service, delegates of Monsieur the Mayor of Nantes, have appeared the Messrs. Gabriel Loyen du Puigaudeau, gentleman of leisure, son-in-law of the deceased, residing hereafter at Couëron, and Francis Guillet, grocer, living on the Quai de la Fosse, of legal age, who have certified in our presence that on this day, at six o'clock in the morning, Jean Audubon, retired ship-captoin, pensioner of the State, born at Les Sables d'Olonne, department of La Vendée, husband of Anne Moinet, died in the house of Mlie. Berthier, in the Chaussée de le Madeleine, No. 24, 4th Canton.

"The witnesses have signed with us the present act, after it was read to them. The deceased was 74 years of age."

C Gabriei, Loyen du Puigaudeau, "Signed in the register: $\left\{\begin{array}{l}\text { GuILLEx, and JOSEPH DE LA } \\ \text { TULLAYE, deputy." }\end{array}\right.$

The Audubons and Du Puigaudeaus were probably buried in one of the large cemeteries at Nantes, since no trace of their graves has been found at Couëron by M. Lavigne. 
standing had been carefully improved both by observation and by self education." Jean Audubon's means in France had been reduced partly by bad debts, for he seems to have been generous in lending money to his friends; Madame Audubon found herself greatly hampered by lack of ready money, although, as her sonin-law remarked, her hands were full of notes.

When Jean Audubon applied for nomination to the naval service of the Republic in 1793, we find a description of his previous life and habits recorded as a part of the information required by the Committee of Public Safety. The commune of Nantes at that time gave a flattering testimonial to his patriotism, in which he was described as an officer of merit, who had acquired through long experience at sea an extensive knowledge of navigation, who was a man of honor, and devoid of any inclination to vice or gambling; his nautical experience had been chiefly gained in American waters, the voyages of his choice being those to Santo Domingo and the United States.

At the age of forty-eight the elder Audubon thus briefly described himself: short in stature, measuring five feet, five inches; face, oval; eyes, blue; nose and mouth, large; eyebrows, auburn; hair and beard turned gray. Contrary to the naturalist's expressed belief, there seems to have been little or no physical resemblance between father and son. At a corresponding age, John James Audubon, according partly to his own account, stood five feet, ten inches in stockings; his hair was dark brown; he had sunken, hazel eyes, flecked with brown, and of remarkable brightness; while his clean-cut profile showed an aquiline nose. "In temper," said the son, to continue the comparison, "we much resembled each other, being warm, irascible, and at times violent, but it was 
like the blast of a hurricane, dreadful for a time, when calm almost instantly returned."

Though passionate at times, Jean Audubon was a man of force and decision, as his career amply shows. If he does not loom large in the history of his time or was but little known beyond the limits of his province, it must be remembered that the time called forth thousands of the ablest men of his nation. 


\title{
CHAPTER VI
}

\author{
SCHOOL DAYS IN FRANCE
}

Molding of Audubon's character-Factor of environment-Turning failure into success-An indulgent stepmother-The truant-His love of nature-Early drawings and discipline-Experience at RochefortBaptized in the Roman Catholic Church.

It is now commonly believed that of the three great factors which mold character-environment, training and heritage, the last is the most important, since it alone is predetermined and unalterable. Environment may be uncertain or unsuitable, training defective or deferred, but blood is the one possession of which the child cannot be robbed; and since it sets the limits to possibility, in no small degree must it determine the acquisitions and accomplishments of a lifetime. This, however, is not the whole truth. Race may account for much, but it does not account for everything; the child is effectually robbed whenever it is not permitted to realize to the full upon its inheritance. To be able to convert possibilities into actualities it must receive fit training and right incentives, and if at critical times the proper spur is wanting, its patrimony may be sadly wasted. The "good environment" for the youth, too often thought to be the soft conditions of an easy life, is in truth that only which provides the proper and necessary stimulus. This may be now fear or pride, now hard necessity or bitter want; again, an awakened sense of responsibility or ambition to excel may be induced 
by concrete examples and fostered, as it often is, by lofty purposes and the uplift of a high ideal.

Audubon's life affords a striking proof of the power which environment can exert in awakening dormant capacity, in developing talents to their full and calling into use every force held in reserve. When we consider what his life work finally became, and what he eventually accomplished in a field for which he had no training, except in drawing, we find it easier to wonder at the man than to criticize him. With a formal schooling in France of the slenderest sort, in which the writing of his own language was never completely mastered, at eighteen he came to America and adopted a new tongue, which he first heard from the Quakers. Twenty years more were to elapse before he had a definite plan,during which his environment was mainly that of a trader and storekeeper in the backwoods, never remote from the white man's frontier, hardly the soil one would seek for the development of budding talents in art, literature or science. Failure in trade was one of the spurs which started Audubon on his ultimate career, for it led to the immediate development of the talents which he possessed; the encouragement which he received from his wife was undoubtedly another. When he finally emerged, like a somewhat wild but well ripened fruit, at the age of forty, rich in experience, ready to absorb what from lack of earlier motives or opportunities he had failed to acquire, and with the determination to succeed, he won recognition as much through his personality and enthusiasm as by his extraordinary versatility and talents.

In an early sketch of his life Audubon said that his father had given both him and his sister an education appropriate to his purse; his teachers were possessed of 
agreeable talents, and he might have stored up much had not the continental wars in which France was then engaged forced him from school at an early age, when, much against his will, he entered the navy as midshipman, at Rochefort. This naval experience terminated, as he then recorded, in 1802, during the short peace between England and France; he was then seventeen years of age. ${ }^{1}$ This was the year following his father's retirement, and the year previous to his first independent visit to the United States.

More details of this early period were given later, when the naturalist spoke with great affection of his foster mother, to whom his education had been mainly entrusted. "Let no one speak of her as my step-mother," said he; "I was ever to her as a son of her own flesh and blood, and she was to me a true mother." His every idle wish was gratified, he tells us, and his every whim indulged, in accordance with the notion that fine clothes and full pockets were all that were needed to make the gentleman: "She hid my faults, boasted to every one of my youthful merits, and, worse than all, said frequently in my presence, that I was the handsomest boy in France."

If Madame Audubon broke the prevailing tradition and by going to the other extreme did her best to spoil this affectionate boy, some allowance must be made for parental over-indulgence. In $\mathbf{1 7 9 3}$, when the future naturalist was eight years old, the public buildings of

${ }^{1}$ Audubon said that he was at the time fourteen years old, which could not have been the case, but when writing in 1835 he placed this experience at shortly before his return to America, which would have been in the winter of 1805-6; "I underwent," to quote this later account, "a mockery of an examination, and was received as a midshipman in the navy, went to Rochefort, was placed on board a man-of-war, and ran a short cruise. On my return, my father had in some way obtained passports for Rozier and me, and we sailed for New York." 
his city had been converted into prisons and its streets were both unsanitary and unsafe, while in the following year, as we have seen, a mortal plague began to rob the prisons and the guillotine. Many had lost their all in the tempest that swept over them; many more had fled, and public schooling at Nantes must have been at a stand or disorganized for a considerable period.

Young Audubon could not have tasted much schooling before the outbreak of the Revolution, when he was seven years old, and but little after it, since this discipline practically terminated in $\mathbf{1 8 0 2}$. His passionate love of nature, which was undoubtedly innate, was manifested at an early day. Living things of every description which he found by the banks of the Loire or along the stonewalls and hedgerows of Couerron gave him the greatest pleasure, but birds were his early favorites. These he soon began to depict with pencil and crayon, but to the dryer discipline of the school he ever turned with laggard feet.

When the versatile Lord Avebury, who became one of the greatest modern students of the powers of ants and other social insects, was four years old, his mother made this record in her diary: "His great delight is in insects. Butterflies, Caterpillars or Beetles are great treasures, and he is watching a large spider outside my window most anxiously." The same boy at eight, when writing home from school, added this postscript to a letter: "I am a favorite with most of the boys because I do not care about being laughed." The boy who has a good inheritance, follows his own bent, and does "not care about being laughed," may be on the road to success and with talents may achieve distinction. John James Audubon was one of those boys, although his path was never strewn with the roses that many have imagined. 
The naturalist tells us that his father hoped that he would follow in his footsteps, or else become an engineer, and he saw that his son was instructed in the elements of mathematics, geography, fencing and music. But as Lieutenant Audubon was continually on the move, supervision in those matters fell to the over-indulgent stepmother, with the result that, instead of doing his duties at school, young Audubon took to the fields. Every night, he said, he would return with his lunch basket well laden with the spoils of the day-birds' nests, eggs, and curiosities of every sort destined for the museum into which his room had already been transformed. He was then in the "collecting stage," when that sense of possession dominates the heart of the boy, which, if well directed, can be turned to excellent account.

Lieutenant Audubon encouraged his son's taste for natural history and for drawing, but did not regard such accomplishments as a substitute for what he considered more serious subjects. He himself had suffered too much from lack of a formal education and was resolved to give his children the best opportunities within their reach. "Revolutions," he once remarked, according to his son, "were not confined to society, but could also take place in the lives of individuals," when they were all "too apt to lose in one day the fortune they had before possessed; but talents and knowledge, added to sound mental training, assisted by honest industry," could "never fail, nor be taken from any one when once the possessor of such valuable means."

When the elder Audubon returned from one of his periodic cruises, "my room," said the naturalist, "made quite a show," and the father complimented him on his good taste; but upon being questioned in regard to the progress made in his other studies, he could only hang his 
head in silence. His sister Rosa, on the contrary, who was also called to account, was warmly commended upon the improvement shown in her musical exercises. 'The next morning at dawn a carriage was drawn up before the Audubon door, and with the father and son, together with the latter's trunk and violin, was soon proceeding in the direction of Rochefort. The sailor had laid his plans and was about to execute them in his own way. Presently, said the son, his father drew forth a book and began to read, thus leaving him to his own resources. In this way they traveled for a number of days, not an unnecessary word being spoken during the entire journey, until the walls of Rochefort had been passed, and they alighted at the door of the father's house in that city. When they had entered, the naturalist continues, "my father bade me sit by his side, and taking one of my hands, calmly said to me: 'My beloved boy, thou art now safe. I have brought thee here that I may be able to pay constant attention to thy studies; thou shalt have ample time for pleasures, but the remainder must be employed with industry and care. This day is entirely thine, and as I must attend to my duties, if thou wishest to see the docks, the fine ships-of-war, and walk around the wall, thou mayest accompany me.','

The youth accepted his father's proposal with good grace, and was presented to the officers whom they met, but he soon found that he was like a prisoner of war on parade. He was enrolled at once in the military school, where he was placed under the immediate care of Gabriel Loyen du Puigaudeau, his future brother-inlaw. It was not long, however, before young Audubon gave his guardian the slip; he jumped from the window of his prison and made for the gardens of the Marine Secrétariat, but a corporal, whom he had recognized as 
a friend, suddenly nipped his plans in the bud; he was ordered, he said, aboard a pontoon, then lying in port, and there was obliged to remain until his father, who was absent at the time, finally released him, "not without a severe reprimand." The following record, written long after, is reminiscent of this period: "This day twenty-one years since $I$ was at Rochefort in France. I spent most of the day at copying letters of my father to the Minister of the Navy. . . . What has happened to me since would fill a volume. . . . This day, January first, 1821, I am on a keel boat going down to New Orleans, the poorest man on it."

Audubon's stay at Rochefort, the date of which is no doubt correctly given in the journal just quoted, was lestined to be short. After a year he returned to Nantes, and later to "La Gerbetière," where as before he spent all of his leisure in roaming the fields and looking for birds, their nests, their eggs and their young. At about this time, when fifteen years of age, Audubon began to make a collection of his original drawings of French birds, which was greatly extended in $\mathbf{1 8 0 5}$ and 1806 .

$\mathrm{He}$ has recorded that at the behest of his foster mother, who was an ardent Catholic, he was confirmed in that Church when "within a few months of being seventeen years old"; he was surprised and indifferent, but "took to the catechism, studied it and other matters pertaining to the ceremony, and all was performed to her liking." Since no record of this act has been found, it is probable that the ceremony in question was confused with that of his baptism, which, as we have noticed, occurred on October 23, 1800, six months before he attained his sixteenth birthday.

After having seen something of the character of Audubon's early training in France, it will not be surpris- 
ing to find that when, at the age of forty-five, he first seriously began to write for publication and in English, which was not his mother tongue, he found himself handicapped in many ways. In after life he wrote that the only school which he had ever attended was that of Adversity, and that his tuition there had been of a prolonged and elaborate character. Though this statement was made under the stress of present feeling, it was not wholly devoid of truth. 


\section{CHAPTER VII}

FIRST VISIT TO THE UNITED STATES, AND LIFE AT "MILL GROVE"

Audubon is sent to the United States to learn English and enter tradeTaken ill-Befriended by the Quakers-Settles at "Mill Grove" farmIts history and attractions-Studies of American birds begun-Engagement to Lucy Bakewell-Sports and festivities.

If there were ever a time when Lieutenant Audubon wished to see his son following the victorious eagles of Napoleon, whom he is said to have idolized, the hated conscription of that day, which was robbing every home in France of its best blood, might well have brought counsels of prudence. Little could the father have thought that by following other eagles of his own choice, his son was destined to add a far greater luster to the family name. Whatever may have turned the scale, in 1803 a decision was quickly reached, and the issue was fortunate for the future of natural science in America; it was decided that young Audubon should emigrate at once to the United States, with what end in view we shall soon see expressed in the sailor's own words. Accordingly, to his "intense and indescribable pleasure," the future naturalist, who had now passed his eighteenth birthday, eagerly prepared for the journey, the first of many that were later to become memorable in the annals of American science. No record of this voyage has been preserved, but from evidence derived from a variety of sources we can fix the time as the autumn of $1803 .{ }^{1}$

${ }^{I}$ Audubon, writing in 18\%0, described himself at this time as "a young man of seventeen, sent to America to make money (for such 
Audubon's introduction to the country of his adoption proved most inauspicious, for, to follow his account, when walking to Greenwich in Connecticut, some thirty miles from New York, to cash the letter of credit that his father had given him, he was seized with the yellow fever. ${ }^{2}$ Fortunately at this critical moment his captain came to his aid, and placed him in the care of two Quaker ladies who kept a boarding house at Morristown in New Jersey. To the faithful ministrations of these kindly sisters the naturalist believed that he owed his life.

When Jean Audubon finally left the United States not far from the beginning of 1790, he placed his business interests in America in charge of an agent, named Miers Fisher, "a rich and honest Quaker of Philadel-

was my father's wish), brought up in France in easy circumstances;" but in the same journal he said that he did not reach Philadelphia until three months after landing, and that "shortly after" his arrival at "Mill Grove" the Bakewell family moved to "Fatland Ford." Mr. G. W. Bakewell, the historian of his family, states that in the spring of 1804, William Bakewell, Audubon's future father-in-law, with his son, Thomas, traveled through Pennsylvania, Virginia and Maryland in search of a farm; they purchased "Fatland Ford," which was then the property of James Vaux. Audubon's account of the Pewee (Ornithological Biography, vol. ii, p. 124) shows that he was at "Mill Grove" before April 10, when "the ground was still partially covered with snow, and the air retained the piercing chill of winter." If these various statements are correct, they would indicate that Audubon left Nantes about the middle of November, 1803, and that he finally reached "Mill Grove" not far from the end of March, 1804. On the other hand, Mr. W. H. Wetherill, the present owner of "Mill Grove," informs me that his records indicate that the Bakewells occupied "Fatland Ford" in January, 1804. If this were the case, young Audubon could not have left France later than August, 1803. Too much weight, however, should not be attached to such references of a biographical character in Audubon's own writings; for in the account referred to above Audubon said that after his first visit to the United States he remained two years in France and returned to America "early in August;" while we know that his sojourn in France lasted but little more than a year and that he landed in New York on the 28th of May.

${ }^{2} A$ plague of genuine yellow fever had visited New York in 1795, but in 1804 and 1805 the city suffered from a malignant fever of another type, and to such an extent that 27,000 persons, or one-third of the entire population, are said to have fled to escape the pestilence. This was possibly the malady which seized young Audubon not far from the beginning of the former year. 
phia," and to the hands of this trustworthy man he now confided his son. Accordingly, when young Audubon had been nursed back to health, word was sent to his father's friend, who came in his carriage and drove the lad to his own home in the outskirts of Philadelphia. To follow the account which the naturalist gave, when writing of this visit a quarter of a century later, his host, finding his charge to be a comely youth, and having a daughter "of no mean appearance," proposed that he should remain with them and become one of the family. Audubon seems to have suspected that this was a premeditated scheme to entangle him in marriage, and as he had no liking for the severity of Quaker manners, determined to make his escape. This, he said, was finally accomplished by appealing to his own rights and to the honest Quaker's sense of duty in seeing him established on the estate which his father had designed for him.

Though effective for the time, as will presently appear, this appeal was quite fanciful, for Jean Audubon's ideas concerning the future of his son were of a more practical character, and he had no intention at this time of establishing him at "Mill Grove," which was soon to be sold. The friend to whom the following letter was addressed is implored to aid in finding a good American family in which his son could acquire the English language as a step to entering trade: ${ }^{3}$

This will be handed to you by my son, to whom, I request you will render every service in your power, wishing that you shd. join Mr. Miers Fisher to procure him a good and healthy place where he might learn english. I come to point out to

${ }^{3}$ The rough draft of a letter in English, evidently written by Lieutenant Audubon to be delivered by his son to the ship's captain, and probably in duplicate to his agent, Miers Fisher, but bearing no name or date. (Lavigne MSS.) 
you Morristown, and look for a good and decent familly in that place to recommend him to her as your own Son. This service from you will deserve my everlasting gratitude. I am Sir, with consideration.

\section{Yr Mo ob Ser-.}

Mr. Miers Fisher, who evidently received a copy of this letter, no doubt considered his own family as good as the best, and in detaining young Audubon at his home, we must credit him with the desire of following the instructions thus received.

"Mill Grove," which was finally reached in the spring of $1804,{ }^{4}$ was a new-found paradise to the young naturalist. Here, however, he was destined to spend but little over a year, though it was doubtless the happiest year of his life. The farm was then conducted by a Quaker, named William Thomas, who was installed as tenant with his wife and family. It was arranged, said Audubon, that he should receive from them a quarterly allowance in ready money, in a sum that "was considered sufficient for the expenditure of a young gentleman." 5

Well might any youth fond of wild life in the country have fallen in love with this secluded spot, the beauty and charm of which are suddenly revealed to the visitor of today as he approaches it from the old Philadelphia road. Standing high on the rugged banks of the Perkioming Creek, which empties into the Schuylkill River just below this point, the old house, facing west, commands a wide and diversified scene, extending from the living waters below, over bottom lands of the valley, to the dim, undulating lines of the Reading hills in the far-

${ }^{4}$ See Note, Vol. I, p. 98.

"The yearly rent of "Mill Grove" in 1804, according to the accounts of Francis Dacosta, who had then acquired a half interest in it, amounted to $\$ 353.34$. 


\section{ther distance. This old landmark ${ }^{6}$ of Colonial times re-} mains today in perfect preservation, thanks to the neverfailing care and interest of the present owner, ${ }^{7}$ who has done all in his power to maintain its historic associations, and to keep the memory of the naturalist green in one of the few spots in America where material landmarks of his career have not been completely effaced. The place has had an interesting history, and though Audubon's occupancy was brief, it affected, as we shall see, his whole after-life.

Audubon thought nothing of walking to and from Philadelphia when no conveyance was at hand, but today the railroad brings the traveler within a mile and a half of his old farm. Not far to the south, beyond the present railway station of Protectory, lies Valley Forge and the wooded hills where Washington's ragged veterans passed in log huts the ever memorable winter of 1777-8. Audubon fancied that his father had made the acquaintance of General Washington at that date, but this was eleven years before the place had come into the possession of his family, and at that time Captain Audu-

6"Mill Grove" farm is in Montgomery County, twenty-four miles northwest of Philadelphia, in the town knowis, after 1833, as Shannonville, but in 1899 rechristened "Audubon;" Norristown is five miles to the east.

${ }^{7}$ Mr. William H. Wetherill of Philadelphia, whose hospitality I have enjoyed and to whom I am indebted for many interesting facts and records pertaining to "Mill Grove." Samuel Wetherill, Mr. W. H. Wetherill's grandfather, was one of the first to bring "black rock," or coal, from Reading to Philadelphia. Samuel Wetherill, Junior, who is said to have started the first woolen mill in the country and to have produced the first white lead made in the United States, purchased "Mill Grove" for" the sake of its minerals in 1813, the war having put a stop to all importations from England at that time. He actually succeeded in extracting se eral hundred tons of lead from the "Mill Grove" mines, doing better, it is thought, than any who preceded or followed him. Samuel Wetherill, Junior, died in 1829, and was succeeded in the lead and drugs industry by his four sons, of whom Samuel Price Wetherill became the owner of "Mill Grove" in 1833. The farm remained in the hands of the Wetherill family until 18\%6, and returned to them again, when the present owner came into possession, in 1892 . 


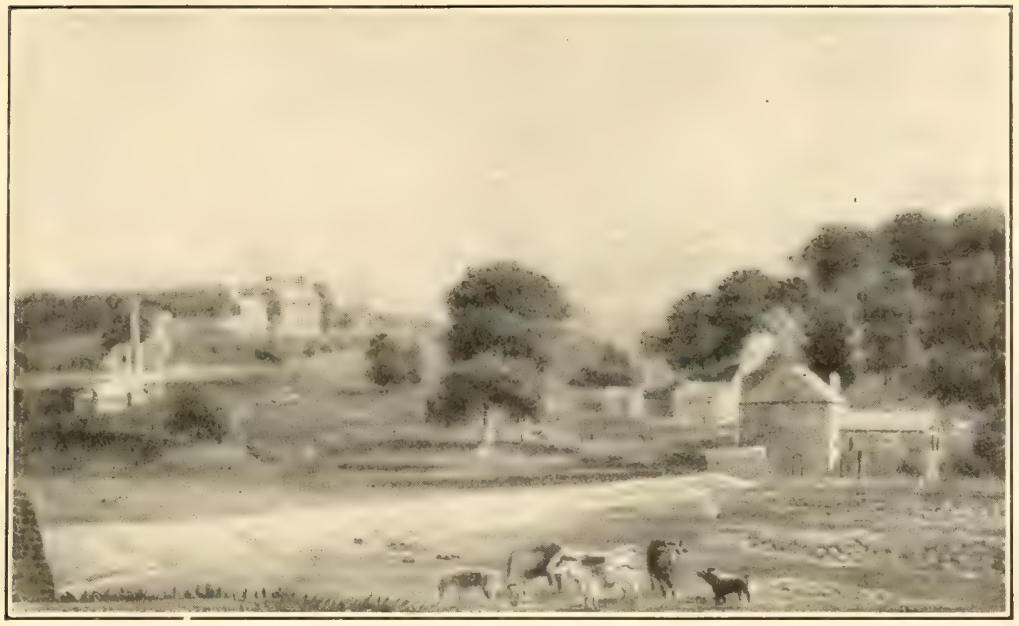

"MILL GROVE" IN 1835, SHOWING THE MIIS ON THE BANK OF PLRKMMNG CREEK, TIE FIRMHOLSE, AXD THE OLD SMELTING WORKS (BUILT BY SATIEL, WETHERIII.), THEN IN DISLSE.

After a water-color painting by charles Wetherill, son of samuel Wetherill, and uncle of William H. Wetherill, the present owner of the estate.

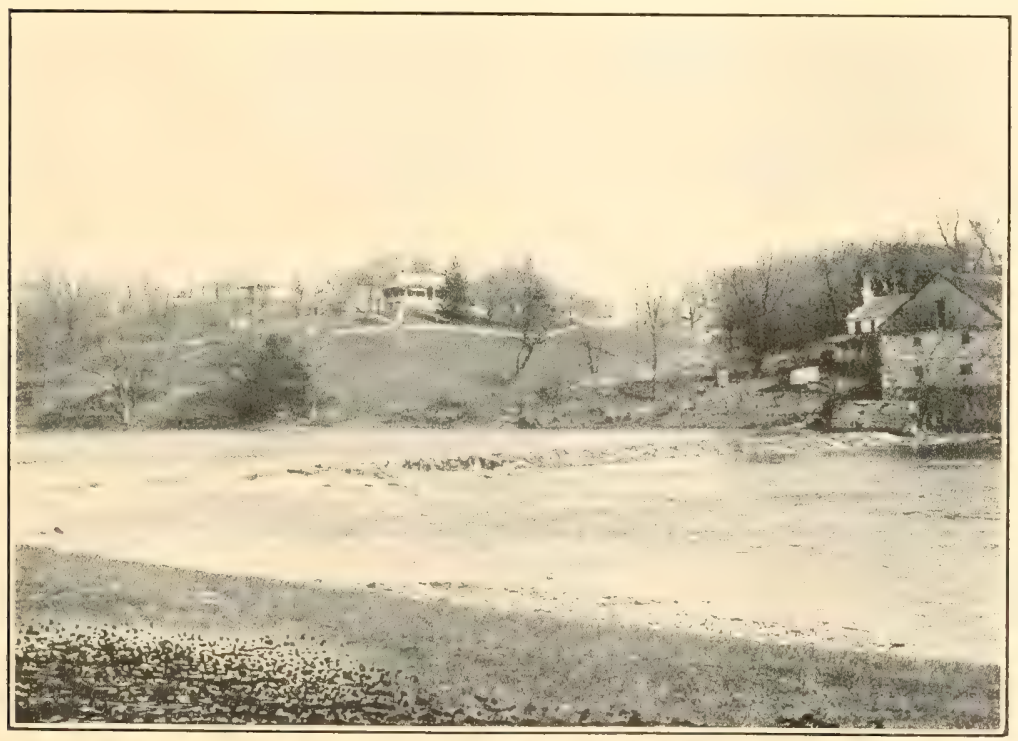

"MILI, GROVE" AS I'T APPEARS TO-DAY.

The ahove from photograph by, and this puhlished by courtesy of, Mr. Wr. H. Wetherill. 

bon was sailing the seas (see Chapter II, p. 32). Equally fanciful also was the idea that his mother had once lived there, which he expressed in a letter (quoted in full in Chapter XXXIII) written from New York on February 10, 1842, to young Spencer F. Baird, at Carlisle, Pennsylvania. The naturalist was assuring his young friend that the slow but beautiful "Little Carlisle" was to be preferred to "Great New York, with all its humbug, rascality, and immorality," and added: "It is now a good long time since I was young, and resided near Norristown in Pennsylvania. It was then and is now a very indifferent place as compared with New York; but still my heart and my mind oftentime dwell in the pleasure that I felt there, and it always reminds me that within a few miles of that village, my Mother did live."

The soil of this farm region is of a dark red color, owing to a friable shale which outcrops everywhere. The high, wooded bank of the Perkioming abounds in caves, scooped out by the hand of nature or man, as well as in great pits and shafts, for deep down under its shale, "Mill Grove" was rich in minerals, particularly the sulphide of lead, associated with copper and zinc, to reach which many excavations have been made. The lead mines of this farm are said to have been famous in Revolutionary times, and have been worked sporadically for a hundred years; if traditions are trustworthy, many a winged bullet that laid a Red-coat low in the War of Independence was a messenger from "Mill Grove." In some of the old conveyances, which go back to the time of Penn, the place was commonly designated as the "Mill Grove Mines Farm." It is recorded that the original tract of two thousand acres, extending from the Schuylkill to the Perkioming as far as the mouth of Skippack Creek, was sold to Tobias Collett by 
William Penn in $\mathbf{1 6 9 9}$ for fifteen shillings. We shall soon see that the mineral wealth which "Mill Grove" was supposed to hide beneath its rugged slopes was a source of no little trouble to the Audubons, the Roziers, and their successors for many a year.

At the foot of the declivity towards the west, half hidden by foliage, stood a picturesque stone mill, at a point where a solid rampart had been thrown across the stream to divert its power to the use of man. Hard by was the miller's house, which antedates the mansion, and which was built and first occupied by James Morgan, who came into possession of the property in $\mathbf{1 7 4 9}$. It was this old mill site, originally distinct from the farm, that gave the name to the place. Behind the gristmill an extensive sawmill, built over the mill race, was also in operation. Today the dam is broken through, and the great mill wheel of wood and iron, twelve feet in diameter and fifteen feet wide, has come to rest after turning for more than a century.

Like the mill, the original house on the hilltop was built of rough-hewn native stone, which is brown or red and very hard. It consists of two stories, with central hall, and a curiously divided attic with dormer windows, which Audubon is said to have converted into a museum. A marble slab in the south gable bears the date of 1762; an addition of the same rough stone was built on the north side, but at a considerably lower level, in 1763 , and the commemorative tablet in this instance bears the initials "J. M.," proving that the construction of the buildings of "Mill Grove" was due to the old miller, James Morgan. The interior, with its odd chimrey-corner, low ceilings, bold fireplace and hand-wrought iron-work, bears witness to a time when honest, substantial construction and pride in workmanship received the 
first consideration. The present owner of "Mill Grove" has added attractive porches at the front and back. Ampelopsis climbs over the walls, which are shaded by handsome trees; one of these, a fine black walnut at the easterly porch, which in August bore its great green balls in full clusters, must have been vigorous in Audubon's day, and possibly suggested the introduction of sprays of this full-fruited tree into some of his plates.

While on a visit from Santo Domingo in 1789, concerned with his business interests, Captain Audubon spent some time in Philadelphia. On March 28, 1789, he purchased the "Mill Grove" property, at that time consisting of 2841/2 acres of land, mansion house, mill, barns, furniture, tools and live stock, from Henry Augustin Prevost ${ }^{8}$ and his wife, for the sum of 2,300 English pounds, in gold and silver. He never lived there, and that he never intended to make it his immediate residence is shown by the fact that in less than a fortnight he leased the farm in its entirety, as already noticed, to its former owner, and gave him a mortgage which stood for seventeen years. ${ }^{9}$

${ }^{8}$ In $1761 \mathrm{~J}$ ames Morgan, the first miller and builder, conveyed one-half of the mill site of five acres to Roland Evans, who came into possession of the other half, witk the adjoining farm, in 1\%r1; the property was sold to Governor John Penn in 17r6; it passed to Samuel C. Morris in 1784, and to the Prevosts in 1786.

${ }^{9}$ The lease, which was drawn up in English, April 10, 1789, reads in part as follows: "This indenture, made on the tenth Day of April in the Year of our Lord, One thousand Seven hundred \& Eighty nine, Between John Audubon, of the Island of St. Domingo, Gentleman, now being in the City of Philadelphia, of the one party, and Augustine Prevost...."The lease included the messuages, grist mills, saw mills, plantation and tract of land, which is described, tools, implements, stock, and furniture of the mills and farm, and was drawn for one year; it was signed in the presence of Miers Fisher, agent and attorney for Jean Audubon.

In the inventory were included one windmill, one pair of scales, with weights of 56, 28 and 7 pounds, "skreen," four bolting cloths, two hoisting tubs, and one large screw and circle for raising the millstones. This lease was renewed in October, 1790, when Jean Audubon, who was then living 
Young Audubon lived at "Mill Grove" from the winter of 1804 to the spring of 1805, and again for a few months in the summer of 1806, the year of its final sale by the Audubons and Roziers (see p. 148). In his journal of 1820 the naturalist wrote that his father had once the honor of being presented to General Washington, and also to Major Crogan, of Kentucky, "who was particularly well acquainted with him." Jean Audubon left at "Mill Grove" oil portraits of himself and of Washington, both by an inferior American artist named Polk, ${ }^{10}$ and it is probable that the one of hinself was painted while he was at Philadelphia in the spring of 1789 ; the drawing is hard and flat, but the appearance of the face clearly indicates a man past middle life, and Captain Audubon had then reached his forty-fifth year.

Young Audubon, we may be sure, lost no time in exploring the resources of this fine estate, where every bird, tree and flower came to him as a new discovery. In following the Perkioming above the mill dam he found a cave, carved out of the rocks, as he thought, by nature's own hand, which was a favorite haunt of the unpretentious but friendly pewees, the first American birds to attract his serious attention. So delighted was the youthful naturalist that he decided to make the pewees' cave his study; thither accordingly he brought his books, pencils and paper, and there made his first studies of American bird life, in the spring of 1804, in the third

at Nantes, agreed to keep the house in good repair from that time onward. It was the Prevost mortgage that Miers Fisher paid but forgot to cancel (see Vol. I, p. 122); it was finally cleared up by Dacosta in Octolser, 1806.

Miers Fisher's Philadelphia residence, called "Ury," which Audubon often visited, was near Fox Chase, now in the Twenty-third Ward. See Witmer Stone, Cassinia, No. xvii (Philadelphia, 1913).

${ }^{10}$ For a photograph of this portrait of Lientenant Audubon here reproduced, I am indebted to Miss Maria R. Audubon; the originals of both portraits are now in possession of Auduhon's granddaughter, Mrs. Morris F. Tyler. 
year of the presidency of Thomas Jefferson. It was early in the season when Audubon chanced upon this quiet retreat; the buds were swelling and maples had already burst into bloom, but snow still lingered in patches through the woods, and the air was piercing chill. The pewees were not yet at home, but one of their nests, fashioned of mud and finest moss, was fixed above the vaulted entrance; their coming was not long delayed, and Audubon, marking the very night or day's dawn when the first pewee arrived, saw them beginning to restore their old home on the tenth of April.

Strange to say, almost at that very time another pioneer in American ornithology, Alexander Wilson, who will enter this history later, was teaching a rough country school at Gray's Ferry, Kingsessing, also on the Schuylkill, and not over twenty-five miles away. Though Audubon's early studies were very desultory, both naturalists began their observations at about the same time, for on June 1, 1803, Wilson wrote to a friend that many pursuits had engaged his attention since leaving Scotland in 1794, and that then he was "about to make a collection of all our finest birds."

It must be set down to Audubon's credit that in the little cave on the banks of the Perkioming, in April, 1804, he made the first "banding" experiment on the young of an American wild bird. Little could he or any one else then have thought that one hundred years later a Bird Banding Society would be formed in America to repeat his test on a much wider scale, in order to gather exact data upon the movements of individuals of all migratory species in every part of the continent. After a few trials, "I fixed," said he, "a light silver thread on the leg of each, loose enough not to hurt the part, but so fastened that no exertions of theirs could remove it." 
In the following spring he had the satisfaction of catching several pewees on their nests farther up the creek, and of "finding that two of them had a little ring on the leg," proving that the young of a migratory bird, steering by the "compass" which is carried in its brain, did sometimes return to its home region, if not to the actual cradle or home site.

Across the Philadelphia road, which today leads to the little railway station, and not more than a quarter of a mile from Audubon's farmhouse, stood another but more pretentious mansion of the Colonial era, called "Fatland Ford," pertaining to an extensive farm of that name which was noted for the fertility of its alluvial acres. A road from the present village of Audubon to the Schuylkill River and the ford runs through the "Fatlands of Egypt," as the most productive parts of this old farm were then called. From the house could be seen the camping grounds of the Revolutionary soldiers, and James Vaux, its owner and builder, is said to have entertained General Howe at breakfast and to have shown him the room which General Washington, his guest of the previous day, had left just in time to avoid an introduction.

Shortly before Audubon reached "Mill Grove," William Bakewell, an Englishman who had emigrated to New Haven in 1802, bought this farm, and with his wife and family took possession in the winter or spring of 1804. ${ }^{11}$ Of the six Bakewell children, the two eldest, Lucy Green and Thomas Woodhouse, were but three years younger than the naturalist. The senior Bakewell, said Audubon, called at "Mill Grove" to pay his respects, but being then from home, and having brought with him a Frenchman's dislike for everything English,

${ }^{11}$ See Note, Vol. I, p. 99. 
he failed to respond. In the autumn, however, when grouse had become plentiful in the woods, a chance meeting brought them together, and young Audubon, who was a great admirer of his neighbor's expert marksmanship and well trained dogs, duly apologized for his neglect and forthwith paid a visit to "Fatland Ford."

We shall let the naturalist tell in his own words of his first meeting with the young woman who afterwards became his wife:

Well do I recollect the morning, and may it please God that I may never forget it, when for the first time I entered Mr. Bakewell's dwelling. It happened that he was absent from home, and I was shown into a parlor where only one young lady was snugly seated at her work by the fire. She rose on my entrance, offered me a seat, and assured me of the gratification her father would feel on his return, which, she added, would be in a few moments as she would despatch a servant for him. Other ruddy cheeks and bright eyes made their transient appearance but, like spirits gay, soon vanished from my sight; and there I sat, my gaze riveted, as it were, on the young girl before me, who, half working, half talking, essayed to make the time pleasant to me. Oh! may God bless her! It was she, my dear sons, who afterward became my beloved wife, and your mother.

When Mr. Bakewell returned, his daughter, Lucy, presided at the tea that was served, and Audubon received his first experience of hospitality in the English style, that was to be repeated in Britain at a later day on a more lavish scale. A hunting expedition was arranged and the men started out at once. Festivities of various sorts, and, later, skating parties, became the order of the day, and it was not long before hospitalities were exchanged, when Audubon, having secured, 
with the aid of his tenant's son, as many partridge as possible, had the whole Bakewell family to dinner under his roof at "Mill Grove."

Audubon's choice of a wife, thus quickly made, marked a turning-point in his career, and the curious fact remains that while he might have ransacked the country from Florida to Maine, as he afterwards repeatedly did in his search after birds, and woefully blundered, the woman who by her sterling qualities of mind and heart was the one to recognize and call forth the best that was in him, should have been placed by circumstances close by his door. Whatever the world has ever owed to Audubon is a debt due to Lucy Bakewell, for every leaf of oak that is plaited for his brow, another of lavender should be twined for hers.

During this gay but brief period of his life, Audubon has described himself as inordinately fond of dress, often cutting, as he said, an absurd figure by shooting in black satin breeches and silk stockings, and wearing the best shirts which the Philadelphia market could afford; he took pride, he adds, in riding the best horse that he could procure, and in having his guns and fishing tackle of the most expensive and ornate description. "Not a ball," he said, "a skating match, a house or riding party took place without me."

While freely acknowledging his follies at this time, he was able to say that he was addicted to no vices. His usual custom was to rise with the dawn, when his bird studies would begin, in the early hours which are best for this purpose. According to his own account, Audubon was extremely abstemious in his youth, for he declared that he had lived on fruits, vegetables and milk, with only an occasional indulgence in game and fish, and that he had not swallowed a single glass of wine or 


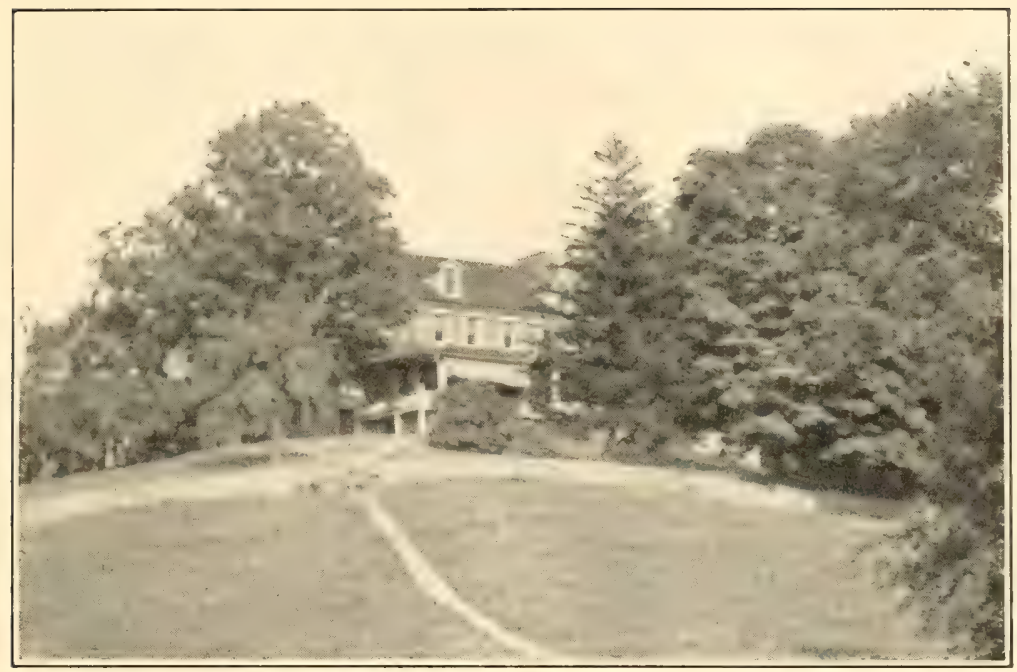

"MILI, GROVE" FARMHOUSE, WEST FRONT, FACING PERKIOMING CREEK.

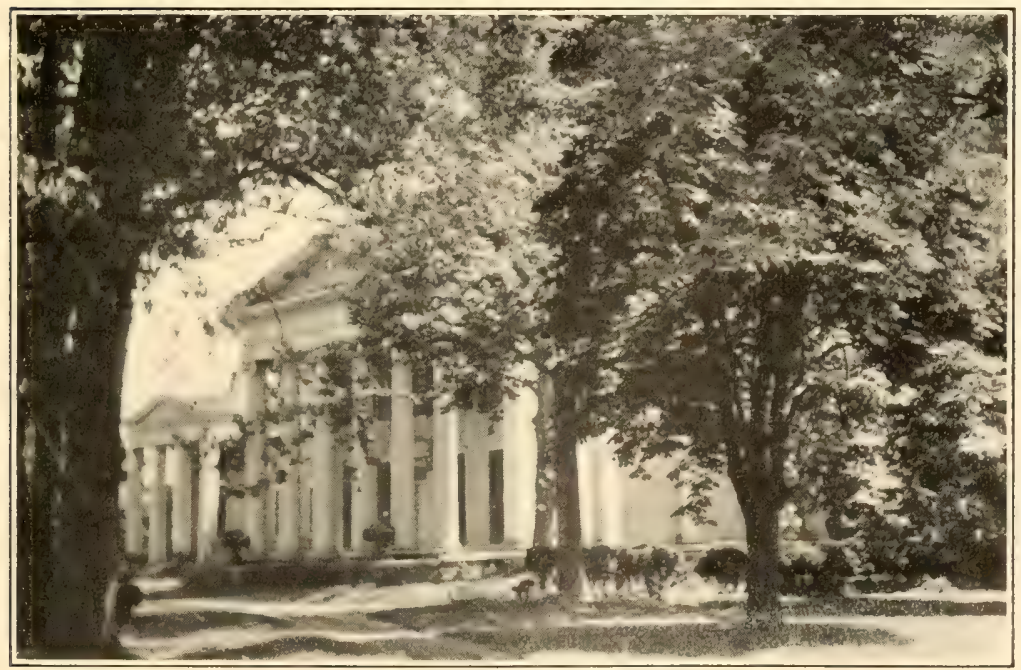

"FATLAXD FORD," THE GIRI,HOOD HOME OF TUCY BAKEWELT, AUDUBON.

This and the ahove after photographs of Iugust $16,1914$. 

spirits until his wedding day. This was the more remarkable in a youth coming from a country which flowed with good wine, where school children are still served with watered wine for lunch, and where the cooks, as Goldsmith believed, could concoct seven different dishes out of a nettle-top, and who, if they had enough butcher's meat (a want that has since been abundantly supplied), would be the best purveyors in the world. Audubon attributed his iron constitution to this simple regimen, which had been followed, he said, from his earliest recollection, though he admitted that while in France it was extremely annoying to all about him; for this reason he would not dine out when his peculiar habits were likely to be the subject of unpleasant comment. To follow this account of himself:

Pies, puddings, eggs, milk and cream, was all I cared for in the way of food, and many a time I have robbed my tenant's wife, Mrs. Thomas, of the cream intended to make butter for the Philadelphia market. . . All this time I was as fair and rosy as a girl, though as strong, indeed stronger than most young men ... and why have I thought a thousand times, should I not have kept to that delicious mode of living, and why should not mankind in general be more abstemious than mankind is? ${ }^{12}$

William Gifford Bakewell, a younger brother of Lucy, has left this interesting record of a visit paid to "Mill Grove" in the summer of 1806 :

Audubon took me to his house where he and his companion, Rozier, resided, with Mrs. Thomas, for an attendant. On entering his room, I was astonished and delighted to find that it was turned into a museum. The walls were festooned with all

${ }^{12}$ For this and the preceding quotation, see Maria R. Audubon, Audubon and his Journals (Bibl. No. 86), vol. i, pp. 18 and 27. 
kinds of birds' eggs, carefully blown out and strung on a thread. The chimney-piece was covered with stuffed squirrels, racoons, and opossums; and the shelves around were likewise crowded with specimens, among which were fishes, frogs, snakes, lizards, and other reptiles. Besides these stuffed varieties, many paintings were arrayed on the walls, chiefly of birds. He had great skill in stuffing and preserving animals of all sorts. He had also a trick in training dogs with great perfection, of which art his famous dog, Zephyr, was a wonderful example. He was an admirable marksman, an expert swimmer, a clever rider, possessed of great activity, prodigious strength, and was notable for the elegance of his figure and the beauty of his features, and he aided nature by a careful attendance to his dress. Besides other accomplishments he was musical, a good fencer, danced well, and had some acquaintance with legerdemain tricks, worked in hair, and could plait willow baskets. 


\section{CHAPTER VIII}

\section{DACOSTA AND THE "MILL GROVE" MINE}

Advent of a new agent at "Mill Grove"-Dacosta becomes guardian to young Audubon and exploits a neglected lead mine on the farmCorrespondence of Lieutenant Audubon and Dacosta-Quarrel with Dacosta-Audubon's return to France.

If young Audubon was playing the rôle of a prodigal son at the "Mill Grove" farm, which in a certain sense was doubtless true, an episode soon occurred which put a check to his carefree existence. Not long after the naturalist had arrived, William Thomas, the tenant, called his attention to the lead-ore deposits, which he thought had been discovered by a Mr. Gilpin in 1791, and the news of this prospect was promptly communicated to the elder Audubon in France. Though the presence of this mineral at "Mill Grove" had been known, as we have seen, at a much earlier day, its rediscovery excited great interest, and may have been a factor of influence in the steps which were soon to be taken. It should be noticed, however, that before May, 1803, a young Frenchman from Nantes, bearing the Portuguese name of Francis Dacosta, had preceded young Audubon to "Mill Grove," and apparently had acquired at that time a certain interest in the farm. ${ }^{1}$ Dacosta soon suc-

${ }^{1}$ In Dacosta's final statement of his account, which was disputed, carried into court, and eventually settled by arbitration at Philadelphia, on August 1, 1807, these items occur: "Omitted, $\$ 300.00$, paid by Francis Dacosta to Miers Fisher, on May 24, 1803;" and "Ditto \$176.67, the proportion of Francis Dacosta in the rent of the first year, which has not been paid to him." (See Appendix I, Document 11a; MSS. in possession of Mr. Welton A. Rozier.) 
ceeded Miers Fisher as Jean Audubon's agent, and becoming enthusiastic over the lead mine, was anxious to exploit it. Acting also upon the senior Audubon's request, he assumed a sort of guardianship over the son.

Dacosta began to dig for ore in the following year. News of his enterprise spread rapidly, and this long neglected mine was heralded in the newspapers as "one of the first discoveries yet made in the United States." On December 15, 1804, Dacosta purchased a one-half undivided interest in "Mill Grove,"3 giving, as we believe, a mortgage, and hoping to pay for his share out of the profits of the lead mine. Thereafter for about two years he continued to conduct the farm and develop the mine, upon the basis of a one-half interest, in addi-

It seems probable that Dacosta was sent to this country by Lieutenant Audubon to act as his agent for the disposition of "Mill Grove," and to succeed Miers Fisher in the conduct of his business affairs. Interest in the neglected and forgotten mine may have diverted them from their original plans.

${ }^{2}$ The following notice, copied from Relf's Gazette, appeared in the New York Herald for Saturday, November 17, 1804:

"The lead mine discovered on Perkiomen creek, in Montgomery county, Pennsylvania, the property of Francis Dacosta, has been lately opened, and attended with great success. The vein proves to be a regular one, and of long continuance. Its course is N.N.E.; its direction is nearly perpendicular, and its thickness from one foot to 15 inches. Two tons of that beautiful ore were raised in a few hours, and one ton more at least was left in the bottom on the pit, which is yet but nine feet deep. From the situation of this mine, its nearness to narigation and market, its very commanding height, its richness in metal, and the large scale it forms on; it is thought by judges to be one of the first discoveries yet made in the U. S.

"From the analysis made of 100 parts, it contains:

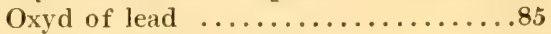

Oxyd of iron ................. 1

Sulphuric acid $\ldots \ldots \ldots \ldots \ldots \ldots \ldots \ldots$

Water ..................... 1

100

"The lead being coupelled, has proved to contain $21 / 2$ oz. fine silver to 100 , which is nearly 3 dollars worth of that metal."

${ }^{3}$ For the sum of 31,000 francs, or $\$ 6,200$, a slight advance on the cost to Jean Audubon, when he had taken over the farm fifteen years before (see Vol. I, p. 105). 
tion to a small salary. ${ }^{4}$ In case the mine proved a success, it was understood that young Audubon was to be taken into the business and thus obtain a means of self-support.

Dacosta was at first averse to forming a company, but the Quaker tenant, William Thomas, who caught the fever, and who was thought to possess more knowledge of the mine than he was ready to divulge, seems to have been taken conditionally into the partnership. Dacosta made full reports of his progress to the old sailor at Couëron, who came regularly to Nantes to send back to America his well considered answers and candid advice. Dacosta also called persistently for money, but as Lieutenant Audubon was unable to meet these demands, he applied to his friend François Rozier, a wealthy merchant at Nantes, to supply the needed capital. Rozier invested 16,000 francs, and to complicate matters took a mortgage upon one-half of the value of "Mill Grove," in which the earlier proprietor, John Augustin Prevost, as well as Francis Dacosta, was also interested. Jean Audubon, Dacosta and Rozier thus became partners in an enterprise which seems to have swallowed up all of the money which was advanced and never to have made any substantial returns.

The eventual failure of the lead mine must be attributed in part to the high cost of materials, as well as to the expense involved in uncovering the ore, a difficulty which all later exploiters seem to have found insuperable. Dacosta also discovered that the manage-

${ }^{4}$ The following item appears in Dacosta's final account: "To compensation claimed by Francis Dacosta for malsing up half of his expenses, in managing the mining works, the mill-repairs, and taking up the formation of a company during two years of constant cares, troubles, and loss of time, at 300 dollars a yeir- $\$ C 0000 . "$ (From statement of disputed claim; see Note, Vol. I, p. 168.) 
ment of his youthful charge was quite as difficult as making a success of the mine. His grievances on this score were duly reported at Couëron, and if he was really trying to carry out the instructions which came from France, it was perhaps no wonder that he received the undisguised contempt of his rebellious pupil. How just the naturalist's charges against his hated tutor may have been, will be considered in the sequel, but Lieutenant Audubon's letters, ${ }^{5}$ to be given presently at length, clearly show that in spite of the strained relations which later ensued, Dacosta continued to enjoy his confidence for some time after young Audubon's return to France in 1805. The more serious troubles that followed seem to have arisen from entanglements into which all were later drawn.

In the first two letters to be given, but the third and fourth of the series, Jean Audubon refers particularly to "Mill Grove" and the prospective mine, and to the proposed marriage of his son to Lucy Bakewell, concerning which he was reluctant to give his consent for reasons which he specifies at length; his sanction was in fact withheld until the young man was on the road to self-support two years later.

\section{Jean Audubon to Francis Dacosta}

[NANTES, 1804-5]

I told you to sell to W. Thomas the portion on the other side. . . but your letter of the 27 th of September with that

${ }^{5}$ For copies of a part of the Audubon-Dacosta correspondence, which is perhaps half of what exists but all that it was possible to obtain, I am indebted to Monsieur Lavigne. The first letter, the present copy of which is incomplete, was evidently written in the winter of 1804-5. Lieutenant Audubon, who at this time was sixty-one years old, was living at Couëron, but came to Nantes to conduct his correspondence. All the letters were carefully transcribed in a separate copybook, and are here translated as literally as possible from the French. 
of Mr. Miers Fisher, who is not in favor of it, has made me change my mind in the meantime. If your plan succeeds, as I wish it may, this part of the farm would become almost indispensable for exploitation [of the mine]. Moreover, has not Mr. W. Thomas intentions, which we do not know? Might it not be possible that in this very same part he had made more valuable discoveries than those which he has shown us? In all these matters, however, I rely entirely on the wisdom of Mr. Miers Fisher and of yourself, and I thank you for your willingness to remain in charge of my affairs, ${ }^{6}$ by accepting anew the power of attorney, which he sends me together with the indenture to be signed by my wife and by myself in presence of witnesses. But you ask that this should be done before the mayor of Nantes, while we have been living, since you departed, in the commune of Couëron; accordingly this will be taken before the mayor of that commune, and legalized by a prefect of the department. That, I believe, will fulfil the same obligations, for should it be necessary for my wife to come to Nantes in the weather that we are constantly having it might cause a delay that would be prejudicial to us. Remember, my dear Sir, I expect that if your plan succeeds, my son will find a place in the works, which will enable him to provide for himself, in order to spare me from expenses that I can, with difficulty, support. Your first letters have almost persuaded me that this so-called mine was of little or no account, but the arrangement that you have made with W. Thomas is so important that I do not doubt you made certain of the value of the object before deciding to grant him a recompense, which was to be only in the thing itself. In this work we should then be making a very great sacrifice, and it would be a loss. If, however, you propose to forestall the payment of the sums that you owe, I accept [the proposition] to be paid in Philadelphia; I will reflect upon it, and will look into it. If I can arrange matters for this [plan] with Mr. Dupuir, my next will be more explicit

"That is, after having become a part owner of the "Mill Grove" property. 
upon this subject. My son speaks to me about his marriage. If you would have the kindness to inform me about his intended, as well as about her parents, their manners, their conduct, their means, and why they are in that country, whether it was in consequence of misfortune that they left Europe, you will be doing me a signal service, and I beg you, moreover, to oppose this marriage until I may give my consent to it. Tell these good people that my son is not at all rich, and that I can give him nothing if he marries in this condition.

\section{Jean Audubon to Francis Dacosta}

NAxtes, le 19 ventose, an 139 March, 1805

Mr. Dacosta, Philadelphia:

I have received at this very moment your duplicate of the twelfth of November, and your letter of December fifth, which is not so favorable for several reasons as the one preceding it, yet this impels us to hope that your last tunnel will not be a deserter, and that the oxides of iron which are present will not vanish upon further digging; this, at least, is my hope. You do well to make every effort to obtain associates. If this does not succeed, and if you should wish to work for our interests, I should always approve of everything that you do, since you have my confidence. In this case I believe . . . that you should make the most urgent repairs, above all at the principal house, before going there to live. As to Mr. W. Thomas, you do well to keep him for yourself for every reason that you give me, and I believe that he will not be stubborn about withdrawing until he has, or has not, deserved his reward.

I am [vexed] Sir; one cannot be more vexed at the fact that you should have reason to complain about the conduct of my son, for the whole thing, when well considered, is due only to bad advice, and lack of experience; they have goaded his selfesteem, and perhaps he has been immature enough to boast in the house to which he goes, that this plantation should fall to him, to him alone. You have every means to destroy this presumption; it is known at Philadelphia that you have the same 
rights as I have, and that you are doing nothing but for our mutual advantage. I am writing to him on this subject, for he does not speak of it to me, and I am giving him the rebuke that his indiscretion deserves. Read this letter, and have the kindness to seal it before delivering it to him. You tell me that I can refer, in regard to his conduct, to the report that Mr. Miers Fisher has given of it in his long letter of the month of September; that, unhappily, I have not received, for $\mathrm{Mr}$. Fisher tells me nothing about him, neither what is good nor bad. As to going to that country, this seems well nigh impossible; to recall my son is not easier; the reasons which made me send him out [there] still remain. Only an instant is needed to make him change from bad to good; his extreme youth and his petulance are his only faults, and if you have the goodness to give him the indispensable, he will soon feel the necessity of making friends with you, and he can be of great service if you use him for your own benefit.

It is necessary then, my dear Sir, that we endeavor, by gentleness, to reclaim him to his duty. If you are indulgent with him, it will be I who should be under every obligation to you. I hope that the enclosed letter will work a change with him. This is my only son, my heir, and I am old. When Mr. Miers Fisher shall have shown my letter to the would-be fatherin-law, he will see that he is mistaken in his calculation upon the assumed marriage of his daughter, for if it should take place without my consent, all help on my part would cease from that instant; this, if you will have the kindness, is what you may say to the would-be father-in-law, that I do not wish my son to marry so young.

Your letters of the 28th of October and the 12th of November are in the country. ${ }^{7}$ I cannot reply categorically upon their contents; I will examine them, and will tell you in my next what I think about them. Your family, which $I$ have seen, is well. Our ladies thank you for your kind remembrance. I am. ...

\footnotetext{
rThat is, at Couëron.
} 
When the preceding letter was written young Audubon was on his way to France, to protest, as he said, against Dacosta's treatment of him. At the date of the letter which follows, he was at Couëron, hunting birds with Dr. d'Orbigny.

\section{Jean Audubon to Francis Dacosta}

\section{Naxtes, 14 June, 1805}

To Mr. Dacosta, Philadelphia:

I have received, at this very moment, your letter of the 8th of April. I have replied to your preceding by duplicate. I.ike yourself I am greatly astonished that you should not have received the contracts which I forwarded to you at once. I have reserved copies of these papers, which I have literally copied.

If I had the least idea that they would not reach you, and that an accident had befallen the ship, I should forward them in duplicate, but as this boat, at the time of its departure, was long delayed by the embargoes as well as by bad weather, I am persuaded that this is the sole cause, and that they will have reached you since.

You are about to appeal to the supreme court to prove your ownership; is there a living being who can contest it? If our deeds, granted in France, have not their full force in that country, nothing can annul them for us who are French. You shall do in this matter what you like; the greatest objection is this, that it stops your operations; but who is to blame? It is due to distance, and not to any negligence.

You say that you will do nothing until you have these documents; if your intention is to work for our benefit, as you say in your preceding, a company still being disagreeable [to you], that ought not to stop you; you have every power, [and] time lost is irreparable. I am much annoyed at the delay that this Mr. Miers Fisher causes you; as you say, he is an honest man, but negligent, and this in consequence of his age, and absorption in his great business. 
We now return to Mr. David Ross, ${ }^{8}$ who in his letter tells a pack of lies. At the close of 1789 I presented myself at his house with the power of attorney of Mr. Formon, ${ }^{9}$ when we settled the business of the "Count of Artois," and the "Annette." 10 There never has been, as he said, any dissolution of the partnership between Mr. Formon and myself. I settlea the accounts at that time both with him and with Samuel Plaisance concerning these vessels, with the exception of a residue of three thousand francs which are due me from Mr. Edward, their associate, who died at London. When I asked him for his certificates, he gave me for excuse that they were at the iron factory above Richmond, and that he had given Mr. Formon a private obligation that he would be very glad to have an exchange for the certificates. This affair has rested there ever since, and according to his letter Mr. Formon has taken out seven thousand, four hundred dollars, which exceeds his share by 1,650 dollars. If the estate of Mr. Formon is not without resources, it is to his heirs that you must apply for this overdraft, and get from Mr. David Ross all that you can, for with such people one cannot rely upon getting anything except with iron hooks.

The son-in-law of Mr. Formon doubtless will have found among his papers all that constitutes the legal basis of my portion; his certificates, his letter of attorney prove it, and this is a title, and I believe thât I have proofs by accounts current. I salute you.

${ }^{8}$ This name appears as "Rost" in all the letters.

${ }^{2}$ Member of the firm of Audubon, Lacroix, Formon \& Jacques, engaged in the Santo Domingo trade (see Chapter II, p. 33). In these letters the name usually appears as "Formont."

${ }^{10}$ Vessels in which Jean Audubon was personally interested, and upon which he endeavored in vain to collect the money and interest due him (see Vol. I, p. 34). In a document in English, dated [Les Cayes] April 9, 1782, concerning the Annette, of which Jean Audubon was captain and part owner, and signed by him and David Ross \& Company, it is stated this vessel was bound for Nantes with a cargo of tobacco, in the purchase and sale of which Captain Audubon was under orders of Mr. Ezekiel Edwards of Nantes. 


\section{Jean Audubon to Francis Dacosta}

NANTES, 22 June, 1805

To Mr. Dacosta:

I have just received your letter of April 23, and hasten to reply to it, in order to prove to you that not one of yours has been neglected, which could be readily seen by my copybook. I am not surprised that at this time you have not received your papers, because they cannot have left before the 10th or 15th of last March, having been held up by the embargoes and the bad weather, as you will see by the date of the letters which accompany them.

They were entrusted to the son-in-law of Mr. Paulin, and if the ship arrives safely as I trust it will, you have now received them.

What negligence on the part of Mr. Miers Fisher! In truth it is unpardonable, to let the mortgages stand after having paid them! ${ }^{11}$ Will you then, I pray, clear this up for the sake of our mutual peace of mind? You speak of repairs to the house, ${ }^{12}$ it needs a complete cover; would it not be better for me to send some slate from here? This would perhaps be less expensive, and well nigh everlasting. Should you consider it advisable I will send you some at once.

I beg you not to neglect the affair of David Ross; if you can collect this sum, you will use it for our needs. I am annoyed that all these mishaps prevent you from working $;^{13}$ be well persuaded that it is no fault of mine, and that I am guilty of no negligence.

You speak of my going to that country; if such had been my intention I should have done it long ago. I am still

${ }^{11}$ This was probably the mortgage which Jean Audubon gave to Prevost when "Mill Grove" was purchased in 1789, for in Dacosta's final account for 1806-1807 this item occurs under October 15, 1806: "To the recorder in Norristown for entering satisfaction of John Audubon mortgage to John Augustin Prevost ... \$2.83."

${ }^{12}$ The principal house at "Mill Grove," which Dacosta was preparing to occupy.

${ }^{13}$ Owing to the delay in receiving his legal papers from France, Dacosta had threatened to carry his case to the courts, and had stopped work at the mine. 
troubled with an inflammation of the lungs; and one ought not to be ill in a foreign country, where he does not receive the care that he enjoys in his own home. You ask me to bring you money. . . You know better than anyone else what was my [financial] position when I sold to you; by that alone you must know how difficult this would be for me. It is necessary to manage so that our object suffices us [or so that the mine pays its way], and if we cannot work on a grand scale, we must needs do the best with our affairs on a lower plane; for that I depend on you. I salute you.

P. S. When you shall have my papers from Mr. Miers Fisher, you will find a promissory note of Mr. Samuel Plaisance of Richmond, for the business of the widow Ross. If there were justice there this sum would be paid to me with the costs.

The foregoing letters show that Dacosta had been asked to oppose the proposed marriage of the younger Audubon to Lucy Bakewell until consent should be given; that he was calling for more money to exploit the lead mine and was urging Lieutenant Audubon to come to America; and that their relations were becoming strained, Dacosta, to prove his title to a one-half interest in the mine and farm, having threatened to take his case to the courts.

This mining experiment was spread over many years. Before turning to the sequel (see Chapter XI), let us glance at the picture which the naturalist has left of his unsympathetic tutor. "Dacosta," he said, "was intended to teach me mineralogy and mining engineering, but in fact" he "knew nothing of either; besides which he was a covetous wretch, who did all he could to ruin my father, and indeed swindled us both to a large amount. I had to go to France to expose him to my 
father to get rid of him, which I fortunately accomplished at sight of my kind parent. A greater scoundrel than Dacosta never probably existed, but peace be with his soul." In one respect only, said Audubon, did he receive any sympathy from his guardian: Dacosta commended his drawings of birds. "One morning," Audubon relates, "when I was drawing a figure of the Ardea herodias [the great blue heron], he assured me that the time might come when I should be a great American naturalist"; however curious it might appear, he adds, that praise "from the lips of such a man should affect me, I assure you that they had great weight with me and I felt a certain degree of pride in these words even then."

To follow Audubon's story further, not only did Dacosta take control of his finances, but he interfered with his personal liberty, first by objecting to his proposed marriage to Lucy Bakewell, and then by cutting off his stipend when he rebelled. ${ }^{14}$ Audubon, being thoroughly aroused, determined to return to France and lay the case before his father in person. With this end in view he walked to Philadelphia, whither Dacosta had gone, to demand the money necessary to take him to Nantes. He was given, as he says, what purported to be a letter of credit to a Mr. Kauman, an agent and banker in New York. Returning with his letter to "Mill Grove," he then started on foot for New York, where he arrived on the evening of the third day. While there he stayed at the house of Mrs. Palmer, ${ }^{15}$ "a lady of

${ }^{14}$ In the light of the preceding letters, Dacosta would appear in these respects to have been only attempting to carry out his instructions.

${ }^{15}$ Probably Sarah White Palmer, Benjamin Bakewell's sister-in-law, and widow of the Rev. John Palmer, who at one time was associated with Joseph Priestley in editing the Theological Repository, an organ of the Unitarians. Her son-in-law, Thomas W. Pears, was later a partner in Audubon's business ventures at Henderson, Kentucky. Her grave is in the Bakewell burying plot at "Fatland Ford." 
excellent qualities," who received him most kindly. Audubon called promptly upon Benjamin Bakewell, for whom he was the bearer of a letter from his brother, William Bakewell, of "Fatland Ford." Instead of an order for money, Kauman's letter, he said, contained only the advice that its bearer be "arrested and shipped to Canton." Perplexed and bewildered beyond endurance, Audubon said that for the first time he felt the call of murder in his blood, and his outraged feelings were not assuaged until his landlady, to whom he had opened his heart, and Mr. Bakewell, had come to his aid. Having secured from this gentleman the necessary funds, he bought a passage in the ship Hope, which was then about to sail direct for Nantes.

Thanks to an old cash account of William Bakewell, we can follow Audubon's movements at this time fairly closely. This record ${ }^{16}$ extends from January 4, 1805, to April 9, 1810, during which time he advanced money to his future son-in-law and received credits due him from various sources. He did the same for the young partners when an association in business had been formed between Audubon and Rozier, and acted as their agent or attorney after the sale of their farm and their settlement in the West; as will be seen he aided Audubon very substantially later when money was needed at Louisville and for the more ambitious projects at Henderson, in which his son was also interested. This particular record shows that he supplied Audubon with small sums of money on January 4 and 12, 1805, just before his departure from "Mill Grove," and that on the eighteenth of the same month he paid his brother, Benjamin Bakewell of New York, $\$ 150$ on the young man's account. This was undoubtedly the passage money

${ }^{16}$ See Appendix I, Document No. 7. 
which Audubon had borrowed from his friend, and as the ship was then ready to sail, the date of his voyage on the Hope is very closely fixed.

After his vessel had passed Sandy Hook and was opposite New Bedford, the captain, in order, as he averred, to make necessary repairs, ran her into that port, where they passed a week. This was thought to be only a ruse on the captain's part to gain time, for, having recently married, he wanted a holiday on shore; accordingly he had ordered a few holes bored below the waterline in the bows of his ship. When they finally put to sea in earnest, they passed "through an immensity of dead fish floating on the surface of the water," a remark which now recalls stories of the famous tilefish, once thought to be extinct, which have been found floating dead in vast numbers in that part of the Atlantic. After nineteen days out the Hope entered the Loire and anchored at Paimbœuf, the lower harbor of Nantes; this was in February, and not far from the eighteenth of that month. 


\section{CHAPTER IX}

\section{AUDUBON'S LAST VISIT TO HIS HOME IN FRANCE}

Life at Couëron-Friendship of D'Orbigny-Drawings of French birdsD'Orbigny's troubles-Marriage of Rosa Audubon-The Du Puigaudeaus-Partnership with Ferdinand Rozier-Their Articles of Association-They sail from Nantes, are overhauled by British privateers, but land safely at New York-Settle at "Mill Grove."

Reaching his home at Couëron in the spring of 1805, Audubon took his parents completely by surprise. He found his father, then in his sixty-first year, still "hale and hearty," and his "chère maman as fair and good as ever." It was a time of momentous events in France; Napoleon had placed the crown upon his head but a few months before; defeat and victory followed in rapid succession. But this did not prevent the young naturalist from spending a year in "the lap of comfort" at Nantes and in the quiet villa of "La Gerbetière," where as usual he hunted birds and collected objects of natural history of every sort.

At this time also Audubon formed a friendship with a young man after his own heart, Dr. Charles Marie d'Orbigny, who "with his young wife and infant-son" was then living near his home. "The doctor," he said, "was a good fisherman, a good hunter, and fond of all objects in nature. Together we searched the woods, the fields and the banks of the Loire, procuring every bird we could, and I made drawings of every one of them-very bad, to be sure, but still they were of assistance to me." ${ }^{1}$ p. 39.

${ }^{1}$ Maria R. Audubon, Audubon and his Journals (Bibl. No. 86), vol. i, 
Charles d'Orbigny, who was Audubon's most intimate early friend and in all probability his father in natural history, was always spoken of in terms of great affection. While at Paris in October, 1829, Audubon learned from the naturalist Lesson that D'Orbigny was then in charge of the museum at La Rochelle and that "his son, Charles, then twenty-one," whom "he had held in his arms many times," was in the city; on October 8 he wrote in his journal: "this morning I had great pleasure in meeting my godson, Charles d'Orbigny. Oh! what past times were brought to my mind." 2

In later life the elder D'Orbigny seems to have fallen on evil times. He appeared as a debtor to Lieutenant Audubon's estate, and the cordial relations that had long existed between the two families were broken; this is shown only too plainly by the following sharp letter ${ }^{3}$ written by Gabriel du Puigaudeau and addressed to the doctor, on August 3, 1819, when the family had become reduced in means:

\section{Gabriel du Puigaudeau to Charles M. d'Orbigny}

Your letter of the twenty-fifth of January reached me in due time. I am grieved to see that you are annoyed because

${ }^{2}$ Dr. d'Orbigny had three sons, all of whom were born in Couëron: Alcide Charles Victor in 1802, Gaston Edouard in 1805, and Charles in 1806; the youngest and eldest became distinguished naturalists. So far as known, Audubon was godfather only to the second, Gaston Edouard, who according to the records of the Catholic church at Couëron, "was born on the $3 d$ day of the present [month], the issue of the legitimate marriage of Mr. Charles Marie d'Orbigny, doctor of medicine, and of Anna Pepart," was christened on August 20, 1805, in the presence of the godfather, John James Audubon, the godmother, Rosa Audubon, the father and mother, together with the "undersigned" (Extracted by Monsieur Lavigne). D'Orbigny appears as a witness to the powers of attorney which Jean Audubon and his wife issued jointly to their son and to Ferdinand Rozier at Couëron in 1805 (see Appendix I, Document No. 8) and on November 20, 1806 (see Vol. I, p. 153).

${ }^{3}$ For copies of this and the following letters, which are here translated from the French, I am indebted to Monsieur Lavigne. 


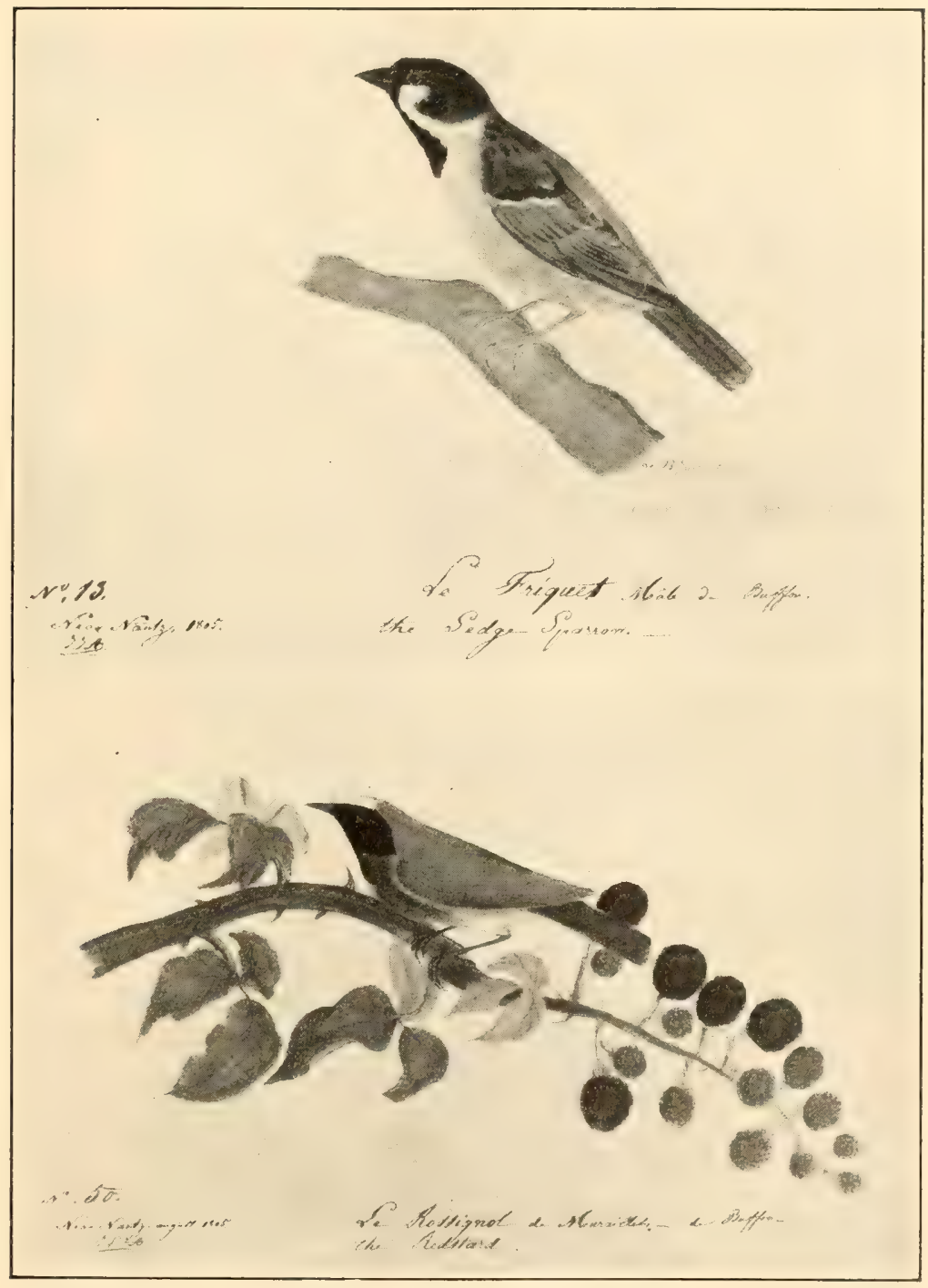

EARLY UNPUBITISTED DRAWINGS OF FRENCH BIRDS: ABOVE, "LE FRIQUET MALE DE: BUFFON. THE SEDGE SPARROW, NO. 13, NE.IR NAXT\%, 1805. J. J. A."; BELOW, "LE ROSSIGNOL DE MURAILIES-DE, BLFFON-THE REDSTART. NO. 50. NEAR NANTK, AUGUST, 1S05. J. L. F. A," Published ly courtesy of Mr. Joseph Y. Jeanes. 

I addressed you through the voice of the mayor of the town in which you live, since I had not the honor of knowing the mayor any more than the enmity which may exist between you; I was in duty bound to find out where you were; I heard it said that Esnaudes was your home and $\mathbf{I}$ wrote you more than a year ago; when I received no reply, the supposition was that I must have been misinformed. I wrote to the mayor of Esnaudes and he had the kindness to reply that you were practicing in his commune. I am writing to you under this cover, persuaded that my last will not have the same fate as my first, which surely had not reached you.

As to the claim that Madame Audubon has upon you, the different credits which you mention are assuredly more than enough to pay the amount, but with forfeitures; unfortunately there are many creditors who do nothing but this; Madame Audubon gets nothing, and finds herself in straightened circumstances, although her hands are full of notes. You say that your creditors can claim only thirty-five hundred francs. I have certain knowledge to the contrary, since already the mortgages on your house reach nearly three thousand francs, while Madame Audubon is your creditor in the sum of at least sixteen hundred francs. I wish in business to be frank, and to have others so with me. You say that you owe rather those who have supplied you with food; you are unwilling then to recall that the sums that the late Mr. Audubon lent you repeatedly were for the same purpose. You tell us to be patient, and who have been more patient than we for the past four years? You speak of reduction of interest; indeed it is impossible that you should have thought of this, or that we should be content with what you should be so good as to give us, and that when you deem it convenient, without our being able to file a protest. I leave you to reflect on what we must think of this matter, and I beg you to see in my manner of writing to you the interpretation that $\mathbf{I}$ have given to what you write yourself.

Madame Audubon does not think that she should exact at once the capital in addition to the interest, but she charges 
me to say to you that, having a right at least to the interest accrued, she begs you to have that money paid to her with the least possible delay.

The following letter concerning D'Orbigny's affairs was also written by Gabriel du Puigaudeau to J. Cornet of Fisnaudes, on June 26, 1819:

\section{Gabriel du Puigaudeau to J. Cornet}

Your honored [letter] of the sixteenth was duly received. It is impossible to be more grateful to you than I am for the information that you have been kind enough to give me about Mlle. Bouff ard ${ }^{4}$ as well as about M. Delouche. I will use it to my profit. As to the question that you put to me concerning M. d'Orbigny, I have the honor to tell you that he has lived in the commune of Vue in this department, and was highly esteemed and regretted when he left to come here. He lived here fifteen years without any one having cause to reproach him in any way. He has always been very well regarded and received by the best society here, and he carried from Vue the regrets of all. He left us to take part in a manufactory of soda, established at Noismoutiers, in the department of La Vendée.

i have had no news of him since. As to his pecuniary resources, I know him to have but one. His wife had a house, at Paimbœuf in this department, which was sold three years ago to satisfy the holders of mortgages. This is all that I can tell you about them; he owes my mother-in-law about fifteen hundred francs (money received at different times from my late father-in-law), for which we have his notes, but God only knows when we shall be paid.

As early as the autumn of 1805, if not before, plans were laid for getting young Audubon again safely out of France, for fear, no doubt, that the remorseless con-

${ }^{4} \mathrm{~A}$ daughter of Catharine Bouffard, regarding whom see Vol. I, p. 56. 


\section{LAST VISIT TO COUËRON}

scription officers of Napoleon would send him to the war if he remained. At that time Lieutenant Audubon and his wife issued jointly to their son and to Ferdinand Rozier a power of attorney for the conduct of their business affairs in America. Parts only of this punctilious document, which was written in French, have been preserved, ${ }^{5}$ and these through the translation of a "notary public and sworn interpreter of foreign languages for the Commonwealth of Pennsylvania, resident in Philadelphia." The names of the grantors, who signed this letter on October 21, 1805, were attested under the signature and seal of the mayor of Couëron; this official upon the same day declared that, in conformity with the rigorous requirements of the laws of the State of Pennsylvania, since "no other act, not even a notarial instrument, can in any manner supply the same," he had examined Anne Moynet Audubon apart, when she admitted that she perfectly understood the nature of the act, which she had "signed, sealed, and delivered of her own free will and accord, without being compelled thereto by her husband, either by threats, or by any other means of compulsion whatsoever." The mayor's signature was authenticated three days later by the subprefect of Savenay, and the formality was finally closed by the attestation of his signature by the prefect, on the 27 th of November.

It was during this last visit to his home in France that Audubon's sister, Rosa ${ }^{6}{ }^{6}$ was married to Gabriel

${ }^{5}$ See Appendix I, Document No. 8.

'The civil ceremony of Rosa Audubon's marriage was performed at the mayor's office in Couëron, on December 16, 1805 (le 26 frimaire, an 14), when the bride was in her eighteenth year; the contract had been drawn on the 12th day of that month (le 22 frimaire, an 14) by notary Martin Daviais, who was mayor of Couëron in the following year, and the religious ceremony was conducted by the Bishop of Nantes. "The following have assisted," so reads in translation the Couëron record, "at 
Loyen du Puigaudeau, who was not, however, as the naturalist has stated, either "the son of a fallen nobleman" or his father's "secretary." Du Puigaudeau came from a family of merchants in easy circumstances, and for a long time lived the life of a country gentleman of leisure - for a period at Port Launay, below Couëron, and later, after Lieutenant Audubon's death, at his own villa, "Les Tourterelles," in that commune, not far from "La Gerbetière." His father, though of a rich family, was not a "gentleman," that is, a member of the aristocracy, as the term was then used in France. Du Puigaudeau was without any settled business, but his revenues, upon which he depended, failed not long after the death of his father-in-law. He and young Audubon appear to have been good friends for many years, and after the latter's return to America they corresponded

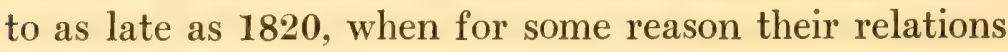
were broken.

In the spring of 1806 Lieutenant Audubon arranged a business partnership between his son and Ferdinand Rozier, to endure for nine years, and also secured passports for both to enable them to emigrate immediately to the United States. To the same hand can also be traced their "Articles of Association," which were drawn with the utmost care and designed to govern them in all their future business relations in the New World: these were signed by "Jean Audubon," and "Ferdinand Rozier," at Nantes, on March 23, 1806. Moreover, eight days before they embarked, a second and more elaborate letter of attorney was issued to

the marriage, aforesaid, on the side of the groom, M. André Loyen du Puigaudeau, his brother, and M. Honoré François Guiraud, his brotherin-law; by the side of the bride, her father, and M. Jean Audubon, her brother, [and these have] undersigned, together with the bridegroom." Audubon's signature reads "J. L. J. Audubon." 
them jointly by the Lieutenant, his wife, and, in this instance, the aged father of Ferdinand, under date of April 4, 1806. ${ }^{7}$ According to the terms of this admirably executed paper the partners were entitled to conduct all the affairs of the grantors in reference to their property in the United States to the best of their judgment and ability; to carry on the "Mill Grove" farm, to the extent of their part ownership in the estate, or to dispose of this interest; "to exploit or cause to be exploited the mine recently discovered on the said farm, to consult in every important matter Mr. Miers Fisher, merchant of Philadelphia, - as a common friend and good counsellor, to keep all necessary books and registers, and at the end of each year, or sooner, to strike a balance of the receipts and expenses of the said farm and the exploitation of the mine, should there be reason for it."

To secure at this time the necessary passports for their young men no doubt taxed all the resources of the elder Audubon; Rozier's, said the naturalist, was written in Dutch, of which he did not understand a single word, while his own letter stated that he was born in New Orleans. These subterfuges worked so well that the inspection officer, after reading Audubon's paper, promptly offered him his congratulations, adding

${ }^{7}$ For the full text of these two documents, which are so interesting for our story, see Appendix I, Documents Nos. 9 and 10; and for translations, Documents Nos. 9a and 10a. For the privilege of examining and reproducing the first of these papers I am indebted to Mr. Charles A. Rozier, of St. Louis, and for the second, as well as the power of attorney of 1805 (see Document No. 8), referred to earlier, to Mr. Tom J. Rozier, of Sainte Geneviève, Missouri. In the case of this second warrant it will be noticed that the grantors signed only the minute which was filed with the notaries, who, with the judge of the Court of the First Instance, affixed their names to the document itself. No better illustration could be given of the dignity which the French attach to the office of notary, to the honored incumbents of which their private affairs are unreservedly entrusted, than this elaborate judicial document. 
that he would be only too glad to leave his unhappy country under as favorable conditions. Audubon and Rozier sailed from Nantes on Saturday, April 12, 1806, on the ship Polly, Captain Sammis, but they did not land in New York until Tuesday, May 28, after a perilous voyage of nearly eight weeks. A fortnight had been passed at sea when they sighted a suspicious looking vessel which immediately gave chase, fired several shots across their bows, and compelled the captain to heave to and submit to being boarded and searched. This proved to be an English privateer, named the

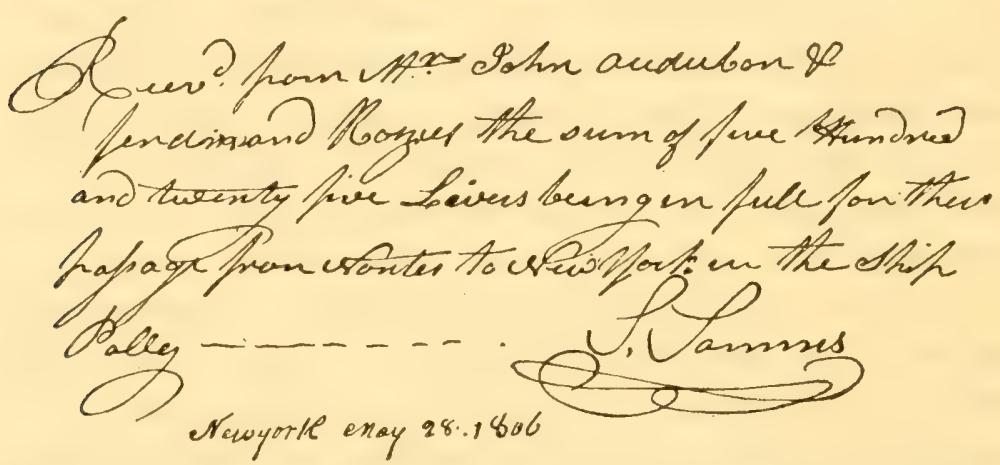

RECEIPT GIVEN BY CAPTAIN S. SAMMIS OF THE "POLLY" TO AUDUBON AND FERDINAND ROZIER FOR THEIR PASSAGE MONEY FROM NANTES TO NEW YORK.

From the Tom J. Rozier MSS.

Rattlesnake. She was rather considerate for a British cruiser of the period, for she merely impressed two of their best seamen and robbed them of their provisions, carrying off, said Audubon, all of their "pigs, sheep, coffee and wine," 8 in spite of loud remonstrances of the captain and of an American Congressman who hap-

${ }^{8}$ In the register of the Central Committee of Nantes it is noted, under date of October 4, 1793, that "owing to the friendly relations then existing between France and the citizens of the United States, and to the good feeling evinced by them in sending to us for food, four American ships are accordingly permitted to leave the port of Nantes, with cargoes of wine, sugar, and coffee, and also to take enough biscuit for the voyage." 
pened to be among the passengers. "The Rattlesnakic," he continued, "kept us under her lee, and almost within pistol-shot, for a day and a night, ransacking the ship for money, of which we had a great store in the run under the ballast which was partially removed, but they did not go deep enough to reach the treasure. The gold belonging to Rozier and myself I put away under the ship's cable in the bow, where it remained until the privateers had departed."

Upon reaching a point thirty miles off Sandy Hook, they learned from a fishing smack that two British frigates lay off the harbor and were impressing American seamen, that, in short, they were even more unwelcome than pirates who sailed under letters of marque. The captain, thus forewarned of one danger, had the misfortune to run into another, for upon taking his vessel into Long Island. Sound, she encountered a storm and was stranded in a gale; no great harm was experienced, however, for the vessel was finally floated off and reached New York on the following day. The passage money paid by Audubon and Rozier to Captain Sammis amounting to 525 livres, or $\$ 125,{ }^{9}$ was entered, according to their articles of agreement, as the first item of their "social expenses." After a brief visit with Benjamin Bakewell they hurried to "Mill Grove," and Audubon to the home of his sweetheart, Lucy.

'The receipt which the captain handed the young men, and which the methodical Rozier preserved, remains as a souvenir of this voyage (in the Tom J. Rozier MSS); it reads as follows:

Recvd. from Mr. John Audubon \& ferdinand Rozier the sum of five Hundred and twenty five Livers being in full for their passage from Nantes to New York in the Ship

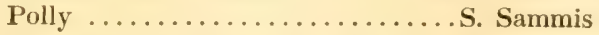

[In Rozier's (?) handwriting] New York May 28, 1806

[Indorsed by Rozier on back] Payé le 11 avril 1806 


\section{CHAPTER X}

\section{"LA GERBETIÉRE" OF YESTERDAY AND TODAY}

Home of Audubon's youth at Couëron-Its situation on the Loire-History of the villa and commune-Changes of a century.

Before following further Audubon's history in America, we shall return for a more intimate view of the happy home which he had left behind him in France. This was at Couëron, a small commune in the arrondissement of Saint-Nazaire, on the right bank of the Loire, nine miles west of Nantes. Here, as we have noticed, his father had acquired a country place at about the outbreak of the Revolution. The old house still stands, though in decay, and is still known as "La Gerbetière," a name possibly referring to the wheat which is harvested from the surrounding fields as of yore. In the records of that district country places are always designated by their proper names, and it is a curious fact that while such names survive, they are seldom or never displayed on door or gate.

In a journal written before 1826, Audubon says: "My father's beautiful country seat, situated within sight of the Loire, about mid-distance between Nantes and the sea, I found quite delightful to my taste, notwithstanding the frightful cruelties I had witnessed in that vicinity not many years previously. The gardens, greenhouses, and all appertaining to it appeared to me of a superior cast." Though it was occupied for many years previously as a refuge from the turmoil or heat 


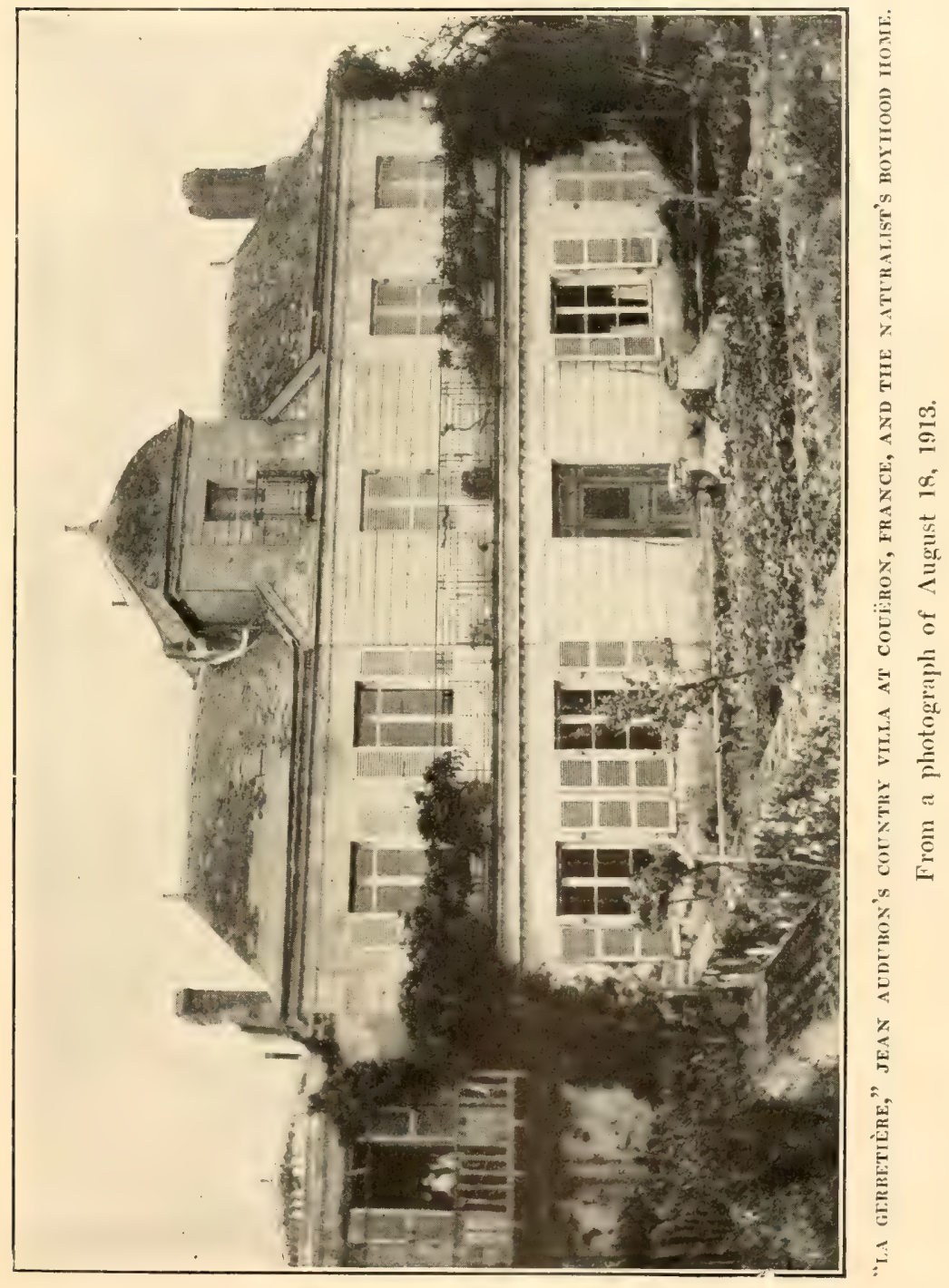



of the city, Lieutenant Audubon made "La Gerbetière" his permanent abode only when he retired from the navy in 1801, still maintaining, as we have seen, a foothold in Nantes.

Upon Audubon's first return from the United States in the spring of 1805 , he said that his vessel entered the mouth of the Loire and anchored off Paimbœuf, the lower harbor of Nantes. "On sending my name to the principal officer of the customs," the narrative continues, "he came on board, and afterwards sent me to my father's villa, La Gerbetière, in his barge and with his own men." It is to be noticed, incidentally, that as the distance to be covered between the lower and upper harbors was twenty-five miles, or sixteen miles to Couëron, such journeys no doubt were made upon the arrival of incoming vessels for the regular business of the service.

It has been suggested, without proof, that Couëron represents the ancient town of Corbilo, mentioned by Strabo at the beginning of our era. Though unquestionably ancient, at the time of the Revolution it was a small and unimportant parish of poor but industrious farmers. It occupies rolling ground, but little raised above the Loire, to the east of Port Launay and nearly opposite Pellerin. As this commune was easily accessible by river-barge from Nantes, the revolutionists seem to have thought it worth watching, though Citizen Audubon found its people in a tranquil mood when he canvassed their district in behalf of the Central Committee in April, 1793. Couëron is still a farming community, but its population ${ }^{1}$ has been considerably

1 The total population of Couëron, as given in the official directory for 1913, was 2,035 , but the total working population is probably three times as great. 
swelled in recent years by the development of a large industry for the treatment of lead; it is the shot tower and forest of chimneys of these great metallurgical works that arrest the eye of the traveler as he approaches Couëron by river at the present day. The town is also accessible by railroad, but the steamer journey from Nantes, which is made in less than an hour, is more attractive as well as more direct. In this section the Loire is flanked on either side by bottom lands, reduced in places to narrow strips, which are followed at intervals by elevations called, by courtesy, hills or buttes. To the west of Couëron, and especially at Pellerin, which stands high, these buttes come close to the river, which is eating them away.

My visit to Couëron, which was made on a warm midsummer's day in 1913, served to correct certain previous impressions, but I found the old Audubon homestead in its essential aspects but little changed, considering that over a century had rolled by since the naturalist's visit which we have just described. After leaving Nantes at the Gare de la Bourse by one of those quaint little trains which still do service in the less traveled parts of France, we traversed the broad Quai with requisite deliberation, passing shops, warehouses and factories in long array. A slight swerve from the river soon brought us to Chatenay, now a part of the city; it is still some distance from that point before the real countryside is reached, and scenes familiar to southern Brittany are in a measure reproduced. There were the old farmhouses of rough stone, dear to every painter's heart, mellowed by age and lichens, and surrounded by great ricks of straw, for the harvest had been gathered and the stubble fields were brown. There also the farms were divided into small plats, marked by willows or 
ramparts of stone. On higher ground stood the windmills, characteristic of Brittany also,-stalwart towers of stone, with broad arms of latticed wood ever ready to take the sails.

The small station for Couëron lies in the commune of Sautron, and at this isolated point the traveler will sometimes find a country conveyance to take him to the village. While we were raising the dust from this old Couëron pike on the eighteenth day of August, swallows hawking with characteristic energy for their insect prey were the only birds we saw to remind us of the ornithologist, who as a youth had doubtless passed this way many times, over a hundred years before. The most direct approach to the old Audubon place from Sautron, as we afterwards learned, is by a path which diverges on the right and leads through stubble fields and cabbage patches, along hedgerows and stone walls. We, however, fared on to the town and soon began to pass shops and small modern houses. On the side of the village the traveler's eye is certain to be arrested by a great crucifix in stone, ${ }^{2}$ which rises high above the street from a lofty pedestal, and is approached by tiers of stone steps. Nearly opposite stands the secrétariat, or official bureau of the commune, where a solitary clerk, who seemed to welcome my intrusion in a place where business was utterly stagnant, closed his office and with characteristic courtesy cheerfully showed me the way. This led directly westward to one side of the center of the town, and after passing down a street of old houses

${ }^{2}$ There is also the grand calvaire, which stands on an eminence in the village. This was erected in 1825 on the foundations of the chateau of the dukes of Brittany, the last of whom, Francis II, died at Couëron in 1488. His tomb is in the nave of the cathedral at Nantes; the grand calvaire was restored by two Coueron families in 1873, and is a very elaborate structure. 
of the humblest description, we were again in the region of brown fields and old farmsteads.

Couëron village, which is marked by a modern church with an aggressive spire, extends along the river bank, but since its streets run parallel with it, the river itself is seen only at certain openings, occurring at irregular intervals. In going to "La Gerbetière" by the course I have described, the Loire was not visible at any point, and was not seen until we emerged from one of the village streets at the steamer's pier. My guide had said that from the rise at the next crossroads we should see the roof of the house which we had come to visit, and his prediction was verified when I recognized immediately its cupola raised above the gray stone walls which there bound every highway and field. The old villa is rather less than a mile from the village, but owing to the rolling nature of the country, it is completely hidden until at close approach it stands suddenly revealed. It lies in a fork of the road, securely inclosed by high, massive walls of stone, now hoary with age, while on the front it is further screened by a natural growth of bushes and trees. Immediately behind and to the west rises a prominent butte which cuts off the view to Port Launay on the river; this forms the one distinctive landmark of the district, as its two windmill towers are visible from all surrounding points. In Audubon's day the house commanded a wide view of the Loire, but the river is now so completely masked by foliage as to be visible only from the upper windows; apparently it once flowed nearer to the house but has been pushed away by the construction of modern dykes. The hilltop to which I have just referred, like the roof of the villa, commands a panorama of the whole region, including Nantes and all the surrounding communes. 
"La Gerbetière" is now a small estate of less than fifty ares, or one and a half acres, of land. The buildings, which form a quadrangle with enclosed court, occupy a corner next the side street, and stand about 200 feet back from the main highway leading from Couëron to Port Launay. The extent of the original property cannot now be determined, but Lieutenant Audubon, who retired at the age of fifty-seven, was never a farmer on a large scale. The original house, which probably dates from early in the eighteenth century, has an easterly wing or L, continued into a long, low section through which the court is now entered from the road at the side; this was probably added by Jean Audubon, but the westerly end and wing are a more modern accretion, built for the accommodation of additional tenants, as many as three families having occupied the place in $185 \%$.

"La Gerbetière" was entered from the main street by a small door which pierces the high enclosing wall, and leads the visitor into what was formerly an ornamental garden, the original design of which can still be traced. At the time of my visit, however, this entrance had long ceased to be an avenue of response. Encouraged by the sight of a peddler's cart, I walked up the side street and entered the court. Here the response was prompt and vigorous enough, and from the guardians of the place, one of which was chafing at his chain close to the doorway. I crossed rather gingerly to an open hallway, opposite the main entrance, and knocked repeatedly, noting here that rooms opened to this small entrance hall on either side, and that a steep stairway led to others above. At last, during a temporary lull in the barking of dogs, the "tok-tok" of sabots was heard on the stairs, and I handed up my card with one 
from the director of the Natural History Museum at Nantes. After various messages had been shouted back and forth, I was led through another passage to the tenant, who was talking with the peddler in the garden. Julien Lebréton, who was a farmer on a small scale, received me kindly and answered my questions to the best of his ability; it did not surprise me that he was both puzzled and suspicious, or that his first thought was of our coming to look over the place with a view to its purchase.

The decayed villa, which stands in the midst of scattered farmhouses of a humble order, reproduces a style characteristic of many parts of France. The original house, of two stories, was built of cream-colored limestone, similar to that for which many French towns are famous. It has a swelled slated roof with beveled gables. Surmounting the roof is a cupola which suggests a third story, carried out in harmony with the lower structure. A narrow balcony, resting upon a molding of stone and protected by an iron grill, without which no such house would be considered complete, runs the length of the second story, and is accessible from every room by glass doors. From the main entrance below one passes directly through to the court, about which are now grouped various stables and other low buildings, not all of which date from Audubon's day.

What was once a small formal garden is still marked by solid boundaries of cut limestone. This was evidently constructed by Jean Audubon, since it occupies the area in front of the original house and the easterly extension which is attributed to him. The remaining available land was devoted to fruit, vegetables, and possibly to the greenhouses which the naturalist mentioned. 


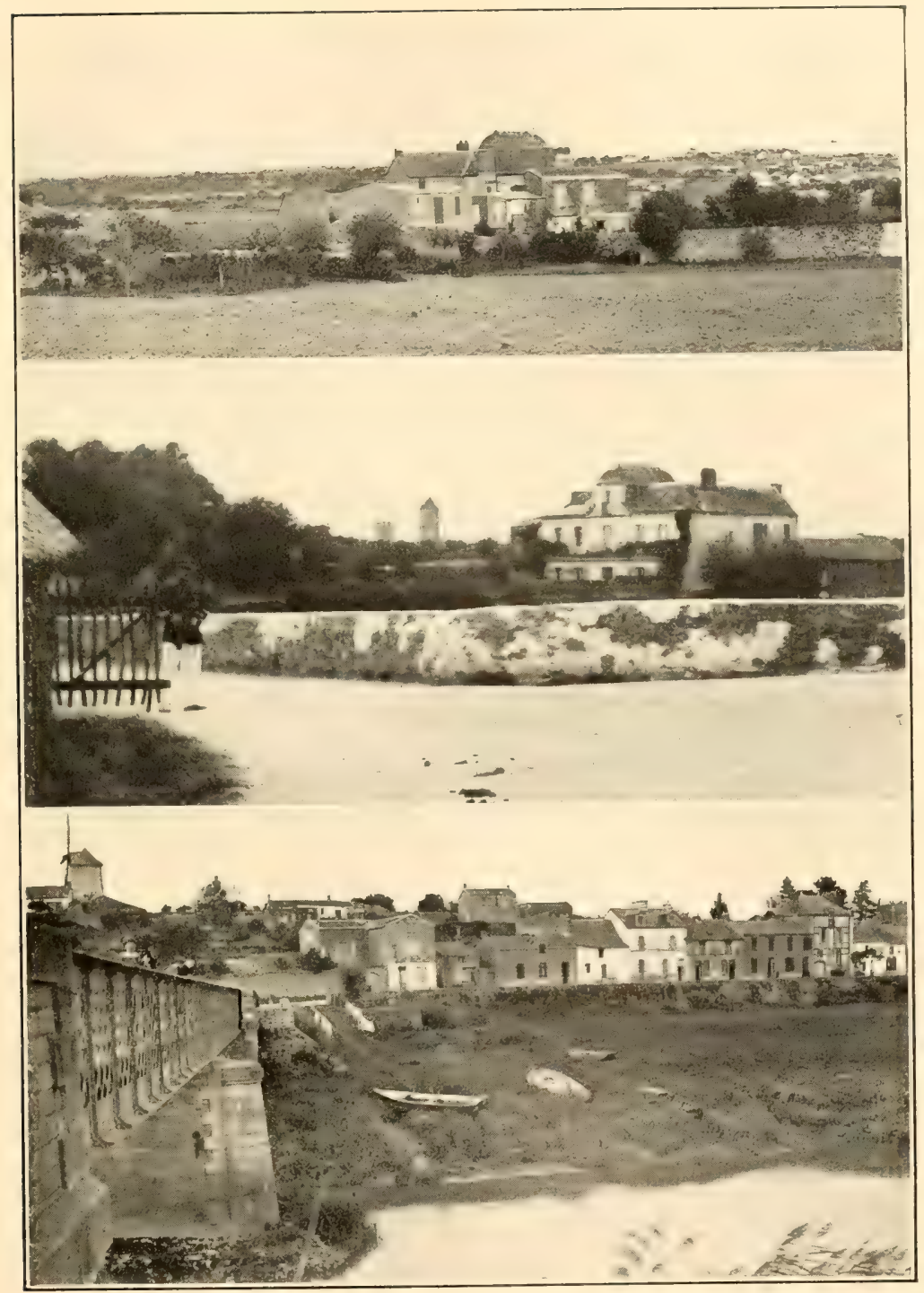

"LA GERBETIÈRE" ANU COUÏRUN, AS SEEN FROM THE WINUMILI. TOWERS ON THE RIDGE OVERIOOKING PORT IAUNAY, ON THE: LOIRE.

"LA GERBETIÉR," AS SEEN WHEN APPROACHED FROM COUËRON VILLAGE BY THE ROAI) TO PORT TAUNAY.

PORT LAUNAY ON TIE LOIRE. 

At one time an orangery occupied some part of the house or court. There are now no large trees on the property; the fruits are all of recent and inferior growth, while the garden I saw was planted to cabbage and running riot with weeds.

When Jean and Madame Audubon passed through the door leading from the main street, they entered upon a paved alley which ran parallel with the high wall, whence they could reach the house by any one of several walks or enter the fruit garden by another. If so inclined, they could turn to the right, ascend a flight of granite steps to a platform on a level with the top of the wall, and under a shady bower of vines and leafy shrubbery, look off on the racing waters of the Loire, scrutinize their visitors before admitting them, or observe such manifestations of life as lonely country roads of that period had to offer. As they passed up the central garden walk they could admire the beds of oldfashioned flowers, kept, we may be sure, in perfect order, for Jean was a very methodical man, and his wife, we believe, an excellent home maker. This walk led to a low terrace, flanked with a heavy wall, which ran the whole length of the house.

What little I saw of the interior of "La Gerbetière" was wholly devoid of interest, which agrees with the experience of another traveler who visited Couëron at a slightly earlier date; ${ }^{3}$ at the time of his visit the place was unoccupied and forlorn, and the vegetation on the garden side so dense that it was utterly impossible to see any distance from the lower windows.

When "La Gerbetière" came into Jean Audubon's

${ }^{3} \mathrm{Mr}$. William Beer, who paid a visit to "La Gerbetière" with Dr. Louis Bureau in 1910, writes me that the woodwork was poor in quality, and that all the rooms had been altered in size and appearance. 
possession it was already venerable with age, and it was completely restored for him by an architect named Lavigne. ${ }^{4}$ In an inventory drawn up shortly after Madame Audubon's death in October, 1821, the property of "La Gerbetière" is described by reproducing the account given in an early deed bearing date of November 11,1769 , which reads as follows:

A house called La Gerbetière, situated near the port of Launay, consisting of a sitting room, drawing room, kitchen, upper chamber ... garret, and other quarters serving as a laundry, stable at the back, with pigeon loft above, court, parterre, vegetable garden to one side, an orangery with orange trees, in the middle of the house, the whole in front of a close surrounded by high walls except on the side of the setting sun, with land belonging to the heirs of M. de la Haye Moricaud, held mutually, ${ }^{5}$ the whole bounded on all other sides by highways. Notice: The aforesaid house and parterre [stand] in an empty field, which serves as a fair-ground, and is partly planted with young trees in serial rows; held in common with the Marquis de la Musse, with another empty field containing about two journals of land. ...

"La Gerbetière," never more than an unpretentious country house with an attractive garden, was idealized in the fervent imagination of Audubon when in after life he drew upon the memories of his youth in France; for it had meant to him escape from the city, which he detested, to the fields and river which he loved. Yet, in spite of the abuse which a long line of poor tenantry inevitably entails, with intervals of total neglect last-

${ }^{4}$ But not related to M. L. Lavigne, to whom I am indebted for extracts from the deed, a translation of which is given below, as well as for many other references.

"That is, the landlord to receive one-half the produce.

"A "journal" of land being as much as a man could cultivate in a day's labor. 
ing for nearly a century, this decayed villa of pre-Revolutionary days still stands in marked contrast to its neighbors, and bears witness to a taste to which they were strangers. The greenhouses, the fruit and shade trees, if such it possessed, and all lesser adornments of the place have vanished long ago, but thanks to the durability of French stone and mortar, much about this old country seat is still well preserved. Whether Audubon ever saw his old Couëron home again after leaving it in $\mathbf{1 8 0 6}$ is doubtful, though one of his sons visited the place, and the naturalist incidentally speaks of a pilgrimage to Les Sables d'Olonne which might have occurred in 1831 or a little later. In following the fortunes of the naturalist's family in France it will be necessary for us to return to La Gerbetière. ${ }^{7}$

${ }^{7}$ See Chapter XVII. 


\section{CHAP'TER XI}

\section{FIRST VENTURES IN BUSINESS AT NEW YORK, AND SEQUEL TO THE "MILL GROVE" MINE}

Audubon and Rozier at "Mill Grove"-Their partnership rules-Attempts to form a mining company lead to disappointment-Decision to sell their remaining interests in "Mill Grove" to Dacosta-Division of the property and legal entanglements-Audubon as a clerk in New YorkBusiness correspondence and letters to his father-Later history of the lead mine and Dacosta-Audubon continues his drawings in New York and works for Dr. Mitchell's Museum-Forsakes the counting room for the fields-Personal sketch.

\section{When Audubon and Rozier reached "Mill Grove"} at the beginning of the summer of 1806, they found the troublesome Dacosta installed as its master by virtue of his interest in the property and his former position as agent, to which they were now to succeed. No doubt they found difficulties in carrying out all the articles of agreement ${ }^{1}$ in their business constitution, for they were to take possession and call Dacosta to account. They were also in duty bound to investigate the lead mine on the farm, and ascertain whether it promised any success, and if the expenses already incurred were war-

${ }^{1}$ For the privilege of examining Ferdinand Rozier's copy of their "Articles of Association" I am indebted to the kindness of Mr. Charles A. Rozier, of Saint Louis. This is written on three sides of hand-made, hand-ruled Government linen, small letter size, with printed revenue stamp (50 centimes) of the French Republic at top, and stamped with the seal of the Department of Registration and Stamps ("ADM. DES DOM. DE L'ENREG. ET DU TIMBRE REP. FRA.-Administration des domaines de l'enregistrement et du timbre, République Française"). The signature of "Jean Audubon" bears a close resemblance to that of the father, Lieutenant Jean Audubon, who was undoubtedly the author of the document. For the "Articles" in full, in French and English, see Appendix I, Documents Nos. 9 and 9a. 


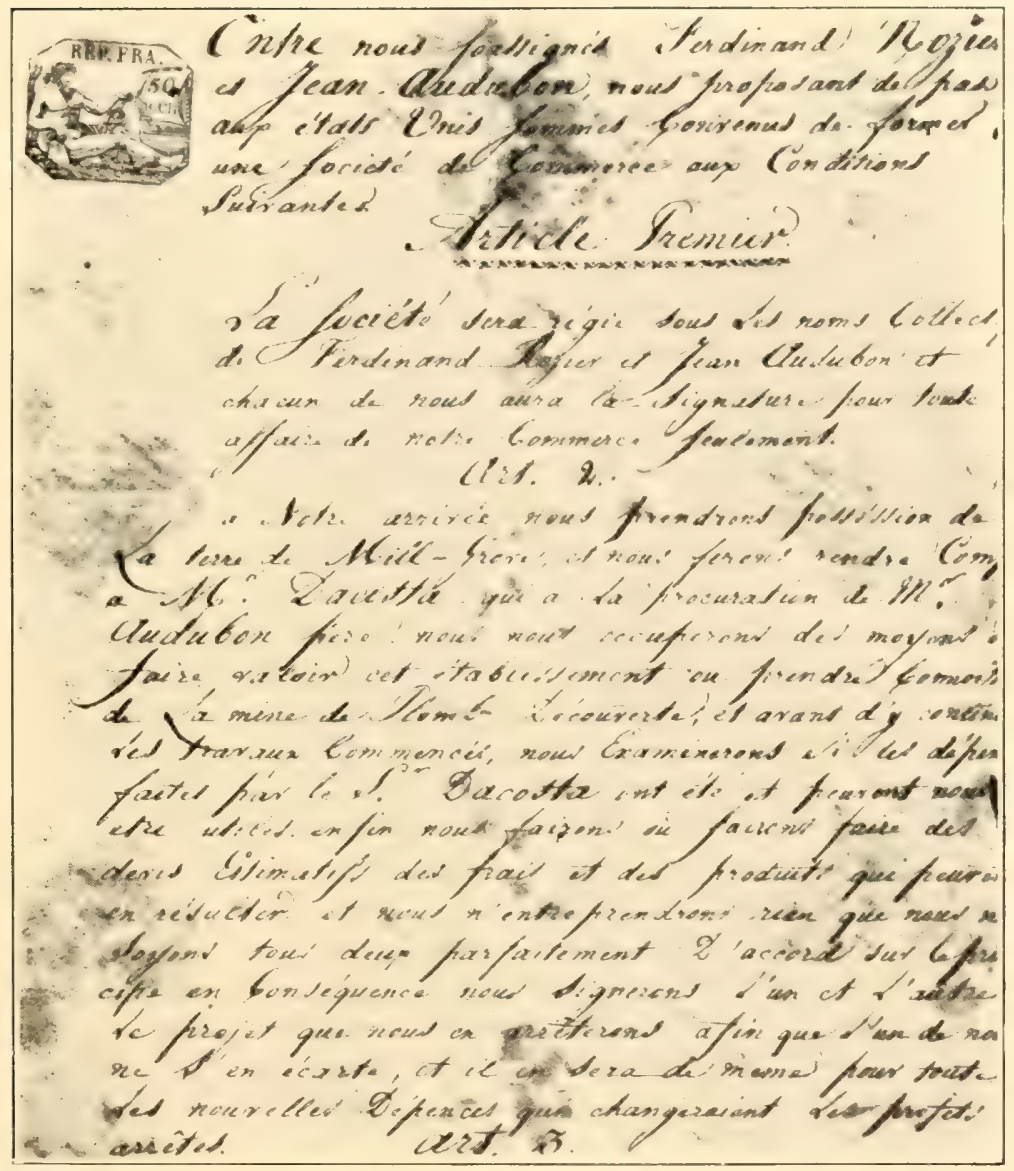

BEGINNING OF THE "ARTICLES OF ASSOCIATION" OF JOHN JAMES AUDUBON AND FERDINAND ROZIER, SIGNED AT NANTES, MARCH $23,1806$.

After the original manuscript of Rozier's copy, in possession of Mr. Charles A. Rozier. 

ranted, before committing themselves to further development. One-half the product of the mine and farm was to be equally divided between them, and in order to visualize clearly their profit and loss, they agreed to keep a "special book for the purpose." "On one side," their third "Article" read, "will be entered the items of expense, day by day, and at the moment this is done, on the other side [shall also be entered] the sales and products of the farms, and of all that can result from this business, in such a way that the profit shall be always apparent by the addition of the items which compose the debit and the credit."

The house at "Mill Grove" was to be treated as an object separate from all business, "in order," so the "Articles" read, "that we may settle matters as completely as we desire." It was also agreed, in the fourth "Article," that they should "add to the expenses of this exploitation those necessary for life, and others of a mutual character, so long as it should suit them to live and dwell together." It was further stipulated that even if the mine proved a failure, they should remain six months on the farm, in order to gather useful information from the country, before embarking in any form of commerce, whether inland or maritime. The cost of their journey to America was to be entered as the first item of their "social expenses," and any expenditure for travel in their mutual interests was to be considered under the same head. In case they should persuade any merchants in America to send goods to M. Rozier, Senior, at Nantes, he should be entitled to one-half the profits, while the partners should divide the other half between them. All other profits and losses resulting from their commercial transactions were to be shared equally. The partners resolved to maintain friendship 


\section{8

and a mutual understanding, but "upon the least difficulty" each should choose one arbitrator, and the two thus chosen were authorized to select a third; the partners were bound to accept the decision thus reached without appealing to any court. In the case of the death of one of the associates, read the tenth "Article," the survivor should have sole charge of making a settlement of the business and should report to the proper heirs. The survivor, in such an event, would be entitled to a commission of ten per cent [in addition to his one-half interest], but in no case should the partnership be dissolved "until after nine years, counting from the day of the date of the present [instrument]." As will be seen, Audubon and Rozier were unable to fulfill all the conditions thus carefully laid down.

Young Audubon's dislike of Dacosta, the uncertainty of the mining project, and other difficulties of the situation soon decided the partners to cut short their stay at "Mill Grove." Both were equally interested in the lead mine, but after working several months without success in an attempt to form a mining company, they wisely decided to leave such experiments to the enthusiastic Dacosta and to seek an opening in trade, where the hazard would be no greater and their ignorance less profound. Following the advice of their Quaker friend, Miers Fisher, they decided to sell to Dacosta their remaining rights in "Mill Grove." As a preliminary it was necessary to divide the property which had been held in common by him and Lieutenant Audubon since 1804, and this division was effected by an agreement drawn up at Philadelphia on the fifth day of September, $1806 .^{2}$ Ten days later the remainder

'Among the elder Rozier's papers was part of an old letterbook belonging to his son; it is written in French, and labeled "Correspondence of Ferdinand Rozier." On one of the four sheets preserved this item 
of "Mill Grove" was conveyed to Francis Dacosta, representing a number of capitalists whom he had managed to interest in the mine, of whom the astute Stephen Girard is said to have been one. The sale was subject to conditions, ${ }^{3}$ dependent upon their success in mining lead, which, as will appear eventually, could not have been fulfilled. These various transactions are so clearly set forth by Ferdinand Rozier in writing to his father at Nantes that we shall reproduce his letter in full: ${ }^{4}$

\section{Ferdinand Rozier to Claude François Rozier}

\section{Duplicate.}

Philadelphia, 12 Sept., 1806

My very dear and venerable Father:

Still in hope of cherished news from you, and replies to my letters of 31 May, 22 June, and 4 July, I have to tell you that we have since succeeded in closing all our business relations with Mr. Francis Dacosta, in the following manner: We are anxious that our method of procedure may be satisfactory to you; we have followed the advice of Mr. Miers Fisher, and have had his approval in all that we have done. What should set you at rest is that as regards your investment, you will find

occurs: "4 July, 1806, Philadelphia; record of an agreement with Mr. Dacosta, proprietor of one half of the Mill Grove farm,--at least of the value of sale." The first entry is dated "19 février-1806, New York," which, if correct, would imply that Rozier spent two years instead of one in the United States when he visited this country in 180.t (or came a second time), and that he returned, with young Audubon, almost immediately after reaching France (see Vol. I, p. 245); the last record is "August, 1807, New York." (MS. in possession of Dr. Louis Bureau, Nantes.)

${ }^{3}$ According to the records of Montgomery County, as collated for Mr. W. H. Wetherill, the remaining half interest in "Mill Grove" was sold by J. J. Audubon (and Ferdinand Rozier) to Francis Dacosta \& Company, for a consideration of $\$ 9,640.33$. The business was conducted mainly by Rozier, acting under the advice of their friend, Miers Fisher.

${ }^{4}$ Translated from the French of Ferdinand's copy, in possession of Mr. Welton A. Rozier, to whom I am indebted for the privilege of reproducing it. 
that I have made quite a neat profit. Here is a copy of the agreement.

"It is agreed between Mr. Dacosta and Mr. J. Audubon that the farm of "Mill Grove," which they now hold in common, shall be divided between them as follows:

"1. Mr. Dacosta shall have the lot of 113 and a half acres, situated on the N.E. side of Perkioming creek, with all the buildings, mines, et cet., and in general all that it contains.

"2. Mr. Audubon shall have the lot of 171 acres, situated on the other side of the creek.

"3. Mr. Dacosta shall pay to Mr. Audubon for the difference [in value] of the lot of $1131 / 2$ acres, and of that which it contains:

"1. The sum of eight hundred dollars, payable with interest, in three years from this day;

"2. The sum of four thousand doliars, upon the first products of the lead mine.

"4. The contract made with Mr. Thomas shall remain to the charge of the two parties.

"Note. Mr. Duponceau is begged to draw up the necessary deeds to put this agreement into execution, which [deeds] we undertake mutually to exchange at the first requisition."

"[Executed] at Philadelphia, this 5th of Sept, 1806."

$$
\begin{gathered}
\text { [Signed] "Fcis Dacosta" } \\
\text { "Ferdinand Rozier" } \\
\text { "J. Audubon" }
\end{gathered}
$$

The futile attempt that we have made to form a company [to work this mine], which is a condition [of success], the slight resources at our command, as well as our lack of knowledge in work of this kind, all have determined us to abandon our rights for the offer of four thousand dollars ${ }^{5}$ upon the first products that shall come from the mine. The expense that must

" "Gourdes," that is, piasters or Spanish dollars. 
be incurred in [working] it will be very heavy; to this must be added the uncertainty of success. The mine may promise much at the beginning, and after that yield nothing. In short an enterprise of this kind can be properly conducted only by a capitalist or by a company. We have regarded this mine as a lottery which can make the fortune of the promoter, or lead him into great losses. As to the agreement with Mr. Wm. Thomas, we do not consider it as very serious; since it is quite uncertain whether he will be paid in whole or in part, as he has not kept his agreements. This is Mr. Dacosta's opinion. As to our half we are decided not to let it go under eight thousand dollars, which is its value as estimated by several farmers. So you see, my dear papa, that our half [as worth] 8,000 dollars, at least, the sum of eight hundred dollars by mortgage, with interest, and that of four thousand dollars upon the first products from the mine, will cover easily the interest on the purchase of sixteen thousand francs.

Since expenses are at least double what they would be in France, owing to the cost of products of every sort, we are determined to go into trade, to cover our expenses, and to choose for ourselves some kind of serious work that can lead us to an honorable establishment. You should be at ease about the manner we shall adopt for our operations, as we wish only to go slowly, and especially [to be] guided by the advice of the respectable persons whose acquaintance we are so fortunate as to enjoy, and who beyond a doubt will aid us along this thorny path.

"By our letter of the 4th July we have sent the account current of Mr. Dacosta, by which Mr. Audubon is charged with 315 dollars and 5 cents; we have begged you to send the documentary evidence which may put us in a position to prove that Mr. Audubon ought not to pay Mr. Dacosta's private expenses, as the matter is to be decided here by arbitrators. We beg Mr. Audubon to use the utmost speed in sending his documents. It is our ardent [hope] also that you have received our first [letter] of May 31, with that of Mr. Bakewell, the merchant in New York, with a remittance of 3,000 and a few francs for 
the purchase of divers objects. I assure you that we are in the greatest anxiety [as to] what is the state of your health, ${ }^{6}$ as well as that of the family, and to learn if you have received our letters. 'The nephew of Mr. Bakewell writes us that his uncle in New York has despatched several vessels consigned to you, for which I congratulate you sincerely. We have also received your letter of the 30 th of June, but I cannot reply to it, since the boat is leaving this evening for Amsterdam, but you can count upon my conforming to its contents. Your personal letter grieved me particularly by your last expressions, and I should wish that you would have done me more justice; I can have made mistakes, but for . . the idea alone has made me shudder. I am delighted that all the family is enjoying perfect health. Embrace dear Mama for me; my kind regards to my brother and sisters; do not forget to remember me to all the family, and to our friend, Mr. Audubon, the father, and his family. Finally, my dear Papa, be assured that I shall forget nothing to increase our intimacy. You give me the means of supporting it with labor. Believe in my sincere and enduring attachment.

Your respectful son,

Ferdinand Rozier.

We are eager to hear of the receipt of our letters, and we beg you to address them to Mr. Bakewell of New York.

The inbred caution, sound sense, and sterling integrity which this letter displays would be a good foundation for any career, and we are not surprised to find that in after life Ferdinand Rozier became a keen and successful trader on the western frontier.

The division and sale of "Mill Grove" probably

${ }^{B}$ Claude François Rozier, at this time an aged man, died at Nantes on September 7, 1807; he had two sons and six daughters, of whom Ferdinand was the second son and the fifth child; his wife, Renée Angelique Colas, died at Nantes, February 9, 1824. 


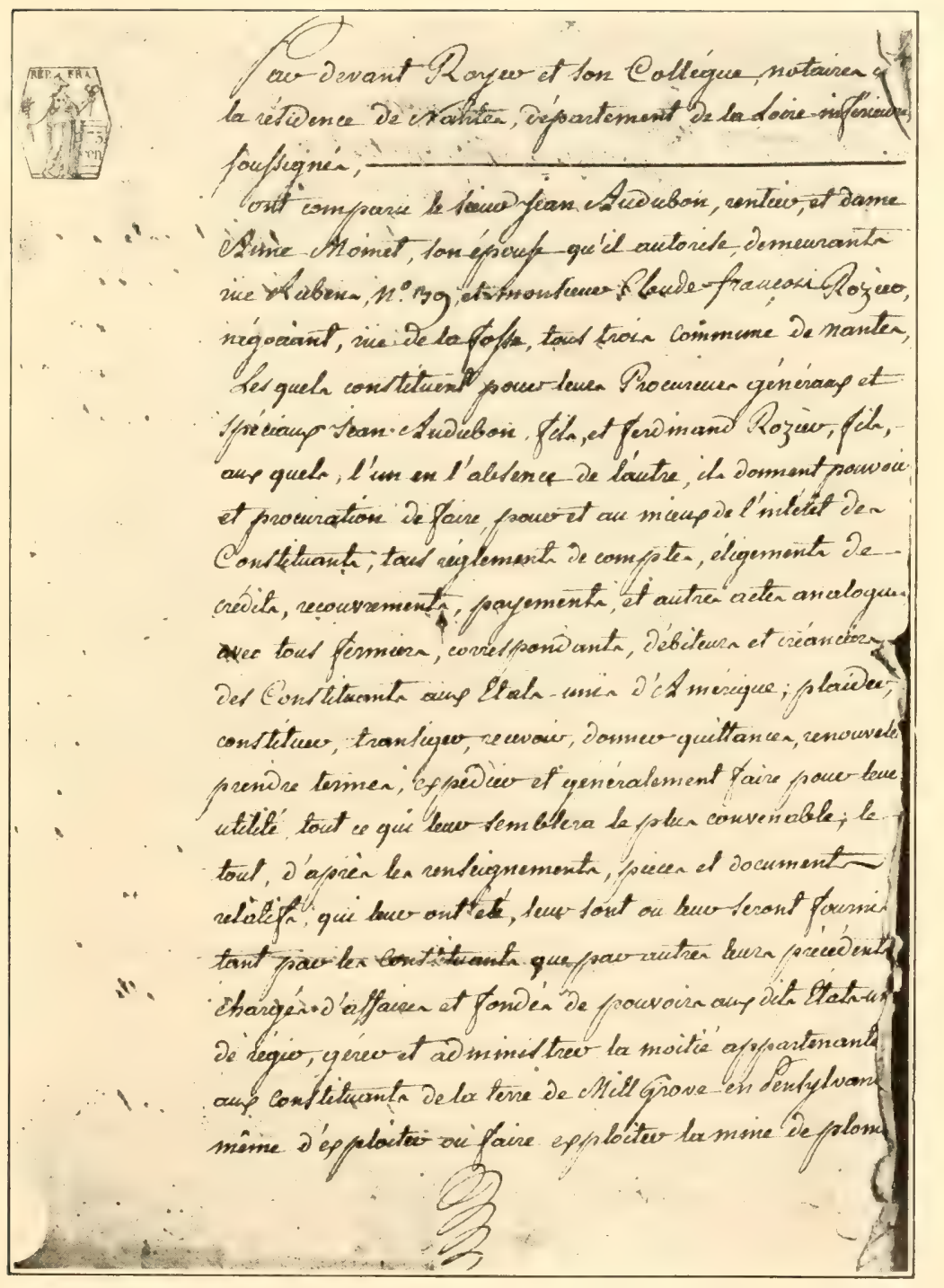

FIRST PAGE OF THE POWER OF ATTORNEY GRANTED BY JEAN AUDUBON, AX XE HOYNET AUDUBON AND CLAUDE FRANCOIS ROsIER TO JOHN JAMES AUDUBON AND FERDINAND ROZIER, NAXTES, APRIL 4, 1806.

After the original manuscript of Ferdinand Cozier's copy, in possession of Mr. Tom J. Ropier. 


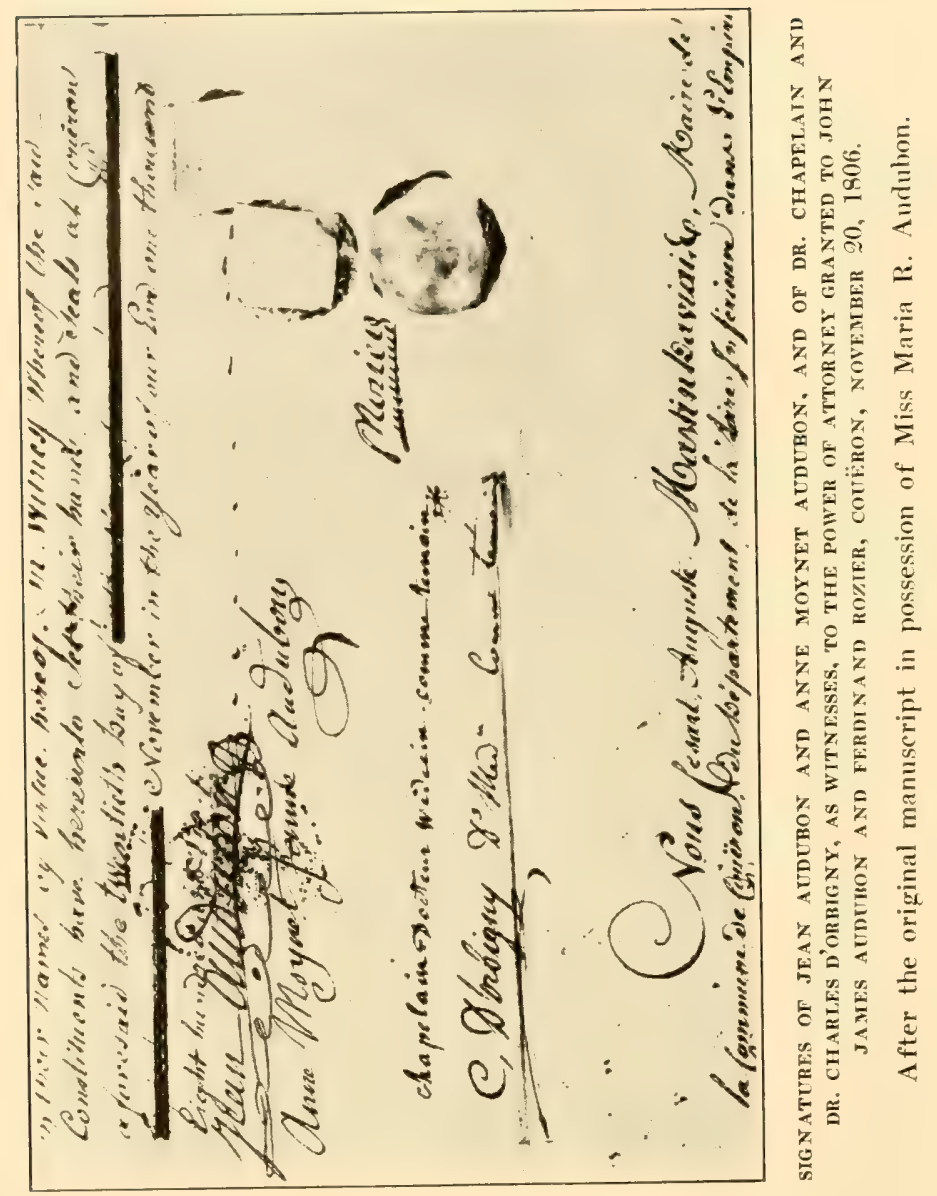




\section{FIRST VENTURES IN BUSINESS}

ended the joint interests of the elder Audubon and Rozier, for in November, 1806, a new power of attorney ${ }^{7}$ was given to the young men by Lieutenant Audubon and his wife; as later events will prove, however, their rights in the property were not completely surrendered with its transfer to Dacosta and his mining company in the autumn of this year. The partners were now free to "choose some kind of serious work," and Ferdinand, who was then twenty-nine, was anxious to make a beginning at once. Since he was not as yet proficient in the English tongue, Rozier engaged as a clerk in the French importing house of Laurence Huron, of Philadelphia, while Audubon, following the advice of his future father-in-law, entered the office of the latter's brother, Benjamin Bakewell, in New York.

In the autumn of 1806 Benjamin Bakewell was conducting a successful wholesale importing business at 175 Pearl Street. He then owned several vessels, and his correspondents were scattered over England, France, the West Indies and the Southern States. With him were associated at this time a number of young men, including his nephew, Thomas W. Bake-

${ }^{7}$ This was issued, so the letter reads, to "their son, John Audubon, and Ferdinand Rozier, both of the said city of Philadelphia, Gentlemen," by "John Audubon, late of the city of Philadelphia, in the commonwealth of Pennsylvania, now residing in the commune of Couëron, near the city of Nantes in France, Gentleman, and Anne Moynette, his wife," to apply to all lands and other property belonging to them in the United States, with the power to "raise or borrow money on the whole or any part or parts of the said lands, tenements, or hereditaments, to serure the repayment of said monies by bond, warrant of attorney, to contest judgment of the mortgage of the said lands, tenements, or hereditaments, or any part or parts thereof...." Written in French and English; signed by Jean Audubon, Anne Moynet, his wife, by Doctors Chapelain and C. d'Orbigny as witnesses, by the mayor of Couerron, the prefect of the arrondissement and the prefect of the department; countersigned on December 4, 1806, by W. D. Patterson, of the "Commercial Agency of the United States at Nantes." For the favor of examining this paper, I am indebted to the kindness of Miss Maria R. Audubon. 
well, Thomas Pears, a nephew of his wife, Thomas Bakewell, his son, as well as John James Audubon. The hospitable family to which young Audubon was now admitted on terms of intimacy, in accordance with the custom of the day, lived in the rear of the countinghouse during the winter months but in summer migrated to the country, the Bakewells going five miles out on the Bloomingdale Road. Benjamin Bakewell had come to this country in 1794, in the same year as the famous chemist, Joseph Priestley, whose friendship he enjoyed and whose religious teachings had drawn both him and his brother, William, from rigid Calvinism to the greater tolerance of the Unitarian belief. At twenty-four he was an independent mercer in Cornhill, London, and was well acquainted in France, where he had spent considerable time during the Revolution, which had destroyed his trade. One of his patrons at this time was Claude François Rozier of Nantes, and inasmuch as the correspondence with him had to be conducted in French, and may possibly in this instance have been due to young Audubon's initiative, it was naturally intrusted to him.

Seven letters of the naturalist, dating from January 10,1807 , to July 19 of that year, by good fortune have been preserved, and they throw into full light another shaded corner of his interesting life. From the contents of these letters, ${ }^{8}$ as well as from other facts, we

${ }^{8}$ For the privilege of examining these letters $\mathrm{I}$ am inclebted to the courtesy of Dr. Louis Bureau, Director of the Museum of Natural History and Professor in the School of Medicine at Nantes, maternal greatgrandson of François, and grandnephew of Ferdinand Rozier. The letters were found in an old trunk that once belonged to his grandfather, François Denis Rozier. Five were written in French (Nos. 1, 2, 4, 6 and 7 ), and addressed from New York to François Rozier at Nantes; one (No. 3) in English and another (No. 5) in French were sent in care of Rozier, to his father, John Audubon, Esq., Nantes, with the direction to be delivered as soon as possible; all are on unruled foolscap, wafer-sealed 
know that Audubon remained in Bakewell's office for nearly a year, from the autumn of 1806 to the summer of 1807. Bakewell's house imported linens, lace, gloves, wines, firearms and any kind of merchandise that promised a ready and remunerative sale in New York; in return they forwarded coffees, sugars and other commodities to Rozier, receiving from him also prices current and introductions to other merchants in France. Another correspondent was the Huron firm in Philadelphia, so it is probable that Ferdinand owed his employment there to Benjamin Bakewell.

While Audubon expressed himself at this time as freely in English as in French, in the former language the tendencies of his French tongue and the influence of his Quaker friends were strangely blended. He never bothered with accents, and took as many liberties with the spelling of French as of English. Some of these lapses are purely phonetic, while others are more original, as "schacket" for "packet," "fither" for "Fisher"; two variations of Rozier's name and of Nantes occur in the same letter. It should be remembered, however, that at the beginning of the nineteenth century bad or random spelling was a very venial offense, which gentlemen of quality, or even scholars, could commit with impunity. In this respect Audubon's early essays in English would probably compare favorably with Gibbon's youthful French.

and each also bears an outside seal in wax, stamped with Bakewell's initial (B). It is not possible to say whether Lieutenant Audubon ever received these letters of his son; if received, it is not very obvious why they should have been left in the old merchant's hands, unless his ill health at the time, and subsequent death were the cause (see Note, Vol. I, p. 152). I am further indebted to Mr. William Beer, for the perusal of his copies, which have heen followed to a large extent.

Since all of these early letters throw an interesting light upon the times as well as upon Audubon's personal history, we shall give them in full, rendering the French into English as literally as practicable. 


\section{John James Audubon to Claude François Rozier} [Letter No. 1, addressed]

M. Fr. Rozier,

Merchant-Nantes.

\section{Dear Sir :}

New YoRK, 10 January, 1807.

We have had the pleasure of receiving by the Penelope your consignment of 20 pieces of linen cloth, for which we send our thanks. As soon as we have sold them, we shall take great pleasure in making our return.

I am truly sorry that you had not received any letters from us when you wrote, and I am also very disconsolate at having no news from my good father. You did us a most acceptable service in making us acquainted with your friends in different parts of France, and in offering to send us such goods as you shall deem scitable. Upon the same proposals I sent you orders several months ago, and did I dare, I should tell you that all articles having much show and little value are the very things that are à la mode, and these in one hundred per cent, [and] I assure you that we should be very happy to receive some small consignments. As soon as we shall have realized our funds, we will make our orders, in accordance with our means. Mr. Bakewell has made a great profit on the consignment that you made him shortly after our arrival. We should be flattered by another like it. Have the kindness to write us often, and to send us prices current as far as possible. I hope that you will have had our letters concerning a plan of business with Mr. Huron. If you will have the kindness to see him, ${ }^{9}$ he can communicate to you his ideas on the subject. His plan, I believe, will be advantageous both to you and to us.

Your son is just about to come from Philadelphia, to live in New York until there is some news; but we will write you more at length by Capt. Sammis, who brought us to this country. I even venture to hope that you will send back some merchandise for us. Have the kindness to forward us invoices,

${ }^{\circ}$ This Philadelphia merchant was evidently in France and intending to visit $\mathrm{N}$ antes at this time. 
with the goods consigned to us, in order to avoid the penalty and the expense of having them taken to a public warehouse, [a proceeding] which is often a great disadvantage on account of the fees. Consign always to Mr. Benjamin Bakewell, who treats us, so far as possible, as good friends.

Present my respects to your family, and believe me ever your faithful servant,

J. J. Audubon.

\section{John James Audubon to Claude François Rozier}

[Letter No. 2, addressed]

Monsieur Fr. Rozier,

Negociant,

Nantes.

Loire Inferieure.

Mr dear Sir:

New York, April 24, $180 \%$.

I am profiting by a good opportunity for Bordeaux to apprise you of the receipt of a duplicate of the orders that you gave us several months ago. You will also know that the wines, consigned to Mr. L. Huron, have arrived in this city and the insurance has been saved. Your son has gone to the spot [the dock in Philadelphia], and by one of his letters advised me that the 60 cases of wine are sold. He tells me that you can count on a net profit of nearly 20 p. c. If it turns out very good, the remainder will not fail to find a purchaser. Mr. Le Ray has arrived and has brought with him a small box of lace for Mr. Benjamin Bakewell here; it ought to arrive in a few days from Philadelphia. Mr. B. B. appeared satisfied with the sale of his squared timber; he is anxious only to see the returns; he is unhappy that the commerce of your town with this country cannot be regularly conducted except by Bordeaux, whence we have vessels every month. As our friend, Ferdinand, will write you from Philadelphia concerning Mr. Huron, I shall not enlarge about him. In several of your letters you intimate that if we decide upon establishing a retail 
shop, you can keep us constantly employed; our ideas upon this subject are in perfect accord, and it would be indeed a pleasure if we could start under the auspices and good advice of Mr. Bakewell here; objects well chosen, favorably bought, and shipped with care, are always sure of meeting a good sale. I venture to hope that the ship La Jeanne, Capt. Sammis, will have arrived in your port, and that the Indigues shipped by Mr. Bakewell will reach there in time for the sale of this merchandise, of which I have some fears, in view of the sum they have cost him.

We thank you for the prices current that you have sent us. In one of my last, directed by way of Bordeaux, I begged you to call on Mr. Fleury Emery for a box of seeds, from Martinique and from this country, for you and for my father. This was aboard the ship, the Virginia, Capt. Roberts, from this section. We hope shortly to send you some merchandise, and possibly Mr. Bakewell will profit by an opportunity that we shall have in a few days for your port. A little more than three weeks ago I was at Mill Grove, and I rented it for a year, being unable to do better for the present. Your son, now in Philadelphia, is trying to settle the accounts of my father with Mr. Dacotta [Dacosta], who does not easily forget the rôle of chicaner. Present, I pray you, my respects and compliments to your good family and wife, and believe in me as your devoted and constant

servant,

J. J. Audubon.

Have the kindness to deliver the enclosed to my good father.

The following quaint and charming letter, which young Audubon enclosed with the preceding and under separate seal, but which his "good father" may not have received, will be transcribed in full, without the change of a letter or mark. Lieutenant Audubon, who was then in his sixty-third year, was living, as we have seen, at Couëron, the small river town nine miles west of 


\section{FIRST VEN'TURES IN BUSINESS}

Nantes, the center of the mails for the Loire Inférieure, and came frequently to that city to conduct his business correspondence.

\section{John James Audubon to Jean Audubon}

[Letter No. 3, enclosed with No. 2, addressed]

John Audubon, Esq.,

Nantes.

pr Bourdeaux

My deAR Father

NEW YoRk April 24th 1807

I send thee by a good opportunity, but going to Bordeaux I deed send about a month ago a small Box containing some very curious seeds \& some useful ones the whole was directed to Mr. Fleury Emery it was given here to the Care of Capt. . Roberts of the Virginia I do hope they are now in thy possession thou have been so often disappointed that it always pains me to think that they have been Miscarried: thou shalt found some of the Best Whatter Missions and Girmonds Called here St. Domingo Schachet ${ }^{10}$ as in a few days I shall have again a good opportunity for Nantz I will send thee a Duplicate of the same Seeds, I have seen in the News Paper that a ship called the Betzey had been in Nantz do make some Enquiries for it there are on board of her Many Birds and a collection of seeds from America for thee The Caps. . Mc Dougal; pray when thou answer to this be kind enough to mantion these little things. I hope that the Jane Cap. . Sammis as reached your Port and given thee some Turtle fit to be eaten in soupe. Mr. L. Huron deed few days ago. Received some Wines on a/c of M. Rozier and hits they prove goods ${ }^{11}$ and will bring a good profit. Mr. F. Rozier the son speaks of going to France some time this summer he is now near $\mathrm{Mr}$. Huron at Philadelphia and will try while he is there to settle the Business between M. .Dacotta and thee M. .Rozier had

1. "Of the St. Domingo packet."

11 "Mr. L. Huron did, a few days ago, receive some wines on a/c of M. Rozier, anci hopes they prove good," etc. 
shosen M. . Huron for arbitrator but I would not agree to it until M. . Miers fither ${ }^{12}$ was to have part in it. I am now waiting for an answer. I am allways in Mr. Benjamin Bakewell's store where I work as much as I can and passes my days 3

happy; about thee weeks ago I went to Mill Grove for a/c of the latter and had the pleasure of seeing there my Biloved Lucy who constantly loves me and makes me perfectly happy. I shall wait for thy Consent and the one of my good Mamma to Marry her. could thou but see her and thou wouldst I am sure be pleased of the prudency of my choice; M..B. Bakewell is allways willing to oblige me and will do many things for me: do not participate the Ideas of M. Rozier Going to France to his father it would perhaps Injure us for a while. I wish thou would wrights to me ofnor and longuely think by thy self how pleasing it is to read a friend's letter. Give my love to all my friends and thine and kiss mamma, Rosa and Brother Pigaudeau ${ }^{13}$ for me I hope they continue to be all happy, do remember to send me thy portrait in miniature dressed as an officer ${ }^{14}$ it will cost thee little and will please me much. Some of thy hair and ask my sister for the Music she does not want. I wish to receive some letter from M. . Dorbign $y^{15}$ whom I have often wrighten and send some curiosities he is yet to answer to my first.

When thou seeist Mr Rozier pray him and try to engage him to send us some-goods then we feel very inclined to set up in a retail store which would do, us a great deal of good.

${ }^{13}$ Miers Fisher, for many years Jean Audubon's trusted agent and attorney in America. See Vol. I, p. 100.

${ }^{13}$ Gabriel Loyen du Puigaudeau, his brother-in-law.

14 That is a miniature of an old portrait of his father in the uniform of a lieutenant-commander, which with its companion, representing Mme. Jean Audubon, his stepmother, then hung in the house of "La Gerbetière" at Couéron. The original portraits, which are reproduced facing page 78, measure $231 / 2$ by $181 / 2$ inches, and were painted probably between 1801 and 1800 ; they were inventoried in documents bearing date of November 14, 15 and 17, 1821, shortly after Mme. Jean Audubon's death. They were restored in Paris about ten years ago for Monsieur Lavigne, to whom I am indebted for the photographs and this information.

${ }^{15}$ Audubon's intimate friend, see Vol. I, p. 128. 


\section{FIRST VENTURES IN BUSINESS 161}

I will send him a letter by this opportunity-Good by farwell good father believe me for life thy most sincere friend be well be happy

thy son

J. . J. . AuduBon

J'espere que tu poura lire-adieu-adieu.

John James Audubon to Claude François Rozier

[Letter No. 4, addressed]

Mr. FCcis Rozier,

Merct, Nantes - Ocean.

Dear Sir :

New York, May 6th, 1807.

I wrote you recently by a ship going to Bordeaux; the letters were carefully intrusted, and I hope that they were received. I notified you of the arrival of the wines to the address of Mr. Huron of Philadelphia, and told you that part of the cases were sold. Your son informed me this morning that wine of so good quality ought never to be exported in cask, and that the profit would have been greater if the whole had been in case. Mr. Benjamin Bakewell has received the bill of lading of Mess Gereche brothers, and the gloves and the lace are at present on the road from Philadelphia to this place; perhaps we shall have them tomorrow; I am afraid that they may be dear. In several of your letters to Ferdinand you speak of a retail store, and my friend begs me tell you that nothing could suit us better than that you should have the kindness to send us enough [goods] to set up a shop at once on a good footing. As soon as advised, we shall order you to stock it with merchandise of your choice. You should have already received the bill of sale of a bale of linen cloth. You can judge that I have learned to shave Messrs the Americans, since I have been with Mr. B. B. In conscience, however, [the goods] have been sold at one third above their value. Should you decide upon sending another [shipment], do not count upon so good a sale. You must know, however, that I am always 
disposed to do everything for your interests, and that I shall always seek to merit your approbation. Should you decide to make [us] a consignment for a retail shop, have the kindness to follow, point by point, the following bill:

60 doz. morocco leather powder flasks-green or gray, copper mounted, like those that you sell at the shop for 25 sols [soldos].

60 doz. d. d. of leather, mahogany color, at the same price.

100 boxes d.

100 music boxes, ${ }^{16}$ in prices from 10 to 18 francs, good pieces and gay music.

100 boxes of seal-wafers, containing 1 gross each, assorted in color [but] more of the red than any other.

10 gross of small boxes of seal-wafers.

3 boxes of pastels, good, well assorted, and chosen by the sons of M. Belloc; more would not return us anything.

If you could procure us good books in English at Paris, M. Bakewell assures me [that we would realize] a great profit on them, and upon the other articles as given above, if well chosen. We hope to sell Mill Grove, and we will credit you with a great part of the profit in colonial merchandise. It is with impatience that I await some news of the indigo of $\mathbf{M r}$. B. Bakewell. Have the kindness, I pray you, to forward the enclosed letter to my father as soon as possible, and will you take from the ship Ocean, the carrier of this letter, a little box [sent] to your address for him, and will you send this to him also? Present my respects to your ladies; accept mine and those of the Bakewell family. Ferdinand is well. I salute you, and I am your devoted friend,

Audubon.

Herewith the bill of lading of the box.

The captain did not wish to make any charge, and has been perfectly polite.

${ }^{10}$ "Serinettes," the old time music boxes, or bird-organs, of Swiss origin, 


\section{John James Audubon to Jean Audubon}

[Letter No. 5, inclosed with No. 4, in French, and addressed]

Mr. FCcis Rozier

Mercht

Nantes

pour Mr. Audubon père

aussitôt que possible

My dear Friend:

Thou wilt find herewith a bill of lading of a small box containing nineteen species of seeds, a bottle of reptiles for Mr. Derbigny [D'Orbigny], and some dried plants also for the latter. I will write thee of Mr. Kauman, by the ship Mentor, which is to leave a little while after this one. Adieu, my good friend! The box will be addressed to $\mathrm{Mr}$. Audubon, $M d,{ }^{17}$ Nantes, with "American seeds" written above; besides two Bs, like this which follows B. ${ }^{18}$ The Capn. promises me to take care

B

of it, and of my letters also. If thou findest in my letter anything which displeases thee, remember that I am thy son. Adieu! Farewell, my good friend! Thine for life.

\section{J. J. Audubon. \\ New York, May 6, 1807.}

Do not forget, I pray thee, to send me for the good Mrs. Bakewell the complete works of Mr. Genlis ${ }^{19}$ by the first opportunity, and for me an exact copy of the departments of France like that which I made, and which is in thy cabinet. I wish thee to copy them for my brother-in-law. ${ }^{20}$

that were very popular in America down to the time of the Civil War, or even later. They were manufactured at St. Croix as late as 1880; instruments of similar type, with dancing figures, have been adapted to the pennyin-the-slot machines common in Switzerland to-day.

${ }^{17}$ Marchand, or retail merchant.

${ }^{18}$ Initials of the head of his firm, Benjamin Bakewell.

19 The reference was to Mme. Stephanie-Felicité de Genlis (1746-1830), teacher of the children of the Duke of Orleans, Philippe-Egalité, and authoress of many works on education, once popular, but now known only to the antiquary and the ragman.

${ }^{20}$ Meaning possibly his prospective brother-in-law, Thomas W. Bakewell, a fellow clerk in the office. 


\section{John James Audubon to Claude Francois Rozier}

[Letter No. 6, addressed]

Monsieur Ficcis Rozier,

Merchant

Nantes

p. Brig Mentor

New Yonk, May 30th, 1807.

Mr. Francis Rozier,

Merchant, Nantes.

DEAR SIR :

By my last, sent on board the ship Ocean, Capt. Bunken, I apprised you of the arrival of the gloves and lace, shipped by your order at Rochelle for the account of my good friend, Benj. Bakewell. I can now inform you of their sale, which is also advantageous, although the principal part was fine and of very great price. The gloves in prices of $23 \# 28 \# \mathbf{D}$, are what is needed for this market here, and especially if they are of any other color than yellow or bottle green they are less apt to soil; further they conceal defects more, and find in consequence more purchasers. The laces were better, although there was a heavy duty. You should know that here the extravagance of the women equals or rather quite balances the circumspection of the men, so that all articles for women should be beautiful, that is to say, conspicuous. I await with a kind of pleasure the arrival of Cap. Sammis, for although I am convinced that the indigoes will meet with no success at Nantes, their return here will compensate us. I am sorry that I did not order from you some little pistols and the guns which would serve perfectly. Believe nothing as to Mr. Bakewell, and be well assured that he is our friend. Have then less fear: I hope shortly to consign, that is to say, Mr. B. B. will consign for us, coffee and sugar from Martinique to your address. Your son is still at Philadelphia with Mr. Huron. They have sold the wines quite well.

But in truth I have been astonished that Mr. Huron did not make you an immediate return. I thank you sincerely for 
the little package that you said had been prepared for us. Be sure that Mr. B. B. will aid us to a sufficient degree, and always in a way that anything which you send us will be promptly returned in merchandise assigned to you. The land, which we cannot sell without a great disadvantage, keeps us very short of cash, and prevents us for the moment from dealing on as large a scale as we should desire; but with your kindness in sending us the materials for starting a grand retail shop with different articles, it will aid us very much. As you well say, it is a little unfortunate that there is no longer a boat from your port here.

I write to my father by the same opportunity. Will you, I pray, get it to him as soon as possible, and I beg you to go aboard for the live birds for him and for you.

Present my respects to your good family, and believe me for ever

\section{Your faithful friend and servant}

Audubon.

I should be very happy if you would send me a good box of pastels, chosen by Mr. Belloc, the younger, at 2 c 3 Louis. ${ }^{21}$

John James Audubon to Claude François Rozier

[Letter No. \%, addressed]

Monsievr Fr. Rozier,

Negociant,

Nantes.

Loire Inférieure.

DeAR Sir:

NEW YoRK, July 19, 1807.

Mr. Benjamin Bakewell as well as myself have received your letters by the Comet, which had a passage of 42 days. We have at present in the warehouse a great part of the merchandise of the latter [vessel], and in good condition; MIr. B. B.

${ }^{21}$ One Louis was equal to twenty francs, or four dollars. 
appears to be satisfied; he is about to send some teas that you have ordered from him. It has grieved me much to see him send a boat to Nantes, and not consigned to you, but his reasons were, I believe, so sound that I did not dare remonstrate. The agents of the house of Rossel and Boudet paid him the $2 / 3$ of the invoice, or a draft upon London for an equivalent sum, that neither Ferdinand nor I were authorized to do; the latter is at Philadelphia. In a short time we are leaving for a voyage upon the Ohio, the details of which you will learn [from him], or from my father, and which I believe will be very advantageous to us. We hope to sell Mill Grove this autumn, which we shall do, however, only at a profit. We received this morning a letter from Mr. Fleury Emery, who urges Mr. B. B. to give him some shipments, but regarding this I do not know his intentions. I have also received a letter to-day from our friend, $\mathbf{F d}$, who is quite well, and longs to be doing something.

Mr. Emery advises me of the receipt of a little box of seeds for my father and you. I think that your gardens are now embellished with foreign trees.

Mr. B. B. is loading tea for you, a thing that gives me much pleasure. I am sending you a letter from Ferdinand that I received yesterday. Presenting you as well as your whole amiable family with humble respects,

I continue to be

your faithful servant,

Audunon.

My regards, I pray to you, to my cousin, the younger.

Audubon's loyalty to his kind-hearted employer is evident in every one of these amiable letters, yet it is plain that they were written upon his own initiative, and a merchant of today might seriously object to such a candid exposition of his dealings as young Audubon's friendly epistles occasionally revealed. 
The numerous references which these letters contain regarding the disposition of the "Mill Grove" farm may well puzzle the reader who has followed the story to this point; we must therefore attempt to unravel the tangled threads of this intricate affair. In the spring of 1807 Audubon, who was then anxious to start a "retail shop," complained that the land, which could not be sold to advantage, kept them short of capital and prevented them from dealing on so large a scale as they could wish. On the 24th of April he wrote that three weeks before he had gone to "Mill Grove" and closed an agreement for renting the property (evidently referring to the farm as distinct from the mine) for a year, being unable to do better, and that Ferdinand was then in Philadelphia trying to settle his father's accounts with Dacosta, who did not readily forget his trickster's rôle. In Audubon's letter of the same day, inclosed in the same packet with the request that it be delivered to his father, there is a similar reference, with the note that Ferdinand, who had charge of the settlement, had .chosen Mr. Huron as arbitrator, but that he would not agree unless honest Miers Fisher had a part in it. Finally, as late as the 19th of July of that year he wrote to Rozier, the elder, that they were hoping to sell "Mill Grove" in the autumn, but would do so only at a good profit; yet at this time the property had been out of their possession, technically at least, for nearly a year.

Still more curious is this statement in Audubon's autobiography, ${ }^{22}$ relating to the year 1813 ; "I bought a wild horse, and on its back travelled over Tennessee and a portion of Georgia, and so round till I finally reached

${ }^{22}$ Maria R. Audubon, Audubon and his Journals (Bibl. No. 86), vol. i, p. 32 . 
Philadelphia, and then to your grandfather's at Fatland Ford. He had sold my plantation of Mill Grove to Samuel Wetherill, of Philadelphia, for a good round sum, and with this I returned through Kentucky and at last reached Henderson once more."

When "Mill Grove" was conditionally sold to Dacosta and his mining company in September, 1806, he gave a mortgage and bond to Miers Fisher, who again became Lieutenant Audubon's agent. Many months elapsed before the necessary legal papers could arrive from France, and meanwhile Dacosta's yearly accounts were contested, and gave no end of trouble. ${ }^{23}$

After operating the lead mine for five years, Dacosta's company failed, and "Mill Grove" again passed into other hands; it was finally sold to Samuel Wetherill

${ }^{23}$ Especially his account current, from June 1, 1806, to July 25, 1807, with the "Mill Grove" farm, and "John Audubon of Nantz," drawn up and signed at Philadelphia on the latter date. Dacosta then claimed a balance due him of $\$ 950.64$ above the returns from farm and mine, of which he was entitled to one-half; this sum included his salary and numerous minor expenditures. When his account was contested and taken out of court for settlement, it was cut by the arbitrators to $\$ 530$. See Appendix I, Document 11a.

The following is a "copy of the Award given by John Laval \& Laurence Huron appointed referees by Francis Dacosta and John Audubon the elder by a rule of reference in the Common Pleas of this county to have their differences in accounts settled:"

"We the within named referees, having heard the parties and examined their respective accounts \& vouchers, do award that there is due by the defendant, John Audubon the elder, to the plaintiff, Francis Dacosta, the sum of five hundred and thirty dollars, which we find to be the full balance of all current accounts between them, and we award that the said ballance be paid by the said John Audubon the elder to the said Francis Dacosta by defalking the same from the account of the condition of the Bond of Eight Hundred Dollars-mentioned in the within rule of reference conformably to the agreement endorsed on the said Bond."

"Witness our hands Philadelphia 1st August, 1807."

$$
\begin{aligned}
& \text { "Signed-Johy Laval." } \\
& \text { "Laurence Hurow." }
\end{aligned}
$$

(Copy of original MS., in possession of Mr. Welton H. Rozier.) 
in $1813 .{ }^{24}$ If our inferences are correct, the mortgages by which the Audubon and Rozier interests were protected were repeatedly transferred, and the first considerable amount of ready money that had appeared in the entire series of transactions was furnished by Mr. Wetherill. It is doubtful if Jean Audubon ever received any returns from his American farm after the advent of Dacosta in 1803. The ultimate failure of the lead mine was assuredly not the fault of this exploiter, but his dubious methods of accounting and probable failure to keep his contracts no doubt led the naturalist to denounce him as a swindler.

It may be recalled that in their "Articles of Association" Audubon and Rozier had agreed that the house at "Mill Grove" should be "an object separate from all business, in order that we may control this property as long as we desire," but the conditional sale to Dacosta apparently included the farmhouse as well as the land.

Many of Audubon's references to "Mill Grove" were apparently wide of the mark, but viewed in the light which we have endeavored to shed upon this involved affair, they would be in harmony with the essential truth; in writing to the elder Rozier, who became a partner in the enterprise, there was no motive which could have led him to depart from it. ${ }^{25}$

${ }^{24}$ In 1811 "Mill Grove" was conveyed by Francis Dacosta \& Company, to Frederick Beates, who in 1813 sold it to Samuel Wetherill, Jr., for $\$ 7,000$, the property having shrunk to less than one-half the value placed upon it in 1806. For the enterprises of the Wetherills, see Note, Vol. I, p. 102.

${ }^{25}$ Since we have been obliged to enter rather minutely into the history of "Mill Grove," in order to trace the relations of the Audubons to it in an important period of the naturalist's career, the reader may be interested in the anticlimax which its famous mines reached at a later day. The Ecton Consolidated Mining Company had been in operation at "Mill Grove" for a considerable period, when, in 1848, the Perkioming Association was formed and ten thousand dollars was at once invested in machinery. In 1851 these two companies were combined under the 
We will now return to the story of Audubon's life in New York. While he was supposed to be learning the exporting business with Benjamin Bakewell, his heart was in the woods and fields, and every hour that could be snatched from the counting-room found him in the pursuit of birds or drawing their portraits. He used the pencil and black crayon point combined with pastels, and while much of his artistic work at this time was hastily done, he was capable of producing excellent likenesses. A very delicate drawing of the Wood Thrush, signed with his initials, and dated at "Mill Grove, Pennsylvania, 14 aout, 1806," is numbered 209, showing that his collection of American birds was already extensive, even if it did not include many that were well known. In the winter of 1806-7, while in New York, Audubon paid most attention to the waterfowl, frequently visiting the shore and the markets for his subjects. The sketches which he then made were all in full size, and, as an evidence of the rapidity with which he worked, it may be noticed that he would often

name of the Perkioming Consolidated Mining Company, which issued 50,000 shares of stock, at six dollars each, thus representing a capital of $\$ 300,000$. A mining settlement quickly sprang up on Audubon's old farm, where numerous buildings of stone, a general store, and miners' houses were to be seen. In the first annual statement issued by this company, the buildings were said to represent an outlay of $\$ 15,000$, while $\$ 140,000$ had been expended on machinery, both above and below ground. A Cornish expert, who was summoned from England, was paid \$1,414 for a verbose report, the substance of which, it was said, was expressed in conveying the information, already known, that the "mineral mined is copper ore" (copper pyrite occurring in association with lead). This company closed its business in 1851, by assessing its stockholders one dollar a share, thus bringing the total loss in this final effort to $\$ 350,000$, nearly onethird of which had been drawn from Philadelphia. After one, or two, further unsuccessful attempts had been made, all the substantial buildings of the mining works became a quarry, from which stone was sold by the perch, the ruins of the old engine house alone remaining to this day as a witness of the follies of the generations that are gone. (This account is based upon reports which have appeared in the press of Philadelphia or in other Pennsylvania newspapers.) 
complete two or more large drawings of ducks on the same day. New York at this time was a city of about 75,000 people; Audubon said that by walking briskly he could pass from one end to the other in a few minutes.

In the foregoing letters we have seen young Audubon sending seeds and live birds to his father and to François Rozier, and reptiles and dried plants to Charles d'Orbigny, and ordering for his own use the best drawing materials from France. While at New York he had the good fortune to become a friend and protégé of the most distinguished naturalist of the metropolis, Dr. Samuel L. Mitchell, ${ }^{26}$ eminent in many walks of life, and at that time a member of the United States Senate. Audubon prepared many birds and mammals for Dr. Mitchell's collections, and the friendship thus early formed proved of much service to him later. He was probably working for Dr. Mitchell when, as the story goes, some of his neighbors lodged a complaint with the municipal authorities on account of the strong odors that habitually issued from his workroom, and a constable was sent to investigate.

${ }^{20}$ Samuel Latham Mitchell (1764-1831), physician, naturalist, politician and voluminous writer on many subjects. In 1797 he founded, in association with Dr. Edward Miller and Dr. Elihu H. Smith, the New York Medical Repository, and was its chief editor. He began also, at the University of New York, one of the earliest collections in natural history, and in 1817 appealed to the Historical Society of his city for the foundation of a Zoölogical Museum; in the same year he organized the Lyceum of Natural History, and was its first president, Joseph Le Conte serving as corresponding secretary, and John Torrey as one of its curators. On April 9, the following subjects were assigned to different members for investigation, "Ichthyology or fishes, Plaxology or crustaceous animals, Apalology or mollusca, and Geology or the earth" being reserved for the president; Constantine Samuel Rafinesque (see Chapter XIX) took charge of "Helmintology or worms, Polypoligy or polyps, Atmology or Meteorology, Hydrology or waters, and Taxodomy or classification;" John Torrey, who became a distinguished botanist, was more modest, and assumed charge only of "Entomology or insects;" while to John Le Conte were given "Mastodology or mammalia, Erpetology or reptiles, and Glossology or nomenclature." See the American Monthly Magazine and Critical Review (New York) for August, 1817, p. 272. 
Audubon remained in New York as late as August 22,1807 , for on that day he made a drawing of the "Sprig-tail Duck," but without doubt he had come to feel the incongruity of his position in a business to which his heart was a stranger. As an instance of his preoccupation at this time, he confesses to have once forwarded but forgot to seal a letter containing $\$ 8,000$. If Benjamin Bakewell failed to make a business man out of Audubon, it was not from lack of kindness, and probably no one else would have been more successful. As it happened, Audubon did not leave his employer any too soon, for at the close of 1807 Benjamin Bakewell's exporting business was ruined by the Embargo Act, through which President Jefferson had hoped to bring Great Britain and France to terms by cutting off their American trade, and for a year or more his estate was in the hands of creditors for settlement.

The naturalist has left a characteristic sketch of himself at this time: "I measured," said he, "five feet, ten and one half inches, was of fair mien, and quite a handsome figure; large, dark, and rather sunken eyes, light-colored eyebrows, aquiline nose and a fine set of teeth; hair, fine texture and luxuriant, divided and passing down behind each ear in luxuriant ringlets as far as the shoulders." The habit of wearing his hair long, thus early acquired and later favored by his wandering mode of life, appears to have lasted more than twenty years. 


\section{CHAPTER XII}

\section{EARLY DRAWINGS IN FRANCE AND AMERICA}

Child and man-His ideals, perseverance and progress-Study under David at Paris-David's pupils and studios-David at Nantes arouses the enthusiasm of its citizens-His part in the Revolution-His art and influence over Audubon-Audubon's drawings of French birds-Story of the Edward Harris collection-The Birds of America in the budAudubon's originality, style, methods, and mastery of materials and technique-His problem and how he solved it-His artistic defects.

Audubon began to draw birds and other animals when a child, and, like most children, was ready to believe that his crude sketches were finished pictures if only they possessed some sort of a head, a tail, and sticks in place of legs. But, unlike the majority of youth, he went direct to nature for his subjects, and his "family of cripples" failed to satisfy him long. He gradually developed a high ideal, and at an early age felt stirring within him the impulse and the power to express it. On stated anniversaries his masterpieces, he tells us, were burned, in spite of the praise and flattery they had evoked; he would then exert all his powers to do better, and this commendable practice was kept up for years.

In this respect the child was father of the man, for on the 5th of March, 1822, when Audubon was living in New Orleans, too poor to buy even a blank-book for a journal, he thus wrote of his work during the previous months: "Every moment $I$ had to spare I drew birds for my ornithology, in which my Lucy and myself alone have faith. February was spent in drawing birds 
strenuously, and I thought I had improved by applying coats of water-color under the pastels, thereby preventing the appearance of the paper, that in some instances marred my best productions. I discovered also many imperfections in my earlier drawings, and formed the resolution to redraw the whole of them." Seldom satisfied with the results attained, he kept up this laborious process of revision and selection by which he approached more closely to his ideal, the truth of living nature, for more than forty years, until, in fact, the last plates of his Birds of America came from the press in England in 1838. An examination of the originals of those plates today ${ }^{1}$ proves that many of their defects were inevitably caused by the makeshifts to which he was sometimes forced by lack of time.

Audubon has credited his father with the only judicious criticism which he ever received at the youthful stage of his art. "He was so kind to me," said the son, "that to have listened lightly to his words would have been highly ungrateful. I listened less to others and more to him, and his words became my law." When he was about seventeen years old, or probably not far from the year $1802,{ }^{2}$ he was sent to Paris to study drawing under Jacques Louis David, the acknowledged leader of French art during the period of the Revolution. This popular artist, who had uttered fierce invectives against "the last five despots of France," became nevertheless court painter under Napoleon; like many another Conventional regicide, he was destined

${ }^{1}$ See Vol. I, p. 185.

${ }^{2}$ Cuvier stated in his report on Audubon's Birds, delivered at the Academy of Sciences, Paris, September 22, 1828, that the author had been twenty-five years before a pupil in the school of David. This would place the date in 1803, but earlier than the autumn of that year, when Audubon started for America. See Note, Vol. I, p. 99. 


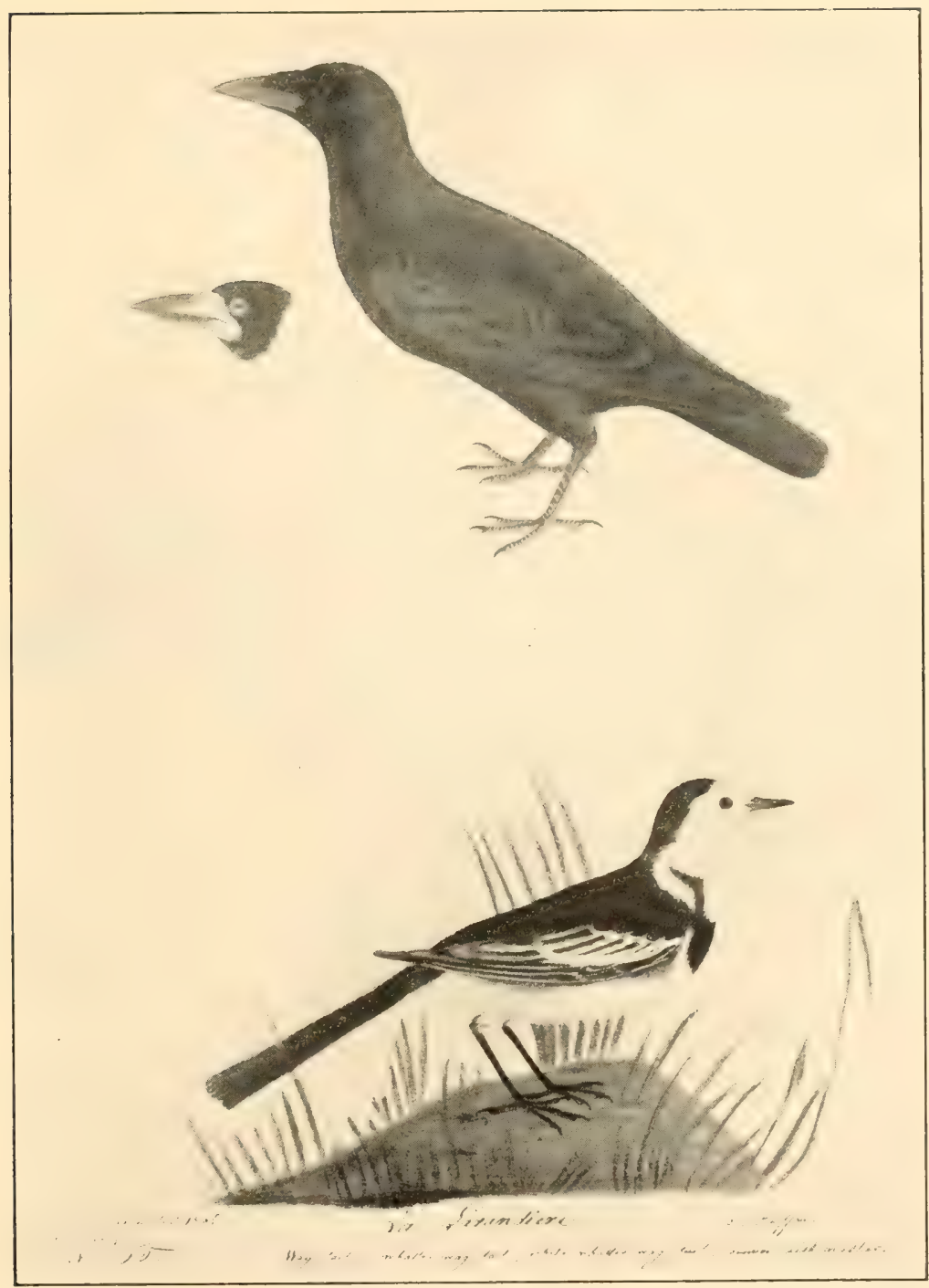

EARLY UNPUBLTSHED DRAWINGS OF FRENCH BIRDS: ABOVE, EUROPEAN CROW WITII HEAD OF ROOK, "LE CORBEAU OU CORNEITIF, NOIRE DE BUPFON, ENGLISH CROW, EN COMPAGNE AUTOER DE NAXTES, GROLE PESTTE GROLE NO.

155;" DETAIL, "BEC DE CA FRAGON NE OU FREYX BTFEON- IEC OF THE JAIG DAW No. 166;" BELOW, WHITE WAGTAIL, "LA

LAVANDIERE DE BUFFON. WAG-TAIL, WHATTER WAG-TAI, WHITE WHATTER WAG TAIL COMMTON DISH W ASIIER, THE 22 OF DÉCEMBER, 1805. NEIR NANT\% No. 6.5."

Published by courtesy of Mr. Joseph Y. Jeanes. 

to end his carcer as an exile from France, and died in Brussels in 1825.

Audubon has said but little of this Paris experience, but he remarked: "At the age of seventeen when I returned from France, whither I had gone to receive the rudiments of my education, my drawings had assumed a form. David had guided my hand in tracing objects of large size." ${ }^{3}$ An interesting sidelight is thrown upon this incident by the fact that, not many years before, David had been warmly welcomed in the city of Nantes, when it is not unlikely that the naturalist's father was one of the throng of citizens who made his acquaintance. The occasion to which I refer was so noteworthy in the annals of Audubon's paternal city as to make a digression at this point of our narrative inevitable. In March, 1790, Daniel de Kervegan, a wealthy merchant who was then serving his second term as mayor, had aroused so much enthusiasm by his public spirit and sterling character that the citizens had voted the sum of 300 livres, or about $\$ 60$, for his portrait, to be executed in oils and placed in one of their public buildings. The commission was offered to David, who accepted it, and with such enthusiasm did he set to work, that upon reaching Nantes he asked the privilege of paying his respects to the Municipal Assembly, which was in session. Upon being admitted to the Chamber, on the 24th of March, he expressed these sentiments:

If ever my art has brought me any gratification, or any success, never before have I had better excuse for boastfulness.

I have made it a duty to respond to the worthy invitations, inspired by patriotism and gratitude, that hallow this most timely and most astounding revolution.

${ }^{8}$ Ornithological Biography (Bibl. No. 2), vol. i, p. viii. 
It is your work, gentlemen, and the respect which you render to the chief of your administration which speaks in praise of your sentiments and virtues and which will transmit their memory, along with your glory, to posterity. ${ }^{4}$

David worked on this portrait for about a month, and on April 23, before his departure for Paris, he asked the privilege of again addressing the Assembly. Not only was the request granted, but he was publicly thanked for the trouble he had taken in coming to their city, and a committee was appointed to express the sentiments of esteem with which he had inspired the whole community. We may add that David seems to have taken this canvas to his studio in Paris, where it was subsequently lost or destroyed in the period of turbulence that followed.

David's radical speeches from the tribune, added to his popularity as an artist, no doubt brought him pupils in plenty from every quarter of republican France. Young Audubon was probably admitted to the most elementary class, for he received no instruction in the use of oils but was directed to study the rudiments of drawing from the cast. As he had hoped to perfect himself in the art of depicting animals, he was disappointed. "Eyes and noses belonging to giants," he said, "and heads of horses, represented in ancient sculpture, were my models." He also spoke of drawing "heads and figures in different colored chalks," and of "tolerable figures" obtained by use of the manikin, but adds: "These, although fit subjects for men intent on pursuing the higher branches of the art, were immedi-

${ }^{4}$ F. T. Verger, Archives curieuses de la ville de Nantes et des départements de l'ouest (Nantes, 1837-41); for further references to David in this chapter I am mainly indebted to Georges Cain, Le Long des Rues (Paris, 1812), and Charles Saunier, Louis David (Paris, no date). 
ately laid aside by me"; yet he "returned to the woods of the New World with fresh ardor," ${ }^{5}$ and there began a series of drawings which were later published.

While this is virtually all that has been recorded of this incident in Audubon's career, a number of interesting facts might be added which throw light upon the surroundings of his life at Paris while under the tuition of this master. At that time David was enjoying the privilege, accorded to eminent artists from an early day, of living with his family and of having his studios in special quarters set apart for the purpose in the palace of the Louvre; this was continued until all the artist tenants were turned out by one of Napoleon's peremptory orders in 1806. David's principal studio was at the corner of the Quai de Louvre and the square, facing the church of St. Germain l'Auxerrois, at a point occupied in the present structure by the grand staircase leading to the Egyptian Gallery. It was here that his more advanced pupils studied; the appearance of its interior, with his pupils at work, as well as the view from one of its windows, by means of which its exact position can be determined, may be seen today in the interesting painting by Matthew Cochereau. This small picture, first exhibited in the salon of 1814, now hangs in the Louvre in company with some of the finest of David's works, and immediately beneath his huge canvas representing the coronation of Napoleon. Over his principal room David had also a private studio, and at one time he had another on the Quai, opposite the Institute of France, while his numerous pupils occupied a series of rooms, one above another, not remote

${ }^{5}$ The implication as to time, which is repeated above, contradicts an earlier statement, which is probably more nearly correct, for when Audubon returned to America in 1806 he was twenty-one. 
from the first. Access to these apartments was gained from the street by means of a spiral stairway, the opening of which may still be seen in the Egyptian Hall.

It is common to speak of this gifted man as if he alone had stifled all the art of the eighteenth century in France, as if he were the molder of his age and not a part of it. Too often has he been judged on the basis of a few, unfortunately conspicuous, theatrical pieces, while his excellent portraits, of which there are many, entitle him to the gratitude of posterity. Buchanan remarked that the mannerism of David could "still be traced in certain pedantries discernible in Audubon's style of drawing," which is a fancy without any basis in fact. If it could be shown that drawing from the casts of antique statues could develop mannerisms in the careful delineation of birds and mammals, it would still appear that Audubon's style was really formed at a later period.

This brief Paris episode, which at most could have lasted but a few months, represented all the formal instruction which Audubon ever received in drawing, although he enjoyed some private tuition at a much later day. As to the sciences now embraced in biology, that is, zoölogy and botany, which would have been most useful to him, the score was blank; even books on any of these subjects were rare in America at the beginning of the nineteenth century.

When Audubon first came to the United States, he brought with him all his drawings of French birds, and a few pieces which may belong to this early period have been described. ${ }^{6}$ Done in a combination of crayon and water color, they represent a European Magpie, a Coot

${ }^{6}$ See R. W. Shufeldt, in The $A u k$ and the Audubonian Magazine (Bibliography, Nos. 184 and 190). 
and a Green Woodpecker, the latter especially, which bore the number " 96 ," showing evidence of care and skill. The year passed at "Mill Grove" was not particularly fruitful, but during the Couëron visit which followed in 1805 and 1806, Audubon said that he made drawings of "about two hundred species of birds," all of which he brought to America and gave to his Lucy. After finally reaching this country in the latter year, these studies were continued, with an alacrity that seldom failed, until 1822, when he began to revise much of his earlier work, substituting water colors more completely for pastels, pencil and crayon point.

In writing to Bachman in 1836, Audubon thus referred to the work of his apprenticeship: 'Some of my early drawings of European birds are still in our possession, but many have been given away, and the greatest number were destroyed, not by the rats that gnawed my collection of the 'Birds of America,' but by the great fire." 7 When the naturalist was in Philadelphia in 1824, in search of a publisher and sadly in need of funds, he made the acquaintance of Edward Harris, ${ }^{8}$ who looked at the drawings he had for sale and said at once that he would take them all and at Audubon's own prices. Upon his leaving that city, this generous friend, we are told, pressed a $\$ 100$ bill in his hand, saying: "Mr. Audubon, accept this from me; men like you ought not to want for money." "I could only express my gratitude," continues the naturalist, "by insisting on his receiving the drawings of all my French birds." The worthy Harris cherished this large series of Audubon's early studies and added to it many specimens of his later work. The entire collection re-

'Referring to the fire of 1835, in New York.

${ }^{8}$ See Chapter XXI. 
mained in his family unbroken and unimpaired until 1892. ${ }^{9}$

This beautiful and unique collection, which represents The Birds of America in the bud, illustrates the development of Audubon's art from about 1800 or a little later to $1821,{ }^{10}$ and clearly shows that the fuller mastery which he attained after the latter date was manifested in no small degree at a much earlier period. His drawings of the Wood Thrush (1806), the Whippoorwill and Kingfisher (1810), the Carolina Parrot (1811), and the Nighthawk (1812), though detached and less ambitious as pictures, for truth of line and delicacy of finish would compare favorably with the best of his later work. After 1820 his ability had so far outstripped his ambition that there was needed only the stimulus of a powerful motive and a well defined plan to bring his powers into full fruition at once. A little later, when he began to revise, enrich and standardize all of his previous work, he used the brush and water colors more freely than ever before. Hundreds of his earlier studies were cast aside; many, to be sure, were

${ }^{9}$ When it passed into the equally worthy hands of Mr. Joseph $\mathbf{Y}$. Jeanes, of Philadelphia. Mr. Jeanes purchased from the estate of Mr. Edward Harris, 2d, directly or indirectly, and at different times, about 110 of these early originals; others were dispersed, four of early date being in the Museum of Harvard University. Mr. Jeanes also possesses a large section of the Audubon-Harris correspondence, which extended over nearly a quarter of a century, and of which little has been published; to his kindness I am indebted for the privilege of reproducing some of the drawings, as well as numerous extracts from the letters, in the present work.

${ }^{10}$ Audubon said that some of the originals of The Birds of America were "made as long ago as 1805," which may well have been the case, but the earliest date which has been preserved on the drawings is that of July 1, 1808, for "Rathbone's Warbler," later recognized as an immature form of the Summer Warbler. The Carbonated Warbler was drawn May 7, 1811. Seven bear the date of 1812, namely: Yellow-rumped Warbler, April 22; Le petit Caporal, April 23; Wood Pewee, April 28; Blackburnian and Bay-breasted Warblers, May 12; Chestnut-sided Warbler, May 17; and Cuvier's Wren, June 8. 
hastily drawn in pastel, crayon and pencil, and had not time failed him at the end, nothing of his earlier American period would have remained in the final product.

Nearly all of these rejected drawings bear serial numbers, which from the lack of sequence now observed, show that they were subject to constant change and that their total number must have been great. All bear the scientific and common names in French or English or both, and many are signed with the artist's initials or name; besides giving the place and date, in some cases the weights and measurements of his subjects are added, with detailed sketches of foot, bill, or eggs. ${ }^{11}$

A large crayon sketch of a groundhog, in excellent drawing, is labeled "Marmotte de sauvage, No. 159, le 6 juin, 1805." The Redstart, executed in August of the same year, is a good example of Audubon's more delicate early work; it shows also the attention which he was then beginning to pay to accessories, his bird being perched on a spray of ripening blackberries. The Wagtail, on the other hand, was a rough crayon sketch, dashed off on December 22 of the same year. A pencil and crayon drawing of the Mountain Titmouse, which is a European bird, was probably made from a captive, and at sea, since it bears the date of January 22, 1805, when Audubon was, I believe, aboard the Hope. ${ }^{12}$ The latest of these French pieces, designated "No. 94. Woodpecker, le 8 mars, 1806. près Nantes; 12 to the tail," was executed about a month before the naturalist finally left France with Rozier to settle permanently in the United States. The excellence of such

${ }^{11}$ For a list of Audubon's early dated drawings see Appendix II. Through the courtesy of $\mathrm{Mr}$. Jeanes, I am able to reproduce a fuller series of Audubon's early drawings of French and American birds than has hitherto been published, and have chosen the subjects to illustrate the development of his style.

${ }^{12}$ See Vol. I, p. 125. 
a drawing as that of the Wood Thrush (1806) is in marked contrast to the more ambitious "Fish Hawk or Osprey, A. Willson, Perkioming Creek, 1809," in which the bird holds a white sucker in its talons but is less happily rendered. Nine large pastels of waterfowl and two smaller pieces, representing a Robin and Brown Thrush, in the same style, are good examples of Audubon's cruder efforts of that time; they were merely hurried sketches or practice work, with no attempt to finish with all the perfection of detail of which he was then capable.

In a full-size pastel of the Black Surf or Velvet Duck, drawn on December 28, 1806, and signed "J. J. L. Audubon," the note is added: "the only specimen of the kind I have ever seen." He became well acquainted with the Velvet Ducks, now better known as the Whitewinged Scoters, and in his account of the species says: "As we approached the shores of Labrador, we found the waters covered with dense flocks of these birds, and yet they continued to arrive there from the St. Lawrence for several days in succession. We were all astonished at their numbers which were such that we could not help imagining that all the Velvet Ducks in the world were passing before us." 13

Several of these drawings are credited to "The Falls of the Ohio," as the rapids of this river at Louisville were then generally called; a number to "Red Banks," the old name of Henderson, Kentucky; while five were done in Pennsylvania, probably when Audubon was at the home of his father-in-law, William Bakewell, in the spring of 1812. An excellent drawing of the Chuck Wills Widow was probably made on the Red River, ${ }^{14}$ in

${ }^{13}$ Ornithological Biography (Bibl. No. 2), vol, i, p. 354.

${ }^{14}$ See Appundix II. 


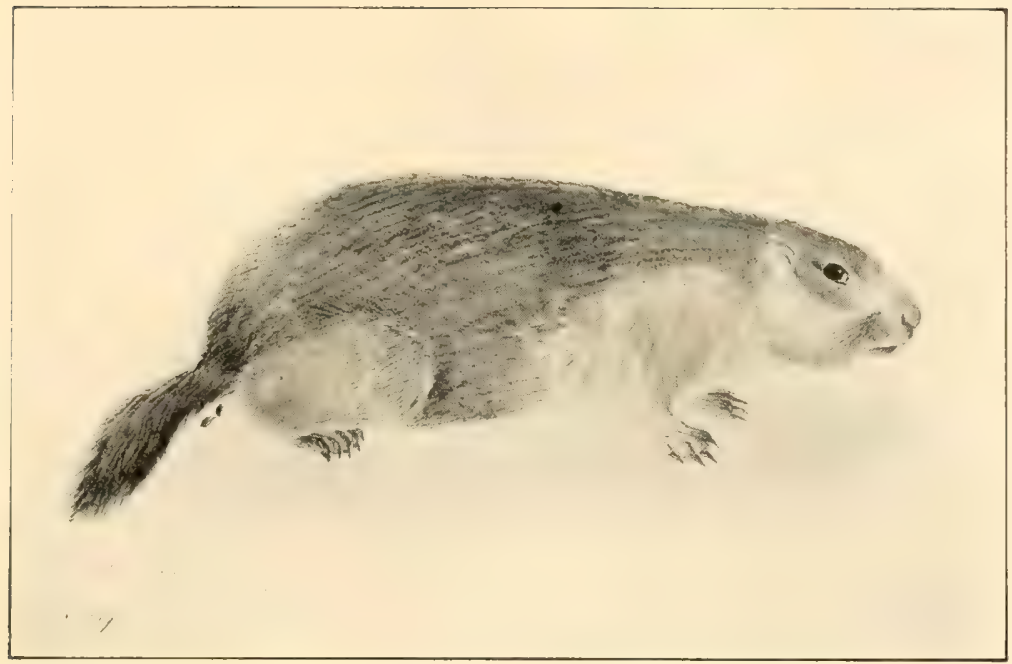

EARLY UNPUBLISHED DRAWING OF THE GROUNDHOG: "MARMOTTE DE SAYAGE, IE 6 JUIN, 1805, o. 159."

Published by courtesy of Mr. Joseph Y. Jeanes.

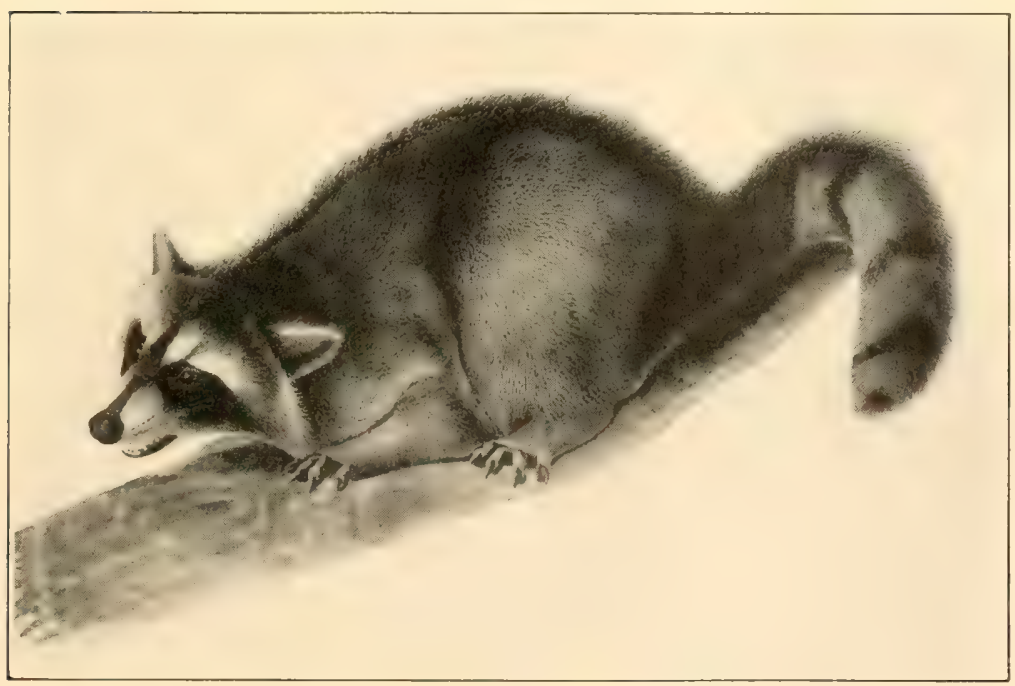

WATER-COLOR DRAWING OF A "YOUNG RACOON OF THIS YEAR, SEPTEMIBE 10, 1841."

Puhlished by courtesy of the American Museum of Natural History, New York. 

Arkansas, when Audubon was exploring that country and slowly making his way to New Orleans in June, 1821, though it should be noticed that a steamboat on which he sometimes traveled was called the Red River.

Audubon began in the usual way, by representing his birds in profile, and often on a simple perch, but gradually introduced accessories which eventually became such an important part of his plan that, after 1822, his plates took on more the character of balanced pictures, literally teeming with the characteristic fruits and flowers of America, as well as with insects and animals of every sort, suggestive of the food and surroundings of his subjects, not to speak of American landscapes drawn from many parts of the country.

Dissatisfied with the older methods of drawing birds in the stereotyped attitudes of most stuffed specimens, Audubon made many experiments at "Mill Grove" before hitting upon what he called his "method" of using wires to pierce and hold the body of the bird in any attitude which he desired to represent. His device, which was simple only for one who possessed the requisite knowledge and skill, was publicly exhibited at a meeting of the Wernerian Society at Edinburgh on December 16, 1826. A recently killed bird was fixed in the position desired by means of wires, and placed against a background ruled with division lines in squares to correspond with similar lines on Audubon's paper. The parts, measured if necessary with compasses, were then drawn in, and every part was rendered in due proportion. As to the difficulty of thus securing natural attitudes, aside from any question of draughtsmanship, we have only to recall the bungling work of most taxidermists; there are careful students of animal life who are able to reanimate their subjects, even when reduced 
to dried and mounted skins, but such ability is not easy to acquire or impart. Method is always subordinate to power, and Audubon at his best, when not hampered by lack of time, was able to represent the living, moving bird in a hundred attitudes never attempted before, which surprised the world of his day by the remarkable skill, freshness and fidelity they displayed.

Some have complained that Audubon, in striving for effect, too often exaggerated the action of his subjects; his birds, like the Frenchman he was, gesticulate too much, while Wilson's were more cautious or sedate, as became a canny Scot. The complaint may be well founded, but the explanation is too trivial for serious consideration. Wilson, like his predecessors, regardless of nationality, merely followed custom, which led by the path of least resistance. Barraband and all the best French artists before him in depicting bird and animal life had done the same, and in their hands the perch, were the subject a bird, became stereotyped to the last degree, as if inserted with a rubber stamp. Audubon followed the same course until he became imbued with the desire of endowing his animals with all the moving energy of which they were capable, whether in seizing their prey, feeding their young, or fighting their enemies. It is well known that many an animal, though ordinarily cautious or even timid, can be roused to vigorous action under the spur of emotion, as when its young are suddenly threatened, and be it warbler, bluebird, or cuckoo, may become a contortionist at a moment's notice. Very few of the 1,065 life-size drawings of birds which appear in his large plates could be truly described as fantastic or unnatural.

Audubon's problem was rendered more difficult by the fact that all of his animals were drawn to the size 
of life, and because his desire and style compelled him to represent the utmost detail, even to the barbs of a feather or the individual hairs of a mammal. When a landscape was to be included it was not an easy task to harmonize life-sized objects in the foreground with receding objects, and here he sometimes failed. Some of his least happy compositions, however, were the result of haste, as an examination of the originals of his Birds of America has clearly shown; when hard pressed for time he would resort to the scissors and paste, in order to combine the parts of several distinct drawings into one plate, and often leave the backgrounds to be supplied entirely by the engraver. One of the few grotesque results of such methods is seen in plate 141, wherein are represented the Goshawk and the Stanley Hawk; the latter, which was originally designed for different surroundings, has quite lost its center of gravity on an islet amid stream. An early reviewer thought that the artist must surely have intended this for a caricature, as in the case of one of Hogarth's famous prints, in which a man on a distant hill is lighting his pipe at a candle held out of a window in the foreground.

The action of Audubon's subjects was sometimes exaggerated; his birds on the wing were occasionally ill drawn, and other defects might be meritioned. But we must admire his boldness for attempting so many difficult positions, and admit that, when all is considered, he succeeded to admiration, and set a new standard for the illustration of works on natural history. 


\section{CHAPTER XIII}

\section{AUDUBON'S MARRIAGE AND SETTLEMENT IN THE WEST}

Audubon and Rozier decide to start a pioneer store at Louisville, Kentucky-Their purchase of goods in New York-"Westward Ho" with Rozier-Rozier's diary of the journey-An unfortunate investment in indigo-Effect of the Embargo Act-Marriage to Lucy BakewellReturn to Louisville-Life on the Ohio-Depression of tradeWilliam Bakewell's assistance-Audubon's eldest son born at the "Indian Queen"-The Bakewells-Life at Louisville.

In the summer of 1807 Audubon and Rozier had decided to try their fortunes in the West, which then meant the Ohio Valley and the wilds of Kentucky, and had fixed upon Louisville as a promising point for pioneer trade. On August 1 they purchased a considerable stock of goods through the commission house of their friend, Benjamin Bakewell, and three days later gave their note, payable in eight months, for over $\$ 3,600{ }^{1} \quad$ Then, or a little later, they had dealings also with Messrs. Robert Kinder \& Company, of New York, as well as the French importing house of Laurence Huron, with which Ferdinand had been recently associated in Philadelphia; apparently also they sent goods to François Rozier at Nantes, and from him received imports through the Bakewell firm, but, as we shall see, all foreign trade was soon cut off. When their plans were complete and their goods had started for the frontier, they set out themselves for Louisville on the last day of August, 1807.

${ }^{1}$ See Appendix I, Document No. 11. 


\section{Ferdinand Rozier kept a record ${ }^{2}$ of this journey,} the formidable nature of which will be best appreciated by reading his matter-of-fact narrative composed from notes daily jotted down. In these easy-going times, when oceans and continents are crossed with ever increasing ease and speed, this simple chronicle of early travel in America is worth preserving, if only for its historical contrasts.

On the thirty-first day of August, 180\%, in company with Audubon, I left Mill Grove for Louisville, Kentucky, where we anticipated engaging in the mercantile business.

Leaving Philadelphia by stage we traveled to Lancaster, Pennsylvania, a distance of sixty-one miles, where we arrived at four o'clock in the afternoon; we dined, and proceeded to Big Chickers, distant nine miles farther, where we spent the night. The roads from Philadelphia to Lancaster were in excellent condition, and at about every two miles we found good taverns. The only remarkable thing we noticed in agriculture was hemp, there being little else of interest. The city of Lancaster was attractive, but the short duration of our stay prevented us from having more than a casual view of it. The tavern where we slept was not very good; from our chambers,

${ }^{2}$ This diary was first brought to my attention by Mr. Ruthven Deane, and for permission to reproduce it I am indebted to the kindness of a great-grandson of Ferdinand, Mr. Welton A. Rozier, of Saint Louis. Mr. Rozier writes that the original French notes have been mislaid or lost, but that they were closely followed in this translation, whenever complete. Though numerous verbal changes have been made in the present draft, these have not altered the meaning in any respect. Ferdinand Rozier's narrative begins as follows:

"I left Nantes, France, in company with John James Audubon, on Saturday, the 12th day of April, 1806, bound for the city of New York, U. S. A., on an American ship named the Polly, commanded by Captain Sammis, and arrived at New York on Tuesday, the 27th day of May. While on the voyage across the ocean our vessel was stopped, overhauled, searched, and robbed by an English privateer, named the Rattlesnake, which detained us a day and a night.

"We remained in New York City for a few days, and then removed to Mill Grove, on Pickering [Perkioming] Creek, in Pennsylvania, a tract of land owned by our fathers, and at that time thought to contain valuable minerals." 


\section{8}

however, we could discern a new bridge, which had two immense arches spanning the river.

At eight o'clock in the morning we left Lancaster for Elizabethtown, distant nine miles. The roads were miserable, and we suffered a severe jolting and shaking up. Arriving there, we procured two additional horses, which made six all told, and went on to Middletown, where we breakfasted at a tavern named the "Eagle"; the village was small, with few houses, and nothing of interest.

Journeying on to Harrisburg without mishap, over roads somewhat improved, we finally arrived, and discovered a very beautiful river called the Susquehanna. The city of Harrisburg itself appeared very attractive to us, and its situation is beautiful; proceeding, we were first compelled to cross the river, which was accomplished by means of a large flatboat propelled by a sweep of generous proportions. The captain, who proved a most voluble person, informed us that the river abounded in fish, and then related marvelous tales of the remarkable catches that had been made; many of his stories, however, were of such glaring improbability that we were forced to doubt his veracity.

Carlisle, sixteen miles distant, was reached in due course, and there we changed horses at a tavern called the "John Mason." This city, though small, presented a fine appearance, having a market place, two large churches, many brick buildings, a large academy, and several attractive taverns. Continuing, we finally came to Walnut Bottoms, where we engaged chambers at a very imposing tavern; this proved far superior to any we had hitherto visited; it was clean and inviting; its appointments were good, and its service excellent. On our journey we were impressed by a tree of great size, that resembled an oak, but upon inquiry learned that it was called Hackberry, ${ }^{3}$ and produced a fruit similar in size to a cherry. On the north and south of us were high mountains which pre-

${ }^{3}$ In the rich bottom-lands of the Ohio River basin the hackberry or sugarberry (Celtis occidentalis) sometimes exceeds one hundred feet in height, and has a diameter of from four to five feet. 
sented an imposing appearance; the foliage was heavy and luxuriant; the soil of the foot-hills appeared fertile, but the crops were inferior.

We were awakened early in the morning so as to begin our journey in good season, and having had a heavy storm during the night we expected to find the roads very bad, but to our delight they were none the worse for the rain. Journeying most of the way through woods, we came to Shipensburg and breakfasted; this village had only one long street, and presented an appearance far from pleasing. A lady with her sock [knitting work] proved a great talker and asked us many questions. This village was intersected by a creek, called the Middlespring. We next came to Chambersburg, ten miles away, and there rested and purchased tickets for continuing our journey. That village lies in a valley, and is composed of two squares containing a post office, an academy, a factory, market place and tavern.

When the stage was at last made ready for its journey we took our places in it, but no sooner was the village left behind than we encountered very rough roads, which for a time caused great discomfort; our feelings were expressed by all the passengers, but at length we reached a tavern named "Cable Roussed," where our horses were changed. We next stopped at the "John Campbell" tavern, and saw many drunkards about; then at "Peter White's," almost at the foot of the mountains, where we were each treated to a glass of excellent fresh milk. Still going on and approaching the mountains, the roads became so excessively rough that Audubon and myself decided to proceed on foot. Though this was a three-mile climb, we managed to cover it in three and a half hours. So bad in truth was the road that it seemed well nigh impossible for any vehicle to ascend the mountain; the stage did go up, however, and reached the summit soon after us. On the heights of the mountain was a small tavern where refreshments were served, and while partaking of a light lunch there we were waited on by a couple named Currie, and James, their hired man. While we were refreshing ourselves, our host told harrowing tales of 
wild-animal hunting in the mountains, and assured us that there were many beasts in the surrounding woods. Leaving the summit in the stage, we continued for some distance, but the jolting, rolling and swaying was so frightful that we decided to descend on foot. The three miles down the mountain was covered quickly, but we were utterly worn out with fatigue when we reached McConnelsburg; this village lies in a valley, has few houses and but little of interest; we made forty miles during the day. Leaving early on the next morning, after traveling thirty-two miles, over better roads, we spent the night at the tavern of B. Mastin.

Having breakfasted at an early hour, we were again on our way by sunrise, and after driving two miles came to the Juniata River, which was crossed in a leaky flatboat. Eight miles beyond this point we saw a very fine and stately mansion which was said to belong to a Mrs. Haily. Finally after a hard and tiresome day we arrived at Bedford. The Juniata River flows along Bedford in a narrow bed, between high mountain walls; the village is situated in the valley, and boasts many fine stores and residences. We were told that about fourteen miles farther on there were mineral springs, the waters of which possessed great curative properties, and that many people visited them each season; time, however, did not permit us to visit this resort.

Six horses were hitched to our stage when we departed the next morning. The mountain roads ascended more gradually, and were less rough; the weather being exceptionally fine, forty miles were easily made before reaching our destination at a village called Somerset, which contained a courthouse that marked it at once as the county seat. At four o'clock of the morning following we were again on our way, and left Somerset in a heavy fog, which at that early hour sharply accentuated the chill in the air. At the end of the day we found ourselves at Laurel Hill, where we passed the night at the tavern of John Arranats.

Again at four in the morning we resumed our journey, and after crossing Laurel Creek once more encountered rough 
roads, but soon reached a tavern called the "Jacob Hoff," where we breakfasted. Still pushing forward, at noon we came to the small house of a family called Margennefs, and procured a meager lunch. At a short distance from this place a change of horses was made, and after driving all the afternoon we entered the attractive village of Greensburg, where we spent the night. Rising reluctantly at peep of day, we continued on our course and made ten miles before breakfasting at a tavern, the "Stewart Auberge" by name. After leaving this point we came to Turtle Creek, when the road descended so abruptly that it was decided to dismount and walk, but the heat was sultry and oppressive, and we suffered greatly. At last, however, the city of Pittsburgh was reached, and there we found good and commodious lodgings at the Jefferson Hotel, conducted by Mr. Galland, a most genial and agreeable host. We remained in Pittsburgh several days, and became acquainted with many of its citizens, among whom were several countrymen of ours who were engaged in business and were very congenial and hospitable. The city does not present a pleasing appearance; it has been increasing in size with astounding rapidity, ${ }^{4}$ and possesses a remarkable commerce; the Ohio River there is most beautiful.

The remainder of our journey was by way of the Ohio, and we made it entirely in an open flatboat, a cumbersome unwieldy craft, managed by hand, and in this particular instance very badly. One who has never had this experience can little understand the terrible monotony, hardships and deprivations encountered on a long journey such as we endured. We were unprotected from the elements, and our beds consisted of bare pine boards, upon which we slept as best we could, enveloped in our great coats.

There were times without number when our boat would run upon hidden sand bars to become grounded, and we were then often obliged to get into the cold water and assist in the work of extricating her. At other times, unprotected as we

${ }^{4}$ The population of the second city of Pennsylvania in 1800 was 1,565 ; in 1840, 4,768; and in 1910, after the annexation of Allegheny, 533,905. 
were, the rains drenched us to the skin, and our clothing was so saturated that it took many hours to dry. At night when it was clear, we continued our course down the river, but, in bad weather, or when very cloudy and dark, we were obliged to tie up to the shore, frequently to the bank of some wild, uninhabited island, and wait there for daylight; then we would resume our slow, tedious and seemingly never ending journey. Added to these hardships, our boat was commanded by a most disagreeable and ungentlemanly captain, named Harris; his language, and demeanor marked him as a person of low birth and bad character.

Among some of the places which were passed en route, I remember the following: Wheeling, Marietta, Market Slough, famous for the conspiracy of Colonel Burr, Belleville, Litards Falls, Point Pleasant, Manchester, Maysville, Cincinnati, and finally our journey's end, Louisville.

At Louisville the partners were attracted by the country and its prospects, as well as by the hospitable character of the people. Their choice, as they then thought, had been well made, and they decided to make it their future home. "We marked Louisville," said Audubon, "as a spot designed by nature to become a place of great importance, and had we been as wise as we now are, I might never have published The Birds of America; for a few hundred dollars laid out, at that period, in lands or town lots near Louisville, would, if left to grow over with grass to a date ten years past [this being 1835], have become an immense fortune, but young heads are on young shoulders; it was not to be, and who cares." 5

Rozier did not say when either they or their goods reached the pioneer settlement, but from an item in

${ }^{5}$ Maria R. Audubon, Audubon and his Journals (Bibl. No. 86), vol. i, p. 28. 
their account current with the Bakewell house, ${ }^{6}$ it is evident that they opened a retail shop in Louisville at once, for on September 29 they were charged with $\$ 57$ for an order of powder horns and shotbags. In the same record there is a more interesting entry under date of December 31, 1807: "advanced per [sailing packet] Jane, for indigo and expences . . \$1,516.43," ordered evidently through Mr. Bakewell, presumably for export to France. This incident Audubon must have had in mind when in after life he wrote: "The mercantile business did not suit me. The very first venture which I undertook was in indigo; it cost me several hundred pounds, the whole of which was lost." It may be recalled that in his letter of April 24 of this year, Audubon wrote François Rozier ${ }^{7}$ that the Bakewell house had sent him a consignment of indigo by the same ship, Captain Sammis, and hoped for its favorable sale in France. No doubt the venture succeeded so well that the young traders were induced to repeat the experiment. As it happened, however, on December 22, a week before this entry for the indigo was made, the famous Embargo Act of President Jefferson had taken effect, with the result of cutting off all exports to England and France and at the same time of paralyzing American trade. The Bakewell house, as we have already noticed, like so many others, immediately went down, and the partners found that their tobacco and other western produce found so little sale in New York that by April 7, 1808, they were obliged to call for an extension of their notes.

Notwithstanding the gloomy outlook for trade, Audubon had no fears for the future. As early as

${ }^{6}$ See Appendix I, Document No. 11.

${ }^{7}$ See Chapter XI, page 158. 
March, 1808, he left Rozier in Kentucky and returned to Pennsylvania. No time was lost in making known his plans to Lucy Bakewell and her family, and having received their approval, the lovers prepared for the adventurous journey that was to celebrate their wedding. Audubon was married to Miss Bakewell, at "Fatland Ford," on Tuesday, April 5, 1808, by the Reverend Doctor Latimer, an Episcopal clergyman of Philadelphia, and on the next morning started with his bride for the frontier. This event must be regarded as the most auspicious in his career, for in all probability the world would never have heard of Audubon had it not been for the spur to his ambition and the balance wheel to his character which came through his admirable wife.

The first stage of their honeymoon involved the long ride of over 250 miles to Pittsburgh, the hazards and discomforts of which we have learned from Rozier's description; it was marked in this instance by an accident, for in crossing the Alleghany mountains their coach was upset and Mrs. Audubon did not escape without severe bruises. At Pittsburgh the Audubons met a number of young emigrants bound westward like themselves, and in their company they prepared to float down the beautiful Ohio in a flatboat or ark. Their entire journey, which, owing to the windings of the river, could not have been much less than a thousand miles, was made in twelve days, and without further mishap.

The wild and varied beauty of the Ohio of that day had great attractions for the naturalist, who often regretted that no facile writer had left a true and vivid picture of it for the benefit of posterity, for he foresaw with great concern the inevitable changes which advancing civilization would quickly produce along its delightful banks. Audubon traversed this mighty highway 
countless times in after life, and some of his musings have lost none of their interest with the flight of time, for he had witnessed the advance of the white man and the retreat of the red, along with the great herds of deer, elk and buffalo that once found peaceful pasturage on its banks. Speaking of a later but hardly less romantic journey, ${ }^{8}$ he said:

As night came, sinking into darkness the broader portions of the river, our minds became affected by strong emotions, and wandered far beyond the present moments. The tinkling of bells told us that the cattle which bore them were gently roving from valley to valley in search of food, or returning to their distant homes. The hooting of the Great Owl, or the muffled noise of its wings as it sailed smoothly over the stream, were matters of interest to us; so was the sound of the boatman's horn, as it came winding more and more softly from afar. When daylight returned, many songsters burst forth with echoing notes, more and more mellow to the listening ear. Here and there the lonely cabin of a squatter struck the eye, giving note of commencing civilization. The crossing of the stream by a deer foretold how soon the hills would be covered by snow.

Many sluggish flatboats we overtook and passed; some laden with produce from the different head-waters of the small rivers that pour their tributary streams into the Ohio; others, of less dimensions, crowded with emigrants from distant parts, in search of a new home.

The margins of the shores and of the river were at this season amply supplied with game. A Wild Turkey, a Grouse, or a Blue-winged Teal, could be procured in a few moments; and we fared well, for, whenever we pleased, we landed, struck up a fire and provided, as we were, with the necessary utensils, procured a good repast.

${ }^{8}$ When Audubon was returning with his wife and infant son from Pennsylvania to Kentucky in the autumn of 1810; see "The Ohio," Ornithological Biography (Bibl. No. 2), vol. i, p. 29. 
Louisville at this time was a small trading and agricultural center of barely a thousand people. ${ }^{9} \quad$ Though the early promises of business there were not fulfilled, Audubon and his wife at once entered upon a happy period, for they made many friends in a new country settled by whole-hearted, well-to-do planters; the men were fond of good horses and of hunting, and the naturalist, who was also a merchant, was welcomed among them as a kindred spirit. But, said Audubon, "birds were birds then as now, and my thoughts were ever and anon turning towards them as the objects of my greatest delight. I shot, I drew, I looked on nature only; my days were happy beyond human conception, and beyond that I really cared not. . . . I seldom passed a day without drawing a bird, or noting something respecting its habits, Rozier meantime attending the counter."

To revert again to the business affairs of the Audubon-Rozier firm at Louisville, an interesting record has been preserved in a letter ${ }^{10}$ written by Thomas Bakewell, a former fellow-clerk of the naturalist in the senior Bakewell's counting-house in New York; this was included with the statement of account, referred to above.

\section{Thomas Baliervell to Audubon \& Rozier}

[At bottom of account sheet] NEW York, Decemr. 13th. 1808

Mess's. J. Audubon \& F. Rozier

Louisville Gent $^{N}$.

I have now the pleasure to hand you your account current with my Father's Estate according to your desire as expressed

${ }^{9}$ In 1800 the population of Louisville was 600 , and in 1810 it had risen to 1,350; see Charles Cist, Cincinnati in 18.41 (Cincinnati, 1841).

${ }^{10}$ For this and the ietter of Thomas Bakewell's uncle, William Bakewell, which follows later, I am indebted to Mr. Tom J. Rozier; see Note, Vol. I, p. 133, and for accompanying "Account Current" of Audubon \& Rozier, Appendix I, Document No. 11. 
in your letter to Mess Robt. Kinder \& $\mathrm{C}^{0}$. under date the $21^{\text {st. }}$.

of Novr. last. I cannot tell what error you allude to of 93 . I suppose it is the amount of commission returned $\$ 93.94 / 100$ which you will perceive is duly at your $\mathrm{C}^{\mathrm{r}}$. in the a/c. I am sorry to say that the tobacco is still unsold \& that there is no prospect of selling it so as to cover the balance of your a/c Mess $^{\mathrm{rs}} \mathbf{R}$. Kinder \& $\mathrm{C}^{\mathrm{o}}$. request me to say that they wish the yarn mentioned in their letter of the [word omitted] to be made of water rotted Hemp \& that they will write you $\mathrm{p}^{\mathrm{r}}$ next post with their account against you as requested by you-

I remain Gent ${ }^{\text {n }}$

with Your $\mathrm{m}^{\mathrm{o}}$. ob $\mathrm{b}^{\mathrm{t}}$. Servt.

Tho . BaKewell

for the assignees of my

Father's estate-

Give my love to $\mathbf{M}^{\mathrm{rs}}$. A. my aunt a rec ${ }^{\mathrm{d}}$. hers last nightS. \& is much as usual-she remains very sick yet.

T B

[Superscribed] Mess"rs. Audubon \& Rozier

Merchants

Louisville

Kentucky

Audubon fraternized with the sporting men of his district, who gladly sent him every rare bird that fell to their guns. At Shippingport also, then an independent center below the falls or rapids, he found a sympathetic spirit in Doctor W. C. Galt, a local botanist, as well as in Nicholas Berthoud, who had become his wife's brother-in-law, and who was a friend on whom he could always rely. The spirit of hospitality so manifest in all these new friends won the heart of Audubon and of his attractive wife, to whom the door of a neighbor's house was sure to open whenever business or adventure 
called her husband away. "We lived," said Audubon, "two years at Louisville, where we enjoyed many of the best pleasures which this life can afford; and whenever we have since passed that way, we have found the kindness of our former friends unimpaired." It was while they were living at Gnathway's hotel of the "Indian Queen," in Louisville, that Victor Gifford Audubon, who was destined to become his father's right hand in the publication of his most important works, was born on June 12, 1809.

When Audubon had reached his twenty-fourth year, nature, his fond nurse from infancy, was calling to him more loudly than ever before, but to most of his contemporaries his devotion to natural history could have seemed little else than sheer madness, or, at best, an utter waste of time. By the year 1810 his portfolios were swelling with upwards of two hundred pictures of American birds, produced, to be sure, without any plan, and far inferior to the best of his later work, but still done to the size of life, in the natural colors, and far excelling in fidelity and charm anything that had been attempted before. At this time, however, the young traders needed money for more practical affairs, and Audubon's father-in-law, William Bakewell of "Fatland Ford," consented to sell a portion of this estate, amounting to 170 acres, in order that his daughter, Lucy, might immediately realize her interest in it. From this sale nearly $\$ 8,000$ was obtained; the money was deposited with Messrs. Robert Kinder \& Company of New York, a firm with which Audubon and Rozier had dealt from the opening of their business at Louisville. This is clearly shown by the following interesting letter: ${ }^{11}$

${ }^{11}$ See Note, Vol. I, p. 196. 


\section{William Bakerell to Audubon \& Rozier}

\section{Mess Audubon \& Rozier}

Fathand Ford $10 A p^{l} 1810$

\section{Gent $^{N}$}

I have at last settled the whole business with $\mathbf{M}^{\mathrm{r}} \mathrm{Jos}^{\mathrm{h}}$ Williams I have allowed him for the two thirds in cash 3 per cent \& have remitted to Messrs Kinder's 7838.50 on your account.-The quantity was surveyed to 170 acres at 47.5 per acre 7998.50, from which was deducted $160 \mathrm{dol}^{\mathrm{s}}$ for discount

As I have had a great deal of trouble \& anxiety in this business \& had to find assistants in surveying with several days attendance, dinners \&c for the whole party several journeys to Norris Town and also to Philad ${ }^{\text {a }}$ with the carriage to convey the money-postages \&c.-I charge you $11 / 2$ per cent on the purchase money which I hope you will think not unreasonable as I believe it is under the charge of the land brokers in Philad ${ }^{\text {a }}$ $\&$ they have no trouble in the business compared to what I have had-I feel as if a great burthen was taken off my back now it is all finished. Out of this you will please to present Lucy with $38 \mathrm{dol}^{\mathrm{s}}$ which was the price the mare sold for-I expected one of you Gent ${ }^{n}$ would have come to the Eastward before now it is $I$ expect $\mathbf{M}^{\mathrm{r}}$ Roziers turn this Spring

I had one forged note returned at the Bank out of the money of $\mathbf{M}^{\mathrm{r}}$ Williams \& one dollar a counterfiet, but I had stipulated that he should take any faulty ones back. He paid about a third of the money in specie so that I was obliged to take the carriage with it. I took it to the Pennsylvania Bank $\&$ got an order on the Manhattan Bank in $\mathbf{N}$ York \& have $\mathbf{M}^{\mathrm{r}}$ Kinder's receipt for the order

They have got a considerable quantity of ore out of the mine ${ }^{12}$ some lead \& some copper but $I$ do not hear of any being yet sold

${ }^{12}$ The lead mine at "Mill Grove," which with the remaining Audubon and Rozier interests in the farm had been taken over by Dacosta's company in September, 1806. The failure of Dacosta followed in about a year after the date of this letter. 
Present the kind regards of our family circle to my daughter, $\mathrm{M}^{\mathrm{r}}$ Audubon, \& my Grandson ${ }^{13}$ who I hope are well

I remain Gent ${ }^{n}$

Yours truly

Wm BAKEWELL

PS

$\mathrm{M}^{\mathrm{r}}$ Kinder is of opinion that there ought to be a renunciation by Lucy of any claim of dower upon this estate to make the title good this may be sent on when you are coming this way

[Addressed] Mess Audubon \& Rozier

Merch $^{\mathrm{s}}$

Louisville

Kentucky-

[Endorsed] Rec ${ }^{\text {d. May }} 5^{\text {th }} \cdot 1810$

Lucy Green Bakewell, Audubon's wife, was three years younger than her husband, having been born at Burton-on-Trent, England, in 1788. Her family were descended from John Bakewell of "Castle Donnington," in Leicestershire; Robert Bakewell, the geologist, who came to the naturalist's defense many years later, and who lived until 1843, was a nephew of her grandfather, Joseph Bakewell of Derby. Left an orphan at an early age, Lucy's father, William Bakewell, was brought up by an uncle, Thomas Woodhouse, a rich bachelor of Crith, Derbyshire, who eventually left him a fortune.

When William Bakewell succeeded to his uncle's estate and manor, he lived the life of a country gentleman, devoting himself mainly to shooting and to the study of chemistry and natural philosophy, while he enjoyed the friendship of such men as Joseph Priestley and Erasmus Darwin. His advocacy of Priestley's republican and

${ }^{13}$ Victor Gifford Audubon, who was then nine months old. 
liberal religious doctrines is said to have cost him the honorary office of justice of the peace in his community and to have determined his emigration to America. His first visit to America was made in the summer of 1798 , when, with his brother Benjamin, ${ }^{14}$ he started an establishment for brewing English ale at New Haven; through his chemical knowledge and skill he is said to have reproduced to perfection the famous Burton ales. William Bakewell brought his family to the United States in 1802, and when a disastrous fire destroyed his business at New Haven, he took up the large farm of "Fatland Ford" in 1804, as already related (p. 108). In that retired spot he devoted much time to his library and laboratory, while living a life of easy independence. If abrupt in manners and inclined to severity in discipline, he was generous, kind-hearted and an ardent republican. Mrs. Audubon's mother, who felt keenly the separation from her own people, died in September, 1804, a few months after reaching "Fatland Ford," and in the following year William Bakewell was married to Rebecca Smith. This lady seems to have taken a strong dislike to Audubon, for when her death was announced in $1821,{ }^{15}$ he referred to her as "my constant enemy ... God forgive her faults."

At this time Audubon studied nature for the pure love of it, without the faintest expectation that his labors in natural history would ever be of any service to the world. But in the year 1810 occurred an event, of seemingly small moment at the time, which nevertheless left a distinct mark upon his career, as will be now related.

\footnotetext{
is See Vol. I, p. 153.
}

${ }_{15}$ William Bakewell died at Philadelphia on March 6, of the same year, after suffering from the effects of a sunstroke, and was, eventually, buried at "Fatland Ford;" in 1822 his farm, originally of 800 acres, passed into the hands of Dr. William Wetherill. See Note, Vol. I, p. 99, and W. G. Bakewell, Bakewell-Page-Campbell (Bibl, No. 200). 


\section{CHAPTER XIV}

\section{A MEETING OF RIVALS, AND A SKETCH OF ANOTHER PIONEER}

Alexander Wilson and his American Ornithology-His canvassing tour of 1810 - His retort to a Solomon of tle Bench-Descriptions of Pittsburgh, Cincinnati and Louisvilile-Meeting with Audubon-Journey to New Orleans-Youth in Scotland-Weaver, itinerant peddler, poet and socialist-Sent to jail for libel-Emigrates to the United StatesFinally settles as a school teacher near Philadelphia-His friendships with Bartram and Lawson-Disappointments in love-Early studies of American birds-His drawings, thrift, talents and genius-Publication of his Ornithology-His travels, discouragements and success-His premature death-Conflicting accounts of the visit to Audubon given by the two naturalists-Rivalry between the friends of Wilson, dead, and those of Audubon, living-The controversy which followed-An evasive "Flycatcher"-Singular history of the Mississippi Kite plate.

On January 30, 1810, a man of rather coarse features, with a head of sandy hair, and possessed of manners that could be winning or aggressive according to his mood, might have been seen leaving Philadelphia afoot, for he had planned to keep his expenses down to a dollar a day and traveling by coach or on horseback suited neither his purse nor the objects of his mission. His clothing was coarse; his luggage, with the exception of a fowling-piece and two red-backed volumes of quarto size, was of the lightest description. But, could we have peered between the covers of those books, our curiosity would have been whetted, for they were filled with colored plates of American birds, the first-fruits of their bearer's untrained eye and hand; the text, moreover, was printed in a style which would have done honor to anv country. 
This man was Alexander Wilson, who, like Audubon, was a pioneer in the study of the birds of his adopted land, but who was twenty years his predecessor in point of publication. The books which he then carried were part of the first edition of his now famous American Ornithology, the second volume of which had appeared in Philadelphia at the beginning of that year. Though not destined to be completed until after his death, this work was to become one of the scientific and literary treasures of the nation, but it is not likely that one in ten thousand had then ever heard of him, whether as poet or as ornithologist, or cared anything about his work or his mission.

Wilson at that moment was starting on his last long journey through the West and South, in search of new birds. He also carried in his pocket a subscription list, and therefore belonged to that class of visitor which is seldom welcomed with rapture. At Lancaster, Pennsylvania, Wilson's first important stopping-place, and at that time the capital of the State, Governor Snyder put down his name for $\$ 120$, the price of the completed work. This seemed a good omen, but, at Hanover, in the same state, an incident occurred which might have discouraged a less determined man; the interview has become historical, and we shall give Wilson's own relation of it: ${ }^{1}$

Having a letter from Dr. Muhlenburgh to a Clergyman in Hanover, I passed on through a well cultivated country, chiefly inhabited by Germans, to that place, where a certain Judge Hustetter took upon himself to say, that such a book as mine ought not to be encouraged; as it was not within the reach of

${ }^{1}$ In a letter to Alexander Lawson, written from Pittsburgh, on February 22, 1810; see Elliott Coues, "Private Letters of Wilson, Ord, and Bonaparte," Penn Monthly, vol. x, pp. 443-455 (Philadelphia, 1879). 
the commonalty; and therefore inconsistent with our Republican institutions! By the same mode of reasoning, which I did not dispute, I undertook to prove him a greater culprit than myself, in erecting a large elegant three story Brick house, so much more beyond the reach of the Commonalty as he called them, and therefore grossly contrary to our Republican institutions. I harangued this Solomon of the Bench more seriously afterwards, pointing out to him the great influence of Science on a young rising Nation like ours, till he began to show such symptons of intellect, as to seem ashamed of what he had said.

\section{At Pittsburgh Wilson met Audubon's old employer} and relative by marriage, Benjamin Bakewell. The picture which he then drew ${ }^{2}$ of that growing hive of industry will be read with interest:

On arriving at the town, which stands on a low flat, and looks like a collection of Blacksmith shops, Glass houses, Breweries, Forges, and Furnaces, the Monongahela opened to the view on the left running along the bottom of a range of hills so high that the sun at this season sets to the town of Pittsburgh at a little past four. This range continues along the Ohio as far as the view reaches. The ice had just begun to give way in Monongahela, and came down in vast bodies for the three following days. It has now begun in the Alleghany, and at the moment $I$ write it is one white Mass of rushing ice. The country beyond the Ohio to the west appears a mountainous and hilly region. The Monongahela is lined with Arks, usually called Kentucky Boats, waiting for the rising of the river, \& the absence of ice, to descend. A perspective view of the town of Pittsburgh at this season, with the numerous arks and covered keel boats preparing to descend the Ohio, the grandeur of its hills, and the interesting circumstance of its three great rivers-the pillars of smoke rising from its Furnaces Glass

a See Elliott Coues, loc. cit. 
works \&c. would make a noble picture. I began a very diligent search in the place the day after my arrival for subscribers and continued it for four days. I succeeded beyond expectation having got 19 names of the most wealthy and respectable part of the inhabitants. The industry of the town is remarkable; every body you see is busy; \& as a proof of the prosperity of the place an eminent lawyer told me that there has not been one suit instituted against a mercht. of the town these three years! The Glass Houses, of which there are 3, have more demands for Glass than they are able to answer. Mr. Bakewell the proprietor of the best, shewed ... yesterday a Chandelier of his manufacture highly ornamented, ... for which he received 300 dollars. It would ornament the . . . in Philada. and is perfectly transparent.

Eight days after he had reached Pittsburgh, Wilson bravely launched a little skiff, which he christened the Ornithologist, and began an arduous and perilous journey to Cincinnati, Louisville and New Orleans, a distance of two thousand miles. "In this lonesome manner," he wrote, "with full leisure for observation and reflection, exposed to hardships all day, and hard berths all night, I persevered from the 24th of February to Sunday evening, March 17th, when I moored my skiff safely in Bear Grass Creek, at the rapids of the Ohio, after a voyage of seven hundred and twenty miles."

Cincinnati, then a town of five hundred houses, was reached on the ninth of March; while there Wilson made the acquaintance of Dr. Daniel Drake, who was later Audubon's friend, and examined a collection of Indian relics which had been taken from a freshly opened mound. He left Cincinnati convinced that its well-todo class must be a very thoughtful people, so many of them, when approached for a subscription to his work, having replied that they would "think about it." Upon 
nearing Louisville at nightfall he became alarmed lest he should be drawn into the suction of the Falls, as no lights could be seen on the banks: cautiously coasting along the shore, where he encountered many logs and sawyers, at last he entered the Creek and secured his skiff to a Kentucky boat; then, "loading myself with my baggage," he wrote, "I groped my way through a swamp up to the town."3 When Wilson had seen the Falls by daylight, he felt that his fears of the night before had been groundless, and declared that he should have no hesitation in navigating them single-handed.

It will be interesting to follow Wilson's journey a little further, before returning to the Louisville visit. After passing a few days in Audubon's town, he struck out into the heart of Kentucky, calling at Shelbyville, Frankfort and Lexington, and eventually reaching Nashville, Tennessee. Not far from the latter place he met a landlord of admirable discrimination, Isaac Walton by name, who showed himself worthy of his illustrious ancestor by declaring that Wilson was evidently traveling for the good of the world, and added: "I cannot, and will not charge you anything. Whenever you come this way, call and stay with me; you shall be welcome."

At Nashville Wilson wrote to Miss Sarah Miller, the lady to whom he was engaged but whom he did not live to marry: "Nine hundred miles distant from you sits Wilson, the hunter of birds' nests and sparrows, just preparing to enter on a wilderness of 780 miles - most of it in the territory of Indians - alone but in good spirits, and expecting to have every pocket crammed with skins of new and extraordinary birds before he reach

${ }^{3}$ Letter to Alexander Lawson, dated at Lexington, April 4, 1810; see Grosart, Poems and Literary Prose of Alexander Wilson, vol. i, p. 189. 
the City of New Orleans." Continuing on his course in search of new birds and subscribers, Wilson arrived at Natchez on May 18, and, passing through Louisiana, on the sixth day of June he entered New Orleans, where his spirits were immediately raised by the accession of sixty new names to his list. After six months of continuous effort, traveling now in a small boat, now on the back of a horse, but frequently on foot, drenched by torrents of rain or scorched by the unaccustomed heat, often compelled to drink the poisonous water of cane brakes in Mississippi (to which must be attributed an attack of malarial fever, which he was able with difficulty to throw off, but from which, in all probability, he never fully recovered), he returned to New York by sea, and on September 2, 1810, was again in Philadelphia.

On this journey Wilson was a pioneer in much of the territory which Audubon had hardly begun to explore, but which later became the scene of his wanderings and adventures for many a year. At Louisville the two naturalists met, but they did not become good friends; though devoted to the same objects, differences in temperament might in any event have kept them apart. Unfortunately, the feelings of jealousy which were then aroused, or which were stirred up at a later day, were fostered by some of Wilson's injudicious friends to such an extent that from the moment Audubon's work became known, and long before he had published a line, they became as thorns in his path, and they continued to vex him for thirty years. It is not easy to reach a fair judgment in this matter now, and it would be impossible to do so without a better understanding of the man who suddenly appeared upon Audubon's horizon at Louisville in 1810 and then vanished. 
Because of the peculiar relations which existed between these two pioneers, we must follow the history of the elder man a little more closely.

Alexander Wilson was the son of a weaver at Paisley, Scotland, where he was born in 1766 ; he was thus Audubon's senior by nineteen years. His father, who was esteemed for his honesty and intelligence, had tasted prosperity, but irremediable poverty fell to his lot in later life. Alexander, the younger son, was motherless at ten, and the stepmother that soon appeared seems to have shown him scant sympathy, or, at all events, never won his affection. Alexander Wilson's youth unhappily coincided with an era of bad feeling in his native land; the times were hard in bonny Scotland, education was stagnant, and the public morals were debased. Wilson was a child of his times; like thousands of other youths, he was bound to suffer from the conditions of his early environment, but unlike many thousands of his day, he was possessed of talents and ambition which bitter adversity tended to sharpen and could never repress.

At thirteen young Wilson was taken from school and apprenticed to a weaver, William Duncan, his brotherin-law, and for three years he was no stranger to hard work and the birchen rod. For nearly three years more, as master weaver, he knew little beyond the grind and grime of the factory and the society of factory hands. At eighteen, however, his rebellious spirit struck, and for ten years he appeared in the rôle of itinerant peddler, poet and orator, and as socialist to the extent of championing the oppressed weaver class. At one time Wilson came into correspondence with Robert Burns and later made his acquaintance. His best dialect poem, "Watty and Meg, or The Taming of a Shrew," pub- 
lished anonymously as a penny chap-book in $1 \% 82$, was his one popular success in the character of poet; according to report it was attributed to Burns, who admitted that he would have been glad to have written the verses, which sold so freely that a hundred thousand copies were disposed of in a few weeks. ${ }^{4}$ In the disputes between capital and labor which arose at Paisley, Wilson took an active part. In connection with them he published a number of lampoons in verse, for which he was convicted of libel and was compelled to burn his satires at the town cross. In one instance, which occurred in February, 1793, a petty tyrant whom he had riddled exacted the fine, ${ }^{5}$ and because of his inability to pay Wilson was sent to jail, where he languished for over three months.

Under the pressure of such persecutions, hard times, and possibly from disappointment in an affair of the heart, Wilson decided to emigrate. Practically driven out in rags from the country which one day was to raise a monument to his memory, at the age of twenty-eight he sailed from Belfast with his nephew, William Duncan, for the Eldorado of the New World. Wilson slept on deck throughout the entire voyage of fifty-three days, and landed at New Castle, Delaware, with the clothes on his back and an old fowling-piece as his only possessions. This was on July 14, 1794, nine years before John James Audubon left Nantes. Taking train "number 11," in the parlance of knights of the road, the two immigrants first walked to Wilmington in search of employment, and finding none there, went on twentynine miles farther to Philadelphia.

'See Grosart, Poems and Literary Prose of Alexander Wilson, vol. i, p. xxiv.

${ }^{5}$ For "The Shark, or Lang Mills Detected," a satire directed against William Sharp, a manufacturer of Paisley; Wilson was fined $£ 12$ 13s. $6 \mathrm{~d}$. 
The story is told that while they made their way through the woods of Delaware, Wilson shot a Red-headed Woodpecker and met with the Cardinal Grosbeak; as he often referred to the pleasure which the sight of these beautiful birds had given him, the incident, if it really occurred, may have played a part in the inspiration, which later came to Wilson, of becoming the historian of American bird life.

After eight hard years of shifting about, during which Wilson tried day-labor, weaving, peddling and school teaching, working long hours at miserable pay, he finally settled as a country school teacher near New York. On the twelf th of July, 1801, he wrote to a fellow teacher and friend, Charles Orr, who was then living at Philadelphia: "I live six miles from Newark and twelve miles from New York, in a settlement of canting, preaching, praying, and snivelling ignorant Presbyterians. They pay their minister 250 pounds for preaching twice a week, and their teacher 40 dollars a quarter for the most spirit-sinking, laborious work-6, I may say 12 times weekly." To the same friend, in 1802 , he confided: "My disposition is to love those who love me with all the warmth of enthusiasm, but to feel with the keenest sensibility the smallest appearance of neglect or contempt from those I regard."

In 1802, at the age of thirty-six, Wilson decided to take up a school at Gray's Ferry, on the Schuylkill River, in Kingsessing Township, then a small settlement four miles from Philadelphia. A year later, in 1803, John James Audubon was sent to America to learn English and enter trade, and, as chance would have it, settled on the banks of the same river, not many miles from Wilson's old schoolhouse. In one respect the 


\section{A MEETING OF RIVALS}

older man was the more fortunate, for, as will be seen, he found close by his door an excellent naturalist who played the part of mentor.

On February 14, 1802, while at Philadelphia, Wilson wrote to Orr:

On the 25th. of this month I remove to the schoolhouse beyond Gray's Ferry to succeed the present teacher there. I shall recommence that painful profession once more with the same gloomy, sullen resignation that a prisoner re-enters his dungeon or a malefactor mounts the scaffold; fate urges him, necessity me. The agreement between us is to make the school equal to 100 dollars per quarter, but not more than 50 are to be admitted. The present pedagogue is a noisy, outrageous fat old captain of a ship, who has taught these ten years in different places. You may hear him bawling 300 yards off. The boys seem to pay as little regard to him as ducks to the rumbling of a stream under them. I shall have many difficulties to overcome in establishing my own rules and authority.

At Gray's Ferry, where he was then settled, Wilson again wrote in July: "Leave that cursed town at least one day. It is the most striking emblem of purgatory, at least to me, that exists. No poor soul is happier to escape from Bridewell than I am to smell the fresh air and gaze over the green fields after a day or two's residence in Philadelphia ...."

George Ord, Wilson's staunch friend, literary executor, biographer, and editor of the last two volumes of the American Ornithology, thus characterized him: "He was of the genus irritabile, and was obstinate in opinion." He would acknowledge error when discovered by himself, "but he could not endure to be told of his mistakes. Hence his associates had to be sparing of criticism, through fear of forfeiting his friendship. With 
almost all his friends he had occasionally, arising from a collision of opinion, some slight misunderstanding, which was soon passed over, leaving no disagreeable impression. But an act of disrespect he could ill brook, and a wilful injury he would seldom forgive."

In 1801, while teaching and studying German at Milestown, Pennsylvania, Wilson had another unfortunate love affair, in this instance with a woman already married. To this he alluded in letters written in the summer of that year to his friend Orr, with whom he later quarreled. On August 7, 1801, he wrote: "The world is lost forever to me and I to the world. No time nor distance can ever banish her image from my mind. It is forever present with me, and my heart is broken with the most melancholy reflections."

At Gray's Ferry, however, Wilson soon found in the estimable William Bartram, then in his sixty-first year, the sympathetic adviser, kind teacher, and judicious friend that he most needed, for though Wilson took the initiative in his ornithological plans, it was the kindly Bartram who eventually extended a helping hand. Both Bartram and Lawson, the engraver, urged him to devote his leisure to drawing, as a foil to his melancholic tendencies. Wilson did not hesitate long, for on June 1, 1803, he confided to a friend in Scotland that he had begun to make a "collection of our finest birds." Early in 1804 his purpose was clearly fixed, and on March 12 of that year he wrote to Alexander Lawson: "I am most earnestly bent on pursuing my plan of making a collection of all the birds in this part of North America . . . I have been so long accustomed to the building of airy castles and brain windmills, that it has become one of my earthly comforts, a sort of rough bone, that amuses me when sated with the dull drudgery of life." A 

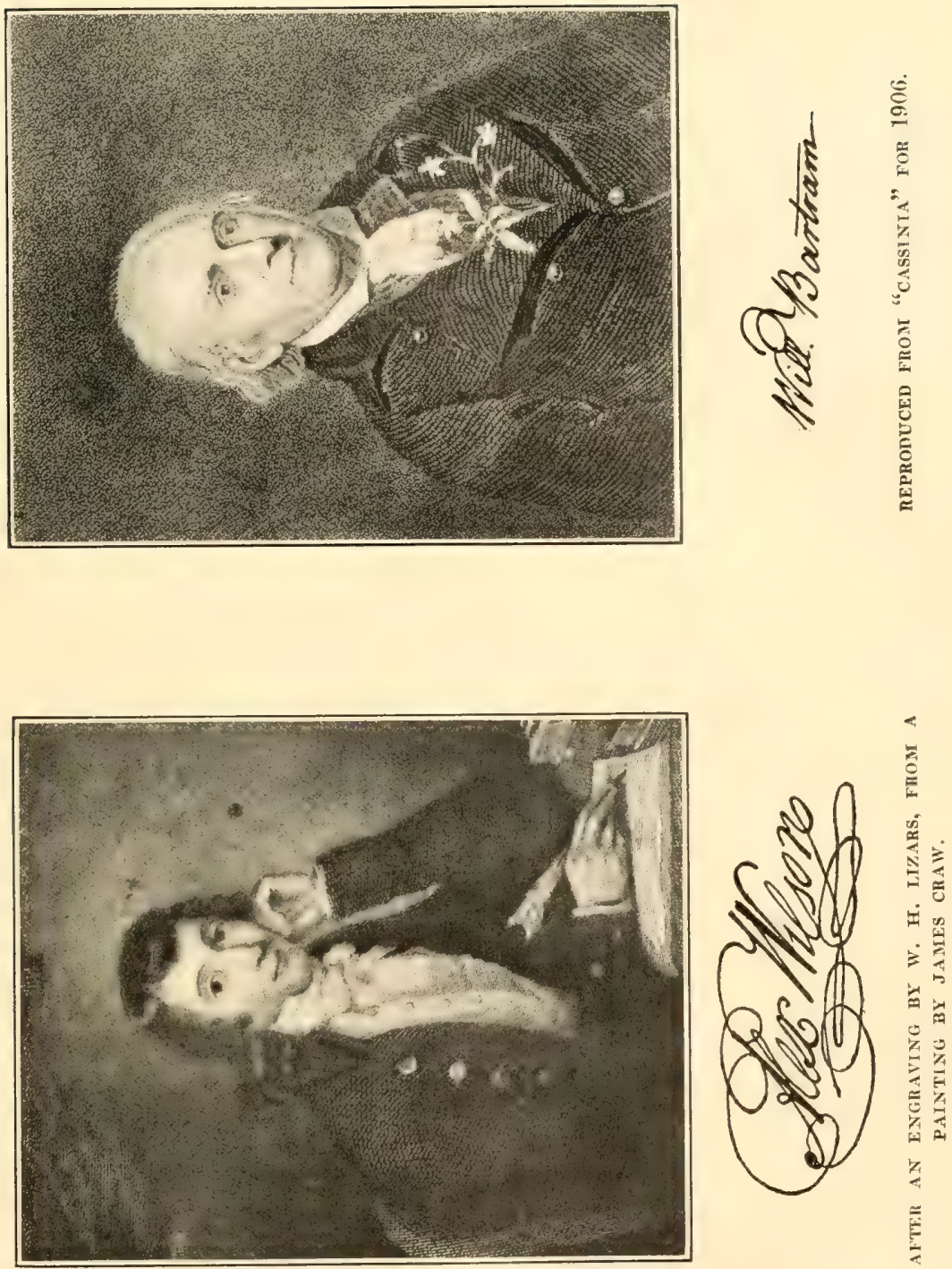

little later in the same month we find him appealing to Bartram for exact names, when he writes:

I send for your amusement a few attempts at some of our indigenous birds, hoping that your good nature will excuse their deficiencies, while you point them out to me. . . They were chiefly coloured by candle-light. I have now got my collection of native birds considerably enlarged, and shall endeavor, if possible, to obtain all the smaller ones this summer. Be pleased to mark on the drawings, with a pencil, the names of each bird, as, except three or four, I do not know them.

Wilson, practically self-taught in everything, with no experience or training in drawing from nature, thus began at the age of thirty-eight to make his drawings of birds, before he knew the names of his subjects, and twenty years before Audubon's talents were known to any but members of his own family and a few intimate friends. The only aid in drawing which Wilson ever received appears to have come from the hints which Lawson supplied. Nevertheless, the best of Alexander Wilson's original drawings represent a degree of excellence and honest workmanship of which he had no need to be ashamed, and in many instances he owed far less to his engraver, Alexander Lawson, than did his great rival to Robert Havell.

In 1880 Dr. Elliott Coues examined a large collection of original Wilson and Audubon drawings and manuscripts, "owned and kept with the greed of a genuine bibliomaniac" by Joseph M. Wade, then editor of $\boldsymbol{F} a$ miliar Science and Fancier's Journal. If not Wilson's portfolio itself, its contents, at least, said Dr. Coues, were then in Mr. Wade's possession, and this series of Wilson's drawings included, he thought, more than half 
of the originals of his famous plates. To quote Dr. Coues: ${ }^{6}$

In handling these drawings and paintings, of all degrees of completeness, one of sensibility could but experience some emotions he would not care to formulate in words . . I I was fairly oppressed with the sad story of poverty, even destitution, which these wan sheets of coarse paper told. Some of Wilson's originals are on the fly-leaves of old books, showing binder's marks along one edge. One of the best portraits, that of the Duck Hawk, is on two pieces of paper pasted together. The man was actually too poor to buy paper! Some of the drawings are on both sides of the paper; some show a full picture on one side, and part of a mutilated finished painting on the other. Some show the rubbing process by which they were transferred. They are in all stages of completeness, from the rudest outlines to the finished painting.

I know full well that in 1804, when Wilson had fairly begun his work on birds, he was poor enough, but I hesitate to believe upon such evidence that he was too poor to buy decent drawing materials. Wilson doubtless practiced economy in these matters as in everything else, through his ingrained habit of Scotch thrift, and he was probably quite as well-to-do then as five years before, when out of his slender earnings he was able to lay money aside. ${ }^{7} \quad$ Later, to be sure, his modest savings were quite consumed by his Ornithology, and then William Bartram came to his aid, even giving him a home in his own house. It is also wide of the mark to con-

${ }^{6}$ See Bibliography, No. 43.

7 At Lancaster, Pennsylvania, on October 3, 1799, Alexander Wilson sent George Simpson, Esq., a State Treasurer's check in favor of Joseph Brown for $\$ 475$, to be entered to the credit of $\mathrm{Mr}$. Brown as one installment on 38 shares of scrip in the new loan at eight per cent, in the names of Thomas Eyes, 14 shares; Alexander Wilson, 14 shares; and Kenneth Sewell, 10 shares. 
clude from his fugitive letters or from his drawings, as this critic has done, that Wilson was possessed of genius only, and "had nothing else, not even talent and ability." Wilson certainly had a talent for writing and cultivated it with marked success; even his verse was not all of a "despicable mediocrity." In the art of drawing, however, his natural gifts were of a very modest sort, and what he achieved was the result of the most painstaking effort. Of course he was not a finished scholar, as graduates from the school of adversity seldom are, but he had a passion for knowledge and the determination to excel. His genius was not fully displayed until a powerful motive, the ambition to make known the birds of his adopted land, had possessed his spirit and taxed his powers to their utmost capacity.

Shortly after he had settled at Gray's Ferry, Wilson's susceptible nature was touched by another romance, which was again unfortunate for the poet and dreamer, but was probably the making of the ornithologist. Bartram's Botanic Gardens, on the outskirts of Philadelphia, had long been famous for their large and choice collection of native plants, gathered by the indefatigable zeal of their worthy founder, John Bartram, Quaker philosopher, traveler, botanist, agriculturalist and nurseryman; but the fairest flower in the whole collection at that time is said to have been Miss Anne Bartram, daughter of John the younger, niece of William, who then superintended the "Kingsess Gardens," granddaughter of the founder, and heiress to the estate. To this Quaker maid Wilson addressed a number of his poems, and he interested her in the drawing of birds; on March 29, 1804, he wrote to her uncle: "I send a small scroll of drawing papers for Miss Nancy. She will oblige me by accepting it." This little incident 
would show that Wilson was no stranger to the use of good drawing materials, however frugal his habits in this respect may have been. The young lady is said to have been not indifferent to her poet lover, and some of her family were friendly; the father, however, had no notion of bestowing his daughter's hand upon a poor schoolmaster, and for the third time Wilson's dreams of domestic bliss were shattered.

Such experiences no doubt tended to chasten the sensitive spirit of this real genius, whose whole life seemed to have been a continuous and losing struggle, while he felt within him an inspiration and a power that had failed to find adequate expression in labor at the loom, in verse, or in the hated vocation of teaching rough country schools at starvation wages. 'Though depressed by his misadventures in love, Wilson does not seem to have been embittered, and by way of diversion, he set out in the autumn of 1804, on a long walking tour from Philadelphia to Niagara Falls and back; in the following winter the experiences of this journey were embodied in a descriptive poem of 2,018 lines which he called "The Foresters," an effort which would have been less prosaic if frankly expressed in prose. Wilson's friendship for the Bartrams continued under the changed conditions, and he was invited to make his home under their hospitable roof. He was now free to devote himself heart and soul to birds and to birds alone.

Wilson etched the first two plates of his American Ornithology before he had obtained an engraver or a publisher. In April, 1806, he resigned his school at Gray's Ferry to accept an editorial position on a New American Cyclopeedia, ${ }^{8}$ then in course of preparation,

${ }^{8}$ This was the American edition of Abraham Rees' revision of Ephraim Chambers' Cyclopadia, which had appeared in London in 1798; it was pub- 
at a salary of $\$ 900$ a year. Samuel F. Bradford, the publisher of this work, soon became interested in Wilson's projected American Ornithology and agreed to publish it. It became the ambition of both author and publisher to produce the work in a superior style, and to make it as perfect and complete an American product as possible. Only the pigments used in coloring some of the plates were imported from Europe. ${ }^{9}$

Wilson issued in April, 1807, an elaborate prospectus of his proposed Ornithology, in which he stated that the completed work would comprise ten volumes, to cost $\$ 120$, and that it would be illustrated by plates, engraved and colored by hand, after the manner of a carefully prepared sample which was issued with the printed announcement. In September, 1808, as already intimated, the first volume of the American Ornithology ${ }^{10}$ appeared

lished at Philadelphia, in forty-one quarto volumes of text and six volumes of plates, by Samuel F. Bradford and the Messrs. Murray, Fairman \& Company, 1810-1824.

"The types," said Charles Robert Leslie, "which were very beautiful, were cast in America, and though at that time paper was largely imported, he [Mr. Bradford] determined that the paper should be of American manufacture; and I remember that Ames, the paper maker, carried his patriotism so far that he declared that he would use only American rags in making it." (Autobiographical Recollections, Boston, 1860.)

${ }^{10}$ The American Ornithology: or, the Natural History of the Birds of the United States: Illustrated with Plates Engraved and Colored from Original Drawings taken from Nature, by Alexander Wilson, was published in nine imperial quarto volumes by Messrs. Bradford and Inskeep, at Philadelphia, 1808-1814. Each volume contained nine plates and from 100 to 167 pages of text, exclusive of prefatory and other matter. The eighth volume, which was nearly ready for press at the time of the author's death, was edited by George Ord, Wilson's friend and executor; the final volume, which was wholly by Ord, and which was issued in the same year, contained a life of Wilson. After the appearance of the initial volume, the edition was extended to 500 copies and the first volume was entirely reset. Ord's life of Wilson was expanded for a three-volume edition of the Ornithology, and from oversheets of this work was produced as a separate volume in 1828 (see Note, Vol. I, p. 223).

Wilson's published lists of subscribers show 449 names, calling for 458 copies, more than half of which were taken by residents of Pennsylvania, New York and Louisiana; 70 were subscribed for in Philadelphia, chiefly by business men, artists, and "those in the middle class of society;" New 
in an edition of 200 copies. Wilson immediately started on a canvassing tour of New England, in the course of which he visited the principal towns and colleges, going east to Portland, Maine, and as far north as Dartmouth College, in New Hampshire, where President John Wheelock and the professors received him with marked attention. On this journey Wilson did not average one subscriber a day, and he was forced to conclude that he had "been mistaken in publishing a work too good for the country"; "it is a fault," he said, "not likely to be repeated, and will pretty severely correct itself." Daniel D. Tompkins, Governor of New York, coolly said to him: "I would not give one hundred dollars for all the birds you intend to describe," not even if "I had them alive"; but a future Governor of that State, De Witt Clinton, the friend of science and scientific men, gave him the substantial encouragement he craved. When his second volume was ready for issue, Wilson wrote to Bartram: "This undertaking has involved me in difficulties and expenses which I never dreamt of, and I have never yet received one cent from it. I am, therefore, a volunteer in the cause of Natural History impelled by nobler views than those of money."

In the autumn of 1808 Wilson made a long and arduous tour of the South, in the course of which he visited every important town along the southern Atlantic seaboard, and though it cost him dear, he obtained

Orleans in seventeen days gave him 60 subscribers; Europe supplied 15, among whom were William Roscoe, later a patron of Audubon, and Benjamin West, the artist. Wilson figured and described 278 species of American birds (within the limits of the United States), of which 56 were supposed to be new, and the total number, given by Wilson and Ord, is said to be 320 . Twenty-three species were erroneously supposed to be identical with their European counterparts, yet all of Wilson's birds except the "Small-headed Flycatcher," referred to at the end of this chapter, have been identified. Considering the time and the difficulties under which he labored, his mistakes were remarkably few. 
250 subscribers; it was then that his publishers decided to extend the original edition of his work to 500 copies. His longer and more perilous journey of 1810 , when his meeting with Audubon occurred, has already been described. In 1812, after the sixth volume of the Ornithology had appeared, he again resumed his travels in the East and went as far north as Burlington, on Lake Champlain; at Haverhill, New Hampshire, he was summarily arrested and thrown into jail, the people of the town, utterly unable to comprehend the nature of his pursuits, suspecting that in his real capacity he was acting as a spy in the employ of the Canadian Government. The seventh and last volume of the Ornithology which Wilson lived to complete made its appearance in the spring of 1813. He had then been obliged to relinquish his work on the Cyclopadia, and was reduced to the pittance derived from the coloring of his own plates.

Alexander Wilson died at Philadelphia, after a brief illness, on August 23, 1813. A story was current that his end was saddened, if not hastened, by the dishonesty of his publishers, but I cannot vouch for it. Audubon may have had this report in mind when he wrote his name in the hotel register at Niagara Falls ${ }^{11}$ on August 24, 1824; and added that he would never die, like Wilson, "under the lash of a bookseller." Even as late as $\mathbf{1 8 7 9}$ Miss Malvina Lawson, daughter of Wilson's friend and engraver, left no doubt as to her belief when she wrote: "and to his other trials was added the fact that killed him,- - the dishonesty of his publisher."12

When we consider that Wilson's entire working period on the Ornithology was not over ten years, and that

${ }^{11}$ See Vol. I, p. 34.0.

${ }^{12}$ See a letter to Professor S. S. Haldeman, dated February 6, 18;9, in Penn Monthly, vol. x (Philadelphia, 1879). 
at the age of forty-seven he was called to lay down his pen and brush forever; that he produced in this brief space a work of great originality and charm, which did inestimable service in promoting the cause of natural history in both America and England, and which is likely to be read and prized for centuries to come, the achievement of this man is little short of marvelous. Knowing also the disabilities under which he labored, we are more than ready to temper our judgment with sympathy, and to overlook any faults which his character may have displayed. These indeed, we believe, were for the most part of a very trifling nature; those who knew Wilson best have all testified to his kindness of heart, his liberality, and his high sense of honor.

We must now return to the meeting of our two pioneers, which has been the bone of so much acrimonious contention. On his long journey to the Middle West and South, Wilson reached Louisville on a Saturday evening, March seventeenth, 1810, and put up at the tavern of the "Indian Queen," where, as it happened, Audubon was then living with his family; after spending five days in and about the town, he again set out on foot for Frankfort, on the morning of Friday, the twentythird. Audubon has given the following account in the "Episode" of "Louisville in Kentucky": 13

One fair morning, I was surprised by the sudden entrance into our counting-room [at Louisville] of Mr. Alexander Wilson, the celebrated author of the "American Ornithology," of whose existence I had never until that moment been apprised. This happened in March, 1810. How well do I remember him, as he then walked up to me! His long, rather hooked nose, the keenness of his eyes, and his prominent cheek-bones, stamped his countenance with a peculiar character. His dress, too, was

${ }^{23}$ Ornithological Biography (Bibl. No. 2), vol. i, p. 437. 
of a kind not usually seen in that part of the country; a short coat, trousers, and a waistcoat of grey cloth. His stature was not above the middle size. He had two volumes under his arm, and as he approached the table at which I was working, I thought I discovered something like astonishment in his countenance. He, however, immediately proceeded to disclose the object of his visit, which was to procure subscriptions for his work. He opened his books, explained the nature of his occupations, and requested my patronage.

I felt surprised and gratified at the sight of the volumes, turned over a few of the plates, and had already taken a pen to write my name in his favour when my partner rather abruptly said to me in French, "My dear Audubon, what induces you to subscribe to this work? Your drawings are certainly far better, and again you must know as much of the habits of American birds as this gentleman." Whether Mr. Wilson understood French or not, or if the suddenness with which I paused, disappointed him, I cannot tell; but I clearly perceived that he was not pleased. Vanity and the encomiums of my friend prevented me from subscribing. Mr. Wilson asked me if I had many drawings of birds. I rose, took down a large portfolio, laid it on the table, and shewed him, as I would show you, kind reader, or any other person fond of such subjects, the whole of the contents, with the same patience with which he had shewn me his own engravings.

His surprise appeared great, as he told me he never had the most distant idea that any other individual than himself had been engaged in forming such a collection. He asked me if it was my intention to publish, and when $I$ answered in the negative, his surprise seemed to increase. And, truly, such was not my intention; for, until long after, when I met the Prince of Musignano in Philadelphia, I had not the least idea of presenting the fruits of my labours to the world. Mr. Wilson now examined my drawings with care, asked if I should have any objections to lending him a few during his stay, to which I replied that I had none: he then bade me good morning, not, however, until $\mathrm{I}$ had made an arrangement to explore 
the woods in the vicinity along with him, and had promised to procure for him some birds, of which I had drawings in my collection, but which he had never seen.

It happened that he lodged in the same house with us, but his retired habits, I thought, exhibited either a strong feeling of discontent, or a decided melancholy. The Scotch airs which he played sweetly on his flute made me melancholy too, and I felt for him. I presented him to my wife and friends, and seeing that he was all enthusiasm, exerted myself as much as was in my power, to procure for him the specimens which he wanted. We hunted together, and obtained birds which he had never before seen; but, reader, I did not subscribe to his work, for, even at that time, my collection was greater than his. Thinking that perhaps he might be pleased to publish the results of my researches, I offered them to him, merely on condition that what I had drawn, or might afterwards draw and send to him, should be mentioned in his work, as coming from my pencil. I at the same time offered to open a correspondence with him, which I thought might prove beneficial to us both. He made no reply to either proposal, and before many days had elapsed left Louisville, on his way to New Orleans, little knowing how much his talents were appreciated in our little town, at least by myself and my friends.

Some time elapsed, during which I never heard of him, or of his work. At length, having occasion to go to Philadelphia, I, immediately after my arrival there, inquired for him and paid him a visit. He was then drawing a White-headed Eagle. He received me with civility, and took me to the Exhibition Rooms of Rembrandt Peale, the artist, who had then portrayed Napoleon crossing the Alps. Mr. Wilson spoke not of birds or drawings. Feeling, as I was forced to do, that my company was not agreeable, I parted from him; and after that I never saw him again. But judge of my astonishment some time after, when on reading the thirty-ninth page of the ninth volume of American Ornithology, I found in it the following paragraph :- 
"March 23, 1810.-I bade adieu to Louisville, to which place I had four letters of recommendation, and was taught to expect much of everything there; but neither received one act of civility from those to whom I was recommended, one subscriber, nor one new bird; though I delivered my letters, ransacked the woods repeatedly, and visited all the characters likely to subscribe. Science or literature has not one friend in this place."

What actually happened at this meeting of the two naturalists will never be certainly known, beyond what can be gathered from their rather widely divergent accounts. It should be noticed, however, that the paragraph which Audubon quoted was extracted from Wilson's private diary; it was no doubt written on the spur of the moment, possibly to humor his own mood, and certainly with no thought of its later publication. It was inserted by George Ord in the biographical sketch of his friend appended to the ninth volume of the A merican Ornithology, which appeared in 1814, the year after Wilson's death. Audubon was not concerned, either directly or by implication, except in the last sentence, for it is evident that he was not one of those to whom Wilson had carried letters of introduction. Thus the matter stood until 1828, when Audubon's Birds of A merica were being engraved in England. In all probability the incident would never have been noticed by Audubon, had not Ord seen fit to revive it when his life of Wilson ${ }^{14}$ was issued as a separate volume in that year. In this edition of the biography Ord inserted fuller extracts from Wilson's journal, with the evident

${ }^{14}$ Sketch of the Life of Alexander Wilson, Author of the American Ornithology, by George Ord, F. L. S. \&c. pp. i-cxcix, Philadelphia, 1828; taken from vol. $\mathrm{i}$ of an octavo edition of Wilson, edited by Ord, and issued by Harrison Hall, in three volumes, at Philadelphia in 1828-29, with folio atlas of plates reproduced from the original work; see Note 10, supra. 
purpose of placing the rival of his friend in an unenviable light.

Wilson's diary, which apparently was never seen by any of Audubon's friends, is now known to us only through such extracts as Ord and Waterton, his bitter enemies, have seen fit to make public; the original has probably been destroyed, for it cannot be traced later than 1840, when it was still in the hands of George Ord. ${ }^{15}$ Charles Waterton gave similar extracts from this famous journal in one of his philippics against Audubon in 1834, when he said that it was the testimony of this record that defeated Audubon's friends in their initial attempt to bring him into the Academy of Natural Sciences at Philadelphia. Wilson's narrative of his adventures at Louisville in 1810, as given by Ord and Waterton, is as follows : ${ }^{16}$

March 17 . Take my baggage and grope my way to Louisvilleput up at the Indian Queen tavern, and gladly sit down to rest myself.

March 18. Rise quite refreshed. Find a number of land-speculators here. ${ }^{17}$

March 19. Rambling round the town with my gun. Examined Mr.__ 's drawings in crayons-very good. Saw two new birds he had, both Motacillæ.

March 20. Set out this afternoon with the gun-killed nothing new. [People in taverns here devour their meals. Many

${ }^{15}$ See Ord's charge of plagiarism against Audubon (Bibl. No. 145) in the Proceedings of the American Philosophical Society, vol. i (1840). So far as could be ascertained in the summer of 1915, Wilson's diary of 1810 was not in the possession of any library or scientific society in Philadelphia, nor was it in the large collection of books which was given by Ord to the College of Physicians and Surgeons of that city at the time of his death in 1866 .

${ }^{10}$ 'The bracketed lines are from Waterton, who once stated that he had examined the original.

${ }^{17}$ This sentence is quoted from Burns' biographical sketch of Wilson (Bibl., No. 161), but tenses are changed to correspond with other entries. 
shopkeepers board in taverns-also boatmen, land-speculaters, merchants \&c.] No naturalist to keep me company. March 21. Went out shooting this afternoon with Mr. A. Saw

a number of Sandhill Cranes. Pigeons numerous. March 20.

March 23. Packed up my things which I left in the care of a merchant here, to be sent on to Lexington; and having parted with great regret, with my paroquet, to the gentleman of the tavern, I bade adieu to Louisville, to which place I had four letters of recommendation, and was taught to expect much of everything there, but neither received one act of civility from those to whom I was recommended, one subscriber, nor one new bird; though I delivered my letters, ransacked the woods repeatedly, and visited all the characters likely to subscribe. Science or literature has not one friend in this place. [Everyone is so intent on making money, that they can talk of nothing else; and they absolutely devour their meals, that they may return sooner to their business. Their manners correspond with their features.]

In this fuller record we learn that Wilson spent five days in Louisville; he examined Audubon's drawings on Monday, March 19, hunted alone on the 20th, went out shooting with Audubon on the 21st, and finally left Louisville on the morning of the $23 \mathrm{~d}$; no record was admitted by Ord for Sunday, the 18th, or for the $22 \mathrm{~d}$, a Thursday. Wilson noticed the drawings of two new Motacillae, or Warblers, in Audubon's collection, and it would have been only natural that he should have felt a strong desire to copy them, yet not a word was said about the loan of drawings to which Audubon refers; Wilson merely stated that from those to whom he was recommended he had received not "one act of civility,one subscriber, nor one new bird." Audubon was evi- 
dently regarded as one of the "many shopkeepers" who boarded "in taverns," and not as a "naturalist," for Wilson said that he had none to keep him company, and it is rather significant that Audubon's name is not once mentioned in his Ornithology.

Twenty-nine years after Wilson's visit to Louisville, when Audubon came to publish the fifth and last volume of his Ornithological Biography, he maintained that Wilson had copied his drawing of a certain bird, called the Small-headed Flycatcher, ${ }^{18}$ without any acknowledgment. 'To quote Audubon's words:

When Alexander Wilson visited me at Louisville, he found in my already large collection of drawings, a figure of the present species, which being at that time unknown to him he copied and afterwards published in his great work, but without acknowledging the privilege that had thus been granted to him. I have more than once regretted this, not by any means so much on my own account as for the sake of one to whom we are so deeply indebted for the elucidation of our ornithology.

This troublesome bird was first described by Wilson in 1812, when he rightly pronounced it "very rare," and said that the specimen from which his drawing was made had been shot in an orchard, presumably near Philadelphia, on the twenty-fourth day of April, and that several had been obtained also in New Jersey. His friend Ord, who came to his defense in 1840, confirmed this statement by declaring to the American Philosophical Society of Philadelphia that he had been with Wilson on the day in question and had examined

${ }^{18}$ Musicapa minuta, which appears in Figure 5, Plate 50, of volume vi of Wilson's American Ornithology (pp. 62-63 of the text), and in Figure 2 , Plate cccexxiv, of Audubon's Birds of America (Ornithological Biography, vol. v, pp. 291-3). 
the specimen. Lawson also affirmed that in engraving the plate he had worked directly from the bird which Wilson had given him.

What has become of this mysterious phantom that has been a wandering and disturbing voice among ornithologists for over a century? It has given rise to no end of conflicting and sharp discussions between the partisans of the two naturalists chiefly concerned, the only thing certain being that if this supposititious species ever existed, it has forsaken its old haunts, if not the earth itself, and has never returned. No doubt it was simply a case of mistaken identity, and both Wilson and Audubon were wrong, each having had in hand and mind an immature representative of one of our numerous Warblers, which are now so much better known. ${ }^{19}$ If Wilson copied Audubon's drawing of the bird, he must have replaced it with one of his own, for the figures of the two naturalists are very unlike. Certainly Audubon should not have made so serious a charge without offering more substantial evidence in proof; perhaps what he had intended to convey was that Wilson had obtained from him his first knowledge of the bird, and he was nettled to find that he had been studiously ignored..$^{20}$

${ }^{19}$ Nevertheless so careful and discerning a naturalist as Thomas Nuttall confidently asserted that his friend, Mr. M. C. Pickering, had "obtained a specimen several years ago near Salem (Massachusetts)"; see A Manual of the Ornithology of the United States and Canada (Cambridge, 1832). Dr. Elliott Coues at one time thought that it might have been the Pinecreeping Warbler, and Professor Baird identified it as the female or young of the Hooded Warbler.

${ }^{20}$ Compare Ornithological Biography, vol. iii, p. 203, where in Audubon's article on the Whooping Crane, there is this note: "Louisville, State of Kentucky, March, 1810. I had the gratification of taking Alexander Wilson to some ponds within a few miles of town, and of showing him many birds of this species, of which he had not previously seen any other than stuffed specimens. I told him that the white birds were the adults, and that the grey ones were the young. Wilson, in his article on the Whooping Crane, has alluded to this, but, as on other occasions, he has not informed his readers whence his information came." 
Among the originals of Audubon's Birds of America in possession of the Historical Society of New York, there is an early drawing of a Warbler which bears in pencil, in the naturalist's hand, the following note: "This bird was copied by Mr. Willson at Louisville." ${ }^{21}$ The misspelling of Wilson's name, which was common with

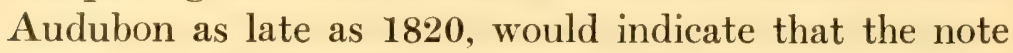
was not added after that time, but if Wilson copied this drawing, there is no evidence that he ever used it.

Ord made another charge in which Audubon does not appear to such good advantage; though it refers to a later day, it is best to consider it now. This critic thought that a complaint of misappropriation came with ill grace from one who had been guilty of it himself, and maintained that Audubon had copied Wilson's figures of the female Red-wing Blackbird (The Birds of America, Plate LXVII), and had also stolen his drawing of the Mississippi Kite (Plate CXVII). Ord was probably mistaken in regard to the blackbird, but without a doubt the lower bird in the Kite plate was taken from Wilson (American Ornithology, Plate 25), though the copyist has reversed the outlines, left out one of the toes, added minor details, and misnamed the sex, which in the Wilson original represents a male. Without a doubt also the odium in this case must fall upon Audubon, but we are not at all certain that he was directly responsible for the theft. Audubon's plate of this species, which is finished in elaborate detail, was probably published towards the close of 1831, when he was in America. He furnished his engraver, we believe, with

${ }^{21}$ What appear to be the original legends, written on this drawing in ink, are as follows: "Chute de l'Ohio. July 1, 1808. No. 31. J. A. Que j'avais figuré [?] 12 pennes à la queue." Above were later added, also in ink, the names, "sylvia Trochilus delicata; Sylvia delicata, Aud." 


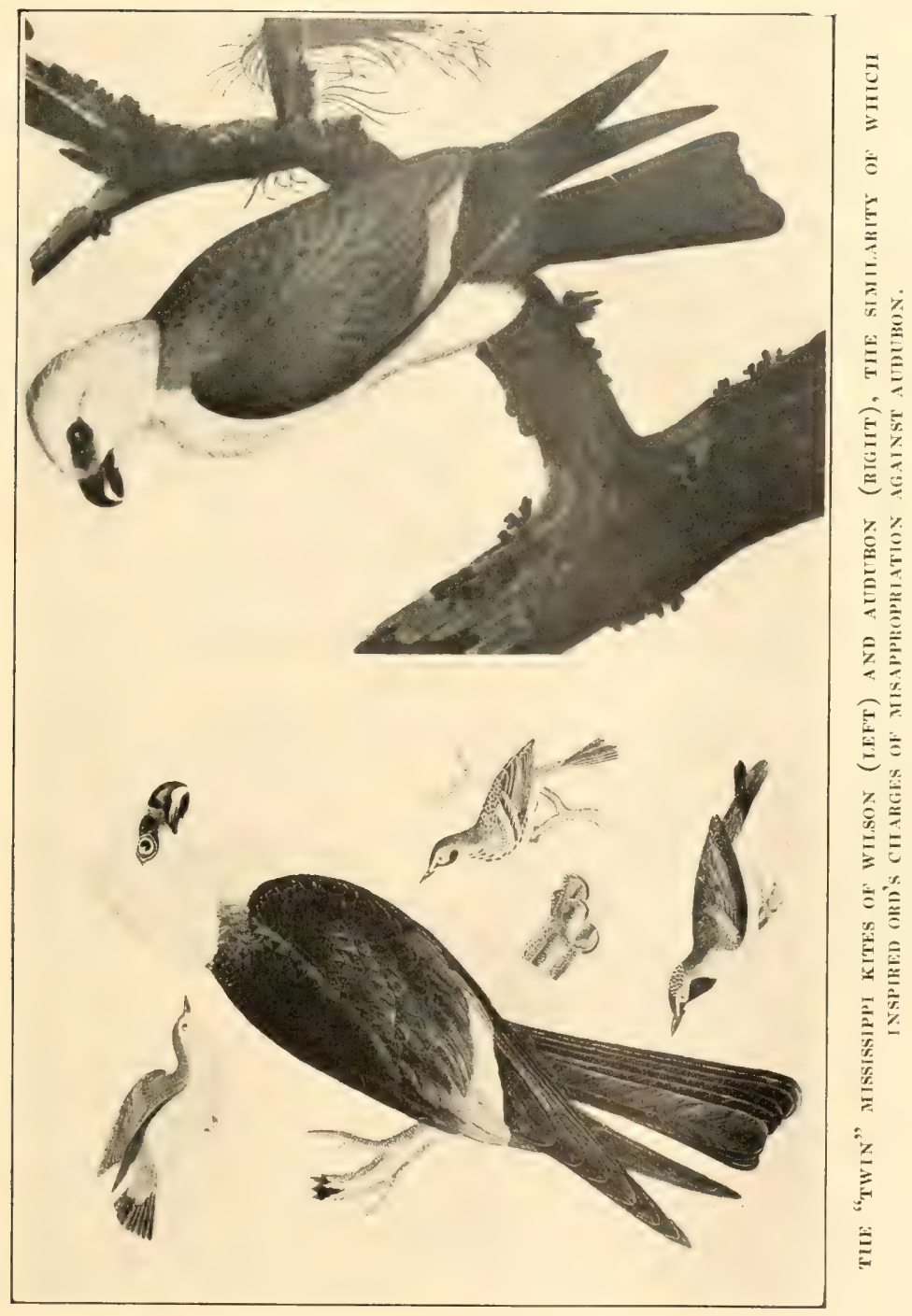



the drawing of the upper bird only, which he designated as a male, and the original still exists, with clearly written notes showing that it was executed in Louisiana in $1821 .^{22}$

Audubon usually made up his drawings for the engraver with great care, but when pressed for time, Havell's skill was such that he often depended upon him to complete or change his figures, to fill in backgrounds, or even to combine several distinct figures into one plate, specific directions for all such changes being usually written on the drawing itself. ${ }^{23}$ Inasmuch as no penciled directions whatever occur on this particular drawing, is it possible that Havell, in piecing it out to improve the composition, followed his own initiative, not fully appreciating the stigma that is rightly attached to such methods? The bird in the lower half of the plate, which was appropriated from Wilson, is misrepresented as a female, so that the composite, as it stands, is a remarkable product, supposedly depicting a pair but in reality showing two males. Although the apparent difference in sex in this bird was admittedly slight, it is improbable that so gross an error could have escaped the naturalist's eye had he been directly concerned with the result.

When Audubon was descending the Mississippi in December, 1820, he saw the kites busily engaged "in catching small lizards off the bark of dead cypress trees," but "having at that time no crayons or paper," he "did

${ }^{22}$ On this drawing, which with Audubon's other originals is in the collections of the Historical Society of New York, the legends are as follows: "Mississippi Kite, Male, Falco mississippiensis; Drawn from nature by John J. Audubon, Louisiana, parish of Feliciana, James Perrie's Esq., Plantation. June 28 th, 18थ1. Length 14 inches; Breadth 3 feet, 1/2 inches; Weight $103 / 4$ ounces; Tail feathers, 12." It is drawn in his usual style of that period, in pastel, water color and pencil, and has been dismounted.

${ }^{23}$ See Vol. I, p. 305. 
not draw one, and determined," as he then wrote in his journal, "never to draw from a stuffed bird." "I first saw the Mississippi Kite," he added, when "ascending in the steamboat Paragon, in June, 1819." Wilson, on the other hand, in his knowledge of this interesting bird was far in advance of his later rival, for his first observations were made in 1810, "in the Mississippi territory, a few miles below Natchez, on the plantation of William Dunbar, esquire, when the bird represented in the plate was obtained, after being slightly wounded; and the drawing made with great care from the living bird." "For several miles, as I passed near Bayo Manchak," Wilson continues, "the trees were swarming with a kind of cicada, or locust, that made a deafening noise; and here I observed numbers of the Hawk now before us sweeping about among the trees like Swallows, evidently in pursuit of these locusts; so that insects, it would appear, are the principal food of this species." ${ }^{24}$ Wilson never succeeded in procuring the female of this graceful hawk, and his editor, George Ord, evidently continued the quest, for we find his correspondent, John Abbot, writing him from "Scriven County Georgia Mar. 1814": "Are you acquainted with the female yet of the Louisiana Kite?"25

We have entered into the detailed history of this plate because of the unfavorable comment which it has provoked, but it is easier to be critical than to be either just or correct, and without more definite knowledge than we possess, it would be unfair to censure Audubon too much or to shift the blame too completely upon the shoulders of another.

${ }^{24}$ American Ornithology, vol. iii, p. 80.

${ }^{20}$ See Witner Stone, "Some Letters of Alexander Wilson and John Abbot," The Auk, vol. xxiii, 1906. 
'To return again to the story of Wilson's diary, it is evident that Wilson would never have published his sentiments in the form in which they later appeared. They were perfectly characterized by a just critic of an early day, ${ }^{26}$ who said that Wilson's words were without doubt written in a moment of keen depression and disappointment and were an exact description of his feelings, though, as we should also add, not of the facts. "A man who has given his heart to the accomplishment of an object, believing that he has no rival, must be somewhat more than human, if he be delighted to find that another is engaged in the same purpose, with equal energy and advantages far greater than his own." Barring his usual inaccuracies, it must be admitted that $\mathrm{Au}$ dubon's account bears the thumbmarks of truth. He could not have known the bitter struggles of the proud spirit whose history we have briefly told; he saw only a stranger, an ardent devotee of nature, it is true, but a man of unbending disposition, who with a little more suavity of address could probably have won his friendship, if not his subscription. Of the literary quality of Wilson's work, now so well appreciated, he could have known nothing at all; after turning its pages in his Louisville store for the first time in 1810, he probably did not see it again for over ten years.

That Wilson was jealous of Audubon as a future rival is probable, but the real "rivalry" between these two pioneers was of later growth. It was fostered in this country chiefly by George Ord and some of his friends, together with others who were interested in the sale of Wilson's work. Ord, who seems to have felt that the mantle of this naturalist had fallen on his own shoul-

${ }^{26}$ In 1840, by W. B. O. Peabody, naturalist; author of a Life of Wilson; see Bibliography, No. 105. 
ders, strove continually, and after 1826 with the aid of Charles Waterton in England, to hamper Audubon's progress, to discredit him as a man of integrity, and to break down his growing reputation as a naturalist. Though Ord was justified to some extent in his attacks upon Audubon which were made over Wilson's shoulders long after that estimable man was laid in the grave, the matter was carried too far. Neither of the rivals was wholly without fault, and a century is far too long to continue any quarrel, especially when one of those whose reputation was concerned was never a party to it.

Audubon, as we have seen, frankly attributed to personal vanity his failure to patronize Wilson's work, and added that "even at that time my collections were greater than his." But it should be noticed that money was far from plentiful with him at that moment. He was, in short, at the point of failure in the Louisville enterprise, and with Rozier was obliged to move down the river not long after the date of Wilson's visit. Audubon has been represented as at this time a well-to-do man of leisure, of fastidious tastes. Nothing could have been wider of the mark. He was still more of a sportsman than a naturalist, and when not occupied with drawing, he spent most of his time in the forest, to the neglect of his trade. We may be sure that he was quite as used to roughing it as any man on the frontier. 


\section{CHAPTER XV}

\section{EXPERIMENTS IN TRADE ON THE FRONTIER}

The Ohio a hundred years ago-Hardships of the pioneer trader-Audubon's long journeys by overland trail or river to buy goods-The "ark" and keelboat-Chief pleasures of the naturalist at LouisvilleThe partners move their goods by flatboat to Henderson, Kentucky, and then to Ste. Geneviève, (Missouri) - Held up by the ice-Adventures with the Indians-Mississippi in flood-Camp at the Great BendAbundance of game-Breaking up of the ice-Settle at Ste. GenevièveThe partnership dissolved-Audubon's return to Henderson-Rozier's successful career-His old store at Ste. Geneviève.

At the beginning of the nineteenth century the banks of the Ohio River were but thinly settled, and over vast areas the virgin forest still reigned in undisturbed vigor and beauty. Yet traders were eagerly pushing westward in ever growing numbers, and by 1810 Audubon and Rozier found that competition at Louisville was already keen. This city, •wrote Alexander Wilson in describing his experiences in the spring of that year, was as large as Frankfort, and possessed a number of good brick buildings and valuable shops; it would have been salubrious, he thought, "but for the numerous swamps and ponds that intersect the woods in its neighborhood," and the indifference of the people, whom he found too intent upon making money to give any heed to the drainage and sanitation of their town.

The prosperity of the partners, as already intimated, was shortlived. Audubon was doubtless right in admitting that his business abandoned him because he could not bear to give it the necessary attention. The 
conditions of life for the merchant-trader at that early day were at best far from easy, and an honest success, as then understood, required not only plenty of rough work but careful planning as well. His goods, purchased in the East, were laboriously transported across the State of Pennsylvania, and if they came from Philadelphia they must needs traverse the rough wagon roads that led through Bedford to Pittsburgh. There was an overland trail from Pittsburgh to Kentucky, but merchants with heavy loads would naturally take the easier river route. In going east to renew his stock in trade, it was a common practice to travel on horseback from as far west as St. Louis, but on returning the merchant would often sell his mount at Baltimore, Philadelphia or Pittsburgh, where a boat could be taken for the remainder of the journey.

The "ark" or flatboat was considered most convenient for the transportation of either passengers or merchandise down the Ohio, for any well-to-do traveler, while floating leisurely with the current, could make himself comfortable by fitting up snug sleeping quarters and a kitchen on deck, and could, go ashore at will, with the certainty of satisfying his appetite for wild turkey, venison and other game in the season. Wilson, who descended the river in April, 1810, boarded and passed many of these "arks," which he described as built in the form of a parallelogram, from twelve to fourteen feet wide and from forty to seventy feet long, with a canopy to protect them from the weather; they were casually helped along by means of two oars in the bow, and steered by another and more powerful one in the stern. "Several of these floating caravans," said Wilson, "were loaded with store goods for the supply of the settlements through which they passed, having a 
counter erected, shawls, muslins," and the like, "displayed, and everything ready for transacting business. On approaching a settlement they blew a tin trumpet, which announced to the inhabitants their arrival." These "arks," he added, descended from all parts of the Ohio and its tributary streams, but in greatest numbers in the spring months. Although they cost originally about $\$ 1.50$ per foot of length, when arrived at their destination they would seldom bring more than one-sixth of that amount. From forty to fifty days were commonly required to cover the entire distance of two thousand miles from Pittsburgh to New Orleans.

Another means of conveyance on the river, frequently used by Audubon, was the keel boat or barge, which, in some cases, was also roofed and would hold about two hundred barrels of flour. ${ }^{1}$ When assisted by oars in the bow, it could reduce the time of a journey to New Orleans by ten or fifteen days. These barges were pushed up stream with the aid of setting poles at an average rate of about twenty miles a day, or, if loaded, they were laboriously "cordelled," or drawn by the hands of men who trudged along the banks pulling at the cordelle.

The chief pleasures which Audubon's business ventures in the West seem to have afforded him were his leisurely journey by river and long horseback rides to Philadelphia to buy goods, when he could roam through his "beautiful and darling forests of Kentucky, Ohio, and Pennsylvania," which gave him grand opportunities to make observations upon birds and animal life of every sort. He would seldom hesitate to swerve from his course to study his favorites, and has related how on one occasion, when driving before him several horses

${ }^{1}$ Vincent Nolte, Fifty Years in Both Hemispheres (Bibl. No. 176). 
laden with merchandise and dollars, he quite lost sight of the pack saddles and the cash they bore, in watching the motions of a warbler. But few coaches, said Audubon, were available in those days, and the post roads were often unfit for lighter carriages. To cover the distance from Louisville to Philadelphia on horseback required about twenty days, and only a capable animal and rider could make forty miles a day; when steamer traffic on the $\mathrm{Ohio}^{2}$ was well in hand this time was reduced to six or seven days, in performing a journey which the modern railroad has shortened to not far from as many hours.

Discouraged by the gloomy prospects which their business at Louisville presented, Audubon and Rozier determined in the spring of 1810 to move 125 miles down the river to Henderson. ${ }^{3}$ Loading the residue of their stock on a flatboat, they resolutely set out for the new field, but great was their surprise to find, in place of the thriving settlement which their imaginations had pictured, only a cluster of log houses on the river bank, with a population of less than 200 people and a demand for little else than whisky, gunpowder and coarse woolen goods. When the partners arrived, the little town was eighteen years old, as the first log cabins were built there in 1792, but the whole country above and below

${ }^{2}$ The first steamboat on the Ohio was the Orleans, a vessel of 200 400 tons, built at Pittsburgh in the summer and fall of 1811, by Robert Fulton and Robert M. Livingston; her first voyage, when she touched at Henderson, was signalized, as it seemed to many, by the great earthquakes of that year. The first Kentucky steamer was built at Henderson in 1817, the same year that a small vessel was constructed by Samuel Bowen and J. J. Audubon at the same place (see Chapter XVI). Compare Edmund L. Starling, History of Henderson County, Kentucky (Bibl. No. 186).

${ }^{3}$ Known first as Redbank or Redbanks, to distinguish it from Yellowbank, or Owensboro, on a similar bend farther upstream; called also Hendersonville, but this term had no official standing. The population of Henderson in $\mathbf{1 8 1 0}$ is given as $\mathbf{1 5 9}$, and that of the entire county, then larger than at present, as 5,000. See Starling, op. cit. 
them was, and for a considerable time remained, one vast canebrake. All the commodities known to the pioneer store were scarce, but the people of Henderson were friendly, and the new settlers had been provident in bringing with them a goodly supply of flour and "bacon hams." Moreover, the Ohio, which was half a mile wide at that point, was well stocked with fish, and the woods and canebrakes were alive with birds, not to speak of larger and more important game. Not many years before, wild turkeys had been so plentiful that they were not sold but were given away, while a large buck deer could be bought in the season for fifty cents.

During their stay at Henderson, Rozier was in his habitual place behind the counter and attended to what little business was done, while Audubon with a Kentucky lad named John Pope, who was nominally a clerk, roamed the country in eager pursuit of rare birds, and with rod and gun bountifully supplied the table. Audubon's first abode in the town was, as he said, "a log-cabin, not a log-house," in which the richest piece of furniture was their child's cradle. He soon began to cultivate a garden, but his experience in horticulture must have been limited, for he naïvely remarks that the rankness of the soil kept the seeds they planted "far beneath the tall weeds which sprang up the first year."

Financial distress and hard times were already being felt in the Blue Grass State, and these conditions were not destined soon to improve. After experimenting for six months, or more, at Henderson, our two "rolling stones" determined to push still farther west and try their luck at a more promising point. They had hoped to reach St. Louis but finally went instead to Ste. Geneviève, then a small French settlement in Upper Louis- 
iana, on the right bank of the Mississippi, a hundred miles north of the mouth of the Ohio.

This new venture promised to be both hazardous and uncertain, and as Mrs. Audubon and Rozier were not on the friendliest terms, Audubon decided to leave his family at Henderson, where a home for his wife and infant son could always be had under the hospitable roof of Dr. Adam Rankin, who became one of the naturalist's staunchest friends. If their stock in trade at this time actually consisted of "three hundred barrels of whisky, sundry dry-goods and powder," as Audubon affirmed, the keel boat which they then engaged was certainly calculated to bear a goodly load. ${ }^{4}$ At all events the partners, with young Pope, their clerk, set out bravely, in a snow storm, in December, 1810. They floated with the current at a rate of about five miles an hour, while they helped their craft along by means of four oars in her bow and steered it with the aid of a slender tree trunk, "shaped at its outer extremity like the fin of a dolphin."

This journey of upwards of 165 miles lasted altogether more than nine weeks. It proved adventurous enough, but it was of no use to Audubon except in furnishing him with drawings of new birds and the raw materials for many "Episodes." The journal of his experiences on the great rivers during that eventful winter of $\mathbf{1 8 1 0}$ and 1811 is interesting for the sidelights which it throws both upon his character and upon the state of the country at an elder day. Held up by the ice for several weeks at Cash Creek, near the mouth of the Ohio, to his own delight but to Rozier's sorrow, Audubon tramped the country and hunted wild swans and larger game with the friendly Shawnee Indians. "When one 
day's sport was over," he said, "we counted more than fifty of these beautiful birds whose skins were intended for the ladies of Europe. There were plenty of geese and ducks, but no one condescended to give them a shot." 'This was Audubon in 1810, when such "sport" was regarded as legitimate enough, and the feather-hunting of such Indians was not considered the nefarious trade that it proved to be. If we shift the scene to twenty years later, when William MacGillivray needed thousands of specimens of American birds for his studies upon their anatomy and variability, we find Audubon supplying him liberally, but he could not then bear to see them killed wantonly or for mere sport; more than once, out of compassion for individual birds that he chanced to be studying, whether in Florida or in Labrador, he would not permit them to be shot even when needed for his collections.

At the Shawnee Indian camp, to relate a characteristic anecdote, Audubon noticed that a squaw who "had been delivered of beautiful twins during the night" was busied on the next day at her usual task of tanning deer skins. "She cut two vines," his record reads, "at the roots of opposite trees and made a cradle of the bark, in which the new born ones were wafted to and fro with a push of her hand, while from time to time she gave them the breast, and was apparently as unconcerned as if the event had not taken place."

When at last our adventurers gained the Mississippi, the mighty volume of which was running three miles an hour, the patron ordered all hands ashore to pull at the bow rope. This characteristic remark of the naturalist is delightful, as showing the "single eye" which it has been declared of old shall be "full of light": "we made," said Audubon, "seven miles a day up the famous river; 
but while I was tugging with my back at the cordella, I kept my eyes fixed on the forests or the ground, looking for birds or curious shells.'

Warping against the current was both difficult and dangerous, and though they rose two hours before the sun, they could make but one mile an hour or ten miles in the day. At night they would go ashore, light a good fire and cook their supper; then, after posting a sentinel to guard against unfriendly surprises, they would roll in their buffalo skins and sleep without further concern. Notwithstanding all their efforts, when they reached the Great Bend at Tawapatee Bottom, they were obliged to unship their cargo, protect their boat as best they could from being crushed in the growing pack, and await the final breaking up of the ice. "The sorrows of Rozier," at this dismal announcement, said Audubon, "were too great to be described; wrapped in a blanket, like a squirrel in winter quarters with his tail about his nose, he slept and dreamed his time away, being seldom seen except at meals." There was not a white man's cabin within twenty miles, but a new field opened to the naturalist, who tramped through the deep forests, and soon became acquainted with all the Indian trails and lakes in the neighborhood.

The six weeks spent at this camp passed pleasantly for Audubon, who devoted much of the time in studying the Osage Indians, whom he thought superior to the Shawnees, as well as in watching for wolves, bears, deer, cougars, racoons and wild turkeys, some of which were attracted by the bones and scraps of food thrown out for them: "I drew," said he, "more or less, by the side of our great camp-fire, every day." While detained at this point, they used for bread the breasts of turkeys, buttered with bear's grease, and opossum and bear's meat, 
until their stomachs revolted and they longed for a little Indian meal, which was procured only with the greatest difficulty.

When at last the ice broke up, splitting with reports like the thunder of heavy artillery, their prospects were dismal indeed, for their boat was immediately jammed by the rushing ice, and they were powerless to move her. "While we were gazing on the scene," to continue Audubon's record, "a tremendous crash was heard, which seemed to have taken place about a mile below, when suddenly the great dam gave way. The current of the Mississippi had forced its way against that of the Ohio, and in less than four hours we witnessed the complete breaking up of the ice." Having reloaded their goods, they were ready to start at a favorable moment, and taking leave of the friendly Indians, "as when brothers part," they pushed on through the floating ice, past Cape Girardeau, to Sainte Geneviève, a town which Audubon characterized as "not so large as dirty," declaring that the time spent there did not yield him half the pleasure he had felt at Tawapatee Bottom. It was near a granite tower which rose from a dangerous rock in the river below Ste. Geneviève that Audubon caught sight of what he afterwards described as "Washington's Eagle," a bird now believed to have been the true "bird of freedom," the "Bald-" or White-headed Eagle, but in an immature state.

Though their whisky was welcomed at Ste. Geneviève and what had cost the traders twenty-five cents, brought them two dollars, a gallon, Audubon heartily disliked the place and its people. Rozier, on the contrary, who had found plenty of Frenchmen with whom he could freely converse, was resolved to stay. Audubon accordingly proposed to sell out his share in the business, 
and the partnership was dissolved on April 6, 1811, Rozier paying part of the price in cash and the remainder in notes. In referring to the incident in his journal of 1820, Audubon wrote: "I parted with Mr. Rozier, and walked to Henderson in four days-165

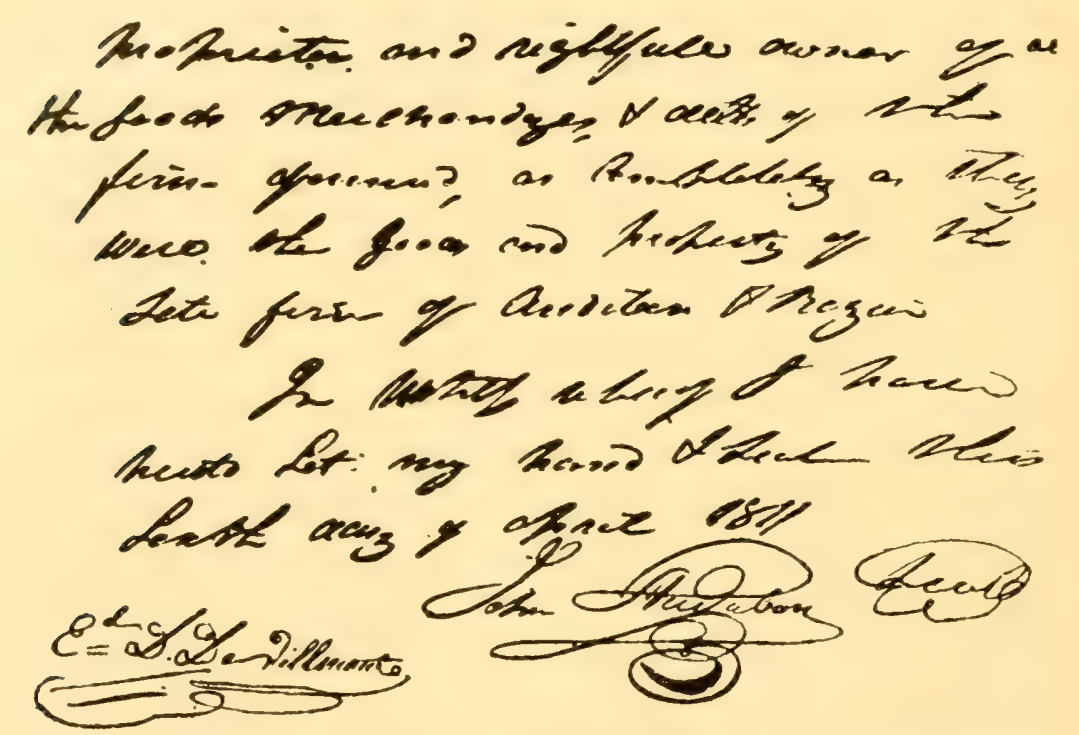

SigNature to THE RELEASE GIVEN BY AUdUbON TO FERdiNAND ROZIER ON THE dissolution of their partinership at ste. Geneviève, april 6, 1811.

From the Tom J. Rozier MSS.

miles"; but this does not agree with a later account, in which he spoke of having "purchased a beauty of a horse," and, happy in the prospect of again seeing his family, set out for Dr. Rankin's house in Kentucky. In the earlier record he also wrote that he once had a friend in trade, referring to Ferdinand Rozier, "with whom he did not agree, and so they parted forever"; but Audubon visited Ste. Geneviève in the autumn of 1811 and in the winter of 1812 , probably for the purpose of collecting his money and settling his affairs, while the following letters of this period show that 
friendly relations with his old partner were not seriously impaired: ${ }^{5}$

\section{John James Audubon to Ferdinand Rozier}

Louisville. 2d November 1811.

Mr. F. Rozier

St. Geneviève.

My Dear Rozier;

I reached here on the 31st of last month a little fatigued, as you can well imagine. Yesterday I wrote to T. W. Bakewell at New Orleans, and doubt not he is sending you regularly the prices current of the market there. I have found here a letter addressed to my brother-in-law from Benj. Bakewell, who complains of us, and says that we ought to settle with him in one way or another; write to him at Pittsburgh; I will be with him, possibly at the same time, and will speak with him; by the bill which he inclosed you will see that we are his debtor for $55 \$$. I am leaving here in 2 or 3 days. I wish you health and prosperity, and with the respects of my wife, I am always your friend \&

\section{Servant}

J. Audubon.

[Addressed] Mr. Fo. RoziER

Merchant

St Generieve

u.L.

John James Audubon to Ferdinand Rozier

Shippingpont, 10th Augst. 1812

My dear Rozier; -

As it is quite likely that the present opportunity is safe, I take pleasure in writing you a few words.

Your letter sent to Philadelphia was duly received, and an-

${ }^{5}$ See translations from copies of the originals, in French, in possession of the Louisiana Historical Society, New Orleans, in Appendix I, Document No. 21. 
swered promptly; since I have heard news of you only by the most indirect means, I would be happy if you can give a few moments to your friends, if you would count me in their number, and would write me from time to time; I left Philadelphia last month with my wife and son; most of this time was spent in descending the Ohio, which is at present very low; we had the barge and crew of G[en]l. Clark, with the company of Mr. R. A. Maupin, and of Mrs. Galt, who had spent several months at New York \& at Phila. I shall probably descend [the river] to New Orleans this autumn with N. Berthoud; [all kinds of] merchandise are extremely scarce and very dear, everywhere, but even more is this true of coarse woolens, which one does not find at all.

I have no doubt your lead is selling very well, this article having increased considerably [in value] since the war. In the latter part of my stay in the East I received a letter from my father, and one from your brother; all your family were then well, that is, four months ago; your brother is very anxious to hear from you; if peace should come at a day not far remote (and may it please God that this be so), I hope to get into communication with him.

I have written to him and I urge you to do the same; your letters can be delivered, if sent to New York, and from thence on the Cartel. ${ }^{6} \quad \mathrm{My}$ wife is well and [so is] my son; may you be the same, and count among the number of your friends him who would esteem you always.

Adieu

J. Audubon.

'Addressed] $\mathrm{MR}_{\mathrm{R}}^{\mathrm{s}}$ F. RozIER ${ }^{\mathrm{s}}$

Merch $^{\mathrm{t}}$

St Generieve

u.L.

Friendly relations with his former partner in trade were occasionally renewed by the naturalist in after life.

${ }^{\ominus}$ Boat for the exchange of prisoners of war. 
At one of their last meetings, in 1842, Rozier, who had then returned from France, visited Audubon at his home on the Hudson, and both were entertained in New York by their mutual friend, Nicholas Berthoud.

Ferdinand Rozier, with whom we now part company, lived to enjoy abundant prosperity as a trader and merchant at Ste. Geneviève. Born in Nantes on November $9, \mathbf{1 7 7 7},{ }^{7}$ at the age of twenty-five he entered the French navy, at a time when Napoleon was contesting with England the supremacy of the sea. He made numerous voyages, and we hear of him at the Cape of Good Hope, the Island of France or Mauritius, at Cadiz, Teneriffe, and at the Island of Bartholomew. Eventually, on April 8, 1804, he embarked on the cutter Experiment, with Captain Upton in charge, bound for the United States, where he visited a number of American ports, including Philadelphia and Norfolk. In the following year he returned to France in the frigate President, Captain Gallic Lebrosse, and entered the harbor of Nantes on March 1, 1805.8 In the spring of that year John James Audubon, as we have seen, had also returned to that city, and plans were eventually laid for their commercial aggrandizement in the New World which both had so lately visited. To what extent Audubon's dreams failed of realization may be gathered from the following chapters.

Having settled finally at Ste. Geneviève, Rozier, at thirty-six, married Constance Roy, a girl of eighteen, who bore him ten children, four of whom, all octogenarians, were living in 1905 . Ferdinand Rozier's thrift and industry soon brought him substantial rewards. In his earlier days he is said to have made six journeys to

${ }^{7}$ Compare Note, Vol. I, p. 152.

${ }^{8}$ See Note, Vol. I, p. 148. 
Philadelphia on horseback to purchase merchandise, and these trading expeditions were uniformly successful. His trade extended over the whole of Upper Louisiana, and he lived to see the great growth of Missouri as a sovereign state, along with the development of the fabulous mineral wealth of the district. ${ }^{\text {? }}$

Rozier's old store at Ste. Geneviève, for long a landmark in that community and considered a pretentious building in its day, was undoubtedly built after the date of Audubon's visit. The front was devoted to the service of customers and a large shed or stock room was placed at the rear, while the family lived in the main section, which was entered by a door not shown in our illustration. ${ }^{10}$ When this building was demolished to make way for modern changes, the wooden pins used in joining the frame were treasured by many as souvenirs of pioneer times.

Ferdinand Rozier, who outlived Audubon by thirteen years, died at Ste. Geneviève on January 1, 1864, at the age of eighty-seven years. If he were one of those who thought that Audubon was wasting his time in his ardent zeal for natural history, it should not surprise us, for their ideals were in conflict, and the naturalist's way of working was certainly not conducive to success in trade.

${ }^{9}$ For this characterization of Ferdinand Rozier I am indebted mainly to an account by his son, Firman A. Rozier, at one time mayor of Ste. Geneviève and member of the State Legislature; see his History of the Early Settlement of the Mississippi Valley (Bibl. No. 202) (St. Louis, 1890).

${ }^{10}$ For a photograph of the old Rozier store at Ste. Geneviève, as well as for the likeness of Rozier, made in 1862, when he was in his eightyfifth year, I am indebted to the kindness of Mr. Ruthven Deane, who received them from a son of Ferdinand, Felix Rozier, in November, 1905, when the latter had attained his eighty-third year. 


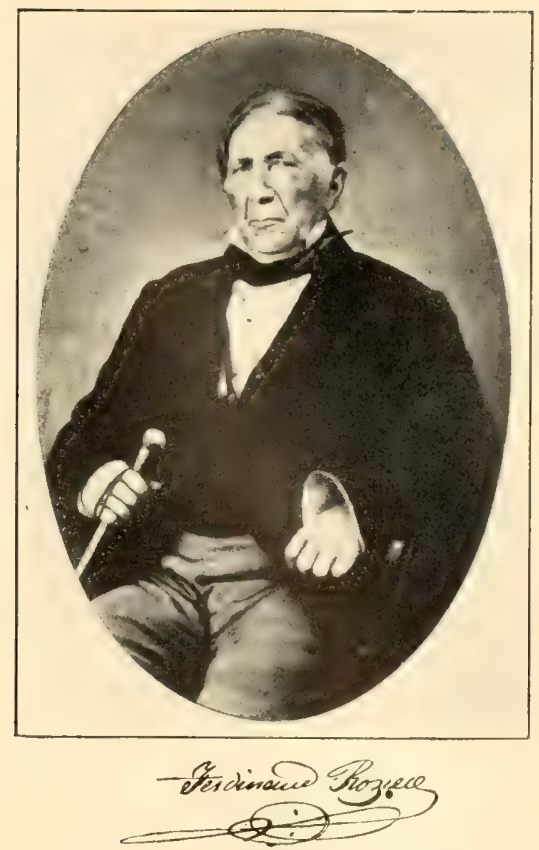

IN HIS EIGHTY-FIFTH XEAR (186?)

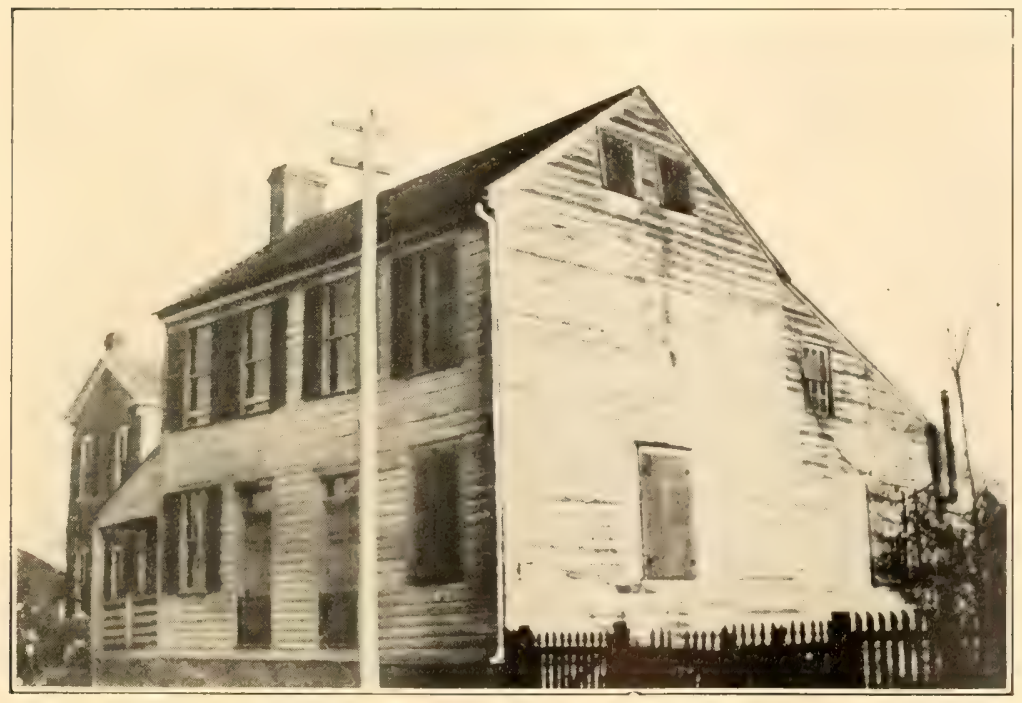

FERdiNAND ROZIER'S OLD STORE AT STE. GENEVIİVE, MISSOURI.

'This and the above published by courtesy of Mr. Ruthen Beane. 



\section{CHAPTER XVI}

\section{AUDUBON'S MILL, AND FINAL REVERSES IN BUSINESS}

Dr. Rankin's "Meadow Brook Farm"-Birth of John Woodhouse Audubon-The Audubon-Bakewell partnership-Meeting with Nolte-Failure of the commission business-Visit to Rozier-Storekeeping at Henderson-Purchases of land-Habits of frontier tradesmen-Steamboats on the Ohio-Popular pastimes-Audubon-Bakewell-Pears partnershipTheir famous steam mill-Mechanical and financial troubles-Business reorganization-Bankruptcy general-Failure of the mill-Personal encounter-Audubon goes to jail for debt.

The seven years which followed the outbreak of war with England in 1812 were the most disastrous in the naturalist's career. In many respects they were critical for the entire country, since hundreds who were not affected directly by the war were ruined by the financial troubles which followed in its wake. To Audubon reverses came at this time in rapid succession. Bereft of one and then another of his children, ${ }^{1}$ with his family in straitened circumstances in France, and reduced to bankruptcy himself, he finally resolved to throw up trade, for which he was never fitted, and to make his avocation the real business of life. We shall see how, by the unstinted use of such talents as he possessed, through unremitting effort, and with the aid of his energetic and capable wife, he was able, at the age of fortyfive, to turn failure into success.

After his return to Henderson in the spring of 1811, Audubon began to look for another opening in trade,

${ }^{1}$ While living at Henderson the Audubons lost their two daughters, Rosa and Lucy, both of whom died when very young. 
living meanwhile with his family at the home of Dr. Adam Rankin, called "Meadow Brook Farm." Dr. Rankin was the first educated physician in his district, and was for many years an officer of the court. A doctor of the older school and a genuine lover of his kind, with a large heart and an open hand, he made his home a hostelry where anyone in need could find refuge without money and without price. No doubt he was attracted to the naturalist by kindred tastes, and it is known that they became life-long friends. The old house, to which Audubon refers in one of his "Episodes," 2 was built of logs, and stood at some distance from the pike, about two miles from the village in a southeasterly direction. There were experienced in greatest frequency, in the winter of 1811 and 1812, the terrific earthquakes that repeatedly shocked the country at that time; there also Audubon's younger son, John Woodhouse, was born on November 30, 1812. The Rankin farm became at a much later day the site of the village of Audubon, which still later was to be incorporated in the growing city of Henderson, when most of the old landmarks had been obliterated. Dr. Rankin built a more commodious and pretentious brick house in the village itself, and was neighbor to the naturalist for many years, their houses being on the same or adjoining lots. He was thrice married and had many children, the eldest of whom, William Rankin, became Audubon's favorite companion in the field; together they ransacked the country for birds and animals of every sort.

Audubon's unfortunate business relations with his brother-in-law, Thomas W. Bakewell, began in the autumn or winter of 1811 , when the naturalist was in the

2 "The Earthquake," Ornithological Biography (Bibl. No. 2) vol. i, p. 280. 
East and Bakewell was about to return to New Orleans in the employ of a firm of Liverpool merchants who dealt in cotton. Bakewell, who had seen much of the South since the failure of his uncle in New York, induced Audubon to join him in an independent commission business, with the assurance that his French nationality would help their undertakings. According to Vincent Nolte, when they were descending the Ohio in December, 1811, Audubon displayed a business card, showing the firm name of "Audubon and Bakewell," and indicating that they were to deal in such homely products as pork, lard and flour. Thomas Bakewell, we are told, taking with him all the disposable funds of Audubon, who continued to send him "almost all the money" that he could raise, opened their business at New Orleans in the winter or spring of 1812, just in time for the war, which broke out in June, to destroy it. When he returned north, in August of that year, Thomas Bakewell, said the naturalist, suddenly appeared one day at "Meadow Brook Farm," while he was making a drawing of an otter, and after bewailing their misfortune in trade, departed.

At the approach of spring in 1812 Audubon was hard pressed for funds, and Rozier's notes to him being then overdue he set out on foot for Ste. Geneviève to collect his money in person. He went out with a party of friendly Osage Indians, but returned, still afoot and unpaid, with his faithful dog as his only companion. ${ }^{3}$ The prairies were then flooded and converted into vast

${ }^{3}$ This journey was probably made in February, though the date is given as April (see Maria R. Audubon, Audubon and his Journals, vol. i, p. 44), if the legends of four drawings of this time are to be trusted; all are labeled Pennsylvania, and bear the following dates: Swamp Sparrow, March, 1812; Spotted Sandpiper, April 22, 1812; White-throated Sparrow, April 24, 1812; and Whippoorwill, May 7, 1812. 
lakes, but Audubon, anxious to reach his home, pressed on, walking, as he said, "one hundred and sixty-five miles in a little over three days, much of the time nearly ankledeep in mud and water." It was probably on this journey, though it may have been in the previous year, that an incident occurred which he has related in "The Prairie," ${ }_{4}$ when, as he declared, for the first time in the course of his wanderings for upwards of a quarter of a century, his life was in actual danger from his fellow man.

When at last he had obtained some ready money, Audubon rode to Louisville, where he purchased on the half-cash, half-credit basis a small stock of goods, and again set up a retail shop at Henderson. This modest venture promised so well that he bought land with the intention of making that town his permanent home. "I purchased," said he, "a ground-lot of four acres, and a meadow of four more at the back of the first." On the latter, to follow this account, were several buildings and an excellent orchard, "lately the property of an English doctor, who had died on the premises and left the whole to a servant woman as a gift, from whom it came to me as a freehold": other land, he added, adjacent to the first, was later secured.

These curiously embroidered statements regarding land transactions at Henderson in $\mathbf{1 8 1 3}$ are not in harmony with the existing records of that frontier town. Henderson, as its historian ${ }^{5}$ tells us, was laid out orig-

${ }^{4}$ Ornithological Biography (Bibl. No. 2), vol. i, p. 81 . In his biographical sketch of 1835 Audubon said that this occurred on his first return from Ste. Geneviève to Henderson (in 1811), a contradiction characteristic of his manner of dealing with biographical and historical details. For an account of this "Episode," see Chapter XVIII.

${ }^{5}$ For early references to Henderson I am indebted mainly to Edmund L. Starling, History of Henderson County, Kentucky (Bibl. No. 186), who had access to all the town and county records. 
CHb! get Minin?

\section{Hendefund 19 the "Dot: 1818}

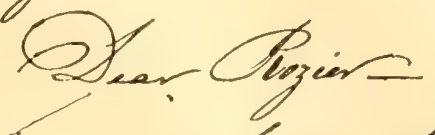

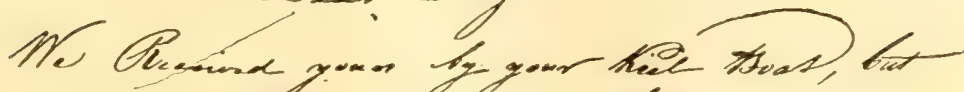

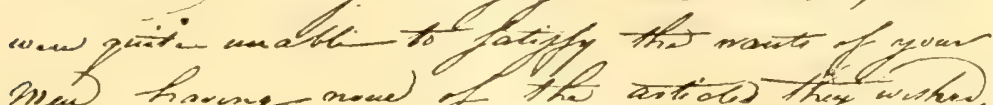

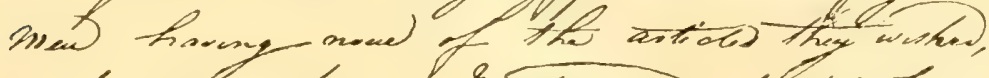

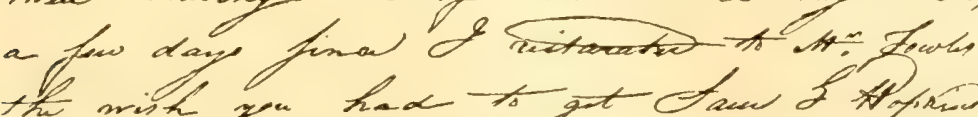

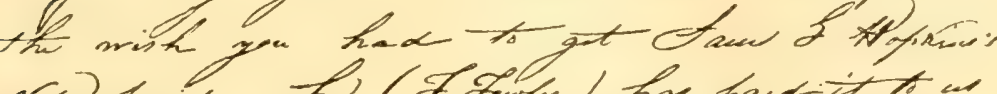

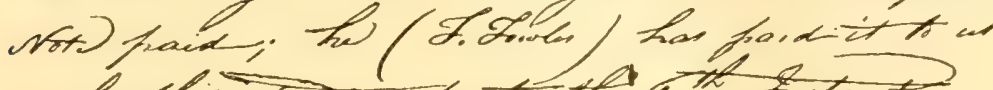

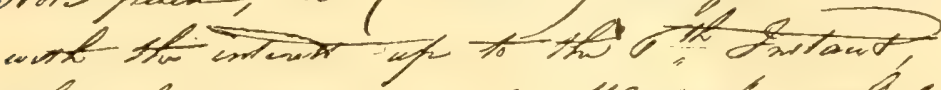

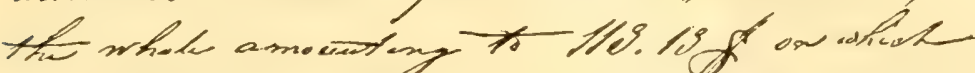

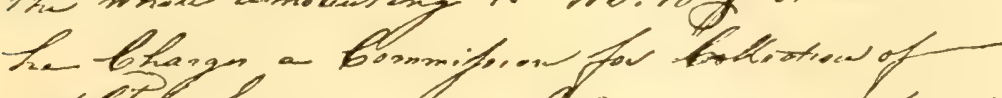

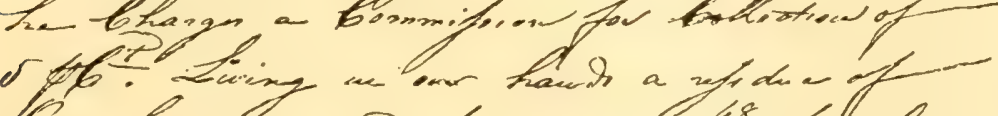

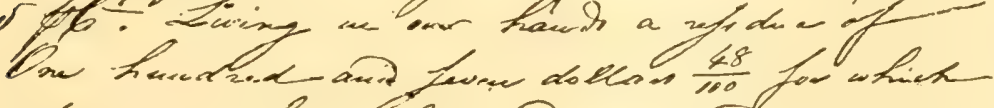
frem we- have bredis?

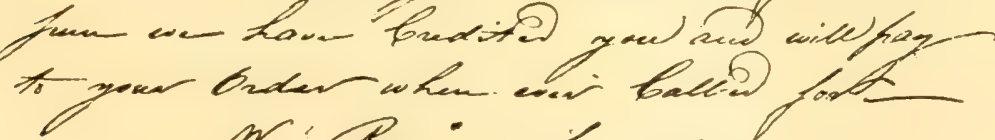

He Meming fimenoly fol

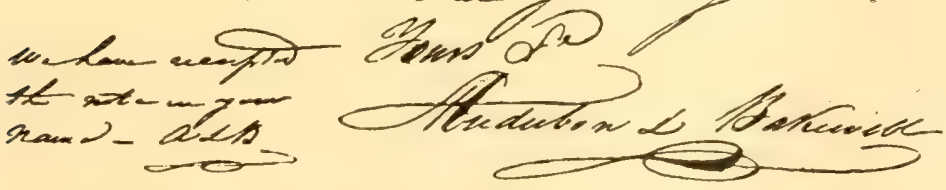

LETTER OF AUDUBON TO FERDINAND ROZIER, SIGNED "AUDUBON \& BAKEWELL," AND DATED OCTOBER 19, 1813, DURING THE FIRST PARTNERSHIP UNDER THIS STYLE.

From the Tom J. Rozier MSS. 
inally in $\mathbf{1 7 9 7}$ into 264 one-acre lots, of which comparatively few had been sold at the time of which we speak, though nominal prices were asked and a few had been given away to encourage settlement. ${ }^{6}$ Audubon is recorded as having purchased four one-acre lots from the town, two in 1813 and two in the following year, while a long lease was taken upon land adjacent to the river where later rose his famous mill. ${ }^{7}$

The old Audubon store for general merchandise, built of hewn logs, in a single story, stood at the corner of Main and Mill Streets (now Second Street), fronting the latter, at a point where a modern departmental establishment has since risen. Adjoining this primitive store, on the main street, was his log dwelling, 8 of one and a half stories, with a square porch at the entrance. Immediately opposite, on the two-acre strip of land purchased in 1814, lay a small pond which Audubon is said to have stocked with turtles in order to gratify his special fondness for this delicacy.

Audubon's winning manners made him a popular

${ }^{8}$ In 1819, the year of Audubon's departure, 129 town lots had been sold, while 29 had been given to privileged persons or to prospective settlers.

"According to the town records, as quoted by Starling, on December 22, 1813, Audubon purchased lots numbers 95 and 96 , which were onehalf of the square lying on the west side of Third Street and between Green and Elm Streets, from General Samuel Hopkins, agent of the Messrs. Richard Henderson \& Company; on September 3, 1814, he bought lots numbers 91 and 92 , or one-half of the square on the west side of Second Street, between Green and Elm. The mill site on the Ohio River was a part of the land given to Henderson by the Transylvania Company, the original owners of a large part of Kentucky; this site was leased for 99 years to J. J. Audubon, was sold and resold, but reverted to the city of Henderson in 1915. In the latter year the project was broached of obtaining the original mill site, together with adjoining property along the river, and converting the whole into a public park dedicated to Audubon.

- It a somewhat later time the naturalist occupied a one-story frame house, built in 1814, which stood at the corner of Fourth and Main Streets; see Starling, op. cit. 
figure among the early settlers of this region, and for the space of three years he enjoyed life as never before; "the pleasures," he said, "which I have felt at Henderson, and under the roof of that log-cabin, can never be effaced from my heart until after death." But in a community of exacting business men he could never have made a permanent success; he was too good a target not to be riddled by many who were ready to take advantage of his liberality and easygoing ways. Traveling from Frankfort to Lexington in 1810, Wilson complained that the people were all traders but no readers, even of the newspaper; every man, he said, had "either some land to buy or sell, some law-suit, some coarse hemp or corn to dispose of; and if the conversation does not to lead to any of these, he will force it."

Many stories, and no doubt much idle gossip, concerning Audubon's life and habits, were current at Henderson long after he left the village. It was said that he would often go into the woods in his pursuit of birds and remain from home for weeks at a time; that he was once known to have followed a hawk for three days in succession and in practically a straight course, swimming creeks when necessary, until it finally fell to his gun. When steamboats made their first appearance on the Ohio, they naturally excited the greatest interest, and a favorite pastime of many of the men and boys was diving from the side of a boat into the river. On one of these occasions Audubon is said to have made his appearance in the crowd of sightseers and to have astonished everyone by plunging from the bow and emerging from beneath the stern of the vessel after swimming under her entire length. According to traditional accounts, Mrs. Audubon, who was also an expert swimmer, 
would enter the river clad in a regular bathing costume and cross with ease to the Indiana shore.

In spite of the hard times Audubon managed to keep out of serious business troubles until he entered into another partnership with Thomas Bakewell, his brotherin-law. Their project in this second association was to erect a steam lumber and grist mill at Henderson, which of all mortal follies the naturalist considered in the retrospect to have been one of the worst. It is recorded that on the sixteenth day of March, 1817, John James Audubon and Thomas W. Bakewell, under the designation of "Audubon and Bakewell," applied to the trustees of the village for a ninety-nine year lease of a section of land on the river front. Their petition was granted, upon a consideration of $\$ 20$ per annum, and the partners began to build their mill on the property and completed it within that year. Thomas W. Pears, ${ }^{9}$ a former fellow-clerk of both Audubon and Bakewell in New York, early joined the enterprise, which was regarded at the time as one of considerable magnitude. Their mill, which stood for ninety-five years, became famous in the annals of the Ohio Valley. ${ }^{10}$ Said the historian of Henderson County, writing in 1879:

The weather boarding, whip-sawed out of yellow poplar, is still intact on three sides. The joists are of unhewn logs, many of them over a foot in diameter, and raggedly rough. The foundation walls are built of flat, broken rock and are four and a half feet thick. Mr. Audubon operated the mill on a large scale for those times. His grist-mill was a great convenience, and furnished a ready market for all of the surplus wheat raised in the surrounding country. His saw-mill also was a wonderful convenience, doing the sawing for the entire county.

${ }^{\circledR}$ See Note 15, Vol. I, p. 124.

${ }^{10}$ A Henderson correspondent of Joseph M. Wade, under the signature of "W. S. J.", August 8, 1883, gave the following account of the structure. 


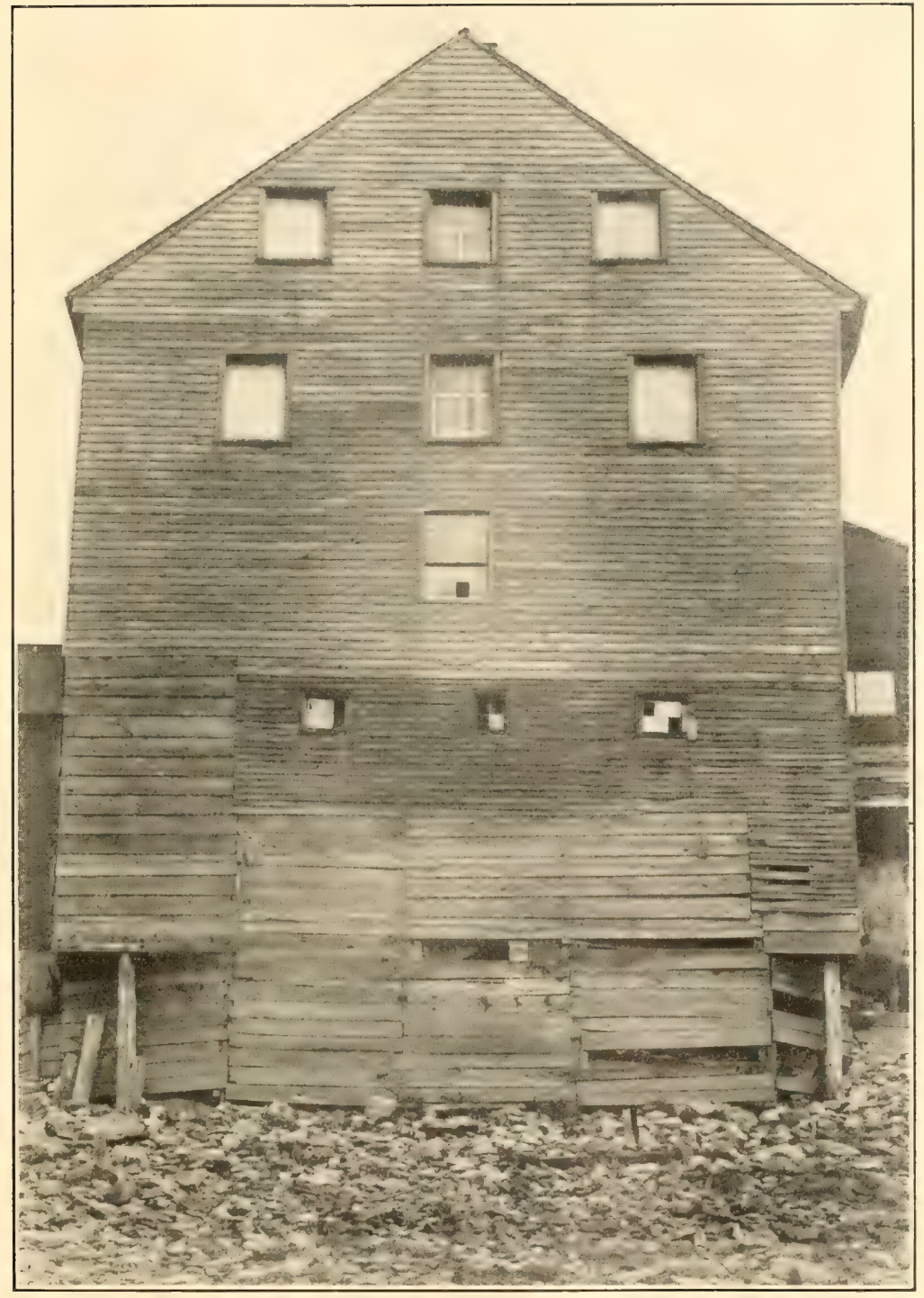

AUDUBON'S MHLL AT HENDERSON, KENTUCKY, SINCE DESTROYED, AS SEEN FROM THE BANK OF THE OHIO RIVER.

Aiter a photograph of 1894 , published by courtesy of Dr. B. W. Evermann. 

Mr. and Mrs. Pears, who had no liking for Henderson, early withdrew and sold their interest in the mill ${ }^{11}$ to Audubon and Bakewell, thus adding to their financial embarrassment. The engines, which seem to have given no end of trouble, were constructed by David Prentice, an intelligent Scotch mechanic; since his first work after coming to this country was to erect a steam threshing mill at "Fatland Ford," his services were probably secured by William Bakewell, who afterwards helped to establish him at Philadelphia. While at Henderson he is said to have fitted a small engine and paddlewheels to a keel boat, which was christened the Pike, and to have taken it up the river to Pittsburgh. Prentice seems to have entered the partnership and to have retired with Bakewell.

In order to extend the sphere of their operations, Audubon is said to have purchased at this time a tract of 1,200 acres of government land, ${ }^{12}$ and to have engaged a band of stalwart Yankees to fell and deliver the timber. According to one account, they were a party of emigrants who had come to Henderson with their families and encamped on the river bank. For a time all went well, but one day when they failed to deliver their usual

The original mill covered forty-five by sixty-five feet, and consisted of four stories and basement; the basement walls of stone stood four feet thick, while at the third story the thickness was three feet; the three upper stories were in frame. The studding measured three by six, and the rafters four by eight, inches. Many of the large timbers that could then be seen were sound and apparently good for a century or more. Parts of the old machinery that had been used in the grist mill were lying about under the eaves; the building was then used as a tobacco stemmery. See Joseph M. Wade (Bibl. No. 182), Ornithologist and Oölogist, vol. viii, p. 79 (1883).

The old Audubon mill in more recent times was incorporated into a warehouse for the storage of leaf tobacco; it was burned to the ground on March 18, 1913.

${ }^{11}$ The mill is supposed to have cost about $\$ 15,000$; of this sum Thomas Pears is said to have contributed from $\$ 3,000$ to $\$ 4,000$, and William Bakewell a similar amount in the interest of his son, while Audubon presumably furnished the balance.

${ }^{12}$ Maria R. Audubon, op. cit., vol. i, p. 4\%. 
supply of logs, it was found that they had decamped and fled down the river towards the Mississippi, taking on their flatboat Audubon's draft oxen and in fact all the plunder that they could lift. Nothing was ever recovered and but one of the fugitives was ever seen again; this man boarded a river boat on which the naturalist happened to be traveling, and it is said that upon being recognized he jumped into the river and swam to the shore like a frightened deer.

When Bakewell finally withdrew, Audubon appears to have been left stranded, and the business was taken over by a new set of men, including another brother-inlaw, Nicholas Berthoud, and Benjamin Page of Pittsburgh, who continued it under the name of J. J. Audubon \& Company. ${ }^{13}$ Agents were also secured at various points on the Ohio and Mississippi rivers. Excepting, as we must assuredly do, his ever staunch friend, Nicholas Berthoud, Audubon believed that he was "gulled by all of these men."

In 1818 a new era of building and general prosperity seemed to dawn in the valley of the Ohio. A new bank was chartered at Henderson, and the woodwork of its brick structure was furnished by Audubon's mill. ${ }^{14}$

${ }^{13}$ In his journal of 1820 Audubon said that after the withdrawal of Bakewell, "men with whom I had long been associated offered me a partnership. I accepted, and a small ray of light appeared in my business, but a revolution occasioned by a numberless quantity of failures put all to an end."

${ }^{1 *}$ One of J. J. Audubon \& Company's bills is here reproduced from Starling, op. cit.

"To the President and Directors of the Bank of Henderson to Henderson steam mill:

"To three pieces of scantling, 56 feet, $41 / 2$ c.......\$2.52

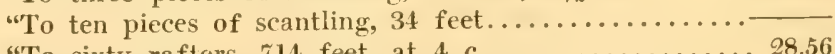

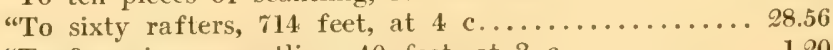

"To five pieces scantling, 40 feet, at $3 \mathrm{c} \ldots \ldots \ldots \ldots \ldots 1.20$

"To fifteen joists [?], 278 $1 / 2$ feet, at 6 c.......... 16.71

"J. J. Audubon \& Co." 
This bank, however, failed in the course of two years, and forty others scattered throughout that section broke in rapid succession, after having done little more than add to the flood of worthless paper notes that was demoralizing business and sending hundreds into bankruptcy.

The mill was in operation barely two years. The machinery, of which a wooden bolting shaft and wooden cog wheels remained as a curiosity to recent times, seems to have worked badly from the start. But aside from the inexperience of the builders and the financial troubles of the day, the enterprise was foredoomed to failure in a district which raised but little wheat, and in which the demand for lumber was then comparatively slight. "How I labored," said Audubon, "at that infernal mill! But it is over now; I am old, and try to forget as fast as possible all the different trials of those sad days."

In the course of the Audubon and Bakewell partnership ${ }^{15}$ the naturalist became involved in a personal quarrel with a man whose initials are given as " $\mathrm{S}$ B-_.." It seems that in $\mathbf{1 8 1 7}$ Audubon's mechanic, David Prentice, had built for him a small steamboat, though for what purpose is not known. When their interests were severed, we are told, Mr. B- purchased this steamer, but paid for it in worthless paper. The captain of the craft ran her down to the Mississippi and thence to New Orleans, and Audubon, who was determined to arrest this man if necessary, started in pursuit in a skiff. He failed, however, to overhaul the fugitive, and reached New Orleans only to find that his vessel

${ }^{15}$ According to W. G. Bakewell, Bakewell-Page-Campbell (Bibl. No. 200), Thomas Bakewell sold his interest in the store and mill to Audubon in $181 \%$, but this is contradicted by other accounts. For the incident which follows, see Maria R. Audubon, op. cit., vol. i, p. 34 . 
had been surrendered to another claimant. This was probably in May, 1819, for in his journal of the following year, under date of November 23, when he was again moving down the rivers but in more leisurely fashion, he speaks of two large eagle's nests, one of which he remembered having seen as he "went to New Orleans eighteen months" before.

Through the researches of a later historian I am now able to give a more exact account of this affair. The purchasers of the steamboat were William R. Bowen, Samuel Adams Bowen, Robert Speed, Edmund Townes, Obediah Smith, George Brent and Bennett Marshall, who immediately sued Audubon in the sum of $\$ 10,000$, on the plea that he had maliciously taken out an attachment upon the vessel in New Orleans, where it had been detained. They represented to the judge of the circuit court, Henry P. Broadnax, that Audubon was about to leave Kentucky, and a warrant was issued to arrest him; he was taken into custody, said the narrator whom I am following, "but executed a bail bond in the sum of $\$ 10,000$ with Fayette Posey as surety, and was released." Convinced that a trial at Henderson would lead only to a defeat of justice, Audubon now served notice that he would apply for a change of venue to another county. "That notice together with the other papers in the action, is among the records of the Daviess circuit court, at Owensboro, Kentucky. It was written and signed by Audubon. Application for a change of venue was made at Hardinsburg and the case was transferred to the Daviess circuit court." When the case was called, the plaintiffs asked for a continuance, and it was granted them, but when the case was called again at the next term of court, the plaintiffs failed to appear, and the action was finally dismissed. 
Returning home, Audubon was obliged to walk from the mouth of the Ohio River to Shawnee Town. Upon reaching Henderson he found that Mr. Bowen had anticipated him. Acting upon advice, he was prepared for an encounter with this man, who as his neighbors declared, had sworn to kill him, and "whose violent and ungovernable temper was only too well known." The anticipated encounter ensued. Audubon, who was then carrying his right hand in a sling from a recent injury received in his mill, waited, as he said, until he had received twelve severe blows from his assailant's bludgeon; then with his left hand he drew a dagger and struck in his own defense. His assailant was felled to the ground, but happily the wound inflicted was not mortal. Mr. Bowen was carried away on a plank, and when the affair was settled in the judiciary court, according to a Henderson tradition, Judge Broadnax gravely left the bench, approached the man who had been under charge of assault, and said: "Mr. Audubon, you committed a serious offense-an exceedingly serious offense Sir-in failing to kill the d- rascal."16 "Thomas Bakewell," added the naturalist, "who possessed more brains than I, sold his town lots and removed to Cincinnati, where he has made a large fortune, and I am glad of it. ${ }^{17}$

When the mill was finally closed and the company dissolved in 1819, Audubon as usual was the heaviest

${ }^{16}$ See Dixon L. Merritt (Bibl. No. 226a), "Audubon in Kentucky," The Taylor-Trotwood Magazine, vol. 10 (1909), p. 293.

${ }_{17}$ Thomas Bakewell later became a successful builder of steamboats, first at Pittsburgh, and after 1824 at Cincinnati, where he was an important factor in the rising commerce of the Ohio Valley, and where he left his mark on the history of that city. As a theoretical mechanic in iron and wood he is said to have had no superior; his business was nearly destroyed in the panic of $183 \%$, and he never regained his financial position. To his credit also it must be added that in 1860, at the age of seventy-two, he began at the bottom of the ladder again by engaging as a clerk with a paper company at Cincinnati, and, refusing the proffered 
loser. Arrested and sent to the Louisville jail for debt, he was able to obtain release only by declaring himself a bankrupt in court. "I paid all I could," ${ }^{18}$ he said in his journal of the following year, "and left Henderson poor and miserable in thought. My intention to go to France and see my mother and sister was frustrated, and at last I resorted to my poor talents to maintain you and your dear mother, who fortunately became easy at her change of condition, and gave me a spirit such as I really needed, to meet the surly looks and cold reception of those who so shortly before were pleased to call me their friend." "I parted," to revert to his later account, "with every particle of property I held, to my creditors, keeping only the clothes I wore on that day, my original drawings, and my gun." Without a dollar in his pocket he left Henderson and walked to Louisville alone; "this," he said on reflection, "was the saddest of all my journies, the only time in my life when the Wild Turkeys that so often crossed my path, and the thousands of lesser birds that enlivened the woods and the prairies, all looked like enemies, and I turned my eyes

aid of his children, he did not give up work until his eightieth year, seven years before his death in 1874. See W. G. Bakewell, Bakewell-PageCampbell (Bibl. No. 200).

${ }_{18}$ Audubon was not so accurate when in his biographical sketch of 1835 he said: "Finally I paid every bill, and at last left Henderson probably forever...," for when at Charleston with Bachman in 1834, one of his former creditors attempted to sue him for deht and apparently carried his case to court. When Bachman asked for an explanation, Audubon wrote from New York, April 5, 1834, as follows: "Respecting the suit let me tell you ... that I went to Gaol at Louisville after having given up all to my creditors, and that I took the benefit of the act of insolvency at the Louisville Court House, Kentucky, before Judge Fortunatus Crosby \& many witnesses, and that a copy of the record of that step can easily be had from that court... I wish friend Donkin to do all he can to put a Conclusion-stop to this matter, for it makes me sick at heart." The lawyer here referred to was probably Judge Dunkin, friend of Bachman and distinguished in his profession, who had a plantation at Waccamaw, near Charleston, South Carolina (see Chapter XXVII, Vol. II, p. 64 . 


\section{FINAL REVERSES IN BUSINESS 261}

from them, as if I could have wished that they never existed."

Passing down the Ohio in the following year Audubon made these entries in his diary:

November $2 n d, 1820$. Floated down slowly within two miles of Henderson. I can scarcely conceive that I stayed there eight years, and passed therein comfortably, for it is undoubtedly on the poorest spot in the country, according to my present opinion.

Nov. 3rd, 1820. We left our harbor at daybreak, and passed Henderson about sunrise. I looked on the mill perhaps for the last time, and with thoughts that made my blood almost run cold bit it an eternal farewell. 


\section{CHAPTER XVII}

THE ENIGMA OF AUDUBON'S LIFE AND THE HISTORY OF HIS FAMILY IN FRANCE

Death of Lieutenant Audubon-Contest over his will-Disposition of his estate-The fictitious $\$ 1 \%, 000$ - Unsettled claims of Formon and RossIllusions of biographers-Gabriel Loyen du Puigaudeau-Audubon's relations with the family in France broken-Death of the naturalist's stepmother-The du Puigaudeaus-Sources of "enigma."

Lieutenant Jean Audubon, as already recorded, died at Nantes in 1818, at a time when his son's financial troubles in America were culminating, and left an estate, then none too large, for the sole enjoyment of his widow during her lifetime. The naturalist, so far as is known, never received a penny in payment of bequests made by either his father or stepmother, but the reasons for this fact were far different from those which his biographers have assigned.

We have referred to the curious wording which appears in the six different wills that were executed by Lieutenant Jean Audubon and Anne Moynet, his wife, between the years 1812 and $1821 .^{1}$ The first four of these documents ${ }^{2}$ were of a mutual nature, and were so drawn that the survivor should enjoy the entire property of the other during his or her lifetime, but this eventually was to be divided between their two children, or heirs of the latter should any exist. In Jean Audubon's last will, made at Couëron on the 15th of March,

${ }^{1}$ See Chapter IX, p. 63.

${ }^{2}$ For complete text of these wills, in the original, See Appendix I, Documents 13-18. 


\section{THE ENIGMA OF AUDUBON'S LIFE 263}

1816, he added the provision that in case his "dispositions in favor of Jean Rabain and Rose Bouffard, wife of Loyen du Puigaudeau, should be attacked and annulled," he bequeathed his entire estate, without exception, to his wife, Anne Moynet, for her sole use. His fears, as already intimated, were well grounded, and his will was immediately contested by four nieces, Mme. Lejeune de Vaugeon of Nantes, Mme. Jean Louis Lissabé, whose husband was a pilot, and Anne and Domenica Audubon, seamstresses at Bayonne. ${ }^{3}$ This trial dragged on in the courts for a long time, and served further to impoverish Madame Audubon, who was obliged to dispose of most of her valuable effects, but it was finaly settled by a compromise in 1820. In that year, at the age of eighty-five, she left "La Gerbetière" to live with her daughter and son-in-law at "Les Tourterelles" close by, where she remained until her death on October 18, 1821.

It seems incredible that Audubon should not have heard of the death of his foster mother, since he had been devotedly attached to her in his youth and was moreover a beneficiary under her will. Yet on August 6, 1826, he wrote in his journal: "My plans now are to go to Manchester, to Derbyshire to visit Lord Stanley, Birmingham, London for three weeks, Edinburgh, back to London, and then to France, Paris, Nantes, to see my venerable stepmother, Brussels, and return to England." On September 30 of the same year he wrote from Liverpool: "I long to enter my old garden on the Loire and with rapid steps reach my mother,-yes, my mother! the only one I truly remember; and no son

${ }^{3}$ See Note 4, Vol. I, p. 27. The suit brought hy these plaintiffs was based upon a French law, which at that time debarred a natural child from inheriting property. 
ever had a better, nor more loving one." 4 Again in 1828 he spoke of this estimable woman as if she were then alive, although she had been dead seven years.

In Madame Audubon's last will, which was made in the July preceding her death, she left her property to be equally divided between her two adopted children, "Mr. Jean Audubon, called Jean Rabin, husband of Lucy Bakewell, and who I believe is at present in the United States of America, and to Rose Bouffard, wife of M. Gabriel Loyen du Puigaudeau, my son-in-law, who is living at Couëron"; she also took care to guard against the pretensions of any spurious heirs, and to make provision for her grandchildren in case of the death of either or both of her heirs direct.

Having given the precise, if somewhat prosaic, recorded facts of the case, we will quote the story narrated by the naturalist's biographers, who never could have seen the legal documents and who thus had only hearsay and conjecture on which to build:

At this juncture [of critical business affairs at Henderson], the father of Audubon died; but for some unfortunate cause he did not receive legal notice for more than a year. On becoming acquainted with the fact he traveled to Philadelphia to obtain funds, but was unsuccessful. His father had left him his property in France of La Gibitère [Gerbetière], and seventeen thousand dollars which had been deposited with a merchant in Richmond, Virginia. Audubon, however, took no steps to obtain possession of his estate in France, and in after years, when his sons had grown up, sent one of them to France, for the purpose of legally transferring the property to his own sister Rosa. The merchant who held possession of the seventeen thousand dollars would not deliver them up until Audubon

4 Maria R. Audubon, Audubon and his Journals (Bibl. No. 86), vol. i, pp. iii and 130 . 


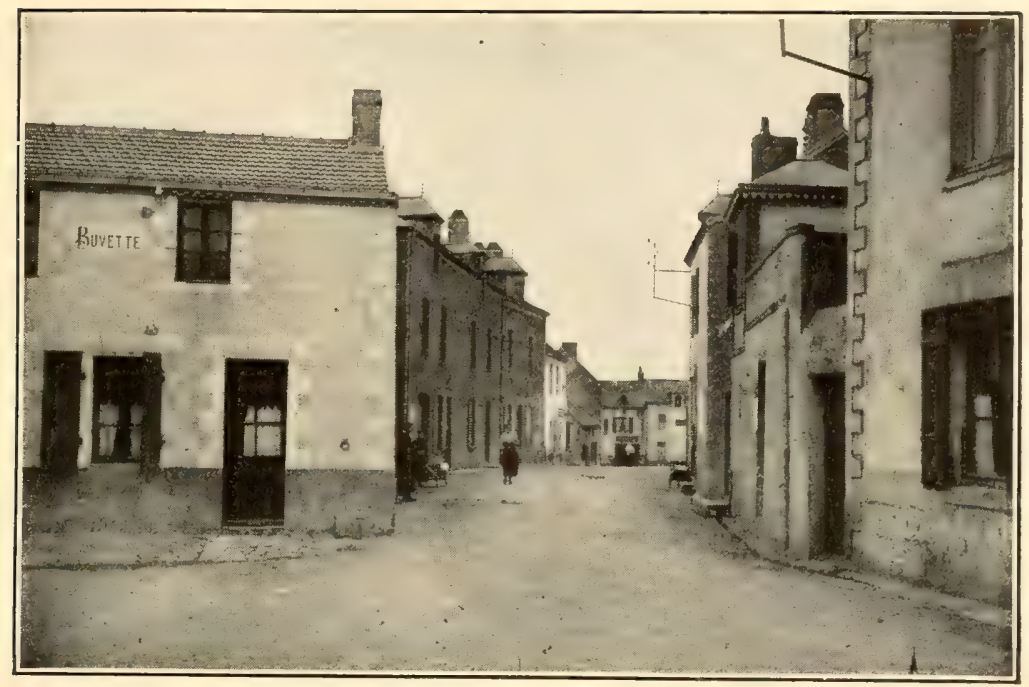

AN OLD STREET IN THE COUËRON OF TO-DAY.

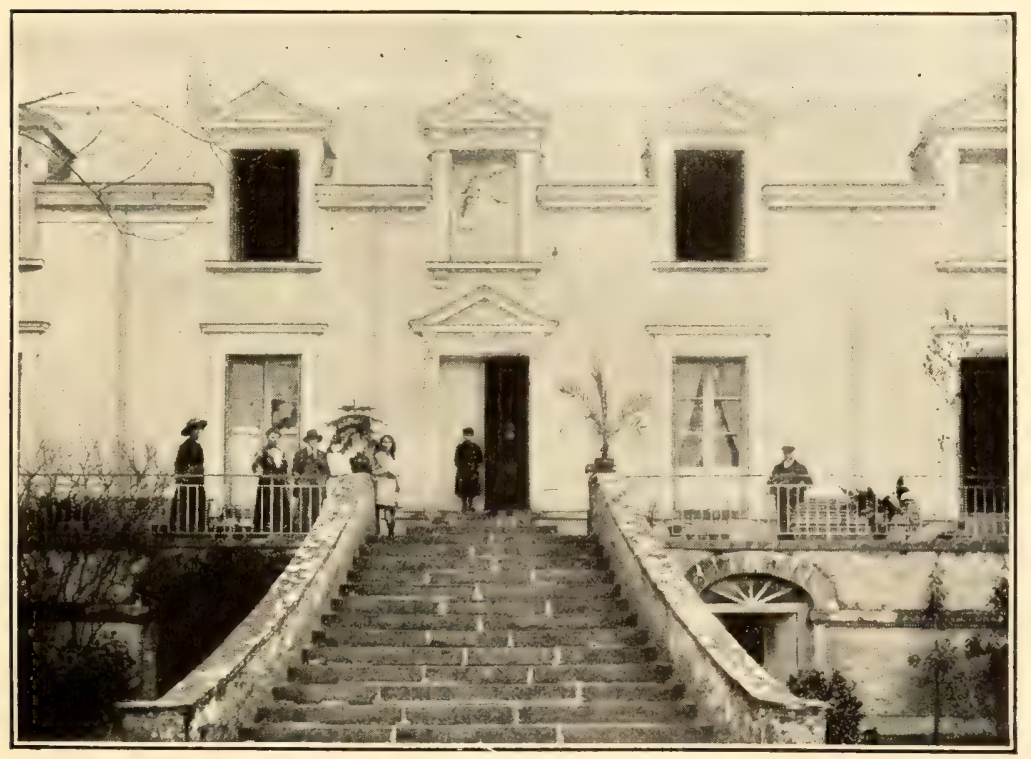

"LES TOURTEREYLS," COUËRON, FIXAL HOME OF ANNE MOYNET AUDUBON, AND THE RESTIYG PLACE OF EXACT RECORDS OF THE NATURALIST'S BIRTH AND EARLY LIFE. 

proved himself to be the son of Commodore Audubon. Before this could be done the merchant died insolvent, and the legatee never recovered a dollar of his money. ${ }^{5}$

A key to the origin of the fictitious seventeen thousand dollars is probably to be found in the letters of Jean Audubon to Francis Dacosta, written in 1805, ${ }^{6}$ where he refers to certain unsettled business claims against his former partners, Messrs. Formon and Ross, who had been respectively interested with him in two vessels, Le Comte d'Artois and the Annette, the history of which has already been noticed. ${ }^{7}$ They were also engaged at a later time in certain iron-works above Richmond, Virginia, but with these Lieutenant Audubon was not directly concerned. Formon, his partner in Santo Domingo trade, who was charged with having drawn $\$ 1,650$ in excess of his share, had died without making any final settlement of their accounts; another associate, Edward, had died in London leaving an unsettled claim of $\$ 300$; while David Ross, who was owing a certain sum, had also died without liquidating his debt. 'The amount of the latter claim probably was not large, since Dacosta was instructed to use this sum for his needs in developing the mine at "Mill Grove" should he be so fortunate as to collect it; "when you receive my papers from Miers Fisher," said Lieutenant Audubon in his letter of the $22 \mathrm{~d}$ of June, 1805, "you will find a promissory note of Mr. Samuel Plaisance of Richmond, for the business of the widow Ross. If there were justice there this sum should be paid to me with the costs."

Lieutenant Audubon was never able to collect these

${ }^{5}$ Lucy B. Audubon, ed., The Life of John James Audubon (Bibl. No. 73), p. 55.

${ }^{6}$ See Chapter VIII, p. 121.

${ }^{7}$ See Chapter II, pp. 33 and 34. 
different amounts, which probably did not much exceed $\$ 2,000$, but an echo of one of these transactions appeared as late as 1819, when Audubon's brother-in-law sent him a document referring to the claim on the Ross estate, in the hope that some money might still be forthcoming, writing as follows: ${ }^{8}$

In turning over some letters I have found a letter of Mr. David Rost [Ross], and a memorandum that I thought pointed to what was referred to in it. As I have sometimes heard it said that this Mr. David Rost owed a considerable sum, it should be possible that this letter, which is in English, might be of use to you. I cannot say anything about it, not knowing your language, and not having ventured to get it translated, from fear of compromising us, I am sending it to you, [and] you will judge of its importance. Should chance will that it bring you money, send me some of it, I beg you, for I am in great need of it.

The same biographer whom we have just quoted said in reference to "La Gerbetière": "This estate was left by Commodore Audubon to his son John James, who conveyed it to his sister without even visiting the domain he so generously willed away." We have now seen what provisions were actually made for the disposition of this property under the terms of the various wills of Lieutenant Audubon and his wife. We need only add that not long after his father's death, the naturalist lost touch with his family in France; his onehalf interest in his stepmother's estate, which was heavily encumbered, was never claimed, and at a much later day was informally relınquished in favor of his sister and her family.

${ }^{8}$ From G. L. du Puigaudeau's copy of his letter to John James Audubon (at Henderson), dated "Couëron, August 15, 1819," translated from the French. (Lavigne MSS.) 
During his Henderson period Audubon was in communication with his brother-in-law, Gabriel Loyen du Puigaudeau, who kept him informed in regard to all that transpired in their French home; on July 26, 1817 , the naturalist had given him a power of attorney, the curious wording of which has already been noticed. ${ }^{9}$ Whether deterred by the legal complications which soon followed, displeased by the mode of settlement, or for what other cause now unknown to us, Audubon seems to have severed all relations with his family at Couëron, or to have written to them only after long lapses of silence. On New Year's Day, 1820, Gabriel du Puigaudeau dispatched to him a friendly letter ${ }^{10}$ of greeting:

I take the opportunity at the renewal of the year, to offer you the good wishes of the entire family. Our every desire is that you, your beloved wife, and dear children may be happy, that you may prosper, that you may enjoy good health, and this is the wish of your nieces also. But, awaiting the pleasure of seeing you all, by what fatality during the past eighteen months have I not had any news of you, why no reply to at least twenty letters that I have written to you? Can I have been so unfortunate that some one has given you any report that would prejudice you against me? I do not believe that there could exist any one who would be able to do this, at least with truth; if some one has really sought to estrange your friendship for me, act with frankness, and tell me your suspicions. I do not believe it would be difficult to destroy them, and I even promise that I would offer you no reproach for having momentarily believed it, should this after all have occurred. For what concerns our business affairs, I refer you to my letters which have preceded this.

${ }^{9}$ See Vol. I, p. 64.

${ }^{10}$ This, and the letter to follow, translated from Gabriel du Puigaudeau's copies. (Lavigne MSS.) 
This letter was sent to Henderson, Kentucky, more than a year after the naturalist had finally left that state; at the moment it was written he was making his way down the Ohio River to New Orleans in a flatboat, "the poorest man aboard," as he thought at the time. Writing in his journal on December 26, 1820, when they had touched at Natchez, Audubon said that on that day he had received letters from his wife, who was then at Cincinnati, written on November 7 and 14, and that the last "contained one from my brother, G. Loyen Dupuigaudeau, dated July 24, 1820." If the month in this instance was misnamed, this might have been the following letter, which was written at Couëron on the twenty-fourth of June, 1820, and sent to Henderson like the last.

Two years have passed without our having any news of you. What a long lapse of time, and in what anxiety are we plunged! In God's name give us some news about yourself, if it be but a word to set us at rest in regard to your condition. I should not know how to persuade myself that you were not on friendly terms with me, since I have given you no cause [for grievance]; if it is so, be generous enough to relieve me from this anxiety. The business matters of Mr. Audubon are at last concluded, and I await only the return of the papers from Cayes to set them in order with justice [to all]. ${ }^{11}$

Profiting by an opportunity for New York, I have only time to refer to my letters of 15 September, 30 October, 19 December, 1818, 1st February, 15 April, 15 May, 3d August, 1819 , in all their contents.

Madam Audubon is coming to live with us; she found herself isolated at "La Gerbetière," and was very dull there; I wish that she may be contented here. She does not cease to

${ }^{11}$ This reference is evidently to the litigation over Lieutenant Audubon's will and the final disposition of his estate. 
speak of you, and is as much astonished as I am that we receive no news of you.

The naturalist's elder son, Victor, visited Couëron about the year 1835, when his cousin, Gabriel Loyen du Puigaudeau the second, who was nearly of the same age, returned from military service to meet him. He was disappointed at the appearance of his father's old home, "La Gerbetière," which had not been occupied by the family for fifteen years. ${ }^{12}$

Rosa Audubon du Puigaudeau, the naturalist's sister, died at "Les Tourterelles" after August 3, 1842, leaving a daughter, Rose du Puigaudeau, who died without issue, October 20, 1881, and, if we are correctly informed, one son, Gabriel Loyen du Puigaudeau the second, who died at "Les Tourterelles," Couëron, June 23, 1892, when past his eightieth year; a daughter of this only son was married to Monsieur L. Lavigne, notary at Couëron. At the time of her uncle's death, his property, including the personal records of Lieutenant Jean Audubon, passed into the hands of Madame Lavigne, who is a grand step-niece of the naturalist, and who aside from her children, so far as known, is the only surviving member of his family in France.

At this point we must examine a little more carefully the peculiar status of what Audubon referred to

${ }^{12}$ It was thought that Victor had come to settle the family's financial affairs, and his uncle and aunt asked if this were the case; he replied that it was not, that the children of Jean Audubon who were in America had taken their [share of the] property in that country, while those in France had theirs in France; he considered that all was settled, but if Rosa's children wished for any money, they had but to ask for it, and the heirs in America would send them what they desired; the subject was then dropped. A considerable correspondence followed this visit, but the letters were all destroyed about twenty-five years ago by Monsieur du Puigaudeau, when putting his effects in order. This account is given on the authority of Monsieur Lavigne. 
as the "enigma" of his life. 'In some of his private journals and letters ${ }^{13}$ he dramatically declared that a mystery had surrounded his early existence, which he was bound by a solemn oath exacted by his father never to reveal, and that this secret must be carried by him to the grave. If it be the duty of a biographer to make the true character of his subject known, the passage of time would now seem to sanction reference to many personal matters which a century ago should have been more rigidly guarded. I enter upon this task solely with the view of placing Audubon's character in a truer and fairer light.

The essential facts regarding Audubon's birth and early years have now been given, and this is the true, though possibly not the complete, story. Anything which we now add, however, can be regarded as little better than speculation. Audubon is said to have received through his father a large sum of money from an unknown or unnamed source, ${ }^{14}$ but as such stories are apt to be exaggerated, especially when an ocean intervenes between a testator and his heir, the statement may be erroneous; we have seen that Lieutenant Audubon was not in a position to make such gifts himself had he been so disposed. If the report were true, the money may have come from the estate of his mother, and through the agency of the mysterious "Audubon of La Ro-

${ }^{13}$ These passages, which were shown to me by his granddaughter, Miss Maria R. Audubon, in 1914, but not for publication, occur in his journals under the following dates; June 4, 1826, at sea; March 15, 1827, at Edinburgh, after describing a visit of Lady Selkirk and her daughter; again on the 18th of March of the same or the following year; and on October 8,1898 , when writing to his wife from Paris and reflecting on the advisability of visiting his old home at Nantes. While these extraordinary passages are not quoted, out of deference to the wishes of his granddaughters, it seems only just to Audubon, in view of the revelations that have already been made, to add this brief reference to the incidents in question.

${ }^{14}$ 'This statement was made to me in 1914 by Miss Maria R. Audubon. 
chelle," who is said to have been a politician. ${ }^{15}$ In some of the passages which we do not quote, the naturalist would have his family believe that he was of noble birth, that his adoptive father was not his true father, and that both he and Lieutenant Audubon had received irremediable injury through the treachery of the mysterious uncle, "Audubon of La Rochelle." Now these strange statements of the naturalist, though not in accord with the facts as they are known to us, should be interpreted, I believe, in the light of possible stories that may have come to him in the glamour of his youth; his mind may have been diverted by them, he may have believed them, but of this nothing now can positively be known. To continue our conjectures, it is possible that the plain conflict between these supposititious tales and the facts that were revealed at his adoption, his baptism, and in the wills of his father and stepmother, as well as by the lawsuit which followed the former's death, all led him to resort to "enigma." We should also remember that the naturalist, who was careless of dates and historical facts, had finally left his home at the age of twenty, when young men as a rule are not curious about their family history, and that he reached the reminiscent stage late in life. It seems probable that the wording of his father's will and the later attempt to annul it finally induced him to wash his hands of the whole matter, even to breaking off relations with his family in France. Feeling, as undoubtedly he did, that public knowledge of those conditions, for which he was in no way responsible, might be a bar to all future aspirations, he was not loath to let the matter rest, so far as he and his immediate family were concerned, under a cloak of mystery. If such were in truth.

${ }^{15}$ See Note, Vol. I, p. 27. 
the case, I think few would find cause to blame him-

When we view the whole subject in this double light, of a duty owed to his family and of the possibility that conflicting stories had come to him at an earlier day, any embroidery or confusion which appears in many of his statements of a personal nature can be better understood. Such an explanation would be quite convincing if payments had actually come to him from his own mother's estate.

We will only add that Mrs. Audubon, who seemed to have shared her husband's intimate thoughts, apparently believed to the last in his high birth. When her younger son, John Woodhouse Audubon, lay at the point of death, in February, 1862, she was summoned to his bedside, but reached it too late to see him alive; upon entering the room Mrs. Audubon is said to have exclaimed: "Oh, my son, my son! you died and never knew!" 


\section{CHAPTER XVIII}

\section{EARLY “EPISODES” OF WESTERN LIFE}

Methods of composition- "A Wild Horse"-Henderson to Philadelphia in 1811-Records of Audubon and Nolte, fellow travelers, comparedThe great earthquakes-The hurricane--The outlaw-Characterization of Daniel Boone-Desperate plight on the prairie-Regulator law in action-Frontier necessities-The ax married to the grindstone.

Audubon's sketches of life and scenery in America, which he designated as "Episodes," were interspersed in his Biography of birds ${ }^{1}$ to brighten the narrative and beguile the reader. Extending to the number of sixty, and dealing mainly with events between the years 1808 and 1834, they abound in tales of adventure and graphic pictures of pioneer life which for their personal charm, local coloring, and human interest are worthy of high praise. Some of these sketches have been copied widely and some have been translated into Audubon's native tongue; some have even found their way into schoolbooks. While they have deservedly won the naturalist many readers, not a few have subjected him to harsh criticism on the score of too vivid coloring or historical inaccuracy, a fault to which he was particularly prone. Whenever Audubon went directly to nature to exercise his pencil or brush or wrote with his subject before him, he was truth itself, but in writing offhand and from memory of past events he was wont

${ }^{1}$ In the first three volumes only of the Ornithological Biography (Bibl. No. 2), being omitted from the last two on account of the exigencies of space. 
to humor his fancy, disregarding dates as readily as he did the accents on French words. This tendency is particularly apparent in the accounts of some of his early adventures in the western country, such as "Louisville in Kentucky" (1808-10), "The Prairie" (1812), "A Wild Horse" (1811-13), and "The Eccentric Naturalist" (1818), the history of which is detailed in the following chapter. We shall examine some of these stories at this point, though their composition belongs to a later period, in order to reach a just conclusion in regard to the author's method, as well as for the intrinsic interest of the narratives themselves.

During Audubon's early life in Kentucky, as we have seen, he frequently visited the East, whether in the interest of birds or business, traveling by way of the river and the forest roads. Incidents of these journeys frequently occur in the "Episodes," but since dates commonly are omitted and the order of events is liable to be blended or confused, they cannot be trusted always for' historical accuracy. Thus, "The Wild Horse" episode ${ }^{2}$ professes to be an account of a single journey from Henderson, in Kentucky, to Philadelphia and back again, whereas some of the events recorded occurred in reality at least two years apart, such as the meeting with Nolte at the Falls of the Juniata River in December, 1811, and the naturalist's return from Pennsylvania with the proceeds of "Mill Grove," which could not have been earlier than 1813, the date of its sale to Mr. Samuel Wetherill, Junior. ${ }^{3}$

Audubon visited Philadelphia in November, 1811,

${ }^{2}$ Ornithological Biography, vol. iii, p. 270.

${ }^{3}$ While the object of this visit is not mentioned in the "Episode," it is stated in the second biographical sketch; the ambiguities connected with the sale of this farm, in which others besides Audubon were then interested, are discussed in Chapter XI. 
and returned to Kentucky in December of that year, but whether it was upon this or some other journey that he rode a wild horse through seven states in going from his home at Henderson to the Quaker city, or whether such a journey ever occurred, is immaterial to the interest of the narrative. In this instance, however, we have the advantage of comparing the notes of a fellow traveler, Vincent Nolte, then a merchant at New Orleans. ${ }^{4}$ First to follow Audubon's account, as given in his "Episode," we are told that he rode a wild mustang, named "Barro," that had never known a shoe, having been recently captured near the headwaters of the Arkansas. In going east he diverged from the beaten track to extend his knowledge of the country and of its bird life. From Henderson he passed through the heart of Tennessee to Knoxville, thence to Abington, the Natural Bridge, and Winchester in Virginia, crossed the corner of West Virginia to Harper's Ferry, then to Frederick, Maryland, and on through Lancaster to Philadelphia; there, he said, he remained four days, and returned by way of Pittsburgh, Wheeling, Zanesville, Chillicothe, Lexington and Louisville, to Henderson. He estimated the whole distance traversed at "nearly two thousand miles," and at a rate of "not less than forty miles a day." Much is said in praise of his favorite bay horse, and its food and daily treatment are duly recorded. This horse was very docile, and would wade swamps, swim rivers, and clear a rail fence like an elk; corn blades as well as corn and oats entered into his daily ration, to which a pumpkin and fresh eggs, when procurable, were occasionally added.

It was upon his return journey that the naturalist met with Vincent Nolte, who twelve years later did his

${ }^{4}$ Vincent Nolte, Fifty Years in Both Hemispheres (Bibl. No. 176). 
chance acquaintance a good turn, when the latter was about to sail for England in $1826 .^{5}$ Nolte, said Audubon,

was mounted on a superb horse, for which he had paid three hundred dollars, and a servant on horseback led another as a change. I was then an utter stranger to him, and when I approached and praised his horse, he not very courteously observed that he wished $\mathrm{I}$ had as good a one. Finding that he was going to Bedford to spend the night, I asked him what hour he would get there: "Just soon enough to have some trouts ready for our supper, provided you will join when you get there." I almost imagined that Barro understood our conversation; he pricked up his ears, and lengthened his pace, on which Mr. Nolte caracolled his horse, and then put him to quick trot, but all in vain; for I reached the hotel nearly a quarter of an hour before him, ordered the trouts, saw to the putting away of my good horse, and stood ready at the door to welcome my companion. From that day to this Vincent Nolte has been a friend to me.

Audubon added that they rode together as far as Shippingport, now a part of Louisville, where his brother-in-law, Nicholas Berthoud, was then living.

We shall now follow the equally circumstantial but widely divergent account of this meeting and the subsequent journey as given by the other traveler. Nolte had sailed from Liverpool in September, 1811, and landed in New York after a perilous voyage of fortyeight days. He had no servant, but was accompanied by a young Englishman, named Edward Hollander, whom he had engaged in a business capacity while in London and with whom he was making his way to New Orleans. Hollander had been sent in advance to Pitts- 
burgh to purchase two flatboats, for in addition to their horses they had planned to carry 400 barrels of flour, from the sale of which in the South they expected to defray the expenses of their journey. Having purchased a fine horse in Philadelphia, Nolte left that city in December, and with saddle-bags strapped to his horse's back, rode on "entirely alone." He crossed the highest point of the Alleghany ridge at ten o'clock of a winter's morning and later in the same day reached a small inn "close by the Falls of the Juniata River." "The landlady," to quote his narrative, "showed me into a room, and said, I perhaps would not mind taking my meal with a strange gentleman, who was already there." This stranger, who immediately struck him as "an odd fish," "was sitting at a table, before the fire, with a Madras handkerchief wound around his head, exactly in the style of the French mariners, or laborers, in a seaport town." In the course of the conversation which then ensued he declared that he was an Englishman, but Nolte was the last person to be deceived on a question of nationality and remarked at once that his speech betrayed him. "He showed himself," to quote our senior traveler again, "to be an original throughout, but at last admitted that he was a Frenchman by birth, and a native of La Rochelle. However, he had come in his early youth to Louisiana, had grown up in the seaservice, and had gradually become a thorough American." When asked how this account squared with his earlier statement, said Nolte, "he found it convenient to reply in the French language: 'when all is said and done, I am somewhat cosmopolitan; I belong to every country.' This man," to conclude, "who afterwards won for himself so great a name in natural history, particularly in ornithology, was Audubon, who, however, 
was by no means thinking, at that time, of occupying himself with natural history.'

In the interview as thus far recorded, Audubon was clearly chaffing his new acquaintance, for not one of the statements attributed to him was true, if we accept the fact of his French extraction. Nolte, to be sure, writes as a somewhat vain and garrulous man, and after a lapse of forty-three years, but he professes to speak the truth and there is no reason to suppose that his narrative is pure invention. Nolte further informs us that Audubon's father-in-law, Mr. Bakewell, "formerly of Philadelphia," was "then residing and owning mills at Shippingport," which was not the case. To continue, finding that Audubon, who was bound for Kentucky, was a companionable man and devoted to art, a field which he had cultivated himself, Nolte proposed that they should travel together, and offered the naturalist a berth on one of his flatboats.

He thankfully accepted the invitation, and we left Pittsburgh in very cold weather, with the Monongahela and Ohio rivers full of drifting ice, in the beginning of January, 1812. I learned nothing further of his traveling plans until we reached Limestone, a little place in the southwestern corner of the State of Ohio. ${ }^{6}$ There we had both our horses taken ashore, and I resolved to go with him overland, at first to visit the capital, Lexington, and from there to Louisville, where he expected to find his wife and parents-in-law. . . . We had hardly finished our breakfast at Limestone, when Audubon, all at once, sprang to his feet, and exclaimed in French; "Now I am going to lay the foundation of my establishment." So saying, he took a small packet of address cards from his pocket, and some nails from his vest, and began to nail up one of the cards to the door of the tavern, where we were taking our meal.

${ }^{6}$ Limestone or, as it was later called, Maysville, was on the left bank of the river, in Kentucky, and about a hundred miles east of Cincinnati. 
Later they rode on together as far as Lexington, where they appear to have parted company.

The discrepancies between these accounts could hardly be greater, and they serve to illustrate the liberties which Audubon sometimes took with facts in composing his "Episodes." The travelers met, not on horseback, but at the supper table of a country inn; Nolte was then alone and had but one horse, while the greater part of the return journey was made by flatboat with Audubon as his guest; corn blades, pumpkins and trout suggest any other season than midwinter, with heavy snows on the mountains and rivers choked with ice. Audubon in this instance, as already explained, combined the incidents of two different journeys and colored the narrative to suit his fancy. There was no apparent motive to mislead the reader, and one of his readers he must have known would probably be Vincent Nolte, though he was not a subscriber to The Birds of America; Nolte did read the story, and was pleased with the "flattering acknowledgment of the little service" that he was able to render Audubon at that time as well as later in his career.

Both travelers felt the great earthquakes while making this journey, but probably not until they had parted company at Lexington. Audubon has given a vivid account of this experience in a characteristic sketch, but as usual there are no dates. ${ }^{7}$ He was overtaken, as he said, while "traveling through the Barrens of Kentucky . . . in the month of November," when he thought his terrified "horse was about to die, and would have sprung from his back had a minute more elapsed, but at that instant all the shrubs and trees began to move from their very roots; the ground rose and fell in successive

“"The Earthquake," Ornithological Biography, vol. i, p. 239. 
furrows, like the ruffled waters of a lake." For "November" he should have written "January" of the year $1812 .{ }^{8}$

This series of memorable earthquakes was followed in 1813 by a hurricane, more terrific than destructive, which swept the lower part of Henderson County, Kentucky, and cut a wide swath through the virgin forests, without causing any loss of life. Audubon's account of this event ${ }^{9}$ is that of a close observer who escaped destruction by a hair's breadth and who related only what he himself had experienced. Critics inclined to be supercilious have complained that he exaggerated the importance of a merely local event and stretched the course of the storm some $\mathbf{8 0 0}$ miles until it had covered several states. "Sir," said Waterton, in pointing a dart through Audubon to another target, "this is really too much even for us Englishmen to swallow, whose gullets are known to be the largest, the widest, and the most elastic, of any in the world." What Audubon said was: "I have crossed the path of this storm, at a distance of a hundred miles from the spot where $I$ witnessed its fury, and, again four hundred miles farther off, in the State of Ohio. Lastly, I observed traces of its ravages on the summits of the mountains connected with the

${ }^{8}$ These historic earthquakes, which were most destructive of life and property in the lower Mississippi Valley, began on December 16, 1811, and therefore before Audubon and Nolte had reached the western country. They were noted for their remarkable frequency and persistence, 221 shocks having been recorded in a single week at Henderson, Audubon's home at that time; though their force was mostly spent after the first three months, they did not wholly die away in the Ohio Valley until December 12, 1813, when the last feeble vibration was recorded by Dr. Daniel Drake at Cincinnati; the worst shocks at this point were experienced on December 16, 1811, on January 23 and February 7, 1812. See Daniel Drake, Natural and Statistical Yiew of Cincinnati, and the Miami Valley; with an appendix, containing observations on the late Earthquakes, (Cincinnati, 1815); and Edmund L. Starling, History of Henderson County, Kentucky (Bibl. No. 186).

๑ "The Hurricane," Ornithological Biography, vol. i, p. 262. 
Great Pine Forest of Pennsylvania, three hundred miles beyond the place last mentioned. In all these different parts, it appeared to me not to have exceeded a quarter of a mile in breadth." Audubon was doubtless mistaken in his hasty inference that marks of forest devastation observed at such widely separated points were due to the same storm, but this would only illustrate a lack of caution which he sometimes displayed.

A contemporary writer ${ }^{10}$ declared that Audubon's account of "Mason," the outlaw, whose name we are told should be spelled "Meason," was altogether fabulous; that he was not killed by a regulator party, nor was his head stuck upon a tree in the way described. ${ }^{11}$ The same critic further discredited the naturalist's account of Daniel Boone, whom he had characterized as follows: " "The stature and general appearance of this wanderer of the western forests approached the gigantic. His chest was broad and prominent; his muscular powers displayed themselves in every limb; his countenance gave indication of his great courage, enterprise, and perseverance." "Boone," said this writer, "was under six feet high, probably not more than five feet, ten inches, and of that round, compact build, which makes little show. Though very active, he had the appearance of being rather slender and did not seem as large as he really was." In the case of the outlaw, Audubon no doubt retold a story that had passed from mouth to mouth, but he later learned to be wary of second-hand information, which in matters of natural history sometimes led him into more serious difficulties. In his description of Boone there was no more apparent

${ }^{10}$ James Hall (Bibl. No. 123), Western Monthly Magazine, vol. ii (1834).

11 "The Regulators," Ornithological Biography, vol. i, p. 105.

12 "Colonel Boone," ibid., vol. i, p. 503. 
motive to deceive than in the case of his own father, to whom his imagination had added nearly half a foot in stature. $^{13}$

When Audubon was returning from Ste. Geneviève in the spring of 1812, an incident occurred in which, for the first time in the course of his wanderings for upwards of twenty-five years, he felt his life to be in danger from his fellow man. ${ }^{14}$ Overtaken by night on the prairie, he approached the hearth fire of a small $\log$ cabin, which at first was mistaken for the campfire of some wandering Indians. On craving shelter, he was admitted by a tall, surly woman in coarse attire, who displayed both an evil eye and a repellent countenance; but she offered him a supper of venison and jerked buffalo meat and bade him to make his bed upon the floor. When she espied his gold watch and chain, her demeanor suddenly changed and she asked to take them in her hand; she put the chain around her brawny neck and by her manner betrayed every token of covetous desire. Meanwhile, a young Indian stoic, who was nursing a recent arrow wound, had been sitting in silence by the fire; though he spoke not a word, he cast an expressive glance in Audubon's direction whenever the woman's back was turned, and having drawn his knife from its scabbard, expressed in pantomime what the confiding stranger might eventually expect.

Audubon's suspicions were at last thoroughly aroused. He asked for his watch, and under pretense of forecasting the weather, took up his gun and sauntered out of the cabin; in the darkness outside he slipped a ball in each of the barrels of his gun, scraped the edges of his flints, renewed the primings, and returned with a

${ }^{13}$ See Chapter V, p. 88.

14 "The Prairie," Ornithological Biography, vol. i, p. 81. 
favorable report of his observations. Then laying some deer skins on the floor in a corner and calling his faithful $\operatorname{dog}$ to his side, he lay down and to all appearances was soon asleep. Presently sounds of approaching voices were heard, and at length two sturdy youths, who were evidently the woman's sons, appeared bearing a dead stag, which they had slung to a pole; they asked at once about the stranger, and called loudly for whisky. Audubon tapped his dog, who showed by eye and tail that he was already alert. Observing that the whisky bottle was paying frequent visits to the mouths of the trio, he hoped that they would soon be reduced to a state of helplessness, but the woman was seen to take in her hands a large carving knife and go deliberately outside to whet its edge on a grindstone; then, calling to her drunken sons, she asked them to settle the stranger and bade them do their bloody work without delay. Audubon cocked both barrels of his gun, touched his dog again, and was resolved to shoot at the first suspicious move. At this dramatic moment the door suddenly opened and two burly travelers with rifles on their shoulders entered the cabin. Audubon sprang to his feet, and welcoming the strangers with open arms, lost no time in making known to them his desperate position. No parley was necessary, for, said he, they were regulators, who then and there took the law into their own hands. The woman and her sons were promptly secured, bound, and left until morning to sober off; they were then led into the woods and shot. "We marched them into the woods off the road," said Audubon, "and having used them as Regulators were wont to use such delinquents, we set fire to the cabin, gave all the skins and implements to the young Indian, and proceeded, well pleased, towards the settlements." 
Would you believe, he added, that not many miles from where this happened, "and where fifteen years ago, no habitation belonging to civilized man was expected, and very few ever seen, large roads are now laid out, cultivation has converted the woods into fertile fields; taverns have been erected, and much of what we Americans call comfort is to be met with? So fast does improvement proceed in our abundant and free country."

I have given a paraphrase of this "Episode" as a further illustration of Audubon's tales of adventure. There is doubtless a certain amount of invention, and it reads like the setting of a dime novel incident, but we see no reason to doubt the substantial truth of either the local coloring or the fact. In answer to the question of a recent commentator, ${ }^{15}$ "Did remote prairie cabins have grindstones and carving knives?" we would reply that the knife and the ax have followed man to the frontier posts of civilization everywhere, and without the grindstone the ax is useless. As a concrete instance in point, compare this minute entered in the Proprietors' Book of Records of Perrytown, afterwards Sutton, New Hampshire, ${ }^{16}$ for the third day of September, 1770: "Voted a grindstone of about 8 shillings to be sent up to Perrystown, for the use of the settlers there"; the first settler had entered that wilderness but three years before, and at the time this vote was taken the number was five.

\footnotetext{
${ }^{15}$ John Burroughs, John James Audubon (Bibl. No. 8\%), p. 37.

10 See History of Sutton, New Hampshire, compiled by Augustus Harvey Worthen, pt. 1 (Concord, 1890).
} 


\section{CHAPTER XIX}

\section{AUDUBON AND RAFINESQUE}

The "Eccentric Naturalist" at Henderson-Bats and new species-The demolished violin-"M. de T.": Constantine Samuel Rafinesque (Schmaltz)-His precocity, linguistic acquirements and peripatetic habits--First visit to America and botanical studies--Residence in Sicily, and fortune made in the drug trade-Association with Swainson-Marriage and embitterment-His second journey to America ends in shipwreck-Befriended-Descends the Ohio in a flatboat-Visit with Audubon, who gives him many strange "new species"-Cost to zoölogy-His unique work on Ohio fishes-Professorship in Transylvania University-Quarrel with its president and trustees-Return to Philadelphia-His ardent love of nature; his writings and fatal versatilityHis singular will-His sad end and the ruthless disposition of his estate.

Audubon's humorous sketch of "The Eccentric Naturalist" has often been quoted, and it presents a picture which is amusing, however short of the truth it may fall or however it may fail in doing justice to its subject. Though his real hero is not named, no doubt as to his identity has ever been entertained. 'This episode occurred at Henderson in the late summer of 1818, and was published thirteen years after in the Biography of birds. ${ }^{1}$ Since the story was not fully told then and the after-effects were productive of much harsh criticism, it cannot be overlooked if we would do justice to both the writer and his subject.

When walking one day by the river, to follow Audubon's story, he saw a man landing from a boat with what appeared like a bundle of dried clover on his back;

" "The Eccentric Naturalist," Ornithological Biography (Bibl. No. 2), vol. i, p. 455 . 
he concluded from his appearance that the stranger must be "an original," a term which had been applied also to himself. A meeting followed, and the stranger, who had inquired for Mr. Audubon's house, explained that he was a naturalist, and had come to see Audubon's drawings of birds and plants; he bore also a letter from a friend, introducing "an odd fish" which might "prove to be undescribed." The visitor was made welcome in Audubon's Henderson home, where, to quote the naturalist,

at table his agreeable conversation made us all forget his singular appearance... A long loose coat of yellow nankeen, much the worse of the many rubs it had got in its time, and stained all over with the juice of plants, hung loosely about him like a sac. A waistcoat of the same, with enormous pockets, and buttoned up to the chin, reached below over a pair of tight pantaloons, the lower parts of which were buttoned down to the ankles. His beard was as long as I have known mine to be during some of my peregrinations, and his lank black hair hung loosely over his shoulders. His forehead was so broad and prominent that any tyro in phrenology would instantly have pronounced it to be the residence of a mind of strong powers. His words impressed an assurance of rigid truth, and as he directed the conversation to the study of the natural sciences, I listened to him with as much delight as Telemachus could have listened to Mentor.

All had retired for the night when of a sudden a great uproar was heard in the visitor's room. To his great astonishment, Audubon found his guest running about the apartment naked, holding the "handle" of his host's favorite violin, the body of which had been battered to pieces against the walls in the attempt to secure a number of fluttering bats which had entered by an open window. "I stood amazed," said Audubon, "but he 
continued jumping and running round and round, until he was fairly exhausted, when he begged me to procure one of the animals for him, as he felt convinced they belonged to 'a new species.' Although I was convinced to the contrary, I took up the bow of my demolished Cremona, and administering a sharp tap to each of the bats as it came up, soon had specimens enough." Other incidents of this visit, which Audubon said lasted three weeks, are fully recorded. The eccentric naturalist collected an abundance of plants, shells, bats and fishes. One evening he failed to appear, and after a prolonged search was nowhere to be found; nor were the Audubons wholly assured of his safety until some weeks later they received a letter with due acknowledgments of their hospitality.

The "M. de T." of this episode was Constantine Samuel Rafinesque, in many respects the most singular figure that has ever appeared in the annals of American science. Although young in years, for Rafinesque was then but thirty-five, he was already old in experience and that of the bitterest sort; and although already known to many in both hemispheres, he had few friends. It is certain that neither Audubon nor anyone else in that part of Kentucky had ever heard of him before.

Born in Constantinople, of a father who was a French merchant from Marseilles and of a mother with a German name who by nativity was Greek, Rafinesque had known life in many lands, and was destined, as he said, to be a traveler from the cradle to the tomb. ${ }^{2}$ His

${ }^{2}$ For the characterization of Rafinesque given in the present chapter I am chiefly indebted, aside from his own writings, to his two most sympathetic biographers, Richard Ellsworth Call and T. J. Fitzpatrick, as well as to David Starr Jordan; see Bibliography, Nos, 198, 228, and 183. Fitzpatrick gives photographic reproductions from Rafinesque's exceedingly diversiform and scattered works; his bibliographic titles extend to 939, and "Rafinesquiana" to 134 . 
first voyage, made with his parents on their return to France, by way of Scutari in Asia, Smyrna, and Malta, led to his first discovery, when he was a year old, for he was able to announce that "infants are not subject to sea-sickness." At eleven he read Latin and collected plants; at thirteen he wrote his first scientific paper, "Notes on the Apennines," which he had seen when traveling from Leghorn to Genoa. His father, who set out for China in 1791, fell in with pirates, but managed to reach America; he died of the yellow fever in Philadelphia in 1793. To escape the Reign of 'Terror in France, Rafinesque's mother fled with her children to Italy, where four years were passed at Leghorn. There Constantine studied with private tutors, but his education was never formal and he was allowed to follow his omnivorous tastes, reading, as he said, ten times more than was taught in the schools. His writings are mainly in French, Italian, and English, and his facility with languages was no doubt remarkable, even if we discount his egotized estimate of his own attainments: "I have undertaken to read the Latin and Greek, as well as the Hebrew, Sanskrit, Chinese, and fifty other languages, as I felt the need or inclination to study them."

In 1802 Rafinesque was sent with his brother to America and became a shipper's clerk at Philadelphia, where he spent all of his spare time in the study of nature, plants being his first and greatest love. Here he was befriended by Dr. Benjamin Rush, and during this period he made the acquaintance of many pioneer naturalists in the United States. In 180.5 the offer of a lucrative situation in Sicily lured him back to the Old World and to a country already known to him. There he soon discovered the medicinal squill, of ancient re- 
pute and thought to be an antidote, which in the form of syrup was long the bane of childhood; this and other medicinal drugs he exported to the European and American markets in such quantities that before the secret of his trade became known to the jealous Sicilians, he had reaped from it, in conjunction with his other enterprises, a small fortune. During the ten years that were spent in Sicily we find him the manager of a successful whisky distillery, the chancellor or secretary of the American Consulate at Palermo, editor, writer, and correspondent of learned men in Europe, as well as traveler and explorer in every part of the island, which he proposed to monograph with all of its contents. At Palermo Rafinesque met the English naturalist, William Swainson, his lifelong correspondent; together they tramped over the island and together they worked for a number of years on the fishes of the western coast. ${ }^{3}$ Swainson, who became the friend of Audubon, was one of the few who later defended Rafinesque.

Rafinesque espoused a Sicilian woman of the Catholic faith, and had by her two children, of whom a daughter lived to maturity; this experience seems to have embittered him against the sex, for no other woman excepting his mother, to whom his Life of Travels was dedicated, was ever mentioned in his writings, and this one was disinherited in his extraordinary will. 'Through fear of being drafted into the French wars, he assumed for a time his mother's family name of Schmaltz, and finally left Sicily in disgust; taking with him his fortune and "fifty boxes of personal goods,"

3 "At Palermo," said Swainson, "I had the pleasure of meeting . . Rafinesque Schmaltz, whose first name is familiar to most zoölogists. In the society of such congenial minds, I passed many happy hours, and made many delightful excursions ... by the inducement of the latter, I was led to investigate the ichthyology of the western coast." (See Bibliography, No. 170.) 
he set out again for America in 1815. Sicily, he declared in epigram, offered "a fruitful soil, a delightful climate, excellent productions, perfidious men, deceitful women.'

This second voyage to the New World began late in July but did not end until 100 days later, when, on the night of November 2, his ship ran on the Race Rocks near New London, at the western end of Long Island Sound, and eventually went down within sight of land with all his possessions. "I had lost everything," he said, "my fortune, my share of the cargo, my collections and labors for twenty years past, my books, my manuscripts, my drawings, even my clothes . . . all that I possessed, except some scattered funds, and the insurance ordered in England for one third of the value of my goods." "I have found men," he continued, "vile enough to laugh without shame at my misfortune, instead of condoling with me! But I have met also with friends who deplored my loss, and helped me in need." One of these friends was Dr. Samuel L. Mitchell of New York, who had given a helping hand to Audubon, ${ }^{4}$ and it was probably through him that Rafinesque obtained a position as private tutor in a family living on the Hudson. Traveling up and down the country, collecting objects in natural histcry, writing, with frustrated attempts at business, occupied a number of the following years; meanwhile ke had aided in founding the Lyceum of New York and had become a member of the Literary and Philosophical Society. At Philadelphia he found another friend in Mr. John O. Clifford, of Lexington, Kentucky, who encouraged him to visit the West, and in the spring of 1818 he descended the Ohio in an "ark" in company with several others who 
had joined him in the enterprise. At Shippingport he was welcomed by the Tarascon brothers, flour merchants, formerly of Marseilles and Philadelphia, and it was through them, possibly, that he first heard of Audubon's drawings of birds.

Such was the "odd fish" who a little later greeted Audubon on the river bank at Henderson. Mad Audubon known the true history of his visitor either then or at a later time, he would not, we believe, have held him up to ridicule in the "Episode" quoted above, and could he have foreseen the unpleasant consequences that ensued, his conduct would assuredly have been different. A part of the episode, which Audubon does not relate, was supplied by another naturalist at a much later day. ${ }^{5}$ Audubon, it seems, was at that time a good deal of a wag, and whether to vent his dislike of species-mongers, to avenge the loss of his violin, or to gratify some spirit of mischief, he played upon the credulity of his guest, in a way that could be deemed hardly creditable, in giving him detailed descriptions and even supplying him with drawings of sundry impossible fishes and mollusks. Rafinesque took the bait eagerly, duly noted down everything on the spot, and, what was more un-

${ }^{5}$ See David Starr Jordan (Bibl. No. 183), Popular Science Monthly, vol. xxix (1886). "The true story of this practical joke was told me by the venerable Dr. Kirtland, who in turn received it from Dr. Bachman;" the latter, I might add, was the friend and correspondent of the "Sage of Rockport" after a visit at his home near Cleveland in the summer of 1852. In the private notebooks of Rafinesque copies of Audubon's drawings are still to be seen, and "a glance at these," said Dr. Jordan, "is sufficient to show the extent to which science through him has been victimized."

Audubon was also responsible for a number of extraordinary "new species" of birds, the most notorious of which was the Scarlet-headed Swallow, of which Rafinesque published the following account in 1820: "Hirundo phenicephala. Head scarlet, back gray, belly white, bill and feet black. A fine and rare swallow seen only once by Mr. Audubon near Henderson, Kentucky . .." See Samuel N. Rhoad, "Constantine S. Rafinesque as an Ornithologist," Cassinia, No. XV (Philadelphia, 1911). 
fortunate for American zoölogy, a year later began to publish the results. The fictitious species of fish, to the number of ten, "communicated by Mr. Audubon," first appeared as a series of articles in a short-lived and long forgotten western magazine, ${ }^{6}$ but in 1820 they were gathered into a little volume ${ }^{7}$ now considered so quaint and rare that it has been reproduced in its entirety. In this pioneer work on the ichthyology of the Ohio River and the great Middle West, 111 kinds of American fresh-water fishes are briefly described. Those ten "new species," representing apparently a number of new genera, "so like and yet so unlike to anything yet known," long remained a stumbling block to American zoölogists; naturally they tended to discredit the work of Rafinesque.

${ }^{6}$ The Western Review and Miscellaneous Magazine, Lexington, 1819-20.

${ }^{7}$ Ichthyologia Ohiensis, or Natural History of the Fishes inhabiting the River Ohio and its tributary Streams, preceded by a physical description of the Ohio and its branches. By C. S. Rafinesque, Professor of Botany and Natural History in Transylvania University, Author of the Analysis of Nature, \&c. \&c. Member of the Literary and Philosophical Society of New-York, the Historical Society of New-York, the Lyceum of Natural History of New-York, the Academy of Natural Sciences of Philadelphia, the American Antiquarian Society, the Royal Institute of Natural Sciences of Naples, the Italian Society of Arts and Sciences, the Medical Societies of Lexington and Cincinnati, \&c. \&c.

"The art of seeing well, or of noticing and distinguishing with accuracy the objects which we perceive, is a high faculty of the mind, unfolded in few individuals, and despised by those who can neither acquire it, nor appreciate its results."

Lexington, Kentucky: printed for the author by W. G. Hunt. (Price one dollar.) (Pp. 1-90. Lexington, 1820.)

Fitzpatrick (see Bibliography, No. 2:8) gives a list of 14 copies of this work, the whereabouts of which are known; we can add another from the library of Dr. Jared P. Kirtland, now in the collections of Western Reserve University; it is bound up with Dr. Kirtland's notebook on birds and fishes, and labeled "Scraps of Natural History. My Note Book;" a written notice on the inside of the cover, imploring the finder to return the volume to its owner if lost, is signed by Dr. Kirtland and dated "Cleveland, O., Oct. 16th, 1839." Probably fewer than 20 original copies of the work now exist. It was reproduced in a limited edition, with a sketch of Rafinesque's life and works by Richard Ellsworth Call, published by the Burrows Brothers' Company of Cleveland in 1899. 


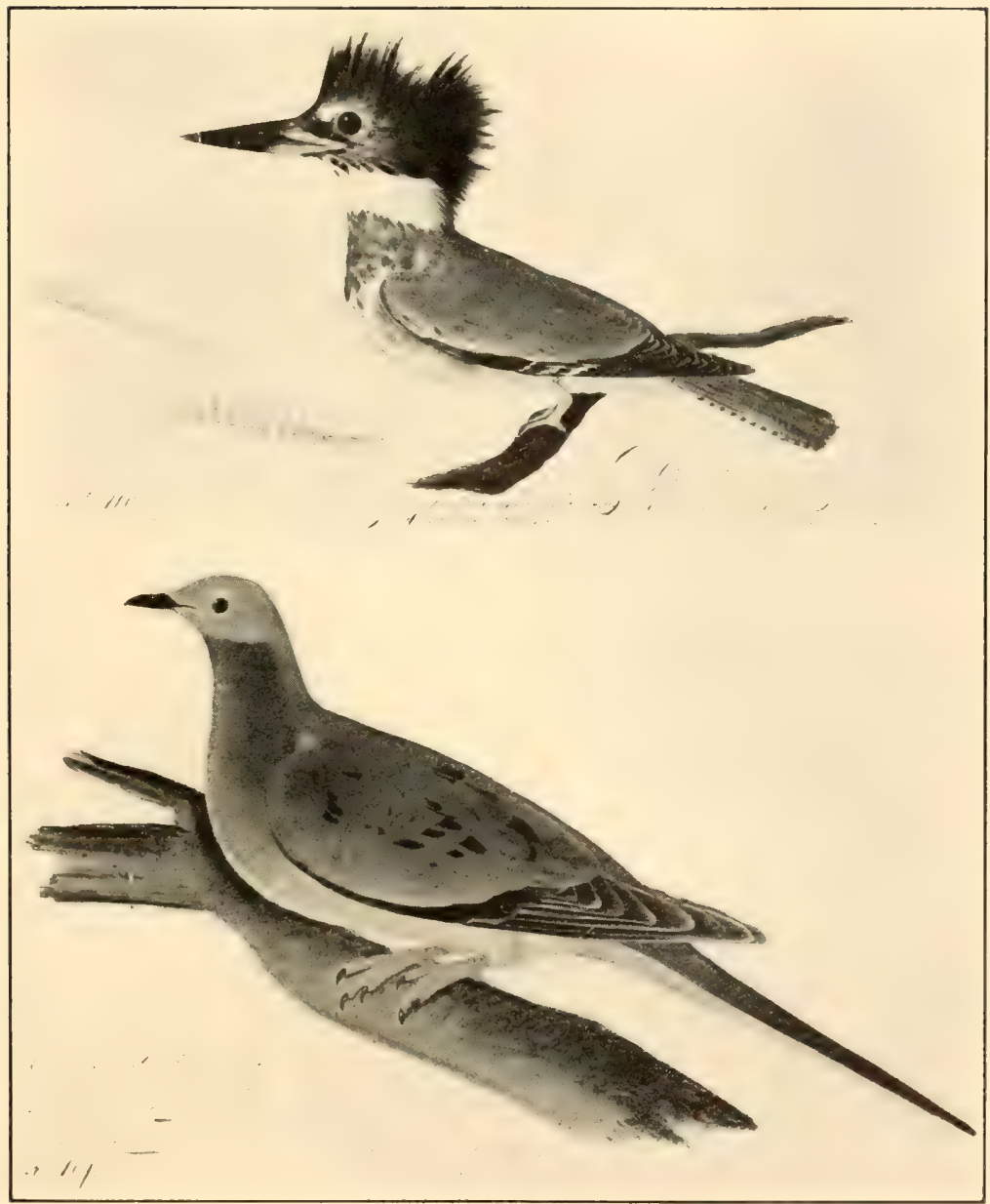

EARLY UNPUBLISHED DRAWINGS OF AMERICAN BIRDS: ABOVE, "L'ALCION D'AMERIQUE SEPTENTRIONAJE BUFFON, KING FISHER. CHUTE DE L'OHIO JULY 15,

1808. BELTED KING FISHER A. W.-J. A. AICEDO ALCION. DRAWN BY J. J. AUDUBON. No, 110 ;" BEIOW, "PASSENGER PIGEON-A. W. COI.UMBA MIRATORIA. CHUTE DE I'OHIO. DECEMB. 11, 1809. 12 PEN NES À LA QUEUE TRES ÉTAGEE. APPEIÉ ICI WILD PJGEON, J. AUd'BON. No. 109."

Published by courtesy of Mr. Joseph Y. Jeanes. 

As a specimen of these spurious fish stories, which were previously published in both America and Europe, we reproduce a part of Rafinesque's description of the "91st. Species. Devil-Jack Diamond-fish. Litholepis adamantinus":

This may be reckoned the wonder of the Ohio. It is only found as far up as the falls, and probably lives also in the Mississippi. I have seen it, but only at a distance, and have been shown some of its singular scales. Wonderful stories are related concerning this fish, but I have principally relied upon the description and figure given me by Mr. Audubon. Its length is from 4 to 10 feet. One was caught which weighed four hundred pounds. It lies sometimes asleep or motionless on the surface of the water, and may be mistaken for a $\log$ or a snag. It is impossible to take it in any other way than with the seine or a very strong hook, the prongs of the gig cannot pierce the scales which are as hard as flint, and even proof against lead balls! Its flesh is not good to eat. It is a voracious fish: Its vulgar names are Diamond fish, (owing to its scales being cut like diamonds) Devil fish, Jack fish, Garjack, \&c. . . . The whole body covered with large stone scales laying in oblique rows, they are conical, pentagonal, and pentædral with equal sides, from half an inch to one inch in diameter, brown at first, but becoming of the colour of turtle shell when dry: they strike fire with steel! and are ball proof!

While we cannot defend Audubon in his treatment of Rafinesque, it would be hardly fair to judge such incidents wholly in the light of after events, for, as our narrative will show, it is unlikely that he ever saw Rafinesque or heard of him again until long years after this incident, certainly not until after his "Episode" was published in 1831. ${ }^{8}$ Rafinesque evidently enjoyed

Probably not before October of that year, when Audubon first met John Bachman, at Charleston, South Carolina. 
this sketch of himself, for he gave unstinted praise to the work in which it was published. As late as 1832, when the appearance of The Birds of America seems to have stimulated him to even more grandiose conceptions of his own merits than was usual, he declared that his discoveries were counted by the thousand, and that he had traveled twenty thousand miles, always collecting and drawing. In view of the fact that drawing was a talent which nature had unequivocally denied him, it is interesting to read this boast that an unfriendly critic drew forth: "My illustrations of 30 years' travels, with 2,000 figures will soon begin to be published, and be superior to those of my friend Audubon, in extent and variety, if not equal in beauty. I shall study and write as long as I live, in spite of all such mean attempts against my reputation and exertions, trusting in the justice of liberal men." 9

After leaving Audubon at Henderson in the summer of 1818, Rafinesque passed down the Ohio into the Mississippi, pausing only to pay his respects at the famous communistic settlement of New Harmony, by the mouth of the Wabash in Indiana, later the abode of Thomas Say, David Dale Owen, and Charles Le Sueur, all of whom have left bright and honored names in the annals of American science. He eventually returned to Philadelphia by way of Lexington, Kentucky, where he was induced to settle and teach natural history and the modern languages in the Transylvania University, at that time the most important seat of learning in the West. After closing up his business

'Reply to a criticism of G. W. Featherstonhaugh (The Monthly American Journal of Geological Science), in Rafinesque's Atlantic Journal and Friend of Knowledge, No. 3, p. 113 (Philadelphia, 1832). Rafinesque occasionally spoke of meeting "my friend Audubon," who, he declared, had invited him to join his expedition to Florida in 1831-32. 
affairs in Philadelphia, Rafinesque entered upon his new labors at Lexington in the autumn of 1819. He was probably the first teacher of these subjects west of the Alleghanies, and certainly the first in that section of the country to use the present object method in the elucidation of natural history. The lot of a pioneer in education has never been a sinecure, and the post which Rafinesque then filled was not a "chair" but a hard "settee." In those days the classics were in the saddle and "rode mankind," while the natural sciences, when tolerated at all, were given short shrift; yet this eccentric foreigner held his position for seven years and accomplished an extraordinary amount of work. As usual he spread his energies over the whole field of knowledge, lecturing, writing and publishing on almost every subject, but concentrating upon none. Meanwhile, he roamed far and wide and made extensive collections.

While at the Transylvania University Rafinesque seems to have applied for the master of arts' degree, but was at first refused, as he said, "because I had not studied Greek in a college, although I knew more languages than all of the American colleges united, but it was granted at last; but the Doctor of medicine was not granted, because I would not superintend anatomical dissections."

One of his many projects, as meritorious as it was impractical, at that time, was a Botanic Garden with a Library and Museum for Lexington, which was then but a small village; though land was actually secured and a start in tree planting begun, the project of course came to nothing and had to be abandoned. Rafinesque also invented, as he believed, the present coupon system of issuing bonds, the "Divitial Invention," as he called 
it; in $\mathbf{1 8 2 5}$ he set out for Washington in order to secure his patent rights, but his journey and idea never brought him any returns. On the contrary, the incident marked the culmination of his troubles with the president of the University and its governing board, whom he seems to have constantly nettled by his independent ways and roaming habits. Upon returning from Washington he found that Dr. Holley, who, he said, "hated and despised the natural sciences" and wished to drive him out altogether, had broken into his rooms during his absence, and had "given one to the students, and thrown all my effects, books and collections in a heap in the other," besides depriving him of certain other privileges. "I took lodgings," he continued, "in town and carried there all my effects; thus leaving the college with curses on it and Holley; who were both reached by them soon after, since he died next year at sea of the yellow fever, caught at New Orleans; having been driven from Lexington by public opinion; and the College has been burnt in 1828 with all its contents."

After this unpleasant experience Rafinesque returned to Philadelphia, where he spent the last and saddest part of his checkered career. His insistent ideas, which were undoubtedly the index of an unbalanced mind, increased, especially his mania for describing "new species" of animals and plants; this mania perverted everything that he wrote, especially toward the end of his life, and made him a thorn in the side of every naturalist who tried to verify his work. A nonconformist and a respecter of no authority but his own is never popular, though a part of the antagonism which Rafinesque aroused was due to the conservatism of his age. He boldly advocated organic evolution when almost the whole world believed that species were fixed 
and unchangeable things, and in many other respects was fifty years ahead of his time; but nothing was ever carefully worked out in his fertile mind, with the consequence that the world paid no heed to his crude and undigested ideas.

The great mass of Rafinesque's books and monographs, his "tracts," broadsides, and ephemeral papers of all sorts, extending to nearly a thousand titles, must have gone into paper rags, when not used to kindle fires, for he was generous in their distribution, and they are now exceedingly rare. He touched nearly everything, it is true, but little that he touched, especially in this later period of his life, did he ever truly ornament. His best pioneer work, in the opinion of competent students, was that done upon the fishes of Sicily and the natural history of the Ohio Valley; his Medical Flora, in two volumes (1828 and 1830), is also admitted to have possessed real value; but his writings are now sought after as literary or scientific curiosities, and as such they are unique.

No doubt Rafinesque was often treated unjustly, either through ignorance or intent, while many naturalists were exasperated by the barbed arrows which he shot into the air or direct at the mark. Others through sheer inability to follow him gave up the attempt, one writer ${ }^{10}$ saying that such an attitude was justified when it appeared that he had made six species out of one, not to speak of several different genera and two subfamilies. If anyone still believes that Rafinesque has been misjudged, says Günther, ${ }^{11}$ let him read his letters to Swainson, from 1809 to 1840 , fifty-three in number,

${ }^{10}$ Isaac Lea, in A Synopsis of the Family of Naiades, pp. 8-9 (Philadelphia, 1836).

${ }^{11}$ See Bibliography, No. 204. 
covering 178 closely written quarto or folio pages, now in possession of the Linnæan Society of London. "Rafinesque," continues this critic, "was a man deeply to be commiserated, not merely on account of the unfortunate circumstances which left him in his youth to himself, without teacher or guide, but still more on the ground of that natural disposition by which his universal failure in life was brought about. He was possessed of a feverish restlessness which entirely disqualified him from serious study of any of the multitudinous subjects which attracted his mind in rapid succession."

Rafinesque, bereft of friends and fortune, unknown even to his neighbors, by whom he seems to have been regarded as a harmless herb doctor, was left to struggle on alone, without recognition and without sympathy or support. Reduced finally to abject poverty, he concocted and sold medicines which were advertised much like quack remedies at the present day, especially his "Pulmel," which without a doubt he thought had cured him of the pulmonary consumption. To advertise this he wrote a little treatise, hoping to realize something from its sale and at the same time to avoid any undue appearance of empyricism.

Toward the very end of his life, Rafinesque projected a savings bank, and, strangely enough, this seems to have been a success, though just how is not clear, since it both borrowed and loaned money at six per cent. He had already attempted to secure rights on a "steam-plough," a "submarine boat," "incombustible houses," and similar novelties which abler inventors have later perfected. For a long time he led the life of a perfect recluse in a garret in a poor quarter of Philadelphia, in the midst of his collections, his books and his manuscripts, never the world forgetting but ever by 
the world forgot. There, in the direst misery, he died in 1840, at the age of fifty-six, without a word of cheer or a tear of regret. His body was barely saved from the dissecting table and given decent burial through the loyalty and promptitude of one of his few remaining friends, Dr. William Mease, who with undertaker Bringhurst, broke into the room where his body lay and let it down through a window by ropes. ${ }^{12}$ Even his will was ruthlessly violated, and all of his effects, in eight dray-loads, were hurried off to the public auction rooms and sold in bargain lots, his books and all else bringing but a mere pittance, not even enough to pay his landlord and the administrator of his estate.

Thus died the "eccentric naturalist" whom Audubon had portrayed, and for whom the world in general had shown scant sympathy. Rafinesque, nevertheless, possessed a mind of extraordinary acumen and an energy and versatility little short of marvelous. He dipped into every field of knowledge, looking for precious metal, but much that he brought to the surface was dross. His restless versatility alone would probably have ruined him, for nothing short of an analysis of the globe with all of its contents would have satisfied his ambitious spirit. His was the ardor of the traveler and the explorer, with a passionate love for nature seldom equaled, but without the incentive and the patience of the investigator or a balance-wheel in the judgment. His ambition in early life was to become the greatest naturalist of his age; had his early training and environ-

12 The landlord, to whom Rafinesque had been in arrears for rent, had locked his body in the room and refused permission for its burial, thinking to find a market for it in one of the medical schools of the city. Rafinesque was buried in a little churchyard, then outside of the limits of the city, known as Ronaldson's cemetery, now at Ninth and Catharine Streets. See Call and Fitzpatrick, Bibliography, Nos. 198 and 228. 
ment been suited to his needs, and had fortune favored him more consistently with her smiles, this ambition possibly might have been realized, but we suspect that in this case nature would have proved stronger than nurture, and that he would have been Rafinesque to the end. 


\section{CIIAPTER XX}

\section{AUDUBON'S 瓜NEID, 1819-1824: WANDERINGS THROUGH THE WEST AND SOUTH}

Pivotal period in Audubon's career-His spur and balance-wheel-Resort to portraiture-Taxidermist in the Western Museum-Settles in Cincinnati-History of his relations with Dr. Drake-Decides to make his avocation his business-Journey down the Ohin and Mississippi with Mason and Cummings-Experiences of travel without a cent of capitalLife in New Orleans-Vanderlyn's recommendations-Original drawings-Chance meeting with Mrs. Pirrie, and engagement as tutor at "Oakley"-Enchantments of West Feliciana-"My lovely Miss Pirrie"The jealous doctor-Famous drawing of the rattlesnake-Leaves St. Francisville and is adrift again in New Orleans-Obtains pupils in drawing and is joined by his family-Impoverished, moves to Natchez, and Mrs. Audubon becomes a governess-Injuries to his drawings-The labors of years destroyed by rats-Teaching in Tennessee-Parting with Mason-First lessons in oils-Mrs. Audubon's school at "Beechwoods"-Painting tour fails-Stricken at Natchez-At the Percys" plantation-Walk to Louisville-Settles at Shippingport.

Audubon's failure at Henderson was the crucial turning point in his career. For the five years that immediately followed he led a peripatetic existence in the southern and western states, seldom tarrying long at one point, often leaving his family for months at a time, living from hand to mouth, but ever bent on perfecting those products of his hand and brain, his life studies of American birds and plants.

At this crisis Audubon could have accomplished nothing but for the intelligent devotion of his capable wife. Generous, emotional, inclined to be self-indulgent, Audubon needed both the example and the spur of a strong character such as his wife possessed, and at this time Lucy Audubon furnished both the motive 
power and the balance-wheel that were requisite for the development of her husband's genius. Without her zeal and self-sacrificing devotion the world would never have heard of Audubon. His budding talents eventually would have been smothered in some backwoods town of the Middle West or South. For the space of nearly twelve years, Mrs. Audubon, now as the head of a small private school, now as a governess in some friendly family who appreciated her worth, practically assumed the responsibility for the support and education of their children in order that her husband's hands might be free, and with her hard-earned savings was able to aid him materially in the prosecution of his labors. When relatives or friends upbraided him for not entering upon some form of lucrative trade, she recognized his genius and always came to his support, being fully persuaded that he was destined to become one of the great workers of the world. Whatever others may have said or done at that time, both Audubon and his wife were confident of the ultimate success of his mission. In short, the work in which the naturalist was engaged became a family interest, in which every member was destined sooner or later to bear a part.

Audubon recalled a somber incident of this time which he thought might furnish a lesson to mankind, and he shall relate it in his own words:

After our dismai removal from Henderson to Louisville, one morning when all of us were sadly desponding, I took you both, Victor and John, from Shippingport to Louisville. I had purchased a loaf of bread and some apples; before you reached Louisville you were hungry, and by the river side we sat down and ate our scanty meal. On that day the world was with me as a blank, and my heart was sorely heavy, for scarcely had I enough to keep my dear ones alive; and yet through those dark 
days I was being led to the development of the talents I loved, and which have brought so much enjoyment to us all. . . .

At Shippingport Audubon was welcomed by his brother-in-law, Nicholas A. Berthoud. Wasting no time in vain regrets, he began doing portraits in crayon, and with such success that he was able to rent a modest apartment and have his family about him again. From no charges for his tentative efforts the price was gradually raised until he received five dollars or more a head; with the spread of his fame orders filled his hands, and he was called long distances to take likenesses of the dying or even of the dead. Audubon's facility in portraiture was a valuable resource, and it kept him from the starving line at many a pinch in later years.

Through the influence of friends the naturalist was offered a position as taxidermist at a museum which had just been started at Cincinnati; here his family joined him in the winter of 1819-20, and here he remained for nearly a year. The published accounts of this Cincinnati experience are strangely confused and have led to aspersions of bad faith which were, we believe, quite undeserved. "I was presented," said Audubon, "to the president of the Cincinnati College, Dr. Drake, and immediately formed an engagement to stuff birds for the museum there, in concert with $\mathrm{Mr}$. Robert Best, an Englishman of great talent," adding that his salary was large; so industrious were they, to continue his account, "that in about six months we had augmented, arranged, and finished all that we could do," but they found to their sorrow "that the members of the College museum were splendid promisers and very bad paymasters." ${ }^{1}$ p. 36 .

${ }^{1}$ Maria R. Audubon, Audubon and his Journals (Bibl. No. 86), vol. i, 
It has been stated that Audubon got nothing from Dr. Drake, but that "Mrs. Audubon afterwards received four hundred dollars, of the twelve hundred due," and that the remainder was never paid. ${ }^{2}$ This matter can now be fully cleared up, and it will appear that the Cincinnati College was in no way involved; Dr. Drake was not its president, although he drew its charter and was one of its trustees; the Museum in which the naturalist worked was an independent foundation; and Mrs. Audubon was probably paid in full for the service which her husband had rendered.

Audubon wrote in his journal in 1820, when this experience was fresh in his mind, that owing to his talent for stuffing fishes he entered the service of the Western Museum at a salary of $\$ 125$ a month; he made no complaint at that time of any lack of pay. Moreover, on the day before he started on his cruise down the Ohio River on the 11th of October of that year, the Rev. Elijah Slack gave him a letter of introduction in which he said that Audubon had "been engaged in our museum for 3 to 4 months, and that his performances do honor to his pencil." Since Mr. Slack, like Dr. Drake, was one of the managers of the Western Museum, he must have known of Audubon's term of service. We are convinced that Dr. Daniel Drake, ${ }^{3}$

${ }^{2}$ Ibid., vol. i, p. 49.

${ }^{3}$ Dr. Daniel Drake (1785-1852) was one of the most versatile and prolific writers on medicine which the West has ever produced, and Cincinnati owed to him much, for he was instrumental in organizing in that city a church, a literary society, a museum, a hospital, a college, and a school of medicine, while he enjoyed a large medical practice, lectured on botany, and was a partner in two mercantile establishments. We might also add that his "Notice concerning Cincinnati" (pp. 1-28, i-iv. Printed for the author at Cincinnati, 1810), of which only three copies are known to exist, is the earliest and rarest published record of that city. This little pamphlet included a "Flora" of the city for 1809, and from it we transcribe this interesting extract (p. $\left.{ }^{27}\right)$ : "May 10. Black locust in full flower." 
whose character was above reproach and who was a keen naturalist himself, was Audubon's good friend, and that no misunderstanding ever rose between them. In writing offhand from memory, years after the events, Audubon misstated the facts but evidently without design.

In 1818 Dr. Drake organized the Western Museum Society, of which he said: "I have drawn up the constitution in such a manner as to make the institution a complete school for natural history, and hope to see concentrated in this place, the choicest natural and artificial curiosities in the Western Country." The first meeting of the Society was held in the summer of 1819 , not long before Audubon was engaged to work for it. The membership fee was $\$ 50$, a considerable sum for that period, but the enterprise was well patronized. It was in charge of a board of whom Dr. Drake was the moving spirit; another member, as we have seen, was Rev. Mr. Slack, who became the first president of the Cincinnati College, which was organized in 1818-19. The collections of the Museum were placed in one of the buildings of the College in order better to serve the students and public, which would account for some of the confusion noted above.

Dr. Drake's hands at this time were more than full; in October, 1819, he wrote to a friend: "The ties which bind me to the world at large seem every day to increase in strength and numbers. The crowd of mankind with

"It is highly probable that the flowering of this beautiful tree, the Robinia pseudocacia of Linnæus, indicates the proper time for planting. the important vegetable the Indian corn. For several successive years I have observed our farmers generally to plant corn during some stage of its flowering. This from the 10th to the 20 th of May."

For the privilege of examining one of the original copies of this paper, I am indebted to Mr. Wallace H. Cathcart of the Western Reserve Historical Society of Cleveland. 
whom I have some direct or indirect concern, thickens around me, and I see little prospect of more leisure, nor any of retirement and seclusion." At this juncture also, when Audubon and Best were working for his Museum, Dr. Drake was experiencing the first disastrous check in his energetic career. In January, 1820, in spite of the opposition and intrigue of professional rivals, he succeeded in organizing the Medical College of Ohio, and Robert Best became the assistant in chemistry and the curator of the Western Museum. Opposition did not abate, but instead of strangling the College which he had founded, the marplots succeeded in .expelling the Doctor from its staff. At last, feeling obliged to leave the city, Dr. Drake accepted in 1823 a position in the rival medical school of Transylvania University, and thus became a colleague of Constantine Rafinesque. It will be seen that Audubon's engagement at Cincinnati fell in a troubled era, and the annoyance which he may have felt at lack of pay was probably no fault of the harassed doctor.

While at Cincinnati Audubon was obliged to resort to his crayon portraits; and he also started a drawing school, but it required all of Mrs. Audubon's skill in management to keep the family out of debt. In 1820 he began for the first time seriously to consider the possibility of publishing his drawings, and under the spur of this incentive began to exert himself as never before. He planned a long journey through the Middle West and South, his intention being to descend the Ohio and Mississippi Rivers, explore the country about New Orleans, and then proceed as far east as the Florida Keys; he wished also to ascend the Red River, cross Arkansas, and visit the Hot Springs, before returning again by river to Cincinnati. Lack of ready money was no draw- 
back, for he was now confident of being able to live by his talents alone.

Accordingly, he left his wife to care for their two boys, and on October 12, 1820, started down river in a flatboat, bound for New Orleans. His companions on this journey were Captain Cummings, ${ }^{4}$ an engineer who had been in the government service, to whom Audubon became much attached; Joseph R. Mason, a promising artist of eleven, in the rôle of pupil-assistant, and his dog "Dash." Although Audubon had no funds, he was careful to provide himself with letters to or from men of mark who could be of assistance to him and this custom was followed to good effect at a much later day. On this occasion he bore recommendations from William H. Harrison, who afterwards became President, to Governor Miller of Arkansas, and from Henry Clay, as well as his letter from Rev. Elijah Slack, in which it was stated that the naturalist was traveling to complete his collection of the birds of the United States which he intended to publish at some future time. Audubon also wrote a personal letter to Governor Miller, fully outlining his plans, and asking for information; he told the Governor that he had been working fifteen years, and that his drawings of birds and plants were all from nature and life-size, showing that the idea of publication which was afterwards realized was then fixed in his mind. Audubon kept a careful journal on this journey, which extended over a year, the last entry being for the close of $1821 .^{5}$

"Sce Audubon's letter to Thomas Sully, reproduced in Vol. II, p. 68. In his Ohio and Mississippi Rivers Journal Audubon wrote on April 5, 1821: "Cap. Cumming left us on the 10 for Phila; the poor man had not one cent with him."

${ }^{5}$ This early journal fills a large unruled book, measuring about 13 by 8 inches, of 201 pages, beginning with Oct. 12, 1820, and closing with December 31, 1821; it forms a part of the John E. Thayer collection of 
As their flatboat stopped at many towns and plantations on the rivers, Audubon could hunt game and birds to his heart's content. Having resolved, as he said, never to draw from a stuffed specimen, he worked at every new bird with the greatest diligence. It seems almost incredible that he should never have met with the Hermit 'Thrush before this journey, yet under date of "Oct. 14, 1820," there is this entry: "We returned to our boat with a Wild Turkey, a Telltale Godwit and a Hermit Thrush, which was too much torn to make a drawing of it; this was the first time I had met with this bird, and I felt particularly mortified at its condition." 6

Their visit to Natchez furnished Audubon with materials for at least two of his "Episodes." 7 This incident of his generosity may be taken as characteristic; finding that one of his companions was down at the heel and as short of ready money as himself, he sought out a shoemaker and offered to do a portrait of the man and his wife for two pairs of boots; the proposal was accepted forthwith, and he set to work; the sketches were finished in the course of two hours, and Audubon

Audubon and Wilson manuscripts and drawings in possession of Harvard University, having been once included in the estate of Joseph M. Wade. The collection embraces four early drawings by Audubon, presumably at one time in the hands of Edward Harris (see Note 9, Vol. I, p. 180); 73 of Audubon's original letters, comprising largely his correspondence with Dr. John Bachman; 60 letters by Victor G. Audubon; and a few by other members of the naturalist's family. See the Annual Report of the Curator of the Museum of Comparative Zoölogy for 1910-1911.

Through the courtesy of Professor E. I. Mark, and the Director of the Museum, Dr. Samuel Henshaw, I have been permitted to examine these numerous documents. In any direct or casual reference to this valuable material, I have endeavored not to overstep the bounds of propriety, in view of the fact that the University contemplates publishing copious extracts from it at an early day. It should be noticed that excerpts from this journal have already appeared in print. See following Note.

"See Ruthven Deane (Bibl. No. 41), The $A u k$, vol. xxi, pp. 334-338.

" "Natchez in 18:0" and "The Lost Portfolio," Ornitho'ogical Biography (Bıbl. No. 2), vol. iii, pp. 529 and 564 . 
and his companion, having selected their boots, went on their way rejoicing.

Audubon left Natchez on December 31, 1820, on a keel boat belonging to his brother-in-law, Nicholas A. Berthoud, who accompanied him, and at one o'clock the steamer Columbus hauled off from the landing and took them in tow. Towards evening, when they were looking up their personal belongings, the naturalist found to his dismay that a portfolio containing all of the drawings that he had made on the voyage down the river was missing. Letters were despatched to Natchez friends, but it was not until the 16th of March that his anxiety was relieved; the missing portfolio had been found and left at the office of The Mississippi Republican, whence it was forwarded on his order, and reached his hand on the 5th of April. "So very generous had been the finder of it," he said, "that when I carefully examined the drawings in succession, I found them all present and uninjured, save one, which had probably been kept by way of commission."

On New Year's Day, 1821, they came to at Bayou Sara, at the mouth of the inlet of that name, which later saw much of Audubon and his family. On the following day he made a likeness of the master of their craft, Mr. Dickenson, for which he was paid in gold; he also outlined two warblers by candle-light in order to have time to finish them on the morrow. The captain of their steamer in his anxiety to make haste had set them adrift at this point, and they were obliged to make their way as best they could, by aid of the current and oars, to the port of New Orleans, which was finally entered on Sunday, January 7, 1821.

Audubon landed at New Orleans without enough money to pay for a night's lodging, for someone had 
relieved him of the little he possessed, and he was obliged to pass several nights on the boat while looking for work. Undismayed by his financial straits, his first visit at daybreak on Monday was to the famous markets of the southern city, where he found dead birds exposed for sale in great numbers-mallard, teal, American widgeon, Canada and snow geese, mergansers, tell-tale godwits, and even robins, bluebirds and red-wing blackbirds; he added that the prices were very dear.

Upon leaving Cincinnati Audubon had resolved upon making one hundred drawings of birds; this was actually accomplished, but only after repeatedly modifying his plans and working in more humble capacities than he was at first inclined to consider. On the 12th of January he wrote in his diary of meeting an Italian painter at the theater, and of showing him his drawing of the White-headed Eagle ${ }^{8}$ at the rooms of Mr. Berthoud; "he was much pleased," and took him "to his painting apartment at the theater, then to the directors, who very roughly offered me one hundred dollars per month to paint with Monsieur l'Italien. I believe really now that my talents must be poor," said Audubon. His refusal of this offer in view of his straitened circumstances, and the entry which followed, were characteristic: "Jan. 13th, 1821. I rose up early, tormented by many disagreeable thoughts, again nearly without a cent, in a bustling city where no one cares a fig for a man in my situation." The following day Audubon applied to a self-taught portrait painter, John W.

${ }^{8}$ The original of this admirable drawing had been shot at New Madrid, on the Ohio, on November 23, and Audubon, who immediately began to work on it, recorded his conriction that the White-headed or Bald Eagle and the "Brown Eagle," which he later called "The Bird of Washington," were two different species; he thought that the young of the former, which was also brown, was much smaller in size. See Vol. I, p. 241. 
Jarvis, and after showing his drawings, was engaged to assist him in finishing the "clothing and ground"; but this artist's manners were declared to be so uncouth and the pay so poor that he left him in disgust.

When he had made a hit, as he said, with the likeness of a well known citizen, orders came to him, and he was able to resume his drawing of birds. On February 22 he recorded that he had spent his time in "running after orders for portraits, and also in vain endeavors to obtain a sight of Alexander Wilson's 'Ornithology,' but was unsuccessful in seeing the book, which is very high priced." Later, however, he appears to have succeeded in this quest, for on the 17th of that month he was able to send his wife twenty drawings of birds, eight of which were marked as "not described by Willson." Among them were the originals of some of the most famous of his plates, such as the Great-footed Hawk, the White-headed Eagle, and the Hen Turkey. ${ }^{9}$

Having seen in a newspaper a notice of an expedition which the Government was about to send to the

${ }^{9}$ These drawings were as follows:

"Common gallinule; Not described by Willson;

"Common gull; Not described by Willson;

"Marsh hawk;

"Boat tailed grackle; Not described by Willson;

"Common Crow;

"Fish Crow;

"Rail or Sora;

"Marsh Tern;

"Snipe; Not described by Willson;

"Hermit Thrush;

"Yellow Red poll Warbler;

"Savannah Finch;

"Bath Ground Warbler; Not described by Willson;

"Brown Pelican; Not described by Willson;

"Great Footed Hawk;

"Turkey Hen; Not described by Willson;

"Cormorant;

"Carrion Crow or Black Vulture;

"Imber Diver;

"White Headed or Bald Eagle." 
Pacific Coast, to survey the boundary of the territory that had been recently ceded by Spain, Audubon became much excited over a possible appointment as draughtsman and naturalist. He sat down at once and wrote a personal letter to President Monroe, while hundreds of imaginary birds of new and interesting kinds seemed to come within the range of his gun; on the 31st of March he was still pondering on the project, and although it is not likely that his letter ever reached the eye of the President, he did receive a recommendation from Governor Robertson of Louisiana. It was with this expedition in view that he sought an interview with $\boldsymbol{J}_{\mathrm{ohn}}$ Vanderlyn, ${ }^{10}$ an eminent painter of historical subjects, then working in New Orleans; according to one version Vanderlyn treated him as a mendicant, and ordered him to lay down his portfolio in the lobby, but ended by giving him a very complimentary note, in which he praised his drawings without stint, particularly his studies of birds.

During the five months spent at New Orleans in 1821, Audubon attempted to support himself and his companion by means of their artistic talents, while he was pushing forward his ambitious design of figuring all of America's birds and most characteristic plants. That he received scant encouragement but many rebuffs is not surprising. They did succeed in obtaining a few pupils in drawing, and Audubon made a number of rapid portraits, but after living for a time on Ursuline Street, near the old Convent, and later shifting from

${ }^{10}$ Vanderlyn, like Audubon, had been a pupil of David at Paris; he produced historical paintings of merit, as well as panoramas, then coming into vogue; some of the latter were exhibited in the "Rotunda" which he erected for that purpose in City Hall Park, New York, but this enterprise failed, and his building was seized by the city for debt. Vanderlyn died in absolute want in 1852. See Samuel Isham, The History of American Painting (New York, 1915). 
one quarter to another, their finances had reached so low an ebb by the beginning of $\mathbf{J}$ une that a move was imperative. Audubon then decided to go to Shippingport, Kentucky, and on the 16th of June, with young Mason, he again boarded the steamer Columbus, John D'Hart, captain, and started up river. An incident now occurred which affected the naturalist's whole after life by introducing him to one of the most favored spots in Louisiana, if not in the whole country, for the study of bird life, not to speak of the impressions which the charm of new scenery, a rich flora, and natural products of the most varied description must have then made on his mind. Mrs. James Pirrie, wife of a prosperous cotton planter of West Feliciana Parish, happened to be their fellow-passenger. Doubtless her curiosity was piqued by the winning manners and flowing locks of the artistic traveler, whose Gallic accent at once betrayed his nationality. Whether Audubon had made her acquaintance previous to this journey or not is not known, but before it was ended his fine enthusiasm and ambitious plans had found a sympathizer, and he was engaged as tutor to Mrs. Pirrie's daughter at $\$ 60$ a month. To further his ornithological pursuits it was understood that he and his companion should live at "Oakley," her husband's plantation, five miles from St. Francisville, on Bayou Sara, and that one-half of his time should be absolutely free for hunting and drawing. Thus, on June 18, 1821, was forged the link that bound the heart of Audubon to the State which was first in his affections, and which he would fain believe might have been the scene of his nativity. Well may the Louisianians of today adopt him as their son, for from that early time he cherished their State as in a peculiar sense his own. 
It was a hot and sultry day when our wanderers landed at Bayou Sara, ${ }^{11}$ a small settlement at the junction of the sluggish stream which bears that name and the Mississippi, and proceeded to climb to St. Francisville, the village a mile away on the hill. Mrs. Pirrie, who seems to have preceded the travelers by carriage, sent some of her servants to relieve them of their luggage, which Audubon said they found light. They rested in the village at the house of Mr. Benjamin Swift, where they were invited to stay to dinner, then at the point of being served, but feeling somewhat ill at ease, they thanked their host and again took to the road. Following their leisurely guides, they now traversed a country so new, so strange, and so enchanting, that the five miles to the Pirrie house seemed short indeed. "The rich magnolias, covered with fragrant blossoms, the holly, the beech, the tall yellow poplar, the hilly ground, and even the red clay," to quote Audubon's record made at the time, "all excited my admiration. Such an entire change in the face of nature, in so short a time, seems almost supernatural, and surrounded once more by numerous warblers and thrushes, I enjoyed the scene."

In passing up the Mississippi from New Orleans, the topography of the country suddenly changes at

"11 "Bayou," in Louisiana, is a term commonly applied to any slowrunning stream. According to the tradition gathered on the spot by Mr. Stanley C. Arthur, both stream and settlement were formerly called "New Valentia," while the present name was derived from an old woman called "Sara," who many years ago lived at the mouth of the Bayou, where she practiced some sort of spurious physic. St. Francisville, on the hill, received its name from the circumstance that the brothers of St. Francis, who had a mission at Pointe Coupée, on the opposite bank, were in the habit of ferrying their dead over the river, in order to bury them on the high ground; "Bayou Sara" and "St. Francisville" are used interchangeably by the inhabitants. See S. C. Arthur (Bibl. No. 230), Times-Picayune, New Orleans, August 6, 1916. 


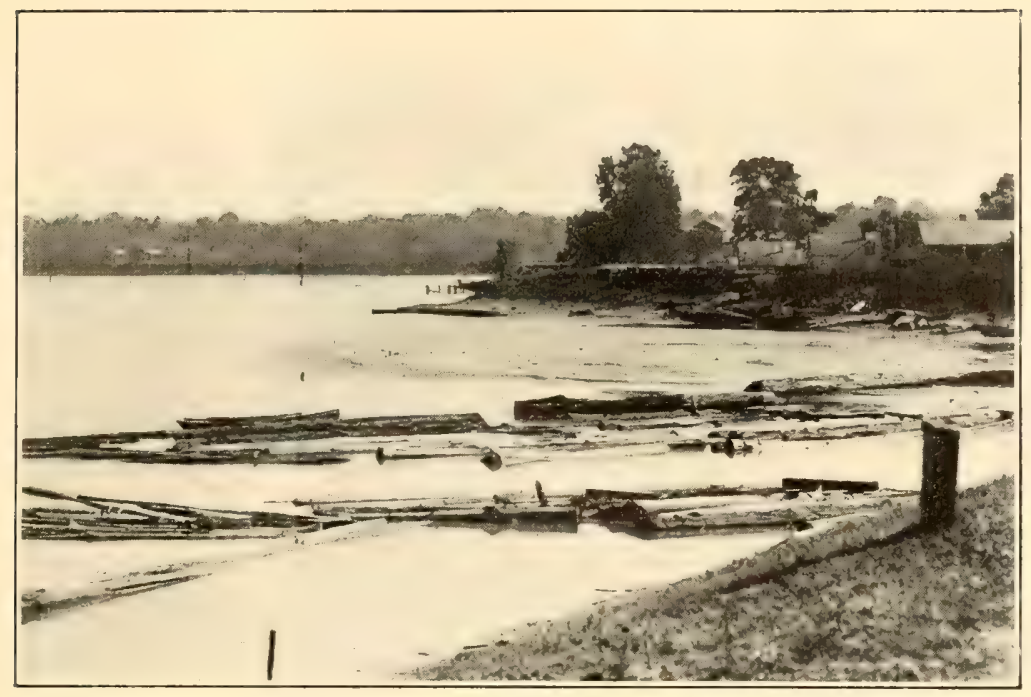

BAXOU SARA LANIING, WEST FELICIANA PARISII, LOUISIANA, AT THE JUNCTION OF RAYOE SARA AND THE MISSISSIPPI RIVER.

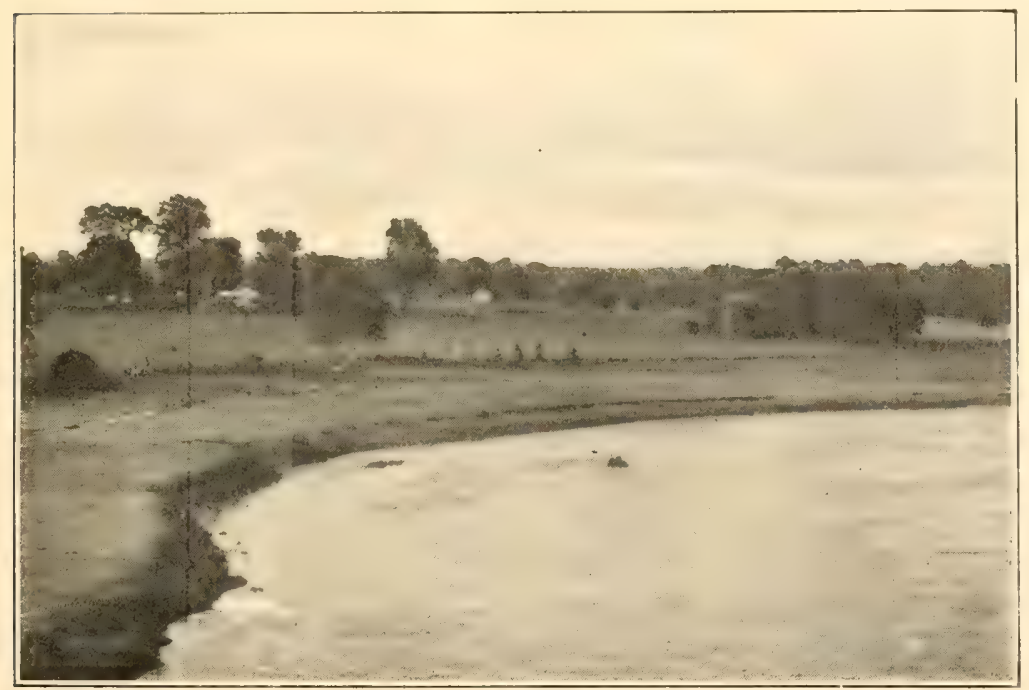

SCENE ON BAYOU SARA CREEK, AUUUBON'S IIUNTING GROUND IN IRZI. This and the above after photographs by Mr. Stanley Clisby Arthur, 1936. 

about this point; in the parish of West Feliciana the alluvial lowlands of the river valley give place to beautiful highlands, which still harbor as rich and distinctive a flora and fauna as in Audubon's day. Following Audubon's course in June, 1916, or ninety-five years later, Mr. Arthur found the region about St. Francisville wonderfully rich in birds, and there noted seventyeight resident kinds which were seen on the same day, from shortly before noon to seven o'clock in the evening.

Upon reaching the plantation house, Audubon and his companion were kindly received by the Scotchman, James Pirrie, who introduced to them his daughter, Eliza, then a beautiful and talented girl of seventeen"my lovely Miss Pirrie, of Oakley," as Audubon once characterized her in his journal-who was to become his pupil in drawing, and who, as after events proved, was destined to a romantic and checkered career.

The "Oakley" house, which by a strange turn of fortune's wheel thus became the naturalist's home in the summer of 1821, has changed but little since that time, but the century that has nearly sped its course has added strength and beauty to the moss-hung oaks which now encompass it and temper the heat of the southern sun in the double-decked galleries which adorn its whole front. Built of the enduring cypress, as my correspondent remarks, the house stands as firm and sound as the gaunt but living sentinels of that order which tower from the brake not far away.

Audubon spent nearly five months at the Pirrie estate. He worked with great ardor at his Ornithology and produced the originals of many of his plates that were afterwards published, while his assistant, Joseph Mason, who had followed him from Cincinnati, labored with equal diligence at the plants that were chosen as a 
setting for the birds. ${ }^{12}$ An early drawing of the Chuck Will's Widow is dated "Red River, June, 1821," and it is probable that he followed this stream into Arkansas, for on leaving Cincinnati in the autumn of the previous year, he had planned to enter that State, and later references in his journals clearly imply that this object was attained. Another favorite hunting ground was Thompson's Creek, and he often recalled its heated banks, where, on a Fourth of July, he once satisfied his hunger by "swallowing the roasted eggs of a large soft shelled turtle."

On August 11, 1821, while Audubon was living at "Oakley," he made this entry in his journal:

Watched all night by the dead body of a friend of Mrs. P-_ ; he was not known to me, and he had literally drunk himself to an everlasting sleep. Peace to his soul! I made a good sketch of his head, as a present for his poor wife. On such occasions time flies very slow indeed, so much so that it looked as if it stood still, like the hawk that poises over its prey.

In the same journal also, for August 25, occurs a record which throws light on one of Audubon's most discussed and questionable pictures, that of the mocking-birds defending their jessamine-embowered nest from the sinister designs of a rattlesnake; ${ }^{13}$ little did he

${ }^{13}$ On the original drawing of the Pine-creeping Warbler The Birds of America (Plate cxl), the following legends appear in Audubon's autograph: "Drawn from Nature by John J. Audubon, James Pirrie's Plantation, Louisiana, July 10, 18थ1. Plant, J. R. Mason."

Sixteen of Audubon's originals, which still bear the designations of time and place, were produced during this interval, in the year 1821; they embrace the Mississippi Kite (Plate cxvii, see Vol. I, p. 2.28), June 28; Yellow-throated Vireo (Plate cxix), July 11; Red-cockaded Woodpecker (Plate ccclxxxix), July 29 ; American Redstart (Plate xl), August 13; Summer Red-bird (Plate xliv), August 27; Prairie Warbler (Plate xiv), Sept. 3; and the Tennessee Warbler (Plate cliv), Oct. 17.

13 The Birds of America, Plate xxi. 
think at the time how much discord this venomous reptile, when coiled in the branches of a tree, could later breed. ${ }^{14}$ The entry was:

Finished drawing a very fine specimen of a rattlesnake, which measured five feet and seven inches, weighed six and a quarter pounds, and had ten rattles. Anxious to give it a position most interesting to a naturalist, I put it in that which the reptile commonly takes when on the point of striking madly with its fangs. I had examined many before, and especially the position of the fangs along the superior jaw-bones, but had never seen one showing the whole [of the fangs] exposed at the same time.

He then described the generous provision which nature has made to keep the rattlesnake in fighting trim, by giving it a dental arsenal on which it can draw in case of loss; he added that the heat of the day was such that he could devote only sixteen hours to the drawing.

At this time Audubon was a handsome and attractive man; his pupil, who did not enjoy the best of health, was attended by a young physician who was also her lover. It is not surprising therefore to learn that jealousy on the part of the doctor led to a misunderstanding, and that the naturalist suddenly made his departure and returned to New Orleans. In recording this incident Audubon could not repress his amusement at the prescription of the physician, who ordered the young lady to abstain from all writing and drawing for a period of four months, but meanwhile permitted her to eat anything which pleased her fancy, in spite of the relapses of fever that occasionally occurred. Audubon was allowed to see her only at appointed hours, as if, he said, he were an extraordinary ambassador to some distant

${ }^{14}$ See Chapter XXVIII, p. 72. 
court, and was obliged to preserve the utmost decorum of manner; he expressed the belief that he had not once laughed in the presence of the young lady during the entire term of his tutorial engagement, which lasted from the 18th of June to the 21st of October. Later, in December of the same year, when his former pupil passed him without recognition in the streets of New Orleans, he indulged in the reflection that she had apparently quite forgotten the great pains with which at her own request he had done her portrait in pastels, but, thanks to his talents, he thought that he could run the gauntlet of the world without her help. ${ }^{15}$

At New Orleans Audubon soon found new pupils, particularly through the aid of Mr. R. Pamar and Mr. William Brand, ${ }^{10}$ who came to his assistance, Mrs. Brand and her son paying him at the rate of three dollars for a lesson of one hour. On November 10, 1821, he wrote:

Continued my close application to my ornithology, writing every day, from morning until night, omitting no observations, correcting, re-arranging from my notes and measurements, and posting up; particularly all my land birds. The great many errors I found in the work of Wilson astonished me. I try to speak of them with care, and as seldom as possible, knowing the good will of that man, and the vast many hearsay accounts he depended on.

${ }^{15}$ The vivacious Miss Pirrie did not marry the young doctor, but eloped to Natchez with the son of a neighboring planter, who died within a month in consequence of a cold, said to have been contracted when he waded a deep stream with his lady-love in his arms. Audubon's pupil was thrice married, and bore five children; she died April 20,1851 , and her ashes now rest by the side of her second husband, the Reverend William Robert Bowman, the parish minister at St. Francisville. See Arthur (Bibl. No. 230), loc. cit.

${ }^{10}$ Mistakenly written "Braud" in the first edition of the present work. 


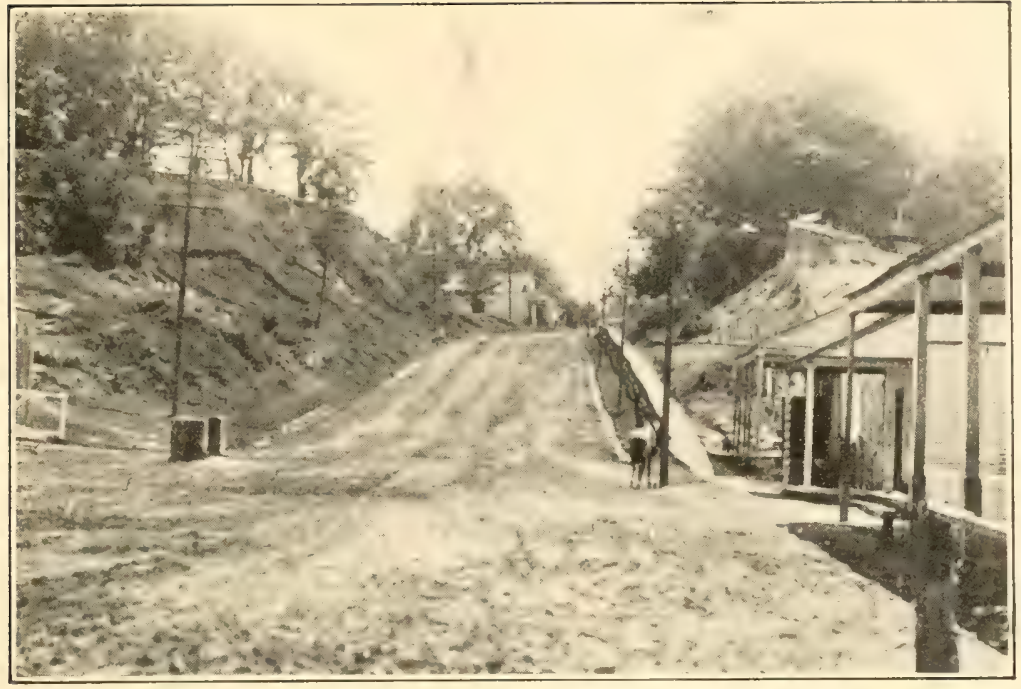

ROAD LEAPING FROM BAYOU SARA LANDING TO THE VILLAGE OF ST. FRANCISVILLE, West Feliciana Parish, LOUisiana.

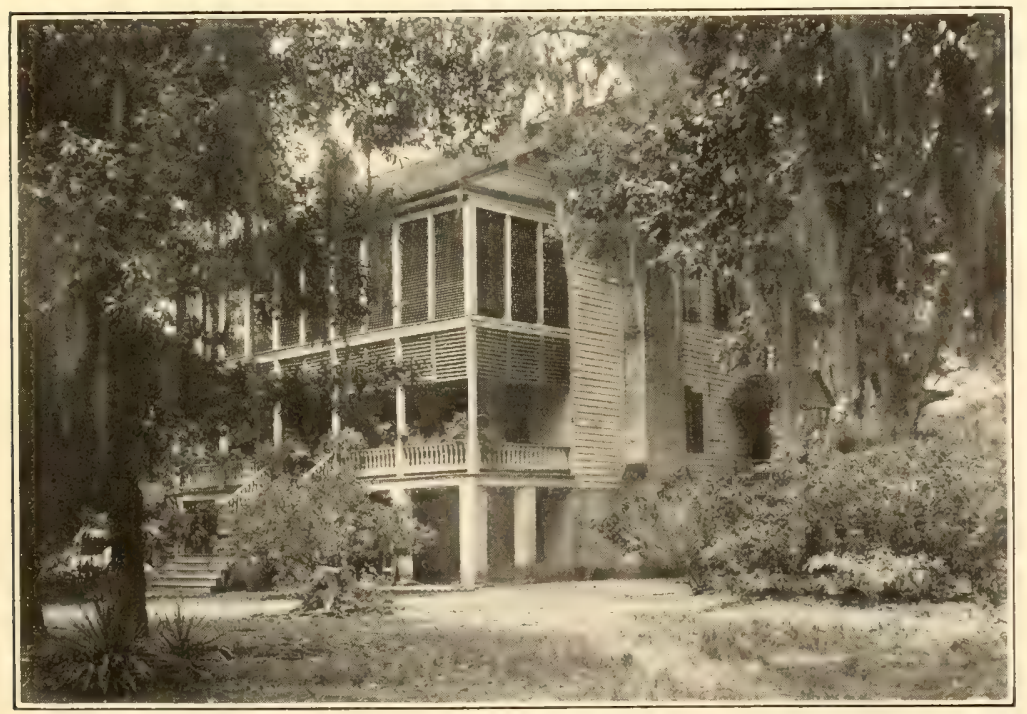

"OAKLEY," JAMES PIRITE'S PLANTATION HOUSE NEAR ST. FRANCISVILLE.

This and the above after photographs by Mr. Stanley Clisby Arthur, 1916. 



\section{Again, on the 25th of that month is this entry:}

Since I left Cincinnati I have finished 62 drawings of birds and plants, 3 quadrupeds, 2 snakes, fifty portraits of all sorts, and the large one of Father Antonio, ${ }^{17}$ besides giving many lessons, and $\mathrm{I}$ have made out to send money to my wife sufficient for her and my Kentucky lads, and to live in humble comfort with only my talents and industry, without one cent to begin on. I sent a draft to my wife, and began to live in New Orleans with forty-two dollars, health, and much anxiety to pursue my plan of collecting all the birds of America.

The close of the year 1821 found Audubon teaching a few pupils at New Orleans, where, he said, his style of work and the large prices he received caused him the ill will of every artist in the city. The figure which he cut in the streets, with his loose dress of nankeen and long, flowing locks, made him wish to appear like other people, and he was soon able to rejoice in a new suit of clothes. Though still in need of work, when he was asked to aid in painting a panorama of New Orleans, he refused, begrudging the time, saying that he did not wish to see any other perspective than that of the last of his drawings.

Having been from home for over a year, Audubon now wished to have his family about him again. ${ }^{18}$ His

${ }^{17}$ Father Antonio de Sedella, popularly known as "Père Antoine," after 1791 pastor of St. Louis Cathedral; an idol of the people, but execrated by historians.

"This seditious priest is a Father Antoine; he is a great favorite of the Louisiana ladies; has married many of them, and christened all their children; he is by some citizens esteemed an accomplished hypocrite, has great influence with the people of color, and, report says, embraces every opportunity to render them discontented under the American Government." Executive Journal of Governor Claiborne. See Charles Gayarré, History of Louisiana, vol. iv, pp. 154-155 (New Orleans, 1903).

${ }^{18}$ This item occurs in Audubon's journal for October 25; "Rented a house in Dauphine street at seventeen dollars per month, and determined to bring my family to New Orleans." 
plan did not appeal to his practical wife, who had many friends at Cincinnati, where she was assured of a good income through her teaching; Mrs. Audubon also felt that to be constantly shifting about was anything but favorable to the education of their children. Her reluctance, however, gave way, and in December she joined her husband in New Orleans, but only to find that the city could afford them no settled means of support. The situation of the Audubon family during the winter of 1821-22 became precarious in the extreme, and for two months Audubon gave up his habit of journalizing, one reason being that he could not afrord the paltry sum necessary to buy a blank book for this purpose.

Compelled at last to make a new move, Audubon started for Natchez, on the 16th of March, 1822, paying for his passage on the steamer $\boldsymbol{E}$ clat by doing a crayon portrait of the captain and his wife. It was while going up the river at this time that he opened a chest containing two hundred of his drawings to find them sadly damaged by the breaking of a bottle of gunpowder, but the loss then sustained was apparently slight in comparison with that which he had experienced in an earlier disaster. To follow his account of this earlier and better known incident, when leaving Henderson for Philadelphia, he carefully placed all of his drawings in a wooden box and entrusted them to the care of a friend, with injunction that no harm should befall them; upon returning several months later, his treasure chest was opened, but only to reveal that "a pair of Norway rats had taken possession of the whole, and had reared a young family imongst the gnawed bits of paper, which but a few months before represented nearly a thousand inhabitants of the air." The heat that was immediately felt 
in his head, said the naturalist, was too great to be endured, and the days that followed were days of oblivion to him; but upon recuperation he took up his gun, his notebook and his pencils, "and went forth to the woods as gaily as if nothing had happened"; after a lapse of three years his portfolio was again filled, and the earlier work replaced by better. Audubon's drawings and plates were also repeatedly ravaged by fires, but this was at a much later day.

While Audubon was engaged in teaching French, music, or drawing, now to private pupils at Natchez, now in a school at Washington, Mississippi, nine miles away, the summer of 1822 passed with the outlook as ominous as ever. On August 23 he wrote: "My friend, Joseph Mason, left me today, and we experienced great pain at parting. I gave him paper and chalks to work his way with, and the double barrelled-gun ... which I had purchased in Philadelphia in 1805." Mason, who, for a year and nine months, was Audubon's aid and constant companion, seems to have settled eventually as an artist in Philadelphia, where we hear of him in 1824 and again in $1827 .{ }^{19}$

In the following December Audubon received a fresh impetus towards the goal of his ambition by the arrival at Natchez of a traveling portrait painter, named John Stein, who gave him his first lessons in the use of oils; his initial attempt was the copy of an otter from one of his own drawings. Audubon and Stein together later painted a full-length portrait of Father Antonio which was sent to Havana. Artists who have worked long in one medium are not always successful in another, but those who have seen some of Audubon's later and better works in oil, such as his large canvas of the Wild

${ }^{19}$ See Audubon's letter to Sully, Vol. II, p. 69. 
Turkeys, ${ }^{20}$ must admit that he attained a high degree of skill. As will be seen, this acquisition was a strong string to his bow; when in England his brush helped largely to pay for the issue of his early plates.

Mrs. Audubon, who joined her husband in New Orleans on December 8, 1821, soon felt obliged to seek employment. She engaged as nurse or governess in the family of Mr. Brand, presumably the same whose wife and son had received instruction in drawing from the naturalist the previous autumn, and remained with that family until September, 1822, when the death of the child that was placed in her charge left her free to follow her husband to Natchez. After attempting a similar position in the home of a clergyman there and finding it impossible to obtain her salary, in January, 1823, she was invited by the Percys to West Feliciana, ${ }^{21}$ then a prosperous cotton district, at the apex of the salient made by the neighboring state of Mississippi and bordered on two sides by the great river. Her worth was evidently appreciated, for she was encouraged to establish a private school on the Percys' plantation, which she conducted successfully for five years.

Captain Robert Percy, who before coming to America in $\mathbf{1 7 9 6}$ had been an officer in the British Navy, was living at this time with his wife and five children at their plantation of "Weyanoke," on Big Sara Creek, fifteen miles from St. Francisville; this town, owing to its large shipments of cotton, was then at the height

${ }^{20}$ Now in the collection of Mr. John E. Thayer, Lancaster, Mass.

${ }^{21}$ Mr. Stanley C. Arthur, whose recent visit to this region has already been noticed, gathered there from the lips of old residents, some of whom were descendants of those who had known the Audubons, a store of reliable data by which the history of the naturalist at this important phase of his life is revealed in its true light; to him I am indebted for a series of excellent photographs of the region, its historic houses and people, as well as for much needed information. See Arthur (Bibl. No. 230), loc. cit. 
of prosperity, and its population no doubt exceeded that of the present day; it now stands at about one thousand souls. Letters and journals of the period constantly refer to "Beechwoods," which was not the mansion house, though it undoubtedly belonged to the Robert Percy estate. There it was that the wife of the naturalist lived, and there she started her school, for the benefit not only of the Percy boys and girls, but also of a limited number of children of their wealthy neighbors; her own son, John Woodhouse Audubon, then eleven years of age, at this time received instruction at her hands. The parish of West Feliciana, at this early period, was one of the richest cotton-producing sections of the entire State; its care-free planters led an easy life until the "king" was unceremoniously dethroned by a small, but not insignificant insect which has proved mightier than either fire or sword, namely, the boll-weevil; now many a fine old estate which has languished under the influence of the pest could probably be bought for a song. "Beechwoods," thus devoted to educational purposes, later came into the hands of Thomas Percy, but the house, like that of "Weyanoke," was long since burned to the ground.

While Mrs. Audubon was establishing her rules and authority at the Percy school, the naturalist was painting with Stein at Natchez, and he remained there with his elder son until the spring of 1823. At this period he wrote in his journal: "I had finally determined to break through all bonds, and follow my ornithological pursuits. My best friends solemnly regarded me as a madman, and my wife and family alone gave me encouragement. My wife determined that my genius should prevail, and that my final success as an ornithologist should be triumphant." 
In March, 1823, Audubon and friend Stein bought a horse and wagon, and in the hope of raising money through their joint efforts as itinerant portrait painters, set out with Victor on a tour of the Southern States. This venture, however, did not succeed, and after visiting $\mathbf{J}$ ackson and a number of other towns, they disbanded at New Orleans. Audubon then started north with his son for Louisville, but upon paying a visit to his wife at the "Beechwoods" school, he was invited by the Percys to remain there for the summer and "teach the young ladies music and drawing." According to a tradition which has survived among the Percy descendants, Audubon spent most of his time in roaming through the woods, but he also taught his wife's pupils to swim in the large spring house at "Weyanoke," where the water could be deepened at pleasure. It was also said that he painted the Wild Turkeys in the woods of Sleepy Hollow near by, but I have already given Audubon's own record in regard to one of these pictures, and, as Mr. Arthur remarks, the places in Louisiana where he drew these famous subjects are as numerous as the beds in which Lafayette slept when at.New Orleans.

Audubon remained with the Percys during the greater part of the summer, or until some misunderstanding arose, when he was again adrift and upon a sea of difficulties. While visiting a plantation near Natchez, both he and Victor were stricken with fever; his faithful wife hastened to them, and after nursing both back to health, she returned with them to the Percy plantation, where they remained from the 8 th to the 30 th of September.

In the autumn of 1823 Audubon was determined to visit Philadelphia, in the hope of finding a sponsor for his "Ornithology." Although the work was then far 
from ready for publication, he felt that at least he might better his condition, and with this end in view he sent his drawings from Natchez to that city; a hasty visit was made also to New Orleans, for the purpose, no doubt, of obtaining credentials to possible patrons in the East. At last, on October 3, he started with Victor on the steamer Magnet ${ }^{22}$ for Louisville. Low water quickly held them up after entering the mouth of the Ohio, and they were obliged to disembark at the little village of 'Trinity, at the mouth of Cash Creek, the scene of Audubon's misadventures with Rozier thirteen years before. The remoteness of the situation and the state of their funds, which corresponded with that of the river, left no alternative but to walk, and they undertook to reach Louisville, several hundred miles distant, afoot. Two other travelers joined them, and with Victor, then a lad of nearly fourteen, the party left the creek at noon on October $\mathbf{1 5}$ and struck across country tlirough the forests and canebrakes. At Green River, which was reached on the 21 st, Victor gave out from sheer exhaustion, ${ }^{23}$ and the remainder of the journey was finished in a Jersey wagon. At length, said Audubon, "I entered Louisville with thirteen dollars in my pocket." At Shippingport, then an independent town at the Falls of the Ohio, he was obliged to settle down for the winter. A place for Victor was found in the countinghouse of Nicholas A. Berthoud, while the father undertook anything that came to hand, painting portraits, landscapes, panels for river boats, and even street signs,

${ }^{22}$ One of the early steamboats on the Ohio that had been built at Pittsburgh, in 1821, by Thomas W. Bakewell, his brother-in-law and former partner.

${ }^{23}$ See "A Tough Walk for a Youth," Ornithological Biography (Bil,l. No. 2), vol. iii, p. 371 ; and "The Hospitality of the Woods," ibid., vol. i, p. 383 . 
so hard pressed was he at times to eke out a subsisterice for them both. Yet Audubon was as sanguine as ever, and on November 9 he recorded the resolution "to paint one hundred views of American scenery," and added: "I shall not be surprised to find myself seated at the foot of Niagara," a prediction which was fulfilled in the following year.

During the winter spent at Shippingport, Audubon lost a gentle friend in Madame Berthoud, ${ }^{24}$ the mother of Nicholas. In his journal for January 20, 1824, we read his emotional words:

I arose this morning by the transparent light which is the effect of the moon before dawn, and saw Dr. Middleton passing at full gallop towards the white house; I followed-alas! my old friend was dead!. . . many tears fell from my eyes, accustomed to sorrow. It was impossible for me to work; my heart, restless, moved from point to point all round the compass of my life. Ah Lucy! what have I felt to-day! . . . I have spent it thinking, thinking, learning, weighing my thoughts, and quite sick of life. I wished I had been as quiet as my venerable friend, as she lay for the last time in her room.

${ }^{2 *}$ This lady had a remarkable history. She was the widow of the Marquis de Saint Pie, and was at one time a dame d'honneur of Queen Marie Antoinette; like many others of noble birth, she had fled from Paris during the Revolution, and emigrated to America, where with her husband she assumed the name of Berthoud. Her son, Nicholas Augustus, had married Mrs. Audubon's sister, Eliza Bakewell, in 1816. 


\section{CHAPTER XXI}

\section{DÉBUT AS A NATURALIST}

Audubon makes his bow at Philadelphia-Is greeted with plaudits and cold water-Friendship of Harlan, Sully, Bonaparte and HarrisHostility of Ord, Lawson and other friends of Alexander Wilson-A meeting of academicians-Visit to "Mill Grove"-Exhibits drawings in New York and becomes a member of the Lyceum-At the Falls of Niagara-In a gale on Lake Erie-Episode at Meadville-Walk to Pittshurgh-Tour of Lakes Ontario and Champlain-Decides to take his drawings to Europe-Descends the Ohio in a skiff-Stranded at Cincinnati-Teaching at St. Francisville.

In 1824 after five hard years of struggle and embarrassment, Audubon decided that the time had come to bring his labors to the light of day. At thirty-nine, he read and spoke two languages but was without adequate training in either; he had never written a line for publication, and to the scientific world he was a stranger. Though without a definite plan, he cherished the ardent hope of presenting the birds of his beloved America as he had depicted them, to the size of life, and with all the added interest and zest that a natural environment could give them.

To Philadelphia the naturalist now turned his steps, for that city was then a Mecca for scientific men. Leaving Shippingport in March, he reached the Quaker capital on the fifth day of April. There he purchased a new suit of clothes, and, dressed "with extreme neatness," paid his respects to Dr. William Mease, the one friend there whom he had known intimately in his younger and more prosperous days. It was primarily 
through this excellent man's interest that Audubon met the leading artists and scientific men of the city, including Thomas Sully, Robert and Rembrandt Peale, Richard Harlan, Charles Le Sueur, and Charles L. Bonaparte, the latter then a rising young ornithologist of one and twenty. It was Bonaparte who introduced Audubon to the Academy of Natural Sciences, where his drawings were exhibited and generally admired. Among his critics on that occasion was George Ord, who from their first interview seems to have looked upon the new luminary with jealous eyes. Whether this was true or not, there is no doubt that Ord became one of his few really bitter and implacable adversaries, and not many days elapsed before Audubon came to feel that many in Philadelphia would be glad to see him return to the backwoods of the Middle West, from which, like an apple of Sodom, he seemed suddenly to have dropped into their midst. Those who were most interested in the continued sale and success of Wilson's Ornithology, he declared, advised him not to publish anything, and threw not only cold water but ice upon all his plans. Thus began that unseemly rivalry, fostered for many years by George Ord in this country, between the friends of Alexander Wilson and those of John James Audubon, the dead embers of which are occasionally stirred even to this day. ${ }^{1}$

Ord, who was about Audubon's own age, was a quiet, persistent, and unassuming worker, held in high esteem by many of his associates. Audubon seems to have done his best to conciliate him then and at a later day, but all to no purpose; Dr. Harlan once advised him to give up the attempt, since Ord, he declared, had no heart for friendship, having been denied that blessing by

${ }^{1}$ See Chapter XIV. 
nature herself. Ord, as we have seen, had edited the eighth and written the ninth, or concluding, volume of Wilson's American Ornithology, as well as a life of its author; the appearance of a new star in the ornithological horizon may not have been a welcome sight. At all events, we soon find him engaged upon a new edition of Wilson's work. ${ }^{2}$ Ord had objected to Audubon's method of combining plants and other accessories with his drawings of birds, a criticism that in the case of purely technical works could be easily sustained, and some of his later charges, though carried too far, were not wholly without foundation. ${ }^{3}$

Bonaparte, ${ }^{4}$ on the other hand, was captivated by

${ }^{2}$ This was the third edition of the American Ornithology, issued by Messrs. Collins \& Company in New York and by Harrison Hall of Philadelphia, in three octavo volumes, with an atlas of 76 plates colored by hand, in 1828-9. Mr. Hall, who appears to have been the person most interested financially in this edition, was a brother of James Hall, author of a notorious review in which this work was praised at the expense of Audubon, who was viciously attacked (see Bibliography, No. 123). Friends of Audubon repeatedly asserted that as soon as his popularity and success began to check the sales of Wilson's work, Ord and a few others, aided by interested publishers, began a systematic series of attacks, some notice of which is taken in Chapter XXVIII.

${ }^{3}$ See Chapter XIV.

${ }^{4}$ Charles Lucien Jules Laurent Bonaparte, Prince of Canino and Musignano, the eldest son of Lucien, and nephew of Napoleon, Bonaparte, was born at Paris in 1803, and died there in 185\%. At this time he was settled with his uncle and father-in-law, Joseph Bonaparte, former King of Spain, at Philadelphia, and there and at Bordentown, New Jersey, where Joseph had an estate, he undertook the study of American birds. His best known scientific works are: American Ornithology, or the Natural History of the Birds of the United States, not Given by Wilson, 4 volumes, quarto, with 27 colored plates, Philadelphia, 1825-1833; and Iconographica della Fauna Italica, Rome, 1833-1841. In 1828 he retired to Italy, where he was devoted to literary and scientific pursuits. He was an early subscriber to Audubon's Birds of America, but their relations were somewhat strained on the publication of the Ornithological Biography in 1831 (see Chapter XXIX). Bonaparte later entered politics in Italy, and was leader of the republican party at Rome in 1848 and 1849 ; after having been expelled from France by the order of Louis Napoleon, he was permitted to return in 1850, and became director of the Jardin des Plantes in Paris.

He was a closet naturalist rather than a field student, but did much for the reform of nomenclature. In his Ornitholony the number of American birds was raised to 366 , nearly one hundred having been added since the 
Audubon's drawings and anxious to secure his services for his own work, then well in hand. This was the American Ornithology, for which Titian R. Peale was then making the drawings, and Thomas Lawson, who had been Wilson's engraver, was engaged on the plates; though quite distinct in itself, this was much in the style of Wilson's earlier work, of which it was virtually a continuation. When Bonaparte introduced Audubon to these men, it is not surprising that the meeting was not productive of the best of feeling on either side. Peale's stiff and rather conventional portraits of birds naturally failed to awaken enthusiasm in "the trader naturalist," as some who looked upon him as a rival rather contemptuously called him. The interview with Lawson, if correctly reported by his friend, ${ }^{5}$ shows that his interest could not have been of the most disinterested sort. "Lawson told me," said this reporter, "that he spoke freely of the pictures, and said that they were ill drawn, not true to nature, and anatomically incorrect." Thereupon Bonaparte defended them warmly, saying that he would buy them and that Lawson should engrave them. "You may buy them," said the Scotchman, "but I will not engrave them . . . because ornithology requires truth in the forms, and correctness in the lines. Here are neither." Other meetings are said to have followed, but to have ended only in mutual dislike. Nevertheless, one of Audubon's drawings was engraved by Lawson and appeared in Bonaparte's work, ${ }^{6}$ but most

work of Wilson was revised by Ord, but he added only two that were new, Cooper's Hawk, (Accipiter cooperi), named after William Cooper of New York, and Say's Phobe (Sayornis saya), dedicated to Thomas Say, and first procured by Titian R. Peale in the Rocky Mountain districts of the Far West. Perhaps his most important technical work, the Conspectus Generum Avium, begun in 1850, was incomplete at the time of his death.

"William Dunlap, History of the Rise and Progress of the Arts of Design in the United States (Bibl. No. 59), vol. ii, p. 402 (New York, 1834).

${ }^{6}$ The Boat-tailed Grackle, vol. i, plate iv. 
of the figures in Bonaparte's concluding volumes were by the hand of a German named Alexander Rider. It was doubtless a fortunate circumstance that the prejudice and obstinacy of this overbearing Scot was a bar to any further absorption of Audubon's talents. ${ }^{7}$

Audubon met at this time a more appreciative engraver in Mr. Fairman, who urged him to take his drawings to Europe and have them engraved in a superior style; on July 12 the naturalist wrote that he had drawn "for Mr. Fairman a small grouse to be put on a banknote belonging to the State of New Jersey." By some lucky chance this incident brought him the acquaintance of Edward Harris, ${ }^{8}$ whom he met that summer in Philadelphia, and who became one of his most constant and disinterested friends. It was Harris who a few days after their meeting took all of the drawings which Audubon had for sale and at the artist's own prices; ${ }^{9}$ who for years was continually sending him rare or desirable specimens of birds; who accompanied him through the Southern States to Florida in 1837 and on the famous

: He seems, however, to have supplied Bonaparte liberally with notes, for after devoting fifteen pages to the biography of the Wild Turkey, Audubon said: "A long account of this remarkable bird has already been given in Bonaparte's American Ornithology, volume I. As that account was in a great measure derived from notes furnished by myself, you need not be surprised, good reader, to find it often in accordance with the above." Ornithological Biography (Bibl. No. 2), vol. i, p. 16.

${ }^{8}$ Edward Harris was born at Morristown, New Jersey, in 1799, where he died in 1863. Without the incentive to earn money or the ambition to acquire fame, he lived the life of a gentleman of leisure, devoted to natural history, to sport and to the cultivation of his paternal acres. He had the gift of friendship, was widely traveled, wrote charming letters, and kept careful records of his observations, but rarely published anything. The breeding of fine stock was one of his hobbies, and as a result of a journey to Europe in 1839, when he visited a horse fair in Normandy, he is credited with having first introduced the Norman breed into America. "The beneficent results of his quiet, unobtrusive life," says an appreciative biographer, "reach down to our time, and, after half a century, we are glad that Edward Harris lived." See biographical sketch by George Spencer Morris, in Cassinia, vol. vi (Philadelphia, 1902).

${ }^{9}$ See Chapter XII, p. 179. 


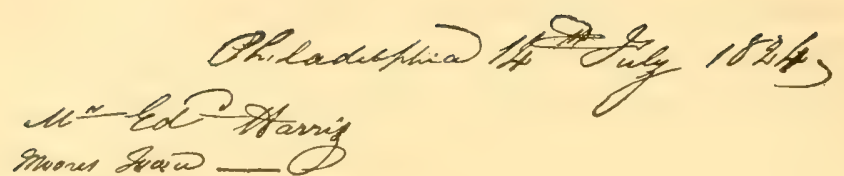

Lear 2 in

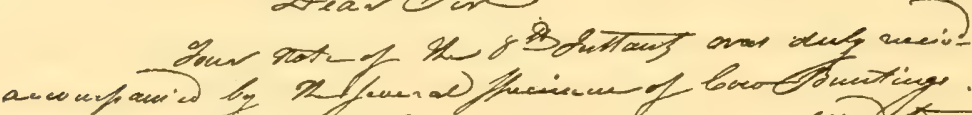

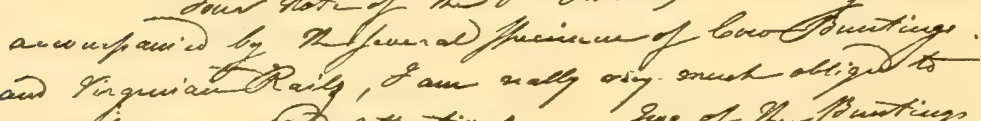

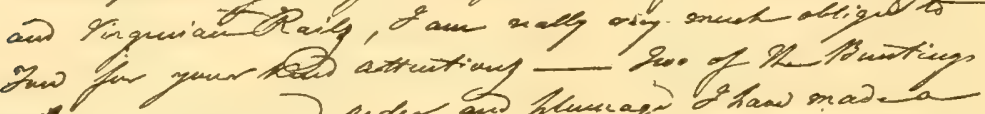

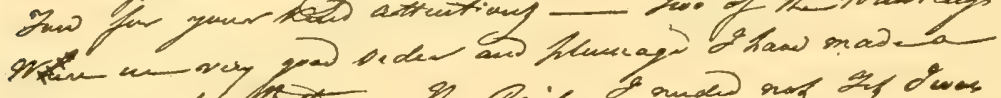

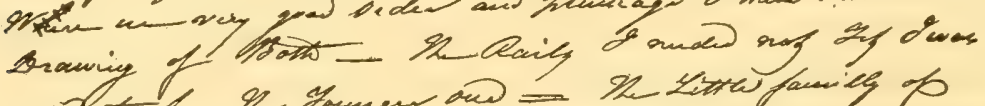

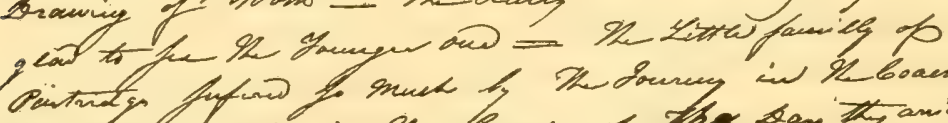

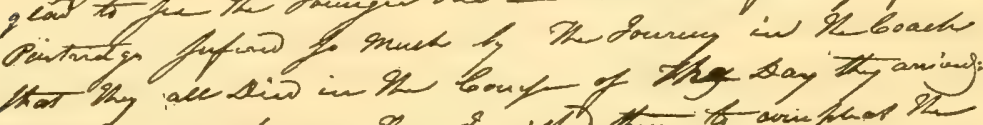

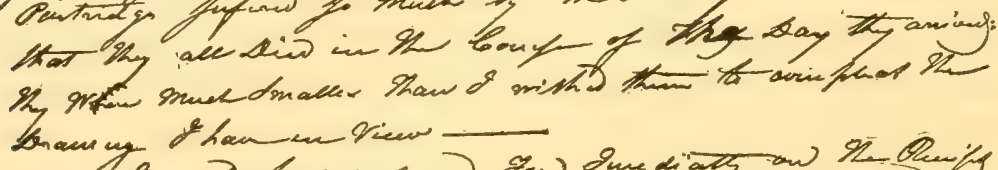

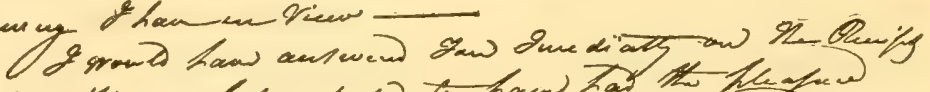

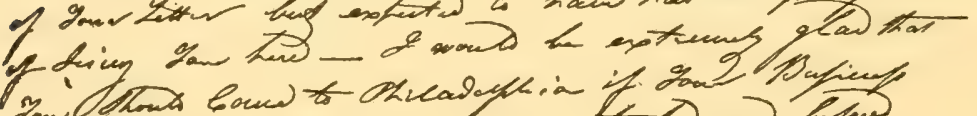

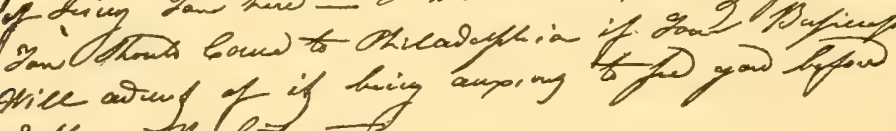
of Lam bea botr

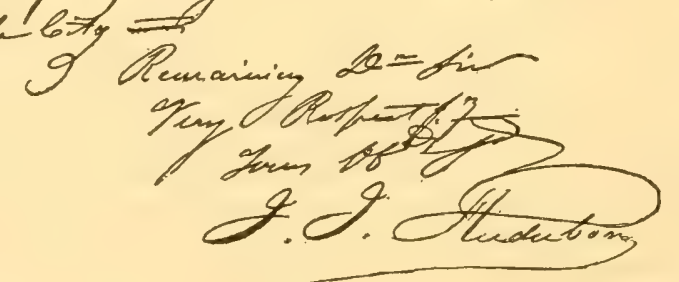

AN EARLY LETTER OF AUDUBON TO EDWARD HARRIS, DATEN JULY 14, 1824, AT THE BEGINNING OF THEIR LIFE-LONG FRIENDSHIP.

From the Jeanes MSS. Audubon's last ietter to Edward Harris, from the same source, is reproduced in Volume II, page 287. 


\section{DÉBUT AS A NATURALIST}

Missouri River Expedition in 1843. Edward Harris became a patron of science through his friendship with scientific men, and many besides Audubon were indebted to him for judicious advice as well as more substantial benefits.

The Academy of Natural Sciences, founded in 1812, was well established at this time, and its rapidly growing Museum was already the largest and most valuable in the New World; ornithology was a favored subject, and the Academy's roll embraced every American pioneer worker of note in the entire field of the natural sciences. The following account of a meeting of the Academy, held on October 11, 1825, when Ord presided, has been preserved in a letter of the period: ${ }^{10}$

A few evenings since I was associated with a society of gentlemen, members of the Academy of Natural Sciences. There were present fifteen or twenty. Among the number were Le Sueur, Rafinesque, Say, Peale, Pattison, Harlan, and Charles Lucien Bonaparte.

Among this collection life was most strikingly exemplified: Le Sueur, with a countenance weather-beaten and worn, looked on, for the muscles of his ironbound visage seemed as incapable of motion, as those on the medals struck in the age of Julius Cæsar. Rafinesque has a fine black eye, rather bald and black hair, and withal is rather corpulent. I was informed that he was a native of Constantinople; at present he lives in Kentucky. Dr. Harlan is a spruce young man. .. Peale is the son of the original proprietor of the Philadelphia Museum, and one who visited the Rocky Mountains with Major Long; he is a young man, and has no remarkable indications of countenance to distinguish him. Say, who was his companion

${ }^{10}$ Written by Dr. Edmund Porter of Frenchtown, New Jersey, to Dr. Thomas Miner of Haddam, Connecticut, on October 25, 1825. See Witmer Stone, "Some Philadelphia Ornithological Collections and Collectors, 1784-1850," The Auk, vol. xvi (New York, 1899). 
in the same expedition, is an extremely interesting man; to him I am particularly obligated for showing me their Museum and Library. I think he told me that their society had published nine volumes. . . Bonaparte is the son of Lucien Bonaparte and nephew to the Emperor Napoleon; he is a little set, black-eyed fellow, quite talkative, and withal interesting and companionable.

Among the working naturalists at Philadelphia Dr. Richard Harlan was possibly one whose friendship was most valuable to Audubon; the artist from whom he received most encouragement was Thomas Sully, the portrait painter, who took him into his studio and gave him lessons in the use of oils. Sully was one of those who saw the good side of Audubon's character, discerned his talent, and predicted for him a great future; at a later day Sully was able to rejoice in finding his prediction amply fulfilled. ${ }^{11}$

Convinced that the advice which Fairman and Bonaparte had given him was sound, Audubon decided to look to Europe for a publisher of his Birds, and with this end in view, set hard to work at his drawings. "I had some pupils offered," he said, "at a dollar per lesson; but I found the citizens unwilling to pay for art, although they affected to patronize it. I exhibited my

${ }^{11}$ Thomas Sully (1783-18\%2), Englishman by birth, who had come to America at an early age, and like Audubon had waged a bitter struggle before success was achieved, became one of the first portrait painters of the early American School.

In 1831 Sully wrote to Audubon that his success in England and France had charmed all of his friends in America, that it was like a personal triumph to them, and that it would soon silence his few remaining enemies; "Be true to yourself, Audubon," he added, "and never doubt of success." It has been said that when Audubon first came to Philadelphia in 1824 he applied to Sully for instruction, saying that he wished to become a portrait painter (see Dunlap, op. cit.); again that he was ready to sell his drawings to the highest bidder; but the records of his journals from 1820 onward are sufficiently consistent to show what his purpose really was. 
drawings for a week, but found the show did not pay, and so determined to remove myself." Audubon remained in Philadelphia until August, and while in doubt as to what step he should take next, he was cheered by a visit to "Mill Grove," made in the carriage of his Quaker friend, Reuben Haines. To quote his journal:

As we entered the avenue, which led to the farm, every step brought to my mind the memory of past years, and I was bewildered by the recollections until we reached the door of the house, which had once been the residence of my father as well as of myself. The cordial welcome of Mr. Wetherill, the owner, was extremely agreeable. After resting a few moments, I abruptly took my hat and ran wildly to the woods, to the grotto where I first heard from my wife that she was not indifferent to me. It had been torn down, and some stones carted away; but raising my eyes towards heaven, I repeated the promise we had mutually made. We dined at Mill Grove, and as I entered the parlor I stood motionless for a moment on the spot where my wife and myself were forever joined.

In this dramatic rehearsal the naturalist clearly implies that he was married in the parlor of his own home, but his excellent wife, who was surely in this instance the better authority, explicitly states that their marriage took place in her father's house at "Fatland Ford." Since Audubon was in the habit of sending extracts from his journal to his family, it is clear that errors of this sort were the simple result of an impulsive temperament; the moment his imagination pictured his wedding as having taken place in his old abode, down went the jotting in the journal, which was written at odd moments anywhere, often at late hours, and with no care in revision or thought of future publication.

On August 1, 1824, Audubon recorded in his diary 
that he had left Philadelphia for New York on the day before, "in good health, free from debt, and free from anxiety about the future." Sully had given him glowing letters of introduction to Gilbert Stuart, Washington Allston and Colonel Trumbull, but then as now midsummer was not a propitious time to find city people at home, and he began to consider the advisability of visiting both Albany and Boston. Alternately elated or depressed by the prospects of the day or the hour, Audubon wrote on August 4 that he had called with a letter of introduction on Dr. Mitchell, who had given him "a kind letter to his friend Dr. Barnes." This hurriedly penciled note from the Nestor of American science of that day has been carefully preserved, and reads as follows: ${ }^{12}$

\section{Dr. Samuel L. Mitchell to Dr. Barnes}

Mr. A. who brings strong testimonial of excellence from our friends in $\mathrm{Pha}$ is now sitting with me- $\mathrm{I}$ have been delighted and instructed by a Display of his Port Folio containing Drawings Done from Life of North American Birds and illustrating the Connect, of ornithology with Botany. he has Superior attainments \& skill in the natural sciences which he has cultivated for more than $20 \mathrm{y}$.

he wishes to show his Elegant performances to the Members of the Lyceum and to be made a Member of that Societyit is his intention to Leave this City for Boston on Sunday morning. Meanwhile I recommend him to your good offices.

Yours Truly as ever

$$
\begin{aligned}
& \text { Sam, L. Mitcheli } \\
& \text { Aug } t 4 \text { t } 1824
\end{aligned}
$$

${ }^{12}$ For the favor of examining a collection of interesting autograph letters written to Audubon in Europe and America, some of which are here reproduced, I am indebted to the kindness of Mr. Henry R. Howland, secretary of the Buffalo Society of Natural Sciences. This note was written on a narrow strip of manila-colored drawing paper. 
at A. who brings droog tostimoni al of Spccilem a fin- ono truens in Ole is now focling with The - o have been beligkn 1. Instmetso by a sichly of his for locta containing Oraurago Done from Life of north american sits

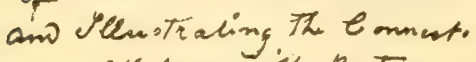
to omithology with 13otany. he has Suphenior att ain menty - Nkele in the ratin al diences which he has anterato for mow than 20 I. Le prishos to Jhow his Elagi... frosfonmiances * the mensers of the Ly cermo and be mave a mesnber of thar dociety- is is his Solention to Law. His Cidy fir Botom - SumDay monnng. Mrianntile g. acecoun riment Lim to your goo officen -

Jom gurb as ever

2. Milchete

$\alpha=$ K. Barng theth any $+4 \times 1824$

NOTE OF DR. SAMUET. L. MTCHELL, WRITTEN HT'RRIEDLY IN PENCIL, RECOMMENDING AUDUBON TO HIS FRIEND, DR. BARXES, AUGUST 4, 1824 From the Howland MSS.

337 
Dr. Mitchell, who was the father and first president of the Lyceum of Natural History, had been a friend of young Audubon when he was clerking in New York in $1807^{13}$ His recommendation was accepted, and the naturalist was enrolled on the Lyceum's list of members; to justify his election, two papers, representing his first contribution to ornithology, were presented to the Society, and appeared in its Annals of that year. ${ }^{14}$ Audubon visited the Lyceum with Dr. DeKay and exhibited his drawings, but said that he felt awkward and uncomfortable. On August 3 he called on John Vanderlyn, the artist, examined his pictures, and "saw the medal given him by Napoleon, but was not impressed with the idea that he was a great painter." Upon meeting Vanderlyn again a little later, he was asked to sit for a portrait of Andrew Jackson; his journal entry regarding the incident was as follows: ${ }^{15}$

August 10. My spirits low, and I long for the woods again; but the prospect of becoming better known prompts me to remain another day. Met the artist Vanderlyn, who asked me to give him a sitting for a portrait of General Jackson, since my figure considerably resembled that of the General, more than any he had ever seen. I likewise sketched my landlady and child, and filled my time.

The context shows that the sitting was given, and as Mr. Stanley C. Arthur remarks, Vanderlyn's portrait, which now hangs in the City Hall in New York, shows "Old Hickory" from the shoulders up, but from the shoulders down it is John James Audubon.

On the 14th Audubon wrote cheerfully to Sully:

${ }^{13}$ See Chapter XI.

${ }^{14}$ See Bibliography, Nos. 15 and 16.

${ }^{15}$ See Lucy Audubon, ed., Life of John James Audubon, the Naturalist (Bibl. No. 73), p. 107. 


\section{Audubon to Thomas Sully}

My reception in New York has surpassed my hopes. I have been most kindly [received], and had I seen Col. Trumball, I would have found him the gentleman you represented, but his absence at Saratoga Springs has deprived me of that pleasure.

New York is now an immense city. Strangers are received here with less reserve generally than at Philadelphia. I found the Academy well supplice with paintings, and sculptures of the Greek masters. The steam boats of the Sweet Ohio, with all their swiftness of motion and beautiful forms, do not interest the eye like those that are here tossing over the foaming billows with the grace of the wild swan. Were I a painter-ah could I, like —- carry in my mind's eye all my mind feels when looking at the Battery at the moon's tender reflections on the farthest sails, forcing the vessel they move with the very wind's heart,--express as he does the quick moving tar hauling in a reef at the yard's end,- - and make on the canvas a noble commander speak, as you have done; then, my dear friend, I could show you New York's harbor and all its beauties. . . .

I cannot part with that Fair City [Philadelphia] this soon; I cannot help thanking Fairman, Peale, Neagle, Le Sueur, and many others besides Mc Murty for their attentions to me. Should you see honest Quaker Haines, beg him to believe me his friend; should you see Mr. Ord, tell him I never was his enemy. Think of me some time, and accept the truest best wishes of

John J. Audubon.

I leave for Boston tomorrow. Should you please to write to me, direct to Care of Messrs. Anshutz \& Co, Pittsburgh, where I shall be in about 40 days.

The very next day Audubon changed his plans and sailed up the Hudson to Albany, where he hoped to meet De Witt Clinton, then at the height of his fame, who in the course of his great undertakings had found time to 
write letters on the natural history and antiquities of his State, and Dr. Beck, the botanist. Failing to find either at home, Audubon was compelled by the depleted state of his pocketbook to give up his plan of visiting Boston, and being determined to see Niagara Falls, he took passage on a canal boat to Buffalo instead. The Falls were reached on the 24th of August, and it was then, on recording his name at an hotel, that Audubon wrote underneath: "Who, like Wilson, will ramble, but never, like that great man, die under the lash of a bookseller." 16 Upon his first view of the Falls he was satisfied that Niagara never had been and never could be painted. He wanted to cross the bridge at Goat Island but was deterred by the necessity of economy. Visitors it seems, had already learned to venture under a small section of the American Falls, and Audubon said that while looking through the falling sheet of water, "at their feet thousands of eels were lying side by side, trying vainly to ascend the torrent." After strolling through the village to find some bread and milk, the naturalist recorded that he ate a good dinner for twelve cents, and that he went to bed "thinking of Franklin eating his roll in the streets of Philadelphia, of Goldsmith traveling by the aid of his musical powers, and of other great men who had worked their way through hardships and difficulties to fame, and fell asleep, hoping, by persevering industry, to make a name for himself among his countrymen."

The schooner from Buffalo to Erie, Pennsylvania, on which Audubon had taken deck passage, as he was unable to afford a berth in the cabin, was caught in a violent gale on the way and was obliged to anchor in the harbor of Presque Isle. "It was on the 29th of Au-

\footnotetext{
${ }^{18}$ See Vol. I, p. 219.
} 
gust, 1824," his diary reads, "and never shall I forget that morning." Captain Judd, of the United States Navy, had sent a gig with six men to its relief, and "my drawings," he continues, "were put into the boat with the greatest care. We shifted into it, and seated ourselves according to direction. Our brave fellows pulled hard, and every moment brought us nearer the American shore; I leaped upon it with elated heart. My drawings were safely landed, and for anything else I cared little at the moment."

At this point Audubon set out with a fellow traveler, who was also an artist, for Meadville, Pennsylvania. The earliest version of his journal ${ }^{17}$ which gives an account of this experience reads as follows:

On the shore of upper Canada, my money was stolen. The thief, perhaps, imagined it was of little importance to a naturalist. To repine at what could not be helped would have been unmanly. I felt satisfied Providence had relief in store. Seven dollars and a half were left to us, two persons, 1500 miles from home, at the entrance of Presque-Isle Harbor.

Five dollars was paid to their driver, and when they reached Meadville, and entered J. E. Smith's "Traveler's Rest," they had but one hundred and fifty cents between them. No time was to be lost, and Audubon at once started out with his portfolio and his artist friend to look for work:

I walked up the Main Street, looking for heads, till I saw a Hollander gentleman in a store, who looked as if he might want a sketch. I begged him to allow me to sit down. This granted, I remained perfectly silent till he very soon asked: "What is in that portfolio"? This sounded well; I opened it.

${ }^{17}$ Probably first published in a newspaper, and rep
form, dated "April 9, 1846"; see Bibliography, No. 49. 
He complimented me on my drawings of birds and flowers. Showing him a portrait of my Best Friend, I asked him if he would like one of himself. He said "Yes, and I will exert myself to gain as many more customers as I can."

According to a story current at Meadville long after the event Audubon made the acquaintance of Mr. Benedict, a merchant, lately come from New Haven, whose attractive daughter, named $\mathbf{J}$ ennett, ${ }^{18}$ was then one and twenty; his family lived at the village tavern, called the "Torbett House," in which Mr. Augustus Colson had a store. It was Mr. Colson, to whom Audubon probably refers, who responded generously to his appeal for work, and called in a number of his young friends as possible patrons. Among them was Miss Jennett Benedict, and the naturalist, attracted by her agreeable manners and pleasing appearance, asked permission to make a portrait-sketch, saying that he would pay for the privilege by presenting her with a copy. This was evidently good business enterprise, for, according to the story, a grain bin in the Colson store was soon converted into a studio, and Audubon was rewarded by a number of sitters. Here is his account from the record just quoted:

Next day I entered the artist's room, by crazy steps of the store-garret; four windows faced each other at right angles; in a corner was a cat nursing, among rags for a paper-mill; hogs-

${ }^{18}$ Miss Jennett Benedict in 1836 became Mrs. Butts; the crayon portrait which Audubon made at this time was carefully treasured by her daughter, the late Mrs. Frederick A. Sterling, of Cleveland, Ohio, to whose kindness $I$ am indebted for the privilege of reproducing it. This original drawing, which is presumably a fair specimen of Audubon's itinerant portraiture, was made on a sheet of buff, water-marked paper, $141 / 2$ by $101 / 2$ inches in dimensions; it was outlined in pencil, and carefully finished in crayon-point; its legend "J. J. Audubon-1824," was inserted in pencil, in a very fine hand at the lower margin of the sketch. The Colson store was at the corner of Water Street and south of Cherry Alley. For an account of this incident I am indebted to Mrs. Sterling, and to an article in the Tribune Republican, of Meadville, for February 7, 1907. 

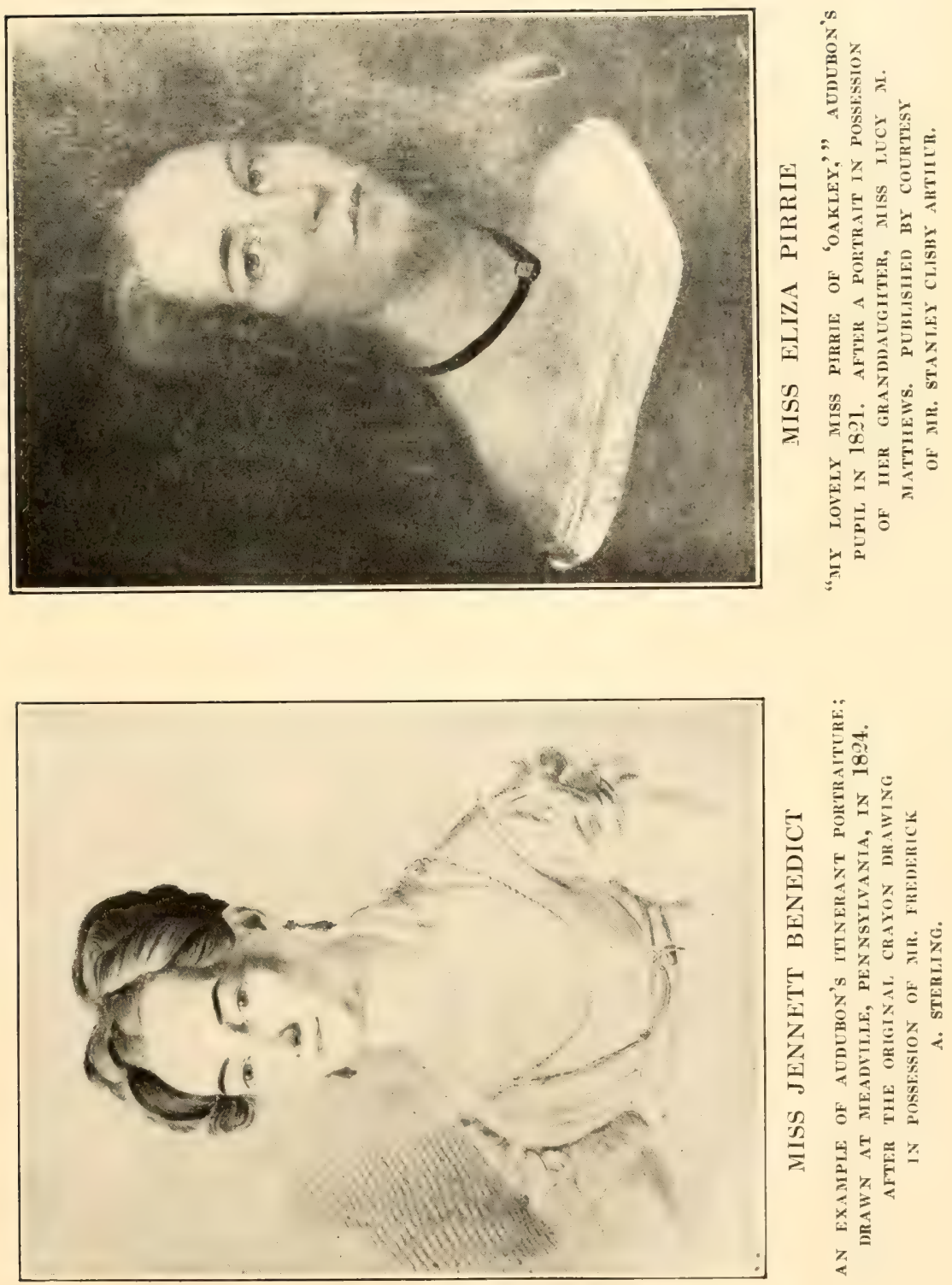

heads of oats, Dutch toys on the floor, a large drum, a bassoon, fur caps along the walls, a hammock and rolls of leather. Closing the extra windows with blankets, I procured a painter's light.

A young man sat to try my skill; his phiz was approved; then the merchant; the room became crowded. In the evening I joined him in music on the flute and violin. My fellow traveller also had made two sketches. We wrote a page or two in our journals, and went to rest.

The next day was spent as yesterday. Our pockets replenished, we walked to Pittsburgh in two days.

A month was spent at Pittsburgh, where Audubon searched the country for birds and continued his drawings. While there he made the acquaintance of the Reverend John Henry Hopkins, a man of superb appearance and rare conversational and oratorical powers, later known as the learned and versatile first Episcopal Bishop of Vermont. Audubon attended some of the ministrations of this remarkable man, through whose influence, he said, "I was brought to think, more than I usually did, of religious matters; but I never think of churches without feeling sick at heart at the sham and show of some of their professors. To repay evil with kindness is the religion that I was taught to practice, and this will forever be my rule."

In the autumn of 1824 Audubon planned another visit to the Great Lakes in search of new birds, and tried to induce his friend, Mr. Edward Harris, to accompany him. While wandering in the forests along those lakes he thought out the plan which was finally followed in the publication of his Birds of A merica:

Chance, and chance alone, had divided my drawings into three different classes, depending upon the magnitude of the objects to be represented; and, although I did not at that time 


\section{AUDUBON, THE NATURALIST}

possess all the specimens necessary, I arranged them as well as I could into parcels of five plates-I improved the whole as much as was in my power; and as I daily retired farther from the haunts of man, determined to leave nothing undone, which my labor, my time, or my purse could accomplish. ${ }^{19}$

Audubon's journal kept on the lakes has been lost, but that journey was fresh in mind when he wrote the following letter to Edward Harris. ${ }^{20}$

\section{Audubon to Edward Harris}

Beechwoods. Near Bayou Sara, La. Jany. 31 1825.

Surely I have not dismerited your esteem; when on the Lakes, both Ontario and Champlain, I wrote to you-again from Pittsburgh, all without any answer, and I am sorry to say that I have been either abandoned or forgotten by all those other persons who had promised to keep up a correspondence with me. . .

The country I visited was new, in great measure, to me. I have been delighted with the tour, but will forever regret that your sister's indisposition could not allow you time to augment my pleasure by your company.

[Audubon offers to send his friend shrubs and fruits from the South, and concludes;] In fact, my dear Mr. Harris, I am yet the same man you knew at the corner of 5th, and Minor Streets [in Philadelphia], and will continue forever the same.

After his tour of the Lakes Audubon returned to Pittsburgh, and on October 24, 1824, started down the Ohio in a skiff, intending to descend to the Mississippi and thence reach his family in Louisiana. Bad weather and lack of funds interfered with this plan, and ere long he was once more stranded in Cincinnati, where he was

${ }^{19}$ Ornithological Biography, vol. i, p. xi.

${ }^{20}$ The Jeanes MSS.; see Note, Vol. I, p. 180. 
beset by claimants for payment upon articles ordered for the Western Museum five years before. Finding it difficult at this time to replenish an empty purse, Audubon felt that he must borrow fifteen dollars, but could not make up his mind how to ask the favor until he had several times walked past the house where he had once been known. Nevertheless, he succeeded in obtaining the necessary funds, took passage on a boat bound for Louisville, and slept cheerfully that night on a pile of shavings which he managed to scrape together on deck. "The spirit of contentment which I now feel," he wrote, "is strange; it borders on the sublime; and, enthusiastic or lunatic, as some of my relatives will have me, I am glad to possess such a spirit"; later he added: "I discover that my friends think only of my apparel, and those upon whom I have conferred acts of kindness prefer to remind me of my errors."

Louisville was reached on November 20, and a number of days were spent in visiting his eldest son, Victor, who was then at Shippingport. ${ }^{21}$ He finally arrived at Bayou Sara in late November, 1824. The captain of his vessel, which was bound for New Orleans, put him ashore at midnight, and he was left to grope his way to the village on the hill. St. Francisville, to his dismay, was nearly deserted, a scourge of yellow fever having driven most of its inhabitants to the pine woods. The postmaster, however, was able to assure him that his wife and son were well, and Mr. Nübling, a friendly German, whom he described as "a

${ }^{21}$ "Shipping Port," as the village below the rapids or falls of the Ohio was then called, was joined to Louisville by the Louisville and Portland Canal, a channel two and one-half miles long, in 1830, two years after the city received its charter. The "Louisville" or "Portland" cement, a name now applied to the product of a considerable district, was first manufactured at Shipping Port, in 18:9, for the construction of this canal. 
man of cultivation and taste, and a lover of Natural Science," gave him refreshment and a horse. In his eagerness to cover the fifteen miles to the Percy house as rapidly as possible, he tried to strike a straight course through the dark forest, but missed his way, and dawn found him on unfamiliar ground; he then learned from a negro that he was two miles beyond the place. When he arrived at last "with rent and wasted clothes, and uncut hair, and altogether looking like the wandering Jew," his wife was busily engaged in teaching her pupils. During his absence of nearly fourteen months she had prospered greatly, and she was not only ready but eager to place her earnings at her husband's disposal.

When he had finally decided to take his drawings to Europe for publication, Audubon set to work to increase his capital, and soon had pupils in French, music, and drawing, while a dancing class of sixty was organized in a neighboring town. His country lads and lassies proved rather awkward material, and he broke his bow and nearly ruined his violin in his impatience to evoke a single graceful step or motion; when, however, he consented to dance to his own music, he never failed to bring down thunders of applause. These efforts were continued for over a year, until he had realized a considerable sum. With this money in hand, supplemented by what his wife could spare, he determined to seek his fortunes in the Old World. 


\section{CHAP'TER XXII}

\section{TO EUROPE AND SUCCESS}

Audubon sails from New Orleans-Life at Sea-Liverpool-The Rathbones-Exhibition of drawings an immediate success-Personal appearance-Painting habits resumed-His pictures and methods-Manchester visited-Plans for publication-The Birds of America-Welcome at Edinburgh-Lizars engraves the Turkey Cock-In the rôle of society's lion-His exhibition described by a French critic-Honors of science and the arts-Contributions to journals excite criticism-Aristocratic patrons-Visit to Scott-The Wild Pigeon and the rattlesnake-Letter to his wife-Prospectus-Journey to London.

When Audubon had reached the age of forty-one, his fortunes were destined to undergo still further kaleidoscopic changes, but the patterns and hue were now of a more agreeable character. He had failed repeatedly in business ventures of various kinds; he had failed also to find either encouragement or support for his ambitious schemes of publishing his drawings in the United States. But there was still a chance for success in the Old World, and thither he was determined to go to try the hazard of fortune in either England or France. Accordingly, he left his family at St. Francisville and went to New Orleans, where he engaged passage on a cotton schooner bound for Liverpool, named the Delos, Captain Joseph E. Hatch. With his drawings, a few books, and a purse, if not ample, at least sufficient for his immediate needs, and fortified with numerous letters, he finally set sail on the 17th of May, 1826.

This voyage, like every other which the naturalist ever made, was turned to good account; the log book 
or journal kept on this occasion abounds in interesting observations upon the life of the sea, particularly on the fishes and birds which were encountered in the Gulf. The first page of this journal, ${ }^{1}$ reproduced with orthographic exactness, reads as follows:

\section{April 1826-}

I Left My Beloved Wife Lucy Audubon and My Son John Woodhouse on Tuesday afternoon the 26 $6^{\text {th }}$ April, bound to England. remained at Doct ${ }^{r}$ Pope at $S^{t}$ Francisville untill Wednesday 4 o'clock P. M.: in the Steam Boat Red River Cape Kimble-having for Compagnons Mess ${ }^{\text {rs }}$ D. Hall \& John Haliday-reached New Orleans Thursday $27^{\text {th }}$ at 12-Visited Many Vessels for My Passage and concluded to go in the Ship Delos of Kennebunk Cap ${ }^{\mathrm{e}}$ Joseph Hatch bound to Liverpool, Loaded with Cotton entirely-

The Red River Steam Boat left on her return on Sunday and I Wrote by her to Thee My Dearest Friend and forward $^{d}$ Thee 2 Small Boxes of Flowering Plants-

saw, spoke to \& walked with Charles Briggs, much altered young man--

Lived at New Orleans at G. L. Sapinot in Company with Costé-

During My Stay at New Orleans, I saw my old and friendly acquaintances the familly Pamar; but the whole time spent

${ }^{1}$ Audubon's 1826 manuscript journal, which I examined through the courtesy of Miss Maria R. Audubon in 1914, was written, mostly in pencil, in a ruled blank book, of similar size and quality to that used on the Ohio River in 1820-21 (see Note, p. 30\%), and was illustrated with a number of pencil sketches, chiefly of fishes. On page $\mathcal{2}$ was a rough outline sketch of first mate Sam L. Bragdon, of Wells, Maine, reading in the booby hatch; to his kindness Audubon paid a written tribute; there was also a drawing of a "Balacuda [Barracouta] Fish, June 17, 1826;" of a "Shark, $7 \mathrm{ft}$. long; off Cuba, Jn. 18" (see reproduction); and of a "Dolphin; Gulph of Florida, May 28;" other sketches were of a line or "thread-winder," a Flying Fish, and outlines of the Cuban coast.

Audubon presented a sketch of the "Dolphin" to Captain Hatch, whose vessel, the Delos, went down on the Grand Banks of Newfoundland in the summer of 1831, but not until her crew and valuables had been transferred to another boat that stood by. (For this note I am indebted to Miss Maria R. Audubon.) 


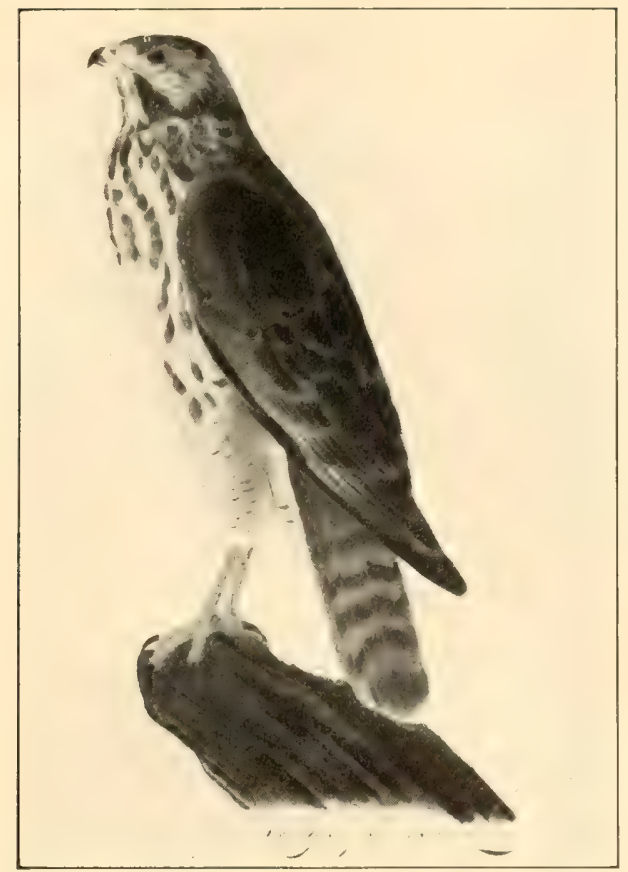

EARLY UNPUBLISHED DRAWING OF THE "FROGEATER," COOPER'S HAWK; "RED BANKS, KY.. NOVEMBER 99, 1810. LOXGECR TOTAL

19 POLCES POIDS 11b. 6oz. QUEUE

12 PENNES."

Published by courtesy of Mr. Joseph Y. Jeanes.

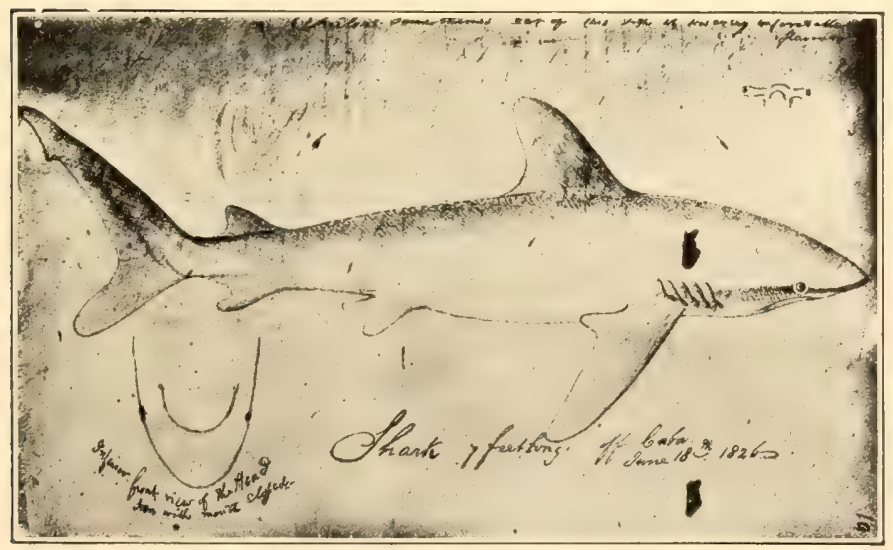

PENCIL SKETCH FROM ALDUBON'S JOURNAI OF HIS VOYAGE TO ENGLAND IN 1826: "SHARK 7 FEET LONG, OFF CUBA, JUNE 18TH, 18?6."

Published by courtesy of Miss Maria R. Audubon. 



\section{6 apice 1826}

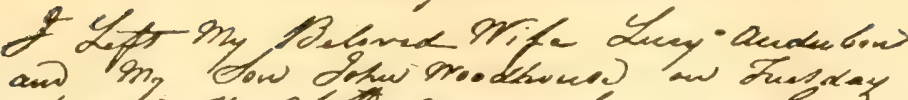

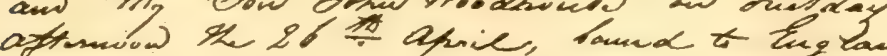

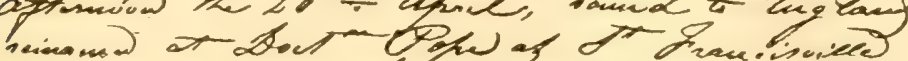

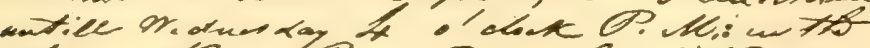

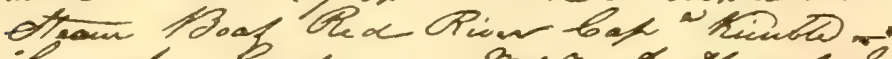

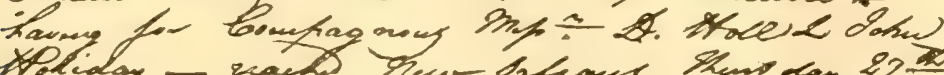

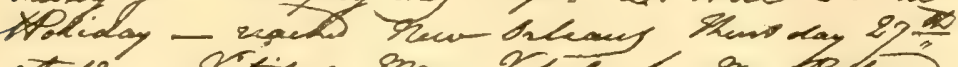

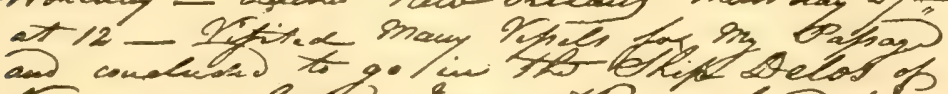

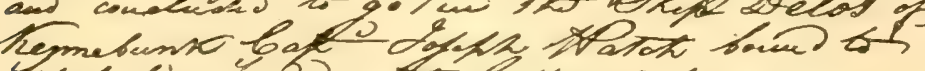

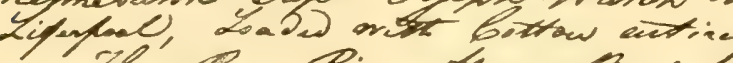

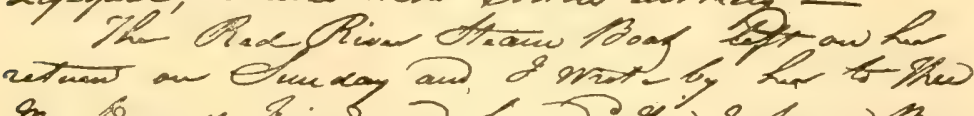

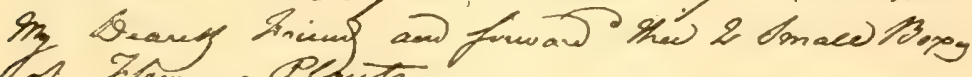

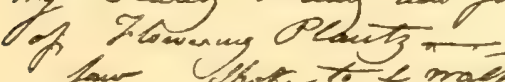

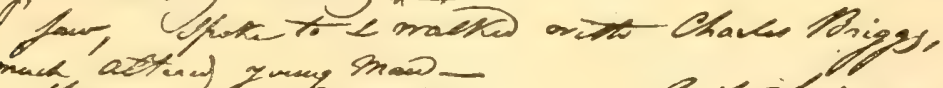

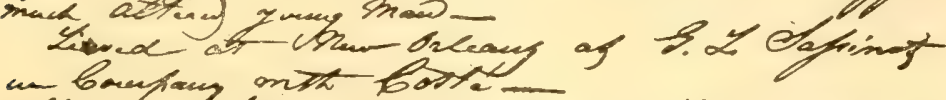

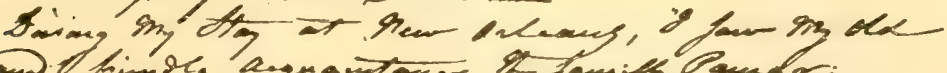

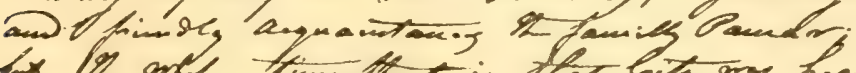

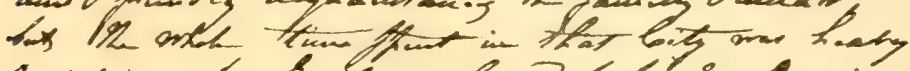

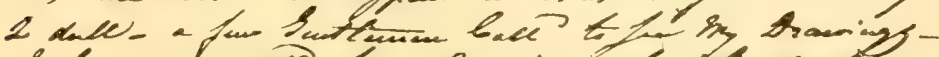

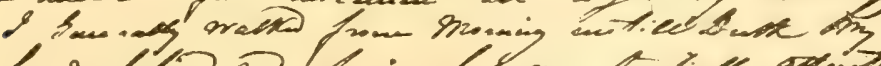

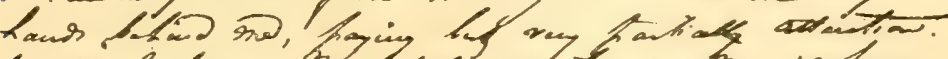

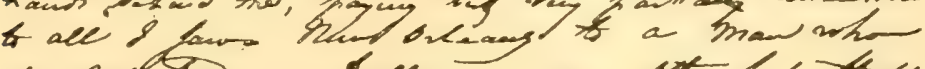

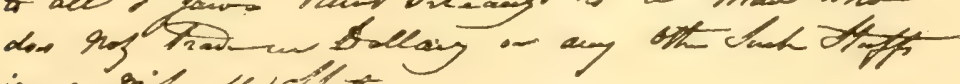
$\therefore$ a milatarara =

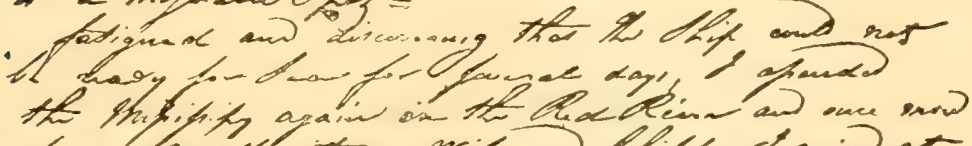

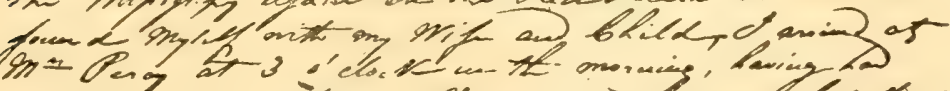

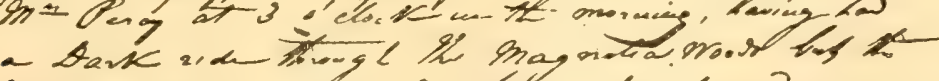

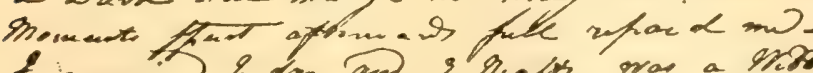

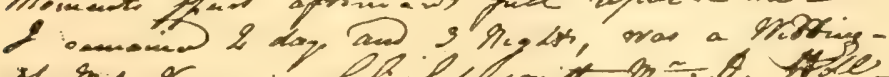

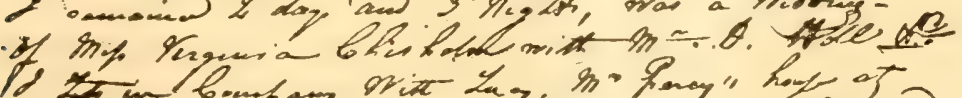

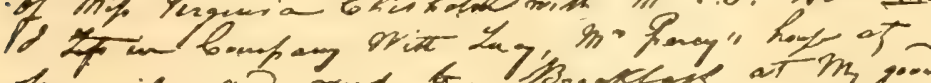
teat as a.

FIRST PAGE OF AUDUBON'S JOURNAL OF HIS VOYAGE FROM NEW ORLEANS TO LIVERPOOL.

Reproduced by courtesy of the Misses Florence and Maria R. Audubon. 
in that City was heavy \& dull-a few Gentlemen Calld to see My Drawings-I Generally Walked from Morning untill Dusk My hands behind me, paying but very partial attention. to all I saw-New Orleans to a Man who does not trade in Dollars or any other Such Stuff s is a miserable Spot=

fatigued and discovering that the Ship could not be ready for Sea for several days, I ascended the Mississipy again in the Red River and once more found Myself with my Wife and Child. I arrived at M ${ }^{\text {rs }}$ Percy at 3 o'clock in the morning, having had a Dark ride through the Magnolia Woods but the Moments spent afterwards full repaid me-I remained 2 days and 3 Nights, was a Wedding-of Miss Virginia Chisholm with $\mathbf{M}^{\mathrm{r}}$. D. Hall $\&^{\mathrm{c}}$. I Left in Company With Lucy $\mathbf{M}^{\mathrm{rs}}$ Percy" house at Sun rise and went to Breakfast at My good [friend's, Augustin Bourgeat].

The captain and mates of the Delos were friendly, and whenever their vessel was becalmed, they would let down a boat so that Audubon could procure the stormy Petrel and numerous other birds which he was anxious to examine in the flesh or depict for his "Ornithology."

During his long voyage of sixty-five days our adventurous traveler was alternately elated or depressed by hopes or fears for the future, until land was at last reached on Friday, July 21, 1826. The appearance of Liverpool, said Audubon, "was agreeable, but no sooner had I entered it than the smoke became so oppressive to my lungs that I could hardly breathe." At the customs he was charged two pence on each of his drawings, "as they were water-colored," but on his American books he had to pay "four pence per pound," a circumstance in which he was possibly favored by the following letter which he had brought with him from a friend in New Orleans: 


\section{TO EUROPE AND SUCCESS}

\section{Edward Holden to George Ramsden}

New Orleans, May 26th., 1826.

George Ramsden, Esq.

Dear Sir.

The present will be handed to you by Mr. J. J. Audubon of this city, whom most respectfully I beg to introduce to you.

The principal object of Mr. Audubon's visit to England is to make arrangements for the publication of an extensive and very valuable collection of his drawings in Natural History, chiefly if not wholly of American Birds, and he takes them with him for that purpose. Can you be of any assistance to him by letters to Manchester and London? If you can I have no doubt that my introduction of him will insure your best attention and services.-Mr. Audubon is afraid of having to pay heavy duties upon his drawings. He will describe them to you, and if in getting them entered Low at the Custom House, or if in any other respect you can further his views, I shall consider your aid as an obligation conferred upon myself. Pray introduce him particularly to Mr. Booth, who I am sure will feel great interest in being acquainted with him, were it only on account of the desire he has always expressed to be of service to the new Manchester Institution, to which Mr. Audubon's drawings would be an invaluable acquisition.

I am Dr. Sir

Yours truly,

Edward Holden.

Among the letters which Audubon carried on this occasion, but which apparently he did not deliver, was the following, addressed by a friend in New Orleans to General Lafayette: ${ }^{2}$

${ }^{2}$ Addressed "General LaFayette,

Paris ou Lagrange."

Translated from the French original, kindly sent to me by $\mathrm{Mr}$. Ruthven Deane. 


\section{Louis P. Caire to General Lafayette}

New Orleans, 15 May, 1826.

\section{My dear General,}

Monsieur Audubon, after having spent twenty-two years in the United States, is returning to Europe in order to publish a work to which he has devoted his entire life. This distinguished ornithologist, who bears letters from the most eminent citizens of the Union, will find, I trust, the encouragement to which his talents and his perseverance so fully entitle him, and however flattering may be the recommendations which his friends are eager to give him, these are yet, my dear General, beneath his merits. I have presumed to assure him of your patronage, and in introducing him to you I am convinced that it will be agreeable to you both.

Adieu my General: give my kind regards to all your family, and permit me to embrace you as I love you.

Louis P. Caire.

Before Audubon left New Orleans, an old acquaintance, Mr. Vincent Nolte ${ }^{3}$ of that city, had also furnished him with credentials, in which it was stated that the naturalist was carrying with him four hundred original drawings, and that his object was "to find a purchaser or a publisher." "He has a crowd of letters," continued Nolte, "from Mr. Clay, De Witt Clinton, and others for England, which will do much for him; but your introduction to Mr. Roscoe and others will do more." This judgment was sound, but the most valuable letter which Audubon carried proved to be that of Nolte himself addressed to Richard Rathbone, Esq., of Liverpool, for it brought him into immediate friendly relations with an influential family of merchants which also included William Rathbone, a brother, as well as their father, William Rathbone, Senior, whose interest

\footnotetext{
${ }^{3}$ For an account of Audubon's meeting with Nolte see Chapter XVIII.
} 
in birds had made him in his younger days an amateur collector and student. Seldom has the rôle of Mreenas been played more effectively and with less ostentation than by those intelligent men of affairs, to whom Audubon, with his fine enthusiasm and bold literary plans, seemed to embody all the romance of the New World. They stood sponsor for his work and worth, and did all in their power to make their new discovery known. At the home of the senior Rathbone, called "Greenbank," three miles out of Liverpool, the naturalist was warmly welcomed, and his excellent hostess, Mrs. William Rathbone, the "Queen bee," as he called her, received from him lessons in drawing and became his first subscriber.

At this period Audubon often complained of shyness felt in meeting strangers, but his "observatory nerves," as he said, never gave way. He studied his English friends as closely as he had the birds of America, and the results of his shrewd observations were often turned to practical account. That he was as diffident as he declared himself to be may be doubted, for he seems to have met nearly everyone of prominence wherever he went, and a list of his acquaintance at the end of his sojourn abroad would read much like a "Blue Book" of the British Isles.

At Liverpool Audubon received much assistance also from Edward Roscoe, botanist and writer, Dr. Thomas S. Traill ${ }^{4}$ and Adam Hodgson, who introduced

${ }^{4}$ Dr. Thomas Stuart Traill, after whom one of our common flycatchers was named, was a founder of the Royal Institution at Liverpool, and later a professor of medical jurisprudence at Edinburgh. When the keepership of the Department of Natural History in the British Museum became vacant through the resignation of Dr. Leech in 1822, Dr. Traill supported William Swainson for the position; when George $J$. Children received the appointment, he was disinclined to accept defeat, and entered upon a crusade against the Museum's trustees in a series of anonymous articles 
him to Lord Stanley. When he came to write his Ornithological Biography, these early friends were all publicly called by name, and we thus had (though, as it afterwards appeared, in name only) the "Rathbone Warbler," 5 "Stanley Hawk," "Children's Warbler," "Cuvier's Regulus," "Roscoe's Yellow-throat," "Selby's Flycatcher," and still possess "Bewick's Wren," "Traill's Flycatcher," "Henslow's Bunting," " "MacGillivray's Finch," and "Harlan's Hawk," to cite a few instances of this form of acknowledgment.

Within barely a week after landing at Liverpool a total stranger, Audubon was invited to show his drawings at the Royal Institution. The exhibition, which lasted a month, was a surprising success; 413 persons, as he recorded, were admitted on the second day, and it netted him one hundred pounds although no charge for admission was made during the first week.

Everyone, said the naturalist, was surprised at his appearance, for he wore his hair long, dressed in unfashionable clothes, rose early, worked late, and was abstemious in food and drink. Shortly after his arrival,

contributed to the Edinburgh and Westminster Reviews. Traill's exposure of the neglect which the natural-history collections had suffered in the custody of the British Museum paved the way to a separate Department of Zoölogy, which in the able hands of John E. Gray, and later in those of Sir Richard Owen, led to the present great Museum of Natural History at South Kensington.

5 In dedicating the Sylvia rathbonia Audubon said: "Were I at liberty here to express the gratitude which swells my heart, when the remembrance of all the unmerited kindness and unlooked-for friendship which I have received from the Rathbones of Liverpool comes to my mind, I might produce a volume of thanks. But I must content myself with informing you, that the small tribute of gratitude which it is alone in my power to pay, I now joyfully accord, by naming after them one of those birds, to the study of which all my efforts have been directed. I trust that future naturalists, regardful of the feelings which have guided me in naming this species, will continue to it the name of the Rathbone Warbler."

" Named after John Stevens Henslow, Professor of Botany in the University of Cambridge, whom Audubon had met in 1828, when Charles Darwin was still his pupil. 
his sister-in-law, Mrs. Alexander Gordon, urged him to have his hair cut and to buy a fashionable coat, but he could not then bear to sacrifice his ambrosial locks, which continued to wave over his shoulders until the following March. If we can accept Sir Walter Besant's characterization of the period, the "long-haired Achran" was no stranger to the streets of London as late as 1837: "brave is the exhibition of flowing locks; they flow over the ears and over the coat-collars; you can smell the bear's grease across the street; and if these amaranthine locks were to be raised you would see the shiny coating of bear's grease upon the velvet collar below.'

Audubon had not been in England three weeks before he resumed his drawing and painting habits, at first in order to repay his friends for their kindness, and later as a means of support; at times he would devote every spare moment to this work, and he was then able to paint fourteen hours at a stretch without fatigue. On October 2 he recorded that he had made in less than twenty minutes a diminutive sketch of the Turkey Cock from his large twenty-three hour picture. This was for Mrs. William Rathbone, Senior, who later presented it to him in the form of a handsome goldmounted seal, inscribed with his favorite motto, "America, my country." 7 The facility which Audubon displayed in producing his pictures of animal life-American wild turkeys, trapped otters, fighting cats, English game pieces, and the like, in a style both novel and individual, added much to his immediate popularity in Eng-

7 This seal, the design of which has since been adapted for a bookplate, was long in use, and though at one time lost, is still in possession of the family. A copy of the large original, which was to serve as his first plate, was presented to the Royal Institution of Liverpool as an acknowledgment of its hospitality, for it had refused remuneration in any other form. 
land, as it later did to his purse. His painting devices are thus referred to in a journal entry for January, 1827:

No one, I think, paints in my method; I, who have never studied but by piece-meal, form my pictures according to my ways of study. For instance, I am now working on a Fox; I take one neatly killed, put him up with wires and when satisfied with the truth of the position, I take my palette and work as rapidly as possible; the same with my birds; if practicable I finish the bird at one sitting,- often, it is true, of fourteen hours, - so that I think they are correct, both in detail and composition.

When he was painting pheasants and needed a white one as "a keystone of light" to his picture, a nobleman sent word that he would be given "leave to see the pictures" in his hall, but this Audubon characteristically refused, being determined to pay no such visits without invitation.

On the 10th of September, 1826, Audubon left Liverpool, in a hopeful mood, for Manchester, with the intention of visiting the chief cities of England and Scotland. He was fortified with a bundle of letters to a long list of distinguished people, including Baron von Humboldt, General Lafayette, Sir Walter Scott, Sir Humphry Davy and Sir Thomas Lawrence. His first step proved a disappointment, and when he finally left the City of Spindles six weeks later, he found himself poorer than when he had entered it. At Manchester, however, he added to his list of interested friends and possible patrons, and acting upon their suggestion, opened a subscription book for the publication of his long meditated work, to be called The Birds of A merica. The Rathbones, as well as other friends whose advice 


\section{TO EUROPE AND SUCCESS}

he esteemed, tried to dissuade him from the plan of publishing his drawings in their full size, which was that of life, on account of the great expense involved and the enormous bulk such a work would assume; but he could not bring himself to give up the idea, in which he received the support of the London bookseller, Mr. Bohn, who, after seeing Audubon's drawings reversed his opinion, saying that they must be brought out in their full size, and that they would certainly pay.

After coming to England Audubon often thought of the shifting scenes and strange contrasts his life had brought. One day he felt the pinch of poverty, but on the next fared sumptuously at the tables of the rich; now a rambler in the wilds of America, glad to accept the hospitality of the humblest prairie squatter, now the guest of some metropolitan aristocrat. "The squatter," he said, when writing in England, "is rough, true, and hospitable; my friends here polished, true, and generous. Both give freely, and he who during the tough storms of life can be in such spots may well say that he has tasted happiness."

While at Manchester Audubon was driven to the town of Bakewell, "the spot," he wrote in deference to his wife, "which has been honored with thy ancestor's name." Shortly after, on October 23, he started by stage for Edinburgh, and the distance of 212 miles was covered in three days; the fare was $£ 55$ s. 5 d., which he regarded as exorbitant, but he complained not so much of the charge as of the beggarly manner of the drivers, who never hesitated to open the door of their coach and ask for a shilling at the slightest provocation.

At Edinburgh Audubon was welcomed so warmly that he began to feel that ultimate success was at last within his reach. Professor Robert Jameson of the 
University did much to make his work known, and invited him to coöperate in an enterprise upon which he was then engaged; ${ }^{8}$ this was pronounced by Dr. Knox of the Medical School to be a "job book," but whatever its merits may have been, Audubon decided after due reflection to stand on his own feet.

Not long after reaching the Scottish capital, Audubon made the acquaintance of Mr. W. Home Lizars, styled "a Mr. Lizard" by a snapshot biographer of a later day, a well known, expert engraver and painter, who engaged in various publishing enterprises. When Audubon had held up a few of his drawings for his inspection, Lizars rose, exclaiming: "My God! I never saw anything like this before." The picture of the Mockingbirds attacked by a rattlesnake particularly struck his fancy, but when he came to the drawing of the Great-footed Hawks, "with bloody rags at their beaks' ends, and cruel delight in their daring eyes," Lizars declared that he would both engrave and publish it. "Mr. Audubon," said he, "the people here don't know who you are at all, but depend upon it, they shall know." Lizars eventually agreed to engrave and bring out the first specimen number of The Birds of America, and about the 10th of November made a beginning with the first plate. On November 28, 1826, he handed Audubon a first proof of the Wild Turkey Cock, a subject chosen to justify the great size of the work, which was to be in double elephant folio, and which in point of size is perhaps to this day the largest extended publica. tion in existence. ${ }^{9}$ This and the second plate, which represented the Yellow-billed Cuckoo ${ }^{10}$ in the act of

${ }^{8}$ See Note, Vol. I, p. 375.

- The plates as issued, untrimmed, measured $391 / 2$ by $291 / 2$ inches; see Bibliography, No. 1.

${ }^{10}$ See Note, Vol. II, p. 197. Incidentally it may be noticed that the "tiger 


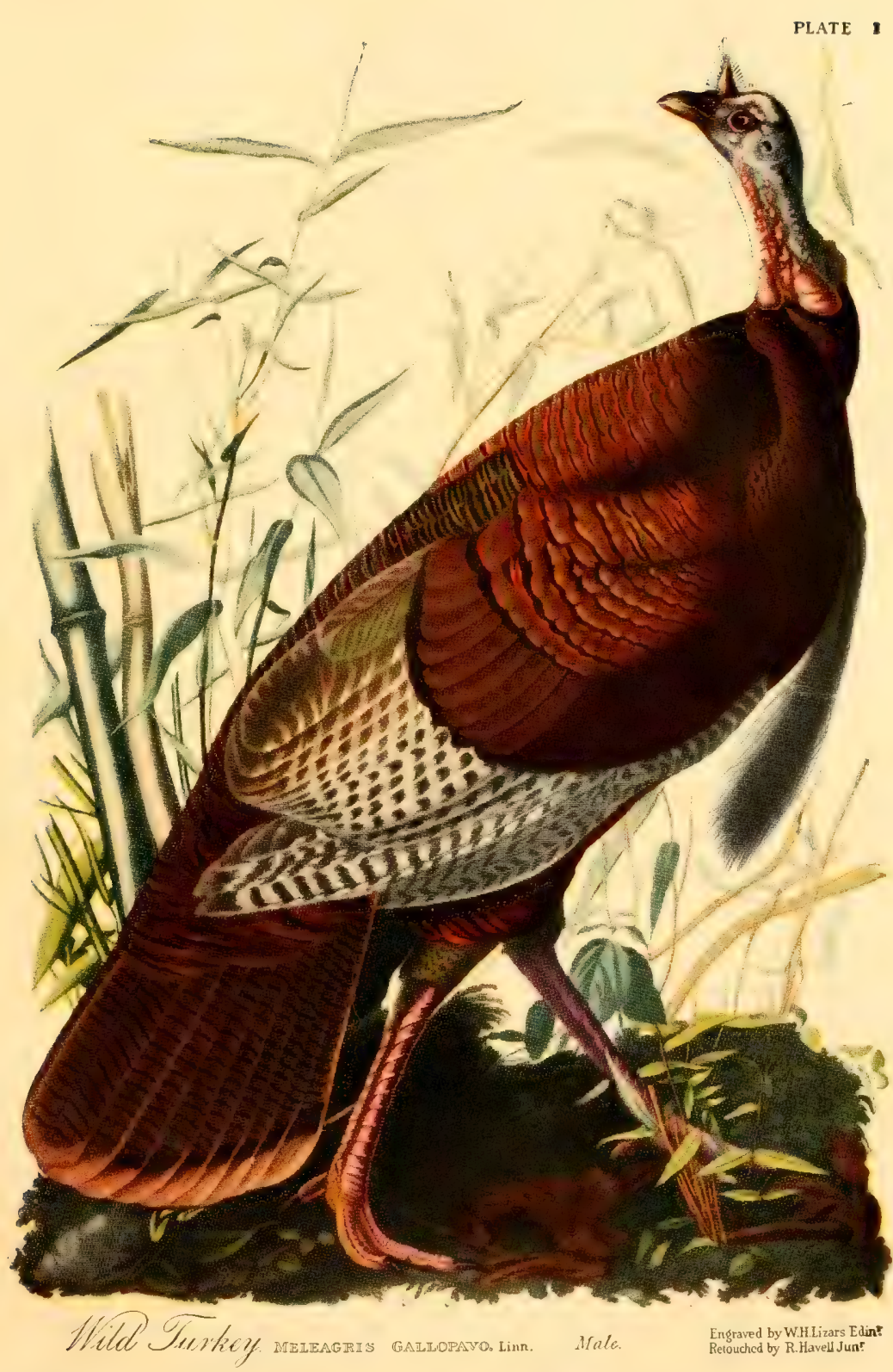

Drown trom nature by J Audubor F. R.S.F.L.S Amercan Cane. Niegia macnspherma. 

seizing a tiger swallowtail butterfly on a branch of the paw-paw tree, were finished by December 10; the first number of five plates was ready some weeks later. Lizars engraved at Edinburgh the first ten of Audubon's plates, but most of these were subsequently retouched, colored and reissued by his successor in London, as will presently appear.

When Audubon's pictures were exhibited at the Royal Institution of Edinburgh, their success was immediate, and like the appearance of a new Waverley novel, they became the talk of the town; the American woodsman had provided a new thrill for the leaders of fashion, as well as for the literati and the scientific men. The "noblest Roman of them all," Sir Walter Scott, refused to attend, but after having met the naturalist he wrote this in his journal: "I wish I had gone to see his drawings; but I had heard so much about them that I resolved not to see them-'a crazy way of mine, your honor.'"

Philarète-Chasles, a well known French critic of the period, has left the following record ${ }^{11}$ of the effect which this exhibition made on his impressionable mind:

We have admired in the rooms of the Royal Society of Edinburgh the public exhibition of [Audubon's] original watercolor drawings. A magic power transported us into the forests which for so many years this man of genius has trod.

swallowtail" in this plate was possibly added for effect, for few of our birds, which habitually hunt moths, ever prey upon butterflies. I have seen the cabbage butterfly and a few of the smaller kinds brought to the nests of the Chebec and Wood Pewee but never a "monarch" or "papilio"; yet some affirm that the Kingbird will attack the "monarch."

11 Translated from Études sur la Littérature et les Mours des AngloAmericains au XIXe siècle, "Audubon," pp. 66-106 (Paris, 1851). Philarète-Chasles, who wrote chiefly on American, English and European anthors and books, has seventy volumes credited to him in the National Library at Paris. 
Learned and ignorant alike were astonished at the spectacle, which we will not attempt to reproduce.

Imagine a landscape wholly American, trees, flowers, grass, even the tints of the sky and the waters, quickened with a life that is real, peculiar, trans-Atlantic. On twigs, branches, bits of shore, copied by the brush with the strictest fidelity, sport the feathered races of the New World, in the size of life, each in its particular attitude, its individuality and peculiarities. Their plumages sparkle with nature's own tints; you see them in motion or at rest, in their plays and their combats, in their anger fits and their caresses, singing, running, asleep, just awakened, beating the air, skimming the waves, or rending one another in their battles. It is a real and palpable vision of the New World, with its atmosphere, its imposing vegetation, and its tribes which know not the yoke of man. The sun shines athwart the clearing in the woods; the swan floats suspended between a cloudless sky and a glittering wave; strange and majestic figures keep pace with the sun, which gleams from the mica sown broadcast on the shores of the Atlantic; and this realization of an entire hemisphere, this picture of a nature so lusty and strong, is due to the brush of a single man; such an unheard of triumph of patience and genius! - the resultant rather of a thousand triumphs won in the face of innumerable obstacles!"’

Another French writer ${ }^{12}$ remarked that Audubon produced the same sensation among the savants of England that Franklin had made at the close of the eighteenth century among the politicians of the Old World; his works, he added, should be translated into his native tongue, and produced in a form which would enable them to reach the library of every naturalist in France.

One after another the scientific, literary, and arts so-

${ }^{2}$ P. A. Cap, in L'Illustration for 1851. Cap's hint was taken by Eugène Bazin, who translated copious selections from the Ornithological Biography, which were published in two volumes in Paris in 1857 (see Bibliography, No. 38). 
cieties of the modern Athens elected Audubon to honorary membership; Combe, the phrenologist and author of The Constitution of Man, examined the naturalist's head and modeled it in plaster, for of course it proved to be a perfect exemplification of his system; Syme, the artist, did his portrait for Lizars to engrave. Meanwhile the press was giving such flattering accounts of the man and his work that Audubon confessed that he was quite ashamed to walk the street. At the annual banquet of the Royal Institution, held at the Waterloo Hotel and presided over by Lord Elgin, Audubon was toasted, and it required all his resolution to rise and, for the first time in his life, address a large assembly; this, however, he managed to do in the following words: "Gentlemen; my command of words in which to reply to your kindness is almost as limited as that of the birds hanging on the walls of your Institution. I am truly obliged for your favors. Permit me to say; may God bless you all, and may this society prosper." On the 10th of December he wrote: "My situation in Edinburgh borders on the miraculous," and he felt that his reception in that city was a good augury for the future. But the life that he was compelled to lead was extremely fatiguing, and he often longed to return to his family and to his favorite magnolia woods in Louisiana. "I go to dine," he wrote, "at six, seven, or even eight o'clock in the evening, and it is often one or two when the party breaks up; then painting all day, with my correspondence, which increases daily, makes my head feel like an immense hornet's nest, and my body wearied beyond all calculation; yet it has to be done; those who have my best interests at heart tell me I must not refuse a single invitation." But notwithstanding the tax which society always levies upon the lion's strength, he wrote almost 
daily in his journal or diary, ${ }^{13}$ and its pages, from which we have been quoting, became a mirror of all that he saw, heard, or did. Audubon was generous with his time, as with everything else, and would never hesitate to lay aside his own work for the sake of a friend who was eager to acquire his method of drawing. But when his entertainment commenced with an invitation to breakfast, he began to be alarmed at the large share of his working hours which had to be surrendered to his friends. "I seem, in a measure," he said, "to have gone back to my early days of society and fine dressing, silk stockings and pumps, and all the finery with which I made a popinjay of myself in my youth . . . It is Mr. Audubon here, and Mr. Audubon there, and I can only hope they will not make a conceited fool of Mr. Audubon at last."

In response to urgent appeals he began at this time to contribute to the scientific journals of the Scottish capital, a step which only served to remind him that the rose was more prolific in thorns than flowers. Dr. Brewster, however, in his Journal of Science, and John Wilson in Blackwoods, sang pæans in his praise, and there is no doubt that "Christopher North," so like and yet so unlike the American woodsman, did much to smooth his path in his own country as well as in Europe. Though keenly feeling the need of literary advice in those early contributions, Audubon was quite shocked at the alterations which Dr. Brewster had made in one of these articles, for though the editor had "greatly improved the style," he had quite "destroyed the matter."

On December 21, 1826, Audubon wrote to Thomas Sully that he would send him a copy of the first number of his Birds, with the request that he forward it in his

\footnotetext{
${ }^{13}$ See Maria R. Audubon, Audubon and his Journals (Bibl. No. 86).
} 
name "to that Institution which thought me unworthy to be a member . . . There is no malice in my heart," he continued, "and I wish no return or acknowledgment from them. I am now determined never to be a member of that Philadelphia Society." Let it be noted, however, that Audubon was elected to membership in the American Philosophical Society, when their recognition could no longer be withheld and when mutual animosities had died down. Three days later he recorded that all of his drawings had been taken from the walls of the Royal Institution, where they had been on exhibition a month, and that he was intending to present to the Society his large canvas of the Wild Turkeys, for which Galley, the picture dealer, had offered him a hundred guineas on the previous day. ${ }^{14}$

Among Audubon's early patrons were Lord and Lady Morton, and more than once he was invited to visit them in their beautiful country seat of "Dalmahoy," where a large, square, half-Gothic building, crowned with turrets and adorned with all the signs of heraldry, overlooked a beautiful landscape to Edinburgh, marked by its famous castle, seen in miniature on the horizon, eight miles away. Being somewhat apprehensive of meeting the former Chamberlain to the late Queen Charlotte, Audubon had imagined the Earl

14 Audubon's copy of this oil painting remained in the possession of his family until a few years ago, when it was sold for a much greater amount. It now adorns the beautiful ornithological museum of Mr. John E. Thayer, at South Lancaster, Massachusetts; it represents a cock and hen turkey in life size, adapted from the subjects of his two most famous plates, and is in an admirable state of preservation. Mr. Thayer's collection also embraces Audubon's large canvas of the Black Cocks, from the Edward Harris estate, a charming study of the Hen Turkey, with landscape setting, and, also in oils, several smaller panels of Flickers and Passenger Pigeons, which, if not the work of the naturalist, are copies after his originals, and possibly made by Joseph B. Kidd. (See Vol. I, p. 446; and for a notice of Mr. Thayer's other Audubonian drawings, Vol. II, p. 227, and Appendix II.) 
to be "a man of great physical strength and size"; instead, however, he saw

a small, slender man, tottering on his feet, weaker than a newly hatched partridge; he welcomed me with tears in his eyes, held one of my hands, and attempted speaking, which was difficult to him, the Countess meanwhile rubbing his other hand. I saw at a glance the situation, and begged he would be seated ... and I took a seat on a sofa that I thought would swallow me up, so much down swelled around me. It was a vast room, at least sixty feet long, and wide in proportion, let me say thirty feet, all hung with immense paintings on a rich purple ground; all was purple about me. The large tables were covered with books, instruments, drawing apparatus, a telescope, with hundreds of ornaments.

After luncheon Audubon's "Book of Nature" was produced, and his drawings spread out and admired. Next day the Countess, who was "a woman of superior intellect and conversation," was given "a most unnecessary lesson" in drawing, for, said the naturalist, "she drew much better than I did; but I taught her to rub with cork, and prepare for water-color." Before he left the Countess wrote her name in his subscription book, and arranged that he should return and resume his instruction.

One of Audubon's early friends at Edinburgh was Captain Basil Hall, ${ }^{15}$ traveler and writer, who was then about to start on a journey through the United States; he told the naturalist that he was a midshipman on board the Leander "when Pierce was killed of" New York," at the time of Audubon's return with Rozier to America in 1806, when Captain Sammis, upon seeing the British

${ }^{15}$ Basil Hall (1788-1844), noted for his travels in China, Korea, and on the coasts of Chili, Peru and Mexico, visited the United States in 182728; his Travels in North America appeared in 1829. 
frigate, "wore around Long Island Sound, and reached New York by Hell Gate." It was at Captain Hall's home that Audubon met Francis Jeffrey. The indomitable critic and reviewer was described as "a small (not to say tiny) man," who entered the room "with a woman under one arm, and a hat under the other." "His looks were shrewd," said the naturalist, his eyes "almost cunning" and though he talked much, he appeared unsympathetic. Their meeting was productive of no friendly feelings on either side.

Three months after reaching Edinburgh, the long awaited opportunity of meeting the greatest literary figure of the day came to Audubon unexpectedly, for he did not wish to be introduced in a crowd. Under date of January 22, 1827, he wrote that Captain Hall came to his rooms and said: "Put on your coat, and come with me to Sir Walter Scott: he wishes to see you now." "In a moment," said Audubon, "I was ready. My heart trembled; I longed for the meeting, yet wished it over." When they were ushered into Sir Walter's study, the great Scot came forward, and warmly pressing the hand of his visitor, said he was glad to have the honor of meeting him. Audubon's record of the meeting continues:

His long, loose, silvery locks struck me; he looked like Franklin at his best. He also reminded me of Benjamin West; he had the great benevolence of William Roscoe about him, and a kindness most prepossessing. I could not forbear looking at him; my eyes feasted on his countenance. I watched his movements as I would those of a celestial being; his long, heavy, white eyebrows struck me forcibly. His little room was tidy, though it partook a good deal of the character of a laboratory. He was wrapped in a quilted morning-gown of light purple silk; he had been at work writing on the "Life of Napoleon." 
He writes close lines, rather curved as they go from left to right, and puts an immense deal on very little paper. . . . I talked little, but, believe me, I listened and observed.

Two days later Audubon paid Scott a second visit, this time with his portfolio, but little was recorded of this interview other than that it was more agreeable than the first, and that he greatly admired the accomplished Miss Scott, to whom he later sent as a gift the first number of his plates. Audubon's drawings were exhibited at a meeting of the Royal Society over which Sir Walter presided, and Scott was also in attendance at the Royal Institution when Audubon's large painting of the Black Cocks was shown. "We talked much" on this occasion, said the naturalist, "and I would have gladly joined him in a glass of wine, but my foolish habits prevented me." This restriction on wine was soon removed, as was that on whisky, whether of the Scotch or Kentucky brand, and during his later life in America Audubon was never a teetotaler by any means. While at the Exhibition Sir Walter pointed to Landseer's picture of the dying stag, saying, "many such scenes, Mr. Audubon, have I witnessed in my younger days." Audubon was doubtless too polite to express an opinion of that popular artist, though of that very picture he had written in his journal three days before that there was no nature in it, and that he considered it a farce; "the stag," he said, "had his tongue out, and his mouth shut! The principal dog, a greyhound, held the deer by one ear, just as if a loving friend; the young hunter had laced the deer by one horn very prettily, and in the attitude of a ballet-dancer was about to cast the noose over the head of the animal."

Scott and Audubon were kindred spirits in their love 
of sport, of wild and untameable nature, as well as of man in his Homeric relation to it. Shortly after their first interview the great Scotsman wrote this handsome tribute in his journal:

January 22 [1827]. - A visit from Basil Hall with Mr. Audubon, the ornithologist, who has followed that pursuit by many a long wandering in the American forests. He is an American by naturalization, a Frenchman by birth; but less of a Frenchman than I have ever seen-no dash, or glimmer, or shine about him, but great simplicity of manners and behaviour; slight in person, and plainly dressed; wears long hair, which time has not yet tinged; his countenance acute, handsome and interesting, but still simplicity is the predominant characteristic.

Of the later visit of which we just spoke we find this account:

January 24.-Visit from Mr. Audubon, who brings some of his birds. The drawings are of the first order-the attitudes of the birds of the most animated character, and the situations appropriate; one of a snake attacking a bird's nest, while the birds (the parents) peck at the reptile's eyes-they usually, in the long-run, destroy him, says the naturalist. The feathers of these gay little sylphs, most of them from the Southern States, are most brilliant, and are represented with what, were it [not] connected with so much spirit in the attitude, I would call a laborious degree of execution. This extreme correctness is of the utmost consequence to the naturalist, [but] as I think (having no knowledge of vertu), rather gives a stiff ness to the drawings. This sojourner in the desert has been in the woods for months together. He preferred associating with the Indians to the company of the Back Settlers; very justly, I daresay, for a civilized man of the lower orderthat is, the dregs of civilization-when thrust back on the savage state becomes worse than a savage. ... 
The Indians, he says, are dying fast; they seem to pine and die whenever the white population approaches them. The Shawanese, who amounted, Mr. Audubon says, to some thousands within his memory, are almost extinct, and so are various other tribes. Mr. Audubon could never hear any tradition about the mammoth, though he made anxious inquiries. $\mathrm{He}$ gives no countenance to the idea that the red Indians were ever a more civilized people than at this day, or that a more civilized people had preceded them in North America. He refers the bricks, etc., occasionally found, and appealed to in support of this opinion, to the earlier settlers,-or, where kettles and other utensils may have been found, to the early trade between the Indians and the Spaniards.

Audubon was anxious to receive a written recommendation from the great "Wizard of the North" touching the merits of his work, the publication of which had just begun, but Sir Walter Scott sensibly demurred, on the ground that his knowledge of natural history was insufficient to qualify him to pass expert judgment. "But," he added, "I can easily and truly say, that what I have had the pleasure of seeing, touching your talents and marners, corresponds with all I have heard in your favor; and I am a sincere believer in the extent of your scientific attainments."

While Audubon was playing the rôle of society's pet lion at Edinburgh in the winter of 1827, he was painting to meet the expense of engraving his first plates, and writing at odd times of the day or night. On February 20 he recorded that his paper on the "Habits of the Wild Pigeon of America" was begun on the previous Wednesday, and finished at half past three in the morning; so completely, said he, was he transported to the woods of America and to the pigeons, that his ears "were as if really filled with the noise of 
their wings"; yet he added that were it not for the facts it contained, he would not give a cent for it, "nor anybody else, I dare say." Four days later, at the Wernerian Society, he read his paper on the rattlesnake, but the torrent of abuse which soon rewarded his efforts in this direction finally led him to reserve all literary efforts for a future and more propitious time. ${ }^{16}$

A large painting begun in January of this year, called "Pheasants attacked by a Fox," was probably a variant of the "Pheasants attacked by a Dog" (illustrated at page 394), the original of which is now in the American Museum of Natural History, New York City. This canvas, which was exhibited by the Scottish Society of Artists in February, 1827, measured nine by six feet, and was the largest piece he had ever attempted. "Sometimes I like the picture," he said, and "then a heat rises in my face and I think it a miserable daub." "As to the birds," he added, "so far as they are concerned I am quite satisfied, but the ground, the foliage, the sky, the distance, are dreadful."

In the spring of 1827 Audubon enjoyed the novel sensation of going to church in a sedan chair, and of hearing Sidney Smith preach. "He pleased me at times," he said, "by painting my foibles with care, and again I felt the color come to my cheeks as he portrayed my sins." Later there was an opportunity to meet the famous preacher with his fair daughter, and to show them his drawings of American birds.

The following letter ${ }^{18}$ was sent at this time to his wife in America:

${ }^{16}$ See Chapter XXVIII.

${ }^{17}$ Maria R. Audubon, op. cit., vol. i, p. 204.

${ }^{18}$ Which I owe to the kindness of his granddaughter, Miss Maria R. Audubon; it is superscribed "Mrs. Audubon, St. Francisville, Bayou Sarah, Louisville, p Wm Penn;" it reached New Orleans on June 13, and is endorsed as answered on June 23. 
Audubon to his Wife

Edinburgh March 12th 1827.

\section{My Dearest Friend}

I am now proud that I can announce thee the result of the last meeting of the Royal Society of Edinburgh. I was unanimously elected a Foreign Member of that Institution on the 5 ${ }^{\text {th }}$ Instant and am at last an F. R. S. - Wilt thou not think it wonderful; to me it is like a dream, and quite as much so when I see the particular attentions paid me by all ranks of the best Society. On the $6^{\text {th }}$ I received the official Letter from the Secretary with the seal of the Society and the arms of Scotland-this along with my other diplomas and Letters, I assure thee enable me to be respected and well received in any portion of the Civilized World. Sir Walter Scott has also been so kind as to give me a Letter that I may exhibit wherever I may go $=$ I have $T$ wo Letters from him very kind $=$ all this $I$ think will afford thee great Pleasure.

I am now preparing to leave Edinburgh and will do so in a few days, I am now anxious to visit London as soon as I possibly can, and yet want to spend a few days at New Castle, York, Liverpool, Dublin, then back again to England, go by Cambridge and Oxford.-If I meet the success that I expect in that Tour it is very probable that soon after my reaching London, I will write for thee to Come, and when I do so, my Lucy may come without the least Hesitation for I will then be ready to receive her!

Since my last of the 22d of February, I have received thine of the $31^{t}$ of December, $3^{d}$ of January and $8^{\text {th }}$ of $\mathrm{D} \frac{\mathrm{o}}{\mathrm{y}}$ this last mostly John's, I am particularly glad that thou hast left the Beech Woods, yet thou might as well have given me at once thy good reasons for doing so. I hope that at this Instant that I am writing, thou art snug and comfortably settled afresh.

The Trees and Segments have not yet arrived, but I hope to hear soon that they have-I have not a word about the Seeds reaching yet. do my Love always say by what vessel any thing comes. as John as concluded to take Lessons of Music 
I have no wish to sell my Gun but wish to give it him as his ow [n] in Fee Simple, as soon as he deserves it from thy own Hands. May God bless him!-if all continues well with me Victor and him may rise to eminence and therefore try Johny's Spunk. do beg or make him draw all kinds of Limbs of Trees or Flowers for me and whenever he kills a bird of any kind tell him to measure the Guts particularly and make a regular list of the names of the Birds, length and thickness of those Guts and their contents $=19$

I wrote a long letter to each Victor and N. Berthoud on the 27 February, but not a word from either of them as yet reached me. I was quite shocked to see thy last letter of the $8^{\text {th }}$ of January without the print of thy new Seals, I am quite frightened at thy watch not having reach ${ }^{d}$ thee, yet $I$ hope every new Letter will bring me better tidings. I now collecting Letters from all my Friends here and will have God knows enough of them. I only hope I may soon be in a regular way of making a comfortable living for ourselves all:

All the papers and books I send thee mention my name. My work is look ${ }^{\mathrm{d}}$ upon as unrivalled in any Country, I will soon know how it will pay.-I can only add that I will write to thee from all the places $I$ visit=Let Victor have a copy of this= Collect all kinds of Curiosities whatever=try to send or bring with thee but send first if Possible Live Birds of hardy kinds such as Blue Jays by Themselves. Red Birds $\mathrm{D}^{\circ}$. red wingd Starling $\mathrm{D}^{\mathrm{o}}$, Partridges $\&^{\mathrm{c}} \& \mathrm{c}$ - present my humble respects to Mr \& M $\stackrel{\text { rs }}{-}$ Johnsons an remembrances to good Friend bourgeat -try to send me an account of the growing of Cotton from A to $\mathrm{Z}$, written by an able Planter-I wish thee to make regular memorandums thyself respecting all about Habits \& Localities $\& c \& c=$ thou wilst scarce believe that this day there [are] in many places 16 feet of snow. the weather has been tremendous-yet with all this no Invitation is ever laid aside

${ }^{19} \mathrm{John}$ Woodhouse Audubon at this time was in his fifteenth year, and this injunction regarding the internal anatomy of birds, to which ornithologists had hitherto paid but little attention, was given three years before his father made the acquaintance of MacGillivray. (See Chapter XXX.) 
and the other evening I went to Diner in a Hackny Coach drawn by 4 Horses, and to church on Sunday last in a Sedan chair to hear the famous Sidney Smith. curious diferences of manners here I assure thee.

I have seen and know personally all the great men of Scotland and many of England.

What a curious interesting book a Biographer-well acquainted with my Life could write, it is still more wonderfull and extraordinary than that of my Father!

Fear not my connecting myself in any way with Charles $\mathbf{M}$. he is a mere worm on the hearth, and since he has abandoned his Grand Flora is out of my books-it has perhaps been an error in our Lives that thou didst not come with me. So much indeed do I now think so that I have advised Capn Hall to take his Lady and child with him. be sure to pave the way for them to Judge Mathews and N. Berthoud to whom I have given him letters to.-I send thee his Travels, read his interview with Napoleon; I write my Journal every day, it seems that that portion of it forward ${ }^{d}$ thee long ago as never reach ${ }^{d}$ thee as thou dost not mention it. I am sorry for all these little misfortunes and can hardly a/c for them. I have not heard from $H$. Clay but will refresh his memory, I hope at the same time to receive a Letter from the President=I hope this day the last beautiful broach $I$ sent thee as a new Years gift is shining on thy bosom, as I have witnessed the brightness of thy own sweet Eyes. oh my Lucy what would I give now in my possession for a kiss on thy Lips and-_-God for ever bless thee thine Husband and Friend for ever- John J. Audubon

F. R. S. E. Fellow Royal Society EdinburghF. A. S.Do D? D? antiquarians-

M. W. S. N. H.-Member Wernerian Society of Natural History

M. S. A.-

Do. Society of Arts of ScotlandM. P. L. S.Do. Philosophical \& Literary Society Liverpool

M. L. N. Y.-

Do Lyceum of New York. 


\section{TO EUROPE AND SUCCESS}

\section{My Dear John-}

I am very thankfull to you for your Letters continue to write from time to time, draw, and study music closely, there is time for all things-I give you my Gun with all my Heart best wishes, but earn it at your Dear Mamma's will-God bless You-

Your Father and Friend-

JoHN J. AUDUBoN

At Edinburgh Audubon met a young landscape painter, Joseph B. Kidd, and the two worked together for some time, Kidd receiving instruction in animal painting and Audubon hints on the treatment of his landscapes, which had always been a source of trouble to him. Kidd was Audubon's Edinburgh agent for a time, and later entered upon the ambitious project of reproducing all of his birds in oils, as will be noticed later. ${ }^{20}$

On March 17, 1827, when the second number of his Birds was in preparation, Audubon boldly issued his "Prospectus," contrary to the advice of some of his friends, who could see only egregious folly in such an undertaking and regarded it as foredoomed to failure. As everybody knows, it is easier to say things than to do them, but all these friendly critics sang a different tune later on, when they had seen more of the indomitable will and self-reliance of the man, who was to carry steadily forward to a successful issue a work which was in press nearly twelve years and which cost over $\$ 100,000$ to produce. In Audubon's original prospectus of The Birds of America the specifications as to the form, size, and cost of the work, which had been determined for some months, underwent little

${ }^{20}$ See Chapter XXV. 
change in subsequent editions of this printed statement. ${ }^{21}$

Audubon left Edinburgh for London on April 5, 1827 , with locks shorn but energy unabated. He followed a roundabout course, visiting Belford, "Mitford Castle," Newcastle-upon-Tyne, York, Leeds, Liverpool, and Shrewsbury, at every point extending his acquaintance, showing his drawings to many, and adding appreciably to his growing list of subscribers. Several days were spent in hunting and drawing birds with the Selbys, at their beautiful country place called "'Twizel House," at Belford, in Northumberland, where he was soon made to feel as much at home as with his older Liverpool friends, the Rathbones, at "Green Bank." P. J. Selby, after whom Audubon named a Flycatcher which appeared in his second number, was an amateur artist and ornithologist, and at that time was engaged upon an extensive publication to which Audubon was

${ }^{21}$ The work, as originally announced, was to appear in parts of 5 plates each, at 2 guineas a part, and in order to distribute the expense to purchasers it was expected to issue but 5 parts a year. The plates, to be engraved on copper, were of double elephant folio size, and printed on paper of the finest quality, all the birds and flowers to be life-size, and to be carefully colored by hand, after the originals; any subscriber was at liberty to take a part or the whole. It was stated in the prospectus of 1829, when 10 parts had been published: "There are 400 Drawings, and it is proposed that they shall comprise Three Volumes, each containing 133 Plates, to which an Index will be given at the end of each, to be bound up with the volume.... It would be advisable for the subscriber to procure a Portfolio, to keep the Numbers till a volume is completed." To avoid the expense entailed by copyright regulations in England, indices and all other letterpress were eventually omitted; the number of parts was extended to 87 , or 435 plates, and the number of volumes to 4, a necessity imposed by the discovery of many new birds, even after the omission of the figures of the eggs, which Audubon had reserved for the close, and the undue crowding of many of his final plates. The "Prospectus" issued with the first volume of the text in 1831 contained a list of the first 100 plates, together with extracts of reviews by Cuvier and Swainson, and a list of subscribers to the number of 180. For further details, see Bibliography, No. 1, and Appendix III, No. 2. 


\section{invited to contribute, a single volume of plates and text}

having then been published. ${ }^{22}$

At Newcastle, where Audubon spent a week, he saw much of its grand old man, Thomas Bewick, "the first wood cutter in the world," and conceived a deep regard for him, which he afterwards expressed in one of his "Episodes." As they parted, this great son of nature held him closely by the hand, and for the third time repeated, "God preserve you!" "I looked at him in such a manner," said Audubon, "that I am sure he understood I could not speak.'

${ }^{22}$ Illustrations of British Ornithology, by Prideaux John Selby. 'The British Museum copy of this work is in two large folio volumes (measuring about $25 \frac{1}{2}$ by $201 / 2$ inches), and was issued originally in numbers which appeared at irregular intervals. Vol. I, plates i-iv (of bills, heads, and feet), i-c (of land birds); most of the plates are by Selby, and many were etched by him and autographed, 1819-1821; plates xiv, xvi, and xx are by Captain R. Mitford, whose home, "Mitford Castle," near Morpeth, Northumberland, was visited by Audubon in April, 1827; published at Edinburgh by Archibald Constable \& Co., and by Hurst, Robinson \& Co., London, 1825 (?)-1827. Volume II, plates i-ciii; printed for the Proprietor \& published by W. H. Lizars, Longman, Rees, Orme, Brown, Green \& Longman, London; and W. Curry, Junr. \& Co., Dublin, MDCCCXXXIV. Quaritch, in offering a copy in 1887, at $£ 55$, stated that there were 383 figures, in 221 colored plates, and that the published price was $£ 105$. Newton (Dictionary of Birds, p. 27) says that the first series of these "Illustrations" was published in coöperation with Sir William Jardine, in 3 volumes of 150 plates, in 1897-1835, after which a second series was started by them, and completed in a single volume of 53 plates, issued in 1843. This was the "job book" mentioned earlier in this chapter (see p. 358), but neither Jardine's nor Jameson's name is mentioned in the volumes which I have examined.

In a letter to Audubon, dated "Sept. 13h 1830 Twizel [1?] House," and postmarked "Belford," Selby said: "I expect to bring my own work to a conclusion during the course of this winter having only the plates of another Number to finish. I am happy to add that the Work is doing well \& is more than paying itself. The second Vol: of letter press will appear with the last No."

Two volumes of text were published in 1825 and 1833 respectively; the first, after readjustment to fit the "quinarian doctrine," to which Selby was a temporary convert (see Vol. II, p. 94), was issued in a second edition at London, in 1841; the second volume bore the imprint of Lizars, who soon after began to work for Audubon.

Selby's plates were for the most part rather crudely drawn, etched and colored, and could be commended only as the work of amateurs who strove for accuracy. 
As he proceeded southward, his subscription list augmented apace, Manchester alone giving him eighteen new names, and he began to feel more sanguine of success, if, he added, "I continue to be honest, industrious, and consistent." 


\title{
CHAPTER XXIII
}

\author{
AUDUBON IN LONDON
}

Impressions of the metropolis-A trunk full of letters-Friendship of Children-Sir Thomas Lawrence-Lizars stops work-A family of artists-Robert Havell, Junior-The Birds of America fly to LondonThe Zoölogical Gallery-Crisis in the naturalist's affairs-Royal patronage-Interview with Gallatin-Interesting the Queen-Desertion of patrons-Painting to independence-Personal habits and tastesEnters the Linnxan Society-The White-headed Eagle-Visit to the great universities-Declines to write for magazines-Audubon-Swainson correspondence "Highfield Hall" near Tyttenhanger-In Paris with Swainson-Glimpses of Cuvier-His report on The Birds of America-Patronage of the French Government and the Duke of Orleans-Bonaparte the naturalist.

Audubon reached London on May 21, 1827, and put up at the "Bull and Mouth" tavern, but soon moved into more permanent lodgings at number 55 Great Russell Street, near the British Museum. Though for a long time eager to see the capital, no sooner had he reached it than he was anxious to be away and more homesick than ever for his family and his beloved America. London then seemed to him "like the mouth of an immense monster, guarded by millions of sharpedged teeth," from which he could escape only by miracle.

He had brought with him a formidable array of letters addressed to the élite of the capital, ${ }^{1}$ and he bore

${ }^{1}$ Among the sixty or more persons to whom Audubon carried written credentials at this time were the following: the Duke of Northumberland, Robert Peel, Sir Humphry Dary, Sir J. D. Aukland, Albert Gallatin. the American Minister, Sir Thomas Lawrence, David Wilkie, Dr. Buckland, Dr. Holland, Dr. Roget, Dr. Wollaston, William Swainson, Sir William Herschel, and his son, afterwards Sir John Herschel, John George Children, R. W. Hay, N. A. Vigors, Captain Cook, John Murray and Robert Bakewell (see Vol. II, p. 134). 
besides nearly a trunkful for the Continent, as well as general letters from Henry Clay, Andrew Jackson and others in America for our consular and diplomatic representatives in Europe. His epistolary basis for the acquisition of useful acquaintances could hardly have been better, and further testimonials were gathered at every stage of his progress to the city of his hopes, but Audubon's best letter of credit, which could be read by all the world, was an open, winning countenance. After he had wandered over London for the greater part of three days without finding a single individual at home, he was tempted to consign his valuable documents to the post, an error which he did not repeat, as it deprived him of the acquaintance of fully one-half of the people to whom they were addressed. One of these London letters which follows, written by Captain Basil Hall to John Murray, the noted publisher and founder of the Quarterly Review, is particularly interesting in showing that Audubon was far from pleased with the progress of his work in Edinburgh, and that he was then contemplating a change which was later effected.

\section{Basil Hall to John Murray}

EnINB 23rd Feby. 1827

\section{My Dear Sir}

This will be delivered to you by my friend Mr John Audubon, an American Gentleman who has been residing here this winter, \& I beg in the most particular manner to introduce him to your acquaintance and to ask for him the advantage of your good offices.

Mr Audubon has spent [a] great part of his life in making a collection of drawings of the Birds of North America, \& in studying their Habits, with the intention of publishing a Complete Ornithology of America. For such a work his materials, both in the shape of drawings and of written notes, are immense 
and he is now going to London in order to set this gigantic work in motion.

$\mathrm{Mr}$ Audubon, however, is not very well versed in the details of such matters, \& therefore I beg of you to have the goodness to aid him with your advice on the occasion-to introduce engravers printers \& so forth to him, and generally speaking to put him in the way of bringing out his work in an advantageous manner to himself.

I trust all this will give you no more trouble than you will be willing to take at my earnest solicitation.

$$
\begin{gathered}
\text { I remain Ever, My Dear Sir, } \\
\text { Most Sincerely Yrs }
\end{gathered}
$$

BaSIL HALL.

John Murray Esqr

Audubon carried also a long letter from "Mr. Hay," 2 dated at "16 Athol Crescent, Edinburgh, 15 March, 1827," and addressed to the care of his brother, Robert William Hay, of Downing Street, West, in which this curious statement occurs: "Mr. A. is son of the late French Admiral Audubon, but has himself lived from the cradle in the United States, having been born in one of the French colonies."

The document which was to prove of greatest service to him, however, was addressed to John George Children, ${ }^{3}$ then in charge of the Department of Zoölogy in

${ }^{2}$ Probably the same that is referred to in his journals as "Mr. Hays, the antiquarian."

${ }^{3} \mathrm{~J}$. G. Children (1777-1852) was early interested in chemistry, and at Tunbridge built a good laboratory, in which Humphry Davy conducted many of his early experiments, and while there was seriously injured in October, 1812. In 1824 Children discovered a method of extracting silver without the use of mercury. When Mr. Children, Senior, became insolvent through the failure of his bank, his son obtained a position at the British Museum; in 1816 he was librarian in the Department of Antiquities, but in 1823 he was transferred to a post in zoölogy which was eagerly sought by William Swainson; he was secretary of the Royal Society in 1826-27, and again in 1835-37. He resigned his position at the Museum in 1840, when Swainson was again an unsuccessful candidate, and 
the British Museum and secretary of the Royal Society. Children assumed the management of Audubon's work when he returned to America in 1829 and again in 1831; to him and Lord Stanley, in 1830, the naturalist probably owed his nomination to membership in the Royal Society.

Soon after reaching London Audubon paid his respects to Sir Thomas Lawrence, for whom he had two letters, and made an appointment for showing his work to this famous artist. He was also gratified to receive the subscription of Lord Stanley and of Charles Lucien Bonaparte, who was then in London.

Audubon had not been in London a month before word was received from Lizars that all his colorers had struck work and that everything was at a stand. Accordingly, he began to search London for skilled workmen, and on June 18 wrote: "I went five times to see Mr. Havell, the colorer, but he was out of town. I am full of anxiety and greatly depressed. Oh! how sick I am of London!" Three days later another discouraging letter came from Lizars, who shortly after threw up his contract and left his patron in a sad predicament-with an enormously expensive work, still-born, on his hands, without adequate funds, and, in short, with all his cherished plans suspended in mid-air. Audubon no doubt realized that if his grand undertaking were to succeed at all, it must experience a new birth in London, where an expert engraver of the requisite enterprise and zeal must be found without delay. $\mathrm{He}$ closed his journal on the second day of July with the

was succeeded by J. E. Gray (see Vol. I, p. 353). Children was not a productive zoölogist, but has been described as a lovable soul, who was never soured by illness or other misfortunes, and who was as zealous in his friendships as in science. See "A. A." (Anna Atkins), Memoir of J. G. Children, Esq. (Bibl No. 175). 


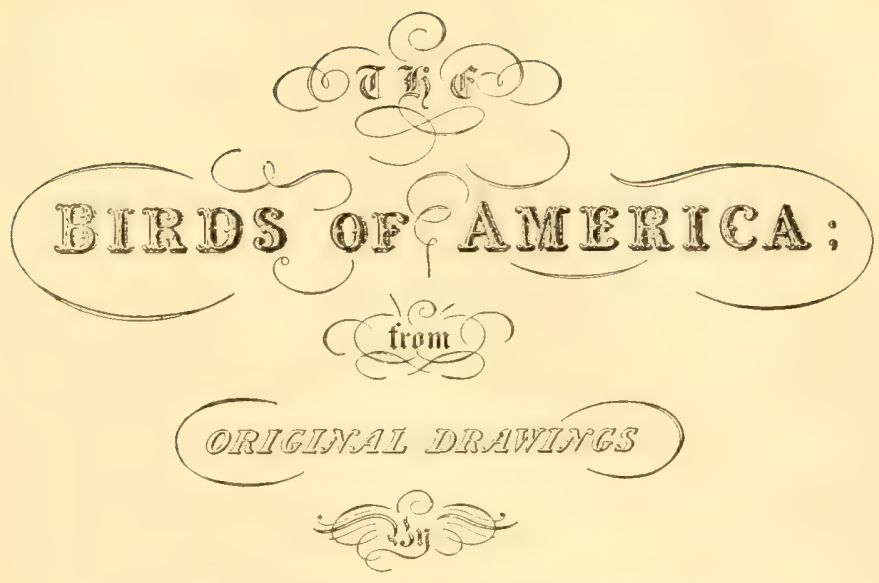

\section{JORN JAMTS AUDUBDN.}

Fellow of the Royal Societics of London \& Edinburgh and of the Linneand Zoolemical Secieties of Londen

Member of the Natural Histery Seciety of Puris of the Lyccum of . Veu Yerke. of the Philosiploical Sociely and tbe Academy of Natural Sciences of Ptriladelphia. of the Natural History Socuty of Boston. of Cbarliston.

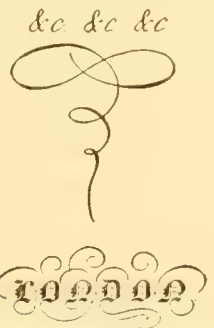

Rublished by the Author.

Vol. II.

1831. 3.

TITLE PAGE OF THE ORTGINAL EDITION OF "THE BIBDS OF AMERICA," Volume 1., 1831-1834. 
remark that he was too dull and mournful to write a line, and it was not opened again for nearly three months.

This gap in Audubon's record can now be filled in reference to some important particulars, for in the interval he made his greatest discovery in England, in Robert Havell, Junior, then a young and unknown artist of thirty-four, who through eleven years of the closest association with his new patron was to become one of the greatest engravers in aquatint the world has ever seen. Until recently the intimate story of Audubon's relation to the Havells has been much obscured. ${ }^{4}$ The reference in the journal record of June 19, just given, was undoubtedly to Robert Havell, Senior, who for many years was associated with his father, Daniel Havell, the first of five generations of artists of that name, in the engraving and publishing business, but who at this time was established independently at 79 Newman Street, London; he also conducted a shop called the "Zoölogical Gallery," at which were sold engravings, books, artists' materials, naturalists' supplies, and specimens of natural history of every sort. His three sons, Robert, George, and Henry Augustus, all became artists, but the eldest, who bore his father's name, was educated for a learned profession. Contrary to his father's injunctions and advice, Robert, who was bent on becoming an artist, abruptly left his home in 1825, determined to shift for himself. He began with an extensive sketching tour on the River Wye, in Monmouthshire, and produced numerous paintings which,

"In the account which follows, as well as in numerous instances in Chapter XXXII, I am most indebted to George Alfred Williams, who in "Robert Havell, Junior, Engraver of Audubon's The Birds of America," (Bibl. No. 232) (Print-Collectors Quarterly, vol. vi, no. 3, pp. 225-259, Boston, 1916), has given the only satisfactory account of the Havell family and the best analysis of the work of the great engraver. 
as his biographer remarks, display all the charm found in the work of his distinguished cousin, William Havell. These won immediate recognition in London, where he received commissions from various publishers, including the house of Messrs. Colnaghi \& Company.

Robert Havell, Senior, then in his fifty-eighth year, though deeply interested in Audubon's adventurous plans, felt himself too old to embark on so extended a work, which it was then believed would require from fourteen to sixteen years for completion; he volunteered, however, to do his best to find a substitute. With this in view, he applied to Mr. Colnaghi, the publisher, and was immediately shown the unsigned proof of a beautiful landscape, exquisitely drawn and engraved by one of the youthful retainers of his establishment. The elder Havell, after scrutinizing it carefully, exclaimed, "That's just the man for me!" "Then," replied the publisher, "send for your own son!" Through this singular coincidence, father and son became reconciled and a partnership between them was soon announced.

As a test of young Havell's skill, to follow the story of his biographer, Audubon gave him his drawing of the Prothonotary Warbler, which had already been engraved and issued by Lizars as Plate iii of The Birds of America earlier in that year. Havell finished the engraving in two weeks, when a proof was struck and the naturalist summoned. Audubon examined the print with the utmost keenness and deliberation; then he seized the sheet, and holding it up, danced about the room, calling out in his French accent: " $\mathrm{Ze}$ jig is up, ze jig is up!" The Havells, who at first thought this might signify disapproval, were quickly disabused when Audubon approached young Robert and, throw- 
ing his arms about his neck, assured him that his longsought engraver had been found at last. Having given this story, I wish it were possible to confirm it, but a close examination of this plate proves either that the story is a fiction, or that some other drawing was used as a test of Havell's skill. ${ }^{5}$

The part which this interesting family played in Audubon's success will be unfolded later. ${ }^{6}$ Suffice it now to say that Messrs. Robert Havell \& Son, in London, undertook afresh the production of The Birds of America in the summer of 1827. The partnership was divided or dissolved in 1828, when Robert, junior, who from the first did all of the engraving, took entire charge of that part of the business, and moved his engraving establishment around the corner to 77 Oxford Street; there it remained until broken up in 1838. Robert Havell, Senior, continued in charge of the printing and coloring until 1830, when he seems to have permanently retired, two years before his death in 1832, events which, as will be seen, are indirectly registered in the legends of some of Audubon's plates. ${ }^{7}$

${ }^{5}$ Mr. Charles E. Goodspeed, who recently sent me two of the original plates of the Prothonotary Warbler, one bearing the legend "Engraved by W. H. Lizars Edinr," and the other, "Engraved, Printed \& Coloured, by R. Havell Junr," called attention to the identity of the two engravings. That these two impressions are absolutely identical in aquatint and line is proved by applying a magnifying glass to any part of their surfaces, and by counting and comparing the lines or dots within any selected area whatsoever; in short, they differ only in their legends, and in the coloring which was applied by different hands. That such methods should have been adopted for excluding Lizars' name is certainly surprising. In the first or Edinburgh impression of Lizars' original plate, the artist's legend reads: . "Drawn by J. J. Audubon M. W. S.," and names of bird and plant appear at the bottom of the plate in three lines: "PROTHONOTARY WARBI.ER. Dacnis protonotarius. Plant Vulgo Cane Vine." In the London edition the corresponding designations are: "Drawn from nature by J. J. Audubon F, R, S. F, L, S.," and PROTHONOTARY WARBLER. Sylvia Protonotarius. Lath, Male. 1. Female, 2. Cane Vine.," in four lines.

- See Chapter XXXII.

${ }^{7}$ See ioid. 


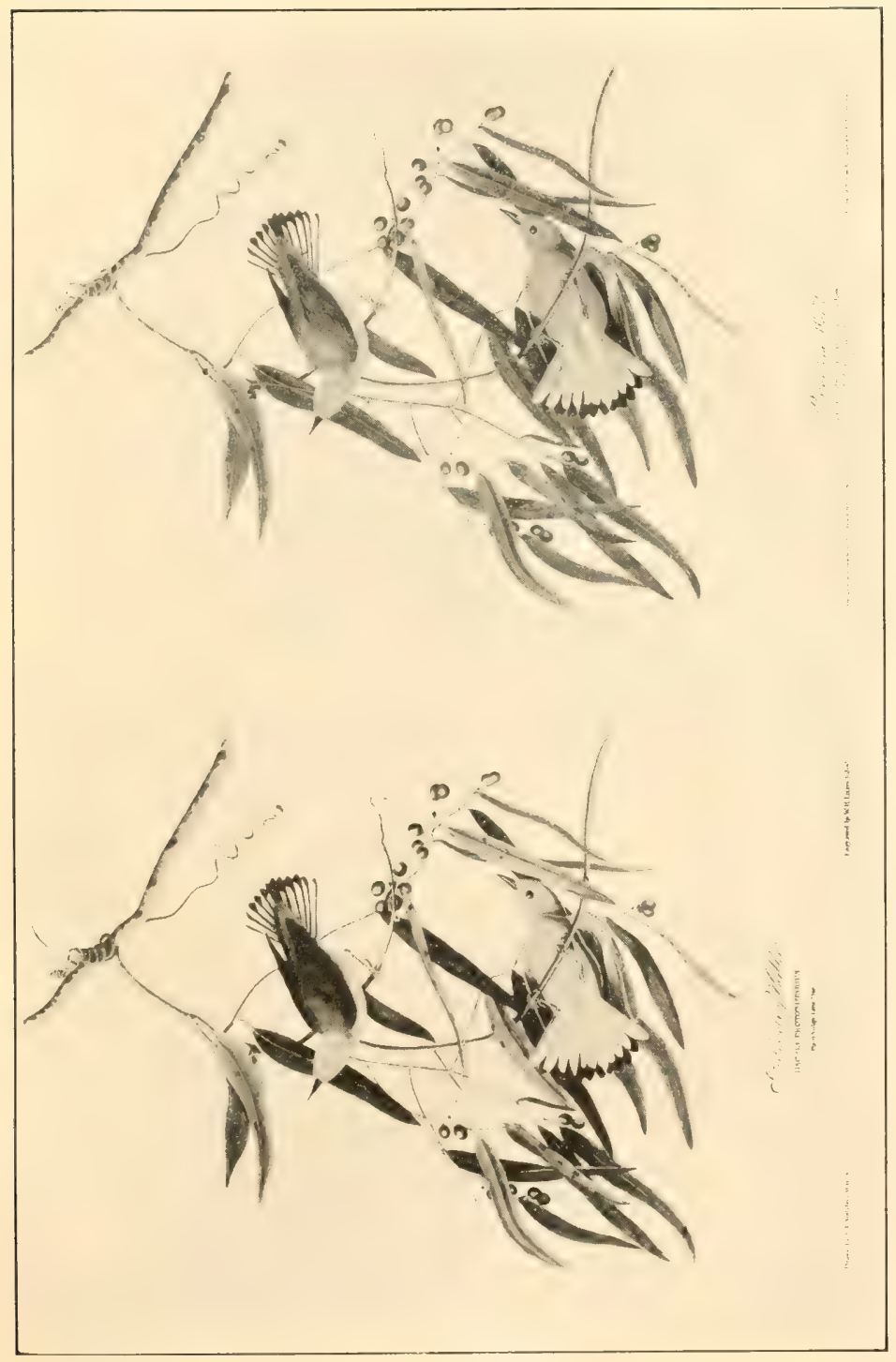

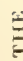
동

告

西

$=z$

道

E

z

产

亲

$\therefore \underline{z}$

$\overline{2}$

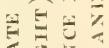

$3 \%=$

$\approx \cong \approx$

$\because \approx$

记

늘

들

乎

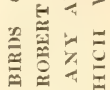

$\ldots=0$

$=2$

○一

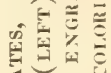

$\pm \approx 5$

$\because \mathrm{Z}$

$=-$

茫

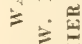

$\cong$

5

는

$\exists$

$\stackrel{5}{\cong}$

를 

Under the younger Havell's guiding hand, Audubon found that his illustrations could be produced in better style, more expeditiously, and at far less cost than in Edinburgh. When Lizars was later shown the third number which the Havells had produced, he called his assistants and observed how completely the London workmen had beaten them; he even offered to resume work on the engraving and at Havell's price, but Audubon was averse to further experimenting. "If he can fall," said he, "twenty-seven pounds in the engraving of each number, and do them in a superior style to his previous work, how enormous must his profits have been; a good lesson to me in the time to come, though I must remember Havell is more reasonable owing to what has passed between us in our business arrangements, and the fact that he owes so much to me."

This characteristic note was sent from Liverpool, December 6,1827 , to his agent, Daniel Lizars, father to W. H. Lizars, at Edinburgh:

I will not ask if you have any new name for me, as I might be disappointed were $I$ to expect an affirmative answer.

If you see Sir Wm. Jardine tell him that Charles Bonaparte has left the U. S. for ever, and has gone to reside in Florence, Italy.

I have wrote to Mr. Havell to send you a No. 5, which I wish you to send to Professor Wilson, or indeed a whole set, to enable him to write the notice he has promised for me the 1st. of next month.

Audubon sent another letter to this agent, from London, January 21, 1828, when he was still waiting for an answer to his last: "When I write to any one I expect an answer, but when I write to a man I esteem, and to whom I entrust a portion of my business, I feel 


\title{
ENGRAVINGS.
}

In submitting this List of Pablications, R. HAvĚLL begs lo stale, he has on Sale a very extensive and well selected Assortment of ENGRAvings and Works of ART, arranged in Portfolios, with the Prices affixed, comprising subjects after Wilkie, Turner, Martin, Lawrance, Newtoo, Burnett, and others. Lithographs. Stadies of Animals, Figures and Heads, \&c. \&c.

Birds of America, by J. J. Audubon, vol. 1 and 2.

Ornithological Biography, by J. J. Andubon, vol. 1 and 2.

Antiquities of Mexico, by Lord Visconnt Kingsborough.

Hexandrian Plants, by Mrs. E. Bary.

African Animals and Scenery, by Daniels. Birds of Paradise, by $F$. Le Vaillaint.

Floral Illustrations of the Seasons, by Mrs. E. Roscoe.
Views in the Ionian Islands, by J. Cartwright.

Court of Persia.

Albanian and Greek Costumes.

Aeronautical View of London.

Ditto ditto of Paris.

Panoramic View of King George's

Sound.

Panoramic View, of Corfu.

Foreign Costumes.

All Works on Natural History.

R. H. begs to observe that all Works entrusted to his care for Pablication are Engraved, Printed and Coloared, ander his entire inspection, on his Establishment, by which means they are not made public antil ready for delivery.

\section{Superfine retater colours,}

\author{
In Cakes or Boxes.
}

R. Havell begs to recommend his Superfine Water Colours, as being prepared with the greatest care, and solicits a Trial.

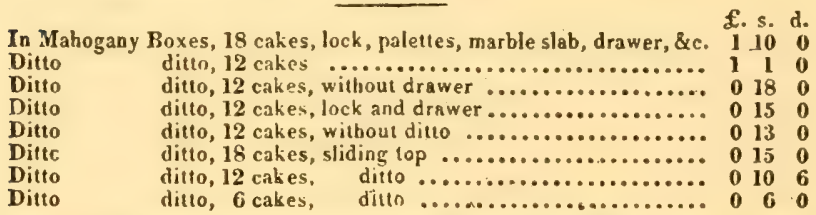

Cumberland Black Lead Drawing Pencils.

CAMEl haIR AND SABLE BRUSHES.

Whatman's Superfine smooth rolled Drawing Paper, sold in sheets, quires or reams.

BRISTOL BOARS OF ALL COLOURS AXD TFICKNESS.

Grnuire Jindian Jink.

English and French Crayon PaPER of all Colours. Ditto ditto Chalxs.

REVERSE OF PANELS OF ROBERT HAVELL'S ADVERTISING FOLDER REPRODUCED ON FACING INSERT 


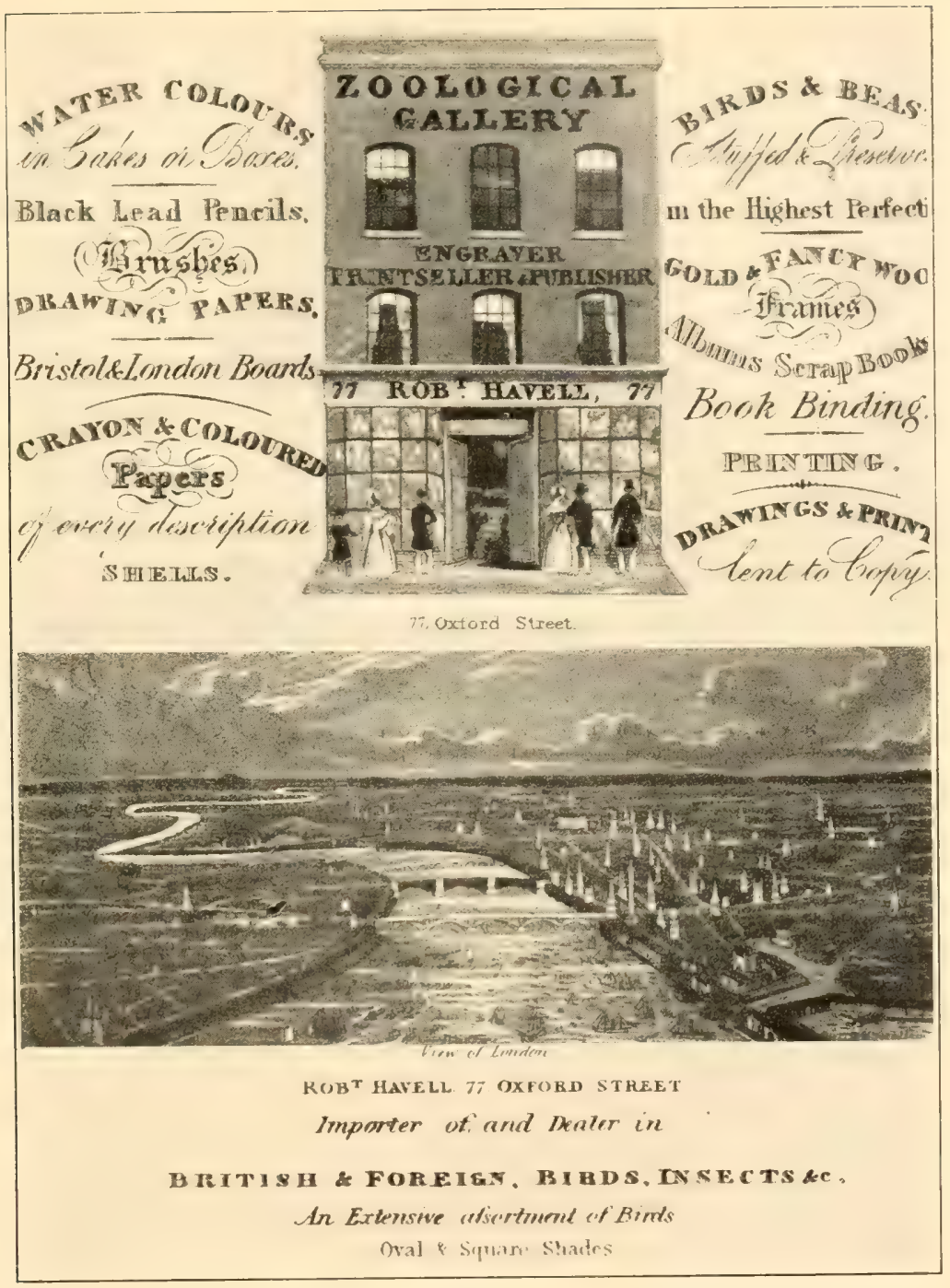

OUTSIDE FNGRAVED PANEIS OF AN ADVERTISING FOLDER ISSUED BY ROBERT HAVELL, ABOUT 1834; THE PRINTTNG ON THE REVERSF IS REPRODUCED

ON THE FACING PAGE.

From the only copy known to exist, in possession of Mr. Ruthven Deane. It is a strip of heavy paper, 18 by $3 \%$ inches in size, printed on both sides, and folded twice, the folded size being $41 / 2$ by $35 / \mathrm{s}$ inches. One side bears the four panels, engraved

by Robert Havell, reproduced on this and the following page; and the reverse, the printed matter reproduced on pages 386 and $38 \%$. 


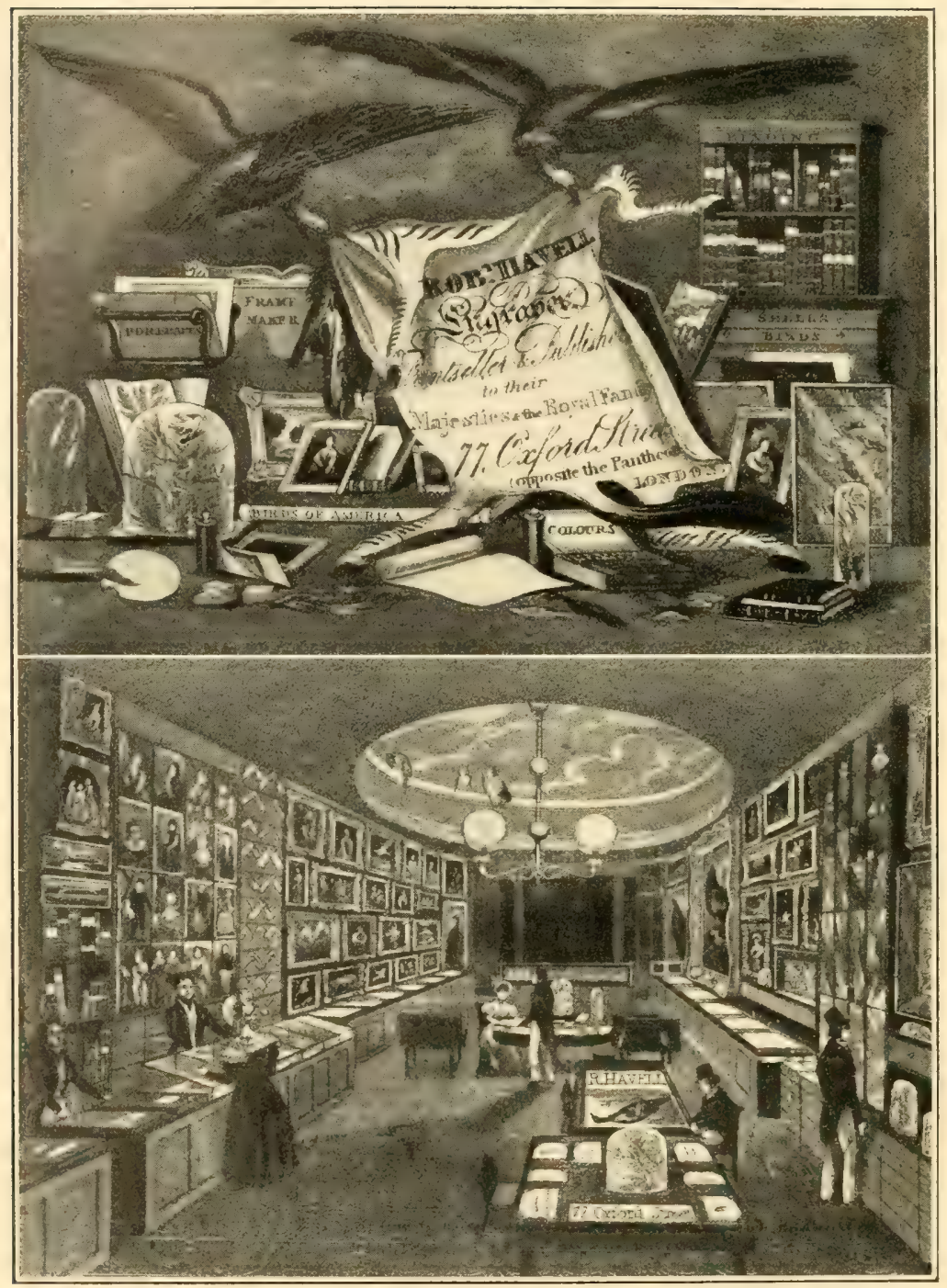

IXSIDE ENGRAVED PANFIS OF THE ADVERTISING FOLDER ISSIEI BY ROBERT IIAVEI., ABOET 1834.

The lower panel shows the interior of the "Zoological Gallery," if Oxford Street. Iudubon's plate of the Cock 'Turkey is heing examined at one of the tahles. 
R. Havell begs to inform Zoological Collectors that, having an extensive correspondence, he is enabled to supply Natural Productions from all parts of the Globe.

\section{Birds and Beasts Stuffed and Preserved}

In the highest perfection, at his Establishment, and the greatest care taken to place the specimens in their natural attitudes and parsnits.

A GOOD ASSORTMENT OF INSECTS, BOTH BRITISH AND FOREIGN:

A greal varicly of Colourcl and Black Eycs.

TAXIDURMIE, or the Art of Collerting \& Preparing Oljects of Nataral History.

\section{Maple, Gold and Black Cases,}

FITTED-UP IN A SUPERIOR STYLE, WITH COLOURED SKY.

GLASS SHADES, OVAL, ROUND AND SQUARE, OF ALL SIZES.

The preseat Collection consists of the most rare LAKD and WATER BIRDs from NORTH AMERICA, \&C.

\section{PICtURES AND PRINTS}

Framed and Glazed, in Gold, Maple, and all kinds of Ornamental and Fancy Woods, Straining, Varnishing, \&c.

\section{DRAWINGS AND PRINTS LENT OUT TO COPY} ON THE FOLLOWING TERMS:

Yearly Subscription .......................... $\frac{f .}{3}{ }_{3} \frac{d}{0}$

Half-yearly ditio .................................. 1116

Quarterly ditto...................................... 0160

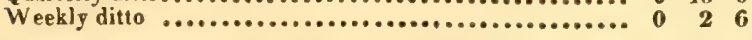

A GREAT VARIETY OF RICE DRAWINGS, AND RICE PAPER OF ALL SIZES.

Plain and Ornamental Albums.

Ditto ditto Scrap Books.

Ditto ditto Blotting Cases.

Ditto ditto ditto, with lock and keg.

MIN IATORE FRAMES AND GLASSE

\section{Sleteh Books of all sizes.}

ORDERS FOR EXPORTATION executed with promptitude, and on the lowest terus, at 77, OXFORD STREET.

REVERSE OF PANELS OF ROBERT HAVELI'S ADVERTISING FOLDER REPRODUCED ON FACING INSERT 
miserable until I hear from him. . . . I am extremely anxious to close my business for 1827 , and cannot do so without receiving your a/c, and the money due by my subscribers."

The summer of 1827 was probably Audubon's most critical period in England. His work was then in the air and ruin of all his hopes seemed inevitable, but with palette and brush he again extricated himself from financial difficulties. At this time, he said, "I painted all day, and sold my work during the dusky hours of the evening as I walked through the Strand and other streets where the Jews reigned; popping in and out of Jew-shops or any others, and never refusing the offer made me for the pictures I carried fresh from the easel." He sold seven copies of the "Entrapped Otter" in London, Manchester, and Liverpool, and from seven to ten copies of some of his other favorite subjects; once when he inadvertently called at a shop where he had just disposed of a picture, the dealer promptly bought the duplicate and at the same price that he had paid for the first.

In the autumn of this year, when it was found that his agents were neglecting their business, Audubon determined to make a sortie to collect his dues and further augment his subscription list. He left London on September 16, and visited in succession Manchester, Leeds, York, Newcastle-on-Tyne, Alnwick Castle and Belford, to see the Selbys, finally reaching Edinburgh on the 22nd of October.

Audubon had set his mark at obtaining 200 subscribers by May, 1828, but he fell far short of realizing it. On August 9 he wrote: “This day seventy sets have been distributed; yet the number of my subscribers has not increased; on the contrary, I have lost some." 
At York he found that a number of his Birds, which had been forwarded from Edinburgh before he had taken his departure, "was miserably poor, scarcely colored at all"; and a copy of his first number which was later examined at the Radcliffe Library in Oxford was so unsatisfactory that he rolled it up and took it away, with the reflection that Lizars, whom he had paid "so amply and so punctually," could have made him a better return. The colorists gave no end of trouble, but he never hesitated to reject their work when it did not meet his requirements, and the defective plates were invariably sent back to Havell's shop to be washed, hotpressed, and done over again. To such watchful care must be ascribed, in large measure, the high degree of perfection which his big work eventually attained. When it is remembered that upwards of one hundred thousand of his large plates had to be colored laboriously by hand, and that at one time fifty persons were engaged at the Havell establishment, we can understand the difficulties involved in maintaining a uniform standard of excellence in a work that was issued piecemeal and spread over a long period of time.

In August, 1827, Audubon wrote to Mrs. Thomas Sully of Philadelphia to announce the removal of his business to London. By this change he expected to save "upwards of an hundred pounds per annum, a large sum," as he remarked, "for a man like me." His third number had then been issued, and he expressed the hope that all would go smoothly after "this first year of hard trials and times," and that he would be able to send for his wife and one of his sons in the coming autumn or winter. He was then painting "a flock of Wild Turkeys for the king, who had honored him with his particular patronage and protection." When writ- 
ing to his young son, John W. Audubon, on the 10th of the same month, he charged him to devote two hours daily to the preparation of bird skins, and to send him not only the skins but live birds and mussel shells, for which he would be duly paid. Said the father:

I would give you 500 dollars per annum, were you able to make for me such drawings as I will want. I wish you would draw one bird only, on a twig, and send it [to me] to look at, as soon as you can after receiving this letter. ... I should like to have a large box filled with branches of the trees, covered with mosses \&c., such as Mama knows I want; now recollect, all sorts of Birds, males and females, ugly or handsome.

Audubon had come to London with the idea of having his work published under the patronage of King George IV ; in order to gain a personal interview with the Sovereign he had brought a letter to Robert Peel, who was then the Home Secretary, but a change in the Cabinet had upset his plans and the letter was returned. He then applied to the American Ambassador, Mr. Albert Gallatin, who upon their first meeting addressed him in French and showed "the ease and charm of manner of a perfect gentleman"; but when the question of an audience with the King was broached, Gallatin laughed at the idea as preposterous. "The king," he declared, "sees nobody; he has the gout, is peevish, and spends his time playing whist at a shilling a rubber. I had to wait six weeks before I was presented to him in my position of ambassador, and then I merely saw him six or seven minutes." When Audubon then suggested that the Duke of Northumberland might interest himself in his behalf, Gallatin, who disliked the English heartily, replied: "I have called hundreds of times on like men in England, and have been assured that his 
UNDER TIIE STECIAL PATHUNAGE

op

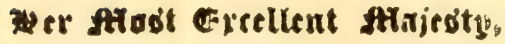

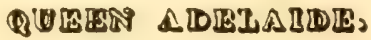

\section{THE \\ BIRDS OF AMERICA,}

ENORUVED TROM

DRA WINGS

MADE IN

THE UNITED STATES AND THEIR TERRITORISS.

BY JOIIN JAMES AUDUBON,

E. ก. ระ. I \& 2 .

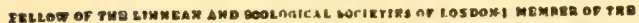

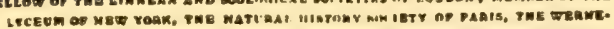

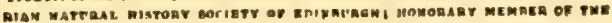

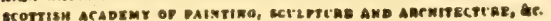

\section{PUBLISHED BY THE AUTHOR:}

AND TO BE SEEN AT

MR R. HAVELL'S JUN. THE ENGRAVER,

77. OXFORD STREET, LONDON.

MDccexXXI.

TITLE PAGE OF AUDUBON's PROSPECTUS OF "THE BIRDS OF AMERICA" FOR 1831. 
grace, or lordship, or [her] ladyship was not at home, until I have grown wiser, and stay at home myself, and merely attend to my political business, and God knows when I will have done with that."

As the American Ambassador had predicted, King George evinced no ardent desire to meet the American woodsman, though he consented to take the work under his patronage and to become a subscriber on the usual terms; this plan, however, fell through, for the King, who was reported to have taken his copy, failed to pay for it. With Queen Adelaide, on the other hand, the naturalist was more successful, and in his "Prospectus" of 1831 she was announced as his special patron, with her name heading his list. Negotiations to interest the Queen were going on when the following note was sent to Audubon by Sir J. W. Waller, who occupied some position in the king's household and was spoken of as "oculist to his majesty":

\section{Sir J.W. Waller to Audubon}

Saturday 9 o clock [1830].

I have scarce an Instant as I am going to Town to breakfast with the Dk. of Gloucester, but yr. Letter is urgent \& therefore I can only desire Mr. A. to send his Number immediately to the Stable Yard, directed to her Majesty, \& the first moment I can see her, I will speak on the subject, but at this Moment I will not promise to mention it to the King for reasons I cannot put on paper.

Yrs. ever,

J. W. WALLER

At Edinburgh Audubon was alarmed to find that subscribers were rapidly deserting him, six having cancelled their names without the formality of giving rea- 
sons. He hoped to supply their places at Glasgow, then a rich city of one hundred and fifty thousand people, but after a visit there of four days in November, 1827, he was obliged to return to Edinburgh with but one new name on his list.

On October 22 he expressed the resolve for the coming year "to positively keep a cash account" with himself and others, "a thing" he had "never yet done." The wisdom of that decision was apparent upon settling his accounts for 1827 with both Lizars and Havell, as appears from this note, written in his journal on January 17, 1828: "It is difficult work for a man like me to see that he is neither cheating nor cheated. All is paid for 1827 , and $I$ am well ahead in funds. Had I made such regular settlements all my life I should never have been as poor a man as I have been; but on the other hand I should never have published the "Birds of America." Again, for February 7 we find this record: "Havell brought me the sets he owed me for 1827 , and I paid him in full. Either through him or Mr. Lizars I have met with a loss of nearly $£ 100$, for I am charged with fifty numbers more than can be accounted for by my agents or myself. This seems strange always to me, that people cannot be honest, but I must bring myself to believe many are not, from my own experiences."

Shortly after reaching London, as we have seen, Audubon had made the acquaintance of Sir Thomas Lawrence, then at the head of the Royal Academy and favorite painter of the Court and fashionable society. The friendship of this influential artist at a critical moment proved most fortunate, for Sir Thomas called repeatedly at his lodgings, and at each visit brought patrons who went away with some of his pictures but not without leaving a handsome toll of sovereigns in 
his lap; the "Entrapped Otter" again did duty by bringing him twenty-five pounds, while others returned from seven to thirty-five pounds. At a later time the artist visited the "Zoölogical Gallery," as the Havell establishment in Newman Street was then known, and saw Audubon's large paintings called "The Eagle and the Lamb," and "English Pheasants Surprised by a Spanish Dog" or "Sauve qui peut." Audubon, who on this occasion missed seeing his distinguished visitor, had written in his journal three days before (December 23,1828 ) that the paintings were what he called "finished," but that, as usual, he could not bear to look at either. Sir Thomas praised the "Eagle," admired an "Otter," which was later exhibited in London, but gave no opinion on the "Pheasants." Afterwards, however, when Audubon proposed to present this canvas to King George, the artist assured him that this picture was worth 300 guineas and that it was too good to be given away; if offered to the King, no doubt, said he, "it would be accepted and placed in his collections, but you would receive no benefit from the gift." According to a later record, this canvas was sold to Mr. John Heppenstall of Sheffield; whether it was ever delivered, or not, I do not know, but either the original or a copy, here reproduced, now forms the central figure in the large Audubon collection in the American Museum of Natural History in New York, and is an excellent illustration of the elaborate and ambitious character of Audubon's larger compositions. These fortunate windfalls came none too soon, for to follow the journal:

Mr. Havell had already called to say that on Saturday I must pay him sixty pounds. I was then not only not worth a penny, but had actually borrowed five pounds a few days before to purchase materials for my pictures. But these pic- 


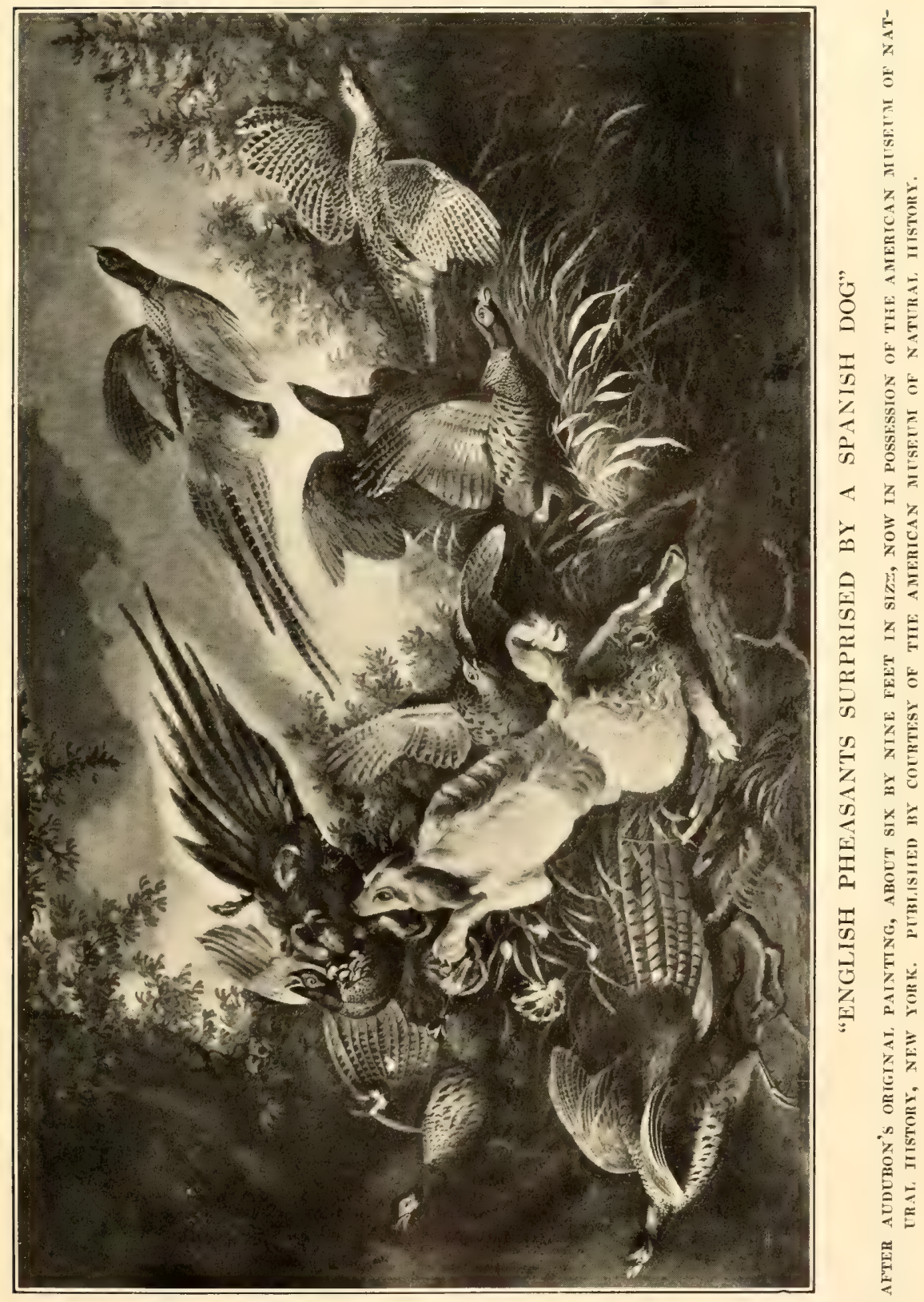



tures which Sir Thomas sold for me enabled me to pay my borrowed money, and to appear full-handed when Mr. Havell called. Thus I passed the Rubicon.

This was before the reform of the penal laws in England, when it seems to have been hard for a man to escape hanging, not to speak of being sent to prison for debt, the chief terror of life in certain circles. There were 223 capital offenses, and in 1829 in the city of London alone 7,114 persons were sent to the debtors' prison. ${ }^{8}$

Without the sale of his pictures in the summer of 1827, Audubon felt that he must certainly have become a bankrupt, yet he was periodically displeased with the results of his efforts in oil colors, and resolved to "spoil no more canvas" but to draw "in my usual old untaught way, which is what God meant me to do"; "I can draw," he continues, "but I shall never paint well." In the fall of 1828, however, he was again working in oils, and produced four large pieces, one of which was called "The Eagle and the Lamb," and two others which were doubtless variations of his "Pheasant" and "Otter" pictures. "It is charity," said the artist, "to speak the truth to a man who knows the poverty of his talents, and wishes to improve; it is villainous to mislead him, by praising him to his face, and laughing at his work as they go down the stairs of his house." Sir Thomas Lawrence had praised some of these pictures and had promised to select one for exhibition at Somerset House. As regards "The Eagle and the Lamb," which Audubon hoped would go to Windsor Castle, William Swainson would give no opinion; the same canvas, or 1909).

${ }^{8}$ See Sir Walter Besant, London in the Nineteenth Century (London, 
else a replica, was in possession of the Audubon family in $1898 .^{9}$

On December 14, 1827, Audubon wrote that, acting upon the advice of Mr. Maury, the American consul at London, he had presented a copy of his Birds to John Quincy Adams, the President of the United States, and another, through Henry Clay, to the American Congress; in order that the latter should be as perfect as possible, Havell was asked to do the coloring himself, but these proposed gifts do not appear to have been executed. ${ }^{10}$

New Year's, 1828, found the naturalist in Manchester, where but a few days before he had received the fifth and last number of his plates for 1827 and expressed himself well pleased with it. While returning to London by coach, he consented to take a hand at cards to accommodate his fellow passengers, but declined to play for money; "I never play," he confessed, "unless obliged to by circumstances; I feel no pleasure in the game, and long for other occupation." "I missed my snuff," he added, and whenever his hands went into his pockets in search of the box, he "discovered the strength of habit thus acting without thought"; but he remembered a resolution he had formed to give up the habit and stuck to it for a time at least; doubtless, like his later friend, John Bachman, he reformed more than once, for in a letter to Victor Audubon, of November 5, 1846, Bachman added this postscript: "To Audubon: The snuff-the snuff, it is here! I have just taken a pinch, and the ladies have blown you upsky-high, for teaching me such a bad practice; I say,

- See Maria R. Audubon, Audubon and his Journals (Bibl. No. 86), vol. i, p. 342, where the "Eagle and the Lamb" is reproduced.

${ }^{10}$ See Vol. I, p. 436. 
however, that you beat me all to pieces in that art."

The first winter in London dragged heavily for the naturalist, who exclaimed in January, 1828: "How long am I to be confined in this immense jail"; when Daniel Lizars reported from Edinburgh the loss of four of his subscribers, he writes, "I am dull as a beetle. Why do I dislike London? Is it because the constant evidence of the contrast between the rich and the poor is a constant torment to me, or is it because of its size and crowd? I know not, but I long for sights and sounds of a different nature," such, we might add, as the flocks of wild duck which were occasionally seen from Regent's Park as they passed over the city and made him more homesick than ever. Audubon hated the city quite as cordially as Charles Lamb ever affected to detest the country, and when leaving it; afoot or by stage, it seemed as if he could never be rid of it. "What a place is London," he would say, but naïvely add: "many persons live there solely because they like it."

On February 4, 1828, Audubon was elected to membership in the Linnæan Society, and in November he presented it with a copy of his work, which was then well under way. This was noticed in a letter to Swainson, written on November 7, when no acknowledgment of the gift had then been received; and he mentioned also the sale of his picture of "Blue Jays" for ten guineas. At a meeting of the Linnæan Society not long after his election, copies of Selby's Illustrations of British Ornithology and of his own work were placed side by side for inspection, and "very unfair comparisons were drawn between the two"; had Selby, Audubon reflected, been given "the same opportunities that my curious life has granted me, his work would have 
been far superior to mine"; "I supported him," he added, "to the best of my power."

Revision of his older drawings demanded much of Audubon's attention during these years. On February 10, 1828, he began the Whiteheaded Eagle (No. 7, Plate xxxi), the original of which had been procured on the Mississippi, where the bird was represented as dining on a wild goose; now, he said, "I shall make it breakfast on a catfish, the drawing of which is also with me, with the marks of the talons of another eagle, which I disturbed on the banks of the same river, driving him from his prey." On the 16 th of that month he was engaged with this drawing from seven in the morning until half after four, stopping only to take the glass of milk which his landlady would bring to him. This plate was engraved in the following April, and on May 1, 1828, a first proof was sent to the Marquis of Landsdowne, president of the Zoölogical Society, as a mark of appreciation by its author, who had become a member of that body in the preceding winter.

A striking characteristic of Audubon's work was its diversity, produced not only by attractive embellishments of many kinds, but by the moving force and action with which he ever sought to vitalize his subjects. It is therefore not surprising that he was nettled by an incident like this:

February 28. To-day I called by appointment on the Farl of Kinnoul, a small man, with a face like the caricature of an owl; he said he had sent for me to tell me all my birds were alike, and he considered my work a swindle. He may really think this; his knowledge is probably small; but it is not the custom to send for a gentleman to abuse him in one's house. I heard his words, bowed, and without speaking, left the rudest man I have met in this land. 
Audubon had not yet visited the great university towns of England, the support of which he knew would be a valuable asset, and on March 3, 1828, he set out by stage for Cambridge. His driver, he remarked, "held confidances with every grog-shop between London and Cambridge, and his purple face gave powerful evidences that malt liquor [was] more enticing to him than water." His reception at Cambridge was hearty; he was entertained by Professors Sedgwick, Whewell, and Henslow, dined repeatedly "in Hall" with the dons, and received the subscription of the librarian of the University. It is interesting to recall that young Charles Darwin, "the man who walks with Henslow," as some of the dons called him, was then an undergraduate at King's College, and that thirty-one years were to pass before modern biology was born in 1859 , the year of the appearance of the epoch-making Origin of Species.

By the 15th of March Audubon was again in London, and on the 24th he started for Oxford. Dr. Williams, as he noted in his journal, subscribed for his Birds in favor of the Radcliffe Library, as did also Dr. Kidd for the Anatomical School; but, though hospitably treated by all, not one of the twenty-four colleges of that great University emulated their example, and the naturalist went away disappointed.

Upon his return to London in early April, Audubon received a call from John C. Loudon, editor of the Magazine of Natural History, and was invited to contribute to that journal. "I declined," he said, "for I will never write anything to call down upon me a second volley of abuse. I can only write facts, and when I write these, the Philadelphians call me a liar." He was then chafing under the criticism which his rattlesnake 
stories had produced. ${ }^{11}$ On April 6 the persistent Mr. Loudon called again and offered Audubon eight guineas for an article, only to be again refused. Still unwilling to admit defeat, the editor proposed to engage William Swainson to prepare an extended review of the naturalist's work, and in this he succeeded so well that Audubon immediately relented and sent him a paper. ${ }^{12}$ Swainson offered to write the review for a copy of the work at its cost price, and Audubon replied in the following letter: ${ }^{13}$

\section{Audubon to William Sreainson}

\section{MY DEAR Sir,}

London, April 9th 1828.

Mr. Loudon called on me yesterday and showed me a letter from you to him, in which many very flattering expressions respecting myself and my works you are so kind as to offer to

${ }^{11}$ See Chapter XXVIII.

${ }^{12}$ The seventh which he had contributed to the scientific press of Europe, entitled "Notes on the Bird of Washington (Falco Washingtoniana), or Great Sea Eagle," now believed to have been mistaken by him for an immature stage of the true "bird of freedom," the Whiteheaded Eagle. It was dated "London, April, 1828," and was published in Loudon's Magazine for July of that year. See Bibliography, No. 23.

${ }^{13}$ From the originals in possession of the Linnæan Society of London. Swainson's scientific correspondence was taken with him to New Zealand, where it remained fifty years, until returned by his daughter, who sent it to Sir Joseph Hooker; it was finally purchased by a number of Fellows of the Society, and presented to its historical collections. It consists of 934 letters written by 236 correspondents, from 1806 to 1840 . Of the 24. letters written by Audubon, and dated 9 April, 1829, to 11 January, 1838, none has been previously published. Dr. Albert Günther, who has given a summary of their contents (Proceedings of the Linnacan Society, 112th Session, 1900; Bibliography, No. 204) found them rather disappointing, since they dealt mainly with personal and domestic matters, and were written in a style characterized as "fantastic and unnatural." Through the kindness of my esteemed friend, George E. Bullen, Esq., of the Hertfordshire County Museum, St. Albans, and through the courtesy of the Council of the Linnæan Society and its secretary, Dr. Daydon Jackson, I am able to reproduce transcripts of the most interesting of these letters, which readers in America will, I believe, find interesting because of their personal details. I am indebted also for their good offices to John Hopkinson, F.L.S., and to William Rowan, Esq. 
review the latter so as to have your opinion in writting in time for the first no. of the magazine that will appear next month.you also desire that I should send you a sett of the works as far as publishing which you wish to keep provided I will let you have it at the price it costs me. I assure you my Dear Sir, that was I to take you at your word it would be a sore bargain for you as the $\mathrm{a} / \mathrm{m}$ would be very nearly double that for which it is sold to my subscribers. - therefore you will permit me to alter your offer and to say that if it suits you to pay 35 shillings per number I will be contented; I would be still more so was I rich enough to present it to you.-

It is the only set on hand at present except one which I must have to exhibit.-

The answer respecting the Shrieke [Shrike] has I hope met with your wishes.-

Ever since $I$ became acquainted with our mutual friend Dr. Fraill [Traill] I have had a great desire to see and speak to you \& I regret that I never have had an opportunity. My time is so completely taken up that it is with difficulty that I can enjoy a day's rest--Should you come to town pray call on me when I may have the pleasure of shaking your hand and to assure you verbally that $I$ am truly and sincerely

$$
\begin{aligned}
& \text { yours obe st } \\
& \text { John J. AUdubon }
\end{aligned}
$$

95 Great Russell St.

Bedford Sq.

Thus began an intimate friendship between William Swainson and John James Audubon which lasted until 1830, and their intercourse did not wholly cease before

From the context of the nine letters which are here reproduced without change, it is evident that Audubon paid little attention to grammar, syntax, or orthography, but if the reader will compare the letters written before and after 1830, or before and after his first serious discipline in English composition (see Chapters XXIII and XXIX), he will find marked improvement in all these respects. 


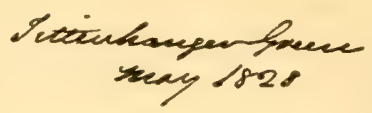

lly aces thes.

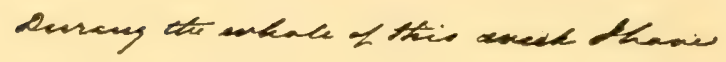

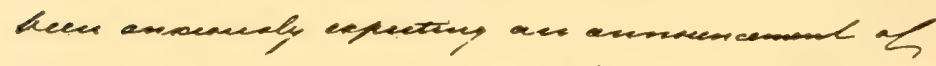

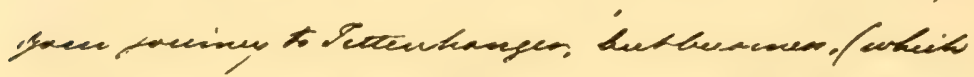

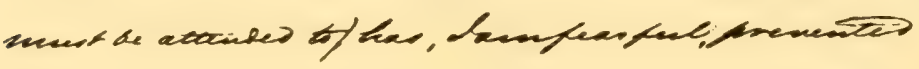

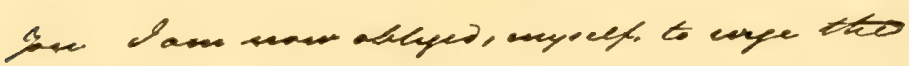

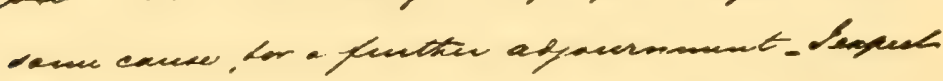

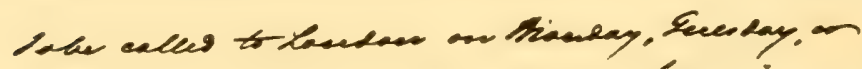

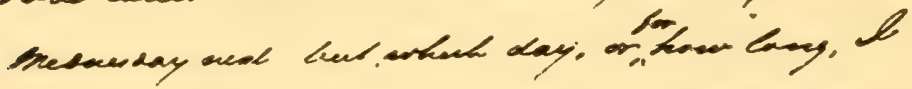

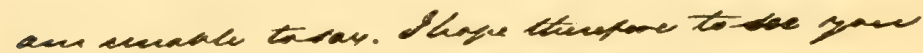

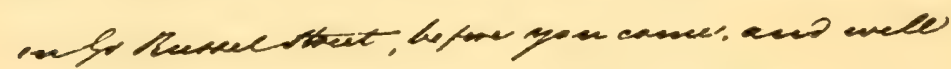

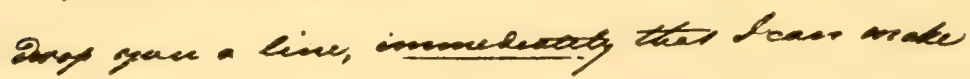

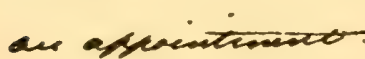

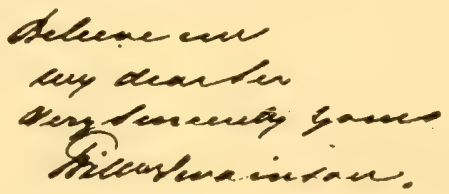

LETTER OF WILLIAM SWAINSON TO AUDUBoN, MAY, 1828.

From the Deane MSS.

1838. In his use of English at this time Audubon was not far behind Swainson, whose mother tongue it was. Swainson, according to Dr. Günther, was "extremely careless in orthography and loose in his style of writing: he persistently misspelt not only technical terms, but also the names of foreign authors, and even of some of his familiar friends and correspondents; he 
knew no other language but his own, and the application of Latin and Greek for the purpose of systematic nomenclature was a constant source of error."

At this time Swainson was living in semi-retirement at a farmstead of considerable size, called "Highfield Hall," ${ }^{14}$ near Tyttenhanger Green, a small settlement, off the highroad, two miles southeast of the historic town of St. Albans, in Hertfordshire; though his letters were always dated from "The Green" at Tyttenhanger, his associations were with the more considerable village of London Colney, but a mile to the south, on the road to Barnet. Audubon had brought a letter of introduction from Dr. Traill, a valiant champion of Swainson at Edinburgh, but was unable to go to the country to deliver it. Swainson, however, attended promptly to the review, and on April 11, 1828, sent it to Mr. Loudon, who published it in the May number of his Magazine. ${ }^{15}$

Swainson's review was extremely laudatory, and Audubon reproduced extracts from it in later editions of his "Prospectus." To quote a characteristic paragraph, he said that the naturalist's ornithological papers

${ }^{14}$ Swainson's house has been kindly identified by my friend, Mr. George E. Bullen, to whom I am indebted also for an interesting photograph, taken from an old print. Mrs. Swainson, who died February 12, 1835, was buried in the parish church, with which she was closely identified, at London Colney, and a tablet to her memory is still to be seen there. Swainson probably preferred the historic associations of Tyttenhanger, a name originally applied to the manor and manor house of the Abbot of St. Albans, a famous abbey property acquired before the Conquest, with a history extending over six hundred years, but he did not live there. The oldest resident now on the spot, a man over ninety, told Mr. Bullen that as a boy he often collected butterflies, moths and other specimens of natural history which he took to "Highfield Hall," and was always paid by one of the Swainson children. Since Swainson's time the original house, which was approached by a long walk, has become almost unrecognizable, having received, an addition to one side; the grass land which then surrounded it has been converted into beautiful lawns.

${ }^{15}$ See Bibliography, No. 95. 
printed in one of the Scotch journals, are as valuable to the scientific world, as they are delightful to the general reader. They give us a rich foretaste of what we may hope and expect from such a man. There is a freshness and an originality about these essays, which can only be compared to the animated biographies of Wilson. . . To represent the passions and the feelings of birds, might, until now, have been well deemed chimerical. Rarely, indeed, do we see their outward forms represented with any thing like nature. In my estimation, not more than three painters ever lived who could draw a bird. Of these the lamented Barrabaud [Barraband], of whom France may be justly proud, was the chief. He has long passed away; but his mantle has at length been recovered in the forests of America.

Audubon spent four days with Swainson and his family at 'Tyttenhanger, from May 28 to June 1, 1828, when they talked birds and made drawings; Audubon also showed Swainson "how to put up birds in his style, which delighted him." The friendship between these men, though very intimate while it lasted, received a sudden check two years later, when Audubon was about to publish the letterpress to his plates, as will be related farther on. ${ }^{16}$

Though his hands were already more than full at this time, Audubon seems to have played with the idea of publishing a work on the birds of Great Britain, but on May 1 he wrote to Swainson that the plan did not meet with favor, and later he relinquished all claims in such a project to his assistant, William MacGillivray. ${ }^{17}$

In the spring of 1828 Audubon began to think of returning to the United States, to renew or revise his drawings and extend his researches. "I am sure," he

${ }^{16}$ See Chapter XXIX.

${ }^{17}$ See Vol. II, p. 130. 
said, "that now I could make better compositions, and select better plants than when I drew mainly for amusement." In order to raise the necessary funds, he resorted again to picture painting, his never failing resource, and worked in oil colors daily from morning light until dusk, unless called to Havell's to decide some question of necessary detail. The following letters to Swainson shed further light on this work and on the progress of The Birds of A merica, the eighth number of which was published early in July:

\section{Audubon to William Swainson}

Londox, July 1st 1828.

MY dear Sir.-

I have been expecting to have the pleasure of seeing you for upwards of a week, having mentioned in your last note that you intended spending a couple of days in London before the end of June.-When are you coming? - the beautifull lamb came quite safe and is now on the canvas (in efigy) for ages to come-I bought a superb Golden Eagle from Mr. Cross that also has helped to fill it - [ [Here apparently some words have been deleted, and it is impossible to read them.] I long to shew them to you.- I have finished the picture of the Turkeys, and painted a white headed eagle - in fact I have worked from 4 every morning untill dark-but the best news I have to tell is; that $\mathbf{I}$ have received 4 letters from my wife, one dated 2nd of May, all well-but not quite settled about coming before the end of summer. I have changed quarters and am now at 79 Newman Street Oxford Street, in Mr. Havell's house where I have taken 3 rooms and feel more comfortable although I have not the little piece of ground to walk on.-I imagine the country to be now quite beautifull and had I time to spare would walk out to see you Mrs S \& the dear little folks at Tittenhanger Green.-I received a visit on Saturday last of the whole of Lord Milton's family who after complimenting the author of the "Birds of America" very kindly subscribed for 
two copies of the work.-I have mended my pen-I should have sent the Blackwood magazine to you, but I so much expected to see you here that it is yet on my table, and will keep it untill you come.-All my exertions to procure live grouses have been abortive here-I have written to Scotland to a friend and perhaps will have some soon.-The 8 th number is now printing and colouring and will be out this month-the 9 th is began.-If you are hungry or thirsty when you come to town please make for my [here a word is omitted], and I will try to manage matters in this way.-May I ask what you are doing?-I saw Dr Fraill's [Traill's] son a few days ago-he inquired after your son and family.-I expect a copy of Loudon's magazine this evening. I feel anxious to see what sort of a cut the Dores make, as well as the birds of Washington.-

With sincerest regards \& esteem to yourself and LadyI am yours most truly

John J. Audubon.

79 Newman Street,

Oxford Street.

\section{Audubon to William Srainson}

I_ondox Thursday July $18 \approx 8$.

My dear Mr Swainson,

Although your last note said that you knew not when I should have the pleasure of seeing you in town, I have hoped every morning to see you that day.-When will you come?There is a talk of my picture of the Eagle and the Lamb going to her Majesty, Sir Walter Waller has been written to on the subject and every thing is in train to lead poor I like a lamb to Windsor Castle!-I am told the picture is a grand one but you, my dear Sir, have not said so! When you come I will show you 13 grouses pretty fairly grouped on one canvas, with seven pheasants with a Fox on another, etc. etc. I have worked hard this month from 4 p.m. untill 7 a.m. [sic] every day-I regretted that your brother did not come to see me-I have a great desire to see you but I cannot at present leave town.- 
My 8th No. is just out.-The 9 th \& 10th are engraving.-I have sent word to my son to land [?] \& bring some skins for you $\&$ perhaps you may have a rare assortment bye and bye.I hope your Lady and dear Children are all quite well Pray remember me kindly to them._L I wish to name a bird after you in the 1st No. of $1829 \&$ wish you to choose a name.

Believe yours ever and truly obliged

J. J. Auduвon

79 Newman Street,

Oxford Street.

By the 9th of August eight pictures had been begun, but none was finished, and the number of his subscribers had fallen to seventy. At about this time Captain Basil Iall ${ }^{18}$ returned from his journey through the United States, and brought direct news from Victor Audubon, who was then at Louisville, from Dr. Richard Harlan and Thomas Sully, to all of whom the naturalist's letters had been delivered the previous year. Towards the end of the month Audubon received the following note from the secretary of the Zoölogical Society, N. A. Vigors, who was also anxious to obtain from him an article for his Journal:

\section{N. A. Vigors to Audubon}

BrUter CT Aug. 23, 1828.

MY DEAR SIR:-

I hope you do not forget your promise of giving us a paper for the Zoological Journal. We should be much gratified by having your name with us: and, if possible, should wish to have whatever you may favour us with within the next ten days. I have been but a few hours in town, and shall leave town again tomorrow for a few days, or I should have called

${ }^{10}$ See Note, Vol. I, p. 364. 
upon you to speak personally upon the subject. I believe I have already mentioned, that we are in the habit of remunerating those of our correspondents who wish for payment for their labours, at a rate not exceeding $\mathfrak{£ 1 0 . 1 0 . 0}$ per sheet.

A letter from you in answer will reach me, if sent to Bruter Ct: before Wednesday on which day a parcel will be forwarded to me from thence.

Believe me my dear Sir,

Yours faithfully,

$$
\mathrm{N}: \mathrm{A}: \text { Vigors. }
$$

[Addressed]

J. J. Audubon Esq.,

69 Great Russell St.;

Bloomsbury.

[Readdressed]

Newman Street,

Oxford Street

Audubon refused this request, saying that "no money can pay for abuse," and this time he did not retract.

Without immediate prospect of seeing his family, for neither Mrs. Audubon nor her sons were enthusiastic over the proposal that they should go to England, the naturalist was momentarily depressed; he turned to Swainson for advice, at the same time suggesting that they visit Paris together. Audubon wrote in his journal for August 16, 1828, that he had invited Swainson to accompany him to France, whither his friend had expressed a desire to go when the subject had been broached at Tyttenhanger; on the 25th of that month he added: "I do not expect much benefit by this trip, but I shall be glad to see what may be done." The letter just referred to follows: 


\section{Audubon to William Srwainson}

Lowdon, Wednesday Augt. 13, 1828.

\section{My dear Mr. Swainson,}

I reached my lodging in great comfort by the side of your amiable Doc ${ }^{\mathrm{r}}$ Davie two hours and a half after we shook hands -I wish I might say as much of my Journey through Life.-I have had sad news from my dear wife this morning, she has positively abandoned her coming to England for some indefinite time, indeed she says that she looks anxiously for the day when tired myself of this country I will return to mine and live although a humbler (Public) Life, a much happier one-her letter has not raised my already despondent spirits in somethings and at the very instant I am writing to you it may perhaps be well that no instrument is at hand with which a woeful sin might be committed - I have laid aside brushes, thoughts of painting and all except the ties of friendship-I am miserable just now and you must excuse so unpleasant a letter-Would you go to Paris with me? I could go with you any day that you would be please to mention, I will remain there as long and no longer than may suit your callings-I will go with you to Rome or anywhere, where something may be done for either of our advantage and to drive off my very great uncomfortableness of thoughts--My two sons are also very much against coming to England, a land they say where neither freedom or simplicity of habits exist and altogether uncongenial to their mode of life.-What am I to do? As a man of the World and a man possessed of strong unprejudiced understanding I wish that you would advise me.-But now on your account I will change the subject-I called on Newman two days ago \& to the following enquiries he gave me yesterday the following answers

What the price of

$1 / 2$ doz best Pure Lake

$1 / 2$

$1 / 2$ " " " UltraMarine

$1 / 2$ " 6 " Vermillion

$1 / 2$ " " " Terra di Verona
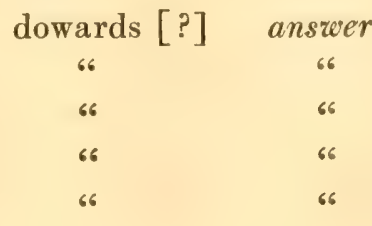

$12 /-$ $20 /-$ $84 /$ $6 /$ $4 /-$ 
As I thought the above prices enormous I have declined advising chalks for you \& will await your advent.-

Should you not feel inclined to go to France at present which by the bye is the very best season on account of seeing the vintage etc. etc.-please write to me so or come to town which would be still more agreeable \& talk the matter over as I think I would persuade you to absent yourself for a month or so-I hope your kind lady continues quite well \& your Dear Little ones-

Believe me yours most sincerely

John J. Audubon.

Please write by return of Post-

79 Newman Street

Oxford Street.

On this journey to Paris Audubon was accompanied by Mr. and Mrs. Swainson and an American artist, named Parker, who had been at work on a portrait of the naturalist in oils. For Audubon it was mainly a canvassing tour; Parker hoped to obtain orders for portraits, and Swainson, new ornithological material at the great museum in the Jardin des Plantes, for a work upon which he was then engaged. ${ }^{19}$

The party set out on the 1st of September, traveling by way of Dover and Boulogne, and reached Paris on Thursday, September 4. They alighted at the Messagerie Royale, Rue des Victoires, and, after looking up lodgings, went at once to the Jardin des Plantes to pay their respects to Cuvier. The Museum of Natural History was closed, but they knocked and asked for the Baron. "He was in," said Audubon, in the journal of his Paris experience,

${ }^{10}$ Fauna Boreali-Americana; or the Zoölogy of the northern parts of British America; Part Second, "The Birds;" by William Swainson and John Richardson (London, 1831). 


\section{AUDUBON IN LONDON}

but, we were told, too busy to be seen. Being determined to look at the great man, we waited, knocked again, and with a certain degree of firmness sent in our names. The messenger returned, bowed, and led the way up stairs, where in a minute Monsieur the Baron, like an excellent good man, came to us; he had heard of my friend Swainson and greeted him as he deserves to be greeted; he was polite and kind to me, though my name had never made its way to his ears. I looked at him, and here follows the result: age about sixty-five; size corpulent, five feet five, English measure; head large; face wrinkled and brownish; eyes gray, brilliant and sparkling; nose aquiline, large and red; mouth large, with good lips; teeth few, blunted by age, excepting one on the lower jaw, measuring nearly three-quarters of an inch square. ${ }^{20}$

They were immediately invited to dine on the following Saturday at six o'clock, and later saw Cuvier at his home, at his Museum, and at the Academy of Sciences, over which he presided.

Geoffroy Saint-Hilaire pleased Audubon greatly and proved to him by his conversation that he understood perfectly the difference between the French and the English. The Duke of Orleans, who then occupied the Palais Royal, seemed to him the finest physical type of man he had ever met. "He had my book brought up," said the naturalist, "and helped me untie the strings and arrange the table, and began by saying that he felt great pleasure in subscribing to the work of an American, for he had been most kindly received in the United States and should never forget it." When the plate of the Baltimore Orioles was held up to view, the Duke exclaimed: "This surpasses all I have seen, and I am not astonished now at the eulogiums of M. Redouté." He conversed in both English and French, had much

${ }^{20}$ Maria R. Audubon, op. cit., vol. i, p. 306. 
to say of American cities and rivers, and added: "You are a great nation, a wonderful nation." 'The Duke wrote his name in Audubon's subscription book, promised to try to enlist a number of the crowned heads of Europe in his behalf, and gave him besides a number of orders for pictures of animals.

Audubon had already made friends with the veteran painter of flowers, Pierre Joseph Redouté, and when it was proposed that they should exchange works, the "Raphael of Flowers". consented, gave Audubon at once nine numbers of his Belles Fleurs, and promised to send "Les Roses."

During this visit of eight weeks Parker painted portraits of both Cuvier and Redouté; Swainson worked steadily at the Museum, where Isidore Geoffroy SaintHilaire gave him the use of his private study; while Audubon, for the most part, was driving from post to pillar in his not altogether successful efforts to extend his subscription list. As already intimated, his greatest success in Paris was in winning the friendship and endorsement of Cuvier, who reported upon his work at a meeting of the Royal Academy of Sciences held on September 22. ${ }^{21}$ Audubon has related how on this occasion he had an appointment to meet the Baron in the library of the Institute at precisely half past one o'clock; he waited; the hall filled, and the clock ticked on, but the great savant did not appear. Finally, said Audubon, after an hour had passed, "all at once I heard his voice, and saw him advancing, very warm and apparently fatigued. He met me with many apologies, and said, 'Come with me'; and as we walked along, he explaining all the time why he had been late, while his hand drove a pencil with great rapidity, and he told me

${ }^{21}$ See Vol. I, p. 3. 


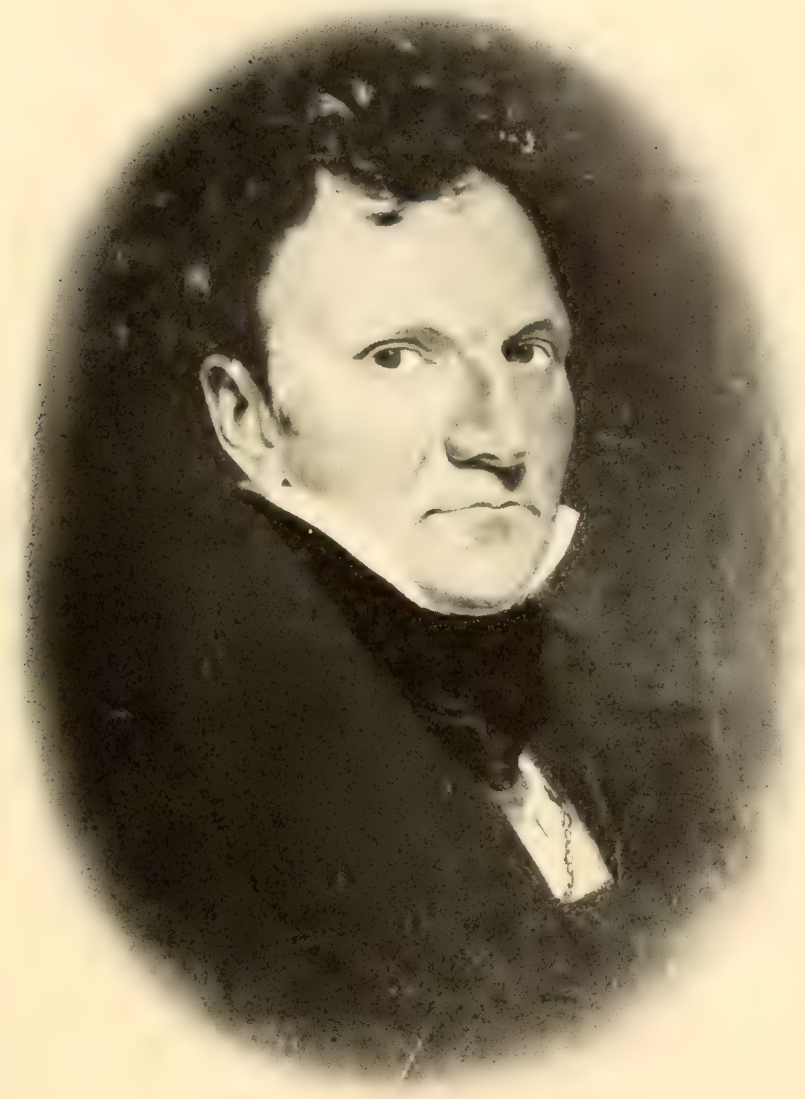

\section{AUDUBON}

AFTER A PORTRAT JN OILS, IITIIERTO UXPCBLISHE,, PAINTED AHOLT 18:6

W. H. HOLAES FOR WALTER HORTON IZNTLEY, OF MANCHESTER, AYD IX 1913 IN POSSESSION OF IIIS GRANDSON, JOHY CONWAY BENTLEX, FORMERIY OF GLASGOW. IX THE ORIGIYAL AUDUBON IS REPRESENTED IY A GREEN COAT, A CRIMSON CLOAK WITH DEEP FUR EDGING THROWN OVER ONE SHOUIOLR, AND WITH PORTFOIL IN IIAND. FROM A PIIOTOGRAPII IN POSSESSION OF MR. RUTHVEN DEANE. 

that he was actually now writing the report on my work!" 22 Cuvier's published report, which was extremely laudatory, showed little signs of haste. After speaking of Audubon's talents and accomplishments he said:

The execution of these plates, so remarkable for their size, seems to us equally successful in the drawing, the engraving, and coloring, and though it may be difficult to represent relief in a colored print with as much effect as in painting proper, this is no disadvantage in works on natural history; naturalists prefer the true color of objects to those accidental shades which result from the diverse inflections of light; necessary though these be for completing the truth of a picture, they are foreign as well as prejudicial to scientific accuracy. ${ }^{23}$

By November Audubon was once more in London, busy at painting to fill his orders and his purse. On the 11th of the month, we find Swainson, whose own exchequer was empty, writing to Audubon for a loan; this letter, and one soon to follow, illustrate some of the characteristics to which we have referred:

\section{William Swainson to Audubon}

Tuesday 11 Nov. 1828.

I had written the enclosed, my dear Mr. Audubon, before -your letter of Monday reached me. It has come this instant, Dreams, you know, must always be interpreted contrareise, we might have lifted up our arms, as you saw in your dream but, if you had not awoke, it was no doubt to have shaken hands! But that my regard for you may be evinced, I will bring myself to lay under an obligation, which I would only ask for one of my own family. I was that moment thinking to which I should

${ }^{22}$ Maria R. Audubon, op. cit., vol. i, p. 323.

${ }^{23}$ See Bibliography, No. 93a. 
write, to ask the loan of $80 £$ for a few months, and now I will ask it of you. If you was aware of the peculiar feelings which we Englishmen have on such occasions, perhaps you would smile, but so it is that we never ask any one, from whom we have the least idea of a refusal. Now, did I not believe you to be a sincere friend, do you imagine I should have told you I was in want of Money much less have asked you to lend me some. The fact is, I have suffered a severe loss during my being in Paris, what little $I$ had on hand has been spent there and in making preparations for the publication of my Zool. Illustrations. Two or three months however, hard work will bring me round again \& repay you.

Let me see your letter to the President of the Zool. Soc. before it goes, and you shall see mine.

I shall be most thankful for the Grouse. I send 2 drawings to Havell to be engraved spur him on for I want to have every thing ready before the new year.

Yours most sincerely,

W. Swainson.

Јону J. Auduron, Esq.

79 Newman St.

In December the Swainsons invited Audubon to dine with them at Christmas; in his letter Swainson said:

Why are you so sad? I would lay ten shillings that old Havell has been disappointing you as he has done me. He is in matters of business a complete daudle-an old woman, and I have done with him. His son I think better of he has a good idea of punctuality in business. . . In one of your walks I hope you have thought about the French Wine that we talked so much about and have ascertained the particulars from your friend, so that we may order a cask. I hope you have not mistaken the price,- for if not, nothing that can be drank in this country is one half as cheap. 
In the following letter Swainson refers to the second series of his Zoölogical Illustrations, ${ }^{2+}$ the sale of which was irritating him, and to N. A. Vigors, with whom he had entered upon a notorious controversy in 1828:

\section{William Srainson to Audubon}

18 January, 1829.

My Dear Mr. Audubon,

I write this in utter uncertainty whether it will find you in London. My first number has now been out three weeks-it has been seen and universally admired, and how many copies do you think the Publisher has sold? now pray guess as the Americans say. 100-no. twentyfive, no. fifteen, no. ten? yes. positively ten copies and no more, has been sold. I blush almost to confess this mortification to even, you, but so it is. Now, my dear Sir, what am I to think of, the "generally diffused taste," as the phrase is, for Natural History.

This allthough vexing to me, may be a consolation to you, who are able to exhibit on what I call your Red Book the names of a good portion of 150 subscribers to a 200 guinea Book. Think yourself my friend exceedingly well off.

The amount of sale must be kept silent, it would be a nice nut to crack for $\mathrm{V}$ [igors]. \& his friends.

I shall be able to do without the water birds, if you have not found any.

I have had a most extraordinary letter from Waterton, which will highly amuse you. The man is mad-stark, staring mad.

\section{Yours very faith'ly}

W. Swainson.

Can you tell me any safe expeditions made of sending and receiving letters and Parcels from Philadelphia.

J. J. Audubon Esq.

79 Newman St.

Oxford St.

${ }^{24}$ The three volumes of this series bear date of 1832-33, but the preface is inscribed "Tittenhanger Green St. Albans, 24 th July, 1829." 
Early in 1829 Bonaparte wrote from Rome, where he had then settled, and the following letter shows that he had then heard of Audubon's visit to France, and was keenly interested in his success:

\section{Charles L. Bonaparte to Audubon}

RoMe January 10 th 1829.

\section{Dear Sir}

I received in due time your favours of November $3 \mathrm{~d} . \&$ December 21 st. \& now come to thank you for them, wishing you or rather expressing to you at the occasion of the renewal of the year, the warm wishes I constantly have for your health, happiness \& especially for the success of your work. From the contents of your letter I clearly perceive that one at least of my letters to you must have miscarried. Nothing could be more interesting to me than the narrative of your journey to France, though I had heard from other quarters the good \& well deserved reception you met with. Your letter of August 20 th. never came at hand, \& it must have been the same with at least one of mine to you. What you mention about Temminck quite astonishes me! . . . I thought he would have undertaken even a journey to see you $\&$ your drawings! ! ! Please let me know when you write whether the Ornithological Illustrations of Jardine, Vigors \& Co are stopped or still going on.-The animals I spoke to you of were reported as delivered to you by Mr Gray of the British Museum who had received them for me from the U. States. Is it not so? ... Corvus Cornix with us is very fond of the sea shore \& feeds occasionally on fish, but I never observed it had the singular habits of C. ossifragus at least as described by Wilson.

I am surprized at Messrs J B's conduct; I have always found them extremely kind and well disposed towards me; \&. although we have settled our accounts I had no reason to believe they would refuse our box. However we can do without their interference quite as well, \& I hope you have already forwarded the box to Leghorn recommending it to the care of my 


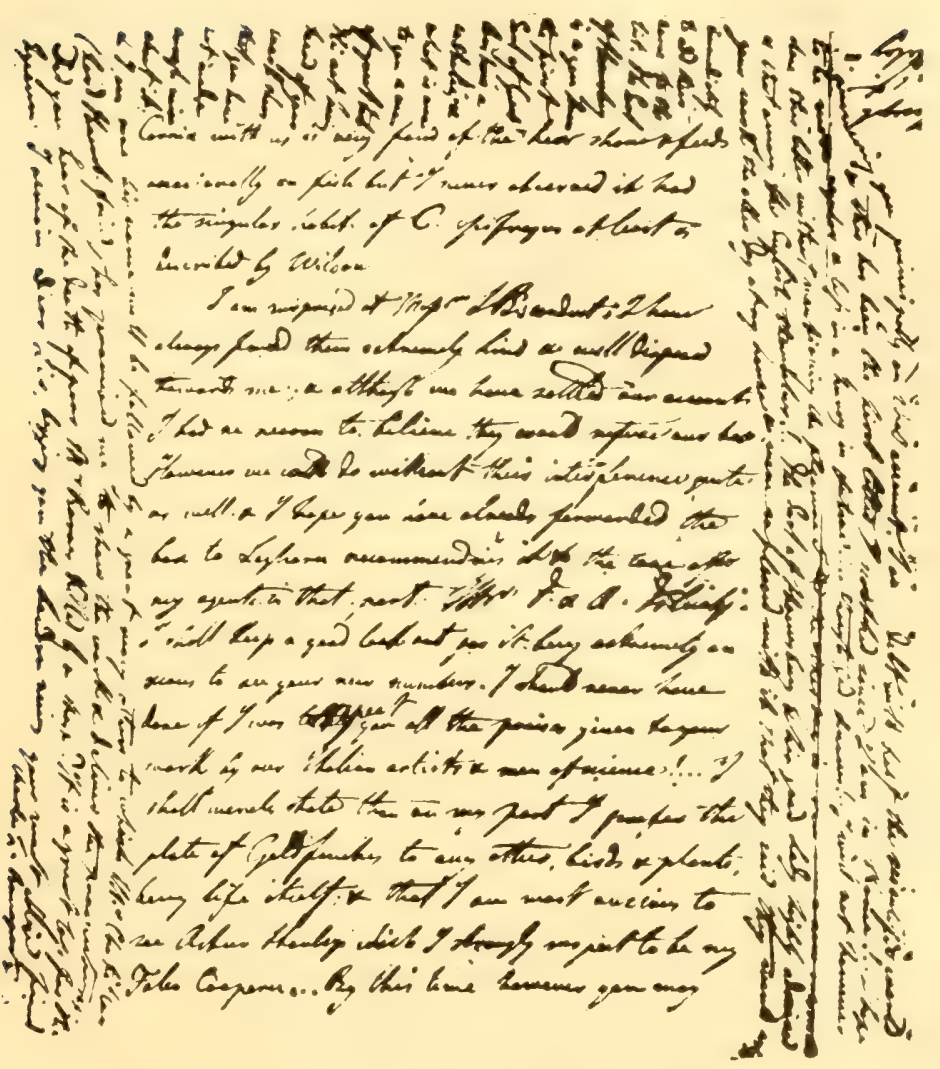

PART OF IETTER OF CHARLES LUCIEN BONAPARTE TO AUDUBON JANUARY 10, 1829. From the Howland MSS.

agent in that port. Messrs F. \& A. Filuchs.(?) I shall keep a good lookout for it being extremely anxious to see your new number. I should never have done if I was [to] repeat [to] you all the praise given to your work by our Italian artists \& men of science!. . I shall merely state that on my part I prefer the plate of Goldfinches to any other, birds and plants, being life itself ; \& that I am most anxious to see Astur Stanleyi which I strongly suspect to be my Falco Cooperii. . . . By this time, however you may have been able to ascertain the fact . . please let me know how the thing stands. It is only 
by your letter that I hear of my work ( $2 \mathrm{~d}$ ) being in London: I have not yet seen a copy myself nor did I know positively that it had been published. You must surely have received one from myself at all events, for I directed Messrs Gay \& Lea to let you have one of the very first out. Let me know whether you have it \& your opinion about it. - I think you are right in going to Russia, especially as in giving them the American Birds you will probably give us the Russians, some of which are hardly known. Try to get for me Pyrrhula longicauda, P. rosea \& Scalopax-thalina, the latter especially. I shall not loose sight of the portrait, but it will be still more difficult to get the signature. I will however endeavor from some of my relations. You were right in supposing me "dans les bras de la paix \& le bonheur d'un heureux père de famille" but greatly mistaken to think I was taking "le plaisir des sciences". Settling and other cursed worldly affairs have so much taken up my time, that I have not looked a specimen or a book since I am in Rome . . my small library itself \& my Cabinet have not even been arranged \& I tremble to find all my birds destroyed when the happy day will come to look into them. In the mean time an addition has been made six weeks ago to my small family. I have another son who has received the names of Lucien Louis Joseph Napoleon \& better than that who is the porthrait of health itself. I am sure you will divide my happiness \& excuse my delay in answering you principally on that account. I am in debt with half the scientific world \& this has been the first letter I scratched since I am in Rome! . . . I hope to be more regular \& less in a hurry in future ... though God knows!... I will not however slose this letter without mentionaing the pleasure I had the other day in getting you a new subscriber \& that among the English themselves.! The Earl of Shrewsbury \& his good Lady highly admired your work the other day at my house $\&$ were so pleased with it that they said they would write immediately to add their name to the list. The Earl of Shrewsbury is as you know the first Earl of Great Britain a catholic \& what is more to you a man of great taste. His not having heard of your work shows that you have not 


\section{AUDUBON IN LONDON}

made enough noise about it: \& I am sure his name will be followed by a great many others to which Mr. Chapittar (Lord Shrewsb. friend) has promised me to show the work \& deliver the prospectuses. Did you hear of the death of poor $\mathrm{Mr}$ Barnes killed by a stag (?). It is a great loss for the Queen. I remain, Dear Sir, begging you the London news your most obliged friend

Charles L. Bonaparte.

[Addressed] Mr. J. J. Audubon

79 Newman Street

Oxford St.

\section{London}

Inghilterra.

[Endorsed] Answered Feby. 8 th. 1829.

$$
\text { J. J. A. }
$$

Audubon continued to work on his paintings during the winter of 1828-9, hoping to put his affairs in such order that he might be able to start for America in the following year. 


\section{CHAPTER XXIV}

FIRST VISIT TO AMERICA IN SEARCH OF NEW BIRDS

Audubon settles for a time in Camden-Paints in a fisherman's cottage by the sea-With the lumbermen in the Great Pine Woods-Work done-Visits his sons-Joins his wife at St. Francisville-Record of journey south-Life at "Beechgrove"-Mrs. Audubon retires from teaching-Their plans to return to England-Meeting with President Jackson and Edward Everett.

Audubon laid his plans to visit America in $\mathbf{1 8 2 9}$ with unusual care, and was fortunate in being able to entrust his publication to the competent hands of John George Children, of the British Museum. This was to be actually his third voyage to the United States, but it was the first which he made from English soil, and after he had become known as an ornithologist and animal painter. He wished to renew at least fifty of his earlier drawings and to obtain new materials of every description. Although he was naturally anxious to see his wife, from whom he had been absent for nearly three years, and his boys, the elder of whom had been left at Shippingport five years before, he felt constrained to devote to his work every moment that could be spared.

When writing to his wife of his difficulties and prospects at this period, he assured her that he would act cautiously, with all due diligence and sobriety, and continued:

Thou art quite comfortable in Louisiana, I know; therefore wait there with a little patience. I hope the end of this year will see me under headway sufficient to have thee with 


\section{TO AMERICA IN SEARCH OF BIRDS 421}

me in comfort here, and I need not tell thee I long for thee every hour I am absent from thee. If I fail, America will still be my country, and thou, I will still feel, my friend. I will return to both and forget forever the troubles and expenses I have had; when walking together, arm in arm, we can see our sons before us, and listen to the mellow sounding thrush, so plentiful in our woods of magnolia. ${ }^{1}$

A little later in $\mathbf{1 8 2 9}$ he also wrote: "I have finished the two first years of publication, the two most difficult to be encountered." At that time he fully expected that fourteen years would be required for the completion of his task, owing to the many difficulties experienced, especially in securing competent workmen, as well as the necessity of distributing the expense for the benefit of his subscribers.

When Havell had been provided with all the drawings needed for the remainder of the year 1829 and the first issue of 1830, Audubon sailed from Portsmouth on the 1st of April, 1829, in the packet ship Columbia, which reached New York on the opening day of May. "I chose the ship," he said, "on account of her name, and paid thirty pounds for my passage."

He paused in New York to exhibit his drawings at the Lyceum of Natural History, of which he had become a member in 1824, but soon hurried to Philadelphia, and finally settled down for work at Camden, in New Jersey, later known to fame as the home of "the good gray poet." There, at a boarding house kept by a Mr. Armstrong, he remained three weeks, from about May 23 to June 13, hunting and painting every day. From Camden he went to Great Egg Harbor, then a famous resort of both land and water birds in great variety, and for three weeks more he lived and

${ }^{1}$ Mary F. Bradford, Audubon (Bibl. No. 85). 
worked in a fisherman's cabin by the sea. It is interesting to recall that Alexander Wilson, in company with George Ord, had spent a month at this point in the spring of 1813.

The following letter ${ }^{2}$ from Swainson was probably the one to which Audubon replied from New Jersey on September 14:

\section{William Swainson to Audubon}

My dear Mr. Audubon

I welcomed the news of your arrival in America yesterday, and as I am making up a packet for Liverpool today, I seize the opportunity of wishing you joy and happiness in the new world. I am surprised and disappointed as not receiving one line from Ward it is at the best negligent, and somewhat ungrateful. Hope you have begun your studies among the birds on a better plan than formerly, that is, in preserving the skins of every one on which there is the least doubt whether the bird is young or old, particularly the former. If you are to give scientific descriptions and definitions of the species this precaution is absolutely necessary. What your Americans do with their money I know not, Mr. Lea tells me he cannot procure one purchaser for my new Illustrations: here it is now going on very well.

You asked me what you can do for me in America. I will tell you. Send me a cart load of shells from the Ohio, or from any of the Rivers near New Orleans. The very smallest, as well as the very largest-all sizes. I have been long expecting those which your son promised you for me near twelve months ago! but I have heard nothing of them! you may spend a few dollars for me and send people to fish the shells at the dry season, when the waters are low, that is the best time.

Things go on here much as usual, but $I$ have not been in London since Xmas. The first volume, containing the Quad-

${ }^{2}$ Published originally by Ruthven Deane (Bibl. No. 218), The $A u k$, vol. xxii, 1905. 


\section{TO AMERICA IN SEARCH OF BIRDS}

rupeds, of Dr. Richardson's work, is out. I am now busy in preparing the second, which contains the Birds. Let me particularly direct your attention to the manners of the Cedar Bird, Ampelis Americana. I suspect it feeds much on Insects in default of fruit, but what is desirable, is to know the way in which it captures Insects, whether as a flycatcher ie. by seizing them on the wing, or like the Gold crest-by picking them up among the branches or leaves. I am now in close correspondance with Charles Bonaparte, \& a most valuble correspondant he is.

Mrs. Swainson is just recovering from her confinement after giving me another little son I am happy today they are both going on well.

Wilson I believe mentions two birds very like the Red eyed Flycatcher, this is a point deserving your attention, but the manners of these birds are much more important. I feel convinced there are several species of my Genus Ammodramus shore finch, in the So. States, they all have narrow pointed tails, like the seasidefinch of Wilson. I further suspect there is more than one species confounded with the Towee Buntling.

I hope soon again to hear more fully from you, and of your ornithological acquisitions. The dear little ones are quite well.

Yours very sincerely,

WM. Swainson

The Grees 26 June 1829.

Mr. John J. Audubon

care of

Mess. Thomas E. Walker \& Co.

Merchants.

New York [Philadelphia]

On the 4th of July Audubon returned to Philadelphia and prepared for a longer sojourn in the Great Pine Forest, or Great Pine Swamp, as it was sometimes called, in Northumberland County, Pennsylvania. In 
this letter to his son we shall find an account of his plans and accomplishments:

\author{
Audubon to his son, Victor
}

Piniladelphia, July 5 th., 1829.

My dear Victor:-

I have been in America two months this day, and not a word from you have $\mathbf{I}$ had in answer to my several letters, dated New York, and at this place. I am also without answer from your Mama, but do not feel so surprised as I know that about 2 months is the time necessary to have a return from Louisiana.

I have come to take your Mama over to England, if her wish inclines her to do so, and have wrote fully to her, giving her all the particulars respecting my situation that I thought could possibly be trusted to a letter.

I have also come to America to redraw some of my earliest productions, and am now closely engaged at this. I remained near this city for 3 weeks, and since have spent 3 more at Great Egg Harbour, from which place I returned yesterday. I have already 13 drawings by me. I have letters from London, up to 30 th. April, when all my business was going $n n$ well with an increase of 4 subscribers. I have no news to transmit; on the contrary, I was in hopes that ere this I should have had at least one long letter from you. I beg you will write me when you last heard from your Mama. Direct your letter to the care of Messrs Thos. E. Walker, \& Co, merchants here, who know all my movements, and will see anything forwarded to wherever I may choose to go to.

I hope your uncle Berthoud \& family are all well; present them my best regards, and to all others who may feel interested in my welfare, and believe me

$$
\text { your affectionate father, }
$$

John J. AUdubon.

I have bought a good gold time-keeper, intended for you, and a copy bound, of my work, and wish to know how it can be forwarded. God bless you. 


\section{TO AMERICA IN SEARCH OF BIRDS}

After outfitting himself in Philadelphia, Audubon proceeded to Mauch Chunk; his provisions for this journey to the forest consisted of a "wooden box containing a small stock of linin, drawing-paper, my journal, colors and pencils, together with twenty pounds of shot, several flints, a due quantum of cash, my gun "Tear Jacket,' and a heart as true to nature as ever." From Mauch Chunk he traveled fifteen miles into the heart of the wooded hills, and was received into the family of Jedediah Irish, lumberman and philosopher, whose praise was celebrated in a later "Episode." ${ }_{3}$ "What pleasure," said the naturalist, "I had in listening to him, as he read his favourite poems of Burns, while my pencil was occupied in smoothing and softening the drawing of the bird before me. Was this not enough to recall to my mind the early impressions that had been made upon it by the description of the golden age, which I here found realized?"

During his stay in the forest Audubon paid particular attention to the smaller land birds, such as finches, warblers and flycatchers, and many of the original drawings which were made in the summer of 1829 still bear his penciled designations of time and place.

${ }^{3}$ See "The Great Pine Swamp," and "Great Egg Harbour," Ornithological Biography (Bibl. No. 2), vol. i, p. 52, and vol. iii, p. 606 .

${ }^{4}$ Though the year is not usually indicated on the originals, the following drawings probably belong to this period:

Black Poll Warbler, New Jersey, May.

Wood Pewee Flycatcher, New Jersey, May.

Small Green-crested Flycatcher, New Jersey, May.

Golden-crowned Thrush, New Jersey, May.

Warbling Flycatcher, Vireo gilvus, New Jersey, May 23.

Yellow-breasted Chat, New Jersey, June 7.

Sea Side Finch, Great Egg Harbour, June 14.

Marsh Wren, New Jersey, June 22.

Bay-winged Bunting, Great Egg Harbour, June 26.

Canada Flycatcher, Great Pine Swamp, August 1.

Pine Swamp Warbler, Great Pine Swamp, August 11.

Black and Yellow Warbler, Great Pine Swamp, August 12. 
About ten weeks ${ }^{5}$ were spent in the woods, from late July until the 10th of October, when the naturalist returned to Philadelphia and settled again for a time in Camden. At this period he was enjoying the best of health and spirits, and he worked during the entire season under the highest pressure of which he was capable. At Camden, October 11. 1829, he wrote:

I am at work, and have done much, but I wish I had eight pairs of hands, and another body to shoot the specimens, still I am delighted at what I have accumulated in drawings this season. Forty-two drawings in four months, eleven large, eleven middle size, and twenty-two small, comprising ninetyfive birds, from Eagles downwards, with plants, nests, flowers, and sixty kinds of eggs. ${ }^{6}$ I live alone, see scarcely any one, besides those belonging to the house where I lodge. I rise long before day, and work till night-fall, when I take a walk, and to bed.

At about the middle of October Audubon set out to join his family in the South. Crossing the mountains by mail-coach to Pittsburgh, where he met his former partner in business, Thomas Pears (see p. 254), he descended once more his favorite river, the Ohio. It was no longer necessary to rough it on a flatboat or to sleep on a steamer's deck; it was to be "poor Audubon" no longer. To be sure, he was not rich, but he had made his way and his mark, and the attention which he now

Hemlock Warbler, Great Pine Swamp, August 12.

Autumnal Warbler, Great Pine Swamp, August 20.

Connecticut Warbler, New Jersey, September 22.

Mottled Owl, New Jersey, October.

s Though Audubon said that he spent only six weeks in the forest, the indications upon his drawings imply a longer period.

- At this time Audubon intended to figure, in full size and natural colors, the eggs of the "Birds of America," for which the concluding numbers of his plates had been reserved, but when the time came, these numbers had to be given over to new acquisitions, so the eggs were eventually crowded out. 


\section{TO AMERICA IN SEARCH OF BIRDS}

began to receive when traveling in his adopted land must have gratified his heart. He paused at Louisville to visit his two boys, the elder of whom, Victor, was then a clerk in the office of his uncle, William G. Bakewell, while John was with another uncle, Nicholas A. Berthoud. Hastening on he reached Bayou Sara on November 17, where he finally joined his wife, who was living at the home of William Garrett Johnson, in West Feliciana Parish, near Wakefield. Some account of this journey is given in the following letter, ${ }^{7}$ written on the eighteenth to Dr. Richard Harlan; in the postscript Audubon gives the first reference to a new hawk which he proposed to name after his friend, and which has given no little trouble to ornithologists ever since: ${ }^{8}$

Audubon to Dr. Richard Harlan

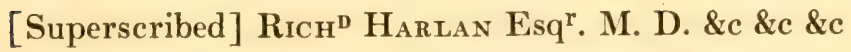
Philadelphia Pens ${ }^{\mathrm{a}}$

St Francisville Louisiana Novembr $18^{\text {th }}$ 1829-

\section{My Dear Friend.-}

You will see by the data of this the rapidity with which $\mathrm{I}$ have crossed two thirds of the United States. I had the happiness of pressing my beloved wife to my breast Yesterday morning; saw my two sons at Louisville and all is well.- - from Philadelphia to Pittsburgh I found the Roads, the Coaches, horses Drivers and Inns all much improved and yet needing a great deal to make the traveller quite comfortable-The slownesse of the stages is yet a great bore to a man in a hurry-I remained part of a day at Pittsburgh where of course I paid my respects to the Iuseum! I was glad to see the germ of

${ }^{7}$ At one time in possession of Dr. R. W. Shufeldt, who received it from Mrs. Audubon; given verbatim by Elliott Coues (Bibl. No. 43), Bulletin of the Nuttall Ornithological Club, vol. v, 1880.

${ }^{8}$ Harlan's Hawk, or the Black Warrior, is now regarded as a southern variety of the Red-tailed Hawk, and is designated under the trinomen, Bueto borealis harlani. 
one- it is conducted by a very young man named Lambdin--I made an arrangement with him [place of seal-paper gone] $\&^{c} \&^{c}$. $\&^{c}$ at Cincinnati I also visited the Museum [paper gone] it scarsely improves since my last view of it, except indeed by wax figures and such other shows as are best suitable to make money and the least so to improve the mind.-I could not see D [illegible] my time was very limited.-The Ohio was in good order for Navigation and I reached Louisville distant from you about 1,000 Miles in one week.=as you spoke of travelling westwardly I give you here an a/c of the Fare-to Pittsburgh all included 21\$.- to Louisville 12\$.- and $25 \$$ more to Bayou Sarah where I Landed. $30 \$$ is the price from Louisville to $\mathrm{N}$. Orleans.=our Steam Boats are commodious and go well-but my Dear Friend the most extraordinary change has taken place in appearance as I have proceeded.The foliage had nearly left the Trees in Pensylvania, the Swallows had long since disapeared severe frost indeed had rendered Nature gloomy and uninteresting-Judge of the contrast: I am now surrounded by Green Trees and Swallows gambole around the house as in Pensylvania during June \& July=The mock bird is heard to sing and during a Walk with my Wife yesterday I collected some 20 or 30 Insects = that is not all, a friend of mine here says that he has discovered 2 or 3 New Birds! ! - new Birds are new birds our days, and I shall endeavour to shew you the Facts Simile when again I shall have the pleasure of shaking your hand--

although so lately arrived, I have established the fact that $M^{r s}$ A. and myself will be on our way towards "Old England" by the $15^{\text {th }}$ of Jan.y. we will ascend the Mississipi and after resting ourselves at Louisville with our sons and other relatives about one month and then proceed with the Rapidity of the Wild Pigeon should God grant our wishes!-

have you seen or heard any thing of Ward?-have you the little sketch of Dear?=we had a passenger on Board the Huntress named Potts from your City who knows you well a lively young Gentleman; has a Brother (a Clergyman) established and married at Natchez.- 


\section{TO AMERICA IN SEARCH OF BIRDS 429}

I will begin Drawing next week having much scratching with the Pen to perform this one, and $I$ am also desirous to make [paper gone] Large Shipment of aborigines both animal and vegetal as soon as possible.-Turkeys, Aligators, Oppossums, Paroekett, and plants, as Bignonias \&c \&c \&c. will be removed to the Zoological Gardens of London, from the Natural ones of this Magnificent Louisiana!-meantimes I will not forget my Friends in Phil ${ }^{a}$. no I would rather forgive all, to all my Ennemies there--assure Dr Hammersley that Ivory Billed and Peleated Woodpeckers will be skinned, and who knows but I may find something more for him. I I will give free leave to Dr. Pickering to chuse amongst the Insects and who knows but I may find something new for him. remember me most kindly to both, nay not in the common manner of saying " $\mathrm{Mr}$ Audubon begs to be remembered" no not [at] all. This way $\mathbf{M}^{\mathrm{r}} \mathrm{A}$ remembers you and you and $I$ will remember you and you and $I$ always!!-

May I also beg to be remembered in humble words to a fine pair of Eyes; divided, not by the Allegany Mountains; but by a nose evidently imported from far East, to a placid forehead, to a mouth speaking happiness to - [dash nearly across page.]

Should you see Friend Sully remember me to him also-and

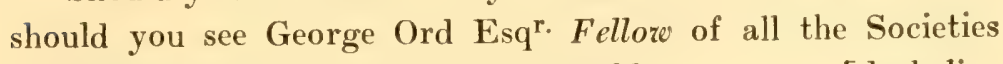
Imaginable present him my most humble — [dash line more than across the page.]

Should you see that good woman where I boarded at Camd'den tell her that I am well and thankful to her for her attentions to me.-

I cannot hope the pleasure of an answer from you here but you may do so, and I say pray do so, directed to the care of N. Berthoud Esq ${ }^{\mathrm{r}}$ Louisville Kentucky.-by the bye my sons are taller than me, the eldest one so much altered that I did not know him at first sight, and yet I have Eyes-

God bless You, Your Friend

John J. Audunon. 
[The following is written across the first page:]

I reopened my letter to say that I have Just now killed a Large New Falcon yes positively a new Species of Hawk almost black about 25 Inches Long and 4 feet broad tail square Eye yellowish White, Legs and Feet bare short \& strong._I will skin it!!!-

remember me to Lehman-

What I have said about the Hawk to You must be Lawful to Academicians and you will please announce Falco Harlanii by

John J. Auduron

$$
\text { F. L. S. L. }
$$

The following extracts are from a letter ${ }^{9}$ written by Swainson, January 30, 1830, and sent to Havell in London to be readdressed:

\section{William Srainson to Audubon}

I know not in what part of the Wilds of America you may now be wandering, but I hope you are fully intent upon your great object, and that you are not only making drawings, and taking notes, but preserving Skins, of all your little favorites. Don't forget the Shrikes, of which I have strong suspicions there are 2 or 3 species mixed up with the name of Loggerhead. Should you be in the land of the Scarlet Ibis, do pray procure a dozen or two of the best skins, they are the most magnificent birds of No. America, and are said to be common towards New Orleans.

You will learn frm the Newspapers how uncommonly severe is our winter the snow has now been upon the ground five weeks and it is still falling. I manage, however, to walk out every day, and thus have acquired better health than $I$ have enjoyed for many years.

Previous to your embarking to England, which I hope you will do very early in the spring you must do me one favor. 1905.

${ }^{9}$ Published by Ruthven Deane (Bibl. No. 217), The $A u k$, vol. xxii, 


\section{TO AMERICA IN SEARCH OF BIRDS 431}

Bring me two Grey Squirrels alive, and a cage full of little birds, either the painted or non-Pareil finch the Blue finch, or the Virginian Nightingale, as they are called, 3 or 4 of each to guard against casualties by death on the voyage. I do not care one farthing whether they sing or not, so that I presume they may be got for a mere trifle. The Squirrels would delight the little people beyond measure, and would prove a neverfailing source of amusement to them. I believe you have other kinds than the grey, so that any will do. If you cannot get them pray supply their place by two Parrots of America.

We continue pretty well at the Green. Seldom go to town, but I find people begin to discover the true character of $\mathrm{V}$ [igors]. and many that were formerly his friends now speak very differently of him. His father having died the property has come to him. He has now taken a fine house in the Regents park, and holds conversaziones (in humble imitation of those of the President of the Royal Society) every Sunday evening during the season!! all this is very grand, and he appears to have abandoned writing any more papers on ornithology, since I have begun to point out his errors.

Ward wrote to me since my last, he is a poor weak fellow, with a good natural disposition, but so little to be depended upon, that he is turned round by every feather, after inserting that he could not go on "in my service" as he called it, under ten dollars a week, he now says he should be most happy to receive four. He says not a word of his marriage, which proves his wish to decive one. I have done with him.... I hope you have got me lots of River shells.

About the beginning of the year 1827 Mrs. Audubon gave up her "Beechwoods" school, and thereafter took a position as governess in the home of Mr. William Garrett Johnson, whose plantation, called "Beechgrove," was situated in the same parish. An anonymous writer thus referred to this house in 1851: ${ }^{10}$ 1851.

${ }^{10}$ Thomas B. Thorpe (Bibl. No. 64), Godey's Lady's Book, vol. xlii, 
In the hospitable mansion of W. G. J-_, in the parish of West Feliciana, if one will look into the parlor, they will see over the piano a cabinet sized portrait, remarkable for a bright eye and intellectual look. The style of it is free, and there is an individuality about the whole that gives assurance of a strong likeness. Opposite hangs a proof impression of the bird of Washington, a tribute of a grateful heart to an old friend. The first is a portrait of Audubon painted by himself ; the other is one of the first [of his] engravings that ever reached the United States.

There Audubon spent nearly two months at the close of 1829, and followed his usual occupations of hunting and drawing, while his wife prepared for their contemplated journey to Europe. He is said to have drawn at this time the "Black Vulture attacking a herd of Deer," several large hawks, squirrels, and heads of deer which were never finished.

Although Audubon's business affairs in England had been left in charge of his trustworthy friend, John G. Children, his engraver, Havell, had become alarmed at the loss of subscribers and the failure of certain of their agents, and particularly M. Pitois of Paris, ${ }^{11}$ to render due returns. Havell, as it proved, was unduly disturbed, but his gloomy accounts tended to hasten the naturalist's departure, a circumstance that was later deplored. These matters are clearly reflected in the following letter written from the Johnson home in Louisiana when the Audubons were preparing to leave it; particularly interesting are the included statements

${ }^{11}$ While in Paris in 1828, Audubon wrote on October 26 that he had received a call from "a M. Pitois, who came to look at my book, with a view to becoming my agent here; Baron Cuvier recommended him strongly, and I have concluded a bargain with him. He thinks he can procure a good number of subscribers. His manners are plain, and I hope he will prove an honest man." See Maria R. Audubon, Audubon and his Journals (Bibl. No. 86), vol. i, p. 339. 


\section{TO AMERICA IN SEARCH OF BIRDS}

through which it was hoped that a competent successor might be secured for the duties of the position which Mrs. Audubon had so ably filled:

\section{Audubon to Robert Havell}

Beech Grove, Louisiana

Decr 16th 1829

\section{My Dear Mr Havell. -}

I received yesterday from New York your letter of the 29th. Sept. which must have reached Philadelphia 3 days after my departure for home=

I am sorry that Bartley should have made you suffer a moment by sending you the intelligence of the failure of the several subscribers you mention in your favor-it cannot be helped-there is none of your fault and $I$ must repair these matters when $I$ reach England again $=$

I am considerably more sorry and much vexed that Sowler should have failed in his witten promise to accept your Dfts.even in a case of the diminution of subscribers he could certainly have sent you a progressional amount-I am now almost sure that Pitois has failed or acted the Rogue=

We are making all preparations in our power to leave Louisiana on the 5 or 10 th. of Jan.y and we will proceed as fast as Steam Boats, Coaches and the weather will admit of and we will sail for England from New York with all possible dispatch. I have made a shipment of Forest trees to England that I hope will turn to good account as they are to be presents to Public Institutions \&c and that I think it necessary to be remembered myself.-

We are both well-our sons are at Louisville, Kentucky where we will see them about the 20th. of next month.-I sent you in my letter a proposal for your sister and should you not have received it I send it you again here in Mrs A.'s. hand writing. -I would advise your sister to come if the money is an object.-I think that besides she will be comfortable with the familly Johnson-if she thinks fit to wait untill we see her, we can tell her all about it. $=$ 
I have received only one letter from friend Children during all this absence against my very many-

I hope the insects I sent him by the Annibal have reached safely. - have no news to give you-Keep up a good heart-we will be in London as soon as possible.- I have not had a letter from Miss Hudson for a long time-I hope her mother \& her are well-Remember me kindly to your Dear Wife and Little ones-Mrs Audubon joins me in all good wishes-If you see Parker my remembrances to him=I will carry with me some Drawings that I know will make the graver and the Acid Grin again.-

\section{Believe me your friend-}

John J. Audubon.

When you present my sincere regards to friend Swanson [Swainson] tell him that I have had only one letter from him and that I am now quite unable to say where Mr Ward is = I had a letter from Henry Havell ${ }^{12}$ the other day merely acknowledging the money I have paid him-he was in New York, I hope quite well-

\section{[Enclosure]}

A friend of ours here named Wm. Garrett Johnson (a cotton planter) a gentleman who resides in a perfectly healthy and agreeable part of the country, desires that I should write to England to procure for him a Governess, one who can teach music, drawing and the usual branches of education to young Ladies. Mr. Johnson will pay the sum of one thousand dollars per annum, board, lodging \&c, also and considered in all respects as a member of the family, to any lady who will undertake occupation (the sum is about $230 \mathfrak{f}$ ) the governess will have to instruct ten or twelve young persons of various ages, and may make the arrangement for five years if desirous of it. I have thought this would suit your sister precisely, and for my part knowing the family Johnson as I do I should think it an excellent thing for her. if not I will look for some one when

${ }^{12}$ Henry Augustus Havell, a younger brother of Robert Havell, Junior; see Vol. II, p. 191. 
I am in England, Sailing from England direct for New Orleans, steam Boats reach the place of Mr Johnson in two days. I)uplicate.

I, Wm. Garrett Johnson do authorize my friend J. J. Audubon to make the above proposition and do by these present obligate myself to comply with them punctually and particularly. Wa. Garrett Johnson.

[Addressed]

Mr $\operatorname{RoB}^{\mathrm{T}}$ Havell $\mathrm{JU}_{\mathrm{U}^{\mathrm{R}}}$

Engraver

79 Newman Street

Oxford Street

London

England

"On January 1, 1830," said the naturalist, "we started for New Orleans, taking with us the only three servants yet belonging to us, namely, Cecilia, and her two sons, Reuben and Lewis. We stayed a few days at our friend Mr. Brand's, with whom we left our servants, and on the seventh of January took passage on the splendid steamer Philadelphia for Louisville, paying sixty dollars fare." ${ }^{13}$ After a long visit with their sons, on the seventh of March they ascended the Ohio to Cincinnati, and at Wheeling took the mail-coach to Washington. At the national capital Audubon met the President, Andrew Jackson, and was befriended by Edward Everett, at that time a leader in the House of Representatives. "Congress," said the naturalist, "was then in session, and I exhibited my drawings to the House of Representatives, and received their subscription as a body." He also recorded that he obtained three subscribers in Baltimore, and left for Philadel-

13 See Lucy B. Audubon, ed., Life of John James Audubon, the Naturalist (Bibl. No. 73), p. 203. 
phia, where they remained a week. The following note, which Edward Everett gave Audubon for New York, is particularly interesting, since it expressly states that at that time the ornithologist had not received a single subscriber in the United States:

\section{Edward Everett to Dr. Wainwright}

WashingtoN 18 March 1830

My dear Sir,

Allow me to introduce to your acquaintance, the bearer of this letter, Mr. Audubon of Louisiana. His drawings of American Birds, of which he will show you some, will I am sure command your approbation, as they have the applause of Europe.-I am sorry to say, that he has not yet procured a single subscriber, in the United States of America. Will not one of your Institutions in New York-or your wealthy and liberal individuals-take a copy? I pray you endeavor to procure him at least one subscriber, in New York.-

Yours with great regard

E. Everett.

Rev Dr Wainwright

Audubon had evidently reconsidered his expressed intention of presenting a copy ${ }^{14}$ to Congress, and to Edward Everett belongs the credit of subscribing to The Birds of America in behalf of the Congressional Library. At about this time also he obtained another subscriber at Washington, in the person of Baron Krudener, the Russian envoy, but later experienced difficulty in collecting his dues. ${ }^{15}$

${ }^{14}$ See Vol. I, p. 396.

${ }^{15}$ See Vol. II, p. 38. 


\section{CHAPTER XXV}

\section{AUDUBON'S LETTERPRESS AND ITS RIVALS}

Settlement in London-Starts on canvassing tour with his wife-Change of plans-In Edinburgh-Discovery of MacGillivray-His hand in the Ornithological Biography-Rival editions of Wilson and BonaparteBrown's extraordinary atlas-Reception of the Biography-Joseph Bartholomew Kidd and the Ornithological Gallery-In London again.

On the 1st of April, 1830, Audubon and his wife sailed from New York in the packet ship Pacific, bound for Liverpool, where they landed after a voyage of twenty-five days. Upon returning to London the naturalist found that upon the 18th of the preceding March he had been elected to membership in the Royal Society, an honor for which he felt indebted to Lord Stanley and his friend Children, of the British Museum; after paying the entrance fee of $£ 50$, he took his seat in that body on the 6th of May. The painting of pictures was at once resumed to meet his heavy expenses, but towards the end of July he started with Mrs. Audubon on a canvassing tour, in the course of which his plans suddenly were changed so that London did not see him again for nearly a year. ${ }^{1}$ On this journey they touched at Birmingham, Manchester, Leeds, York, Hull, Scarborough, Whitby, New Castle, and Belford, to visit the Selbys, and on the 13th of October reached Edinburgh, where they were soon comfortably settled in the naturalist's old lodging place, the house of Mrs. Dickey, Number 26, George Street.

${ }^{1} \mathrm{His}$ correspondence with William Swainson from this point, and the history of his letterpress so far as that naturalist was concerned, will be unfolded later (see Chapter XXIX). 
Audubon was now ready to begin the text of his Birds of America, to be called Ornithological Biography, which is often referred to as his "Biography of Birds." 'This work, which was eventually extended to five large volumes of over three thousand pages, was published at Edinburgh from 1831 to 1839 . He had made crude beginnings with this in view as early as 1821, and on October 16, 1830, he wrote: "I know that I am not a scholar ..." but, "with the assistance of my old journals and memorandum-books, which were written on the spot, I can at least put down plain truths, which may be useful, and perhaps interesting, so I shall set to at once. I cannot, however, give scientific descriptions, and here must have assistance." To supply this need, as we have seen already, he had earlier applied to William Swainson, but the negotiations with that naturalist were soon broken off, and led to a sharp and acrid discussion upon the authorship of the work itself. ${ }^{2}$

By a rare stroke of genius or good fortune, Audubon chose for his assistant a young Scotch naturalist, William MacGillivray, who had been introduced to him by another naturalist, James Wilson, soon after he reached the Scottish capital. MacGillivray agreed "to revise and correct" his manuscript at the rate of two guineas per sheet of sixteen pages, and in the latter part of October, 1830, they set to work. We shall soon have occasion to speak more fully of his debt to this estimable Scotchman, ${ }^{3}$ and will only add here that a better trained or more competent helper than MacGillivray could hardly have been found in Great Britain or elsewhere.

${ }^{2}$ See Chapter XXVIII, p. 87.

${ }^{3}$ See Chapter XXX. 


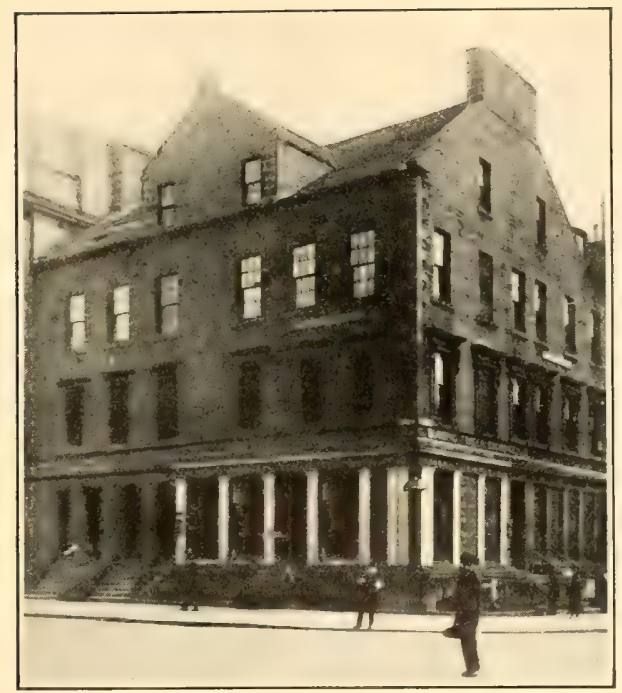

MRS, DICKIE'S "BOARDING RESIUENCE," 26 GEORGE STREET, EUINBCRGH, WHERE AUDUBON OCCUPIED APARTMENTS AND PAINTED AND WROTE IN 18:6-27 AND 1830-31. A LARGE PUBLIC BUILDING NOW OCCUPIES THE SITE.

After a photograph in possession of Mr. Ruthven Deane.

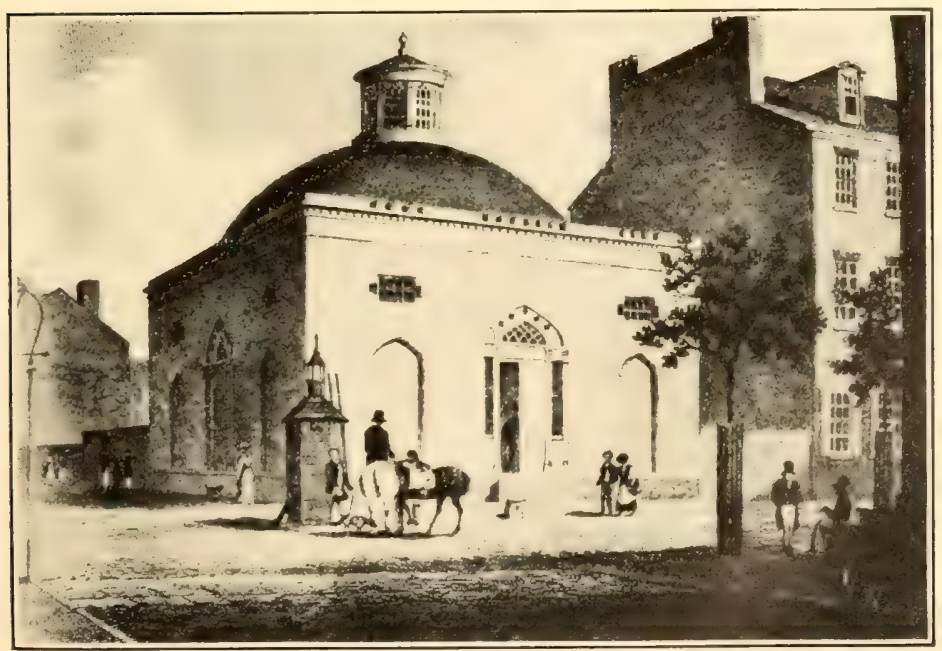

THE ACADEMY OF NATURAL SCIENCES OF PHILADELPHA.

After an old print; reproduced from Cassinia for 1910. 

No sooner had Audubon begun to write than it was learned that "no less than three editions of 'Wilson's Ornithology' were about to be published, one by Jameson, one by Sir W. Jardine, and another by a Mr. Brown." The outlook could not be considered encouraging, but this intelligence only nerved him to greater effort, and he was determined to push his own publication with such unremitting vigor as to anticipate them all. "Since I have been in England," he wrote in his journal, "I have studied the character of Englishmen as carefully as I have studied the birds in America, and I know full well that in England novelty is always in demand, and that if a thing is well known it will not receive much support." Audubon worked continuously at his Biography, rising before the dawn and writing all day, while the able worker at his side carried his efforts far into the night, and in three months the first volume was ready for the printer; Mrs. Audubon meanwhile copied their entire manuscript to be sent to the United States in order to secure the American copyright. When this work was offered to the publishers at Edinburgh, however, not one of them, said the naturalist, would offer a shilling for it, but this did not deter him from publishing it at once and at his own expense. ${ }^{4}$ On March 13, 1831, he wrote: "The printing will be completed in a few days, and I have sent copies of the sheets to Dr. Harlan, and Mr. McMurtie, at Philadelphia, and also one hundred pounds sterling to Messrs. T. Walker \& Sons, to be paid to Dr. Harlan to secure the copyright, and have the book published there."

${ }^{4}$ The first volume of the Ornithological Biography in the European edition bears the imprint of "Adam Black, 55 North Bridge, Edinburgh;" in the four subsequent volumes this was changed to "Adam and Charles Black," while the entire work was printed by "Neill \& Co., Printers, Old Fish Market, Edinburgh." See Bibliography, No. 2. 
The following friendly letter from one of Wilson's editors belongs to this period:

\title{
Sir William Jardine to Audubon
}

\author{
Jardine Hall $3 d$ Decr. 1830 -
}

MY deAr Sir,

I only learnt a few days since that you were to winter in Edinburgh, and perhaps since you are not Hurried for time in Trovelly [?] will come out to spend a day or two with me-If you can come out before the 10 th. when I shall have the pleasure of shewing you some Blackgame Shooting- The season expires on the Tenth of the Month partridges have bred so ill that there is scarsely any in the whole country, and pheasants have been so lately introduced that they are yet rather scarce- In a wet day you may have your easel \& brushes I should wish much to hear your account of Wilson during the times you hunted with him-and also some account of the New Species you figure in the american Ornithology-

I am happy to learn you intend figuring the learned Men of America as accompanyment to your work particularly the ornithologists, do you know the painter of the portrait of Wilson- I have three portraits of him in the House, and also a profile taken by the machine I should like to have your opinion of them one of the portraits was painted from an original that went to America-

I shall expect to hear you are coming soon-Mr Lizars will tell you about coaches- \&c

With best regards believe me

Sincerely yours

WM J ARDINE

[Addressed] J. Audubon Esqr

$$
\begin{gathered}
\text { Care of W. H. Lizars Esqr } \\
3 \text { James Square } \\
\text { Edinburgh. }
\end{gathered}
$$

Audubon was not outstripped by his Edinburgh rivals, who to all appearances had planned to cover the 


\title{
Hilliam Mackillivay. ORNITHOLOGICAL BIOGRAPHY,
}

OR AN ACCUUN'T OF THE. HABI'S OF TIRE:

\section{BIRDS OF 'THE UNITED STATES OF AMERICA :}

ACCOMPANIBD BY DKSCIIITIONS OF 'THF ODJECTS RHPRESENTEI

IN THE WOIK H:NTITLED

\section{THE BIRDS OF AMERICA,}

AND INTERSPERSED WITII DELINHATIONS OF AMIFRICAN

SCENERY AND MIANNBIRS.

BY JOHN JAMES AUDUBON, 1..R.SS.L\& E.

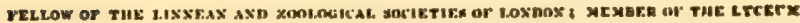
AXD LIXXEAX GXIETY OF XI: YORX, OP THE XATCM.L. HETTEY WOCIETY OP PARIS TUE

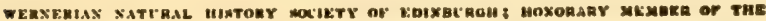

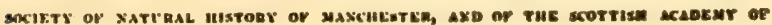
PAIXтIXG, ARCUITXCTERK, AKB ECTLPTIRK, AR.
\end{abstract}

\section{EDINBURGH :}

ADAM BLACK, 55. NORTH BRIDGF, EDINBURGH:

2. HAVELL JUN, ENGRAVEK, 77. OXFORD STREET, ANI) LONGMAN, REES, BROWN, \& GREEN, LONDON, GEOHGE SMITH, TITHFHAHR STREET, LIVEHPOOL; T. SOWLER, MANCHESTKR, MRS ROBINSON, LEEUS; E. CHARNLEY, NEWCAYTLE; POOL \& BOOTH, CHESTLR; $\triangle N D$ BEILUY, KNOTT, \& BEILDY, BLMUNGHAN.

\section{$\operatorname{MDCCCXXXI.}$}

TITLE PAGE OF VOLUME I OF THE "OR NITHOLOGICAL BIOGRAPITY."

From a copy presented by Audubon to William MacGillivray and bearing the latter's signature. 
field of American ornithology so thoroughly as to render his work a drug on the market, if not to make it superfluous. Whether this were really true or not, there is no doubt that Audubon's activity furnished the stimulus to the sudden appreciation of the work of his predecessor that was manifested in Edinburgh at this very moment of time. It will be interesting to see just what these rival enterprises were. Professor Jameson, who had been of great service to Audubon at the beginning of his undertaking, prepared a pocket edition of Wilson's and Bonaparte's Ornithology, with miniature plates which were issued separately, and the two works, which were intended to go together, were published in 1831. ${ }^{5}$ Sir William Jardine brought out an edition of Wilson's and Bonaparte's work, in three large volumes, with plates engraved by W. H. Lizars after the originals and carefully colored by hand. ${ }^{6}$ This was thor-

"American Ornithology, or the Natural History of the Birds of the United States. By Alexander Wilson and Charles Lucien Bonaparte. Edited by Robert Jameson ... Regius Professor of Natural History in the University of Edinburgh. Appearing as vols. Ixviii-lxxi of Constable's Miscellany, 4 vols., 18mo., Edinburgh and London, 1831. This was the fourth (?) edition of Wilson's work, and the first (?) to appear in Europe; with portrait of Wilson and vignettes on titles engraved by Lizars, memoir of Wilson by W. M. Hetherington, and extracts from Audubon, Richardson, and Swainson.

The plates of this edition were issued in numbers, under title of Illustrations of American Ornithology; reduced from the work of Wilson; 18mo., Edinburgh and London (1831). In a notice of the first number which appeared in the Caledonian Mercury (Edinburgh) for Oct. 29, 1831, it was stated that the plates were issued in small size to be bound up with Jameson's edition of the text, and that they were intended "for a different class of purchasers from those likely to take the folio edition, then being brought out by the publishers of Constable's Miscellany. The plates were engraved in line and executed in a very superior style, both plain and colored."

"American Ornithology; or Natural History of the Birds of the United States, by Alexander Wilson, with a Continuation by Charles Lucien Bonaparte, Prince of Musignano. The Illustrative Notes and Life of Wilson by Sir William Jardine, 3 vols., 8vo., London and Edinburgh, 1832 .

The second (?) European edition of Wilson and Bonaparte, with $\mathbf{9 7}$ hand-colored plates engraved by Lizars. The Caledonian Mercury in 
oughly legitimate enterprise, but the climax was reached when Captain Thomas Brown began to publish an "Audubonized edition" of Wilson's and Bonaparte's plates, or an attempt to present their plates of American birds in the Audubonian manner, to the extent at least of showing the characteristic flowers, trees, and insects of the American continent, a plan to which some of Audubon's earlier critics in Philadelphia had offered strenuous objection. Brown's large atlas of plates ${ }^{7}$ was

noticing the work, October 29, 1831, said: "It must be highly gratifying to the friends and connections of poor Sandy Wilson to see such honor, at last, paid to his memory in his native land."

${ }^{7}$ Illustrations of the American Ornithology of Alexander Wilson and Charles Lucien Bonaparte, Prince of Musignano. With the addition of numerous Recently Discovered Species, and Representations of the Whole Sylva of North America. By Captain Thomas Brown [etc., etc.]. Folio, with engraved title, engraved dedication, index, and 124 engraved and hand-colored plates. Edinburgh, Frazer \& Co., 54 North Bridge, William Curry, Jun'r \& Co., Dublin \& Smith, Elder \& Co., 65 Cornhill, London, MDCCCXXXV.

It is stated by the editor of this extraordinary work that he had added 161 birds, and that 87 have been considerably enlarged. There are 167 representations of American trees and shrubs, said to have been copied for the most part from Michaux' Silva. The striking Hibiscus grandiflorus (plate xli) was taken without acknowledgment from Audubon's drawing of the Blue-winged Warbler (The Birds of America, plate $\mathrm{xx}$ ). For the most part the figures of birds are redrawn from Wilson and Bonaparte and given new positions and backgrounds. A few of the plates, as that of the California Vulture (no. 1), bear the legend, "Drawn by Captn. Tho. Brown;" all are uneven, and many extremely poor in execution, the fourteen by W. H. Lizars being the best. J. B. Kidd, for a time associated with Audubon (see Vol. I, p. 446) is credited with four plates; other engravers employed on the work were James Turvey, who executed the elaborate title, Samuel Milne, James Mayson, R. Scott, J. \& J. Johnstone, E. Mitchell, William Davie, S. A. Miller, John Miller, Audw. Kilgour, Wm. Warwick, and W. McGregor. Plate xiv, the Snowy Owl, Strix nyctea, engraved by the editor, has the interest of a caricature. Some plates show as many as fourteen birds in a medley of brilliant foliage, flowers and fruits. The violence of the coloring is often such as to destroy the effect of the best plates, and gaudy butterflies flit through the pages as if they were the common food of every species, not excluding the American grouse (see Note, Vol. I, p. 359 ).

Captain Brown's Illustrations were said by a writer in the Edinburgh Literary Journal for April 9, 1831, "to form a companion to the letterpress in Constable's Miscellany (see Note, Vol. I, p. 442); price, colored, 15 shillings; plain, 10s. 6d. A few in elephant folio (same size as Selby's British Ornithology); colored, 1 guinea. To be completed in 10 parts, each con- 
issued in parts, from 1831 to 1835 , and was intended as a further companion to Jameson's text for all who could afford that expensive form of illustration. By a curious coincidence Audubon's Ornithological Biography (vol. i), Jameson's edition of Wilson and Bonaparte (vol. i), and Brown's Illustrations (pt. i), were all noticed on the same page of the London Literary Gazette for April 9, 1831. "This day is published," so reads the

taining 5 colored plates; 22 inches long by 17 inches broad, being considered more than double the size of the original work." The first number of this work was reviewed in the London Literary Gazette for October 8, 1831, when it was said that in it were represented 25 birds, 13 forest trees, and 12 insects; the completed work would comprehend "all the forest trees of America, with their fruits, together with the principal insects of the country," as well as all the birds that had been discovered up to the time of issue.

Brown's piratical work must have had a very limited circulation, since it is now so rare that not even the British Museum possesses a copy, and, so far as known, it is not found in any public library of the United States. I was told at Wheldon's, the London shop devoted to works on natural history, that but two copies had ever been handled, and that they commanded a high price. The work was originally sold at £26. The only copy known to me is in the library of the Zoölogical Society in London, from which the present citation is made; on one of its fly-leaves is written this note: "I have seen the wrapper of No. 1 of this work. It is dated 1831. There is no information as to its contents. C. Davis Sanborn. 22.5.05." This copy was referred to by Dr. Theodore Gill; see The Osprey, vol. v, pp. 31 and 109 (Washington, 1900 and 1901). Dr. Walter Faxon has traced two other copies, one formerly in possession of Professor Alfred Newton, and another, but very imperfect set, in a private library at Tarrytown, New York. According to Faxon, a single brown paper wrapper preserved in the Tarrytown copy bears a full printed title, which differs, however, from that which was subsequently engraved for the completed work; for fuller citation, see "A Rare Work on American Ornithology," The A $u k$, vol. xx (1903), pp. 236-241.

Mr. Ruthven Deane has written me that several years ago he secured in New York a fragment of this work, consisting of the paper wrappers of four Parts, Nos. 1-4, the last three of which contained five plates each; there were in addition 10 scattered plates, making 25 plates in all; the price of " 21 Shillings" is printed on each of the wrappers, which also bear the date "1831," but no titles.

Another pirated work, Illustrations of the Genera of Birds, by the same author, was begun in 184.5, but met with even less success, and was never completed; this was taken from $A$ List of the Genera of Birds, published in 1840 by George Robert Gray, and according to Alfred Newton (A Dictionary of Birds, London, 1896, p. 30, note) was "discreditable to all concerned with it." 
advertisement of Audubon's work, "price 25s. in royal octavo, cloth, Ornithological Biography. ..." If the desire of these various editors were to cripple the work of the American naturalist, their efforts were certainly vain, for he was able to make his way against all competitors. Brown's work was a failure, so few copies having been distributed that it is doubtful if more than one ever came to this country, and only one is known to be in possession of any large library in England.

Audubon's initial volume of the Biography was well received and drew forth immediate and unstinted praise from many sources. He was anxious that MacGillivray should contribute some account of it to the London Quarterly Review, then under the editorial management of John Gibson Lockhart, but his suggestion was coldly received and drew forth the following declaration of independence from his able, if as yet undistinguished, coadjutor: ${ }^{8}$

With respect to the review, I can only say that if $\mathrm{Mr}$. Lockhart is so doubtful as to my powers, he may doubt as long as he lists. I shall not submit any essay of mine to his judgment. If you had informed me that he or the conductor of my other review would print a notice of your works, I should have agreed to write one with pleasure, but under existing circumstances I shall not, it being repugnant to my feelings and contrary to my practice and principles to sue for favor with any man. I have already written three reviews of your books which have been printed, and when I am applied to for a fourth I shall write it too, with "an elegance of style, a power of expression, and knowledge of the subject" equal to those usually displayed by the editor of the Quarterly.

${ }^{8}$ See Ruthven Deane (Bibl. No. 209), The $A u k$, vol. xviii (1901). The extract is from a letter dated "Edinburgh, 22 Warriston Crescent 7th May, 1831." 
Some of the criticism, whether friendly or hostile, which this work eventually evoked will be considered in a later chapter.

Shortly after his arrival in London, Audubon received a call from Joseph Bartholomew Kidd, a young artist whom he had met at Edinburgh the previous March, and was attracted so much by his "youth, simplicity and cleverness" that he again invited him to paint in his rooms. On the 31st of March, 1831, an agreement was made with $\mathrm{Kidd}^{9}$ to copy some of his drawings in oils and put in appropriate backgrounds. "It was our intention," said Audubon, "to send them to the exhibition for sale, and to divide the amount between us. He painted eight, and then I proposed, if he would paint the one hundred engravings which comprise my first volume of the Birds of America, I would pay him one hundred pounds." In 1832 Captain Thomas Brown gave this notice of the undertaking in the Caledonian Mercury:

About a year ago Audubon conceived the grand idea of a Natural History Gallery of Paintings, and entered into an agreement with Mr. Kidd to copy all his drawings of the same size, and in oil, leaving to the taste of that excellent artist to add such backgrounds as might give them a more pictorial effect. In the execution of such of these as Mr. Kidd has finished, he has not only preserved all the vivacious character of the originals, but he has greatly heightened their beauty, by the general tone and appropriate feeling which he has preserved and carried throughout his pictures.

Kidd worked intermittently on some such scheme for about three years, and produced numerous pictures

${ }^{9}$ Kidd, who was twenty-three at the time he began to work for Audubon, died in 1889, when he had attained his eighty-first year. 
on canvas or mill-board. He was thus engaged in 1833 when he wrote to ask for an advance of from twelve to fourteen pounds on account of an accident that had befallen him on the 16th of May of that year. Kidd said in his letter that while he was attending a sale of Lord Eldin's pictures, the floor of the building suddenly gave way with a crash and precipitated the whole company, together with the furniture, into a room below; that he had sustained many bruises himself, not to speak of a dislocated arm, but what with blisters, cupping, nurses and remedies of all sorts, he was then slowly mending. Another of their projects was to publish Kidd's copies of Audubon's drawings as individual pieces, and a notice of this appeared in Blackrood's Magazine for 1831. John Wilson, in reviewing Audubon's work in the magazine for that year said: "it is expected that there will be completed by Audubon, Kidd, and others,-Four Hundred Subjects. Audubon purposes opening, on his return [from America], an Ornithological Gallery, of which may the proceeds prove a moderate fortune!" All such plans, however, seem to have been delayed or frustrated, and a misunderstanding with Kidd brought them suddenly to a close in 1833. Audubon's explicit directions under this head were given in a letter to his son Victor, written at Charleston on Christmas Day of that year. ${ }^{10}$

When his letterpress was finished, Audubon left Edinburgh with Mrs. Audubon on April 15, 1831. Newcastle, York, Leeds, and Manchester were again visited, and a pause of several days was made at Liverpool before proceeding to London, when, as the naturalist recorded, they "traveled on that extraordinary road, called the railway, at the rate of 24 miles an hour." In

${ }^{10}$ See Chapter XXVII, p. 62. 
May ${ }^{11}$ they visited Paris, Audubon no doubt wishing to collect the money due from his agent there, as well as to introduce his wife to the unrivaled attractions of the great city. Upon returning to London in July he had the pleasure of again meeting his fidus Achates, Edward Harris, ${ }^{12}$ of Moorestown, New Jersey, and immediately began to put his affairs in order for a long period of absence.

While Audubon was in Paris, the following letter ${ }^{13}$ was written by his staunch friend and supporter in Congress, Edward Everett, who, as has been seen, fully appreciated the national character of his great undertakings. The effort of this able advocate to give The Birds of America free passage to their native land, however, do not appear to have been successful until two years later, as a letter to be quoted in due course clearly indicates.

\section{Edward Everett to Audubon}

Charlestow N, Mass., May 19th, 1831.

MY DEAR SIR

I duly received your favor of the 1st. of Nov. accompanied with some copies of the Prospectus, and a few days since your letter of the 5th. March reached me. I owe you an apology for being so tardy in my reply to the former letter. It reached me at Washington, while I was confined with a severe illness,

${ }^{11}$ An indication of the time of this visit is given by the following inscription written in the copy of the first volume of the Ornithological Biography, which was presented to Cuvier at this time:

To

Baron G. Cuvier,

with the highest respect of the author.-

Paris- 17 th. May, 1831.

${ }^{12}$ On Wednesday evening, July 27, 1831, Audubon sent the following note to Mr. Harris: "Come to meet me tomorrow, precisely at twelve o'clock, at our lodgings, 121 Great Portland street."

${ }^{13}$ For the perusal of this letter the reader is indebted, as in so many other instances, to Mr. Ruthven Deane. 
with which, since Oct. last, I have till lately been much afflicted. I was, most of the session, in such a state of health, as to be kept at my lodgings, and when in my place, in the House of Representatives, little able to attend to business. As soon as I went abroad, after the receipt of your letter, I consulted some of the most influential members of Congress, as to the probability of being able to pass a bill for the free introduction of your work. Last winters session was the short session, terminating by the Constitution on the 3d. of March. At this session, it is always very difficult to pass any bills, originating during the session. The time is regularly taken up by bills, prepared the previous winter. In addition to this circumstance, more than half of the last session was taken up, by an impeachment before the Senate. A procedure, which suspended during its continuance, the legislative business of the two Houses, and left no time for scarce anything, beyond the annual appropriation bills for the support of the government. Under these circumstances, the gentlemen, whom I consulted, were of opinion with me that it was impossible, for want of time, to pass a bill in your favor, and that it was therefor better not to attempt it, at the late session, but to reserve it for next winter, when it can be brought up seasonably, and with good hope of success. I shall take great pleasure to seize the first moment, at the opening of the next session, to bring the subject before Congress.

The portions of your work, which arrived at Washington before I left it, were publicly exhibited in the library, and attracted great attention and unqualified admiration. The same is true of the copy received by the Boston Athenaeum. The plates were specially exhibited in the great hall of the Athenaeum, to the entire satisfaction and delight of those who saw them.

The copy-right law authorizes any citizen of the U. States to take out a copy-right of his work, on depositing a printed copy of the title page in the office of the District Court. I infer from your letter of the 5th. of March, that you had sent copies of the printed sheets of your work to Drs. Harlan and 
M. Mertrie [McMurtie] of Philadelphia with a view of having the copy-right.

I have distributed a part of your prospectuses, and shall do the same with the rest, in the manner that may seem most likely to promote your interest. I regret to say, that I have not yet been able to add another, to the list of your subscribers.

You mention, in each of your letters, the little picture you were so kind, as to propose sending me. This alone leads me to say, that whenever it comes to hand, it will be most welcome: but that, engaged as you are in laboring in the cause of science and of America, you must not feel obliged to consume one hour of your precious time at the sacrifice of those higher objects.

I am happy to be able to say to you, that my health, though not wholly restored, is greatly improved, and that if you will continue to favor me with your commands, I will prove myself, hereafter, a more punctual correspondent.

I look forward with sincere pleasure, to the prospect of meeting you again, on this side of the Atlantic, and with my respectful compliments to Mrs. Audubon, I beg leave, dear sir, to tender you the assurance of my high respects, and with it my most friendly salutations.

Edward Everett.

P. S. Since the foregoing was written, I have received your favor of the 23d. of April. I beg leave particularly to thank you for your kindness in reference to the picture. I shall prize it, not merely on account of its scientific value and beauty as a work of art, (both of which I feel assured it will be found to possess) but as a token of your friendly regard. It will give me great pleasure to furnish you any letters in my power, for your adventurous south western tour. These I shall have the pleasure of handing you, when we meet this side the water.

You were elected in November last a fellow of the American Academy of Arts and Sciences, on the nomination which I had the honor to submit to that body. Owing to a change in the 
secretaryship a delay arose in preparing your diploma, which will however be forwarded in a few days.

Upon balancing his accounts with The Birds of America at about this time, Audubon thought it was truly remarkable that $\$ 40,000$ should have passed through his hands for the completion of the first volume.

Who would believe that once in London I had only a sovereign left in my pocket, and did not know to whom to apply for another, when at the verge of failure; above all, that I extricated myself from all my difficulties, not by borrowing money, but by rising at four o'clock in the morning, working hard all day, and disposing of my works at a price which a common labourer would have thought little more than sufficient remuneration for his work? To give you an idea of my actual difficulties during the publication of my first volume, it will be sufficient to say, that in the four years required to bring that volume before the world, no less than fifty of my subscribers, representing the sum of fifty-six thousand dollars, abandoned me! And whenever a few withdrew I was forced to leave London, and go to the provinces, to obtain others to supply their places, in order to enable me to raise the money to meet the expenses of engraving, coloring, paper, printing ...; and that with all my constant exertions, fatigues, and vexations, I find myself now having but one hundred and thirty standing names on my list. 



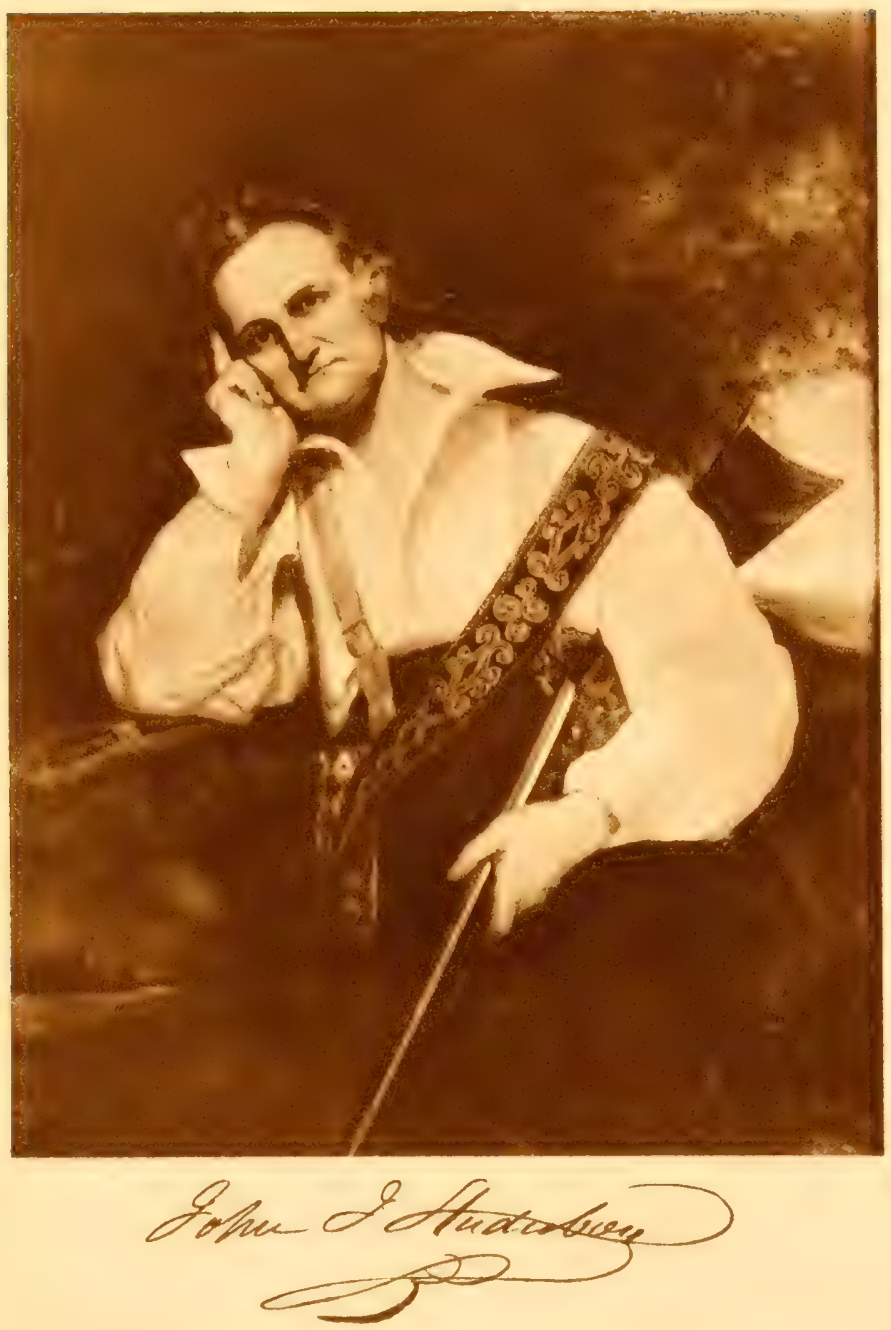

AFTER PORTRAIT BY GEORGE P. A. HEALY, 1838; ORIGINAI. IN POSSESSION OF THE BOSTON SOCIETY OF NATURAL HISTORY. 



\section{AUDUBON \\ THE \\ NATURALIST}

\section{VOLUME II}




\section{SONNET}

TO J. J. AUDUBON, ESQ., ON BEHOLDING HIS DRAWINGS.

Is there delight in Nature's solitudes,

Her dark green woods, and fragrant wilderness, In scenes, where seldom human step intrudes,

And she is in her wildest, loveliest dress?

Is there delight in her uncultured flowers,

Each ripened bloom or bright unfolding dye,

Or in the tribes which animate her bowers,

And through her groves in living beauty fly?

Then, on thy canvas as they move and live,

While taste and genius guide the fair design, And all the charms which Nature's works can give

With equal radiance in thy colours shine;

Amidst the praise thy country's sons extend,

The stranger's voice its warm applause shall blend.

J. E. R. [Jane Elizabeth Roscoe].

The Winter's Wreath, 1832. 


\section{AUDUBON THE NATURALIST}

\section{CHAPTER XXVI}

\section{EXPLORATIONS IN FLORIDA AND THE SOUTH ATLANTIC}

Obituary published in London on dav of his arrival in New York-Assistance from the Government-John Bachman becomes his friendWinter in Charleston-His folios as gifts-To Florida with two assistants-Letters to Featherstonhaugh-St. Augustine-Misadventures in the mud of East Florida-Audubon on Florida's future- $\mathrm{At}$ the sources of the St. John's-Aboard the Harion-Return from Key West-A merchant of Savannah--Disbanding of party at Charleston.

In the summer of 1831 Audubon felt that he must again return to America and extend his researches to the north, south and west, as well as begin a campaign for subscribers in the United States. His large folio was now running into its second volume, and the first installment of his text had been published; the time was favorable to his plans, and he hoped to remain in the country two or three years.

For the second time the publication of his plates was entrusted to friend Children, and with Mrs. Audubon he set sail for New York on August 2, 1831. From the American metropolis he wrote to Joseph B. Kidd on September 7 as follows: ${ }^{1}$

${ }^{1}$ Quoted by Captain Thomas Brown (Bibl. No. 163) in the Edinburgh Caledonian Mercury, November 3, 1831. 
We landed on the $3 \mathrm{~d}$... [of September] after a remarkably fine passage of 33 days. In two days more I proceed to the woods, and away from white man's tracks and manners. I hope you are going on well with your work. . . I have a new subscriber here. The papers and scientific journals (we have not many,) are singing the praises of my work, and, God willing, I may yet come out at the broad end of the horn; at all events, I will either break it or make a spoon! I shot sixteen birds on the passage, which I got through the kind attention of our commander. I killed fifty more, when the "Columbia" was going too fast to stop for the purpose of picking them up. My young man is now busily engaged in skinning, and killed a bag-full of warblers yesterday ... prices of peaches, first quality, 75 cents per bushel,- - apples, half that price;-water melons are dull of sale, as also cantelopes and nutmeg melons. Fish alive in the markets, and, vive la joie, no taxes on shooting or fishing."

What Audubon actually did was to proceed to Philadelphia, where Mrs. Audubon left him to visit her sons in Louisville, and where he laid his plans for exploring the Southern States, especially the islands and eastern coast of the Florida peninsula. For this expedition he engaged two assistants, one of whom was Henry Ward, the "young man" mentioned above, an Englishman who had come with him to America as taxidermist, while the other was George Lehman, a Swiss landscape painter whom he seems to have found at Philadelphia. With them he soon started for Washington to obtain assistance from the Government.

On the very day that Audubon landed in New York, there appeared in the London Literary Gazette a seriocomic notice under the title of "Wilson the Ornithologist," who, it may be remembered, had died in Philadelphia eighteen years before. Said the editor of the Gazette: 
We observe with sorrow an account of the death and burial of poor Wilson, somewhere in the state of Philadelphia, even while the Edinburgh journals are anticipating his return, laden with scientific treasures. We have now before us No. 1 of his Illustrations of American Ornithology, on a reduced scale, to sort with Professor Jameson's edition-a pretty and attractive publication. The coloured prints are extremely correct and well done.

When on September 8 the Edinburgh Caledonian Mercury had called attention to this egregious blunder regarding Wilson, the Gazette explained that his name had been confused with that of Audubon, whose obituary presently appeared in its issue of October 29, the editor remarking that this naturalist's death was equally, if not more, to be deplored than that of Wilson. Captain Brown then sent to the Caledonian Mercury Audubon's letter to Kidd, quoted above, which was written from New York four days after the naturalist's death was announced in England. "What is the editor of the Literary Gazette about," exclaimed a writer in the Edinburgh paper; "he first resuscitates a man who has been dead 18 years, only to kill him again, and then, by way of correcting his error, kills another, who is now clearly proved to have been alive and well several days after the date of his obituary in London."

As was often the case, Audubon's ambitious hopes for exploring the continent far outran his means and powers of accomplishment. Colonel John James Abert, whose counsel he sought in Washington at this time, said:" "His plan is first to examine the peninsula

${ }^{2}$ Extract of letter of Colonel Abert. See G. W. Featherstonhaugh (Bibl. No. 164), Monthly American Journal of Geology and Natural Science, vol. i, p. 229 (1831).

John James Abert (1788-1863), long associated with the Bureau of Topographical Engineers of the United States Army, became brevet 
of Florida; then the regions west of the Mississippi, Mexico, and if possible penetrate into California. He also contemplates crossing the Rocky Mountains and pursuing the Columbia River to its mouth, and thinks that he will be absent from us about two years." In November G. W. Featherstonhaugh, the geologist, also made this announcement in his Monthly American Journal of Geology and Natural Science:

We are authorized to state that information of the progress of Mr. Audubon will be given, from time to time, to the scientific world, in the pages of this journal.

We are gratified in being able to state, that he was received in the most cordial manner, at Washington, and that the distinguished gentlemen in authority there, have given him such letters to the military posts on the frontiers, as will assure him the aid and protection his personal safety may require. We anticipate the most interesting reconnaisances, both geological and zoölogical, from this enterprising naturalist, who is accompanied by Mr. Lehman, as an assistant draftsman, and by an assistant collector who came with him from Europe.

The "distinguished gentlemen" at Washington who particularly aided Audubon at this time, besides Colonel

lieutenant-colonel in charge of that office in 1837; according to Ruthven Deane (see Bibliography, No. 216), he was an organizer of the National Institute of Science, afterwards merged with the Smithsonian Institution at Washington; an ardent friend of Audubon, he assisted him in many ways, and, as Dr. Richard Harlan affirmed, paid dearly for his support by being rejected for membership in the American Philosophical Society at Pliladelphia. Harlan wrote to Audubon on January 2\%, 1832, that out of twenty-five members present on the occasion referred to, five, led by Mr. George Ord, Mr. Isaac Lea, and Dr. Hays, had voted against him: in his opinion no possible grounds could be found for opposing so desirable a member excepting his friendship for Audubon and his support of the snake "Episode" (see Chapter XXVIII). In 1832 Abert's paper on the "Habits of Climbing of the Rattlesnake," which was written in the previous year, had appeared in a Philadelphia journal (see Bibliography, No. 107). To this friend Abert's Squirrel, Sciurus aberti, was later dedicated; see Audubon, The Viviparous Quadrupeds of North America (Bibl. No. 6), plate 153. 
Abert, were Edward Everett, Levi Woodbury, Secretary of the Navy, and Lewis McLane, Secretary of the Treasury. He was particularly anxious to obtain accommodation for his party aboard a government vessel, but it was some time before a suitable one was available. They left Washington about October 15, 1831, and went by steamer to Norfolk and Richmond, Virginia, where the Governor, John Floyd, whom Audubon had known in his Kentucky days, gave him numerous letters of introduction. At Charleston, their next stopping-place, he had hardly begun work in the field when he was sought out by the Rev. John Bachman, by inclination a naturalist of the old school and by profession a Lutheran minister, who at once took the whole party under his hospitable roof, where they remained a month. Thus began a life-long and almost ideal friendship between these two men, so unlike in character, in temperament and in training, which was quite as important to the modest German-American divine as to the impulsive Franco-American painter and student of birds. It was Audubon's infectious enthusiasm which kindled to an ardent flame that love of nature which was innate in Bachman, and which eventually brought his name and work to the attention of the scientific world.

Audubon remained at Charleston with the Bachmans until November 15, when the opportunity which they had awaited came suddenly, and they sailed for St. Augustine, Florida, on the government schooner Agnes. On that day Bachman wrote to Mrs. Audubon, in compliance "with a request of your kind and worthy husband, who laid an injunction on me this morning": ${ }^{3}$

${ }^{3}$ C. L. Bachman, John Bachman, D.D., LL.D., Ph.D. (Bibl. No. 191), to which work I am indebted for numerous extracts from Bachman's letters to Audubon and for various incidents relating to the different members of both families. 
The last has been one of the happiest months of my life. I was an enthusiastic admirer of nature from my boyhood, and fond of every branch of Natural History. Ornithology is, as a science, pursued by very few persons-and by none in this city. How gratifying was it, then, to become acquainted with a man, who knew more about birds than any man now livingand who, at the same time, was communicative, intelligent, and amiable, to an extent seldom found associated in the same individual. He has convinced me that I was but a novice in the study ; and besides receiving many lessons from him in Ornithology, he has taught me how much can be accomplished by a single individual, who will unite enthusiasm with industry. For the short month he remained with my family, we were inseparable. We were engaged in talking about Ornithologyin collecting birds - in seeing them prepared, and in laying plans for the accomplishment of that great work which he has undertaken. Time passed rapidly away, and it seems but as yesterday since we met, and now, alas! he is already separated from me-and in all human probability we shall never meet again.... I need not inform you that Mr. Audubon was a general favorite in our city. His gentlemanly deportment, his travels and experience, his information and general talents, caused him to be sought after by all. But your husband knew that the great objects before him required his unremitted attention, and he was obliged to deny himself to his friends, on many occasions, and devoted to them only his evenings.

There seems quite a blank, in my house, since l.: has gone, for we looked on him as one of our family. He taught my sister, Maria, to draw birds; and she has now such a passion for it, that whilst $\mathrm{I}$ am writing, she is drawing a Bittern, put up for her at daylight by Mr. Audubon.

On December 23 Bachman wrote to Audubon: "Your visit to me gave me new life, induced me to go carefully over my favorite study, and made me and my family happy." His sister-in-law, Miss Maria Martin, 


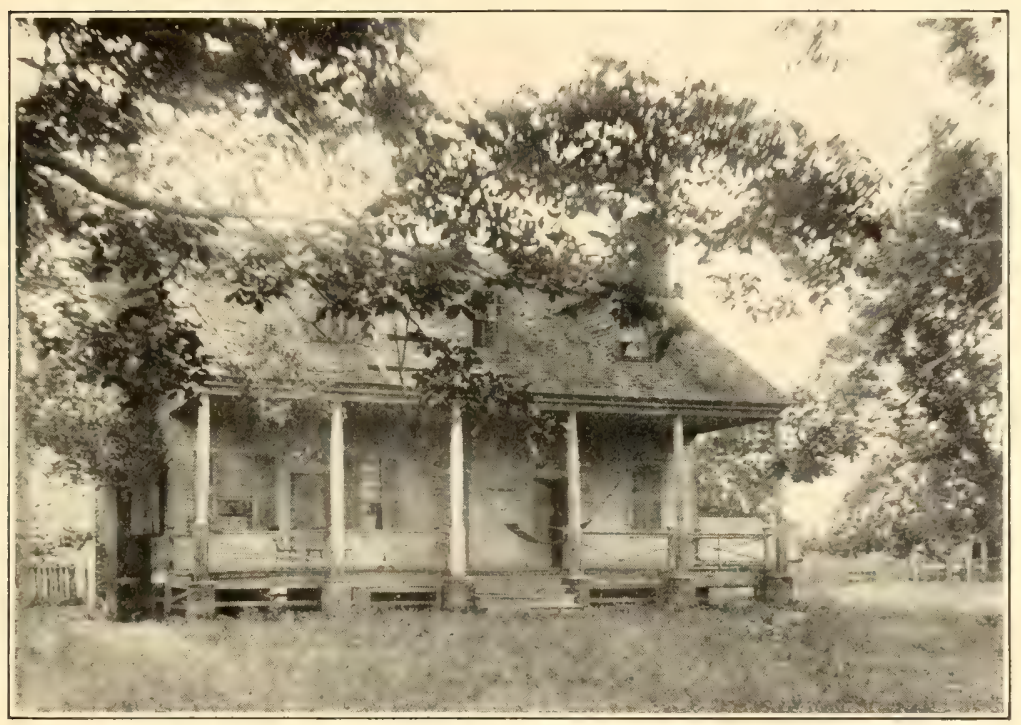

"BEECHGROVE," WILLTAM GARRETT JOHNSON'S PLANTATION HOUSE TN WEST FELICIANA PARISH, LOUISIANA, WHERE MRS. AUDUBON LIVED AND TAUGHT FOR TWO YEARS, $182 \gamma-1829$.

After a photograph by Mr. Stanley Clisby Arthur, 1916.

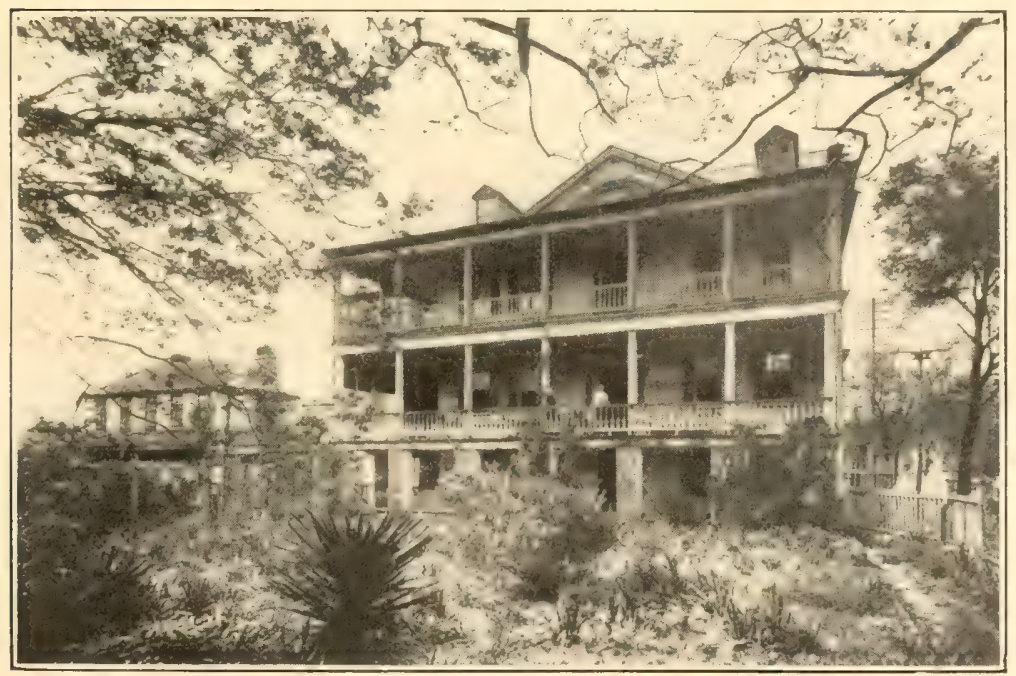

JOHN BACHMAN'S HOUSE IN CHARTESTON, SOUTH CAROLINA.

After a photograph in possession of Mr. Ruthven Deane. 

who possessed considerable artistic talent, became one of Audubon's enthusiastic helpers, and not only drew birds for him but painted many of the flowers and insects which were later used for the embellishment of his plates. John Bachman's serious contributions to natural history also date from this visit. To repay him and his family for their hospitality, Audubon presented them with the first volume of The Birds of America, but the folio was not received until some time later; he was referring to this when he wrote to Bachman, just before sailing from New York, on April 5, 1834, and asked him to accept "the superbly bound book" from "your old Friend, in part atonement for the troubles I have given you, and the leatherings you may yet receive at my hands at chess." In a letter to Miss Martin, written also from New York on the following day, he said: "The Great Volume which Maj. Glassel did fortunately return into your hands, I give with all my heart to my valued friends, the Bachmans, and shall try to furnish them the sequel in like binding." 4

Audubon scattered detached plates and numbers of his large work freely among his friends, and sometimes spoke of a gift of the whole. The costly nature of such a present in most cases, no doubt, led to a change of mind if not of heart, but not in all, for a number of his presentation copies still exist. One was given to David Eckley ${ }^{5}$ of Boston, a noted sportsman who had aided

"This "Great Volume," bound in fine Russia leather, was still in possession of the Bachman family in 1888, and is said to represent one of the earliest impressions of the plates, which Audubon had selected and used for exhibition purposes. See C. L. Bachman, op. cit., p. 101.

${ }^{5}$ This unique copy of The Birds of America bears the inscription: To my worthy Friend

D d. Eckley, Esq., of [Boston]

this volume is given with

his sincere and good wishes.

Johy J. Audubon. 
Audubon in collecting materials for his work. In a letter written at Charleston, January 1, 1837, to young Thomas M. Brewer, Audubon said: "Please to call on my good friend David Eckley, Esq., present to him and to his family my very best regards, and ask of him whether he has collected any hawks or owls for me. If so, take them from him, and place them in the general receptacle of "pale-faced rum.'" Another copy is said to be in possession of the Public Library of Manchester, Fngland, and to have been bequeathed to that institution by the Earl of Crawford. A complete set of the Birds was also presented to his friends, the Rathbones of Liverpool, and is still in possession of the family.

We shall now return to our narrative and fulfill our promise of reproducing Audubon's own account of his journey from Richmond to Florida: ${ }^{6}$

\section{Audubon to G. W. Featherstonhaugh}

I am now seated in earnest to give you an unceremonious summary of my proceedings up to this time, since we left Richmond, in Virginia. As a geologist, I venture to suppose you would have been but indifferently amused, if you had been with us in our journey from this latter place to Charleston, in South Carolina; and as an ornithologist, I cannot boast of the

The plates thus dedicated were unbound, and apparently in their original covers, which consisted of plain brown sheets. They passed through the hands of Messrs. Burrows Brothers' Company, Cleveland, to Mr. Robert H. Sayre of South Bethlehem, Pennsylvania, and were originally received by the American dealers from the Messrs. Sotheran \& Company of London. Possibly this was the set mentioned by Coues, who says "Trubner... quotes the work with plain plates. I have never seen one in that condition" (Birds of the Colorado Valley, p. 612; Bibl. No. 181). After Mr. Sayre's death, his library was dispersed by public auction at Philadelphia, when this complete set of Audubon plates, though in an uncolored state, brought $\$ 3,200$; see Public Ledger, November 9, 1907. But according to Ruthven Deane the Sayre plates were colored.

${ }^{\circ}$ Letter (No. 1) from Audubon to the editor of the Monthly American Journal of Geolog!y and Natural Scirnce (Bibl. No. 34), published in vol. i, p. 358 (1832); dated "St. Augustine, East Florida, Dcc. 7, 1831." 
enjoyment I found; pooi coaches, dragged through immense, deserted pine forests, miserable fare, and neither birds nor quadrupeds to be seen. We at length approached Charleston, and the view of that city from across the bay was hailed by our party with unfeigned delight. Charmed, as we were, with having terminated our dreary journey, it did not occur to us to anticipate the extraordinary hospitality which awaited us there, and which led to a residence of a few of the happiest weeks I ever passed.

I had passed but one night in the city, when I was presented to the Rev. Mr._- This benevolent man, whom I am proud to call my friend would not suffer the "American Woodsman" to repose any where but under his roof; and not him alone-all his assistants too. When I tell you that he was an old friend of Alexander Wilson, that he shoots well, is an ornithologist, a philosophical naturalist, and that during the time we enjoyed his hospitality, he took us all over the country with his carriages and servants, in search of specimens, and that he was every thing a kind brother could be to me, you may suppose that it is with great sincerity I say, and ever shall say, God bless him! When I first saw this excellent man, he was on horseback, but upon my being named to him, he leaped from his saddle, suffered his horse to stand at liberty, and gave me his hand with a pressure of cordiality that electrified me. I saw in his eyes that all he said was good and true; and although he spoke of my labours in terms far exceeding what is due to them, I listened to him pretty well assured that he did not intend me to play the part of Gil Blas over again; for myself, my assistants, George Lehman and Henry Ward, were removed in a jiffy to his own mansion, introduced to the family, and at work the very next morning.

Although the weather was "shockingly hot," they prepared three hundred specimens, embracing about

These letters, which were hurriedly written in the field, appeared in a short-lived and forgotten publication; they are here given in part on account of the general interest of the narrative. 
sixty land and water birds, and sent all the "pickled specimens to our mutual friend $\mathbf{H} \_$_ [Dr. Harlan, of Philadelphia] for safe keeping until their return.

I jumped at once into my wood-hunting habits. All hands of us were up before day-break, and soon at work, either in the way of shooting, taking views, or drawing birds; after sunset-scribbling in our journals. . . In the early part of November the alligators had gone into their winter quarters; the migratory birds were passing swiftly on towards the south, although we had had no frost. The planters considered the country as still unhealthy, and resorted to the city at night. If I had been governed by the practice and advice of many, I should not have put a foot in the mud, either salted or fresh; but difficulties of this character must be disregarded by the American woodsman, while success, or the hope of it, is before him.

It is impossible to do justice to the generous feelings of the Charlestonians, or to their extreme kindness towards me. Many of the gentlemen took the greatest interest in my pursuits; one, Dr. Foundland dog, and other valuable memorials of his regard. Another, Dr. cent waters. The ladies presented me with a capital supply of snuff. ${ }^{7}$ Desirous of going to Cole's Island, distant about 25 or 30 miles, to look after some marine birds, a boat, four hands and a pilot, were immediately offered to me, free of all expense, with the liberty to detain them as long as was agreeable to me. It is not possible for me to express properly the sense I feel of the kindness I received from that warm-hearted and intelligent people.

And now, as you have good naturedly listened to what I have felt bound to say on the score of gratitude, I will tell you what I know you are impatient to come to-something about my proceedings at Cole's Island. It lies south from Charleston about 25 or 30 miles; there we arrived and encamped for the

'See Audubon's New Year's resolution against snuff, Vol, I, p. 396. 
night: certain beef-steaks we brought with us we roasted upon sticks, and the adjacent shore provided us with excellent oysters: gaiety, good appetites, and our hearts all right, made the time pass pleasantly, and it was with some reluctance we spread our blankets, and arranged the fire preparatory to going to rest. Nothing is more valuable to a naturalist, and particularly to an ornithologist, than the first hours of the day; therefore, long ere the sun had glowed over the broad sea that lay before our camp, we had reached another island where birds resort to roost by thousands; but, notwithstanding these multitudes, not a new species did we procure. We, however, had the pleasure of observing two noble "birds of Washington," 8 sailing majestically over the broad watery face.

But it was necessary to bring my stay in Charleston to a close, and it was somewhat difficult too. My friends had increased in number; they were in the habit of accompanying me in my shooting excursions; I was becoming very much attached to them; invitations poured in from various parts of the country; and I really believe that had I been willing, we might have remained there and in the neighborhood, if not all our lives, at least as long as would have caused a rare scarcity of the feathered tribes, in that portion of the Carolinas. But my mind was among the birds farther south, - the Floridas, Red River, the Arkansas, that almost unknown country, California, and the Pacific ocean. I felt myself drawn to the untried scenes of those countries, and it was necessary to tear myself away from the kindest friends.

We embarked on the schooner Agnes; the wind was fair, and we hoisted all sails for the Floridas. Our passage was not short; the wind changed, and we put back into St. Simon's Island Bay. This was one of the few put backs in life of a fortunate kind for me. I made for the shore, met a gentleman on the beach, presented him my card, and was immediately invited to dinner. I visited his gardens, got into such agreeable conversation and quarters, that $I$ was fain to think that 
I had landed on some one of those fairy islands said to have existed in the golden age. But this was not all; the owner of this hospitable mansion pressed me to stay a month with him, and subscribed to my Birds of America in the most gentlemanly manner. This was T. B. K., Esq. ${ }^{9}$ But the wind shifted; I was sent for, and our voyage to St. Augustine resumed.

St. Augustine, whatever it may have been, is far from being a flourishing place now. It lies at the bottom of a bay, extremely difficult of access, even for vessels of light draft, which seldom reach the "city" in less than a day. I cannot say much for the market, nor for the circumjacent country. Oranges and plenty of good fish seem to contribute the wealth of the place. Sands, poor pine forests, and impenetrable thickets of cactus and palmettos form the undergrowth. Birds are rare, and very shy; and with all our exertions, we have not collected one hundred skins in a fortnight that we have been here. I have received many kind attentions, and numerous invitations to visit plantations, on our way to the south, where I shall direct my steps in a few days. I have drawn seventeen species, among which one mongrel vulture, which I think will prove new. You will see it, I hope, very soon.

I will give you a sketch of our manner of passing the time. We are up before day, and our toilette is soon made. If the day is to be spent at drawing, Lehman and I take a walk, and Ward, his gun, dog, and basket, returning when hungry or fatigued, or both. We draw uninterruptedly till dusk, after which, another walk, then write up journals, and retire to rest early. When we have nothing on hand to draw, the guns are cleaned over night, a basket of bread and cheese, a bottle with old whiskey, and some water, is prepared. We get into a boat, and after an hour of hard rowing, we find ourselves in the middle of most extensive marshes, as far as the eye can reach. The boat is anchored, and we go wading through mud and water, amid myriads of sand-flies and mosquitoes,

' Thomas Butler King, of St. Simon's Island, Georgia. 
shooting here and there a bird, or squatting down on our hams for half an hour, to observe the ways of the beautiful beings we are in pursuit of. This is the way in which we spend the day. At the approach of evening, the cranes, herons, pelicans, curlews, and the trains of blackbirds are passing high over our heads, to their roosting places; then we also return to ours. If some species are to draw the next day, and the weather is warm, they are outlined that same evening, to save them from incipient putridity. I have ascertained that feathers lose their brilliancy almost as rapidly as flesh or skin itself, and am of opinion that a bird alive is 75 per cent more rich in colours than twenty-four hours after its death; we therefore skin those first which have been first killed, and the same evening. All this, added to our other avocations, brings us into the night pretty well fatigued. Such, my dear friend, is the life of an active naturalist; and such, in my opinion, it ought to be. It is nonsense ever to hope to see in the closet what is only to be perceived-as far as the laws, arrangements and beauties of ornithological nature is concerned,--by that devotion of time, opportunities, and action, to which I have consecrated my life, not without hope that science may benefit by my labours.

As to geology, my dear Friend, you know as well as myself, that I am not in the country for that. The instructions you gave me are very valuable, and I shall be vigilant. The aspect of the country will soon begin to change, and as I proceed, I will write to you about all we see and do. . . . Do not be afraid of my safety; I take a reasonable care of my health and life. I know how to guard against real difficulties, and I have no time to attend to that worst of all kinds of difficulties,-imaginary ones. Circumstances never within my control, threw me upon my own resources, at a very early period of my life. I have grown up in the school of adversity, and am not an unprofitable scholar there, having learnt to be satisfied with providing for my family and myself by my own exertions. The life $\mathbf{I}$ lead is my vocation, full of smooth and rough paths, like every vocation which men variously try. My physical constitution has always been good, and the fine flow of 
spirits I have, has often greatly assisted me in some of the most trying passages of my life. I know I am engaged in an arduous undertaking; but if I live to complete it, I will offer to my country a beautiful monument of the varied splendour of American nature, and of my devotion to American ornithology.

John James Audubon.

Ther., this day, at 2 p. m.,

$78^{\circ}$ Fahr.

On the following day, December 8, 1831, Audubon sent the following request to Dr. Harlan of Philadelphia: "I wish you also to send me-to Key West-, 20 more pounds of powdered arsenic from Friend Wetherell's shop, ${ }^{10}$ and also a double barelled gun of usual length, as good as you can procure for $\mathbf{3 0}$ dollars; probably a second hand one may be procured; it must be percussion and, if possible, back action." Dr. Richard Harlan, who often transmitted to Mrs. Audubon any news which came direct from her husband, wrote to her on December 10, 1831, as follows: ${ }^{11}$

I have just rec ${ }^{d}$ a letter from Mr Aud-dated St. Augustine Nov. 24th they enjoy health amidst their fatiguing avocations-has obtained another subscriber, living on $\mathbf{S}^{\text {t. Simons }}$ island named $\mathrm{Th}^{\mathrm{o}}$. Butler King - to whom I am to send the work as soon as the Copies exported arrive from London-he has good expectations of adding some new birds to his listhave you seen the Sonnet addressed to $\mathrm{M}^{\mathrm{r}}$ Aud. in the "Wreath" a London annual for 1832? - una'er the signature of J. E. R? -our newspapers announce the arrival, departure \& progress of $\mathrm{M}^{\mathrm{r}}$ Audubon, as if he was an Embassador-and so he is, one of Natures-

${ }^{10}$ Then belonging to the four sons of Samuel Wetherill, who succeeded to the white lead and drugs industry after his death in 1829 .

${ }^{11}$ For the favor of reproducing this and another letter by Dr. Harlan given in Chapter XXVII, as well as the sonnet referred to, which will be found facing page 1 of this volume, I am indebted to Mr. Ruthven Deane. 
The winter season at St. Augustine proved unfavorable for the naturalist's work, and he anxiously awaited the coming of the government vessel, the $S$ park, to the commander of which he bore letters from Washington. After spending about three weeks in the neighborhood of the city, the party proceeded through the inlet which divides Anastasia Island from the mainland, to the plantation of General Hernandez, thirty-five miles distant, where they were entertained for ten days. On Christmas morning they set out afoot for the plantation of John Bulow, of Bulowville, fifteen miles away. To follow the naturalist's account:

A wagon was sent for our baggage and horses for ourselves were offered at the same time, but it was not my desire to give unnecessary trouble, and above all upon an occasion when I was glad to see the country in as much detail as possible, and anxious to avail myself of every occasion to get new birds.

During the whole long stay with Mr. Bulow, there was no abatement of his kindness, or his unremitted efforts to make me comfortable, and to promote my researches. I shall ever feel grateful to one of the most deserving and generous of men.

On December 28 their host proposed that they should descend the Halifax River in search of new and valuable birds to a point about forty miles from that place and eighty miles from St. Augustine. ${ }^{12}$

Accordingly, the boat, six hands, and "three rohite men," with some provisions, put off with a fair wind, and a pure sky. ...We meandered down a creek for about eleven miles-the water torpid yet clear-the shore lined with thousands of acres covered by fall grapes, marshes, and high palm trees,

${ }^{12}$ The following account is quoted from Audubon's second letter to G. W. Featherstonhaugh (Bibl. No. 35), dated "Bulowville, East Florida, December 31, 1831;" published, loc. cit., vol. i, p. 407 (1832). 
rendering the shore quite novel to my anxious eye. Some birds were shot, and secured so as to be brought back, in order to undergo the skinning operation. Before long we entered the Halifax river, an inland arm of the sea, measuring in breadth from a quarter to nearly a mile.

\section{They reached a spot, called "Live Oak Landing,"} where a schooner from New York was then anchored, and there passed the night.

At sunrise the next morning, I and four negro servants proceeded in search of birds and adventures. The fact is, that I was anxious to kill some 25 brown Pelicans . . . to enable me to make a new drawing of an adult male bird, and to procure the dresses of the others. I proceeded along a narrow, shallow bay, where the fish were truly abundant. Would you believe it, if I were to say, that the fish nearly obstructed our head-way? Believe it, or not, so it was; the waters were filled with them, large and small. I shot some rare birds, and putting along the shore, passed a point, when lo, I came in sight of several hundred pelicans, perched on the branches of mangrove trees, seated in comfortable harmony, as near each other as the strength of the boughs would allow. I ordered to back water gently; the hands backed water. I waded to the shore under cover of the rushes along it, saw the pelecans fast asleep, examined their countenances and deportment well and leisurely, and after all, levelled, fired my piece, and dropped two of the finest specimens I ever saw. I really believe I would have shot one hundred of these reverend sirs, had not a mistake taken place in the reloading of my gun. A mistake, howcver, did take place, and to my utmost disappointment, I saw each pelecan, old and young, leave his perch, and take to wing, soaring off, well pleased, I dare say, at making so good an escape from so dangerous a foe.

After shooting more birds, and pushing or pulling their boat "over oyster banks sharp as razors," they 
made the schooner at the landing again. "The birds, generally speaking," he continues, "appeared wild and few-you must be aware that I call birds few, when I shoot less than one hundred per day."

Such remarks as we have just quoted might convey the impression that the American woodsman, with whose name the cause of bird protection is now associated in this country, was a reckless destroyer of all bird life, but this was far from the case. It must be remembered that this was over eighty years ago, when the unrivaled abundance of our birds was such that the necessity of their conservation had hardly entered the dreams of the most discerning. Audubon no doubt had gradually yielded to the prevalent mania for describing and figuring new species, and to make out all the minute specific differences a large series of specimens was necessary; still more were needed for the detection of individual variation, which did not escape him, and much less his assistant, William MacGillivray, who demanded large numbers for his anatomical studies. Furthermore, Audubon counted upon defraying a part of his expenses by collections of skins of American birds, which were then desiderata among the museums of Europe. ${ }^{13}$

When it was proposed that they should return,

preparations were accordingly made, and we left the schooner, with tide and wind in our teeth, and with the prospect of a severe, cold night. Our hands pulled well, and our bark was as light as our hearts. All went on merrily until dark night came on. The wind freshening, the cold augmenting, the provisions diminishing, the waters lowering, all-all depreciating except our enterprising dispositions. We found ourselves fast in the mud about 300 yards from a marshy shore, without the least hope of being able to raise a fire, for no trees except palm

${ }^{13}$ See Vol. II, p. 129. 
trees were near, and the grand diable himself could not burn one of them. Our minds were soon made up to do-what? Why, to roll ourselves in our cloaks, and lay down, the best way we could, at the bottom of our light and beautiful barque. Good God, what a night! To sleep was impossible; the cold increased with the breeze, and every moment seemed an hour, from the time we stretched ourselves down until the first glimpse of the morn; but the morn came, clear as ever morn was, and the north-easter as cold as ever wind blew in this latitude. All hands half dead, and masters as nearly exhausted as the hands - stiffened with cold, light-clothed, and but slight hope of our nearing any shore; our only resort was, to leap into the mire, waste-deep, and to push the barque to a point, some five hundred or six hundred yards, where a few scrubby trees seem to have grown to save our lives on this occasion. "Push, boys, push! Push for your lives!', cry the generous Bulow, and the poor Audubon.- "All hands push!" Aye and well might we push: the mire was up to our breasts, our limbs becoming stiffened at every step we took. Our progress was slowly performed as if we had been clogged with heavy chains. It took us two and a half hours to reach the point, where the few trees of which I have spoken were; but, thank God, we did get there.

We landed . . . and well it was that we did ; for on reaching the margin of the marsh, two of the negroes fell down in the marsh, as senseless as torpidity ever rendered an alligator, or a snake; and had we, the white men, not been there, they certainly would have died. We had carried them into the little grove, to which, I believe, all of us owe our lives. I struck a fire in a crack; and, in five minutes, I saw, with indescribable pleasure, the bright, warming blaze in a log pile in the center of our shivering party. We wrapped the negroes in their blankets-boiled some water, and soon had some tea-made them swallow it, and with care revived them into animation. May God preserve you from being ever in the condition of our party at this juncture; scarcely a man able to stand, and the cold wind blowing as keenly as ever. Our men, however, gradu- 
ally revived-the trees, one after another, fell under the hatchet, and increased our fire-and in two hours I had the pleasure of seeing cheerful faces again.

Their predicament, however, was still serious, for, to continue the narrative, they were

confined in a large salt marsh, with rushes head high, and miry; no provisions left, and fifteen miles from the house of their host.

Not a moment was to be lost, for I foresaw that the next night would prove much colder still. The boat was manned once more, and off through the mud we moved to double the point, and enter the creek, of which I have spoken, with the hope that in it we should find water enough to float her. It did happen so, thank God! As we once more saw our barque afloat, our spirits rose,- and rose to such a pitch that we in fun set fire to the whole marsh: crack, crack, crack! went the reeds, with a rapid blaze. We saw the marsh rabbits, scampering from the fire by the thousands, as we pulled our oars.

Their pleasure in being afloat was short-lived, for "the northeaster had well nigh emptied the creek of its usual quantum of water," and they were again obliged to wade to effect a landing, their object being to gain the east Florida coast and thus make their escape. This was finally attained after abandoning their boat, when began a long tramp on the beach, in the teeth of the wind,

through sand that sent our feet back six inches at every step of two feet that we made. Well, through this sand we all waded, for many a long mile, picking up here and there a shell that is nowhere else to be found, until we reached the landing place of J. J. Bulow. Now, my heart, cheer up once more, for the sake of my most kind host. . . I I assure you, I was glad to see him nearing his own comfortable roof; and as we saw 
the large house opening to view, across his immense plantation, I anticipated a good dinner with as much pleasure as I ever experienced.

All hands returned alive; refreshments and good care have made us all well again, unless it be the stiffness occasioned in my left leg, by nearly six weeks of daily wading through swamps and salt marshes, or scrambling through the vilest thickets of scrubly live oaks and palmitoes that appear to have been created for no other purpose but to punish us for our sins.

Readers of the following account who have visited eastern Florida may conclude that Audubon was not a good prophet, but probably at that early day no one could have made a better forecast of the future:

The land, if land it can be called, is generally so very sandy that nothing can be raised upon it. The swamps are the only spots that afford a fair chance for cultivation; the swamps, then, are positively the only places where plantations are to be found. These plantations are even few in number; along the coast from St. Augustine to Cape Carnaveral, there are about a dozen. These, with the exception of two or three, are yet young plantations. General Hernandez's, J. J. Bulow's, and Mr. Durham's are the strongest, and perhaps the best. Sugar cane will prosper, and doubtless do well; but the labour necessary to produce a good crop, is great! great!! great!!! Between the swamps of which I now speak, and which are found along the margin laying west of the sea inlet, that divides the main land from the Atlantic, to the river St. John of the interior of the peninsula, nothing exists but barren pine lands of poor timber, and immense savannas, mostly overflowed, and all unfit for cultivation. That growth, which in any other country is called underwood, scarcely exists; the land being covered with low palmitoes, or very low, thickly branched dwarf oaks, almost impenetrable to man. The climate is of a most unsettled nature, at least at this season. The thermom- 


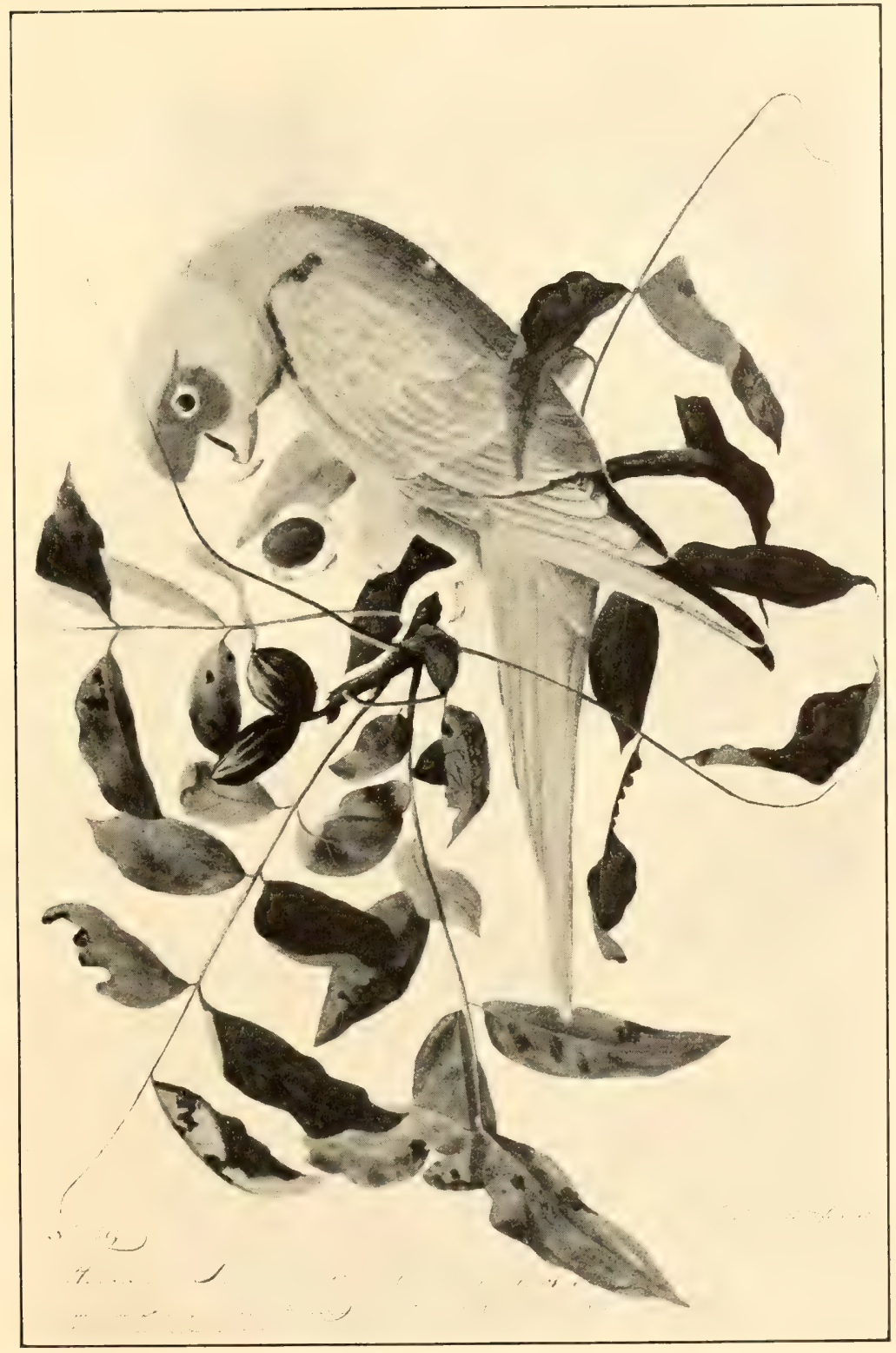

EARLY UNPUBLISHED DRAWING IN WATER-COLOR OF THE CAROIINA PARIROT, ON BRANCH OF THE HICKORY, DATED "HENDERSON, JUNE 9TH, 1811."

THE ORIGINAL BEARS THE NOTE: "POOR IMTTATION OF COLOR, THE NATURAL BIRD BEING EXTREMELY GLOSSY AND RICH."

Published by courtesy of Mr. Joseph Y. Jeanes. 

eter has made leaps from 30 to 89 degrees in 24 hours, cold, warm, sandy, muddy, watery,-all these varieties may be seen in one day's travelling. . . Game and fish, it is true, are abundant; but the body of valuable tillable land is too small to enable the peninsula ever to become a rich state.

On January 6, 1832, the party started to visit a famous spring near the sources of the St. John's River, which was described in his third letter to Featherstonhaugh as well as in a later "Episode." 14 There his host, Colonel Rees, who utilized the abundant flow from this curious spring for grinding the whole of his sugar cane, took them down the Spring Garden Creek to a series of muddy lakes which emptied into the St. John's. The mud on this occasion was the cause of great disappointment to the naturalist, for it made it impossible for him to recover what he believed to represent a new species of Ibis, which was shot in one of those bottomless pits. "Being only a few yards distant from us," to quote from Audubon's third letter, ${ }^{15}$ "and quite near enough to ascertain the extent of my loss, I submitted to lose a fine pair of a new species, the which if I ever fall in with it again, I shall call Tantalus fuscus."

When they had reached the borders of Woodruff's Lake, after noon, fatigued and hungry, he continued:

We landed on a small island of a few acres, covered with a grove of sour orange trees, intermixed with not a few live oaks. The oranges were in great profusion on the trees-everything about us was calm and beautiful and motionless, as if it had just come from the hand of the Creator. It would have been a perfect Paradise for a poet, but I was not fit to be in

${ }^{14}$ See following Note; and "Spring Garden," Ornithological Biography (Bibl. No. 2), vol. ii, p. 263.

${ }^{15}$ See Bibliography, No. 36; undated; published, loc. cit., vol. i, p. 529 (1832). 
Paradise; the loss of my ibis made me as sour as the oranges that hung about me. I felt unquiet, too, in this singular scene, as if $I$ were almost upon the verge of creation, where realities were tapering off into nothing. The general wildness the eternal labyrinths of waters and marshes, interlocked, and apparently never ending; the whole surrounded by interminable swampsall these things had a tendency to depress my spirits, notwithstanding some beautiful flowers, rich looking fruits, a pure sky, and ample sheets of water at my feet. Here I am in the Floridas, thought I, a country that received its name from the odours wafted from the orange groves, to the boats of the first discoverers, and which from my childhood I have consecrated in my imagination as the garden of the United States. A garden, where all that is not mud, mud, mud, is sand, sand, sand; where the fruit is so sour that it is not eatable, and where in place of singing birds and golden fishes, you have a species of ibis that you cannot get when you have shot it, and alligators, snakes, and scorpions.

Mr. Bartram was the first to call this a garden, but he is to be forgiven; he was an enthusiastic botanist, and rare plants, in the eyes of such a man, convert a wilderness at once into a garden.

When we had eaten our humble repast at the sweet little Orange Grove Island, we left it "alone with its glory," but not without a name. It was determined, nolens volens, that it should be called Audubon's Island, on the St. John's river. Lat. $29^{\circ} 42^{\prime}$.

Early in February, 1832, Lieutenant Piercy took Audubon and his assistants aboard the government schooner $\boldsymbol{S}$ park at St. Augustine, and sailed for the mouth of the St. John's River, which he had orders to ascend in the interests of the Revenue Service. On February 12, when they had reached a point one hundred miles from the mouth of the river, the vessel, being in need of repairs, was suddenly recalled. Audubon, with 
two men, thereupon engaged a boat and attempted to return to St. Augustine across country, by a short cut to the eastward. They were soon stranded and the party divided. Audubon with his dog and one companion then endeavored to make their way by land to the town, eighteen miles distant, but they were overtaken by a terrific gale and thunder-storm, and in order to keep to the trails were often obliged to grope their way on hands and knees. ${ }^{16}$

At about this time the publishers of the Journal of Geology and Natural Science, from which we have quoted, failed, and Featherstonhaugh, who assumed their debts to all subscribers, was obliged to bring it to a close with the completion of the first volume; Audubon's third and last letter appeared in the valedictory number for June, 1832.

Again the naturalist applied to the government officials at Washington for assistance, and, as the following letter shows, Edward Everett again came to his aid, as did also Levi Woodbury, Secretary of the Navy, to whom Audubon later received a personal introduction from Chief Justice Taney of the Supreme Court:

\section{Levi Woodbury to Louis McLane}

\section{Navy Department}

February 241832

Sir,

The letter of the Honorable Mr. Everett of the 18 th. inst. relating to Mr. Audubon \&c and referred by you to this Department, has been received.

I regret that the impaired condition of the Spark made it necessary some weeks ago, to order that vessel to Norfolk to be refitted.

${ }^{16}$ See "St. Johr's River in Florida," Ornithological Biography, vol. ii, p. 291 . 
I have heretofore taken much pleasure in furnishing $\mathbf{M r}$. Audubon with credentials to the officers of the Navy, and requesting [them] to furnish every aid, in the prosecution of [his] scientific researches: and shall be happy to afford any further facilities within the power of the Department.

I am very respectfully

\&c \&c

Levi Woodbury

Honorable. L. MC Lane

Secy of the Treasury

Finally, on April 15, 1832, Audubon and his party were able to board the revenue cutter Marion, commanded by Robert Day, and the opportunity thus afforded for exploring the dangerous east Florida coast amply repaid them for their long and vexatious delays. They visited the islands from St. Augustine to Key West, and examined every part of the shore which it was the duty of the Marion to approach. At Indian Key the deputy collector, Mr. Thurston, gave Audubon the services of his pilot, a veteran sailor and hunter, who accompanied him on the Marion for a number of weeks and led many boat journeys to lonely islands, where vast colonies of sea fowl then dwelt in undisputed possession. The leisurely movements of the vessel also enabled the naturalist to produce many finished drawings, and to obtain materials for fresh "Episodes." ${ }^{17}$ At Key West Audubon was hospitably received by Major Classel, ${ }^{18}$ and by Dr. Strobel, who was of great assistance both to him and to Bachman in procuring new birds from that little known point.

The unexpected delays experienced in Florida, and the expense which the presence of his assistants neces-

${ }^{17}$ See "The Florida Keys," Ornithological Biography, vol. i, pp. 312 and 345, and "The Turtlers," ibid., vol. ii, p. 370.

${ }^{18}$ See Vol. II, p. 7. 
sarily entailed, in all probability, deterred the naturalist from the more hazardous and uncertain enterprise of attempting to reach the Rocky Mountains and the Pacific Coast, which for years had been the great object of his ambition. At all events, after their work was finished at Key West, the party returned to Charleston. When returning previously they had boarded the packet schooner Agnes, which was to bear them with their collections to Charleston. Audubon, however, left the vessel at Savannah, in order to deliver letters from the Rathbones of Liverpool to a number of their rich merchant friends in the former city. One of these, named William Gaston, ${ }^{19}$ at first declined to subscribe to The Birds of America, on the ground of its great expense and the demands made upon his purse by charity, but his indifference was quickly overcome: not only did he write his name on Audubon's list, but he immediately went out and obtained three other subscribers; he even insisted on becoming Audubon's agent at Savannah, and saw to it that none of those subscriptions was ever allowed to lapse in after years. Savannah eventually gave him six subscribers, which was more than were credited to either Philadelphia or Baltimore.

At Charleston the party disbanded. Lehman returned to Philadelphia, whither Audubon later followed him, but Henry Ward obtained a position with the Museum of Natural History, in which Bachman was interested, and he appears to have been of much assistance both to Bachman and to his friend in procuring for them specimens of new or desirable birds and mammals; at a later day, however, he seems to have fallen into disesteem on account of unpaid debts.

19 See "A Merchant of Savannah," Ornithological Biography (Bibl. No. 2), vol. ii, p. 549 . 


\section{CHAPTER XXVII}

\section{EASTERN VISIT AND EXPLORATIONS IN THE NORTH ATLANTIC}

Bachman's success as a canvasser-Boston visit-Journey to PortlandAscent of the St. John's-Return overland-Victor Audubon becomes his father's agent-Winter in Boston-The Golden Eagle-Stricken with illness-Expedition to Labrador planned-American supportSails from Eastport with five assistants-Discoveries and adventures on the Labrador-Safe return-Another winter at Charleston-Sued for old debts-Experience with vultures-Advice and instruction to a son-Working habits-Return to England.

Foiled in his attempt to see the Florida coast at the season best suited to his purposes, and disappointed in his ambition to penetrate to the Far West, Audubon now turned his attention to the East and determined to follow the migratory birds to their summer homes in the North Atlantic. He left Charleston in early June, 1832, and went to Philadelphia, ${ }^{1}$ where he remained about a month, waiting, it seems, for his wife and two sons to join him. In a letter to Edward Harris, dated at Philadelphia, June 9, 1832, he said that he had left the "National hotel, on account of the too high price, I found I would have to pay there, and removed to Camden, at a Mr.

${ }^{1}$ It was possibly during his visit to this city that an experiment was made in bringing out some of his plates by lithography. Two copies of a large plate, possibly the only one produced, lithographed without colors, were shown to me by Mr. Goodspeed, of Boston, in the summer of 1910; these represented the "Rallus crepitans-Marsh Hen," and bore the following legends: "By John J. Audubon, F.R.S., \&c., \&c.," and "Drawn \& Printed by Childs \& Inman, Philadelphia, 1832." Three birds are here figured in place of the two which appear in the plate of this species which Havell later engraved, and in composition the two publications are quite distinct. 
Armstrong's, where I formerly boarded"; he asked Harris to send him "a pair of fine woodchucks," as he wished to secure a drawing of those animals.

It is interesting to notice that while Audubon had been absent in Florida, his friend Bachman had busied himself in his behalf and eventually succeeded in placing three copies of The Birds of America in public institutions in Charleston. On December 23, 1831, he wrote to Audubon, who was then at St. Augustine:

I arrived in Columbia, S. C., almost too late, for the "House" had just resolved that the State was too poor to subscribe for Audubon's work. I felt that it would be a disgrace to the State; and, for the first time in my life, I turned to electioneering. And now, behold me among the back countrymen, spinning long yarns. The thing however, took, and your book is subscribed for. . . I I read what was said in your favor with regard to the "Rattlesnake Story," and thus far, they have not found a wrong twist in your yarn; but be careful in describing the wonders of the South and West.

Audubon wrote to Bachman from Philadelphia, July 1, 1832: "G. Ord has caused a most violent attack on my veracity to be inserted in a London journal; how will he stand mine eye, on Tuesday next at the Society, is more than I can at present tell. . . . Mr. Berthoud will ship you 3 volumes of the Birds of America, and the succeeding numbers; he will send a bill of sale of those."

His plan was now to visit Boston and Maine, and he left Philadelphia with his family in early August; they traveled by stage to New York, but upon finding that the city was then suffering from a periodic scourge of the cholera, tarried but a day and hastened on. The following letter which Richard Harlan sent after his 
friend in August of this year shows that his own city did not escape the pest:

\section{Richard Harlan to Audubon}

[Addressed] J. J. Audubon Esqr.

No Pearle st.

Boston

[Philadelphia, August, 1832.]

DeAr Sir-

I have just rec ${ }^{\text {d. }}$ your favour of the $5^{\text {th }}$ inst-by which I perceive you are not in possession of the letter I addressed you to the care of $M^{r}$ Berthoud, the day after your departure. I have since forwarded two others one from N. Orleans, also to care of $\mathbf{M}^{\mathrm{r}}$. Berthoud--The Cholera has raged dreadfully in some localities here-I was engaged on Monday superintending the removal of the sick prisoners from the jail in arch $S^{t}$ at the request of the City authorities-I was there three times during the day -60 were sick at one time, the suffering, and agony of the dying wretches, was an awful sight to witness, 26 died there that day, and about as many more who were removed to the various local Hospitals - I have treated altogether up to present date 35-of whom 18 from prison. 16 have diedand only one remains today-my success is rather encouraging considering the habits of the poor wretches whose cases fell under my care - most of the fatal cases were in a dying state when admitted-I would not have rec ${ }^{\mathrm{d}}$. them, but for the wish to alleviate suffering and scatter the tenants of the infected rooms of the jail-The Newspepers do not give an accurate account, because numbers are cured in the early stages whose cases are never reported - the statements of deaths are more accurate- and I suppose the greatest mortality has not exceeded 100 per diem-today only 26 deaths reported, there will probably be more tomorrow-I am happy to hear of $\mathrm{yr}$. safe arrival and reception in Boston, in $\mathrm{M}^{\mathrm{r}}$ Perkins you will find an aimable, liberal, and efficient patron, $\mathrm{M}^{\mathrm{r}}$ Featherston [Featherstonhaugh] has been in town, but is at present at 
Braddywine springs - his may $\mathrm{N}^{\circ}$ has just appeared-he told me it would be in time to strike out Vignolas name-in the next No My term of duty as Surgeon to the alms House commenced at the $1^{\text {st }}$ of August-the sik for the surgical wards have also suffered, but not so much as the poor tenants of the cells, it has nearly cleaned them out-some respectable, but weakly families in the city have already suffered-My time is usefully, at least, if not profitably employed, night and day. cholera, cholera, cholera! ! ! ! - Tho' I may have no time to write much-I always think of absent frd- Remember to Nuttall, and all yr. family,

Most truly yrs

R HarLaN

Audubon's visit to Boston in the summer of 1832 was a red-letter period in his career. So warmly was he then welcomed by the leading public and professional men of the city that he could never say enough in praise of the Bostonians. Dr. George Parkman, Dr. George C. Shattuck, and Col. Thomas H. Perkins, ${ }^{2}$ who was already one of his subscribers, were among his most enthusiastic supporters. Of Parkman Audubon said: "He it is, whose memory is most dear to me." It was doubtless Parkman, then a prominent physician in Boston, who introduced Audubon to the president of Harvard University, Josiah Quincy, whose name was added to his list.

On August 14, shortly after reaching Boston, Audubon wrote to his friend Harris:

${ }^{2}$ In a letter written to Audubon by his engraver, January 20, 1831, Havell said: "Since writing my last, I have a new subseriber from America, the Honble. T. H. Perkins, Boston Athenæum. I packed it in a tin case, and a wooden one; for the whole I am paid thro. the banking house of the Baring Brothers, \& Co., Bishopsgate St."

The copy of The Birds of America in possession of the Boston Society of Natural History bears the following in autographic inscription on the fly-leaf of the first volume:

Cost $\$ 1125-$

T. H. Perkins

1837. 
We left Camden, pushed by the season, and the desire I have to fulfil towards my subscribers, the world, and indeed myself, the task allotted me by nature,- the completion of my work. . . Allow me to say that with my work, as in the days of '\%6, the Bostonians have proved themselves the best supporters of a good cause in the country. We expect the support of the Cambridge University, that of the Natural History Society, \& again of the State! (Pray remember how anxious we are to have all the States.)

I made drawings of 3 rare species; one is the Marsh Wren, for which I searched in vain when near Salem; the $\mathbf{2} \mathrm{d}$. is a Flycatcher, described by Mr. Nuttall, and the last a Thrush.

We leave tomorrow for Portland, in Maine, through which we will merely pass, and ere one week expires, expect to be at the Bay of Fundy.

The Audubon family now traveled by carriage and mail-coach along the entire coast of Maine, but made no prolonged stay until they reached Eastport, where excursions were taken into the surrounding country, and the woods and shores were thoroughly ransacked. At Dennisville they made the acquaintance of Judge Lincoln's family, which rendered their stay of a number of weeks "exceedingly agreeable"; as will appear later," it was this agreeable family that furnished Audubon with a valuable recruit for his expedition to Labrador. Towards the end of September they entered New Brunswick and began to ascend the St. John River. A week was passed at Fredericton, where they were hospitably received by Sir Archibald Campbell. Thence they continued in a small boat, which was towed upstream by mules, to Woodstock, N. B. There a cart was procured, in which they proceeded overland to Houlton, in Aroostook County, then "A neat village, 
consisting of some fifty houses," and after a few days passed at this garrison town in looking for new birds, they started for Bangor, following the old military road which led along the Penobscot River to Old Town. Said the ornithologist of this journey:

Autumn, with her mellow tints, her glowing fruits, and her rich fields of corn, smiled in placid beauty. Many of the fields had not been reaped; the fruits of the forests and orchards hung clustering around us, and as we came in view of the Penebscot river, our hearts thrilled with joy. ...

The road which we followed from Old Town to Bangor was literally covered with Penobscot Indians, returning from market. On reaching the latter beautiful town, we found very comfortable lodgings in an excellent hotel; and the next day we proceeded by the mail to Boston. ${ }^{4}$

Audubon felt that he ought to remain in America for at least another year, and decided to send his son, Victor, to England to take charge of his publication. This work had now become a paramount family interest, and for the nineteen years of life that remained to the elder Audubon, his two sons virtually became his assistants, John as an active collector and companion in the field, and Victor as his business agent and secretary. In writing again to Edward Harris, from Boston, November 1, 1832, Audubon noted that they had found the Canada Grouse in abundance, and that he was assured of its breeding commonly within the Union; Victor, he added, had sailed to England, "on the tenth of last month" on the packet ship South America.

The autumn of 1832 and the following winter were spent in Boston, where the naturalist was busily engaged in drawing and in laying plans for the now famous ex-

"See "Journey in New Brunswick and Maine," Ornithological Biography (Bibl. No. 2), vol. ii, p. 467. 
pedition to the coast of Labrador. Meantime Bachman, who was keenly interested in his success, was urging him to return to Charleston; on October 20, 1832, he wrote: "A month in your society would afford me greater pleasure than the highest prize in a lottery. I cannot, I find, feel myself at home with new birds without having the skins to refer to. My cabinet is enlarging every day. Henry Ward now prepares the skins-a pair of each. ... What ducks, that are not likely to be obtained for you in Boston, would you like Maria to draw for you?"' Writing again on the 26 th of October, he said: ${ }^{5}$

I wish to know what you are doing-what progress your work is making; and, whilst I feel deeply interested for your fame. ... I feel also a particular interest in your personal welfare, and that of all that belongs to you; . . . Besides, I want to see you once more to ascertain whether you have stuck to your good resolutions, viz., never to swear (which is a vulgar practice for one who is conversant with the most beautiful of God's works, the feathered race), and never to work on Sundays. However, you are now under the tutorage of your good wife, and, I doubt not, you are as obedient to her in these things, as you ought to be. . . . You say new birds are scarce. So they are, and yet, in my opinion, we will occasionally find them for half a century to come. (November 11) Maria has figured for you the "White Hibiscus," and, also, a red one, both natives and beautiful; a Euonymus in seed, in which our Sylvia is placed; the white Nondescript Rose; the Gordonica, a Begonia. . . . She is prepared to send them to you; shall she ship them at once to Boston? ... Y Your resolution to publish the $3 \mathrm{rd}$. Vol. of Water Birds, you will recollect was partly entered into here, and from that moment, my mind was at ease. It will give you four or five years in advance, and will enable you, in a 5th. Vol., to add all recent

${ }^{5}$ C. L. Bachman, John Bachman, D.D., LL.D., Ph.D. (Bibl. No. 191)。 

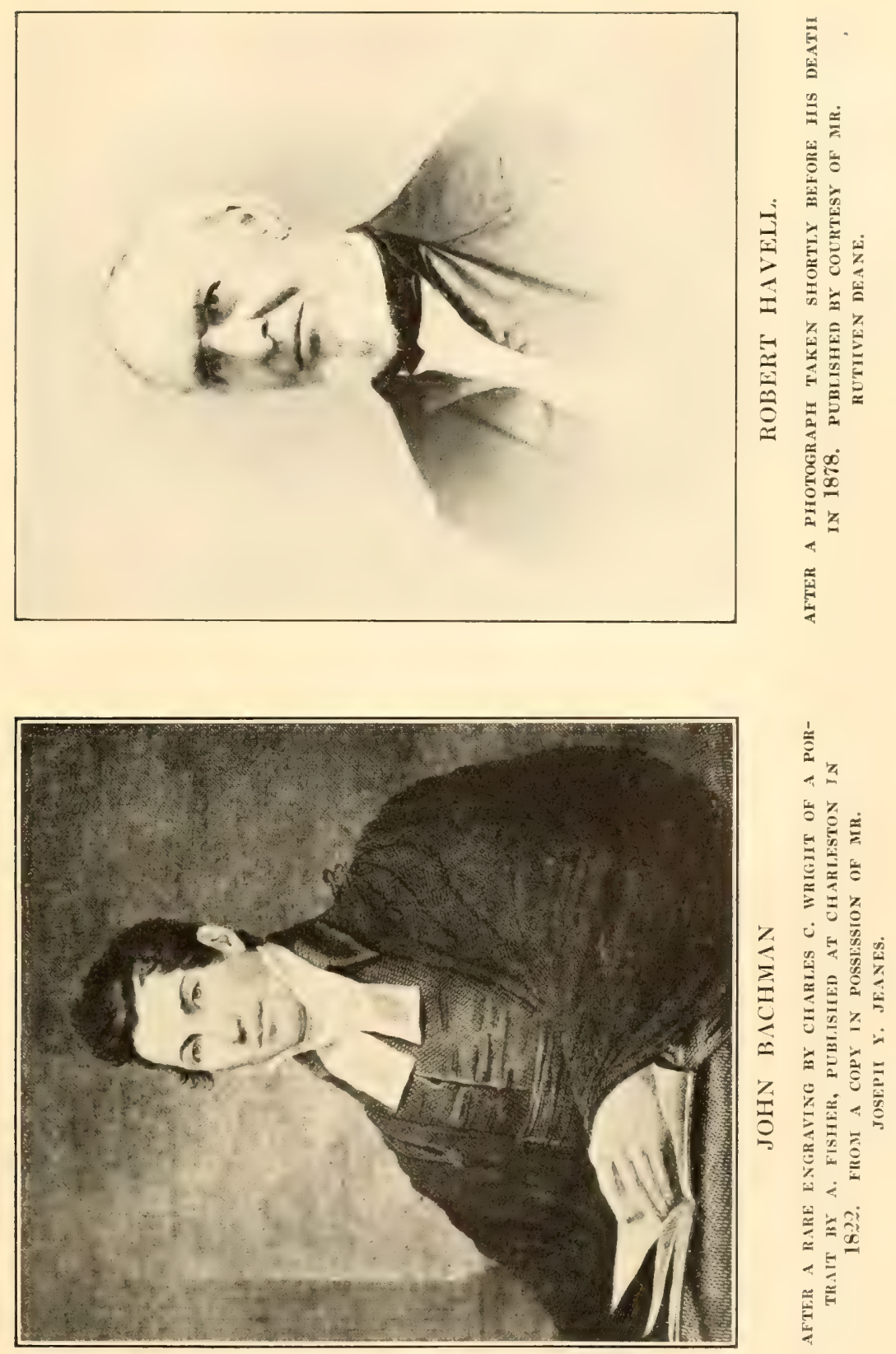

discoveries of Land and Water Birds. Should you, yet be able to go to Florida and the Pacific, I apprehend that you will extend our American Ornithology to 460 or 470 species, perhaps more. Your sons being able to skin birds and paint them, is a great desideratum; it should be mentioned in the preface to your next volume. The talents of the family combined. . . will now place the work beyond the fear of falling through, even in case of your death, and the public ought to know it. But you must push for subscribers. If your son Victor can do nothing in Europe, you must go there yourself, and sooner than let the work suffer, you must go on a pilgrimage throughout all the great cities of our Union. Should God spare your life, I want to hear of you enjoying, in your old age "Otium cum dignitate," and to see your children reaping some of your recompense.

Under date of December 20, 1832, his friend "had nothing to write but bad news," and hoped "to see our political atmosphere a little brighter. Do not ask me about birds; I do not know a Buzzard from a King Bird. ... Oh, what an enjoyment it would be for me to escape, just for one week, from the hydra-headed 'Nullification,' and sit by your side and talk birds!"

Audubon was anticipating his third volume of plates, devoted mainly to water birds, which was begun with Number 45, in 1834, when the following letter was sent to his son in London:

Audubon to his Son, Victor

My dear Victor-

Boston, Jany, 17 th, 1833-.

The Columbia arrived yesterday at New York, and N [icholas]. B [erthoud]. has forwarded us Mr. Havell's letter and yours, both dated 30 th. of November last-. I hope soon to see the drawings to work on them-. You give no 
account of that of The Bartram Sandpiper and of The Spotted Sandpiper-; probably they have escaped you-let me know so that I may renew these should they be missing-, but I think my Friend Children has them--enquire-

The Charlotte is not yet in. She had not left Deal on the 27th of Nov r.-

Your Dear Mother \& John wrote to you this morning and you will probably receive this, and that letter at the same moment-.

We will keep all the half Bound Copies of Volume 1st. in America where I hope soon to dispose of them-go on and push the Work with care and all will be well-give our best regards to Havell \& his wife \& family-I had expected the Death of his Father ${ }^{6}$ sometimes-remembrances to our good friend Children, Cuthbutton \&c., \&c. I will be able to arrange 100 Drawings of Water Birds, ready, and in that finest of style for Publication-Tell Havell I will write to him in a very few Days, and to keep up a good Heart-I hope we will all meet early in the Spring of 1834-

God bless you my Dear Victor: employ your time well and [you] cannot fail being as Happy, at least as it is possible to be, far away from your Dear Mother, John \& Your ever affectionate Father \& Friend,

\section{John J. Audubon}

Send the Gun \& Drawing Paper of $\mathrm{N}$-Largest \& Middle Size as quick as possible-

[Addressed] Victor G. Audubon Esqr.,

Care of

Roвt. Havelt, Esqr.,

Engraver,

77 Oxford Street,

London.

While at Boston in the winter of 1833, Audubon obtained from the proprietor of the New England Mu-

\footnotetext{
${ }^{6}$ For notice of Robert Havell, Senior, who died in 1832, see Vol. I, p. 382.
} 
seum, in Court Street, a superb specimen of the Golden Eagle, which had been caught in the White Mountains in a trap set for foxes. Possessed with a desire to depict this noble bird, he worked so hard at the drawing that, as he said, it nearly cost him his life; he was suddenly seized with "a spasmodic affection," which prostrated him for a time and greatly alarmed his family, but thanks to a strong constitution and to the aid of his medical friends, Doctors Parkman, Warren and Shattuck, the crisis was averted, and he was soon able to continue his labors. "The drawing of this Eagle," said the naturalist, "took me fourteen days, and I had never before laboured so incessantly excepting at that of the Wild Turkey." He was at work on this painting when the following letter ${ }^{7}$ was dispatched to his eldest son:

\section{Audubon to his Son, Victor}

Boston.

f'eb. 5 th 1833.

\section{My deAR FRIENDS}

I am just now quite fatigued by the drawing of a Golden Eagle which although it will make a splendid plate has cost me sixty hours of the severest labor I have experienced since I drew the Wild Turkey. You shall I hope see it through the care of $\mathrm{Mr}$. Gordon. ${ }^{8}$ Do not ever ship any more Nos. to this port unless on vessels that are intended as packets. The Charlotte has not come and it will be a rubber if $\mathbf{I}$ can get enough cash to establish our going to Labrador until she does. Push Jos. B. Kidd of Edinburgh if he can be pushed to paint copies of our drawings. I look on that series as of great importance to us all. Havell's blunder in not having the num-

${ }^{7}$ Originally published by Ruthven Deane (Bibl. No. 48), The Auk, vol. xxii, 1905.

${ }^{8}$ Alexander Gordon, who married Ann Bakewell, youngest sister of Mrs. Audubon. For notice of Jos. B. Kidd, mentioned below, see Vol. I, p. 446 . 
bers and paper on board the New York in time, is one which, with him I can never correct. If you can do more than I on this score of punctuality I will be gratified. I shall proceed to New York as soon as the weather moderates, on Sunday last the thermom. was 12 below zero. The work is now I am assured free of duty. When you write give a word of recollection to Dr. Parkman who is a most desirable and worthy friend.

God bless you, forever yours

J. J. Audubon.

In the spring of 1833 Audubon was determined to carry out a long cherished desire to explore the coast of Labrador, where he hoped not only to discover many new birds, but to ascertain the summer plumages and breeding habits of a host of water fowl that were known to resort in the milder season to that stern and rockbound shore. Accordingly, he set about with characteristic energy to organize and finance an expedition upon his own responsibility. The number of his American subscribers was steadily increasing, and at that moment he felt a degree of confidence in the future of his work to hazard almost any undertaking. In April, when his plans were fixed, he went to New York to consult with his wife's brother-in-law and agent, Nicholas $\mathbf{A}$. Berthoud, and to settle his business affairs before leaving the country. While there he wrote the following long letter ${ }^{9}$ to his son, Victor, filled, as usual, with careful instructions and interesting personal details. It will be noticed that when he took pen in hand the number of his American subscribers stood at 51, but before he laid it down it had risen to 54 ; his belief that his efforts in the cause of natural science would receive a hearty response in his own country was fully justified.

${ }^{\circledR}$ Originally published by George Bird Grinnell (Bibl. No. 54), The $A u k$, vol. xxxii, 1916. 


\section{Audubon to his Son, Victor}

NEW York April 28th 1833-

My dear Victor-

On opening the box containing the numbers last sent to this place for distribution, we found the contents Wet and of course some of them damaged. We have however dried them and made of them that could be done and they will all go on Monday (tomorrow) to their Several destinations-In future I recommend that Each parcel of numbers for the different individuals are rolled up in separate Parcel, inclosed in good stout brown Paper, and each directed outside, enumerating the numbers therein contained-then put all the Rolls in a Boxin this manner they all will be less liable to Injury, will not need to be undone here for we have no trouble at al! at the Custom House, and it will Save the handling of the Plates at the Compting House.-

N. Berthoud rendered me his account yesterday I send you inclose a Copy of it-and I also send you a Copy of a general \& particular memorandum left with him, by the assistance of which the Business is clearly exhibited, so that each Subscriber's Standing with the Work Shows at once.-

The Balance in our favor in N. Berthoud's hands is $\$ 1358.91-W e$ have due South of this $\$ 1834.48$. and at Boston $\$ 1220.00$-altogether $\$ 4413.39$. - The Boston amount will be ready for me when I reach there on Thursday next.-I take from N. B's hands here $\$ 800: 00--300 \$$ of which I give to your Dear Mother-when at Boston I will take $500 \$$ more and send the Balance to N. Berthoud-he will then have about $\$ 1278.91$ of cash out of which he will send you $100 £$ say $480 \$$ leaving still with him about $\$ 798.91$. besides what he will collect from the South the amount which is mentioned above, all of which I hope will be collected ere I return to this Place, as early as I can without losing the opportunity of doing all that can be done.

You will easily perceive by all this that we have been extremely fortunate of late on this Side of the Water, and the 
$400 £$ forwarded to you will fully enable you to meet the demands of Havell $\&^{c}$ for the 20 Volumes you have to send here $\&$ other emergencies.-We have at Present 51 Subscribers in the U. States, without the name of Docr Croghan from whom not a word has been heard, and also without that of Baron Krudener who is now at Washington City, but who has not taken any cognisance of the letter I sent him. N. Berthoud is going to write to him and I hope the Baron will take the work. - he certainly ought.

I found the Plates sent here better coloured than usual and with your present assistance I greatly hope the goodness of the Work will still improve.-Nicholas will forward you Two very beautiful Numbers-the Plates are as follows,

No 3\%. Plate 181. Golden Eagle........... Figures 1 "-182. Ground Doves......... " " 5

"_-183. Golden crested Wren.... " " 2

"-184. Mangrove Humming Bird. " 5

"-185. Bachman's Warbler ..... 2

No 38. - "-186. Pinnated Grous.........

"-187. Boat Tail Grackle...... " 2

"-188. Tree Sparrow ....... "

"-189. Snow Bunting ........ " 3

"_-189. Yellow bellied Woodpecker. " 2

I should have sent you 2 more Numbers had I The Two large Plates for them, but hoping that I may meet with something Large \& perhaps New I Shall not do so, until I return which will be Still time enough.-I am very anxious to See the $2 \mathrm{~d}$ Volume finished and for this reason invite you to push the Work, as much as you can \& have it very well executed meantime.

The State of Maryland is subscribed to by D. Ridgely M.D. Librarian of that State. he desires the $1^{\text {st }}$ Volume and the following numbers forwarded as soon as can be.--Send it here - as he has authorized N. B. to draw on him for Payment.- 
Miss Harriet Douglass also desires to have her Number sent here for the Future. I hope the Copies for $\mathrm{Co}^{1}$ Perkins \& othere at Boston \& vicinity, as well as for $\mathrm{W}^{\mathrm{m}}$ Oakes, \& John Neale will soon arrive.-

April $30^{\text {th }}$-Since the above, I have obtained Two more Subscribers-the names of whom are

1. Rich ${ }^{d}$ F. Carman. New York

1. L. Reed-— Do Do.-

I was told last night that the State has also Subscribed, but cannot tell until I see this day's Paper-Whilst at the Lyceum of Natural History last evening, I was promised their Subscription on Monday next-being the Society's day of business.

I have concluded to send the 2 Numbers of Drawings by the Packett-The Tin case containing them, will be given to the special care of the $\mathrm{Cap}^{\mathrm{n}}$ on whom you will do well to call immediately. - I have given a $1^{\text {st }}$ Volume to Nicholas Berthoud; there are many enquiries made to see the Work and it answers that purpose well.

John \& I leave for Boston either this afternoon or tomorrow-perhaps tomorrow as we have much to do.-It is not probable that $\mathbf{E d}^{\mathrm{d}}$ Harriss will join us at East Port and go to Labrador with us-I shall write to you at every opportunity as these may occur, and doubtless from Halifax.

$M^{\mathrm{r}}$ Inman has painted my Portrait in Oil, and $I$ say that it is a truer portrait of me than even the Miniature.-Now my Dear Victor exert yourself in the having all the Volumes compleated which I have written for-See that they are carefully packed with Paper between each $\&^{\mathrm{c}} \&^{\mathrm{c}} \&^{\mathrm{c}}$ I shall not close this until I have given the Box to the $\mathrm{Cap}^{\mathrm{n}}$ and when I hope to add the Subscription of this State-

2, o'clock-I have just returned from the bustle of the Lower part of the City-the State has Subscribed! Therefore add that valuable one. There is no Packet for London Tomorrow, therefore the Drawings will go off on the $10^{\text {th }}$ of May by the $\mathrm{Cap}^{\mathrm{n}}$ in whose particular care they 
will be given.-These 10 Drawings have been insured this morning against all Risk, for $2,000 \$$ at $1 / 2$ per Centum-I hope you will receive them in perfect order; they are carefully packed by myself in a Tin Box securely sodered $\&^{c} \& c$.

We have now 54. Subscribers in America.

$M^{r}$ Inman is going to Paint the Portrait of your Dear Mother, and I have not a doubt that it will be "good \& true." The Weather is extremely Warm-The Thermometer ranges at nearly 72. The Martins are flying over the City and Tomorrow I shall fly toward the Coast of Labrador-If fortunate I shall bring a load of Knowledge of the Water Birds which spend the Winter in our Country and May hope to Compete in the study of their Habits with any Man in the World.

My Good Friend Charles Bonaparte as (I am told) taken umbrage at a Passage in My Introduction (first Volume) ${ }^{10}$ Which proves how difficult it is to please every one-I am going to write to him by Duplicate to try to correct that Error of his-God ever bless You my Dear Son, and May We all meet Well \& Happy

Yours ever affectionately,

John J. Audubon.

Audubon was particularly anxious to enlist a number of enthusiastic young men in the Labrador enterprise, and had hoped that his friend, Edward Harris, would join the party. Upon his return to Boston he started at once for Eastport, Maine, where he expected to charter a vessel and complete his preparations. On May 9, 1833, he wrote to Harris from that point:

The more I approach the desired object of this voyage, the more bouyant my spirits, and the greater my hopes that when I return I will bring a cargo (not of codfish) but of most valuable information. Make up your mind; shoulder your firelock, and away to the fields where science awaits us with ample

${ }^{10}$ See Chapter XXIX, p. 119, and the letter which Audubon wrote to Bonaparte at this time. 
stores, the contents of which are the rarest materials ever employed by nature.

To this friend he wrote again from Eastport on the 14th of the same month:

As to my making use of your name in my letterpress, I shall act as you desire, and yet I hope and fully expect no denial on your part, on such occasions as will grant me the pleasure of giving public notice of the treatment I have received from you. I owe such a thing to you as a trifling, very trifling, mark of my gratitude towards one, whom I shall never cease to admire and esteem.

The National Gazette of Philadelphia for May 2, 1833, devoted an editorial to Audubon and his prospective Labrador journey, in which the writer said: "We wish him a degree of success and prolongation of vigor equal to his great merits: indeed, for the past at least, success is fully assured." He added that between fifty and sixty subscribers to The Birds of America had then been obtained in the United States; Boston had furnished eighteen; New York, eleven; Philadelphia, four; Baltimore, eight; Savannah, seven; Louisville, two, and New Orleans, three; moreover, the legislatures of Massachusetts, New York, Maryland and South Carolina and the Congressional Library were subscribers for one copy each. The writer continued:

A contribution to Mr. Audubon equal at least to that of Boston or New York, would seem due from Philadelphia. The subscription price may be considered as large $(\$ 1,000)$, but how rich, ornamental, instructive, and entertaining is the work, and how much preferable to the merely personal gewgaws or transitory gratifications, upon which greater sums are as frequently expended! There are few minds of any refinement or 
elevation, to which an act that rewards genius and fosters science, would not yield higher and more durable pleasure than any ordinary luxury.

We learn that Mr. Audubon will return to the United States next autumn, and make a short sojourn before his embarkation for Europe. Eight or nine more years, it is supposed, will yet be necessary for the consummation of his grand design. His constitution appears to be still vigorous; his zeal is unabated; his powers of graphic delineation have suffered no decay; we may, therefore, expect that he will realize all his own laudatory hopes and projects, and in so doing confer new obligations on the votaries of natural history, and reflect additional honor on his country.

While Audubon was still at Eastport, and looking anxiously for young recruits, the following letter was received from Dr. George Parkman: ${ }^{11}$

\section{Dr. George Parkman to Audubon}

\section{J. J. Audubon Esqr.}

Boston, May 25 th. 1833.

\section{DeAR Sir}

Through the unceasing \& active good-will of our Friend, Dr. Shattuck, I present to you Mr. Ingalls, son of Dr. Ingalls, one of our senior physicians \& an experienced public teacher of Anat.y \& Surg y-

The son is the father's pupil; \& we have reason to expect that he will prove a satisfactory disciple to you.

The enclosed I claim for you the right to read, \& for myself to repossess, when we meet again.

$$
\text { respectfully }
$$

\section{G. Parkman.}

${ }^{11}$ Most readers will doubtless recall that Dr. George Parkman was the victim of an almost unbelievable tragedy in 1849 , when he met his death at the hands of a colleague; the entire country was then aroused as it seldom had been by an event in the annals of crime. 
Edward Harris was unable to accompany his friend, and the four young men eventually chosen were $\mathbf{J}$ oseph Coolidge, ${ }^{12}$ William Ingalls, of Boston, Thomas Lincoln, of Dennisville, Maine, and Greorge Cheyne Shattuck, ${ }^{13}$ the son of Dr. George C. Shattuck of Boston; these, with John Woodhouse Audubon and the natural-

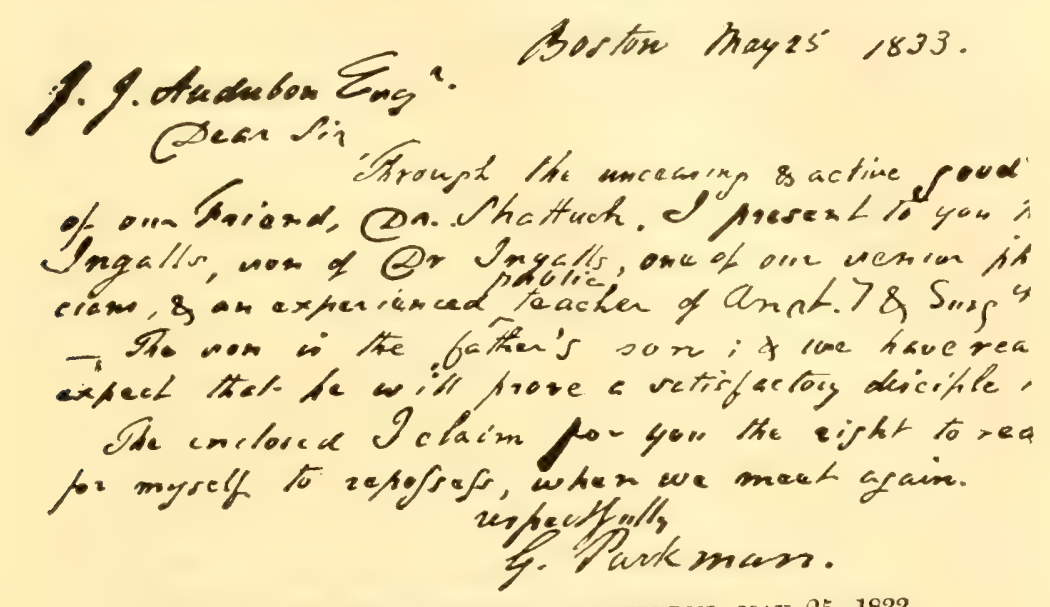

LETTER OF DR. GEORGE PARKMAN TO AUDUBON, MAY 25, 1833.

From the Howland MSS.

ist, made up the party. 'The schooner Ripley, a staunch new vessel of 106 tons, was chartered at Eastport, and the expedition was ready to start by the latter part of May. During his stay at Eastport Audubon visited Grand Manan Island, a favorite resort for sea birds in the Bay of Fundy, and cruised about the coast in a revenue cutter. On May 31, he wrote to Victor: ${ }^{14}$

${ }^{12}$ In 1897 Mr. Joseph Coolidge, who was then living in San Francisco, was the sole survivor of this expedition; see Maria R. Audubon, Audubon and his Journals (Bibl. No. 86), vol. i, p. 347.

${ }^{13}$ Dr. George Cheyne Shattuck, like his father a philanthropist, and an ardent patron of all good works, in 1855 planted a seed on the rocky soil of New Hampshire which has since shown a marvclous vitality; to him primarily, and to the revered schoolmasters, the Reverend Dr. Henry Augustus Coit and the Reverend Dr. Joseph Howland Coit, the world owes that great foundation, St. Paul's School.

${ }^{14}$ Maria R. Audubon, op. cit., vol. i, p. 346. 
I have been working hard at the Birds from Grand Menan, as well as John, who is overcoming his habit of sleeping late, as I call him every morning at four, and we have famous long days. ..

The hull of the vessel has been floored, and our great table solidly fixed in a tolerably good light under the main hatch; it is my intention to draw whenever possible, and that will be many hours, for the daylight is with us nearly all the time in those latitudes, and the fishermen say you can do with little sleep, the air is so pure.

After repeated delays the Ripley sailed from Eastport for Labrador on June 6, 1833, and the journey proved arduous and hazardous enough. Although disappointing in respect to the number of new species of birds discovered, Audubon's visit was well timed; he was aided by a band of devoted and energetic youth, and they spent two months on the coast of a wild country, then but little known save to a nefarious crew of egg robbers and a few enterprising fishermen. His published journal of the voyage shows that he worked to the full limit of his physical power's in studying and portraying the wonderful bird life which the party encountered. Despite the miseries of seasickness, an incompetent pilot, tempestuous weather, and the cramped quarters of a small schooner, where all his drawings had to be done under an open hatch, he accomplished wonders, considering the shortness of his stay. By rising at three o'clock in the morning and working for seventeen hours, he succeeded in completing many large drawings of birds, as well as studies of characteristic flowers; he also journalized voluminously and saw much of the coast and its adjacent islands.

From Eastport they passed through the Gut of Canso and steered for the Magdalen Islands, where they 
landed and made collections. On June 14 they approached the famous Bird Rock, which at a distance seemed to be covered with a mantle of new-fallen snow, an illusion soon dispelled as their vessel bore them nearer and a vast concourse of Gannets rose in great clouds from the rock; "all stood astonished and amazed," said Audubon, and he felt that such a sight had of itself fully repaid them for their journey. On June 17, the twelfth day out from Eastport, they passed Anticosti Island, and soon began to see what appeared like white sails on the horizon; these proved to be snow drifts on the Labrador, and on the 18th they landed at the mouth of the Natashquan River. Ducks, Geese, Auks and Guillemots were there in great multitudes, as well as Gulls and Terns; many were breeding, and all seemed wilder than at points farther south, a circumstance which was explained as soon as they discovered the astounding proportions which the traffic in eggs of sea fowl had attained even at that time. ${ }^{15}$

On June 27 they procured a new bird ${ }^{16}$ which Audubon named after his young companion, Thomas Lincoln of Dennisville, Maine, and which is still known as "Lincoln's Finch." This reference is found in his journal for the 4th of July: "I have drawn all day, and have finished the plate of the Fringilla lincolnii, to which $I$ have put three plants of the country; to us they are very fitting to the purpose, for Lincoln gathered them."

The Ripley left its anchorage at American Harbor or Natashquan on June 28, and stood out to sea, their usual recourse to avoid the intricacies of the coast. After proceeding fifty miles or more they touched at numerous

${ }^{15}$ See "The Eggers of Labrador," Ornithological Biography (Bibl. No. 2), vol. iii, p. 82 .

${ }^{16}$ Lincoln's Finch, Fringella lincolnii, now Melospiza lincolni. 
islands, where Guillemots, Puffins, and Black-backed Gulls were breeding in vast numbers, and managed to anchor safely, in spite of that "ignorant ass" of a pilot, at a wild and desolate point which a recent traveler has identified as the harbor of Wapitagun. ${ }^{17}$ July the second was such a beautiful day for Labrador that Audubon went on shore, where he drew this vivid picture of that desolate land in sunshine: ${ }^{18}$

The country, so wild and grand, is of itself enough to interest any one in its wonderful dreariness. Its mossy, grayclothed rocks, heaped and thrown together as if by chance, in the most fantastical groups imaginable, huge masses hanging on minor ones as if about to roll themselves down from their doubtful-looking situations, into the depths of the sea beneath. Bays without end, sprinkled with rocky islands of all shapes and sizes, where in every fissure a Guillemot, a Cormorant, or some other wild bird retreats to secure its egg, and raise its young, or save itself from the hunter's pursuit. The peculiar cast of the sky, which never seems to be certain, butterflies flitting over snow-banks, probing beautiful dwarf flowerets of many hues [that are] pushing their tender stems from the thick bed of moss which everywhere covers the granite rocks. Then the morasses, wherein you plunge up to your knees, or the walking over the stubborn, dwarfish shrubbery, making one think that as he goes he treads down the forests of Labrador. The unexpected Bunting, or perhaps Sylvia, which perchance, and indeed as if by chance alone, you now and then see flying before you, or hear singing from the creeping plants of the ground. The beautiful fresh water lakes, on the ragged crests of greatly elevated islands, wherein the Red and Black-necked Divers swim as proudly as swans do in other latitudes, and where the fish appear to have been cast as

${ }^{17}$ See Charles W. Townsend (Bibl. No. 234), The Auk, vol. xxxiv, p. 133 (1917).

${ }^{28}$ Maria R. Audubon, op. cit., vol. i, p. 386. 


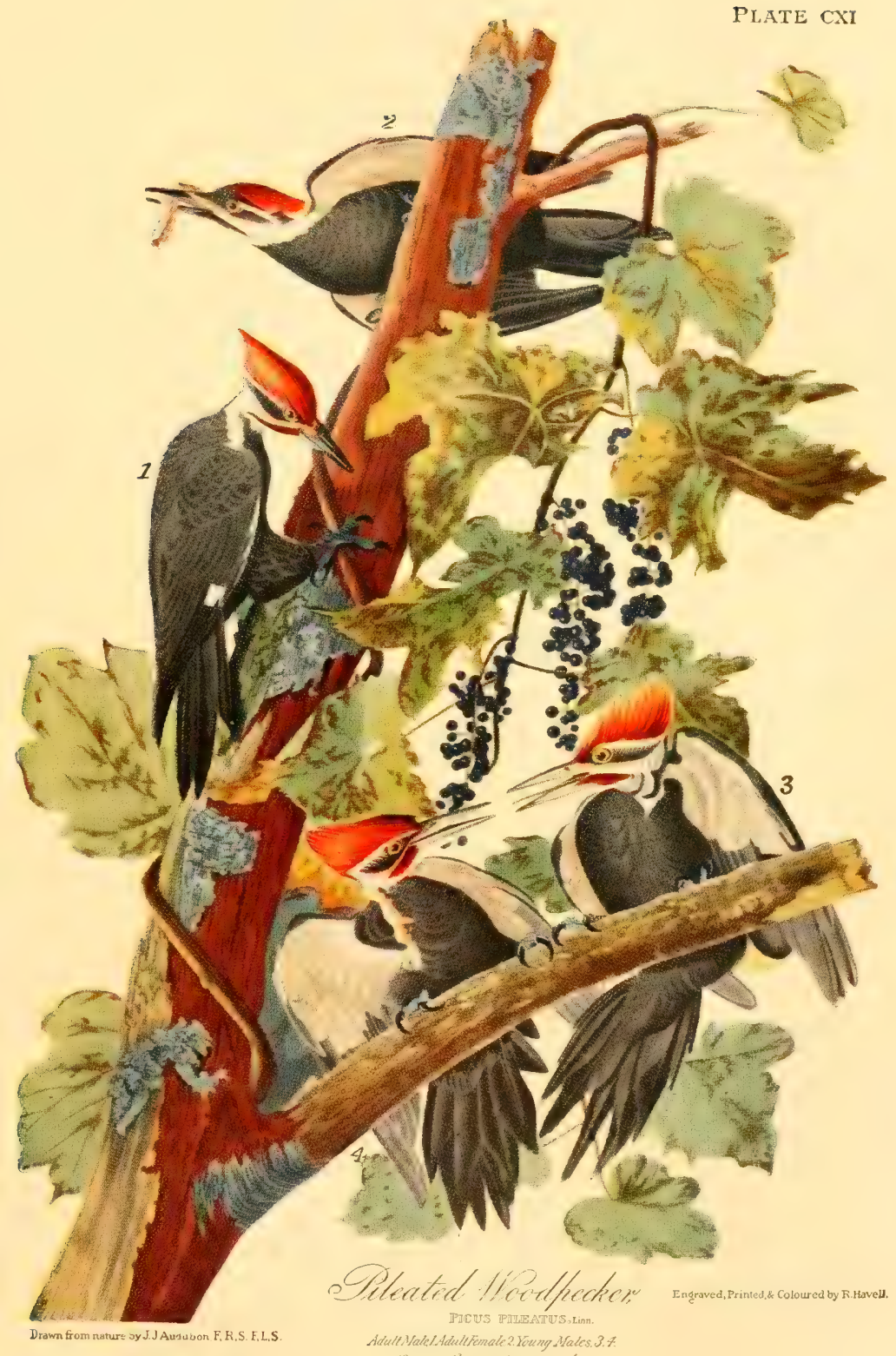



strayed beings from the surplus food of the ocean. All-all is wonderfully grand, wild-aye, and terrific. And yet how beautiful it is now, when one sees the wild bee, moving from one flower to another in search of food, which doubtless is as sweet to it, as the essence of the magnolia is to those of favored Louisiana. The little Ring Plover rearing its delicate and tender young, the Eider Duck swimming man-of-war-like amid her floating brood, like the guardship of a most valuable convoy; the White-crowned Bunting's sonorous note reaching the ear ever and anon; the crowds of sea-birds in search of places wherein to repose or to feed: how beautiful is all this in this wonderful rocky desert at this season, the beginning of July, compared with the horrid blasts of winter which here predominate by the will of God, when every rock is rendered smooth with snows so deep that every step the traveller takes is as if entering into his grave; for even should he escape an avalanche, his eye dreads to search the horizon, for full well does he know that snow, - - snow, is all that can be seen. I watched the Ring Plover for some time; the parents were so intent on saving their young that they both lay on the rocks as if shot, quivering their wings and dragging their bodies as if quite disabled. We left them and their young to the care of the Creator. I would not have shot one of the old ones, or taken one of the young for any consideration, and I was glad my young men were as forbearing.

\section{On the 6 th of July he wrote: ${ }^{19}$}

By dint of hard work and rising at three, I have drawn a Colymbus septemtrionalis [Great Northern Diver] and a young one, and nearly finished a Ptarmigan; this afternoon, however, at half-past five, my fingers could no longer hold my pencil, and I was forced to abandon my work and go ashore for exercise. The fact is that I am growing old too fast; alas! I feel it,- -and yet work I will, and may God grant me life to see the last plate of my mammoth work finished. 
On the seventh there is this note:

Drawing all day; finished the female Grouse and five young, and prepared the male bird. The captain, John, and Lincoln, went off this afternoon with a view to camp on a bay about ten miles distant. Soon after, we had a change of weather, and, for a wonder, bright lightning and something like summer clouds. When fatigued with drawing I went on shore for exercise, and saw many pretty flowers, amongst them a flowering Sea-pea, quite rich in color... The mosquitoes quite as numerous as in Louisiana.

On July 14 the Ripley took the party forty-three miles farther east to Little Maccatina, or Hare Harbor, as it is called today, where they remained until July 21, proceeding thence to Baie de Portage. Here they were able to enter their small boats, and visited the captain of a whaling schooner from New Brunswick, a Canadian trapper, and a Scotchman, Samuel Robertson by name, who was engaged in the sealing industry at Sparr Point, all of whom Audubon pumped for information on the country and its products. On July 25, they started for "Chevalier's Settlement," but were caught in a storm, and came to in Bras d'Or (Bradore) Bay; there they found the Labrador Duck, which in 1875, but forty-two years later, had become totally extinct.

At the approach of August the brief Labrador summer, of barely one month, was drawing to a close, and Audubon was exerting his utmost efforts to accomplish his purposes. Under date of August 10 he wrote: ${ }^{20}$

$\mathrm{My}$ reason for not writing at night is that $\mathrm{I}$ have been drawing so constantly, often seventeen hours a day, that the weariness of my body at night has been unprecedented, by such work at least. At times I felt as if my physical powers

${ }^{20}$ Ibid., p. 425. 
would abandon me; my neck, my shoulders, and, more than all, my fingers, were almost useless through actual fatigue at drawing. Who would believe this? Yet, nothing is more true. When at the return of dawn my spirits called me out of my berth, my body seemed to beg my mind to suffer it to rest a while longer; and as dark forced me to lay aside my brushes I immediately went to rest as if I had walked sixty-five miles that day, as I have done a few times in my stronger days. Yesternight, when I rose from my little seat to contemplate my work and to judge of the effect of it compared with the nature which I had been attempting to copy, it was the affair of a moment; instead of waiting, as I always like to do, until the hazy darkness which is to me the best time to judge of the strength of light and shade, I went at once to rest as if delivered from the heaviest task I ever performed. The young men think my fatigue is added to by the fact that I often work in wet clothes, but I have done that all my life with no ill effects. No! no! it is that I am no longer young. But I thank God that I did accomplish my task; my drawings are finished to the best of my ability, (and) the skins well prepared by John.

On the 11th of August all hands parted with Labrador without regret, and the captain of the Ripley steered for Newfoundland, where they landed in St. George's Harbor on the 13th. That region was searched for five days, when a fresh start was made for Pictou, Nova Scotia, but when they encountered head winds, Audubon and his party were landed on the nearest shore and made their way overland to the town. Thence they proceeded to Truro and Halifax, and after three days went on to Windsor, where they watched the famous tides in the Bay of Fundy-emptying and filling a broad river, and rising, in course, to a height of sixty-five feet. From that point a steamboat was taken to St. John, New Brunswick, where the faithful Harris awaited the naturalist with tidings of his wife and elder 
son; ${ }^{21}$ this intelligence induced him to abandon his contemplated course through the woods of Quebec and hasten back to the United States. The party finally reached Eastport on August 31, after being out nearly twelve weeks. When the Ripley had docked and their collections were securely packed, all but Coolidge and Lincoln returned to Boston, and on September 7 Audubon was again in New York.

The Labrador experience was in a measure disappointing, but the naturalist brought back twenty-three large drawings of birds, complete or nearly so, and seventy-three bird skins, as well as considerable collections of marine animals and plants. The expenses of the journey had been heavy, amounting, as he told his son, to "about $\$ 2,000$," but one fine morning when they had flushed a Black Poll Warbler from its nest, Audubon felt that he was amply "refunded in the sight," though this bird was later found to have a much wider breeding range than he then supposed.

The National Gazette of Philadelphia ${ }^{22}$ published a long editorial upon Audubon's return, as well as an extended account of his journey, extracted from the Boston Patriot. To quote the editor's comment:

The distinguished naturalist returned from his northeastern excursion to Boston Wednesday last. We believe that there is no one who will not be gratified to learn the progress of his arduous and unremitted labors in a branch of science, which he has made peculiarly his own; and he has kindly fa-

${ }^{21}$ As a memento of the Labrador experience, Audubon presented Harris with his pocket companion, The Genera of North American Birds and a Synopsis of the Species, by Charles Lucien Bonaparte (New York, 1828), and inscribed it as presented to his friend at "Eastport, Sept. 1, 1833." This volume, which saw much hard usage on this voyage and is filled with Audubon's manuscript notes, is now in possession of Mr. Joseph Y. Jeanes.

${ }^{22}$ For Tuesday, September 10, 1833. 
vored us with information on the subject of his recent tour, which we are glad to lay before our readers; regretting only that we are unable to present it in his own rich and animated language, and to invest it with the attractions which it would derive from his own descriptive powers.

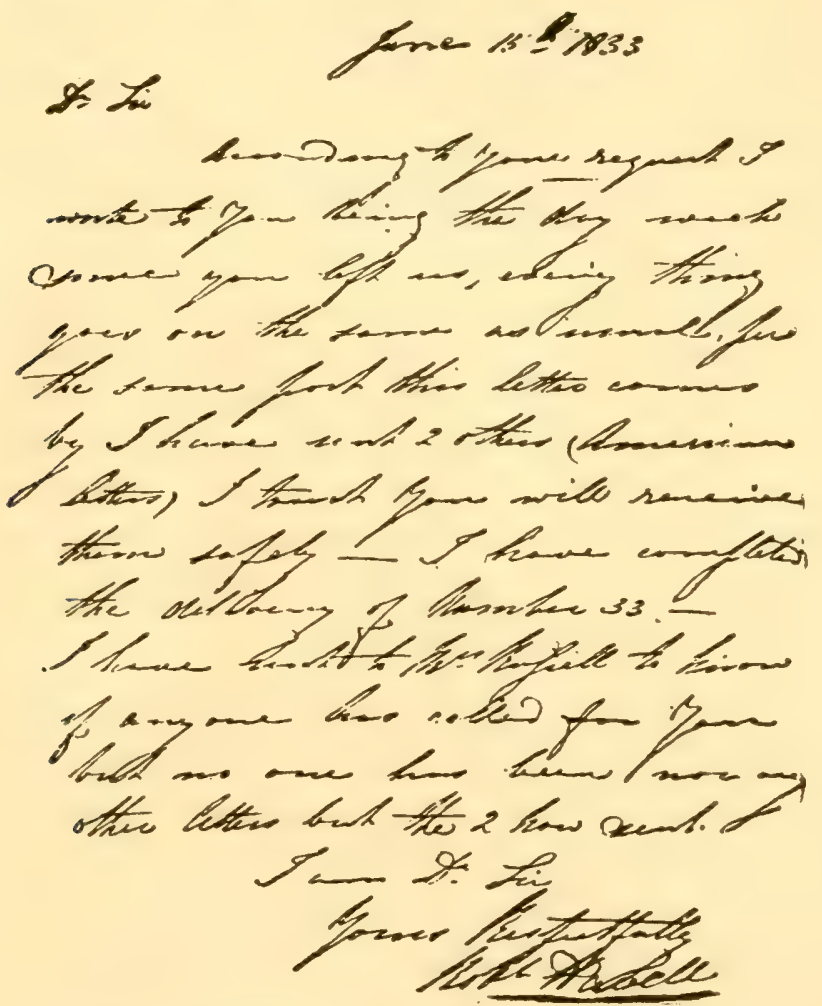

LetTer of robert havell to auduon, june 15, 1833.

From the Deane MSS.

While at Halifax Audubon received a congratulatory letter from Bachman, who urged him to visit Charleston and to bring his family. The invitation was accepted, and early in September Audubon returned to New York, where he immediately prepared the new drawings for dispatch to London; thirteen of the land 
birds were for the completion of his second volume, and seventeen, representing water fowl, were to form the initial series of the third; all, as usual, were heavily insured.

Audubon left New York with his wife on September 25 and spent nearly a month en route to Charleston, while John, who intended to accompany his father to Florida, went direct by water. Dr. Thomas L. McKenney, of Philadelphia, in a letter to Lewis Cass, Secretary of War, said: ${ }^{23}$

Mr. Audubon makes no more of tracking it in all directions over this, and I may add other countries, than a shot star does in crossing the heavens. He goes after winged things, but sometimes needs the aid of-at least a few feathers, to assist him better to $\mathrm{fly}$. He means to coast it again round Floridamake a track through Arkansas - go up the Missouri-pass on to the Rocky Mountains, and thence to the Pacific. He will require some of your official aid.

As a contrast to the warmth of Audubon's greeting in Philadelphia, while in that city he was arrested for debt, and was on the point of being taken to jail when he was offered bail by a friend. "This event," he said, "brings to my mind so many disagreeable thoughts connected with my former business transactions, in which $\mathbf{I}$ was always the single loser, that I will only add I made all necessary arrangements to have it paid."

Four new subscribers were obtained at Baltimore, but when the naturalist applied to Secretary Cass at Washington for the privilege of accompanying an expedition to the Rocky Mountains under the patronage of the Government, he met with a cool reception, and

${ }^{23}$ Lucy Audubon, ed., Life of John James Audubon, the Naturalist (Bibl. No. 73), p. 377. 
though he had forgotten his letter from Dr. McKenney, he was resolved not to trouble that official further. At this juncture he met Washington Irving, who did his best to save the situation, and thought that Audubon had been mistaken in his judgment of the Secretary; "I might have been," he said, "but those eyes of mine have discovered more truth in men's eyes than their mouths were willing to acknowledge." Irving accompanied him to the offices of Mr. Taney, the Secretary of the Treasury, who at once gave the naturalist the privileges of the revenue cutter service on the southern coast.

At Richmond Audubon met Governor Floyd, who promised to try to induce the legislature of his State to subscribe for a copy of the Birds. From that point to Charleston we shall follow their itinerary as given in his journal under date of October $16:{ }^{24}$

We left Richmond this morning in a stage well crammed with Italian musicians and southern merchants, arrived at Petersburg at a late hour, dined, and were again crammed in a car drawn by a locomotive, which dragged us twelve miles an hour, and sent out sparks of fire enough to keep us constantly busy in extinguishing them on our clothes. At Blakely we were again crammed into a stage, and dragged two miles an hour. We crossed the Roanoke River by torchlight in a flatboat, passed through Halifax, Raleigh, Fayetteville, and Columbia, where we spent the night. Here I met Dr. Gibbs, at whose house we passed the evening, and who assisted me greatly; at his house I met President Thomas Cooper, who assured me he had seen a rattlesnake climb a five-rail fence on his land. I received from the treasury of the State four hundred and fifty dollars on account of its subscription for one copy of the "Birds of America." 
For a number of years Audubon's snake stories had subjected him to no little ridicule in certain quarters, and this notice of a climbing rattlesnake pleased him so much that he asked the venerable president to put his statement in writing; he willingly complied, and his interesting letter on the subject will be given in a later chapter. ${ }^{25}$

When Audubon and his wife reached the Bachman home on October 24, he was prepared to push on to the South, but changed his plans, on account, he said, "of the removal of my good friend Captain Robert Day from his former station to New York, and I did not like to launch on the Florida reefs in the care of a young officer unknown to me." The winter of 1833-4 was passed under the hospitable rooftree of his friend, in the usual occupations of painting, writing and hunting birds. At this time an attachment sprang up between his younger son, John Woodhouse Audubon, and Maria Rebecca, the eldest daughter of the Bachman household. Here Audubon wrote the first drafts of many of the bird biographies contained in the second volume of his letterpress, and with Bachman conducted a series of careful experiments on the power of smell in vultures, in order to settle a question which had then become acute among naturalists. ${ }^{26}$ This subject is referred to in the following intimate letter, ${ }^{27}$ which reveals the confidence which Audubon felt in his sons and in their united ability to bring his great undertaking to a successful issue, as well as the infinite pains which he bestowed upon every part of it. Audubon, who was now in his fortyninth year, felt that he was aging very fast, and de-

${ }^{25}$ See Chapter XXVIII, p. 78.

${ }^{26}$ See ibid., p. 81.

${ }^{27}$ Which $\mathrm{I}$ am able to reproduce through the kindness of Miss Maria R. Audubon. 
clared that one year then would be equal to three, three years from that time.

\section{Audubon to his Son, Victor}

Charleston, Dc., 24, 1833.

My dear beloved Victor:-

Your last letter to us is dated at London, $r$ th. Octbr. It has given us all ample and sincere pleasure. The copy of your reply ${ }^{28}$ to Mons. Waterton is excellent; that from Swainson ought to prove a death-blow to the Demerara Gent! I hope that these letters are now before the world, for my mortification has been great enough respecting the blackguardism of G. Ord and others, and yet I am heartily glad that I never paid personally any attention to them through the press or otherwise. Here my friends are as much shocked as myself, and the moment is at hand when these T. . will be glad to find some hiding place to resort to, and wait for time to obliterate their obvious jealousy and falsehood.

John Bachman and myself have begun a second series of experiments, such as I made before, connected with the nosesmelling of Turkey Buzzards; as far as we have gone through them, these experiments have proved perfectly satisfactory to my good friend and myself, and depend [upon] it, from next Wednesday, the American World will know that Turkey Buzzards are first, Gregarious, as well as the Carrion Crow [Black Vulture], that they eat fresh meat in preference to putrid stuff; that they eat birds, fresh killed, either plucked or not, even of their own species; that they suck birds' eggs, and devour their callow young; that they come to their food by their sense of sight, and not that of smell, and lastly that they cannot discover by any sense of smell the most putrid matter, even when this putrid stuff is within a few feet of them, out of sight of their eyes. Were Snakes as abundant near

28 The reference is to Victor G. Audubon's second article in defense of his father, which appeared in Loudon's Magazine of Natural History (see Bibliography, No. 118). Swainson's paper, under the same title (see Bibliography, No. 117), was published in the same number. 
Charleston as Buzzards, that business would soon be also set at rest, but for this, however, time is required, and the time I think will come. The experiments we are making will be repeated in the presence of the faculty of this city, ${ }^{29}$ and their Certificates attached to the whole, and immediately published in the Annals of the Philosophical Society of Phila. ${ }^{30}$ those of the Lyceum of New York. A copy will be sent to be read at the Linnean, or Royal Society of London, and Royal Institute of France; then let those laugh who win. We have attracted Turkey Buzzards with pieces of fresh beef, not more than an inch square, and we have seen others pass unnoticed the body of a hare or fowl within 20 steps. We have now 3 fine birds of this species to experiment upon, and their olfactory nerves will be examined by the faculty here, where there are some highly talented men.

Our friend Bachman has written a very fine paper for Loudon's Mag. ${ }^{31}$ which will be forwarded to you in a few days by duplicate, and which I wish you to give to our friend J. G. Children, and ask him to have it read at the $\mathbf{R}$. and $\mathbf{L}$. Societies, and inserted in the above mentioned Mag. afterwards. We hope all this will be accomplished by the 1 st. March next.

Now to other subjects. We are deeply at work. John has drawn a few Birds, as good as any $I$ ever made, and in a few months I hope to give this department of my duty up to him

${ }^{20}$ For an account of this discussion see Chapter XXVIII, where the memorial drawn up and signed by the faculty of the Medical College of South Carolina is reproduced.

${ }^{30}$ When in New York, awaiting the sailing of his vessel, in April, 1834, Audubon referred to Bachman's paper on the Turkey Buzzard in writing to Miss Maria Martin, as follows: "At Phila., Mr. Lee and Docr. Hays managed to have it not read at Philosoph. Socy, but the Lyceum of New York, after reading it, have sent it to Professor Silliman, in whose Journal it will appear. John Bachman may consider himself a member of the Lyceum of New York, and 'mayhap,' a fellow of the Linnean Society of London." Bachman's paper was actually published in the Journal of the Boston Society of Natural History for 1834; see Bibliography, No. 125.

${ }_{31}$ This paper, entitled "Remarks in Defense of [Mr. Audubon] the author of the Birds of America," was published in volume vii of Loudon's Magazine of Natural History for 1834, and is dated "Charleston, Dec. 31, 1833"; see Bibliography, No. 124. 
altogether; his improvements on other subjects are equally pleasing. I write a [biography of a] Bird or so every evening, and our friend grants me all his knowledge of the habits of those with which he has become well acquainted, belonging to this part of the Union. I have nearly one 100 drawings of Water Birds ready for publication \& I pronounce them equal to any previous ones. I am much pleased at the news you give me respecting Havell; I hope he will continue with hand and heart to do all in his power for the fame of our work, and for himself. We have not seen Nos. 34, 35, tho. from your letter we suppose them to be in New York. Wm. Oakes, I have written you, has paid all, up to No. 33; Arnold, of New Bedford, for all he has had; John Neal has his copy, but I do not know if he has yet paid Dr. Parkman, who is our kind friend and agent in that part of the Country. I wish you had forwarded first volumes bound, as you had those on hand, as several would have been disposed of and paid for by this time; do send all, or whatever of them you have ready, as soon as possible. It will be well for you to have friend Bachm's. paper published in toto, in some good circulating paper in London \& Edinboro. Brushes! Brushes! Brushes! I am glad to hear of Kidd \& Co.'s publication of Parrots, but I regret that my face should have been there from Syme's picture, which in my estimation is none of the best. Push Kidd with the pictures; have them, and take care of them. Sell all the Shells you please; write to John Adamson, of New Castle, about them, but keep smug all the Bird Skins. I cannot do without them when I write my Synopsis, which will be when I am with you. Our voyage round the Floridas, Gulph Mexico \&c. will begin about the 1st. February. This will be my last journey, after which John and I will hunt for Subscribers, procure a round number, and join you as soon as possible. Your dear Mama will in all probability join you in May or June next. In about a fortnight I shall send you more land Birds for the end of the $2 \mathrm{~d}$. volume, extra small plates, and several numbers of Water Birds. I am anxious to hear something about the little edition. Do not omit to let me know when you want money, for tho. our expenses are always 
great, the Work must not, and shall not suffer, as long as my eyes and hands can work.

Dec. 23 d., last evening, we had the pleasure of yours of the 28 Oct, and one from Havell of the 9 th. Regarding Havell, we are glad that all is well with him, and hope he will not trouble us about extra prices, not even for the Water Birds. The safe arrival of my last drawings has relieved me of that anxiety. You are quite right on the score of advice. You in England, will do best to act as you may think proper. We, in America, are trying to do equally well, and our little Alliance is as efficient as the Holy one at least. That Subscribers should die is an event we cannot help; that such fellows as V. should act so cannot be controlled, but depend upon our industry, our truth, and the regular manner in which we publish our work; this will always prove to the world and to our Patrons that nothing more can be done than what we do; nay, I doubt if any family, with our pecuniary means, ever will raise for themselves such a monument as the "Birds of America" is, over their tomb.

How comes it that Harlan has not money enough to pay his expenses in Europe? I shall remember the $20 \mathrm{f}$, and the exchange. Chamley, of New Castle, was never prompt pay; indeed, my dear Victor, were you fully acquainted with the great difficulties which I had to surmount and did surmount, it would give you less fear than you now feel or experience. We shall be glad to receive the Brushes that are, I hope, now under way for us. Mr. Miesson resides [at] No. 2 Rue Pigalle, on the east side of the grand Boulevards. Present my regards to $\mathrm{Mr}$. Yarrell, and thank him in my name for his kind offer of eggs, and add that I shall have it in my power to present him with many which $I$ think he has not found, that our two collections will most likely comprise the whole of those published in my 4 volumes. I fear that to give the eggs in the $2 \mathrm{~d}$. of Biography would render that volume too large, and again too costly, and that a few plates of eggs at the end of the large work will answer better. ${ }^{32}$ The plates ought to

${ }^{32}$ See Note, Vol. I, p. 426. 
be insured for at least 4 or 5 times the cost, for should they by an accident be destroyed, the amount of their cost would prove a poor remuneration, when compared with the time it would require to have them renewed. Attend to this as soon as you can. Henry Ward has rendered himself very obnoxious here. a letter came to Mr. B. on last evening from St. Augustine, to inquire how a certain amount left by him unpaid was to be settled. Mr. Bachman will inform you of the particulars.

Do forward the bound volumes as soon as possible, for with them I could at once make you a considerable remittance, which would enable you to prepare the Nos. of the $2 \mathrm{~d}$. Vol. for those who do not wish to have it complete. I am trying to receive some money on Act. of the $2 \mathrm{~d}$. Vol. through the mediums of Dr. Parkman, N. Berthoud, John Bellonis, Wm. Gaston, and will let you know the result. The Plate ... . which you sent me is extremely well engraved, but let us keep to Havell as long as he behaves with propriety, and does good work.

I have now replied to your letter fully, except on what you say about my immediate return. The following are my views, but if after all, you say-come on, $I$ shall do so. Our country is becoming more wealthy every day. Science is looked upon with more congeniality every year. Subscribers in this Dear Country of ours do not drop off unless they die. They pay punctually on demand, and to have more of them in this land than in Europe is a thing that may prove of the greatest importance to us. When I visited our woods on my first return from England, I was absent about 12 months. The Rathbones and Mr. Children wrote to me many times to return, or expect the work to fall. I went back to Europe before I was ready to go, and on my arrival there, to my surprise and joy, I found everything going on as well as usual; but I was again obliged to come to our Country to renew my researches, and improve my head, as well as my collection of drawings. I had then left no one like you in England. Now you, my Dear Son, are there; thank God for it! You prove to be a better man at carrying on the publication than myself, and to tell you 
more, I doubt if I could procure more subscribers there than yourself. I am truly desirous for your sake, and that of your dear Mother and Brother, to do all in my power for the completion of this great work. I wish to finish here all that is to be done both in the way of drawing, and increase of knowledge, in black and white, and also in Patrons, as much as possible, ere I return to Europe, where, when I do go, I must remain several years, if not until the completion of the engraving. I am growing old very fast; in 3 or 4 years my career as a traveller will be ended, and should I be obliged to renew my fieldlabours, it is doubtful if my constitution could bear it. One year now is equal to 3, 3 years hence. I receive much assistance from the Government, and have John to accompany me. I am still able to undergo some fatigue, and, as I have said, I am anxious, very anxious, to do all that can be done ere I return to Europe. Now the whole time which I conceive necessary to enable me to perform these desideratums cannot exceed 12 or 15 months. What pleasure it would be to us all, when I take your hand and press you to my heart, I should also have a list of 100 new names from America!; all the drawings and the manuscripts ready for the completion of this our wonderful undertaking. I would advise you to address a circular letter to all those who may be concerned in Europe, to acquaint them with what $I$ call the necessity of my being in America, for the sole purpose of increasing the value of our publications, either Illustrative or graphical. This, and the constant improvement now exhibited to them with each new number of the work, could not fail, I think, to render them quiet, if not pleased, that I am now doing all I can for the advantage of the work. Tell them the facts, that I have greatly added to the Ornithology of the United States since my absence from Europe, that the number of species which I now have, and that are not given by Wilson or Bonaparte, combined, amounts to nearly one hundred, and that the Water Birds will be fully equal in point of interest and beauty, to any of the land Birds that are published. And, not the least part of this, my remaining in America has already [given], and will con- 
tinue, to give me the power of portraying the habits of the Water Birds with more truth and completeness than has ever yet been done. Next, have extracts of my letter to you, before the world's eye, through the medium of Papers. Visit such of our friends, and ask them to say those things to their acquaintance; go on yourself, as you have done, and depend upon it, we shall all be greatly benefitted. In your most kind letter to John you mention with unexampled modesty what you are attempting to do in the way of self-improvement, but my Dear Victor, you cannot convey more thoroughly to us the march of your improvement than you have done by sending your letters, and the result of your actions, so well delineated as this is, and we all feel deeply gratified and most happy. Cruickshank is right; by drawing you are enabled to study the lights and shadows of bodies, again the beautiful mellowness with which, altho. all powerful in the effect, these blend themselves with each other. The reflective power of bodies will also strike your discerning attention, and when these combinations of the true Materia are well understood, the artist is a Master! Nature after all, has done all for us; she groups, and most beautifully, every thing that is presented to our eye or mind, so completely also, that if one observes a number of bodies, no matter what these bodies are, whether horses or apes, he sees at once the general elegance of their arrangement in contour, the force of the light and shadows, the mellowness existing between these, and as the eye passes on to the finishing of that natural picture, it at once pronounces it complete.

Do not forget to take from Kidd whatever pictures of ours he may have finished, and take good care of them. We have pretty nearly kilt G. Ord and Waterton with our Buzzard experiments. You say you wish you could see us at friend Bachman's; I assure you my pleasure at such an event would be equal to yours. We are indeed happy in having such a friend. Miss Martin, with her superior talents, assists us greatly in the way of drawing; the insects she has drawn are, perhaps, the best I've seen; at night we have some music and reading. 
When you receive Bird Skins, perhaps it would be as well to form a collection of each species in pairs, and variety of age or color.

24 Dec. We have just received yours of 18 th. October. You are, my Dear Son, too low spirited respecting my immediate appearance in England. Cheer up, my beloved Victor! Believe me, when I repeat that our own Dear Country will support the efforts of us all, and will grant us more Patrons than the whole of Europe together; by the way of a nightcap, let me give you the name of Wm. J. Rees, of Sumpter district, Statesbury, South Carolina, who put his name to my list this afternoon at the moment when the Vultures lost their olfactory powers, for I daubed the imitation of a sheep, and the very first one that passed over the picture rounded and came to it.

Respecting Kidd, and his prospectus, depend upon it, nothing is to be feared from that quarter; that work is dead at the moment $I$ write, and as to his publishing the intention of the pictures, it signifies nothing. All you have to do is to take all the pictures from him, by goodwill or otherwise, and give him no more originals to copy.

If I regret anything at this moment, it is that you should have kept the 20 volumes in London, when, if I had them in America, I should at once be enabled to make you a valuable remittance. Ship them, ensured, as fast as possible, and doubt not my disposing of them. Lewis Atterbury writes me to night that all the numbers 34,35 , which Havell has shipped, are injured greatly by salt water. I do not know yet if they were insured or not. I write to him this evening. Do not ship anything without insurance; it is better to lose time in this case than money. I will write again in a few days, and I shall forward you Water Birds in good time. God bless you, my dear fellow; keep up your spirits, and again may God bless you.

Ever your affectionate father,

J. J. Audubon.

Honest John Bachman, who had lived and worked 
with Audubon for months at a time, and who probably knew him better than did any one in America outside of the naturalist's own family, gave this account of his habits in 1834, when, at the age of forty-nine, he was still working at his best:

He rises at the earliest dawn, and devotes the whole of the day, in intense industry, to his favourite pursuit. The specimens from which he makes his drawings are all from nature; carefully noting the colors of the eye, bill, and legs; measuring, with great accuracy, every part of the bird. When differences exist, either in the sexes or young, several figures are given on the same plate; sparing no labour in retouching old drawings or in making new ones, in all cases where he conceives there may be a possibility of making an improvement. In this way, he has already succeeded in figuring nearly the whole of the birds necessary to complete his splendid and important work.

He keeps a journal, and regularly notes down every thing connected with natural history. This journal is always kept in English: a language which, it must be acknowledged he writes very correctly, when it is taken into consideration that he spent nearly the first seventeen years of his life in France. Besides this, he keeps separate journals, in which he notes every thing that he learns each day on the habits of every bird. In all his travels, he carries these journals with him; and he never suffers business, fatigue, or pleasure to prevent him each evening from noting down every interesting observation. In this way, a mass of information has been accumulated from year to year. When he sits down to write the history of a bird (which is usually in the evening), he first reads over all the memoranda which he has made with regard to its habits and he is generally able to write an interesting paper on the subject in the course of an evening. At some leisure moment this is again revised and corrected: the scientific details he leaves to the last. 
Early in March, 1834, Audubon left his friends in Charleston, and with his wife and son passed northward to Washington and Baltimore. From the latter city, on March 9, he wrote to Edward Harris, in part as follows:

Friends such as you have been, and are still, are the only recompense such poor individuals such as I am can enjoy in this world, and the more valued as they are so very rare.

We came from Charleston by land to Norfolk; thence to Washington City by steamer in 20 hours, and in 8 to the city here, well fatigued but safely. . . . At Washington, where we remained only an hour, Col. J. Abert told me something connected with the climbing of Rattlesnakes upon trces \&c. that will make your mouth water, and your generous heart leap with joy, when you read [about] them, which you shall do ere long, I give you my word for it.

Audubon was still in Baltimore on March 15, for on that day he gave Harris a letter of introduction to Edward Everett. New York was reached in April, when he wrote to Bachman that they had secured berths in "that fine packet ship the North A merica," which was to sail on the tenth of that month.

Toward the close of Audubon's Charleston visit he had an unpleasant experience; he was sued for an old debt, which no doubt dated from his Henderson period and the failure of his mill in $1819 .^{33}$ Apparently the case was carried into court, where the naturalist was defended by a lawyer named Dunkin, who, if my inference is correct, later became a distinguished judge and Chief Justice of the Supreme Court ${ }^{3+}$ of South Carolina. The incident was referred to by Audubon in letter's written from New York at this time; on

${ }^{33}$ See Vol. I, p. 260.

${ }^{34}$ See Audubon's statement of the case, given in Note 18, Vol. I, p. 260. 


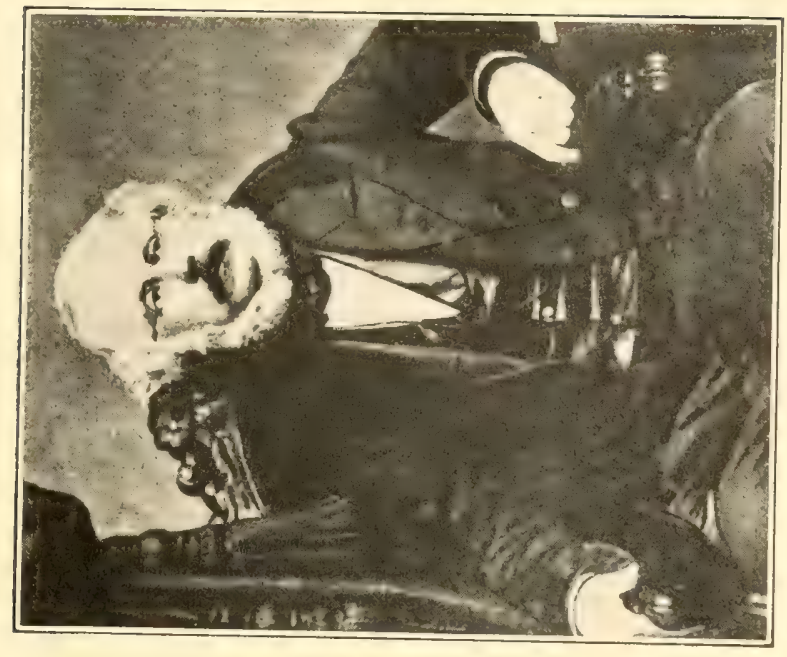

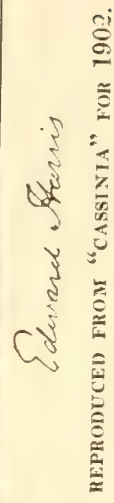

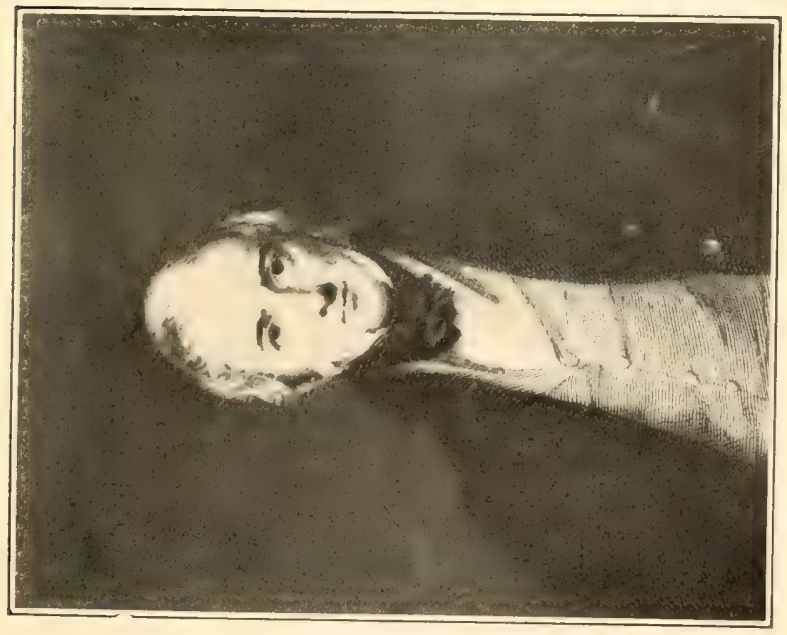

f 

April 6, he wrote to Miss Maria Martin as follows:

I told friend Bach. in my letter of yesterday that I knew nothing of Mr. Pettigrue, connected with my business at Charleston, and that if that gentleman had presented himself before the court, it must have been for charity's sake; indeed, from the conversations that passed between Friend B. \& I respecting Mr. Dunker [Dunkin], it would have been absurd in me to think for a moment of employing any other person than Mr. D.

In the letter just quoted Audubon said also that he had spent all of the morning of the previous day in going from shop to shop with friend Harris to procure some models for "the dear girls," but in vain; New York with its two hundred and fifty thousand souls, possessed but two drawing masters; "these instruct in 3 months," he added, "and starve for the nine of the year." In reference to financial matters, he said that he had managed to collect about $£ 600$ sterling, and had sent 500 to Victor in bills of exchange, so that when they reached London, they would be tolerably well off, considering that they were "naturalists from the wilds of America." "Nothing starts the blues so effectually," he continued, as "constant unemployment; for myself who have done next to nothing since I left you, have had horrors all around me; dreams of sinking and burning ships at night, fears of lost drawings, \& failures of subscribers by day, have ever and anon been my companions." "Victor," he added, "has sent 6 boxes of pills, which will be divided into 3 parts, the largest for $\mathbf{G}$. Ord."

The Audubons finally sailed from New York on April 16, 1834. On the preceding day the naturalist sent his friend, Edward Harris, a parting letter, in which he said: 
To tell you that I am surprised at your generous conduct in remitting to me Four hundred, Ninety dollars in advance, for all the numbers of my book, would be a poor gratification to me. I feel your generosity, and I cannot say any more. God bless you.

Nos. $36 \& 37$ have reached this place; my drawings shipped from Charleston are safely in the hands of Victor at London. I have been able to forward him $650 \mathrm{f}$, and I have 30 sovereigns to defray our expenses from Liverpool to the Great Metropolis. In 1824, poor J. had dreams, but how far was I then from believing that I should ever have succeeded as I have; who will believe my story? Only one or two besides yourself, have an Idea of what I have undergone, but, if God grants me life, I shall publish that story, and send you the sheets thereof, as they are struck by the printer.

Audubon took with him to England all the collections which he had accumulated during nearly three years of travel and search in different parts of the United States and the British possessions. During this eventful period he had renewed one hundred of his older drawings, executed many new ones, discovered new birds, extended his acquaintance, and added sixty-two names to his list of patrons.

After they had reached Liverpool, he wrote to Bachman, May 8, 1834, that they had returned on the "superb packet of 650 tons, called the North A merica, commanded by an admirable gentleman, named Dixie of Philadelphia"; the voyage was made in not quite twenty days. A little later they joined their son, Victor, in London. 


\title{
CHAPTER XXVIII
}

\author{
THORNS ON THE ROSE
}

Contributions to magazines-Attacked in Philadelphia-Statement to Sully-The rattlesnake episode-Behavior of a Philadelphia editorMistaken identity in account of the reptile-Lesson of the serpent's tooth-Audubon's long lost lily rediscovered-"Nosarians and AntiNosarians"-Bachman and Audubon on vultures-Aim of the criticsAuthorship in the Biography-His most persistent heckler-Pitfall of analogy.

We have seen that $J_{\text {ohn }}$ James Audubon had attended the school of adversity many years before he was known to the public in either America or Europe. The difficulties inseparable from such colossal undertakings as those in which he engaged were well nigh insuperable; but to these were added others which perhaps might have been avoided but which could hardly have been foreseen. From the moment he began to write for publication, he was bitterly and persistently assailed by a number of detractors, who seemed bent upon ruining his reputation and thus undermining the work to which he was devoting his life and upon which he depended as a means of support.

Were no worthy purpose to be served, it would be folly to resurrect the animosities of a past generation, but since a few "fed fat the ancient grudge they bore him," and since this hostility, handed down through the years, is occasionally echoed at the present day, the impartial historian is left no choice; he must weigh the merits of the case to the best of his ability. The reader, I think, will find that the law of compensation has 
worked fairly well in respect to all these matters, for if Audubon possessed faults, he was not lacking in merits; if he was assailed by a few bitter enemies, he was supported by a host of judicious friends.

As soon as Audubon became known in England, he was importuned to contribute to the scientific magazines, and in response to this demand wrote five articles, which were published in Edinburgh and London in 1827. Some of these papers, which dealt with the habits of the 'Turkey Vulture, the Alligator, the Carrion Crow or Black Vulture, the Wild Pigeon, and the Rattlesnake, ${ }^{1}$ were roundly scored in the Philadelphia press, and Audubon was called a romancer of the first order. Thomas Sully, the artist, who was then living in that city and who had taken a deep interest in the naturalist since their meeting in 1824, wrote in November, 1827, and told him what had occurred. Since Audubon's reply was practically the only answer which he ever made to attacks of this sort, and since his friend was given permission to make such use of it as he saw fit, we shall reproduce this letter nearly entire. ${ }^{2}$ In writing to his wife on the same day Audubon said: "Now my Lucy, I am going to answer Sully's letter; it is no difficult task, so far as truth be connected with my answer, but as regards my feelings it is perhaps the severest one $I$ have had to encounter for many years."

\section{Audubon to Thomas Sully}

LIVERPOOL, Decr 22, 1827.

My dear Mr. Sully :-

I received from your truly friendly letter of the 7 th. of November the long wished for intelligence that you and your

${ }^{1}$ See Bibliography, Nos. 17-21.

${ }^{2}$ For this privilege I am indebted to Miss Maria R. Audubon. 


\section{THORNS ON THE ROSE}

family were well. I am not much astonished that in Philadelphia, remarks such as you allude to, should have been made respecting some papers on the habits of objects of Natural History, read by me to different institutions in this country, but I am grieved at it.

The greatest portion of my life has been devotedly spent in the active investigation of Nature, her beauties \& her objects in granting to different individuals, classes, or species, such privileges as best suit their form, situation, or habits. This arduous task I have followed with unremitting diligence, and with a degree of industry that has caused to my family and to myself more troubles than any person in Philadelphia can be aware of. For more than 20 years I have been in the regular habit of writing down every day all the incidents of which $I$ have been an eye-reitness, on the spot, \& without confiding to my memory, as many travellers have done and still do. You have read some portion of this journal, and have also been an eye-witness of many of the occurrences, and to this I now owe the gratification of possessing your esteem, but, $\mathrm{My}$ dear Mr. Sully, you are not the only evidence. Mr. Joseph Mason, who is now, I believe, an artist in your city, accompanied me on a hunting excursion, beginning at Cincinati, and ending in the State of Louisiana, which lasted 18 months. He drew with me; he was my daily companion, and we both rolled ourselves together on bufaloe robes at night. James Cummings, Esq., past captain, the author of a treatise on the navigation of the rivers Ohio and Mississippi, was one of the party, and he saw me write in my Journal, and read it frequently. Every member of my family has seen the whole of those Diaries and could readily assert the truth of the whole of their contents, to many of which they were party, present and acting.

The papers alluded to in your estimable letter, are merely copies from those journals; they were transcribed in Edinburgh, and the style corrected by patrons, who saw the originals, nearly worn out by time and the casual dampness, which journals like mine must often be exposed to. I read these papers to the different societies, of which I have the honor to 
be a member, and read them with a sensation of pleasure that nothing but a full persuasion of their truth could bestow.

Those persons in Philadelphia that have felt a desire to contradict my assertions cannot, without lowering themselves very much indeed affect to conceive that the members of the Wernerian Society would have listened to my "say so," without investigating the subject, even if they had not been well versed in the habits of the objects I treated of. Neither can they believe that all my acquaintance and particular friends would permit me to proceed in relating Tales of Wonder, which if untrue, would load me with disgrace, ruin my family, nay, prove me devoid of all honor! Could I suffer myself to be so blinded at the very moment when I am engaged in the publication of a work of unparalled magnitude, of which the greatest naturalists and best judges both in America and in Europe have given the fullest praise and firmest support, \& from which my very means of pecuniary comfort are to be drawn? It would certainly be highly unfair to conceive $\&$ assert that at the time whilst I was portraying individuals, animal and vegetable, I should have rambled so wide and so far from facts in a portion of science so intimately connected with \& necessary to the support of those delineations, as well as to the general standing of my reputation! Mere interest would suggest a very contrary line of conduct, and I hope I am not so devoid of common sense as to lose sight of all that can render life desirable in this world or the world hereafter.

No, my dear Mr. Sully, I have written with care what I have seen, and have felt a great desire to spread the knowledge I have obtained in the great field of Science for the benefit of the world at large, and I rest content with this motto: "Le temps découvrira la vérité." To whom then, my dear Mr. Sully, can I ascribe the birth of the animadversions expressed in the papers of Philadelphia! Is their author one [who] comes avowedly forward with a life spent in the woods, loaded with facts differing in every respect from mine, one who like me can bring forth vouchers, and who can by respectable witnesses support what he says? Or, is he one, who, writing at 
random and without any knowledge of his subject, merely wishes to push himself into notice by a blunt denial of my veracity, and would edify \& please some of his friends, at the price of my reputation. I think, my dear Mr. Sully, the latter much more applicable, and must belong to the author of the report current in your city.

I have not read any of the Philadelphia papers since I came to England, and do not know the tone of the attacks upon me, but judging from your friendly letter, I feel assured that the pen that traced them must have been dipped in venom more noxious than that which flows from the jaws of the rattlesnake!

To you, my dear Friend, I solemly affirm that however unnatural my observations may appear, they are all facts, without a word of exaggeration. My fate in this instance differs not from that of many others, but believe me, will differ widely from that of the illustrious Bruce; those attacks will not make me die of sorrow!

With this, my dear Friend, I will close the subject, giving you meanwhile full liberty to use this letter in any manner that may best suit your feelings, and I will now pass on to other things.

My success in the mother country continues to augment apace. I have many most valuable friends and patrons, and discovered soon after my landing that Science has no particular country. The 5 th. number of my work is now published, \& completes my labor for 182\%. During my progress I have often received letters from highly distinguished characters, expressive of the highest approbation, \& I hope by regular industry to be able to go on with the performance, with credit to myself \& benefit to my family.

I shall leave this town for London in a few days, when I will convey your wishes to Robert Sully, \& [when] there I hope to see the picture which you have sent to the Marquis of Wellesley. ...

The attack referred to in the letter just quoted was called forth by Audubon's unfortunate paper on the 
Rattlesnake, ${ }^{3}$ which was read before the Wernerian Society of Edinburgh in the winter of $\mathbf{1 8 2 7}$ and published by Robert Jameson in the New Philosophical Journal in April of that year. The controversy then started was long and bitter, while the merits of neither side were ever fully established; in the history which follows we shall see that the naturalist was, on the whole, more sinned against than sinning.

In July, 1828, Dr. Thomas P. Jones ${ }^{4}$ appropriated Audubon's Rattlesnake article, and published it without acknowledgment in the Franklin Journal and A merican Mechanics' Magazine at Philadelphia. It should be noticed that at the close of 1827 Audubon's famous plate of the Mocking Birds defending their nest against the sinister designs of this formidable reptile had also been published in London. In this remarkable picture the rattlesnake was represented coiled about the nest, at the fatal moment when ready to strike its bold defenders, and in a tree. The anomaly was apparent, for the climbing habits of rattlesnakes were not then generally understood. This circumstance, together with some of $\mathrm{Au}$ dubon's notes, repeated in certain cases from stories current in rural communities, furnished his detractors with a powerful lever, which they seized with avidity; snakes coiled in trees seemed suddenly to have produced a brood of another order which lurked in the grass, and it was many years before Audubon heard the last of his snake stories. The attack in the American press was laid to the door of George Ord, and it was not long before it was renewed with great vigor by his friend and corre-

${ }^{3}$ See Bibliography, No. 21.

${ }^{4}$ At one time superintendent of the Patent Office at Washington, and professor in the medical department of Columbia College; he was later professor of mathematics in the Franklin Institute of Philadelphia and editor of the Franklin Journal, and American Mechanics' Magazine. 


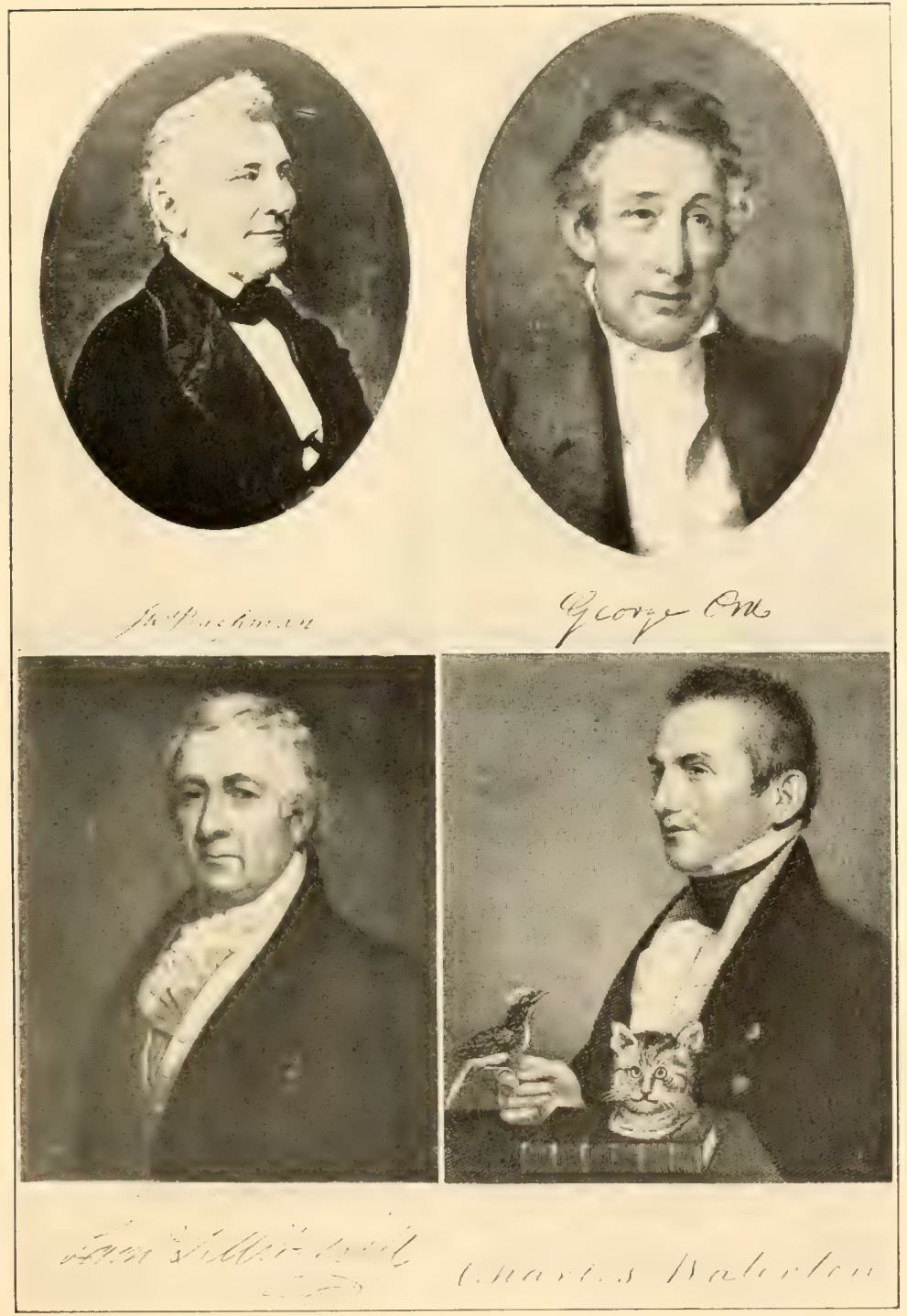

\section{JOHN BACHMAN}

GEORGE ORD

SAMUEL LATHAM MITCHELL CHARLES WATERTON

BACHMAN FROM C. L. BACHMAN, "JOHN BACHMAN, D.D., LL.D."; ORD FROM "CAS-

SINIA" FOR 1908; MITCHELL AFTER AN ENGRAVING BY GAMRER AND DICK OF A PORTRAIT BY HENRY INMAN: WATERTOY FROM MOORE'S EDITION OF WATERTON'S "ESSAYS." 

spondent in England, Charles Waterton, who proclaimed Audubon as a new and greater Münchhausen. ${ }^{5}$

Dr. Jones immediately repudiated the article which he had unceremoniously appropriated, and under the title of "The Romance of the Rattlesnake" inserted the following notice in the August number of his magazine: ${ }^{6}$

Just as the Editor was leaving Philadelphia for Washington, he was pressed for "more copy" by his printer, and hastily marked some articles for insertion, among which were "Notes on the Rattlesnake," by John James Audubon, F.R.S. E., M.W.S., \&c. Time did not admit of reading the article, but it was seen that the writer professed to offer the "fruits of many years' observation, in countries where snakes abound." This with his titles, and the bold and splendid assurances which we had seen respecting the publication of his works, served as a password to his tissues of falsehoods, which would have been expunged from the proof, but for absence from the press.

We had determined to publish a notice like the foregoing, when we received a note from a scientific friend, whose remarks are, at once, so pointed and correct, and so fully express our own ideas upon the subject, that we gladly adopt and insert them.

It is a tissue of the grossest falsehoods ever attempted to be palmed upon the credulity of mankind, and it is a pity that any thing like countenance should be given to it, by reproducing it in a respectable Journal. The romances of Audubon rival those of Münchausen, Mandeville, or even Mendez de Pinto, in the total want of truth, however short they may fall of them in the amusement they afford.

This was rather a stiff charge to be made flatly against the reputation of any one without the most

${ }^{5}$ See Bibliography, No. 115.

'See Bibliography, No. 93. 
careful investigation, even upon the authority of "a scientific friend." Let us see, then, what basis, if any, really existed for such sweeping charges. In the paper which caused the trouble Audubon had described in great detail how he had seen a large rattlesnake pursue, capture, kill by constriction, and devour a gray squirrel. Before quoting his description of this singular encounter, we shall recall a passage which Audubon wrote in his journal at the time when it occurred, ${ }^{7}$ when he was at "Oakley," the plantation of James Pirrie at St. Francisville, Bayou Sara, in the summer of 1821: "August 25. Finished drawing a very fine specimen of a rattlesnake, which measured five feet and seven inches, weighed six and a quarter pounds, and had ten rattles. Anxious to give it a position most interesting to a naturalist, I put it in that which the reptile commonly takes when on the point of striking madly with its fangs." After describing a rough dissection which he made of the rattlesnake's dental arsenal and poison apparatus, he added: "The heat of the weather was such that I could devote only sixteen hours to the drawing." The drawing thus referred to was undoubtedly used in the composition of his celebrated plate.

To revert now to a mooted passage in Audubon's published paper:

Rattlesnakes hunt and secure for their prey, with ease, grey squirrels that abound in our woods; therefore they must be possessed of swiftness to obtain them. Having enjoyed the pleasure of beholding such a chase in full view in the year 1821, I shall detail its circumstances. Whilst lying on the ground to watch the habits of a bird that was new to me, previous to shooting it, I heard a smart rustling not far from me, and turning my head that way, saw, at the same moment, a

${ }^{7}$ This episode was referred to in Chapter XX, p. 316. 
grey squirrel full grown, issuing from a thicket, and bouncing off in a straight direction, in leaps of several feet at a time, and, not more than twenty feet behind, a rattlesnake of ordinary size, pursuing, drawn apparently out to its full length, and sliding over the ground so rapidly that, as they both moved away from me, I was at no loss to observe the snake gain upon the squirrel. The squirrel made for a tree, and ascended to its topmost branches as nimbly as squirrels are known to do. The snake performed the same task considerably more slowly, yet so fast that the squirrel never raised its tail nor barked, but eyed the enemy attentively as he mounted and approached. When within a few yards the squirrel leaped to another branch, and the snake followed by stretching full two-thirds of its body, whilst the remainder held it securely from falling. Passing thus from branch to branch, with a rapidity that astonished me, the squirrel went in and out of several holes, but remained in none, knowing well that, wherever its head could enter, the body of its antagonist would follow; and, at last, much exhausted and terrified, took a desperate leap, and came to the earth with legs and tail spread to the utmost to ease the fall. That instant the snake dropt also, and was within a few yards of the squirrel before it began making off. The chase on land again took place, and ere the squirrel could reach another tree, the snake had seized it by the back near the occiput, and soon rolled itself about it in such a way that, although $\mathbf{I}$ heard the cries of the victim, I scarcely saw any portion of its body. So full of its ultimate object was the snake, that it paid no attention to me, and I approached it to see in what manner it would dispose of its prey. A few minutes elapsed, and I saw the reptile loosening gradually and opening its folded coils, until the squirrel was left entirely disengaged, having been killed by suffocation. The snake then raised a few inches of its body from the ground, and passed its head over the dead animal in various ways to assure itself that life had departed; it then took the end of the squirrel's tail, swallowed it gradually, bringing first one and then the other of the hind legs parallel with it, and sucked with difficulty, and for some time, 
at them and the rump of the animal, until its jaws became so expanded, that, after this, it swallowed the whole remaining parts with apparent ease.

Audubon then described the appearance that the snake presently assumed, which suggested "a rouleau of money, brought from both ends of a purse towards its centre," and its ineffectual attempts to move off; "when having cut a twig," he continued, "I went up to it, and tapped it on the head, which it raised, as well as its tail, and began for the first time to rattle."

Now every careful reader of this remarkable story, provided he is at all conversant with the habits of snakes, will perceive that it could not possibly have been invented, for it is strictly and minutely in accord with facts, except in one important particular; the snake whose behavior Audubon watched and so accurately described was not the rattlesnake, but the blue racer or black snake (Bascanion constrictor) ; substitute "blue racer," for "rattlesnake," and this record is photographically correct. $^{8}$ The black snake does all the things which are here so minutely described-pursuing its prey with astounding agility, constricting about it as a prelude to swallowing it, ascending trees readily, coiling when brought to bay as if about to strike, and even vibrating the tip of its tail on the ground or leaves, as if in emulation of the genuine rattler, a kind of behavior which was looked upon by Darwin as a case of protective mimicry. No one could have known the rattlesnake better than Audubon from his constant encounters with it in the field; he made drawings of it, dissected its poison apparatus, and had kept it for months in confinement in

${ }^{8}$ This was very clearly pointed out in 1908 in an excellent article by Mr. George W. Colles, entitled "A Defence of Audubon" (Bibl. No. 160), in Scientific American, vol. xcviii, p. 311. 
order to study its habits; but by some curious twist of his notes or his memory, or led astray by the record made of the rattling habit, the species became confused in his published account. His error was gross and he paid dearly for it, but it certainly does not prove him to be the king of nature fakirs.

Audubon's critics were probably right in affirming that the rattlesnake never ascends trees for the purpose of destroying birds, but some overshot the mark by denying that the reptile was able to climb at all. Nor could it have been said with greater justice that the brilliant but sluggish coral snake (Elaps fulvius), which Audubon had also placed in a tree, ${ }^{9}$ really never aspires to this distinction. When the snake controversy was waxing warm in America, a number of Audubon's friends, including Colonel John J. Abert ${ }^{10}$ and Richard C. Taylor, ${ }^{11}$ investigated the question and proved that the rattlesnake was a ready climber at certain times of the year and under certain conditions, a fact which is now better known. Mr. Taylor's party in the course of explorations in the Alleghanies killed forty-one large rattlesnakes during the month of August on a single ridge bordering the Lycoming Valley, and in rendering his report, this geologist said: "I have repeatedly endeavored to verify Mr. Audubon's account of the rattlesnake ascending trees, which has been confirmed."

We have already referred to Audubon's meeting with Thomas Cooper at Columbia, South Carolina, in October, 1833. This versatile man, sometime English lawyer, revolutionist in France, friend of Priestley, judge in the Court of Common Pleas of Pennsylvania,

${ }^{9}$ See Plate lii, of the Chuck-will's-widow.

${ }^{10}$ See Vol. II, p. 3; and Bibliography, No. 107.

${ }^{11}$ An English geologist, who made a survey of the bituminous coaldeposits of the Alleghany mountains in 1834. See Bibliography, No. 129. 
professor of chemistry in Dickinson College as well as in the University of Pennsylvania, and at this time president of South Carolina College at Columbia, was able to confirm Audubon's account of the climbing habit of the rattlesnake, and probably wrote this statement at his request:

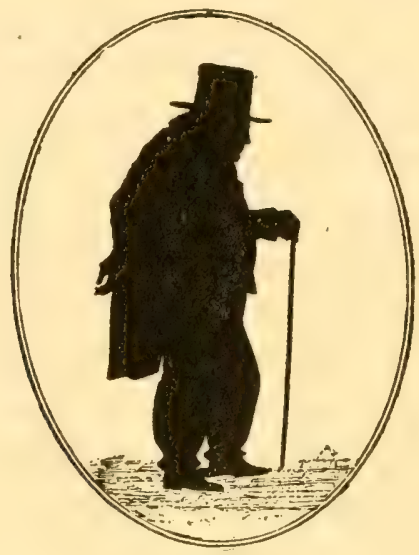

DR. THOMAS COOPER.

After a contemporary silhouette.

Thomas Cooper to Audubon

Columbia S. Carolina

Octr 21. 1833

Mr Audubon

DeAr Sir

About three weeks ago, my son and two of my black servants, observed a very large rattle snake climbing up the fence that separates my garden from the road, at my country house. The snake put himself in the attitude of striking; whereupon one of the men ran for a gun, and shot the snake on the last rail but one of the fence. The snake was 4.3 long; as thick as my wrist, and had seven rattles.

I am Dear Sir

Your obedient servant

Thomas Cooper 
Waterton maintained that Audubon's drawing of the rattlesnake, to which we have referred, was a monstrosity, "a fabulous Hydra, with its eyes starting out of their sockets," and a point repeatedly ridiculed was his representation of the fangs as slightly recurved, or bent up at their tips. Who had ever heard of such an anomaly? Certainly not the doughty lord of "Walton Hall," who declared that the fangs of poisonous snakes were always curved like a scythe, with their points bent downwards. Waterton prided himself on his knowledge of these reptiles, and certainly was not lacking in selfconfidence. According to his own account, he went eleven months in the forests of Brazil without shoe or stocking to his foot, and on a certain occasion in London secured with his hands and removed from its cage a live rattlesnake; but, like so many sophisticated writers on natural history, he took to analogy like a duck to water.

W aterton's statement sounds plausible enough, but obviously could be proved only by extensive observations and comparisons. When Audubon was proceeding up Galveston Bay to Houston, Texas, in the spring of 1837, with his son, John, and Edward Harris, they stopped at the plantation of Colonel James Morgan, near Red Fish Bar. "There, among other rarities," said he, "we procured a fine specimen of the climbing rattlesnake with recurved fangs, which with several others of the same kind, is now in my possession." ${ }^{12}$ In writing to Thomas M. Brewer, from Charleston, on June 12 of this year, he alluded to this subject as follows: "I must not forget to say to you that I had the good fortune to procure specimens of my ' $\mathrm{Cl}$ i m b ing $\mathbf{R}$ a $\mathrm{t}$ t l es n a ke with DOUBLE recurved fangs' which, I am told, will prove a new genus! and therefore the

\footnotetext{
${ }^{12}$ Ornithological Biography (Bibl. No. 2), vol. iv, p. xviii.
} 
Messrs. Ord and Waterton-good souls! -will be perfectly delighted at the sight of this strange reptile." ${ }^{13}$ Unfortunately a large part of Audubon's collections made upon this expedition were lost. I have seen no other reference to this extraordinary peculiarity, and there the matter seems to have rested until the present time.

Audubon's judgment or memory might play him false, but his pencil, in such a matter, could be relied upon to tell the truth. It is therefore a pleasure to be able to confirm his accuracy in reference to the serpent's tooth, for the true representation of which he was roundly abused during his lifetime. The reader will perceive the point by examining the accompanying photograph, which represents the skull of a large diamond-backed specimen from Florida. ${ }^{14}$ In the prairie rattlesnake, and probably in some others, the fangs are sickle-shaped, as Waterton maintained, but upwards of eleven species of rattlesnakes have been found on the continent of North America, and, true to Audubon's disputed drawing and account, in this Florida specimen the fangs are slightly, but very distinctly, bent upwards at their tips! Let nature writers, inclined to the easy path of analogy, remember the rattlesnake's fang, for it teaches a salutary lesson.

As I have not hesitated to speak of Audubon's real or supposed mistakes, I will give another and more striking instance of his tardy vindication. In his plate of the American Swan (No. ccecxi), which was published in

13 See Thomas M. Brewer, (Bibl. No. 79), Harper's New Monthly Magazine, vol. lxi, p. 666 (1880).

14 This specimen, which was presented to me by the late Dr. X. C. Scott of Cleveland, measured 6 feet, and showed eight rattles and a button; the skin and skeleton are preserved in the Biological Laboratory of Western Reserve University. Position of fangs incorrectly shown in the photograph. By opening the mouth they are directed outward. 


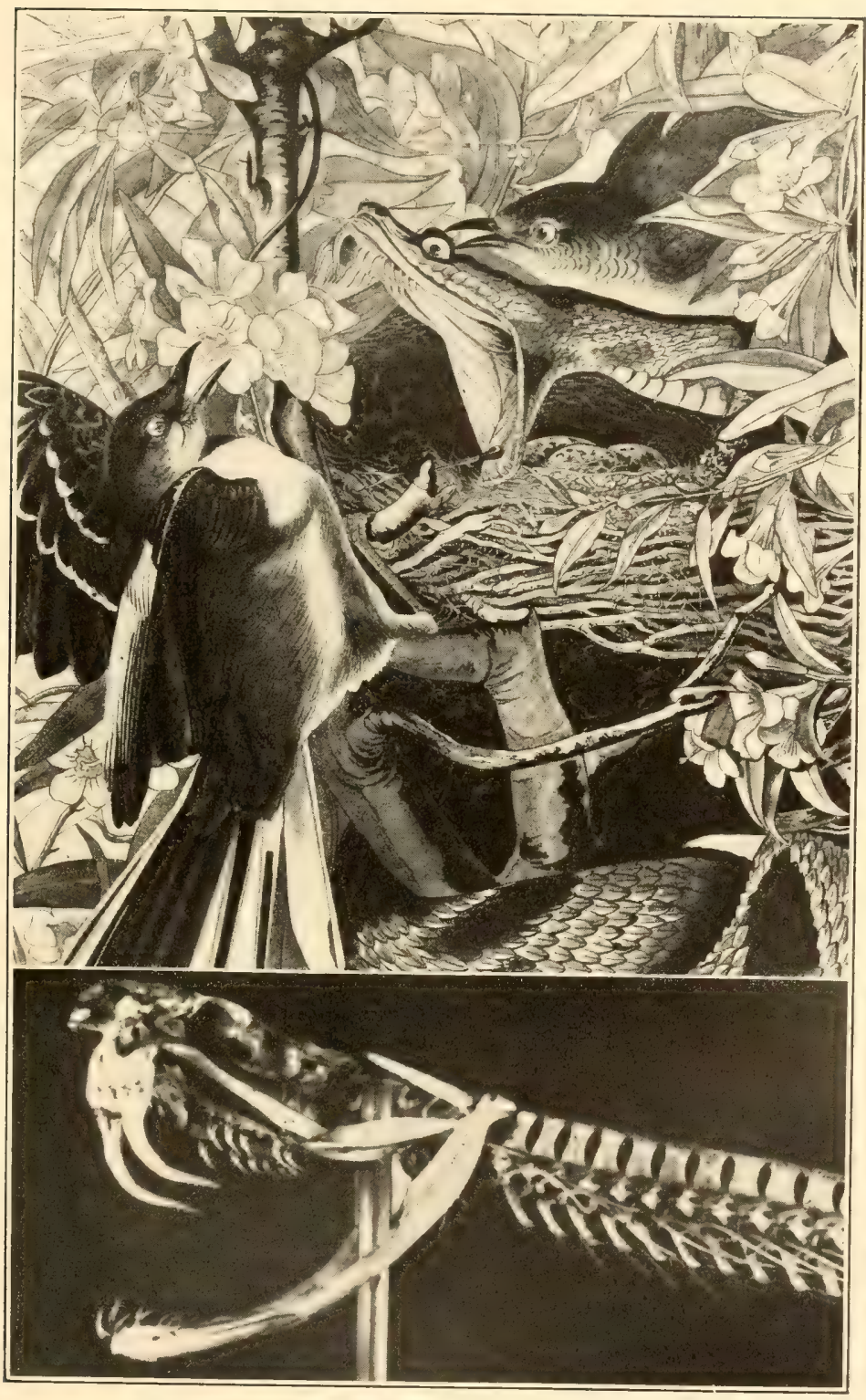

A VINDICATION OF AUDUBON'S REPRESENTATION OF THE FANGS OF THE SOUTHERN RATTIESNAKE: ABOVE, DETAII. OF THE "MOCKIXG BIRUS," PLATE XXI (UNCOIORED) OF "THE BIRDS OF AMERICA"; BELOW, THE SKULI. OF A RECENT FLORIDA SPECIMEN, SHOWING THF SAME RECURVATURE OF FANG. 

1838, there is represented a yellow water lily, under the name of Nymphaea lutea. Since this lily was then quite unknown to botanists, it was ignored and treated as a fable, or as an extravagant vagary of the naturalist's imagination, until the summer of $\mathbf{1 8 7 6}$, when it was rediscovered in Florida by Mrs. Mary Treat. Audubon's long lost lily was then identified and acknowledged by Professor Asa Gray, the botanist, who, with poetic justice, proposed to rename it after the discredited enthusiast, in view of the fact that it had been originally discovered and faithfully depicted by him a generation before.

While the snake controversy was acute in America, another of a purely academic character, which assumed even wider proportions, was started on the smelling powers of the vulture. We have already seen a reference to this in the naturalist's letter to his son, Victor, written at Charleston, where he was conducting with Bachman a new series of experiments to settle the question. ${ }^{15}$ The idea, commonly accepted, that the scavengers of the Southern States were possessed of a keenness of scent comparable with that of a beagle hound, had been vigorously combated by Audubon, who showed by numerous experiments ${ }^{16}$ that they were guided to their prey

${ }^{15}$ See Vol. II, p. 55.

${ }^{10}$ Bachman's account of these experiments is interesting: "A coarse painting," he said, was made on canvas, "representing a sheep skinned and cut open. This proved very amusing-no sooner was this picture placed on the ground than the Vultures observed it, alighted near, walked over it, and some of them commenced tugging at the painting. They seemed much disappointed and surprised, and after having satisfied their curiosity, flew away. This experiment was repeated more than fifty times, with the same result. The painting was then placed within two feet of the place where the offal was deposited-they came as usual, walked around it, but in no instance evinced the slightest symptoms of their having scented the offal which was so near them.

"The most offensive portions of the offal were now placed on the earth; these were covered over by a canvass cloth-on this were strewn several pieces of fresh beef. The Vultures came, ate the llesh that was in sight, 
by the sense of sight only; thus it was found that they would come readily to the effigy of a calf or sheep painted on canvas and set up in plain view, or to a skin stuffed with straw, but failed to detect their quarry when the dead bodies of these animals were placed on the ground and screened from their eyes, if only by the thinnest cover, though the carrion was calling loudly to the nose but a fraction of an inch away. An attack by Waterton, ${ }^{17}$ who hurried to the fray whenever a statement in his jealously guarded $\boldsymbol{W}$ anderings was called in question, led to a lively tilt, in which the advocates of the nose and the eyes were sometimes humorously referred to as the "Nosarians" and the "Anti-Nosarians," some of the most eminent anatomists of the day eventually taking part.

Bachman felt keenly the aspersions which were cast upon his friend, and in the winter of 1833 he undertook with Audubon the series of experiments to which we have referred. The tests which were then made supported Audubon's statements in every particular, and the faculty of the Medical College of South Carolina were invited as a body to witness them; this they did

and although they were standing on a quantity beneath them, and although their bills were frequently within the eighth of an inch of the putrid matter, they did not discover it. We made a small rent in the canvass, and they at once discovered the flesh and began to devour it. We drove them away, replaced the canvass with a piece that was entire; again they commenced eating the flesh exhibited to their view, without discovering the hidden food they were trampling upon.

"As it [the organ of smell] does however exist, (although in an inferior degree, I am not disposed to deny to birds the power of smell altogether, nor would I wish to advance the opinion that the Vulture does not possess the power of smelling in the slightest degree, (although it has not been discovered by our experiments). All that I contend for is, that he is not assisted by this faculty in procuring his food-that he cannot smell better for instance, than Hawks or Owls, who it is known are indebted altogether to their sight, in discovering their prey."

${ }^{17}$ See Bibliography, No. 104, and Vol. II, p. 55; also Ornithological Biography, vol. ii, p. 46 . 
willingly, and the following memorial signed by all the witnesses present was published by Bachman in $1834 .{ }^{18}$

We, the subscribers, having witnessed several of the experiments made on the habits of the vultures of South Carolina (Cathartes aura and C. atratus), commonly called the turkey buzzard and the carrion crow, feel assured that these species respectively are gregarious, the individuals of each species associating and feeding together; that they devour fresh as well as putrid food of any kind, and that they are guided to their food altogether through their sense of sight, and not of smell.

In a letter written to Ord, on March 4, 1834, Waterton said:

You will see that the Charleston parson [Bachman], Doctors, Surgeons and Professors are up in arms against me and are determined to cut off the Vulture's nose. But do not be alarmed for me, I promise you that I will answer them to your heart's content and tomorrow I shall send up a paper to Loudon for his May number which will make your Philosophers appear very small and put Audubon's claim to literature and ornithology in so clear a light that no one will be in doubt hereafter. ... Audubon's gulled friends and supporters in London are in the highest spirits and feel sure that I cannot answer the Charleston letter. By the first of May next their crowing will cease.

When anatomists came to consider the question and found that well developed olfactory lobes and nerves were present in these birds, they favored the theory of smell, ${ }^{19}$ and Edinger has more recently expressed the opinion that this consideration renders the possession of

${ }^{18}$ See Bibliography, No. 125, and for the quotation to follow, Samuel N. Rhoads, "George Ord," Cassinia, No. xii (Philadelphia, 1908).

${ }^{19}$ See W. Sells (Bibl. No, 140), Proceedings of the Zoölogical Society of London, pt. $\nabla$, p. 33 (183\%). 
an olfactory sense in such birds highly probable. His contention is weakened, however, by the fact that granivorous and insectivorous birds also possess true olfactory nerves, and yet are proved by experiment to have little or no effective sense of smell. It is a problem for students of behavior to solve, and so far as the American vultures are concerned, Audubon's and Bachman's experiments, I believe, have never been repeated or extended with sufficient care to settle the question. The little that has been done, however, suggests that while the vulture in its daily and never ending search for food is mainly guided by its keen eyes, the nose, possibly, may be a coöperating factor when the wind and other conditions are favorable.

While critics were driving the pen, Audubon was hard at work in the field, but his friends did not long remain silent. Favorable notices of his work, actual or prospective, had appeared in the scientific and literary press of England, by David Brewster, Robert Jameson, William Swainson, and "Christopher North" of Blackwood's Magazine. The first American notice appeared in the American Journal of Science for 1829, and this was followed by G. W. Featherstonhaugh, the English geologist, in his recently established but shortlived Monthly American Journal of Geology and Natural Science, to which we have already referred. ${ }^{20}$ A little later the London Athenceum gave the first of eleven extended articles on Audubon's work; in reviewing his second volume of letterpress, which appeared in 1834, the writer said: "There is amply sufficient remaining in Audubon's pages for fully a dozen more notices, were we disposed to follow the exhausting system. We have admired Audubon's gorgeous drawings, but our

\footnotetext{
${ }^{20}$ See Vol. II, pp. 4 and 23 , and Bibliography, No. 106.
} 
interest in them has been increased a thousand fold, in knowing that they are the spoils of a life's campaign." 21 Again a series of able articles was started by a just critic, W. B. O. Peabody, in the North American Review for April, 1832. ${ }^{22}$ Featherstonhaugh deserves credit for having given Audubon a fair hearing at a critical time, when baiting the American Woodsman was a popular pastime in certain circles at Philadelphia; in reviewing the Ornithological Biography in 1832, this plain spokesman gave what he called "a true history of a conspiracy, got up to utterly break down and ruin the reputation of one of the most remarkable men America ever produced." 23

Audubon's silence under fire of hostile criticism tempted someone in the capacity of a reporter to call on him in London to obtain, if possible, a personal statement, but his lips were then sealed and he would only say: "Had I wished to invent marvels, I need not have stirred from my garret in New York or London." However, in writing to Featherstonhaugh from Bulowville, East Florida, December 31, 1831, Audubon made this comment: ${ }^{24}$

If I did not believe the day to be gone by when it was necessary to defend my snake stories, I could send you many curious accounts of the habits of those reptiles; and I should do it, if it were not that I might be thought to enjoy-too much that triumph which the feeble hostility of three or four selfish individuals has forced upon me. I receive so many acts of real friendship and disinterested kindness, that, I thank God, there is no room left in my heart to cherish unkind feelings towards any one. Indeed, I am not now so much sur-

${ }^{21}$ See Bibliography, No. 136.

${ }^{22}$ See Bibliography, No. 105.

${ }^{23}$ See Bibliography, No. 106.

${ }^{24}$ See Bibliography, No. 35. 
prised at the incredulity of persons who do not leave cities, for I occasionally hear of things which even stagger me, who am so often a denizen of woods and swamps. What do you think of rattlesnakes taking to the water, and swimming across inlets and rivers? I have not seen this, but I believe it; since the most respectable individuals assure me they have frequently been eye-witnesses of this feat. I can conceive of inducements which reptiles may have for traversing sheets of water to gain dry land, especially in a country much intersected by streams, and subject to inundations, which compel them to be often in the water. In such countries, it is not an uncommon occurrence to find snakes afloat and at great distances from the shore. This appears, no doubt, surprising to those who live where there is almost nothing but dry land; still they ought to be good natured, and believe what others have seen. It has now been made notorious, that numerous respectable individuals, whom duty, or the love of adventure, have led into the woods of our country, have often seen snakes -and the rattlesnake too-in trees; the good people, therefore, who pass their lives in stores and counting houses, ought not to contradict these facts, because they do not meet with rattlesnakes, hissing and snapping at them from the paper mulberries, as they go home to their dinners. . .

Audubon's most persistent heckler was Charles Waterton, ${ }^{25}$ who during two of his most prolific years, 1833 and 1834, published no less than fourteen lucubrations against the "foreigner," and "stranger" as the American was called; all were characterized by quizzing interrogatories, shallow criticism and personal vituperation, for the most part unworthy of serious consideration. Long noted for his eccentricities, Waterton had little or no standing among English zoölogists, against many of whom, from time to time, he issued broadsides or breezy polemics, whenever their statements cast a

${ }^{25}$ See Bibliography, No. 104 et seq. 
shadow on his Wanderings. Some of these accusing articles were answered by Victor Audubon and other friends of the naturalist, but they never drew his own fire; probably they benefited him in the end, for when it appeared that the charges brought against him were in large measure the work of envious calumniators, a strong current set in his favor on both sides of the Atlantic.

When Audubon's name was first proposed for membership in the Academy of Natural Sciences at Philadelphia, it was rejected, according to report, through the influence of George Ord and a few of his partisans, while Waterton, who was Mr. Ord's close friend and correspondent, affirmed that Audubon was rejected by the Society on the strength of Alexander Wilson's personal diary, ${ }^{26}$ a statement which appears to be utterly incredible. $^{27}$

In 1833, two years after the first volume of Audubon's "Biography of Birds" had made its appearance, Waterton raised another controversy, in this instance with ammunition supplied by his friend, George Ord of Philadelphia. He boldly proclaimed ${ }^{28}$ that Audubon was not the author of the work which bore his name, a charge similar to that which had been brought to the door of the French ornithologist, Le Vaillant, whose history resembled Audubon's in many ways. "I request the English reader," said Waterton, "to weigh well in his own mind what I have stated, and I flatter myself that he will agree with me, when I affirm that the cor-

${ }^{26}$ See Vol. I, p. 224.

${ }_{27}$ "I myself, with mine own eyes, have seen Wilson's original diary, written by him at Louisville, and I have just now on the table before me the account of the Academy of Sciences indignantly rejecting Mr. Audubon as a member, on that diary having been produced to their view." See Bibliography, No. 119.

${ }^{25}$ See Bibliography, No. 119. 
rect and elegant style of composition which appears through the whole of the Biography of Birds cannot possibly be that of him whose name it bears." Waterton maintained that, while Audubon's earlier papers were the work of an illiterate person, his Biography betrayed the hand of a finished scholar from beginning to end. In a reply to Victor Audubon, written July 6, $1833,{ }^{29}$ Waterton declared, upon the authority of George Ord, whom he quoted, that William Swainson had been importuned to write Audubon's work for him, but declined when Audubon insisted upon his own name being given to the world as author. This direct accusation called forth an immediate explanation from Swainson, who said: ${ }^{30}$

In reply to that gentleman (G. Ord, Esq.), regarding the assistance it was expected I should have given my friend, Mr. Audubon, in the scientific details of his work, my reply was, that the negotiation had been broken off from an unwillingness that my name should be printed on the title-page. I was not asked to write the work, nor did Mr. Audubon "insist upon his own name being given to the world as the author" of such parts as he wished me to undertake. . . . I have read Mr. Audubon's original manuscripts, and I have read Mr. Waterton's original manuscripts. I think the English of one is as good as the English of the other-but here the comparison ends."

The controversy thus started did not reflect much credit on Audubon's detractors, but reverberations of the charge were heard at a much later day.

Robert Bakewell, the geologist, who was a relative of Mrs. Audubon, then living at Hampstead, entered

${ }^{29}$ See Bibliography, No. 115.

${ }^{30}$ See Bibliography, No. 117. 
this controversy, and in June, 1833, replied ${ }^{31}$ to one of Waterton's fulminations, which he attributed to envy and jealousy, saying that posterity would regard Audubon as "the most distinguished ornithologist of the present age."

Charles Waterton began his travels at eighteen, but early settled down to a life of leisurely independence on his ancestral estate in Yorkshire, where he studied birds to little purpose and wrote extensively on natural-history subjects; he is best known for his $W$ anderings, ${ }^{32}$ which has passed through numerous editions and is still read. From youth Waterton enjoyed exceptional advantages, and according to one of his biographers, "lived to extreme old age without having wasted an hour or a shilling." He was the twenty-seventh "lord of Walton Hall," the manor house of the family, which stood on an island in a lake; the estate of 260 acres was mainly converted into a preserve for wild birds. His young wife died in 1829, after having given birth to a son, and he lived on his paternal acres in semi-retirement ever after. It was said that Waterton would never don evening clothes or a black coat, but insisted on wearing a blue frock with gold buttons until an anxious policeman in the neighboring village of Wakefield persuaded him to make a change; he told the Reverend J. G. Wood in 1863 that he had been bled 160 times, mostly by his own hand. When, in his sixty-ninth year, he had the misfortune to fall from a pear tree and break an elbow joint, the first remedy tried was the extraction of thirty ounces of blood; shortly after this a careless servant withdrew a chair as he was seating himself at table, and

${ }^{31}$ See Bibliography, No. 114.

${ }^{32}$ Wanderings in South America, the North-West of the United States, and the Antilles, in the years 1812, 1816, 1820, \& 1824. Originally in 4to., London, 1825. 
thirty more ounces were immediately required. The wage of one of his laborers is said to have sufficed for his personal needs, and his sleeping apartment had neither bed, chair, nor carpet; he lay on bare boards, wrapped in a blanket, with an oaken block for pillow; and he is said to have never tasted fermented liquor and to have eaten but sparingly of meat. His daily habit was to retire at eight and rise at three o'clock in the morning, and he was always dressed by four; an ardent Roman Catholic, he would spend an hour at devotion in his private chapel; he then read Latin and Spanish authors, wrote his polemics against Audubon or any others with whom he came in conflict, and received the reports of his bailiff, all before breakfast, which was at eight o'clock; the remainder of the day was mostly devoted to his birds and other animals, to preserve which he surrounded his entire estate with a high rampart of stone, said to have cost, all told, $\$ 50,000$.

Though a devout Romanist, as someone has remarked, Waterton never hesitated to adopt the same mode of reasoning which Hume had employed in his argument against miracles. Thus he rejected with scorn Edward Jenner's account of how the young parasitic Cuckoo, when but a day old and hardly able to stand, turned out of their nest its rightful occupants. This account, which was generally accepted then, and has been repeatedly verified and recorded by the camera since, "carries," said Waterton, "its own condemnation, no matter by whom related, or by whom received." Trusting to analogy again, he maintained that Audubon's description of the Ruby-throated Hummingbird gluing bits of lichen to the surface of its nest with saliva was false, because "the saliva of all birds immediately mixes with water," and the first shower of rain 
would immediately undo the work of the bird. No account was taken of the Chimney Swift, which not only glues together the twigs of its nest but secures the whole to a support through an abundant salivary secretion, although this habit had long been known. In the instance of this hummingbird, however, both Audubon and Waterton were partly right and partly wrong, as a careful examination of the nests of five species of hummingbirds, including the Ruby-throat, has clearly shown. ${ }^{33}$ It proved that saliva was only casually used on the surface of the nest, the lichens in the case referred to being adherent by means of spiders' silk and fine vegetable fibers of various sorts; the saliva of the Rubythroat, when dry, moreover, was found to be practically insoluble in cold water, even after an immersion of several days; but more interesting than this is the fact that the nest itself is glued to its supporting twig by a large salivary wafer, which represents this hummingbird's first step in the work of nest construction.

Shortly after his arrival at Edinburgh, and before he had published anything, Audubon wrote in his journal on November 5, 1826: "I returned home early and found a note from Mr. John Gregg, who came himself later, bringing me a scrubby letter from Charles Waterton," so it would appear that the lord of "Walton Hall" had been warned to keep an eye on the dangerous American, and Waterton's American correspondent was Mr. Ord, of Philadelphia. Later on Waterton wrote to Swainson an extraordinary letter of some four thousand words, ${ }^{34}$ afterwards published in his Essays on Natural History, which for petty vanity and personal animosity

\footnotetext{
${ }^{33}$ See "Nests and Nest-Building in Birds," Pt. 2, Journal of Animal Behavior, vol. i (1911).

${ }^{34}$ See Bibliography, No. 138.
} 
has seldom been surpassed, but with this effort his ammunition seems to have been exhausted.

Charles Waterton, who lived to his eighty-third year, and who wrote nineteen polemics against Audubon and his friends, was probably sincere in his attacks upon the American Woodsman, whom he seems to have regarded as a dangerous charlatan. Waterton was a curious compound of fearless independence, kindness, credulity, pedantry, vanity, and intolerance. He should be given credit, however, for having done much to spread abroad a love of natural history and for his attitude towards an artificial system of classification, then much in vogue, which, though only an amateur, he had the good sense to reject. 


\section{CHAPTER XXIX}

\section{SIDELIGHTS ON AUDUBON AND HIS \\ CONTEMPORARIES}

What was a Quinarian?-Controversy over the authorship of the Ornithological Biography-Audubon's quaint proposal-Swainson's reply-Friendship suffers a check-Species-mongers-Hitting at one over the shoulders of another-Swainson as a biographer-His careerBonaparte's grievance-A fortune in ornithology-Labors of John Gould and his relations with Audubon-The freemasonry of naturalists.

Few, probably, ever attain marked success in their chosen field without exciting jealous rivalry or misrepresentation on the part of some of their contemporaries. Audubon was no exception to the rule, but in this respect he has been subject to so much misunderstanding that the reader is entitled to know the truth, whenever it can be ascertained. An instance of this sort was furnished by the English naturalist, William Swainson, whose relations with Audubon have been touched upon in earlier chapters.

In April, 1828, Swainson published an eulogistic account of some of Audubon's plates, and shortly after they became good friends, as their familiar letters already reproduced amply testify $;{ }^{1}$ in the autumn of that year, as we have related, they visited Paris together, and they kept up a correspondence for a number of years. At this time Swainson was known as a systematic zoölogist of merit and an excellent draughtsman, hav-

${ }^{1}$ See Chapter XXIII. 
ing published a series of "Zoölogical Illustrations" that seem to have been well received. Moreover, as early as 1824, he had adopted the notorious "Circular System" of the classification of animals, and at this time was its most zealous advocate in England. The tenets of this curious doctrine, often called "Quinarianism" from the recurrence of the number 5 , was confused in a mystical jargon which conveys little meaning to a reader of today; it was derived from William Sharp MacLeay, who had advocated a similar system in his Horae Entomologicae, published in 1821. According to Swainson's creed, "all things that have life have been created upon one plan, and this plan is founded on the principle of a series of affinities returning into themselves; which can only be represented by a circle." "This sublime discovery," which, as Swainson thought, was sufficient "to immortalize a name," was duly attributed to his "illustrious countryman." 2

In the summer of 1830 , when Audubon was ready to prepare the letterpress of his mammoth plates and needed assistance in its technical details, he applied to his friend Swainson, who, as we have seen, was then living at a farmstead in the Hertfordshire country, not far from St. Albans. ${ }^{3}$ Some of the letters which passed between the two naturalists after the return of the former to England, in the spring of that year, will now be given, without amelioration or change of any sort. It should be remembered that Swainson at this time was in an overwrought state, since he was dependent mainly

${ }^{2}$ Swainson expounded the Quinarian or Circular System in the Fauna Boreali-Americana; or the zoölogy of the northern parts of British America, published in collaboration with John Richardson, and the first zoölogical publication issued by the British Government; but $A$ Treatise on the Geography and Classification of Animals contained his most authoritative thesis upon this grotesque concept.

${ }^{3}$ See Vol. I, p. 403. 
upon his scientific writings for the support of a family of five children, oppressed by pecuniary difficulties, and, no doubt, irritated by lack of success and the rebuffs which a leading part in the Quinarian movement was certain to entail. Audubon's letter ${ }^{4}$ which follows served to answer that of Swainson, bearing date of January 30, 1830, ${ }^{5}$ which had been received in America but too late for the fulfillment of its commissions. References to Audubon's "book," which unfortunately proved a stumbling block in the path of friendship, are noticed here and in Swainson's reply for the first time.

\section{Audubon to William Swainson}

\section{My dear Mr. Swainson,}

London, May 5th 1830.

You may be assured that nothing but an over [word undecipherable] or [another similar word] has stopt me from writing to you sooner, Yet I would have had the pleasure of announcing you my return to good old England had I not been informed by Mr. Havell that you we apraised of it when last in town \& that more over you were quite well.-I hope that your kind wife and children are equally so and happy.-I brought my good wife with me to Liverpool where she is for a while with her sister Mrs. Gordon \& the family Rathbourn We had a rough voyage of 25 days $\&$ glad to be back on this hospitable shore. I am sorry to say that your last letter to me (I presume) did not reach me in time to enable me to procure either squirrels or birds for you.-I have indeed brought about 150 birds and some of them good singers and beautifull but all are on Double Elephant Paper-they may and I hope they will please your eyes, when I have the satisfaction to shake you by the hand the first time you come to

' For the history of the Audubon-Swainson correspondence, see Note, Vol. I, p. 400. Swainson's letter which follows was first published by Ruthven Deane (Bibl. No. 218), The Auk, vol. xxii, p. 248 (1905).

${ }^{5}$ Reproduced in Vol. I, p. 430. 
town.-I called on Mr. Lea at Philadelphia, but he told me that you had countermanded your wishes to me \& has given me a memorandum to that effect-Mr. Gilpin on whom I also called told me that your travelling boxes had forward ${ }^{d}$. I saw Mr Ward at New York he is doing extremely well if what he told me is true. I saw M. le Comte also.-I have just taken the Reins of my Mammoth Publication which by the way I am glad to find in a good way of process or progress. I am greatly indebted to Mr. Children and grateful to him-Havell has done his part I think well and now I will set about procuring subscriptions with new ardour. Now in return of this packet of information I am very desirous to know what you are engaged at present in the way of science; I feel as if I had a world of talk for you.-Bonaparte's 4th volume is printing have you seen the third? I have it at Liverpool by this time.-I wrote to the author this morning.-I am well pleased with my voyage $I$ think it will be of material advantage to my work my health \& my comfort-We have left our two sons quite well and doing well at the Falls of the Ohio where I killed a fine Turkey about forty days since. Those sent to the Zoological Gardens alive have had ill luck. They received only one and 3 Oppossums-The blue Jays and Parakets are not yet arrived, and Mr. Rathbone as well as Mr. Shepherd told me (to my great sorrow) that the last shipment of 10,000 forest trees were all dead. How did those sent to you?-I have commenced the having a complete collection of the Birds of America in skins \& have instituted some agents in the U. S. to provide for me. So much have I seen of those dear creatures of the feathered creation that $I$ feel even now as if $I$ heard their notes and saw their all elegant movements.- I am going to write a book! but more of this when we meet.- do you know that the poor woodsman who now is scribling to you will take his seat at the Royal Society of London tomorrow-the very words make my head whirl and I will stand it I do not know-I will indeed be glad when I am seated.-Mrs A and myself had the pleasure of being very kindly received and treated by our President Jackson Congress subscribed, I procured there four 
more and an act will be passed to enter my works Paintings etc free of the customs.- It is past 5 and I have to pay a penny, I wish I were allowed to write untill time made it a shilling so much do I think I could still trouble you with. however as time and tide wait neither for me or others I must conclude by begging that you will remember me most kindly to your amiable wife-kiss your little Folk and believe me

\section{sincerely your friend}

John J. Audubon

\section{William Srainson to Audubon}

Saturday, 1[10?] May, 1830.

Welcome once more, my good friend to merry England:

I had indeed heard from Havell, with the greatest pleasure, that you had safely landed at Liverpool; and I regret very much that you did not reach London before I had left it; for I am now much seldomer in town than formerly, and I know not when I may have the power to do so again. My old and most valued friend Mr. Burchell has also, to my great delight, just returned to England after six years spent in wandering over the Forests and Andes of South America bringing with him collections, that will make everything else in this country sink into utter insignificance, he too, is longing to see me, and if I possibly can get away for a day next week, with two such desirable objects I will, but my literary engagements bind me, hand and foot.

You think that I do not know that you are an F. R. S.you are mistaken, furthermore, you will be surprised at knowing I have been fighting your battles against a rising opposition which originated among some of your Ornithological friends (at least so I strongly suspect) for the purpose of your name being blackballed. But more of this when we meet, such matters had better not be committed to paper.

The whole of your bundle of young trees reached me as withered sticks, not a spark of life in any one of them. 
So you are going to write a book 'tis a thing of little moment for one who is not known, because they have no reputation to loose, but much will be expected from you, and you must, therefore, as the saying is, put your best leg foremost. I am coming fast round to the prejudice, as you may think it, against the Americans.

Dr. Richardson's and my own volume on the Arctic Birds, is now in press. Not being able to refer to your plates, I have not had the power to quote your work, you know how repeatedly I have applied on this head, both to you and Mr. Havell in vain.

Prince C. Bonaparte has long promised me his second \& third volume but they have never come. Ward ${ }^{6}$ is a regular Scamp he has taught me a good lesson-fool that he isand that is, to steal my heart against distress such as his was, and to consult, like all the rest of the world, my own interest only. I am sick of the world and of mankind, and but for my family would end my days in my beloved forests of Brazil.

So Mr. Lea ${ }^{7}$ did not settle my account with you? I have found him out, also, to be no better than he should be. He also is one of your friends who would, if he could, cut your throat. Another friend of yours has been in England, Mr. Ord and has been doing you all the good he can: if these are samples of American Naturalists, defend me from ever coming in contact with any of their whole race.

Mrs. Swainson's health I am grieved to say, has suffered much the last twelve months, she is now at Birmingham with the children. I have not failed to mention your kind inquiries

' Possibly Henry Ward, who came to America with Audubon in 1831 as his assistant and taxidermist (see Vol. II, p. 2); a Frederick Ward is also mentioned in Audubon's letters.

${ }^{7}$ Isaac Lea, naturalist and Philadelphia publisher; Mr. Lea was a member of the firm of Messrs. Carey \& Lea, at one time the principal proprietors of Wilson's American Ornithology, and it was thought that the prejudice which he manifested towards Audubon and his friends was traceable to his desire to maintain the sales of that work. His attitude was compared with that of Judge Hall, whose brother, Harrison, was also an interested publisher. See Vol. I, pp. 223 and 281. 
after both, whenever Havell has a parcel for me, I hope you will occasionally accompany it with a few lines.

\section{Yours my dear Sir very faith'ly}

W. Swainson

John J. Audubon

at Mr. Haveli's

79 Newman St.

Oxford St.

As already noticed, Audubon started on a canvassing tour late in July, 1830, as announced in the following letter to Swainson, but he changed his plans, and instead of returning to London, went to Edinburgh, and again settled there for the winter.

\section{Audubon to William Sreainson}

July 26th 1830.

My dear Friend,

I was particularly pleased at receiving yours of the 22nd this morning, I cannot well say where it has rambled since it was dated, but certainly its migration has not been that of a Swallow for instance.-

Thank you about the Jay-It has been my misfortune to have been rather misunderstood by you respecting what you please to call "Poor Nomenclators" had I not some regard for you all of that nobler breed I would not borrow names in my work but would have like some others, made new ones right out.-If you have a new Woodpecker from the visited states, a new species, I will feel greatly honoured to have it dedicated to me, and the more so by you who first dared in good faith to write respecting an unknown woodsman-one of my case [s] is come to hand, I gave from it to the British Museum thirty skins several of which are very rare indeed and 3 of which I [here a word is apparently omitted by the woriter] as 3 new [here another word is omitted] - I have males and females of the woodpecker you speak of quite at your service for a few 
weeks - and I have also a few duplicates for you altogether as I promised.- Say how I am to send them-I go to Bristol tomorrow in search of subscribers for ten days-To Paris on the 15th of August-have written to queen Adelaide this pleasant morning \& am glad to see that you are all well. Mrs. A. joins in respects to you all \& I am as ever your friend most truly

John J. Audubon

[The following note is written up the side of the page across the main letter:]

I cannot at present say When we can avail ourselves of your kind invitation but will let you know in good time should we but find it convenient to you when we return.-

It should be noticed that the revolution in France which upset the Bourbon dynasty occurred just as Audubon was leaving London, and that the House of Orleans, in the person of Louis Philippe, was seated on the throne the day the following letter ${ }^{8}$ was written; very likely Audubon was not reluctant to change his plan of visiting Paris after hearing of these events, although he had enjoyed an interview with the new king, who was his patron.

\section{William Sroainson to Audubon}

Saturday 7 August 1830.

My dear Mr. Audubon

as you was on the point of leaving London, when you wrote your last letter, I did not reply to it. This will probably find you returned from your excursion, and I hope with every success, on the score of increased subscribers, that you had anticipated, If you will be so good as send me your specimens of the Woodpeckers to Havell's, I shall be very glad to see them, and they shall be returned to you after examination with

${ }^{8}$ From the Howland MSS. 


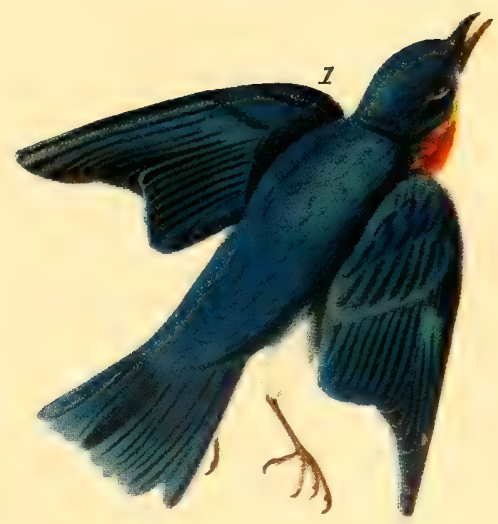

Plate Cait

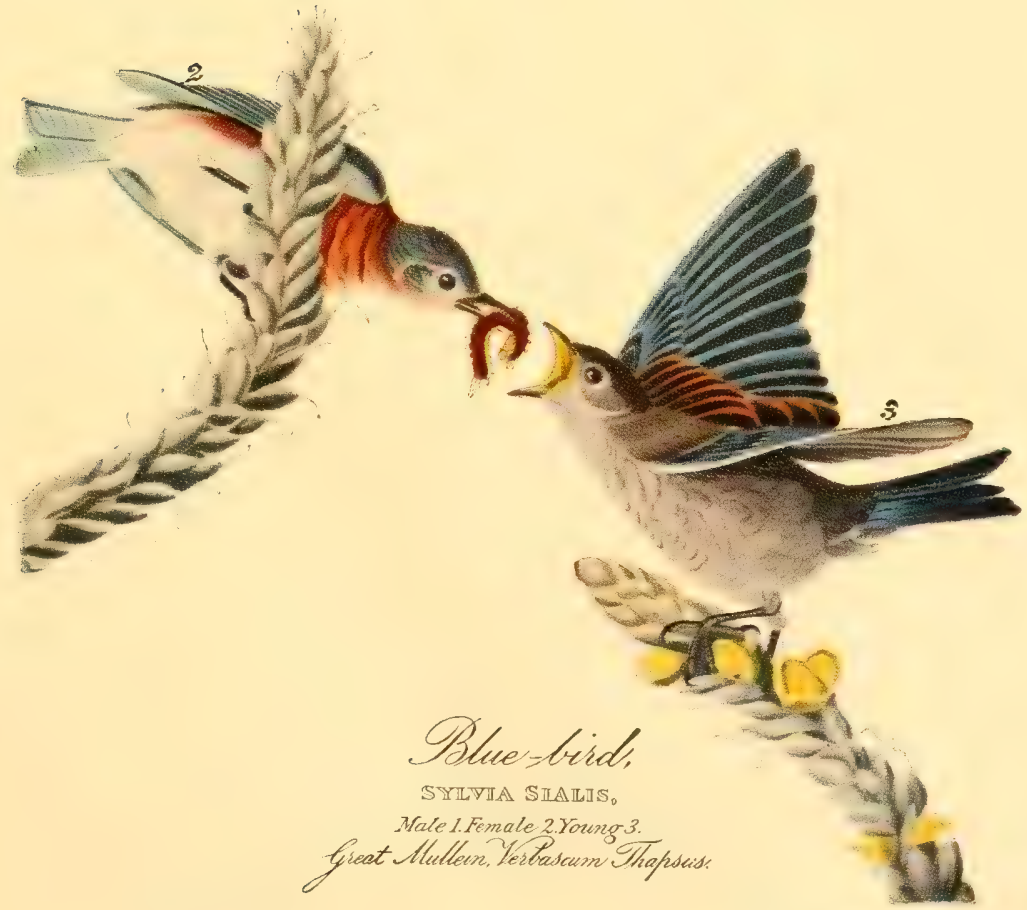

Drawn from nalure by J J Auduber F. R.S. E, L.S. 



\section{SIDELIGH'TS ON CONTEMPORARIES 101}

the Arctic ones. You will assist me very much by any Duplicates you can spare me, I particularly want a pair of the Ivory billed Woodpecker. the No Am: Parrots. Summer red birds and the Painted Buntlings also the Pinecreeping Warbler. m \& fem.

I do not expect that these most wonderful events in France will deter you from going, seeing that everything is now quiet. The french are certainly a great nation. I never had such an opinion of them as I now have.

I suppose you will be at the Dinner to Cuvier on Tuesday, when you will no doubt hear complements passing about, and a long speech from Mr Vigors. I have neither time nor health for such things.

Our united true regards to Mrs Audubon In haste very faithfully yours

W SwaInson

J. J. Audubon Esq.

43 Great Russell Street,

Bloomsbury.

From Manchester Audubon sent Swainson this letter, in which he makes a quaint proposal regarding the text of his projected work, suggesting that they combine their resources and their families, he to provide the ideas, as well as his own wine or ale, while Swainson furnished the science.

\section{Audubon to William Srainson}

Manchester 22nd August 1830.

My dear Mr. Swainson, -

At the time that I sent you the Woodpeckers skins, I had not a moment to spare or be assured I would have answered your note-When I opened my boxes of skins I had the mortification to find most of them touched by insects-I felt a desire that those nondescribed specimen [s] which I had should go to a public institution \& I therefore presented them to the 
British Museum through my friend Children-I sent others to New Castle upon Tyne some to this place and some to our friends Selby \& Sir Wm Jardine.-respecting the Woodpeckers which you look upon as knew I will merely say that if for instance it differs from all others known by having the top of the head entirely red that it may be a young bird, I say this because I do not know if you are acquainted with the fact that almost all the Woodpecker tribe have this in their youth more or less extended but after the first moult they assume the red in the form they are to wear it during life. I sent you a young of the Downy in that state-and if I recollect well also one of the Golden Winged-had you sent me your specimen, I think I could assisted you in determining if or no it is a new bird.should you become satisfied on that head, and I am honoured with its being named after me, I will feel gratified and thankful to you.-Mrs. Audubon is with me \& we are bound to the Scotch Lakes \& will return in about 2 months.-I am desirous to hear from you if you can have the time to spare \& the inclination to Bear a hand in the text of my work.-by my furnishing you with the ideas \& observations which $I$ have and you to add the science which I have not!-If it would suit you and Mrs Swainson to take us as borders for few months when being almost always together I could partake of your observations \& you of mine.-I would like to receive here your ideas on this subject $\&$ if possible what amount you would expect from us as remuneration.-My first volume will comprise an introduction and one hundred letters addressed to the Reader referring to the 100 plates forming the first volume of $\mathrm{my}$ illustrations. - I will enter even on local descriptions of the country.-Adventures and anecdotes, speak of the trees \& the flowers the reptiles or the fishes or insects as far as I know-I wish if possible to make a pleasing book as well as an instruction one.-In the event of my living with you we will furnish our own wines, porter or ale.-

I hope you know me well enough to write to me your ideas without fearing any offence done us should you find it either disagreeable or inconvenient, indeed this is simply to know 


\section{SIDELIGHTS ON CONTEMPORARIES 103}

from you if such a thing is at all likely to be advantageous to all parties.-We leave this on Saturday for Leeds and I will be glad to hear from you then-I have a confounded steel pen that scratches abominably.-Present Mrs Audubon's kind regards to your good Lady \& accept Yourself our united good wishes,

\section{your friend}

John J. Audubon.

Address to the care of

Thos Fowler Esq.

Bookseller

Aug 22nd 1830

Manchester.

[Superscribed] WM Swainson Esq.

Tittenhanger Green

$\mathrm{Nr}$

St Albans,

Herts.

In Swainson's clear and candid reply, ${ }^{9}$ which followed at once, all was figured "to a nicety"; he would supply his share of the matter at the rate of three dollars and seventy-eight cents per printed page, with an extra charge for corrections; he would follow his own ideas, but strive to avoid any conflict of opinion, and would expect his name to stand on the title.

\section{William Swainson to Audubon}

[between August 24 and 28, 1830]

My dear Mr. Audubon. Thursday

I received your letter yesterday, and hasten to reply to it. By some mistake or other, of Havell's, he has not sent the birds to which you allude, and I did not of course know that you had left them with him, now to your two propositions.

${ }^{\theta}$ First published by Ruthven Deane (Bibl. No. 217), The Auk, vol. xxii, p. 31 (1905). 
First, as to boarding with us, you do not know probably, that this is never done in England, except as a matter of necessity or profession, in which case the domestic establishment is framed accordingly. But this consideration would have no influence with me, in your case did other circumstances allow of it. It would however be attended with so many changes in our every-day domestic arrangements, that it becomes impossible.

Secondly, as to the proposition I once made to you, I am fearful you have put it out of my power to do so much as I might have done, from your having distributed the very birds which would have been the materials I was to work upon; and upon which only, any scientific observations truly original, ( \& therefore worth putting into your book), must be founded. Fortunately, however, my own collection is not poor in North American Specimens, and these would still furnish a mass of interesting information to the Scientific. It would be, however, highly advisable that all these species which I have not, but which you have brought home, and given away, should be borrowed back again, without delay.

Next as to plan. I have always told you that the plan you mention, so far as your own narrative goes, is the very best which could possibly be chosen. You have to speak of the birds as they are alive, $I$ to speak of their outward form, structure, and their place in the great System of their Creator, for the true system, if I have, or anybody else, has discovered is not a Human System. If my views are correct, every observation you make, plain, unvarnished, and strictly accurate, will fully and perfectly harmonize. Our parts are totally distinct, and we have no occasion to consult with each other what we should say at every page. Where our views may differ, I shall not, of course, say anything. My own remarks had better be kept distinct, in the form of "Scientific Notes" to each letter, at the end, and in this way you will make the work, the standard authority on American Ornithology, which without Science, it certainly would not be, however interesting or valuable in other respects. 


\section{SIDELIGH'TS ON CONTEMPORARIES 105}

As to time, and remuneration, I shall have completed all my portion of Dr. Richardson's works in two months. I can then derote a portion of each day to yours. The terms of my remuneration will be those which $I$ always receive from the Booksellers, and which are fixed, worth twelve guineas a sheet of the same size and Type as the Zoölogical Journal, each sheet being 16 pages, and each page averages 390 words, the calculation is there brought to a nicety, and you may spend as much as you choose. If I have to revise and correct the proofs, make alterations etc. that will be something additional, I always charge this by the time each sheet takes me, and would come to from $5 /$ to $7 / 6$ a sheet but the booksellers generally give me a round sum, which I name after trying the three first sheets of a work, with Dr. Richardson's the case was different, I there had $300 £$ for my assistance and drawings. It would of course be understood that my name stands in the title page as responsible for such portion as concerns me.

Should we arrange this matter, it will be time enough to fix on other minor points. But I should like to know your decision soon, as I have been applied to in another quarter. Indeed I am already so full of business, that $I$ have two years active employment ahead of me. I go for two days to assist Burchell ${ }^{10}$ in the arrangement of his African Birds prior to publication, at the end of the month, I shall bear in mind what you say on the Woodpecker but I have peculiar notions on Species, which, as I believe them correct, so I do not suffer to be influenced by others, you will see more of this in my Book of American Birds. ${ }^{11}$ Our kindest remembrance to Mrs. Audubon, and always look upon me as your sincere, but very plain spoken friend,

\section{W. Swainson.}

${ }^{10}$ William John Burchell (1782?-1863), an indefatigable collector and explorer, especially in Africa and Brazil; the zebra, Equus burchelli, and many animals and plants which he discovered have been dedicated to him.

${ }^{11}$ Referring to the Fauna-Boreali Americana, the second part of which, on "Birds," published in 1831, was by Swainson; see Vol. I, p. 410. 
P. S. I had a long letter from Chas. Bonaparte the other day, Vigors is gone to Rome!!

[Addressed] J. J. Audubon

c/o Mr. Thomas Fowlen, Bookseller,

Manchester.

[Endorsed by Audubon:] Answered 29th Aug. 1830. J. J. A.

Audubon's next letter, which was written from Manchester on August 29, must have been distinctly provocative, to judge from the following caustic reply ${ }^{12}$ which it drew forth; this is dated, "Tittenhanger Green, 2d October, 1830":

\section{William Swainson to Audubon}

\section{MY DR SIR}

I have refrained from replying to your letter until I thought you had returned to London.

Either you do not appear to have understood the nature of my proposition on supplying scientific information for your work, or you are very erroneously informed on the matter in which such assistance is usually given. Dr. Richardson, and a hundred others, similarly situated, might with equal justice say that no name should appear but their own; as it would rob them of their fame, because notes are furnished by one or two other persons, your friends would tell you, if you enquired of them, that even my name would add something to the value of the "The Birds of America" You pay me compliments on my scientific knowledge, and wished you possessed a portion; \& you liken the acquisition of such a portion to purchasing the sketch of an eminent painter-the simile is good. but allow me to ask you, whether, after procuring the sketch, you would mix it up with your own, and pass it off to your friends as your production? I cannot possibly suppose that such would be your duplicity and I therefore must not suppose that you

${ }^{12}$ First published by Elliott Coues (Bibl. No. 203), The Auk, vol. xv, p. 11 (1898); reproduced by Theodore Gill (Bibl. No. 205), The Osprey, vol. v, p. 23 (1900). 


\section{SIDELIGH'TS ON CONTEMPORARIES 107}

intended that I should give all the scientific information I have laboured to acquire during twenty years on ornithologyconceal my name,-and transfer my fame to your pages \& to your reputation.

Few have enjoyed the opportunity of benefiting by the advice and assistance of a scientific friend so much as yourself; and no one, I must be allowed to say, has evinced so little inclination to profit by it. When I call to mind the repeated offers I have made you to correct the nomenclature of your birds, from the first time of our acquaintance, and recollect the dislike you appeared to have to receiving any such information or correction, I cannot but feel perfect surprize at you now wishing to profit by that aid, you have hitherto been so indifferent about.

Let me however urge upon you one advise which, for your own sake, I should be sorry you despised. It is to characterize yourself, or get some friend to do so for you, all your new species. The specimens, you tell me, are now in England, \& the task will be comparatively easy. I urge this, because you may not be aware that a new species, deposited in a museum, is of no authority whatsoever, until its name and its character are published. I have repeatedly set my face against such authorities, so has Mr. Vigors, so has Ch. Bonaparte, and on this head we are all perfectly unanimous. Unless, therefore, this is done, you will, I am fearful, loose the credit of discovering nearly all the new species you possess, and this $I$ again repeat, for your own sake I should be sorry for. To me, individually, your not doing so, would rather be advantageous.

The more a book is quoted, the more is its merits admitted, and its authority established. it was on this account I so repeatedly requested the use only, of a copy of your book, that it might have been cited in "Northern Zoölogy" 13 not having it-I could not therefore mention it

I shall always be as thankful to you as formerly for any information on the habits, economy, and manners of birds;

${ }^{13}$ See Note, Vol. II, p. 105. 
but, as to species, I want not, nor do I ever ask, the opinions of any one. that is quite a different matter, and entertaining peculiar ideas on that subject, you must not feel surprised at my differing from you in almost every instance. My reasons will always be laid before the public. In the present case, we totally differ about species of Woodpeckers. I shall not, however propitiate a favourable opinion from you, or any one, by a compliment and therefore I will wait for some species which you yourself will admit, which I shall then give your name to, I am rather glad you did not accept my offer, for I am now assisting in bringing out an Octavo edition of Wilson, by Sir W Jardine which will be arranged according to my nomenclature.

$$
\begin{aligned}
& \text { Yours my dr Sir } \\
& \text { Very faithy }
\end{aligned}
$$

\section{W Swainson}

The letter just quoted naturally served as a check to their intimacy, but Audubon did not withdraw his friendly hand, as shown by his letters to follow later, though his answer to this has not been preserved. ${ }^{14}$

Audubon reached Edinburgh early in October, soon after receiving Swainson's decisive reply, and immediately made an arrangement with MacGillivray, as already related..$^{15}$ It is evident from Swainson's letter that when Audubon called upon him for editorial aid,

${ }^{14}$ But three other letters of Audubon to Swainson, after this date, are noted by Albert Günther (Bibl. No. 204) in the Proceedings of the Linnacan Society, 112th session (1900): one of "6 June, 1831," announces Audubon's prospective return to America in August of that year; another, dated "6 Dec. 1837," asks for the loan of some bird skins; and the last of "11 Jan. 1838," is reproduced in Chapter XXXII. Swainson is said to have been negotiating at this time with Charles L. Bonaparte in reference to a joint compilation for a work on the birds of the world; Bonaparte estimated that there were then between 7,000 and 8,000 known species to be characterized, but Swainson's terms were not satisfactory, and nothing came of the project. To the above list should be added the letter, evidently misdated, of "April 98 th. 1831," soon to follow.

${ }^{15}$ See Vol. I, p. 438. 


\section{SIDELIGHTS ON CONTEMPORARIES 109}

he was by no means ready to defer to him wholly in the matter of naming his birds, a subject in which Swainson regarded himself as the first of living authorities. Swainson's pride was also wounded at Audubon's apparent lack of appreciation of the weight which his name would carry if allowed to grace the title pages of his works, and he speaks of Audubon as if he were ready to bargain for scientific information but determined to withhold that credit which is every writer's just due. It is only fair to say that Swainson's vanity seems to have outrun his candor, for when the controversy over the authorship of Audubon's Biography of Birds was started in 1833, he publicly denied that any such proposal had been made. ${ }^{16}$ According to Swainson's own statement, quoted earlier, Audubon was ready to grant him whatever credit was due, but it is evident that he was not then disposed to adopt Swainson's peculiar ideas upon the classification of birds or to enter upon a thoroughgoing arrangement of joint authorship. Though no philosopher himself, it seems clear that the American woodsman was by no means disposed to swallow all the vagaries of the "Circular System" to which his friend was committed, and which was later held up to ridicule.

The craze for describing ncw species of animals was all too common in both England and America at the time of which we write; the chief aim of many naturalists seems to have been to attach their names to as many of nature's forms as possible. Swainson, who "never went to bed without describing a new species," as Audubon said at a later time, had admonished his friend above all else to hasten to publish descriptions of every new bird which he had obtained in America, lest he lose

${ }^{16}$ See Vol. II, p. 88. 
credit for the discovery; but Audubon, who had not hesitated to poke fun at the species-mongering Rafinesque, was still inclined to look with disdain upon work of this sort. He not only rejected Swainson's advice but answered it rather tartly in the first volume of his letterpress, which appeared in the following year. A passage which caused the naturalist no little annoyance on another score was as follows: ${ }^{17}$

Since I became acquainted with Mr. Alexander Wilson, the celebrated author of the well known and duly appreciated work on American Birds, and subsequently with my excellent friend, Charles Lucien Bonaparte, I have been aware of the keenness with which every student of Natural History presses forward to describe an object of his discovery, or that may have occurred to travellers in distant countries. There seems to be a pride, a glory in doing this, that thrusts aside every other consideration; and I really believe that the ties of friendship itself would not prevent some naturalists from even robbing an old acquaintance of the merit of first describing a previously unknown object. Although I have certainly felt very great pleasure, when, on picking up a bird, I discovered it to be new to me, yet $I$ have never known the desire above alluded to. This feeling I still cherish; and in spite of the many injunctions which I have received from naturalists far more eminent than I can ever expect to be, I have kept, and still keep, unknown to others, the species, which, not finding portrayed in any published work, I look upon as new, having only given in my Illustrations a number of them proportionate to the drawings of already known species that have been engraved. Attached to the descriptions of these, you will find the place and date of their discovery. I do not, however, intend to claim any merit for these discoveries, and should have liked as well that the objects of them had been previously known, as this would have saved some unbelievers the trouble of searching for

${ }^{17}$ Ornithological Biography (Bibl. No. 2), vol. i, p. xvii. 


\section{SIDELIGHTS ON CONTEMPORARIES 111}

them in books, and the disappointment of finding them actually new. I assure you, good reader, that, even at this moment, I should have less pleasure in presenting to the scientific world a new bird, the knowledge of whose habits I do not possess, than in describing the peculiarities of one long since discovered.

It is a pity that Audubon did not maintain so admirable an attitude towards the description of new species as was here expressed, but at the close of his career in England, when he desired to make his work on American ornithology as complete as possible, he appeared as keen to describe and publish new birds as any of his contemporaries.

Shortly after his return to London in the spring of 1831, Audubon sent Swainson the following letter with a copy of the first volume of his Biography of Birds, but his one-time friend was not the author of an extended and impartial review of the work, which appeared in the Edinburgh New Philosophical Journal in the same year. ${ }^{18}$

${ }^{18}$ Signed "Ornithophilus" (see Bibliography, No. 97), and attributed by Coues (see Bibliography, No. 181), with a question mark, to Swainson, but the internal evidence shows conclusively that he was not its author. The writer of this article said that it was not enough to state that Audubon "has invented a new style in the representation of natural objects; for so true are his pictures, that he who has once seen and examined them, can never again look with pleasure on the finest productions of other artists. To paint like Audubon, will henceforth mean to represent Nature as she is. ... To relieve, as Mr. Audubon says, the tedium of those who may have imposed upon themselves the task of following an author through the mazes of descriptive ornithology, he has interspersed descriptions of American scenery and manners, gloomy forests, tangled cane-brakes, dismal swamps, majestic rivers, floods, tornadoes, and earthquakes; the migration of the white man, the retreat of the red; the character and pursuits of the backwoodsman.... Much, therefore, is it to be wished that Mr. Audubon would undertake the delineation of the birds of Great Britain, which, with his matchless talents, aided by those of Mr. Havell, would eclipse, not only all other representations of these birds, but even the 'Birds of America,' unrivalled as that work now is." 


\section{Audubon to William Swainson}

London April 28th 1830 [1831]

\section{My dear Mr Swainson,}

We arrived here last evening \& I found your favour of the 17 th instant for which I offer you my sincere thanks-I had began to think that I was erased from your list.-I have now the pleasure of sending you a copy of my first volume of ornithological biography which I hope you will accept as a small memento of the high regard I have for your self \& your talents.-My inserting your name was not a matter merely of duty but of great pleasure and believe when I say that I never will be ungrateful to anyone who has been kind to me.-

We are going to Paris on Friday week \& will be absent about a month-on the first day of August next we sail from Liverpool to America where I intend to beat the bushes once more-my peregrinations will extend in all probability \& God willing to the Pacific Ocean into California etc-After my return I wish to settle in England somewhere, but where is yet undetermined.-

I have felt much grieved at reading the article of yours respecting French Naturalists. I say grieved, because I am always so when I see men of superior talents employing their pen time and mind at sparring instead of peacably giving to the world those results of their investigations \& experience at all times so desired by everyone bent on studying the wonderful laws \& beauties of nature. I do not wish to read a lecture to you but from my heart I am sorry you should be à la joute [?] with any one \& will conclude by sincerely hoping that you will have no more of this sort of warfare.-

I am over head in business as you may well suppose after an absence of 8 months but will be most happy to hear from you. Have you heard from C. Bonaparte lately? Is he still at Rome? it is now two months since I heard from him.-

Present our united kind respects to your good Lady, accept the same yourself \& believe me your friend

J. J. Audubon.

77 Oxford Street. 


\section{It is interesting to notice that Swainson kept his} promise about the woodpeckers, and in 1831 named one, which had been obtained from Louisiana, Picus auduboni; ${ }^{19}$ although Audubon later repudiated it, saying that he believed it to represent only an immature state of the common Downy Woodpecker, he returned the compliment by dedicating to Swainson one of his warblers, Sylvia, now Helinaria, swainsonii.

When William Swainson brought to a close his labors on the Cabinet Cyclopadia in 1840, a part of the eleventh volume was devoted to a biography of naturalists. ${ }^{20}$ In this little work Audubon was accorded a page, Alexander Wilson received eight, while the author devoted fourteen pages to himself. The talented MacGillivray, whose memorable History of British Birds had then advanced to its third volume, was studiously ignored, and was referred to only in a footnote as "Mr. Gilvray"; but he was of necessity a sharer in the follow-

${ }^{19}$ See Ornithological Biography, vol. v, p. 194; and Theodore Gill (Bibl. No. 206), The Osprey, vol. iv and v. It seems that Dr. James 'Trudeau, out of ignorance or disregard for Swainson's designation, later named a woodpecker, obtained near New Orleans in 1837, Picus auduboni, and by a strange coincidence, as Dr. Gill has noticed, the same name was given by two different naturalists to the same bird, now regarded as a variety and known as Dryobates villosus auduboni.

${ }^{20}$ The Cabinet Cyclopadia was published by Messrs. Longman, Orme \& Company, and edited by Rev. Dionysius Lardner. Swainson wrote eleven of the twelve volumes devoted to natural history. The volume to which we refer is entitled Taxidermy, Bibliography, and Biography, by William Swainson, A. C. G. [Assistant Commissary-General], F. R. S. \& L. S., Hon. F. C. P. S. etc., and of several foreign societies (see Bibliography, No. 170). The Literary Gazette for August 8, 1840, in noticing this work, said: "Perhaps the amusing and frequent illustration of his character is to be found in the autobiographical sketch of himself, which he has not only included in this portion of his volume, but induced his publishers to forward on a separate sheet with the subjoined note:

"Messrs. Longman, Orme, \& Co., will feel particularly obliged if the Editor of the .................... will permit the above Autobiography to appear in his columns at the first suitable opportunity.' " '39 Paternoster Row, July 29, 1840.'”

Quoted by Theodore Gill (Bibl. No. 206), The Osprey, vol. iv, p. 105 $(1900)$. 
ing criticism of Audubon's Biography of Birds: "a want of precision in his descriptions, and a general ignorance of modern ornithology sadly disappoint the scientific reader." The technical descriptions in that work were written, as Swainson must have known, by his young rival, William MacGillivray, then one of the ablest exponents of the anatomy of birds in Great Britain; but anatomy, the master key to relationship, Swainson affected to regard with contempt, though overzealous friends had compared him with Cuvier, one of the greatest masters of anatomy of all time. To follow the comment of a later critic, ${ }^{21}$ Swainson probably regarded the title of "the British Cuvier" as rather derogatory, since he had pronounced Cuvier to have been "totally unacquainted with the very first principles of the natural system." To Swainson, however, as the same commentator explains, "the natural system" implied the concept of a magical number and a circle, ideas which Cuvier would have been the first to repudiate or ignore.

The ardent MacGillivray was naturally scornful of Swainson's unscientific attitude, which he had roundly scored in the introduction to his History of British Birds that had begun to appear in 1837; he then said that Swainson could exclaim: "How superficially do we study nature," while in anatomy his own studies were a century behind the times and his opinions on the subject worthy of the Dark Ages.

In his biographical notice of Audubon, Swainson refers to their Paris experience in the following words:

It is singular how two minds, possessing the same tastes, can be so diversified, as to differ in toto respecting the very same objects. During the whole of Mr. Audubon's residence

${ }^{21}$ Theodore Gill, loc. cit. 
in Paris, he only visited the Ornithological Gallery twice, (where I was studying for hours, almost daily), for the purpose of calling upon me; and even then he merely bestowed that sort of passing glance at the magnificent cases of birds, which a careless observer would do while sauntering in the room.

Audubon, to be sure, was never much of a closet naturalist or an admirer of stuffed specimens; but in reading this criticism of an estranged friend, one wonders if the writer had really forgotten that while his own expressed desire in going to Paris in 1828 was to study in the Museum, Audubon's sole purpose was to extend his subscription list; that after innumerable interviews with ministers of state and running from post to pillar for two months, his friend was obliged to come away with but thirteen additional names or orders for his work. Had Swainson also forgotten that during all that time Audubon acted as his interpreter, assisting him in all his visits and purchases, and that but shortly after, when hard pressed for money, he had called on Audubon for a considerable sum?

As a parting shot to his former friend, Swainson also said:

He can shoot a bird, and make it live again, as it were, upon canvass; but he cannot describe it in scientific, and therefore in perfectly intelligible terms. Hence he found it necessary, in this part of his work, to call in the aid of others; but being jealous that any other name should appear on the title page than his own, he was content with the assistance of some one who, very good naturedly, would fall in with his humour.

What was here said of Audubon might have been true in 1830, but it was not true in 1840. Swainson could never understand that his friend was a man who 
never stood still. Audubon drew heavily upon his more learned associates, and he could give as well as take. When working under the influence of a powerful motive, he improved as rapidly in his use of English words as he had in the finish and composition of his pictures; he soon came to write not only with fluency but at times with eloquence, and the technicalities of his science did not remain to him a sealed book, though for the drudgery of detailed description he had confessedly no stomach.

We have referred to William Swainson's advocacy of the "Circular" or "Quinarian" system of the classification of animals, with him amounting almost to a monomania, which was one of the most notorious examples of reasoning in a circle of which zoölogists have ever been guilty. It was a serious attempt to rationalize nature in a wholly irrational manner, and must be regarded as a curious by-product of minds fixed in the belief of a special creation,-to whom every form of evolutionary doctrine was sacrilegious and abhorrent. Its advocates, nevertheless, were sincere, and Swainson probably regarded himself as a martyr to the cause. As a later critic remarked, the system served him well by investing with a cloak of originality his treatises on those classes of animals with which he had little first-hand knowledge. His work on fishes is regarded as "a literary curiosity, the appearance of which was a misfortune to a man who, by his indefatigable industry under by no means favorable circumstances, had contributed as much as any of his contemporaries to the advancement of Zoölogy and its diffusion among the people." 22 This egregious doctrine, which its disciples called "the natural system" without grasping the true meaning of

${ }^{22}$ Albert Günther, loc. cit. 


\section{SIDELIGHTS ON CONTEMPORARIES 117}

"affinity," or "homology," to use the more modern word, vitiated most of their writings; abler men played with it for a time, only to cast it aside, and no one but a historian or a psychologist would now give it a passing thought.

So far as Swainson was concerned, Audubon's conduct appears to have been above reproach, and it must be regarded as fortunate that this ardent "Quinarian" did not have a hand in the Biography of Birds, for if it were really true that Audubon could have brought himself to accept the artificial system then in vogue, American ornithology, as Elliott Coues remarked, escaped a great affliction.

Swainson's early life affords a striking illustration of nepotism, and his later years reflected some of its disastrous consequences. At fourteen he was appointed as a junior clerk in the Liverpool Customs House at a salary of eighty pounds a year, to service under his father, who had in turn succeeded his grandfather in the office of Collector. At eighteen he received an appointment in the commissary department of the English army and went to Sicily, where he remained eight years, during which he worked industriously at natural-history pursuits. Having attained the rank of Assistant Commissary-General, at twenty-six he was retired on halfpay because of ill health. Upon returning to England he became a member of the Linnæan Society, in 1816, before his departure for Brazil, where with Henry Koster he collected birds for nearly two years. Having settled again at Liverpool, he entered the Royal Society, on the recommendation of Sir Joseph Banks, in 1820, the year in which he began to publish the results of his studies. Swainson was married in 1825 , but upon the death of his father in the following year, his income was so much reduced that he resorted to authorship as 
a profession; of course he found it a poor crutch, though he worked with indefatigable industry and produced from one to two illustrated volumes each year. Eventually he became embittered against Audubon and towards the world of men and things in general, especially after 1835, when domestic bereavement and trouble of many kinds pressed hard upon him. He repeatedly applied to the Zoölogical Department of the British Museum for a position which went to others; he tried to sell his collections to the Museum and failed; he applied for an appointment on the Civil List but was denied; then he decided to give up the struggle of authorship in England and leave the country.

In 1840 Swainson emigrated with his family to New Zealand, where he seems to have met with no better success, although his scientific activity did not wholly cease. Being four years younger than Audubon, he outlived him five years, dying in 1856. His excellent draughtsmanship, tireless industry, and punctilious habits were deserving of recognition, but he suffered from the lack of a liberal education, and was rather too vain, too inclined to jealousy and to quarrel with his contemporaries, to have achieved great success.

In a paragraph already quoted from the Ornithological Biography, in which Audubon portrayed the eagerness with which some naturalists pressed forward to describe new species of birds, too often forgetting every propriety in their eagerness to outstrip a rival, the name of his "excellent friend, Charles Lucien Bonaparte," 23 had been indiscreetly mentioned. Though there was no evident intention of giving offense, this reference was keenly resented. Bonaparte, it may be recalled, was still engaged upon his American Orni-

${ }^{23}$ For notice of Bonaparte see Note, Vol. I. p. 329. 


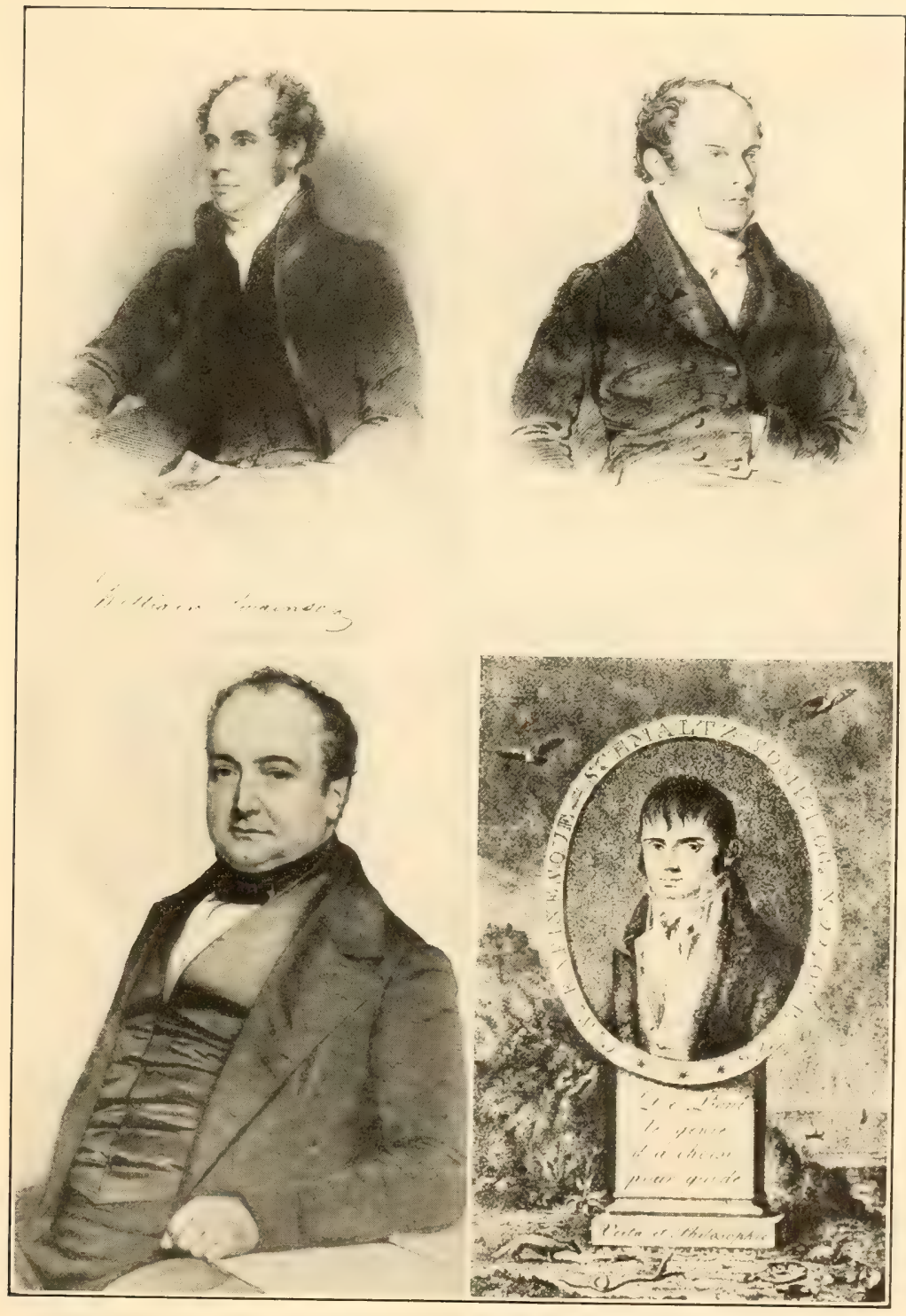

WILIIAM SWAINSON CHARLES L. BONAPARTE

THOMAS NLTTALL CONSTAN'TINE S. RAFINESQUE SWAINSON FROM HIS "BIOGRAPHY OF ZOÖLOGISTS"; NUTTALI. FROM AN ENGRAVING AFTER DERBY, 1825; BONAPARTE FRONT A PHOTOGRAPH IN POSSESSION OF MR. RUTHVEN DEANE, FIRST PUBIISHED IN "CASSINIA"; AND RAFINESQUE FROM RICHARD ELLSWORTH CALL, "RAFINESRIE," 

thology, the last volume of which was not published until 1833, and was therefore, in a degree, a rival of Audubon in the ornithological field. Audubon did his best to smooth over the difficulty but with little success. In writing to his son, Victor, from New York in 1833, ${ }^{2+}$ he referred to the following letter which he was about to send "by duplicate, to try to correct that error" of his early friend:

\section{Audubon to Charles Lucien Bonaparte}

To Charles Bonaparte,

Prince of Musignano, \&c., \&c., \&c.

\section{My dear Sir:-}

I am sadly grieved to hear through our friend, Wm. Cooper, of this city, that you have taken umbrage to a passage in the Introduction to my first volume of Ornithological Biographies.

To tell you that not even a thought of disparagement ever existed in my mind towards you, would not be enough. I have always repeated to all my Friends, nay, to all persons who have ever spoken of you, of the superior talents you possess, and of the Intrinsic value connected with all your ornithological or otherwise scientific productions.

I am a plain sailing man. You know full well that I derive no knowledge from classical education, and that being the case, connected with my being honest, I always try to say what I think truth, at once. Could I have praised you at one place, and attempted to lower you in the estimation of the Scientific World at another? If so-I would acknowledge myself unworthy the good wishes of any one, much less of the good wishes of Charles Bonaparte! the very being who brought me forward into worldly notice by his kind advice. Nay, Nay; take me for what $I$ am in truth

Your Friend \& ever your well wisher, as well as your obt. Sert.

John J. Audubon. 
Bonaparte was too much of a man of the world to permit such an incident to cause any sudden break in their relations. We know that they met in London in 1837, when, as Audubon said in a later letter to Harris ${ }^{25}$ he "pumped him sadly too much"; at his request Bonaparte then drew up a list of American birds, to the number of 425. ${ }^{26}$ Although his subscription to The Birds of America was permitted to lapse, Bonaparte's name was retained on the list to the end. When the business was being closed up in London, however, Audubon wrote to Havell, from Edinburgh, under date of 15 May, 1839: "As respects my old Friend, C. Bonaparte, unless he pays the long standing balance which he owes me of £8.18.6, and also the price of the set of Nos. 81-87, on the nail, he is not to receive the latter." Again on the thirtieth of June he wrote: "I have no numbers for Charles Bonaparte, and no 5 th. vol. of Biog. for Mr. Gould; let the Gentlemen purchase or procure what they want where they can."

In 1838 Bonaparte published a paper ${ }^{27}$ in which appeared this comment:

Throughout the list I have quoted, as types of the species

${ }^{25}$ See Vol. II, p. 184.

${ }^{28}$ This manuscript list is preserved with the original drawings of The Birds of America, in possession of the Historical Society of New York, where I was permitted to examine it. It bears the following attests of both naturalists in autograph:

"The above list of the Birds of America was made at London on the 15 th. of December, 1837, when it was supposed to contain all the known species.

\section{"JoHN J. AUDUBoN,} of Louisiana."

"The above list of North American Birds was drawn up by myself to please Mr. J. J. Audubon.

"London, 15 December, 1837.

"Charles L. Bonaparte.

"The total number of good species, 460," has been added in pencil.

"Comparative List of the Birds of Europe and North Americe. London, 1838. 


\section{SIDELIGHTS ON CONTEMPORARIES 121}

under consideration, the figures of the great works of $\mathrm{Mr}$. John Gould and Mr. Audubon on the Ornithology of the two regions, as they must be considered the standard works of the subject. 'The merit of Mr. Audubon's work yields only to the size of his book; while Mr. Gould's work on the Birds of Europe though inferior in size to that of Mr. Audubon-is the most beautiful work that has ever appeared in this or any other country.

A reviewer in America, ${ }^{28}$ who could not repress his resentment at the last remark, said: "It would be invidious to make any comment on this-to even insinuate a wonder that a personage bearing this world renowned name would consent to resign his reputation as a man of science, through all time, to the doubtful association of such an expression of mere professional spite."

John Gould, to whom Bonaparte referred, was perhaps the only ornithologist who ever grew rich at his profession. He was the author of forty large, illustrated folios, produced at the rate of about one a year, on the birds of Great Britain, Europe, Asia, and Australia, as well as those of numerous families of the tropical Orient. Audubon, in response to Bachman, thus referred to him when writing in London, April 30, 1835: "Gould is a man of great industry and has the advantage of the Zoölogical Society, museums, gardens, \&c., and is in correspondence with Temminck, Jardine, Selby, James Wilson and the rest of the scientific gentry. His wife makes his drawings on stone. She is a plain, fine woman, and although their works are not quite up to nature, both deserve great credit."

Acting no doubt upon this expressed belief, Audubon became a subscriber to Gould's Century of Birds,

${ }^{28}$ See Note, Vol. II, p. 122. 
published in 1831, and also to his Birds of Europe (1832-37). In the preface to the latter work, "J. J. Audubon, Esq.," and twenty others are thanked "for the warm interest which they have at all times taken in the present work"; it was also said that the greater part of the plates of this series, those of his Century of Birds from the Himalaya Mountains and his Monograph on the Trogons, as well as three-quarters of those of the Monograph on the Toucans, "have been drawn and lithographed by Mrs. Gould, from sketches and designs by myself always taken from nature." It should be noticed also that Gould appeared as a subscriber to The Birds of America in 1838, but his name was soon dropped.

Gould was preëminently a museum naturalist, of strong commercial instincts, and spent but little time in the field. His books were mainly composed of illustrations made by artists from stuffed specimens, with a text of so thin a quality as to possess little scientific value; but, as Alfred Newton has remarked, a scientific character was so adroitly assumed that scientific men have often been deceived. In his best work, that on the Humming Birds, ${ }^{29}$ the plates are enlivened by numerous specimens of tropical flowers and fruits, an accessory not so noticeable in his early productions. It has been said that Gould sought and received Audubon's aid in the composition of some of his plates, and that thereafter his figures began to show more vitality. The over-zealous writer quoted above ${ }^{30}$ made the charge that Gould not only received much unacknowledged aid from Audubon, but copied his drawings; he mentioned five

${ }^{29}$ A Monograph of the Trochilida, or Family of the Humming-Birds;

5 vols., fol., with Supplement by Bowlder Sharpe, London, 1861.

${ }^{30}$ Charles Winterfield, see Bibliography, No. 148. 
cases of what he called "picking and stealing," in one of which the Red-headed Pochard is declared to have been copied from Audubon's Scaup Duck: "here the trick is so shallow," he adds, "that detection cannot for a moment be at fault. You see that the Scaup Ducks have been accurately outlined, then lifted from the original 'grounding,' and let down upon a new one, by Gould, who found it safer for his pencil to adjust earth and water differently beneath them, than to tamper in the slightest degree with the proportions of the figures themselves." Suffice it to say that there is little or no substantial basis for such odious charges.

Gould is said to have possessed a kind heart under a rather gruff exterior. The following anecdote of his methods comes at second hand from his friend and collaborator, Mr. Bowlder Sharpe. Mr. Gould was invited to dine at a well known country estate, where were gathered numerous representatives of wealth and aristocracy. The attention of the ornithologist was soon directed from the guests to a bird on the lawn, which he was watching intently when dinner was announced; abruptly leaving the table with the remark that dinner was of no consequence to him when he could study a bird, he returned to the window and stood there munching a roll or piece of bread. Of course the seated guests began to inquire who the peculiar individual was, and were quietly informed by their host that it was "Mr. Gould, the famous ornithologist." The meal over, Gould selected a promising looking young nobleman and began to tell him about the habits of the bird which had so fascinated him; "that species," he said, "I have described in my Birds of Europe. Of course, you have seen my Birds of Europe." The nobleman was obliged to admit that he had not. "Why," said Mr. Gould, "you must 
have seen it; every country gentleman has it in his library. Won't you let me put you down for a copy?" Naturally he could not refuse a work which every country gentleman possessed, and down went his name on the list; later he received the volumes and also a bill for fifty pounds. John Gould is said to have left a fortune of eighty thousand pounds.

Probably no class of men with kindred tastes are bound together with stronger ties of good fellowship than the naturalists. Their free-masonry extends to every clime and race, and knows no distinction of language, class or station; but, as with all serious workers, occasional jealousies or disputes occur to ruffle the serenity of their lives. Though we have been obliged to touch upon some of these incidents, they are nevertheless quite exceptional. 


\section{CHAPTER XXX}

\section{AUDUBON AND MACGILLIVRAY}

In London once more-MacGillivray's assistance continued-Return to Edinburgh-MacGillivray's character and accomplishments-Audubon's acknowledgments-Tributes of "Christopher North"-Results of overwork-Fusilades from "Walton Hall"-Progress of the large plates.

Audubon's return voyage, begun in mid-April, lasted twenty days, and was one of the uneventful, "not unpleasant sort." Liverpool was reached in early May, and later in the month the Audubons were again settled in London, where on June 1, 1834, the naturalist wrote to Edward Harris:

We found Victor at home in the evening of our arrival; I thought that the very sight of him was a restoration of life to me, and our happiness was as complete as it may ever be expected on this Earth.

After all, I long to be in America again, nay, if I can go home to return no more to Europe, it seems to me that I shall ever enjoy more peace of mind, \& even Physical comfort than I can meet with in any portion of the world beside. ${ }^{1}$

While at Charleston in the previous winter, Audubon had worked diligently at his letterpress, and no doubt, before returning to Europe had his "biographical" materials well in hand. We have seen that at Edinburgh in the autumn of 1830 he entered upon a businesslike arrangement with William MacGillivray to as-

${ }^{1}$ From letter written at 73 Margaret Street, Cavendish Square, and sealed with turkey-cock seal. (Jeanes MSS.) 
sist him with the technical portions of the Ornithological Biography. The part which his young assistant played in this work was long a subject of dispute, until letters of both which showed the precise character of the relations between them were finally published.

Immediately upon his return to England Audubon again applied to his young friend, and received from him the following letter: ${ }^{2}$

\section{William MacGillivray to Audubon}

Edinburgh, 11 Gilmore Place. 28 th May 1834.

DeAR Sir,

I am glad to hear of your safe arrival, which I did not expect so soon, and pleased to find you in good health and high spirits. As you have the kindness to inquire respecting myself and family, I am happy to inform you that we are all very well, contented and busy. My head and hands are quite full-abundance of work and sufficient pay-time to ramble now and then for the purpose of hammering rocks, pulling plants, and shooting birds.

You say you have accumulated a mass of materials which you are desirous of sening in print, and propose that $\mathbf{I}$ should revise it as before. I shall be glad to do so, if you please, and willing that you confer the benefit on another, if you find it expedient. As to the terms, let them be such as you please with respect to money; but as time is valuable to me, I should like that arrangements be made so as to prevent unnecessary loss of it, by letting me have manuscripts, books, \&c. in due array.

The skins of which you speak I apprehend cannot be disposed of here to any great extent; but I believe shells might be sold to advantage, and bring higher prices than in London.

You ask if I draw Birds yet, with a view to publish. My

${ }^{2}$ First published by Elliott Coues (Bibl. No. 43) in the Bulletin of the Nuttall Ornithological Club, vol. v (1880). 


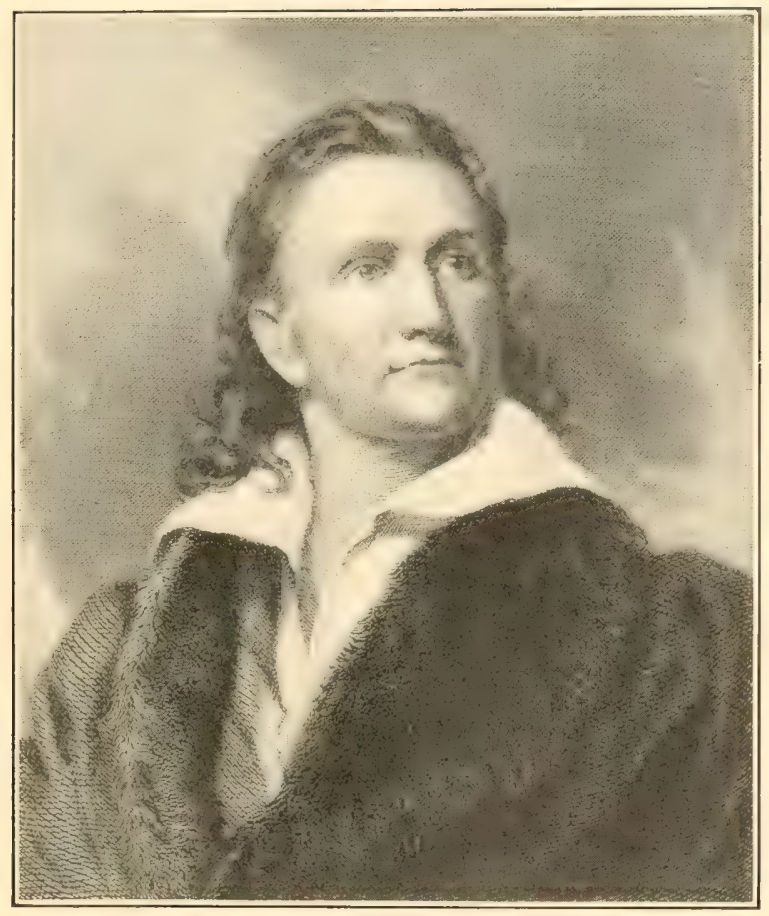

\section{$\triangle \mathrm{UDUBON}$}

AFTER THE EXGIRING BY IT, B. HAR, OF TIIE POITRAIT PAINTED BY HENRY INMAN IN 1833. 

answer is that I dissect, describe, and draw Birds, Quadrupeds, whales, reptiles, and fishes, with view of astonishing the world, and bettering my condition. I have about a hundred drawings, all the size of life, excepting two dolphins. But I have determined nothing as yet respecting publication. Some time ago a friend of mine called on Mr. Havell with a letter in which I desired that person to engrave for me a few of my drawings, for the purpose of being exhibited at the meeting of naturalists. I had no answer, and so Mr. Havell may go to Jerico, or elsewhere, as he lists; but further your correspondent saith not.

I am decidedly of opinion that, although you should continue the publication of the Ornithological Biography, you might bring out various other works which could not fail to be popular; for example a biography of yourself, and sketches of American scenery. But of these matters it is impossible to speak to purpose unless I had the pleasure of seeing you, a pleasure which I hope I shall have at the time of the general assembly of the naturalists.

With best respects to Mrs. Audubon, and best wishes for the prosperity of all that bear that name, I have the honour to be, Dear Sir, yours in sincerity,

\section{W MacGillivray.}

[Superscribed] John J. Audubon, Esqr. Mr. Havell, 77 Oxford St. London.

A satisfactory arrangement was made and MacGillivray set to work on Audubon's second volume. On the 16 th of June he wrote from Edinburgh:

If you send me twenty or twenty-five articles, I can revise them without the books to which you refer, and without your own presence, provided your descriptions be full, and the drawings or plates sent to me. The skins and books might be consulted afterwards, when we might go over the articles in company. Should you come here for the purpose, it would not, I 
believe, be necessary for you to stay more than three weeks or so. . . To be methodical I should like twenty-five birds, that is description of birds, by your first parcel; but I cannot state precisely at what time they might be revised, only I think were you to send them, you might make a trip to France and be back before I should be done. ${ }^{3}$

By the 9th of July MacGillivray had received the twenty-five descriptions of birds called for, and on the 18th of that month he wrote to report progress as follows:

I commenced my operations on the 1 st of July, and have transcribed and corrected eighteen articles, one for each day, but not one on each, the work of Sunday being transferred to Monday. This volume will certainly be much richer and more interesting. ... You wish to know my opinion as to the improvement of your style. It seems to me to be much the same as before, but the information which you give is more diversified \& more satisfactory.

On more than one occasion MacGillivray urged $\mathrm{Au}-$ dubon to reduce the size of his text, and in the letter just quoted he said: "Had it been of the post 8 vo size, in two volumes it would have gone off in style; but your imperial size and regal price do not answer for radicals, or republicans either. Could you sacrifice the first volume, reprint it of a small size and continue the series to the end?" He remarked that if twenty woodcuts or engravings were added to each volume, "it would spread over the land like a flock of migratory pigeons. Even without the embellishments it would fly, but were you to give it those additional wings, it would sweep along in beautiful curves, like the nighthawk or the

${ }^{3}$ For this and extracts in the two following paragraphs, see Ruthven Deane (Bibl. No. 209), The Auk, vol. xviii (1901). 
purplebreasted swallow." "I have often thought," he continued, "that your stories would sell very well by themselves, and I am sure that with your celebrity, knowledge, and enthusiasm, you have it in your power to become more popular than your glorious pictures can ever make you of themselves, they being too aristocratic and exclusive."

Audubon kept MacGillivray supplied with materials, while he remained in London during the summer of 1834. On the 25th of August he wrote Bachman that he had sold bird skins to the British Museum to the amount of fifty-two pounds sterling, and again for twenty-five pounds, while Havell had disposed of a goodly number more, so that "he would not be a loser in that way"; he added: "My own double collection I have in drawers at home." Acting evidently upon Swainson's advice, Audubon began to accumulate a large and valuable collection of the skins of American birds, which he brought with him to America in $1839 .^{4}$ Though rightly criticized for not having deposited in some museum a complete series of the forms which he described, Elliott Coues certainly was not justified in remarking that his interest in a bird ceased from the moment he had made a drawing of it; on the contrary, he spent no end of time and lavished large sums of money on collections to illustrate variation of every description, as well as for anatomical dissection.

A hint thrown out by MacGillivray seems to have been well taken, for in the letter just quoted Audubon said: "This coming winter I will spend at writing my own Biography, to be published as soon as possible, and to be continued, as God may be pleased to grant me life." As already noticed, ${ }^{5}$ this effort resulted only in 
a fragmentary sketch, which was not published for over half a century.

Audubon started for Edinburgh in September of 1834. He wrote to Edward Harris from Liverpool, on the 15th of that month, to inquire into the truth of a report, which had circulated in London, of the failure of the house in New Orleans "in which our friend N. Berthoud is concerned." "I wish you would have the kindness to inform me," he adds, "if he is a sufferer by this mishap, and I wish you to keep this quite entre nous." At a slightly earlier day Audubon had entertained the idea of illustrating the birds of Great Britain on a scale commensurate with his work on those of America, but on May 1, 1828, he wrote Swainson that no one favored the project, and it was quickly given up. The subject is referred to by MacGillivray, in a letter written from Edinburgh, May 7, 1831: "As I understand your proposals respecting the Birds of Britain to have ended in nothing, and as you do not allude to the subject, I shall suppose all your ideas to have dispersed, and shall think of the matter myself." The first volume of MacGillivray's History of British Birds appeared six years later. ${ }^{6}$ It is evident that he wished to obtain Audubon's criticism of some of the drawings subsequently used in this work when he sent the following formal note $^{7}$ to his lodgings at Edinburgh:

William MacGillivray to Audubon

Eninburgh, 22d. october, 1834.

Dear Sir,

I take the liberty of sending you a collection of drawings made by myself, and intended for a work on the vertebrate

${ }^{6}$ See Vol. II, p. 135.

7 This, and the letter of MacGillivray soon to follow, are from the Howland MSS. 
Lear dr;

\section{Edenibugh, 22:. octoter, 1834 .}

Fate the liberty of cending you a Pollection of prawnip made by myreg, ano nikekder for a work on the bectebrate aminal of heat Aritout. The atimil. my rucep with whice you Have defricted awhole clap of the protruckowi of yerce noctive cand, as evenced in the

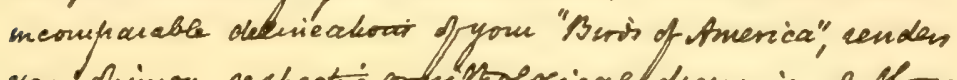

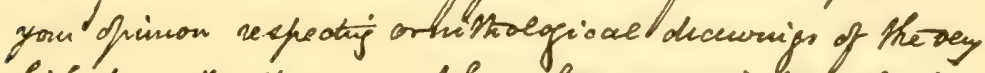

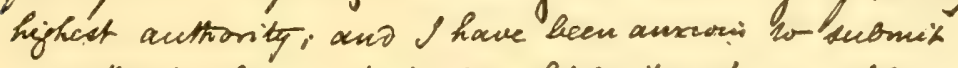
ny attempt- lo you decievis, whice, if unfowouable,

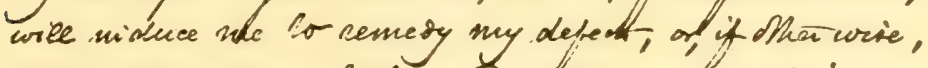

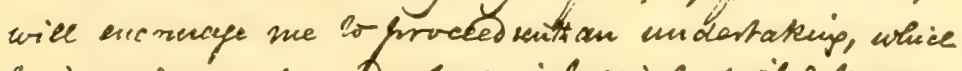

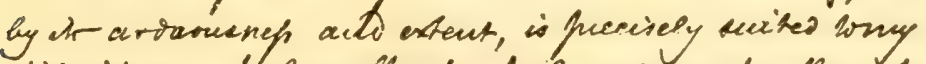

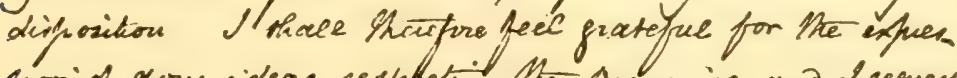

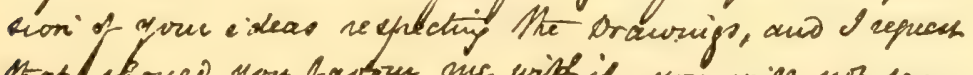
stat thoued you fachu one with it, yose wile not tene.

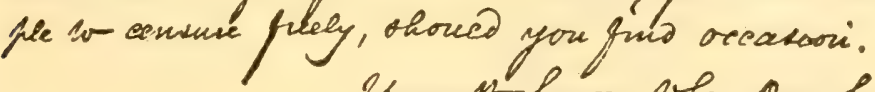
Ihave the howoun to the, Dean fir.

L F. audubon Sye you mout oberient tervant. Hiellachilieviay. Ederibuph.

IETter of William Macgillivray to aUdubon, october 22. 1834. From the Howland MSS. 
animals of Great Britain. The astonishing success with which you have depicted a whole class of the productions of your native land, as evinced in the incomparable delineations of: your "Birds of America," renders your opinions respecting ornithological drawings of the very highest authority; and I have been anxious to submit my attempts to your decision, which, if unfavourable, will induce me to remedy my defects, or, if otherwise, will encourage me to proceed with an undertaking, which by its arduousness and extent, is precisely suited to my disposition. I shall therefore feel grateful for the expression of your ideas respecting the Drawings, and I request that should you favour me with it, you will not scruple to censure freely, should you find occasion.

I have the honour to be, Dear Sir, your most obedient servant,

W. MacGillivray.

[Addressed] To J. J. Audubon, Esqe.

Edinburgh.

Audubon and MacGillivray finished their work in November, and by the first of December the manuscript of the second volume of the Ornithological Biography was in the printer's hands. On the 10th of the latter month Audubon wrote to Bachman from Edinburgh: "I am quite sure I never have been half as anxious as I am at this moment to do all in my power to compleat my vast enterprise, and sorrowful indeed would be my dying moments if this book of mine were not finished ere my eyes are for ever closed." The naturalist was thinking of materials for new "Episodes" for the work when he added:

Try to study the habits of the alligator, the time of its propagation, number of eggs, form of the nest, \&c., \&c., \&c. I long to possess all respecting this reptile (amphibian) [sic] for my article of the Wood Ibis and Sand Hill Crane, for it 


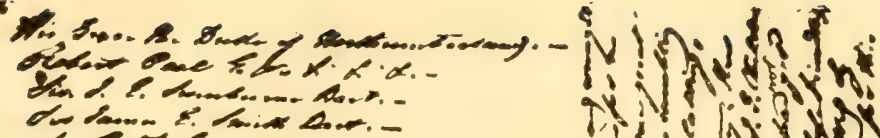

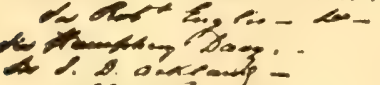

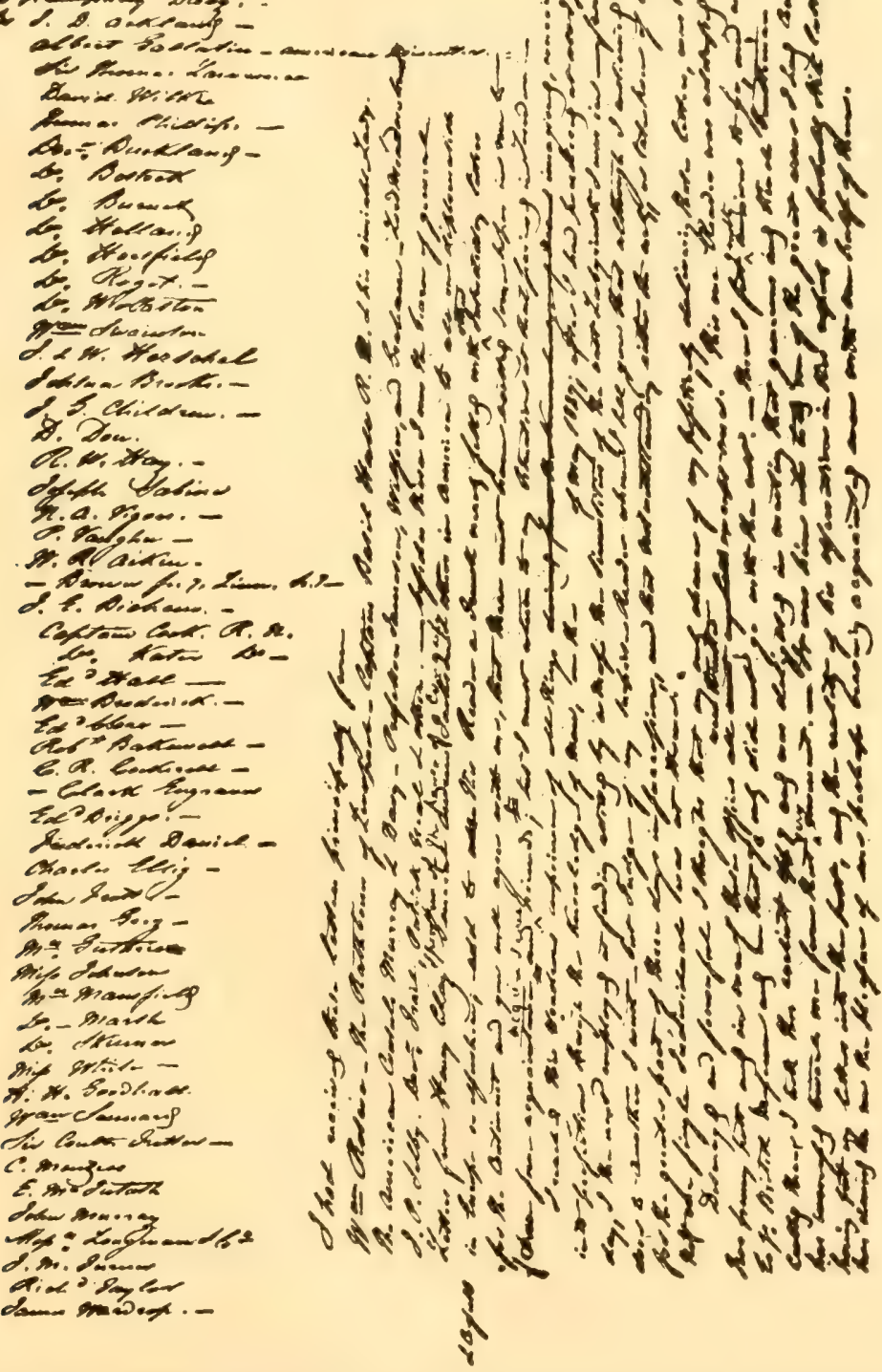

PART OF THE ORIGINAL DRAFT OF AUDUBON'S MANUSCRIPT FOR THE INTRODUCTION TO VOLUME II OF THE "ORNITHOLOGICAL BIOGRAPHY," GIVING NAMES OF PERSONS TO WHOM HE CARRIED LETTERS OF INTRODUCTION 
will make a fine picture on paper, and I can show Waterton the bold astride of one's bare back in great style.

By now Docr. Parkman has at least a portion of the letter press and I hope has begun printing the second vol. of Biog. 750 copies for America, and the same number are printing here. I wish you would cut out from all newspapers the pros and cons about me.

We thus have from Audubon himself a definite statement in regard to the publication of his Biography of Birds in America, and as to the number of copies issued.

MacGillivray immediately agreed to "revise and correct" Audubon's forthcoming third and fourth volumes, and that he was quite satisfied with their method of cooperation is shown by the following definite statement of his contract:

\section{William MacGillivray to Audubon}

Dear Sir,

Edinburgh 15 th December 1834.

Agreeably to your request I hereby bind and oblige myself to revise and correct the third and fourth volumes of your work entitled "Ornithological Biography" at the same rate as the two first volumes, namely at Two Pounds Two Shillings per sheet; as well as to revise, for a sum to be subsequently determined, any other work which you may intend to publish.

I have the honour to be Dear Sir, your most obedt. Servant W. MacGillivray.

To John J. Audubon Esq.

When William MacGillivray first met Audubon, in the autumn of 1830, he was an enthusiastic naturalist of four and thirty, young, but, as we have seen, a thor- 
ough anatomist, who stood firmly on his own feet and was destined to advance his favorite study in a notable degree. Audubon at this time was forty-five, but in anatomy the older man gladly sat at the feet of the younger and acknowledged him master; while this young anatomist was dissecting, Audubon in the rôle of student was seated by his side, and we may be sure that little escaped his penetrating eye and keen intelligence. To MacGillivray, on the other hand, Audubon was master of his art, and to him he looked for criticism of his own artistic efforts; after him he named a son, and to him dedicated a child of his brain. In short, MacGillivray looked upon Audubon as his best friend in the world, and the latter fully appreciated his indebtedness to this able assistant. MacGillivray continued to aid Audubon with his letterpress, revising and probably contributing most of the technical details; in the fourth and concluding volumes, published in 1838 and 1839, the large store of anatomical matter and many excellent drawings were duly acknowledged as coming from his hand. His own writings were varied and numerous, but were generally characterized by a high degree of excellence. His History of British Birds, in five volumes (1837-1852), was too extended and too technical ever to become popular, but in that work, for the first time in the history of science, classification was place? on a strictly anatomical basis. MacGillivray even followed Audubon to some extent by introducing into this work "delineations of British scenery and character," but under another head. 'The sixth of his "Lessons in Practical Ornithology" recounts in dialogue form the

${ }^{8}$ The Rapracious Birds of Great Brituin, by William MacGillivray, was dedicated to Audubon "in admiration of his talents as an ornithologist, and in gratitude for many acts of friendship." 
experiences of two friends in tramping the Pentland Hills together; says "Physiophilus" [himself], "You must have many fine songsters in America"; to which "Ornithologus" [Audubon] replies:

That we have indeed. The Mocking Bird, of course, stands first in my opinion, and is unrivalled. Then, perhaps on account of my own sensitive nature, I would place next the Wood Thrush, although the Cat Bird is far its superior in many points, as is also the Turdus rufus. Think of our Rose-breasted Pine and Blue Grosbeaks, how mellow and sweet their continuous songs are, whether by day or during calm nights. Watch the varied ditties of the Orchard Oriole, and the loud and more musical notes of its brother, the Golden Hangnest. You have never heard the Tawny Thrush or the Hermit Thrush, otherwise, believe me, you would have enjoyed much delicious pleasure. ...

William MacGillivray was a man of the finest character and an honor to the best traditions of British scholarship; in his enthusiasm and indefatigable energy he was fully a match to Audubon. For nearly twelve years (1841-1852) he was an honored lecturer and professor in Marischal College and University, Aberdeen, where he died, probably as a result of overwork in the field, in 1852, thus outliving his older friend but one year. His last completed work, Natural History of Deeside and Braemar, was published under the patronage of Queen Victoria and by her command privately printed, under the editorship of E. Lancaster, in 1855. MacGillivray's surviving son, whose career as a field naturalist was also cut short by too strenuous work, accompanied Huxley, then an assistant surgeon in the Royal Navy, on the memorable voyage of the Rattlesnake under Captain Owen Stanley in 1842. MacGillivray was honored when 
alive, and though dead has not been forgotten; in $\mathbf{1 8 9 0}$ a beautiful tablet was dedicated to him in Aberdeen, and at the same time a worthy monument was raised to his memory at Edinburgh. ${ }^{9}$

In authorship the public is mainly interested in seeing merit duly acknowledged. Said Audubon, in the introductory address to his first volume:

There are persons whose desire of obtaining celebrity induces them to suppress the knowledge of the assistance which they have received in the composition of their works. In many cases, in fact, the real author of the drawings or the descriptions in books on Natural History is not so much as mentioned, while the pretended author assumes to himself all the merit which the world is willing to allow him. This want of candour I could never endure. On the contrary, I feel pleasure in here acknowledging the assistance which $\mathrm{I}$ have received from a friend, Mr. William MacGillivray, who being possessed of a liberal education and a strong taste for the study of the Natural Sciences, has aided me, not in drawing the figures of my Illustrations, nor in writing the book now in your hand, although fully competent for both tasks, but in completing the scientific details, and in smoothing down the asperities of my Ornithological Biographies.

\section{In the introduction to Volume IV he added that the}

anatomical descriptions, as well as the sketches by which they are sometimes illustrated, have been executed by my learned friend, William MacGillivray, who in the most agreeable manner consented to undertake the labour, by no means small, of such a task, and to whom those who are interested in the progress of Ornithological science, as well as myself, must therefore feel indebted.

${ }^{9}$ For an excellent account of the life of William MacGillivray and of his lahors in natural science, see William MacGillivray, A Memonial Tribute to William MacGillivray (Bibl. No. 211). 
Audubon evidently believed that this printed acknowledgment was just; MacGillivray was as plainly satisfied, so that complaints which have been made against the naturalist on this score seem to have been rather groundless. It might be noticed that bookmaking at that time was regarded as more of a trade than at present; as Sir Walter Besant remarks, a traveler would of ten give his notes to a bookseller, who in turn would hand them over to a literary hack to be cast into suitable form.

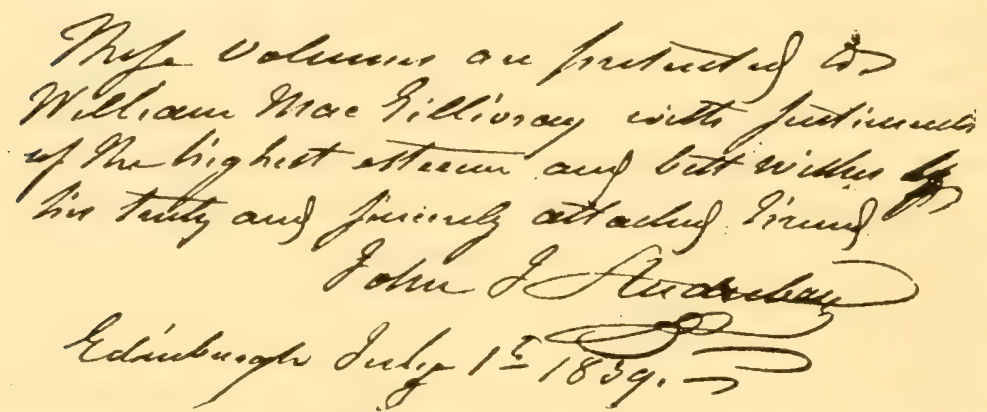

AUDUBON'S INSCRIPTION IN THE COPY OF THE "ORNITHOLOGICAL BIOGRAPHY" PRESENTED TO WILliam MaCgILliviay

A fine token of the friendship which existed between these two men was discovered in the summer of 1903 in a London bookshop, where it was found reflected in the pages of a handsomely bound copy of Audubon's Biography of Birds; on the title pages were inscribed the autographs of William MacGillivray, while on the first page of the introduction to the first volume the hand of Audubon had written this dedication:

These volumes are presented to

William MacGillivray with sentiments of the highest esteem and best wishes by his truly and sincerely attached friend John J. Audubon

Edinburgh July 1 t 1839. 
Professor John Wilson gave the third volume of the Ornithological Biography a very handsome notice in Blackwood's Magazine, and on New Year's Day, 1836, Audubon acknowledged the compliment in the following letter: ${ }^{10}$

Audubon to John Wilson ("Christopher North")

My Dear Friend :-

The first hour of this new year was ushered to me surrounded by my dear flock, all comfortably seated around a small table in middle-sized room, where I sincerely wished you had been also, to witness the flowing gladness of our senses, as from one of us "Audubon's Ornithological Biography" was read from your ever valuable Journal. I wished this because I felt assured that your noble heart would have received our most grateful thanks with pleasure, the instant our simple ideas had conveyed to you the grant of happiness we experienced at your hands. You were not with us, alas! but to make amends the best way we could, all of a common accord drank to the health, prosperity, and long life, of our generous, talented, and ever kind friend, Professor John Wilson, and all those amiable beings who cling around his heart! May those our sincerest wishes reach you soon, and may they be sealed by Him who granted us existence, and the joys heaped upon the "American woodsman" and his family, in your hospitable land, and may we deserve all the benefits we have received in your ever dear country, although it may prove impossible to us to do more than to be ever grateful to her worthy sons.

Accept our respectful united regards, and offer them to your family, whilst I remain, with highest esteem, your truly thankful friend and most obedient servant,

John J. Audubon.

Wilson had said in his earlier review:

${ }^{10}$ See Mrs. Gordon, "Christopher North:" A Memoir of John Wilson (Bil)l. No. 44). 
We do not believe that till within these few years, he had any practice in composition. . . Y Yet Genius, if from circumstances behindhand in any common accomplishment, soon supplies it-soon makes up its lee-way-or rather, it has only to try to do what it has never done before, and it succeeds in it to admiration. Audubon, who had written but little even in his native tongue-French-under a powerful motive, took to writing English; and he was not long in learning to write it well, not only with fluency, but eloquence, as the fine extracts we have quoted show in unfading colours.

The following comment on Audubon's second volume of the Biography appeared in the Athencum for 1835:

If only considered as evidence that it is in the power of man to achieve whatever he wills, and that no obstacles are too great to be overcome by energy and devotion of purpose, it would claim our good will and best wishes.

He has told what he has seen and undergone, not perhaps in the smooth nicely balanced periods of a drawing-room writer ... but with unstudied freedom, rising at times to eloquence, nor been ashamed to utter the thousand affectionate and benevolent feelings which a close and enthusiastic communion with nature must nourish. The work is full of the man.

The winter and spring of 1835 were spent in London, and though suffering from the strain of overwork, Audubon kept doggedly at his tasks. On April 20 he wrote to Bachman:

Immediately on my arrival in London I set to writing, and finished in one month, one 4 th. of the Biographies of my $3 \mathrm{~d}$. vol. This rendering me puffy, I could scarcely breathe-my appetite was gone-my digestion bad-in other words I was attacked by Dyspepsia as bad as ever. Then I thought of a change of work-for in change of labour the body and the mind 
undergo sure and certain relief. I took to Drawing! and what do you think-I have positively finished 33 drawings of American birds in England. This has enabled me to swell my 3 d. vol. of Illustrations with 57 species not given by Wilson and therefore forestalling my friend Charles Bonaparte.

On the 28th of April Audubon wrote to Edward Harris, begging him to send specimens of certain birds which he needed, as well as a circumstantial account of the shad fisheries of the Delaware River as material for an "Episode" for the third volume of his Biography; the fiftieth number of his illustrations was then in the hands of the colorist. He continued: ${ }^{11}$

I thought better to push my publication on account of the woeful dulling of the times in this country, where political strife engrosses the mind of every person so much that arts and sciences are, as it were, put on the shelves. Ministers are beings of six weeks lives now-a-days. The Reformers are struggling against the Tories, and vice versa. The Churchmen are aghast at the prospect of the future, and all this puts a complete stoppage to business, independent of such matters. Even since my return to England I have obtained only two or three subscribers, and have lost more than a dozen; nay, I may safely say, two dozen. In America, on the contrary, things appear to go on more prosperously. May God's will grant a long continuation of this to our only Land of Liberty. France, you will have heard, has at last passed an order for the payment of her debts to the citizens of the United States, and I hope that this may prove amply sufficient to save us from having a war with that powerful nation. . . . I wrote you that Dr. George Parkman, of Boston, would have my $2 \mathrm{~d}$. volume of Biographies reprinted in his city. I have seen 100 pages of this reprint here, but do not know if the Vol. (American Ed.) has appeared before the Public?

${ }^{11}$ This and extracts from letters which follow $\therefore$ from the Jeanes MSS. 
My-Friends-erton, Ord \& Co. keep up their curious animadversions against me still-methinks they must be shockingly mortified at my stubborn silence toward them. Some unknown friends now \& then reply to their absurdities.

His persistent heckler, Charles Waterton, was quite busy at this time, four articles having been directed against Audubon or his friends in 1835, though this was not his most prolific year. A similar reference occurs in a letter written to Bachman from Edinburgh on the 20th of July: "As to the rage of Mr. Waterton, or the lucubrations of Mr. Neal, who by the bye is a subscriber to the Birds of America (bona fide), I really care not a fig-all such stuffs will soon evaporate, being mere smoke from a Dung Hill.'

In the summer of 1835 Audubon was again established in Edinburgh and working with unremitting vigor at his Biography; some idea of the speed which he maintained when able to devote himself unreservedly to this task can be gathered from the fact that after the issue of his second volume, of 620 large pages, in December, 1834, the third, of 654 pages, was published in just a year from that time. He wrote to Edward Harris from Edinburgh on the 5th of July, when engaged in this work:

I intend to write a few ["Episodes"] of such extraordinary men, now deceased, with whom I have been acquainted-Thomas Bewick, and Baron Cuvier, for example.

We receive no new subscribers in Europe. The taste is passing for Birds like a flitting shadow--Insects, reptiles and fishes are now the rage, and these fly, swim or crawl on pages innumerable in every Bookseller's window. When this is also passed, naturalists will have to turn over a new leaf and commence afresh, or go to the antipodes in search of materials to 
please the taste for novelty's sake.-However my work will I hope be finished ere I leave this world, and must be appreciated in years to come, when perhaps my childrens' children will feel proud of their gone ancestor, "The American Woodsman." You see my Dear Friend how far enthusiasm and a portion of the like for standing fame carries even your humble servant a man with no other means than his industry and prudence as a means of support, and one with scarce the motive of education. There are moments, and they are not far between, when thinking of my present enormous undertaking, I wonder how I have been able to support the extraordinary amount of monies paid for the work alone, without taking cognizance of my family and my expeditions, which ever and anon travelling as we are from place to place and country to country are also very great. When I publish my Life and let the world know that Audubon like Wilson, was at Phila. without the half of a Dollar, and that had it not been for benevolent generosity of a certain Gentleman whose name is Edward Harris, Audubon must have walked off from one of the fairest of our Cities like a beggar does in poor Ireland, left destitute of all things save his humble talents, and his determination to produce something worthy of the soul of man: I say my dear Harris will not the world stare! Poor Wilson was only better off than I on account of his superior talents over me at driving the goose quill, but much similarity still seems to have [existed] in both of us, as I could drive the pencil, the brush, the Fiddle bow and even the "Fleuret" [better] than he.

Audubon wrote to Harris again from Edinburgh, on September 5, when he said:

Between you and I the measurements of different Birds given by Wilson are hardly to be depended upon, as I constantly discover a great deficiency in this part of his descriptions which indeed in some cases are otherwise slack, and given as if when fatigued or vexed. Nay I even think at times that he has copied Authors and not nature? as in the instance of the Oyster. 
Catcher, which I fear he made \& figured from a European one in the Philadelphia museum, took the descriptions from Latham, and described the Habits of Palliartus which is our own Bird and it seems the only species to be met with in America, at least on our Atlantic coast. Wilson committed the same blunder with the Rallus elegans which he figured and described the habits of the R. capitans for it! I could enumerate more instances of carelessness, but poor Wilson is dead and may God bless his soul!

The third volume of his letterpress, ${ }^{12}$ which dealt with the water birds of America, made its appearance at the close of 1835; in the introduction he said:

I look forward to the summer of 1838 with an anxious hope that I may then be able to present you with the last plate of my Illustrations, and the concluding volume of my Biographies. To render these volumes as complete as possible, I intend to undertake a journey to the southern and western limits of the Union, with the view of obtaining a more accurate knowledge of the birds of those remote and scarcely inhabited regions. On this tour I shall be accompanied by my youngest son, while the rest of my family will remain in Britain to direct the progress of my publication.

Audubon returned to London with his family early in 1836, visiting Newcastle, York, Leeds, Manchester and Sheffield by the way, and took a house at Number 4, Wimpole Street, Cavendish Square. As Mrs. Audubon's health was anything but good, they were fortunate in having as a neighbor in this street an eminent surgeon, Benjamin Phillips, ${ }^{13}$ and this friend was also a subscriber to The Birds of America. "Were I to mention," said Audubon,

${ }^{12}$ See Bibliography No. 2.

${ }^{13}$ For letter written to Dr. Phillips in 1842, see Vol. II, p. 244. 


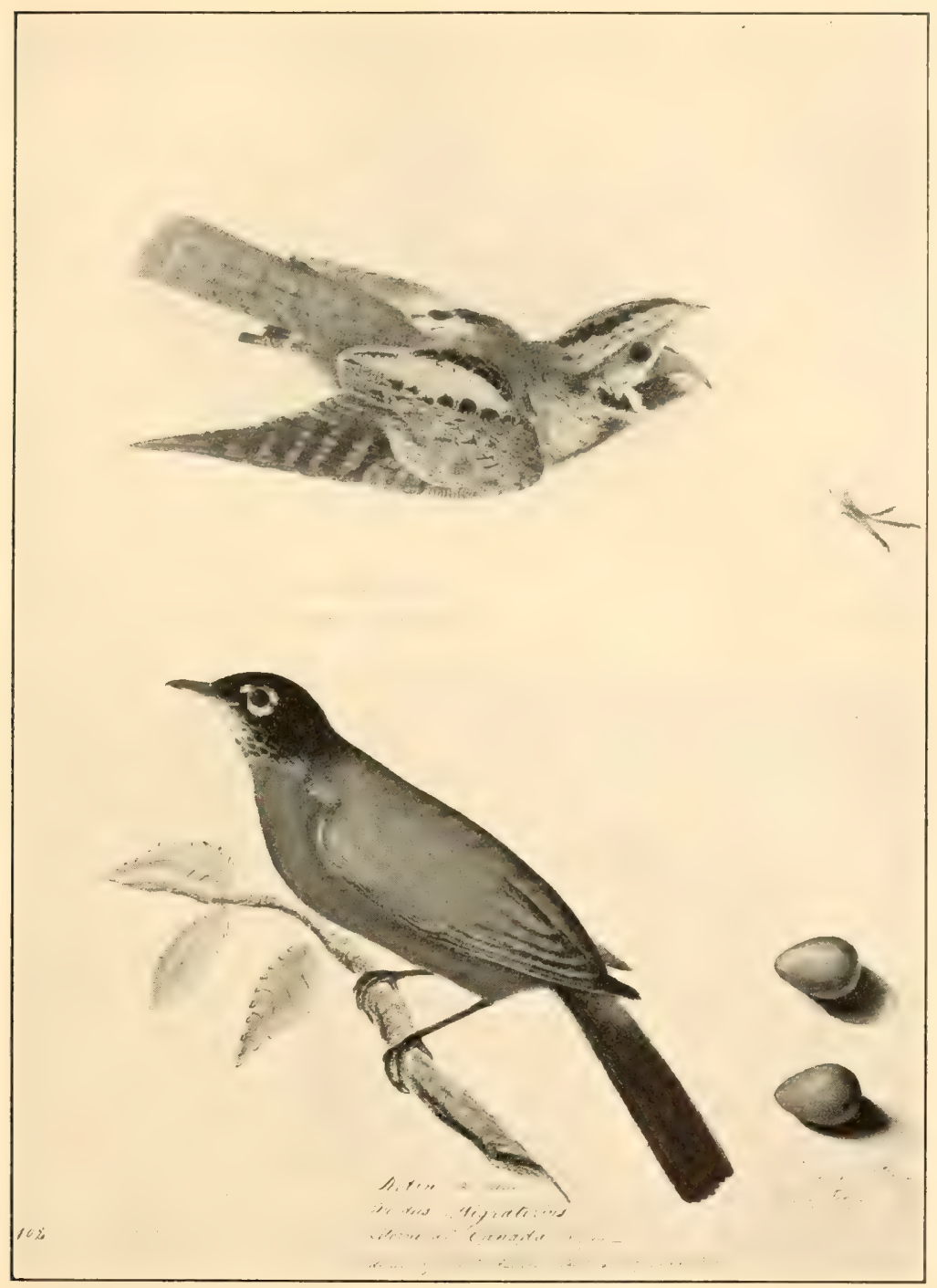

FARIY UNPUBIISHED DRAWINGS OF AMERICAN BIRDS: ABOVE, "CAPRIMCIGUS VOCIFERUS. WHIPPOOKWILI. FEMELIE. A. W. MAY 7TH, 181?, PENYSA. NO. 11"; BET.OW, "ROIIN A. WIJISOX. TLRDLS MIGR.TTORILS, LITORNE DU CANADA-MALE-BUFFON-DRAWY BY J, J. AUDUBON JANY. 4, 1807- NEW YORK. Yo. 10?."

Published by courtesy of Mr. Joseph Y. Jeanes. 

the many occasions on which he has aided me by his advice and superior knowledge of the world, you would be pleased to find so much disinterestedness in human nature. His professional aid too, valuable as it has proved to us, and productive of much inconvenience to him, has been rendered without reward, for I could never succeed in inducing him to consider us his patients, although for upwards of two years he never passed a day without seeing my wife.

In the spring of 1836 Audubon's two sons made a tour of France and Italy; on the 9th of March he wrote to Harris that they expected to leave England in a week, be gone three and a half months, visit Paris, Rome and Messina, and return by way of Marseilles and Paris. With the passage of 1836 he had completed 70 numbers, of 350 plates, of his larger work, leaving but 85 plates yet to be engraved. Though anxious to see this greatest of his tasks brought to an end, he still looked with longing eyes to the Rocky Mountains and the Pacific Coast, and began preparations for his last journey to obtain materials and subscribers in the United States. 


\title{
CHAPTER XXXI
}

\author{
THIRD AMERICAN TOUR, 1836-1337
}

In New York harbor-Collections from the Far West-Audubon's efforts to secure thern-Return to Boston-Friendship of Daniel WebsterRenewed efforts to obtain the Nuttall-Townsend collection-Expedition to the west coast of Florida-Deferred governmental aid-Another winter with Bachman-Overland journey to New Orleans-On board the Crusader-Mistaken for pirates-With Harris and his son explores the Gulf Coast--The Republic of Texas-Visit to its capital and president-Meeting in Charleston-Marriage of his son-Their return to England.

Audubon left London with his son, John, July 30, 1836, and on the second day of August sailed from Portsmouth on the packet Gladiator, bound for New York. Two hundred and sixty live birds had preceded them to the ship, while three dogs came as a present from the Earl of Derby, and "a brace of tailless cats from our friend George Thackeray, D.D., provost of King's College": all had suffered somewhat from lack of care, but the dogs, one of which was sent to John Bachman of Charleston, and some of the birds crossed the Atlantic in safety. Five weeks were spent at sea; when the Navesink Highlands at last hove into view the welcome news spread rapidly over the ship; rockets were sent up later to attract a pilot, and when anchor was grounded on American soil, Audubon confessed that he cried like a child and devoutly thanked God for their preservation. He continued:

All was now bustle and mutual congratulations; our commander was praised for his skill by some, and others praised his whisky, which the waiters handed about, and the night was 
nearly spent in revelry; but John and myself retired at two o'clock. . . As a gleam of daylight appeared, my eyes searched through the hazy atmosphere to catch a glimpse of the land, and gradually Staten Island opened to my view; then the boat of the custom-house appeared, and soon he boarded us, arranged the sailors and passengers on deck, and called their names. Then followed breakfast, and soon another boat, with a yellow flag flying, landed the health officer, and there being no sickness on board, myself and John returned to Staten Island in the doctor's boat, and were taken by the steamer Hercules to the city. ${ }^{1}$

Audubon remained in New York from the 7 th to the 13th of September. On Sunday, the 12th, he wrote to Edward Harris, in part as follows: ${ }^{2}$

\section{Audubon to Edward Harris}

My dear Friend-

... Whilst running over the interesting list of the Species of Birds procured by Nuttall \& Townsend in the Rocky Mountains, and the shores of the Pacific, I became so completely wrapt up with the desire to see these as soon as possible that $\mathbf{I}$ have concluded to go to Philadelphia tomorrow by the 10 o'clock boat. I will stay at Harlan's for two or three days and hope that you will meet me there, that I may have the pleasure of pressing your hand and talking to you.

You well know how anxious I am to make my work on the Birds of our Country as compleat as possible within my power: - you know that to reach this end I have spared neither time, labours or money: you are also aware that although this undertaking may never remunerate me, I am so enthusiastic as to indulge in the hope that God will grant me life to effect all this; but I am becoming old, and though very willing doubt whether

${ }^{1}$ Lucy B. Audubon, ed., Life of John James Audubon, the Naturalist (Bibl. No. 73), p. 385.

${ }^{2}$ The Jeanes MSS. 
I could support the fatigues connected with a journey of several years, and separated from my dear Family. Well the desiderata has come to Philadelphia at least in part, and if I could be allowed to pourtray the new species now there as an appendix to the Birds of America, I should be proud and happy to do so, but do you think that the Academy is likely to indulge me in this my wish? Do join me at Harlan's as soon as you can, and lend me a hand and try to promote my views through mutual Friends attatched to that Institution.

Audubon also communicated at once with John Bachman, whom he had planned to visit on his journey south, but soon learned that the cholera had broken out in Charleston and that the Seminoles were on the warpath in Florida. Said Bachman, writing on September 14:

With regard to Florida, nothing will be done by naturalists for at least two years. Your Indian friends, the cut-throats, have scalped almost every woman and child south of St. Augustine, save those on Key West. They have burnt and plundered every plantation; and although they will probably be, in a great measure, put down next winter, yet there will, undoubtedly, remain many small predatory bands that will make no bones of scalping an Ornithologist secundum artem; and would ask no questions whether he were the friend or enemy of William Penn. Of Texas, I think better, and thither, or along its borders, you may, I think, venture-for the Texans are our friends. I suppose Genl. Gaines will keep the Comanches quiet. ${ }^{3}$

Bachman kept his friends informed of the progress of the epidemic, which had placed an embargo over his city; at the same time he sent news of the Anhingas, Caracara Eagles and Cormorants, which had been successfully held in captivity for the naturalist, and added:

${ }^{3}$ C. L. Bachman, John Bachman, D.D., LL.D., Ph.D. (Bibl. No. 191). 
"These are awful times in money matters, but of this you will hear enough when we meet. Everyone nearly has failed, but the Parsons and Ornithologists."

On September 13 Audubon started for Philadelphia, anxious to see with his own eyes those western collections which had so stirred his curiosity. It seems that in 1834, Dr. Thomas Nuttall and Dr. John Kirk Townsend set out on a journey to the mouth of the Columbia River; Nuttall was first of all a botanist, and is said to have carried no gun, but Townsend was an experienced ornithologist and made extensive collections of birds, a part of which he sent in care of Nuttall to Philadelphia in 1835, although he himself did not return east until the close of 1837. One of Audubon's great ambitions had been to explore the regions which they had recently visited, and in the circumstances we can sympathize with his desire to acquire so valuable an acquisition for the work upon which he had been long engaged. The object of his immediate quest apparently had been entrusted to the Academy of Natural Sciences, an institution which had not always shown itself friendly to his claims, and which in this instance is said to have assisted the travelers with funds to prosecute their journey. The collection, said Audubon, contained "about forty new species of birds, and its value cannot be described." Balked in his initial efforts to obtain the coveted prize, after two days of fruitless efforts on the part of his Philadelphia friends, he returned to New York; Edward Harris then came forward with the offer of $\$ 500$ for the purchase of the collection outright, but negotiations were not immediately successful.

With his hunger still unappeased, Audubon now visited Boston on a canvassing tour, while his son remained with Nicholas Berthoud at New York. Setting 
out on the 20th of September, he traveled by the steamer Massachusetts and the Providence Railroad, paying seven dollars fare, "which included supper and breakfast"; the sail up Providence Bay in early morning was like a "fairy dream," and the locomotive in waiting then pulled the passengers from "Providence to Boston at the rate of fifteen miles an hour." We arrived, said he, at four in the afternoon: "a cart took my trunk, and placing myself by the side of the owner, we drove to the house of my friend, Dr. George C. Shattuck."

On the day after his arrival, Audubon visited Thomas M. Brewer, then a young ornithologist living at Roxbury, to examine his collection of bird skins and eggs, and upon his return called on David Eckley, "the great salmon fisher," to whom he later presented a copy of his folio plates of The Birds of America. ${ }^{+}$Brewer, who later became a physician and distinguished ornithologist, for many years was one of Audubon's valued correspondents and supplied him with much interesting material. On the following day Audubon met Thomas Nuttall, ${ }^{5}$ who at once promised him duplicates of all the new birds which he had brought from the West. Colonel Thomas II. Perkins, an early subscriber, Edward Everett, who had befriended him in Washington, and who in 1836 became Governor of Massachusetts, Josiah Quincy, president of Harvard College, Dr. Bowditch, and

${ }^{4}$ See Note, Vol. II, p. 7.

5 Thomas Nuttall (1786-1859), a native of Yorkshire, was brought up a printer; in 1807 he emigrated to the United States, and became noted for his wide botanical explorations, for his Journal of Travels in the Arkansas Territory in 1819, and for his excellent Manual of the Ornithology of the United States and Canada (1833-1834), which has had several editions. From 1822 to 1834 he was professor of Natural History and curator of the Botanical Gardens at Harvard University; in 1834 he crossed the Rocky Mountains along the sources of the Platte, explored Oregon and Lpper California, and visited the Sandwich Islands. He returned to England, where he had inherited property, in 1842, and died at St. Helen's, Lancashire, September 10, 1859. 
other prominent characters, all extended a helping hand. He visited Salem to deliver his letters, and was successful in obtaining a number of subscribers; upon invitation of the curator of the Natural History Society there, he examined "the young collection of that newborn institution," and had "the good fortune to find one egg of the American bittern." On the 25th of September he wrote Harris: "Nuttall has arrived-he breakfasted with me the other day-gave me 6 new species of Birds and tells me that he will urge both Townsend and the Society at Philadelphia to allow me to portray all the species which they have procured within the limits of our Territories."

In Boston, September 27, 1836, Audubon made this note in his journal: ${ }^{6}$ "The citizens are all excitement; guns are firing, flags flying, and troops parading and John Quincy Adams is delivering a eulogy on the late President Madison. The mayor of Boston did me the honor to invite me to join in the procession, but I am no politician and declined." He noted on the same day also that Dr. Shattuck had completed the subscription list of the Boston Society of Natural History "by presenting me to his lady, who subscribed for one-tenth, and the Dr. then put down his son George's name for one-twentieth, making his own family one-fourth of the whole, or two hundred and twenty dollars, for which he gave me his cheque. Without the assistance of this generous man, it is more than probable that the Society never would have had a copy of "The Birds of America.'" Two days later he met Daniel Webster at the rooms of the Historical Society, and on the same evening at the home of Isaac P. Davis, where, said Audubon, "we took tea, talked on ornithology and orni-

${ }^{6}$ See Lucy B. Audubon, ed., op. cit.; and Note, Vol. II, p. 29. 
thologists; he promised to send me some specimens of birds, and finished by subscribing to my work." Webster also gave him a general note of recommendation, in which he said: " "I take this mode of commending Mr. Audubon to any friends of mine he may meet in his journey to the west. I have not only great respect for Mr. Audubon's scientific pursuits, but entertain for him personally much esteem and hearty good wishes." Mr. Davis exerted his influence in other directions, and in this instance acted as agent for the transmission of Audubon's plates to their distinguished friend; on October 7 , he wrote: ${ }^{8}$ "I received the half Nos of the 'Birds of America' for the worthy and sublime Danl. Webster - they shall be delivered safely on his return." After urging Audubon to visit Buffalo, where Dr. Bowditch and his friends thought that a number of new subscribers might be procured, he appended a list of twelve likely names of residents of that city, and added: "Bowdoin College shall be remembered as the opportunity offers."

Webster, who was an ardent sportsman and well acquainted with the water fowl of the coast, had volunteered to procure for Audubon specimens of the Labrador Duck, which was even then extremely rare and has since become extinct, but was unable to fulfill his promise. Audubon had already found that many American birds, like the common crow, which had been regarded as identical with those of the Old World, were in reality distinct, and was now anxious, as he wrote to Thomas Brewer, "to compare the anatomy of all our birds with those of the same families in Europe." His letters

${ }^{7}$ See Lucy B. Audubon, ed., op. cit., p. 391.

"In a letter signed "I. P. Davis," and superseribed to "John J. Audubon Esqr at Mr. Berthoud's, 106 Broad Street New York." (Howland MSS.) 
to young Brewer at this time show how eager he was to secure the promised specimens. On October 23 he wrote from Philadelphia: "I hope you will not forget to call on our enlightened statesman D. Webster, and remind him of his kind promise to assist you in the procuring of specimens for me. This winter and next spring are my only chances, and I beg you to do all you can for me." He wrote again from Charleston, January 1, 1837: "I am sorry that the Hon. D. Webster has not attended to his promises, and will write to him; yet I would beg you, being on the spot, to trouble him a good deal."

After returning to New York, Audubon had a visitor for whom he expressed the greatest admiration, Washington Irving, who had aided him in 1833; he now received from his hands letters to Martin Van Buren, the President-elect, and Benjamin F. Butler, who then occupied the post of Attorney-General. Irving called attention in his letter to the national character of Audubon's work, and warmly commended it to the patronage of the country at large. On October 8 Audubon wrote MacGillivray from New York that he had obtained twelve new subscribers, two at Salem, four at Boston, and six in New York, but a little later, through the aid of Nicholas Berthoud, in one week's time eighteen new naines were added to his subscription list in New York City alone.

Meanwhile Nuttall's and Townsend's birds had not been forgotten, and on October $\mathbf{1 5}$ he started with his son for Philadelphia, where he was again welcomed by Dr. Richard Harlan. No sooner, however, were efforts renewed to gain permission to study the desired objects

${ }^{\circ}$ See Thomas M. Brewer (Bibl. No. 79), Harper's New Monthly Magazine, vol. lxi, p. $666(1880)$. 
than new obstacles were encountered. To quote the naturalist: ${ }^{10}$

Having obtained access to the collection sent by Dr. Townsend, I turned over and over the new and rare species, but he was absent at Fort Vancouver, on the shores of the Columbia River; Thomas Nuttall had not yet come from Boston, and loud murmurs were uttered by the soi-disant friends of science, who objected to my seeing, much less portraying and describing, those valuable relics of birds, many of which had not yet been introduced into our Fauna.

At length, "it was agreed," to continue his account of the transaction,

that I might purchase duplicates, provided the specific names agreed upon by Mr. Nuttall and myself were published in Dr. Townsend's name. This latter part of the affair was perfectly agreeable to my feelings, as I have seldom cared much about priority in the naming of species. I therefore paid for the skins which I received, and have now published such as proved to be new, according to my promise. But, let me assure you, Reader, that seldom, if ever in my life, have I felt more disgusted with the conduct of any opponents of mine, than I was with the unfriendly boasters of their zeal for the advancement of ornithological science, who at that time existed in the fair city of Philadelphia.

While still in Philadelphia, on October 23, Audubon wrote to Thomas Brewer that Dr. Morton, the corresponding secretary of the Academy, had not only permitted him to portray the new birds but had sold him "ninety odd of the skins, forming a portion of the collection," and added that with his other acquisitions they would swell his "catalogue to the number of 475 , all of which must be introduced in my fourth volume."

${ }^{10}$ Ornithologicai Biography (Bibl. No. 2), vol. iv, p. xi. 
For many years Audubon had expressed great contempt for all seekers after priority in the naming of new species of animals, but now he began to find the pressure from without too strong to be resisted. Rivalry in this field had become keen on both sides of the Atlantic, and in the commendable desire to render his work as complete as possible, he was inevitably drawn into a struggle in which the higher aspirations of scientific men are all too apt to be obscured by petty vanities, suspicions and disputes.

While at Philadelphia Audubon paid this fine tribute to the ornithologist whom he had met at Louisville twenty-six years before, and whose name had long been a cover for the jealousies and animosities of supposititious friends: "Passed poor Alexander Wilson's schoolhouse, and heaved a sigh. Alas, poor Wilson! Would that I could once more speak to thee, and listen to thy voice!"

Audubon was planning during the coming year to explore the west coast of Florida, in company with his son and Edward Harris, and to proceed as far as possible along the coast of Texas. From Philadelphia he went to Baltimore, and on November 8 he arrived at Washington. His steadfast friend and supporter, Colonel John James Abert, then at the head of the Topographical Bureau, took him to the White House to call on President Andrew Jackson and present his letters. The General, said Audubon, looked well and was smoking a pipe; after reading his letters attentively, he said at once: "Mr. Audubon, I will do all in my power to serve you, but the Seminole war, will, I fear, prevent you from having a cutter; however, as we shall have a committee at twelve o'clock, we will consider this, and give you an answer tomorrow." Levi Wood- 
bury, Secretary of the Treasury, was as friendly as ever, and offered the party passage to Charleston on the Campbell, a vessel of fifty-five tons carrying three guns and twenty-one men, but Audubon, who was a poor sailor, preferred to travel by land and await the coming of this boat at the Bachman home. Before leaving the capital the naturalist and his son were invited to dine informally at the White House, and he had the opportunity of studying at close range "a man who had done much good and much evil to our country." Said Audubon of this dinner:

I sat close to him; we spoke of olden times, and touched slightly on politics, and I found him very averse to the cause of the Texans. ... The dinner was what might be called plain and substantial in England; I dined from a fine young turkey, shot within twenty miles of Washington. The general drank no wine, but his health was drunk by us more than once; and he ate very moderately, his last dish consisting of bread and milk. ${ }^{11}$

Audubon, with his son, John, left Washington on the 10th of November, and after traveling six days on one of "the most extraordinary railroads in the world," they reached the city of Charleston, where, under the hospitable roof of John Bachman, the party eventually passed the winter, though momentarily expecting their vessel, which did not arrive. During this long interval of waiting, Audubon made drawings of all the new birds in the Nuttall-Townsend collection, representing upwards of seventy figures, and Miss Maria Martin, Bachman's sister-in-law, again assisted him in drawing plants and insects.

${ }^{11}$ Lucy B. Audubon, ed., op. cit., p. 398. 
As spring approached and the long awaited Campbell had not arrived, Audubon, with Harris and John, started overland for New Orleans. After several days of hard traveling by coaches they reached Montgomery, and descended the Alabama River by steamboat to Mobile. When that district had been ransacked for birds, they went on to Pensacola, where they learned that the Government cutter would soon be at their service at New Orleans; accordingly they retraced their steps to Mobile, passed through the lakes, and entered the southern capital, the city in which the naturalist had nearly starved, a penniless stranger, sixteen years before, but which, less than three-quarters of a century later, was to raise a monument to his memory. He was still destined to a degree of disappointment, when it was learned that the Campbell could not be put in readiness before the last of March, but he was delighted to find that the old pilot of the Marion, Napoleon Coste, was to command this vessel. At New Orleans Audubon met for the last time "good M. Le Sueur," artist and naturalist, who had spent many years at New Harmony, Indiana, and whose acquaintance he had first made at Philadelphia in 1824.

Audubon and his party finally left New Orleans on the 1st of April and entered the Gulf by the Southwest Pass, where, on the 3rd of the month, they were joined by the Crusader, a schooner of twelve tons which was attached to the Revenue Service; on this journey she carried a crew of four, with as many guns, and acted as a tender to the larger vessel. The expedition was provisioned for two months, and aimed to explore the keys, bayous and shoreline from the Mississippi to the Bay of Galveston. Some of Audubon's experiences on this cruise were described in a letter to William Mac- 


\section{Gillivray,"12 dated "Côte Blanche, 18 April, 1837," which we will now reproduce:}

\section{Audubon to William MacGillivray}

\section{My Dear Friend,--}

Being just now snugly anchored in a bay, the description of which may prove agreeable to you, I sit down to give you an account of what I have been doing since I last wrote to you.

After visiting "Rabbit Island," on which, as I have already told you, not a single Rabbit or Hare is to be seen, we made our way between it and Frisky Point, by a narrow and somewhat difficult channel leading to the bay in which $\mathrm{I}$ now write. The shores around us are entirely formed of a bank, from twenty to thirty feet high, and composed of concrete shells of various kinds, among which the Common Oyster, however, predominates. This bank, which at present looks as if bleached by the sunshine and rain of centuries, is so white that it well might form a guiding line to the vessels which navigate this bay even in the darkest nights. The bay, however, is so shallow, that it is rarely entered by vessels larger than schooners of about seventy tons burthen, which visit its shores to take in the sugars and cottons grown in the neighbouring country.

The "Crusader" is a somewhat curious craft, small, snug withal, and considerably roguish looking. She has not fewer than four "grunters" on her fore deck, her sails are of pure white cotton, and although she bears the lively flag of our country at the peak, her being painted purely black gives her the aspect, not merely of a smuggler, but of a pirate. But here she is, at the entrance of a canal of a sugar plantation, and close to another craft, much the worse for wear, and, for aught $I$ know to the contrary, belonging to the captain alone, who, I would almost venture to assert, belongs to no country at all.

${ }^{12}$ Printed in the Edinburgh Journal of Natural History (Bibl. No. 37), vol. i, p. 17 (December, 1838). 
It is now four weeks since a razor came in contact with my chin. All my companions are equally hircine; or, if you please, hirsute. As to our clothing, were you to see us at this moment, you would be ready to exclaim, "What vagabonds these fellows are!" Coats and trousers plastered with mire, shirts no longer white, guns exhibiting the appearance of being in constant use, and all sorts of accoutrements that pertain to determined hunters, complete our tout ensemble. But, as I have said, here we are, and on shore must go. "Man the gig," quoth our captain. In a trice the gig is manned. One after another, for there are five or six of us, we swing ourselves into the aftersheets. The word is given, the oars are plied, and now we are once more on terra firma.

The crossing of large bays, cumbered with shallow bars and banks of oyster-shells, is always to me extremely disagreeable, and more especially when all these bars and banks do not contain a single living specimen of that most delectable shell-fish. Nay, I am assured by our pilot, who is no youngster, that ever since he first visited this extensive waste, not an oyster has been procured in these parts. But now, in single file, like culprits or hungry travellers, we proceed along the margin of the canal. Ah, my dear friend, would that you were here just now to see the Snipes innumerable, the Blackbirds, the Gallinules, and the Curlews that surround us; - that you could listen as I now do, to the delightful notes of the Mocking-bird, pouring forth his soul in melody as the glorious orb of day is fast descending towards the western horizon; - that you could watch the light gambols of the Night Hawk, or gaze on the Great Herons which, after spreading their broad wings, croak aloud as if doubtful regarding the purpose of our visit to these shores! Ah! how well do I know you would enjoy all this; but, alas! we are more than four thousand miles apart.

Hark! what's that? Nothing but $s$ parcel of men coming to greet us. Here they are, seven or eight Negroes. Who lives here my good fellows? Major Gordy, massa. Well, now show us the way to the house. Yes, gentlemen, come along. So we follow our swarthy guides. 
The plantations here are of great value, both on account of their proximity to the Gulf of Mexico, and the excellence of the soil, which, as in other parts of Louisiana, is composed of a fat, black mould. The Indian corn was at least six feet high, and looked most beautiful. As we approached the mansion of Major Gordy, I observed that it has a pleasant aspect, and was furnished with a fine garden, and a yard well stocked with cattle, together with a good number of horses and mules, just let loose from labour. A mill for grinding corn and making sugar particularly drew our notice to it, as the Crusader happened just then to be destitute of both articles; and as I saw some women milking the cows, my heart fairly leaped with joy, and the hope that ere long we might procure a full bowl of the delightful and salubrious beverage. The short twilight of our southern latitudes had now almost involved every object in that dim obscurity so congenial to most living creatures after the toils of the day, as allowing them to enjoy that placid quiet which is required to restore their faded energies.

Near the entrance of the mansion stood an elderly man, of tall stature and firm aspect, leaning on what I would call a desperate long gun. As I approached this Côte Blanche planter, I thought that something not so very friendly as I could have wished was expressed in his countenance. As he rested his heavy frame on his monstrous rifle, he neither moved his head, nor held out his hand to me, until I presented mine to him, saying, "My good sir, how do you do?" His answer was a rather suspicious look at me and my companions; but notwithstanding, and probably because he was on his own ground, he asked us what was our wish, and then desired us to walk in.

Côte Blanche Bay, you must be informed, has for ₹ number of years been infested by a set of rascally piratical vagabonds, who have committed extensive depredations, in consequence of which, a few years ago, a United States' revenue cutter was sent to protect the coast. I have no doubt that the major took us, to a man, for members of the gang who had more than once visited, not his house, but his plantation, on 


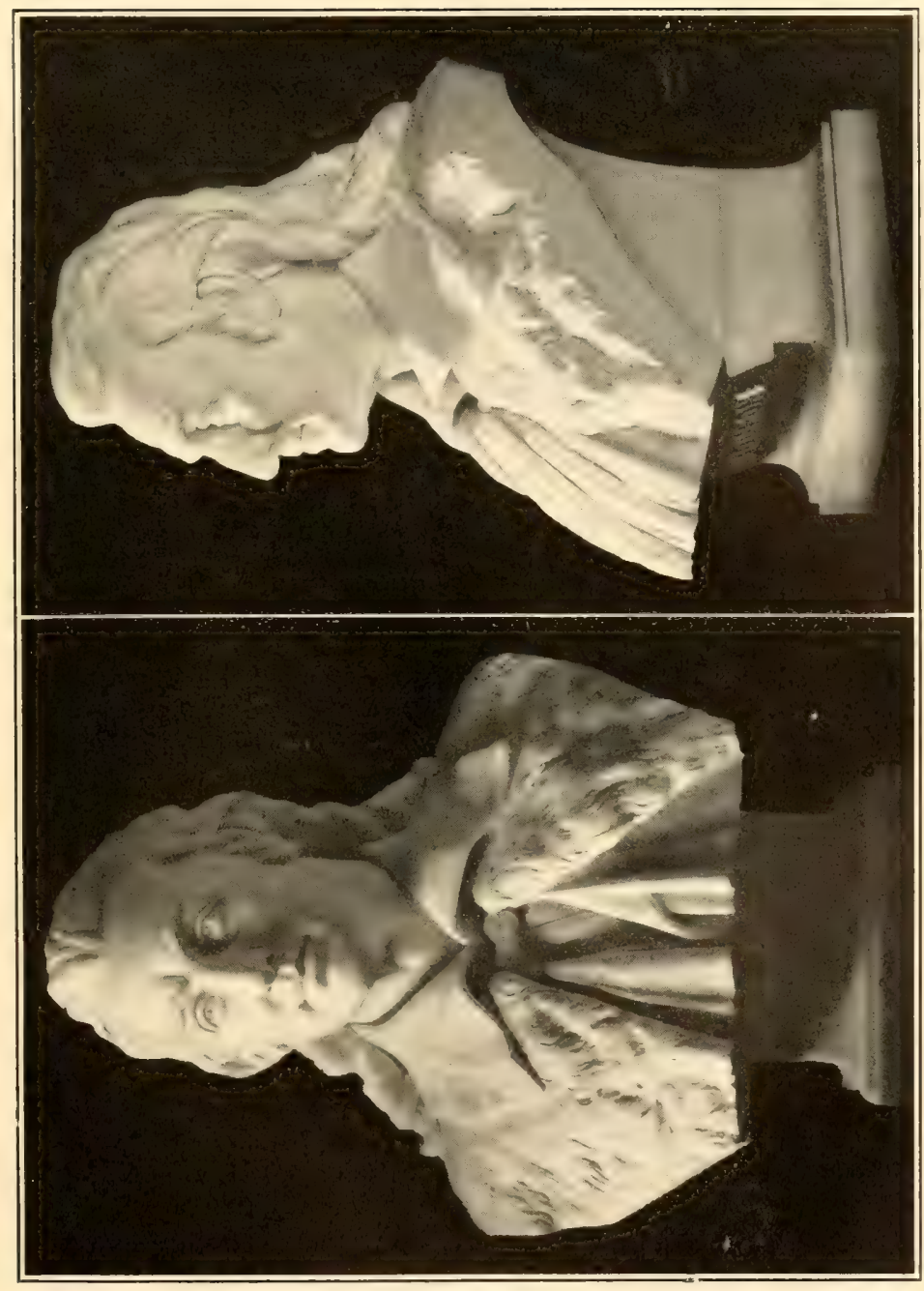

(1) 

which they had played many wanton and atrocious freaks.

We now, however, had entered the house. Candles were lighted, and we at once came face to face, as it were. It curiously happened that our captain was without his uniform, and fully as rough looking otherwise as any of us. I was, however, much pleased to see that the major himself was not much superior to us in respect of apparel; nor had his razor been employed for many days. I happened to have about me some unequivocal credentials, from the head departments of the United States, which, on my observing that some degree of suspicion still remained, I placed in his hands. He read them, spoke kindly to us, promised to forward our letters to the nearest post-town, and invited us to consider his dwelling as our own. From that moment until we returned to our vessel, we were all as comfortable and merry as men can be when distant from their own dear homes.

Next morning we received from Major Gordy a barrel of sugar, another of corn meal, some pails of milk, and a quantity of newly made butter, together with potatoes and other needful articles-and all this without being allowed so much as to offer him the least recompense. The day after, we returned to breakfast by invitation, and found in the house several strangers armed with rifles and double-barrelled guns. After we had been introduced to all around, we seated ourselves, and made a vigorous attack upon our host's eggs and bacon, coffee, tea, and milk. As this important business was proceeding, I was delighted to hear the following anecdotes, which I hope you, my dear friend, will relish as much as I did.

"Gentlemen," said our host, straightening himself up in his chair, "I am considerably suspicious as regards the strangers who happen to anchor within the range of my dominions. Indeed, gentlemen, I must acknowledge that even after you returned on board last night, I sent off some of my men in various directions, to let my neighbours know that a strange craft had anchored near the landing-place; and here, gentlemen, are those neighbours of mine; but as it happens that the name of the gentleman who calls himself a 'Naturalist' is well known to some 
of them, I now feel quite satisfied as respects the purposes you have in view. But let me tell you what happened to me some years ago.

"Such a shark-looking craft as the one you call the Crusader happened to drop its anchor abreast of my landing-place, about dusk one evening, and as I guessed that the fellows on board were not better than they should be, I watched their motions for a while from my back piazza. But nothing happened that night. Next morning, however, I heard the firing of guns down the meadows where my cattle and hogs were in the habit of feeding. So I took my rifle, walked towards the spot, and soon found, sure enough, that the rascals had killed a fine ox and several hogs, which they were dragging to the shore. Indeed, gentlemen, I saw the yawl crammed with the spoils of my plantation. Well, I took as good an aim as I could at the nearest man, and cracked away, but without hitting. At the report of my gun the fellows all took to their heels, and getting on board hoisted sail and went off. I have never heard of them since. Well, gentlemen, about the same hour next morning, a black-looking barge, hardly as large as your Crusader, came to, off the very same spot, and although I watched it and every one on board nearly the whole night, and it was a beautiful moon-shining one, not a soul of them came on shore until morning. Then, however, I saw some bustle on board. Several men got off in a very small affair, which was fastened astern of the large boat. I saw them land, and deliberately walk towards the meadows. No sooner had they reached the wettest part, and that is where my hogs generally root for food, than crack, crack, crack, went off their guns in all directions. You may well suppose how vexed I was at all this, and conceive how soon I mustered my men with clubs, and armed myself with my rifle. On reaching the ground, think, gentlemen, what were my thoughts, when I saw the fellows all advancing towards me and my people, as if they were the honestest men in the world. I was so mad when they came close up, that I had a mind to shoot the one in front, for he looked for all the world as if he cared not a pin for any one. However, I did 
not shoot, but asked him why he was shooting my hogs? 'Hogs! good man, you are quite mistaken; we are shooting snipes until we come in contact with the rascally pirates who infest the coast, and lay waste your plantations. My name, my good sir, is Captain - of the United States Navy; and these are some of my men. Will you come on board, and breakfast with us on your own snipes?" No wonder that the major, having been subject to the visits of these marauders, should have taken us in the dusk, armed as we were, and withal not having precisely the aspect of sober citizens, for persons not quite as good as we should be. But I must now conclude, and in my next you shall hear something of the result of my expedition into the marshes.

After wading through mud for whole days, exposed to scorching heat, and constantly annoyed by myriads of insects in the course of their numerous excursions on shore, they reached Galveston Bay on the 24th of April. The fort of Galveston returned their salute of " 26 fires," given by the big gun on the Campbell, and shortly after they received a visit from the Secretary of the Navy of the Republic of 'Texas, which under Sam Houston had declared its independence but a few weeks before their arrival, and were invited to proceed to the seat of government, at Houston, eighty miles distant, in the interior. They landed on the 26th of April, and after three weeks had been spent in exploring Galveston Island and its adjacent shores for birds and animals of all sorts, they started for Houston on the 8th of May. After making about twelve miles, their vessel grounded on Red Fish Bar, and the party then took to tender and gig, reaching their destination on the 15th; wild turkeys, ibises, and ducks of many kinds were seen in great numbers along their course.

${ }^{13}$ See Lucy B. Audubon, ed., op. cit., p. 411. 
Audubon has left a graphic account ${ }^{13}$ of what he then saw at the capital of this short-lived infant Republic, including its picturesque President, the mêlée of dejected Mexican prisoners then gathered there, and its drunken Indians, "halooing and stumbling about in the mud in every direction." Houston's abode was a small log house, "consisting of two rooms, with a passage through, after the Southern fashion."

The moment we stepped over the threshold, on the right hand of the passage, we found ourselves ushered into what in other countries would be called the ante-chamber; the ground floor, however, was muddy and filthy; a large fire was burning; a small table, covered with paper and writing materials, was in the centre; camp-beds, trunks, and different materials were strewn around the room. We were at once presented to several members of the cabinet, some of whom bore the stamp of intellectual ability, simple though bold, in their general appearance. ...

The President was engaged in the opposite room on national business, and we could not see him for some time. Meanwhile we amused ourselves by walking to the capitol, which was yet without a roof, and the floors, benches and tables of both houses of Congress were as well saturated with water as our clothes had been in the morning. Being invited by one of the great men of the place to enter a booth to take a drink of grog with him, we did so; but I was rather surprised that he offered his name, instead of the cash, to the bar-keeper.

We first caught sight of President Houston as he walked from one of the grog-shops, where he had been to prevent the sale of ardent spirits. He was on his way to his house, and wore a large gray coarse hat, and the bulk of his figure reminded me of the appearance of General Hopkins of Virginia, for like him he is upwards of six feet high, and strong in proportion. But I observed a scowl in the expression of his eyes, that was forbidding and disagreeable. We reached his abode 
before him, but he soon came, and we were presented to his excellency. He was dressed in a fancy velvet coat, and trowsers trimmed with broad gold-lace; around his neck was tied a cravat somewhat in the style of seventy-six. He received us kindly, was desirous of retaining us for awhile, and offered us every facility within his power. He at once removed us from the anteroom to his private chamber, which by the way was not much cleaner than the former. We were severally introduced by him to the different members of his cabinet and staff, and at once asked to drink grog with him, which we did, wishing success to his new republic. Our talk was short; but the impression which was made on my mind at the time by himself, his officers, and his place of abode, can never be forgotten.

The party left Texas on the 18th of May, and on the 27th reached New Orleans, which was then oppressively hot and nearly deserted. Here Audubon's collections and equipment were packed to be sent north; his dog was given to his brother-in-law, William Bakewell, and on the last day of the month the party began to retrace their steps of the previous March. After more hard traveling by car, coach and railroad, Charleston was reached in eight and a half days, on June 10, 1837. Edward Harris, who ascended the Mississippi from New Orleans for the purpose of making further collections, later rejoined the party at Bachman's home in Charleston. Audubon said that he lost twelve pounds in weight during this journey, which proved exceedingly trying, and the hardships encountered were hardly commensurate with the returns in bird and animal lore; yet Audubon was by no means dissatisfied at the results, as shown by the following account which he gave Thomas Brewer two days after his return: ${ }^{14}$

The weather during the principal portion of our absence

${ }^{1 *}$ Thomas M. Brewer (Bibl. No. 79), loc, cit. 
was unusually cold, even for the season, and this gave us, perhaps, the very best opportunities ever afforded to any student of nature to observe the inward migrations of myriads of the birds that visit us from the south and west when the imperative laws of nature force them from their winter retreats towards other countries to multiply. To tell you all regarding this would be more by a thousand times than can be given in a letter written in haste, and I will therefore at once touch the spring with whose sound you are most in harmony. We procured many eggs for you-ay, a great number-and as soon as we reach New York I will make up a large box, and take it to you myself. . . One thing that will interest you most, as it did me, is that we found west of the Mississippi many species of ducks breeding as contented as if in latitude $68^{\circ}$ north. There is, after all, nothing like seeing things or countries to enable one to judge of their peculiarities, and I now feel satisfied that through the want of these means many erroneous notions remain in scientific works that can not otherwise be eradicated. We found not one new species, but the mass of observations that we have gathered connected with the ornithology of our country, has, I think, never been surpassed. I feel myself now tolerably competent to give an essay on the geographical distribution of the feathered tribes of our dear country, and I promise that I will do so, with naught but facts and notes made on the very spot, and at the fitting time.

Maria Rebecca Bachman, eldest of the nine Bachman children, was married at this time to John Woodhouse Audubon, and the entire party started north before the end of June. They went by steamer to Norfolk, and thence to Washington, where Audubon presented his letters to President Van Buren and tendered his thanks in person to the various officers of the Government and friends who had aided his expedition; they passed rapidly through Baltimore and Philadelphia, to New York, where Audubon remained a fortnight, while 


\section{THIRD AMERICAN TOUR 167}

his son and daughter-in-law were enjoying a honeymoon at Niagara Falls. All sailed from New York on the packet $\boldsymbol{E}$ ngland, and landed at Liverpool on the $2 \mathrm{~d}$ of August. Five days later the family was united in London. 


\section{CHAPTER XXXII}

\section{AUDUBON'S GREATEST TRIUMPH}

Extension of his work-Financial panic and revolt of patrons-New western collections-His "Book of Nature" completed-Work on the letterpress in Edinburgh-Vacation in the Highlands-Commissions to Harris-Parting address to the reader-Dissolution of the Havell engraving establishment-The residuum of The Birds of AmericaRobert Havell, engraver, and his family-Lizars' first edition and the Havell reissues of plates-Brief manual for collectors-AppreciationsTotal edition of The Birds of America-Past and present prices-The Rothschild incident.

After Audubon's return to England in the summer of 1837, the completion of his magnum opus occupied but two years. Certain now of the ultimate success which would crown his efforts, he worked with a furious ardor, determined not only to execute his original plans, but to extend them, if necessary, to include every bird which had been discovered in America, or, at least, in the United States.

Audubon wrote Thomas Brewer in September that, for some unexplained cause, a large part of his collections made in Texas had probably been lost; when writing on October 29, the box containing all the eggs collected on the Gulf of Mexico had not come to hand. He continued: ${ }^{1}$

I authorize you to offer and to pay as much as five dollars for an old raven, in the flesh, and perfect as far as internals

${ }^{1}$ For this and the quotations in the following paragraph, see Thomas M. Brewer (Bibl. No. 79), Harper's New Monthly Magazine, vol. Ixi, p. $666(1880)$. 


\section{AUDUBON'S GREATEST TRIUMPH 169}

are concerned. European writers who a few years since were all agog to prove that our apparently analogous species were identical with those of Europe have suddenly "faced about," and pronounce our birds to be quite distinct species, and of course now say that our raven is indeed our raven! and all this because I proved that the Corvus corone of Europe existed not in America. All this induces the present natural student of nature to have his eyes and all his senses fully open, and to see into things further than we can into grindstones. . . .

Charles Bonaparte, who has just this moment left me, has kindly proffered me his new North American species, and I hope to figure them all, thereby rendering my work the more complete, if not quite perfect, as far as truly well-known species are now thought to exist in the limits of our country, or indeed those of North America.

When writing his young friend again, on November 18, he implored him to proceed

with all possible industry, in procuring the birds of my list, in rum. I hope you will have a pair of pied ducks (Fuligula labradora) for me. Send me all the drawings of eggs you can so that they reach me here by the 1 st to 10 th of March next. If the birds arrive in London by the middle of April, it will do. .. I send you inclosed the copy of an advertisement of my work, which I wish you to hand over to our most generous friend George Parkman, Esq., M. D., and ask him to have it inserted in one or more of the Boston newspapers as soon as convenient.

Again, on the 22nd, he admonished his friend not to send his "drawings of eggs by letter," but to forward all such to N. Berthoud, "and ask him to send them by captains of London packets. The postages are very heavy these hard times, and I am not a prince."

Although Audubon's "Prospectus" called for only 
eighty parts of 400 plates, by 1837 the number of new discoveries had multiplied to such an extent that he faced the dilemma of either enlarging his work or issuing it in an incomplete state. In the summer of that year large numbers of his British patrons discontinued their subscriptions, a result, no doubt, of the disastrous panic which had driven many into bankruptcy, and still more refused to take any plates in excess of the stipulated number. To alleviate this anticipated difficulty, he had already begun to admit composite plates, on which from two to six different kinds of birds were grouped together, much in the older style which he abhorred; but, in spite of this concession and omission of the eggs, colored figures of which he had hoped to give at the end, he was obliged to add seven parts, thus swelling the total number of large plates to 435 , which represented 489 supposedly distinct species of American birds.

When Audubon was facing such protests in England, Dr. J. K. Townsend ${ }^{2}$ returned to Philadelphia with a second great collection from the Far West. How eager he was, at this psychological moment, to gain access to these ornithological treasures is clearly shown in the following letter ${ }^{3}$ to Edward Harris:

\section{Audubon to Edward Harris}

[Outside address] To EDD $\mathrm{H}_{\mathrm{ARR}} \mathrm{Esq}^{\mathrm{r}}$.

Moorestown New Jersey

9 miles from Philadelphia Pennsylvania U. S. A.

\section{Duplicate}

Lownon, Oct. 26 th., 1837.

I have this moment received your dear letter of the 4 . instant, for the contents of which, I do indeed most truly thank

${ }^{3}$ See S. N. Rhoads (Bibl. No, 46), The $A u k$, vol. xx, p. 377 (1903). 


\section{AUDUBON'S GREA'TES'T TRIUMPH 171}

you, but the most important point contained in it, Dr. Spencer is now at Paris quite well and happy. I have not heard of his supposed intentions to visit Russia, at least not until you have shown yourself in Europe for awhile. When will you come? I have not received one single letter from Dr. Morton since my return to England, and have been the more surprised at this, because I look upon him as a worthy good man and as one whom, since my last visit to him, I cannot but consider as my friend.

The return of Dr. Townsend to our happy land has filled me with joy, and trebly so when you tell me that he is as friendly disposed to me as I ever have been towards him. I congratulate you my dear friend, in the step which you have so kindly taken in my favour, by first selecting all such Birdskins as you or Townsend have considered as new, and also in having given freedom to Dr. Morton to pay Dr. Townsend Fifty Dollars for the skins selected by you, under the prudent considerations or restrictions talked of in your letter. May I receive all the Bird skins very soon, for depend upon it, now or never is for me the period to push on my publication. If I have any regret to express it is, that Townsend or Dr. Morton or yourself did not at once forward to me the whole of the Bird skins brought latterly by Townsend, for I can assure you that it has become a matter of the greatest niceity to distinguish the slight though positive species lines of demarkation between our species of Birds-and if on this reaching you, the least doubt exists amongst yourselves respecting any one, why send it to me at once by the very earliest conveyance. If by New York, with letter to N. Berthoud to lose not a day, provided a packet, either to Liverpool or London, is ready to sail! Had Townsend sent me the whole of his disposible birds, I might now have perhaps been able to have mad[e] him a remittance in cash, which the single arrival of the German Naturalists, who are now in California may hereafter put an end to. Mention this to him, nay, shew him this letter if you please and assure him that I am willing to exert myself in his behalf. Indeed, I wish you to urge him in forwarding me either his own manuscripts or a copy 
of all such parts as appertain to Birds, as soon as possible, knowing (I think) that he will not undertake to publish them himself under his present ( $I$ am sorry to say) embarrassed pecuniary circumstances. Tell him that I want all about the habits of any Birds which he has written upon, especially, however, those found from the beginning of his journeys until his return, and appertaining to species belonging to our fauna or otherwise. Their exact measurements, dates, localities, migratories or vice versa inclinations, descriptions of nests, eggs \&c. periods of breeding; in a word all that he can, or will be pleased to send me-and you may assure Townsend, that all he will confide to me will be published as coming from him, although I may think fit to alter the phraseology in some instances. Tell him to be extremely careful in naming his new species, and that [if] he thinks of difficulties in this matter, to leave it to me, as here I am able to see all the late published works (and they are not a few) and work out the species with more advantage than any one can at present in Philadelphia. Do not take this as egotism far from it, it is in friendship and for his sake that $I$ venture on undertaking such an arduous task. I am exceedingly [anxious] to receive a letter from him (for Nuttall, though an excellent friend of mine and a most worthy man, will not answer me in time on this subject) of all the birds contained in the plates now at the Academy of Natural Sciences in Philada., which he saw on the Rocky Mountains, over those mountains, on the Columbia River and off the coast of our Western boundaries. This I want much, and if he would simply dictate to you plate 1 , not there, plate 2 , there, plate 3 there \&c. \&c. this would amply answer my purpose, and this I wish you not to neglect to forward me as soon as possible by duplicate! Of course I cannot speak upon any one of the new species of which you speak until I have examined them all. To talk of new species in London is a matter not now understood in any part of America, and sorry will you be as well as himself, when I assure you that out of the twelve supposed to be, and published by Dr. Morton, from Townsend's first cargo, not more than six are actually undescribed, although I have taken 
upon myself the risk of publishing his names to the Birds on my plate, but which of course I am obliged to correct in my letter press. The little beautiful owl, I would venture to say has been described by Vigors at least ten years ago, \&c. \&c. Swainson never goes to bed without describing some new species, and Charles Bonaparte, during his late visit to London, has published as many as 20 of a night at the Museum of the Zoological Society Insects \&c. \&c. Stir, work hard, [be] prompt in every thing. My work must soon be finished, and unless all is received here by the month of May next, why I shall have to abandon to others what I might myself have accomplished. God bless you, many happy years. We are all well, thank God, just now. Remember me and us kindly to all around and every friend and believe me ever your most truly and sincerely attached friend,

\section{John J. Audubon,}

To Edward Harris, Esq ${ }^{\text {re }}$.

Addressed, care "Messrs. Rathbone, Brothers \& Co.

When you send to Liverpool.

Liverpool."

If Townsend has brought Birds Eggs, ask him to send them me. I will return all to him that he may want. I greatly regret that you did not find me the reater Birds of which you speak, as I might have perchance found something new or curious among them. The Golden Eye Duck especially, if any be had?

In reference to the new species of birds which had come into his hands, Audubon said:

What was I to do? Why, to publish them, to be sure; for this I should have done, to the best of my power, even if every subscriber in Europe had refused to take them. What! said I, shall the last volume of the "Birds of America" be now closed, at a time when new species are in my hands? No! And in spite of threats from this quarter and that, that such and such persons would discontinue their subscriptions (which indeed 
they have done), and refuse to take the few numbers that would have rendered their copies complete, my wish to do all that was in my power has been accomplished.

Doubtless we should hesitate to blame many of Audubon's subscribers for wishing to be relieved from an obligation which for a period of ten years had cost them from $\$ 50$ to $\$ 100$ per annum, not to speak of any who had met financial disaster in the panic of that day, but at this juncture he really had no choice. When his eightieth Number, originally intended to be the last, appeared in 1837, many important kinds of birds, including ducks, swan, tern, and the Flamingo, as well as grouse, warblers and woodpeckers, were still calling loud for recognition. So generous of space had he been in the earlier phase of his undertaking that twenty species were each shown on two distinct plates, while in the end the need of compression compelled him to introduce thirtyfive composite plates.

Subscribers to The Birds of America at the beginning had been permitted to take a part or the whole, and many incomplete sets were circulated, upwards of 120 , as Audubon declared in 1839, having then discontinued their subscriptions. Towards the end of his undertaking, owing to the great expense and uncertainty involved, he was disinclined to supply any but regular subscribers, as shown by the following letter written from London, May 25, 1838, to William A. Colman of New York: ${ }^{4}$

We find that six of the plates you want are not only largest figs, but some of them extremely full and difficult to colour, and he [Mr. Havell] says that our Printers and our Colourers would not undertake to go throu them without charg-

${ }^{1}$ From MS. in the Public Library, New York. 


\section{AUDUBON'S GREATEST TRIUMPH}

ing a most extravagant price. I have no extra plates whatever on hand, and in consequence of this must be obliged to decline furnishing you with them.

If at the conclusion of my publication I find any of the plates you want they will be sent to you forthwith, but I wish you not to calculate upon this until you hear again from me, or from my sons on this subject.

My work will [be] entirely finished by the end of next month, when our engraving and Printing establishment will be broken up, and few will indeed there be copies to be had by any one, who has not subscribed to the "Birds of America."

Should you see any of my American subscribers who have not as yet seen any portion of the work, please to assure them that as soon as the fourth volume is quite finished, and bound according to their desires, their copies will be forwarded at once to their respective homes, or to whomsoever they have directed me to send their copies.

On May 26 Audubon wrote Thomas M. Brewer that "Edward Harris, one of the best men of this world," had reached his house "yesterday at noon, after a pleasant passage of fourteen days and a few hours." "My illustrations," he said, "will be finished on the 20th of next month, and the fourth volume of text shortly afterward"; at the end he added: "When I return to our beloved land, I intend to spend a full season about the lakes in Northern Vermont, for, from what I hear, much knowledge is to be acquired there and thereabouts." After returning to New York in September of the following year, he again alluded to the ramble he would like to take "along the borders of the famous lakes of New Hampshire and Vermont," but was unable to bring it to pass at that time.

To depart but slightly from the chronological sequence, the last to be preserved of Audubon's letters to 
William Swainson, ${ }^{5}$ written at a time when his great work was drawing to a close, will be given at this point:

\section{Audubon to William Srainson}

\section{Londos 11th Jan 1838}

\section{My dear Mr Swainson,}

The severe indisposition of my good wife which has continued almost unabated now since $I$ had the pleasure of seeing you, is my excuse for not having ere this answered your two notes, especially the last of the 8th instant.-

Your box \& contents came perfectly safe to hand, and I think will soon again be in your possession in like good order. I certainly should like to see the Buteo [?] vulgaris to compare it with mine (that at the mouth of the Columbia) and the one described by Nuttall before the return from America of D. [Dr. John] Richardson \& of which it seems you were not aware.I am glad nevertheless that if differing from the European bird of that name the Transatlantic bird will be honoured by your own name.

Charles Bonaparte is at Paris \& is to remain there. I am well informed for about a fortnight.- - He left London in great haste and I assure you has left no parcels or letters for you or anybody else either with us or with Havell.-I am sorry that he should have disapointed you \& your dear Children but-.

I cannot say just now whether I have a specimen of Muscicapa Trailli "the Prince" having two of my giving, if however, I have another I will send it to you with great good will \& pleasure - As regards your queries respecting several species of quiscalus or Crow black birds You are correct for I have myself discovered two in America one in the Floridas the other in the Arkansaw River, both of which will be given in my work. - That more exist I have no doubt especially further South and West.

You have described a swan in the Fauna Boriali Americana

${ }^{5}$ The Linnæan Society's MSS. See Chapter XXIII, Note 13. 
under the name of the Cygnus Bewicki, but as your measurements there and then given are very far from those of the swan now known under the name of Old Bewick I should feel obliged to you to let me know whether the specimen you described from was the identical bird procured by Captain Lyons, and of which that gentleman described the nest? And again I should like you to tell me whether you have seen the Clangula vulgaris of Linn. that in the months of April \& May?

Many thanks for all your kind wishes \& may you and yours enjoy the like return of many many new \& happy years.-Call upon us when you come to Town and believe me my dear Mr Swainson ever sincerily

\section{yours attached friend}

JoHn J. AuduBon

I have had the jawache for nearly one week $\&$ have not been out of the house

4. Wimpole Street

Audubon's day of greatest triumph came on June 20,1838 , when he had the supreme satisfaction of seeing the last plate of his "Book of Nature," The Birds of America, completed. Having been begun virtually in the autumn of 1826, it was in press nearly twelve years. The sumptuous character of this work, its commanding beauty, as well as its surprising accuracy, considering all the obstacles of time and circumstance, mark it, when combined with its letterpress, as one of the most remarkable and interesting undertakings in the history of literature and science in the nineteenth century. Unique as it was in every detail of its workmanship, it will remain for centuries a shining example of the triumph of human endeavor and of the spirit and will of man. This is true in spite of any errors it may disclose, and even if it be conceded that bare bones and plain photographs are more valuable for elucidating the technicali- 
ties of science than the most artistic productions of the pen, pencil or brush.

Audubon's labors in England, however, did not end with the completion of his plates, for two volumes of his "Biographies" still remained to be published. He was in London during the early summer of 1838, when he recorded a visit from $\mathbf{J}$ ohn Bachman, who had come to Europe for the recuperation of his health. He was then obliged to hasten to Edinburgh, where he was soon joined by both Bachman and Victor Audubon and later by other members of his family. For the convenience of work he took rooms near the museums, on the south side of the city, not far from Lauriston Place and within easy reach of "The Meadows," a well known recreation ground.

The following letter, ${ }^{6}$ sent to his son John soon after his arrival at the Scottish capital, and addressed "No. 4 Wimpole Street, London," abounds in interesting personal details, but the student of birds would find more significant its clear statement of his relations with MacGillivray; it shows us the anatomist at work, and Audubon as his student and "secretary." "Under his kind tuition," he said, when writing at a little later time, "I think I have learned something of anatomy, which may enable me, at some future period, to produce observations that may prove interesting ...."

\section{Audubon to his Son, John}

Edindurgh, July 1 st, 1838, Sunday.

MY DEAREST FRIENDS

Your joint letter of the 27 th Wednesday, did not reach me until yesterday afternoon, probably because the steamer

${ }^{6}$ First published by R. W. Shufeldt (Bibl. No. 45), in The $A u k$, xi (1894); see also Maria R. Audubon, Audubon and his Journals (Bibl. No. $86)$. 

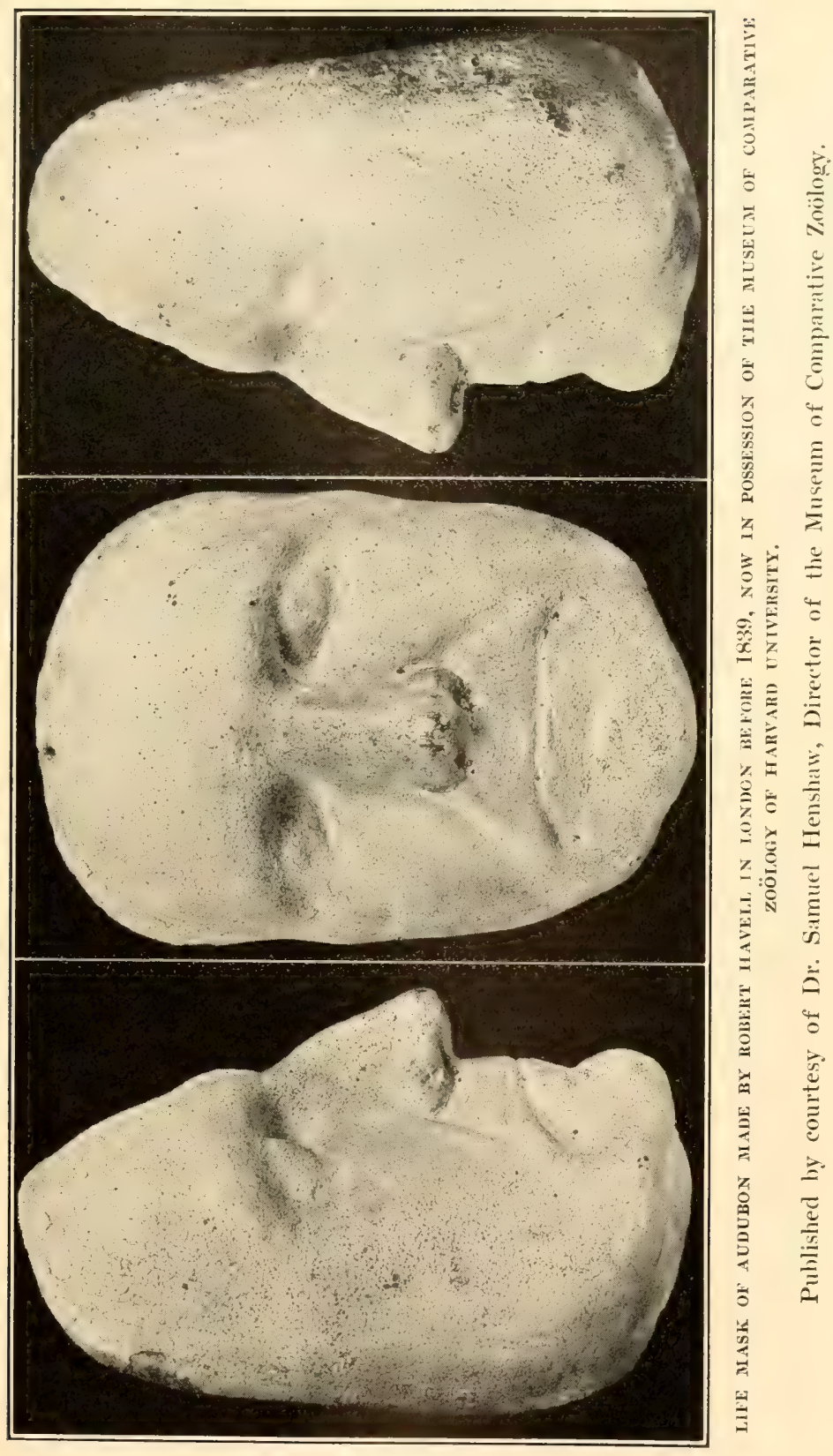



\section{AUDUBON'S GREATEST 'TRIUMPH 179}

which brought it did not leave London on that evening on a/c of the coronation etc., Here the festivals were poor beyond description, and although scarcely anything was to be seen, the whole population was on foot the entire day, and nearly the whole night, gazing at each other like lost sheep.-No illuminations except at two shops, Mr. Henderson's and another close by him.-The fireworks at the castle consisted merely of about one hundred rockets, not a gun was fired from the batteries. MacGillivray \& I went to see the fireworks at 10 p.m, and soon returned disgusted.-His museum (College of Surgeons) and the Edinburgh Museum were thrown open gratis, and were thronged to excess Upwards of 20000 in the first, and about 25000 in the other; all was however quite orderly. The day was showery; cloudy and dismal at times, but the evening was clear and fine--Mr. Hill's father died on the morning of the 27th and I have not seen Alexander H., since. Many thanks to Maria for her bunch of letters, and the few lines of her own to me, I hope that everything will go on well with you all.

We begin printing tomorrow $2 d$ of July, 1838!! remember that Mesdames et Messieurs! and I intend to proceed with all possible despatch and care. All the birds in rum will be inspected as far as internal or digestive organs, trachea \&c are concerned, and as I am constantly present in the dissecting room, I think I shall know something about the matter anon.I am almost in hopes to see Victor tomorrow night but cannot be sure. There are somewhere at home the nests of the birds found on the Columbia by Nuttall and Townsend, I believe that of Bewick's Wren is among them; send them all, very carefully packed. I want the journal of my first trip to the Floridas, which was cut out of my large leather journal, previous to going to Labrador, also a letter on the habits of the Yellowbellied Cuckoo, by a gentleman at Charleston. If it cannot be found perhaps Maria will recollect his name, being a friend of John Bachman, if so send me that, in full if possible. It is the gentleman in whose garden I procured the small and large cuckoos in the same nest.-

I have written fortyfour articles for my appendix and 
will continue whenever I am not otherwise engaged, so as to save time at last.-I am sorry for the death of poor Wickliffe but glad that his brother was with him at New York previously, and that we, at least, have done all that we could for him. MacGillivray is quite well, and works very hard, poor fellowI am glad of John's repainting the head by VanDyke, two copies of such heads are valuable to him, besides his improving by so working-When Victor has left for this place, John must pay much attention to the colourers and cxll also at the bookbinder. Havell ought to exert himself in having some 4th vols; delivered as soon as possible.

My last letter which was written last Sunday, was put too late in the office, which closed on that day at two o'clock, and did not therefore leave this till four o'clock on Monday afternoon; this one will have a better chance, for I will take it myself to the general office. I have seen no one hardly since my last, I am indeed as busily engaged as ever, and rarely go to bed before eleven-being with Mr. MacGillivray until generally past ten, describing etc., I rise at four or earlier, he at ten; but I go to bed at eleven, he at two. I discovered that he was adverse to the examination of the intestinal canals etc., because many of my birds which are common to both countries will be published before his $2 \mathrm{~d}$ vol., can now possibly be; but as soon as I told him that I had already said in my introduction, that the anatomical structure was declared to be his, he was much pleased and began on the instant.

Today is very dismal, and it will rain probably until night; I wish we had here some of the warm weather of which dearest Mamma speaks. I have had but one walk to Arthur's Seat, but now and then I stroll to the meadows which are close to me, and now look well.-From the window of my sitting room I overlook the garden of Mr. Frazer our printer, and now and then speak to him there, I have not yet however visited him.-I will recollect the Queen's farthing when next I see Professor Wilson, but doubt much if he will recollect the least idea of it. Has Charley written or said anything to Victor about the review of the work; remember me to Healey.- 


\section{AUDUBON'S GREATEST 'TRIUMPH 181}

I suppose that the crown of England sits very quietly down, and that all was very superfine. I have not so much as seen a paper since I left you.

God bless you all, dearest friends, and take good care of Mamma and Maria,

Ever your firmly attached father and friend J. J. Audubon.

No. 7 Archibald Place,

Lauriston.

Audubon's fourth volume, the printing of which was announced in this letter, was published in November, and at the conclusion of the introduction he said:

I believe the time to be fast approaching when much of the results obtained from the inspection of the exterior alone will be laid aside; when museums filled with the stuffed skins will be considered insufficient to afford a knowledge of birds; and when the student will go forth not only to observe the habits and haunts of animals, but to procure specimens of them to be carefully dissected.

These prophetic remarks, which were no doubt inspired by the studies of MacGillivray, have found ample justification in the later history of ornithology; to give a single illustration, it was through the aid of anatomy only, in this instance, of the vocal organs, that modern students have been able to define the true Passerine or Oscine birds, as distinguished from all others, and as the highest representatives of the avian class.

In the autumn of 1838, when Mrs. Audubon was still suffering from impaired health, the naturalist paused in his work to indulge in a short vacation, the first in many years. On September 14, he wrote to Edward Harris, who was then in Scotland: ${ }^{7}$

${ }^{7}$ See S. N. Rhoads (Bibl. No. 46), loc. cit. 


\section{Audubon to Edward Harris}

Edinburgh, 14 Sep', 1838.

\section{MY Dear Friend :}

Not having hecrd anything from you in answer to my last, I suppose that you may yet be away from Glasgow, but as we ourselves are going off tomorrow to the "Highlands," with a view to be at Glasgow on Thursday next, I write to you now, with the hope of meeting you then. Nothing of importance has occurred here since my last, but the book has considerably swollen in its progress towards completion.

We all unite in best wishes to you and I remain as ever your most truly attached and sincere friend,

\section{John J. Audubon}

We intend being home again on Saturday next.

[Addressed] To Edward Harris Esq ${ }^{\mathrm{r}}$.

Comrie's Royal Hotel,

Glasgow.

With MacGillivray as guide, Audubon and his family visited Stirling, Doun and Callander, where they "marched in a body to the Falls of Bracklin, guided by a rosy-cheeked Highland lassie, stopping now and then by the way to pick up a wild flower, - a blue-bell, a 'gowan,' or a dog-rose, or to listen to the magpies and titmice." From Callander they ascended to Loch Katrine, and explored the Trossachs, "admired by many, chiefly or entirely on account of Scott's description of them"; at the tavern there, said Audubon, "with that most curious innate desire which there is in us of becoming older, for the purpose of enjoying the morrow, I went to rest, anxious to see the morn, and discover what existed beyond the crags that had bounded my view."

From the wild and beautiful scenes about Loch Katrine, which stirred the naturalist's emotions and 


\section{AUDUBON'S GREATEST TRIUMPH 183}

evoked the desire to remain until the curtain of night had gradually and peacefully closed the landscape from their view, they proceeded to the rocky shores of Loch Lomond, where they found "a few small stone cabins, some fat bairns, abundance of ale, and a sufficiency of capital whisky." After crossing to Tarbet and examining both the head and the foot of the lake, they went on from Balloch to Dumbarton by stage, and thence by steamer to Glasgow; there they spent a few days, and returned to Edinburgh by way of Dunbarton and Lanark. Steamers and coaches, slow as they then were, were all too fast for Audubon on this journey, and he declared that if ever again he visited the Highlands, it should be on foot, "for no man, with nerve and will, and an admirer of the beauties of nature, can ever truly enjoy the pleasures of travelling, unless he proceed in this manner."

Mrs. Audubon's health had not improved by the journey, for shortly after their return she was again taken ill; she was placed in the care of Dr. John Argyle Robertson, for whose efficient aid and "kind and gentle treatment," said Audubon, "we can never cease to cherish the most lively feelings of affection." "It is a curious part of my history," he continues, "that during the whole of my sojourn in Britain, none of the principal medical advisers whom we had occasion to employ would receive any recompense from us."

By the 5th of November, 1838, but a few days after the issue of the fourth volume of his "Biographies," the printing of the fifth and last had already begun. The following letter ${ }^{8}$ is interesting for its personal details, and in showing that his confidence in the existence of the "bird of Washington" " had not been shaken:

$$
{ }^{8} \text { See ibid. }{ }^{9} \text { See Vol. I, p. } 241 .
$$




\section{Audubon to Edward Harris}

Eidndurgh December 19th., 1838.

\section{My dear Friend:}

Your letter of the 13 th. instant to Victor reached us this morning, and glad were we aili to hear from you.

My object in writing to you is, for the purpose of assuring you that I feel great [pleasure] in preparing a box of bird skins for you according to your desire. It is true, however, that I am now on the eve of commencing my synoptical arrangement of our birds, I shall not be able to show you as many of my specimens [as] I could otherwise have done, but you must take the will for the deed. The Box will be taken as far as London by Victor, who will leave us on the first of January. You will find in it a list of the contents, and I trust such bird skins as may answer your purpose well. Besides these Victor will also attend to your request as soon as in New York and will ship to you by way of Havre as you direct.

I am glad that you should have seen what you conceive to be the great rara avis $\mathbf{F}$. Washingtonii. I am sorry you could not have pocketed it, but who knows if it is not left yet in store for you - and I to shoot a pair of these noble birds at The West, and that, after having satisfactorily examined its habits, its eggs, or its young! Bonaparte, between you and I, is exceedingly ignorant as regards our birds, as I found to my cost when he was in London, and where he pumped me sadly too much, but it is now over and I forgive him as I do all others who have or who may try to injure me.

John Bachman wrote to me that he had left in commission to Trudeau, the purchase for me of a copy of Vieillot's Oiseaux de l'Amérique Septentrionale, and also a copy of Boié or Bojé work ${ }^{10}$ on birds generally, but I have received neither books or

${ }^{10}$ Voyage Autour du Monde, exécuté par ordre de sa Majesté l'Empereur Nicholas ler, sur la Corvette Le Séniavine, 1526-18?\%. Par Fréderic Lutké, Capitaine de vaisseau. Partie Historique, avec un atlas, lithographié, d'après les dessins originaux d'Alexandrie Postels et du Baron Kittlitz. Traduit du Russe sur le manuscrit original, sur les yeux de l'auteur, par I.e Conseiller D'Etat F. Boyé. Text in 3 vols. 8vo. Paris, 1835-36. The first two volumes are historical, and the third, entitled "Travels of the 
promises of them from Trudeau as yet, perhaps you would undertake the task yourself, and show to Havell as soon as possible, for I shall be sadly in want of them in a few weeks more. I should also like you to try to find Mr. Augustus Thorndike of Boston, to whom Victor wrote a few days ago, with the view to inquire from that Gentleman when he wished his copy of the Birds of America to be delivered. Victor addressed his letter to "his Hotel" or to the care of the "American Embassy." We are not sure, however, whether he is in Paris at present, and let me know what discoveries you have made as regards this.-Victor will remain ten days in London and wishes you, should you write to him there, to put your letter under cover to Havell and request him to keep it. Victor will write you from thence,

I cannot account why Trudeau has not written to me in answer to my last, now full two months old? Should you perchance discover a specimen of the Bird of Washington in Paris and purchase the same, I should like you to send it to me on loan to enable me to compare it with mine, and the Immature of the F. Albicilla of Europe!

I have got twelve sheets of the 5 th. Vol. of Biographies already printed, and I expect to have quite finished by the 1 st. of April next. I have decided on the Trichas resembling Sylvia Philadelphia of Wilson. It is a distinct species, but what will probably surprise you more, the $\boldsymbol{S}$. Agilis of the same author is also perfectly distinct from either. All this you will plainly see when you read their separate descriptions and compare the three species.

I wish you would ask Trudeau whether he recollects the specimen of an Eagle send by Townsend in his first collection, numbering 54 and which the latter has lost, though he considered it as a new species. It was procured in California. Townsend speaks sorrowfully of the loss of this specimen. It never came under my eye, did it come under yours? Ask Tru-

Naturalists," is translated by Alexandre Postels. The expedition traversed the Behring Sea, touched at some of the Aleutian Islands, and then explored South America as far as the coast of Chili. 
deau whether he ever saw my Hirundo Serripennis in America. Bachman wrote to me that Trudeau thought he had in the skins of Frederick Ward. I think Trudeau will be pleased with the anatomy of our birds, as it opens misteries hitherto unknown in connection with the relative affinities of some species toward others and assists in the formation of groups \&c., in what some day or other, will be called a Natural arrangement!

I wish I could have spent a few weeks in Paris with you and Trudeau, as I readily imagine that some new species of North American birds, may yet be found there unknown to the World of Science. I have written to Mr. Chevalier and to Townsend, but will not, I dare say, hear anything more of the former until through Victor, who intends to see him very shortly after his arrival in America.

My Dear Wife is much better than when you saw her, and I hope that when once again she has been safely landed on our shores and enjoyed the warmth of our own Summers, her health will be quite restored.

The Little Lucy has grown as fat as butter, and the rest of us are well.

We all unite in kindest best wishes to you and to Trudeau, and I remain as ever, my Dear Friend,

$$
\text { Yours, }
$$

John J. Audubon.

6 Alva Street.

In May, 1839, Audubon's fifth and last volume of the Ornithological Biography, consisting of 704 pages, was issued. It was followed almost immediately by $\boldsymbol{A}$ Synopsis of the Birds of North America, in which the efficient aid of MacGillivray was again enlisted. On May 4 Audubon wrote to Havell that this work was in press and would be ready in about a month's time; again, on the 30th of $\mathbf{J}$ une he announced that it was finished and in the hands of the binder. With this methodical catalogue of the birds of North America 
then known and described, to the number of 491, fiftytwo of which were new, Audubon's life and labors in England were brought to a close.

The introduction to the last volume of his "Biographies" begins as follows:

How often, Good Reader, I have longed to see the day on which my labours should be brought to an end! Many times, when I had laid myself down in the deepest recesses of the western forests, have I been suddenly awakened by the apparition of dismal prospects that have presented themselves to my mind. Now, sickness, methought, had seized me with burning hand, and hurried me away, in spite of all my fond wishes, from those wild woods in which I had so long lingered, to increase my knowledge of the objects which they offered to my view. Poverty, too, at times walked hand in hand with me, and on more than one occasion urged me to cast away my pencils, destroy my drawings, abandon my journals, change my ideas, and return to the world.

Later on he says: "You may well imagine how happy I am at this moment, when 。. I find my journeys all finished, my anxieties vanished, my mission accomplished"; and he concludes: "I have pleasure in saying that my enemies have been few, and my friends numerous. May the God who granted me life, industry, and perseverance to accomplish my task, forgive the former, and forever bless the latter!"

Audubon's introductions to the five volumes of his "Biographies," from which we have frequently quoted, are characteristic; in them he cheers his subscribers, calls all his helpers and correspondents by name, and takes the public into his confidence by recording the acts which marked the steady progress of his work. Frequent appeals to the "good" and "gentle reader" have gone out of fashion, but in this instance they seem in keeping with 
the style and character of the man, and they were not made in vain. Audubon's belief in his mission was so plainly sincere, his power so manifest and his enthusiasm so ardent, that there were few who did not gladly acclaim the extraordinary success of the man who twelve years before had landed in Liverpool poor and unknown.

In the winter and spring of 1839, while Audubon was engaged in Edinburgh and Victor was in America, the settlement of his business affairs in London was entrusted mainly to Robert Havell, his engraver. At that time Havell was also pulling up roots, for he had caught the spirit of his patron and had decided to emigrate with his family to the United States; this involved disposing of his stock and breaking up his engraving and printing establishment at 77 Oxford Street. Havell had acquired distinction as well as a competence through his long engagement with Audubon, and being then in his forty-sixth year, he doubtless looked to America as a field for the fuller expression of his artistic aspirations and talents. How anxious Audubon was at this juncture regarding the disposition of the residual stock of his plates, his drawings, and his books, then in Havell's hands, is seen by the following letter, ${ }^{11}$ written at Edinburgh, in the winter of this year.

\section{Audubon to Robert Havell}

Edinburgh, Feb. 20th, Monday, 1839.

My dear Mr. Haveli

I perceive by the date of your letter of the 16 th instant that you must have been some days beyond my expectations,

${ }^{11}$ First published by Ruthven Deane (Bibl. No. 225), in The Auk, vol. $\operatorname{xxv}$ (1908). Mr. Deane writes me that he has a copy of a receipt from William MacGillivray to Audubon for the final amount due him for work on the technical parts of Volume $\mathrm{V}$ of the Ornithological Biography; at the bottom of this paper Audubon made a memorandum, under date of November 21,1838 , to the effect that the total amount which he had paid MacGillivray for his work upon this volume was $£ 47-11-1$. 


\section{AUDUBON'S GREATEST TRIUMPH 189}

in the receiving of my parcel to you, and that on that account my letter of Saturday last crossed yours of the same date. I thank you for what you say as regards the balance in my favor at Wright and Co.

Does Henry sail from London Docks or from Portsmouth? and pray what is the name of the Captain of the "Wellington"? I do not precisely understand what you mean by the loose sets which you desire to know how they should be packed? let me hear what they are and how many of them by return of mail. The fire perfect sets I think might all go into one case, tinned as usual and insured of course to the full amount of their value, as well as all others and to which I pray you to attend as if for your own self. It is impossible for me to go to London at present and indeed I cannot exactly tell when I will, and I trust to you entirely for the seeing that all the volumes are fair and good and passed through your own inspection of them before they are packed. No volumes of Biographies must be put in the same boxes.

When you have disposed of your buisiness, what will you do with what you have on hand belonging to us? This requires an answer from you at once. You have a great number of volumes of Biographies, Pictures, \&c. \&c., a regular list of which you ought to send me. I cannot yet say when the 5th vol. of Biographies will be finished, but will let you know as soon as I can. I received yesterday morning a letter from a gentleman who has procured a copy of the work through Mr. Eame the bookseller, he says that he has called upon you to say that he is missing one plate and begs to have a copy of the plate struck and remitted to Mr. Eame who will pay you whatever price the extra trouble on this account may amount to, but he does not say what plate it is, and I therefor suppose that you do? If so as he is the brother-in-law of Mr. Walker of Ravensfield Park, one of our good subscribers I would say do it for him! My wife begs of you to save all the loose prints which were returned to you by our son Victor, as well as any others whatever, perhaps among them you might find one to send Mr. Eame's subscriber? 
On the 4th of this month the 'Great Western' was nearly half way across the Atlantic!! Sir William Jardine has published a capital review of the work! What a strange world we do learn in! Be sure to let me know about the original drawings at Henry's, if he has finished them, where they are \&c. \&c. We all remain as usual with kind good wishes to you all,

\section{Your friend}

John J. Audubon.

6 Alva St.

[Superscribed]

Robert Havell Esq.

Engraver.

77 Oxford st

London.

How fully Audubon's injunctions in regard to his residual stock, and particularly to scattered plates of the Birds, were followed, is not known, but it is certain that a part of this residuum remained in England, where it is occasionally turned up even at the present day. In a considerable number of the original plates which were found in a bookshop in New Oxford Street in August, 1912, twelve were in the uncolored state, and several had the appearance of rejects; moreover, in a collection of these plates received from England in 1910, there were nine copies of the same subject, the Painted Bunting (No. 11, Plate 53). Though a complete set of the plain plates is known, ${ }^{12}$ and a considerable number were probably dispersed in America, they are very rare.

Audubon wrote to Havell again on the 13th of March, when he complained of the gross mistakes made

${ }^{12}$ See Note 5, Vol. II, p. \%. Mr. John Hardin (see Vol. II, p. 295) showed me an uncolored print of the Hen Turkey which John W. Audubon had given him, and a correspondent in New Orleans informs me that a relative possesses a number in this condition, which were received many years ago as a gift from Mrs. Audubon. Mr. Charles E. Goodspeed, of Boston, was the recipient of the Painted Bunting plates, noticed above. 


\section{AUDUBON'S GREATEST TRIUMPI 191}

by the "idle rascals" who were employed in filling orders in his shop, and who had so sadly mixed matters that no less than twelve numbers of his Birds had come back to him, some of them containing one, three, and five copies of the same plate, instead of a "Number," and mixtures of the most incongruous sort; he thought that "a clever young man as a clerk was worth a hundred thick heads," and begged Havell again to send him "a correct list of what he shipped to America on his account, and that list not made by any other person than either himself or Mrs. Havell." His next injunction, on May 4, was to insure his copper-plates of The Birds of America for $£ 5,000$, and to send them to either Victor Audubon or Mr. N. Berthoud, Number 2 Hanover Street, New York. At that moment Audubon was planning to return to America with his family by the Great Western on July 6. In writing again on June 30, he remarked that he was not at all certain that Havell, who was then visiting at his native Reading, in Berkshire, would really sail on the 25th of July, since he had already postponed the journey so many times; he added that it would not even surprise him if his work on the Quadrupeds of America might not be out before they could fish and shoot together in his "native land."

Havell eventually came to America with his wife and daughter on the ship Wellington, in September, 1839; they landed at New York after the 15th of that month, and for a time were the guests of the Audubons at Number 86 White Street. His brother, Henry, ${ }^{13}$ who visited the United States in 1829, returned at about this time and established a print shop in Broadway, New York, but according to Robert's biographer,

${ }^{13}$ Henry Augustus Havell (1803-1840), painter, engraver, and at one time assistant to his elder brother, Robert Havell, Junior. 
his enterprise was ruined by a fire, when he went back to England and he died there about 1840. After a brief residence in Brooklyn, Robert Havell settled at Sing Sing, now Ossining, at a beautiful spot on the Hudson, overlooking the Palisades, which he named "Rocky Mount." There he devoted himself with characteristic energy to painting and sketching, but he also engraved and published a number of excellent views of his favorite river, the Hudson, as well as of New York and other American cities. In $\mathbf{1 8 5 7}$ he established himself at Tarrytown, where he built a house and studio, and where in his later years he produced many meritorious works in oils. "He never tired," says his biographer, "of the great, broad, sweeping Hudson, and propped up in bed, that he might gaze at will on this mighty river," he died at the age of eighty-five, November 11, 1878. ${ }^{14}$

Havell has been described as quite the opposite of Audubon in many of his characteristics, calm, deliberate, not easily discouraged, and fully his equal in industry, perseverance and determination. Audubon sometimes complained of his friend's lax business habits, but their long sustained and cordial relations were never broken during life, and their mutual debt was great. The engraver's first son, who lived but a year, was named Robert Audubon, and the naturalist, who was his godfather, held the child at its baptism at old St. James Church, Oxford Street, in 1827. A descendant of Luke Havell, who was a drawing master at Reading, uncle of Rohert the second, possesses a silver loving-cup which Audubon presented to his engraver upon the completion of the second volume of his illustrations; it is inscribed "To Robert Havell, from his friend J. J. A. 1834."

${ }^{14}$ George Alfred Williams (Bibl. No. 232), Print-Collectors Quarterly, vol. vi, p. 225 (1916). 


\section{AUDUBON'S GREATEST TRIUMPH 193}

When we consider the size of Audubon's plates, which required for the portrayal of his largest subjects, such as the Whooping Crane or Wild Turkey, an area of no less than five square feet, it will be seen that his engraver was compelled to adopt the most expeditious methods. This and kindred difficulties were overcome by Havell's skillful union of aquatint with etching and line engraving, but some of his smaller figures, as the Snow Birds (Plate 13), appear to have been etched in the usual way, with but slight use of either aquatint, dry-point or burin. In aquatinting the plate was usually bitten to the desired depth for the softer shading of feathers or foliage, or for the entire expression of sky, water or landscape. Says George Alfred Williams: ${ }^{15}$

Aquatint proper consists entirely of gradations of tone produced by biting with aquafortis into the copper through a resinous ground broken into a multitude of fine granules, that render the personal touch practically negligible, and in consideration of this we can appreciate the exceptionally skillful use Havell, Junior, made of the difficult process. The graining of the aquatint grounds is produced by allowing fine dust particles to settle upon the freshly prepared plate. It is to these grainings of different degrees of fineness that the engraver must look for the subtlety of the tonal surfaces, but strength is obtained usually through the use of the etched line. The chief limitation of the aquatint process lies in the great difficulty of getting more than a few differences of shade, as the ground goes to pieces rather rapidly under successive bitings, and the transitions from one tone to another are very few, so that half tones are not readily obtainable. It is in the economical use of these half tones that Havell, Junior, achieved so much and thereby produced a chiaroscuro seldom, if ever, equaled in aquatint.

${ }^{15}$ Loc. cit. 
Artists have sometimes frowned upon this combination of aquatint with other forms of engraving, especially when executed with the burin, for "like the permanent misery of a quarrelling married couple, they may ruin everything with discord" ; but any such lack of harmony, when not overcome by Havell's skill, was usually completely subdued by the color which was subsequently applied to the printed sheet. This is seen by a comparison of the plain proof of such an elaborate plate as that of the rattlesnake attacking the mocking birds (Plate xxi) with the result attained in the finished impression. In replying to a criticism of Havell's work in 1830, Audubon expressed his conviction that "no birds were ever so beautifully and softly represented on copper," and any hardness, which his plates rarely showed, was not due to aquatinting, the inherent quality of which is softness. To quote our authority again:

In Havell's hands aquatint gave the essential structure of forms by a judicious use of the process called "feathering." This he often did upon the bare copper plate without a ground, allowing the acid to bite its own granular surface. In this way he produced the soft gradations and telling accents so necessary to the portrayal of birds, but by a further judicious use of line the accurate forms of both bird and plant life were given with great force and delicacy.

When Audubon first proposed to present the Congressional Library at Washington with a copy of his Birds, he asked Havell to do all the coloring himself; Havell

colored his prints in the usual manner by flowing washes of pure water-color tints over the monochrome proof which was printed from the copper plate. In this phase of the process the great charm of his genuine talent for water-color painting 


\section{AUDUBON'S GREA'TEST TRIUMPII 195}

asserted itself. Aside from the first crude washes, put on by artists or colorists employed for the purpose, he himself applied the salient tones and all the more delicate tints.

Much misunderstanding has arisen in regard to the engraving and publication of Audubon's earlier plates owing to the complex relations which existed between Lizars, the two Havells of the same name, and the naturalist himself; this involved the reissue of the first two numbers of the work, and a confusing series of legends upon the plates themselves, occasioned partly by a division of labor between father and son, and by the death of Robert Havell, Senior, in 1832. The errors into which some commentators have fallen, however, are due to their examination of but one set of plates. 'The account which follows is based upon a collation of complete copies at the British Museum, the Radcliffe Library, Oxford, the Jardin des Plantes, Paris, and the Boston Society of Natural History, and of numerous scattered plates. Lizars engraved the first ten plates only of the large folio, but before the summer of 1827 a considerable number of these early impressions had been distributed. The Havells, as we have seen, started the work anew, and Robert, the younger, retouched the greater part of Lizars' plates, so that their reissue in London constitutes for the bibliophile a second, and in some cases a third, edition. Moreover, the plates which were eventually executed by the younger Havell, to the number of 425 , were repeatedly printed from to meet the requirements of new subscribers; on such occasions errors were corrected, minor changes in the artist's or engraver's name introduced, and the nomenclature of the birds and plants more or less completely revised. Frequently the Whatman water-marks, or, indirectly, 
Audubon's titles, postdate the year of publication as printed on the plate itself. Conflicting legends, particularly on the earlier plates, which have often puzzled collectors, are mainly due to one or another of the conditions named. Nearly every plate underwent alterations of some sort, but the various legends show conclusively whether the print belongs to a first or a subsequent impression. In the British Museum copy, the younger Havell's first independent legend appears on Plate lxxvi (Virginia Partridge), as "Engraved, Printed, \& Coloured by R. Havell Jun ${ }^{r}$. 1830." The word "London" was later added, but was eventually discarded. After the senior Havell's death in 1832, the son naturally dropped the suffix from his own name; thereafter his brief designation of name and date became gradually stereotyped. It should be noticed, however, that when Robert Havell needed to reprint from plates which were executed before his father's death, he would frequently remove only the "Junior," and let the original date stand, so that legends like the following are not uncommon: "Engraved, Printed, \& Coloured by R. Havell, London-1831"; to avoid the lacuna, designation of place and date were, at times, erased also. The naturalist's name underwent a different evolution on the plates, but after 1830, the date of his election to membership in the Royal Society, his designation gradually settled into the phrase: "Drawn from nature by J. J. Audubon, F. L. S. F. R. S." (as in Plate lxxxi, 1830); accordingly, all plates which bear these titles, but an earlier date, are second or later editions. The previous hints, with examples to be given presently, will enable collectors to determine whether a given plate is a first or subsequent impression.

Lizars' first edition of plates, Numbers i to $\mathrm{x}$, bore 
g
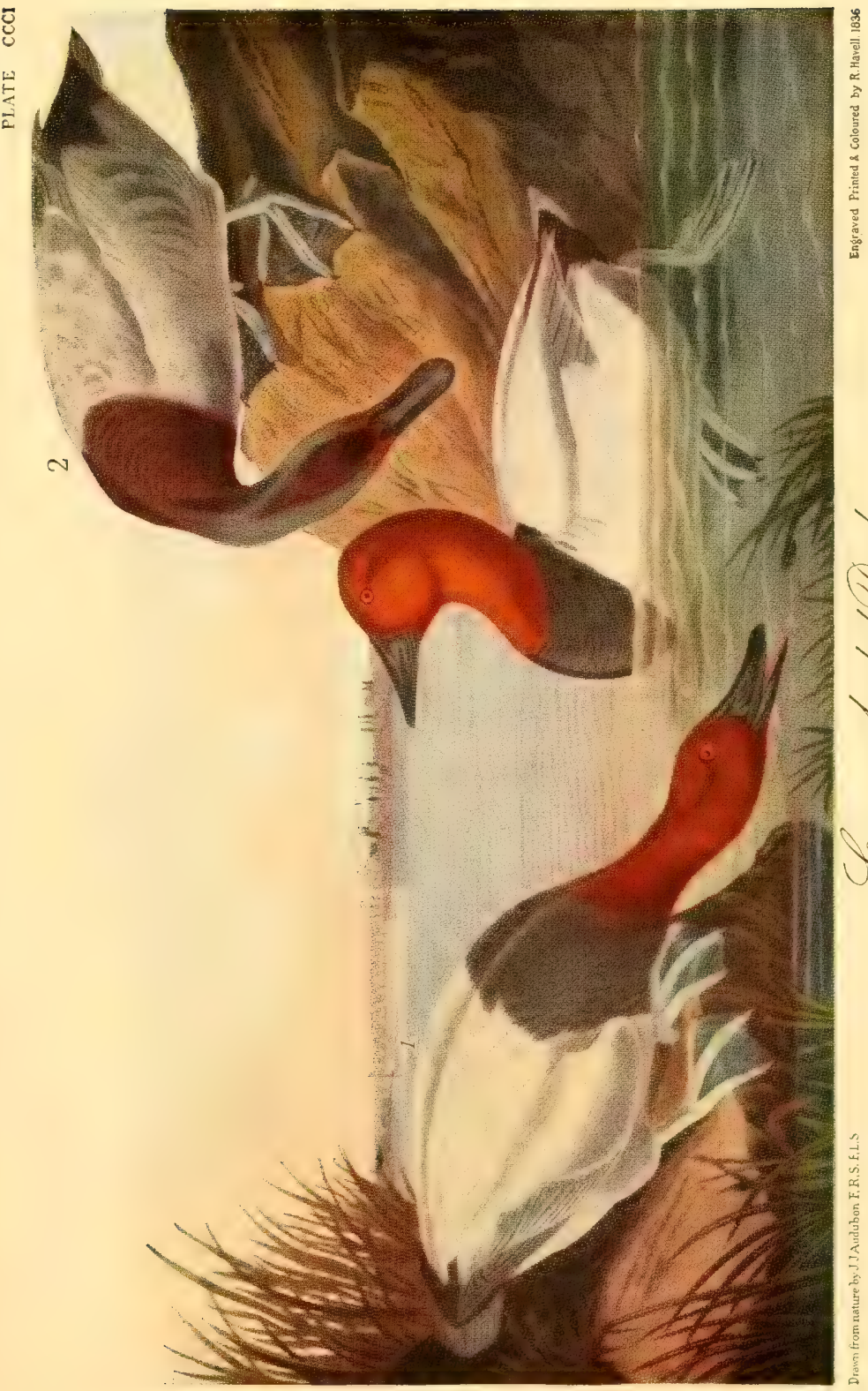

ป⿺辶

(i) 虫

ᄂ

है 氙的

रे है क्ष

ว

¿

त 9

$\approx$ 岛

है

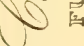



no dates, and, so far as known, the first date of the entire series was "1828," which was added to Plate 31 (the White-headed Eagle), but was erased from later issues. When Robert Havell, Junior, retouched Lizar's engraving of the Turkey Hen (No. II, Plate vi), he added the date "1829," but in a third or later edition the name was changed and the date removed. This same date appears also on the retouched Plate ii, of the Yellow-billed Cuckoo, and on that of the Purple Grackle or Crow Blackbird (Plate vii). A curious error crept into the first impressions of the former plate, which was mislabeled "Black-billed Cuckoo," a bird then recognized as quite distinct. ${ }^{16}$ Plates xxxi to lxxv (182829) were all dated in the first issue, and bore the names of both Havells; the legends are: "Fngraved, Printed \& Coloured by R. Havell \& Son, London, 1828," and "Engraved by Robt. Havell, Jun ${ }^{\mathrm{r}}$. Printed \& Coloured by R. Havell Sen'. London, 1828," or "1829" (British Museum copy), but when later printed by Robert, the younger, the dates were erased. All subsequent dating of the plates was somewhat irregular until 1834 (Plate ccii), but from that point to the end of the series, the year of issue was consistently added to each plate. Ornithologists are specially interested in the time of publication, since forty-seven new specific names occur on Audubon's large plates, and should date from them and not from the letterpress which followed.

To illustrate what has been said of successive editions of Audubon's plates, we shall give the legends of two or three of the most famous, taken from copies in

${ }^{10}$ In 1914 Dr. Samuel Henshaw showed me an impression of this suppressed plate, and also a large printed label, cut from a board backing, which bore within an ornamental border the title "Audubon's Birds of America-Engraved, printed, and colored by Lizars \&c. \&c." This suggests that Lizars may have issued the first two numbers, which he engraved, in portfolio. 
the British Museum and Boston Society of Natural History libraries or from detached plates obtained in London, in 1903:

Plate i (1st edit., Lizars; Brit. Mus.).-_"Great American Cock Male-Vulgo (Wild Turkey) Meleagris Gallopavo. Drawn by J. J. Audubon, M. W. S. Engraved by W. H. Lizars Edin ${ }^{\mathrm{r}}$."

Plate i (2nd or later edit., Havell; Boston Soc. Nat. Hist.)."Wild Turkey. Meleagris Gallopavo. Linn. Male American Cane. Miegia macrosperma. Drawn from nature by J. J. Audubon F, R, S. F, L, S. Engraved by W. H. Lizars Edin r. Retouched by R. Havell Jun ${ }^{r}$."

Plate vi (1st edit., Lizars; Brit. Mus.).—"Great American Hen \& Young, Vulgo, Female Wild Turkey-Meleagris Gallopavo. Drawn from Nature by John J. Audubon F.R.S.E. M.W.S. Engraved by W. H. Lizars Edin ${ }^{\mathrm{r}}$."

Plate vi (2nd or later edit., Havell; detached plate).-The same with the exception of "F.L.S.," added to Audubon's name, and "Retouched by R. Havell. Jun'. London, 1829."

Plate vi (3rd or later edit., Havell; Bost. Soc. Nat. Hist.)."Wild Turkey, Meleagris Gallopavo. Linn Female and Young." (Artist's name apparently cut off by binder.) "Engraved by W. H. Lizars. Retouched by R. Havell. Jun ${ }^{r}$."

Plate 31. (1st edit., Havell. Brit. Mus.).-_White-headed Eagle, male. Falco Leucocephalus. Fish Vulgo-Yellow mud Cat. Drawn from Nature \& Published by John J. Audubon, F.R.S.E., F.L.S., M.W.S. Engraved, Printed \& Coloured by R. Havell \& Son, London, 1828."

Plate xxxi (2nd or later edit, Havell; Bost. Soc. Nat. Hist). - "White-headed Eagle, Falco Leucocephalus. Iinn, Male. Yellow Cat-fish. Drawn from Nature and Published by John J. Audubon. F,R,S. F,L,S. Engraved, Printed \& Coloured, by R. Havell." 


\section{AUDUBON'S GREATEST TRIUMPH 199}

Plates which were wholly the work of Lizars have naturally become extremely rare; they were evidently disregarded by Audubon when he recorded on July 2, 1827, that he had given Mr. Children a proof of his first number, which he called "the first in existence," and declared that the two guineas then received was the first money that had been returned to his hands. Lizars' initial number had actually been finished in the previous winter, and a copy of this is recorded as having been given to the daughter of Sir Walter Scott on the 9th of March, $182 \%$.

When Audubon had finally closed all his business affairs in Edinburgh and London, late in the summer of 1839, he returned to America, with the remaining members of his family, and settled in New York, where he purchased a house at Number 84 White Street, then in the uptown district.

An anonymous writer in the London Athenceum ${ }^{17}$ in giving a final review of Audubon's labors in 1839, paid this interesting tribute:

It seems but as yesterday that we were walking about with a transatlantic stranger, picturesque enough in his appearance and garb, to arrest the eye of every passing gazer; a tall stalwart man, with hair sufficiently long to qualify him to serve as a model to Gray's "Bard," and trousers ample almost as petticoats of "good Harmony cloth," so absorbed in the enthusiastic prosecution of his gigantic plan--a life's labouras to be heedless of the singularity of those meteoric locks, and those liberal nether garments. Some dozen of years, however, have elapsed since that day; the American Woodsman's hairlong since cut short-has grown white: his magnificent undertaking is completed, and he is now on the point of quitting England, to settle himself for the remainder of his days whether

\footnotetext{
${ }^{17}$ See Bibliography, No. 112.
} 
by the side of a bayou, in some forest clearing, or as an inhabitant of one of the American cities which have learned to know his value, report saith not.

We shake hands with the author, tendering him our hearty congratulations on the completion of a task almost as arduous as has ever been proposed to a literary man. . . .

The confidential simplicity of Mr. Audubon's own prefaces would make yet more personal leave-takings and farewells, on the critic's part, natural and graceful,-but it must suffice to say, that few have quitted England, carrying with them a larger portion of honest regard and sincere good wishes.

Possibly it was the same writer who gave this striking picture of Audubon in the pages of the same journal, thirty years later: ${ }^{18}$

We can remember when his portfolio excited delight in Edinburgh, London, and Paris, rivalling in smaller circles a new Waverley novel. The man also was not a man to be seen and forgotten, or passed on the pavement without glances of surprise and scrutiny. The tall and somewhat stooping form, the clothes not made by a West-end but by a Far West tailor, the steady, rapid, springing step, the long hair, the aquiline features, and the glowing angry eyes,- the expression of a handsome man conscious of ceasing to be young, and an air and manner which told you that whoever you might be he was John Audubon, will never be forgotten by anyone who knew or saw him.

We will add to this the musings of an anonymous American writer ${ }^{19}$ in the North American Review for the following year (1840) :

It must have been with mingled and varied feelings that Audubon published his concluding volume. He was sure then 


\section{AUDUBON'S GREATEST TRIUMPH 201}

that he had raised an imperishable monument to commemorate his own renown. All anxieties and fears which overshadowed his work in its beginning had passed away. The prophecies of kind but overprudent friends, who did not understand his selfsustaining energy, had proved untrue; the malicious hope of his enemies, for even the gentle lover of nature has enemies, had been disappointed; he had secured a commanding place in the respect and gratitude of men; he had secured a treasure of rich and glowing recollections, to warm his own heart in his declining years, and to kindle enthusiasm in his children's children....

On the other hand he had lost an employment which for years had kept all the powers of body and mind in healthy though intense exertion; whatever else he might do, the great work of his intellectual life was finished. . . His trumpet of victory at the result must have given an uncertain sound, partly exulting in his success, and partly lamenting that his great work was finished.

It has often been asked, how many complete sets of Audubon's folio of The Birds of America were distributed, and how many are in existence today. No definite answer can be given to either question. His final lists, appended to the last volume of his "Biographies" in 1839, and reproduced in Appendix III to the present work, gave the number of standing names as 161 (calling for 166 copies), of which 79 (with 84 copies) pertained to Europe, and 82 were American; inasmuch as 118 subscribers had dropped off, with incompleted sets on their hands, this brought the total number of original patrons at that time to 279 , and the number of copies which had been originally ordered to 284. On the other hand, the following advertisement, evidently from the hand of Audubon himself, appeared in The Athencum, under date of "London, November 
1, 1837," and was reprinted in America a few weeks later: ${ }^{20}$

The number of perfect copies at present subscribed for does not exceed 190, of which upwards of 80 are subscribed for in America; and the expense of getting them up is so great, that not more than ten or fifteen copies, above the number subscribed for, will be prepared.

The Establishment necessary for its publication will be broken up when the last Number is coloured; and any applicacation for the Work must be made to the Author, 4, Wimpole - -street, London; or Mr. R. Havell, Engraver, 77 Oxfordstreet, before the first of May next, as after that time no subscription can be received.

Assuming that Audubon's final published lists, calling for 166 copies, were correct, and that ten additional sets were prepared, this would bring the total original number known to have been complete to 176 , which agrees with an estimate attributed to Victor Audubon, who once expressed the belief that "about 175 copies" were in existence, of which about 80 were in America. ${ }^{21}$ It is probable, however, that of the $\mathbf{1 1 8}$ persons who allowed their subscriptions to lapse, a number completed their sets from the residual stock, which must have been great, though the later plates would be the hardest to obtain; in this event the number of perfect sets of Audubon's Birds probably never exceeded 190 or 200.

${ }^{20}$ See Samuel N. Rhoads (Bibl. No. 231) The Auk, vol. xxxiii, p. 130 (1916); transcript of a clipping which apparently had been taken from a New York newspaper of January, 1838; the reading of the American notice is the same, excepting the statement that applications in this country should be made to "N. Berthoud, Esq., New York; Dr. George Parkman, Boston; Rev. Jno. Bachman, Charleston, S. C.; James Grimshaw, Esq., New Orleans, or W. G. Bakewell, Esq., Louisville." It is dated "New York, 11 Jan, 1838."

${ }^{21}$ Maria R. Audubon, Audubon and his Journals (Bibl. No. 86), vol. i, p. 71 . 


\section{AUDUBON'S GREATEST TRIUMPH 203}

The proprietor of a well known Philadelphia bookshop ${ }^{22}$ has stated that during his experience as an antiquary, he has had personal knowledge of forty or fifty copies of the folio edition of Audubon's Birds in America, and he thought it probable that a single New England print dealer, in the course of twenty years, had broken up thirty or forty volumes for the purpose of selling the plates. This is not surprising, since from the sale of a single volume upwards of $\$ 1,500$ might be realized in this way, but no reputable dealer would now think of breaking up an unimpaired set.

Mr. Ruthven Deane, who has compiled a careful record of copies of The Birds of America known to exist in the United States, recorded in 1908 that he had ascertained the resting-place of seventy-five sets which, with few exceptions, were complete and in good condition. "A set in the library of the Mechanics-Mercantile Institute, San Francisco, California, which had been there for some thirty years, and another set in the San Francisco Art Association, presented in 1894 by Mr. Edward F. Searles, Methuen, Massachusetts, were both destroyed by the disastrous earthquake and fire which visited that city April 18, 1906." ${ }^{23}$

Audubon's own copy of his Birds, the plates of which were naturally selected with the greatest care, was sold by Mrs. Audubon after the death of her last surviving son, in 1862, to John T. Johnson, of New York, for $\$ 1,200$; the subsequent history of these volumes has not been traced. Havell brought with him to America a copy, every plate of which is said to have been selected by himself, and it is undoubtedly one of the finest sets in existence. It passed from the family's possession to the

${ }^{22}$ See Rhoads (Bibl. No, 231), loc. cit.

${ }^{23}$ Ruthven Deane (Bibl. No. 225), The Auk, vol. xxv, p. 401 (1908). 
hands of the publishers and booksellers, Messrs. C. S. Francis \& Company, of 554 Broadway, New York, who in 1856 had charge of the sale of all of Audubon's works, ${ }^{24}$ and was later purchased by Dr. W. Gurdon Russell, of Hartford, Connecticut, who presented it to Trinity College, July 10, $1900 .^{25}$

After recording the facts of the case, so far as they have been ascertained, the following extract from the minutes of a meeting of the New York Historical Society, held October $3, \mathbf{1 8 6 5}$, will be read with interest: ${ }^{26}$

The Librarian presented the following copy of a manuscript memorandum preserved in the first volume of Audubon's Ornithological Biography, formerly belonging to the late J. Prescott Hall, ${ }^{27}$ and now in possession of David G. Francis, Esq. :

${ }^{24}$ Eight in number, the aggregate cost of which was then $\$ 1,624$ : The Birds of America, with its letterpress, was offered at $\$ 1,000$; library, or octavo edition, with reduced plates, in 100 Parts, at $\$ 100$; The Quadrupeds of North America, 2 vols., folio, with 3 vols. text, in 8 vo., $\$ 300$; text of the same, according to binding, from $\$ 31$ (paper) to $\$ 40$ (full Turkey mor.); Birds and Quadrupeds, library ed., 10 vols., 650 plates, $\$ 150$ to $\$ 160$, according to style; Synopsis of Birds of America, \$4; The Viviparous Quadrupeds of North America, 3 vols., text only, \$9. See Mrs. Horace St. John, Life of Audubon (Bibl. No. 71), in advertisement inserted in volume. These prices were similar to those that prevailed during the lifetime of the naturalist.

According to Mr. Ruthven Deane, Audubon's account books show that on January 8, 1840, a box was sent to Dr. George Parkman, of Boston, containing a set of The Birds of America, in full binding, at $\$ 1,075$; a set of the same, half bound, at $\$ 950$; and the "Biographies" at $\$ 27$.

The highest recorded price of The Birds of America is believed to be $\$ 4,350$, which the Kemble set brought at auction at Philadelphia, in 1906 (See Prices Current for 1906); the highest price paid for a single plate, that of the Turkey Cock (Plate No. 1) upwards of $\$ 140$; and the highest price asked for the octavo edition of the Birds (in original parts), $\$ 750$. The Quadrupeds in 2 vols., original folio, now brings about $\$ 500$.

${ }^{25}$ Ruthren Deane (Bibl. No. 225), loc. cit.

${ }^{28}$ For a copy of this minute, the substance of which was published in 1877 (See Bibliography, No. 179), I am indebted to the present librarian, Mr. Kelby.

${ }^{27}$ Jonathan Prescott Hall (1796-1862), eminent lawyer and jurist, was at one time district attorney for the southern district of New York, and author of Reports of Cases in the Supreme Court of City of New York- 
"This work is presented to J. Prescott Hall by his poor Friend and sincerely attached servant

JohN J. Audubon"

"New York April 4, 1844."

"Mr Audubon told me in the year 184- that he did not sell more than 40 copies of his great work in England, Ireland, Scotland, and France, of which Louis Phillippe took 10.

"The following received their copies but never paid for them: George IV., Dutchess of Clarence, Marquis of Londonderry, Princess of Hesse Homburg.

"An Irish lord whose name he would not give, took two copies and paid for neither. Rothschild paid for his copy, but with great reluctance.

"He further said that he sold 75 copies in America, 26 in New York and 24 in Boston; that the work cost him

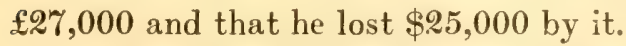

"He said that Louis Phillippe offerred to subscribe for 100 copies if he would publish the work in Paris. This he found could not be done, as it would have required 40 years to finish it as things were then in Paris. Of this conversation I made a memorandum at the time which I read over to Mr. Audubon and he pronounced it correct.

$$
\text { "J. Prescott Hall." }
$$

As regards the subscription of Rothschild the following account of his interview with the famous banker has been recorded by Audubon himself. ${ }^{2 s}$ The naturalist, it appears, received a letter to Baron Rothschild from the American banking-house of Prime, Ward \& King, and presented it in the summer of 1834. The banker was

1828-29 (2 vols., New York, 1831-33). Mr. Hall was a subscriber to the octavo editions of Audubon's Birds and Quadrupeds.

${ }^{28}$ According to Lucy B. Audubon, ed., The Life of John James Audubon (Bibl. No. 73), from which we have drawn numerous extracts from his journals; see p. 381, under date of May 12, 1834. 
not in when Audubon and his son, Victor, called upon him, but "soon a corpulent man appeared, hitching up his trousers, and a face red with the exertion of walking, and without noticing any one present, dropped his fat body into a comfortable chair, as if caring for no one else in this wide world but himself." When Audubon presented his credentials, the banker asked: "Is this a letter of business, or is it a mere letter of introduction?" " As Audubon had not read the letter, he was obliged to answer rather awkwardly that he could not tell. "The banker then opened the letter, read it with the manner of one who was looking only at the temporal side of things, and after reading it said, "This is only a letter of introduction, and I expect from its contents that you are the publisher of some book or other and need my subscription.'" Audubon continues:

Had a man the size of a mountain spoken to me in that arrogant style in America I should have indignantly resented it; but where I then was it seemed best to swallow and digest it as well as I could. So in reply . . I I said I should be honored by his subscription to the "Birds of America." "Sir," he said, "I never sign my name to any subscription list, but you may send in your work and I will pay for a copy of it. Gentlemen, I am busy, I wish you good morning." We were busy men, too, and so bowing respectfully, we retired, pretty well satisfied with the small slice of his opulence which our labor was likely to obtain.

A few days afterwards I sent the first volume of my work half bound, and all the numbers besides, then published. On seeing them we were told that he ordered the bearer to take them to his house, which was done directly. Number after number was sent and delivered to the Baron, and after eight or ten months my son made out his account and sent it by Mr. Havell, my engraver, to his banking-house. The Baron looked at it with amazement, and cried out, "What, a hundred 


\section{AUDUBON'S GREATEST 'TRIUMPH 207}

pounds for birds! Why, sir, I will give you five pounds, and not a farthing more!" Representations were made to him of the magnificence and expense of the work, and how pleased his Baroness and wealthy children would be to have a copy; but the great financier was unrelenting. The copy of the work was actually sent back to Mr. Havell's shop, and as I found that instituting legal proceedings against him would cost more than it would come to, I kept the work, and afterwards sold it to a man with less money but a nobler heart, What a distance there is between two such men as Baron Rothschild of London and the merchant of Savannah! 


\section{CHAPTER XXXIII}

\section{NEW ENTERPRISES AND LIFE AT “MINNIE'S LAND”}

Settlement in New York-The Birds in miniature, and work on the Quadrupeds-Marriage of Victor Audubon-Coöperation of Bachman in the Quadrupeds secured-Prospectuses-History of the octavo edition of the Birds-Baird's enthusiasm and efficient aid-Parkman's wren-Baird's visit to Audubon in New York-"Look out for Martens!" and wildcats-New home on the Hudson-Godwin's pilgrimage to "Minnie's Land" in 1842.

After thirteen years of unmitigated labor, Audubon could have basked in a fame already secure, and could have enjoyed, for a time at least, a leisure handsomely earned. But no sooner had he settled in New York than he entered upon two formidable tasks: one of these was the complete revision of his Birds of America, to be issued with its text in "miniature," as its reduced form was sometimes described; the other, which he did not live to see brought to completion, was an elaborate work on the Quadrupeds of North America, eventually carried forward in collaboration with the Reverend John Bachman.

In his confident and characteristic manner, Audubon at once issued a "Prospectus" of both these undertakings. The more cautious Bachman, in writing on September 13, 1839, to congratulate him upon their safe return, "in spite of storms, calms, and hurricane," said:

I am glad that you are about to do something with regard to the "Small Edition of Birds." But are you not too fast in issuing your prospectus of The Birds and Quadrupeds, with- 
out having numbers of both works, by which the public can judge of their merits? My idea, in regard to the latter, is that you should carefully get up, in your best style, a volume about the size of "Holbrook's Reptiles." This would enable you to decide on the terms of the book, I think that two thousand subscribers at $\$ 1.00$ for each number, might be obtained. But it must be no half-way affair.

The animals have never been carefully described, and you will find difficulties at every step. Books cannot aid you much. Long journeys will have to be undertaken. Several species remain to be added and their habits ascertained. The drawings you can easily make, if you can procure the specimens. I wish I had you here, if only for two days. I think that I have studied the subject more than you have. You will be bothered with the Wolves and the Foxes, to begin with. I have two new species of Bats and Shrews to add. The Western Deer are no joke, and the ever varying Squirrels seem sent by Satan himself, to puzzle the Naturalists.

It is evident from this letter that Audubon was then intending to proceed with the work on the Quadrupeds alone and that Bachman's active coöperation was secured later. On September 15, shortly after his return to America, he wrote to Thomas M. Brewer on this subject as follows: ${ }^{1}$

Now that I am about to commence the publication of the Quadrupeds of North America, I will expect your assistance in the procuring for me of all such subjects as may easily be obtained around you. John Bachman is about to give the whole of his collections and his notes to me; and as I intend to open a pretty general correspondence in different parts of the Union, I trust to be enabled to proceed roundly on this fresh undertaking.

${ }^{1}$ See Thomas M. Brewer (Bibl. No. 79), Harper's New Monthly Magazine, vol. lxi, p. 666 (1880). 
Victor Gifford Audubon, who had preceded his father to America early in 1839, was married in that year to Mary Eliza, second daughter of John and Harriet Bachman. 'This double union of the two naturalists' families called forth mutual congratulations, but Bachman, who was inconsolable at the departure of his children, preferred to talk of birds: "By that time," said he, "four or five numbers [of the "Small Edition of the Birds'] are published, you may turn over the work to your sons; but, till then, you should carefully review every page and plate. The next thing will be to get subscribers. This would be purgatory to me; but it is necessary to success. While drumming up subscribers, you may obtain specimens for the Quadrupeds." When writing again January 13, 1840, Bachman, whose cooperation in the proposed work had been sought, continued:

The descriptions in the "Small Edition of Birds" will have to be abridged-your "worthy friend" and other humbugs may be left out to advantage. I am not at all surprised at your success at getting subscribers; but let me say, cities are not the only places to obtain them. Birds sing and nestle among the groves of the country - The planters and farmers are the men to become subscribers. An intelligent planter from the up country said, a few days ago, that if the right person would thoroughly canvass the whole State of South Carolina, he would insure three hundred subscribers to the "Small Work." old Jostle would be the man, and when his legs failed, the Young Jostle should go forward. Get the Editors to notice your work - this is a puffing world-from the porpoise to the steamboat.

When we meet, we shall talk about the partnership in the quadrupeds. I am willing to have my name stand with yours, if it will heip the sale of the book. The expenses and the profits 

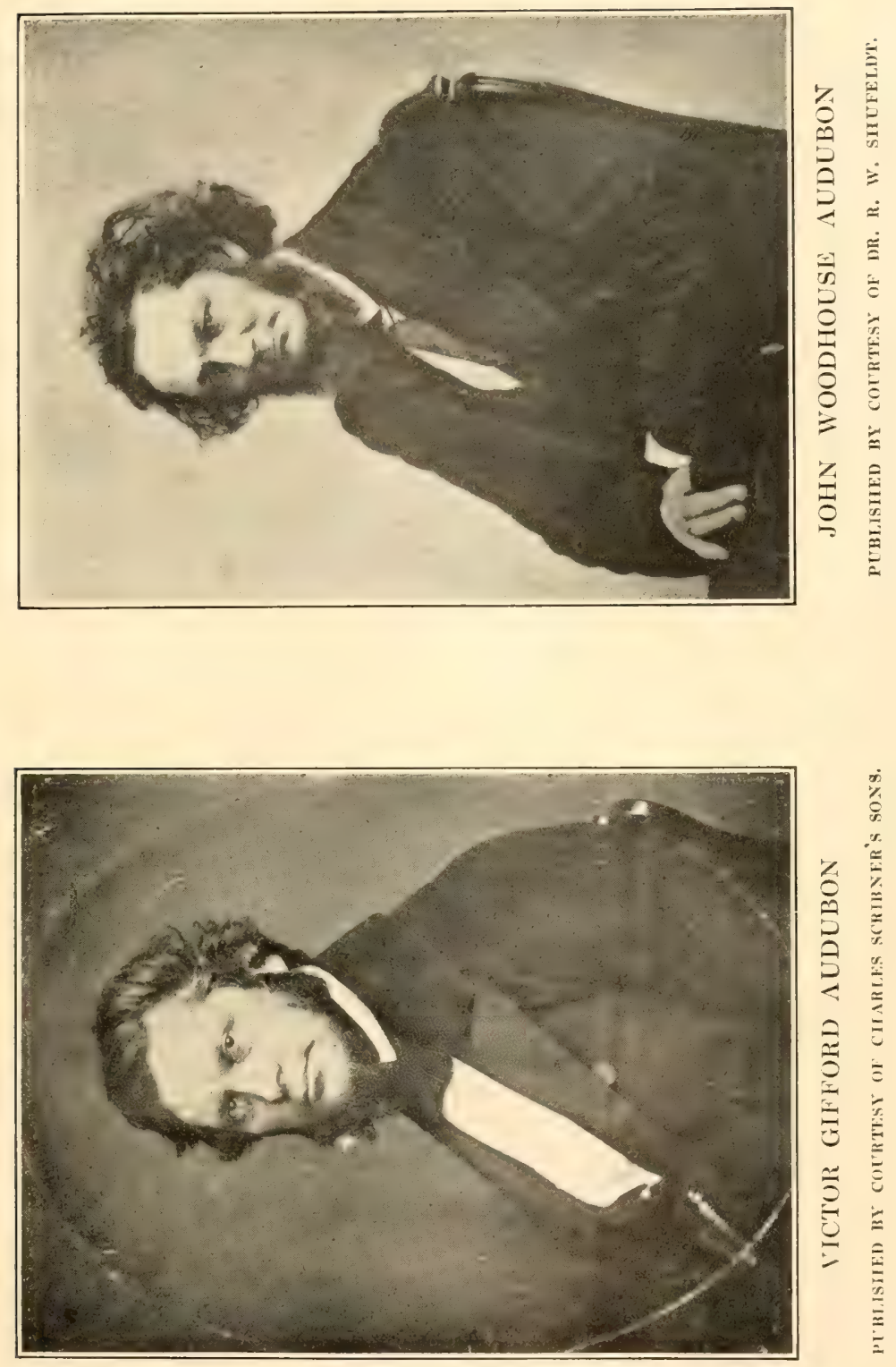

shall be yours or the boys'. I am anxious to do something for the benefit of Victor and John, in addition to the treasures I have given them-and this is all I can do. . . Employ yourself now in drawing every quadruped you can lay your hands upon. If you can find me a live Ermine, buy it in New York. I must once more examine and study its change of pilage.

Don't flatter yourself that the quadrupeds will be child's play. I have studied them all my life. We have much, both in Europe and America, to learn on this subject. The skulls and the teeth must be studied, and color is as variable as the wind; down, down in the earth they grovel, while we, in digging and studying, may grow old and cross. Our work must be thorough. I would as soon stick my name to a forged Bank Note as to a mess of soupmaigre.

\section{The "Prospectus" of Audubon's "miniature" edition} of the Birds was as follows: ${ }^{2}$

${ }^{2}$ From last page of paper covers, in which parts of the work were originally issued.

Below are the following notices:

"Persons desirous of subscribing to the above work are respectfully requested to apply to $J . J . A u d u b o n, 86$ White street, Henderson Greene, 377 Broadway, or W.A. Colman, Broadway, New York; to J. B. Chevalier, 70 Dock street, or Orrin Rogers, 67 South Second street, Philadelphia; C. C. Little or James Brown, Boston; J. P. Beile, or Geo. Oates, Charleston, S. C.; Gideon B. Smith, Baltimore; David Ridgely, Annapolis, Md.; J. S. Kellogg \&. Co., Mobile, Ala."

"S. H. Stevenson, Travelling Agent for Kentucky and Virginia; and William A. Pierce for Pennsylvania."

This first octavo edition of Audubon's Birds was issued by J. J. Audubon, and J. B. Chevalier, Philadelphia, in 100 parts, of five plates each, to be bound in 7 volumes, 1840-44. Complete sets in parts are now very rare; previous to 1907 a set is said to have been sold for $\$ 500$; in 1914 one was offered in Philadelphia for $\$ 750$. The introduction to No 1 , is dated "New York, Nov. 1839," and the fifteenth number, beginning volume ii, "N. Y., Aug., 1840." The first five volumes (1840-42) were issued with the coöperation of J. B. Chevalier, lithographer, 70 Dock Street, Philadelphia, but, according to Mr. Ruthven Deane, he was an agent who received a commission on sales, and, for a time, a share in the profits, but not a co-publisher with Audubon; it is also stated that when misfortune visited Chevalier in later life, he was cared for by Audubon or his sons, up to the time of his death. For fuller details, see Bibliography, No. 4. 
To those who have not seen any portion of Mr. Audubon's Original Drawings, it may be proper to state, that their superiority consists in the accuracy as to proportion and outline, and the variety and truth of the attitudes and positions of the figures, resulting from peculiar means discovered and employed by him, and his attentive examination of the objects portrayed, during a long series of years. Mr. Audubon has not contented himself with single profile views, but in many instances has grouped his figures, so as to represent the originals in their natural avocations, and has placed them on branches of trees decorated with foliage, blossoms and fruits, or amidst plants of numerous species-some are seen pursuing their prey in the air, searching for food amongst the leaves and herbage, sitting on their nests, or feeding their young; whilst others, of a different nature, swim, wade, or glide in or over their allotted element. The insects, reptiles and fishes that form the food of some of the birds, have now and then been introduced in the drawings. In nearly every instance where a difference of plumage exists between the sexes, both male and female have been represented, and the extraordinary changes which some species undergo in their progress from youth to maturity, have been depicted.

The plants are all copied from nature, and as many are remarkable for their beauty, their usefulness, or their rarity, the Botanist cannot fail to look upon them with delight.

The particulars of the plan of the work can be reduced to the following heads:

1. The size of the work is royal octavo, the paper being of the finest quality.

2. The Plates representing the Birds are correctly reduced from the original drawings, and are coloured in the most careful manner.

3. The work will appear in numbers, on the first and fifteenth of every month.

4. Each number will consist of Five Plates, accompanied with full descriptions of the habits and localities of the birds, their anatomy and digestive organs, (with occasionally wood 


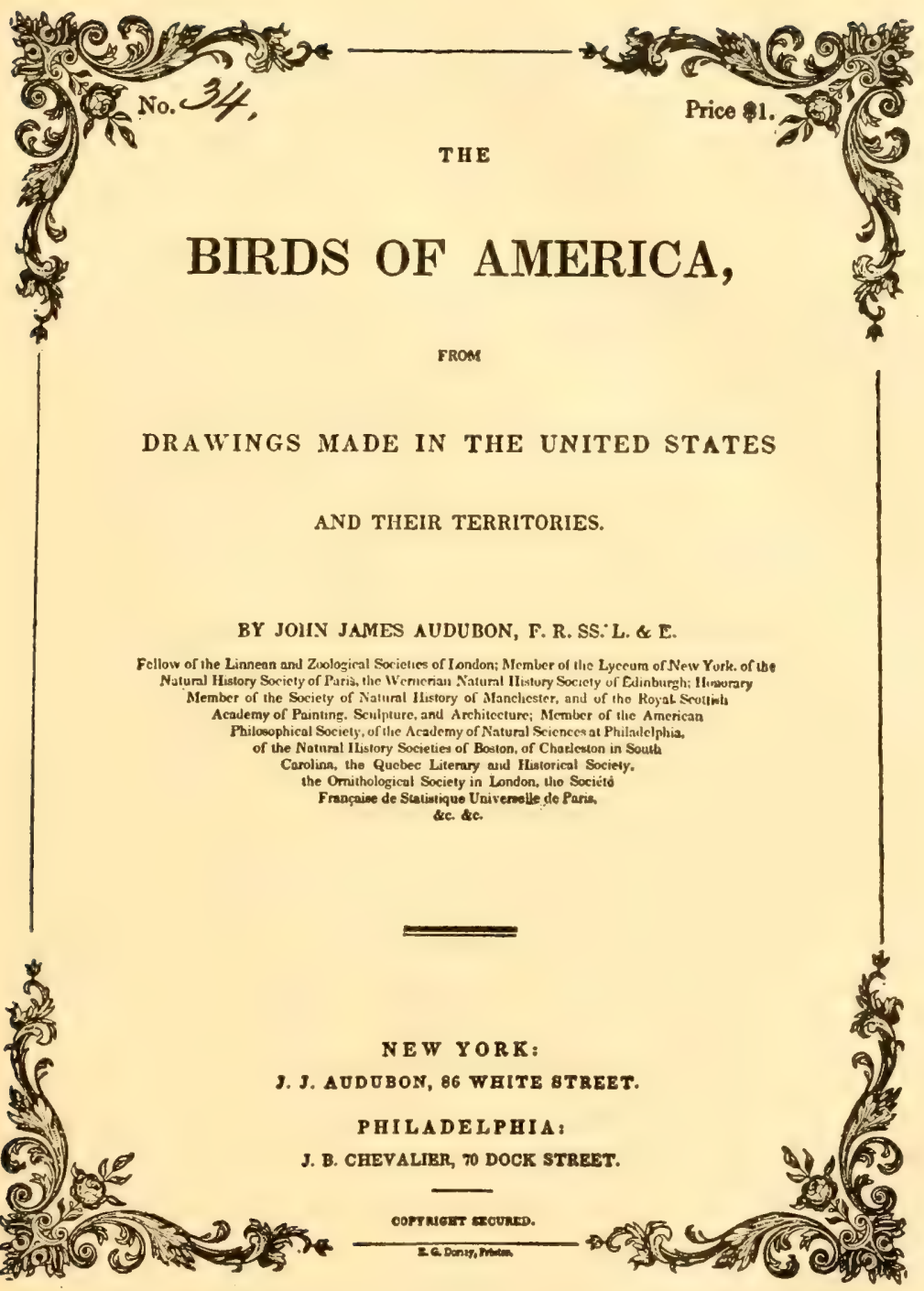

TITLE PAGE OF PAPER COVERS IN WHICH PARTS OF THE FIRST AMERiCAN (OCTAVo) EDITION OF "THE BIRDS OF AMERICA" WERE ORIGINALLY ISSUED. 
cuts representing the latter, ) and will be furnished to subscribers for one dollar, payable on delivery.

5. The work will be published in accordance with a scientific arrangement of the genera and species, and will complete the Ornithology of our country, it is believed, in the most perfect manner.

The octavo edition of Audubon's Birds began to appear, in parts, late in 1839 , and was in press four years. It was illustrated with 500 lithographic plates, which were reduced by John Woodhouse Audubon from his father's old or new originals, with such changes as the breaking up of composite plates and other considerations rendered necessary. Many new flowers and trees made their appearance in these plates, and seventeen new birds were added to the last volume; the text was also greatly improved by the process of addition and subtraction, as well as by the correction of many errors which it was then possible to effect: as twelve species were noticed without figures, this brought the total number of American birds finally recognized by Audubon to 507.3 The first considerable list of American birds with any pretense to accuracy appeared in Notes on Virginia, published in 1782, by Thomas Jefferson, who then named 109 species peculiar to the United States; William Bartram, in 1791, gave 191; Alexander Wilson, 278; Wilson and Ord, in 1808-14, 320, and Charles Bonaparte, in 1825-33, is said to have extended

${ }^{3}$ Of these, according to Mr. Witmer Stone (see Bibliography, No. 221), 474 are sanctioned in the present "Check List" of the American Ornithologists' Union; seventeen have proved to be identical with others; ten are extra-limital; two are hybrids; and five have never been found since; of Atdubon's suppressed species, two have been resuscitated. Audubon is thought to have been personally acquainted with 385 American species, others being known to him only through specimens sent by collectors, or discovered in museums. 
the number to 382 . The present number of North American birds, omitting sub-species, admitted to the third revised edition of the "Check-List," prepared by a Committee of the American Ornithologists' Union and published in New York in 1910, is 768 . To this is added a hypothetical list of 26 names, the validity of which is still in doubt; these embrace Townsend's BuntingSpiza townsendi (Audubon); Carbonated WarblerDendroica carbonata (Audubon), Blue Mountain Warbler-Dendroica montana (Wilson), known only in the works of Wilson and Audubon; the mysterious Smallheaded "Flycatcher," or Warbler-Musicapa minuta (Wilson) or Wilsonia (?) microce phala (Ridgway), an account of which is given in Chapter XIV and which is known only in Wilson's and Audubon's works; and Cuvier's Regulus-Regulus cuvieri (Audubon), which has never been seen beyond the covers of The Birds of America, and its descriptive text: "I shot this bird," said Audubon, "on my father-in-law's plantation of Fatland Ford, on the Skuylkill River in Pennsylvania, on the 8 th June 1812, while on a visit to my honoured relative Mr. William Bakewell ... I have not seen another since."

Audubon was soon canvassing the principal cities for this work, with what success is shown by the following letter ${ }^{4}$ to his family:

\section{Audubon to his Family}

Baltimore, Feb. 21. 1840.

11 o'clock at night.

MY DEAR FRIENDS

So far so good, but alas! I am now out of numbers to deliver to my subscribers here. Here! where I expected to pro-

${ }^{4}$ First published by Ruthven Deane (Bibl. No. 48b), The Auk, vol. xxv (1908). 
cure a good number more. This list is composed of excellent men and all good pay. I have in my pocket upwards of one hundred names, whom I am assured are likely to subscribe. Therefor I will not leave Baltimore for some days to come at least. I forward a copy of this list to Chevalier by the same mail and yet you may as well inquire if he has received it. More numbers I must have as soon as possible as all my subscribers here are anxious about receiving their copies, unfortunately I had only 90 No. 2. I look upon this list as a capital list. I have sent Mr. Ridgley of Annapolis a No. 1 and a prospectus, and expect some names tomorrow evening from that quarter.

I will remit money to Phila. and let you know how much as soon as I can. The box has arrived here safely and tomorrow or Monday I will deliver Biographies \&c. D. Potter is very ill and poor and yet $\mathbf{I}$ hope to get his note before I leave here.

I received a note from dear Jonny dated at Norfolk, all well and going on. I expect they are at this moment at John Bachman's. I am fatigued beyond description and had the misfortune last evening of skinning my shin bones, they bled profusely however, and I hope will soon get well, though feel rather sore at this very moment, but $I$ will take care of them.

The amount of attention which $I$ have received here is quite bewildering, the very streets resound with my name, and I feel quite alarmed and queer as I trudge along. Mess. Meckle, Oldfield and the Brune family have all assisted me in the most kind and brotherly manner, indeed I may say that my success is mostly derived from these excellent persons.

I have written to Mr. Mifflins. I feel that Theodore Anderson will not live long. Mr. Morris has not yet returned from Annapolis. See that the notice in the Baltimore Patriot which I sent you yesterday is inserted in the Albion, the New York Gazette and if possible in the Courrier and Enquirer.

I have sent one to Chevalier and another to Dr. Parkman. I ought to have at this moment 300 copies Nos. 1, 2, 3, 4, for Washington City and really I think it would be better to stop the publication of the work for one month to effect this. There- 
for loose no time in urging Mr. Bowen (write to him) and Chevalier also on this all important subject.

If ever I was in want of assistance it is at this moment and you my dear Victor must be on the alert and second my endeavors to render you all Happy! I would be delighted to have a few lines from Mamma and Eliza at the end of your next letter, which I hope to receive in immediate answer to this, Here. I have marked all your items in your last letter. Call from time to time at the Mercantile Library. I am glad you have remitted to the Rathbone's. Do write to Mr. Hoppenstall and see the daughter of Capt. Brittan. I was invited last evening to a great ball, and should have gone had not my accident of shin bones prevented me. I am told that I would have had some 20 names there.

Recollect that our agents name is Gideon B. Smith and a most worthy man he is, highly recommended by Robert Gilmor and others.

[No signature]

To the gratification of Audubon and his friends, the octavo edition of his Birds of America was an immediate and great success. Only 300 copies of the plates of the first number, which was ready on December 3, 1839, were printed, but in little more than a month 300 more were demanded, and the number of plates required rose steadily until January 9 , 1841, when it stood at 1,475 copies. ${ }^{5}$ The total number of subscribers given

"See "Original Account Book of J. J. Audubon" (Bibl. No. 223), The Nation, vol. lxxxiv, from which the following data regarding issues and sales of this work are drawn. The total edition of the plates for No. 2 was $1,34.5$, and of No. 3, 1,339. No. 11 of the plates was the first to run to 1,000 copies in the first printing, and this issue was continued to No. 50 , inclusive, excepting Nos. 3, 28, 29, and 30, of which 1,500 seem to have been printed; the plates of these numbers were done at the lithographic establishment of Endicotts, New York, all others being the work of J. T. Bowen, Philadelphia. When subscriptions began to fall off with No. 51, the edition was reduced to 1,150 , and again with $\mathrm{No} .5 \%$, to 1,050 , which remained constant to No. 84, or as far as this record goes. Of the text, printed by E. G. Dorsey, 1,200 copies formed the first edition of No. 1, 
in Audubon's published lists was 1,198, of which 198 are credited to Boston, 164 to Baltimore, 141 to New York, sixty-five to Philadelphia, and forty-three to foreign countries, ten of which went to England; Mr. George Oates of Charleston subscribed for seven copies. Such a reception for an expensive work on natural history was unprecedented in the United States, and has had few parallels in any country.

At the very beginning of this new undertaking, the hand of disease and bereavement rested heavily on the Audubon and Bachman families; they were obliged to see first one and then another of their daughters swept by the same terrible malady, tuberculosis, to an early grave. Mrs. John Woodhouse Audubon died at her old home in Charleston, whither she had gone for the benefit of her health in the previous winter, on September 15, 1840, at the age of twenty-three; and Mrs. Victor Audubon, after a long sojourn in Cuba, and shortly after returning to her home in New York, died there on May 25, 1841, at the age of twenty-two. Audubon was very fond of his daughters-in-law, and his "beloved Rosy," as Victor's wife was familiarly called, is said to have been a particular favorite and the life of his family circle. If work at this time brought no pleasure, it at least afforded him relief from painful thoughts.

In June, 1840, a boy who lived in Carlisle, Pennsylvania, mustered up courage to write to the naturalist and give him an account of a new bird, the Yellowbellied Flycatcher, which he and his brother had dis-

1,000 copies that of No. 2 , and of successive numbers to No. 23. With No. 24, the edition was increased to 2,000, and in February, 1841, the carlier numbers were reprinted, thus forming a second edition of these parts, and affording a chance for correction of errors. (See Audubon's letter quoterl above.) 
covered, under the very noses, as it were, of all the ornithologists in America. With that fine sense of modesty which characterized the man in after life, for his name was Spencer Fullerton Baird, he wrote: ${ }^{6}$ "You see Sir that I have taken (after much hesitation) the liberty of writing you. I am but a boy, and very inexperienced, as you no doubt will observe from my description of the Flycatcher."

Audubon, who had just returned from the sick-bed of his daughter-in-law, replied promptly as follows:

\section{Audubon to Spencer Fullerton Baird}

\section{DeAr SIR,}

New York, June 13, 1840.

On my return home from Charleston S. C. yesterday, I found your kind favor of the 4th inst. in which you have the goodness to inform me that you have discovered a new species of fly-catcher, and which, if the bird corresponds to your description, is, indeed, likely to prove itself hitherto undescribed, for although you speak of yourself as being a youth, your style and the descriptions you have sent me prove that an old head may from time to time be found on young shoulders!

I wish you would send me one of the stuffed specimens as well as the one preserved in spirits, and wish you also to rest assured that if the little Muscicapa stands as a nondescript that I shall feel pleased to name it after your friend.

I have never seen a male of the Cape May warbler with the upper part of the head pure black. Have you compared the Regulus with the description of Regulus Curieri? Could you not send me your bird to look at? Being on the eve of publishing the Quadrupeds of our Country, I have thought that you might have it in your power to procure several of the

${ }^{6}$ See Ruthven Deane (Bibl. Nos, 47 and 49-51), The $A u k$, vols, xxi, xxiii, and xxiv (1904-7), Passim; and William H. Dall, Spencer Fullerton Baird, a Biography (Bibl. No. 52) (1915); to these admirable accounts I am indebted for such abstracts of this correspondence as are here reproduced. 
smaller species for me, and thereby assist me considerably. Please write to me again soon, as I must resume my travels in 8 or 10 days. Have you seen a copy of the small edition of The Birds of America which I am now publishing? Believe me, dear sir,

With good wishes, your obt. sert,

Joнn J. Audubon

Thus began a correspondence between the youth of fifteen and the veteran of fifty-five, which led to an intimate friendship that lasted during Audubon's active career, and was an undoubted stimulus to young Baird, whose talents, enthusiasm and industry were quickly appreciated by the older naturalist. Baird answered Audubon's letter on June 20, and proffered his services in collecting mammals, saying that while they were more difficult to find than birds, he hoped "by increased exertion to make up the difference"; he also added: "I have seen some numbers of your work now publishing, and admire them very much. I have no doubt that it will do more to spread a love of Natural history, than any work ever published. For my part I read the description of birds and the episodes in your Ornithological Biography with the same motive of pleasure as I used to read a favorite novel." In Audubon's immediate reply of the 22nd, he said:

It is impossible at present for me to give you any precise idea of the work on our quadrupeds which I have in contemplation to publish, any further than to say to you, that it is my intention, as well as that of my friend, the Rev John Bachman, of Charleston, S. C., assisted by several others of our best naturalists, to issue a work on the Mammalia of North America worthy of the naturalist's attention, both at home and abroad.-Through our joint efforts, and assisted as we hope and trust to be, by numerous friends and acquaintances in 


\section{LIFE A'T "MINNIE'S LAND”}

different portions of our Wide Union, we expect to collect, not only new species, but much of valuable matter connected with their geographical range, and particular habits. For instance, in your assistance in this department as well as in ornithology, you may be able to send us valuable intelligence respecting the Shrews, Mice, Rats, Squirrels, etc., found in your immediate vicinity \&c.-and by saving and forwarding specimens to us, be able also, in all probability, to place into our hands, objects never before known to the World of Science. Whatever information we thus receive is sacredly published under the name of the friend from whom we receive the information, etc. I have sent you the Zoological report of Docr. De Kay. His Corvus cocolotle [cacolotl] is really our Raven. Supposed by some inexperienced European naturalists to be distinct from the Raven of Europe, which, however, is a gross error. $^{7}$...

The thrush which you have described, and which you kindly offer to send me, may be new, but perhaps you are not acquainted with the Turdus Nanus of my work, to which it appears, if not the same, probably a new variety! Nous verrons.

Please to collect all the Shrews, Mice, (field or wood), rats, bats, Squirrels, etc., and put them in a jar in common Rum, not whiskey, brandy or alcohol. All of the latter spirits are sure to injure the subjects.

Audubon, who was now "killing two birds with one stone"-collecting subscribers for one work and mammals for another, had found a strong and willing helper in the young naturalist of Carlisle. On December 10 of the same year Baird wrote that he had discovered another Flycatcher, as well as a small Woodpecker, which was apparently new, and had shot a "Bay Lynx or Wild Cat a mile \& a quarter from Carlisle; the cat . . . was $21 \%$ feet long \& weighed $121 \%$ pounds. . . . It was a

\footnotetext{
${ }^{7}$ See Vol. II, p. 169.
} 
source of great regret," said Baird, "that I was not able to meet you in Philadelphia when I was there during the latter part of September. I saw Mr. Chevalier ${ }^{8}$ several times, and found him a very agreeable gentleman." Audubon replied to this letter on Christmas Day, as follows:

\section{Audubon to Spencer Fullerton Baird}

New Yonк, December 25, 1840.

MY DEAR SIR,

On my return yesterday from a tour of a month, I found your kind favor of the 10 th inst. at my house. I regret exceedingly that you and I should not have met at Philadelphia, as I feel sure by the style and contents of your letters to me that you are fond of the study of natural objects, as much as I am.

I have no doubt that your journey during the last summer and autumn was a pleasing one to you, as I can well conceive from the fresh recollections of my many rambles.

You would oblige me much by sending me (through Mr. Chevelier) the Muscicapa you obtained Oct. 12th, and also the small woodpecker "with the very broad bill" I am anxious to see those birds, and will take especial care of them, and also return them to you, free of all expense.

I cannot at this moment return to the specimens you have already sent me, but in my next letter, I will assure you of the names of the subjects. I wish I could see your Bay Lynx, as I feel somewhat confident that we have more than two species within our limits.

Your anecdote connected with the sagacity of the Weasel is quite pleasing to me, and will appear in my biographies of quadrupeds bye and bye. I cannot, as yet, give you any estimate of my work on the Quadrupeds of our Country but will do so as soon as possible. With my best wishes, for your health

${ }^{8}$ See Note, Vol. II, p. 211. 
and prosperity, I pray you to consider me as your friend and obt. servant,

John J. Audubon.

In the following letter by William Yarrell, ${ }^{9}$ English naturalist and sportsman, are interesting references to Audubon's smaller edition of The Birds of America as well as to the writer's History of British Birds, which later became the standard work on the ornithology of Great Britain:

\section{William Yarrell to Audubon}

[Addressed] J. J. Auduвол Esq ${ }^{\mathrm{r}}$

No. 86 White Street

New York.

[Superscribed by Audubon] March 10. 1841.

[English postmark] D

\section{Paid}

4. MR 4

1841

My dear Sir,

Your letter, and also that of your son, are now before me, both received so long ago as the middle of last year-how time flies with those who are fully occupied-I reproach myself for having allowed them to remain so long unansweredand hope my numerous avocations, which absorb my whole time, will be admitted as my excuse. I see $\mathbf{M}^{\mathrm{r}}$. B. Phillips every now and then, we meet only to talk about you-I have received from his hands the first $17 \mathrm{~N}^{\text {os }}$ of your smaller American Birds and like them much-as I could not afford to have the large

'William Yarrell (1784-1856) was the author of $A$ History of British Fishes (1835-36), and $A$ History of British Birds (1839-43) in three volumes; the latter has passed through several editions, the fourth and best being by Alfred Newton in four volumes (1871-85). For the favor of reproducing this letter, and another by Yarrell given in Chapter XXXIV, I am indebted to Mr. Ruthven Deane. 
work I make myself content with the small one, and shall be happy to receive the continuation-pray tell me to whom shall I make payment for them, shall it be to $\mathrm{M}^{\mathrm{r}}$. Phillips if so, let me or him know, and it shall be done immediately-I am quite of your opinion that there would be some sale for it here-if it was advertised and made known, but a commission of 10 . p cent will not tempt any London Bookseller who is sufficiently known and influential to be of any service to you-I exhibited my numbers at the meetings of the Linnean and Zoological Socities and gave the loose plates between them to lay on the table, but without the name of a London Bookseller on the cover no one knows where to get the work if Desirous of buying it.

I will now answer your inquiries for English Friends. Earl Derby remains much the same-very well in health, but deprived of the use of one side entirely, limbs as well as bodyunable to attend to other things, he appears to devote himself almost entirely to Zoology-Thomson his Superintendent of the Aviary is at this time in London buying some new or rare pheasants lately arrived here from China-and will have a valuable addition to the stock to take back with him-Lord Derby came to London by the Rail Road last March (1840) and Thomson tells me, his Lordship means to come up again this Spring. The Prince of Musignano now P. of Canino I hear of by report from others-He is quite well, continually publishing, and we hear that he means to visit London in the course of the present year- of $\mathbf{M}^{\mathrm{r}}$. Lear we hear the most satisfactory accounts-generally through $\mathbf{M}^{\mathrm{r}}$. Hullmandill-he is greatly improved in health and finances-a favorite with every body, patronized by all who go there-and he too, we hear, means to visit England in the course of the present year. MI $^{\mathrm{r}}$. Gould returned safe to England in August last, after an absence of two years and 8 months-Two years of the time were passed on Van Diemans land and various parts of New Holland - he did not go to New Zealand-He has brought home a very large collection of Birds, with, in many cases, the eggs and nests-He has commenced the publication of the Birds on the 


\section{LIFE A'T "MINNIE'S LAND”}

same scale as his Birds of Europe, but improved in execution -two parts are out: it is to be published every three months. I sent off a letter this day to your Edinburgh friend $\mathbf{M}^{\mathrm{r}}$. MacGillivray - he is a candidate for the Professorship of Natural History in the Marischall College of Aberdeen and wrote to ask me for a testimonial of recommendation-this was the object of my letter to him.- My second volume of the British Birds will be complete in July next, I will send it to you in one lump. Pray remember me to your good lady and thank your son Victoire for me for his letter. I hope you are all well, and with best wishes for a continuance to you of all that is good-I remain very sincerely yours

Wm. YARRELL.

\section{J. J. Aunubon Esq ${ }^{\mathrm{r}}$}

New York-

Spencer Baird and his brother, William, were soon able to announce another discovery, now well known the country over as the Least Flycatcher, and in some sections by the onomatopœic name of Chebec. In referring to it in his letter of June 21, 1841, Baird wrote:

There is one flycatcher respecting which we are in doubt, and which was very abundant this spring. It is the one we had considered M. Pusilla but a thorough examination of the Biography, has thrown doubt on this supposition, it agrees pretty well with the M. Acadica of Nuttall, but not with the Acadica, of the Synopsis. I will send you one as soon as possible, as there is no set of Plates in Carlisle to which we might refer.

In conclusion Baird added: "May we not expect to see you in Carlisle before a great while? It would give us very great pleasure indeed."

Though Audubon gladly admitted this new-found species of bird at a later day, he was not at first dis- 
posed to accept its validity, as will appear in the following interesting letter which he sent to his young friend:

\section{Audubon to Spencer Fullerton Baird}

New YoRK, July 29, 1841.

\section{My dear Sir,-}

I have not had time to answer your interesting favor of the 21st until this morning, being now constantly engaged in the figuring, \&c., of the Quadrupeds of Our Country; by which I mean that I actually work from daylight every day until I retire to my necessary repose at night.

Your observations upon the birds of passage the last spring are what they have been almost throughout the U.S. The very backward spring which we have experienced this year did no doubt retard the coming into the States the millions of passenger birds that come to us from beyond our limits. The Fly-catcher of which you are in doubt is nevertheless the M. Pusilla, and you must not be surprised to find perhaps some discrepancy between the specimens you have procured and the descriptions you may have read, as among mine these differences are quite obvious and belonging to either sex or age, as is indeed the case with most of our birds as well as among many of our quadrupeds. ...

I cannot at present tell you when I may have the pleasure of meeting you at your own domicile, and yet this may happen quite unexpectedly.

Do you pay attention to the quadrupeds around you? If not, I wish you would!-and moreover I should be highly pleased to hear of your procuring for us all such as may be found in your vicinity. You have Bats, Wood Rats, \& Mice, Weasels, \&c., \&c., all of which I should like to possess specimens at your hands. Could you not save all that you come across with in this way, place them in common good Rum, and forward them to me at once or as soon as you have some 2 or three species. I will most cheerfully pay all expenses to Philadelphia addressed to J.B. Chevalier, No. 70 Dock Street. 


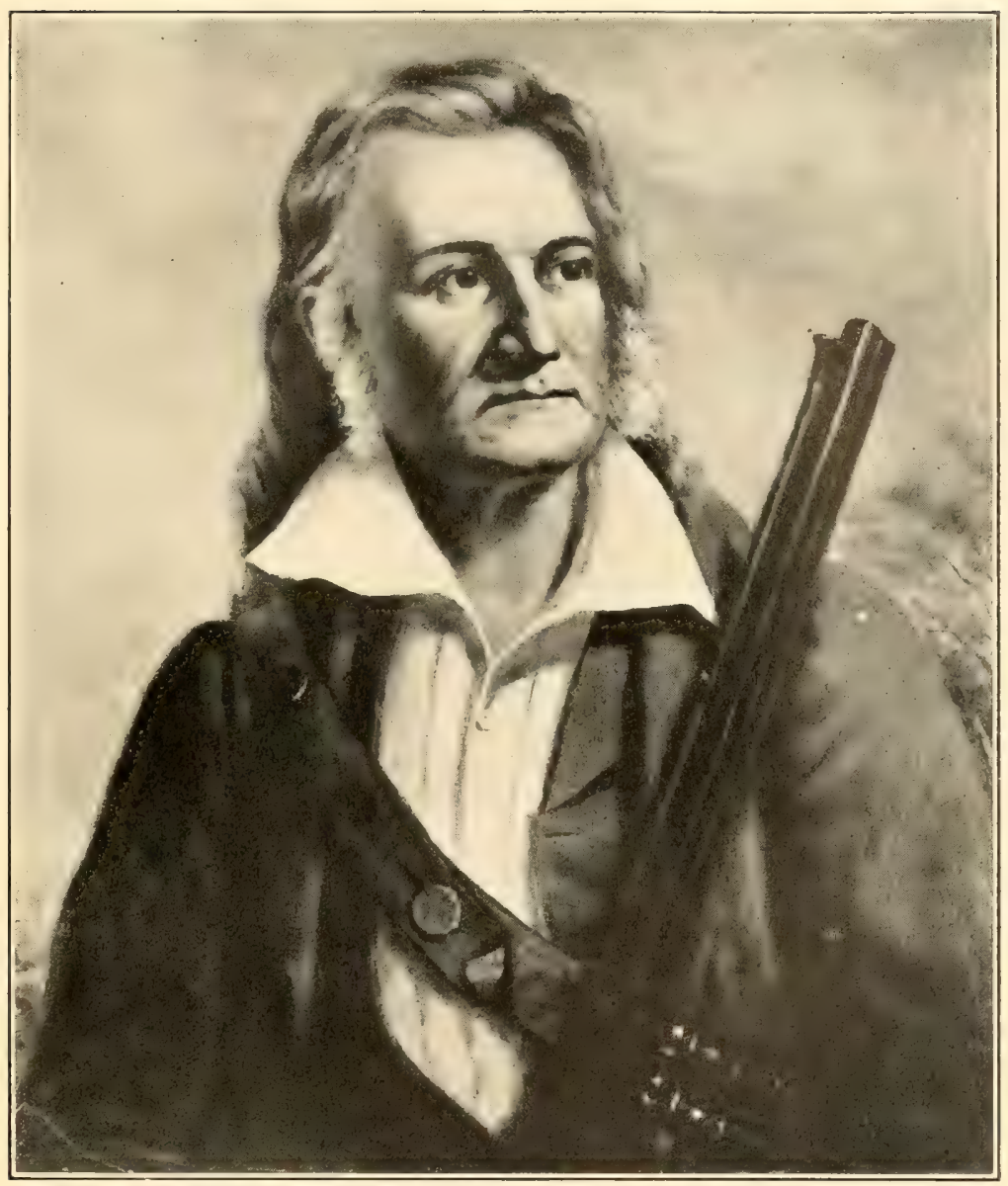

\section{AL'DUBON}

AFTER A PORTRAIT PAYNTED BY JOIN WOODIOISE AND VICTOR GIFFORD AUDUBON ABOUT 1841, NOW IN MOSSESSION OF TIE AMERICAN MUSEUM OF NATURAI HISTORY, NEW YORK. PIBIISIHE BY COURTESY OF THE AMEIRICAN MUSEUM OF NATERAY IIISTORY. 

I am now as anxious about the publication of the Quadrupeds as I ever was in the procuring of our Birds, indeed my present interest in Zoology is altogether bent toward the Completion of this department of Natural Science.

Do please write to me often as I am always glad to hear from you, and when I am somewhat slow in answering your letters, be assured that it is altogether on a/c of the excess of Labour that I have to go through.

Believe me with sincere good wishes

Your friend and servant,

John J. Audubon.

Although Audubon never went to Carlisle, young Baird, as we shall see, repeatedly visited him in New York and became a favorite with his family. A description of the new Flycatchers was published by the Baird brothers in 1843, and represented Spencer's first contribution to his favorite science; Audubon included their discovery in the Appendix to the seventh and last volume of The Birds of America in $\mathbf{1 8 4 4 .}$

Audubon's occupations in the summer of this year are clearly reflected in the following letter ${ }^{9}$

\section{Audubon to Dr. George Parkman}

NEw YoRk, June 20th 1841

\section{My Dear Friend.-}

I intended having written to you yesterday by Miss Shatuck, who was good enough to spend the day with us, but I was so deeply engaged on a drawing of Rocky Mountain Flying Squirrels, that the time of her departure came suddenly and I could merely ask of her to say to you, that your last letter and remittance had reached us in safety, and with the

${ }^{9}$ See John E. Thayer (Bibl. No. 53), The Auk, vol. xxxiii (1916). Mr. Thayer's Ornitholngical Museum now contains the original specimen of Parkman's Wren, to which Audubon refers; it is "mounted on a twig, in a paper box with a glass front," and is "in excellent condition." 
unexampled promptness shewn by you on the three occasions you have been troubled with the delivery of 46 parts of our work to 46 of our Boston subscribers; and for which as I have said before I am very sorry to have nought but our sincerest thanks and gratitude to you for this, so remarkable proceeding. May God reward you and yours for all your generous actions.

I thank you also for your memorandums about the quadrupeds in the Boston Museum as I see that our animal there may save me the trouble of going to the State of Maine for it. When I was last under the hospitable roof of our Friend Doc ${ }^{r}$ Shattuck, I saw in George's room a No. of the "Penny Magazine" in which there is a plate representing a family of Beavers at work, that reminded me greatly of what $I$ have seen in the ponds of Indiana some thirty years ago, and which I should like to have for a few days to assist in part in the making of the background to my Drawing of these animals, drawn from the Individual you procured for me. I will take good care of the No. and will return it safely very soon.

Should George Shattuck have forwarded that $\mathbf{N}^{\text {o. to }} \mathbf{M}^{\mathrm{r}}$. B. of Baltimore, pray ask him to write to the later to send it to me as soon as convenient. If per chance you could procure for me a live Hare in the Summer dress (It is pure white in winter) pray do so and do not mind the price or the cost of its conveyance to me. This animal is abundant in the northern portions of your State and is fully double the size of the common Hare called the "Rabbit."

With sincerest regards and kindest remembrances to all around you and our mutual Friends,

believe [me] yours always

ЈоHn J. Audubon.

' The "Parkman Wren"

well mounted will soon be on your chimney mantle!

'The unique specimen of the little Wren, referred to in the postscript of this letter, had been discovered on 
the Columbia River by Dr. Townsend some years before, and though Audubon had described it in 1839, his figure of it had but just appeared; this was doubtless included, as Mr. Thayer remarks, in the parts of the octavo edition of The Birds of America, which Dr. Parkman distributed at Boston in the summer of this year.

As an indication of the zeal and energy with which Audubon undertook his work on the quadrupeds, the following letter (dated "New York, August 15, 1841," and addressed to "W. O. Ayres, ${ }^{10}$ Esq., Miller's Place, Suffolk county, Long Island, New York") will be read with interest:

\section{Audubon to W. O. Ayres}

I am now closely engaged in conjunction with my friend the Revd. John Bachman - of Charleston, S. C., in the preparing of a work on the viviparous quadrupeds of North America, and I have already drawn about one hundred figures of these, including thirty-six species.

Now knowing the interest you feel towards the advancement of Natural Science, in every department, I have thought that should you assist us in the procuring specimens, whether in the flesh or skin, dead or alive; that we would be much benefitted by such aid.-Long Island possesses rare and valuable species, and although many of them are plentiful they are rarely procured unless accidentally as it were. In your Rambles after the feathered Tribe, you surely come across at times with quadrupeds, and if you were good enough to shoot them or to catch them and send them to me in the manner mentioned below, I personally would feel extremely obliged to you.

Bats, Wood Rats and Wood Mice, Shrews, Shrew Moles

${ }^{10}$ Baird wrote to Audubon, November 4, 1846: "Please tell me the address of your friend Ayres. I have been collecting fishes for some weeks, and wish to correspond \& exchange with him on this subject." A woodpecker, Colaptes ayresii, was named after this friend by Audubon, in The Birds of America, vol. vii, in 1843. 
and all the smaller animals can be forwarded in an earthern jar immersed in good Yankee Rum.-The larger kinds can be skinned, preserving the skull entire, and also the legbone and the clavicles. One fore $\&$ one hind foot ought to be pinned on a board or cork until perfectly dried, and actual measurements and weights forwarded with the specimens. Nos. accordingly with the notes of localities and dates. Young and old are wanted. The Cat Squirrel is now and then procured about you of a very large size-the Woodchuck \&c. but it is unnecessary for me to give you a list as we are anxious to procure every thing we can from every portion of the Union with the view to ascertain their geographical range.

The expense involved in producing the early numbers of the small edition of his Birds must have been great, and Audubon was feeling the strain, when the letter, ${ }^{11}$ dated "New York-April 29, 1841," from which the following extract is taken, was sent to his Boston agent: "I doubt much if you are actually aware that we have at this moment in this city and at Philadelphia upwards of Seventy persons employed upon the present work, and that all these ... are to be paid regularly each Saturday evening, and that when we are out of temper it is not without cause."

When Baird visited the Audubons, in New York, in January, 1842, he was fascinated by the masterly drawings of birds and quadrupeds which were then being produced, and was determined to pay more attention himself to an art for which presumably he had little natural aptitude; he seems also to have received a hint for the improvement of his somewhat loose chirography. Upon leaving, Audubon presented his pupil with a copy of the Biography of Birds. After returning to his

${ }^{11}$ Addressed to Messrs. Little \& Brown, booksellers, acknowledging the receipt of a check for $\$ 214.20$. 
home, Baird wrote from Carlisle, on February 8 of that year:

\section{Spencer Fullerton Baird to Audubon}

After a trial of two weeks I begin to find that I am getting over the shock caused by the sudden transition from the bustle of Broadway to the lifelessness of Carlisle, and hope that by the application of the proper means I may in time perfectly recover. Philadelphia seemed dull but Carlisle was death itself. My visit now however seems but as a dream, and I have settled down into my old regular monotonous life as if $\mathrm{I}$ had never been absent a day. When I arrived my friends had a great many questions to ask of course, but almost the first ones on every lip were about Mr. Audubon,- -how he looked? What was his age, whether the idea they had formed of him from his writings was correct, many queries also were respecting Mrs. A. and her sons; and they all said that they would be ever grateful to them for their kindness, to one away from home. . . .

For want of other objects I have commenced to draw the sternal and shoulder apparatus of our birds, a pretty large collection of which I have been making for a year past. . . . Have you heard from Mr. Lyon of Bedford yet about the money he owes you? I was asking about him the other day, of an acquaintance of his, who told me that he was as good as gold in all his debts, \& expressed some surprise at his not having paid, as he generaly is very punctual. . . . Last week I walked up to Pinegrove an iron works about sixteen miles in the mountains where resides the Mr. Ege I have so often spoken about as the mighty Nimrod of our county. On my arrival I found a fine wild cat hanging in the stable which had been killed a few days before. On returning the next day I took the cat with me slung across my shoulders, and on reaching home after measuring \& weighing it skinned it. I am in hopes of getting some more from here, as they promised to catch all they could for me. 
Baird signed himself "Your affectionate pupil," and added in a postscript: "I forgot to say that $I$ had a fine steak of the wild cat broiled and it tasted like a tender piece of fresh pork. I will certainly eat the whole of the next one obtained. I intend to taste all the Quadrupeds inhabiting this part of the country."

Audubon's interesting reply was in part as follows:

\section{Audubon to Spencer Fullerton Baird}

New York, Feby. 10, 1842.

My dear young Friend.

It is about half an hour since I had the real pleasure of receiving your letter of the 8 th inst. and my earnest thanks to you for it and its contents; to all of which I will try to answer at your request.

That beautiful Carlisle, its surrounding hills bordering its valleys, all within the bosom of quiet nature should appear to you as a small affair when compared to our largest city in the Union, is not at all remarkable, but let me ask you the following questions. Did you meet all your dear Parents and Friends quite well? Did they not receive you with the kindest of welcomes? Were not their hearts and feelings towards you the same as ever? Surely all this was fact, and being so, would you not after all prefer Little Carlisle than Great Nerw York with all its humbug, rascality, and immorality? Surely or do I mistake your nature sadly, you do! It is now a good long time since $\mathbf{I}$ was young, and resided near Norristown in Pennsylvania. It was then and is now a very indifferent place as compared with New York; but still my heart and mind oftentime dwell in the pleasure that I felt there, and it always reminds me that within a few miles of that village, my Mother ${ }^{12}$ did live, and it was there also that my good fortune led me to know and to marry the excellent Wife I have yet, at whose hands yourself have tried to be rendered comfortable. Say

${ }^{13}$ See Vol. I, p. 103. 
what you will. "there is nothing like home" . . I I wish I could be with you, if only for one week, for then I imagine that between your friends of the mountains, yourself, and myself, we could Tree a "Catamount" and soon untree him. The tugging part of that far-famed animal, I would cheerfully give up to your youthful shoulders, but not so with the figuring of it, yet for a while. Is there such a Beast in existence? Do let me know as soon as you can. I am heartily glad that you have procured a wild cat from the mountainous part of Pennsylvania, and that you have preserved its skin, which I beg you to forward as soon as you please, along with whatever other quadrupeds you may have in hand, that we may say more on those Beasts of the Central States, than has ever been before told. . . .

Look out for Martens, and try to find me some youself! I am glad that you find wild cat meat pretty good, as it corroborates the sayings of many others, who pronounce it equal to young veal.

Let me say to you ("en passant") that your handwriting is considerably improved, and depend upon it that your attention to Drawing will soon enable you as of "copper plate." Go ahead!

I now wish you earnestly to offer our joint respects, regards, and best wishes to all your family and friends, and to believe me always,

\section{Yours most truly, Jornn J. Audubon. \\ 86 White Street.}

P. S. Thank you for what you say of the Bedford gentleman. When I write next, I will mention him at greater length. I wish you could let me know whether we could procure first rate peach trees from your vicinity, and how much 50 of them would cost. I should like to have them assorted, soft, and clings yellow, or red, or blood-red. We wish to plant these as early in March as possible, if young trees, two years old could be had, we might, perhaps, have fruit on some of them during the 
next summer? Try what you can do for your New York friend. [The following on outside of letter-sheet] I will make up a box for you in a few days, and send it to you through Mr. Chevalier.

Audubon, who ever found city life irksome, as early as $\mathbf{1 8 4 1}$ had begun to look about for a farm, or some retired spot within easy access to New York, where he could establish the families of himself, of his two sons, and have about him many of the animals which he then wished to study and depict for his new work. Edward Harris would have been glad to have had him for a neighbor, and wrote from Moorestown, New Jersey, on July 5, 1841, suggesting that he examine "a small farm close to his village, containing about 25 acres of very good land," which the owner was then willing to sell for $\$ 3,500$, though, added Harris, "when Mr. Havell was here, he asked $\$ 5,000$ for it." A spot more to his liking, however, was found on the Hudson River, in Carmansville, later known as Washington Heights, where he purchased from thirty to forty acres of land which had a river frontage of a thousand feet, from the present One Hundred and Fifty-fifth to One Hundred and Fifty-eighth Streets, and extended to the easterly limits of the village at the old Bloomingdale Road, near the present Amsterdam Avenue. This tract was well wooded, and among the grand forest trees on the place a large tulip or white wood attracted general attention from its great girth and commanding height. Audubon decided to place his house at the foot of the river bluff, amid a cluster of fine oaks, chestnuts and evergreens, and a clearing had to be made before the site could be laid off; it was some years before the railroad came to mar his river view and interrupt access to the 
beach. Audubon began to build in 1841, and on February 24, 1842, Victor wrote to Edward Harris: "Our house in the country is going on well, and will probably be ready for us in about two months. John is at work out there every day"; they were planning, he said, to raise pigs and poultry, and he inquired after "draining tiles, such as are made near Philadelphia."

Audubon named his new estate "Minnie's Land," in honor of his wife, Lucy, to whom he deeded the property, the Scotch form of her name having no doubt come into familiar use during their residence abroad. In April, 1842, they turned their backs on the city and occupied their new home. Spencer Baird, when writing on May 3 of that year, said:

I have been in some doubt where this letter should be addressed, since "86 White St." will not reach you, and you must by this time be snugly fixed I hope in your beautiful place up the River. Do not laugh therefore if I prefix "Formerly" to the old superscription.

I suppose that the First Number of the "Quadrupeds of North America" is out by this time, I hope that it will be hailed by a large list of subscribers, and will do what I can for this desirable end.

Submerged as Audubon was, with painting the Quadrupeds, keeping the small edition of his Birds in motion, and canvassing for subscribers to both works, which he published himself, he nevertheless found time for an extraordinary number of letters, which were written with an elegance of chirography that diverts our attention from their orthographic defects. In the labor of drawing and in all his business affairs he was constantly aided by his sons.

In Audubon's time the center of Carmansville was 
a quarter of a mile to the east of his house, while at a short distance below, on the river, lay Manhattanville, at the present One Hundred and Twenty-fifth Street, from which men frequently came on summer evenings to help handle the seine, fish then being plentiful in that part of the Hudson. The place came to possess a good garden and orchard, with stable, dairy, and poultry yards; enclosures also were made for deer, elk, wolves, foxes and other wild animals. The old barn of the Audubon place stood higher on the slope where the naturalist built his studio or painting house, but no traces of either now exist. Though standing low, the house commanded a wide sweep of the river with the Palisades on its opposite shore, and such attractive surroundings were a never failing source of delight and inspiration to the naturalist to his dying day.

In describing Audubon's activities, Parke Godwin made this note in the spring of 1842: ${ }^{13}$

During the last winter, which he spent in this city, he has worked on an average fourteen hours a day, preparing a work on the Quadrupeds of America, similar to his work on the Birds. The drawings already finished, of the size of life, are master-pieces in their way, surpassing if that be possible, in fidelity and brilliancy, all that he has done before. Early in the summer he will depart to continue his labors in the woods.

Before we glance at the half-submerged relic of Audubon's old house as it stands today in upper New York, ${ }^{14}$ we shall follow the same writer in a visit which he made to "Minnie's Land" in the summer of 1842 but did not describe until eleven years later ${ }^{15}$ we will only

${ }^{13}$ See Bibliography, No. 60.

${ }^{14}$ See Chapter XXXVI.

${ }^{15}$ Parke Godwin, The Homes of American Authors (Bibl. No. 68) (1853). 


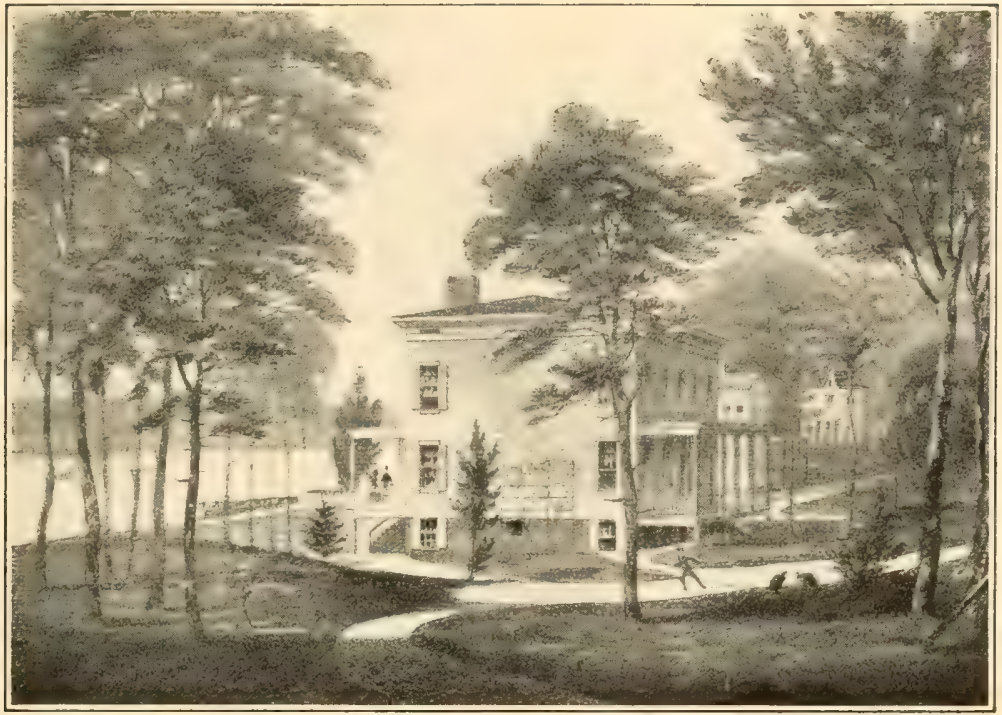

"MINNIE'S LAND" AS IT APPEARED IN 1865.

After a lithograph published in D. T. Valentine's Manual of the Comncil of the City of New York.

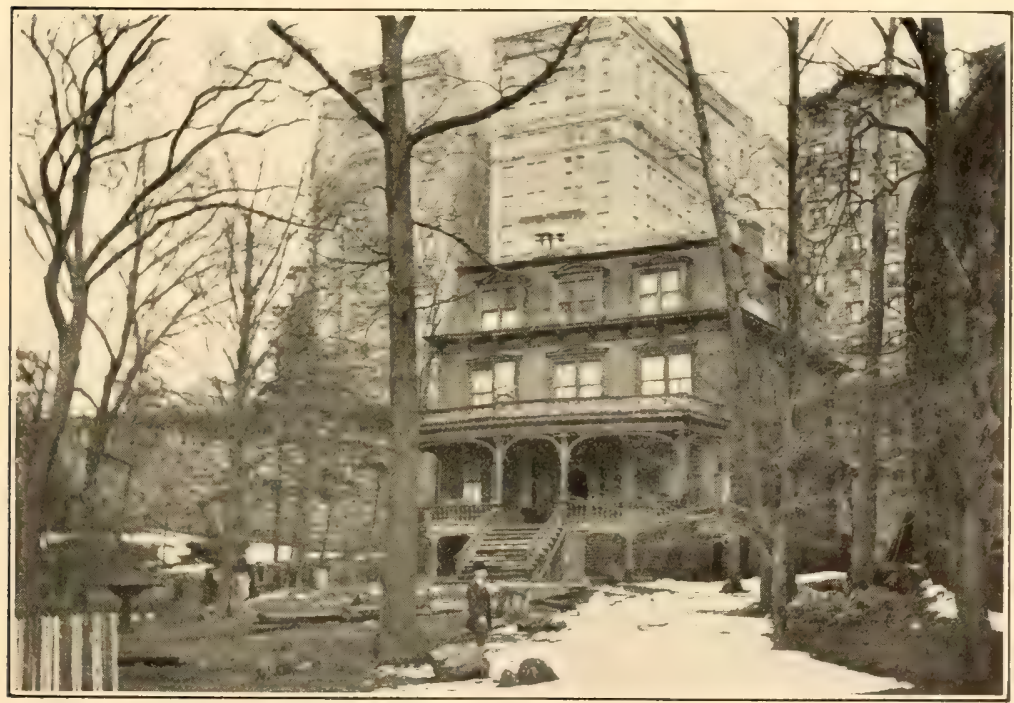

"MINNIE'S LAND" AS IT APPEARED IN 1917 FROM THE RIVER FRONT, POCKETED BY THE RETAINING WALL OF RIVERSIDE DRIVE. 

add that at this time Audubon was in his fifty-eighth year, and not over sixty, as this writer surmised. After passing beyond the outposts of the city of that day, and turning into a rustic road which led directly to the river, his walk

soon brought a secluded country house into view,- - a house not entirely adapted to the nature of the scenery, yet simple and unpretending in its architecture, and beautifully embowered amid elms and oaks. Several graceful fawns and noble elk were stalking in the shade of the trees, apparently unconscious of the presence of a few dogs, and not caring for the numerous turkeys, geese, and other domestic animals that gabbled and screamed among them. ...

"Is the master at home?" I asked of the pretty maid-servant who answered my tap at the door, and who after informing me that he was, led me into a room on the left side of the broad hall. It was not, however, a parlor, or any ordinary reception-room that I entered, but evidently a room for work. In one corner stood a painter's easel, with a half-finished sketch of a beaver on paper; in the other lay the skin of an American panther. The antlers of elks hung upon the walls, stuffed birds of every description of gay plumage ornamented the mantle-piece; and exquisite drawings of field-mice, orioles, and woodpeckers were scattered promiscuously in other parts of the room, across one end of which a long rude table was stretched to hold artist materials, scraps of drawing paper and immense folio volumes filled with the delicious paintings of birds taken in their haunts.

\section{The master, who soon appeared,}

was a tall, thin man, with a high arched and serene forehead, and a bright penetrating gray eye; his white locks fell in clusters upon his shoulders, but were the only signs of age, for his form was erect, and his step as light as that of a deer. The expression of his face was sharp, but noble and commanding, 
and there was something in it, partly derived from the aquiline nose and partly from the shutting of the mouth, which made you think of the imperial eagle.

His greeting, as he entered, was at once frank and cordial, and showed you the sincere and true man. "How kind it is," he said with a slight French accent, and in a pensive tone, "to come and see me; and how wise, too, to leave that crazy city!" He then shook me warmly by the hand. "Do you know," he continued, "how I wonder that men can consent to swelter and fret their lives away amid those hot bricks and pestilent vapors, when the woods and fields are all so near?"

When writing in 1845, Godwin gave further intimations of the naturalist's appearance: "His forehead [was] high, arched, and unclouded; the hairs of the brow prominent, particularly at the root of the nose, which was long and aquiline; chin prominent, and mouth characterized by energy and determination. The eyes were deep-gray, set deeply in the head, and as restless as the glance of an eagle." 


\section{CHAPTER XXXIV}

\section{EXPEDITION TO THE UPPER MISSOURI}

Ambitions at fifty-seven-Plans his last expedition in the rôle of naturalist-Credentials from public men-Canvassing tour in Canada described-Baird's plans to accompany Audubon west frustratedWestern expedition begun-Ascent of the Missouri and YellowstoneDiscoveries of new birds-A wilderness that howls-Buffalo huntingPassing of the great herds-Return from Fort Union-Incident on the canal boat-Completion of the octavo edition of the Birds.

In the summer of 1842 , when his two new undertakings were well in hand, Audubon was planning a journey which he felt would help them both, his long cherished but ever deferred expedition to the Far West; in the dim perspective his mind's eye could trace the snowy summits of the Rocky Mountains, a promised land he was never destined to see, though, with true poetic justice, one of those grand peaks now bears his name. At this time he was in his fifty-eighth year, and although his family thought him too old for so arduous a journey, he would not be thwarted, for his eye was undimmed and his natural force unabated.

The letters which passed between Audubon and Baird at this time show how eager was his young friend to attach himself to the party. While in Washington, July 27, 1842, Baird wrote:

After making several unsuccessful efforts to get a second sight of you day before yesterday, I was obliged to give up the attempt in despair. I went to the Capitol at half past twelve and wandered over the whole building, Library, Senate 
Chamber and House, without being able to see or hear anything of your excellency. In the evening as in the morning I was again at Fuller's without avail, went up the street, listened awhile to the Circus music, came back, you were in bed.

One thing $\mathbf{I}$ wanted to ask you about, was respecting your proposed trip next spring. . . Nothing would delight me more than to go, if I can afford it. Next what preparation would I have to make to fit myself to accompany you. The journey ought to be a sort of "Humboldt \& Bonpland" one, for the purpose of increasing the general sum of knowledge in every department of science, physical as well as natural. . . If there is anything I can do for you here, do not hesitate to command me.

Audubon's interesting reply to this letter will be given in full:

\section{Audubon to Spencer Fullerton Baird}

New YoRK, July 30, 1842.

\section{My Dear Young Friend, -}

Your letter of the 27th Inst. reached me yesterday. I am truly vexed that I should have missed you at the Library or the Congress Chambers, where I went (perhaps too late) between 3 and 4 o'clock of the afternoon, having been detained at the different Departments of State where it was my duty to call, preparatory to the next coming Great Western Journey.

Now it proves by your letter that you feel favorably disposed to accompany me on this long thought-of and contemplated Tour, and wish me to give you some idea of the expenses, attached to such an undertaking; but to this question I am quite unable to reply at present, although I may do so in a few weeks, and which I shall do, provided you write to me again on the subject.

I have no very particular desire to embark as deep in the Cause of Science as the great Humboldt has done, and that, simply because I am too poor in pecuniary means and too in- 
competent; but I wish nevertheless to attempt to open the Eyes of naturalists to Riches untold, and facts hitherto untold. The portions of the country through which it is my intention to pass, never having been trodden by white Man previously.

I have some very strong doubts whether the results of the Antarctic Expedition will be published for some time yet; for, alas, our Government has not the means, at present, of paying some half a Million of Dollars to produce publications such as they should publish, and connected with the vast stores of Information, collected by so many Scientific Men in no less than Four Years of Constant Toil and privation, and which ought to come to the World of Science at least as brightly as the brightest rays of the Orb of Day during the Mid-summer Solstice. Oh, my dear young friend, that I did possess the wealth of the Emperor of Russia, or of the King of the French; then, indeed, I would address the Congress of our Country, ask of them to throw open these stores of Natural Curiosities, and Comply with mine every wish to publish, and to Give away Copies of the invaluable Works thus produced to every Scientific Institution throughout our Country, and throughout the World.

As you however appear desirous to present my thoughts of your capabilities as one of the assistants in that Stupendous undertaking, I send you enclosed what I hope most sincerely may prove beneficial for such purposes.

Now as you have been kind enough to offer me your services at Washington, I ask you to call upon Mr. Cushing, M. C., of Mass.tts, and to ask him to have the goodness to forward me the Letter promised me by the President of the U. S., for, as I have not yet had it, I somewhat fear that it has been missent.

Write me at once, and believe me,

Your friend, John J. Audubon.

Audubon enclosed with this letter a warm recommendation of his friend for the position of curator of 
the rich collections made by the United States Exploring Expedition to the Antarctic, under command of Lieutenant Charles Wilkes, then stored at the Patent Office and National Institute, but nothing came of it and Baird went away disappointed.

During the summer, in accordance with his usual custom, Audubon had taken pains to fortify himself with credentials from the Government, and had obtained excellent letters from President John Tyler, Daniel Webster, Secretary of State, General Winfield Scott, who then held the highest commission in the Army, John C. Spencer, Secretary of War, and Lord Ashburton, a member of a special commission to settle the disputed boundary between Maine and the British provinces. The letters given him by Daniel Webster and President Tyler were as follows: ${ }^{1}$

\section{Daniel Webster to Whom it May Concern}

United States of Amenica, Department of State.

To ALL to whom these PRESENTS SHALL COME-GREeTING.

Know Ye, that the bearer hereof, John James Audubon, a distinguished naturalist and native citizen of the United States, has made known to me his intention of travelling on the continent with the view principally of aiding the cause of science by extending his researches and explorations in natural history, and as he is known to me to be a man of character and honor and worthy of all friendly offices and of all personal regard, these are therefore to request all whom it may concern, to permit him to pass freely, without let or molestation, and to extend to him all such aid and protection as he may need, and which becomes the hospitality of civilized and friendly nations.

In testimony whereof I, Daniel Webster, Secretary of State of the United States, have hereunto set my hand and caused

\footnotetext{
${ }^{1}$ See Ruthven Deane (Bibl. No. 224), The Auk, vol. xxv (1908).
} 


\section{EXPEDITION TO THE MISSOURI}

the seal of this department to be affixed at the City of Washington, this the 24 th day of July, A. D. 1842.

[Signed] Daniel Webster

\section{President John Tyler to Whom it May Concern \\ United States of America, Washington, 28 th July 1842.}

The bearer of this, John James Audubon, is a native citizen of the United States, who has informed me of his intention of travelling on the continent of America, chiefly to promote the cause of science by researches in natural history. $\mathrm{He}$ is known to me to be a naturalist of eminent acquirements and estimation, a man of character and honor and worthy of all personal respect and regard. I recommend him to my countrymen abroad and to the authorities and inhabitants of other countries that he may receive the friendly offices, aid and countenance which are due to the interests of science and the rites of hospitality among civilized nations.

\section{John TYler, \\ President of the U. States.}

John Bachman, who had agreed to be responsible for the letterpress of the Quadrupeds, was already at work, as shown by the following note ${ }^{2}$ sent to Audubon at this time:

\section{John Bachman to Audubon}

My Dear Friend:

Charleston, August, 1842.

I have just returned from a visit to the country, where I left Mrs. Bachman for the benefit of her health. I have a season ticket on the railroad, and, on my weekly visits, I do much of my writing on Natural History. The moment the

${ }^{2}$ See C. L. Bachman, John Bachman, D.D., LL.D., Ph.D. (Bibl. No. 191), p. 199. 
clock strikes four I am up, and soon at work. From this hour until seven, I have no interruptions. I hope in this way to steal time to write about Quadrupeds. When I get fairly under way, as I am now, I am not easily diverted from the object before me, and nothing but ill health or domestic affliction will keep me back.

J. B.

On September 12 Audubon set out on a canvassing tour of Canada, on which he went as far north as Quebec; as he passed his home, he hailed his sons, who were sailing on the river, and the sight of them at this moment brought tears to his eyes. Whitehall, New York, was reached on September 13, St. Johns, Canada, on the following day, and on the 15th he was in Montreal; three days were spent at Quebec (September 16-18), where, as at other points, he met with the most gratifying success. After reaching home in October, the following glowing account of this tour and of the attractions of his new estate on the Hudson was given in a letter to Dr. Benjamin Phillips of London, ${ }^{3}$ dated from "New York, 7th Nov., 1842":

\section{Audubon to Dr. Benjamin Phillips}

I went on a tramp to the Canadas, leaving our comfortable abode on the 12th of Sepr. last and was absent for a whole month. My Journey extended to something like 1500 miles: during which I visited for the first time, the North-American Gibralter [Quebec], the sight of which was as new to me as it was wonderful in the days of old. The views (for I must speak in the plural) from the Citadel, are as far as I have seen the grandest and the most sublime I ever gazed upon. The St. Laurence River, is noble indeed, and when we know that that stream carried forth to the Atlantic the congregating

\footnotetext{
${ }^{8}$ See Vol. II, p. 144.
} 


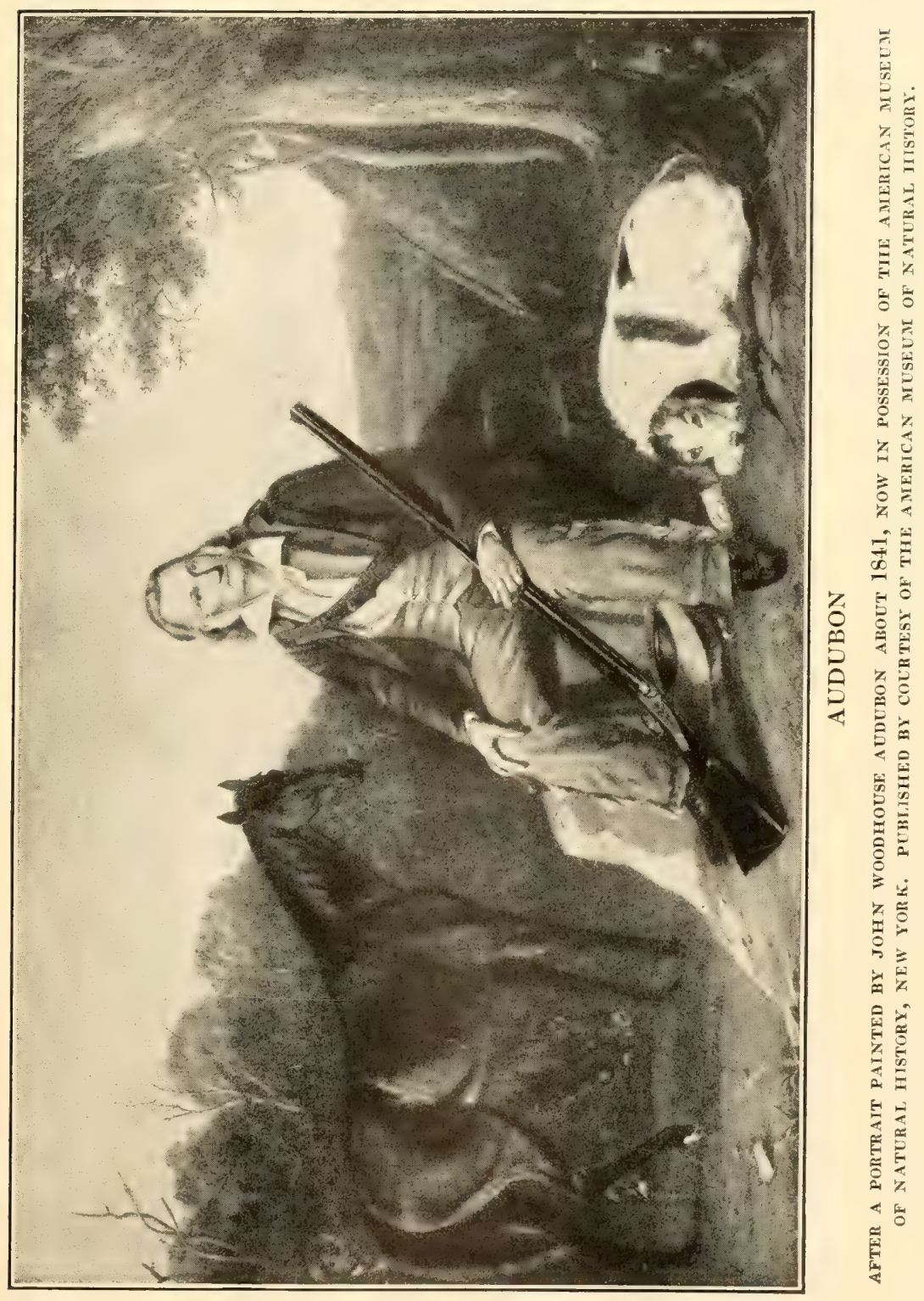



waters of all our sea-lakes, we must not be astonished at her great breadth, depth, and strength of current to about 60 miles below Montreal. About the latter city that noble stream is intercepted by many rapids and a vast number of Islands, the latter of which so intersect the view that in some instances it would prove quite out of the question to discover with certainty either of the main shores. I visited the falls of Montmorency, those of the Rivierre Serria and of La Chan[u]diere. $I$ besides made many an acquaintance and a few very valuable friends. At Quebec I sold a copy of our large Work to the Earl of Caledon who also subscribed to our quadrupeds. At Montreal I sold several Copies of our Small Edition of the Birds of America and procured several good names to the quadrupeds. At Kingston where I had the pleasure of becoming acquainted with Sir Charles Bagot and family (all delightful persons) I sold two copies of the large work to both Houses of Parliament, and also procured their double subscriptions to the Animals. Thus I returned home highly pleased with all that I had done and seen. The more perhaps because I procured in the meantime most valuable specimens of rare quadrupeds and a fund of information that can never be met with unless on the ground of action...

Our dear "Minnie's Land" is improving as fast as our poor pecuniary means will allow. We have done a good deal since our purchase of it, in a wild state as it was, and next spring we will have a good garden and probably some fruit from our own young trees, of which we have planted nearly 200 of the very best description, including pears, aples, quinces, apricote, plumbs, vines, nectarines, apricotes, etc., etc. ... We have fish whenever we draw the seine, and this summer we have caught one sturgeon that measured upwards of 8 feet . . weight more than 200 pounds . . . The "Boys" take a sailing pretty frequently in their sail boat, but I never join them in that, for attempts I have crossed the Atlantic pretty frequently I have an inward dislike to the water, after it is more than 2 or 3 fathoms deep! We have now been enjoying that delightful season, which our Americans call the "Indian Summer" and not 
a drop of rain have we had for several weeks. . . Would that you all were here at this moment, at my elbow, from which by a peep at the window, I gaze on the "Pallisades" and the breath of the Hudson, between the trunks of the many trees that stand at rest at present awaiting the return of spring for a renewal of fragrant verdure, and fruits innumerable. . .

We would be glad if you would ascertain whether a good agent can be had to procure subscribers in England for it [the Quadrupeds], or whether a responsible bookseller would buy the copyright, \& a certain number of plates either coloured or plain.

A few weeks later Audubon wrote also to William Yarrell, hoping to interest him in the foreign sale of his new publication, but as will be seen by his friend's reply, now to be given, with indifferent success:

\section{William Yarrell to Audubon}

[Superscribed by Audubon] Recd 28 Jany

1843

[Addressed] J. J. Audubon Esq ${ }^{\text {r. }}$

77 William Street

New York

[Superscribed by Yarrell]

single letter.

P. Paid, W.Y.

Ryder STREet SṬ JaMes

London 17th Decr. 1842.

My dear $M^{\text {R. Audu bon, }}$

I have this morning received your letter of the $28^{\text {th. }}$ Novr. last, and as it is strictly a letter of business, I reply to its various parts immediately.

About a month ago I received a note from $\mathrm{M}^{\mathrm{r}}$. Phillips to saysthat he had received the Plates of the first number of your work on the Quadrupeds of America-would I come and look at them, and would I exhibit them at the meetings of the 
Societies I belonged to for the promotion of Natural History. I went to see them, and have with pleasure exhibited them at the Linnean Society on the third Tuesday in Novr. and at the Scientific evening, as well as the monthly general, meeting of the Zoological Society, both of which occurred early in Dec ${ }^{\text {r. }}$ and I then returned the 5 Plates to $M^{\mathrm{r}}$. Phillips-They were very much admired but $I$ did not obtain any request for a supply.

In reference to your next request, I must decline any connection with the sale or publication of this, or indeed any other foreign work, in this country. The truth is, that having now been in the business nearly forty years, I begin to be tired of work; the last part of my History of British Birds will be published on the $1^{\text {st }}$ of June 1843 ; with that part I shall give up my pen, and write for money no more.

You are kind enough to give me some credit for experience as a publisher, and some knowledge of the persons who are likely to be purchasers of works on Natural History hereMy conviction is that you would gain more by paying full commission to an established Bookseller in London who would by advertising make your works known, and where they might be obtained-than you will by the best efforts of any private friend, even though his kindness should induce him to take all the trouble for nothing.

You say nothing about your family. I hope they are all well.

$$
\begin{aligned}
& \text { I remain, Dear Sir, } \\
& \qquad \begin{array}{l}
\text { Yours very truly } \\
\text { W }^{\mathrm{m}} \text { Y }_{\text {ARReLL. }}
\end{array}
\end{aligned}
$$

J. J. Audubon Esq ${ }^{\text {r. }}$

77 William Street.

New York.

In the following letter to Spencer Baird Audubon was able to outline more fully his final plans for the western journey: 


\section{Audubon to Spencer Fullerton Baird}

NEW YoR K, Nov. 29, 1842.

\section{My dear Young Friend,}

It seems to me as if an age had already elapsed since I have heard from you or your whereabouts. Neither do I know clearly whether in the way of correspondence, you are in my debt, or I am in yours. Nevertheless I now write to you, and request you to read this letter more than once, and think deeply on the purport of its contents that you may be the [more] able to form a true Idea of what I intend to say [to] you, and for yourself to give me a true answer, on which I can depend, no matter whether it is to my liking or not.

It is now determined that I shall go towards the Rocky Mountains at least to the Yellowstone River, and up the latter Stream four hundred miles, and perhaps go across the Rocky Mountains. I have it in my power to proceed to the Yellowstone by Steamer from St. Louis on the 1st day of April next; or to go to the "Mountains of the Wind" in the very heart and bosom of the Rocky Mountains in the company of Sir William Drommond Stewart, Baronet who will leave on the 1st of May next also from St. Louis.

It has occurred to me that perchance you would lile to spare a few months of your life, to visit the great Western Wilderness, and perhaps again prefer going in my Company in preference to that of any other person? Of this of course I cannot Judge without your answer to this. I thought that you would have been in New York long ere this, but not a Word of you has reached any friend of yours here for several months. I have had an abundance of applications from different sections of the country, from Young Gents who proffer much efficiency, etc., but I do not know them as I know you, and if the terms which I am about to propose to you will answer your own views, I wish you to write to me at once so that I may know how to prepare myself for such a Journey, and under such circumstances.

Would you like to go with me at any rate? By which I 
mean, whether by Land, or by Water, and undertake, besides acting towards me as a friend, to prepare whatever skins of Birds or Quadrupeds, I may think fit for us to bring home. The Birds, you might have one half as your own, the Quadrupeds, (should you wish it) you might have a $4^{\text {th }}$ or every $4^{\text {th }}$ specimen of the same species, reserving to myself all that is new or excecdingly rare.

I will procure and furnish all the materials for skinning, preparing, and saving whatever we may find in Ornithology and in Mammalia, and in all probability (if you think it absolutely necessary) pay one half your expenses from the time we leave St. Louis until our return to that city. You will have to work hard, of course, but then I trust to that the knowledge alone which you must acquire would prove a sufficient compensation, and as you already know me pretty well, I need not say to you that I am not "hard on the trigger."

It will be necessary for you to provide a good double barrelled Gun, and an excellent Rifle, Shot bag, powder flask, \&c, a good hatchet, and a sufficiency of clothes for something like a 12 month's Campaign. But if you will write me at once upon the subject, I can give you a more and a better a/c of all my intentions, than is at present necessary.

If all goes on as I trust it will go on, we may be back home by Octr. or Novr. next, $18+3$.

Do not lose a moment in writing to me in answer to this after you have thought deeply upon the matter.

Remember me kindly to all your friends, and believe me, Yours Always, John J. Audubon.

y. Williams Street, New York.

Baird was unable to reach a decision in the matter, and Audubon actually wrote five more letters on the subject and kept a place open for his young friend for nearly three months. On January 2, 1843, he said that while it was impossible to determine with any degree of 
accuracy the amount of money the journey might require, he could "safely say that the sum of $\$ 500$. would prove all sufficient, as our passages to the Yellow Stone will be granted us free; and the expenses from here or from Carlisle cannot exceed $50 \$$ to St. Louis, and may be less." "I have given up," he added, "all Idea of going South this season, being determined to draw quadrupeds until a few days of my leaving home for this grand and Last Journey, I intend to make as a Naturalist." Again, on January 31, he wrote:

It appears from the whole tenure of your letter, that that rascally article cash is the cause which prevents you from going along with me to the Yellowstone River and back. Now, it happens that although we are far from being rich, we are all desirous that you should go along with me, because we all know you, and I particularly so. Therefore, if you will go with me, and assist me all you can, in the way of hunting, measuring and dissecting Specimens when I am otherwise engaged, etc. etc. I will furnish you with all that may be necessary for your expenses, excepting your clothing and your gun or guns, as you may have them.

\section{In still another letter, of February 10, Audubon said:}

That your kind mother should feel great reluctance in the premises, does not astonish me, as my own good Wife was much against my going on so long a Journey; but her Strong Sense of what is best for us all, and as well as in myself, the perfect confidence that our Maker's Will will be done, she has now no Scruples of any kind, and as for myself $I$ rely as much as I ever have done in the Support of the Almighty Being who has supported and secured me against evils of all sorts in my Various undertakings, and with this Idea at my heart, I feel confident that although an Old Man, I could undertake any Journey whatever, and no matter of their lengths or difficulties. 


\section{Mydaw ho}

\section{Monutown ckint. 31" 1840}

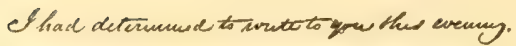

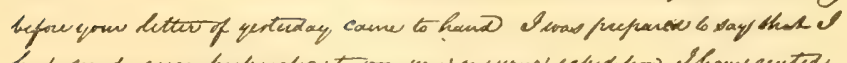

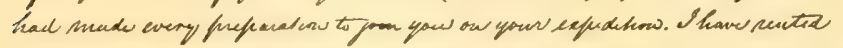

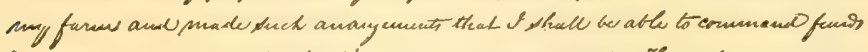

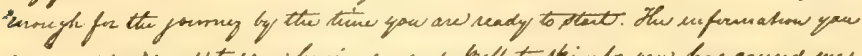

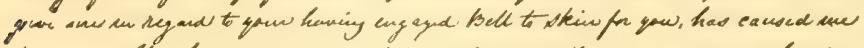

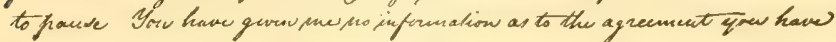

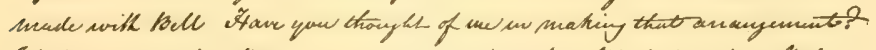

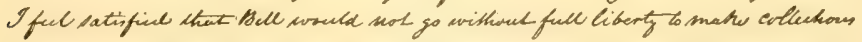

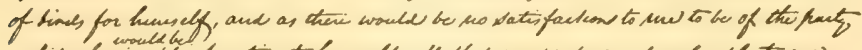

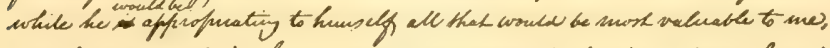

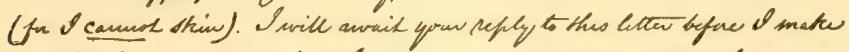

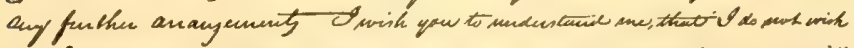

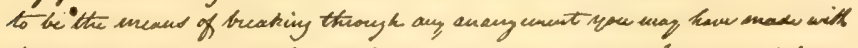

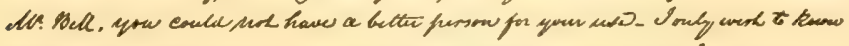

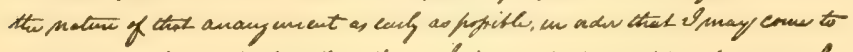

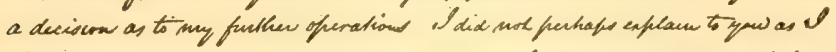

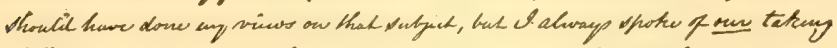

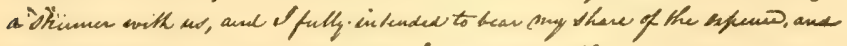

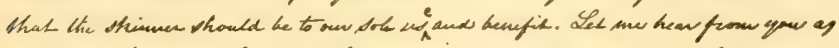

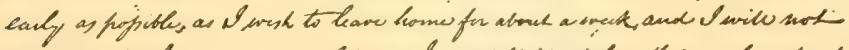

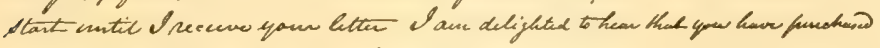

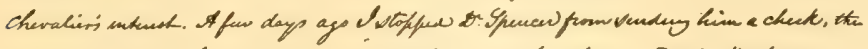

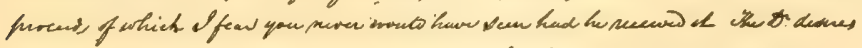

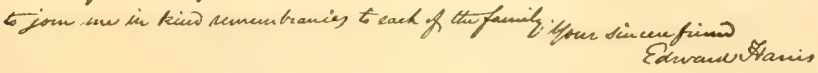

LETTER OF EDWARD HARRIS TO AUDUBON, REgARDING HIS INTENTION OF JOINING THE EXPEDITION TO THE UPPER MISSOURT, JANUARY 31, 1843.

From the Deane MSS. 
But I wish you would assure your good mother that to go to Yellow Stone River, in a good Steamer, as passengers by the courteous offers of the President of the American Fur Company who himself will go along with us, that the difficulties that existed some 30 years ago in such undertakings are now rendered as Smooth and easy as it is to go to Carlisle and return to N. Y. as many times as would make up the Sum in Miles of about 3000: Our difficulties (if any there are) will be felt on our return; when we must come back to St. Louis in one or 2 open boats in Sep ${ }^{r}$ and part of Oct ${ }^{r}$ next. The passage being longer or shorter accordingly with the state of the Missouri at that Season. ${ }^{4}$

Young Baird would gladly have accompanied Audubon, but the fears of his friends for his health and safety interposed, and the party as eventually made up comprised, beside the naturalist, John G. Bell, as taxidermist, Isaac Sprague, artist, Lewis Squires, general assistant and secretary, and his old friend Edward Harris.

Audubon left his home on March 11, 1843, with Victor, who accompanied him as far as Philadelphia, where a rendezvous was made before starting west. The party went first to Baltimore, and by steam cars to Cumberland, then by coach through the Gap, and across the Alleghanies to Wheeling, where a steamer took them down river to Cincinnati. On March 19 they reached Louisville, where Audubon spent four days with his brother-in-law, William G. Bakewell, and on the 28th they arrived at St. Louis, where the party completed their outfit. On April 25 they began their ascent to the Missouri, in the steamer Magnet, a small vessel belong-

${ }^{4}$ See William H. Dall, Spencer Fullerton Baird, a Biography (Bibl. No. 52), pp. 88-91, for the complete letters from which the preceding extracts have been taken. 
ing to the American Fur Company, with a motley crowd of trappers, employed by the Company, representing French creoles, Canadian French, Indians, and other nationalities.

During this journey, which lasted eight months, Audubon kept a voluminous journal, which was written in a fine hand on large sheets of linen paper that could be easily rolled and carried in his pocket; this was afterwards sent to Bachman, was returned, and was lost for fifty years, or until 1896, when it was recovered from an old secretary by Audubon's granddaughters, one of whom published it in $1898 .{ }^{5}$ It is a highly interesting and spirited narrative from beginning to end, and abounds in graphic pictures of the Indians and trappers, the military posts and pioneer settlements, the abundant bird life and big game, the biggest of which, the buffalo, was then seen by Audubon in a state of nature for the first time, the grand and turbulent rivers, and the smiling or frowning face of the great wilderness so soon to be changed by the devastating hands of civilized man.

What Audubon thought to be a new finch, discovered near the Snake Hills in Missouri, was named for Edward Harris, and though it proved to have been previously described, the bird is still known as "Harris' Finch"; a few days later a new vireo, Vireo bellii, received the name of $\mathbf{J}$ ohn G. Bell, his taxidermist, and similar honors were passed to artist Isaac Sprague, to whom was dedicated the little titlark, Alauda spragueii, now Anthus spraguei.

In those days of river navigation, the frequent tying up for fuel or necessary repairs, not to speak of ground-

${ }^{5}$ See Maria R. Audubon, Audubon and his Journals (Bibl. No. 86), vol. $i$, pp. 453-532, and vol. ii, pp. 1-196. 
ing in a treacherous channel, gave almost daily opportunities for the hunters to go ashore, and these occasions seldom failed to produce something interesting, new, or rare. In the Indian country, at Bellevue, Nebraska, where they touched to land a part of their cargo, Audubon "saw a trick of the trade, which made him laugh. Eight cords of wood were paid for with five tin cups of sugar and three of coffee-value at St. Louis about twenty-five cents."

They began to meet with buffalo about the mouth of the James River, in South Dakota, on May 20; the ground, said Audubon, was literally covered with their tracks, and the bushes with their hair. On the same day they discovered "Meadow Larks whose songs and single notes were quite different from those of the Eastern States," and this proved to be the first notice of the Western Meadow Lark, which later appeared as the Sturnella neglecta in the small edition of his Birds of America, then in course of publication.

Audubon's opinion of the Indian was modified considerably after having seen him in the western wilderness, and his confidence in George Catlin's descriptions was completely shattered; "His book," he said, "must, after all, be.altogether a humbug. Poor devil! I pity him from the bottom of my soul; had he studied, and kept up to the old French proverb that says, 'Bon Renommé vaut mieux que ceinture doré,' he might have become an honest man-the quintessence of God's works."

After forty-eight days and seven hours out of St. Louis, on the 12th of June, they reached Fort Union, at the mouth of the Yellowstone, where the Omega left them and returned down river. 'The country proved so interesting that the naturalist remained two months at 
the fort, where he occupied the room which had been used by Maximilian, Prince of Neuwied, when traveling through the western parts of America ten years before; here Audubon made many drawings. Buffalo were abundant on all sides, and a favorite occupation was shooting wolves from the ramparts of the fort. On June 18 they killed two antelope and two deer before noon, and "immediately after dinner," he said, "the head of the old male was cut off, and I went to work outlining it; first small, with the camera lucida, and then by squares." On the 30th he wrote: "I began drawing at five this morning, and worked almost without cessation till after three, when becoming fatigued for want of practice, I took a short walk, regretting that I could no longer draw twelve or fourteen hours without a pause, or thought of weariness."

On the 15th of July they started up the shore of the Yellowstone in a cart. The party soon had had enough of buffalo hunting, and on one day the naturalist was nearly speared by a charging bull that had been wounded. "What a terrible destruction of life," he says, "as it were for nothing, or next to it, as the tongues only were brought in, and the flesh of these fine animals was left to beasts and birds of prey, or to rot on the spots where they fell. The prairies are literally covered with the skulls of the victims, and the roads the Buffalo make in crossing the prairies have all the appearance of heavy wagon tracks." Foreseeing the departure of the buffalo, he wrote:

One can hardly concelve how it happens, notwithstanding these many deaths and the immense numbers that are murdered almost daily on these boundless wastes called prairies, besides the hosts that are drowned in the freshets, and the hun- 
dreds of young calves who die in early spring, so many are yet to be found. Daily we see so many that we hardly notice them more than the cattle in our pastures about our homes. But this cannot last; even now there is a perceptible difference in the size of the herds, and before many years the Buffalo, like the Great Auk, will have disappeared.

On the 9th of August he added: "I have scarcely done anything but write this day, and my memorandum books are now crowded with sketches, measurements, and descriptions." Those who maintain that a "howling wilderness" is a place that never howls, should read his note for August 19: "Wolves howling, and bulls roaring, just like the long continued roll of a hundred drums"; or this for the 21st: "Buffaloes all over the bars and prairies, and many swimming; the roaring can be heard for miles."

At Fort Union they built a Mackinaw barge forty feet long, which they christened the "Union," and on the 16th of August they started for St. Louis, which was reached in safety on the 19th of October. There they unloaded, and "sent all things to Nicholas Berthoud's warehouse." "Reached home," said Audubon, "at 3 p. m., November 6 th, 1843, and thank God, found all my family quite well."”

When Audubon was returning by the canal route from Pittsburgh to Philadelphia, he was sought out by a young traveler, who afterwards related the following incident. ${ }^{6}$ The naturalist, he was told, was under "a huge pile of green blankets and fur," which he had already noticed on one of the benches, and had taken for the fat pile of some western trader. Having waived

${ }^{6}$ Charles Winterfield (Bibl. No. 149), The American Review, vol. i (1845); see also Charles W. Webber, Romance of Natural History (Bibl. No. 173) (1852). 
his choice of a berth in Audubon's favor, he observed that "the green bale stirred a little,- - half turned upon its narrow resting place, and after a while sat erect, and showed us, to our no small surprise, that a man was inside of it. A patriarchal beard fell white and wavy down his breast; a pair of hawk-like eyes glanced sharply out of a fuzzy shroud of cap and collar." When this stranger, drawn by a sense of irrepressible curiosity, had ventured near enough to recognize the "noble Roman countenance" thus obscured, he saw that it was Audubon in his wilderness dress; he was "hale and erect, with sixty winters upon his shoulders, and like one of his old eagles, feathered to the heel." Audubon's conversation, said this writer, was impulsive and fragmentary, but he showed him with pleasure some of his original drawings of animals, as well as a living collection of foxes, badgers and Rocky Mountain deer, which he was bringing home.

\section{To follow this narrator further:}

The confinement we were subjected to on board the canalboat was very tiresome to his habits of freedom. We used to get ashore and walk for hours along the tow-path ahead of the boat; and I observed with astonishment that, though over sixty, he could walk us down with ease. ... His physical energies seemed to be entirely unimpaired. . . . Another striking evidence of this he gave us. A number of us were standing grouped around him on the top of the boat, one clear sunshiny morning; we were at the time passing through a broken and very picturesque region; his keen eyes, with an abstracted, intense expression, peculiar to them, were glancing over the scenery we were gliding through, when suddenly he pointed with his finger towards the fence of a field, about two hundred yards off. "See! Yonder is a Fox Squirrel, running along the top rail. It is not often $I$ have seen them in Pennsylvania." Now 
his power of vision must have been singularly acute, to have distinguished that it was a Fox Squirrel f for only one other person ... detected the creature at all.

The second Mrs. Victor G. Audubon ${ }^{7}$ said that on the day the naturalist returned, "the whole family, with his old friend, Captain Cummings, were on the piazza waiting for the carriage to come from Harlem ... He had on a green blanket coat with fur collar and cuffs; his hair and beard were very long, and he made a fine striking appearance. In this dress his son John painted his portrait." 8 This interesting portrait, which is still in possession of the family, and which is reproduced by his granddaughter in the work from which we have just quoted, shows a man whose apparent age, as suggested by his flowing white hair and grayish white beard, overshoots the clearer testimony of his smooth face and bright eye; as already noticed, Audubon had not then attained his sixtieth year.

Upon his return at this time Audubon is said to have been mistaken for a Dunker, or member of a sect of Quakers noted for their ample beards. On November 29 Bachman wrote: "I am glad to hear that your great beard is now cut off. I pictured you to myself, as I saw you in my home, when you came from Florida, via Savannah. You jumped down from the top of the stage. Your beard, two months old, was as gray as a Badger's. I think a grizzly-bear, forty-seven years old, would have claimed you as "par nobile fratrum.'" Bachman was apparently disturbed about Audubon's personal habits at this time, for he added in the letter just quoted: "I am a teatotaler. I drink no wine, and do not

${ }^{7}$ See Vol. II, p. 294.

${ }^{8}$ See Maria R. Audubon, op. cit., vol, ii, Note on pp. 175-6. 
use snuff. I hope that you are able to say the same." 9

Spencer Baird wrote to Audubon from Washington, November 24, 1843, to congratulate him upon the safe return of his western party, saying: "From time to time short notices of your whereabouts and doings appeared in the newspaper and a thousand times I wished that the fears of my friends had not prevented me from accompanying you to the scenes of action." Audubon thought that he might well regret the difficulties that had stood in his way; in replying he said that he had seen "not one Rattlesnake and heard not a Word of bilious fever, or [experienced] anything more troublesome than Moschitoes and of these by no means many"; they had brought home a Swift Fox, an American Badger, and a live Deer, which they thought might prove to be new, fifteen new birds, as well as a certain number of quadrupeds, besides "many of the Birds procured on the Western side of the Big Rocky Hills by Nuttall and Townsend." He felt that much still remained to be done, his only regret being that he was not what he "was $\mathbf{2 5}$ Years ago, Strong and Active, for willing he was as much as ever."

In 1844 Audubon brought to a close his octavo edition of the Birds by adding seventeen species, eleven of which were new and represented his discoveries on the Upper Missouri of the previous year. The 500th plate, and last of the series which marked the end of Audubon's life-long labors in ornithology, was dedicated to "Baird's Bunting," Emberiza bairdii. "If a trace of sentiment be permissible in bibliography," said Elliott

${ }^{9}$ At the close of the Civil War, Bachman wrote to a friend: "I had been a snuff-taker for forty years, and I had tried three times to wean myself from the vice. I have done it effectually now...." 
Coues, ${ }^{10}$ "I should say that the completion of that splendid series of plates with the name bairdii was significant; the glorious Audubonian sun had set indeed, but in the dedicating of the species to his young friend Spencer F. Baird the scepter was handed to one who was to wield it with a force that no other ornithologist of America has ever exercised."

${ }^{10}$ Bibliographical Appendix to Birds of the Colorado Valley (Bibl. No. 181 ). 


\title{
CHAPTER XXXV
}

\author{
FINAL WORK DAYS
}

Painting the Quadrupeds-Assistance of Bachman and Audubon's sonsCopper plates of the Birds go through the fire in New York-Audubon a spectator at the ruins-Bachman's ultimatum-Success of the illustrations of the Quadrupeds-Bachman's letterpress-Recommendation of Baird-John W. Audubon in London-Bachman's assistants-His life and labors-Decline of Audubon's powers-Dr. Brewer's visit-Audubon's last letters-His death at "Minnie's Land."

After 1844 Audubon's remaining energies were devoted exclusively to his work on the Quadrupeds, in which it is necessary to discriminate between the large folio of illustrations, which began to appear, in parts, as early as 1842 and which was completed in 1846; the text, of which he lived to see but one volume finished; and lastly, the first and only composite edition of both text and plates, which was published by Victor Audubon in 1854. ${ }^{1}$ This series of works, as already noticed, was produced in collaboration with the Reverend John Bachman, of Charleston, South Carolina; Bachman assumed entire responsibility for the text, but owing to his comparative isolation from large libraries, and to the demands of professional duties, he depended on the Audubons to supply him with specimens and books.

Honest John Bachman, whose motto was, "Nature, Truth, and no Humbug," was suffering sadly, he said, from lack of tools, when he wrote to Victor Audubon in November, 1844: ${ }^{2}$

${ }^{1}$ See Bibliography, Nos. $5-7$. 191).

${ }^{2}$ See C. L. Bachman, John Bachman, D.D., LL.D., Ph.D. (Bibl. No. 
The books are to be found in New York and Philadelphia, but are expensive. I would not have you buy them; but could you not copy for me such articles as we need?

I enclose my plan. I wish always, a month before the time, that you would give me notice of the species you intend to put into the hands of the engraver, and send me, at the same time, the specimen. I cannot describe without it; I will guess at nothing.

I find the labor greater than I expected, and fear that I may break down and, therefore, cry in time, "Help me Cassius or I sink!" Writing descriptions is slow and fatiguing work. I cannot, in the careful manner that I am doing them write more than three in a week. My son-in-law, Haskell, has copied forty-two closely written pages for me. I cannot shorten the articles, many of them I ought rather to lengthen. With patience and the help of all, I hope, however, to get onthe work may be lighter as we proceed.

The following is my daily practice: I am up at 4 A. M., and work till breakfast, and recently, when parochial duties would permit, have kept on until 3 P. M.

The brush of my old friend, Audubon, is a truth-teller. I regard his drawings as the best in the world. Let us be very careful to correct any errors of description that have crept in on the plates-I see a few in the lettering-they can be corrected in the letter-press; and let us be so cautious as to have nothing in the future to correct. There is but one principle on which a just man can act; that is, always to seek the truth and to abide by it.

\section{Bachman wrote again on the 29th of that month:}

About the little mouse-I cannot see a needle in a haystack; or give it a name without knowing what it is. Friend, descriptions cannot be written, as a man works at making Jews-harps - so many a dozen in a given time. My credit, as well as your father's, is so deeply concerned, that I will not publish a day before I am ready. . . 
I have such confidence in you, that I believe that you will do all that I wish. In doing this, however, you will have your hands full. Mine are so-God knows! Will not my old friend, Audubon, wake up, and work as he used to do, when we banged at the Herons and the fresh water Marsh-hens?

Bachman explained that he was the "schoolmaster," and when the boys were a little lazy, he would have to apply the whip.

In March, 1844, Spencer Baird sent Audubon a live Pennant's Marten or Fisher, a rather rare animal even at that time, and now all but extinct. Said Baird: ${ }^{3}$

It was found in company with an older one, in Peter's mountain, six miles above Harrisburg about five weeks ago. After a most desperate resistance the old one was killed, having beaten off a large pack of dogs, to whose assistance the hunters were obliged to run. This individual ran up a tree, and being stoned by the men, jumped off to a distance of forty feet! when being a little stunned by the leap they ran up quickly and threw their coats over it, and then secured it. The old one measured three feet and a half from nose to end of tail, and was about one third larger than this. . . I It seems to be in very good health, and is without exception the most unmitigatedly savage beast I ever saw. The Royal Bengal Tiger, or the Laughing Hyena are neither of them circumstances to it.

Audubon used this marten as the model for his illustration of the species (shown in natural size, Plate xli of the Quadrupeds) ; in noticing its habits later, he said: ${ }^{+}$

${ }^{3}$ See Ruthven Deane (Bibl. No. 51), The $d u k$, vol. xxiv (1907). To Mr. Deane I am indebted for Audubon's copy of a letter to John Bachman, soon to follow; this was written on several blank sheets at the end of his "Copy of my Journal from Fort Union homeward. Commencing (Sunday) Aug. $16^{\text {th }}(1843)$ at 12 o'clock, the moment of our departure."

"The Viviparous Quadrupeds of North America (Bibl. No. 6), vol. i, p. 312 (London, 1847). 
We kept this individual alive for some days, feeding it on raw meat, pieces of chicken, and now and then a bird. It was voracious, and very spiteful, growling, snarling and spitting when approached, but did not appear to suffer much uneasiness from being held in captivity, as, like many other predacious quadrupeds it grew fat, being better supplied with food than when it had been obliged to cater for itself in the woods.

Baird also tried to secure for Audubon the "farfamed catamount" alive, which, from stories related by hunters, he thought might be different from the young of the panther or puma, and also a specimen of the true black fox in the flesh; though unsuccessful in either quest, his efficient aid was greatly appreciated by his friend. In February, 1845, Baird paid a visit to the Audubons at their Hudson River home, where he was warmly received; as his biographer relates, ${ }^{5}$ upon leaving he was invited to select any duplicate bird skins he desired from the naturalist's collection, then at John G. Bell's taxidermist shop in New York; he accepted this generous offer, and chose about forty specimens.

It is evident that some trouble-maker had disturbed the serenity of John Bachman's mind when the following interesting letter was written by Audubon to balm the feelings of his old friend. It is evident that Audubon at this time expected to collaborate in the letterpress of their work, but that plan, according to Bachman's own statement, was never carried out:

\section{Audubon to John Bachman}

My deAr Friend

[Minnie's Land] Jan. 8, 1845.

Never have I been so much astonished as I have been at reading your letter to Victor, and to which I feel myself bound to answer at once.

${ }^{5}$ William H. Dall, Spencer Fullerton Baird, a Biography (Bibl. No. 52), p. 121. 


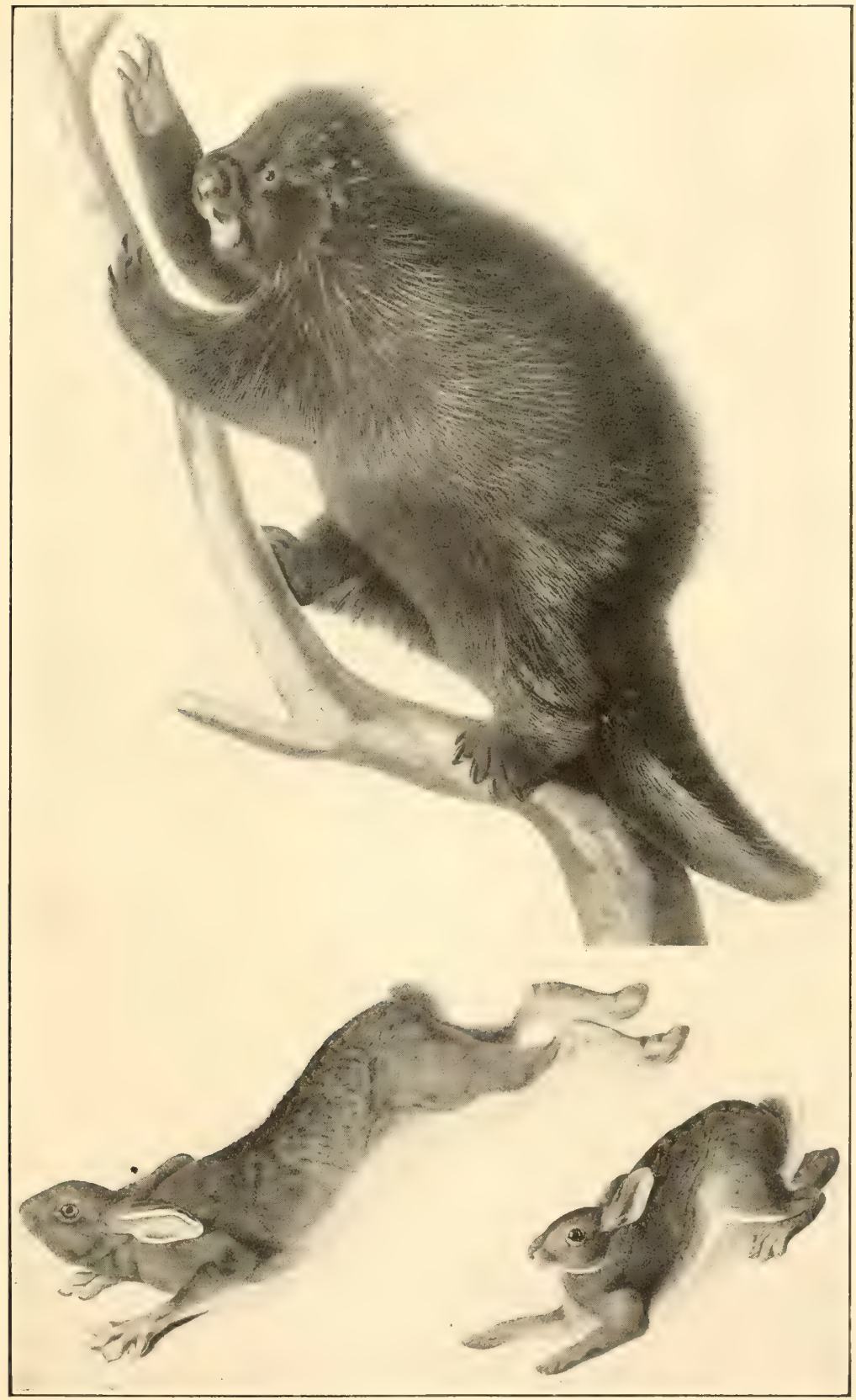

DRAWINGS FOR "THE VIVIPAROUS QUADRUPEDS OF NORTH AMERICA": ABOVE, AMERICAN PORCUPINE, DATED "NFW YORK, MARCH 6, 184\%," AND PUBLISHED IN 1844; BEI,OW, RABIBTS.

After the originals in water color in possession of the American Museum of Natural History, New York.

Published by courtesy of the American Museum of Natural History. 

In the first place you must have been most unmercifully misled by the "mutual friend" of whom you speak, when saying that through that individual you did understand that I never used your name as a coadjutor in the work, which is now publishing on the Quadrupeds of North America under the names of both I and you-Why you should have taken such a report or saying as truth is actually beyond my most remote thought, and again, why did you not long ago, write to me at once on this mysterious subject.

But to put an end to all this stuff, let me assure you that nothing of the kind has ever taken place, and this I could well prove by upwards of one hundred of our last subscribers, all of whom would be ready to testify that before receiving their names on my list, I always mentioned your name to each of them, and many that know you were glad that I had so good and so learned a man at my elbow-I should amazingly be glad to know who the "mutual friend" is, as I think I could give him a lesson on propriety, being a mutual friend, that would serve that kind gentleman for the residue of his life-But enough of this, and all that I am sorry for is that you should not have answered "my short letters," in some of which I particularly requested you to forward me a fine black bear and one or two wolves, by which you would have saved me fully fifty dollars as I have had to pay sixty dollars for two of these vile rascals, and two hundred dollars for a pair of Elks. besides paying the highest of prices to draw other animals--

Now my friend I wish you would set in real earnest, and whenever it is convenient to you in preparing the letter-press for our work. I have made a beginning and have written Ten articles already in days, to wit all the plates of $\mathrm{N}^{0} 1$, and the first of $\mathrm{N}^{\circ} 2$ which are as follows-

Lynx Rufus-Wild-Cat

Arctomys monax-Maryland Marmot

Lepus Townsendii

Neotoma Floridana

Sciurus Richardsonii

Canis (Vulpes) fulvus 


\section{The Beaver \\ The history of the Bison 28 pages \\ and Fiber Zybethicus (muskrat) 12 pages, \\ Tamias quadrivittatus}

This will shew you that I have not been very Idle since I began and I should like to know from you, whether you would like to see what I have said of these, as if you do, I will have them copied as soon as I receive your letter, and will forward the whole, and the additional written in the interim, at the same time. I have a beautiful drawing of a fine male moose, that of the Elk is already engraved, and next week we will forward to the engraver no less than five or six drawings of the best quality. by the way I am sorry that you should look upon the Texan Skunk as a bad figure. The animal is an ungraceful one in its Singular Colouring, but it is nevertheless quite true to nature, with all its specific characters to a $T$.

Victor wrote to you that I was anxious to have your opinion about the Title page and I hope you will send me your ideas forthwith on that subject. I send you now by mail a long article about our work which I conceive and hope will prove to you that the "mutual friend" knew but very little of my feelings or actions or sayings as regards you-

I really \& most truly regret that you should have been put out, and mis-led about this our work by a third party, who must to say the least of it [have] abused your credulity to the very extreme.

However, the sooner forgotten, the sooner mended. it is with deeply felt regret from every one of my Family that we read the account in your letter of the condition of your dear wife, but hope that she will accompany you early next spring to visit our humble but comfortable residence. Now do Come! Present our joint regards to every one of your family, and believe me when I say that none will ever feel more delighted than I, to hear of the welfare of the beautiful "Rabbit"-

And now that I am exceedingly fatigued, having been writing for upwards of seven hours, I will wish you good night \& all the blessings that God may grant to [the] good man and 
to every member of his family-Do not forget me near your Sweet heart.

Your ever faithfully attached \&

Sincere friend

$$
\text { J. J. A. }
$$

In July, 1845, a destructive fire devastated a large section of the city of New York, including the warehouse in which the copperplates of Audubon's Birds were stored; many believed that the plates had been ruined, and one of these was the writer who after witnessing the event gave the following dramatic account: ${ }^{6}$

But who had lost most of all that pale crowd that hung like ghosts around the scene, and gazed with watery eyes, and blue compressed lips, over the ruin? An erect old man, with long white hair, glanced his strong bright eye as coldly over the glowing, smoking desolation, as an eagle would, who watched the sunrise chasing mists up from the valley. J. J. Audubon looks over the grave of the labor of forty years!

The Plates of the Birds of America are buried beneath those smoldering piles! Ye money changers dare not break the stillness with a sob, though the last cent of your sordid hoards be gone!... go away! Ye have lost nothing! ... Yet that dauntless old man is not dismayed; he and Fate knew each other's faces in battle long ago. Let those who know how to love and venerate such labors - to sympathize with such grievous calamities, exhibit it in their prompt patronage of the new work now issuing-The Quadrupeds of America-and in the care which shall be taken to preserve the volumes of the Plates of the Birds, now in existence-the value of which will be fivefold increased!

When Baird heard the untoward news, he wrote from Carlisle, August 4, 1845: "It is with sincerest re(1845).

${ }^{8}$ Charles Winterfield (Bibl. No. 150), The American Review, vol. ii 
gret that I see by the papers that your copper plates were injured or perhaps ruined by the fire which occurred a few weeks ago. Various reports are circulated respecting your loss, and among so many contradictory ones it is difficult to get at the truth of the case. Might I ask you to let me know the truth of the matter." In a postscript to this letter he added: "I forgot to say that $I$ have been elected professor of Natural History in Dickinson College. The situation is entirely nominal, nothing to do \& no salary whatever." Audubon replied promptly on the 7th of August: " "You have been too well-informed about the plates of our large work. They have indeed passed through the great fire of the $19 \mathrm{ul}^{\circ}$; but we are now engaged in trying to restore them to their wonted former existence; although a few of them will have to be reingraved for use, if ever that work is republished in its original size at all."

Bachman, who paid a long visit to the Audubons in the late summer or early autumn of 1845, said that while he was at "Minnie's Land," Audubon painted "Le Conte's Pine Mouse" with his usual facility and skill, but he detected a change in his mental powers. For a long time Bachman had complained of the want of books, which the younger Audubons failed to supply, and of lack of specimens, which no doubt their father wished to retain for use in his own studies, until at length his patience was gone and he tried another form of appeal. The following letter ${ }^{8}$ to their mutual friend, Edward Harris, shows that he was then determined to throw up the responsibility which had been assumed in the Quadrupeds unless what he regarded as "reasonable requests" were complied with forthwith:

${ }^{7}$ William H. Dall, op. cit., p. 124.

${ }^{8}$ Jeanes MSS. See Note, Vol. I, p. 180. 


\section{John Bachman to Edward Harris}

Charleston, Decem. 24, 184.5.

Friend Harris, you can be of service to me, to the Audubons $\&$ the cause of science. I will tell you how.

I find the Audubons are not aware of what is wanted in the publication of the Quadrupeds. All they care about is to get out a No. of engravings in two months. They have not sent me one single book out of a list of $100 \mathrm{I}$ gave them and only 6 lines copied from a book after having written for them for 4 years. When he published his birds he collected hundreds of thousands of specimens. In his Quadrupeds-tell it not in Gath-He never collected or sent me one skin from New York to Louisiana along the whole of the Atlantic States. Now he is clamorous for the letter press-on many of the Quadrupeds he has not sent me one line $\&$ and on others he has omitted even the geographical range-I know nothing of what he did in the West having never received his journal \& not twenty lines on the subject. I am to write a book without the information he promised to give-without books of reference \& above all what is a sine qua non to me without specimens. In the meantime my name is attached to the book, and the public look to us to settle our American species, and alas I have not the materials to do so.

Now this you can do for me. I am willing to write every description and every line of the book. I do it without fee or reward. But-1. Books of reference or copies of them he must obtain. 2. He must publish no species without my approbation. He has made some sad mistakes already. 3. He must procure such information as I shall write for. 4. He must send some person-say when John returns-to make a tour for collecting specimens through the states of the west especially. I find the smaller Rodentia differing every 600 miles. Richardson's species differ from those of New York-ours are once more different from those of N. Y. Leib [?] found a number of new species in Illinois. The New Orleans squirrels differ from ours-California once more new. Now on this last par- 
ticular-the necessity of giving me specimens to describe fron I wish you to speak to Audubon. I cannot consent to impose on the public. I cannot settle the species without specimens. [Tell] him what I have written and [of what I have] complained. Show him this letter if you should [think] it will accomplish the end. I shall soon have the volume finished as well as I am able from the scanty materials with which I am furnished. Then they will be clamorous for the second volume. Now I do not like to make any threats, but if my reasonable requests are not complied with $I$ have made up my mind not to write another line at the end of the first volume. I have not made up my mind hastily. It is the result of four years remonstrance, mortification, and disappointment. Once and for nearly a year I gave up the matter in hopeless despair. I again resumed it on the solemn promise of Victor to do all I wished. Three months have since gone round and not one book sent-only ten lines copied-and a constant clamor for the letter press. But I am called off.

If Audubon was remiss in supplying the necessary materials, it is possible that Bachman, in turn, may have failed to appreciate the load which his friend's shoulders had carried for the five years then past. To Bachman specimens and books were, of course, absolutely essential, but Audubon needed them also, as well as subscribers and the large sums of money necessary to keep his great enterprises in orderly movement. At all events, Bachman's ultimatum brought immediate results, and it might not be wide of the mark to affirm that to the tactful Harris we virtually owe the completion of that admirable work, The Viviparous Quadrupeds of North America. It should be noticed that at the time the complaining letter was sent, John W. Audubon was in Texas, engaged in making collections, though, as it proved, with little success; Victor searched the country 
for the needed books, and his father's Missouri River journal was despatched to Charleston, without delay. On New Year's Day, 1846, Bachman wrote to his friend:

As I do not like to disappoint you in anything, I send you one of the articles. It is about a fair sample of the whole. . . . I try to incorporate as much as I can of your own, but, in most cases, your notes have come too late.

You see how plain Haskell writes: I should think that by this time, he has copied three hundred pages as correctly as the inclosed.

In his letter of March 6 he said:

For the last four nights, I have been reading your journal. I am much interested, though I find less about the quadrupeds than I expected. The narratives are particularly spirited, and often instructive, as well as amusing. All that you write on the spot, I can depend on, but I never trust to the memory of others, any more than to my own. . . .

To return to your Journal. I am afraid that the shadows of the Elk, Buffalo, and Bighorn hid the little Marmots, Squirrels and Jumping Mice. I wish you had engaged some of the hunters to set traps. I should like to get the Rabbit that led you so weary a chase. Write to S. ${ }^{9}$ and find out some way of getting - not his princess brain-eating, horse-straddling squaw,

?For "C," meaning Alexander Culbertson, a young Englishman, famous rider and shot, then in charge of Fort Union at the mouth of the Yellowstone. Audubon, with the assistance of Sprague, painted his portrait and that of his wife, a Blackfoot Indian princess, who also was noted for her skill in horsemanship. "I lost the head of my first [buffalo] bull head," said Audubon, "because I forgot to tell Mrs. Culbertson that I wished to save it, and the princess had its skull broken open to enjoy its brains. Handsome, and really courteous and refined in many ways, I cannot reconcile myself to the fact that she partakes of raw animal food, with such evident relish." (Maria R. Audubon, Audubon and his Journals, vol. ii, p. 111). p. 208.

For previous and following extracts, see C. L. Bachman, op. cit, 
but what is better than such a specimen from the Blackfoot country-1st. The Skunk; 2nd, Hares, in Winter colors; and $3 \mathrm{rd}$, the Rabbit that you chased. In your Journal your descriptions of Buffalo hunts are first rate. I don't like my article on the "Beaver"; I shall have to write it over again. If I could only borrow Temminck's large work. Every library here is open to me, and you would be astonished to see the number of books in my own library; but the scientific works of close comparison are not among them. I had written letter after letter, but might have saved ten dollars postage.

Audubon wrote to Baird on February 2, 1846, to remind him of the Catamount, which was thought not to be "the Cougar," and of the Black Fox: "for the latter," he said, "I do give you my word that I would willingly pay you 'Twenty Dollars by a draft upon us at Sight." In another letter from "Minnie's Land, N. Y.," of March 14, he said: ${ }^{10}$

Could you procure a black and a Silver Fox for us, we will be willing to give a good price for either in the flesh, and preserved in common New England Rum, and forwarded by express to 78 John St, N.Y.

We expect to see John at home in about Six or Seven weeks. He has made a very poor Journey of this one, and will have to go to Europe this summer, I have no doubt.

Concerning his son's journey to Texas, Audubon had written Spencer Baird, September 30, 1845: ${ }^{11}$

My son John will leave this for the West and South-West, as far as the confines of Texas, about the last of next month, and intends being absent until the first of March. Would you like to go with him provided you can pay your own expenses?

${ }^{10}$ See William H. Dall, op. cit., pp. 130-2.

${ }^{11}$ Il id., p. 126. 
He will take one of our Servant men along to help him in the procuring of Quadrupeds and Birds, of which he hopes to procure some, if not a good number of new Species.

As Baird gave no reply, Audubon sat down on Christmas Day, 1845, and wrote again to his young friend: ${ }^{12}$

I hope and trust that you were not offended at my letter, when I wrote you on the Subject of accompanying our son John to Texas where he is now I hope safe and sound, and I believe at Corpus Christi. ...

... I have at last received a fine Red Fox from our Friend Ed. Harris, who although he did not kill it, obtained the Cunning Animal very shortly after its death. I have drawn it to the size of life, and I think made a good figure of it.

I have been drawing pretty constantly these last past weeks and have finished 6 plates for the Engravers. . . . We are all hard at Work preparing the letterpress for the 1 st Vol. of the Quadrupeds, a copy of which I hope to send to you about the beginning of April.

Audubon's prediction in regard to his son was correct, and after John's return from Texas, in April, 1846, he started for England on June 10, with his wife and family; he remained in Europe until May, 1847, engaged, as his father said, "in making figures of those arctic animals, of which accessible specimens exist only in the museums of that quarter of the globe."

The Audubons, as we have seen, now tried to keep John Bachman better supplied, and in the spring of 1846 sent him several boxes of skins, with the urgent request that all which pertained to animals that had not been figured be returned as soon as possible. On March 13 Victor wrote that Temminck's monograph could not be found in all America, not in Boston, or Philadelphia, 
but that a copy would be ordered from Europe at once. In those days Charleston was farther removed in time from New York than California is now from Boston; two weeks was required for a letter of one naturalist to reach the other, and the difficulties of coöperation were correspondingly great. On May 31 Audubon acknowledged the return of the skins, but said: "Judge of my astonishment, when I could not find a single one of the small animals, Shrews, and Scalops argentatus, the latter of which I am anxious to draw at once."

The summer and autumn of 1846 bore heavily on John Bachman, subject as he then was to a "thousand calls and interruptions," and "bowed down, and almost distracted, with anxieties and grief." 13 But the first volume of the letterpress which had given him so much trouble was finished in November, and was published by Audubon at the close of this year. It was at once recognized as a standard and authoritative work, which was then without a competitor in America, and as Louis Agassiz affirmed, without an equal in Europe. At the time of its issue the twentieth number of the folio illustrations was nearly ready; the text itself had 271 subscribers, calling for 281 copies, ${ }^{14}$ though only the eastern cities had then been canvassed.

Early in 1846 Baird wrote to Audubon: ${ }^{15}$ "I have made drawings of the sculls of our quadrupeds which are at your service if you want them. They are Mink,

${ }^{18}$ Mrs. Harriet Bachman died in July, 1846, and almost immediately a daughter was stricken with a fatal disease; "It seizes," said the father, "with a deadly hold, weakens the cords of life; and only relinquishes its fatal grasp, when life is extinct." (See C. L. Bachman, op. cit.)

${ }^{14}$ New York City furnished (for vol. i) 82 subscribers, who took 86 copies; Philadelphia, 33; Boston, 27 (28 copies); and Baltimore, 15. In 1854 Victor Audubon obtained 199 subscribers for the second edition (published with reduced plates) in three days.

${ }^{15}$ For this and the following extract, see Ruthven Deane (Bibl. No. 51), loc. cit., p. 65 . 
THE

\section{VIVIPAROUS QUADRUPEDS}

o)

\section{NORTH AMERICA.}

By

JOHN JAMES AUDUBON, F.R.S. Erc. Erc.

AND

THE REV. JOHN BACHMAN, D.D. ETC ETC.

\section{VOL. I.}

\section{LONDON.}

WILEY AND POTNAM.

$\overline{1847}$

TITLE PAGE OF VOLUME I OF THE ENGLiSH EDITTON OF THE TEST OP

"THE VIVIPAROUS QUADHUEDS OF NORTH AMERICA." 


\section{Wild Cat, Ground Hog, Lepus Sylvaticus, Neotoma} F'loridana and others. I have got a Camera Lucida now and intend trying to draw with it. Anything I can do for you in this way will be cheerfully done." When he wrote again, towards the close of this year, some important events had happened, as shown by this letter:

\section{Spencer Fullerton Baird to Audubon}

Carlisle Nov. 4, 1846.

\section{Dear Mr. Audubon}

I have been intending to write for a long time, to find out how you all are at Minnie's Landing, and how yourself is particularly, but have put it off from time to time for various reasons. I can do so no longer, and must beg you to let me know these particulars.

Since my last visit to you, two pretty important events have happened to me. The first was getting married, the second, settling down steadily in my Professional chair. ${ }^{16}$ My wife is the only daughter of Col. Churchill Inspector Gen. of the Army, now with Gen. Wool in Mexico. She suits me exactly, being as fond of birds \& snakes \& fishes etc. as myself. I have even given her a lesson or two in taxidermy.

My duties as professor consist in teaching Animal Physiology, Natural Theology \& Mathematics. My salary is small $\$ 400$ but I hope will be larger hereafter. I have to work hard, but that is good for me.

Please let me know how the quadrupeds get along. Is the first vol. published? How does John get along in England? What has become of his Texas birds?

Please to tell me the address of your friend Ayres. I have been collecting fishes for some weeks, and wish to corre-

${ }^{16}$ In the summer of 1846 Baird's nominal position in Dickinson College had been changed to an active one by his election to a professorship of chemistry and natural history, and his marriage had followed in August. The college had about one hundred students enrolled at that time, and the grammar, or preparatory, school attached to it, about half as many more. See Ruthven Deane (Bibl. No. 51), The Auk, vol. xxiv, p. 65 (1907). 
spond \& exchange with him on this subject. I can send him a good many species.

Please give my love to all your kind family. My wife (to whom two years ago I gave a picture of yourself, as the most acceptable present) sends hers also, and desires exceedingly to see one to whom her husband owes so many obligations of every kind. Believe to be as ever

Yours most affectionately

SPENCER F. Baird.

Audubon's immediate reply was as follows: ${ }^{17}$

Audubon to Spencer Fullerton Baird

Minniestand.

Nov. 8th, 1846.

My dear Friend,

We were very happy to hear of your Success in obtaining a Professorship. I wish you had been more minute as to the amount of your Salary as I consider $400 \$$ as a very small sum. If you have not a house, fuel, and furniture, \&c \&c \&c to compensate for so small a sum, and having so much to perform for it. We are all glad that you have a good helpmate in the shape of a wife, and we would be very glad to have you under our roof, even now ; but as the winter is now fast approaching we hope to see you certainly some time next spring, or during the summer, as you know that then our place is worthy to reside at. The fishing is then Capital. The residence of our Friend, W. O. Ayers, is on Long Island, and I think that a letter addressed to him at Sag-Harbor, will be sure to be received by that good Friend of ours.

He will be glad to receive the collection of fishes which you have procured for him, and I know will be most happy to exchange for other fishes or subjects if you should desire any at his hands. Please to give your Dear Lady our best love, and congratulations on her having such a capitally perfect

${ }^{17}$ For this and the two following letters, see ibid., pp. 66-69. 
husband. We are all well at present. I have not done anything with the Birds which, indeed, my son Victor has sent to the Academy of Philadelphia. I suppose I need not look any more for a Black Fox in the flesh from you during the next winter.

Consider me always my Dear Friend,

Your most sincerely attached,

John J. Audubon.

Should you procure a black fox, be sure to forward him uncut to our office New York 78 John Street. Adieu, and God bless both you and your Dear Wife.

This is a mistake, I brought them back, V. G. A.

The letter press will be ready in a few days. I will forward a Copy to you to Philada. from whence you can no doubt easily get it. I will join my Father, dear Mr. Baird, in congratulations, and in sincere wishes for your happiness \& welfare.

Yours faithfully,

V. G. Audubon.

Victor Audubon's gift of the volume was acknowledged by Baird on January 19, 1847, when he said:

I have been trying for some time past to find time for writing and thanking you for the copy of the Viviparous text. Never had mortal man such a feast as $I$ in turning over the pages and reading the interesting and copious accounts of the habits of animals, many of which were unknown to me beyond the name. I was exceedingly gratificd by the kind terms I found myself mentioned throughout the book, more so than I deserve. Be assured that no effort of mine however humble shall be spared to assist in the perfecting a labor so stupendous and important as that in which you are engaged. Would that I could be of more substantial aid by sending half a dozen subscribers, I may do so yet, who knows. 
There was soon another matter of vital importance which Baird wished to announce to his friend, and, on February 8, he wrote Audubon:

Very much to my astonishment I received last Saturday a letter from Mr. Dana saying that he had written to Dr. Pickering that I would make a good curator of the Smithsonian institute, and advising me if I wished the place to write immediately to Prof. Henry and enclose my credentials. Now I would like the situation amazingly and write to ask you to make out a flaming recommendation for the place $\&$ send me as soon as possible. Say what you please about qualification \&c. I would be obliged to you for the exertion of any personal influence you may have on the board of Regents. When there I would hope to be materially useful to you in your labors.

This was followed, on February 11, by a cordial letter from Audubon, in which he said:

I am quite convinced myself that no one can easily be found so well adapted for such a trust as yourself and if my testimoney as to your knowledge and high character and industry, and your zeal in seeking a perfect acquaintance with the various branches of Natural History, and all the scientific and literary pursuits which have heretofore occupied you, may be of any service, please present this note to the Honorable Board of Regents, who I trust will receive it as an evidence of my ardent desire for your success, the more readily as I have the honor, I think, of knowing some of the Board personally.

Spencer Fullerton Baird's subsequent career, following his appointment as Assistant Secretary of the Smithsonian Institution in July, 1850, as successor to Professor Henry, its first Secretary, as the organizer of the United States National Museum and the Fish 
Commission, now the Bureau of Fisheries, as one of the ablest students of birds and fishes which the country has ever produced, as well as the friend of science and scientific men everywhere, is now well known, and has been ably set forth by his most recent biographer. ${ }^{18}$

John W. Audubon spent the winter of 1846-47 in London, where he was engaged in painting subjects for his father's work on the Quadrupeds. While he was

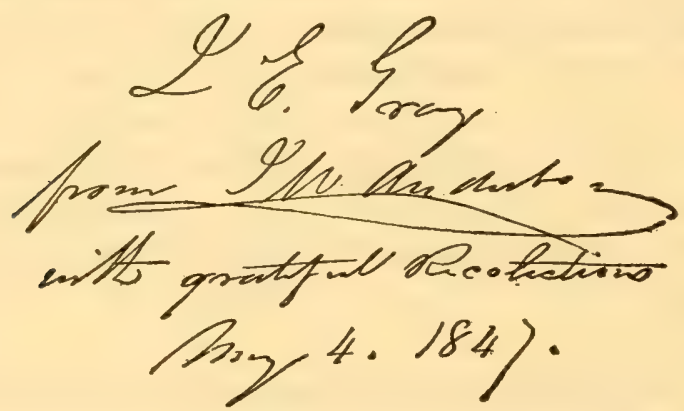

JOHN W. AUDUBON'S INSCRIPTION IN A COPY OF VOLUME I OF THE TEXT OF THE "QUADRUPEDS" (ENGLiSH EDITION) PRESENTED TO JOHN E. GRAY.

there, arrangements were made for the publication in that city of the first volume of the letterpress; this appeared in May, $1847,{ }^{19}$ closely following the American edition of the previous year, and it was the only European issue of the text of that work. At this time also John Audubon made the acquaintance of the distinguished zoölogist, John Edward Gray, then in charge of the great collections which were being brought together under his direction at the British Museum. Gray was asked to furnish descriptions of the animals which the younger Audubon had painted, but, as will appear from the following letter, he declined: ${ }^{20}$

${ }^{18}$ William H. Dall, op. cit., which see also for preceding extract.

${ }^{10}$ See Vol. II, p. 275; and Bibliography, No. 6.

${ }^{20}$ This hastily written note, possibly a duplicate of the one actually sent, was inserted in a copy of The Viviparous Quadrupeds of North 

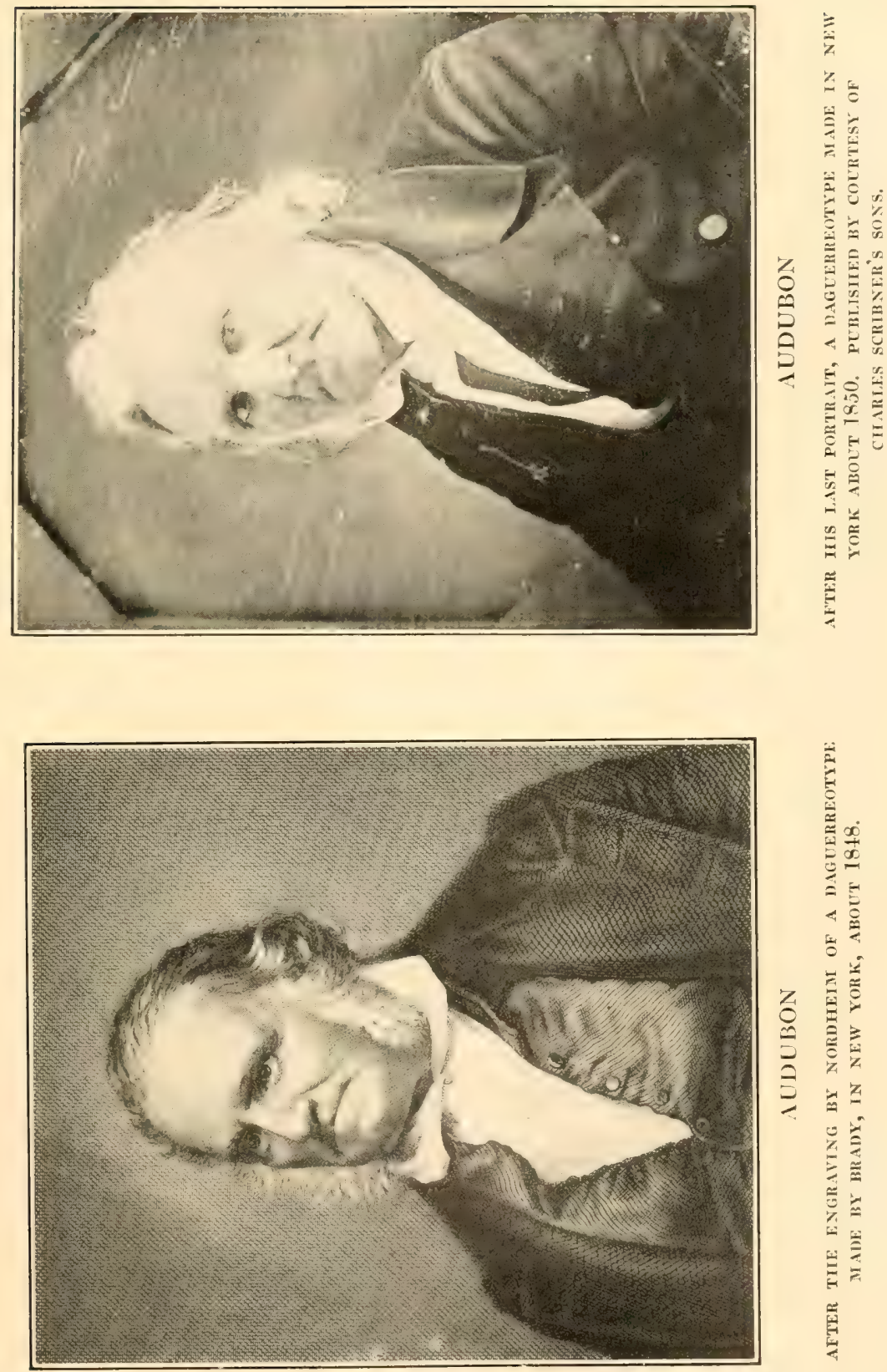



\section{John Edreard Gray to John Woodhouse Audubon}

4 May 1847

\section{My deAR Sir}

Brit. Museum

I am very sorry that I am so occupied that I cannot undertake to furnish you with the descriptions of the American Mammalia which you have figured here but I think you will find that Dr Richardsons descriptions are so accurate and detailed that you had better copy them for the work than have more imperfect descriptions by a less experienced and minute describer.

at the same time should Dr Bachman on composing the Work want any note or the distinction between any two species or the description of any one wh have not contained in Richardson Work \& he will write to me I shall have great pleasure in immediately replying to his request-

Wishing you and your family a pleasant voyage believe me Yours truly

$$
\text { J. E. GRAY }
$$

Bachman was married in $\mathbf{1 8 4 9}$ to Maria Martin, ${ }^{21}$ his former wife's sister, who had aided Audubon in drawing the accessories of his large plates. While engaged upon the Quadrupeds, he wrote to Victor Audubon, from Madison Springs, Georgia, on June 30 of that year, as follows: ${ }^{22}$

I began working four hours a day, now I can work for twelve. I shall lessen the hours, should I find my strength fail-

America (vol. i, London, 1847) which I purchased in London, August, 1913, and which bore this inscription, in autograph, on the title:

J. E. Gray.

from $J$ W. AuduBow

with grateful Recolections

May 4. 1847.

${ }^{21}$ Her assistance to Audubon was recognized in his dedication to her of "Maria's Woodpecker," Picus martina (see Ornithological Biography vol. v, p. 181).

${ }^{22}$ See C. L. Bachman, op. cit., p. 270. 
Dear Pis,

In lackery

my flater of two. qeacorufereg

Ifiud of hace ufe to to 16 plate 80 is to dany got to 19 up to q5 -

Sund henaberer

ch Iy of to 18 are hointing you will alelige me ky dendeng thene hy the levot fuowe of to go uncluosere

4 oblije yetescels

Waty yetox IF \%

$$
1846
$$

IETTER OF JOHN BACHMAN, NOVEMBER 7, 1846, ADDRESSED TO MR. GEORGE OATES, CHABLESTON, SOUTH CAROLINA. From the Jeanes MSS.

282 
ing. This is my tenth working-day. I have finished seventeen articles, and arranged notes for another. I have used as many of your notes as I could. Maria copies carefully. She lops off to the right and the left with your notes and mine: she corrects, criticizes, abuses, and praises us by turns. Your father's notes, copied from his journal, are valuable - they contain real information; some of the others are humbug and rigmarole; but you have done so well as to surprise us. . . .

I hope that if nothing untoward happens, the Second Volume will be finished in a month, and the Third Volume next winter.

About thirty years later, when Victor Audubon's sister-in-law ${ }^{23}$ was making a disposition of his literary effects, a bundle of manuscripts was saved and given to Mr. George Bird Grinnell. Included in it were a number of Audubon's letters, which are now reproduced, as well as a considerable section of the printer's copy of The Viviparous Quadrupeds of North A merica, Volume $\mathbf{I}$; this was in various handwritings, including little of Bachman's himself, much of Victor's and of John G. Bell's; a little of this copy also was made by the second Mrs. Bachman and by other and unknown hands, possibly those of one of Bachman's daughters and of his son-in-law, Reverend John Haskell, all of whom are known to have assisted in this labor.

When we recall the disadvantages under which John Bachman worked, it must be acknowledged that he was deserving of all the credit which he received. Born of Swiss and German stock at Rheinbeck, New York, in 1790, he clearly remembered walking in the mock funeral procession that was held in his village when the country was mourning the death of Washington in 1799 .

${ }^{23}$ Miss Eliza Mallory, who in 1874 was living in the Victor Audubon house. 
From early boyhood he was an ardent enthusiast in the study of nature, at a time when such studies were generally frowned upon in country districts as not only idle but positively harmful. He trapped the beaver, and from the sale of its skins was able to make his first purchase of books on natural history. While a young man he became acquainted with Alexander Wilson and learned to know him well, having joined him in field excursions and collected birds for him in northern New York; on Wilson's recommendation he succeeded both him and his nephew, William Duncan, in the Elwood School, at Milestown, Pennsylvania, where he taught for a year. While there, a youth of barely fifteen, he was invited, no doubt through the influence of Wilson, to meet Alexander von Humboldt at a dinner given in honor of the great traveler at Philadelphia in $\mathbf{1 8 0 4}$. From a pastorate in Shagticoke, New York, Bachman in 1815 went to Charleston, South Carolina, where he presided over the Lutheran church for nearly sixty years, and became thoroughly identified with the South. Beloved as few men ever are in their community, he was widely honored for his attainments in natural science.

In an address on Humboldt, dictated by Bachman when in his eightieth year, and too feeble to deliver it himself, he alluded to the event noticed above to show "how scanty, in those days, was the material in natural science." Among the few naturalists who were present on the occasion of the dinner, which was held in Peale's Museum, were, he said: ${ }^{24}$

the two Bartrams, Wilson, the ornithologist, Lawson, his engraver, George Ord and a few others. . . . Few speeches were

${ }^{24}$ See C. L. Bachman, op. cit., p. 391. John Bachman died at Charleston, February 24, 1874. 
made and those were short-there was no formality. . . Humboldt was then, as he was afterwards, in every society, "the observed of all observers" .. I I saw him every day during the few days he remained in Philadelphia. He inserted my name in his note-book, and for the last sixty years we corresponded at long intervals. . . It would be very gratifying to me, and interesting to your societies, if I could have exhibited to you his autograph in some of his letters; but, alas! my whole library and all my collections in Natural History, the accumulation of the labors of a long life, were burnt by Sherman's vandal army, and, with the exception of a single letter, which, by accident, fell into the hands of another member of my family, I possess no memorials of one who condescended to speak of me as a friend.

As we have noticed, Audubon's large illustrations of the Quadrupeds were completed in 1846; this marked the ebb tide of his powers, and his son, John, who had painted nearly one-half of the originals of the large plates, like Victor, continued to aid Bachman in the prosecution of that work. The first number of this lithographic series was introduced by the common American wildcat, or Lynx rufus, in three-quarters natural size, followed by the proverbial ground hog, "Maryland marmot," or woodchuck, shown in both young and adult state, in the size of life. Plate No. 4 reproduced an exquisite drawing of four Florida rats climbing over a pine branch. Some of the elder Audubon's plates of squirrels are particularly fine and recall the best of his more famous bird pictures; the gray fox (No. 3, Plate xxi) is sniffing at a feather blown from a farmer's yard; in another drawing a rascally old black rat and its three young ones are robbing a hen's nest and breaking up the eggs; Hudson Bay squirrels reach after hazel nuts which hang in clusters from green boughs above; 
opossums, with sardonic grin, are making for the ripe, orange fruits of the persimmon, holding to the branch with their rat-like, coiled tails; the swift fox (Vulpes velox) sits on the ground, barking like a dog, with head up-turned, while the better known red fox (No. 18, Plate lxxxvii) struggles in an old-fashioned steel trap, the toothed jaws of which have gripped a paw above the heel, and you observe that his tail is where, in the circumstances, it is bound to be-between his legs. While many of these plates are of the highest degree of excellence, the colors are apt to be too vivid and the execution is far from uniform.

Thomas M. Brewer, a valued friend and correspondent, ${ }^{25}$ in response to an urgent request, "ere it be too late," paid a visit to the famous naturalist on the Fourth of July, 1846, of which he has given this record: ${ }^{26}$

I found him in a retreat well worthy of so true a lover of nature. It was a lovely spot, on a well-wooded point running out in the river. His dwelling was a large old-fashioned wooden house, from the veranda of which was a fine view, looking both up and down the stream, and around the dwelling were grouped several fine old forest trees of beech and oak. The grounds were well stocked with pets of various kinds, both birds and beasts, while his wild feathered favorites, hardly less confiding, had their nests over his very doorway. Through the grounds ran a small rivulet, over which was a picturesque rural bridge.

The patriarch ... had greatly changed since I had last seen him. He wore his hair longer, and it now hung in locks of snowy whiteness over his shoulders. His once piercing gray eyes, though still bright, had already begun to fail him. He could no longer paint with his wonted accuracy, and had at last, most reluctantly, been forced to surrender to his sons the task of completing his Quadrupeds of North America. Sur- 


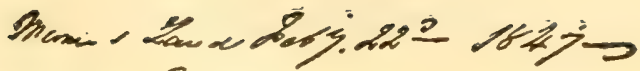

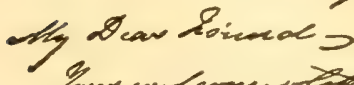

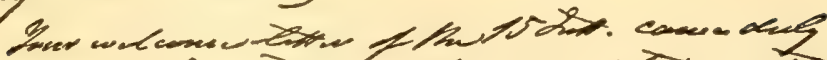

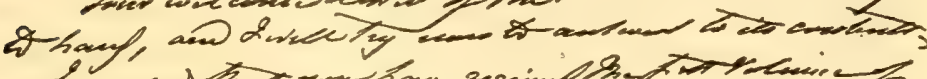

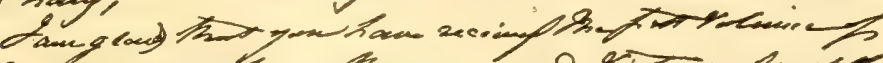

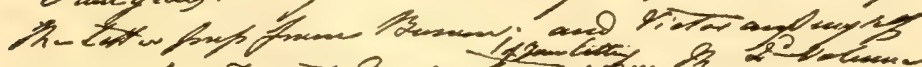

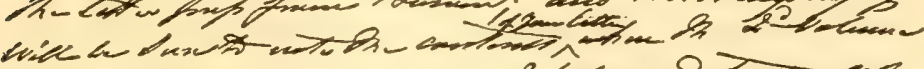

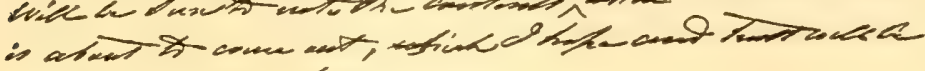

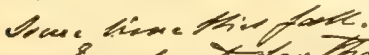

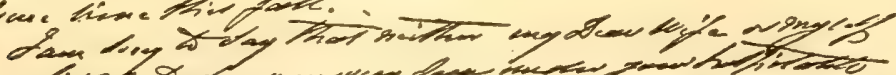

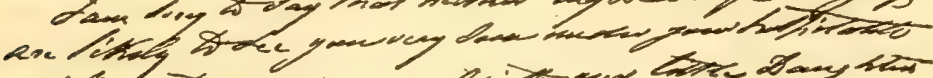

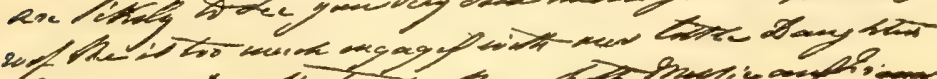

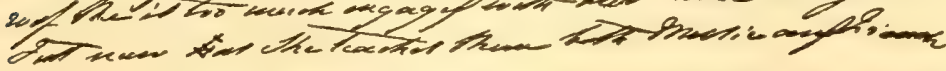
ency deny fthementis

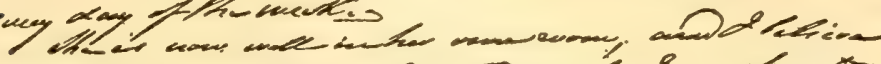

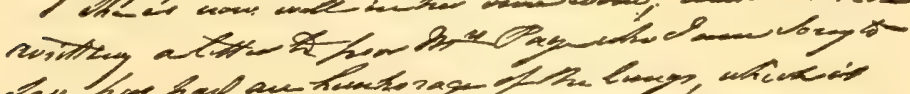

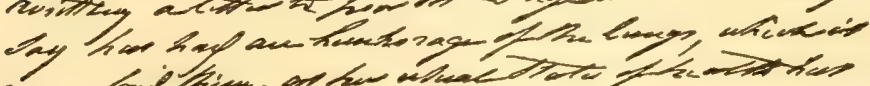

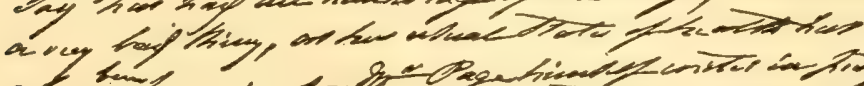

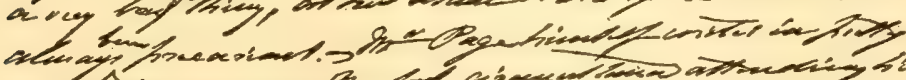

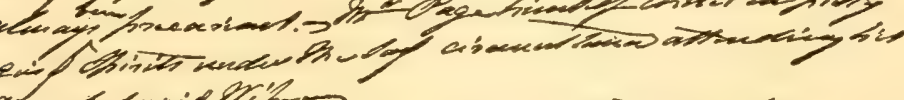

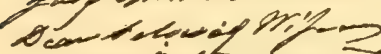

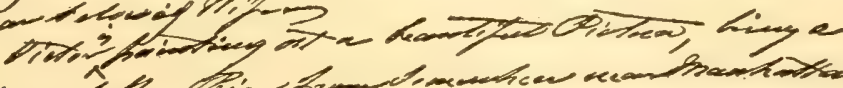

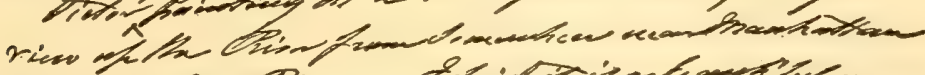

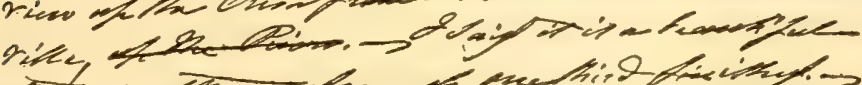

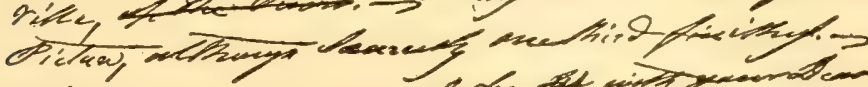

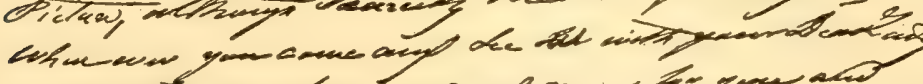

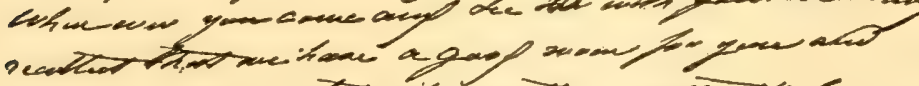

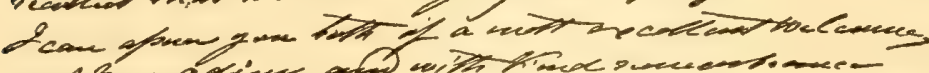

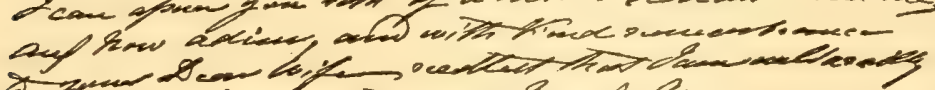

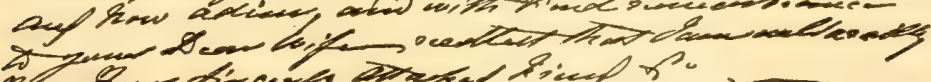

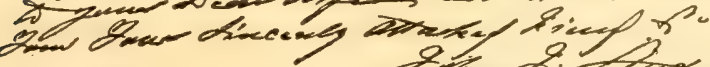

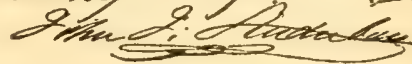

AUDUBON'S LAST (?) LETTER TO EDWARD HARRIS, FEBRUARY $22,1847$. From the Jeanes MSS. 
rounded by his large family, including his devoted wife, his two sons, and their wives, his enjoyment of life seemed to leave little to him to desire. He was very fond of the rising generation, and they were as devoted in their affectionate regards for him. He seemed to enjoy to the utmost each moment of time, content at last to submit to an inevitable and well earned leisure, and to throw upon his gifted sons his uncompleted tasks. A pleasanter scene or a more interesting household it has never been the writer's good fortune to witness.

Audubon's last (?) letter to Edward Harris, here reproduced, is dated at "Minnie's Land, Feby 22, 1847," and refers to the letterpress of the Quadrupeds. His last published letter to Baird, in which he recommended him to the Board of Regents of the Smithsonian Institution, ${ }^{27}$ was written at "Minnie's Land, Feb. 11, 1847." In Spencer F. Baird's last published letter ${ }^{28}$ to him, dated at "Carlisle April 24, 1847," he refers to "a fine specimen living of a Red Fox," and added: "If you want him let me know immediately and I will send him on immediately." On July 16 of that year Baird entered this note in his diary: "Went to Mr. Audubon's by stage. Found him much changed."

While Audubon never became blind, as has been erroneously stated, it troubled him to use glasses, and when from failing powers he could no longer paint, his heart seemed broken. Like Jonathan Swift, who compared his own case with that of the proud forest tree whose withering top showed to every passerby the first sign of decrepitude, so the mind of Audubon gave way before his splendid physique utterly broke down.

Bachman, who visited his old friend in the spring of

${ }^{27}$ See Vol. II, p. 279.

${ }^{28}$ See Ruthven Deane, loc. cit., p. 70.

${ }^{20}$ See William H. Dall, op. cit., p. 155. 
1848, has given this picture of the naturalist's household in a letter ${ }^{30}$ from "Minnie's Land, May 11, 1848":

I found all well here, as far as health is concerned. Mrs. Audubon is straight as an arrow, and in fine health, but sadly worried. John has just come in from feeding his dogs. Audubon has heard his little song sung in French, and has gone to bed. Alas, my poor friend, Audubon, the outlines of his countenance and his form are there, but his noble mind is all in ruins.

The following letter was written by Victor Audubon to his father-in-law, John Bachman, before February 8,1849 , when his brother started on the ill-fated expedition to which he refers:

My brother will leave in a few days for California, he will be absent, perhaps for eighteen months.

This journey is undertaken with the hope that he may be able to get gold. What may be the result, God only knows. John will be accompanied by Col. H. L. Webb, as military leader; the party consists of about eighty picked men. One of Dr. Mayer's sons wished to go with John, but unluckily, his application came after the party was made up, so they could not take him.

I should like much to see you all, but now it will be impossible for me to go so far from home.

My dear old father is apparently comfortable, and enjoys his little notions; but requires constant care and attendance; the rest are well. Your granddaughters are growing finely, and are well educated; soon we shall call in a "Maitre de danse," to polish them up and improve their understanding.

I am just about to start for Washington, to get letters from the President for John and I will try and see the collection brought back by the exploring expedition, including the p. 274 .

${ }^{\text {so }}$ For this and the following letter, see C. L. Bachman, op. cit., 
famous Black-tail Deer. I am in a great bustle, the office is full of Californians.

The California party, which eventually consisted of nearly one hundred young men, sought to reach the goldfields by way of Texas, Mexico and Arizona; attacked by cholera in the valley of the Rio Grande and deserted by their leader, a remnant of the company chose in his stead young Audubon, who bravely conducted them to their destination. John Audubon returned in the following year, after thirteen of the members of the party and $\$ 27,000$ had been lost in the venture.

Like a patriarch of old, as a friend had once pictured him, Audubon passed the end of his days surrounded by loving and able retainers, who, like "ministers of state," were only too glad to execute his every wish. Distinguished and handsome in age, appearing to many older than he actually was, for years his snowy locks and benign countenance attracted every passer on the street, and for each he had a friendly look, word, or greeting, until in him were fulfilled the words of the prophecy: "When thou wast young, thou girdedst thyself and walkedst whither thou wouldest; but when thou shalt be old, thou shalt stretch forth thy hands, and another shall gird thee, and carry thee whither thou wouldest not." On the 27th of January, 1851, Jean Jacques Fougère Audubon died, before attaining his sixtyseventh year, "as gently as a child composing himself for his beautiful sleep." 


\section{CHAPTER XXXVI}

\section{AFTERWORD: AUDUBON'S FAMILY IN AMERICA}

Bachman completes his text on the Quadrupeds-Victor Audubon's success in canvassing-John Woodhouse Audubon's family-New houses at "Minnie's Land"-Second octavo edition of the Birds-Victor Audubon's illness and death-Attempt to reissue The Birds of America in America-The residual stock of this imperfect edition-Death of John Woodhouse Audubon-His career and work as an artist and field collector-Mrs. Audubon resumes her old vocation-Fate of "Minnie's Land"-Death of Mrs. Audubon-Her share in her husband's fameStory written on Audubon's original drawings-Fate of the original copper plates of the Birds-A boy comes to the rescue- "Minnie's Land" today-The "Cave" - A real "Audubon Park."

After the death of the elder Audubon, his sons, under the leadership of Bachman, continued the work on the Quadrupeds until the third and last volume of the letterpress was completed in 1852. On March 13 of that year Bachman wrote to Edward Harris: ${ }^{1}$

Rejoice with me, the book is finished. I did not expect to have lived to complete it. But Victor Audubon came on, and I made him hold the pen, while I dictated with specimens and books before me, and we went on rapidly; we worked hard, and now we are at the end of our labors. I have, at last, prevailed on them to give the Bats. At the end of the work, I intend to give a synopsis and scientific arrangement of all our American species, including seals, whales and porpoises.

${ }^{1}$ See C. L. Bachman, John Bachman, D.D., LL.D., Ph.D. (Bibl. No. 191), p. 276. The suggestion made to Mr. Harris was adopted, which accounts for the six colored plates inserted in the third volume of the text; the "Large Work" referred to the folio plates without accompanying text, the "Small," to the first composite edition of both text and plates; see Bibliography, Nos. 5-7. 
This will be included in the letter-press of the Third Volume.

Here I will venture to consult you in regard to the publication of additional plates of species, not figured in the Large Work. A very small Arvicola and Shrews, we may not obtain, and they cannot be figured; but nearly all are within our reach. Some of the subscribers have bound up their plates, and there cannot be a sufficient number to make even half of another Volume. I propose, as all these figures will be contained in the Small Work, that they should be inserted in the letter-press of the Large Work, so that subscribers, by merely paying the cost of the small plates, would have the work complete-what do you think of this?

What do you think of Victor's obtaining one hundred and twenty-nine subscribers in about three days, and $I$ think he will double the number next week; so, if the "Large Work" will not pay, the "Small" one, and this is large enough, is sure to do it.

When Victor was canvassing the South for the second or composite edition of this work, Bachman wrote to a friend in Savannah, on March 25, 1852: ${ }^{2}$

My son-in-law, Victor G. Audubon, is on a rapid visit to the South, and has a week or two to spare, which he is desirous of devoting to the obtaining of subscribers to the "American Quadrupeds." The Work (Miniature) will be complete in about thirty numbers, furnished monthly at $\$ 1.00$ per number.

The figures were made by the Audubons, and the descriptions and letter-press were prepared by myself.

I have no pecuniary interest in this work, as I have cheerfully given my own labors without any other reward than the hope of having contributed something toward the advancement of the cause of Natural History in our country. I am, however, anxious that the Audubons should, by a liberal sub-

'See C. L. Bachman, op. cit., p. 278. 


\section{AUDUBON'S FAMILY IN AMERICA 293}

scription, receive some remuneration for the labors and heavy expenses incurred in getting up this work. Of the character of the work it does not become me to say much. I will only add that in my department is summed up the result of investigations pursued through a long life, and, I think, the figures have never been equalled in any publication either in Europe or America.

May I bespeak from you a little aid to my esteemed son-inlaw, Mr. Audubon, in assisting him to procure subscribers. He is a stranger in your city; his time is limited, and his stay among you will necessarily be short.

By the aid of two friends here, he obtained two hundred and fifty subscribers in a few days.

On the 9th of April Bachman wrote to his son-inlaw: "Will you not return to New York by the way of Charleston and sail from here, take a manuscript volume in your pocket, and four hundred good and true names on your list?"

The reception accorded to the illustrations and text of this work had encouraged the brothers to do for the Quadrupeds what their father, with their aid, had so successfully accomplished for the Birds, by presenting text and plates, as Bachman said, in "Miniature." In this they succeeded as admirably as before, John reducing all the large plates, by the aid of the camera lucida, for the octavo edition which was published in $\mathbf{1 8 5 4}$.

The following historical evidence of the appreciation which Audubon's works have received at the hands of the National Government I owe to Mr. Ruthven Deane, to whom the reader of these pages is already indebted for many illuminating facts. Dr. Theodore S. Palmer was recently inspecting governmental records at Washington, when he accidentally came upon the following entry: 
Chap. CXXIX.-AN act making appropriations for certain Civil Expenses of the Government for the Year ending the thirtieth of June, eighteen hundred and fifty-seven.

To enable the Secretary of State to purchase one hundred copies, each, of Audubon's "Birds of America" and "Quadrupeds of America," for presentation to foreign governments, in return for valuable works sent by them to the Government of the United States, sixteen thousand dollars. [Act of August 18, 1858 (LL State., 90).]

In John Woodhouse Audubon's family there were two sets of children, two by his former wife, Maria $\mathbf{R}$. Bachman, and seven by Caroline Hall, to whom he was married on October 2, 1841. Victor Gifford Audubon, who had no children by his first wife, May Eliza Bachman, was married on March 2, 1843, to Georgiana Richards Mallory, of New England, and six children were born to them between 1845 and 1854. Of the naturalist's fifteen grandchildren, six are believed to be now living (1917). ${ }^{3}$

In 1852-3 Audubon's sons built houses for their

3John W. Audubon's children by Maria Bachman were: (1) Lucy Audubon (Mrs. De Lancey Barclay Williams), 1838-1909; (2) Harriet Bachman Audubon, 1839-1933; by Caroline Hall, who died in 1899: (3) John James Audubon, 1842 (lived one day); (4) Maria Rebecca Audubon, 1843-1925; (5) John James Audubon, 1845-1893; (6) William Bakewell Audubon, 1847-1932, who emigrated to Australia, where he engaged in sheep-raising, and had two children, Leonard Benjamin and Eleanor Caroline Audubon; Leonard Benjamin Audubon (born in 1888) fought in the World War with the 55th Battalion of the Australian contingent, and in the spring of 1917 he was promoted from the ranks "on account of great bravery under unusual conditions"; if still living, he is the sole male representative of the American branch of the Audubon family; (7) Jane Audubon, 1849-1853; (8) Florence Audubon, 1853- ; (9) Benjamin Phillips Audubon, 1855-1886.

Victor G. Audubon had six children by his second wife, Georgiana R. Mallory, who died in 1882: (1) Mary Eliza Audubon, 1845- ; (2) Rose Audubon, 1846-1879; (3) Victor Gifford Audubon, 1847-1915; (4) Delia Talman- (Mrs. Morris Frank Tyler), 1849- ; (5) Lucy Bakewell Audubon, 1851-1898; and (6) Anne Gordon Audubon, 1854-1907. 


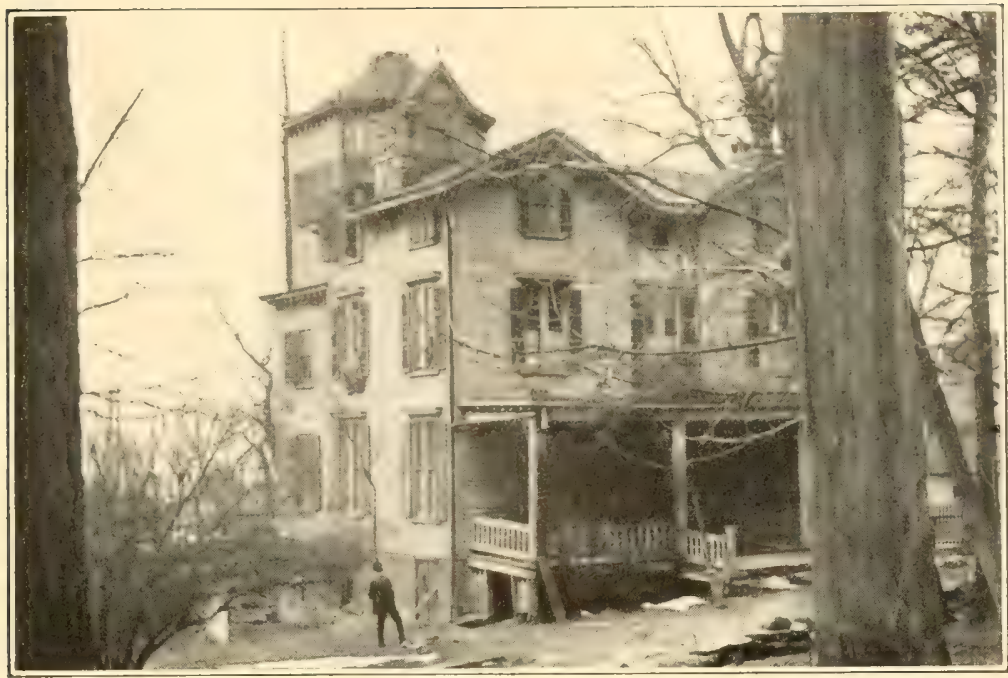

HOLSE FORMERLY BELONGIXG TO VICTOR GIFFORD AUDUBON, EAST FRONT, AS IT APPEARS TO-DAY; MRS. JOII JAMES AUDCHX KEPT HER PRIVATE SCHOOL

IS THE CORNER ROOM OY THE SECOY1) FLOHR.

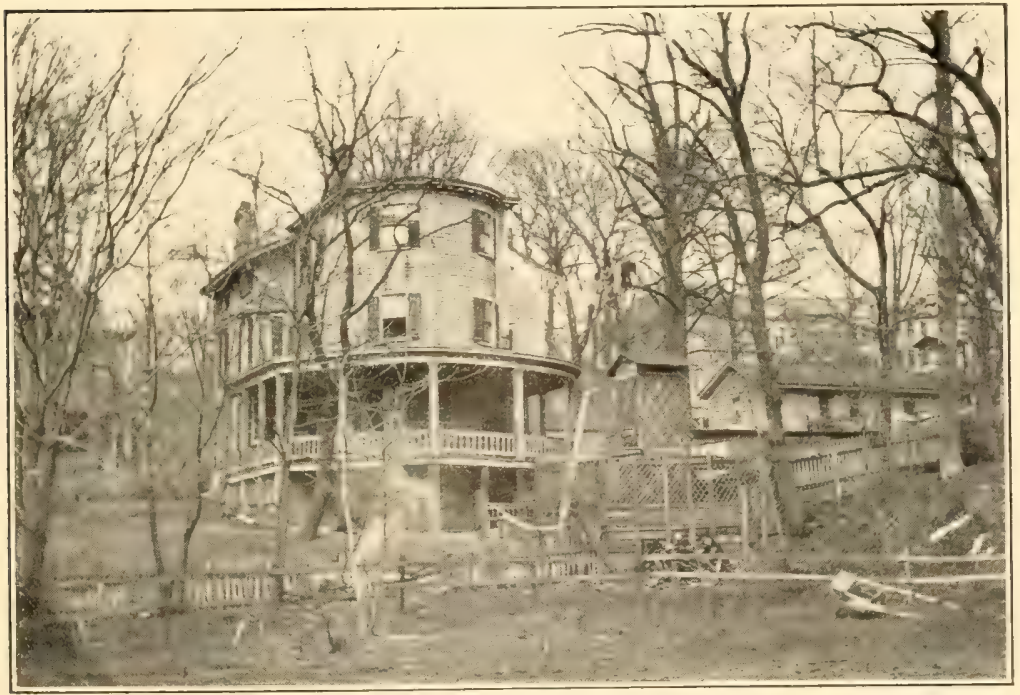

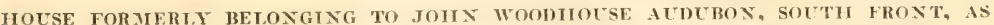
IT APPE.ARS TO-DAY; AT TIE RICHT IS "THE CAIE," WHERE TIIE COPPER PI.ITES OF "THY BIRHS OF AMLRICI" WERE STORED. 

growing families on their mother's estate; Victor's was placed just north of the original homestead, and John's not far away. On the slope behind John Audubon's house, a small building, later known as the "Cave," was specially constructed for the safer keeping of the famous copper plates, which had already passed through fire, ${ }^{4}$ and not wholly unscathed. Mr. John Hardin, now (1915) a serene and clear-eyed man of eighty-four, who settled in that neighborhood in 1852 and who was intermittently employed by the younger Audubons for a decade, has told me that he boxed with his own hands all of the copper plates, after wrapping each in tissue paper, and stored them in that building; whenever John Audubon wanted a plate, John Hardin would go to the "Cave" and get it for him.

In 1856 Victor Audubon published a second reduced edition of his father's Birds of America, in which the text and plates of the first octavo were reproduced with little or no change. At about that time Victor suffered an injury to the spine, ${ }^{5}$ and after 1857 he was completely invalided; he died in his own home, August 18, 1860.

To quote the daughter of John W. Audubon: ${ }^{6}$

During this long period of my uncle's illness all the care of both families devolved on my father. Never a "business man," saddened by his brother's condition, and utterly unable to manage, at the same time, a fairly large estate, the publication of two illustrated works, every plate of which he felt he

${ }^{4}$ See Vol. II, p. 267.

${ }^{5}$ Due, it was believed, to a fall into the "well" (now guarded by an iron rail), which led to a basement window of his house, though one who knew John W. Audubon well, said that Victor's illness resulted from a fall from a railroad train; see Jacob Pentz (Bibl. No. 81), Shooting and Fishing, May 11, 1893.

'Maria R. Audubon, in biographical memoir of her father in Audubon's Western Journal, 1849-1850 (Bibl. No. 219). 
must personally examine, the securing of subscribers and the financial condition of everything - what wonder that he rapidly aged, what wonder that the burden was overwhelming! After my uncle's death matters became still more difficult to handle, owing to the unsettled condition of the southern states where most of the subscribers to Audubon's books resided, and when the open rupture came between north and south, the condition of affairs can hardly be imagined, except by those who lived through similar bitter and painful experiences.

In 1858 or 1859 John W. Audubon entered upon an ambitious project, which the outbreak of the Civil War, aided, it is believed, by the unscrupulous dealings of business partners, rendered disastrous. In association with Messrs. Roe Lockwood, \& Son, New York, and the lithographers, Messrs. J. Bien \& Company, Number 180 Broadway, with whom considerable money had been invested, a second and American edition of his father's great folio on The Birds of America was attempted. An atlas of 106 double elephant plates, reproduced in colors on stone with slight but numerous changes from the original copper plates, was completed as Volume $I$ in $1860 ;^{7}$ the war, which broke immediately afterwards, completely ruined the enterprise, so that but few copies of the work were dispersed and an immense stock of plates was rendered useless; the burden of debt was undoubtedly increased by the issue of seven octavo volumes of text. ${ }^{8}$

Many years later, hundreds of persons who knew of Audubon's work only through its great reputation, and

${ }^{7}$ For fuller details, see Bibliography, No. 9, and for Prospectus of this work, Appendix III, No. 3.

${ }^{8}$ For conflicting accounts of this text, see Bibliography, No. 10, and for a definitive statement, Appendix III, No. 3. Miss Maria R. Audubon has told me that during the War, the Bien firm issued a patriotic poster, showing an eagle, taken from one of her grandfather's original drawings, and the American flag; it was thought that a large number of copies were sold. 
who had never learned to discriminate between a handcolored copper-plate engraving and a lithograph, were deceived by an adroit, but essentially spurious advertisement of these inferior reproductions when they were being exploited by a firm of Boston book dealers. The original bulk of these large lithographs must have been vast indeed, if the following story, which was attributed to a member of the firm in question, be true: "We bought the entire stock of those plates, many years ago," so this man is reported to have said, "and, though the sales of every succeeding year since have been sufficient to cover the original cost, the number of plates has not appreciably diminished."

When this larger venture failed, one of the publishers, who was not satisfied with the surplusage of books and plates left on his hands, is said to have placed encumbrances upon the Audubon estate. At about this time John W. Audubon's health broke down; "Worn out," as his daughter has said, "in body and spirit, overburdened with anxieties, saddened by the condition of his country, it is no matter of surprise that my father could not throw off a heavy cold which attacked him early in 1862." He died at the age of forty-nine, on the 18th of February of that year.

John Woodhouse Audubon, like his brother, Victor, had inherited decided artistic abilities, and from a youth had been his father's assistant, field companion and friend. Victor Audubon, on the other hand, was never a field collector, but aided his father more in a financial and secretarial capacity. Both in adult life were fond of music and good cheer, and at one time John was probably as devoted to adventure and sport as his father had ever been in his palmiest days. One of his youthful

${ }^{\bullet}$ Maria R. Audubon, op. cit. 
pranks is thus guardedly referred to by the senior Audubon when writing at American Harbor, on the coast of Labrador, June 25, 1833: ${ }^{10}$ "The young men, who are always ready for sport, caught a hundred codfish in half an hour, and somewhere secured three fine salmon, one of which was sent to the 'Gulnare' with some cod." Whether the fishermen at American Harbor, who had obstinately refused to sell, ever missed those fine salmon from their pounds, is not recorded. Another adventure has been related by Mr. Fraser, ${ }^{11}$ whose family was on intimate terms with the Audubons and MacGillivrays at Edinburgh, when John Audubon, John MacGillivray (William MacGillivray's eldest son), and himself were caught in the Ravelston woods while shooting birds; the boys, he said "were rather roughly handled," but got off by giving up their guns.

Under his father's tuition. John Audubon became an observant and self-reliant collector in the field, and an animal painter and draughtsman of no mean powers. At twenty-one, as we have seen, he accompanied his father's expedition to Labrador, was with him and Harris in Florida and Texas in 1837, made successive visits to England, and traveled again in Texas and in Mexico, all in the interests of his father's works. He painted nearly one-half of the large plates of the Quadrupeds of North America, besides reducing all the drawings for the smaller editions of the Birds and Quadrupeds, an enormous labor in itself, representing the redrawing, with numerous alterations, of 655 elaborate octavo plates. After his return from California in 1850, he began to bring out an account of his western travels,

1) Maria R. Audubon, Audubon and his Journals (Bibl. No. 86), vol. i, p. 380 .

"See William MacGillivray, A Memorial Tribute to William MacGillivray (Bibl. No. 211), p. 40. 
projected for ten monthly numbers, but this never advanced beyond the first part. ${ }^{12}$

If not a "business man" by instinct or training, John Audubon in emergencies could turn his hand to many things. For a time he superintended the building of houses, including his own and Victor's, which were completed in 1853, as well as another that was built on the Audubon estate for Mr. Hall, a brother-in-law; he also took charge of lighting the streets, and at another time was superintendent of a quarry in Vermont. "He was a bluff, gruff, but friendly man," writes George Bird Grinnell, ${ }^{13}$ and was always willing to talk about birds, mammals, or, indeed, any natural history object, to any boy who asked him questions." On the other hand, an ardent sportsman, who had lived with the family for years, ${ }^{14}$ has described him as a lovable companion, "genial in speech, full of anecdote, and a capital conversationalist . . . ; in person of more than median height, and of commanding appearance, his face told plainly of the humanity of the man; he was as tender-hearted as a girl, and his expressive voice could command any key of which the vocal organs were capable; to the last he retained the Southern habit of softly clipping the ends of words."

John Woodhouse Audubon will be remembered chiefly as his father's aid and companion, although in his Western Journal, ${ }^{15}$ written in his thirty-eighth year but not published until forty-two years after his death, he has left a record of which anyone could be rightfully proud.

Mrs. John James Audubon was very active in body

${ }^{12}$ See Bibliography, Nos. 174 and 219.

${ }^{13}$ See Bibliography, No. 54.

14 Jacob Pentz (Bibl. No. 81), loc. cit.

${ }^{15}$ See Bibliography, No. 219. 
and mind for a long period after her husband's death, and in 1857, when in her seventieth year, she returned in a degree to her old vocation of school teaching, which had been so successfully followed in Ohio and Louisiana when her husband was on the threshold of his extraordinary career. Her pupils now consisted of some of her numerous grandchildren and a few others drawn from the neighborhood; among the latter was the well known writer and father of the original Audubon Society, George Bird Grinnell, who pointed out to me the room in Victor Audubon's old house where his revered and venerable teacher had gathered her little flock. "She loved to read, to study, and to teach," said one who had known her, and "she knew how to gain the attention of the young, and to fix knowledge in their minds. 'If I can hold the mind of a child to a subject for five minutes, he will never forget what I teach him,' she once remarked; and, acting upon this principle, she was as successful, at three score and ten years, in imparting knowledge, as she had been in early life when she taught in Louisiana."

Mrs. Audubon's own house was rented and eventually sold. Meanwhile, it seems, she lived for a number of years with the family of her eldest son, and it was at Victor's house, as just noticed, that she started a small school. Finally, in 1863, at the age of seventy-five, bereft of children and fortune, she left the scenes of her once happy home, then "Minnie's Land" no longer, and for a considerable period lived with a granddaughter at Washington Heights, as that section on the river, including Carmansville, came to be called, and a little later at Manhattanville, a short distance below; there at the home of the Reverend Charles Coffin Adams, who prepared the original draft of the Life of her husband, the 


\section{AUDUBON'S FAMILY IN AMERICA 301}

history of which has been given, ${ }^{16}$ she passed a number of years after 1865 .

In a letter written to a relative from "Washington Heights, N. Y., July 11, 1865," Mrs. Audubon spoke thus of the present, while memories, not untinged with sorrow, filled the retrospect:

We have passed through a very cold winter which tried both my Granddaughter . . . and myself much. I have hoped until I almost despair that [she] would have a short Holiday so that we could go up to Hudson for a week and see you all and mingle with those who sympathize and care for us, but in a Boarding house, one seems a stranger in the world, and as I pass my days alone generally from breakfast till our dinner hour six o'clock evening when [my granddaughter] comes home from her music Pupils of whom she has now ten, and from that time I am glad when she is invited out to refresh her mind.

I seldom leave home but to go up to see my other Grand Daughter Lucy Williams, but being sixteen miles off we do not go there often....

I have heard from my Sister Gordon lately of Orleans, she has her Son at home! but they are likely to lose all their Property on account of Sister's Son having been engaged in the Confederate War. It does seem to me . . as if we were a doomed family for all of us are in pecuniary difficulty more or less. As to myself $I$ find it hard to look back patiently upon my great ignorance of business and the want of a wise adviser who I now find could have saved me half the property I have under errour and ignorance sacrificed and have just enough left to keep us but not enjoy life by any travelling about in this beautiful World. I sat on Sunday night after Church on the Piazza contemplating the beautiful Moon \& its Creator, and I cannot yet say I wish to leave it, notwithstanding all my disappointments and mortifications. Excuse this

${ }^{16}$ See Chapter I. 
long detail about myself. I cannot help looking back as well as to the present and future.

After Mrs. Audubon had passed her eightieth year she left New York and again made her home in the West. In 1874, when with a granddaughter at Louisville, she dictated and signed the following letter to a gentleman who had asked for an autograph of her husband:

\section{Mrs. Audubon to William R. Dorlan}

Louisvile Jan. 30 1874

Mr. Wm. R. Dorlan

DEAR Sir

I regret that your letter of Jan. 10th has remained so long unanswered, but my granddaughter who usually writes for me, is so constantly occupied with her pupils that until to-day she has not been able to find time to write to you. I regret that I cannot give you a letter of my husband John James Audubon with the autograph attached.

The enclosed, the best $I$ have to send you is one from which the autograph and a portion of the letter were cut off many years ago.

With many regrets that I cannot more fully grant your request

I am dear Sir

Yours respectfully,

\section{Lucy Audubon}

Mrs. Audubon's closing days were spent at the home of her sister-in-law, Mrs. William G. Bakewell, at Shelbyville, Kentucky, where she died, with her mental faculties unimpaired, at the age of eighty-six, June 18, 1874, having outlived this sister-in-law and her younger sisters, Mrs. Alexander Gordon, of New Orleans, 
and Mrs. Nicholas Augustus Berthoud, of St. Louis.

Not long after John W. Audubon's death, his family disposed of their house on what had been the "Minnie's Land" estate, and lived successively at Harlem, New Haven, Connecticut, and Salem, New York, where Mrs. John W. Audubon died, and where her daughter, Maria Rebecca, the biographer of her father and grandfather, with a sister, still resides. Victor Audubon's family, with some of their kinsfolk, remained at the Hudson River place, which was included in the section known as "Audubon Park," until May, 1878, when they took a house in New York, where Mrs. Victor Audubon died in 1882.

A brother of Mrs. Victor Audubon, Mr. H. C. Mallory, in writing to a friend in Buffalo from "Audubon Park, August 31, 1874," said that it was a source of deep regret to Mrs. John James Audubon that her last years were not passed with them, under the shadow of her old home on the Hudson; and he continued: "She was a kind and good friend, very intelligent, and much beloved here; I remember her telling a young lady, who asked her if she had read some fashionable novel, that she had no time; 'at my age,' said she, 'I must make the most of my time.' As she was a wide reader, it was a great trial when, in age, her eyesight completely failed her. The minister who pronounced her eulogy ${ }^{17}$ said:

Many of you can recall that aged form and benignant countenance, as she moved along these streets upon errands of usefulness and benevolence, with benedictions on her tongue, and smiles that were a blessing to all who met her.

${ }^{17}$ Charles Augustus Stoddard; for his memorial sermon, see Bibliography, No. 178. In the absence of the rector of the Church of the Intercession, the pastor of the Washington Heights Presbyterian Church was called to officiate at the funeral of Mrs. J. J. Audubon, June 22, 1874. 
Madame Audubon interested herself in all that pertained to the welfare of the neighborhood where she lived. Although it was not without a pang that she saw her sylvan home invaded by the growth of the city, and all old associations broken up, she did not treat those who came to live near her as strangers. She had a large and generous heart, and with her husband had always exercised a liberal hospitality and hearty kindness towards all. In prosperity and adversity she was equally sincere and humble, a friend of all worthy people. . . .

Mrs. Audubon, during the period of her husband's greatest activity, had traveled much and met people distinguished in every walk of life. If, as some have thought, when Audubon was struggling for recognition, he was somewhat oblivious of the privations which his wife endured, in the sunshine of later years, when fame and fortune had smiled upon him, he showed by every token of affection how fully he realized his debt. Let it also be remembered that the monument by which Americans have signalized their appreciation of his labors, is honored by the ashes of his beloved Lucy, which rest by his side.

The original drawings of the plates of The Birds of America were sold by Mrs. Audubon on June 2, 1863, to the Historical Society of New York, ${ }^{18}$ and a few of them are now displayed in its building in that city; it is still hoped that a fire-proof and adequately lighted hall can be constructed so that the whole of this great series of pictures may be exhibited under more perfect conditions. The artistic beauty and historical value of these drawings, with the added charm which personal association has so richly supplied, would render Audubon's "Book of Nature" one of the most unique and interest-

${ }^{18}$ For the privilege of examining this unique collection $I$ am indebted to the courtesy of the Society, and of its librarian, Mr. Kelby. 

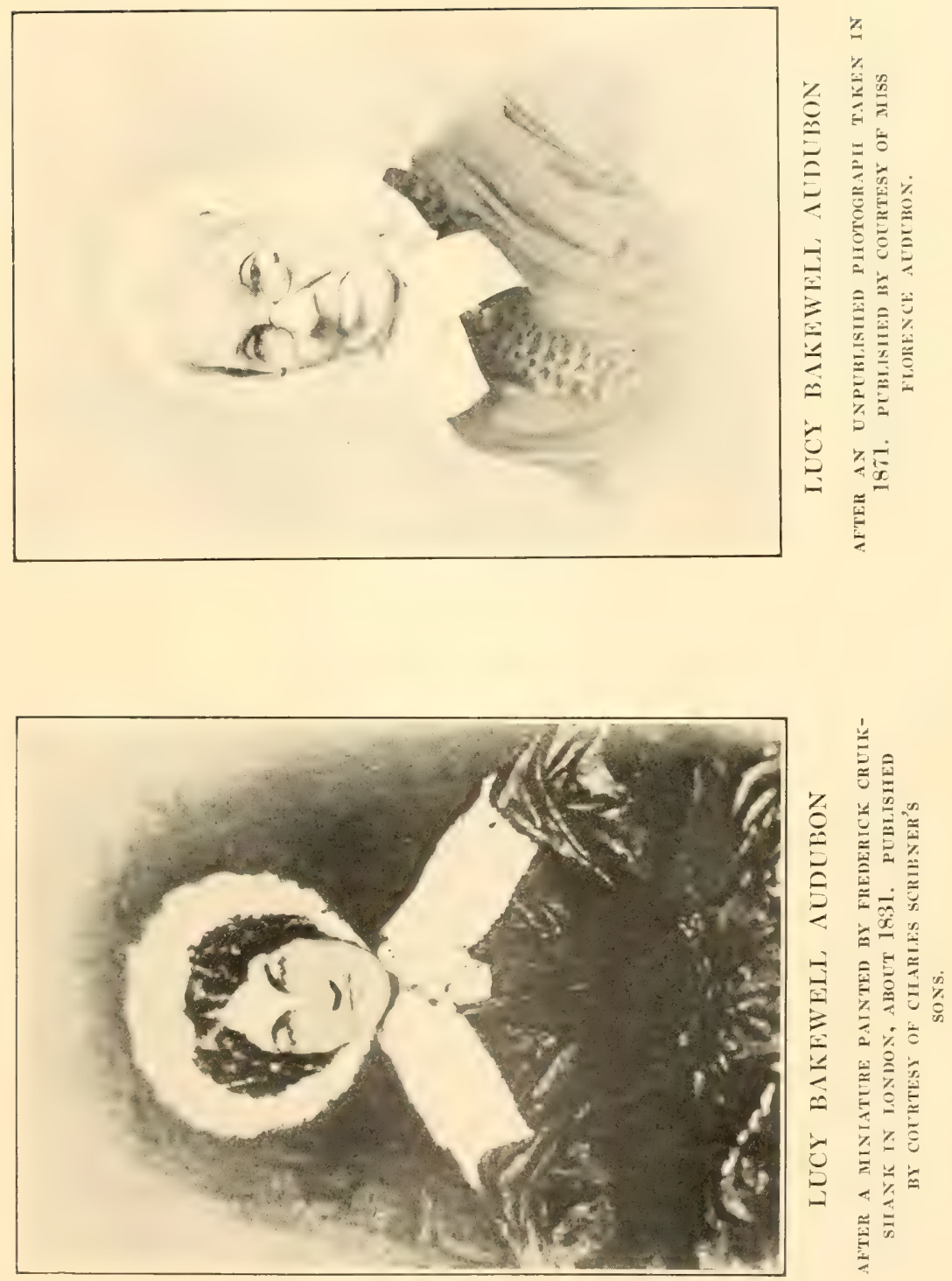

ing exhibits in the New World. The collection appears to be nearly complete, although some notable pieces, such as the Wild Turkeys, are lacking, but there are other drawings, and some of early date, which were never reproduced; all are inclosed in the original portfolios, scarred by hard knocks and the tooth of time, massive, leather-bound containers, which two strong arms would raise with difficulty from the ground. Most of these originals are mounted on a gray backing, with plate margins in each case indicated by ink lines. As was noticed in an earlier chapter, many original legends and notes written by Audubon's pencil or pen still remain on the drawings, though many have been trimmed off or erased; these include names of localities and dates, and directions to the engraver for changes in the background and composition or for any improvement of the whole or a part.

As a further illustration of the care which Audubon exercised over the minute details of his great undertaking, we will reproduce the penciled orders on the drawing of the Great White Heron (Plate cclxxxi), which shows an adult male performing the gymnastic feat of seizing a large striped fish, a view of Key West forming the background: "Keep closely to the sky in depth \& colouring! have the water a Pea-green tint. Keep the division of the scales on the leg in fact white in your engraving-The colouring over these will subdue them enough! finish the houses better from the original which you have; have the upper back portion very mellowing in the outline." Again, on the drawing of the Great Cinereous Owl (Plate cccli), we read: "Raise the bird about 4 inches on the copper-higher than in the Drawing, and put in a landscape below of Wild Mountains," a direction which in this instance was not followed, for 
the bird was eventually shown on a branch against the sky.

In many instances towards the end of his work, Audubon furnished Havell with drawings of the birds only, with directions to supply "an old rotten stick" for perch, or to "amend this rascally sky and water"; as we have already seen, he often depended upon him to combine several detached pictures into one plate, but not always with happy results. The following note was written on a drawing of the Carolina Parrot, reproduced in a very striking plate (No. xxvi), in which seven gaudy individuals of this nearly extinct species are represented feeding on a favorite weed, the cockle-bur: "The upper specimen was shot near Bayou Sarah, and appeared as very uncommon having 14 Tail feathers all very distinct-uniformly affixed in 14 distinct receptacles that I drew it more to exhibit one of those astonishing fits of nature than anything else-it was a female. - The Green headed is also a Singular although not so uncommon a variety as the above one. LouisianaDecember (1821?) J. J. Audubon." The upper bird, which is here referred to, is noticed in his "Biography" of the species as "a kind of occasional variety."

On the drawing of the Swamp Sparrow (Plate lxiv), which was published in 1829, Audubon wrote, evidently with the wish of having his wife's name appear: "Drawn from Nature by Lucy Audubon, Mr. Havell will please have Lucy Audubon name on this plate instead of mine ...!"

Vandalism is always short-sighted, but seldom has its vision been more myopic and sinister than in the case of the copper plates of The Birds of America, most of which were sold for old metal and converted into copper bars. Had they been preserved to this day, their value 


\section{AUDUBON'S FAMILY IN AMERICA 307}

would have been an hundred-fold greater than that of the few paltry tons of metallic copper which they were supposed to represent. Mr. Ruthven Deane, whose researches in the field of "Auduboniana" have added greatly to this subject, has given a history of these plates, ${ }^{19}$ and of the interesting way in which a remnant came to be snatched, as it were, from the very mouth of the furnace, through the persistence and enthusiasm of a lad of fourteen. To follow this writer's account, it seems that shortly after the death of her son John, Mrs. Audubon sold the copper plates to a firm in New York, where they remained until about 1865, stored in the warehouse of Messrs. Phelps, Dodge \& Company. Not far from that time the plates were sorted and a few were given away; the large remainder was sent to a brass and copper company, of which William E. Dodge was president, at Ansonia, Connecticut. How some of these were fortunately rescued, in about the year 1873, is told in a letter to Mr. Deane from Mr. Charles A. Cowles, of Ansonia:

At that time I was about fourteen years old. I was beginning the study of taxidermy, and was naturally deeply interested in birds. I happened to be at the refinery watching the process of loading one of the furnaces, and noticed on one of the sheets of copper that a man was throwing into the furnace, what appeared to me to be the picture of a bird's foot. I took the plate from him, cleaned it with acid, and thereupon discovered the engraving, or as I termed it, the picture, of a bird (Plate cvi, Black Vulture), I made an immediate but unsuccessful request to the foreman of the furnace not to melt the plates; and then I appealed to the superintendent, but without avail. I next brought the matter to the general manager of the concern, my father, from whom I re-

${ }^{10}$ Ruthven Deane (Bibl. No. 225), The Auk, vol. xxv (1908). 
ceived no encouragement. This sort of treatment was evidently what I needed, for I hastened back to the works in a state of mind so determined that I succeeded in having all the plates, that had not been melted, removed to a place of safety. This occurred in the spring of that year; and the plates remained undisturbed until the annual inventory was taken the first of the following year. At that time the disposition of the plates was taken up. I appealed to my mother and interested her to such an extent that she drove to the factory and looked at one of the plates. She of course recognized that they were Audubon plates; and instructions were given by my father to keep them intact. The plates were subsequently submitted to a treatment which removed all oxidation and then taken to the main office of the company, and to the best of my recollection, distributed as follows: Mr. Wm. E. Dodge, president of the company, had a few plates sent to the American Museum of Natural History, New York City, and a few plates to the Smithsonian Institution, Washington, D. C., and I think he retained one or two for himself. The remainder of them, with the exception of two, my father kept; and they have since come into my possession by purchase from the estate. The two plates just excepted were Nos. xxii and lxxxii [Purple Martin and Whippoorwill], and they particularly struck my fancy, so much that when the plates were first discovered I managed to secure them on the quiet, cleaned them myself and hid them; and when the plates were distributed no one knew of the existence of these two and they later became my property.

It was thought possible that some of these plates had been sold in New York City before the bulk of them were condemned as junk and sent to Connecticut, but in $1898 \mathrm{Mr}$. Deane was able to give the designation and resting place of only thirty-seven; ${ }^{20}$ among these, how-

${ }^{20}$ At that time the American Museum of Natural History, New York, possessed nine; the Smithsonian Institution, six; Princeton University, four; Wesleyan University, Middletown, Connecticut, one, while the remainder were in private hands. 


\section{AUDUBON'S FAMILY IN AMERICA 309}

ever, were the Wild Turkeys, Canada Goose, Great Northern Diver, Raven, American Robin, and Rubythroated Hummingbird, all among the finest of the original 435.

Under the guidance of Mr. George Bird Grinnell, on April 6, 1916, I paid a visit to "Audubon Park," now "Minnie's Land" no longer, where country roads have given way to business streets and forests to subways and skyscraper apartment houses. Notwithstanding the momentous changes which the extension of upper New York City has effected both above and below ground during the recent era of rapid transportation, the old Audubon houses still remain, like boulders amid stream, the impact of the city which has flowed around and beyond them being checked for the moment by a rampart of solid masonry, the retaining wall of the farfamed Riverside Drive, which rises above Audubon's old house close to its rear veranda and there makes a wide turn. For Mr. Grinnell this was a return to the scenes of his boyhood; the home of his father, $\mathbf{M r}$. George Blake Grinnell, stood on the hill just above the Audubon house, not far from the present "Riviera" building at One Hundred and Fifty-Seventh Street; the Grinnell apartment house which towers aloft close at hand stands in their old cow pasture, while their garden site is marked by the present entrance to the subway station on Broadway.

The first part of Audubon's original tract to be sold was the easterly section, extending from what is now the east side of Broadway to the Bloomingdale Road, and between the present One Hundred and Fifty-sixth and One Hundred and Fifty-seventh Streets; on that portion John Woodhouse Audubon built a large frame structure which, for a number of years, served as a 
boarding house for workmen employed in the sugar refinery of Messrs. Plume \& Lamont that stood on the river-bank, at the foot of the present One Hundred and Sixtieth Street. Victor and John W. Audubon also built three houses on the hill, one of which, between One Hundred and Fifty-sixth and One Hundred and Fifty-seventh Streets, was occupied by Mr. Grinnell; another, at one time the dwelling of Henry A. Smythe, a former Collector of the Port of New York, was on land now covered by the Numismatic Building, while a third, which was occupied by Wellington Clapp, was on a part of the Archer M. Huntington estate, south of One Hundred and Fifty-sixth Street, and stood a little easterly of the present Riverside Drive; all of these houses have disappeared. In September, 1842, the Corporation of Trinity Parish acquired from Richard F. Carman, in Carmansville, the tract of land later known as "Trinity Cemetery"; this extended from Bloomingdale Road to the River, and between the present One Hundred and Fifty-third and One Hundred and Fiftyfifth Streets. ${ }^{21}$

The original Audubon house, standing in the angle nearly opposite One Hundred and Fifty-fifth Street, is all but concealed, except from the river side, but may be approached by a lane which leads off from One Hundred and Fifty-eighth Street. In 1913, when this old landmark was in imminent danger of demolition, the Commissioner of Public Parks made an eloquent plea for its preservation to the Audubon Societies and to lovers of birds and nature everywhere. It was then suggested that instead of permitting the historic structure to be destroyed, the city should acquire it, float it

${ }^{21}$ For the substance of this paragraph, I am indebted to the Report of the American Scenic and Historic Preservation Society, New York, 1913. 
up the Hudson River to Fort Washington Park, and reestablish it there as a permanent memorial to the naturalist; it was also noticed that the public interest was enhanced by the fact that the father of telegraphy, Samuel F. B. Morse, had worked upon his invention while Audubon's guest, and that the first message to be received from Philadelphia came over a wire which entered his room at the northwest corner of the building.

An early engraving ${ }^{22}$ represents the naturalist's house essentially as it appeared during his lifetime, surrounded by goodly forest trees of oak and chestnut, but these, when standing at all, are now reduced to gaunt and scarred remnants. A later print ${ }^{23}$ shows the three Audubon houses, the river, and between it and the lawn "that eye-sore of a railroad," ${ }^{24}$ which was built not long after Audubon settled upon his estate. The original house was sold before $1862,{ }^{25}$ and about eight years later its new owner occupied it, after having given it a mansard roof and made numerous changes which were sanctioned by an era of bad taste. The naturalist's house overlooked the river and commanded a grand view from its high veranda on the front, while Victor's, which later adjoined it to the north, owing probably to the encroachments of the railroad, was built to face the hillslope opposite; a top studio, at a corner of its roof, is an addition of a later purchaser. ${ }^{26}$

Adjoining Victor's house on the north was that of his

${ }^{22}$ See Mrs. Horace St. John, Audubon, the Naturalist of the New World (Bibl. No. 71), New York, 1856.

${ }^{23}$ See Valentine's Manual of the City of New York, New York, 1865.

${ }^{24}$ On October 30, 1847, Bachman wrote John and Victor Audubon that he proposed to visit them in the following May, when he would leave his two daughters with them awhile, "to hear you and Victor grumble about that eye-sore of a railroad, and to enjoy your good company, and your fish and shrimps."

${ }^{25}$ To Mr. Jesse Benedict.

${ }^{28} \mathrm{Mr}$. Charles F. Stone, whose sister was an artist. 
brother, John, and on the east side of this was built the "Cave" and a barn since converted into a dwelling; at one time the loft of this barn was piled with boxes of bird skins and the surplus stock of the Ornithological Biography, good copies of which now bring from $\$ 30$ to $\$ 50$.

The three houses which were built and occupied by the great nature lover and his two sons, though in dire neglect, are not beyond repair; if such a project were practicable, they should be converted into a museum, and their walls once more ornamented with those beautiful pictures of birds and beasts which father and sons united to create. The triangle of ground between Riverside Drive and the Hudson River should be spared by the proud city that for years was the home of America's pioneer naturalist and animal painter, as well as the scene of his youthful experiments in trade, and converted into a true "Audubon Park." Such a memorial would contribute to the instruction and pleasure of all the people, for every generation of Americans that is to come. 


\section{APPENDICES}

\section{APPENDIX I}

Original Documents 
1. Copy of the original bill rendered by Doctor Sanson, physician at Les Cayes, Santo Domingo, to Jean Audubon, containing the only record known to exist of the birth of his son, Jean Jacques Fougère Audubon (see entry for April 26, 1785). Les Cayes, December 29, 1783-October 19, 1785; paid, June 7\%, $178 \%$.

\section{DOIT Mr. AUDUBON ngt. A SANSON}

Chirurgien aux Cayes

\section{SAVOIR \\ L}

$1783 \mathrm{X}^{\text {bre }}$

1784 janvier

" 29 " ipecacuanha pour un nègre Bossal ..... "6 $\quad 6$ " “

" 31 " ipecacuanha pour un nègre Bossal...... "6 6 " 6 " 3 " une medecine pour un nègre Bossal ......

" 5 " une medecine pour un nègre Bossal ......

" 7 " wne medecine pour un nègre Bossal ......

" 9 " une medecine pour un Bossal ...........

" 10 " une medecine pour un Bossal ..........

" 14 "6 une medecine pour le mulâtre joue ......

"26 " une medecine pour $\mathrm{M}^{\mathrm{r}}$ audubon $\ldots \ldots \ldots$ 6 $10^{66}$ mars " 27 " inoculé cezard 30 " inoculé jupiter 30 inoculé Rose 30 "... * 90 “ “ 
1a. Translation of the Sanson bill. (For comment, see Chapter IV.)

M. AUDUBON, merchant, to SANSON,

Physician at Cayes

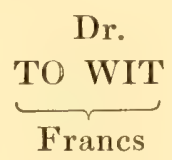

1783 December " 29 "Ipecacuanha for a negro Bossal ...... * 6 " 6 “

" 31 " Ipecacuanha for a negro Bossal ...... "6 6 " "

1784 January " 3 "A medicine for a negro Bossal ........6" 6 6" "6

" 5 "A medicine for a negro Bossal ........6"6 $66^{66 " 6}$

" 7 " A medicine for a negro Bossal .........6" 6 " 6

" 9 " A medicine for a Bossal " 6 " "

" 10 "A medicine for a Bossal " 6 "6

"14 " A medicine for the mulatto Joue ${ }^{1} \ldots$. 6 6 "6

" 26 "A medicine for M. Audubon ......... " 10 "6

March "27 "Inoculated Cæsar, 30f; inoculated Jupiter, $30^{\mathrm{f}}$; inoculated Rose, $30^{\mathrm{f}} \ldots \ldots \ldots \ldots \ldots+60^{*} \quad 90 *$

${ }^{1}$ For probable meaning of this term, see Note, Vol. I, p. 54. 
1. The original Sanson bill-Continued.

avril

may

juin

juillet
" 1 " apozême purgatif pour joue mulâtre .....6 6 6 "6

6 3 " une medecine pour le mulâtre joue ..... " 6 " "

“ 8 " apozême purgatif pour le nègre Dominique. " $\quad 6 \quad 6$ " 6

" 10 " une medecine pour Dominique ...... "6 6 " "6

" 15 " une medecine pour Zemire ........6" 6 "6

" 20 " une medecine pour Rose " 6 " " 6 6 " apozême purgatif pour jupiter .......6" $66^{66}$

21 " une medecine pour Dominique ......6" $6^{66}$ " 2 " une medecine pour la negresse therese... “6 6 6 “

" 11 " pour soins, visites et remedes pendant la petite verole du mulâtre joue......." " 66 "6

"21 "Liqueur minerale d'hoffman pour mlle. Rabin ........6" 6 "6 " 20 " inoculé un petit nègre Bossal nommé joue. " " 30 " " " 20 "Remis a $\mathrm{m}^{\mathrm{r}}$ audubon le compte du traitement de la galle de marianne et de sa fille, tout acquité... " 36 " "6 
1a. Translation of the Sanson bill-Continued.

April " 1 "Purgative decoction for

Joue, [the] mulatto "6 $\quad 6$ " 6

" 3 "A medicine for the mulatto, Joue..... " 6 " 6

" 8 " Purgative decoction for the negro Dominique " 6 " 6 "6

" 10 "A medicine for Dominique ........6 66 6 6 6

" 15 " A medicine for Zemire. " 6 " " 6

"20 " A medicine for Rose... " 6 6 " 6 6

" Purgative decoction for Jupiter . . . . . 6 6 6 " 6

" 21 " A medicine for Dominique $\ldots \ldots \ldots$ * $66^{6 *}$

May " 2 "A medicine for the negress Theresa...."6 6 "6 "

" 11 "For attentions, visits, and remedies during the smallpox of the mulatto Joue..... " 66 " "

" 21 "Hoffman's mineral water for Mlle. Rabin. " 6 " "6

June " $\quad 20$ " Inoculated a little negro Bossal named Joue. . " 30 " " July " 20 " Account rendered to M. Audubon for treatment of the gale $^{2}$ in Marian and her d a u g h e r, all receipted ......... " 36 " "

${ }^{2}$ Or acariasis, an affection of the skin caused by the mange-mite, Demodex folliculorum, a microscopic arachnid parasite found in the sebaceous glands of dog and man. 
1. The original Sanson bill-Continued.

ybre

" 14 " apozême purgatif pour le nègre jean maçon.

" 16 " une medecine pour jean maçon .........

" 21 " saigné au bras $\mathrm{m}^{\mathrm{r}}$ audubon........

" 23 " eau de tamarinds compee. pour $\mathrm{m}^{\mathrm{r}}$ audubon ...........

" 24 " une medecine en deux

Dozes pour $\mathrm{m}^{\mathrm{r}}$ audubon...$\ldots \ldots$.

$8^{\text {bre. }}$ " 22 " une medecine pour le negrillon joue.......

"6 6 " 6
6" 23 " traité soigné et fourni le medicament a joue attaqué de piano... " 132 " “

\section{L $\quad 513$ “ “ \\ 513}

\section{[Page 2]}

Suite de l'autre part L 513 "6 "6

$8^{\text {bre. }}$

$9^{\text {bre }}$
" 25 " saigné au bras m"lle. Rabin ............

" 26 " Liqueur $\mathrm{m}$ in e $\mathrm{r}$ a $\mathrm{le}$ d'hoffman pour mlle. Rabin .......... " 30 " une medecine pour le negrillon joue..... * 6 " " 15 " une medecine pour le negrillon joue...... ${ }^{66} \quad 3^{66} 66$ $66^{66} 6$

$3^{66} 6$ $10^{666}$ $10^{666}$ 66 6
$66 \quad 666$ 
1a. Translation of the Sanson bill-Continued.

September " 14 " Purgative decoction for the negro, John Mason [or John, ma$\operatorname{son}(?)] \ldots \ldots \ldots$

" 16 " A medicine for John Mason ........ " 6 "6

"2I "Bled M. Audubon at the $\operatorname{arm} . . \ldots \ldots \ldots$ " 3 " "

" 23 " Tamarind water compound for M. Audubon ..........6" 10 "6 "

"24 " A medicine in two doses for M. Audubon...." " 10 " 6

October " 22 "A medicine for the little negro Joue.... 6 6 $\quad 6^{\text {"6 }}$ "6

" 23 " Treated, attended, and furnished remedies for Joue attacked by the $\operatorname{pian}^{3} \ldots \ldots \ldots$ " 132 " "

L 513 “

\section{[Page 2]}

Brought forward from other part........ L 513 "6

October " 25 " Bled Mlle. Rabin at the $\operatorname{arm} . . \ldots \ldots \ldots$ " $\quad 366$

" 26 "Hoffman's mineral water for Mlle. Rabin. "6 6 "6 "6

" 30 " 1 medicine for the little negro Joue.... " 6 " 6

November " 15 " A medicine for the little negro Joue.... « 6 "6

A skin disease to which negroes in Central America are specially prone. 
1. The original Sanson bill-Continued.

1785 janvier
$\mathrm{X}^{\text {bre }}$

" 8 " une medecine pour joue "

6 6 6

" 18 " une medecine pour $\mathrm{m}^{\mathrm{r}}$ audubon ..........

" 21 " une medecine pour le negrillon joue....... fevrier “ 15 " $2^{\text {once. }}$ manne pour $\mathrm{m}^{\text {lle. }}$ Rabin ......... $66 \quad 364$

" 18 " une medecine pour le tonneliere .......

6 "6

mars

" 6 " une medecine pour le tonneliere .......

$6^{66} 66$

" 10 " une medecine pour le tonneliere .......

$6^{66} 6$

" 11 " trois Dozes de kina pour le tonneliere.. " 9 " "

" 12 " trois Dozes de kina pour le tonneliere. " " 9 "

" 13 " trois Dozes de kina pour le tonneliere. " " 9 " "

" 14 " trois Dozes de kina pour le tonneliere. "6 9 "6 " avril " 2 " une visite de nuit pour

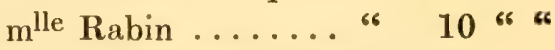

" 3 " une Lotion pour un Erésipèle, que $\mathrm{m}^{\text {lle. }}$ Rabin a à la jambe. " 6 " 6 " 5 " une Lotion pour m m $^{\text {lle. }}$ Rabin .......... " 7 " une Lotion pour $\mathrm{m}^{\text {lle. }}$ Rabin ........... 66 $6^{6 " 6}$ $6^{66} \quad 6^{66}$ "6 " 8 " une medecine pour le tonneliere ....... 
1a. Translation of the Sanson bill-Continued.

December " 8 " A medicine for Joue... " 6 " “ " 1785 January " 18 " A medicine for M. Audubon ......... 610 " $"$

" 21 " A medicine for the little negro Joue.... « 6 “ “

February " 15 "Two ounces of manna for Mlle. Rabin.... " 3 “ "

" 18 "A medicine for the cooper ......... "6 6 " "

March "6 "A medicine for the cooper......... "6 "6

" 10 "A medicine for the cooper .........6" 6 " "

" 11 " Three doses of kino ${ }^{4}$ for the cooper...." 9 " "

" 12 " Three doses of kino for the cooper ...... " 9 " “

" 13 " Three doses of kino for the cooper ...... * 9 " “

" 14 " Three doses of kino for the cooper ....... " 9 " " April " 2 " A night visit for Mlle. Rabin ......... " 10 " "

" 3 " A lotion for an erysipelas which Mlle. Rabin has on the leg " 6 " " “5 " A lotion for Mlle. Rabin ......... " 6 " " "7 "A lotion for Mlle. Rabin ........ " 6 " "

" 8 "A medicine for the cooper ......... " 6 " " 
1. The original Sanson bill-Continued.

"9 " trois Dozes de kina pour le tonneliere... 66 9646 " 10 " trois Dozes de kina pour le tonneliere... 66 $99^{66} 66$ " 11 " trois Dozes de kina pour le tonneliere... 66 $99^{66} 66$ " 12 " trois Dozes de kina pour le tonneliere... 66 996 " 24 " Passé la nuit pres de $\mathrm{m}^{\text {lle. Rabin. en mal }}$ d enfant ......6" 66 " "6

" 25 " Passé la nuit pres de

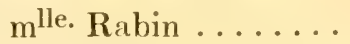
${ }^{66} \quad 66^{666}$ " 26 " m"lle. $\mathrm{R}$ a bi $\mathrm{n}$ est accouchée ......... may " 2 " une visite de nuit et Liqueur $\mathrm{m}$ i n e $\mathrm{r}$ a $\mathrm{le}$ d'h.p.m ${ }^{l l e}$ Rabin....

" 3 " Liqueur $\mathrm{m}$ in e $\mathrm{r}$ a le d'hoffman p.m lle. Rabin ............ \$6 " 4 six Bouteilles d'eau b la n che pour les cataplasmes nécessaires au mal de sein de mlle. Rabin..... "6 18 " “6 juin " 19 " ouvert un abcès au sein de $\mathrm{m}^{\text {lle. Rabin soins }}$ et pour pansements. "6 36 "6

"26 " une medecine pour augustin negrillon....6 6 6 6 “ 
1a. Translation of the Sanson bill-Continued.

" 9 "Three doses of kino for the cooper......6 $69^{66}$ "6

" 10 "Three doses of kino for the cooper ........

" 11 "Three doses of kino for the cooper ....... * 9 " 6

" 12 " Three doses of kino for the cooper .......6" 9 "6 6 "24 "Passed the night with Mlle. Rabin [who was] in child-birth. . " 25 " Passed the night with Mlle. Rabin ...... " 66 " " " 26 " Mlle. Rabin is delivered " . " " " "

May

66 2 " A night visit and Hoffman's mineral water for Mlle. Rabin. . . " 16 " "

" 3 "Hoffman's mineral water for Mlle. Rabin. " 6 " 6

66 46 Six bottles of eau

blanche for poultices needed in an affection of the breast of Mile. Rabin ...... " 18 " "

June " 19 " Opened an abscess in the breast of Mlle. $\mathrm{R}$ a b in ; for attentions and dressings. " 36 " " " 26 " A medicine for the little negro Augustine. " $\quad 6$ "6 6 
1. The original Sanson bill-Continued.

\section{[Page 3]}

Suite de l'autre part. . L 897 "6 "

juin

juillet

aout

ybre.

$8^{\text {bre }}$
" 30 " une medecine pour augustin ......... L $\quad 6^{* 6}$ " 1 " une medecine pour la vielle jeanne...... " 16 " une medecin e pour m[lle.] Rabin......." 10 "6 " 15 " une medecine pour m m $^{\text {lle. }}$ Rabin .......... s eau blanche pour $\mathrm{m}^{\mathbf{r}}$ audubon .......6 $\quad 3$ " 6

" 20 " une medecine pour $\mathrm{m}^{\mathrm{r}}$ aubinais commis.... " 10 " " " 22 " une medecine pour $\mathrm{m}^{\mathrm{r}}$ aubinais ........ 10 " " 24 " tinture de Rhubarbe pour $\mathrm{m}^{\mathrm{r}}$ aubinais... " $\quad 6 \quad$ " “ " 26 "tinture de Rhubarbe pour $\mathrm{m}^{\mathrm{r}}$ aubinais... "6 $\quad \mathbf{6}^{\text {6 }}$ "6 " 23 " une bouteille vin medicinal pour le nègre enflé ........... 15 " 6

" 27 " une medecine pour la vielle jeanne...... * 6 " 6 " " 7 " une medecine pour le nègre enflé ...... * 6 6 " *

66 11 " une medecine pour le nègre enflé ....... * 6 " * " 16 " une medecine pour thérése ......... 
1a. Translation of the Sanson bill-Continued.

[Page 3]

Brought forward from the other part..... L 897 " "f June " 30 " A medicine for Augustine $\ldots \ldots \ldots \ldots$ 6 6 6 6 " "6

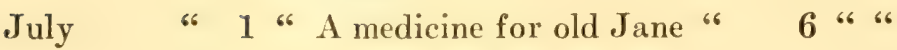

" 16 "A medicine for M[lle.] Rabin ......... 10 " 6 August " 15 "A medicine for Mlle. Rabin ......... 10 " "

" Eau blanche for M. Audubon ........." 3 " 6

"20"A medicine for M. Aubinais, clerk...." " 10 " "

" 22 "A medicine for M. Aubinais ......6" 10 "66

"24 "Tincture of rhubarb for M. Aubinais... 6 $\quad 6$ " 6 " 26 " Tincture of rhubarb for M. Aubinais... " 6 "6 6 September " 23 "A bottle of medicinal wine for a swollen negro ..........

" 27 " A medicine for old Jane " 6 " " " 6

October " 7 " A medicine for the swollen negro.....6 $66^{666}$

" 11 "A medicine for the swollen negro.....6" 6 " " 6 " 16 " A medicine for Theresa " 6 " "6 
1. The original Sanson bill-Continued.

" 19 " une medecine pour

therese ........ " 6 " *

acceptée apercu [?] Le 12 octob L 1009 “ “

1786

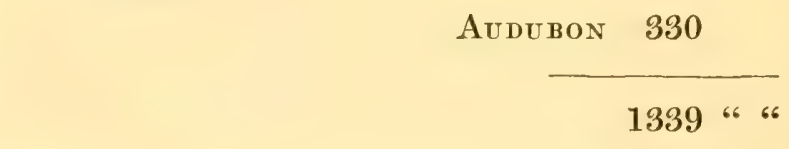

Pour acquit aux cayes ce 7 juin 1787

SANSON

Recu de $\mathbf{M}^{\mathbf{r}}$

Sanson

\%. Juin 1787.

1784 janvier traité $\mathrm{m}^{\mathrm{r}} \ldots$

soins et fourni services... 330 66 
1a. Translation of the Sanson bill-Continued.

" 19 "A medicine for Theresa "6 6 " 6

Accepted viséd [?] October 12 L 1009 "6

1786

$\frac{\text { Audubon } 330}{1339666}$

Paid at Les Cayes this 7 th June, 1787

M. Sanson's receipt

June $\%, 178 \%$.

1784 January Treated

M....For care and serv-

ices rendered ..........330 "6 
2. Copy of the Act of Adoption of Fougère (John James Audubon) and Muguet (Rosa Audubon). Nantes, March \%, 1794. (For translation, see Chapter IV.)

Extrait des registres des naissances des sections de la Halle et de Jean-Jacques de la commune de Nantes, département de la Loire-Inférieure, le 17 Ventose, an 2 de la République, une et indivisible, 10 heures du matin.

Devant moi Joseph Theulier, officier public élu pour constater l'état-civil des citoyens, ont comparu en la maison commune Jean Audubon, commandant la corvette "le Cerbère," bâtiment de la République, âgé de 49 ans, natif des Sablesd'Olonne, département de la Vendée et Anne Moinet son épouse, agée de 58 ans, native de la ci-devant paroisse de Saint-Léonard, de cette commune, lesquels assistés de René Toussaint Julien Beuscher, fabricant, âgé de 25 ans demeurant section de la Halle rue Rubens et de Julien Pierre Beuscher, chirurgien marin, âgé de 24 ans, demeurant section de la Fraternité, rue du Marchix, et employé par continuation sur la dite corvette le Cerbère, m'ont déclaré adopter et reconnaître dès ce moment comme leurs propres enfants savoir:

Un enfant mâle nommé Fougère, issu depuis le mariage d'eux comparant contrôlé le 24 Août 1772 dans la commune de Paimboeuf en ce département de lui Jean Audubon avec une habitante de l'Amérique morte il y a environ huit ans et une enfant femelle nommée Muguet issue aussi depuis le mariage sus dit de lui Jean Audubon d'une autre habitant de l'Amérique nommée Catherine Bouffard dont il ignore le sort.

Les deux enfants ci-présents, âgés le premier de 9 ans qui échoieront le 3 Floréal prochain, le second de 7 ans que échoieront aussi au 7 Floréal prochain tous deux nés en Amérique d'après cette déclaration que les témoins ci-dessus ont certifié véritable, j’ai rédigé le présent acte que le père naturel et la mère adoptive ainsi que leurs témoins ont signé avec moi les dits jour et an.

Signé au registre: Auduron

Citoyenne Anne Monnet Jean Audubon, Beuscher \& Beuscher Jeune. 
3. Copy of the Act of Baptism of Jean Jacques Fougère Audubon. Nantes, October 23, 1800. (For translation, see Chapter IV.)

Premier brumaire, an neuvième.

Nous soussignés certifions avoir baptisé ce jour, premier brumaire, an 9 de la République, Jean Jacques Fougère Audubon fils adoptif de Jean Audubon lieutenant de vaisseau de la République et d'Anne Moinet sa légitime épouse, présents et certifiant l'adoption qu'ils ont fait du dit Fougère ainsi et de la même manière qu'il est porté dans l'acte ci-dessus.

Signé: Tardiveau, prêtre de SaintSimilien de la Ville de Nantes. 
330

\section{APPENDICES}

4. Copy of a bill of sale of Negroes rendered by Monsieur Ollivier to Monsieur Audubon. Les Cayes, Santo Domingo, 1785.

1785.-M. Audubon doit à Ollivier ce qui suit:

$$
\begin{array}{ccccc}
\text { Juillet pour } & 4 & \text { négresses à } & 1750 & 7.000 \\
-\quad- & 1 & \text { "6 } & 1750 & 1.750 \\
-\quad- & 1 & \text { négresse borgne } & 1.600 \\
-\quad-\quad 1 \text { négritte } & 1.200 \\
& & & 11.590
\end{array}
$$

Pour acquit en compte et billet à mon ordre sous la réserve d'une augmentation de cent livres sur la négritte si elle vit au delà de six mois.

Aux Cayes, le 25 Juillet 1785.

Signé : Ollivier. 
5. Statement of Accounts of Messrs. Audubon, Lacroix, Formon, \& Jacques in the purchase of negroes from M. Th. Johnston, Les Cayes, Santo Domingo, 1785. (For comment, see Chapter III.)

Compte de vente frais et net produit de quarante nègres achetés de Monsieur 'Th. JOHNSTON, de compte à demi entre MM. AUDUBON LACROIX FORMON \& JACQUES, pour prix la somme de soixante mille livres, payée au dit sieurs la dite somme comme suit:

$\left.\begin{array}{ll}\text { Par Monsieur Audubon } & 20.000 \\ \text { Par Lacroix Formon \& Jacques } & 40.000\end{array}\right\}$

60.000

1785 Vendu par Monsieur AUDUBON, dont il se charge:

\begin{tabular}{|c|c|c|c|c|}
\hline Février & 11 & 1 & à. Reynaud Chateaudun & f 1650 \\
\hline - & 12 & 1 & - Garreau & 2100 \\
\hline- & 12 & 3 & - Bourseret & 6000 \\
\hline 一 & 12 & 1 & — Lui-même & 1500 \\
\hline 一 & 14 & 2 & - Cossard & 3564 \\
\hline 一 & 15 & 1 & - Lenoir & 1782 \\
\hline - & 18 & 1 & - Blanchet & 1782 \\
\hline 一 & 19 & 3 & - Jacques Bourry & 6000 \\
\hline Mars & 24 & 3 & - Bouffard & 4950 \\
\hline - & 24 & 1 & — Lui-même & 1500 \\
\hline 一 & 24 & 1 & - Ch. Gettée & 1800 \\
\hline- & 24 & 1 & - Bouffard & 1650 \\
\hline
\end{tabular}

19 têtes 
Vendu par Lacroix Formon \& Jacques dont il se charge:

$\begin{array}{lllll}\text { Février } & 12 & 3 & \text { à. Bourseret } & 6000 \\ - & 12 & 1 & - \text { Menard } & 2000 \\ - & 12 & 2 & - \text { Reynaud fils } & 3780 \\ - & 13 & 2 & - \text { Peridigon } & 3800 \\ - & 13 & 3 & - \text { Maillet Lacoste } & 5700 \\ - & 15 & 1 & - \text { Dugay } & 1712 \\ - & 19 & 3 & - \text { Jacques Bourry } & 6000 \\ - & 19 & 1 & - \text { Lui-même } & 1782 \\ - & 19 & 1 & - \text { Eux-mêmes } & 1500 \\ - & 19 & 1 & - \text { Begon M. } & 1700 \\ - & 19 & 2 & - \text { Millet } & 3300\end{array}$

Mars 2 A. 1 de mort chez Villeneuve chirurgien pour mémoire........... ; 37.274 f .... 71.552

Frais à deduire payés par Lacroix Formon \& Jacques

Pour 80 régimes de bannanes $\mathbf{1 5}$

- 8 têtes de boeuf

Payé à Villeneuve chirurgien pour le traitement du nègre mort

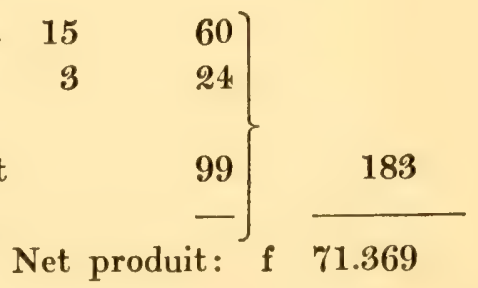

La demi de Monsieur Audubon 35.684 .10

Il a reçu en les reprises dont il se charge: 


\section{ORIGINAL DOCUMENTS}

Clos et arrêté le présent compte en double par lequel il résulte que M. Audubon doit à Lacroix Formon \& Jacques dix mille livres pour sa demi du payement des dits nègres dont il les débite au compte courant arrêté ce jour en double, et les dits Lacroix Formon \& Jacques devant au dit Sieur Audubon celle de cent six livres dix pour sa demi qui lui revient du net produit de la vente des dits nègres, lesquels portés au crédit des deux comptes courant, dont quitté aux Cayes, le plus porté au crédit de M. Audubon la somme de dix sept cent quatrevingt deux livres pour la demi du billet du sieur Collard qui nous reste aux Cayes le 16 Septembre 1785.

Pour MM. Lacroix Formon \& Jacques Signé: Clerr

Nous avons reçu de M. Audubon la somme de trente mille livres pour la portion d'achat des dits nègres au-dessus. Aux Cayes, le 16 Septembre 1785.

Pour MM. Lacroix Formon \& Jacques Signé: Clere. 
6. Copy of bill of sale of Negroes to Monsieur Audubon, and a statement of his account with Messrs. Lucas Brothers $\&$ Constant. Les Cayes, Santo Domingo, August 7\%, 1785June 9, 1788. (For comment, see Chapter III.)

Nous soussignés déclarons avoir vendu et livré à Monsieur Audubon, négociant de cette ville les nègres ci-après, nation Hibo et Canga ....

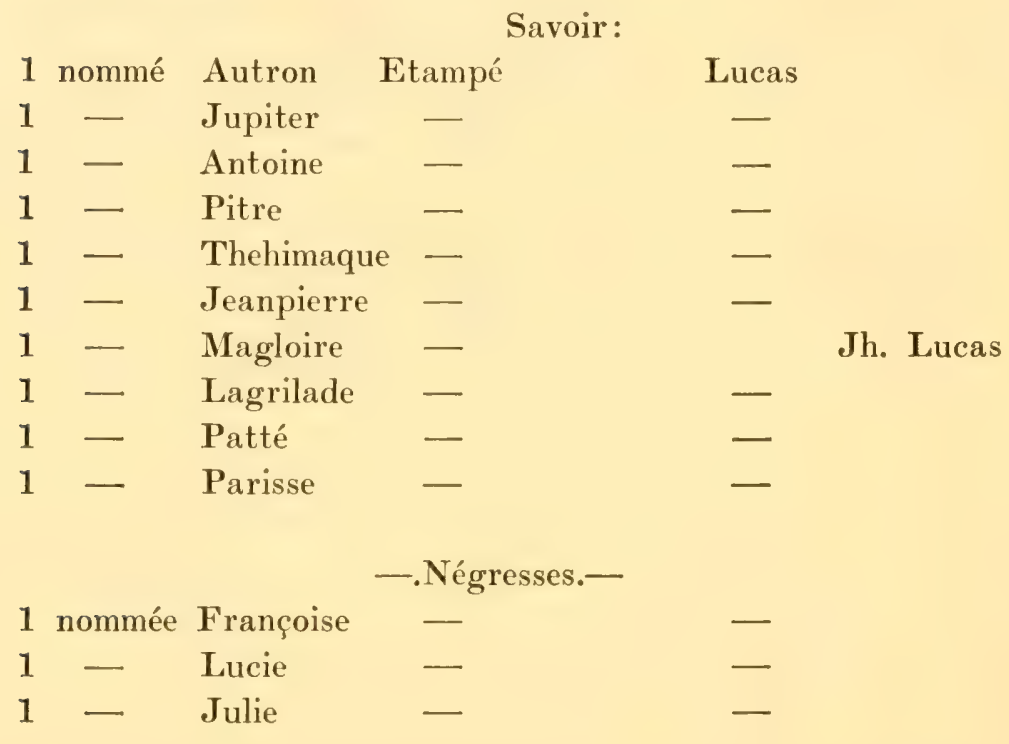

13 Ensemble treize nègres ou négresses à deux mille livres chaque formant la somme de vingt six mille livres sur laquelle somme nous avons reçu vingt-quatre mille livres comme suit:

16.000 en un mandat en sucre sur MM. Lacroix Formon \& Jacques.

7.100 - 17-8 en un billet de Formon Plumardière. $889-24$ en son billet.

24.000 pour payement et à compte des treize nègres 


\section{ORIGINAL DOCUMENTS}

ci-dessus détaillés, dans le nombre desquels le nommé Patté pour engagement de le livrer à M. Audubon dès qu'il sera en état de se rendre aux Cayes. Le dit sieur Audubon se réservant vue dessus quand nous lui en ferons la remise pour le prix de la somme de deux mille livres en argent comptant et moi Audubon accepte le dit marché et déclare avoir reçu livraison des douze têtes de nègres ou négresses que j'ai bien vus et visités et desquels je suis satisfait, aux Cayes, le 7 Août 1785.

Signé: Audubon-Lucas frères.

Nous avons reçu à compte de M. Audubon $\quad 162$

660

882

Pour acquit porté en debit de notre compte courant arrêté ce jour, au Fond, le 9 Juin 1788.

Lucas frères \& Constant. 
7. Accounts of William Bakewell, of "Fatland Ford," as protégé of his future son-in-law and as attorney or agent for Audubon \& Rozier, giving certain exact indications

Mess $^{\text {rs }}$ Audubon \& Rozier

1805

Jan

4 Cash for sundries

$12 \mathrm{~d}^{\mathrm{o}}$

$1 . . .$.

18 Brother

1807

Apl

22

Advertis'ts in Philad ${ }^{\mathrm{a}}$ \& Norristown .. $66 . \ldots \ldots$

Cash $\mathrm{p}^{\mathrm{d}}$ M Fisher ..............

\%......

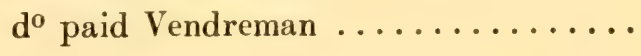

$40 . \ldots$.

$3 . . .$.

1808

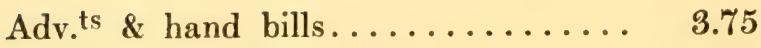

Cash Mr Pears ............ 14.50

May 3 Exps of Horses to Philad ${ }^{a} \ldots \ldots \ldots .4 .76$

20 Sundries .............. 18.50

June 8 Cash ................. 3.18

17 Smith's work $\ldots \ldots \ldots \ldots \ldots \ldots \ldots .5 .00$

Advertise $^{t} \ldots \ldots \ldots \ldots \ldots \ldots \ldots \ldots$

Oct 10 Exchange of Horse ........... 10....

Keep of Horses 23 weeks ........ 42.50

Dec $^{r} \quad 31$ Cash $p^{d} M^{r}$ Pears ............ 18.92

Note hy THE Authon. This record proves that Audubon upon his first return to France from the United States, must have left "Mill Grove" on the 12th of January, 1805, or not more than a day later; three days were required to walk to New York, which could not have been reached later than the 15th, and probably as many more were needed for a letter to go to "Fatland Ford." He probably sailed for Nantes shortly before January 
of the naturalist's movements and personal relations, before and after finally leaving "Mill Grove." January 4, 1805A pril 9, 1810. (For further reference, see Chapter VIII.)

in a/c with $\mathbf{W}^{\mathrm{m}}$ Bakewell

$\mathrm{C}^{\mathrm{r}}$

1805

March 18 Cash .................. 5....

1807

Apl 1 Cash of Miller .............. 150.....

$\mathrm{d}^{0}$ of Jackson ............... $50 \ldots \ldots$

1808

Jan $8 \mathrm{~d}^{0}$ of Longacre ............ $50 \ldots \ldots$

Apl $2 \mathrm{~d}^{\mathrm{o}}$ of Longacre $\ldots \ldots \ldots \ldots \ldots \ldots \ldots . \ldots \ldots$

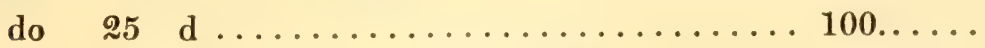

May $12 \mathrm{~d}^{0}$ formon $\ldots \ldots \ldots \ldots \ldots \ldots \ldots \ldots . . \ldots \ldots$

Dec 20 Cash of Longacre ........... $30 . \ldots$

18, the day when William Bakewell recorded that he had sent his "brother," Benjamin Bakewell, commission merchant in New York, $\$ 150$; this was undoubtedly in payment of the loan which the brother in New York had made to young Audubon for his passage to France. The next item, of April 22, 1807, was for money advanced to Ferdinand Rozier, probably when he was acting as clerk to Laurence Huron, in Philadelphia; "ad- 
\%. Accounts of William Bakewell, of "Fatland Ford," as protégé of his future son-in-law and as attorney or agent for Audubon \& Rozier, giving certain exact indications

Mess $^{\text {rs }}$ Audubon \& Rozier

1809

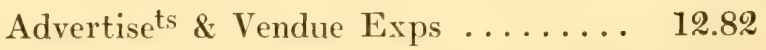

25 Bills payable to W. Thomas ........ $60 \% .10$

Cash $\mathrm{p}^{\mathrm{d}} \mathrm{M}^{\mathrm{r}}$ Page for pow ${ }^{\mathrm{r}}$ of Attorney 1.37

13 Paid Attachment fees .......... 9.28

Cash paid for $\operatorname{tax} \ldots \ldots \ldots \ldots \ldots \ldots .2 .91$

25 mortes $[?] \&$ half taxes.......... $7 . . .$.

Commission 7998 a 1 1-2 per Cent . . . 119.97

Jany 23 omitted Exps at Vendue........ 3.77

$\$ 1176.91$

vertisements in Philadelphia and Norristown" possibly had reference to the lease and final sale of "Mill Grove" of the year before. Miers Fisher was the Quaker merchant, who for many years served as Lieutenant Audubon's American agent and attorney, and who was later the adviser of his son and Ferdinand Rozier. Thomas W. Pears, a relative by marriage of the Bakewells, was with Audubon in Benjamin Bakewell's office in New York, and afterwards associated with him and Thomas W. Bakewell in their disastrous mill experiment at Henderson, Kentucky. The bill of William Thomas, former Quaker tenant of "Mill Grove," was possibly in liquidation of his claim against Lieutenant Audubon and Dacosta in their mining operations at this farm (see the letters to Dacosta, Vol. I, p. 117). The credit entry under May 12, 1808. "formon-31.84," may represent interest collected on an unsettled claim of Lieutenant Audubon against Mr. Formon, a former partner in Santo Domingo, in relation to the sale of the ships, the Count of Artois and the Annette (see Chapter II, p. 33). Dacosta had been urged to apply to Mr. Formon's son-in-law, who appears to have lived at Philadelphia, but was unable to obtain anything from the Formon estate. The "Cash of Dacosta 299.44" possibly represented interest on the mortgage which we have assumed was given to Audubon and Rozier when Dacosta and his mining company came into possession of "Mill Grove," September 15, 1806 (see Chapter XI, p. 148). 
of the naturalist's movements and personal relations, before and after finally leaving "Mill Grove." January 4, 1805April 9, 1810. Continued.

in a/c with $W^{m}$ Bakewell

1809

Apl $\quad 18$. Clennell ............... 20....

Sept $30 \quad$ Kymar $\ldots \ldots \ldots \ldots \ldots \ldots \ldots \ldots \ldots$

Oct $27 \quad \mathrm{~d} \quad \ldots \ldots \ldots \ldots \ldots \ldots \ldots \ldots \ldots$

Nov $6 \mathrm{~d} \quad \ldots \ldots \ldots \ldots \ldots \ldots \ldots \ldots \ldots . \ldots \ldots 2.50$

Dec $23 \quad \mathrm{~d}^{\mathrm{o}} \ldots \ldots \ldots \ldots \ldots \ldots \ldots \ldots \ldots$

1810

Jan 23 Cash of Dacosta ............ 299.44

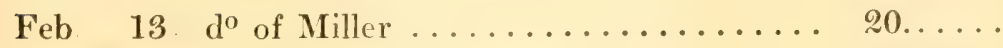

Balle of Neckland........... 237.32

$\begin{array}{ccccc}\text { Apl } & 3 & \text { Miller } & \ldots \ldots \ldots \ldots \ldots \ldots \ldots \ldots \ldots \ldots & 8 \ldots \ldots \\ & 9 & \mathrm{~d}^{\mathrm{o}} & \ldots \ldots \ldots \ldots \ldots \ldots \ldots \ldots & 6.19 \ldots \ldots\end{array}$

$\$ 1159.221 / 2$ 
8. Concerning a Power of Attorney issued by Lieutenant Audubon and Anne Moynet Audubon to Ferdinand Rozier and John Audubon, the Younger, at Couëron, France, in 1805; parts in French translated by a Philadelphia notary; signatures of original document authenticated by the Mayor of Couëron, October 21, 1805; his attest of the legality of Anne Moynet Audubon's signature, at Couëron, October 27, 1805; authentification of the signature of the Mayor of Couëron by the Subprefect of Savenay, November 27 , 1805; attest of the Subprefect's signature by the Prefect. (Remainder of document missing.)

Commonwealth of Pennsylvania ss:

I, Peter Stephan Du Ponceau, notary public \& Sworn Interpreter of foreign Languages for the Commonwealth aforesaid, residing in the City of Philadelphia, do hereby certify that I have carefully translated into English so much of the Instrument of writing hereunto annexed as is written in the French language, as follows, to wit:

At the bottom of the Deed [act] and immediately after the Signatures of the Witnesses, there is a Certificate in France [French], which being translated, is as follows:

Seen by us, the Mayor of the commune of Coueron, who attest the above Signatures of G. Loyen, assistant mayor, C. D'orbigny, Doctor of medicine, Audubon, \& Anne Moynet Audubon, to which full faith and credit is to be given, whereever it may be necessary-Done in our Office at Coueron, the thirtieth of vendemiaire fourteenth year of the French Empire [sic].

G. VALLIN, mayor. 
And on the back of the said Deed [Act] is written in French what follows.

We, Germain Vallin, Mayor of the commune of Coueron in the Department of Lower Loire in the French Empire, certify to all whom it may concern, that on this day, personally appeared before me John Audubon and Anne Moynette, his wife, both now residing in this said commune, and represented to us, That in order to give its full force \& effect to the Instrument written on the other side hereof, in the English language, which they have declared to be a letter of attorney in favor of Messieurs Ferdinand Rozier, \& John Audubon, junior for the purposes therein mentioned, it was necessary that the said Instrument be by them acknowledged before us, according to the forms prescribed by the Laws of the State of Pennsylvania, and that the said Anne Moynette Audubon should be examined by us separate from her said husband, in order to declare that she has signed and executed the said Deed [Act] of her own free will and accord, and without being compelled thereto by her husband; That this formality is rigorously required by the Laws of the State of Pennsylvania, and no other act, not even a notarial Instrument, can in any manner Supply the same.

In consideration thereof, we have received the acknowledgment which the said appearers have made before us, by which they have declared and acknowledged that the said Instrument, written in the English Language on the other sides hereof is their own Act and Deed, and that they desire that it may be recorded as such, whenever it may be necessary.

And the said John Audubon having withdrawn, we have examined the said Anne Moynette Audubon separately and apart from her said husband, and She declared to us, That She knows \& perfectly understands the contents of the said Deed [Act], and that She has Signed, Sealed, and declared [deliv- 
ered] the same, of her own free will and accord, without being compelled thereto by her said husband, either by threats or by any other means of compulsion whatever. In faith whereof, we the Mayor aforesaid, have Signed the present Certificate, and have caused the Seal of this mayoralty to be thereunto affixed-Given at Couëron the thirtieth of vendemiaire fourteenth year of the French Empire [sic]

\section{G. VALLIN.}

[Seal of the mayoralty of Couëron.]

(Afterwards is written also in the French Language, as follows :)

I have seen the above and attest the Signature of G. Vallin, mayor of the commune of Couëron, above and on the other side affixed.

Done in the Subprefect's office, at Savenay, the fifth Brumaire fourteenth year.

The Subprefect of the first District.

Magonet Tremelotrie

[Seal of the District

of Savenay] 
I attest the above Signature of Magonet Tremelotrie.-

Nantz, the $7^{\text {th }}$. Frimaire $14^{\text {th }}$. year

\author{
The Prefect \\ Betleville \\ which [remainder \\ wanting.]
}


9. Articles of Association of Jean Audubon and Ferdinand Rozier to govern their partnership in business; drawn up at Nantes, March 23, 1806. (See Chapter IX.)

[stamp] REP. FRA. et J e a n A u d u b o n, nous proposant de passer 50 cen aux états Unis sommes Convenus de former une société de Commerce aux Conditions Suivantes.

\section{Article Premier.}

L a s o c i ét é sera régie sous les noms Collectifs de Ferdinand Rozier et Jean Audubon et chacun de nous aura la Signature pour toute affaire de notre Commerce seulement.

\section{A r t. 2.}

a Notre arrivée nous prendrons possession de La terre de Mill-Grove, et nous ferons rendre Compte a $\mathrm{M}^{\mathrm{r}}$. D a c os t a qui a la procuration d $\mathrm{M}^{\mathrm{r}}$. A u d u b o n pére . nous nous occuperons des moyens de faire valoir cet établissement ou prendre Connoissance de La mine de Plomb Découverte, et avant d'y continuer les travaux Commencés, nous Examinerons si les dépenses faites par le $\mathrm{S}^{\mathrm{r}}$. D a costa ont été et peuvent nous etre utiles. enfin nous fairons où fairons faire des devis Estimatifs des frais et des produits qui peuvent en résulter. et nous n'entreprendrons rien que nous ne soyons tous deux parfaitement d'accord sur le principe en Conséquence nous signerons l'un et l'autre le projet que nous en arrêterons afin que l'un de nous ne s'en écarte, et il en sera de meme pour toute les nouvelles Dépences qui changeraient les profits arrêtes.

\section{A r t. 3.}

Il est convenu que la Moitié du produit de cette habitation seront entre nous par Moitié et pour en Connoitre ainsi 


\section{ORIGINAL DOCUMEN'TS}

9a. Translation of the Articles of Association of John Audubon and Ferdinand Rozier.

[stamp] We, the undersigned, Ferdinand Rozier and John REP. FRA. Audubon, who are intending to go to the United 50

cen States, are agreed to form a partnership in business upon the following conditions:

\section{Article First.}

The partnership will be administered under the joint names of Ferdinand Rozier and John Audubon, and each of us will have the power of signature for all matters of our business only.

\section{A r t.2.}

Upon our arrival we will take possession of the farm of Mill-Grove, and we will call to account Mr. Dacosta, who has the power of attorney of Mr. Audubon, Senior. We shall take measures to improve the establishment, or make an investigation of the lead mine discovered [on the property], and before continuing the work already begun we will ascertain whether the expenditures made by $\mathrm{S}^{\mathrm{r}}$. Dacosta, have been, and can still be, advantageous to us. Finally we shall prepare, or attempt to prepare, estimates of the expenses and the products which accrue from these, and we shall undertake nothing upon which we are not both perfectly agreed in principle; consequently we shall both subscribe to the project which we shall decide upon, in order that neither of us may depart from it, and it will be the same for all new expenses which might alter the plans that are reached.

$$
\text { A r t. } 3 .
$$

It is agreed that half the product of this plantation shall be divided between us on a one half basis, and in order to 
que la perte, nous aurons un Livre particulier pour cet Objet, d'un Coté seront Inséres les articles de dépences par Jour, et au moment que nous en fairons, de l'autre Coté les ventes et Produits des fermes et de tout ce qui pourra résulter de cette Opération en sorte que le Bénéfice se verra tous les jours par l'addition des articles qui Composeront le débit et le Crédit.

\section{A r t. 4 .}

La Maison cy dessus sera un objet distinct. de tout Commerce afin de pouvoir régler cette propriété tant et tant de fois que Nous le désirerons. il est même Convenu que joindrons aux frais de cette Exploitation ceux nécessaires pour la vie et autres dépences communes tant qu'il nous Conviendra de vivre et d'habiter ensemble.

\section{A r t. 5 .}

Il ne peut nous etre interdit de faire tout autre Commerce, mais avant d'en entreprendre nous resterons six mois a prendre des Informations aux pays de ce qui pourroit nous etre avantageux, alors nous nous livrerions à quelque opération de commerce ou Intérieur ou Maritime.

\section{A r t. 6 .}

Nous pourrons l'un et l'autre faire quelque voyage a l'effet de nous procurer des Connoissances, et s'il arrivait que nous decidions quelque Négociants a envoyer des Marchandises à la vente ou à la Consignation de $\mathbf{M}^{\mathrm{r}}$. Rozier pére nous fairions la Condition que le Bénéfice qui resulteroit de ces Consignations seroit partages entre nous et le $S^{u r}$. F. Rozier pere.

$$
\text { Art. } \% .
$$

Tous les bénéfices comme les pertes résultant de nos Opérations Commerciales seront partagées Egalement entre les associes. 
recognize this [profit], as well as the loss, we shall keep a special book for the purpose; on one side shall be entered the items of expense, day by day, and, at the moment this is done, on the other side [shall also be given] the sales and products of the farms, and of all that can result from this business, in such a way that the profit shall be always apparent by the addition of the items which compose the debit and the credit.

\section{A. $r$ t. 4 .}

The house above mentioned [Mill-Grove farmhouse] shall be an object separate from all business, in order that we may settle matters as completely as we desire. It is agreed that we shall add to the expenses of this exploitation, those necessary for life, and others of a common character, so long as it shall suit us to live and dwell together.

\section{A r t. 5 .}

We cannot be prevented from engaging in any other kind of business, but before undertaking it we shall remain six months in order to gather from the country information of a kind that would be advantageous to us; we shall then apply ourselves to some commercial occupation, whether inland or maritime.

\section{A r t. 6 .}

We are both at liberty to make any journey in order to procure information, and should it happen that we persuade any merchants to send goods to Mr. Rozier, Senior, we would establish the condition that the benefit which might result from these consignments would be divided between us and the $\mathbf{M}^{\mathrm{r}}$. F. Rozier, Senior.

$$
\text { A r t. } \% \text {. }
$$

All the benefits as well as the losses resulting from our commercial transactions shall be divided equally between the partners. 


\section{A r t. 8.}

Les frais de Passage et autre communs entre nous fairont le premier article de nos dépences sociales...

\section{A r t. 9.}

Nous nous promettons l'un et l'autre a mitié et In-$\mathrm{t} \mathrm{e} 1 \mathrm{li} \mathrm{g}$ e $\mathrm{n} \mathrm{e}$, et convenons très expressement qua la moindre difficulté, nous prendrons chacun un arbitre qui sera authorisé a se choisir un troisieme et nous engageons sur notre honneur a en passer par tout ce qui sera décidé, sans que jamais nous puissions en faire appel devant aucuns tribunaux.

\section{A r t. 10.}

En cas de mort de l'un ou l'autre (ce qu'a Dieu ne plaise) le survivant sera seul charge de la Liquidation pour en tenir Compte à qui de droit, c'est a dire aux héritiers du Déffunt. mais la societé ne pourra etre dissoute que neuf années à Compter du Jour de la Datte du présent. ce Cas seulement arrivant, il sera alloué au survivant une Commission sur les produits de l'Etablissement fixe à Dix pour Cent.

Fait double et de bonne foy entre nous.

Nantes ce 23 Mars 1806.

$$
\begin{aligned}
& \text { JEA N A UDUBON } \\
& \text { FER DINAND ROZIER }
\end{aligned}
$$




\section{A r t. 8.}

The expenses of the journey and others of a common nature shall make the first item of our social expenses. . . .

$$
\text { A r t. } 9 .
$$

We both resolve to maintain friendship and mutual understanding, and we agree very expressly that, upon the least difficulty, we shall each select one arbitrator, who will be authorized to choose a third, and we promise upon our honor to fully accept the decision that shall be reached, without ever having it in our power to make an appeal from it before any courts.

\section{A r t. 10.}

In case of the death of one or the other (which, God forbid), the survivor shall have sole charge of making a settlement, in order to give an accounting to those entitled to it by law, that is to say to the heirs of the deceased, but the partnership cannot be dissolved until after nine years, counting from the day of the date of the present [instrument]. Only in this event, the survivor will be allowed a commission upon the products of the establishment fixed at ten per cent.

Done in duplicate and in good faith between us.

Nantes this 23 March 1806.

John Audubon FERDINAND RozIER 
10. Power of Attorney issued by Lieutenant Jean Audubon, Anne Moynet Audubon, and Claude François Rozier to their respective sons, Jean Audubon and Ferdinand Rozier, at Nantes, France, April 4, 1806, eight days before the latter embarked to America to enter upon their partnership in business.

[stamp] Par devant Royer et Son Collégue, notaires à la REP. FRA. résidence de Nantes, département de la Loire-incen férieure soussignés, ont comparu le Sieur Jean Audubon, rentier, et dame Anne Moinet, son épouse qu'il autorise, demeurants rue Rubens, No$^{\circ}$. 39, et monsieur Claudefrançois Rozier, négociant, rue de la fosse, tous trois commune de nantes, Les quels constituent pour leurs Procureurs généraux et spéciaux Jean Audubon, fils, et ferdinand Rozier, fils, aux quels, l'un en l'absence de l'autre, ils donnent pouvoir et procuration de faire, pour et au mieux de l'intérêt de Constituants, tous réglements de comptes, éligements de crédits, recovrements, payements, et autres actes analogues avec tous fermiers, correspondants, débiteurs et créanciers des Constituants aux Etats-unis d'Amérique; plaider, constituer, transiger, recevoir, donner quittances, renouveler, prendre termes, expedier et géréralement faire pour leur utilité, tout ce qui leur semblera le plus convenable; le tout, d'après les renseignements, pieces et documents relatifs, qui leur ont été, leur sont ou leur seront fournis tant par les constituants que par autres leurs précédents chargés d'affaires et fondés de pouvoirs aux dits Etatsunis de régir, gérer et administrer la moitié appartenante aux constituants de la terre de Mill Grove en Pensylvania même d'exploiter ou faire exploiter la mine de plomb récemment découverte sur la dite terre: consulter dans tous les cas importants, monsieur Miers fisher,- - négociant à Philadelphie, comme ami commun et bon conseil; tenir tous livres et registres nécessaires, faire à la fin de chaque année ou plutôt, la balance de la recette et dépense pour la régie de la dite terre et l'exploitation de la mine, s'il y a lieu; vendre aux prix, charges, clauses 
10a. Translation of the Power of Attorney issued by Jean Audubon, Anne Moinet Audubon, and Claude François Rozier to Jean Audubon and Ferdinand Rozier, April 4, 1806.

[stamp] In presence of Royer and his colleague, notaries,

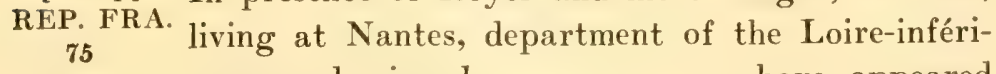
eure, undersigned, have appeared Sieur Jean Audubon, capitalist, and Madame Anne Moinet, his wife, whom he authorizes [to act], living at Number 39, rue Rubens, and Monsieur Claude François Rozier, of rue de la Fosse, all three of the commune of Nantes: who empower, to act as their general and special attorneys, Jean Audubon, the younger, and Ferdinand Rozier, the son, to whom, jointly and severally, they give authority and warrant of attorney to make, for and in the best interest of the grantors, all settlements of accounts, assignments of credits, recoveries of debts, payments, and other analogous acts with all tenants, representatives, debtors and creditors of the grantors in the United States of America; to go into court, settle, compromise, receive, to give receipts, to renew [loans or notes], to grant time, to expedite, and in general to do for their benefit all that shall seem to them most fitting; the whole, according to the instructions, papers, and documents relating thereto, which have been, are, or shall be furnished them, as well by the grantors as by their previous agents and attorneys in the aforesaid United States, to govern, conduct, and administer the half, belonging to the grantors, of the farm of Mill Grove in Pennsylvania, as well as to exploit, or cause to be exploited the lead mine recently discovered on the said farm; to consult, in every important matter, Mr. Miers Fisher,--merchant at Philadelphia, as a common friend and good counsellor; to keep all necessary books and registers; at the end of each year, or sooner, to strike the balance of receipts and expenses for the control of the said farm and the exploitation of the mine, should there be reason for it; to sell at prices, charges, stipulations, and conditions, 
et conditions dont il conviendront, mais d'accord avec monsieur Dacosta, propriétaire de l'autre moitie, la moitié de la dite terre de Mill grove, appartenante aux constituants, en toucher le prix, en donner quittances, faire tous partages, accepter tout lot et généralement faire pour l'intérêt des constituants tous actes conservatoires et definitifs en tous tribunaux, devant toutes administrations et officiers publics, qui leur paraitront nécessaires ou utiles; à l'effet de quoi, tous pouvoirs analogues exprimés ou non exprimés pour tous cas prévus ou imprévus, même de substituer en tout ou partie des dits pourvoirs, qui bon leur semblera et de le revoquer, leur sont donnés par la présente procuration qui ne sera pas sujette à surannation.

fait et passé en l'étude et au rapport de Royer, l'un de nous, sous les seings des comparants, après lecture, ce jour trois avril mil-huit-cent six. la minute est signée des parties et des Notaires soussignés; elle est restée à Royer, l'un d'eux, enregistrée à nantes le trois avril mil-huit-cent-six par Dufau, qui a reçu un franc dix centimes.
V A R S A V A U X
J. N O Y E R

vu par nous président du tribunal de première instance séant à nantes, pour légalisation des Signatures varsavaux et Noyer apposées ci-dessus.

Ce jour trois avril mil huit cent six

GA N D O N

\section{Commercial Agency of the United States of America}

I William D. Patterson Commercial agent of the United States of America for the Port and District of Nantes do hereby certify that the Signatures affixed to the foregoing Document are those of Mess ${ }^{\mathrm{rs}} \mathrm{J}$ Royer and Varsavaux both Notaries publick for the City of Nantes and of $\mathbf{M}^{\mathrm{r}}$ Gandon 
upon which they shall agree, but in accord with Monsieur Dacosta, owner of the other half, the half of the said farm of Mill Grove, belonging to the grantors; to receive the price thereof, to give receipt for it, to make all divisions, to receive all allotments, and in general to perform for the interest of the grantors all conservative and final acts in every court of justice before all jurisdictions and public officers, which shall seem to them necessary or useful: to the effect of which all analogous powers, expressed or unexpressed, foreseen or unforeseen, even of substituting in whole or in part of the aforesaid powers, whosoever shall seem good to them, and of revoking him, are given to them by the present bill of attorney, which will not be subject to expiration.

Done and granted in the office and on the report of Royer, one of us, under the signatures of the persons in appearance, after reading, this third day of April, one thousand eight hundred and six. The minute is signed by the parties and the undersigned notaries; it remains with Royer, one of us, recorded at Nantes the third of April one thousand eight hundred and six, by Dufau, who has received one franc, ten centimes.

VARsavaUX

J. Royer

[S e a l] Examined by us, judge of the Court of the First Instance, sitting at Nantes, for the authentication of the signatures Varsavaux and Royer, affixed above, this third day of April, one thousand eight hundred and six.

Gandon

President of the Tribunal of premiere Instance at the said City and that to their Signatures and Ads as such, full faith and Credit is and ought to be due and given

[S e a l] In testimony whereof I have hereunto Set my Hand \& affixed my Seal of Office at Nantes this $4^{\text {th }}$. of april 1806.

W D P A T TER O N 
11. Account Current of John Audubon and Ferdinand Rozier with the estate of Benjamin Bakewell, late commission merchant in New York, showing their dealings and standing with this house during the first sixteen months of their

1807

Augt 1 To Sundry Merchdize $\mathrm{p}^{\mathrm{r}}$ Invoice.......\$2482 35

31 "Cash sundry expences on the above.. 644

Sept ${ }^{\mathrm{r}} 29$ " Merchdize Powder Horns shot bags \&c 57

Nov 13 " W Taylor exp ${ }^{\mathrm{s}}$ on $\mathrm{D}^{\circ}$ to Pittsburgh

" Cash certificate property $\mathrm{p}^{\mathrm{r}}$ Mentor to Nantes .............. 2

30 " $\mathrm{D}^{\circ}$ postage sundry french letters.. 314

Decer 31 "Adv ${ }^{\mathrm{t}} \mathrm{p}^{\mathrm{r}}$ Jane \# for Indigo \& expences ................ 151643

1808

Jany 29 " Cash $\mathrm{fr}^{\mathrm{t}}$ \& cartge Oil from Philad ${ }^{\mathrm{a}}$.

$30 \quad$ "6 $D^{0} p^{d}$ Hislop for breast pins on your $\mathrm{a} / \mathrm{c} \ldots \ldots \ldots \ldots \ldots \ldots \ldots$

Balance.............. 69512

1808

478750

March 1 To Merche $\mathrm{p}^{\mathrm{r}}$ Bill @6 mos..........\$161

April 7 " your note due this day......... 3647 29

"R. Henderson $\mathrm{am}^{\mathrm{t}}$ due him by you.. 7212

June 27 " Cash cartge \& Lighterage on tobacco 750

"Freight \& primage- " $\mathrm{D}^{\circ} \ldots .105$

July 28 " your note due this day......... 78773

Sept 23 "Mdse 1 doz sans paraitres........ 24 24

$\$ 480490$

$\operatorname{Dec}^{\mathrm{r}} 13$ To Balance .............. \$924 49

Note bY The Author. For brig Mentor, see Chapter XI, Vol. I, p. 163, and for the ship Jane, Captain Sammis, ibid., p. 158. For Messrs. Robert 
business experience in the West. Covers the period, August 1,1807 to December 13, 1808. (Statement accompanying the letter of Thomas Bakewell, reproduced in Vol. I, p. 196.)

in Account Current with Ben.jn Bakewell $\mathrm{C}^{\mathrm{rs}}$.

1807

Augt. $\quad 4 \quad$ By your note at $8 \mathrm{mo}^{\mathrm{s}} \ldots \ldots \ldots \ldots \ldots 36 \pm 729$

Decr. 31 " net procceds sales on 4.50

your a $/$ c .......... $319.35 \quad 32385$

“Francis Rozier balance his a/c... 81656

$\$ 478750$

1808

Feby 1 By Balance as $\mathrm{p}^{\mathrm{r}}$ a/c rendered........\$69512

March 1 " your dft on U S Bank Philada.... 2000

" commission on goods al-

lowed you .......\$118.20 [paper torn]

deduct $1 / 3$ profit on

french goods ....... 24.26 [ $93.94 \quad]$

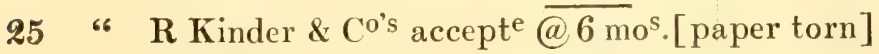

“ L Huron's note - " 9 days. [ " ]

“your note@ $4 \mathrm{mo}^{\mathrm{s}}$ for balance..[ " $]$ Balance............. [ 924.49$]$

New York Decem ${ }^{\mathrm{r}} \cdot 13^{\text {th }} \cdot 1808$

for the Assignees of the [estate of Benjamin

Bakewell]

Th[omas Bakewelu]

Kinder \& Company, see accompanying letter of Thomas Bakewell, Vol. I, p. 196, and letter of William Bakewell, his uncle, ibid., p. 199. Laurence Huron was a French importer, resident in Philadelphia; for his award in the disputed Dacosta claim, see Vol. I, p. 168. At this time Benjamin Bakewell's importing business was in the hands of his creditors, but his son, Thomas Bakewell, was still employed in the office. 
11a. Final Account of Francis Dacosta, rendered July 25, 1807, to Lieutenant Jean Audubon, his partner in the unfortunate

Dr. Mill Grove Farm-in account

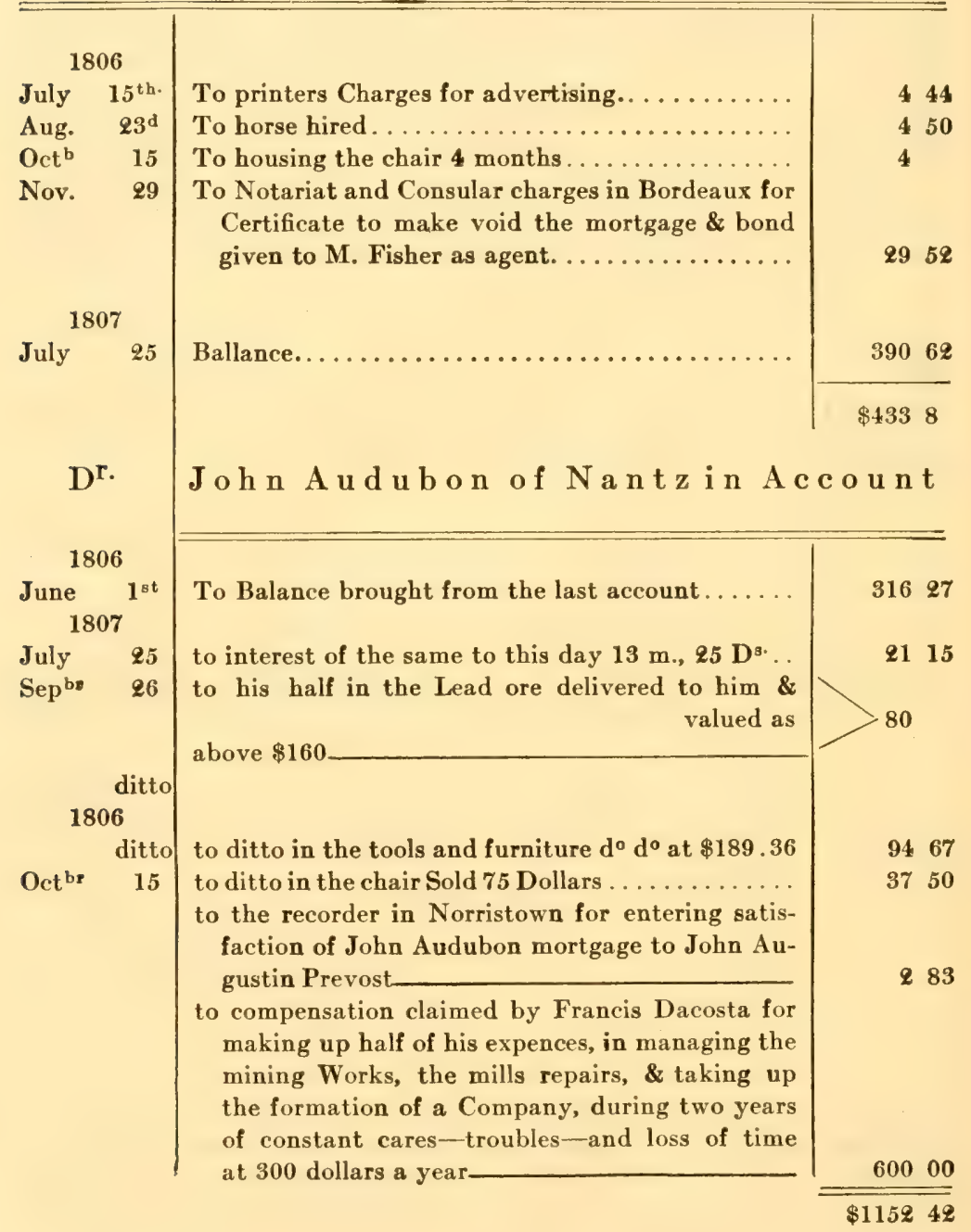


mining enterprise at "Mill Grove"; later contested and settled by arbitration. (For comment, see Vol. I, p. 168.)

with Francis Dacosta

$C^{r}$.

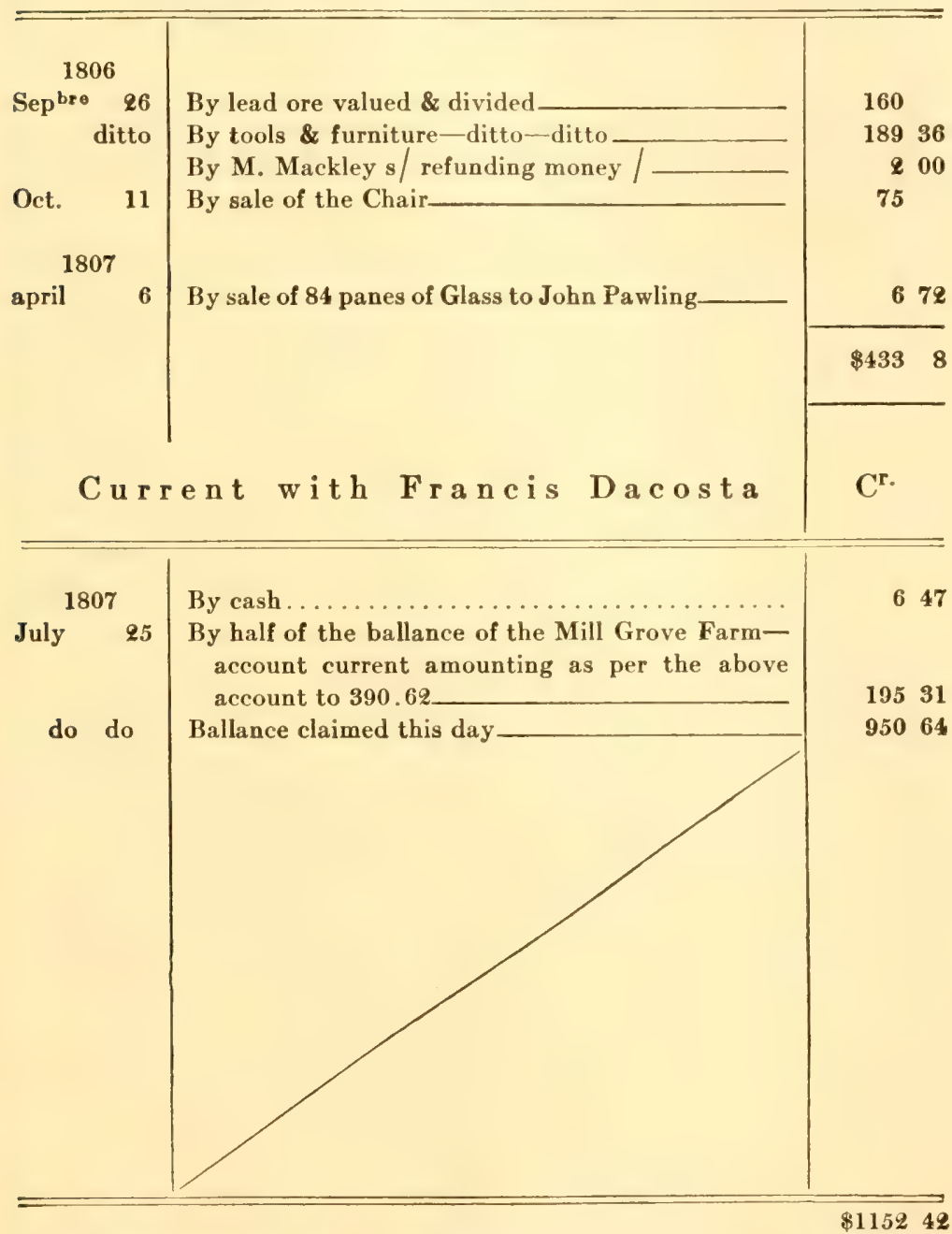

E. E. Philadelphia the $25^{\text {th }}$ July 1807

[Signed] Francts Dacosta. 
11a. Final Account of Francis Dacosta, rendered July 25, 180\%, to Lieutenant Jean Audubon, his partner in the unfortunate mining enterprise at "Mill Grove"; later contested and settled by arbitration.-Continued.

Erreurs à réléver dans le Compte de M. J. Audubon

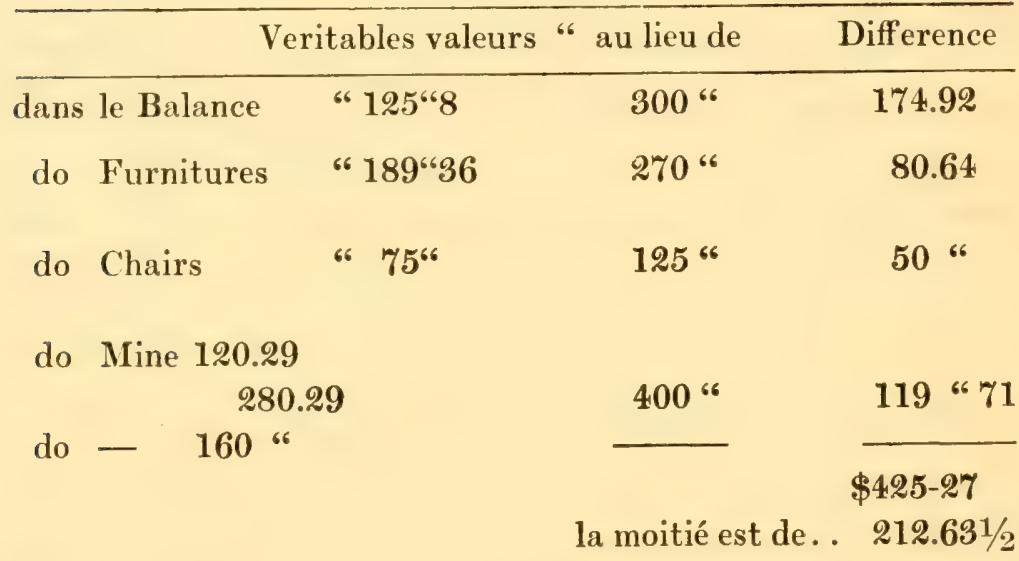

Omis $\$ 300$ payé par francis Dacosta à Miers Fisher

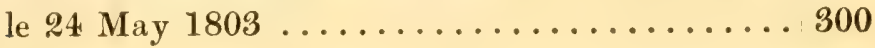

Ditto $\$ 176^{66} 67$ La proportion de Fis Dacosta dans la rente de la premiere annee qui ne lui a pas été payé ......................... 176.67 
12. Quit Claim or Release given by John James Audubon to Ferdinand Rozier on the Dissolution of their Partnership in Business at Sainte Geneviève, Upper Louisiana (Missouri), April 6, 1811.

I John Audibon having this day by mutual Consent with Ferdinand Rozier, dissolved and forever closed the partnership and firm of Audibon \& Rozier, - and having Received from said Ferdinand Rozier, payments and notes to the full amount of my part of the goods \& debts of the late firm of Audibon \& Rozier-I the said John Audibon one of the firm aforesaid, do hereby release and forever quit Claim to all or any Interest which I have or may have in the Stock on hand and debts due to the Late Firm of Audibon \& Rozier unto him the said Ferdinand Rozier, all my rights titles, claimes and Interest in the goods merchandise and debts due to the late Firm of Audibon \& Rozier - and do hereby authorize and empower him for my part to collect the same in any manner whatseer . either privately or by suit or suits in law or equity-hereby acclaiming him sole and absolute proprietor and rightful owner of all the goods merchandises \& debts of the firm aforesaid, as completely as they were the goods and property of the Late firm of Audibon \& Rozier-

In witness whereof $I$ have hereto Set my hand \& Seal this Sixth day of April 1811

[Seal]

\section{John Audubon}

$\mathrm{E}^{\mathrm{d}}$ D. De Villmonte

Note BY THE Authon. It will be noticed that the naturalist writes his name seven times as "Audibon," in this document, but signs in the way usual with him at the period. See Vol. I, p. 24. 
13. Copy of a portion of the first Will of Lieutenant Jean Audubon. Couëron, May 20, 1812. this and documents Nos. 14 to 18, see Chapter IV.)

Jean AUDUBON, propriétaire demeurant à sa maison de la Gerbetière commune de Couëron, lequel sain d'esprit a fait son testament comme suit:

Par les présentes mon testament.

Je donne et lègue à dame Anne Moinette mon épouse, la part et portion disponible en usufruit à raison de ce que j'aurai ou non de descendants de généralement tous les biens meubles et immeubles qui m'appartiendront à l'instant de mon décès.

Je donne et lègue à Monsieur Jean Audubon que je crois actuellement aux Etats-Unis sans cependant en être sûr, la moitié en toute propriété de généralement tous les biens meubles et immeubles qui m'appartiendront à l'instant de mon décès pour par lui en faire et disposer en toute propriété et à sa volonté à la charge toutefois par lui de laisser dame Anne Moinette mon épouse jouir sur iceux du legs fait ci-dessus en sa faveur.

Je donne et lègue à dame Rose Bouffard épouse de Monsieur Gabriel Loyen du Puigaudeau, demeurant actuellement au Port-Launay en Couëron, la moitié en propre de généralement tous les biens meubles et immeubles qui m'appartiendront à l'instant de mon décès pour par lui en faire et disposer en toute propriété et à sa volonté à la charge toutefois par elle de laisser dame Anne Moinette mon épouse, jouir sur iceux du legs que je fais ci-dessus en sa faveur.

Je veux et entends qu'en cas de mort de Monsieur Audubon ou de madame Puigaudeau, mes deux derniers légataires aux présentes ou même de tous les deux, les héritiers en ligne directe de l'un ou de l'autre recueillent entr'eux le legs fait en leur faveur, c'est-à-dire que les héritiers de M. Audubon recueilleront le legs qui lui est fait et ceux de Madame Puigaudeau celui fait à la dite; en cas toutefois que les sieurs Audubon et la dame Puigaudeau ne recueilleraient pas eux-mêmes le legs, soit parce qu'ils précéderaient moi le testateur, ou autrement, . . . 


\section{Copy of the second and last Will of Lieutenant Jean Audubon. March 15, 1816.}

Moi, soussigné, Jean AUDUBON, demeurant à la Gerbetière en la commune de Couëron, département de la LoireInférieure.

Par les présentes mon testament.

Je donne et lègue à dame Anne MOINETTE, mon épouse la part et portion disponible en usufruit à raison de ce que j'aurai de descendants de généralement tous les biens meubles et immeubles qui m'appartiendront à l'instant de mon décès.

Je donne et lègue à Monsieur Jean RABAIN créole de SaintDomingue, que je crois actuellement aux Etats-Unis, sans cependant en être sûr, époux de Mademoiselle Lucy BACKWELL, la moitié en toute propriété de généralement tous les biens meubles et immeubles qui m'appartiendront à l'instant de mon décès pour par lui en faire et disposer en toute propriété et à sa volonté, à la charge toutefois par lui de laisser dame Anne Moinette, mon épouse jouir sur iceux du legs fait ci-dessus en sa faveur.

Je donne et lègue à dame Rose BOUFFARD, créole de Saint-Domingue épouse de M. Gabriel Loyen du Puigaudeau, demeurant actuellement au Port-Launay en Couëron, la moitié en propre de généralement tous les biens meubles qui m’appartiendront à l'instant de mon décès pour par elle en faire et disposer en toute propriété et à sa volonté, à la charge toutefois par elle de laisser à dame Anne Moinette, mon épouse jouir sur iceux du legs fait ci-dessus en sa faveur.

Je veux et entends qu'en cas de mort de M. RABAIN ou Madame Puigaudeau, mes deux derniers légataires aux présentes, ou même de tous les deux, les héritiers en ligne directe de l'un ou de l'autre recueillent entr'eux le legs fait en leur faveur.

Cela dit, que les héritiers de M. RABAIN recueilleront le legs qu'il lui est fait et ceux de dame Puigaudeau celui fait à la dite dame en cas toutefois que les dits sieurs Rabain et dame 
Puigaudeau ne recueilleront pas eux-mêmes les legs faits, parce qu'ils précéderaient moi le testataire, ou autrement et dans le cas ou par quelque motif que ce puisse être les présentes dispositions en faveur de Jean Rabain et Rose Bouffard épouse Loyen du Puigaudeau seraient attaquées et annulées, je déclare donner mes biens meubles et immeubles sans exception quelconque à la dame Anne Moinette mon épouse en toute propriété. Fait dans ma demeure susdite à la Gerbetière en Couëron le 15 Mars 1816. Vive le Roi!

Signé: Audubon. 
15. Copy of a portion of the first Will of Madame Anne Moynet, wife of Lieutenant Audubon. December 4, 1814.

Par les présentes mon testament.

Je donne et lègue à Monsieur Jean AUDUBON, mon mari, la jouissance en toute propriété des biens meubles et celle en usufruit des biens immeubles qui m'appartiendront à l'instant de mon décès, pour qu'à l'un et l'autre titre de cette epoque, il en jouisse fasse et dispose comme de tous ses autres biens sans être tenu d'en donner caution, voulant et entendant qu'il puisse faire sur les immeubles tous changements, coupes de bois et autres qu'il lui plaira, le tout avec dispense des dommages et intérêts.

Je donne et lègue en toute propriété à Monsieur Jean Audubon fils et à dame Rose Bouffard, épouse de Monsieur Gabriel Loyen du Puigaudeau à chacun par moitié, la totalité de tous les biens qui composeront ma succession immobilière à l'instant de mon décès, duquel néanmoins par suite du legs fait ci-dessus en faveur de mon mari, ils ne pourront se mettre en possession qu'a sa mort.

Arrivant que mon mari fut mort avant moi, je veux et entends que M. Jean AUDUBON fils et la dame Rose Bouffard, épouse Puigaudeau, recueillent aussi ma sucession mobilière à l'effet de quoi le cas arrivant, je leur lègue et donne en toute propriété.

Mes intentions que si M. Jean Audubon fils ou la dite dame Puigaudeau étaient morts l'un ou l'autre avant moi ou même tous les deux, leurs enfants soient mes légataires, c'est-à-dire que les enfants de M. Audubon recueilleraient entr'eux ce que celui-ci doit avoir et que ceux de Madame Puigaudeau recueilleraient aussi entr'eux ce que celle-ci doit avoir à l'effet de quoi je les donne et lègue aux dits enfants.

Si à ma mort l'un ou l'autre de M. Audubon fils ou de Madame Puigaudeau étaient eux-mêmes morts sans enfants, je veux que ce soit alors les survivants d'eux deux ou ses enfants qui recueillent ma succession entière, pourquoi à cette cause, je lègue la totalité de mes biens meubles et immeubles, . . . 
16. Copy of a portion of the second Will of Madame Jean Audubon. May 10, 1816.

\section{..... Je donne et lègue à Monsieur Jean AUDUBON,} mon époux, la part et portion disponible en usufruit à raison de ce que j'aurai ou non d'enfants de généralement tous les biens meubles et immeubles qui m'appartiendront à l'instant de mon décès pour par lui en jouir sa vie durant, sans pouvoir être tenu à en fournir caution et à ma mort mes héritiers les prendre dans l'état où ils seront.

Je donne et lègue en toute propriété à M. Jean RABIN, créole de Saint-Domingue, époux de demoiselle Lucy BACHWELL, laquelle je crois aux Etats-Unis d'Amérique, sans cependant en être sûre et à dame Rose Bouffard, créole de Saint-Domingue, épouse de Monsieur Gabriel Loyen du Puigaudeau, demeurant au Plessis commune de Couëron, la généralité de tous les biens meubles et immeubles qui m'appartiendront à l'instant de mon décès, pour par eux s'en mettre en possession, les partager par moitié et chacun jouir faire et disposer de ceux qui lui échoieront comme de ses autres biens propres de ce jour. Si M. Jean Audubon mon époux, est mort avant moi, mais seulement du jour de sa mort s'il me survit parce que je veux expressément que le legs fait ci-dessus en sa faveur ait sa pleine et entière exécution de préférence et avant tout.

Je veux et entends qu'en cas de mort de Monsieur RABIN ou de Madame Puigaudeau mes deux derniers légataires ou même de tous les deux, les héritiers en ligne directe de l'un ou de l'autre réunis recueillent le legs fait en faveur de leur auteur, c'est-à-dire que les héritiers de M. RABIN recueuilleraient le legs à lui fait et ceux de Madame PUIGAUDEAU ce que celle-ci aurait recueilli.

Arrivant que les libéralités faites en faveur de Monsieur Rabin ou celles faites en fabeur de Madame Puigaudeau ou même toutes les deux par quelles causes ou raisons que ce soit viendraient à être déclarées nulles, je veux que Monsieur Audubon, mon époux recueille en toute propriété les biens meubles 


\section{ORIGINAL DOCUMENTS}

et immeubles qui en font l'objet et auraient passé aux mains de celui ou ceux qui ne pourraient les faire à l'effet de quoi je l'institue mon héritier en droits, fonds et propriétés pour les biens que mes autres autres légataires ci-dessus ou l'un d'eux seulement ne recueilleraient pas,.... 
17. Copy of the third Will-"No 169-of Madame Anne Moynet, widow of M. Jean Audubon, living at his house of La Gerbetière, situated near the village of PortLaunay, not far from Couëron." December 26, 1819.

Par les présentes mon testament;

Je donne et lègue en toute propriété à Monsieur Jean RABIN époux de dame Lucy BACKWELL, que je crois présentement aux Etats-Units d'Amérique et à dame Rose BOUFFARD, épouse de M. Gabriel Loyen du Puigaudeau aîné la généralité de tous les biens meubles et immeubles de toute espèce et nature qui m'appartiendront à l'instant de mon décès en quelles mains et lieux qu'ils soient et par quelques personnes qu'ils soient dûs ou possédés pour par eux deux en jouir faire et disposer en toute propriété comme de leurs autres biens, et ainsi qu'ils le jugeront convenable, sauf à les partager par égale portion s'ils le trouvent à propos et nécessaire et sans que qui que ce soit étant ou se prétendant mes héritiers, puissent y apporter aucune opposition, parce que par ces mêmes présentes, j'institue le dit M. Rabin et la dame Puigaudeau, mes seuls et uniques héritiers.

Je veux que dans le cas de mort de M. Rabin, ses enfants recueillent entr'eux le legs fait en sa faveur, je veux également qu'en cas de mort de Madame Loyen du Puigaudeau, ses enfants recueillent entr'eux le legs fait en faveur de la dite leur mère.

Je veux également qu'en cas de mort de M. Rabin sans enfants, Madame Loyen du Puigaudeau ou ses enfants, recueillent seuls la totalité de ma fortune et par ces mêmes raisons, qu'en cas de mort de Mme Loyen du Puigaudeau sans enfants, Jean Rabin ou ses enfants recueillent seuls la totalité de ma dite fortune. 
18. Copy of a portion of the fourth and last Will of "Madame Jean Audubon, living at the house of Les Tourterelles ('The Turtle Doves') at Couëron." July 16, 1821.

Par les présentes, mon testament,

Je donne et lègue en toute propriété à Monsieur Jean AUDUBON, dit Jean RABIN, époux de dame Lucy BACKWELL, et que je crois présentement aux Etats-Unis d'Amérique et à dame Rose BOUFFARD, épouse de Monsieur Gabriel Loyen du Puigaudeau aîné, demeurant à Couëron. Je leur donne et lègue, dis-je la généralité de tous biens meubles et immeubles de toute espèce et nature que je laisserai et qui m'appartiendront à l'instant de mon décès, en quelques mains et lieux qu'ils soient et par quelques personnes qu'ils soient dûs ou possédés pour par eux deux en jouir, faire et disposer comme de leurs autres biens et ainsi qu'il le jugeront convenables, sauf à les partager par égale portion quand et comme ils le voudront sans que qui que ce soit se disant ou prétendant les héritiers puissent y apporter aucune opposition parce que par les dites présentes, j'institue les dịts M. Jean Audubon, dit Jean Rabin et la dame Rose Bouffard, épouse Loyen du Puigaudeau, les deux seuls et uniques héritiers de mes droits, actions, possessions et généralement tous autres, sans exception pas même pour les prétentions.

Je veux et entends que dans le cas où l'un ou l'autre ou même tous les deux ne pourraient pas recueillir les effets de ma libéralité, soit parce que je leur survivrais ou par toute autre raison, les enfants qu'ils laisseraient soient mes héritiers et légataires, c'est-à-dire que les enfants de Monsieur Jean Audubon dit Rabin, recueilleraient entr'eux la moitié de ma succession que je leur lègue et ceux de dame Rose Bouffard, épouse Loyen du Puigaudeau, recueilleraient aussi ensemble l'autre moitié que je leur lègue également.

Je veux et entends qu'avant de mort avant moi de Monsieur Jean Audubon, dit Jean Rabin sans enfants, Madame Rose Bouffard épouse Loyen du Puigaudeau ou ses enfants re- 
cueillent seuls la totalité de ma fortune, et par même raison qu'en cas de mort avant moi de Madame Rose Bouffard, épouse Loyen du Puigaudeau; sans enfants, Monsieur Jean Audubon, dit Jean Rabin ou ses enfants recueillent seuls cette totalité,... 
19. Notice of the Death of Lieutenant Jean Audubon, from the Official Registry of Nantes. Nantes, February 19, 1818. (For translation, see Chapter V.)

Extrait du registre des actes de décès des $3^{\circ} \& 4^{\circ}$ cantons de la Ville de Nantes, département de la Loire-Inférieure.

L'an 1818, le 19 Février à 11 heures du matin, devant nous soussignés, adjoints et officiers de l'état civil, délégués de $M$. le Maire de Nantes, chevalier de Saint-Louis, ont comparu les sieurs Gabriel Loyen du Puigaudeau rentier, gendre du défunt ci-après demeurant à Couëron et François Guillet, épicier demeurant quai de la Fosse, majeurs, lesquels nous ont déclaré que ce jour à six heures du matin, Jean Audubon, ancien capitaine de navire, pensionnaire de l'Etat, né aux Sables d'Olonne département de la Vendée, époux de dame Anne Moinet, est décédé en la demeure de demoiselle Berthier, située chaussée de la Madeleine, $\mathrm{N}^{\circ}$ 24, $4^{\circ}$ canton.

Les déclarants ont signé avec nous le présent acte, d'après lecture leur faite. Le dit défunt âgé de 74 ans.

Signé au registre: Gabriel Loyen du Puigaudeau, Gillet et Joseph de la Tullaye, adjoint. 
20. Letter of Lieutenant Jean Audubon to Francis Dacosta, his American agent and attorney, relating to the conduct of his son and to the lead mine at "Mill Grove" farm; transliterated from photographic copy of duplicate (Letter No 4) in Jean Audubon's letter-book. Nantes, March 10, 1805. (For translation, see Chapter VIII.)

\section{Nantes Le 19 ventose an 13, 10 mars 1805}

\section{$M^{r} D_{A \cos t a}$}

a phyladelphie

\section{p Duplicata.}

Je viens de recevoir dans ce moment votre duplicata du 12. $9^{\text {bre }}$ \& la votre du 5. Decembre, qui n'est pas aussi avantageuse, Sous plusiers rapports que votre précédente, mais enfin il faut esperer que l'item vous prouvera que votre dernier sillon ne sera point déserteur, et que les occides de fer qui se trouvent se dissiperont en fouillant plus avant, au moins c'est ce que je désire. vous faites bien de faire tous vos efforts pour avoir des associés \& Si cela ne reussit pas, \& que vous vouliez travailler pour notre compte Je trouverai toujours bon, tout ce que vous ferez, puisque vous avez ma confiance dans ce cas je crois que vous s . . igé [?], de faire faire des reparations les plus urgentes Surtout à la maison principale, Devant vous y loger. Quand à $\mathbf{M}^{\mathrm{r}} \mathrm{W}$. Thomas, vous ferez bien de vous le garder, pour toutes les raisons, que vous me dites \& Je crois qu'il ne doit pas sopiniatrer à se retirer, qu'il ne sache, s'il à mérité, oui ou non, sa récompense.

Je suis $\mathbf{M}^{\mathrm{r}}$. on ne peut plus faché de ce que vous ayez à vous plaindre, de la conduite de mon fils, car le tout, bien considéré n'est occasionné, que par de mauvais conseils \& un deffaut d'usage on a aiguillonné son amour propre, et peut être avait-il été assez jeune pour se vanter, dans la maison ou il va que cette plantation devait lui echoir, à lui seul; vous avez tous les moyens de detruire cette présomption, on n' ignore point a philadelphie, que vous avez autant de droits que moi \& que vous ne faites rien que pour notre mutuel avantage. 
Je lui ecris a ce sujet, car il ne men parle point, et je lui donne la cémonce que mérite son indiscrétion; vous lirez cette lettre et voudrez bien avoir la complaisance de la cacheter avant de lui remettre. Vous me dites que je puis m'en rapporter sur son compte au rapport que m'en fait $\mathbf{M}^{\mathrm{r}}$. Meyers fisher, dans sa longue lettre du mois de Septembre que Malheureusement je n'ai pas reçu, car $\mathbf{M}^{\mathrm{r}}$ fisher, ne me parle point de lui, ni en bien, ni en mal. Quand à venir dans le pays, cela me parraît presqu'impossible, rappeller mon fils nest pas plus aisé, les raisons qui me l'en fait l'envoyer existent toujours; il ne faut qu'un instant pour le faire changer du mal au bien, sa grande jeunesse et sa petulance sont tous ses torts et si vous avez la Bonté de lui donner l'indispensable, il sentira bientot la Nécessité de se rapprocher de vous et pourra vous être d'une grande utilité, si vous exploitez par vous même.

Il faut donc Mon cher monsieur, que nous tachions de le ramener par la douceur à son Devoir. Si vous avez de l'indulgence pour lui ce sera moi qui vous en aurai toute l'aubligation; j'espere que la lettre cy-jointe operera chez lui un changement. C'est mon seul fils, mon heritier, \& je suis vieux. Quand $M^{\mathrm{r}}$ Meiers fisher aura montré ma lettre au prétendu beaupere, il verra qu'il s'est trompé dans son calcul sur le prétendu Mariage de sa fille, car s'il avait lieu sans mon consentement tout secours de ma part cesserait des cet instant; et c'est ce que vous pouvez bien si vous voulez avoir cette bonté, dire au prétendu beau pere, ne voulant pas que mon fils se marie aussi jeune; vos lettres du 28 Octobre \& 12 Novembre sont à la campagne. Je ne puis point répondre categoriquement sur leurs contents; Je les examinerai \& vous dirai par ma prochaine ce que J'en pense. Votre famille que J'ai vu se porte bien. Nos dames vous rémercient de votre bon souvenir. Je suis \& .

[Jean Audubon.] 
21. Letters of John James Audubon to Claude François Rozier, father, and to Ferdinand Rozier, son, immediately preceding and following his active partnership in business with the latter: 1807 and 1812. (For translations see Chapters XI and XV.)

\section{[Letter No. 2, superscribed] Monsieur Fr. Rozier,}

Negociant

Nantes.

Loire inferieure.

Mr. Rozier Negociant

Nantes

Mon Cher Monsieur

Je profite d'une bonne occasion pour Bordeaux pour vous accuser reception d'un Duplicats des pouvoirs que nous vous demandai plusieurs mois passes. Vous saurez aussi que les vins consignes a M. L. Huron de Philadelphia sont arrives en cette ville et ont sauves les assurances; votre fils s'est transporte sur la place et par une de ses lettres m'apprend que les 60 caisses sont vendues il me dit que vous pouvez compter sur un profit net d'a peu pres 20 p. ct. s'il s'est trouve tres bons et le reste ne manquera de trouver acheteur: $\mathbf{M}^{\mathrm{r}}$. Le Ray est arrive et a apporte avec lui une petite Boite de dentelles pour M. Benjamin Bakewell d'icy elle doit arriver en peu de jours de Philadelphia. Mr. B. B. a paru satisfait de la vente de son Bois Futtie. il lui tarde seulement de voir les retours il est malheureux que le commerce de votre ville avec ce pays ne soye pas aussi regulierement suivi qu'a Bordeaux d'ou nous avons des Batiments tous les mois et par plusieurs. Comme notre ami Ferdinand vous ecriva de Philadelphia concernant $M^{r}$. Huron je ne m'ettendray pas sur son compte: dans plusieurs de vos Lettres que si nous nous decidions obtenir un magasin de detail que vous pourriez nous tenir constamment employe nos idees sur ce sujet sont par faitement d'accord et ce serait avec bien du plaisir que nous commenserions sous auspices et les bons 
avis de Mr. Bakewell ici; les objects bien choisis bien achette et envoye avec soins sont toujours sur de rencontrer un bon marche: j'ose esperer que le Navire la Jeanne Capt Sammis sera arrive a votre port et que les Indigos charges par M. B. Bakewell pourront y etre venu en temp de vente de cette marchandise dont $\mathrm{j}$ 'ai neanmoins quelque crainte vu le prix qu'ils lui avaient coute. Nous vous remercions sincerement pour le prix courant que vous nous avez envoye, dans une de mes dernieres ecrite par voye de Bordeaux je vous priais de demander a $\mathrm{M}^{\mathrm{r}}$. Fleury Emery une boite de graines de la Martinique et de se pays cy. nous esperons sous peu vous envoyer quelque marchandises et peut etre $\mathbf{M}^{\mathrm{r}}$. Bakewell profitera d'une occasion que nous allons avoir en peu de jour pour votre port. A peu plus trois semaines passees Je fus a Mill Grove et l'affermais pour un an ne pouvant faire mieux pour le present. Votre fils a Philadelphia a present va essayer de terminer les comptes de mon pere avec $\mathbf{M}^{\mathrm{r}}$. Dacotta [Dacosta] qui n'oublie pas aisement d'etre chicanneur... presentez Je vous prie mes respects et amities a votre bonne famille et epouse et croyez en moi comme votre devoue

$$
\begin{aligned}
& \text { et constant } \\
& \text { serviteur } \\
& \text { J. J. AUdubon }
\end{aligned}
$$

Ayez la complaisance de faire parvenie l'incluse a mon bon pere.

[Superscribed]

$$
\begin{aligned}
& \text { Mrs F. Rozier } \\
& \text { Merch }^{\mathrm{s}} \\
& \text { St Genevieve }
\end{aligned}
$$

u. L.

\section{Mon Cher Rozier :-}

Shipping Port . 10th. Augst. 1812

Come il est presque probable que l'occasion que je trouve est sur, je suis avec elle le plaisir de t'écrire quelque mots-

Je reçus en temps ta lettre envoyé a Phila a lequelle je repondis alors; depuis je n'ai entendu de tes nouvelles que par 
voies très indirectes, je serais bien content si tu peux donner quelques instants a tes amis que tu me compte aux nombre et m'écrire par temps; je partis avec ma femme et mon fils de Phil a au mois passé, la plus grande parties de ce temps a été à descendre L'Ohio qui est actuellement très bas nous avons eu la Barge et L'Equipage du $\mathrm{G}^{\mathbf{l}}$ Clark, avec la compagnie de $\mathbf{M}^{\mathbf{r}}$ R. A. Maupin et de $\mathbf{M}^{\text {de }}$ Galt qui avaient rester plusieurs mois a New York \& a Phila. Je vais probablement descendre a la N. Orléans cet autumn avec N. Berthoud, les merchandizes sont extremement rare et très chere, partout, mais plus encore les gros Lainages que l'on ne trouve du tout.

Je n'ai pas de doute que ton plomb ne se vende tres bien cet article ayant augmenté considerablement depuis la guerre.dans les derniers jours que j'etais dans l'Est j'ai recu une lettre de mon père et une de ton frère toute ta famille se portait alors bien dit 4 mois passés, ton frère désire beaucoup entendre de toi, si la paix vient un jour non bien loin (ce qu'à Dieu plaise) j'espere entrer en liaison avec lui.

Je lui est écrit et l'engage a faire de même tes lettres pouront se rendre si envoyers a N. York et de la dans la Cartel. Ma femme se porte bien et mon fils sois de même et compte au nombre de tes amis est ce que dison celui qui t'estimera toujours. Adieu

J. Audubois 


\section{APPENDIX II}

\section{Audubon's Early Dated Drawings Made in \\ France and America}

Drazeings now in the Collections of Mr. Joseph $Y$. Jeanes, of Philadelphia, and formerly belonging to Mr. Edward Harris, of Moorestown, New Jersey; of Mr. John E. Thayer, Lancaster, Massachusetts; and of Harvard University. (See Chapter XII.)

In addition to the serial numbers, here given, the drawings usually bear French and English names, with various notes in French relating to weights and measurements, and rarely with sketches of detail.

Mr. Jeanes' collection contains the following:

No. 5 . Long-tailed Mountain Tit, 22 January, 1805 13. Sedge $\mathrm{S}$ parrow, near Nantes, 1805

22. Reed S parrow, near Nantes, 1805

78. Hawk's E y e, -Spotted Plover,-France,

97. The Creeper, France, 18 March, 1805 [?]

86 . Shrike, near Nantes, June 7, 1805

93 . Nuthatch, near Nantes, July, $\quad 1805$ Terns, France, July 9, 1805 July 12, $\quad 1805$

50 . The Redstart, near Nantes, August, 1805 


\section{APPENDICES}

No. 61. The Great Swallow (Le

martin noir), near

Nantes,

65. The Wagtail, near Nantes, Dec. 22,

1805

69. The Green Finch, near

$$
\text { Nantes, Dec., }
$$

1805

92. L'Ecorcheur à tête rouge,

$$
\text { near Nantes, }
$$

6. "Grosbec," near Nantes,

94. Woodpecker, near Nantes, March 8,

1806

Fish Hawk, Perkioming

Creek,

1806

209. Wood Thrush, Mill Grove, August 14, 1806

145. Long-tailed Duck, New

York,

Dec. 17 ,

1806

Golden Eye, New York,

Dec. 28,

1806

153. American Widgeon, New

York,

Dec. 28,

1806

102. Robin (eggs dated May

8th), New York,

Jany. 4,

1807

156 . Shelldrake, New York,

Jany. 28,

1807

143 . Widgeon, New York,

Feby. 23, 1807

146. Canvasback, New York,

March 22, 1807

163 . Shoveller, New York,

April 3,

1807

163 . Sprig-tail, New York,

Feby. 22, $\quad 1807$

Wood Duck,

48. Orchard Oriole, Falls of the Ohio,

June 5,

1808

214. Chimney Swallow, Falls of the Ohio,

July 27,

1808

188. Kentucky W a r b 1 e r, 20 miles from Philadelphia, (June?), 1809

109 . Passenger Pigeon, Falls of the Ohio,

Dec. 11,

1809

Hooded Merganser, Falls of the Ohio, 
No. 41 . Catbird, Red Banks, June, 1810

105. Red-wing Blackbird, June, 1810

81. The Frog-eater (Hawk),

Red Banks, Nov. 29, 1810

186 . Killdeer,

200, 201. Pewit, and G re a t-

c r ested Flycatcher,

Henderson, May 22, 1811

207 . Carolina Parrot, Hender-

son, June 9,

1811

49. Swamp Sparrow, Pennsylvania, March 12, 1812

6 . Spotted Sandpiper, Pennsylvania,

April 22, 1812

11 . Whippoorwill, Pennsylvania,

May \%, 1812

10. Nighthawk,

May 8,

1812

58. Great American Shrike, Henderson,

Nov. 30, 1812

76 . Red-crowned black Woodpecker, Henderson,

Oct. 15, 1814

66 . Black-capped Nuthatch,

Henderson,

Feby. 16, 1815

Willet, Henderson,

May 8,

1815

Snipe, Henderson,

March 17, 1816

300 . Yellow-billed Rail, Henderson,

Oct. 9,

1816

Purple Gallinule, New Orleans,

April 23, 1821

Chuck Wills Widow, Red

River,

June,

1821 
The Harvard University collections contain the following:

No. 91 . L'Ecorcheur,

42. The $\mathrm{S}$ e d g e - b i $\mathrm{rd}$, near

Nantes,

1805

43. The Nightingale, n e a $\mathbf{r}$

Nantes, July 6, 1805

57 . Brown Thrush, near New

York,

May $10, \quad 1807$

Excellent examples of Audubon's early work in the collection of Mr. John E. Thayer are:

No. 96 . Woodpecker: $\mathrm{p}$ ri o r to

1803 (see note, vol. i, p.

178).

112. Water Thrush, Mill

Grove, Pennsylvania, Aug. 2,

1806

144 . 64. Malaga Shell Drake.

Goosander, M e r gu s

Merganser A. W. Chute

de L'Ohio

17 December, 1809

175. Crested Titmouse, Redbanks, July 1,

1810

71 . 44. The Spirit or Butter-

ball-Bufflehead, Henderson,

Mar. 19,

1815

154. Golden Crested Wren A. W., Sylvi a Regulus, Shippingport, K e ntucky; drawn by J. J. Audubon - Mistletoe on Black Walnut.

Jany. 28, 1820

Hermit Thrush, opposite

Fredericksburg, Ky., $\quad$ Oct. 16

1820

315. Rose-breasted Grosbeak

(on spray of dogwood). 
Among the drawings of the Harris-Jeanes collection which may be earlier than 1805 , though they bear no date, are "The Black Crow of Buffon, Corneille noire," also the head of a Jackdaw wholly in crayon and pastel: "No. 160, Le grand Duc, âgé vingt un an, Buffon,- the large horned owl, Eagle owl. J. J. L. Audubon," a crayon sketch on paper measuring eighteen by twenty-six inches, and water-marked "J. Kool"; also "No. 164. La corneille mantelle de Buffon, Royalton crow, Sea crane, hooded crow, crow-British,-J. J. L. Audubon," a crude sketch in pastels of the same size as the last.

The following legends appear on the drawing of the Canvasback Duck: "Cet Oiseau est nommé Canvas Back Canard very much esteemed par les Americans and very rare ici [c] elui est male et étais beau"; "New York le 22 Mars 1807J. J. L. Audubon" "No. 146." 


\section{APPENDIX III}

\section{"The Birds of America"}

1. Final Lists of Subscribers to "The Birds of America," folio edition, as published by Audubon in 1839. (See Ornithological Biography, vol. v, pp. 647-651.)

\section{List of American Subscribers}

1. Library of Congress of the United States, Washington City.

2. State Departments, Washington City.

3. Library of the General Court of Massachusetts.

4. Legislature of South Carolina, for the Columbia College.

5. Legislature of Louisiana.

6. Legislature of Maryland.

7. Legislature of New York.

8. Legislature of Michigan.

9. Boston Athenæum.

10. Harvard University, Cambridge, Massachusetts.

11. Providence Atheneum, Rhode Island.

12. Salem Atheneum, Salem, Massachusetts.

13. American Philosophical Society, Philadelphia.

14. Academy of Natural Sciences, do.

15. Columbia College of New York.

16. Boston Natural History Society.

17. Charleston Library, South Carolina.

i8. Charleston Natural History Society, South Carolina.

19. Charleston Citizens' Library, do

20. Richard Harlaw [Harlan], Esq., M.D., Philadelphia. 
21. John P. Wetherell, Esq. Philadelphia.

22. Mrs. Ford, do.

23. Mrs. Douglas Cruger, New York.

24. Edward Prime Esq., banker, New York.

25. James G. King, Esq. do. do.

26. Cornelius C. Low, Esq. do.

27. P. J. Stuyvesant, Esq., M.D. do.

28. Robert Ray, Esq. do.

29. J. L. Joseph, Esq. do.

30. Richard N. Carman, Esq. do.

31. Mrs. Bailey, do.

32. Stephen Van Rensselaer, Esq., Albany, New York.

33. Hogden Haggerty, Esq. do.

34. W. L. Colman, Esq. do.

35. Samuel Swartout, Esq. do.

36. James Watson Webb, Esq. do.

37. Thomas H. Faile, Esq. do.

38. Lewis Rogers, Esq. do.

39. Jer. Van Rensselaer, Esq. M.D. do.

40. H. C. De Rham, junior, Esq. do.

41. Stephen A. Halsey, Esq. Long Island, do.

42. Edward Harris, Esq. Moorestown, New Jersey.

43. Thomas H. Perkins, Esq. Boston.

44. J. G. Cushing, Esq. do.

45. Samuel Appleton, Esq. do.

46. George C. Shattuck, Esq. M.D. Boston.

47. P. J. Jackson, Esq. do.

48. James Brown, Esq. do.

49. Frederick Tudor, Esq. do.

50. The Honourable Daniel Webster, do.

51. Augustus Thorndike, Esq. do.

52. L. Baldwin, Esq. Civil Engineer, do.

53. E. Greenwood, Esq. Museum, do.

54. George Pratt, Esq. do.

55. William Sturges, Esq. do.

56. Robert Gilmor, Esq. Baltimore.

5\%. John B. Morris, Esq. do. 
58. — Smith, Esq.

Baltimore.

59. Thomas Edmonston, jun. Esq. do.

60. William Gaston, Esq. Savannah, Georgia.

61. James Potter, Esq. do. do.

62. Alexander Telfair, Esq. do. do.

63. Thomas Young, Esq. do. do.

64. John David Mongin, Esq. do. do.

65. Daniel Blake, Esq. do. do.

66. Thomas Butler King, Esq. St. Simon Island, Georgia

67. Thomas Metcalf, Esq. Augusta, Georgia.

68. E. Geddings, Esq. M.D., Charleston, South Carolina.

69. William J. Rees, Esq. Stateburgh, do.

70. R. O. Anderson, Esq. Georgetown, do.

71. Miss Burley, Salem, Massachusetts.

72. Miss Elizabeth L. Pickman, Salem, Massachusetts.

73. William Oakes, Esq. Ipswich, do.

74. James Arnold, Esq. New Bedford, Rhode Island.

75. Garnet Duncan, Esq. Louisville, Kentucky.

76. John Croghan, Esq. M.D. do. do.

77. Henry Clay, jun. Esq. Ashland, do.

78. James Grimshaw, Esq. New Orleans.

79. Gustavus Schmidt, Esq. do.

80. J. J. Hughes, Esq. Manchester, Mississippi.

81. John Hunt, Esq. Mobile, Alabama.

82. Henry Hunt, Esq. Mobile, Alabama.

\section{Europe}

1. Her Most Excellent Majesty, Queen Adelaide, England.

2. (His Most Christian Majesty, Charles X).

3. His Majesty Philippe I. King of the French.

4. Her Royal Highness Mademoiselle d'Orleans.

5. Prince Massena, Paris.

6. His Grace the Duke of Rutland, London.

7. The Honourable W. C. Wentworth Fitzwilliam, London.

8. The Right Honourable the Countess of Ravensworth, Ravensworth Castle. 


\section{"THE BIRDS OF AMERICA"}

9. The University of Edinburgh.

10. The Society of Writers to her Majesty's Signet, Edinburgh.

11. Henry Witham, Esq. of Lartington, Durham.

12. John Rutter, Esq., M.D., Liverpool.

13. Doctor Bickersteth, Liverpool.

14. Armorer Donkin, Esq. Newcastle-upon-Tyne.

15. Yorkshire Philosophical Society, York.

16. John Clough, Esq., Oxton Hall, Yorkshire.

1\%. Jos. S. Crompton, jun., Esq., Eshott Hall, Bradford, Yorkshire.

18. Thomas Walker, Esq. Killinbeck, near Leeds.

19. Leeds Philosophical and Literary Society.

20. John Marshall, jun. Esq., Headlinglay, Leeds.

21. Samuel Greg [Gregg], Esq., Quarry Bank, near Manchester.

22. Edward Lloyd, Esq., Greenhill, near Manchester.

23. The Manchester Society for the promotion of Natural History.

24. The Reverend Peter Horden, M.A., for the Cheetham Library, Manchester.

25. G. W. Wood, Esq., Manchester.

26. Mrs. Rattsbone [Rathbone], Greenbank, Liverpool.

2\%. J. G. Children, Esq., British Museum, London.

28. The Right Honourable the Earl of Caernarvon, London.

29. S. P. Atkins, Esq., Walbrook, London.

30. The Right Honourable the Earl of Derby, P. Z. S. [President of the Zoological Society], \&c. \&c. \&c.

31. The Right Honourable Earl Spencer, London.

32. John Heathcote, Esq., London.

33. Joseph John Gurney, Esq. Earlham Hall, Norfolk.

34. James Darbyshire, Esq., Manchester.

35. John Blackwell, Esq., Manchester.

36. A. J. Cresswell Baker, Esq., Prowin Park.

37. Reverend Edward Craig, Edinburgh.

38. The College of Glasgow, as Trustees of the Hunterian Museum. 
39. John Buddle, Esq., Newcastle-upon-Tyne.

40. The York Subscription Library, York.

41. Kirk Patrick, Esq., London.

42. T. B. L. L. Baker, Esq. Christ Church, Oxford.

43. Doctor Lodge, for the University Library, Cambridge.

44. George Thackeray, D.D., Provost of King's College, Cambridge.

45. The Cambridge Philosophical Society.

46. The Fitzwilliam Museum, by M. Davy, Vice Chancellor.

47. Dr. Kidd, for the Anatomical School, Christ Church, Oxford.

48. Doctor Williams, for the Radcliffe Library, Oxford.

49. James Pickering Ord, Esq., Hedge Hill, near Derby.

50. The Right Konourable Viscount Milton, London.

51. M. Feuillet, for the Library of the Royal Institute of France.

52. Vicounte [Viscount] Simeon, for the Ministry of the Interior, 6 copies.

53. M. Pitois, Paris.

54. Mrs. Warden, London.

55. Mr. Hearne, bookseller, London.

56. Henry Ellisan, Esq., Beverly, Yorkshire.

5\%. Benjamin Smith, Esq. M. P., London.

58. The Right Honourable the Earl of Bradford, London.

59. Thomas Frost, Esq., Gorton Hall, near Manchester.

60. John G. Reeves, Esq., Birmingham.

61. Birmingham Old Library, by Beilby, Knott, and Beilby.

62. Joseph C. Dyer, Esq., Manchester.

63. Thomas Walker, Esq., Ravensfield, near Doncaster.

64. George Lamb Fox, Esq., Yorkshire.

65. Haarlem Library, Holland.

66. Mrs. [Miss] Euphemia Gifford, Duffield Bank, Derby.

6\%. Charles Fox, Esq., Perrair, near Truro, England.

68. George Lane Fox, Esq., Yorkshire.

69. Sir John Tobin, Liverpool.

70. His Grace the Duke of Buccleuch, Dalkeith Palace, Scotland. 
71. His Imperial and Royal Highness the Grand Duke of Tuscany, \&c. \&c. \&c.

72. London Institution, by Mr. Bradley, Librarian.

73. Benjamin Phillips, Esq., F. R. S. L., \&c. \&c. \&c. 17 Wimpole Street, London.

74. Henry G. Bohn, Esq., London.

75. Charles J. Warde, Esq. Welcomb, near Stratford-onAvon.

76. The British Museum, London (in part).

7\%. His Grace the Duke of Northumberland, \&c. \&c. \&c.

78. Earl Hardwicke, \&c. \&c. \&c. Wimpole, Arrington, Cambridge.

79. Sir Jacob Hastley, Bart, \&c. \&c. \&c., Cavendish Square, London. 
2. Prospectus of "The Birds of America," as issued in 1828, when ten Numbers of the original folio were engraved. (Compare Ornithological Biography, vol. i, pp. 1-16, as supplementary text, at the end.)

Under the Particular Patronage and Approbation of

His Most Gracious Majesty

BIR D OF A M R I A

from

D r a w ing s

made

During a Residence of Twenty-five Years

in

The United States and its Territories,

by

John James A udubon,

Citizen of the United States.

Member of the Lyceum of New York; Fellow of the Royal Society of Edinburgh; of the Linnean Society of London; Member of the Wernerian Natural History Society of Edinburgh; of the Zoölogical Society, London; Fellow of the Society of Scottish Antiquaries; Member of the Society for promoting the useful Arts of Scotland; of the Literary and Philosophical Societies of Cambridge, Liverpool, and Newcastle-uponTyne; of the Horticultural Society of Edinburgh; of the Natural History Society of Manchester; of the Scottish Academy of Painting, Sculpture and Architecture, \&c., \&c.

\section{PROSPECTUS.}

To those who have not seen any portion of the Author's splendid Collection of Original Drawings it may be proper to explain, that their superiority consists in every specimen being of the full size of life, portrayed with a degree of accuracy as to proportion and outline, the result of peculiar means dis- 
covered and employed by the Author, and lately exhibited to a meeting of the Wernerian Society. Besides, in every instance where a difference of plumage exists between the two sexes, both the Male and Female Birds have been represented. The Author has not contented himself with single profile views of the originals, but in very many instances he has grouped them, as it were, at their natural avocations, in all sorts of attitudes, either on branches of trees, or amidst plants and flowers: some are seen pursuing with avidity their prey through the air, or searching diligently their food amongst the fragrant foliage; whilst others of an aquatic nature swim, wade, or glide over their allotted element. The Insects, Reptiles, or Fishes, that form the food of the birds, have been introduced into the drawings; and the nests of the birds have been frequently represented. The Plants are all copied from Nature, and the Botanist, it is hoped, will look upon them with delight. The Eggs of most of the species will appear in the course of the publication.

The Particulars of the Plan of the Work will be found detailed below:-

1. The Engravings in every instance to be of the exact dimensions of the Drawings, which, without any exception, represent the Birds of their natural size.

2. The Plates will be Coloured, in the most careful manner, from the original Drawings.

3. The Size of the work will be Double Elephant, and printed on the finest Drawing Paper.

4. Five Plates will constitute a Number; one Plate from one of the largest Drawings, one from one of the second size, and three from the smaller Drawings.

5. There are 400 Drawings; and it is proposed that they shall comprise Three Volumes, each containing about 133 Plates, to which an Index will be given at the end of each, to be bound up with the Volume.

6. Five Numbers will come out annually.

\%. The Price of each Number will be Two Guineas; payable on delivery. 
TEN Numbers being now completed, will give an exact idea of the nature and style of the Work. All the other Numbers will at least equal these in interest and execution. It would be advisable for the Subscribers to procure a Portfolio, to keep the Numbers till a Volume is completed.

** Persons desirous of becoming Subscribers are requested to apply to Mr. Audubon, or Mr. Robert Havell, Jun. (Engraver), 79, Newman Street, Oxford Street, London.

Where Specimens of the Work may be seen: or, to any of the following Agents:-Messrs. Treuttel, Würz \& Co., Soho Square, and Mr. S. Highly, Fleet Street, London; MM. Levrault and Pitois, Paris; Messrs. Robinsons, Liverpool; Mr. T. Sowler, Manchester; Mr. M. A. Barclay, York; Messrs. Hernaman and Robinson, Leeds; Mr. E. Charnley, Newcastle-uponTyne; and J. B. Kidd, Esq., Edinburgh.

Note by The Author. Audubon's first Prospectus was issued on March 17, 1827, when two Numbers of his large work were ready, and the last which I have seen bears the date of 1831, when one hundred plates had been published. The present citation is from a copy in possession of the Boston Public Library; it is printed on two sides of white paper, octavo, and bears the autograph of "Wm. Everett, Esq., Aug. 7, 1867." 
3. Prospectus of the Second (partial) Edition of "The Birds of America," issued by John Woodhouse Audubon, through Messrs. Triibner \& Company, London, 1859. (See Bibliography, Nos. 9 and 10.)

\section{A U D U B O N'S}

Celebrated Work

\section{B IR DS OF NORTH AMERICA}

To be published in Numbers, by Subscription only, at one half the original price.

The undersigned proposes to publish, by Subscription, this well-known Work of his late Father, J. J. Audubon, F.R.SS.L.\&E., etc., from the original Copperplates transferred to stone.

This Edition, in softness, finish, and correctness of coloring, will be superior to the first, and every Plate will be colored from the original Drawings, still in possession of the family.

It will contain all the Plates and Text of the original Work, embracing more than one thousand figures of Birds, all of the size of nature, represented in action amid the scenes or on the plants most common to their habits,- together with seven volumes royal octavo, of Ornithological Biography.

The Work will be issued in forty-five numbers viz., fortyfour of Plates and one of Text, each number of Plates containing ten-printed on seven sheets double-elephant paper, of the best quality for the purpose, 27 by 40 inches, and will be delivered to Subscribers Monthly, at $\mathfrak{f 2}$, 8s per number; the last Number, comprising seven volumes of Text, to be delivered bound with the fifteenth number.

It is intended that each Number shall contain as follows: Viz. two large Plates, each occupying the whole sheet; two of a medium size, each occupying also the entire sheet; and six of the smaller size, two Plates on a sheet; thus presenting ten of the original Plates on seven sheets, giving a variety in 
each number. The text is properly and scientifically classified, and when the Work shall be completed the Plates can be placed and be bound corresponding with the order of the Text, in either three or four Volumes. The regular issue of the Numbers will commence so soon as the number of Subscribers will justify the undertaking.

As the Work will be published for Subscribers alone, few or none being printed beyond the number subscribed for, it is not possible that its pecuniary value can ever be much reduced; on the other hand, the probabilities are that it will rather be increased. Nor will there ever be a time when it can be published at a less price than the present; for in estimating the cost the mere expense of manufacturing has been taken into consideration, without reference to the original cost of the Copper-plates, which was nearly One hundred thousand Dollars; and a very small profit has been charged on the expense thus estimated.

The first Number is considered superior in many respects to the same Plates in the first Edition, and it is confidently hoped that subsequent Numbers will exhibit still greater superiority as the Artists gain experience. A full list of Subscribers will be published with the Work. The Numbers will not be sold separately, except the first, which will be sent, properly packed, as a Specimen, to any part of the country, free of expense, on the receipt of $£ 2,8 \mathrm{~s}$.

Orders or communications to Trübner \& Co., Booksellers, 60, Paternoster Row, London.

New York, March 31, 1859.

J. W. Audubon.

Trübner \& Co. also offer to the Trade and the Public the following Editions of Audubon's Birds and Quadrupeds of North America:

Birds of North America-Library Edition, 7 vols., royal 8vo, with 500 finely colored Plates, from Drawings made in the United States and their Territories. Price £25. 
Quadrupeds of North America,-By J. J. Audubon and Rev. John Bachman. Original Edition, 3 vols. imperial folio, bound in half russia. One hundred and fifty superbly colored Plates. With descriptive letter-press, in 3 vols., royal 8 vo. Price $\{63$. The same work,-Library Edition, 3 vols. royal 8 vo. with one hundred and fifty-five finely colored Plates. Price £9, 9s.

Note by the Author. For the citation of this rare document, from the only copy known to exist, I am indebted to the kindness of Mr. Ruthven Deane, who writes: "I found this Prospectus bound in the first volume of The Ibis (1859). This copy was previously in possession of the late Pierre Verreaux, of Paris, France, and is now in the John Crerar Library, Chicago, Illinois."

Ornithologists will be pleased to find that it immediately sets at rest numerous disputed questions concerning the plates and text of this sole, but ill-fated, attempt at the republication of the original folio of The Birds of America in America. (See Bibliography, Nos. 9 and 10, and Chapter XXXVI, p. 296.)

Mr. Ruthven Deane has written me that an examination of the account books kept by the Audubons during the publication of the large and small editions of The Birds of America showed partial payments on the Folio by 23 subscribers; the only name among those not listed in the Ornithological Biography was that of J. R. Peters, who was credited with a payment of \$412.00. Mr. Deane adds: "I have a list of the subscribers to the 1840, 8vo., edition, of 1,095 names, New York, Baltimore and Boston taking 501; also a list of subscribers to the Quadrupeds of North America, 3 volume, 8 vo., edition, of 2,004 names, New York, Boston and Charleston, South Carolina, taking 1,10\%." 


\section{APPENDIX IV}

Authentic Likenesses of Jean Jacques Fougère Audubon

1. 1822.-Oil portrait by himself; painted at "Beech Woods," Mrs. Jane Percy's plantation, West Feliciana, Louisiana; given by Audubon to Mrs. Wm. G. Johnson; inherited by her daughter and granddaughter, and now in possession of Dr. D. G. Murrell, Paducah, Kentucky. Size of original, 12 by 9 inches. Reproduced in The Auk, vol. iii, 1886 (see Bibliography, Nos. 184 and 264).

2. $1826($ ?).-Oil portrait by himself (?), 18 by 32 inches, West Feliciana; presented by Audubon to Col. Edward Durrive's father, later acquired by Mr. E. Curtis, and now in the possession of Mr. Thomas P. Thompson, New Orleans.

My information concerning this doubtful portrait has been derived entirely from Mr. Ruthven Deane. Now not thought to be authentic.

3. 1826.--Pencil sketch by himself; signed

"Audubon at Green Bank

Almost, Happy!!-

Sep 1826."

Made at the home of Mr. William Rathbone, Sr., and presented to Mrs. Rathbone; now in possession of Mr. Richard R. Rathbone, Gleny-Menai, Anglesey; for reproduction see The Life and Adventures of John James Audubon, 
edited by Robert Buchanan, and Maria R. Audubon, Audubon and His Journals.

4. 1828.-Oil portrait by C. R. Parker, 36 by 28 inches; painted for Audubon's friend, Walter Horton Bentley, Manchester, England, and in possession of the Bentley family ever since. Audubon is represented in a green coat, a crimson cloak with deep fur edging thrown over one shoulder, and with portfolio in hand.

For information concerning this fine but little known portrait, as well as for the photograph reproduced in Vol. I, p. 416, I am indebted to Mr. Ruthven Deane. In 1913, Mr. John Conway Bentley, a grandson of the former owner, formerly of Glasgow, but then living in Cheshire, England, attempted to dispose of the Parker portrait in this country.

5. 1826.-Oil portrait by John Syme; painted at Edinburgh, November, 1826; supposed to have been engraved by W. H. Lizars, but no trace of painting or engraving has been found. See Maria R. Audubon, op. cit., vol. i, pp. 157 and 165 .

On November 27, 1826, Audubon wrote: "At twelve I went to stand up for my picture, and sick enough $\mathrm{I}$ was of it by two; at the request of Mr. Lizars I wear my wolf-skin coat, and if the head is not a strong likeness, perhaps the coat may be." In writing to his son, Victor, in 1833 (sce Chapter XXVII, p. 57), Audubon said: "I am glad to hear of Kidd \& Co.'s publication of Parrots, but I regret that my face should have been there from Syme's picture, which in my estimation is none of the best."

6. 1828.-Oil portrait painted in London by an American artist named Parker, in August, 1828; Parker subsequently accompanied Audubon and 
Swainson to Paris, where he is said to have executed portraits of Cuvier and Redouté. On August 25, a few days before starting on this journey, Audubon wrote: "Mr. Parker has nearly finished my portrait, which he considers a good one, and so do I" (Maria R. Audubon, op. cit., vol. i, p. 303). No further mention of this painting has been found. Same as No. 4 .

7. 1831.-Miniature painted on ivory by Frederick Cruikshank, probably in London, and before Audubon's return to America on August 2, 1831. This portrait has become well known through the excellent engraving of it by C. Turner, A.R.A., first published in London, "Jany. 12, 1835, for the Proprietor, by Robert Havell, Print-seller, 7\%, Oxford Street," with Audubon's characteristic autograph. Good copies of the original engraving have become very rare. (See Frontispiece, Vol. I.)

Miss Maria R. Audubon possesses a very faint water-color sketch of the original, which, as she has recently written me, "was destroyed by fire at Shelbyville, Kentucky, with many other rare and valuable belongings of my grandmother's, soon after her death [in 1874]."

8. 1833.-Portrait in oils by Henry Inman; half-length, natural size; in possession of Miss Harriet B. Audubon. "Mr. Inman has, painted my Portrait in Oil, and $I$ say that it is a truer portrait of me than even the Miniature" (see Chapter XXVII, p. 39). Engraved by H. B. Hall for the second Octavo Edition of The Birds of America, published in 1856, and the same engraving has appeared in later editions of The Life of John James Audubon, the Naturalist, edited by Lucy Audubon; for re- 
production of a photograph of the original portrait, see Maria R. Audubon, op. cit., vol. i, p. 206; and for reproduction of the Hall engraving, Vol. II, p. 130, of the present work.

This portrait, like the Cruikshank miniature, has become well known through frequent reproduction; both represent the naturalist at the full meridian of his working powers, and are among the finest likenesses of him extant.

9. 1834.--John J. Audubon"; portrait drawn and engraved on steel by J. Brown; published by Geo. Henderson, 2, Old Bailey, Ludgate Hill, London, 1834. A poor drawing of Audubon, in hunting dress, published with a biographical sketch, in an English edition of Cuvier's Le régne animal (see Bibliography, No. 56). This drawing served as the basis of a wood engraving, in which Audubon is represented as a much younger man, three-quarters length, gun in hand, with thumb on trigger, which appeared in Gleason's Pictorial for 1852 (see Bibliography, No. 6\%.).

10. (Before) 1839.-Life Mask, made in London by Robert Havell, Junior, and formerly in his possession; acquired from his daughters, Mrs. Amelia Jane Lockwood and Miss Marion Elington Havell, by Mr. John E. Thayer, and by him presented to Harvard University. For reproduction of the mask, for excellent photographs of which I am indebted to Dr. Samuel Henshaw, Director of the Museum of Comparative Zoölogy, Harvard University, see Vol. II, p. 188.

The original was made from a dark colored plaster (?), and has a decidedly coarse texture. Mr. Harry P. Havell, who possesses a replica of the original in wax, writes that he obtained from the Misses Havell, his cousins, the information 
that this mask was made while Audubon was at their home in London; the matter was treated in a jocular way, as Audubon lay upon a sofa with straws in his nose, while submitting to the rather unpleasant ordeal of having a mold made of his countenance. Mr. Havell, to whom I am indebted for the substance of this note, also possesses the silver loving cup, which Audubon presented to Robert Havell upon the completion of the second volume of his illustrations in 1834 (see Chapter XXXII, p. 192). For notice of another mask by O'Neill, Edinburgh, 1827, see Maria R. Audubon, op. cit., vol. i, p. 205.

11. 1838.-Portrait in oils, three-quarters length, by George P. A. Healy; represents Audubon in hunting shirt, with flowing collar open at neck, knapsack at side and gun in hand (see Frontispiece, Vol. II) ; painted in London upon the initiative of the artist, still struggling for recognition.

This portrait, with a number of other paintings, was raffled at Boston, at a later day, when it was won by the artist, who then gave it to a former patron, Mr. Bradlee, by whom it was presented to the Boston Society of Natural History, and it now hangs in the library of that institution. The present reproduction is from a photograph received through the kindness of Mr. Ruthven Deane, who still owns the negative, which was reproduced in Mr. Healy's Reminiscences (see Bibliography, No. 197).

12. 1845.-Cameo, by John C. King; original intaglio, in shell, a cast of which was given by the artist to Mr. Kennard, and is now in possession of Mr. Frederic H. Kennard, of Boston; cast first reproduced by C. Hart Merriam, in The A $u$ k for 1908 ( see Bibliography No. 226).

Mr. King was a Scotch artist and sculptor, who died at Boston, April 21, 1882.

13. 1841 (?).--Portrait in oils, full length and size, by John Woodhouse Audubon; figure seated, with land- 
scape background; gun resting on arm, and dog at side. For reproduction, see Maria R. Audubon, op cit. This or the following used as the basis of a painting by Alonzo Chappel (see No. 23).

14. 1841 (?).-Half-length portrait in oils, natural size, by John Woodhouse and Victor Gifford Audubon. Original presented to the American Museum of Natural History by Mr. Fordham Morris in 1900 ; for reproduction, see Vol. II, p. 226.

15. 1841 (?).-Full-length portrait, in oils, by John Woodhouse Audubon; original now in possession of the American Museum of Natural History; for reproduction, see Vol. II, p. 250.

16. 1842.-Pencil sketch by Isaac Sprague (1811-1895), an artist noted for his paintings of plants and birds. Sprague accompanied Audubon on his expedition to the Missouri River in 1843. According to Miss Maria R. Audubon, the original drawing is still in possession of the Sprague family, Wellesley Hills, Massachusetts. For reproduction, see Maria R. Audubon, op. cit.

17. 1843.- Half-length portrait in oils, by John Woodhouse Audubon, representing the naturalist as he appeared when returning from his expedition to the Missouri River in November, 1843, with flowing white hair and beard; he wears a green overcoat, with fur collar, and with both hands holds a favorite gun. The original, which was never quite finished, is now in possession of his granddaughters, at Salem, New York. For reproduction, see Maria R. Audubon, op. cit, vol. i. frontispiece. 
18. 1844.-Cameo by John C. King, now known only from the photograph made from a cast of the original intaglio, which the artist presented to the father of Mr. O. A. Farwell, of Detroit, in 1871.

"My father and Mr. King were great friends, and on one occasion, when father dropped into Mr. King's studio, he found Mr. Audubon sitting for the cameo. Mr. King introduced the two gentlemen and asked them to start a conversation, which was continued during the sitting. The two men became so animated in their very interesting conversation that they forgot where they were, and thus the artist was enabled to catch the natural and striking expression of the great ornithologist." See "The King Cameos of Audubon," by C. Hart Merriam (Bibl. No. 226), who published the first account of this photograph, and of the previously mentioned Kennard cast, with reproductions, in 1908. No trace of the original cameos, which were cut in shell, has yet been found. The Farwell photograph has been reproduced as a medallion on the covers of the present work.

19. 1848-49 (?).-A daguerreotype made by Brady, in New York, probably before 1850 , since it was published in that year, and a considerable interval of time is clearly represented between this first camera likeness and the last which was ever made of the naturalist ( see No. 20, and Vol. II, p. 280). This daguerreotype was first published as a steel engraving by D'Avignon, in Lester's Gallery of Illustrious Americans (for which it was, in all probability, originally made), in New York, 1850 ( see Bibliography No. 62).

The same sun portrait was again engraved on steel ( $\operatorname{size} 41 / 4$ by $31 / 4$ inches) by Nordheim, and published by Hermann J. Meyer, 164 William Street, New York. It also appeared as a 
wood engraving, brought out by M. P.-A. Cap, in Le Muséum D'Histoire Naturelle, p. 175, Paris, 1854: a better reproduction, by the same process, was given in Scribner's Magazine, vol. xiii, p. 275 (see "Audubon's Story of his Youth," by Maria R. Audubon, Bibl. No. 40), in 1893.

The original daguerreotype was finally discovered in the collections at the National Museum, at Washington, where it had been deposited by Mrs. Elizabeth Berthoud Grimshaw, a daughter of Mrs. Nicholas Berthoud, and niece of Mrs. Audubon; it was again published by Dr. R. W. Shufeldt, and Miss M. R. Audubon, in 1894 (see "The Last Portrait of Audubon," Bibl. No. 196). According to the writers just cited, the daguerreotype was formerly in possession of Mrs. Gordon, a sister of Mrs. J. J. Audubon, who gave it to the present owner.

20. 1850 (?).-A daguerreotype, representing Audubon as he appeared at the close of his career; original in possession of Miss Mary Eliza Audubon; for reproduction see Audubon and his Journals, vol. i, p. 74, and Vol. II, p. 280, of the present work. As to the probable date of this picture, see the preceding notice.

21. 1851.-Death mask; profile from original, since destroyed by fire, reproduced in Scribner's Magazine, vol. xiii, by Maria R. Audubon (Bibl. No. 40), March, 1893.

22. 1851.-Profile of head; pencil sketch, after death, made by John W. Audubon; reproduced by Maria R. Audubon, Audubon and his Journals, vol. ii, p. 526 .

23. 1861.-Oil portrait by Alonzo Chappel, engraved on steel for Duyckinck's National Portrait Gallery of 
Eminent Americans (see Bibliography, No. 74), and published by Messrs. Johnson, Fry \& Company, New York, 1862.

The original of this portrait, which was evidently drawn, with slight changes, from the large painting of the same subject by John Woodhouse Audubon, executed about 1841 (see No. 13), is now in possession of Mr. Ruthven Deane, who has written me that it is done in black and white, like all of Chappel's work which was designed for the purposes of steel engraving, and measures 12 by 17 inches. Concerning this artist, Mr. Arthur Lumley wrote to Mr. Deane on April 26, 1905, as follows: "I knew Chappel in my boyhood days, when he ranked next to Felix O. C. Darley as an illustrator; at the same time he was a good portrait painter in oil. Chappel, in many ways, was a gifted man, and his historical pictures were fine in composition and color. He held a high rank, and had no occasion to seek orders, having all he could do, and at his own terms; most of his work was reproduced by steel-plate engravings": Chappel, he adds, who died about 1875, was "a quiet, genial gentleman who was ever ready to help and guide rising aspirants in the field of art."

24. 1907 (unveiled).-Bust by William Couper; unveiled at the American Museum of Natural History, New York, December 29, 1906. Reproduced through courtesy of the Museum, at p. 160 of Vol. II of the present work.

25. 1910 (unveiled).- Statue, by Edward Virginius Valentine; unveiled in Audubon Park, New Orleans, November 26, 1910; reproduced at p. 14 of Vol. I of the present work.

26. 1927 (unveiled).-Bronze bust by A. Stirling Calder, in American Hall of Fame, New York University, New York. 


\section{APPENDIX $\mathrm{V}$}

\section{BiBLIOGRAPHY}

Besides the published writings of Audubon, I have included in this Bibliography such references to his life and times as occur in the text or which possess some degree of merit; all other important literary and historical authorities are cited in footnotes to the text. The titles appear in a single numerical series, but the arrangement under each head is strictly chronological. All references to this list in the text are indicated usually by title, with the name of the author, and always by Arabic numerals, in correspondence with the series which follows. If some chaff has been admitted to this garner, no corn, I hope, has been thrown into the fire.

\section{a. Principal Works}

1. Audubon, John James:

The Birds of America, from Original Drawings by John James Audubon, Fellow of the Royal Societies of London \& Edinburgh and of the Linnæan \& Zoölogical Societies of London, Member of the Natural History Society of Paris, of the Lyceum of New York, \&c. \&c. \&c. 4 vols. colored plates, double elephant folio. Published by the Author. London, 1827-1838.

Issued without text, titles excepted, to subscribers, in $\mathbf{8 7}$ Numbers of 5 plates each, or 435 copper-plate engravings, colored by hand, and representing 1,065 life-size figures of 489 supposedly distinct species of birds. Titles the same, except that in volumes II-IV, after "New York," in list of societies following author's name, is added, "of the Philosophical Society 
and the Academy of Natural Sciences of Philadelphia." Begun at Edinburgh in autumn of 1826, and completed in London, June 20, 1838.

A more detailed citation is:

Vol. I. Parts 1-22, pll. i- cx, 1827-30.

Vol. II. Parts 23-44, pll. cxi- ccxx, 1831-34.

Vol. III. Parts 45-66, pll. ccxxi- cccxxx, 1834-35.

Vol. IV. Parts 67-87, pll. ccexxxi-ccccxxxv, 1835-38.

More exact data on publication of individual plates are:

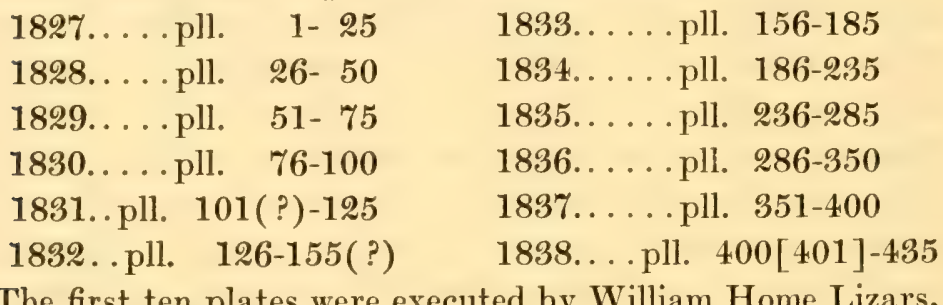

The first ten plates were executed by William Home Lizars, Edinburgh, 1826-7, but were later retouched or reëngraved (?) by Robert Havell, Junior, who produced all the rest in London; printed on Whatman's drawing paper, size (untrimmed), $391 / 2 \times 291 / 2$ inches, and colored after the originals. A considerable number of the plain plates were dispersed, and at least one complete set exists in this state (see Note, Chapter XXVI, Vol. II, p. 7, and also Chapter XXXII, Vol. II, p. 190); scientific and common names, with legends of author and engraver, and eventually the date of publication, were given on each plate. Issued to subscribers at two guineas a Part, and sold in Europe at $£ 182,14 \mathrm{~s}$; in America, at $\$ 1,000$. The Turkey Cock (Plate No. 1) now brings upwards of $\$ 140$, and perfect sets upwards oi $\$ 4,000$, according to binding and state. Total number of original sets probably did not exceed 190 or 200.

2. Audubon, John James, F. R. SS. L. \& E. [with list of societies ] :

Ornithological Biography, or an account of the habits of the Birds of the United States of America; accompanied by descriptions of the objects represented 
in the work entitled The Birds of America, and interspersed with delineations of American scenery and manners. 5 vols. roy. 8vo. Edinburgh, 1831-1839.

Vol. I (original ed.). Preface dated "March 1831." Pp. i-xxiv, 1-512, and 1-16, including "Prospectus," "Contents" to Vol. I, and names of subscribers to The Birds of America. Text to accompany plates $\mathrm{i}-\mathrm{c}$ of the large folio. Adam Black, 55 North Bridge (with names of agents; Neill \& Co. Printers, Old Fishmarket), Edinburgh, MDCCCXXXI.

Vol. I (American reprint). Pagination the same. Judah Dobson, Agent, 108 Chestnut St., and H. H. Porter, Literary Rooms, 121 Chestnut St., Philadelphia, MDCCCXXXI. Copyright by R. Harlan, M.D., 1831. Printed by James Kay, Jun. \& Co., Printers to the American Philosophical Society, No. 4 Minor St.

Vol. I (American reprint). The same, but bearing the imprint of E. L. Carey and A. Hart, Chestnut St., Philadelphia, MDCCCXXXV.

Vol. II (original ed.). Preface dated "1st December 1834." Pp. i-xxxii, 1-588. Text of plates ci-cc. Adam and Charles Black. Edinburgh, MDCCCXXXIV.

Vol. II (American reprint). 'The same, but with imprint of Hilliard, Gray, and Company. Boston, MDCCCXXXV.

Vol. III (original and only ed., as are IV and V). Preface dated "1st December 1835." Pp. i-xvi, 1-638, with 9 woodcuts. Text to plates cci-ccc. Same imprint as Vol. II. Edinburgh, MDCCCXXXV.

Vol. IV. Preface dated "1st November 1838." Pp. i-xxviii, 1-618. Text to plates ccci-ccclxxxvii. Imprint, the same. Edinburgh, MDCCCXXXVIII.

Vol. V. Preface dated "1st May 1839." Pp. i-xl, 1-664, with 98 woodcuts. Text to plates ccclxxxviii-cccexxxv. Same imprint. Edinburgh, MDCCCXXXIX.

According to Stone, 5 species recognized in the folio are 
suppressed in the "Biography"; 26 new names are given, and 502 species are recognized, but as 11 were more or less hypothetical, 491 remain in supposedly good standing.

3. Audubon, John James, F. R. SS. L. \& E. Member of various scientific associations in Europe and America: A Synopsis of the Birds of North America. Pp. i-xi, 1-359. 8vo. Adam and Charles Black, Edinburgh; Longman, Rees, Brown, Green and Longman, London. MDCCCXXXIX.

A methodical index to the birds of America, with special reference to the large folio plates and Ornithological Biography; 45 families and 139 genera are defined; 5 new names are added, making the total number of recognized species 491 .

4. Audubon, John James, F. R. SS. L. \& E. (\&c., \&c.) :

The Birds of America from Drawings made in the United States and its Territories. 7 vols. of text and plates, roy. 8vo. Published by the Author and J. B. Chevalier. New York and Philadelphia, 1840-1844.

The "Birds in Miniature," or first octavo edition of text and plates combined; issued to subscribers in 100 Parts, each with 5 lithographic colored plates, at $\$ 1.00$ a Part.

Vol. I. Parts 1- 14; pll. 1- 70; pp. i-viii, 9-256. 1840.

Vol. II. Parts 15- 28; pll. r1-140; pp. i-viii, 9-206. 1841.

Vol. III. Parts 29- 42; pll. 141-210; pp. i-viii, 9-236. 1841.

Vol. IV. Parts 43- 56; pll. 211-280; pp. i-viii, 9-324. 1842.

Vol. V. Parts 57- 70 ; pll. 281-350; pp. i-viii, 9-348. 1842.

Vol. VI. Parts 71- 84; pll. 251-420; pp. i-viii, 9-460. 1843.

Vol. VII. Pts. 85-100; pll. 421-500; pp. i-x, 9[11]-374. 1844.

In this "miniature" edition, the "delineations of American scenery and manners" are omitted, the text revised, and the nomenclature made to conform with the Synopsis; the plates of the large folio were broken up, and their accessories reduced, so that but one species appears on each; 7 species, described in the Biography and Synopsis are figured for the first time in an 
Appendix, in which also appear 17 species that had been neither figured nor described before, thus bringing the total number of birds represented on the octavo plates to 500 ; four of the largest birds receive two plates each, thus leaving the number of distinct species figured at 496 , while the 12 species herein described brings the total number of species recognized by Audubon in 1844 to 508 . The plates of this edition are rearranged and renumbered to conform with the new arrangement of the text, which was considerably improved. The series begins with the California Vulture, and ends with Baird's Bunting.

Vols. I-V were published by J. J. Audubon, New York, and simultaneously issued by J. B. Chevalier, Philadelphia; Vols. VI-VII, published by J. J. Audubon, 77 Williams St., New York, and 34 North First St., Philadelphia.

The Numbers or Parts were issued in blue paper covers, or drab when without plates ( $7 \times 11$ inches), on which were printed the "Prospectus," lists of subscribers and agents, besides other information which the author wished to convey to his patrons. The printer's legend at the right lower corner reads: "Lith". Printed \& $\mathrm{Col}^{\mathrm{d}}$. by J. T. Bowen, Philad a." Parts in original covers are extremely rare; a set in this condition was offered in 1914 at $\$ 750$.

5. Audubon, John James, and Bachman, Rev. John:

The Viviparous Quadrupeds of North America. 2 vols. of 150 lithographic, colored plates; imp. folio. Published by J. J. Audubon, New York, 1845-1848.

Vol. I. Parts 1-15, pll. 1- 75, 1845-1846.

Vol. II. Parts 16-30, pll. 76-150, 1846-1848.

Issued to subscribers in 30 Parts of 5 plates each, size $28 \times 22$ inches, at $\$ 10$ a part, or $\$ 300$, without text except titles, tables of contents, and names on plates; 76 of the originals by J. J. Audubon, and $\mathbf{7 4}$ by J. W. Audubon, assisted by V. G. Audubon. Author's and printer's legends read: "Drawn from Nature by J. J. Audubon, F. R. S. F. L. S.," and "Lith. Printed \& $\mathrm{Col}^{d}$. by J. T. Bowen, Phila. 1842 [-1845]." 
6. Audubon, John James, F. R. S. (\&c., \&c.), and Bachman, Rev. Јон,, D. D. (\&c., \&c.) :

The Viviparous Quadrupeds of North America. 3 vols., roy. 8vo. Published by J. J. Audubon and V. G. Audubon, New York, 1846-1854.

Issued to subscribers, as text to foregoing:

Vol. I. Pp. i-xvi, 1-390. Text only. Published by J. J. Audubon, New York, 1846.

Vol. I (European ed.). The same as foregoing with imprint of Wiley \& Putnam, London, 1847.

Vol. II. Pp. 1-336. Text only. Published by V. G. Audubon, 1851.

Vol. III. Pp. i-vi, 1-350. Text, with 6 colored plates. Published by V. G. Audubon, 1854.

7. Audubon, John James, F. R. S. (\&c., \&c.), and Bachman, REv. Јонм, D. D. (\&c., \&c.) :

The Quadrupeds of North America [in "Miniature"]. 3 vols., roy. 8vo., with 155 colored plates. Published by V. G. Audubon, New York, 1854.

Vol. I. Nos. 1-10, pll. i-1, pp. i-viii, 1-384.

Vol. II. Nos. 11-20, pll. li-c, pp. 1-334.

Vol. III. Nos. 21-31, pll. ci-clv, pp. i-vi, 1-348.

First complete edition of the text and plates reduced to octavo size; most of the plates lithographed, printed and colored by J. T. Bowen. In Vol. I the introduction is cut down, the list of subscribers omitted, and tables of contents and genera placed at end; Vol. II is same as first edition, with omission of subscribers' lists; Vol. III same as in first edition, except for omission of table of genera at back. All plates in Vol. I, and 28 in Vol. II, or 78 in all, are by J. J. Audubon, and ry are by J. W. Audubon.

8. Audubon, John James, F. R. S. (\&c., \&c.) :

The Birds of America, from Drawings made in the United States and their Territories. Vols. I-VII, roy. 8vo. Published by V. G. Audubon, New York, 1856. 
The second octavo edition of the Birds, with 500 plates, published without change, except in pagination. The portrait of Audubon, which appears in this or in some of the later editions, was engraved by H. B. Hall after the painting by Henry. Inman.

\section{Audubon, John James:}

The Birds of America; from Original Drawings by John James Audubon, Fellow of the Royal Societies of London \& Edinburgh, \&c., \&c., \&c. Reissued by J. W. Audubon. 1 vol. of 106 double elephant folio plates, in chromolithography, by J. Bien, 180 Broadway, representing 151 of the original copper plates. Roe Lockwood \& Son, Publishers. New York, 1860.

The only (and partial) reissue of the original folio; plates, in many instances double, renumbered to correspond with the octavo edition, with backgrounds often simplified or changed, and much inferior to the original hand-colored engravings; the plates are dated "1858" or "1859." Checked by the Civil War, the residual stock of plates found a ready sale thirty years later. Citation from copy in the Public Library, New York City. (See Appendix III, Document No. 3).

10. Audubon, $\mathrm{J}_{\text {ohn }} \mathrm{J}_{\text {Ames }}$ :

The Birds of America, from Drawings made in the United States and their Territories, by John James Audubon, F. R. S., \&c., \&c. Reissued by J. W. Audubon. Vols. I-VII, roy. 8vo. Text only. Roe Lockwood \& Son, Publishers. New York, 1861. Vol. I, pp. i-viii, 11-246; Vol. II, pp. i-viii, 11-200; Vol. III, pp. i-viii, 9-234; Vol. IV, pp. i-viii, 9-322; Vol. V, pp. 1-viii, 9-346; Vol. VI, pp. i-viii, 2-456; Vol. VII (not seen). Issued as the letterpress of the imperfect folio (see No. 9) described above. According to Sabin, quoted by Coues (see No. 181 of this Bibliography), only 4 royal octavo volumes of this text was issued; the present citation is from the 6 volumes 
in the Public Library of New York; all are without plates, and it should be noted that Vols. I and II, and III and IV are bound as two volumes. In 1914 a set of this edition, in seven volumes, bound in cloth, was advertised by a bookseller in New York at \$40. (See Appendix III, Document No. 3).

\section{Audubon, John James:}

The Birds of America. . . Reissued by J. W. Audubon, in 7 vols., imper. 8vo., with 500 colored plates, $10 \times 7$ inches. Roe Lockwood \& Son. New York, 1861.

Third complete octavo edition, to be distinguished from the 7 vols. (No. 10) referred to above, and the V. G. Audubon reissue of 1856 (No.8). Reference partly from Coues.

12. Audubon, John James:

The Birds of North America: a popular and scientific description of the Birds of the United States and their Territories. New edition. New York, 1863.

Not seen, but given on the authority of Coues.

13. Audubon, Јонn $J_{\text {Ames : }}$

The Birds of America. .. 8 vols. 8vo. New York, 1865.

According to Coues, a later edition of J. W. Audubon's reissue of 1861 , but in 8 instead of 7 volumes.

14. Audubon, John James, F. R. S. (\&c., \&c.):

The Birds of America, from drawings made in the United States and their Territories. Vols. I-VIII, imper. 8vo. George R. Lockwood, late Roe Lockwood \& Son, 812 Broadway, New York. No date. Vol. I, pp. i-viii, i-xv (memoir), 11-246, pll. 1-70; Vol. II, pp. i-vii, 11-199, pll. 71-140; Vol. III, pp. i-viii, 9-233, pll. 141-210; Vol. IV, pp. i-viii, 9-321, pll. 211280 ; Vol. V, pp. i-viii, 9-346, pll. 281-250; Vol. VI, 
pp. i-vii, 9-298, pll. 351-394; Vol. VII, pp. i-vii, 9-285,

pll. 395-440; Vol. VIII, pp. i-viii, 9-256, pll. 441-500. (Pagination taken from Coues.)

Seventh and last complete octavo edition of text and plates, being a reissue of the 1865 edition. In the biography, signed "G. R. L[ockwood]., 1870," it is stated that Jean Audubon died "at Rochefort on the Loire [sic], where he had a large estate" at the age of ninety-five, and that J. J. Audubon was born on his father's plantation at New Orleans in 1780. This memoir was issued separately as an advertising pamphlet by J. L. Sibole ("Fine Book Dealer, 109 So. 15 th. Street, New York"), to exploit the octavo editions of the Birds and Quadrupeds ( $\mathrm{pp} .1-15$, paper cover, no date).

\section{b. Minor Papers and Reprints}

15. Auduron, John James:

"On the Hirundo fulva of Vieillot." Annals of the Lyceum of Natural History of New York, vol. i, pp. 163-166. New York, 1824.

16. Audubon, Јонn James:

"Facts and Observations connected with the permanent residence of swallows in the United States." Annals of the Lyceum of Natural History of New York, vol. i, pp. 166-168. New York, 1824.

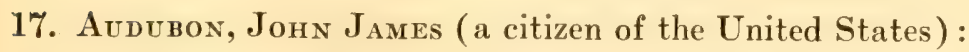

"Account of the Habits of the Turkey Buzzard (Vultur aura) particularly with the view of exploding the opinion generally entertained of its extraordinary power of Smelling." In a letter to Professor Jameson. [Note.] This communication was originally intended to be sent to a friend unaquainted with the habits of birds-J. J. A. Edinburgh Nerw Philosophical Journal, vol. 2 (Oct.-Apr.), pp. 172-184. Edinburgh, 1826182\%. Dated "Edinburgh, Dec. 7, 1826." 
18. Audubon, John James:

"Observations on the Natural History of the Alligator." In a letter to Sir William Jardine, Baronet, \&c. Edinburgh New Philosophical Journal, vol. 2, (Oct.-April), pp. 2\%0-280. Edinburgh, 1826-182\%.

Gives the first account of the nesting habits of the American alligator.

19. Audubon, John James:

"Account of the Carrion Crow or Vultur atratus." Edinburgh Journal of Science, vol. vi (Nov.-April), pp. 156-161. Edinburgh, 1826-1827.

Notices the nesting and other habits, and maintains that this species, like the Turkey Buzzard, is guided to its food by sight and not by smell.

20. Audubon, John James:

"Notes on the Habits of the Wild Pigeon of America, Columba migratoria." Edinburgh Journal of Science, vol. vi (Nov.-April), pp. 256-265. Edinburgh, 1826$182 \%$.

Read before the Royal Society of Edinburgh, February 19, $182 \%$.

21. Audubon, John James :

"Notes on the Rattlesnake (Crotalus horridus), in a letter addressed to Thomas Stuart Traill, M. D., \&c." Edinburgh New Philosophical Journal, vol. 3 (AprilOct.), pp. 21-30. Edinburgh, 182\%.

Read before the Wernerian Society of Natural History, February 24, 182\%. Reproduced in Journal of the Franklin Institute and American Mechanics' Magazine, vol. ii, N. S., pp. 32-37. Philadelphia, 1828. Later repudiated by the editor; see Thomas P. Jones, "The Romance of the Rattlesnake," No. 93 of this Bibliography. 
22. Audubon, J. J.:

"Account of the Method of Drawing Birds employed by J. J. Audubon, Esq., F. R. S. E." In a letter to a friend. Edinburgh Journal of Science, vol. viii, pp. 48-54. Edinburgh, 1828.

22a. Audubon, John James:

"Journey up the Mississippi." The Winter's Wreath for 1829, pp. 104-127. Liverpool and Philadelphia, 1828.

23. Audubon, John James:

"Notes on the Bird of Washington-(Falco Washingtonia) or Great American Sea Eagle" (with figure). Loudon's Magazine of Natural History, vol. i, pp. 115120. London, 1828-1829.

Dated "London, April, 1828."

24. Audubon, John J.:

"The Flood of the Mississippi," Edinburgh Literary Journal. February, 1831, pp. 140-142.

See "Episode" entitled "A Flood," Ornithological Biography, vol. i.

25. Audubon, J. J. :

"An Account of the Habits of the American Goshawk (Falco palumbarius, Wils.)." In a letter to Sir William Jardine, Bart. Edinburgh Journal of Natural and Geographical Science, vol. 3 (March), pp. 145-14\%. Edinburgh, 1831.

26. Audubon, John James:

"Improvements in the Navigation of the Mississippi." Edinburgh Literary Journal, March 26, 1831, pp. 194-195.

See Ornithological Biography, vol. i. 
2\%. Audubon, John James:

"Hunting the Cougar, or the American Lion." Edinburgh New Philosophical Journal, vol. 11, pp. 103115. Edinburgh, 1831.

See "The Cougar," Ornithological Biography, vol. i. "It having been remarked, and rather sharply, that in our article on 'Audubon's Ornithological Biography,' we have overrated that gentleman's talents, we, in our own vindication, and as proofs of Audubon's descriptive powers, submit to the judgment of our readers the above sketch, taken at random from his work." (Editor's note.)

28. Audubon, J. J.:

"Account of a Hurricane in North America." Edinburgh New Philosophical Journal, vol. 12 (Oct.-April), pp. 278-281. Edinburgh, 1831-1832.

See "The Hurricane," Ornithological Biography, vol. i.

29. Audubon, J. J.:

"The Ohio." Edinburgh New Philosophical Journal, vol. 12, pp. 122-126. Edinburgh, 1832.

See the same, Ornithological Biography, vol. i.

30. Audubon, J. J., and Bachman, Rev. John, D. D. :

"Descriptions of New Species of Quadrupeds inhabiting North America." Journal of the Academy of Natural Sciences, vol. viii, pt. ii, pp. 280-329. Philadelphia, 1839-1842.

Read, Oct. 5, 1841.

31. Audubon, J. J., and Bachman, J.:

"Descriptions of New Species of Quadrupeds inhabiting North America." Proceedings of the Academy of Natural Sciences, vol. i (Oct., 1841), pp. 92-103.

Philadelphia, 1843. 
32. Audubon, John James, and Bachman, John:

"Description of a new North American Fox, genus Vulpes, Cuv., (Utah)." Proceedings of the Academy of Natural Sciences, vol. vi, pp. 114-116. Philadelphia, 1852-1853.

33. Audubon, John $J_{\text {Ames }}$ :

"Earthquake in Kentucky." Reproduced in Magazine of American History, vol. 16, pp. 342-344, with portrait. New York, 1886.

See "The Earthquake," Ornithological Biography, vol. i.

\section{c. E pistolary Articles}

34. Audubon, John James:

"Letter to the Editor" (No. 1). Dated "St. Augustine, East Florida, Dec. 7, 1831." Monthly American Journal of Geology and Natural Science, vol. i, pp. 358363. Philadelphia, 1832.

35. Audubon, J. J.:

"Letter from J. J. Audubon to the Editor" (No. 2). Dated "Bulowville, East Florida, December 31, 1831." Monthly American Journal of Geology and Natural Science, vol. i, pp. 407-414. Philadelphia, 1832.

36. Audubon, J. J.:

"Letter to the Editor" (No. 3). Monthly American Journal of Geology and Natural Science, vol. i (June), pp. 529-537. Philadelphia, 1832.

37. Audubon, J. J.:

"Letter from J. J. Audubon to William MacGillivray." Edinburgh Journal of Natural History, vol. i (for Dec., 1838), p. 171. Edinburgh, 1835-1839.

Dated, "On board the Crusader, Cote Blanche, 18 April, 183\%." 


\section{d. Translations}

38. BaZIN, EugÈne:

Scènes de la Nature dans les Etats-Unis et le Nord de l'Amérique. Ouvrage traduit d'Audubon, avec Preface et Notes du Traducteur. T. 1-2, pp. 1-460, 1-512. 8vo. Paris, 1857.

Selections from the Ornithological Biography, with Introduction; dedicated to Charles Lucien Bonaparte.

39. (ANon.) :

"Drei Ziegenmelker Nordamerika's." Naumannia: Archiv für die Ornithologie, vorzugsweise Europas, herausg. von E. Baldamus, pp. 158-163. Stuttgart und Leipzig, 1858.

\section{e. Autobiography}

40. Audubon, Maria R.:

"Audubon's Story of his Youth." Scribner's Magazine, vol. xiii, pp. 267-287, illust. New York, 1893.

First appearance of autobiographical sketch, entitled, "Myself, J. J. Audubon." Reproduced also in Audubon and his Journals ( see No. 86), vol. i.

\section{f. Journals}

41. Deane, Ruthuen:

"Extracts from an Unpublished Journal of John James Audubon." The Auk, vol. xxi, pp. 334-338. Cambridge, 1904.

Including entries for fourteen days, extending from October 12, 1820, to November 25, 1821. 
42. (ANon.):

"A Story of Meadville from John J. Audubon, F. R. S., August 28, 1824." Pamphlet (in blue paper cover), pp. 1-4. Dated April 9th, 1846.

An early version, taken from the original journal, and probably given by Audubon himself to some of his friends, possibly Spencer F. Baird, who visited him in both early and late April of this year. For passages not since reproduced, see Vol. I, p. 341. Citation from copy in the Public Library, New York City.

For fuller journal records, see Audubon and his Journals (No. 86), including "European Journals," (1826-1827), vol. i, pp. 79-242 ; the "Labrador Journal," 1833, vol. i, pp. 343-446; and the "Missouri River Journals," 1843, vol. i, pp. 447-532, and vol. ii, pp. 1-196.

\section{g. Familiar Letters}

43. Coues, Elliott :

"Behind the Veil." Bulletin Nuttall Ornithological Club, vol. v, pp. 193-204. Cambridge, 1880.

Gives interesting letters by Audubon and MacGillivray, which are reproduced in the present work.

44. Gordon, Mrs.:

"Christopher North": A Memoir of John Wilson. New York, 1894.

For letter of J. J. Audubon to J. Wilson, no date [Jany. 1, 1836], see pp. 363-364.

45. Shufeldt, R. W., and Audubon, M. R.:

"The Last Portrait of Audubon, together with a Letter to his Son." The Auk, vol. xi, pp. 309-313. New York, 1894. 
46. Rhoads, S. N.:

"Auduboniana," The Auk, vol. xx, pp, 377-383. Cambridge, 1903.

Gives three letters to Edward Harris, partly reproduced in the present work.

47. Deane, Ruthuen:

"Unpublished Letters of John James Audubon and Spencer F. Baird," The Auk, vol. xxi, pp. 255-259. Cambridge, 1904.

First installment.

48. Deane, Ruthyen:

(a) "A Hitherto Unpublished Letter of John James Audubon," The Auk, vol. xxii, pp. 170-171. Cambridge, 1905.

(b) See also "An Unpublished Letter of John James Audubon to his Family," The Auk, vol. xxv, pp. 166-169. Cambridge, 1908.

49. Deane, Ruthven:

"Unpublished Letters of John James Audubon and Spencer F. Baird," I, The Auk, vol. xxiii, pp. 194-209. Cambridge, 1906.

Second installment.

50. Deane, Ruthuen:

"Unpublished Letters of John James Audubon and Spencer F. Baird," II, The Auk, vol. xxiii, pp. 318-334. Cambridge, 1906.

Third installment.

51. Deane, Ruthuen:

"Unpublished Letters of John James Audubon and Spencer F. Baird," III, The Auk, vol. xxiv, pp. 53-70. Cambridge, $190 \%$.

Fourth installment. 
52. Dali, William Healey:

Spencer Fullerton Baird: A Biography. Pp. i-xvi, 1-462. 8vo. 19 illust. Philadelphia and London, 1915.

Reproduces eighteen letters of Audubon to Baird, dating from June 13, 1840, to February 11, 1847.

53. ThaYer, John E.:

"Auduboniana," The Auk, vol. xxxiii, pp. 115-118, 4 plates. Cambridge, 1916.

Reproduces four original water-color drawings, and two letters addressed to Dr. George Parkman, dated "New York, June $20^{\text {th }}$," and "August $13^{\text {th }} 1841 . "$

54. Grinnell, George Bird:

"Some Audubon Letters," The Auk, vol. xxxiii, pp. 119-130. Cambridge, 1916.

Gives two letters written to Victor G. Audubon from New York, April 28 and Sept. 9, 1833.

See also Caledonian Mercury, November 3, 1831, for letter to Joseph B. Kidd (No. 163), Brewer (No. 79), Bachman (No. 191), Günther (No. 204), Deane (No. 225), and Alexander Bliss, in Autograph Leaves of our Country's Authors, for facsimile letter of Audubon to Thomas Sully, dated "Manchester (England), Sept. 16, 1826" (Baltimore, 1864).

\section{h. Biographies}

55. Christopher North (John Wilson):

"Noctes Ambrosianae," No. XXX, Blackwood's Edinburgh Magazine, vol. xxi (Jan.), pp. 112-105 (sic). Edinburgh, 1827.

56. (ANoN.):

"Biographical Sketch of John James Audubon," with portrait (drawn and engraved by J. Brown); in- 
sert in G. Cuvier and P. A. Latreille, The Animal Kingdom, vol. i, pp. 197*-204*. London, 1830.

57. Lander, Sir Thomas Dick, Bart., and Brown, Capt. Thomas:

Biographical Sketch, with engravings by Joseph B.

Kidd. Pp. i-x, 1-184, 16mo. Edinburgh, 1833.

Mainly extracted from vol. i of the Ornithological Biography; refers to the false rumor of Audubon's death in October, 1831, and to his plan of forming a Gallery of Paintings in Natural History, started in association with Kidd.

58. (ANoN.) :

"Biographical Sketch of J. J. Audubon." Miscellany of Natural History, vol. i. 1833.

Not seen.

59. Dunlap, William:

History of the Rise and Progress of the Arts of Design in the United States. 2 vols. New York, 1834. For John James Audubon, see vol. ii, pp. 402-408.

60. (Anon.) Godwin, Parke:

"John James Audubon." United States Magazine and Democratic Review, N. S., vol. x, pp. 436-450. New York, 1842.

See also Out of the Past; Critical and Literary Papers, pp. 89-110 (New York, 1870), and Homes of American Authors; for the last, see No. 68.

61. Griswold, Rufus W.:

The Prose Writers of America, article "Audubon." Philadelphia, 1847.

62. Lester, C. Edwards (editor):

The Gallery of Illustrious Americans, containing the Portraits and Biographical Sketches of Twenty- 
four of the most eminent Citizens of the American Republic since the death of Washington. Plates from daguerreotypes by Brady; engraved by D'Avignon. Published from 205 Broadway, New York, by G. P. Putnam, D. Appleton \& Company, and C. S. Francis \& Company. New York, 1850.

Issued in 24 Parts. For John James Audubon, see Part No. 7; reproduced in Spooner's Biographical History of the Fine Arts, vol. i, pp. 53-55 (New York, 1867). See also No. 196.

63. Philarète-Chasles:

Etudes sur la Littérature et les Moeurs des AngloAméricains au xixe siècle. Pp. i-viii, 1-516. Paris, 1851. See "Audubon. Le Voyageur et le Naturaliste," pp. 68-106.

An excellent review by an experienced French critic and author, who appears to have met Audubon and to have attended one of his exhibitions in Edinburgh.

64. (Anon.) Thorpe, Col. Thomas B.:

"Incidents in the Life of Audubon," Godey's Lady's Book, vol. xlii, pp. 306-309, with portrait. Philadelphia, 1851.

65. Griswold, Rufus W.:

"John James Audubon," International Monthly Magazine, vol. ii, pp. 469-474. New York, 1850-1851.

66. $\mathrm{C}_{\mathrm{AP}}$, P. A. :

"Jean Jacques Audubon," L'Illustration, vol. xviii, pp. 70-71, illust. Paris, 1851.

67. (Anon.) :

"Audubon, the Naturalist," Gleason's Pictorial, vol. iii, p. 196, with portrait of Audubon as a young man. Boston, Sept. 25, 1852. 
Audubon is said to have been born in New Orleans, May 4, 1780, and "in 1810 he embarked in a skiff with his wife and young child for his only companions, and with his gun and pencil for baggage, and commenced an adventurous and wandering life-the life of a hunter and naturalist, which he did not abandon until 1834."

68. Godwin, Parke:

"John James Audubon," in The Homes of American Authors. New York, 1853.

See also "The Home of Audubon," The Leisure Hour, vol. 2, pp. 300-303 (London, 1853), and Little Journeys to the Homes of American Authors, New York and London, 1896.

69. Smiles, Samuel:

Brief Biographies. Boston, 1861. See "Audubon the Ornithologist," pp. 171-197.

70. St. John, Mrs. Horace:

Life of Audubon, the Naturalist in the New World. His Adventures and Discoveries. Pp. i-xiv, 1-172. London, 1856.

\%1. St. Јohn, Mrs. Horace:

Life of Audubon, the Naturalist of the New World. His Adventures and Discoveries. Revised and corrected, with additions, and illustrated with engravings by J. W. Orr from original designs. Pp. 1-24, 1-312. Boston, 1856.

First American edition, followed by others in 1861, 1864, 1870,1876 and later; citation from edition of 1864 .

72. Buchanan, Robert (editor):

The Life and Adventures of John James Audubon, the Naturalist. Edited from materials supplied by his widow. 8vo. Pp. i-viii, 1-366. Portrait and vignette on title. London, 1868. 
This was followed by a second and third English edition in 1869 , the latter without frontispiece, but with vignette stamped on cover. The editor assumed no responsibility for the fidelity of his record, which was based on a manuscript by the Rev. Charles Coffin Adams, of New York. Reproduced in "Everyman's Library," with an Introduction by John Burroughs (originally appearing as a review of Buchanan's work in 1869; see No. 153). 12mo. Pp. i-xx, 1-336. London and New York (no date).

73. Audubon, Lucy (editor):

The Life of John James Audubon, the Naturalist. Edited by his Widow. With an Introduction by James Grant Wilson. 8vo. Pp. i-x, 1-444. Portrait, and vignette on title. New York, 1869.

Reprinted at various times; citation from a copy bearing date of 1906. This work is a reproduction, with but slight changes, of Buchanan's rendering of the original Adams manuscript.

74. Duyckinck, Evert Augustus:

"John James Audubon," in the National Portrait Gallery of Eminent Americans, illustrated from paintings by Alonzo Chappel. 2 vols., 4to. New York, 1862. For Audubon, see vol. i, pp. 47-54.

75. Parton, Jamfs:

Peoples' Book of Biography, or Short Lives of the most interesting Persons of all Ages and Countries. Hartford, 1869. For Audubon, see pp. 163-167.

A second edition appeared under the title Illustrious Men and their Achievements, \&c. (New York, 1881).

76. (ANon.):

“Audubon," Chambers' Journal, vol. 46, pp. 85-89. London and Edinburgh, 1869.

A compilation from Buchanan's Life. 
77. (ANON.) :

"The Life of John James Audubon, the Naturalist," Harpers' New Monthly Magazine, vol. xxxix, pp. 613614. New York, 1869.

78. Audubon, Maria R. :

"Reminiscences of Audubon by a Granddaughter," Scribner's Monthly Magazine, vol. xiii, pp. 333-336. New York, 1876.

79. Brewer, Thomas M. :

"Reminiscences of John James Audubon," Harper's New Monthly Magazine, vol. lxi, pp. 666-675. New York, 1880.

Reproduces a number of interesting letters.

80. (Anon.) Larrabee, W. H.:

"Sketch of J. J. Audubon," Popular Science Monthly, vol. xxxi, pp. 687-697, with portrait. New York, 1887.

See also reprint in Pioneers of Science in America. Sketches of their lives and Scientific Work. From the Popular Science Monthly, with additions. "John James Audubon, 1780-1851," pp. 152-156. New York, 1896.

81. Pentz, JАсов :

"The Audubons." Shooting and Fishing, May 11, 1893, illust. New York.

Interesting reminiscences and portraits of John Woodhouse Audubon and his family, with whom the author lived for a number of years.

82. Elliot, Daniel Giraud :

"The Life and Services of John James Audubon," Transactions of the New York Academy of Sciences, vol. xiii, pp. 43-57. New York, 1893. 
An address delivered before the New York Academy of Sciences, April 26, 1893.

83. Godwin, $P_{\text {ARKe : }}$

"John James Audubon," in Commemorative Addresses, pp. 149-192.

An interesting sketch by one who had known Audubon as early as 1842, but replete with errors in dates and questions of fact; condensed from earlier papers. See Nos. 60 and 68.

84. Mitchell, Donald G.:

American Lands and Letters. 2 vols. London, 1897, 1899. For Audubon, see vol. i, pp. 204-213.

85. Bradford, Mary Fluker:

Audubon. Pp. 1-72, illust. New Orleans, 1897.

Originally read before the Quarante Club, and privately printed in the interests of a fund for the erection of a monument to Audubon in New Orleans, a project which has since been realized (see Vol. I, p. 13).

86. Audubon, Maria R.:

Audubon and His Journals, with zoölogical and other notes by Elliott Coues. With 37 Illustrations, including 10 Portraits of Audubon, and 3 hitherto unpublished Bird Drawings. 2 vols., 8vo. Vol. i, pp. i-xiv, 1-532; vol. ii, pp. i-viii, 1-554. With reproduction of diplomas, etc. New York, 1898.

The first volume of this excellent work is devoted to a biography of the naturalist, pp. 1-78, and to his Journals (see No. 42); the second continues the Journals, and reproduces most of the "Episodes" from the Ornithological Biography.

87. Burroughs, John:

John James Audubon. Pp. i-xviii, 1-144. With portrait. 16mo. and (large paper) 8vo. Boston. 1902. Citation from second edition of 1904 . 
88. Merriam, C. Hart :

"John James Audubon," Popular Science Monthly, vol. lxx, pp. 301-303, with portrait. New York, $190 \%$.

Delivered on the occasion of the unveiling of marble busts of ten eminent scientific men at the American Museum of Natural History, December 29, 1906.

89. Merriam C. Hart :

"John James Audubon," Bird Lore, vol. 9, pp. 3-5. New York, 1907.

89a. Stone, Witmer:

"John James Audubon," in Leading American Men of Science, ed. by David Starr Jordan, pp. 71-8\%. New York, 1910.

90. Bakewell, Rev. Gordon:

"Reminiscences of John James Audubon." Publications of the Louisiana Historical Society, vol. v, pp. 31-41. New Orleans, 1911.

An address delivered before the Louisiana Historical Society, November 16, 1910. Affirms, on the testimony of Bernard de Marigny, that Audubon was a Louisianian by birth. See Vol. I, p. 69 of the present work.

\section{i. Reviews and Criticism}

91. (Anon.) Brewster, David:

"Mr. Audubon's Ornithology of the United States of America," Edinburgh Journal of Science, vol. vi, p. 184. Edinburgh, 1826-1827.

This highly commendatory paper by David Brewster, and that by Robert Jameson, which follows, gives the first formal announcement of Audubon's work in the scientific journals of the day. 
92. (Anon.) J JMeson, Robert :

"Mr. Audubon's great work on Birds of the United States of America," Edinburgh New Philosophical Journal, vol. 2, pp. 210-211. Edinburgh, 1826-182\%.

The editor stated that Audubon had spent twenty-two years in the study of American birds, and that the engravings, of which several had already appeared, would be accompanied by a quarto volume of letterpress, containing all his observations on the natural history of the species, in the form of letters, an example of which was given in the paper on the Turkey Buzzard in the present number of that Journal (see No. 17).

93. (Anon.) Jones, Thomas P.:

"The Romance of the Rattlesnake," Franklin Journal and American Mechanics' Magazine, vol. ii (August), N. S., p. 144. Philadelphia, 1828.

This notorious attack upon Audubon's veracity was followed by Waterton (see No. 115), and referred to by Victor Audubon (see No. 118), in his reply. Audubon's original article ( see No. 21) was published by this editor, who knew so little of its author that not even his name was given correctly.

93a. Cuvier, Georges:

"Rapport verbal fait à L'Académie Royale des Sciences, sur L'Histoire naturelle des Oiseaux de L'Amérique Septemtrionale, de M. Audubon," Le Moniteur, $1^{\text {re. }}$ octobre. Paris, 1828.

For extracts from Cuvier's report, see Chaptcr XXIII, p. 413.

94. (AnON.):

"Ueber die Abbildungen von Vögeln," in Froriep, Notizen, Bd. xxi, col. 49-54. Berlin, 1828.

95. W[illiam]. S[wainson].:

"Some Account of the Work now publishing by Mr. Audubon," Loudon's Magazine of Natural History, vol. i, pp. 43-52 (May). London, 1828-1829. 
Dated at "Tittenhanger Green. April 11, 1828." A highly laudatory article on Audubon's plates, quoted in his "Prospectus" of The Birds of America.

96. (Anon.):

"Report of a committee appointed by the Lyceum of Natural History of New York to examine the splendid work of Mr. Audubon upon the Birds of North America; May, 1829," American Journal of Scicnce and Arts, vol. xvi, pp. 353-354. New Haven, 1829.

Applauds The Birds of America, and recommends that the Lyceum become a subscriber.

97. "OrnithophiLus":

"Remarks on Audubon's Birds of America, and Ornithological Biography," Edinburgh New Philosophical Journal, vol. 10, pp. 317-332. Edinburgh, 18301831.

A highly favorable and elaborate review, mistakenly attributed to Swainson. Reprinted in the National Gazette and Literary Register, vol. xii (June 10), Philadelphia, 1831. In an editorial note it is said that the Ornithological Biography is about to be reprinted in Philadelphia by James Kay, Jr., \& Company.

98. Christopher North (John Wilson):

"Audubon's Ornithological Biography Introduction," Blackwood's Edinburgh Magazine, vol. xxx, pp. 1-16 (July). Edinburgh, 1831.

The second of Wilson's articles in praise of Audubon; reprinted with his later reviews of the same work in Critical and Miscellaneous Essays, vol. v, pp. 91-149.

99. Christopher North (John Wilson):

"Audubon's Ornithological Biography. Second Survey. Wilson's American Ornithology," Blackwood's 
Edinburgh Magazine, vol. xxx, pp. 247-280. Edinburgh, 1831.

100. (ANon.):

"Ornithological Biography. . . . B By John James Audubon. \&c. \&c. Edinburgh, 1831," Edinburgh Literary Journal or Weekly Register of Criticism and Belles Lettres, April 16, 1831, pp. 248-249.

101. (Anon.) Featherstonhaugh, G. W.:

"Ornithological Biography. By John James Audubon, F. R. S. Published by Judah Dobson and H. H. Porter, Literary Rooms, Philadelphia," Monthly American Journal of Geology and Natural Science, vol. i, September, pp. 136-139. Philadelphia, 1831.

102. (ANon.):

"Ornithological Biography," American Quarterly Reviere, vol. x, pp. 245-258. Philadelphia, 1831.

103. (ANon.):

"The Birds of America. . . B By John James Audubon, F. R. S. . . . . . vol. i. folio. London, 1831. Ornithological Biography . . . . . 1 vol. 8vo. Edinburgh, 1831," Quarterly Reviere, vol. xlvii, pp. 332-366. London, 1832.

In the same article are reviewed Jameson's edition of Wilson's American Ornithology, and Part II of Swainson's and Richardson's Fauna Boreali-Americana.

104. Waterton, Charles :

"On the Faculty of Scent of the Vulture," Loudon's Magazine of Natural History, vol. v (April), pp. 233241. London, 1832.

Signed "Walton Hall, Dec. 21, 1831"; the first of nineteen critical and polemical articles extending over a period of five years, and directed against Audubon and his friends. 
105. (Anon.) Peabody, W. B. O.:

"Audubon's Biography of Birds. Ornithological Biography of Birds. ..... Philadelphia, 1831," North American Review, vol. xxxiv, pp. 364-405 (April). Boston, 1832.

The first of three able articles by the same anonymous writer which appeared in this Reviere. See Nos. 130 and 143.

106. (Anon.) Featherstonhaugh, G. W.:

"Audubon, Author of The Birds of America, and Ornithological Biography," Monthly American Journal of Geology and Natural Science, vol. i, pp. 456-468 (April). Philadelphia, 1832.

A laudatory review, in which the author professes to give "a true history of a conspiracy, got up to utterly break down and ruin the reputation of one of the most remarkable men America ever produced."

107. Abert, John:

"Habits of Climbing of the Rattle-snake. Extract of a letter from Col. Abert, of the U. S. Topographical Engineers, to Dr. Harlan of Philadelphia," Monthly American Journal of Geology and Natural Science, vol. i, pp. 221-223. Philadelphia, 1832.

Dated "Washington, Oct. 21, 1831." Supports Audubon's account of the climbing habits of the rattlesnake, which had become the subject of acrimonious dispute.

108. (Anon.) :

"Audubon," The Athencum, vol. for 1833, pp. 817818. London, 1833.

In number for November 23. An account, partly from private sources and partly from a New York newspaper, of Audubon's present researches and plans, with detailed comment on his Florida and Labrador expeditions. 


\section{BIBLIOGRAPHY}

109. Hunter, Perceval:

"Means by which the Vulture (Vultur Aura, L.) traces its Food," Loudon's Magazine of Natural History, vol. vi, pp. 83-88. London, 1833.

Dated "Oxford, Jul. 2, 1832." Defends Audubon's account of lack of sense of smell in the Vulture, published in 1826 (see No. 17).

110. Waterton, Charles:

"The Means by which the Turkey Buzzard traces its Food," Loudon's Magazine of Natural History, vol. vi, pp. 162-163. London, 1833.

Signed "Walton Hall, Jany. 1, 1833." A caustic reply to the last. Reprinted in Essays in Natural History, chiefly Ornithology, First Series. London, 1838.

111. Waterton, Charles:

"Remarks on Mr. Audubon's Account of the 'Habits of the Turkey Buzzard (Vultur Aura), particularly with the View of exploding the Opinion generally entertained of its extraordinary Powers of Smelling," "Loudon's Magazine of Natural History, vol. vi, pp. 163171. London, 1833.

A characteristically flippant article, ending thus: "But here I will stop: I have been too long on carrion,- 'neque enim toluare vaporem ulterius potui' (Ovid Met., ii, 301)."

112. Waterton, Charles:

"The Gland on the Rump of Birds," Loudon's Magazine of Natural History, vol. vi, pp. 274-27\%. London, 1833.

Denial that birds ever oil their feathers in preening, as Audubon had maintained for the eagle. Reprinted, with many controversial articles, which follow, in Essays on Natural History, First Series, referred to above. 
113. Audubon, V. G. :

"[Mr. Audubon, Jr.] in Reply to Mr. Waterton's Remarks on Audubon's Biography of Birds," Loudon's Magazine of Natural History, vol. vi, p. 369. London, 1833.

Signed "121 Great Portland St., Jn. \%, 1833." Victor Audubon's defense of his father, who was then in America.

114. R [oBERT] B [AKEWELL]:

"Observations on Mr. Waterton's Attacks on Mr. Audubon," Loudon's Magazine of Natural History, vol. vi, pp. 369-372. London, 1833.

Signed "Hampstead, Jn. 10, 1833."

115. Waterton, Charles:

[Mr. Waterton in reply to Mr. Audubon, Jun.], Loudon's Magazine of Natural History, vol. vi, pp. 464-465. London, 1833.

Signed "Walton Hall, July 6, 1833"; Refers to Dr. Jones' "Romance of the Rattlesnake" (see No. 93), and quotes a letter by George Ord, in explaining why Swainson did not write the "Biography of Birds."

116. Waterton, Charles:

"Mr. Audubon again," Loudon's Magazine of Natural History, vol. vi, pp. 465-468. London, 1833.

A reply to Robert Bakewell, in which the author says that his only object in attacking Audubon was to defend his own account of the vulture.

117. Swainson, William:

"Mr. Audubon, and his Work, the 'Biography of Birds': Mr. Swainson in reply to Mr. Waterton," Loudon's Magazine of Natural History, vol. vi, p. 550. London, 1833.

Dated Sept. 17, 1832. 
118. Audubon, V. G.:

"Mr. Audubon, and his Work, the 'Biography of Birds': Mr. Audubon, jun., in Reply to Mr. Waterton," Loudon's Magazine of Natural History, vol. vi, pp. 550-553. London, 1833.

Signed "121 Great Portland, Sept. 19, 1833." Quotes articles by Jones, Featherstonhaugh and Abert; see Nos. 93, 101, 106 and $10 \%$.

119. Waterton, Charles:

"Retrospective Criticism," embracing the following minor articles: "Mr. Audubon, and his Work, the Biography of Birds" (signed "Walton Hall, Nov. 7, 1833) ; "Mr. Audubon, jun."; "Aerial Encounter of the Eagle and the Vulture" (see the "Biography of Birds," vol. i, p. 163) (signed "Walton Hall, Nov. 7, 1833"); "Audubon's Humming-bird" (see the "Biography of Birds," vol. i, p. 248) ("Walton Hall, Nov. 19, 1833"); "The Virginian Partridge," Loudon's Magazine of Natural History, vol. vii, pp. 66-74. London, 1834.

The three last reprinted in Essays on Natural History, First Series, referred to above.

120. Waterton, Charles:

"Retrospective Criticism," embracing the following minor articles: "The Vulture's Nose" ("Walton Hall, March 6, 1834"); "Audubon's Claim to the Authorship of the Biography of Birds"; "Audubon and his Ornithology"; "The Passenger Pigeon" ("Walton Hall, Jany. 19, 1834"). Loudon's Magazine of Natural History, vol. vii, pp. 276-283. London, 1834.

The first and last articles reprinted in Essays on Natural History, First Series, referred to above.

121. (ANon.):

"The Birds of America. No. XXXVII. By J. J. Audubon, Esq. Coloured Plates. Elephant folio. Lon- 
don, Havell," Athenaum, vol. for 1834, p. 350 (May 10). London, 1834.

At the same time was also reviewed Part ii of $A$ Manual of the Ornithology of the United States, by Thomas Nuttall.

122. (ANon.):

"The Birds of America. By J. J. Audubon, F.R.S., F.L.S. Parts XLI, XLII, XLIII. London, Havell," Athenaum, vol. for 1834, pp. 653-654. London, 1834.

Describes the Wood Duck (Plate ccvi) as perfect, and compliments the engraver, Robert Havell, on "the accuracy with which he has appreciated and retained the spirit of the originals."

123. (ANon.) HaLL, James:

"American Ornithology," The Western Monthly Magazine, vol. ii, pp. 337-350 (July). Cincinnati, 1834.

A comparative review of the ornithological works of Alexander Wilson, Thomas Nuttall, and John James Audubon, very laudatory of the first two but condemnatory of the last, by Judge Hall, whose brother, Harrison Hall, was an interested publisher of Wilson's work. "How shall we venture to dissent from the almost unanimous expression of public sentiment, which has set him [Audubon] up as a sort of 'greatest and best,' against whom to speak in dispraise, would be a species of treason. Yet it must be done, and it is our vocation to do it: the critic must not be silent when the interests of science require, and the honor of his country demands, that he should proclaim the truth. .... The exaggerations contained in these sketches ["Episodes"] are such as to weaken our confidence in the entire work."

124. Bachman, JoHn :

"Retrospective Criticism. Remarks in defence of the Author of the Birds of America," Loudon's Maga- 
zine of Natural History, vol. vii, pp. 164-175. London, 1834.

A reply to Waterton, and an appeal for as much justice for Audubon as was shown to Wilson, his predecessor. Dated "Charleston, Dec. 31, 1833."

125. Bachman, John :

"An account of some experiments made on the habits of the Vultures inhabiting Carolina,- the Turkey Buzzard and the Carrion Crow, particularly as it regards the extraordinary powers of smelling usually attributed to them," Journal of the Boston Society of Natural History, vol. i, pp. 15-31. Boston, 1834.

Bachman did not deny the power of smell to the vultures, but maintained that they were guided to their prey by sight alone.

126. (ANON.):

"Audubon's Birds of America and Ornithological Biography," Edinburgh Nere Philosophical Journal, January, 1835.

"All is life, health, and beauty. Never before were birds so represented, and if ever again they will be, still Audubon will be the chief of a school, of whom it will be said that it studied nature. Turn now to any volume of plates that you can find, and what presents itself? not a bird surely, but an effigy stuffed with straw, and more worthy of being burnt, than that of a Tory statesman by a radical mob."

12\%. BaChman, John:

"Defence of Audubon," Bucks County Intelligencer, 1835.

Not seen.

128. (ANon.):

"Ornithological Biography . . . . Volume ii, published at 25s.," Loudon's Magazine of Natural History, vol. viii, pp. 184-190. London, 1835. 
129. TAYlor, Richard C. :

"On the Geology and Natural History of the NorthEastern Extremity of the Alleghany Mountain Range: in Pennsylvania, United States," Loudon's Magazine of Natural History, vol. viii, pp. 529-541. London, 1835. Confirms Audubon's account of the climbing habits of the rattlesnake.

130. (Anon.) Peabody, W. B. O.:

"Audubon's Biography of Birds; Ornithological Biography," North American Review, vol. xli, pp. 194231. Boston, 1835.

131. Christopher North (John Wilson):

"Audubon's Ornithological Biography," Blackwood's Edinburgh Magazine, vol. 37, pp. 107-124. Edinburgh, 1335.

132. Waterton, Charles:

"On Snakes, their Fangs, and their Mode of procuring Food," Loudon's Magazine of Natural History, vol. viii, pp. 663-668. London, 1835.

Reprinted in Essays on Natural History, First Series, referred to above.

133. Waterton, Charles, Esquire, of Walton-Hall:

"A Letter to James [Robert] Jameson, Esq." [followed by 21 lines of fine print, giving titles and membership in scientific societies]. Pp. 1-14. Wakefield, 1835.

Privately printed, and designed mainly to hit Audubon and his snake stories over Jameson's shoulders. Signed, "WaltonHall, January 27, 1835." "Should you honor me-- with a reply, I promise you that I will take an immediate and dispassionate notice of it; and I will address to you a second, a third, and a fourth letter, and so on. As you have first 
attacked me through Audubon, through him I will continue to point my dart at you. .... This mode of carrying on the warfare will answer well my ends. It will give me an opportunity of again bringing on the stage certain individuals with whom I have not yet quite squared up accounts; and, at the same time, I trust it will be to you a kind . . . . . of hint, a warning-lest you make another false step in your exertions to sound again in the public ear, O Candour! whither art thou fled? Certainly not to Walton Hall. ... Pray, sir, where were your brains (whither had they fled? Certainly not to Walton Hall) when you received, and approved of, a narrative at once so preposterous and so palpably fictitious?" Reprinted in Essays on Natural History, edited by Norman Moore (London, 1871). Citation from pamphlet in Library of British Museum.

134. Waterton, Charles, Esquire, of Walton-Hall:

"Second Letter to Robert Jameson, Esq." [with same titles as in last]. Pp. 1-16. Wakefield, 1835.

Ridicules in particular Audubon's accounts of the Vulture, the Passenger Pigeon, and a hurricane in North America. Signed "Walton-Hall. March 2nd., 1835."

135. Waterton, Charles:

"Audubon's Plates of the Birds of America," Loudon's Magazine of Natural History, vol. viii, pp. 236238. London, 1835.

Accuses Audubon of misrepresentation in his statements of the time required to produce his drawings.

136. (ANON.):

"Ornithological Biography, or an Account of the Habits of the Birds of the United States of America. . . . . By J. J. Audubon. vol. ii \&c. First Notice," Athenaum, London, January 3, 1835, pp. 5-7.

The same: "Second Notice," Athencum, January 17, pp. 43-45. 
The same: "Third Notice," Athenæum, January 31, pp. 87-89.

"There is amply sufficient remaining in Audubon's pages, for fully a dozen more notices, were we disposed to follow the exhausting system."

137. (ANon.) :

"Ornithological Biography ... vol. iii, First Notice," Athenaum, pp. 41-42, January 16, 1836. London.

The same: "Second Notice," Athenaum, January 23, 1836, pp. 62-63.

138. Waterton, Charles, Esq., Walton-Hall :

"An Ornithological Letter to William Swainson, Esq., F.R.S. \&c. \&c." Pp. 1-16. Wakefield (Richard Nichols, Bookseller), 1837.

Signed "Walton-Hall, March 10, 1837," and reprinted in Moore's edition of Essays on Natural History, referred to above. A long and bitter tirade against both Swainson and Audubon. "You have seen fit to laud one man exceedingly, for his zoological acquirements, who to my certain knowledge, paid other people for the letterpress and drawings, which were to appear in his work." Citation from pamphlet in British Museum Library.

139. (ANon.):

"Ornithological Biography . . . . by John James Audubon. vols. i-iii," Oken's Isis, Bd. xxx, pp. 922928. Leipzig, 1837.

140. Selts, W.:

"On the Habits of the Vultur aura, with notes on the dissections of the two heads of two specimens by $\mathbf{R}$. Owen," Proceedings of the Zoölogical Society of London, Pt. v, pp. 33-35. London, 1837. 
Favors the view that the vulture is guided to food by the sense of smell.

141. (ANon.):

"Ornithological Biography . . . . . vol. iv . . . ." Athenaum, London, Dec. 1, 1838, pp. 849-852.

142. (ANON.):

"Ornithological Biography . . . . vol. v . . . . ." Athenaum, London, vol. for 1839, p. 77.

143. (Anon.) Peabody, W. B. O.:

"Audubon's Ornithological Biography," North American Revierw, vol. i, pp. 381-404 (April). Boston, 1840.

144. (ANon.):

"Audubon's Ornithology. A Synopsis of the Birds of North America. Edinburgh, 1839. The Birds of America. London and Edinburgh, vol. 1. New York, 1840," American Journal of Sciences and Arts, vol. xxxix, pp. 343-35\%. New Haven, 1840.

145. Ord, George:

[Reply to Audubon's charge against Wilson, and countercharge against Audubon.] Proceedings of the American Philosophical Society, vol. 1, pp. 272-273. Philadelphia, 1840.

Report of meeting held September 18, 1840.

146. (ANon.):

"The Birds of America . . . vol. vii, octavo edition . . . . . published by J. J. Audubon, and J. B. Chevalier," American Journal of Science and Arts, vol. xlii, pp. 130-136. New Haven, 1842.

"Mr. Audubon has now nearly a thousand subscribers to his work; an instance of liberal support of a work on natural his- 
tory certainly without a parallel in the New World, and hardly with one in the Old."

14\%. (Anon.) :

"A Synopsis of the Birds of North America, by J. J. Audubon. London, 1839," Oken's Isis, Bd. xxxvii, pp. 713-718. Leipzig, 1844.

148. Winterfield, Charles:

"American Ornithology (The Birds of America and Ornithological Biography)," The American Review: A Whig Journal, vol. i, pp. 262-274. New York 1845.

149. Winterfield, Charles :

"About Birds and Audubon," The American Review: A Whig Journal, vol. i, pp. 371-383. New York, 1845.

Refers to a meeting with Audubon on a canal boat in Pennsylvania, when the latter was returning from his Missouri River expedition in 1843. See No. 173.

150. Winterfield, Charles:

"A Talk about Birds and Audubon," The American Reviere: A Whig Journal, vol. ii, pp. 279-287. New York, 1845.

Interesting reference to "the great fire [of July 19, 1845] which so lately devastated so large a part of this proud city [New York]," in which the copper plates of Audubon's Birds were thought to have been destroyed (see Chapter XXXV, p. 267).

151. (Anon.) :

"Audubon, the Naturalist," Athenæum, London, vol. for 1856, p. 283.

Review of Mrs. Horace St. John's Life of Audubon (see No. 71 ). 
152. (ANON.):

"The Life and Adventures of John James Audubon," Athenæum, London, vol. for 1868, pp. 833-834. Review of Buchanan's Life (see No. 72).

153. (Anon.) Burroughs, John:

"The Life of Audubon . . . . edited by Mrs. J. J. Audubon" [see No. 73], The Nation, vol. ix, pp. 13-14. New York, 1869.

Reprinted in Buchanan's Life of Audubon, "Everyman's Library" (see No. 72).

154. (ANON.):

"The Adventures of Audubon," . . . Edinburgh Revier, vol. exxxii, pp. 250-275. Edinburgh, 1870. Review of Buchanan's Life.

155. Shufeldt, R. W.:

"Shedding Horns of Antelope," Shooting and Fishing, New York, March, 1896.

For critical articles by the same author, see also the following: "On the Terrestrial Attitudes of Loons and Grebes," The Ibis, London, January, 1898; "Audubon's Figure of the Mountain Partridge," Field and Stream, New York, September 1899; "Scaup Duck," Shooting and Fishing, New York, November 26, 1903; and "The Nest of the Orchard Oriole," The Wilson Bulletin, Oberlin, June, 1903.

156. (ANon.):

"A Great Naturalist," Blackrwood's Edinburgh Magazine, vol. clxiv, pp. 58-69. Edinburgh, 1898.

Review of Audubon and his Journals.

157. (Anon.) Merriam, C. Hart:

"Audubon," The Nation, vol. LXVI, pp. 151-152. New York, 1898. 


\section{APPENDICES}

See also Science, N. S., vol. VII, pp. 289-296, with plate. New York, 1898.

Reviews of Audubon and his Journals.

158. M[IALI], L. C. :

"Audubon," Nature, vol. lvii, pp. 286-28\%. London, 1896-1898.

A dour review, in which the writer remarks that Audubon's Birds of America "has great artistic merit but less scientific value than a good series of photographs from life."

159. Hutт, W. N.:

"Audubon the Original Nature Fakir," Scientific American, vol. xcviii, p. 59. New York, 1908.

A feeble echo of the slanderous charges brought against Audubon by Thomas P. Jones in 1828 (see No. 93).

160. Colles, George W.:

"A Defense of Audubon," Scientific American, vol. xcviii, p. 311. New York, 1908.

An excellent rejoinder to the egregious article quoted above.

161. Burns, Frank L.:

"Alexander Wilson," Pts. I-VIII, The Wilson Bulletin, vols. xx-xxii. Oberlin, 1908-1910.

See particularly, I. "The Audubon Controversy," vol. xx, pp. 3-18, and II. "The Mystery of the Small-headed Flycatcher," vol. $\mathrm{xx}, \mathrm{pp}$. 63-79.

\section{j. Auduboniana and Miscellanea}

162. (AnON.) :

"Wilson the Ornithologist," The Literary Gazette, and Journal of Belles Lettres, Arts and Sciences, London, Saturday, September 3, 1831, p. 574.

A grotesque notice, based on a rumor, said to have originated in a Philadelphia newspaper, of the death of Audubon 
in America, but confounding his identity with that of Alexander Wilson, whose death had actually occurred at Philadelphia eighteen years before. In the issue of October 15, the editor acknowledged his error in resurrecting and then killing Wilson, but explained that the obituary was intended for Audubon.

163. Brown, Capt. Thomas:

"Mr. Audubon," Caledonian Mercury, Edinburgh, Thursday, November 3, 1831.

Quotes a letter written by Audubon, to Joseph B. Kidd and dated "New York, Sept. 7, 1831," four days after his death had been announced in England. In its issue of September 8, this paper had already corrected the London editor's error respecting Wilson.

164. (Anon.) Featherstonhaugh, G. W.:

"Audubon's Expedition to California and the Rocky Mountains," Monthly American Journal of Geology and Natural Science, vol. i, p. 229. (November.) Philadelphia, 1831.

165. (ANon.):

"Mr. Audubon," New York Mirror, vol. 10, p. 325. New York, April 20, 1833.

166. (ANon.) :

"Audubon and his Labrador Expedition." Editorial in the National Gazette and Literary Register, Philadelphia, vol. xiii, No. 3808, September 10, 1833.

"We wish him a degree of success and prolongation of vigor equal to his great merits; indeed, for the past at least, success is fully assured."

167. (Anon.) :

"Mr. Audubon," National Gazette and Literary Register, Philadelphia (extracted from the Boston Patriot), vol. xiii, No. 3919, September 10, 1833. 
Welcomes Audubon on his return to Boston, and gives detailed account of his successful Labrador expedition.

168. MacGilliviay, Wrlliam:

A History of British Birds, indigenous and migratory, 5 vols., 8vo. Illust. London, 1837-1852.

See Practical Ornithology, 6th. Lesson: "Ornithologus [Audubon], and Physiophilus [MacGillivray]," pp. 462-474 (1839).

169. Swainson, William:

Taxidermy, Bibliography, and Biography. The Cabinet Cyclopadia, conducted by the Rev. Dionysius Lardner. 12mo. London, 1840. For "J. J. Audubon, Animal Painter," see pp. 116-11\%.

170. Freiligrath, F.:

"Epistel an Audubon nebst einer Antwort aus Amerika." Pp. 1-16, 18mo. Philadelphia, 1844.

This rare little pamphlet bears on its cover a woodcut of an Indian brandishing a gun and knife: the poem begins:

"Mann der. Wälder, der Savannen!

Neben rother Indier Speer,

An des Mississippi Tannen

Lehntest du dein Jagdgewehr!"

and the response:

"Audubon, den Vogelfänger

Sangst du an, mit Herzeleid;

Freiligrath, o grosser Sänger!

Deine Lieder fliegen weit."

See also J. Bayard Taylor, "Audubon. From the German of Ferdinand Freiligrath," Graham's American Monthly Magazine, vol. xxvi, p. 264. This poem consists of twenty stanzas, the first four and best of which are: 


\section{BIBLIOGRAPHY}

Man of forests and savannas!

On the Mississippi's tide,

Leanest thou thy hunting-rifie

Oft the Indian spear beside;

With the forest's tawny chieftains

Thou the friendly pipe dost light-

Seest the wandering pigeon's journey

And the eagle's silent flight.

With thy shot thou lam'st his pinion;

And the trackless region through,

On the mighty river's mirror

Pliest thou thy swift canoe.

O'er the green and grassy prairie

Boldly flies thy fiery steed;

Deer and forest-fruits the manna

God has given thee in thy need!

Ferdinand Freiligrath (1810-1876), well known German lyric poet and apostle of democracy, was more than once forced to flee his native land on account of his political sentiments; he went to England seven years after Audubon had finally settled in America, and that country became his refuge for over twenty years; his translations from the English included Longfellow's poem of "Hiawatha."

171. (ANoN.):

"Mort de Jean Jacques Audubon, célèbre naturaliste américain," illust., L'Illustration, Paris, vol. xvii, No. 416, February 28, 1851, p. 128.

172. (ANon.):

"John James Audubon," Harper's Nerw Monthly Magazine, vol. ii, pp. 561-563 (March). New York, 1851. 


\section{Webber, Charles Wilkins:}

Romance of Natural History; or Wild Scenes and Wild Hunters. 8vo.; pp. 1-8, 17-610. Philadelphia, 1852.

An abridgment of the author's Wild Scenes and Wild Hunters, 1851, and also issued under the title The hunter naturalist; also published as The Romance of forest and prairie life; narrative of perilous adventures \& wild hunting scenes (H. Vizetelly. London, 1853). Gives an anecdote of meeting Audubon on a canal boat in Pennsylvania, when he was returning from the Upper Missouri in 1843 (see No. 149) and is quoted here for no other reason.

\section{Audubon, John Woodhouse:}

Illustrated notes of an expedition through Mexico and California. Pp. 1-48, 4 plates, plain or colored. J. W. Audubon. New York, 1852. Reprinted as Extra Number 41 of The Magazine of History, with Notes and Queries. Pp. 1-83, 4 colored plates (including frontispiece). W. Abbatt. Tarrytown, 1915.

It was planned to issue this work monthly in ten numbers, if it should receive sufficient public support. The drawings are exquisitely reproduced, and as works of art are deserving of the highest praise. See No. 219.

175. A[nNa]. A[TKins $]$ : :

Memoir of J.G. Children, Esq., including some unpublished poetry of his father and himself. Printed for private distribution. Pp. 1-314. Westminster, 1853.

Refers to Audubon's relations with Children, and to his naming of "Sylvia childreni," which later proved to be an error.

176. Nolte, Vincent :

Fifty Years in both Hemispheres: or Reminiscences of a Merchant's Life. London, 1854. 


\section{BIBLIOGRAPHY}

English edition of a work originally published at Hamburg in the same year. See particularly his version of the meeting with Audubon in 1810, and of their descent of the Ohio in Nolte's flatboat to Louisville in the winter of that year.

17\%. WaLLACE, W. Ross:

"Audubon's Hymn in the American Forests," Harper's Nere Monthly Magazine, vol. xix, p. 619 (October). New York, 1859.

178. Stoddard, Charles A[ugustus]:

"A Noble Woman's Life: A Memorial Sermon to the late Madame Audubon." Printed by request. Pp. 1-24, 18mo. Anson D. F. Randolph \& Co., r/0 Broadway, cor. 9th St., New York, 1874.

179. F.

"Audubon's Birds of America," Magazine of American History, vol. 1, pp. 252-253. New York and Chicago, 1877.

Reproduction of a note by J. Prescott Hall concerning Audubon's subscribers.

180. Lockwood, SAMUet:

"Audubon's Lily Rediscovered," Popular Science Monthly, vol. x (April), pp. 675-678. New York, $187 \%$.

Records the rediscovery of Audubon's long lost and discredited yellow water lily, Nymphaa flava, by Mrs. Mary Treat, in Florida, in the summer of 1876 . Originally figured by Audubon, with the Common American swan, on Plate ccccxi, of The Birds of America, in 1838.

181. Coues, Elliott :

Birds of the Colorado Valley, Bibliographical Appendix: "List of Faunal Publications relating to North American Ornithology," pp. 567-746. 8vo. Washington, 1878. 
Gives full citations of the various editions of Audubon's works. "It takes an inspired idiot to be a good bibliographer" (Coues).

182. WADE, Joseph M.:

"Letter to J. M. Wade on Audubon's Mill," Ornithologist and Oölogist, vol. 8, p. 79. Boston, 1883.

183. Jordan, David Starr:

"Rafinesque," Popular Science Monthly, vol. xxix, pp. 212-221 (June). New York, 1886. Reproduced in Pioneers of Science in America, edited by William Jay Youmans (New York, 1896).

184. Shufeldt, R. W. :

"On an old Portrait of Audubon, painted by himself, and a word about some of his early Drawings," The $A u k$, vol. iii, pp. 418-430, with portrait. New York, 1886.

185. Saunders, Frederick:

The Story of Some Famous Books. For Audubon, see pp. 141-144. London, 1887.

186. Starling, Ediund L.:

History of Henderson County, Kentucky. 8vo., pp. 1-832. Henderson, 1887.

Gives an account of Audubon's mill and of his other business ventures at Henderson, but when departing from local records is inaccurate and unreliable.

187. MARTiN, D. S.:

"Audubon's Grave," Science, vol. x, pp. 68-69 (Aug. 5). New York, $188 \%$.

Refers to the project set on foot to raise funds for erecting a monument to the naturalist. 
188. ShufELdt, R. W.:

"Audubon's Grave," Science, vol. x, p. 108 (Aug.

28). New York, $188 \%$.

Proposes that the remains of Audubon should eventually rest in the crypt of the Cathedral of St. John the Divine, New York City.

189. (ANon.):

[Audubon's Grave], Science, vol. x, p. 205 (Oct. 28). New York, $188 \%$.

Announces the appointment of a committee by the New York Academy of Sciences to secure funds for the erection of the proposed monument.

See also the same, vol. x, p. 278 (Dec. 9).

190. Shufeldi, R. W.:

"Audubonian Sketches," The Audubonian Magazine, published in the interests of the Audubon Society for the protection of birds, vol. i (January), pp. 267-271, illust., and vol. ii (February), pp. 3-6, illust. New York, 1888.

See files of the same magazine, vol. i, pp. i-xi, 1-288, February, 1887-January, 1888, and vol. ii, pp. i-vi, 1-264, February, 1888-January, 1889, New York, for various comments on Audubon's life and services.

191. BaChman, C. L. :

John Bachman, D.D., LL.D., Ph.D. 8vo, pp. i-xii, 1-436, with portrait. Charleston, 1888.

Reproduces numerous letters which passed between the Bachman and Audubon families.

192. Loomis, Leverett M.:

"A Forgotten Volume," The Auk, vol. viii, p. 230. New York, 1891. 
193. (AnoN.) :

"Report of the Audubon Monument Committee of The New York Academy of Sciences," Transactions of the Academy, vol. xiii, pp. 23-69. New York, 1893.

194. Shufeldt, R. W.:

"Audubon the Naturalist," illust., The Great Divide, San Francisco, September, 1893.

"More about Audubon the Naturalist," ibid., February, 1894.

195. Duke, BasiL W.:

"Audubon," Southern Magazine, vol. iii, August, 1893, pp. 3-19, portrait and illust. Louisville, 18931894.

196. Shufeldt, R. W., and Audubon, M. R. :

"The Last Portrait of Audubon, together with a letter to his son," The Auk, vol. xi, pp. 309-313, portrait. New York, 1894.

The original of D'Avignon's engraving, published in 1850 ; see No. 62.

197. Healy, George P. A.:

Reminiscences of a Portrait Painter. Chicago, 1894.

Gives an account of his successful manœuvres to obtain sittings for his portrait of Audubon in 1838.

198. Call, Richard Ellisworth:

The Life and Writings of Rafinesque. Filson Club Publications, No. 10. 4to. Pp. i-xii, 1-227. Louisville, 1895 .

Takes Audcibon severely to task for his treatment of Rafinesque at Henderson in the summer of 1818 ; see pp. 2429 . 
199. "Renignolds" (E. R. Shattuck):

"Audubon's Plates sold for Junk," Forest and Stream, New York, September 12, 1896.

200. BaKeWELL, W. G.:

Bakerwell-Page-Campbell. Being an account of the descendants of John Bakewell, of Castle Donnington, Leicestershire, England, born in 1638, \&c., \&c. Wm. H. Johnston \& Company. Pittsburgh, 1896.

Gives genealogy of the Bakewells, and of the families of J. J., J. W. and V. G. Audubon.

201. Coues, Elliott :

"Letter by Audubon to Charles Bonaparte, dated New York, May 1, 1833," The Osprey, vol. ii. Washington, 1897.

202. Rozier, Firman A.:

Rozier's History of the early Settlement of the Mississippi Valley. 8vo., pp. 1-338. St. Louis, 1898.

See Part X for some account of the business relations of Audubon with the author's father, Ferdinand Rozier.

203. Coues, Elliott :

"William Swainson to John James Audubon, The $A u k$, vol. xv, pp. 11-13. Cambridge, 1898.

Letter dated "Tettenhanger Green, $2^{\mathrm{d}}$ October 1830"; reprinted in The Osprey, vols. iv and v (Washington, 1900).

204. Günther, Alubert :

"The unpublished correspondence of William Swainson with contemporary naturalists (1806-1840)," Proceedings of the Linncan Society, 112th session, pp. 14-24. London, 1900.

Lists twenty-four letters of Audubon to Swainson, dating from 1 May, 1828, to 11 Jany., 1838, with brief reference to 
their contents. For abstract of this paper see Theodore Gill, "Swainson's Correspondence." The Osprey, vol. v, pp. 29-30 (Washington, 1900).

205. Gill, Theodore:

"Correspondence of and about Audubon with Swainson," The Osprey, vol. v, pp. 23-25. Washington, 1900.

206. Gill, Theodore:

"William Swainson and his Times," The Osprey, vols. iv and v. Washington, 1900.

207. (Anon.) :

"Recent Sales of Audubon's Works," The Osprey, vol. v, pp. 31 and 63. Washington, 1900.

Copy of The Birds of America sold by Bangs, February 6, 1896, for $\$ 1,250$, and another by Sotheran, London, 1892, for $£ 345$ (about $\$ 1,725$ ), the first with the Ornithological Biography included.

207a. Bohemian (C. S. Boutcher):

"Early Days in the Lehigh Valley," Black Diamond Express, vol. iv, pp. 3-15. New York, 1900.

Describes Audubon's visit to Mauch Chunk in 1829, and gives also a detailed account of the copy of The Birds of America formerly the property of David Eckley, of Boston, and then in possession of Robert H. Sayre, of South Bethlehem, Pennsylvania (for which see Chapter XXVI, p. 17).

208. (Anon.) :

"Audubon in the [American] Museum [of Natural History]," with explanatory notes by Maria R. Audubon, The American Museum Journal, vol. 1, pp. 82-84, with portrait. New York, 1900-1901.

Describes portrait of Audubon painted by his sons towards the close of his life, and given to the Museum by Mr. Fordham 
Morris, of New York, an oil painting of wild turkeys, the original of which was made by Audubon in 1826 for the Royal Institution of Liverpool, and several other paintings and plates. In vol. ii, page 42, of the same journal is reproduced an unpublished painting of the Red-eyed Vireo by Audubon.

209. Deane, Ruthuen:

"Unpublished Letters of William MacGillivray to John James Audubon," The Auk, vol. xviii, pp. 239249. Cambridge, 1901.

210. Coues, Elliott:

"Auduboniana and Other Matters of Present Interest," Bird Lore, vol. iii, p. 9. New York, 1901.

210a. Clark, Edward B.:

"Relics of Audubon," Chicago Evening Post, February 7, 1901.

An account of Auduboniana and other literary rarities in possession of Mr. Ruthven Deane.

211. MacGillivray, William:

A Memorial Tribute to William MacGillivray, M.A., LL.D. Ornithologist; Professor of Natural History, Marischal College and University, Aberdeen. 4to, pp. i-xvi, 1-204, with illust. Edinburgh, 1901.

Contains sketch of MacGillivray's life and work, with an account of the monument placed over his grave, and of a beautiful memorial tablet inscribed to his memory at Marischal College, with an unpublished "Journal" by MacGillivray, and extracts from his other writings.

212. Butterworth, Hezekiah:

In the Days of Audubon; A Tale of the "Protector of Birds." Illustrated. P. x-xii, 1-236. New York, 1901. 
213. Job, Herbert K. :

"Following Audubon among the Florida Keys," Outing, vol. xliii, pp. 71-79, illust. New York, 1903.

214. Howe, Reginald Heber:

"Audubon's 'Ornithological Biography,", The Auk, vol. xxi, p. 286. Cambridge, 1904.

Note on volume $\mathrm{i}$ of the American edition, bearing the imprint: "Philadelphia: Judah Dobson, Agent, 108 Chestnut Street; and H. H. Porter, Literary Rooms, 121 Chestnut Street. MDCCCXXXI." See also Ruthven Deane, The Auk, vol. xxiv, 1907, p. 111, and Nathaniel E. Janney, the same, p. 349.

This writer at one time proposed to bring out a revised edition of the Ornithological Biography, but the project was abandoned from lack of support.

215. (Anon.) :

"[John James Audubon]; Notice of the Commemoration of the one hundred and twenty-fifth anniversary of his birth," The Auk, vol. xxii, p. 334 (July). Cambridge, 1905.

See Chapter I, Note 6.

216. Deane, Ruthuen:

"John James Abert to John James Audubon" (hitherto unpublished letters), The Auk, vol. xxii, pp. 172-175. Cambridge, 1905.

217. Deane, Ruthven:

"William Swainson to John James Audubon" (a hitherto unpublished letter), The Auk, vol. xxii, pp. 3134. Cambridge, 1905.

218. Deane, Ruthuen:

"William Swainson to John James Audubon," The $A u k$, vol. xxii, pp. 248-258. Cambridge, 1905. 
219. Audebon, John W.:

Audubon's Western Journal: 1849-1850. Being the MS. record of a trip from New York to Texas, and an overland journey through Mexico and Arizona to the gold-fields of California. With a biographical memoir by Maria R. Audubon, and edited by Frank Heywood Hodder. Map, portrait, and original drawings. Pp. 1250, 8vo. Cleveland, 1906.

For the original edition of Part 1 of J. W. Audubon's Journal, see No. 174 of this Bibliography.

220. Clatborne, F.:

Simple Love and Occasional Pieces in Verse, with A Notice of Audubon. Pp. 1-60. New Orleans, 1906.

221. Stone, W

"A Bibliography and Nomenclator of John James Audubon," The Auk, vol. xxiii, pp. 298-312. Cambridge, 1906.

Most complete and accurate analysis of Audubon's ornithological works yet given.

222. (ANon.):

"Abstract of Audubon's Account Books, kept at Philadelphia, while the Octavo edition of the Birds was being issued," Ezening Post, New York, Saturday Supplement for December 29, 1906.

223. (ANON.):

"Original Account Book of J. J. Audubon," The Nation, vol. lxxxiv, p. 12 (June 3). New York, 1907.

See the preceding; gives interesting data regarding the issue of the first octavo edition of The Birds of America in parts, at Philadelnhia. 1840-1844. 
224. Deane, Ruthven:

"Unpublished Letters of Introduction carried by John James Audubon on his Missouri River Expedition," The Auk, vol. xxv, pp. 170-173. Cambridge, 1908.

225. Deane, Ruthuen:

"The Copper-Plates of the Folio Edition of Audubon's 'Birds of America,' with a brief Sketch of the Engravers," The Auk, vol. xxv, pp. 401-413. Cambridge, 1908.

226. Merriam, C. Hart :

"The King Cameos of Audubon," The Auk, vol. xxv, pp. 448-450, with plate. Cambridge, 1908.

226a. Merritt, Dixon L. :

"Audubon, the Ornithologist, in Kentucky," The Taylor-Trotwood Magazine, vol. 10, pp. 293-298. Nashville, 1909.

226b. Derby, EARL of:

In letter, to Audubon, dated January 17, 1835. Reproduction of "The Eagle and the Lamb." Forest and Stream, June 26, 1909, pp. 1011-1012. New York, 1909.

427. ShufeldT, R. W., M.D.:

"An hitherto unpublished painting by Audubon," The Wilson Bulletin, N.S., vol. xii, pp. 3-5, illust. Oberlin, 1910.

Oil painting of cock and hens, but original in poor state of preservation.

228. Fitzpatrick, T. J.:

Rafinesque. A Sketch of his Life with Bibliography. 8vo., pp. 1-242, with portrait and reproductions of rare titles. Historical Department of Iowa, Des Moines, 1911. 
Cites 939 separate publications by Rafinesque, numerous manuscripts and 134 Rafinesquiana.

229. Arthur, Stanley Clisby:

"John James Audubon, and the Birds of Louisiana,"

Times-Picayune, New Orleans, May 2, 1915.

Gives an account, with illustrations, of "Fontainebleau," and of the house at Mandeville which is regarded as "the probable birthplace" of Audubon.

230. Arthur, Stanley Clisby:

"Audubon in West Feliciana," Times-Picayune, New Orleans, August 6, 1916.

Follows Audubon's footsteps in Louisiana, and gives an interesting account, with illustrations, of the plantation houses at which Mr. and Mrs. Audubon lived at various intervals from 1821 to 1829 .

231. Rhoads, SAMUel N.:

"More Light on Audubon's Folio 'Birds of America," The Auk, vol. xxxiii, pp. 130-132. Cambridge, 1916.

232. Willitams, George Alfred:

"Robert Havell, Junior, Engraver of Audubon's 'The Birds of America,", Print-Collector's Quarterly, vol. 6, No. 3 (October), pp. 225-257, illust. Boston, 1916.

Presents a genealogy of the Havell family, and gives an excellent analysis of the work of the eminent engraver.

233. (ANon.):

"More Buried Treasure in a Noted Basement," New York Tribune, Sunday, March 11, 1917.

An appeal for a better treatment of the originals of Audubon's Birds of America. "The original charter of the New York Historical Society signifies that the organization was 
formed to preserve the history of the United States, and especially the history of the City of New York. If Audubon's wonderful drawings of the birds of America are not United States history and New York City history rolled into one, then what, in the name of Herodotus, Father of History, is?"

234. Townsend, Charles W. :

"In Audubon's Labrador," The Auk, vol. xxxiv, pp. 133-146, illust. Cambridge, 1917.

235. Neal, John:

"Audubon, the Ornithologist," New England. Galaxy, Boston, January 3, 1935 ; continued February 7, 1935, and with "The Birds of America," April 18, 1935.

236. Audubon, John James :

"Myself," written about 1835. For further reference, see No. 40.

237. Audubon, John James:

"Audubon," The New World, New York, vol. vii, July 15, 1842.

Letter to Dr. Gideon B. Smith, dated "Missouri River, May 24, 1843."

238. SPEed, John Gilmer:

The Poems of John Keats with Annotations of Lord Houghton and a Memoir by Speed. New York, 1883.

Reproduces letters of John Keats to his brother, George, with charges against Audubon. Letters from George Keats, to which these were in reply, are not given.

239. Haycraft, Samuel :

"Elizabethtown, Kentucky, and its Surroundings," Elizabethtown Neres, 1869. Republished 1889-90.

States that Audubon and Rozier were merchants in Elizabethtown at an early date. Probably an error, but quoted by 
Albert J. Beveridge in Abraham Lincoln, 1809-1858, vol, i, p. 18.

240. W ALSH, J AMES J.:

"Audubon the Naturalist," Records of the American Catholic Historical Society of Philadelphia, vol. xv, pp. 8-21. Philadelphia, 1904.

States that Audubon "was born on the Island of San Domingo not long before the negro insurrection on that island." I owe this reference to a letter of the late William Beer in 1925.

241. Trudeau, Edward Livingston, M. D.:

An Autobiography, New York, 1916.

The father, Dr. James Trudeau of New Orleans, is said to have helped Audubon with the anatomy of his birds and in making drawings of them and their eggs. The son possessed a painting of his father in Indian costume, said to have been done by Audubon in the early eighteen-forties.

242. SAGE, John H.:

"Description of Audubon," The Auk, vol. xxxiv, pp. 239-240. Cambridge, 1917.

A picture of Audubon in St. Louis in 1843. Originally published in The Buffalo Courier, August 22, 1843, and in The Sentinel and Witness, Middletown, Connecticut, September 5, 1843.

243. Herrick, Francis Hobart:

Audubon the Naturalist: A History of his Life and Time. In two volumes, pp. i-xl, 1-452, i-xiv, 1-494. New York, 1917.

244. Bolton, Reginald Pelham:

"Old Names and Places on the Heights. Audubon's Minniesland," The Home News, New York, November 7, 1917. 
245. Herrick, Francis H. :

“Audubon's Bibliography," The Auk, vol. xxxvi, pp. 372-380. Philadelphia, 1919.

"The present list is more nearly correct than any that has preceded it, but it would be remarkable if further emendation were not needed."

246. Geiser, Samuel Wood:

"Audubon in Texas," Southrest Review, vol. 16, pp. 108-135. Dallas, 1931. One of eight articles by the author which appeared in the Southwest Review, vols. 14-16, 1928-1931, under the title "Naturalists of the Frontier." See volume with same title, Dallas, 1937.

247. Lewis, Harrison F.:

"Some Canadian Auduboniana," The Canadian Naturalist, vol. xlvii, pp. 162-172. Ottawa, 1933.

Reproduces four letters by Audubon to Thomas McCulloch, Jr., 1836-1841.

248. Knappen, Phoebe:

"Some Additional Audubon Copper-Plates," The Auk, vol. li, pp. 343-349. Philadelphia, 1934.

Lists 85 of the original 435 copper-plates of The Birds of America, now, or once, known to exist.

249. Audubon, John James:

Journal Made While Obtaining Subscriptions to His "Birds of America," 1840-1843. Edited by Howard Corning; foreword by Francis H. Herrick. Pp. i-viii, 1-182. The Club of Odd Volumes, Boston, 1929.

250. Audubon, John James:

Journal Made During His Trip to New Orleans in 1820-21. Edited by Howard Corning; foreword by Ruthven Deane. Pp. i-x, 1-236. The Club of Odd Volumes, Boston, 1929. 
251. Muschamp, Edward A.:

Audacious Audubon: The Story of a Great Pioneer, Artist, Naturalist and Man. Pp. 1-312. New York, 1929.

252. Dounce, Henry Esty:

"Gilding Audubon," The Saturday Revier of Literature, May 10, 1930. New York.

253. Audubon, John James:

Letters, 1826-1840. Edited by Howard Corning. In two volumes, pp. i-viii, 1-280; 1-280. The Club of Odd Volumes, Boston, 1930.

254. (ANON.):

"Preservation of the Audubon House, at 155th Street and Riverside Drive; Report of Committee on its Removal and Restoration." New York, November 2, 1931.

Fifteen thousand dollars were required for the removal of the house to a new site, and ten thousand dollars for a new foundation and restoration. Failure to obtain the required amounts before November 30 led to the abandonment of the project.

255. Richards, Irving T.:

"Audubon, Joseph R. Mason and John Neal," American Literature, vol. vi, pp. 122-140. Durham, N. C., 1934.

256. (ANon.):

"A Memorial to Audubon," Nere York Times, October $27,1935$.

Plan for the Audubon Memorial Park, including the Audubon Museum, in which will be housed the collection of Audubon relics assembled by the Henderson (Kentucky) Historical Society. To be dedicated in 1938. 
257. Bakewell, Thomas :

"Audubon and Bakewell, Partners; Sketch of the Life of Thomas Woodhouse Bakewell, written by Himself," The Cardinal, vol. iv, Sewickley, Pa., 1935.

"My individual loss by Mr. Audubon, exclusive of the debt due to my father, is about $\$ 14,000$, so that you can see $I$ have had a full share of bad luck in worldly matters." (In letter to his stepmother, Mrs. Rebecca Smith Bakewell, from Louisville, April 8, 1821.)

258. Herrick, Francis H.:

"Audubon's Sesquicentennial." Address at the Edgeworth Club, Sewickley. The Cardinal, vol. 4, pp. 31-33. Sewickley, Pa., 1935.

259. Peattie, Donald Culross:

Singing in the Wilderness: A Salute to John James Audubon. Pp. i-xvi, 1-246. New York, 1935. An imaginative story, well told.

260. Peatite, Donald Culross:

Green Laurels: the Lives and Achievements of the Great Naturalists, pp. i-xxiv, 1-370. New York, 1936.

261. Rourke, Constance:

Audubon. Pp. 1-342. New York, 1936.

For criticism of this and the following, see the "Foreword and Postscript" to this volume.

262. Tyler, Alice Jaynes:

I Who Should Command All. Pp. 1-64. New Haven, 1937.

263. (Anon.) :

"The Clumber Library Sale," London Times Literary Supplement, June 26, 1937. 
Records the sale of a copy of Audubon's Birds of America, from the library of the Duke of Newcastle, at two thousand four hundred pounds, sterling. See Vol. II, p. 204.

264. Arthur, Stanley Clisby:

Audubon: An Intimate Life of the American Woodsman. Pp. 1-518. New Orleans, 1937.

265. Rourke, Constance:

"The Mystery of Audubon," New York Herald Tribune Books, July 25, 1937.

A review of $I$ Who Should Command All, by Alice Jaynes Tyler.

266. Audubon, John James:

The Birds of America, with 435 reproductions of the double elephant folio plates, and 65 of later origin, all in color; with text by William Vogt. 4to. Pp. i-xxv with 250 sheets of plates. New York, 1937.

26\%. Herrick, Francis Hobart:

"Audubon and the Dauphin," The Auk, vol. liv, pp. 476-499. Cambridge, 1937. 



\section{INDEX}

Abert, John James, on Audubon's plans, ii, 3; his career and the rattlesnake episode, ii, 3, 77; “Abert's squirrel," ii, 4, 64, 155.

Abolitionists (Les Amis des Noirs), activity in France, i, 43; their opposition to white planters and fomenting of rebellion in Santo Domingo, i, 49.

Academy of Natural Sciences (Philadelphia), introduction of Audubon to, i, $3 \approx 8$; foundation and work of, $i, 333$; notice of meeting of, i, 333; Waterton on rejection of Audubon by, ii, 8\%.

Accipiter cooperi, i, 330.

Adams, Rev. Charles Coffin, history of his manuscript on the Life of Audubon; his career and writings, i, 18; ii, 300 .

Adams, John Quincy, i, 396.

Adelaide, Queen of England, patronage of, i, 391.

Allston, Washington, i, 336.

American Ornithologists' Union, number of species of American birds recognized by (in 1910), ii, 215; doubtful species in "CheckList" of, ii, 215.

American Ornithology, story of the author, production and publication of, $i, 202-219$; original drawings for, $i, 213$; the engraver and publisher of, i, 213, 217; the Prospectus and character of, $i, 217$; the issue and patronage of, $i, 217$; death of the author of, i, 219 ; publication of the last volume of, $i$, 223; second American edition of, $i$,
223; diary of the author of, i, 224; Audubon's charge against the author of, i, 226; counter charge of Ord in defense of the author of, i, 227 .

American Philosophical Society, Audubon to Sully on his rejection by, i, 362; his later membership in, i, 363; Harlan on rejection of Abert by, ii, 3-4; 27.

Anthus spraguei, Sprague's Titlark, ii, 253.

Antonio de Sedella, Father, portrait of, i, 319, 321 ; Governor Claiborne on, i, 319 .

"Ark." See Flatboats.

Arthur, Stanley Clisby, i, 314; on the bird-life of the St. Francisville region, i, 315; ii, 318; on Audubon and West Feliciana, i, 322-323; 338.

"Articles of Association" of Audubon and Ferdinand Rozier, description and reproduction of original of, i, 146-148; ii, 344-349.

Ashburton, Lord, Baron (Alexander) Baring, ii, 24 ?.

"Astur (Falco) Stanleii," i, 354, 417. See "Stanley Hawk."

Athenaum (London), on Audubon, ii, $84-85,140,199-200$; advertisement of The Birds of America, ii, 201.

Aubinais, M., i, 55.

Audibon (or Audubon?), Pierre, in the American Revolution, i, 24. Audubon, Anne, suit by, i, 28, 263. Audubon, Catherine Françoise. See Mme. Jean Louis Lissabé. 
Audubon, Claude, and his family, i, 27.

Audubon, Dominica, suit by, i, 28, 263.

Audubon, Jean, his command at Yorkstown and checkered career, i, 24; his parentage and father's family, i, 26-28; birth and baptism, i, 27; beginning of life at sea and capture at Louisburg, i, 28; a prisoner in England, i, 28; enters French Merchant marine and begins his voyages to New Foundland, i, 29; enlists in French navy and appears at Nantes, i, 30; reënters merchant marine and begins voyages to Santo Domingo, $i$, 30 ; his ships and commands, i, 31 ; his marriage, $\mathrm{i}, 32$; fight in $L e$ Comte d'Artois and capture by the English, i, 32; prisoner in New York, and release, i, 32; joins the American Revolution and commands a ship at the siege of Yorktown, i, 34; later commands in the United States and fight with a British privateer, i, 34; residence in the West Indies, i, 36; travels in the United States and purchase of "Mill Grove," i, 36; joins the National Guard at Les Cayes, i, 37; epitome of Santo Domingo career, $i, 37$; engagement with Coirond Brothers with interests at Les Cayes and St. Louis, i, 38; rapid rise to wealth as planter, sugar refiner, and slave dealer, i, 39; light cast by his dealings in slaves, i, 39; ii, 330-335; his West Indian fortune and final settlement of estate, i, 40-41, 268; treatment of slaves and dependents, i, 41, 54; Santo Domingo experience compared with that of a contemporary planter at Jaquemel, i, 44-48; birth of his son at Les Cayes, i, 52; discovery of bill of his physician, i,
53; see also i, 54, and ii, 314-327; his son, Fougère, and daughter, Muguet, taken to France, i, 57; his reference to Audubon's mother, i, 59 ; designation of his children in his wills, i, 63, ii, 360-362; dual personality expressed by his son, i, 63; joins National Guard at Nantes, i, 74; possible refuge of his family during Revolution in France, i, 76 ; activities immediate$1 y$ before and during French Revolution, i, 77-82; Revolutionary offices, i, 78 ; report as Civil Commissioner, i, 78; mission to Pornic and Paimbøuf, i, 79; signature during Revolution, i, 79; mission to Les Sables d'Olonne, and letters to the Administration, $i$, 80; his reimbursement for services to the Republic, i, 81; operations as ensign commander, and encounter with the Brilliant, i, 82; his later commands and elevation to rank of lieutenant de vaisseau, i, 82; his financial losses in Santo Domingo, i, 82; indemnity from the French Government, i, 83; respective rank and service in the French merchant marine and navy, $i$, 83 ; his certificate of service, $i$, 83 ; retirement and pension, i, 83 , 85 ; settlement and occupations at "La Gerbetière," i, 85; Santo Domingo interests described in power of attorney, i, 85; residences at Nantes, i, 86 ; see also i, 57,58 ; his death, i, 87; his son's tribute, i, 87 , 88; financial vicissitudes, i, 88 ; see also i, 85; habits, abilities and physical characteristics, i, 88; letter soliciting aid for his son, i, 100 ; interest in "Mill Grove" and the Prevost mortgage, i, 105; lease and inventory of the property, $i$, 105; portrait at age of forty-five (?), i, 106; mining project with 
Dacosta, i, 113; sale to Dacosta of a one-half interest in "Mill Grove," and its lead mine, i, 114; expectations for his son, i, 115; financial aid from Claude François Rozier, i, 115 ; correspondence with Dacosta, i, 116-123; instructions regarding his son's proposed marriage, $\mathrm{i}$, 117 ; appeal in answer to Dacosta's complaints concerning his son, i, 118; instructions for settlement of claims against the Ross and Fotmon estates, i, 121-123; his uncanceled mortgage, i, 122; instructions concerning the farmhouse at "Mill Grove," i, 122; as grantor of powers of attorney, i, 131, 132-133, 153; see also i, 85-87; marriage of his daughter, i, 131; arranges a business partnership for his son, i, 132; his former country villa as it appears to-day, i, 135-145; division of the "Mill Grove" property and sale of his remaining interests, $i$, 149-150, 152-153; letters of his son, i, 159-161, 163; portrait at Couëron, i, 100; troubles with Dacosta and contest over his final accounts, $i, 168$; bequest of his property in usufruct to his wife, and testamentary designation of his children, i, 262; contest of relatives over wills, i, 263; unfounded statements of biographers of his son, $i$, 264; his claims against the RossFormon estates as a basis of fiction, i, 265; final settlement of his financial affairs, i, 268; his descendants in France and last of his name in America, i, 269, ii, 294. Audubon, Mme. Jean (Anne Moynet), her marriage and property at Paimbœuf, i, 32, 40, 57, 80; adoption of children by, i, 59 ; baptism of adopted son, i, 60-61 ; characterization of her son in wills, i, 62, 262-264; as grantor of powers of attorney, i, 131, 132133, 153; legal troubles and impoverishment, i, 263; removal from "La Gerbetière," i, 263, 268; her death at "Les Tourterelles," i, 263 ; disposition of her estate, i, 266,269 ; break in relations of her adopted son with his family in France, i, 266-269; attack upon her husband's estate and its final settlement, i, 263, 268; her testaments, ii, 363-368.

Audubon, Jean Jacques Fougère (John James Audubon, see also Fougère and Jean Rabin), his masterpiece, i, 1; his greatest working period, i, 2; experience in Paris in 1828, i, 2; Cuvier's eulogy and patronage of the French Government, i, 3; rarity and cost of his publications, i, 4; personality and talents, i, 5; attacks upon his character, i, 6; his historical background and hitherto unwritten history, i, 7; his Americanism, i, 8; characteristics of his writings, $i$, 8-10; his Ornithological Biography, i, 9 ; drawings of birds and mammals, i, 10; influence on American ornithology, i, 10; honesty of purpose, i, 11; memories of him in London, i, 11; public monuments and other honors in America, i, 13; Societies and Clubs dedicated to his memory, $\mathbf{i}, 14$; his bibliography, i, 15; attempt at autobiography, i, 16; first formal Life of, i, 17; true history of Buchanan's Life, i, 1822; Mrs. Audubon's revision of Buchanan's Life, i, 22; Miss Maria R. Audubon's Life and Journals, i, 22; accepted account of his birth and early life in light of new discoveries, i, 22; parentage and early names; a creole of Santo Domingo, i, 52; his baptismal name, i, 53; discovery of the bill rendered by 
the physician who assisted at his birth, i, 53; feeble health and death of his mother, i, 56; birth of his sister, creole of Santo Domingo, i, 56; taken with his sister to France, i, 57; his foster mother and home at Nantes and Couëron, i, 57; his adoption and text of act, i, 59; suppression of his mother's name, i, 60; his baptism and text of act, i, 60; assumed name of "La Forest," i, 61; his signatures, i, 61, 63; his names appearing in wills, i, 62; his dual personality in a power of attorney, i, 64; first date given in his autobiography, i, 65; record in his Ohio River journal, i, 66; his later autobiographic sketch, i, 66-68; traditional date of birth, i, 68; myth concerning birth in Louisiana, i, 68-72; account given by the Rev. Gordon Bakewell, i, 69; influence of environment on character, i, 90; his limited schooling, i, 91-93; the spur his ambition needed, i, 91 ; experience in the French navy, i, 92; early passion for nature and for drawing, i, 93; as truant, i, 94; his father intervenes and takes him to Rochefort, i, 94; return to Couëron, i, 96 ; baptized in the Catholic Church, i, 96; first return to the United States, i, 98; illness at Morristown, i, 99; befriended by his father's American agent, i, 99; his father's letter and intentions in sending him to America, i, 100; his settlement at "Mill Grove" farm, and period of stay there, i, 101-103; begins his studies of American bird-life, i, 106; makes first "banding" experiment on young of a wild bird, i, 107; visit to "Fatland Ford," and choice of a wife, i, 110; his gayety and cxtravagance, i, 110; abstemi- ous habits in youth as regards food and drink, i, 111; his account of himself, i, 111; his accomplishments described by a future brother-in-law, i, 111; opposition to his marriage, i, 116; Dacosta's grievances, i, 116-119; quarrels with Dacosta and returns to France, $i$, 123-125; voyage on the Hope, i, 126; life at Couëron and friendship with D'Orbigny, i, 127; receives with Ferdinand Rozier a power of attorney from his parents, i, 131; attends the marriage of his sister and signs the record, i, 131; his relations with his brother-in-law, i, 132; his partnership with Rozier and second letter of attorney, i, 132; returns, with $\mathrm{Ro}_{0}$ zier, to the United States, i, 134; voyage of the Polly, and receipt of Captain Sammis, i, 134 ; experience with British privateers, $i$, 134; boyhood home at Couëron, i, 136-145; his description of "La Gerbetière," i, 136; his abortive attempt, with Rozier, to administer the "Mill Grove" mine and farm, i, 146-149; their "Articles of Association," i, 146-148; ii, 344349 ; sale of remaining rights in "Mill Grove" to Dacosta and Company, i, 148-149 ; receives, with Rozier, new power of attorney, $i$, 153; enters business office of Benjamin Bakewell in New York, $i$, 153; his associates and correspondence with the elder Rozier, i, 153166 ; letters to his father, i, 159161, 163-164; his use of English and French, i, 155; ii, 372-374; plans a retail business with Rozier, i, 157-158, 160-162, 165; dispatch of live birds, and other objects of natural history to France, i, 158$159,160,162,165-166$; conflicting references to "Mill Grove" ex- 
plained, i, 158-160, 162, 165-168; his drawings and preoccupation in New York, i, 170-172; works for Dr. Mitchell's collections in natural history, i, 171; term of service in the Bakewell office, i, 154-155, 171172; his account of himself, i, 172; his early drawings, ideals and perseverance, i, 173-174, 178-183; study under David in Paris, i, 174$175,176-178$; cause of certain defects in his published work, i, 174; date of his Paris experience, $i, 174-$ 175, 177; encouragement from his father, i, 174; David's supposed influence on his style, $i, 178$; patronage of Edward Harris and history of the Harris-Jeanes collection of his early drawings, i, 179183; his drawing methods, i, 183185; his ambition, difficulties and defects, i, 184; purchases goods in New York, and with Rozier starts west, i, 186; Rozier's diary of their journey, i, 187-192; settles at Louisville, $i, 192$; venture in indigo and effect of the Embargo Act, i, 193; his marriage to Lucy Green Bakewell, and return to Louisville, i, 194; a later journey on the Ohio River, i, 195; occupations at Louisville, i, 196, 197-198; business with assignees of the Bakewell firm, i, 196; birth of his elder son, $i, 198$; his drawings of birds and plants, i, 198; his wife receives a portion of her father's estate, i, 198; meeting with Alexander Wilson, and the troubles which ensued, i, 207; stories of Audubon and of his rival compared, i, 220-225; charges and counter charges, i, 226; his merits and demerits, i, 227-232; his difficulties and pleasures as western trader, i, 232-236; moves with Rozier to Henderson, i, 236; again they move to Ste. Geneviève, i, 237-241; held up at Cash Creek, i, 238-240; experience at the Great Bend, i, 240; dissolution of his partnership with Rozier and return to Henderson, i, 241; after-relations with Rozier, i, 243; in troubled times, i, 246; befriended by Dr. Rankin, i, 248; birth of their younger son, i, 248; enters the commission business with a brother-in-law, i, 249; his visit to Ste. Geneviève, i, 249; reënters trade at Henderson and buys land, i, 250; town records of his purchases, i, 250, 252; his store and house of logs, i, 252; his popularity, i, 252; Henderson gossip and anecdotes, i, 253; his second partnership with Thomas W. Bakewell, i, 254; they lease land and build a steam grist-, and lumbermill, i, 254; partnership of Thomas W. Pears, i, 254; the Henderson mill at a later day, i, 254; their mechanical difficulties, i, 254; lease of timber land and plunder of workmen, i, 255; bill of lumber rendered by J. J. Audubon \& Co., i, 256; financial depression and failure of the mill, i, 257; quarrel over steamboat and encounter with Bowen, i, 257-259; legal history of the suit, i, 258; the opinion expressed to him by the judge, i, 259 ; goes to Louisville jail for debt, i, 260; declares himself a bankrupt and is released, i, 260; his walk to Louisville, i, 260; later account given to Bachman, i, 260 ; reflections on passing his old mill in $1820, \mathrm{i}, 261$; light on his enigma, i, 262-272; his designations in wills, i, 262-264; probable history of a fictitious "bequest," i, 264266; his brother-in-law's letters, i, 266-269; attempt of relatives to break his father's will in France, 
and impoverishment of his stepmother, i, 263; his step-mother's death, i, 263; the last of his family in France, i, 269; his elder son's visit to Couëron, i, 269; his reference to "Audubon of La Rochelle," i, 270; his "Episodes" and methods of composition, i, 273-284; discrepancies and inaccuracies of some of his narratives, i, 273-274, 279291; his account of meeting Nolte and Nolte's account of meeting him, i, 274-279; on horseback from Henderson to Philadelphia, i, 275; description of the famous earthquakes and the hurricane, i, 279291; criticism of his account of Daniel Boone, i, 291; "Episode" of "The Prairie," i, 274, 282-284; answer to a criticism of, i, 284; his sketch of "The Eccentric Naturalist" and comment, i, 285-300; practical jokes, and cost to Zoölogy, i, 291 ; the "Scarlet-headed Swallow" and "Devil-Jack Diamond Fish," i, 291-293; his later relations with Rafinesque, i, 294; his Eneid, 1819-1824, i, 301-326; debt to his wife, i, 301; begins to work at portraiture at Shippingport, i, 303; removal to Cincinnati, i, 303 ; history of his engagement as taxidermist at the Western Museum, and friendship with Dr. Drake, i, 303-306; starts a drawing school and plans a journey through the West and South, i, 306; starts with Captain Cummings and Joseph R. Mason for New Orleans, i, 307; his Ohio and Mississippi Rivers journal, i, 307; experience at Natchez; boots and portraits, i, 308 ; loss and recovery of a portfolio, i, 309 ; stranded at New Orleans, i, 309; resorts to portraiture again, i, 311; his drawings of birds, i, 311; interview with Vanderlyn, i, 312; leaves New Orleans with Mason, i, 313; meeting with Mrs. Pirrie and engagement at "Oakley," i, 312; enchantments of the West Feliciana country and introduction to St. Francisville, i, 313-315; experience as tutor to "my lovely Miss Pirrie of Oakley," i, 315, 317-318; leaves abruptly and returns with Mason to New Orleans, i, 318; his industry and fruits, i, 318; joined by his family in New Orleans, $i, 319$; crisis in financial affairs and losses of drawings, i, 320; as teacher at Natchez and Washington, i, 321; parts with his pupil assistant, $i$, 321; his first lessons in the use of oil colors, i, 321; engagements of his wife at New Orleans, Natchez and St. Francisville, i, 322; his wife's "Beechwoods" school, i, 322; resolution to pursue his ornithological studies, i, 323; misadventure with Stein, i, 324; ill and adrift, i, 324; decides to visit Philadelphia to find a publisher for his drawings, i, 325; settles, with his elder son, at Shippingport, $i, 325$; experience in Philadelphia in 1824, i, 327-335; his exhibition at the Academy of Natural Sciences, i, 328; meeting with Bonaparte and Ord, i, 328; opposition encountered, i, 328-330; criticisms of Ord and Lawson, i, 329 ; his work for Bonaparte, i, 330; appreciation of Fairman and Harris, i, 331; assistance of Edward Harris and beginning of their friendship, i, 331, 333; early letter to Harris, i, 332; Thomas Sully, as friend and teacher, i, 334; visit to "Mill Grove," i, 335; reception in New York and assistance of Samuel Latham Mitchell, i, 336; election to membership in the Ly- 
ceum of Natural History, i, 338; acts as model for Vanderlyn's portrait of Andrew Jackson, i, 338; to Thomas Sully, i, 339; visit to Albany and Niagara Falls, $i$, 339 ; misadventure at Presque Isle, i, 340; the Meadville "Episode," i, 341-343; residence at Pittsburgh, $i$, 313 ; journey to Lakes Ontario and Champlain, where plans of his publication are matured, i, 343; stranded at Cincinnati, i, 344; returns to St. Francisville, and resorts to teaching, i, 346; sails with his drawings from New Orleans, i, 347 ; journal of the voyage of the Delos, i, 348-350; lands in Liverpool, i, 350; his credentials, i, 351; introduction to Lafayette, i, 351; customs duties, i, 350; Nolte's letter to the Rathbones, i, 352; aid of the "Queen Bee" of "Greenbank," i, 353; his "observatory nerves," i, 353; ornithological dedications, i, 354; exhibition of his drawings at the Royal Institution, i, 354; appearance and habits, i, 354; paintings as gifts, and the Turkey Cock seal, i, 355; painting methods, i, 355; opens a subscription book of The Birds of America at Manchester, i, 356; plan of the work, i, 356; his life of contrasts, i, 357; journey to Edinburgh, i, 357 ; invitation to merge his work, i, 357; meeting with Lizars, who agrees to engrave his first number, i, 358; first proof of the Turkey Cock received, i, 358; publication of the first ten plates in Edinburgh, i, 358; success of his Edinburgh exhibition, i, 359 ; impressions of Philarète-Chasles, i, 359; Cap's hint taken, i, 360; cast of his head made and his portrait painted, i, 361; response at banquet of the Royal Institution, i,
361 ; society's tax on his strength, i, 361 ; contributions to journals, i, 362; blackballed by an American Society, i, 362; proposed gift to the Royal Institution, i, 363; visit to "Dalmahoy," i, 363; friendship of Basil Hall, i, 364; characterization of Francis Jeffrey, i, 365; first meeting with Scott, and his record of the interview, i, 365; exhibits his drawings at Sir Walter's home, i, 366; Scott, on Audubon, i, 367; papers on the Wild Pigeon and the Rattlesnake, i, 368; his painting of "Pheasants attacked by a fox," i, 369 ; Sidney Smith, i, 369 ; to his wife, $i, 369-373$; first meeting with Kidd, i, 373; issues his Prospectus, i, 373; visit to Selby at "Twizel House," 374; with Thomas Bewick at Newcastle-upon-Tyne, i, 375; success in canvassing, $i, 3 \pi 6$; in London, i, 377-410, 413-418; his credentials for the metropolis, i, 376-380; abandonment of his work by Lizars and discovery of Robert Havell, Junior, i, 380-384; his Birds of America fly to London, i, 384 ; painting his way to liberty, i, 388 ; canvassing experiences, i, 388 ; efforts to secure the patronage of the King, i, 390, 392; the Queen becomes his patroness, $i, 392$; visit to Glasgow, i, 393; difficulties with his publishers, i, 393; timely aid from Sir Thomas Lawrence, i, 393396 ; exhibition and sale of his paint.ings, i, 394; resolutions on snuff, i, 396; dislike of London, i, 397; his work and Selby's compared, i, 397; revision of his drawings, $i$, 398 ; calls by appointment upon an earl, i, 398; visits the great Universities, $i, 399$; solicitations of publishers and contributions to magazines, i, 399; friendship with Swainson, and original letters of 
their correspondence, i, 400-403; Swainson's review of his work, i, 403; visit at Tyttenhanger, i, 404; to Swainson, i, 405-407; request for further contributions to magazines refused, i, 407; visit to Paris with the Swainsons and Parker, i, 408413; his picture of Cuvier at fiftynine, i, 411 ; patronage of the Duke of Orleans, i, 411; exchange of works with Redouté, i, 412; with Cuvier at the Royal Academy, i, 412; Cuvier's report on his work, i, 413; correspondence with Swainson, i, 413-415; Bonaparte to, i, 416-419 ; first journey from England to America, i, 420-436; to his wife, i, 420; exhibition of drawings in New York, i, 421; painting at Camden and Great Egg Harbor, i, 421; Swainson to, i, 422; sojourn in the Great Pine Forest, i, 423, 425-426; to Victor Audubon, i, 424; "Episodes" and record of work, i, 425; visits his sons and joins his wife at "Beechgrove" (St. Francisville) in Louisiana, i, 427 ; to Harlan, i, 427430 ; Swainson to, i, 430 ; occupations at "Beechgrove," i, 432; preparations to return, with Mrs. Audubon, to England, i, 432; to Havell, i, 433; proposition for a successor to the position held by his wife, i, 434 ; reception at Washington, and accessions of subscribers, i, 435; aid of Edward Everett, i, 435; his letterpress and its rivals, $i, 437-451$; membership in the Royal Society, i, 437 ; settlement in Edinburgh and publication of the Ornithological Biography, i,437; engages William MacGillivray to assist him, i, 438; rival publications, i, 439, 442-445; issue of his first volume of letterpress, i, 439; Sir William Jardine to, i, 441; MacGil- livray as his reviewer, i, 445; undertakes a Natural History Gallery of paintings with Kidd, i, 446 ; notices and final abandonment of the enterprise, $\mathrm{i}, 446$; to London and Paris, i, 447; Edward Everett to, i, 448-451; financial difficulties overcome, i, 451; explorations in Florida and the South Atlantic, ii, 1-25; returns to America with his wife, and a taxidermist as assistant, ii, 1; to Kidd, ii, 1; his obituary in the London Literary Gazette, ii, 2; Abert and Featherstonhaugh announce his plans, ii, 3 ; promise of governmental aid at W ashington, ii, 4 ; visits Charleston and meets John Bachman, ii, 5; sails from Charleston for Florida with two assistants, ii, 5; Bachman on, ii, 5 ; dedication to Bachman of a copy of his Birds, ii, 7; his Birds of America as gifts to others, ii, 7; his journey described in Featherstonhaugh's Journal, ii, 8-14; account of meeting with Bachman, ii, 9 ; hospitality of the Charlestonians, ii, 10; impressions of St. Augustine, ii, 12; methods of work, ii, 12; Harlan to his wife, ii, 14; misadventures at Bulowville, ii, 1520; shooting birds at Live Oak Landing, ii, 16; narrow escape from the marshes, $\mathrm{ii}, 17-19$; as a prophet on the future of eastern Florida, ii, 20; the ibis of Orange Grove Island, ii, 21; his plans delayed, ii, 22-24; journey from St. Augustine to Key West, ii, 24; return to Savannah and Charleston, ii, 25 ; eastern visit and explorations in the North Atlantic, ii, 2666 ; settles again in Camden, ii, 26; an experiment in lithography, ii, 26; correspondence of Harlan, ii, 28; his welcome at Boston, ii, 29; to Edward Harris, ii, 29 ; journey to 
Maine coast and New Brunswick, ii, 30; winter and illness in Boston, ii, 31, 34-35; sends his son to England to take charge of his publications, and plans an expedition to Labrador, ii, 31; Bachman to, ii, 32; to Victor Audubon, ii, 33; drawing of the Golden Eagle, ii, 34 ; to his son, ii, 35-40; financial affairs, ii, $37-38,65$; on his portrait by Inman, ii, 39; his American subscribers, ii, 39-41; letters to Harris, ii, 40 ; organization of his proposed expedition, ii, 42-44; George Parkman to, ii, 43; sails in the Ripley for Labrador, ii, 44; journal of his experiences, ii, 44-50; at Bird Rock, ii, 45; discovers a new finch, ii, 45; scenes of work at Wapitagun, ii, 46-48; his efforts and accomplishments, ii, 48; return to Eastport and Boston, ii, 49; editorial comment, ii, 50; letter from Havell, ii, 51; Thomas L. McKenney on, ii, 52; arrested in Philadelphia, ii, 52; Washington Irving's aid in Washington, ii, 53; itinerary from Richmond, ii, 53; winter at Bachman's, ii, 54; letter to his son, ii, 55-6?; on Ord and Waterton, ii, 55, 61; on his buzzard experiments, ii, 55; on Syme's portrait, ii, 57 ; his family alliance, $\mathrm{ii}, 58$; on his American subscribers, ii, 59, 62; on Robert Havell, ii, 59; on growing old, ii, 60 ; on self-improvement, ii, 61 ; on Kidd, ii, 57, 62; Bachman, on his working habits, ii, 62 ; to Harris, ii, 64; echo of his early business troubles, ii, 64 ; his statement of the case, ii, 65 ; return to England, ii, 65; gratitude to Edward Harris, ii, 66; as target of critics and detractors, ii, 67-92; questionable essays, $\mathrm{ii}, 68$; his reply to Sully, ii, 68-71; the rattlesnake controversy, ii, 71-80; charges of an editor, ii, 72; his original drawing and account of the rattlesnake, ii, 74-76; his errors and vindication, ii, $76-80$; letter of Thomas Cooper, ii, 78; on the bend of the rattlesnake's fang, ii, 79; rediscovery of his discredited lily, ii, 80 ; on the buzzard's sense of smell, and present state of the controversy, ii, 81-84; his champions of the scientific and literary press, ii, 84; on his snake stories, ii, 85; his most persistent heckler, ii, 86-92; Waterton and Swainson, on the authorship of his Ornithological Biography, ii, 87; on the rivalries of contemporaries, ii, 93124; to Swainson, ii, 95-97, 99-100, 101-103, 112; Swainson to, ii, 9799, 103-108; his appeal to Swainson for assistance on his letterpress, ii, 94, 98, 102-103, 104-107; check in friendship and engagement of MacGillivray, ii, 108; resulting controversy over the authorship of the Ornithological Biography, ii, $87-88,109$; on the craze for describing new species, ii, 110; “Ornithophilus" on, ii, 111; Swainson as biographer of, ii, 113-115; his reference to Bonaparte resented, ii, 118; his letter to Bonaparte and their subsequent relations, ii, 119-121; comment on Gould, ii, 121-124; return to England in 1834, ii, 125; to Edward Harris, ii, 125; on his relations to William MacGillivray, ii, 125-138; MacGillivray to, ii, 126-128, 130 132, 134; his ornithological collection, ii, 129; completion of the second volume of his letterpress, ii, 139; to Harris, on the alligator and the American edition of his Ornithological Biography, ii, 132, 134; MacGillivray's contract with, 
ii, 134; MacGillivray's assistance and friendship, ii, 134-137; his acknowledgments and dedication to MacGillivray, ii, 137; to John Wilson, ii, 139; on the effects of overwork, ii, 140; letters to Harris, ii, 141-144; on Alexander Wilson, ii, 143; issue of his third volume of the Ornithological Biography, ii, 144; on his journey, ii, 144; third American tour, ii, 146 ; landing in New York, ii, 146; efforts to secure the Nuttall-Townsend collection of western birds, ii, 147149, 153-154; thwarted in Philadelphia, ii, 149; in Boston and Salem, ii, 149-151; meets Brewer and Nuttall, ii, 150; friendship and recommendation of Daniel Webster, ii, 151 ; success of canvassing in New York, ii, 153; efforts to obtain the collections in Philadelphia renewed, ii, 153 ; rivalry of priority seekers, ii, 155; plans an expedition to Florida, and visits Washington for governmental aid, ii, 155; entertained at the White House, ii, 156; on Andrew Jackson, ii, 156; winter spent with Bachman, ii, 156; overland with Edward Harris and his younger son to New Orleans, ii, 15\%; experiences in the Gulf of Mexico and Texas, ii, 157-165; adventures with the Crusader, ii, 158-163; at Galveston $\mathrm{Bay}$, ii, 163; visit to Houston, ii, 164; his party disbands at Charleston, ii, 165; his son's marriage, and return to England, ii, 166; to Thomas Brewer, ii, 168; extension of his Birds and revolt of British patrons, ii, 170, 174; to Harris on Townsend's second collection of western birds, ii, 170173; eagerness to render his work as complete as possible, ii, 173; on extra plates and partial sub- scribers, ii, 174; to William Swainson, ii, 176; his day of greatest triumph, ii, 177; return to Edinburgh and completion of his letterpress, ii, 178-186; to his son, ii, 178-181; at work with MacGillivray, ii, 178181; publication of the fourth volume of the Ornithological Biography, ii, 181; impairment of the health of his wife, $\mathrm{ii}, 181,183,186$; their tour in the Scottish Highlands, ii, 182; to Edward Harris, ii, 184-186; completion of his labors in England, ii, 186; number of American species of birds recognized in 1839, ii, 186; valedictory to the "gentle reader," ii, 187; prepares to return with his family to America; directions to Havell, ii, 188-191; intimate history of the work of his engraver, with manual for collectors, ii, 191-199; the Athencum on, ii, 199 ; Peabody on, ii, 200 ; on the original and existing numbers of copies of his Birds, ii, 201-203; on his own and $\mathrm{Ha}-$ vell's copy of The Birds of America, ii, 203; original and present prices of his works, ii, 204 ; singular attest of J. P. Hall regarding, ii, 205; Audubon's account of the Rothschild incident, ii, 206-208; settles in New York, and immediately undertakes two new works, ii, 208; Bachman to, on a revised edition of The Birds of America, and the Quadrupeds, ii, 208; to Brewer on the Quadrupeds of North America, ii, 209; marriage of his elder son, ii, 210; Bachman, on his coöperation in the Quadrupeds, ii, 210; prospectus of the octavo edition of the Birds, ii, 211-212, 214; its composition and number of American species of birds recognized, ii, 214215 ; to his family while canvassing 
in Baltimore, ii, 215-217; original account book of, ii, 217; extraordinary success of his Birds in "miniature," ii, 217; bereavements of his family, ii, 218; his friendship with a rising young naturalist, ii, 218; opening correspondence with Spencer Fullarton Baird, ii, 219223; William Yarrell to, ii, 223225; new birds from Baird, ii, 219 , 225 ; their correspondence continued, ii, 226 ; letter to George Parkman, and the "Parkman Wren," ii, 227-229; to W. O. Ayres on collecting quadrupeds, ii, 229; on the expenses of his publication, ii, 230 ; Baird on his first visit to his friend, ii, 230-232; consolation and advice to his pupil, ii, 232; purchase of land and house-building, ii, 234; "Minnie's Land" on the Hudson, ii, 235; his activities, ii, 235; Parke Godwin on Audubon and "Minnie's Land," in 1842, ii, $236-238$; in 1845, ii, 238 ; his expedition to the Upper Missouri, ii, 239-258; correspondence with Baird, ii, 239-241; credentials from the Government, ii, 242; Daniel Webster's letter, ii, 242; his letter from President Tyler, ii, 243; Bachman on the Quadrupeds, ii, 243; canvassing tour to Canada, ii, 244; description of Canadian visit in letter to Benjamin Phillips, ii, 244246; William Yarrell to, ii, 246; overtures to Baird to join his western expedition fail, ii, 248250, 252; Edward Harris to, ii, 251; his party, ii, 252; rendezvous at Philadelphia and beginning of journey, ii, 252; ascent of the Missouri in the Magnet, ii, 252; his journal of their experiences, ii, 253 ; discovery of new birds, ii, 253; on George Catlin, ii, 254; at Fort Union, ii, 254-256; first ex- perience with buffalo, ii, 254; forecast of its fate, ii, 255 ; in a wilderness that howls, ii, 256 ; his return, ii, 256 ; on a canal boat homeward bound, ii, 257 ; mistaken for a Dunker, ii, 258; portrait by his son, ii, 258; to Baird, ii, 258; completion of his Birds in octavo, and dedication to Baird, ii, 259; his final work on the Quadrupeds, ii, 261; on Pennant's marten, ii, 263 ; to Bachman on mischief makers, and letterpress of the Quadrupeds, ii, 264-267; his copper-plates of The Birds of America pass through fire in New York, ii, 267; as a spectator at the ruins, ii, 267; reply to Baird on the results of the fire, ii, 268; Bachman's visit in 1845, ii, 268; Bachman's complaints and ultimatum through Harris, ii, 269; Bachman on his Missouri River Journal, ii, 271; correspondence with Baird, ii, 272273, 275-278, 279; recommendation of Baird, ii, 279; his son visits England to paint for the Quadrupeds, ii, 280; manuscript of the Quadrupeds of North America, ii, 283 ; illustrations and completion of plates of the Quadrupeds, ii, 285 ; Brewer on a visit to "Minnie's Land" in 1846, ii, 286-288; letter to Harris in 1847, ii, 287; Baird's note of last visit in 1847, ii, 288; Bachman on his visit of 1848 , ii, 288 ; last days and death at "Minnie's Land," ii, 290; work of his sons, and his family in America, ii, 291-312; appropriation by the Government to procure copies of Audubon's works for presentation to foreign countries, ii, 293; manuscript notes and legends on original drawings of the Birds, ii, 305.

Audubon, Mrs. John James, as edi- 
tor of a Life of her husband, i, 18, 22; her girlhood home, i, 108; Audubon's account of their meeting and his debt to, i, 109; her father anri uncle as protégés of Audubon, i, 125; Audubon on, i, 160; her marriage and journey West, i, 194; her children, i, 198, 247,248 ; her realization in her father's estate, i, 198-200; her father and family, i, 199, 253-254; as spur and balance wheel, i, 301; at Cincinnati, i, 303, 306, 307, 320; the Western Museum incident, i, 304; at New Orleans, i, 320, 322; engagements at Natchez and St. Francisville, i, 322; her "Beechwoods" school, i, 322; Audubon to, i, 370-372, 420-421, 424, 428; at "Beechgrove," i, 431-435; accompanies her husband to England, i, 435-436; ii, 1; John Bachman to, ii, 5; Richard Harlan to, ii, 14; her activities and school at "Minnie's Land," ii, 299; breaking up of her home and the Life of her husband, ii, 300 ; to a relative on her family's affairs, ii, 301; to William R. Dorlan on her husband's autograph, ii, 302; her last years and death, ii, 302; a eulogy, ii, 303; disposal of the original drawings of The Birds of America, ii, 304; ascription of drawing to, ii, 306.

Audubon, John Woodhouse, his birth, ii, 248; 323, 371; his father to, ii, 373, 390; ii, 43, 44, 54, 56-57, 156; marriage to Bachman's daughter, ii, 166 ; journey to Texas, ii, 272; goes to England to paint for the Quadrupeds, ii, 273, 280; dedication to John Edward Gray, ii, 280; J. E. Gray to, ii, 281; part in painting the originals of the folio plates of the Quadrupeds of North America, ii, 285; his unfor- tunate California venture, ii, 289, 290; his marriage to Caroline Hall, ii, 294; children and descendants, ii, 294; his house at "Minnie's Land," ii, 295, 311-312; his illness and death, ii, 295-296, 297; his project for reproducing the original folio of The Birds of America in America, checked by the War, ii, 296, 389-391; residual stock of the incomplete work, ii, 296; as his father's aid, ii, 297, 299; activities and characteristics as boy and man, ii, 297-299, 309-310; his Western Journal, ii, 299 ; death of his second wife, ii, 303 .

Audubon, Mrs. John Woodhouse (Maria Rebecca Bachman), her marriage, ii, 166; her death, ii, 218; her children, ii, 294.

Audubon, Mrs. John Woodhouse (Caroline Hall), her marriage, children and descendants, ii, 294; her death, ii, 294.

Audubon, Lucy, death of, i, 247.

Audubon, Maria Rebecca, publication of Audubon's Autobiography by, i, 16; Audubon and his Journals by, i, 22, 28, 63, 66, 106, 153, 270,369 .

Audubon, Marie Rosa (Mme. de Vaugeon), i, 27; suit by, i, 28, 263.

Audubon, Pierre, service in the French merchant marine, $i, 26$; his son, Jean, and his family, $i, 27$; at siege of Louisburg, i, 28.

Audubon, Rosa (Mme. Gabriel Loyen du Puigaudeau, see Muguet), her birth, i, 56; taken to France, i, 57 ; act of adoption, $i, 59$; as godmother, i, 128; marriage contract and marriage of, i, 131; her home, children and death, i, 269.

Audubon, Rosa, i, 247.

Audubon, Victor Gifford, his birth, i, 198; 269, 325, 371, 396, 427; 
takes charge of his father's publications in England, ii, 31; his father to, ii, 33-40,43-44, 55-62; in his father's defense, ii, 55,$88 ; 65$, $81,119,178,189$; on the number of sets of The Birds of America issued, ii, 202; married to Mary Eliza Bachman, ii, 210; on "Minnie's Land," ii, 235; John Bachman to, ii, 261-263, 281-283; to Spencer F. Baird, ii, 278; Baird to, ii, 278; as amanuensis to Bachman, ii, 283, 291; to Bachman, ii, 289 ; success in canvassing, ii, 292; Bachman's recommendation, ii, 292; his issues of the Quadrupeds and Birds, ii, 293, 295; his second marriage and children, ii, 294; his house at "Minnie's Land," ii, 295, 311; his illness and death, ii, 295; death of his wife, ii, 303.

Audubon, Mrs. Victor Gifford (Mary Eliza Bachman), her marriage, ii, 210; her death, ii, 218. Audubon, Mrs. Victor Gifford (Georgianna Richards Mallory), ii, 258; her marriage and children, ii, 294; her death, ii, 294.

"Audubon of La Rochelle," i, 27, $270,271$.

Audubon (Montgomery County, Pennsylvania), i, 102.

Audubon and his Journals, i, 22.

Audubon Association and Societies, history and aims of, i, 14 .

Audubonian Epoch and Period in American ornithology, i, 10.

Aukland, Sir J. D., i, 377.

Ayres, W. O., Audubon, on collecting quadrupeds, to, ii, 229-230; 277.

Bachman, Rev. John, i, 291, 293; meeting and friendship with $\mathrm{Au}$ dubon, ii, 5, 9; to Mrs. Audubon, ii, 5; Audubon's gift of his Birds of America to, ii, 7; as canvasser for Audubon, ii, 27; Audubon to, ii, 27 ; to Audubon, ii, 32-33, 51; buzzard experiments, ii, $55-56 ; 57$, 59,61 ; publication of his paper on the Turkey Buzzard, ii, 56; on Audubon's working habits, ii, 6365 ; account of experiments on the sense of sight and smell in vultures, ii, 81-83; Audubon to, on the effects of overwork, ii, 140$141 ; 146$; on conditions in the South, ii, 148; Audubon's winter with, ii, 156; marriage of daughter of, ii, 166; in London, ii, 178, 179; 184; to Audubon on his "Small Edition of Birds" and Quadrupeds, ii, 208-209; marriage of the daughter of, ii, 210; on his cooperation with Audubon in the Quadrupeds, ii, 210-211; 216, 220 ; to Audubon on the Quadrupeds, ii, 243-244; 258-259; on the Quadrupeds of North America, ii, 261$263,269-272,281-283$; calls for help, ii, 262; Audubon to, on mischief-making of a "mutual friend," and the letterpress of the Quadrupeds, ii, 264-267; on Audubon in 1845, ii, 268; his ultimatum to Edward Harris as mediator, ii, 268-270; on Audubon's Missouri River Journal, ii, 271; difficulties of coöperation, ii, 273; domestic bereavement, ii, 274; his second marriage, ii, 281; working methods, ii, 281; facsimile letter, ii, 282; manuscript on the Quadrupeds, ii, 283; early life and career, ii, 284; on Alexander von Humboldt, ii, 284; on Audubon in 1848, ii, 288; completion of the text of the Quadrupeds, ii, 291; recommendation of Victor Audubon and statement of his part and interest in the work, ii, 292-293; 311.

Bachman, Mrs. John (Harriet Martin), death of, ii, 274. 
Bachman, Mrs. John (Maria Martin), marriage of, ii, 281 .

Bachman, Maria Rebecca. See Mrs. John Woodhouse Audubon.

Bachman, Mary Eliza. See Mrs. Victor Gifford Audubon.

Baco, mayor of Nantes, proclamation of, $\mathrm{i}, 74$.

Baird, Spencer Fullarton, his friendship with Audubon, ii, 218-920; Audubon to, ii, 219-222, 232-233; discovers new birds, ii, 219, 221, 225; visits Audubon in New York, ii, 230; to Audubon, ii, 231-232, 235 ; correspondence with Audubon on the Missouri expedition, ii, 239241 , 248-250, 252; 259; dedication of Audubon to, ii, 259-260; Coues on, ii, 260; correspondence with Audubon on quadrupeds, ii, 263, 264, 272-273, 274-278; on Pennant's marten, ii, 263; first visit to Audubon, ii, 264; on fate of Audubon's copper-plates, ii, 267; his marriage and appointment in Dickenson College, ii, 276; on Victor Audubon's gift, ii, 278; on the curatorship of the Smithsonian Institution, ii, 279; his recommendations by Audubon, ii, 279; last letter and visit to Audubon, ii, 288.

Bakewell, Benjamin, as protégé of young Audubon, i, 125; Audubon's engagement with, i, 153, 154-155, 171-172; his establishment, correspondents and clerks, i, 153-154; his residence and previous business career, i, 154; his New York business and correspondents, i, 155 ; dealings with Claude François Rozier, as told in Audubon's letters, i, 156$158,161-163,164-166$; ruin of his trade by the Embargo Act, i, 172; his business dealings with Audubon and Rozier, i, 186, 193; emigration to America and establish- ment in New Haven, i, 201; Wilson at his glass works in Pittsburgh, i, 204 .

Bakewell, Eliza. See Mrs. Nicholas Augustus Berthoud.

Bakewell, Rev. Gordon, on Audubon's birth, i, 69 ; Audubon's portrait of, i, 69 .

Bakewell, G. W., on William Bakewell, i, 99.

Bakewell, John, i, 200.

Bakewell, Joseph, i, 200.

Bakewell, Lucy Green. See Mrs. John James Audubon.

Bakewell, Robert, i, 200, 377.

Bakewell, Thomas Woodhouse (of Crith, Derbyshire), i, 200.

Bakewell, Thomas Woodhouse, i, 153; statement of accounts of Audubon \& Rozier with his uncle's estate, i, 193; see also ii, 354-355; letter to Audubon \& Rozier, i, 196; failure of his commission business with Audubon at New Orleans, i, 248; second partnership with Audubon, and history of their mill enterprise at Henderson, i, 254-255; 259 ; lease of land, i, 254; investment in mill, i, 255; withdrawal from business partnership, i, 256; subsequent successful career at Pittsburgh and Cincinnati, i, 259; his financial reverses, fortitude and death, i, 259.

Bakewell, William, his purchase of "Fatland Ford" and settlement upon this estate, i, 99, 108; his daughter, Lucy Green, i, 108-110; his private accounts and aid to Audubon and Rezier, i, 125; sale of a portion of his farm in the interests of his daughter, i, 198; to Audubon and Rozier regarding the sale, i, 199; his family and history, i, 200; emigration to the United States and business at New Haven, i, 201; death of his first 
wife, $i, 201$; his second marriage, i, 201; his death, i, 201; death of his second wife, i, 201; financial assistance to son $\mathrm{by}, \mathrm{i}, 255$.

Bakewell, William Gifford, record of a visit to "Mill Grove," i, 111-112; 427; ii, 252.

Bakewell, Mrs. William Gifford, ii, 302.

Banks, Sir Joseph, ii, 117.

Barraband, Pierre Paul (1767-1809), his method of drawing birds, i, 184, 404 .

Bartram, Anne, i, 215.

Bartram, John, and his Botanic Gardens, i, 215.

Bartram, William, as mentor to Alexander Wilson, i, 212; Wilson, in letter to, i, 213; his hospitality, i, 214, 216; his niece, and the Botanic Gardens of his father, i, 215; on numbers of American birds, ii, 214.

Bascanion. See Black snake.

Bayou Sara, introduction of Audubon to, i, 309; life of Audubon at, i, 314-318; village and origin of name of, $i, 314$.

Bazin, Eugène, translations by, i, 360.

Beates, Frederick, purchase and sale of "Mill Grove" by, i, 169.

Beer, William, i, 143, 155.

Bell, John, ii, 252; dedication of Audubon to, ii, 253.

Benedict, Jennett, Audubon's itinerant portrait of, i, 342.

Benedict, Jesse, ii, 311.

Berthoud, Mme., death of, i, 326.

Berthoud, Nicholas Augustus, i, 197, $256,303,309$; engagement of Victor G. Audubon with, i, 325; mother and family name of, i, 326; 427 ; ii, $27,28,33,36,37,38$, 130.

Berthoud, Mrs. Nicholas Augustus, i, 326; ii, 303.
Besant, Sir Walter, on London in 1837, i, 355, 395.

Best, Robert, and the Western Museum, i, 303, 306.

Bewick, Thomas, Audubon's visit to, i, 375 ; ii, 142.

Bibliography, i, 15; ii, 40I-456.

Bien, J., and Company, ii, 396.

"Bird of Washington" ("Aquila washingtonii"), Audubon's supposed discovery of, i, 241, 400, 406; ii, 185.

Birds of America (folio), cost and rarity of, i, 4; defects in drawings of, i, 174, 184-185; destruction of drawings designed for, i, 179, 320321 ; in embryo, i, 180-183; presentation copies of, i, 356; plans of publication, i, 343; first subscriber to, i, 353; first engraved plate of, $i, 359$; Lizars' part in engraving of, $i, 359$; issue of first number of, i, 362; first prospectus of, i, 373, see also ii, 386-388; title of, i, 381; the Havells in relation to, i, 380385 ; rebirth of, in London, $i, 384$; the singular history of plate No. ii, i, 384; difficulties with colorists, i, 389; the Queen as patroness, i, 392; revision of drawings, i, 398; Swainson's review, i, 403; progress of, i, 405; Cuvier's report, i, 413; Bachman as canvasser for, ii, 27; Thomas H. Perkins' copy, ii, 29; Audubon's directions for dispatch of parts of, ii, 37; his financial accounts with, ii, 37; American subscribers, ii, $36-41$; insurance of drawings for, ii, 40; editorial comment, ii, 41; revolt of patrons at extension of plan, ii, 170, 174; Audubon on extra plates and partial subscribers to, ii, 174; completion of, ii, 177; Audubon on residual stock of plates, ii, 188-190; uncolored plates of, ii, 190; on insurance of cop- 
per-plates of, ii, 191; intimate history of the engravers and plates, with manual for collectors, ii, 191-199; story told in artists' and engravers' captions or legends, ii, 196-198; dates, errors and editions in plates, ii, 196-198; original and present known numbers of complete sets, ii, 201; Audubon's and Havell's copies of, ii, 204; original and present prices, ii, 204; curious attest of J. P. Hall, ii, 205; original drawings for plates, ii, 304; manuscript records and legends on original drawings, ii, 305 ; story of fate of original copper-plates of, ii, 295, 306-309; final lists of subscribers, ii, 380385 ; prospectus of 1828 , ii, 386388.

Birds of America (in octavo), prospectus, ii, 208-212, 214; agents' original and present prices of, ii, 211; titles on original parts, ii, 213; beginning of publication, ii, 214; number of birds and doubtful species, ii, 214; Audubon as canvasser for, ii, 215-217; remarkable success of, ii, 217; account-book of Audubon in business of, ii, 217; William Yarrell on, ii, 223; "Parkman's Wren" in, ii, 228; expense of publication of, ii, 230 .

Birds of America (partial American issue in folio), ii, 296; residual stock of plates of, $\mathrm{ii}, 297$; original prospectus of, ii, 389-391.

Birds of Europe, ii, 122; anecdote of, ii, 123.

Blackbird, Red-winged (Angelaius phoniceus), Ord's charge concerning Audubon's drawing of, i, 228.

Blackcocks (Tetrao tetrix), original painting of, i, 363,366 .

Black snake, "blue racer" (Bascanion constrictor), confused with rattlesnake, ii, 76.
Blackwood's Magazine, John Wilson on Audubon and Kidd, i, 447; John Wilson on Audubon, ii, 139.

Blarchard, Jean François, as attorney of Jean Audubon at Les Cayes, i, 85.

Blue Jays (Cyanocitta cristata), painting of, i, 397 .

Bohn, Henry G., on Audubon's drawings, i, 357.

Bonaparte, Charles Lucien, introduces Audubon at Philadelphia, i, 328; his career and work as an ornithologist, i, 329-331; his artist and engravers, i, 330; Audubon's contribution to his American Ornithology, i, 330; his account of the Wild Turkey, i, 331; characterization by a contemporary, $i$, 334; his subscription to The Birds of America, i, 380, 385; to Audubon, i, 416-419; 423; ii, 40, 49-50; $96,98,106,107,108,110,112,118$; Audubon to, ii, 119; his list of American birds, ii, 120; his comment on Audubon's work, ii, 120,169 ; on publication of new species by, ii, 173; 176, 184, 214, 224.

Bonnabel, Antonio, acquisition of lands from, by Bernard Marigny, i, 70 .

Boone, Daniel, Audubon's characterization of, criticized, i, 281.

Bossals and creoles in Santo Domingo, i, 42, 47 .

Boston Patriot, ii, 50.

Bouffard, Catharine, designation of, in legal documents, $i, 56$; mother of Muguet (Rosa Audubon), i, 56 ; her appearance in France, $\mathrm{i}, 56$; mother of Louise, i, 56.

Bouffard, Louise, inquiry concerning, i, 56; her birth, i, 57, 130.

Boulart (General), letter to Citizen Audubon, i, 80. 
Bowen, Samuel Adams, his steamboat at Henderson, i, 236; Audubon's encounter with, i, 257-259; suit against Audubon by, i, 258; conclusion of bench in action brought by, i, 259.

Bradford, Mrs. J. L., i, 13.

Bradford, Samuel F., as publisher of Wilson's American Ornithology, i, 217, 219.

Bragdon, Sam L., i, 348.

Brand, William, Audubon as teacher in family of, i, 318; Mrs. Audubon's engagement with family of, i, 322.

Brewer, Thomas Mayo, ii, 8; Audubon on the rattlesnake, ii, 79, 150; Audubon to, ii, 152-153, 165-166, $168-169,175,209$; on Audubon in 1846, ii, 286-288.

Brewster, Sir David, i, 362; ii, 84.

Brilliant, Jean Audubon's encounter with, i, 82.

Broadnax, Henry P., judge in case of Samuel Adams Bowen and others vs. Audubon, i, 258; his decision in a case of assault, $i, 259$.

Brown, Capt. Thomas, curious history of Illustrations of the American Ornithology by, i, 443-445; limited circulation, rarity and piratical character of the work, $i$, 443-445; his Illustrations of the Genera of Birds, i, 444; contemporary and later notices of his atlas, i, 444.

Buchanan, Robert Williams, true story of his Life of Audubon, i, 18-22; his struggles, talents, idiosyncrasies and death, i, 19, 21, 22.

Buckland, William, D.D., i, 377.

Buffalo (New York), Audubon's visit to, in 1824, i, 340.

Buffalo hunting on the Upper Missouri and Yellowstone in 1843, ii, 254-256.

Bullen, George E., i, 400, 403.
Bulow, John, welcome or Audubon and their adventures at his plantation, ii, 15-20.

Bunting, Henslow's (Passerherbulus henslowi), i, 354.

Burchell, William John, ii, 97, 105.

Bureau, Louis, i, 143, 149 ; manuscript letters of, i, 154 .

Burns, Robert, relations of Alexander Wilson with, i, 208.

Butler, Benjamin F., ii, 153.

Butterflies, as food of birds, i, 358 .

Cabinet Cyclopadia, Swainson in, ii, 113.

Caire, Louis P., to Lafayette, i, 352. Caledonian Mercury, Notice of Jameson's edition of Wilson and Bonaparte's Ornithology in, i, 442; notice of Jardine's edition in, i, 442-443, 446; Audubon to Kidd in, ii, 2; on the Wilson-Audubon obituary, ii, 3.

Call, Richard Ellsworth, i, 287, 299. Camden (New Jersey), work of Audubon at, i, 421, 426; ii, 26-27, 30. Campbell, Sir Archibald, ii, 30.

Cap, P. A., i, 360.

Caporal, Le petit, date of original drawing of, i, 180.

Carolina Paroquet (Conuropsis carolinensis), early drawing of, i, 180. Carrier, Jean Baptiste, mission and infamy of, $\mathbf{i}, 75$; denounced by $\mathbf{J u}$ lien, $i, 76$; reign of terror at Nantes under, $i, 75$; recall of, $i$, 76.

Cass, Lewis, ii, 52.

Catlin, George, ii, 254.

Cayes (Les Cayes), delivery of slaves at, i, 31; Jean Audubon's business interests in, i, 39 ; its prerevolutionary importance, i, 38; corruption of its name, $i, 38$; slave trade at, i, 39-41; first touched by the Revolution, i, 50; birth of Fougère (John James Audubon), and 
Muguet (Rosa Audubon), at, i, 52-53, 56; Jean Audubon's fortune and financial losses at, i, 82; final settlement of Jean Audubon's estate at, i, 268.

Cedar-bird (Bombycilla cedrorum), habits of, i, 423.

Central Committee (at Nantes), extract from register of, $\mathbf{i}, 134$.

Century of Birds, ii, 121.

Cerberus, Jean Audubon's command of, and encounter in, i, 82.

Chapelain, Doctor, as witness, i, 153.

Charette, siege of Nantes under, i, 74 ; execution of, $\mathrm{i}, 76$.

Charles $\mathrm{X}$, patronage of, i, 3-4, 27. Charleston, meeting of Audubon and Bachman at, ii, 5, 9; Audubon's tribute to hospitality of people at, ii, 10 ; bird-hunting at, ii, 10 ; return of Audubon's party, ii, 25; Bachman's services at, ii, 284.

Chat, Yellow-breasted (Icteria virens), Audubon's original drawing of, i, 425 .

Chevalier, J. B., ii, 211, 216, 222, 226, 234.

Children, John George, i, 377; his career and friendship with Audubon, i, 379-380, 420, 437; ii, 34, 56, 59, 199.

Chouanerie, i, 27.

Chuck-will's-widow (Antrostomus carolinensis), Audubon's early drawing of, i, 182.

Cincinnati (Ohio), in 1810, i, 205; record of earthquakes at, i, 280; settlement of Audubon at, i, 303; Dr. Drake and the Western Museum, i, 303-306; early "Notice concerning," and activities of Dr. Drake, i, 304-306; organization of a college and medical school, i, 305; Audubon stranded at, i, 344. Cincinnati College, relations of Dr. Daniel Drake to, i, 304; foundation and first president of, $\mathbf{i}, 305$.
Clapp, Wellington, ii, 310.

Clay, Henry, i, 307, 372, 378, 396.

Clifford, John O., i 290.

Clinton, De Witt, i, 2, 218, 339.

Cochereau, Matthew, painting of David's studio by, i, 177.

Coirond Brothers, i, 33, 38.

Coirond (Coyron), Mme., i, 86.

Coit, Rev. Dr. Henry Augustus, ii, 43.

Coit, Rev. Dr. Joseph, ii, 43.

Coleman, William A., Audubon to, ii, 174.

Colles, George W., on Audubon's account of the rattlesnake, ii, 76.

Collett, Tobias, i, 103.

Colnaghi and Company, i, 383.

Colson, Augustus, i, 342.

Columbus, incident on voyage of, $\mathbf{i}$, 312.

Combe, Andrew, i, 361.

Cook, Capt. James, i, 377.

Coolidge, Joseph, ii, 43, 50.

Cooper, Thomas, and the climbing habits of the rattlesnake, ii, 5354, 77-78; to Audubon, ii, 78 .

Coot, Audubon's early drawing of, i, 178.

Couëron, discovery of documents at, i, 53; settlement of Jean Audubon at, $i, 57,83$; condition in 1793, $i$, 80,137 ; the D'Orbignys at, i, 127128, 130; history and characteristics of, 136-140; present industry and population of, 137 ; record of visit to, in 1913, $i, 138-140$; grand calvaire at, i, 139; history of Audubon's boyhood home at, i, 140145.

Coues, Elliott, on Audubon, i, 110; on Alexander Wilson, i, 213; ii, 129.

Count of Artois (Le Comte d'Artois), encounter of Jean Audubon and his capture in, i, 32; armament and fate of, i, 33; bill of 
sale of, $i, 33$; unsettled claims concerning, i, 121, 265.

Couper, William, bust of Audubon, by, i, 13.

Cowles, Charles A., story of his rescue of a remnant of Audubon's copper-plates, ii, 307.

Crane, Whooping (Grus americana), i, 227 .

Crosby, Fortunatus (Judge), court record under, i, 260.

Crusader, Audubon's adventures in, ii, 157-163.

Culbertson, Alexander, ii, 271.

Cummings, Capt. James, i, 307; ii, $69,258$.

Cushing, Caleb, ii, 241.

Cuvier, Baron Georges, his eulogy on Audubon's Birds, i, 1; his patronage, $i, 2$; his death, $i, 4$; report at the Royal Academy of Sciences, i, 174, 412-413; Audubon's description of, i, 410-411; ii, 101, 142, 448 .

Cyclopædia, New American, Wilson's editorial work on, i, 216-217, 219.

Dacosta, Francis, and the Prevost mortgage, i, 106; first appearance at "Mill Grove," and his interest in its mine, i, 113; early exploitation, i, 114; as Lieutenant Audubon's attorney and guardian of his son, i, 114; his purchase of a one-half interest, i, 114; his salary and grievances, i, 115; difficulties with young Audubon and with the mine, i, 115 ; correspondence of Lieutenant Audubon, i, 116-123; Lieutenant Audubon's appeal in answer to complaints, i, 118; instructions for settlement of claims, i, 121-123; rebellion of young Audubon, i, 123; his praise of Audubon's drawings, $i, 124$; succeeded by Audubon and Rozier, i, 132; called to account, $i, 146$; acquisition of the remaining Audubon and Rozier in- terests, i, 148-150; his "rôle of chicaner," i, 151, 158; his failure and disputed claim, i, 168; award of arbitrators in case, $\mathrm{i}, 168$; reproduction of his contested accounts, ii, 355-358.

"Dalmahoy," Audubon's visit to, i, 363 ,

Darwin, Charles, i, 354, 399.

Darwin, Erasmus, i, 200.

David, Jacques Louis, i, 3, 174, 175, $1 \% 6$; his revolutionary ardor, patriotism and popularity, i, 174, 176; his exile and death, i, 174; his portrait of the mayor of Nantes, i, 174176; his reception at Nantes, i, 175 ; his address to the Municipal Assembly, i, 175; his studios and pupils at the Louvre, i, 177; his works and influence, i, 177; influence on Audubon's style, i, 178.

Davis, Isaac P., ii, 151; on Webster's copy of The Birds of America, ii, 152.

Davy, Sir Humphry, i, 356, 377, 379.

Deane, Ruthven, i, 246, 444, 448; ii, 14, 188; on copies of The Birds of America in America, ii, 203, 204; 211, 263, 293; on the copper-plates of The Birds of America, ii, 307309.

Debtors, terrors of, in England, i, 395.

Declaration of Rights, voted by the National Assembly of France, and its effect upon Santo Domingo, i, $37,49$.

De Genlis, Stephanie-Felicité, i, 163.

De Kervegan, Daniel, popularity and portrait of, as mayor of Nantes, i, 175 .

De La Luzerne, his recomrnendation of Jean Audubon, i, 32, 34.

Delos, Audubon's voyage on, i, 347350 ; subsequent fate of, 348 .

De Marigny, Ecuyer Sieur, and his 
family, $i, 69$; true story of his family, and of "Fontainebleau," which has been erroneously attributed to him, i, 69; his summer house at Mandeville, i, 71 .

Derby, Earl of, ii, 146.

De Vaugeon, Mme. Le Jeune, i, 28; suit by, i, 262.

De Vaugeon, Pierre, i, 27.

De Wimpffen, Baron. See Francis Alexander Stanilaus.

Dickenson College, Baird's appointment and position at, ii, 268, 276.

Dodge, William E., ii, 307.

D'Orbigny, Alcide Charles Victor, i, 128.

D'Orbigny, Dr. Charles Marie, as friend of young Audubon, i, 120, 127-128; his family, i, 128; Audubon as godfather to son of, i, 128; financial troubles of, i, 128-130; Gabriel Loyen du Puigaudeau to, i, 129 ; as debtor to Lieutenant Audubon's estate, i, 129; inquiries concerning, i, 130; as witness, i, 153; Audubon's correspondence with, i, 160, 163, 171.

D'Orbigny, Charles (the younger), i, 128.

D'Orbigny, Gaston Edouard, birth and baptism of, i, 128.

Dorlan, William R., ii, 302.

Drake, Dr. Daniel, and Alexander Wilson, i, 205; record of earthquakes at Cincinnati by, i, 280; his engagement of Audubon as taxidermist, i, 303; his foundation of the Western Museum and Audubon's connection with it, i, 304306; his varied activities, i, 304; his early "Notice concerning Cincinnati," $i, 304$; his organization of the Cincinnati College and medical school, $i, 305$; his troubles with rivals, i, 306; his appointment at the Transylvania University, i, 306.
Duck, Labrador (Camptorhynchus labradorius), at Bradore Bay, ii, 48; extinction of, ii, 48, 152.

Duck, "Velvet," White-winged Scoter (Oidemia deglandi), Audubon's early drawing of, i, 182; description of, i, 182.

Duncan, William, i, 208; ii, 284.

Dunkin, Judge, i, 260; ii, 64.

Dupré ('Tête-Carée), raid of Nantes by, $i, 77$.

Du Puigaudeau, Gabriel Loyen, Audubon's power of attorney to, $i$, 64 ; to D'Orbigny, i, 128-130; to J. Cornet, i, 130; his marriage, i, 131 ; his family, occupation and residence, i, 132; to Audubon, i, 266269.

Du Puigaudeau, Mme. Gabriel Loyen. See Rosa Audubon.

Du Puigaudeau, Gabriel Loyen (the Second), death of at "Les Tourterelles," i, 269.

Eagle, "Brown." See "Bird of Washington."

Eagle, Golden (Aquila chrysaëtos), Audubon's drawing of, ii, 35.

Eagle, "Washington's." See "Bird of Washington."

Eagle, White-headed (Haliaetus levcocephalus), Audubon's original drawing of, i, 310.

Eagle and Lamb, original painting of, i, 394-396, 405, 406.

Earthquakes in the Ohio and Mississippi Valleys, 1811-1813; casual and exact records of, $i, 279$.

Eckley, David, dedication of copy of The Birds of America to, ii, 7 ; history of copy formerly owned by, ii, 7; ii, 150.

Ecton Consolidated Mining Company, i, 169.

Edinburgh, first visit and success of Audubon at, i, 357-373; beginning of The Birds of America at, i, 
358; exhibition of Audubon's drawings at, i, 359; meeting with Sir Walter Scott at, i, 365; issue of Audubon's Prospectus at, i, 373.

Edinburgh Literary Journal, notice of Brown's Illustrations of the American Ornithology in, i, 443.

Edinburgh New Philosophical Journal, ii, 111.

Edward (Ezekiel Edwards ?), unsettled claim of Jean Audubon against, i, 121.

Edwards, Bryan, on the products and wealth of French Santo Domingo, i, 30; on the Santo Domingo blacks, i, 43.

Edwards, Ezekiel, i, 121.

Eggleston, Thomas, i, 13.

Elaps. See Coral snake.

Embargo Act, of President Jefferson, effect of, on Audubon and Rozier, i, 193.

"Episodes." Seo Ornithological Biography.

Evans, Roland, acquisition of "Mill Grove" by, i, 105.

Everett, Edward, patronage and aid of, i, 435; letters of, i, 436, 448451; his efforts for the removal of import duties on The Birds of America, i, 448; his nomination of Audubon to fellowship in the American Academy of Arts and Sciences, i, 450; ii, 5, 23, 64 .

Falco Cooperii (Accipiter cooperi), i, 330, 417. See "Stanley Hawk."

"Fatland Ford," William Bakewell's acquisition of, i, 98, 108, 201 ; mansion house and farm of, i, 108; Audubon's introduction to, i, 108; Generals Washington and Howe at, i, 108; marriage of Lucy Bakewell at, $i, 194$; realization of Mrs. Audubon in, i, 198.

Faxon Walter, i, 444.

Featherstonhaugh, G. W., Rafines- que's reply to, i, 294; on Audubon's plans, ii, 4; Audubon's Florida letters to, ii, 8-14, 15-22; suspension of Journal of, ii, 23, 28, 84 .

Feliciana, West, characteristics of, i, 314-315; former prosperity of, i, 323.

Finch, MacGillivray's, MacGillivray's Seaside Sparrow (Passerhebulus maritimus macgillivraii), i, 354.

Fisher, Miers, as Jean Audubon's attorney and protégé of his son, i, 99; Jean Audubon to, i, 100; residence in Philadelphia, i, 106; and the Prevost mortgage, i, 106, 122; succeeded by Dacosta, i, 113-114; 120-122; as counselor of Audubon and Rozier, i, 148, 149, 160, 167; resumption of duties as agent and attorney by, i, 168.

Fitzpatrick, T. J., i, 287, 292, 299.

Flatboats, on the Ohio River in $\mathbf{1 8 1 0}$, i, 234; convenience of, i, 234; cost of, at Pittsburgh, i, 235; time of passage of, from Pittsburgh to New Orleans, i, 235; floating trade of, i, 234 .

Flicker (Colaptes auratus), original painting of, $\mathbf{i}, 363$.

Florida, Audubon's explorations in, ii, 12-25; Audubon, on the future of the east coast of, $\mathbf{i i}, \mathbf{2 0}$.

Floyd, John, ii, 5.

Flycatcher, Least (Empidonax minimus), discovery by the Baird brothers, in 1843, ii, 225.

Flycatcher, "Selby's," i, 354.

Flycatcher, "Small Green-crested," i, 425.

Flycatcher, "Small-headed," curious history of, i, 218, 226-227; reference to, by Thomas Nuttal, i, 227; identifications of, by Cowes and Baird, i, 227 ; ii, 215.

Flycatcher, Traill's (Empidonax trailli), i, 354. 
"Fontainebleau," myth and true story of, i, 69, 71.

Formon de Boisclair, Jean Audubon's dealings with, and claims against, i, 33-34, 121, 265, 338. See Lacroix, Formon \& Jacques.

Fort Union, Audubon's experiences at, ii, 254-256.

Fougère, i, 53, 57, 59, 61 ; ii, 328, 329. See Jean Jacques Fougère Audubon.

Francis, C. S., and Company, ii, 203.

Francis, David G., ii, 204.

Franklin Journal, Audubon's article, and Jones' "Romance of the Rattlesnake" in, ii, 72.

Fulton, Robert, first steamer on the Ohio River, built by, i, 236.

Gallatin, Albert, i, 377; Audubon's interview with, i, 390.

Galt, W. C., i, 197.

Gannet Rock, Audubon's account of approach to, i, 9.

Gannets (Sula bassana), i, 10.

Gaston, William, aid rendered Audubon by, at Savannah, ii, 25, 59.

General Assembly (Santo Domingo), new Constitution of, i, 49.

Geoffroy Saint-Hilaire, i, 411.

George IV, Gallatin on, i, 390.

George Street (Edinburgh), Audubon's apartments in, i, 437 .

Gill, Theodore, i, 444 ; ii, 113.

Girard, Stephen, his reputed interest in Dacosia's mining enterprises at "Mill Grove," i, 149.

Godwin, Parke, on Audubon's drawing of quadrupeds, ii, 236; on a visit to Audubon at "Minnie's Land," ii, 236-238; on Audubon in 1845, ii, 238.

Goodspeed, Charles E., i, 384, ii, 26, 190.

Gordon, Mrs. Alexander, ii, 302.

Gould, John, Bonaparte on, ii, 121;
Audubon on, ii, 121; works of, ii, 121 ; charges against, ii, 122; anecdote of, ii, 123; financial success of publications of, ii, 124 ; 224-225. Gould, Mrs. John, Audubon on, ii, 121.

Grackle, Boat-tailed (Megaquiscalus major), Audubon's drawing in Bonaparte's Ornithology, i, 330.

Gray, Asa, ii, 81.

Gray, John Edward, i, 354, 380, 444; dedication to, ii, 280 ; to J. W. Audubon, ii, 281.

Gray's Ferry (now Philadelphia), settlement of Alexander Wilson as teacher at, i, 210, 211, 212, 216.

Great Bend (of the Mississippi), Audubon's and Rozier's experience at, in 1810, i, 240.

Great Egg Harbor, work of Audubon at, i, 421, 424; visit of Wilson and Ord, i, 422; drawings of Audubon, i, 425 .

Great Pine Forest (Mauch Chunk), sojourn and work of Audubon at, i, 423, 425-426.

Great Russell Street (London), old print dealer of, i, 11-12, 377.

Great Western, ii, 190.

Grinnell, George Bird, ii, 283, 299, 309.

Groundhog, Audubon's early drawing of, $i, 181$.

Guépin, M. A., i, 73, 77 .

Ginther, Albert, on Rafinesque's letters and character, i, 297; on Swainson and his correspondence, i, 400-403.

Hackberry, in the Ohio River basin, i, 188.

Haines, Reuben, visit of Audubon to "Mill Grove" with, i, 335, 339.

Haiti, i, 38, 52.

Hall, Capt. Basil, on the Leander, i, 364; as Audubon's friend, i, 365, 367; to John Murray, i, 378; re- 
turn to England from the United States, i, 407.

Hall, Harrison, publication of, i, 329 ; ii, 98.

Hall, James, notorious review of, i, 329 ; ii, 98.

Hall, J. Prescott, memorandum regarding The Birds of America, ii, 204.

Hardin, John, ii, 295.

Harlan, Richard, i, 328; on Ord, i, $328-329$; 333, 334, 407, 439; ii, 9; on Abert, ii, 3; Audubon to, ii, 14; to Mrs. Audubon, ii, 14; to Audubon, ii, 28-29; 58.

Harris, Edward, meeting with Audubon, i, 331; his friendships and career, i, 331, 333; early letters to Audubon, i, 332, 344; Audubon to, i, 448; Audubon to, ii, 26-27, 30, $31,40-41$; memento to, ii, 49; $\mathrm{Au}-$ dubon to, ii, 64-66, 125, 132, 134, $141-144,147-148 ; 149,151,155,157$, 165; Audubon to, ii, 170-173; 175 ; Audubon to, ii, 182, 184-186; 234 ; to Audubon, ii, 251; dedication to, ii, 253; Bachman's ultimatum to, ii, 268-270; in rôle of mediator, ii, 270; Audubon to, ii, 287; Bachman to, ii, 291.

Harrison, William Henry, i, 307.

Harvard University, drawings and manuscripts at, i, 180, 307-308.

Haskell, Rev. John, ii, 271, 283.

Hatch, Capt. Joseph E., i, 347.

Havell, Daniel, i, 382.

Havell, George, i, 382.

Havell Henry Augustus, i, 382; ii, 189, 190, 191-192.

Havell, Robert, Senior, his family, i, 381-383; his shop in Newman Street, i, 382; partnership with his son, i, 383; their enterprise in undertaking The Birds of America, i, 384; his death, i, 384; their relationship as read in the legends of Audubon's plates, ii, 195-198.
Havell, Robert, Junior, i, 12; Audubon's discovery of, i, 382; a family of artists, i, 382; partnership with his father and rebirth of The Birds of America in London, i, 384; his "Zoölogical Gallery," i, 384 ; advertisement of his business, i, 386 ; story of the Prothonotary Warbler, i, 383-384, 405; Swainson on, i, 414; Audubon to, i, 433; ii, 33, 34, 35, 38; to Audubon, ii, $51,57,58,62,174,180,186$; Audubon on closing up his business, ii, 188-191; settlement in the United States, ii, 191-192; his work, characteristics and death, ii, 192; $\mathbf{A u -}$ dubon's memento to, ii, 192; his genius and mastery of aquatint, ii, 193-195; as Audubon's engraver, ii, 195; history of his engravings of Audubon's Birds, ii, 196-198; his copy of the work, ii, 203.

Havell, Robert, \& Son, i, 12.

Havell, William, i, 383.

Haverhill (New Hampshire), experience of Alexander Wilson at, $i$, 219.

Hawk, Cooper's. See Falco Cooperii. Hawk, Great-footed, Duck Hawk (Falco peregrinus anatum), original drawing of, $\mathbf{i}, 311$.

Hawk, Harlan's (Buteo borealis harlani), i, 311.

Hay, Robert William, i, 377, 379.

Henderson (Kentucky), removal of Audubon and Rozier to, i, 236; settlement, early name and population of, i, 236; game and character of the country at, in 1810, $i$, 236; first Kentucky steamer built at, i, 236; Audubon's activities in 1810, i, 237; return of Audubon to, in 1811, i, 242; houses of Dr. Adam Rankin, i, 248; original plot of town, i, 250, 252; his purchase of land at, i, 250, 252; his $\log$ bouse and store, $i, 252$; town rec- 
ords, i, 252 ; record of earthquakes, i, 280; Rafinesque's visit, i, 285287.

Hendersonville. See Henderson.

Henry, Joseph, ii, 279.

Henshaw, Samuel, i, 308; ii, 197.

Henslow, John Stevens, i, 354, 399.

Heppenstall, John, i, 394.

Herschel, Sir William, i, $37 \%$.

"Highfield Hall," residence of William Swainson near Tyttenhanger Green, i, 403.

Hirundo serripennis (Stelgidopteryx serripennis), ii, 186.

Historical Society (New York), unpublished drawing in collections of, i, 228; original drawings of The Birds of America at, ii, 304306.

History of British Birds (MacGillivray), ii, 113, 114, 130, 135; (Yarrell), ii, 223; on his completion of, ii, 225.

Holden, Edward, to George Ramsden, i, 351.

Holland, Dr. Henry, i, 377 .

Hollander, Edward, i, 276.

Hope, Audubon's voyage in, i, 125.

Hopkins, Rev. John Henry, Audubon's acquaintance with, at Pittsburgh, i, 343.

Hopkins, Samuel, i, 252; Audubon's purchase of land, i, 252.

Hopkinson, John, i, 400.

Houston, Sam, Audubon's visit to, ii, 163; his characterization of, $\mathrm{il}, 164$.

Howe, General William, visit at "Fatland Ford," i, 108.

Humboldt, Baron Alexander von, i, 356; and Bachman, ii, 284; Bachman's account of dinner to, ii, 284.

Huntington, Archer M., ii, 310.

Huron, Laurence, engagement of Ferdinand Rozier, with, i, 153; his business relations with the Bakewell firm and with Rozier, the eld- er, i, 156-157, 159-161, 165; his award in the settlement of the contested accounts of Francis Dacosta, i, 168; dealings of Audubon \& Rozier, i, 186.

Ingalls, William, Parkman's recommendation of, ii, 42.

Indigo, history of Audubon's investment in, i, 193.

Indians (Shawnee), feather hunting of, i, 238; incident at camp of, i, 239 ; (Osage), Audubon's experience with, i, 240.

Irish, Jedediah, i, 425.

Irving, Washington, ii, 53, 153.

Jackson, Andrew, Audubon as model for portrait of, i, 338; 378; ii, 155; Audubon on, ii, 156.

Jackson, Daydon, i, 400.

Jameson, Robert, i, 357 ; edition of Wilson's and Bonaparte's Ornithology, i, 439, 442; ii, 84.

Jaquemel (Santo Domingo), planter's experience at, i, 44-48.

Jardine, Sir William, to Audubon, 440 ; edition of Wilson and Bonaparte's Ornithology, i, 442; ii, 102. Jay, Harriet, on Robert Buchanan, i, 21.

Jeanes, Joseph Y., his collection of original Audubon drawings and manuscripts, i, 180, 181 ; ii, 50, 375379.

Jefferson, Thomas, Embargo Act of, i, 193; on the numbers of species of American birds, ii, 214.

Jenner, Edward, announcement of discovery of vaccination, $i, 55$; account of behavior of young cuckoo (Cuculus canorus) discredited by Waterton, ii, 90.

Johnson, John, ii, 203.

Johnson, Samuel, on biography, i, 7. Johnson, William Garrett, Audubon at home of, i, 427, 432; engage- 
ment of Mrs. Audubon by, i, 431; authorization to fill position at home of, i, 434.

Jordan, David Starr, i, 287, 291.

Joue, i, 54 .

Julien (of Paris), heroic conduct of, i, 76 .

Juniata River, i, 274, 277.

Keel boats, on the Ohio and Mississippi, i, 234; Audubon's journey by, in 1810, i, 238-241.

Kidd, Dr. John, i, 399.

Kidd, Joseph Bartholomew, i, 363, 373, 443; and the "Ornithological Gallery," i, 446; Audubon to, ii, $1 ; 35,57,61,62$.

Kinder, Robert \& Company, dealings of Audubon and Rozier with, i, 186, 197-199; ii, 355.

King, Thomas Butler, ii, 11-12, 14.

Kingfisher (Ceryle alcyon), Audubon's early drawing of, i, 180.

Kirtland, Dr. Jared P., i, 291; "Note Book" of, i, 292.

Kite, Mississippi (Ictinia mississippiensis), Ord's charge concerning, i, 228; similarity in one of Wilson's and Audubon's figures of, i, 228; misnaming of sex in, i, 229; Audubon's legends on original drawing of, i, 229; Wilson's and Audubon's first experience with, i, 229230 ; 316.

Knox, Dr. John, i, 358.

Koster, Henry, ii, 117.

Krudener, Baron, i, 436; ii, 38.

Labrador, Audubon's experiences in, ii, 45-49; expense and results of expedition to, ii, 50 .

La Caille, i, 29.

Lacroix, Formon de Boisclair \& Jacques, Jean Audubon's claims against, $i, 33$; bills of slaves of, ii, $331-333$; 338.

La Dauphine, i, 31.
Lafayette, Marquis de, Louis $\mathbf{P}$. Caire to, i, 351.

"La Gerbetière," i, 85, 96, 120, 126; as boyhood home of Audubon, $i$, 136-137, 144-145; Audubon's last visit to, $i, 13 \tau$; situation of, $i, 136$ 138; in 1913, i, 138-143; Jean Audubon's restoration of, i, 143; description in old deed of, i, 144; changes of a century, i, 144 .

Lake Champlain, tour of Audubon to, in 1824, i, 343.

Lake Ontario, tour of Audubon to, in $1824, \mathrm{i}, 343$.

Lamarck, Jean Baptiste Antoine de Monet, i, 13.

La Marianne, Jean Audubon as cabin boy in, i, 28; at Louisburg, i, 28; Jean Audubon as lieutenant of, i, 29 .

Landsdowne, Marquis of, i, 398.

Landseer, Sir Edwin, criticism of painting by, i, 366 .

Lanman, Charles, proposal of, i, 17. L'Annette, Jean Audubon's command of and interest in, i, 34; concerning sale and settlement of claims in, i, 121, 265.

La Rochelle, as port of Jean Audubon's ships, i, 29, 277. See "Audubon of."

Laval, John, award in the settlement of Dacosta's disputed accounts, i, 168.

Lavigne, L., i, 34, 46, 57, 83, 87, 116 , 128, 144, 269.

Lavigne, Mme. L., i, 269

Lawrence, Sir Thomas, i, 356, 377, 380, 393-394.

Lawson, Alexander, Wilson to, i, 212; Wilson's debt to, as the engraver of his Ornithology, i, 213; the daughter of, i, 219; his statement regarding the mysterious flycatcher, i, 227; as Bonaparte's engraver, i, 330 ; report of his interview with Audubon, i, 330. 
Lawson, Malvinia, on Wilson's publisher, i, 219.

Lea, Isaac, on Rafinesque, i, 297 ; ii, $4,56,95,98,422$.

Leach, William Elford, i, 353.

Le Comte d'Artois. See Count of Artois.

Le Conte, Joseph, i, 171.

Lehman, George, ii, 2, 9, 12, 25.

Le Marquis de Lévy, Jean Audubon's command of, i, 31.

Le Printemps, i, 29.

Le Propre, i, 30.

Les Sables d'Olonne, Pierre Audubon's family at, i, 26; its hostility to the Revolution, i, 27; as home port of Jean Audubon's ships, i, 28; mission of Jean Audubon to, i, $80-81 ; 83$.

Leslie, Charles Robert, comment on the American Ornithology, i, 217.

"Les Tourterelles," death of Mme. Audubon at, i, 263; death of Rosa Audubon at, i, 269.

Le Sueur, Charles Alexandre, i, 294, 328 ; appearance of, i, 333; ii, 157.

Letters in facsimile, "Audubon \& Bakewell” to Rozier, i, 251; Audubon to Edward Harris, i, 332; Samuel Latham Mitchell to Dr. Barnes, i, 337; William Swainson to Audubon, i, 402; Charles Lucien Bonaparte to Audubon, i, 417; George Parkman to Audubon, ii, 43; Robert Havell to Audubon, ii, 51; William MacGillivray to $\mathbf{A u -}$ dubon, ii, 132; Edward Harris to Audubon, ii, 251; John Bachman to George Oates, ii, 282; Audubon to Edward Harris, ii, 287.

L'Eveillé, Jean Audubon's command of, i, 82 .

Lincoln, Thomas, ii, 43; "Lincoln's Finch," ii, 45, 50.

Linnæan Society, Audubon's election to, $i, 397$; manuscripts in possession of, i, 400 .
L'Instituteur, Jean Audubon's command of, i, 82.

Lissabé, Mme. Jean Louis, suit by, i, 28, 263.

Literary Gazette (London), on Brown's Illustrations, i, 444; announcement of publication of the Ornithological Biography, i, 444; Audubon's premature obituary in, ii, 2.

Little and Brown, Messrs., ii, 230.

Liverpool, arrival of Audubon at, in 1826, $i, 350$; his reception and friends at, i, 352-355; exhibition of Audubon's drawings at, i, 354 .

Livingston, Robert M., first steamer on the Ohio River, built by, i, 236.

Lizars, Daniel, Audubon to, i, 385.

Lizars, William Home, as Audubon's engraver, i, 358-359, 361, 375, 384, 442-443; his plates of The Birds of America, i, 195-199.

Lockhart, John Gibson, i, 445.

London Colney, residence of William Swainson at, i, 403; death of Mrs. Swainson at, i, 403.

London, recollections of Audubon in, i, 11; site of Havell's engraving establishment in, i, 12; Audubon in, i, 377-419; his first impressions of, i, 377; rebirth of The Birds of America in, i, 384; his dislike of, i, 397 ; completion of his Birds in, ii, 177 .

Loon (Gavia immer), "Great Northern Diver," original drawing of, ii, 47.

Loudon, John C., editorial enterprise of, $i, 399$.

Louisburg, Jean Audubon made prisoner at, i, 28.

Louisville (Kentucky), diary of a journey from Philadelphia to, in 1807, i, 187-192; establishment of Audubon \& Rozier at, i, 192 ; prospects and hospitality of the people, i, 196-198; birth of Victor 
Gifford Audubon at, i, 198; arrival of Alexander Wilson at, i, 205; a meeting of rivals at, $i, 220-226$; in 1810, i, 233; Audubon's legal troubles at, i, 260.

Lubbock, Sir John, baron Avebury, characteristics in youth of, $\mathrm{i}, 93$.

Lyceum of Natural History (New York), activities of in 1817, i, 171; introduction of Audubon to, i, 336.

Macaulay, Thomas Babington, on Addison, i, 6.

MacGillivray, John, ii, 298.

MacGillivray, William, i, 12; ii, 108, 113-114; his assistance to Audubon, ii, 125-138; to Audubon, ii. 126-128, 130-132, 134; his methods of work, ii, 127-129; his History of British Birds, ii, 130, 135-136; his contract with Audubon, ii, 134; character and scholarship, ii, 134136; his writings, ii, 135; Audubon's acknowledgments to, ii, 137; his copy of the Ornithological Biography, ii, 138; Audubon at work with, ii, 178-180, 181 ; Audubon's tour with, ii, 182; Audubon's memorandum of account with, ii, 188.

MacLeay, William Sharp, ii, 94.

Magpie (Pica rustica), Audubon's early drawing of, i, 178.

Mallory, E., on Mrs. John James Audubon, ii, 303.

Mallory, Eliza, ii, 283.

Mallory, Georgianna Richards. See Mrs. Victor Gifford Audubon.

Manchester, visit of Audubon at, in 1826, i, 356; Audubon's success in canvassing at, i, 376.

Marigny, Bernard, his birth, i, 70; acquisition of "Fontainebleau," i, 70; his service in France and return to the United States, i, 71; act of the Government to estab- lish his disputed claim to land, i, 71 ; origin of "Fontainebleau," and description of his property, i, 71; foundation of Mandeville, i, 71; friendship with Audubon, i, 72; his death, i, 72 .

Marigny myth, i, 68-71.

Mark, Edward L., i, 308.

Marten, Pennant's, Fisher (Mustela pennanti), Baird and Audubon on, ii, 263.

Martin, Catharine, i, 27.

Martin, Maria, ii, 6, 32, 61 ; Audubon to, ii, 65,156 ; marriage of, ii, 281; dedication to, ii, 281, 283. See Mrs. John Bachman.

Martin, Marie Anne, i, 26.

Martin, Pierre, Jean Audubon as sailor under, i, 30.

Mason, Joseph R., as Audubon's assistant in 1820-1822, i, 307, 312, 313-316; his return to Philadelphia, i, 321 ; ii, 69.

Mauch Chunk. See Great Pine Forest.

McKenney, Thomas L., on Audubon, ii, 52.

McLane, Louis, ii, 5; Levi Woodbury to, ii, 23.

Meadville (Pennsylvania), "Episode" of Audubon at, in 1824, i, 341-343; and itinerant portrait at, i, 342.

Mease, Dr. William, i, 327.

Merchant-traders, means of travel and hardships of, i, 234-236; their journeys by flatboat and horse to and from the West, i, 234-236.

Mill of Audubon, Bakewell and Pears, at Henderson (Kentucky), history of the building, operation and failure of, $i, 254-257$; lease of land for, i, 254; description of relic of, in 1879 and 1883 , i, 254; difficulties with operation of, $\mathbf{i}$, 255; cost, conversion and destruction of, i, 255; reorganization for working of, i, 256; bill rendered 
for products of, $\mathrm{i}, 256$; final failure and closure of, i, 257; Audubon's financial and legal troubles following failure of, i, 257-261.

"Mill Grove," Jean Audubon's purchase, i, 37, 105; Audubon's arrival at, i, 99-101; tenant and rent of, i, 101; acquisition and preservation by the Wetherills, i, 102; situation and characteristics, i, 102 ; old conveyances and designation, i, 103; first miller and builder, i, 104; mills and farm house at, i, 104; the Prevost mortgage, i, 105, 122; Jean Audubon's lease and inventory, $\mathrm{i}, 105$; stay of $\mathrm{Au}$ dubon at, i, 106; Jean Audubon's portrait at, i, 106; bird studies at, i, 106; discovery of lead and arrival of Dacosta, i, 113; Dacosta's onehalf interest and exploitation of mine, i, 114; analysis of his lead ore, i, 114; Claude François Rozier's interest, $\mathrm{i}, 115$; the Audubon, Dacosta, Rozier partnership and its difficulties, i, 115; instructions concerning farmhouse at, $i, 118$; Audubon and Rozier as agents for conduct and sale of, i, 132; $\mathrm{Au}-$ dubon's and Rozier's duties at, i, 146; status of house in their "Articles," i, 147; story of later mining enterprises at, i, 148-150, 152153, 167-170; consideration for sale of remaining Audubon and Rozier interests to Dacosta and Company, i, 149; division of the property, and sale of the Audubon and Rozier rights, i, 150, 152-153; Audubon's conflicting references to sale of, i, 158, 159-160, 162, 165-168; difficulties over conditional sale of, i, 168; unraveling the tangle, $i$, 169; Dacosta's contested accounts, and award in their settlement, $i$, 168 ; sequel to story of mine at, i, 169 ; products of mine at, $i, 199$.
Milestown (Pennsylvania), Alexander Wilson, as teacher at, i, 212.

Miller, Sarah, Wilson to, i, 206 .

"Minnie's Land," purchase of estate of, ii, 234; building of house at, ii, 234; Audubon at, ii, 236-238; Audubon's account of, ii, 245-246; houses of Audubon's sons at, ii, 294-995, 311-312; the "Cave" at, ii, 295, 312; departure of Mrs. John James Audubon from, ii, 300; building activities and changes at, ii, 309 ; present condition of original houses at, ii, 309-311; early representations of Audubon's house at, ii, 311.

Miquelon Island, voyage of Jean $\mathrm{Au}$ dubon to, i, 29.

Mississippi River, Audubon's cruise on in $1820, \mathrm{i}, 307$.

Missouri River, Audubon's experiences and discoveries on, in 1843, ii, 252-256.

Mitchell, Doctor Samuel Latham, his friendship with Audubon, i, 171; his repute and activities, $\mathbf{i}, 171$; as friend of Rafinesque, i, 290; his introduction of Audubon and letter to Dr. Barnes, i, 336.

Mocquard, Françoise, i, 55, 86.

Morris, George Spencer, i, 331.

Morris, Samuel C., purchase of "Mill Grove" by, i, 105.

Morristown (New Jersey), stay of Audubon at, i, 99.

Morse, Samuel Finley Preese, as Audubon's guest, ii, 311.

Morton, Countess of, as patron and pupil of Audubon, i, 365.

Morton, Earl of, record of a visit to the home of, i, 363 .

Morton, Samuel George, ii, 154, 171, 172.

Moynet (Moynette, Moinet), Anne. See Mme. Jean Audubon.

Muguet, i, 56, 57, 59, 61. See Mme. Gabriel Loyen du Puigaudeau. 
Mulattoes, numbers and plight of, in Santo Domingo, i, 43; as slave holders, i, 44; revolt under Ogé, i, 50 ; first clash with whites at Les Cayes, i, 50; union with the blacks and beginning of general revolt, i, 51 .

Murray, John, i, 377; Basil Hall to, i, 378 .

Nantes, Jean Audubon at, i, 30-32; his places of residence, i, $36,57-58$, 86-87; in the Revolution, i, 59, 7374; Committee of Public Safety and National Guard of, i, 74; attack and siege of, $i, 74$; acceptance of republican constitution by, i, 75; reign of terror under Carrier at, $i, 75$; fate of Vendeans at, i, 75; savior of, $i, 76$; victims of Carrier and the plague at, i, 75; execution of Charette at, $i, 76$; raided by "Tête-Carée," i, 77; restoration of peace at, $i, 77$; revolutionary records of, $i$, 78; Jean Audubon's activities, i, 78-82; his death at, i, 87; his appreciation by, i, 83.

Natchez (Mississippi), visit of $\mathrm{Au}-$ dubon, i, 308; loss of his portfolio at, i, 309; as teacher at, i, 321; his first lessons in oils, i, 321; engagement of Mrs. Audubon, i, 322; illness of Audubon, i, 324.

National Assembly of Paris, Declaration of Rights, of, i, 49; vacillating policies of, i, 51 .

National Gazette, on Audubon, ii, 41-42, 50-51.

Natural History of Deeside and Braemar, ii, 136.

Neuwied, Maximillian, ii, 255.

Newark (New Jersey), Alexander Wilson at, i, 210.

New Castle (Delaware), landing of Alexander Wilson at, $\mathrm{i}, 209$.

New Haven (Connecticut), establish- ment of William and Benjamin Bakewell at, i, 201.

Newman Street, Havell's shop in, i, 12.

New Orleans (Louisiana), memorial to Audubon at, i, 13; Alexander Wilson at, i, 207; Audubon at, i, 306-310; his struggles to gain a footing at, i, 310-312; as teacher at, i, 318; settlement and financial difficulties at, i, 319 ; engagement of Mrs. Audubon at, i, 322; Audubon embarks for Liverpool at, i, 347; his observations at, i, 348.

Newton, Alfred, i, 444; ii, 223.

New York (New York), memorials to Audubon at, i, 13; Jean Audubon a prisoner at, i, 32 ; his release, $\mathrm{i}, 32,34$; disbanding of the British army at, i, 35; Audubon's introduction to, i, 99; pestilencè at, i, 99 ; 135; Audubon's original drawings at, i, 228; Vanderlyn's portrait of Andrew Jackson in City Hall of, i, 338 ; Audubon's description of landing at, in $\mathbf{1 8 3 6 ,}$ ii, 146; his success in canvassing at, ii, 153; his old residence and estate, ii, 234-236, 310-312.

New York Horald, account of "Mill Grove" mine in, i, 114.

Niagara Falls (New York), Alexander Wilson at, i, 216; Audubon at, i, 340; ii, 167.

Nighthawk (Chordsiles virginianus), Audubon's early drawing of, i, 180. Nolte, Vincent, on Audubon in 1811, i, 277; his journey from Pittsburgh to Lexington, i, 276-279; 352.

Northumberland, Duke of, i, 377.

Nuttall, Thomas, collection of western birds of, ii, 147, 149, 153-154; 156; meeting with Audubon, ii, 150; career and writings, ii, 150.

Nymphar. See Water-lily. 
"Oakley," plantation and house of, $\mathrm{i}$, 313-315; Audubon's pupil and his life as tutor at, i, 315-318; his drawings at, i, 316 ; ii, 74.

Oates, George, ii, 211, 218.

Ogé, James, rebellion and death of, i, 50; its effect upon the Santo Domingan whites, i, 50.

Ohio River, Audubon's description of journey on, i, 195; Wilson's journey in 1810, i, 205; traffic of the "ark" and keel boat, in 1810, i, 234-236 ; first steamer, and steam traffic on, i, 236; Audubon's experience at the mouth of, i, 238; breaking up of the ice in, i, 241; Rafinesque on fishes of, i, 292; Audubon's descent of, in 1820, $\mathrm{i}, 307$.

Ord, George, on Alexander Wilson, i, 211; as Wilson's editor and biographer, i, 217, 223-225; his octavo edition of Wilson, i, 223; defense of Wilson and charge against Audubon, i, 226-228; 230; basis of his attack on Audubon, i, 227, 231232; his opposition to Audubon, i, $328-329$; 333, 339, 422; ii, 4, 27, 55, $61,72,80,83$; as Waterton's correspondent, ii, 87-88, 91; 98, 284.

Orleans, Duke of, as Audubon's patron, i, 3, 411-412.

Ornithological Biography, description of Bird Rock in, i, 9; story of the Pewee, i, 99, 106-107; on the Velvet Duck, i, 182; journey down the Ohio River, i, 195; Alexander Wilson's visit to Louisville, i, 220223; Wilson on the Whooping Crane, i, 227; discrepancies in "Episodes" in, i, 273; "Louisville in Kentucky," i, 274; "The Prairie," i, 274, 282-284; "A Wild Horse," i, 274-276; "The Eccentric Naturalist," i, 274, 285-300; "The Earthquake," i, 279; "The Hurricane," i, 280; "The Regulators," i, 281; "Colonel Boone," i, 281;
Natchez, i, 308; on The Birds of America, i, 343; publication of, $\mathrm{i}$, 438; MacGillivray's assistance in, i, 438 ; rivals of, i, 438-439; 442445 ; American copyright of, i, 439 ; publisher's announcement, i, 444445,448 ; the Athenceum on, ii, 84$85,140,142$; W. B. O. Peabody on, ii, 85; Featherstonhaugh on, ii, 85 ; on the authorship of, ii, 87-89, 102-103, 103-109; on new species in, ii, 109-111; "Ornithophilus" on, ii, 111, 112; Swainson on, ii, 113; and MacGillivray, ii, 125-138; Audubon on American Edition of, ii, 134, 141; MacGillivray's copy of, ii, 138; John Wilson on, ii, 139; third volume of, ii, 144, 178-180; fourth volume of, ii, 181 ; completion of, ii, 186; valedictory to reader, ii, 187 ; memorandum of accounts with MacGillivray for assistance in, ii, 188; Audubon on residual stock of, ii, 189.

Ornithological Gallery, plan and abandonment of, by Audubon and Kidd, i, 446.

Orr, Charles, correspondence of Alexander Wilson, with, i, 210-212. Osprey, Fish Hawk (Pandion haliaëtus), early drawing by Audubon, i, 182 .

Otter, original painting and exhibition of, i, 394.

Oven-bird (Seiurus aurocapillus), "Golden-crowned Thrush," Audubon's original drawing of, i, 425.

Owen, David Dale, i, 294.

Owen, Sir Richard, i, 354.

Owensboro (Kentucky), i, 236.

Oxford Street (London), i, 11.

Page, Benjamin, i, 256.

Paimbœuf, i, 32, 80, 137.

Palmer, Sarah White, i, 124.

Palmer, Theodore Sherman, ii, 293.

Pamar, R., i, 318, 348. 
Paris, in 1828, i, 2; Audubon at, i, $74,408-413,448$; his reception and patronage at, i, 410-413.

Parkman, Dr. George, ii, 29, 35, 36 ; to Audubon, ii, 42-43; 57, 59, 134 , 141 ; Audubon to, ii, 227.

Patterson, W. D., i, 231; ii, 352.

Peabody, W. B. O., i, 231; ii, 200.

Peale, Rembrandt, i 328.

Peale, Robert, i, 328.

Peale, Titian R., his drawings of birds, i, 330.

Pears, Thomas W., i, 124; as partner of Audubon and Bakewell, i, 254; his withdrawal, i, 255, 426.

Peel, Sir Robert, i, 377.

Penal laws, in England, i, 395.

Penn, John, i, 105.

Penn, William, land purchase by, i, 103.

Percy, Capt. Robert, Mrs. Audubon's school at plantation of, $i$, 322; Audubon at plantation of, $i$, 324.

Perkins, Thomas H., ii, 28, 29, 39, 150.

Perkioming Consolidated Mining Company, i, 169.

Perkioming Creek, i, 103-104, 106.

Perrytown (Sutton, New Hampshire), i, 284.

Pewee, Phœbe (Sayornis phobe), Audubon on, i, 99; his first study of, $i, 106$; original drawing of, $i$, 180.

Pewee, Wood (Myiochanes virens), Audubon's original drawing of, i, 180, 425.

Philadelphia (Pennsylvania), reception of Audubon at, i, 327-335; a meeting of the Academy of Natural Sciences at, i, 333; ii, 154 .

Philarète-Chasles, impressions of Audubon's exhibition at Edinburgh, i, 359.

Phillips, Dr Benjamin, ii, 144-145, 223-224; Audubon to, ii, 244-246.
Phœbe, Say's (Sayornis sayus), i, 330.

Picus auduboni, ii, 113.

Pigeon, Passenger (Ectopistes migratorius), Audubon's original painting of, i, 363; Audubon on, i, 368 .

Pirrie, Eliza, as Audubon's pupil, and her romantic history, i, 315, 317-318.

Pirrie, James, i, 315; Audubon's drawings made at plantation of, $\mathrm{i}$, 316.

Pirrie, Mrs. James, engagement of Audubon by, i, 313; her home and family, i, 313-318.

Pitois, M., i, 432.

Pittsburgh (Pennsylvania), record of journey from Philadelphia to, in 1807, $\mathrm{i}, 187-191$; characterization, growth and population of, i, 191; Wilson's description of, in 1810, i, 204; 343, 344.

Plaisance, Samuel, i, 123, 265.

Planters (Santo Domingo), their prosperity and grievances, i, 4244; their morality and vicissitudes, i, 44-46; their revolt, i, 49-51.

Polly, Audubon's and Rozier's voyage on, i, 134-135, 187.

Pope, John, i, 237.

Pornic, mission of Citizen Audubon to, i, 79 .

Porter, Dr. Edmund, to Dr. Thomas Miner, i, 333.

Posey, Fayette, i, 258.

Presque Isle, i, 340.

Priestley, Joseph, i, 154, 200-201.

Prospectus, of American Ornithology (Wilson), i, 217; of The Birds of America, i, 373; of first octavo edition, ii, 211-214; reproduction of (for 1828) for original folio, ii, 386-388; reproduction of (by J. W. Audubon), for second (partial) American edition of original folio, ii, 389-39i. 
Provost, Henry Augustin, i, 105-106, 122.

Quadrupeds of North America, i, 17; Bachman to Audubon on, ii, 208; Audubon to Brewer on, ii, 209; on Bachman's coöperation in, ii, 210; Audubon to Baird on, ii, 219-221, 222, 226-227, 233; Audubon to Parkman, ii, 227; to W. O. Ayres, ii, 229; Parke Godwin on, ii, 236; editions of, ii, 261; Bachman on text of, ii, 261-263, 269272, 281-283; Baird on materials for, ii, 263, 264, 274, 276-277, 278; Audubon on letterpress of, ii, 265 ; Harris as mediator in difficulties with letterpress of, $\mathrm{ii}, 269$; coöperation of authors in, ii, 273; subscribers to, ii, 274; Louis Agassiz on, ii, 274 ; title of text of, ii, 275 ; English edition of first volume of text of, ii, 280; dedication copy of first volume of text of, ii, $280 ; \mathrm{J}$. E. Gray on, ii, 281; manuscript of text of, ii, 283; Illustrations of, ii, 285 ; in octavo, ii, 293.

Quebec, Audubon's visit and success in, ii, 244.

Queen, Jean Audubon's fight in, i, 35. Queen Charlotte (La Reine Charlotte), Captain Jean Audubon's command of, at Yorktown, i, 34.

Quinarianism, curious tenets and advocacy of, ii, 94, 95, 104, 109, 114, $116,117$.

Quincy, Josiah, ii, 29, 150.

Rabin, Mlle, birth of son of, i, 52; as characterized by Jean Audubon, i, 52; record of physician of, $i$, 53; her feeble health and death, i, 56 ; suppression of her name, i, 60 ; early and assumed names of her son, i, 62; as characterized by her son, $i, 63,66$; fictitious account of death of, i, 67 .
Rabin, Jean, i, 53, 57, 61, 62, 63, 64, 263, 264; ii, 361, 362, 364. See Jean Jacques Fougère Audubon.

Rafinesque, Constantine Samuel (Schmaltz), i, 171; his travels, writings and career, i, 285-300; Audubon on, i, 285; and the bats, i, 286; his early life and precocity, i, 287; his bibliography, i, 287; visit to America, i, 288; life in Sicily, i, 288; marriage and embitterment, i, 289; return to America and shipwreck, i, 290; visits Audubon, i, 290; his "scarlet-headed swallow" and fictitious fishes, $i$, 291; his Ichthyology of the Ohio River and "Devil-Jack Diamondfish," i, 292; at Transylvania University, i, 294; originality and independence, i, 295; impractical projects and inventions, i, 295-296, 298; troubles at Lexington and return to Philadelphia, i, 296; his mania for new species, i, 296; his letters, i, 297; his multifarious writings, final struggles and death, i, 297-299; his ardor and fatal versatility, i, 299; contemporary notice of, i, 333.

"Rafinesquiana," i, 287.

Rambler, i, 7 .

Ramsden, George, Edward Holden to, i, 351 .

Rankin, Dr. Adam, i, 238, 242; his "Meadow Brook Farm," i, 248; birth of John Woodhouse Audubon at home of, i, 248 .

Rankin, William, i, 248.

Rathbone, Richard, introduction of Audubon to, i, 352.

Rathbone, William, Sr., assistance rendered Audubon by, i, 352.

Rathbone, Mrs. William, Sr., at "Greenbank," i, 353; gift to Audubon by, i, 355.

Rathbone, William, Jr., i, 352.

Rattlesnake, Audubon's account of 
drawing of, i, 316; climbing habits of, ii, 53-54, 64; Audubon on, ii, 71-76; Dr. Jones' charge concerning, ii, 72; Audubon's error in description of, ii, 76-78; vindication of Audubon's drawing and account of the fangs of, ii, 79 .

Rattlesnake, encounter of the Polly with, i, 134-135, 187.

Redbanks. See Henderson.

Redbird, Summer Tanager (Piranga rubra), Audubon's drawing of, i, 316.

Redouté, Pierre Joseph, works and friendship of, i, 411.

Red River (Arkansas), drawing of the Chuck-will's-widow on, i, 182.

Redstart, American (Setophaga ruticilla), Audubon's early drawings of, i, 181, 316.

Rees, Abraham, i, 216.

Rees, William J., ii, 62.

"Regulus cuvieri," "Cuvier's Wren," i, 180, 354; ii, 215, 219.

Rhoads, Samuel N., i, 291; ii, 202.

Richardson, John, ii, 98, 105, 106.

Ricordel, Mme. See Mme. Jean Audubon.

Rider, Alexander, i, 331.

Ridgely, D., ii, 38.

Ripley, the voyage of, ii, 43-50.

Robertson, John Argyle, ii, 183.

Robin, American (Planesticus migratorius), Audubon's early drawing of, $i, 182$.

Rochambeau, Comte de, i, 34 .

Rochefort, i, 30, 83, 93, 94.

Roe Lockwood \& Son, ii, 296.

Roget, Dr. Peter Mark, i, 37 .

Roscoe, Edward, i, 352, 353, 354.

Roscoe, William, i, 218.

Ross, David (and Company), i, 5i, 121-123, 265, 266.

Rothschild, Baron, Audubon's account of interview with, ii, 206.

Rowan, William, i, 400.

Roy, Constance (Rozier), i, 245.
Royal Society (London), Audubon's election to membership in, i, 437; William Swainson on his election, ii, 97.

Rozier, Charles A., i, 146.

Rozier, Claude François, i, 147; Ferdinand Rozier to, i, 149-152; his family, i, 152; his death, i, 152; and Benjamin Bakewell, i, 154; Audubon to, i, 154, 156-158, 161163, 164-166.

Rozier, Felix, i, 246.

Rozier, Ferdinand, i, 146; his "Articles," i, 147; to his father, i, 149152; at Philadelphia, i, 153; as attorney for Lieutenant Audubon and his wife, i, 153; his business plans, i, 156-158, 161-162, 165; his diary, i, 187-192; Thomas Bakewell to, i, 196; William Bakewell to, i, 199; removes from Louisville to Henderson, i, 236; removes with Audubon to Ste. Geneviève, i, 237-241; dissolves partnership with Audubon, i, 241; Audubon to, i, 243; career of, i, 244-246; his death, i, 246; "Audubon \& Bakewell" to, i, 251; ii, 359.

Rozier, Firman A., i, 246.

Rozier, François Denis, i, 154.

Rozier (Colas), Renée Angelique, death of, i, 152 .

Rozier, Tom J., i, 196.

Rozier, Welton A., manuscripts in possession of, i, 149, 168, 187.

Rue de Crébillon, Jean Audubon's home in, i, 57.

Rush, Dr. Benjamin, i, 288.

Russell, W. Gurdon, ii, 204.

Saget (mayor of Nantes), i, 77 .

St. Albans, i, 403.

St. Augustine, Audubon's description of, ii, 12; hunting birds at, ii, 12.

St. Francisville (Louisiana), engagement of Audubon at, i, 313; origin of name, i, 314; character 
of country and abundance of birds, i, 314; Audubon as tutor at, i, 315-318; Mrs. Audubon's school, i, 322; former wealth of country, i, 323, 345 .

Sainte Geneviève (Missouri), Audubon's journey to, i, 237-241; dissolution of partnership with Rozier at, i, 241; Audubon's subsequent visits, i, 242; Ferdinand Rozier's career at, i, 244-247.

St. John, Mrs. Horace Roscoe Stebbing, $i, 17$.

St. Johns, ii, 244.

Saint Louis (Santo Domingo), i, 39, 41.

Sammis, Capt. S., i, 131, 156, 158, 159, 164, 187.

Sandpiper, Spotted (Actitis macularia), Audubon's early drawing of, i, 249.

Sanson, Dr., as Jean Audubon's physician, i, 53 ; his bill of services, resources and favorite remedies, $i$, 53; his inoculations for smallpox, i, 55; his treatment of Audubon's mother, i, 56; for complete text of bill, with translation, see ii, 314327.

Santo Domingo, pre-revolutionary lure of, i, 36; Jean Audubon's career in, i, 36-38; effect of the Declaration of Rights on, i, 37; slave trade at, $i, 39-41$; cost of slaves at, $i, 40$; prosperity and praise of, i, 42; population of whites and blacks in $1790, i, 42$; plight of mulattoes and history of slavery in, i, 43; Baron de Wimpffen's experience with society and plantation life, i, 44-48; unjust taxation, i, 44, 46; debasement of morals, i, 45; bossals, creoles and mulattoes, i, 44-47; outbreak and progress of the Revolution, i, 4951; the Revolution in relation to the history of Jean and Jean
Jacques Fougère Audubon, i, 50; Les Cayes first touched by Revolution of, i, 50; first blood drawn in the North, i, 50; Ogé's futile rebellion, i, 50; later events in rising of blacks and mulattoes against whites, i, 50; physicians and their remedies in, i, 54 .

Sautron, i, 139.

Savenay, i, 78.

Say, Thomas, i, 294, 330, 333-334.

Sayornis saya, i, 330.

Sayre, Robert H., ii, 7.

Scott, Sir Walter, on Audubon's exhibition, i, 359; Audubon on, 1, 365 ; on Audubon, i, 366-368; 370. Scott, Winfield, ii, 242.

Searles, Edward F., ii, 203.

Seaside Finch (Passerherbulus maritimus), original drawing of, i, 425. Sedgwick, Adam, i, 399.

Selby, Prideaux John, Audubon's visit to, i, 374; Illustrations of British Ornithology by, i, 375; to Audubon, i, 375; ii, 102.

Serinettes, i, 163.

Shannonville (Pennsylvania), i, 102. Sharp, William, i, 209.

Shattuck, Dr. George C., ii, 29, 35, $43,150,151,228$.

Shattuck, Dr. George Cheyne, as Audubon's assistant, ii, 43; as philanthropist, ii, 43; 228.

Shippingport (Kentucky), Audubon as peripatetic portrait painter at, i, 303; 326, 345 .

Slack, Elijah, on Audubon's term of service at the Western Museum, i, 304; as president of Cincinnati College, i, 305.

Slaves (in Santo Domingo), numbers delivered at Les Cayes, i, 31; as a basis of wealth, i, 39; trade in, $i$, 39-41 ; numbers and mortality of, i, 42, management of, i, 43-47; diseases of, i, 46; cost and taxes of, i, 46; revolt of, i, 49-51. 
Smallpox, i, 55 .

Smith, Rebecca (Bakewell), i, 201.

Smith, Rev. Sidney, i, 369, 372.

Smythe, Henry A., ii, 310.

Sparrow, Baird's (Emberiza bairdii, Audubon, 1844; now Ammodramus bairdi), ii, 259.

Sparrow, Harris's (Zonotrichia querula), ii, 253.

Sparrow, Swamp (Melospiza georgiana), Audubon's early drawing of, i, 249 .

Sparrow, Vesper (Poœcetes gramineus), "Bay-winged Bunting," original drawing of, i, 425.

Spencer, John C., ii, 242.

Sprague, Isaac, ii, 252.

Stanilaus, Francis Alexander (Baron de Wimpffen), i, 44; his experiences and observations as planter in Santo Domingo, i, 44-48.

Stanley, Edward George Geoffrey Smith (fourteenth Earl of Derby), i, 354, 380, 437 .

"Stanley Hawk" (Falco stanleyi, now Accipiter cooperi), Cooper's Hawk. See Falco.

Starling, Edmund L., i, 236, 250, 252, 256-257.

Sterling, Mrs. Frederick A., i, 342.

Stoddard, Rev. Charles Augustus, tribute to Mrs. John James Audubon, ii, 303.

Stone, Charles F., ii, 311.

Stone, Witmer, ii, 214.

Stuart, Gilbert, i, 336.

Sturnella neglecta, Western Meadow Lark, ii, 254.

Sully, Thomas, i, 2, 328; Audubon as pupil of, i, 334; to Audubon, i, 334; Audubon to, i, 339; ii, 68-71.

Sully, Mrs. Thomas, Audubon to, i, 389.

Swainson, William, on Rafinesque, i, $289,377,395$; correspondence of, i, 400; Audubon to, i, 400-401, 405407, 409-410; ii, 95-97, 99, 101-103,
112, 176-177, 353; to Audubon, 1 , $402,413-414,429-423,430-431$; ii, 97-101, 103-108; characteristics, i, 402; on Audubon, i, 403; Audubon at home of, i, 404; with Audubon in Paris, i, 408-412; 415; ii, 84; in controversy over the Ornithological Biography, ii, 88, 93-109; as leader in the Quinarian movement, ii, 9395, 114, 116-117; Audubon's proposal for assistance of, ii, 102; his response and answer to a later letter, ii, 103-108; their subsequent relations, ii, 111-114; as biographer, ii, 113-116; Literary Gazette on, ii, 113; as the "British Cuvier," ii, 114; his career and adversities, ii, 117; his emigration and death, ii, $118 ; 173$.

Sylvia (Helinaria) swainsonii, il, 113.

Syme, John, i, 361.

Synopsis of Birds of North America, publication of, ii, 186; number of species recognized in, 186.

Tawapatee Bottom, i, 240.

Taylor, Richard C., ii, 77.

Thayer, John E., i, 307, 363; ii, 227, 229.

Tête-Carée. See Dupré.

Texas, Audubon's visit to Republic of, ii, 163-165.

Thackeray, George, ii, 146.

The Foresters, i, 216.

Thomas, William, i, 101, 113, 115, $116,117,118,150,151$.

Thrush, Hermit (Hylocichla ustulata), i, 308.

Thrush, Wood (Hylocichla musteli$n a)$, Audubon's early drawing of, i, 180.

Title pages, in facsimile, The Birds of America, original folio, i, 381; prospectus of The Birds of America, i, 391; of covers of parts, of octavo (second) edition of the 
Birds, ii, 213; of English edition (Vol. I) of The Viviparous Quadrupeds of North America, i, 275. Titmouse, Mountain, Audubon's early drawing of, i, 181.

Torrey, John, i, 171.

Townsend, Dr. John Kirk, ii, 147, 149, 153-154, 156, 170-173, 179.

Traill, Dr. Thomas S., i, 353.

Transportation by steam, in the Atlantic, i, 2; on the Ohio River, $i$, 236.

Transylvania Company, i, 252.

Transylvania University, i, 294-296, 306.

Treat, Mary, ii, 81.

Trinity Cemetery, i, 13.

Trudeau, James, ii, 184, 185, 186.

Turkey, Wild (Meleagris gallopavo), i, 311, 355, 358, 363; ii, 198.

"Twizel House," i, 374.

Tyler, John, Audubon's credentials from, ii, 242.

Tyttenhanger (or Tittenhanger), Green, i, 403.

Valentine, Edward Virginius, i, 14. Valley Forge (Pennsylvania), i, 102. Van Buren, Martin, ii, 153, 166.

Vanderlyn, John, i, 312, 338.

Vaux, James, i, 108.

Vendée, La, i, 24-2i.

Vendeans, characteristics and revolt of, i, 26; Nantes besieged by, i, 74 ; defeat and fate of, $i, 75$; execution of leader of, i, 76-77; 80 .

Vigors, Nathaniel Augustus, i, 377; to Audubon, i, 407-408; 415; ii, 101, 107.

Vireo belli ( $V$. bellii, of Audubon, 1844), Bell's Vireo, ii, 253.

Vireo, Warbling (Vireosylva gilva), Audubon's original drawing of, $i$, 425.

Vireo, Yellow-throated (Lanivireo flavifrons), Audubon's original drawing of, i, 316.
Vulture, Turkey (Cathartes aura), and Black, or "Carrion Crow" (Catharista urubu), controversy over the sense of smell in, ii, 8184; experiments of Audubon and Bachman on, ii, 55-56, 61, 81-82 ; memorial of the faculty of the South Carolina Medical College on, ii, 83; present condition of the question, ii, 83.

Wade, Joseph M., i, 213, 254.

Wagtail, White (Motacilla alba), Audubon's early drawing of, i, 181.

Wainwright, Rev. Dr., Edward Everett to, i, 436.

Waller, Sir J. Walter, to Audubon, i, $392 ; 406$.

Walton, Isaac, i, 206.

Warbler (Sylvia trochilus delicata, sylvia delicata), Audubon's unpublished drawing of, i, 228.

Warbler, Bay-breasted (Dendroica castanea), "Autumnal Warbler," Audubon's original drawing of, i, 426.

Warbler, Blackburnian (Dendroica fusca), "Hemlock Warbler," Audubon's original drawing of, i, 180, 426.

Warbler, Black-poll (Dendroica striata), Audubon's original drawing of, i, 425 ; ii, 50.

Warbler, Black-throated Blue (Dendroica carulescens), "Pine Swamp Warbler," Audubon's original drawing of, i, 425.

Warbler, Canada (Wilsonia canadensis), "Canada Flycatcher," Audubon's original drawing of, i, 425.

Warbler, Carbonated (Dendroica carbonata), Audubon's original drawing of, i, 180.

Warbler, Chestnut-sided (Dendroica pennsylvanica), Audubon's original drawing of, i, 180. 
Warbler, "Children's," Yellow Warbler (Dendroica astiva), i, 354.

Warbler, Connecticut (Oporornis agilis), Audubon's original drawing of, $i, 426$.

Warbler, Magnolia (Dendroica magnolia), "Black and Yellow Warbler," Audubon's original drawing of, i, 425.

Warbler, Pine-creeping (Dendroica vigorsi), Audubon's original drawing of, $i, 316$.

Warbler, Prairie (Dendroica discolor), Audubon's original drawing of, i, 316.

Warbler, "Rathbone," i, 180, 354.

Warbler, Tennessee (Vermivora peregrina), Audubon's original drawing of, $i, 316$.

Warbler, Yellow-rumped, Myrtle Warbler (Dendroica coronata), Audubon's original drawing of, $i$, 180.

Ward, Henry, ii, 2, 4, 9, 12, 25, 32, 59.

Washington, General George, at Valley Forge, i, 102; Polk's portrait of, i, 106; at "Fatland Ford," i, 108.

Water-lily, yellow (Nymphaa $h$ tea), ii, 80.

Waterton, Charles, i, 12, 224-232, 415; ii, 55, 61, 73; on Audubon's drawing of the rattlesnake, ii, 79; on the vulture's olfactory sense, ii, 82; to George Ord, ii, 83; his Wanderings, polemics and life at Walton Hall, ii, 86-92; on Alexander Wilson's diary, ii, 87; on the Ornithological Biography, ii, 87; on the young Cuckoo and Hummingbird's nest, ii, 90-91; 142.

Watty and Meg, i, 208.

Webster, Daniel, as Audubon's patron, ii, 151; his letter of recommendation and promise of ducks, ii, 152; Audubon's credentials from, ii, 242 .

Wellington, ii, 189, 191.

Wernerian Society, i, 183; ii, 72.

Westerman, General, to Citizen Audubon, i, 80.

Western Journal, ii, 298.

Western Museum, Audubon as its taxidermist, and story of its foundation, i, 303-306.

Wetherill, Samuel, Junior, i, 102, 169 ; ii, 14 .

Wetherill, Samuel Price, i, 102.

Wetherill, Dr. William, i, 201.

Wetherill, W. H., i, 99, 102, 149.

Wheelock, John, i, 218.

Whewell, William, i, 399.

Whip-poor-will (Antrostomus vociferus), Auduwon's early drawings of, i, 180, 249.

Whitehall (New York), ii, 244.

White-throated Sparrow (Zonotrichia albicollis), Audubon's early drawing of, i, 249.

Wilkie, David, i, 377.

Williams, George Alfred, on the ancestry and achievements of Robert Havell, Junior, i, 382; ii, 193-195.

Wilson, Alexander, i, 107; his life and accomplishments, i, 202-220; his journey of 1810 , i, 202; his rebuke to a judge, i, 203; description of Pittsburgh, i, 204; descends the Ohio, i, 205; impressions of Cincinnati and Louisvilie, i, 205; success in New Orleans, i, 207; his meeting with Audubon, i, 207; early life and struggles, i, 208; success as a dialect poet, i, 208; champions the oppressed weavers, is fined and sent to jail, i, 208; emigrates to America, i, 209; unfortunate love affairs, i, 209, 212, 215, 216; to Charles Orr, i, 210212; George Ord on, i, 211 ; friendship with Bartram and Lawson, i, 212; his poverty and thrift, i, 214- 
216; his talents and genius, i, 214; The Foresters, i, 216; his American Ornithology begun, i, 216; his prospectus and first volume, i, 217; canvasses New England, i, 218; journey South and extension of his work, i, 218; second New England tour, and his arrest as a spy, i, 219 ; completion of his seventh volume and his premature death, $\mathrm{i}$, 219; his character, i, 219; Audubon's account of their meeting in Louisville, i, 220-223; Ord's revival of the incident, i, 223; his diary in light of later events, i, 224-232; his evasive flycatcher, $i, 226$; the "twin" Mississippi Kites, i, 227230 ; as a later "rival" of Audubon, i, 231-232, 234-235, 311, 422; mistaken obituary of, ii, 2; Audubon on, ii, 143; number of species of American birds recognized, ii, 214; and Bachman, ii, 284.

Wilson, James, i, 438.

Wilson, John, i, 362, 385, 447; ii, 84; Audubon to, ii, 139.

Winterfield, Charles, ii, 121, 256-258; on Audubon at the ruins of a fire, ii, 267.

Wollaston, Dr. William Hyde, i, 37\%.
Wood, Rev. J. G., on Waterton, ii, 89.

Woodbury, Levi, ii, 5; to Louis McLane, ii, 23.

Woodpecker, Green, Audubon's early drawing of, i, 178, 181.

Woodpecker, Red-cockaded (Dryobates borealis), Audubon's early drawing of, i, 316.

Wren, "Cuvier's." See "Regulus." Wren, Bewick's (Thryomanes bewicki), Aildubon's original drawing of, i, 180.

Wren, Marsh (Telmatodytes palustris), original drawing of, i, 425.

Wren, Parkman's (Troglodytes ä̈don parkmani), original specimen, ii, 227.

Yarrell, William, ii, 58; to Audubon, ii, 223-225, 246-247.

Yellow-throat, "Roscoe's," Maryland Yellow-throat (Geothlypis trichas), i, 354.

Yorktown (Virginia), Jean Audubon's command at, i, 24.

Zoölogical Gallery, i, 12, 382, 394.

Zoölogical Society (London), i, 398 . 444. 





